MARIA BEATRIZ PESTANA BARBOSA

\title{
Wayfinding na jornada da pessoa com deficiência visual no sistema metroferroviário
}

Tese apresentada à Faculdade de Arquitetura e Urbanismo da Universidade de São Paulo para obtenção do título de Doutor em Arquitetura e Urbanismo

Área de concentração: Tecnologia da Arquitetura

Orientadora: $\operatorname{Prof}^{\mathrm{a}} \operatorname{Dr}^{\mathrm{a}}$ Sheila Walbe Ornstein

São Paulo 
Autorizo a reprodução e divulgação total ou parcial deste trabalho, por qualquer meio convencional ou eletrônico, para fins de estudo e pesquisa, desde que citada a fonte.

e-mail: mbeatriz@usp.br

Catalogação da Publicação

Barbosa, Maria Beatriz P.

B238w Wayfinding na jornada da pessoa com deficiência visual no sistema

Metroferroviário / Maria Beatriz P. Barbosa. -São Paulo, 2015. 549 p. : il.

Tese (Doutorado - Área de Concentração: Tecnologia da Arquitetura) - FAUUSP.

Orientadora: Sheila Walbe Ornstein

1.Acessibilidade ao meio físico (Diagnóstico; Melhoramento)

2.Avaliação pós-ocupação 3.Deficiência visual 4.Terminais de passageiros - São Paulo (SP) 5.Veículos sobre trilhos

6.Wayfinding I.Título

CDU 72.051.6 
Um novo projeto é sempre uma oportunidade e uma possibilidade para que sejam debatidas questões, quer sejam de ordem técnica, urbana, intrínseca ao edifício ou, ainda, de outra natureza, que envolvam áreas do conhecimento distintas, questões que são preocupações externadas pela sociedade ou por setores dela, por arquitetos e teóricos, questões que envolvam a compreensão do momento no qual se inserem. (FEHR, 2010, p. 83) 


\section{AGRADECIMENTOS}

À Faculdade de Arquitetura e Urbanismo da Universidade de São Paulo - FAUUSP e à Companhia do Metropolitano de São Paulo - CMSP por fornecerem os recursos e as oportunidades ao meu desenvolvimento acadêmico, profissional e pessoal.

À minha orientadora, $\operatorname{Prof}^{\mathrm{a}} \operatorname{Dr}^{\mathrm{a}}$ Sheila Walbe Ornstein, por compartilhar seu conhecimento e me estimular na busca da aprendizagem contínua.

Aos meus pais Paulo Henrique e Maria José e à minha irmã Maria Paula, pelo apoio e ajuda incondicional que sempre deram, ainda maiores durante a realização desta tese.

Ao Rafael e ao José Eduardo, que sempre apoiaram e incentivaram minha dedicação acadêmica e profissional.

Aos professores da pós-graduação da Faculdade de Arquitetura e Urbanismo, que proporcionaram que a informação fosse transformada em conhecimento por meio das aulas, seminários e discussões.

Agradecimento especial aos professores que participaram das bancas de qualificação de mestrado, de passagem para o doutorado direto, de qualificação de doutorado e da banca examinadora, pelas contribuições para melhoria deste trabalho.

Ao sempre presente amigo Vagner José de Almeida, pelas ilustrações desta tese e pela companhia durante as viagens de férias para realização das visitas técnicas.

Às amigas Tania Pietzschke Abate, Tarsila Miyazato, Cintia Mello, Ligia Catarina Fischer, Denise Daud, Vera Massa e Adriana de Almeida Prado, e ao amigo Fernando Moreno, pelo apoio e compartilhamento de experiências, ideias e literatura em diferentes momentos.

À Simone Tostes, pela revisão cuidadosa.

Agradecimentos especiais ao Eng. Conrado Grava de Souza e ao Fís. Roque de Lázaro Rosa, da Diretoria de Operação da Companhia do Metropolitano de São Paulo, por viabilizarem as visitas técnicas às empresas operadoras. 
Aos colegas das empresas Transport Metropolitans de Barcelona - TMB, Metrô de Madrid S.A., Régie Autonome des Transports Parisiens- RATP, Société Nationale des Chemins de Fer Français - SNCF, London Underground - LUL, Transport for London - TFL, Metrô do Rio de Janeiro - MetrôRio e Companhia do Metropolitano do Distrito Federal - Metrô-DF por me receberem e possibilitarem a realização das visitas técnicas.

A todos os participantes desse estudo, em especial às pessoas com deficiência visual e aos profissionais que atuam na Companhia do Metropolitano de São Paulo e nas instituições de reabilitação e de normalização, fundamentais para que os objetivos desse trabalho fossem alcançados.

Aos profissionais com quem tive contato nesses anos, em congressos, reuniões ou eventos relacionados à acessibilidade, que se tornaram grandes amigos e incentivadores. 


\section{RESUMO}

A rede metroferroviária é constituída por um conjunto de estações, trens e vias que proporciona transporte de pessoas na região metropolitana. Por se caracterizar como um serviço público deve oferecer condições adequadas de utilização por todos os cidadãos, independentemente de sua condição física ou sensorial. A adaptação das estações e trens existentes, a construção de novas estações acessíveis e a aquisição de novos trens consideraram os avanços tecnológicos e de acessibilidade ao longo dos anos. Apesar disso, o elevado número de solicitações de auxílio por pessoas com deficiência visual pressupõe a existência de fatores que interferem ou impedem o uso independente do sistema metroferroviário. Esta pesquisa tem como objetivo identificar tais fatores e propor recomendações para o desenvolvimento do projeto das instalações e dos serviços oferecidos como forma de melhorar as condições de percepção e facilitar a cognição das pessoas com deficiência visual nas diversas etapas da sua viagem. Trata-se de uma pesquisa qualiquantitativa cuja estratégia está baseada na jornada do usuário com deficiência visual em estações e trens operados pelo Metrô na cidade de São Paulo, com diferentes graus de complexidade e condições de acessibilidade. A aplicação de métodos e técnicas da Avaliação Pós-Ocupação gerou evidências para elaboração do diagnóstico da acessibilidade da jornada do usuário, considerando os requisitos legais e normativos, as boas práticas verificadas, os dados levantados junto aos especialistas, pessoas-chave e usuários com deficiência visual. A identificação dos elementos de wayfinding permite dotá-los de características que facilitem sua percepção e, consequentemente, a orientação espacial das pessoas com deficiência visual, proporcionando segurança e independência. A sistematização das recomendações permite sugerir acréscimos às normas técnicas vigentes bem como auxiliar a atuação de planejadores, projetistas e gestores na realimentação do processo de projeto do sistema metroferroviário, relacionando a configuração dos ambientes à gestão das informações e aos serviços ofertados, uma vez que são partes integrantes de um mesmo contexto.

Palavras-chave: Avaliação Pós-Ocupação, acessibilidade, deficiente visual, terminais de passageiros, veículos sobre trilhos. 


\begin{abstract}
The subway network is constituted by a number of stations, trains and railways which provide transportation for people in the metropolitan region. As a public service, it should offer suitable conditions for all citizens, regardless of their physical or sensory conditions. The adaptation of existing stations and trains, the construction of new accessible stations and the purchase of new trains have taken into account technological advances and accessibility over the years. Nevertheless, the high number of requests for assistance by persons with visual impairment suggests the existence of factors that interfere with or prevent the independent use of the subway system. This research aims to identify such factors and present recommendations for the development of the design of the facilities and services offered as a way to improve the conditions of perception and cognition of people in various stages of their journey. This is a qualiquantitative research whose strategy is based on the journey of users with visual impairment in stations and trains operated by Metrô in the city of São Paulo, with varying degrees of complexity and accessibility conditions. The application of methods and techniques of Post-Occupancy Evaluation provided evidences for the diagnosis of the accessibility of the user's journey considering the legal and regulatory requirements, the best practices observed, the data collected by experts, key people and users with visual impairment. The identification of wayfinding elements favors features that facilitate their perception and, consequently, the spatial orientation of people with visual impairment, assuring safety and independence. The systematization of recommendations permits to suggest additions to existing technical standards as well as to assist the activities of planners, designers and managers in the feedback process of railroad transportation system design, relating the configuration of environments to the management of information and services offered, once they are an integral part of the same context.
\end{abstract}

Keywords: Post-Occupancy Evaluation, visually impaired, passenger terminals, railroad vehicles. 


\section{LISTA DE FIGURAS}

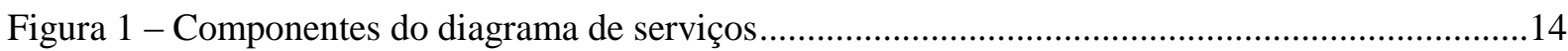

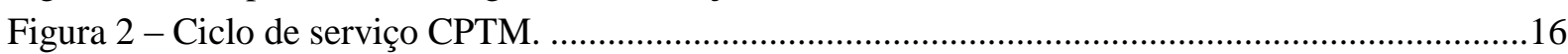

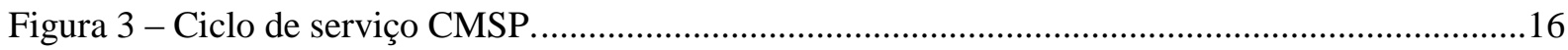

Figura 4 - Conceito de acessibilidade aplicado ao sistema de trens urbano e metropolitano................24

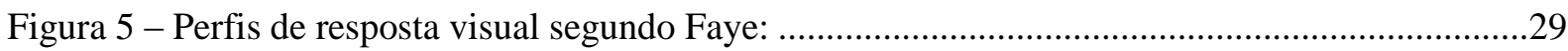

Figura 6 - Evolução da profundidade das estações do Metrô de Madrid - 1919-2003_........................48

Figura 7 - Critérios de projeto das estações do metrô de Madrid - seção longitudinal e perspectiva.. 48

Figura 8 - Arquitetura da informação nas estações do Metrô - RJ. .....................................................49

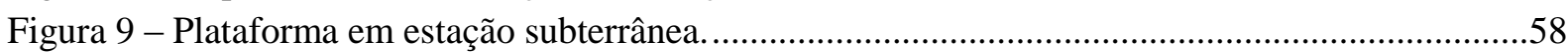

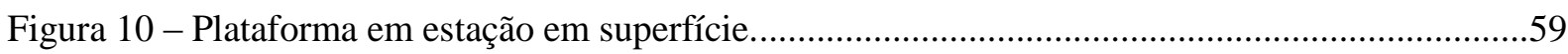

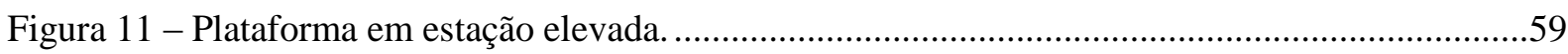

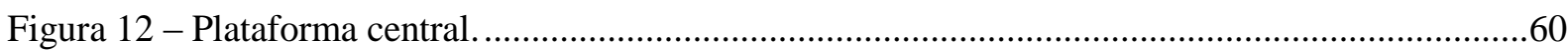

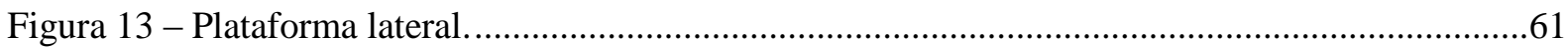

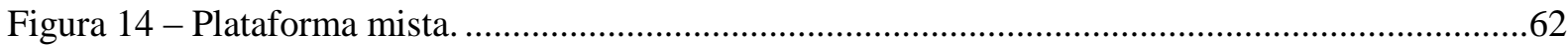

Figura 15 - Transporte Metropolitano RMSP 2030 - ampliação da rede e dos pontos de conexão..... 71

Figura 16 - Evolução das normas técnicas e das premissas de projeto das estações metroviárias. ...... 72

Figura 17 - Equipamentos de Acessibilidade na Rede Metropolitana de Transporte.............................74

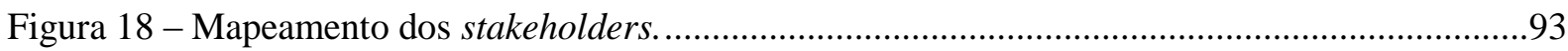

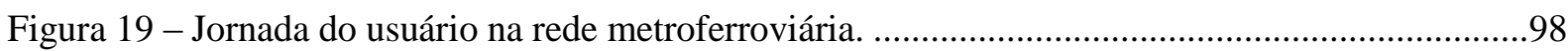

Figura 20 - Diagrama de Serviços do Metrô de São Paulo....................................................................101

Figura 21 - Estação Ana Rosa - terminal, mezanino, plataformas Linha 1 e Linha 2. ......................159

Figura 22 - Estação Palmeiras-Barra Funda - acesso, terminal, mezanino, plataforma.......................159

Figura 23 - Estação Sacomã - plataforma, acesso, terminal, mezanino............................................160

Figura 24 - Estação Tamanduateí - acesso, mezanino, plataformas CPTM e plataforma metrô. ........160

Figura 25 - São Paulo - Sinalização tátil e visual nos degraus das escadas rolantes. ..........................163

Figura 26 - São Paulo - Sinalização visual do sentido de deslocamento das escadas rolantes...........163

Figura 27 - São Paulo - Escada rolante isolada ou em conjunto com outras escadas. ..........................164

Figura 28 - São Paulo: bloqueios com diferentes dispositivos para leitura de cartões.........................165

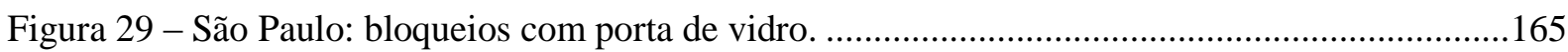

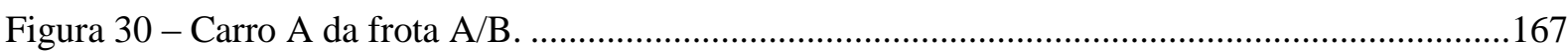

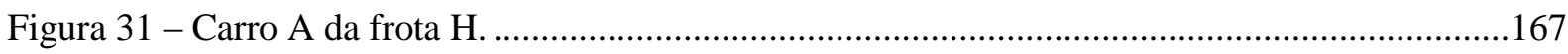

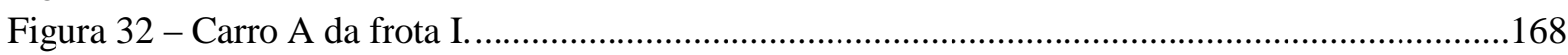

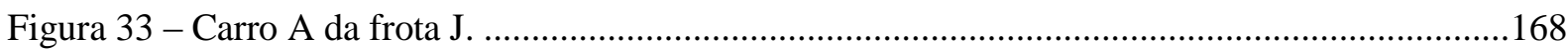

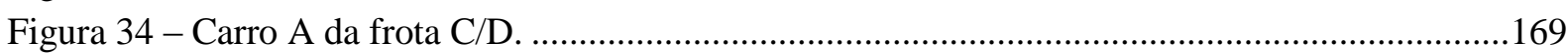

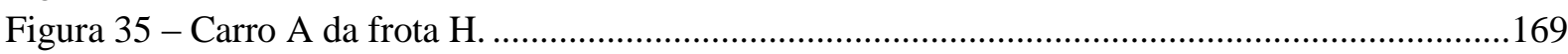

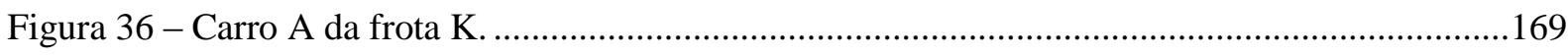

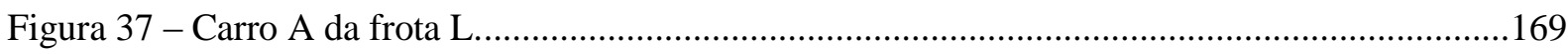

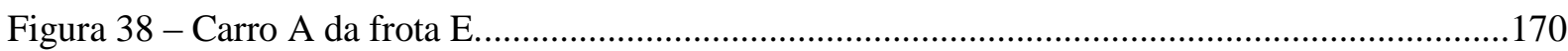

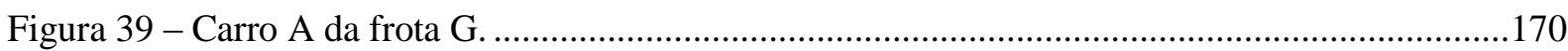

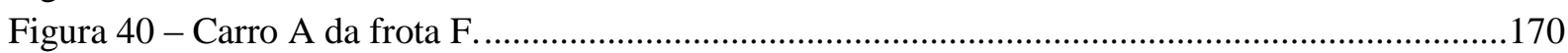

Figura 41 - São Paulo/Ana Rosa - sinalização indicativa do embarque preferencial. .........................175

Figura 42 - São Paulo/Ana Rosa - local de embarque preferencial. .................................................176

Figura 43 - São Paulo/Ana Rosa - Auxílio antes da estratégia de embarque preferencial...................177

Figura 44 - São Paulo/Ana Rosa - Auxílio após a estratégia de embarque preferencial. ....................177 
Figura 45 - São Paulo/Ana Rosa - Permanência indevida dos demais usuários no local de embarque

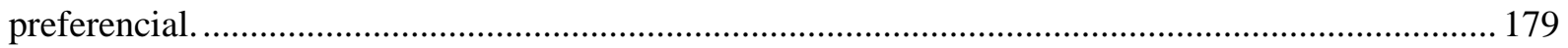

Figura 46 - São Paulo - Plataforma mista para embarque e desembarque. ........................................ 180

Figura 47 - São Paulo/Palmeiras-Barra Funda - locais de desembarque preferencial ....................... 181

Figura 48 - São Paulo/Palmeiras-Barra Funda - locais de embarque preferencial.............................. 181

Figura 49 - São Paulo/Palmeiras-Barra Funda - Desembarque na plataforma lateral-1 .................... 182

Figura 50 - São Paulo/Palmeiras-Barra Funda - Desembarque na plataforma central-2 . ................. 183

Figura 51 - São Paulo/Palmeiras-Barra Funda - Desembarque na plataforma central-1 . .................. 183

Figura 52 - São Paulo/Palmeiras-Barra Funda - Embarque com auxílio na plataforma central-2 .... 184 Figura 53 - São Paulo/Palmeiras-Barra Funda - Embarque independente na plataforma lateral-2.... 184

Figura 54 - São Paulo/Sacomã - Embarque com auxílio de funcionário ............................................ 185

Figura 55 - São Paulo/Sacomã - Embarque com auxílio de acompanhante....................................... 185

Figura 56 - São Paulo/Tamanduateí - Embarque com auxílio de estagiário........................................ 186

Figura 57 - São Paulo/Tamanduateí - Embarque de usuário e cão-guia com auxílio de estagiário... 187

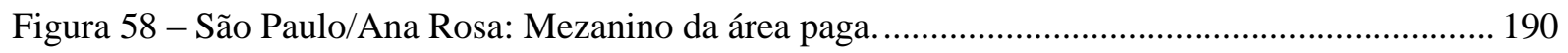

Figura 59 - São Paulo/Ana Rosa: Elementos orientadores de fluxo junto às escadas fixas................ 190

Figura 60 - São Paulo/Ana Rosa: Esquema de fluxos. ................................................................ 191

Figura 61 - São Paulo/Ana Rosa: Conflito entre fluxos de embarque, saída e conexão entre linhas. 191

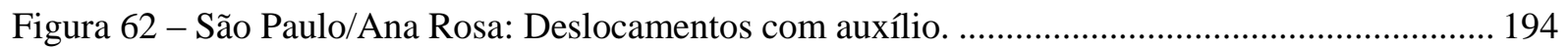

Figura 63 - São Paulo/Ana Rosa: Deslocamentos com independência. ............................................. 194

Figura 64 - São Paulo/Palmeiras-Barra Funda: Mezanino área paga ................................................. 195

Figura 65 - São Paulo/Palmeiras-Barra Funda: Esquema de fluxos............................................... 196

Figura 66 - São Paulo/Palmeiras-Barra Funda: Fluxo junto aos bloqueios da passarela.................... 197

Figura 67 - São Paulo/Palmeiras-Barra Funda: Fluxo junto aos bloqueios de transferência............... 197

Figura 68 - São Paulo/Palmeiras-Barra Funda: Fluxo junto aos bloqueios de transferência............... 198

Figura 69 - São Paulo/Palmeiras-Barra Funda: Fluxos e deslocamento com independência............. 199

Figura 70 - São Paulo/Palmeiras-Barra Funda: Fluxos e deslocamentos com auxílio. ....................... 199

Figura 71 - São Paulo/Palmeiras-Barra Funda: Embarque e deslocamento com auxílio. .................. 200

Figura 72 - São Paulo/Palmeiras-Barra Funda: Conexão e deslocamento com auxílio....................... 200

Figura 73 - São Paulo/Sacomã: Mezanino área paga...................................................................... 201

Figura 74 - São Paulo/Sacomã: Esquema de Fluxos. ................................................................... 201

Figura 76 - São Paulo/Sacomã: Fluxo junto ao bloqueio do mezanino da área paga. ......................... 202

Figura 76 - São Paulo/Sacomã: Fluxos e deslocamento com auxílio.............................................. 204

Figura 77 - São Paulo/Tamanduateí: Mezanino da área paga........................................................... 205

Figura 78 - São Paulo/Tamanduateí: Elementos de circulação vertical - embarque Vila Madalena. 206

Figura 79 - São Paulo/Tamanduateí: Fluxo de embarque na linha de bloqueios da passarela. .......... 206

Figura 80 - São Paulo/Tamanduateí: Fluxo de transferência do trem metropolitano para o Metrô.... 207

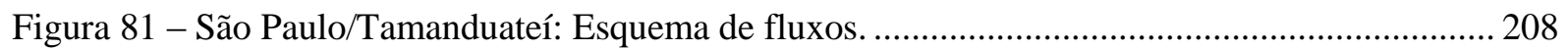

Figura 82 - Reconhecimento e utilização da escada rolante......................................................... 212

Figura 83 - Reconhecimento do percurso de embarque.................................................................. 212

Figura 84 - Reconhecimento do dimensionamento e da configuração externa do trem. .................... 212

Figura 85 - Reconhecimento do dimensionamento e da configuração interna do trem..................... 212

Figura 86 - Barcelona - Sinalização tátil até o local de embarque preferencial nas estações antigas. 214

Figura 87 - Barcelona - Sinalização tátil até o embarque preferencial - estações modernizadas. ..... 215

Figura 88 - Barcelona - Sinalização tátil até o embarque preferencial - estações automáticas......... 215

Figura 89 - Barcelona - Centro de Controle do Metrô de Barcelona. ................................................. 215 
Figura 90 - Madri - Adaptação e sinalização tátil do local de embarque preferencial nas estações antigas.

Figura 91 - Madri - Configuração e sinalização tátil do local de embarque preferencial nas estações acessíveis

Figura 92 - Madri - Interface trem-estação no local de embarque preferencial...................................217

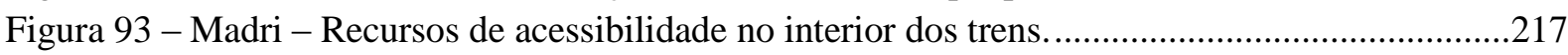

Figura 94 - Londres - Plataforma das estações antigas.................................................................218

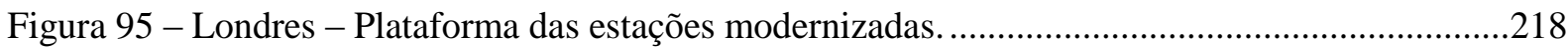

Figura 96 - Londres - Plataforma das estações acessíveis. .............................................................219

Figura 97 - Paris/estação Bastille - Portas de plataforma das estações modernizadas.........................220

Figura 98 - Paris/estação Concorde - Portas de plataforma das estações modernizadas. ....................221

Figura 99 - Paris - Sinalização integrada (tátil e sonora) do mezanino da estação..............................221

Figura 100 - Tóquio - Sinalização do mezanino da estação. ..........................................................222

Figura 101 - Tóquio - Sinalização da plataforma da estação em curva. .............................................223

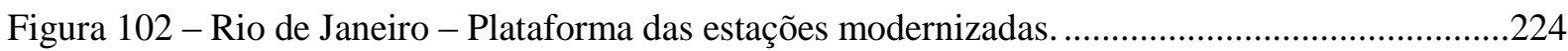

Figura 103 - Rio de Janeiro - Plataforma das estações acessíveis. …................................................224

Figura 104 - Rio de Janeiro - Sinalização de embarque e desembarque a partir da plataforma e do

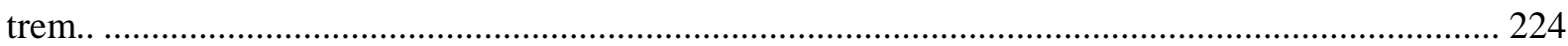

Figura 105 - Rio de Janeiro - Sinalização de segurança nas escadas fixas......................................225

Figura 106 - Rio de Janeiro - Sinalização tátil no piso para conjunto de equipamentos de circulação

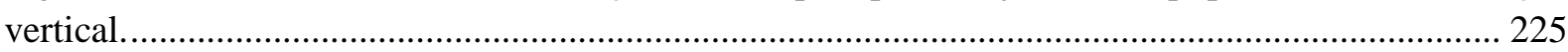

Figura 107 - Londres - Mapa da rede - fonte ampliada, versões colorida e preto e branco. ...............233

Figura 108 - Londres - Mapa, gabarito e detalhes do vão e do desnível em cada estação...................233

Figura 109 - Brasília - Mapa tátil da rede de transporte metroviário....................................................234

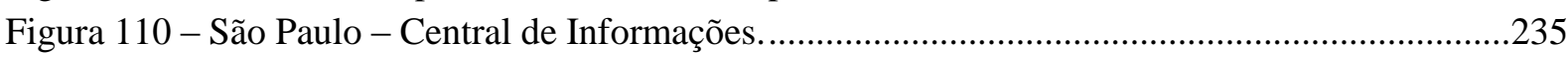

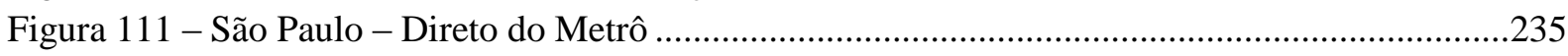

Figura 112 - São Paulo - Simulador de trajeto - tela do sítio eletrônico do Metrô de São Paulo...... 235

Figura 113 - São Paulo - Mapa do Transporte Metropolitano - Condições de acessibilidade das

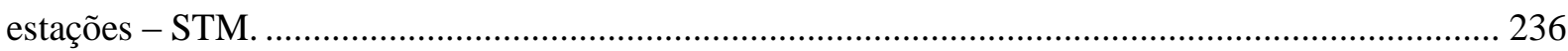

Figura 114 - São Paulo - Mapa do Transporte Metropolitano - Condições de acessibilidade das

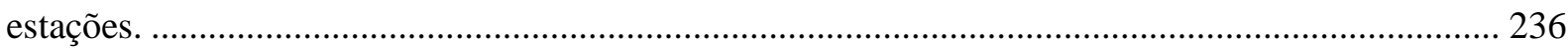

Figura 115 - Madri - Sinalização tátil direcional entre o ponto de parada de ônibus e o acesso da

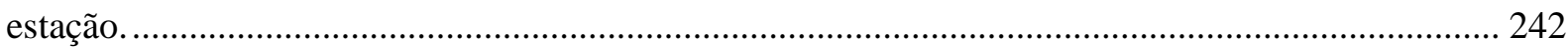

Figura 116 - Madri - Aspecto visual e sinalização dos acessos das estações .....................................242

Figura 117 - Hong Kong - Aspecto visual e piso tátil nos acessos das estações. ................................243

Figura 118 - Hong Kong - Mapa tátil nos acessos das estações. ......................................................243

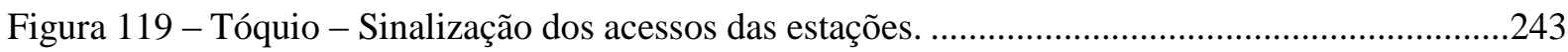

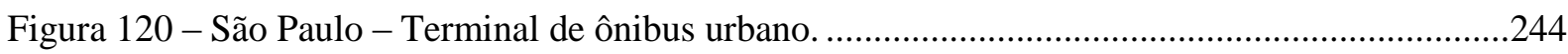

Figura 121 - São Paulo - Ponto de parada no passeio público.......................................................245

Figura 122 - São Paulo - Distância entre os terminais de ônibus urbanos e o mezanino.......................247

Figura 123- São Paulo - Distância entre o acesso e o mezanino........................................................247

Figura 124 - São Paulo - Contraste tátil e visual entre o piso tátil e o piso intertravado ou com o

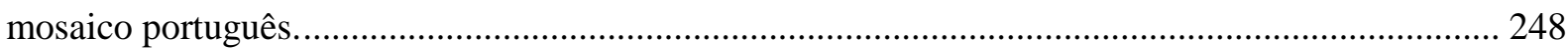

Figura 125 - Paris - Acesso das estações de trem operadas pela SNCF. ……..................................252

Figura 126 - Rio de Janeiro - Configuração dos acessos e detalhe do mapa tátil da estação............. 252

Figura 127 - Rio de Janeiro - Configuração dos acessos e detalhe do mapa tátil da estação.............. 253 
Figura 128 - São Paulo - Acessos das estações localizados no passeio público e no alinhamento do lote. 254

Figura 129 - São Paulo - Vista geral do acesso nos períodos diurno e noturno.................................. 254

Figura 130 - São Paulo - Dimensionamento dos corredores de acesso............................................ 256

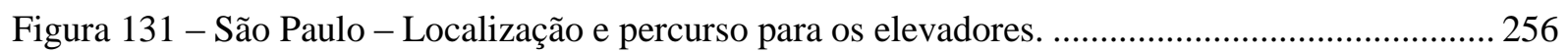

Figura 132 - São Paulo - Percurso em curvas em substituição aos percursos ortogonais. .................. 257

Figura 133 - São Paulo - Excesso de sinalização nos acessos.......................................................... 257

Figura 134 - São Paulo - Escadas fixas como único recurso de circulação vertical no acesso........... 261

Figura 135 - Paris - Sinalização tátil complementada por sinalização visual indicativa da sua

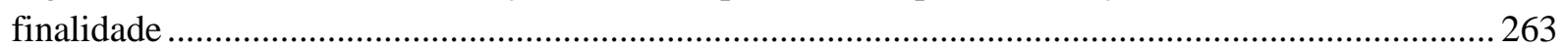

Figura 136 - Paris - Sistema de informação tátil e sonora dos percursos............................................ 264

Figura 137 - Paris - Sinalização tátil associada à informação sonora. ................................................ 264

Figura 138 - Madri - Contraste dos elementos de acabamento e sinalização tátil do percurso........... 264

Figura 139 - Rio de Janeiro - Mapa e sinalização tátil direcional no piso indicando diferentes

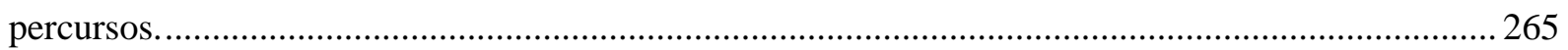

Figura 140 - São Paulo - Áreas de circulação no mezanino - área livre............................................ 266

Figura 141 - São Paulo - Localização do piso tátil direcional no eixo dos corredores de acesso atende

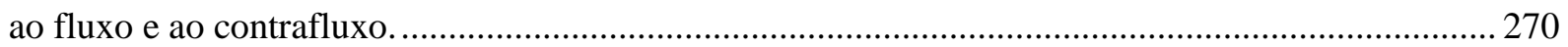

Figura 142 - São Paulo - Falta de contraste tátil em estações com piso emborrachado..................... 271

Figura 143 - Barcelona - Máquinas de autoatendimento para aquisição de bilhetes. ......................... 276

Figura 144 - Madri - Máquinas de autoatendimento para aquisição de bilhetes................................. 276

Figura 145 - Rio de Janeiro - Máquinas de autoatendimento para aquisição de bilhetes. .................. 276

Figura 146 - São Paulo - Sinalização e configuração das bilheterias terceirizadas e dos equipamentos

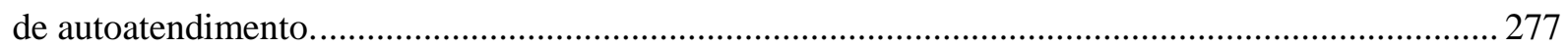

Figura 147 - São Paulo - Sinalização e configuração das bilheterias Metrô....................................... 278

Figura 148 - Madri - Equipamentos de controle de acesso e dispositivo para auxílio........................ 281

Figura 149 - São Paulo - Equipamentos de controle de acesso com torniquetes. .............................. 282

Figura 150 - São Paulo - Equipamentos de controle de acesso com portas de vidro. ......................... 282

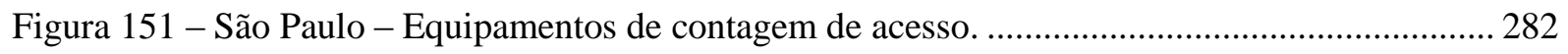

Figura 152 - Elementos de controle de acesso.............................................................................. 284

Figura 153 - Madri - Contraste visual e sinalização tátil direcional indicativa do percurso de

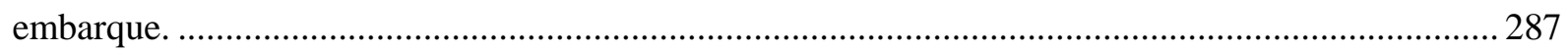

Figura 154 - Hong Kong - Mapa tátil/sonoro indicativo da configuração da estação........................ 287

Figura 155 - Rio de Janeiro - Mapa e sinalização tátil direcional do percurso de embarque.............. 288

Figura 156 - São Paulo - Circulação no mezanino - área paga......................................................... 288

Figura 157 - São Paulo - Circulação no mezanino - estratégias para organizar fluxos. ..................... 289

Figura 158 - São Paulo - Sinalização de embarque do mezanino para plataforma lateral. ................ 289

Figura 159 - São Paulo - Sinalização de embarque do mezanino para plataforma central. ................ 289

Figura 160 - São Paulo - Proximidade entre o piso tátil direcional e a linha de bloqueios................. 292

Figura 161 - São Paulo - Sinalização tátil direcional instalada para fluxos simultâneos de embarque e

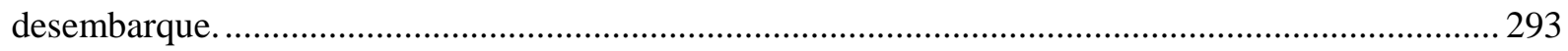

Figura 162 - São Paulo - Lotação, conflitos e cruzamentos de fluxo no mezanino. ........................... 293

Figura 163 - São Paulo - Elevador associado às escadas fixas e rolantes para acesso à plataforma.. 293

Figura 164 - São Paulo - Sinalização de alerta insuficiente em fechamentos de vidro....................... 295

Figura 165 - São Paulo - Inexistência de escadas rolantes na plataforma da Linha 2 - Verde.......... 300

Figura 166 - São Paulo - elevador e escadas fixas e rolantes no centro da plataforma ....................... 301 
Figura 167 - Barcelona - Sinalização do percurso nas plataformas central e lateral, com e sem porta de

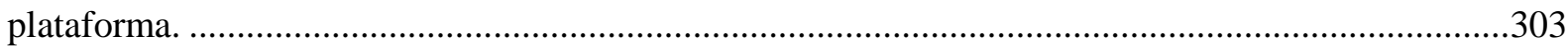

Figura 168 - Tóquio - Sinalização da plataforma central...............................................................304

Figura 169 - São Paulo - Plataformas centrais (a, b) e mistas (c) ......................................................304

Figura 170 - São Paulo - Vista geral e sinalização da plataforma central.............................................305

Figura 171 - São Paulo - Vista geral e sinalização da plataforma lateral. .............................................305

Figura 172 - São Paulo - Vista geral e sinalização da plataforma mista.............................................305

Figura 173 - São Paulo - Largura insuficiente e lotação das plataformas.............................................308

Figura 174 - São Paulo - Porta de proteção na plataforma lateral. ....................................................309

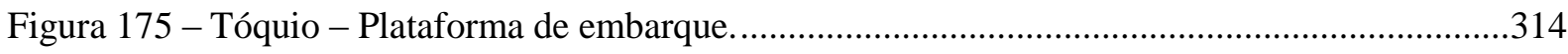

Figura 176 - Barcelona - Sinalização do local de embarque preferencial em plataformas mista e

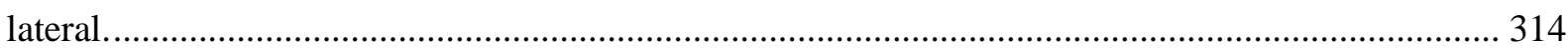

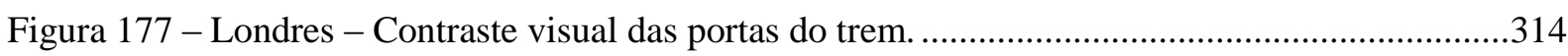

Figura 178 - Madri - Piso tátil com sinalização fotoluminescente e borda antiderrapante na

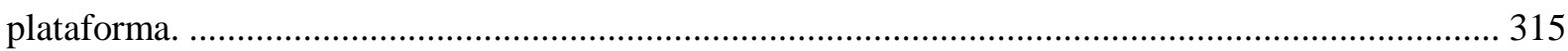

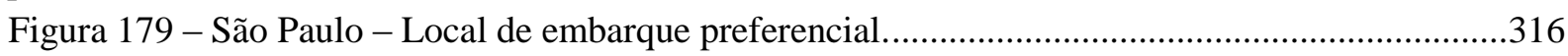

Figura 180 - São Paulo - Local de embarque preferencial.................................................................319

Figura 181 - São Paulo - Permanência indevida dos demais usuários no local de embarque

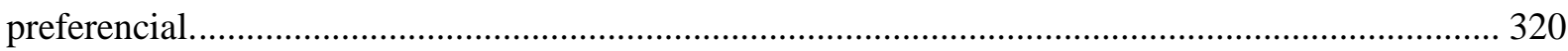

Figura 182 - Madri - Dispositivo para reduzir o vão e desnível entre o trem e a plataforma. .............323

Figura 183 - Régua para medir o vão e o desnível entre o trem e a plataforma. ...................................324

Figura 184 - São Paulo - CPTM - Estribo para eliminação do vão entre o trem e a plataforma.........324

Figura 185 - Madri - Rampa para eliminação do desnível entre o trem e a plataforma.......................324

Figura 186 - Londres - Eliminação do desnível entre o trem e a plataforma.......................................325

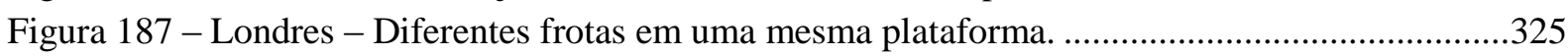

Figura 188 - Tóquio - Sinalização do vão entre o trem e a plataforma...............................................325

Figura 189 - Hong Kong - Barras horizontais entre carros nas frotas antigas. ..................................325

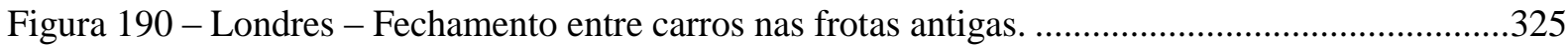

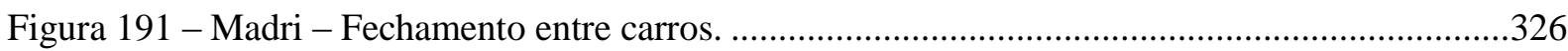

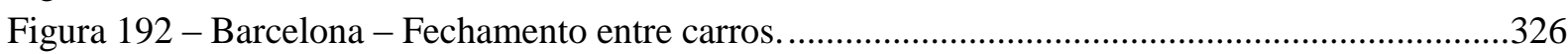

Figura 193 - São Paulo - Vão e desnível entre o trem e a plataforma. .................................................327

Figura 194 - São Paulo - Monitoração do deslocamento de embarque pelo atendente. .......................330

Figura 195 - São Paulo - Monitoração do deslocamento pelo CCO e pela SSO .................................330

Figura 196 - Barcelona - Localização e sinalização do assento preferencial........................................335

Figura 197 - Madri - Configuração e sinalização do assento preferencial para pessoas com cão-guia

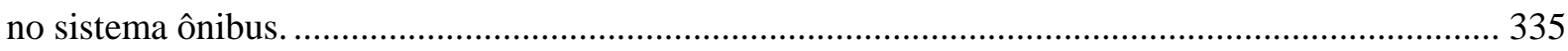

Figura 198 - São Paulo - Configuração da barra de apoio junto às portas em diferentes frotas. ..........336

Figura 199 - São Paulo - Acomodação do cão-guia sob o assento do trem......................................336

Figura 200 - Madri - Contraste visual das barras de apoio verticais e altura livre dos assentos para

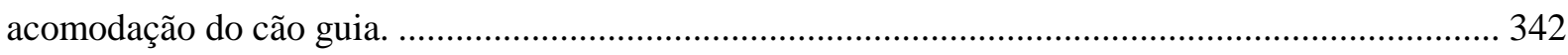

Figura 201 - Londres - Contraste tátil e visual do piso no interior dos trens, junto às portas..............342

Figura 202 - São Paulo - Configuração das barras de apoio e balaústres nas diferentes frotas...........343

Figura 203 - Madri - Dispositivo no trem para reduzir vão e desnível entre o trem e a plataforma...350

Figura 204 - Londres - Símbolo de identificação na plataforma da estação........................................350

Figura 205 - São Paulo - Sinalização do local de parada e dos vãos e desníveis entre o trem e a

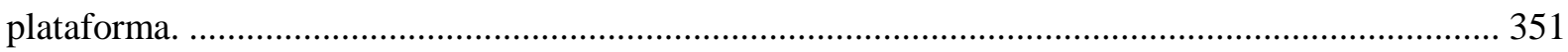

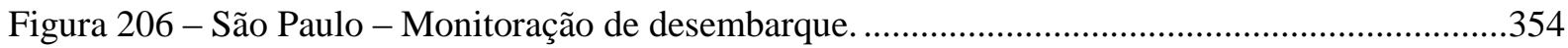


Figura 207 - São Paulo - Monitoração de embarque e desembarque simultâneos............................... 354

Figura 208 - São Paulo - Monitoração de desembarque em estação com porta de plataforma........... 354

Figura 209 - São Paulo - Deslocamento com independência em estação com porta de plataforma. . 354

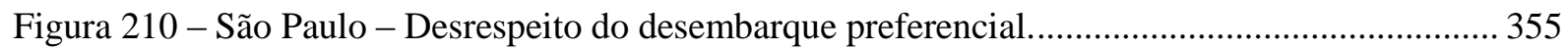

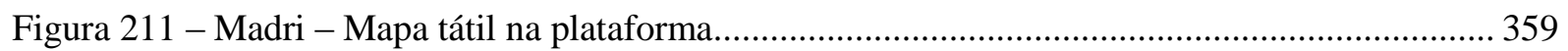

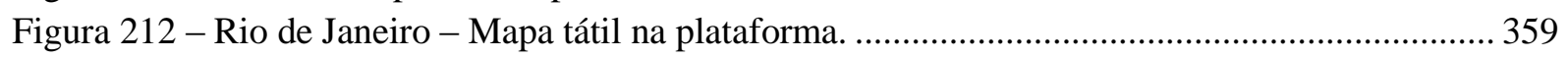

Figura 213 - Londres, Barcelona e Madri - Intercomunicadores nas plataformas. ............................. 360

Figura 214 - São Paulo - Sinalização tátil das plataformas no percurso entre o local de desembarque e

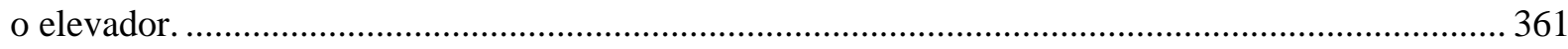

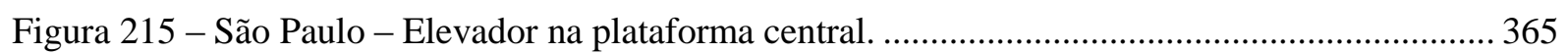

Figura 216 - São Paulo - Local de desembarque próximo à escada rolante......................................... 365

Figura 217 - São Paulo - Lotação, obstáculos e conflitos de fluxo na plataforma.............................. 365

Figura 218 - São Paulo - Falta de contraste de cores entre piso e pilares. Destaque da cor dos painéis e

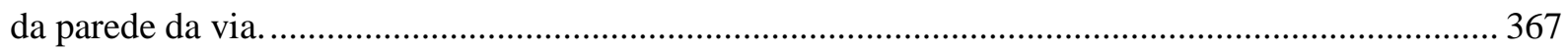

Figura 219 - Madri - Contraste visual e sinalização tátil direcional indicativa do percurso de saída.374 Figura 220 - Rio de Janeiro - Mapa e sinalização tátil direcional indicativa do percurso de

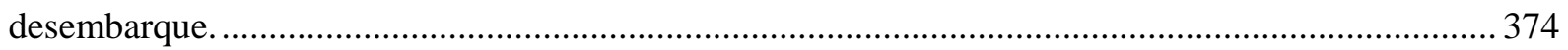

Figura 221 - São Paulo - Sinalização tátil no percurso entre o elevador e os equipamentos de controle

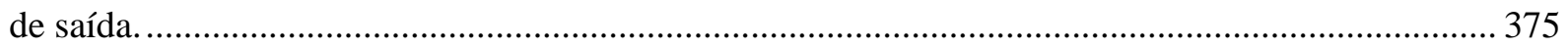

Figura 222 - São Paulo - Elementos orientadores de fluxo colocados sobre o piso tátil. ................... 377

Figura 223 - Madri - Sinalização suspensa sobre os equipamentos de controle de saída. .................. 382

Figura 224 - Barcelona - Sinalização suspensa sobre os equipamentos de uso preferencial. ............. 382

Figura 225 - São Paulo - Sinalização visual (suspensa e no equipamento) e tátil indicativa do percurso

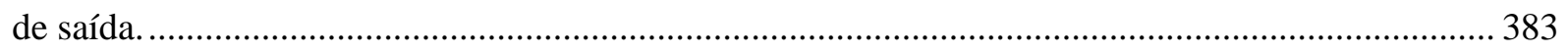

Figura 226 - São Paulo - Sinalização visual (suspensa e no equipamento) e tátil indicativa do percurso

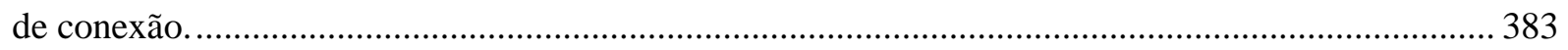

Figura 227 - São Paulo - Elementos de controle de saída (a) ou de transferência (b,c)..................... 384

Figura 228 - Hong Kong - Piso tátil direcional com cores contrastantes........................................... 387

Figura 229 - Rio de Janeiro - Mapa tátil indicativo das ruas do entorno das estações........................ 387

Figura 230 - São Paulo - Sinalização tátil e visual indicativa do percurso de saída. ........................... 388

Figura 231 - São Paulo - Sinalização de alerta nos espelhos dos degraus. ........................................ 397

Figura 232 - Barcelona - Urbanização no entorno dos acessos em áreas consolidadas...................... 399

Figura 233 - Madri - Urbanização no entorno dos acessos - expansão da rede................................. 399

Figura 234 - São Paulo - Urbanização no entorno dos acessos das estações. ...................................... 400

Figura 235 - Jaú - Dispositivo de comunicação entre motorista e usuário de ônibus. ......................... 405

Figura 236 - São Paulo - Pontos de parada de ônibus nas calçadas. ................................................ 405

Figura 237 - São Paulo - Pontos de parada de ônibus nos terminais urbanos...................................... 406

Figura 238 - São Paulo - Complexidade e distância entre o mezanino e os terminais de ônibus urbanos

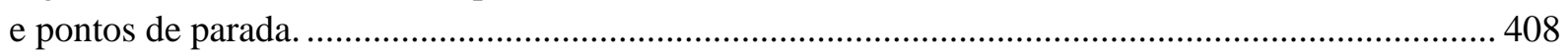

Figura 239 - São Paulo - distância entre o mezanino e o acesso.......................................................... 408

Figura 240 - São Paulo - inexistência de acesso do outro lado da rua. .............................................. 409

Figura 241 - São Paulo - Quiosques e mobiliário sobre o piso tátil................................................... 409

Figura 242 - Paris - Consulta pública às pessoas com deficiência para avaliação dos protótipos de

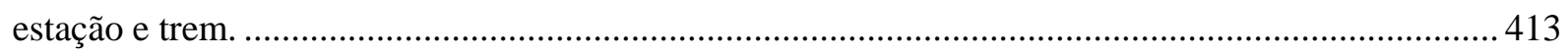

Figura 243 - Londres - Consulta pública às pessoas com deficiência................................................ 414

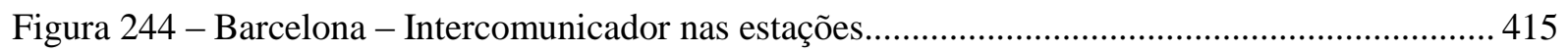

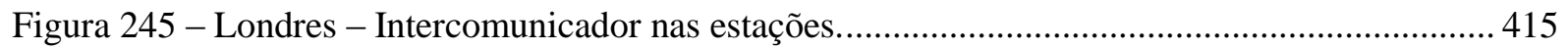


Figura 246 - Rio de Janeiro - Intercomunicador nas estações.

Figura 247 - São Paulo - Visita técnica às estações juntamente com pessoas com deficiência..........416

Figura 249 - São Paulo - Avaliação do piso tátil pelas pessoas com deficiência visual....................417

Figura 250 - São Paulo - Meios de comunicação disponibilizados nas estações..............................418

Figura 251 - São Paulo - Usuários aguardam a chegada de auxílio para desembarque....................421

Figura 252 - Madri - Acesso com escadas fixas, escadas rolantes e elevadores integrados. .............424

Figura 253 - Londres - Rampa com corrimão lateral em cor contrastante em relação à parede.........424

Figura 254 - Porto Alegre - Sinalização de fluxo em rampa de acesso/saída.................................424

Figura 255 - Tóquio - Escada fixa - corrimão duplo, sinalização visual e tátil..............................425

Figura 256 - Londres - Escada fixa - corrimão em cor contrastante, sinalização tátil. .....................425

Figura 257 - Madri - Suporte com contraste visual e sinalização tátil no corrimão. ........................425

Figura 258 - Paris - Sinalização tátil no corrimão. .................................................................425

Figura 259 - Hong Kong - Barreira de segurança e indicação do sentido de deslocamento da escada

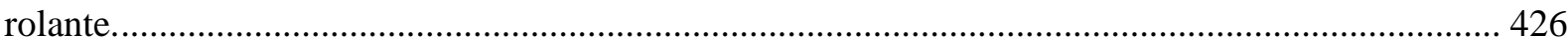

Figura 260 - Barcelona - Escada rolante iluminada...............................................................426

Figura 261 - Madri - Escada rolante em cor contrastante........................................................426

Figura 262 - Rio de Janeiro - Piso tátil para escada rolante......................................................426

Figura 263 - Londres - Contraste visual no elevador e esquema gráfico indicativo dos percursos....427

Figura 264 - Hong Kong - Botoeiras indicativas dos diferentes pavimentos. .................................427

Figura 265 - Madri - Botoeiras em cor contrastante indicativas dos diferentes pavimentos. ............427

Figura 266 - Barcelona - Botoeiras indicativas das linhas nas estações de integração.....................427

Figura 267 - São Paulo - Mezanino com escadas fixas, escadas rolantes e elevadores integrados. ...429

Figura 268 - São Paulo - Rampa com corrimãos lateral e central e sinalização tátil no piso. ...........429

Figura 269 - São Paulo - Escada fixa com corrimão lateral e central, além de sinalização visual e tátil

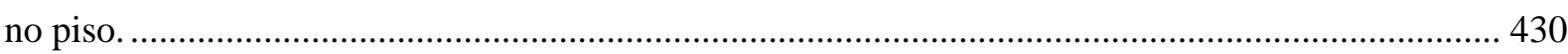

Figura 270 - São Paulo - Escada rolante com sinalização tátil de alerta e sinalização visual indicativa do sentido de deslocamento............................................................................................... 431

Figura 271 - São Paulo - Escada rolante - elementos de apoio ou reforço de sinalização. ................431

Figura 272 - São Paulo - Sinalização externa e interna dos elevadores..........................................431

Figura 273 - São Paulo - Sinalização externa e interna das plataformas de elevação. .......................432

Figura 274 - São Paulo - Sinalização visual de alerta nos espelhos dos degraus..............................437 


\section{LISTA DE GRÁFICOS}

Gráfico 1 - Aspectos avaliados pelos sistemas metroferroviários nacionais.......................................73

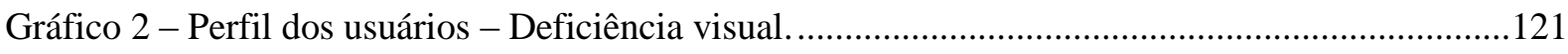

Gráfico 3 - Perfil dos usuários - Participação em treinamento de orientação e mobilidade. ...............121

Gráfico 4 - Perfil dos usuários - Frequência de uso do sistema metroviário ao longo da semana......121

Gráfico 5 - Perfil dos usuários - Busca por informações sobre trajeto ou funcionamento. .................122

Gráfico 6 - Perfil dos usuários - Autonomia nos deslocamentos na cidade.......................................122

Gráfico 7 - Perfil dos usuários - Autonomia nos deslocamentos no metrô..........................................122

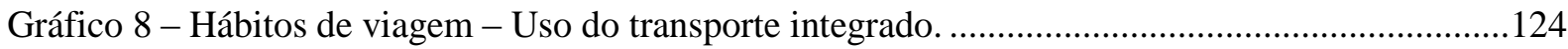

Gráfico 9 - Condições de acessibilidade das estações - todos os respondentes..................................124

Gráfico 10 - Condições de acessibilidade das estações - segundo treinamento de O\&M. .................125

Gráfico 11 - Atendimento às necessidades da pessoa com deficiência visual.....................................126

Gráfico 12 - Atendimento às necessidades da pessoa com deficiência visual - segundo treinamento de

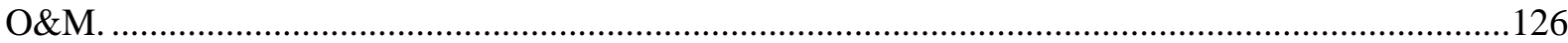

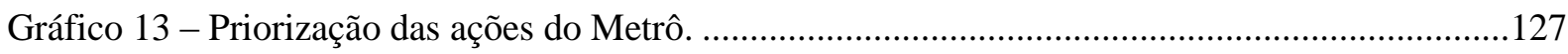

Gráfico 14 - Aspectos que interferem no deslocamento das pessoas com deficiência visual. .............127

Gráfico 15 - Aspectos que interferem no deslocamento das pessoas cegas e com baixa visão............128

Gráfico 16 - Motivos para auxílio às pessoas com deficiência visual...............................................150

Gráfico 17 - Dificuldades enfrentadas pelos estagiários durante a prestação do auxílio......................151

Gráfico 18 - Origem das manifestações recebidas no período de 2007-2013 ....................................155

Gráfico 19 - Reclamações, elogios e solicitações recebidos no período de 2007-2013 ......................155

Gráfico 20 - Classificação das ideias centrais identificadas nas manifestações dos usuários. .............156

Gráfico 21 - Classificação das ideias centrais identificadas nas manifestações dos usuários. ............156

Gráfico 22 - Manifestações recebidas sobre o tema serviço na estação (2007-2013) .........................157

Gráfico 23 - Fonte de informação para o planejamento do deslocamento. ...........................................237

Gráfico 24 - Avaliação da etapa 1 - Planejamento do deslocamento pelos usuários ............................238

Gráfico 25 - Avaliação da etapa 2 - Desembarque do sistema integrado. ...........................................246

Gráfico 26 - Avaliação da etapa 5 - Deslocamento no mezanino - área livre.......................................268

Gráfico 27 - Avaliação da etapa 8 - Deslocamento no mezanino - área paga.....................................291

Gráfico 28 - Avaliação da etapa 10 - Deslocamento até o local de embarque......................................306

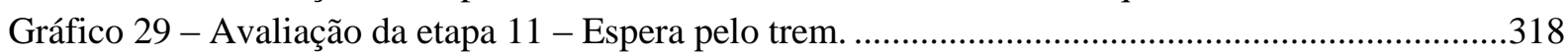

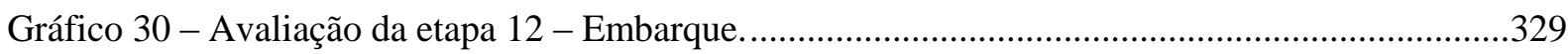

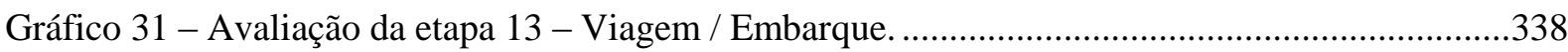

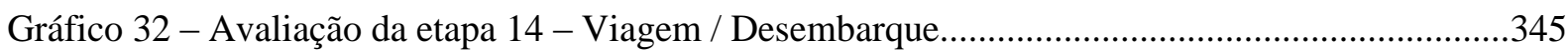

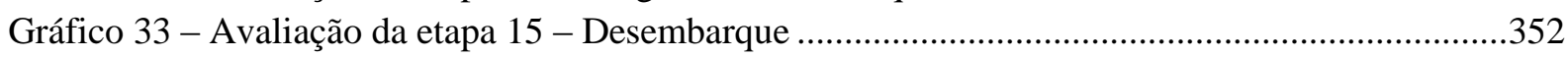

Gráfico 34 - Avaliação da etapa 16 - Deslocamento até a saída da plataforma...................................363

Gráfico 35 - Avaliação da etapa 18 - Deslocamento no mezanino - área paga....................................376

Gráfico 36 - Avaliação da etapa 20 - Deslocamento no mezanino - área livre. ...................................390

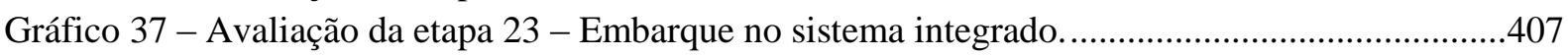

Gráfico 38 - Avaliação do piso tátil pelas pessoas com deficiência visual. ........................................417

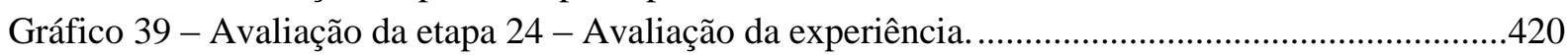

Gráfico 40 - Avaliação da circulação vertical - sem especificar o local............................................434

Gráfico 41 - Avaliação do deslocamento horizontal na estação - sem especificar o local. .................443

Gráfico 42 - Aspectos críticos apontados pelos usuários com deficiência visual. ................................451

Gráfico 43 - Avaliação das etapas da jornada do usuário pelas pessoas com deficiência visual. ........452

Gráfico 44 - Grau de criticidade das ideias centrais segundo as pessoas com deficiência visual. .......453 
xviii 


\section{LISTA DE QUADROS}

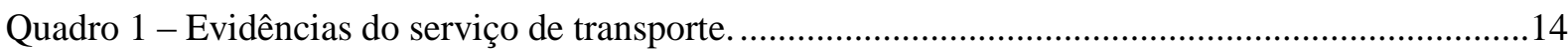

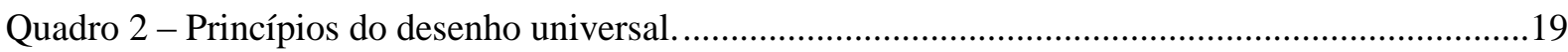

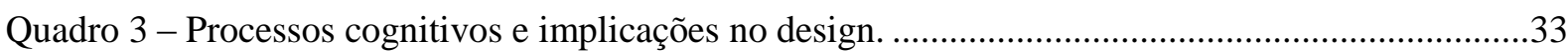

Quadro 4 - Manipulações espacial-cognitivas fundamentais para encontrar caminhos. ........................36

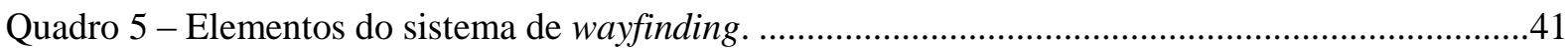

Quadro 6 - Estratégias de wayfinding utilizadas por videntes e pessoas com deficiência visual..........44

Quadro 7 - Requisitos de desempenho relacionados à acessibilidade em estações e trens. ...................70

Quadro 8 - São Paulo - Quantidade de estações/linhas, segundo a posição e a configuração das

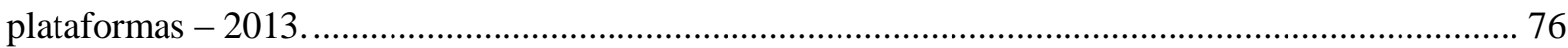

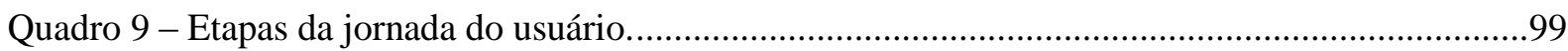

Quadro 10 - Temas abordados no questionário "modelo 2"............................................................119

Quadro 11 - Classificação das ideias centrais identificadas nas questões abertas..............................130

Quadro 12 - Classificação das ideias centrais relacionadas à configuração. .......................................130

Quadro 13 - Classificação das ideias centrais relacionadas ao sistema de informação, comunicação e

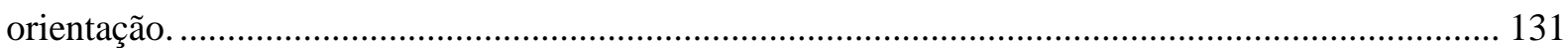

Quadro 14 - Classificação das ideias centrais relacionadas à gestão e prestação do serviço. .............131

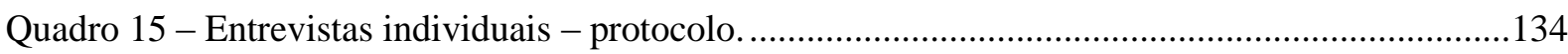

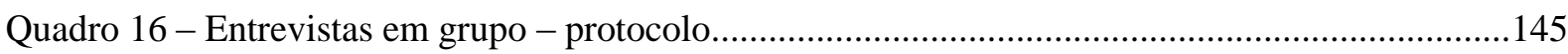

Quadro 17 - Realização de walkthrough em estações com diferentes tipologias................................159

Quadro 18 - Atividades de campo - Observações..........................................................................172

Quadro 19 - Deslocamentos e trajetos realizados na estação Ana Rosa.............................................193

Quadro 20 - Deslocamentos e trajetos realizados na estação Palmeiras-Barra Funda. ........................199

Quadro 21 - Deslocamentos e trajetos realizados na estação Ana Rosa..............................................203

Quadro 22 - Deslocamentos e trajetos realizados na estação Tamanduateí. ......................................209

Quadro 23 - Instrumentos aplicados, ambientes, públicos-alvo e objetivos.........................................226

Quadro 24 - Elementos de wayfinding da Etapa 1 - Planejamento do deslocamento...........................240

Quadro 25 - Elementos de wayfinding da Etapa 2 - Desembarque do sistema integrado...................249

Quadro 26 - Elemento de wayfinding da Etapa 3 - Acesso à estação. .............................................258

Quadro 27 - Elementos de wayfinding da Etapa 5 - Mezanino - área livre........................................273

Quadro 28 - Elementos de wayfinding da Etapa 6 - Aquisição do bilhete...........................................279

Quadro 29 - Elementos de wayfinding da Etapa 7 - Controle de entrada - validação do bilhete.......285

Quadro 30 - Elementos de wayfinding da etapa 8 - Deslocamento no mezanino - área paga............296

Quadro 31 - Elementos de wayfinding da Etapa 10 - Deslocamento até o local de embarque na

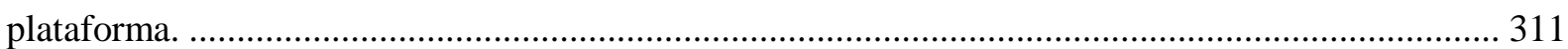

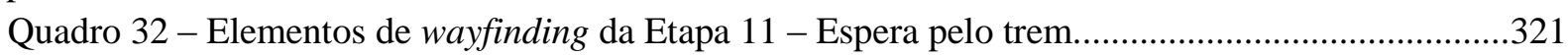

Quadro 33 - Elementos de wayfinding da Etapa 12 - Embarque. .....................................................333

Quadro 34 - Elementos de wayfinding da Etapa 13 - Viagem / embarque........................................340

Quadro 35 - Elementos de wayfinding da Etapa 14 - Viagem/desembarque......................................347

Quadro 36 - Elementos de wayfinding da Etapa 15 - Desembarque...................................................356

Quadro 37 - Elementos de wayfinding da Etapa 16 - Deslocamento até a saída da plataforma..........368

Quadro 38 - Elementos de wayfinding da Etapa 18 - Deslocamento no mezanino - área paga..........379

Quadro 39 - Elementos de wayfinding da Etapa 19 - Controle de saída.............................................385

Quadro 40 - Elementos de wayfinding da Etapa 20 - Deslocamento no mezanino - área livre. .........393

Quadro 41 - Elementos de wayfinding da Etapa 22 - Saída da estação - área externa........................403

Quadro 42 - Elementos de wayfinding da Etapa 23 - Embarque no sistema integrado. ......................411 
Quadro 43 - Elementos de wayfinding da Etapa 24 - Avaliação da experiência................................ 422

Quadro 44 - Elementos de wayfinding da Etapa 30 - Circulação vertical........................................... 439

Quadro 45 - Elementos de wayfinding da Etapa 40 - Circulação horizontal. ..................................... 447

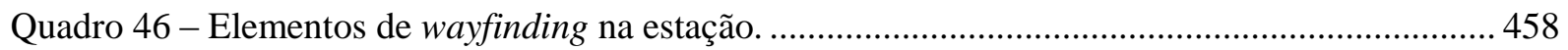

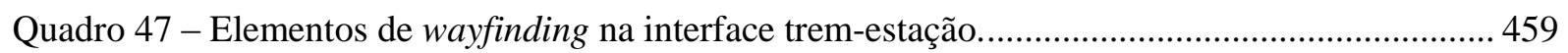

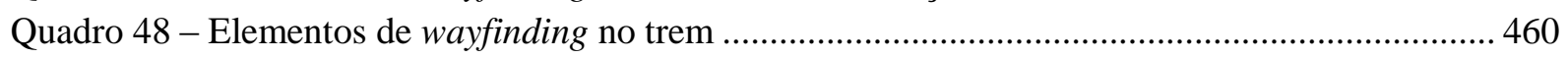

Quadro 49 - Requisitos para incorporação nas normas técnicas vigentes. ......................................... 476 


\section{LISTA DE TABELA}

Tabela 1 - Composição da população com deficiência visual segundo faixa etária (em \%). .32

Tabela 2 - São Paulo - Quantidade de estações segundo a conexão com outros modos de transporte/ empreendimentos -2013.

Tabela 3 - São Paulo - Quantidade de estações segundo a demanda - 2013 .......................................77

Tabela 4 - São Paulo - Quantidade de equipamentos típicos de estações -2013 ................................78

Tabela 5 - São Paulo - Quantidade de estações segundo os equipamentos das plataformas. ................79

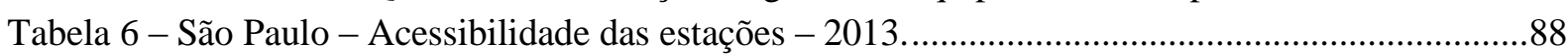

Tabela 7 - Monitoramentos solicitados no período 2006-2013 _............................................................95

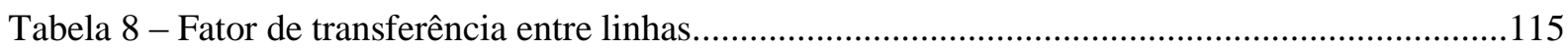

Tabela 9 - Frequência de uso do sistema metroviário ao longo da semana.........................................116

Tabela 10 - Configuração do carro líder nas diferentes frotas da Linha 1 - Azul ................................167

Tabela 11 - Configuração do carro líder nas diferentes frotas da Linha 3 - Vermelha.........................168

Tabela 12 - Configuração do carro líder nas diferentes frotas das Linhas 2 - Verde e 5 - Lilás........170

Tabela 13 - Características dos trens da frota metroviária. ................................................................171

Tabela 14 - Embarque/desembarque preferencial na estação Ana Rosa............................................178

Tabela 15 - Embarque/desembarque preferencial na estação Palmeiras-Barra Funda.........................182

Tabela 16 - Embarque/desembarque preferencial na estação Sacomã. ...............................................185

Tabela 17 - Embarque/desembarque preferencial na estação Tamanduateí........................................186

Tabela 18 - Matriz de avaliação da etapa 1 - Planejamento do deslocamento.....................................238

Tabela 19 - Matriz de avaliação da etapa 2 - Desembarque do sistema integrado. .............................245

Tabela 20 - Matriz de avaliação da etapa 5 - Deslocamento no mezanino - área livre........................267

Tabela 21 - Matriz de avaliação da etapa 8 - Deslocamento no mezanino - área paga........................290

Tabela 22 - Matriz de avaliação da etapa 10 - Deslocamento até o local de embarque.........................305

Tabela 23 - Matriz de avaliação da etapa 11 - Espera pelo trem. ....................................................317

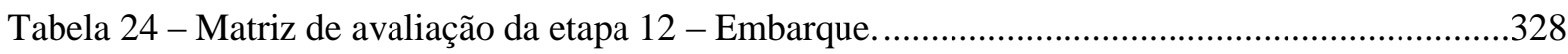

Tabela 25 - Matriz de avaliação da etapa 13 - Viagem / Embarque.....................................................337

Tabela 26 - Matriz de avaliação da etapa 14 - Viagem/Desembarque..................................................344

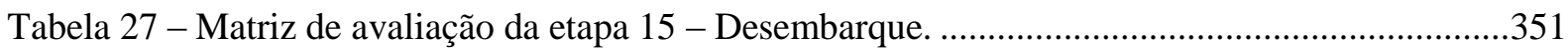

Tabela 28 - Matriz de avaliação da etapa 16 - Deslocamento até a saída da plataforma.....................362

Tabela 29 - Matriz de avaliação da etapa 18 - Deslocamento no mezanino - área paga......................376

Tabela 30 - Matriz de avaliação da etapa 20 - Deslocamento no mezanino - área livre.....................389

Tabela 31 - Matriz de avaliação da etapa 23 - Embarque no sistema integrado...................................406

Tabela 32 - Matriz de avaliação da etapa 24 - Avaliação da experiência...........................................418

Tabela 33 - Matriz de avaliação da etapa 30 - Circulação Vertical - sem especificar o local.............432

Tabela 34 - Matriz de avaliação da etapa 40 - Circulação horizontal na estação - sem especificar o

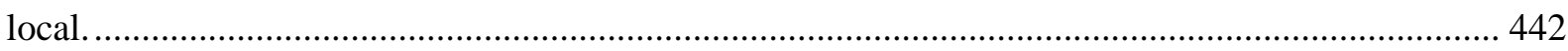

Tabela 35 - Avaliação da acessibilidade pelas pessoas com deficiência visual. ..................................461 
xxii 


\section{LISTA DE SIGLAS}

ABNT Associação Brasileira de Normas Técnicas

AENOR Asociación Espanôla de Normalización y Certificación

ADU Avaliação de Desempenho em Uso

AEAMESP Associação dos Engenheiros e Arquitetos do Metrô de São Paulo

ALAMYS Associación Latinoaericana de Metros y Subterraneos

ANTAC Associação Nacional de Tecnologia do Ambiente Construído

ANTP Associação Nacional de Transportes Públicos

APO Avaliação Pós-Ocupação

CCO Centro de Controle Operacional

CEPAM Centro de Estudos da Administração Municipal

CIF Classificação Internacional de Incapacidade, Funcionalidade e Saúde

CMSP Companhia do Metropolitano de São Paulo

COMET Community of Metros

CPTM Companhia Paulista de Trens Metropolitanos

CTA Canadian Transport Agency

ECMT European Conference of Ministers of Transport

EMTU Empresa Metropolitana de Transportes Urbanos S.A.

ENTAC Encontro Nacional de Tecnologia do Ambiente Construído

FAUUSP Faculdade de Arquitetura e Urbanismo da Universidade de São Paulo

FGC Ferrocarrils de la Generalitat de Catalunya

IBGE Instituto Brasileiro de Geografia e Estatística

IDEA Center for Inclusive Design and EnvironmentalAccess

IMSERSO Instituto de Migraciones y Servicios Sociales

IMTT Instituto da Mobilidade e dos Transportes Terrestres

ISBERG International Suburban Rail Benchmarking Group

LUL London Underground Limited

MEC Ministério da Educação e Cultura

MINTRA Comunidad de Madrid-Consejeria de Infraestructura e Transportes

NOVA Group of Metros

OMS Organização Mundial da Saúde

O\&M Orientação e Mobilidade 


\section{LISTA DE SIGLAS (continuação)}

ONCE Organización Nacional de Ciegos Espanõles

ONU Organização das Nações Unidas

OPAS Organização Panamericana da Saúde

RATP Régie Autonome des Trasnports Parisiens

RMSP Região Metropolitana de São Paulo

RTSC Railway Technology Strategy Center

SNCF Societé Nationale dês Chemins de Fer Français

SPSS Statistical Package for Social Sciences

STM Secretaria de Estado dos Transportes Metropolitanos

TFL Transport for London

TMB Transports Metropolitans de Barcelona

UITP Union Internationale des Transports Publics

UFRJ Universidade Federal do Rio de Janeiro

USP Universidade de São Paulo 


\section{SUMÁRIO}

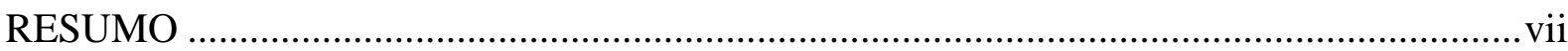

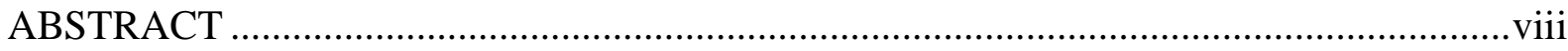

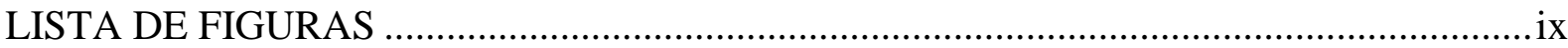

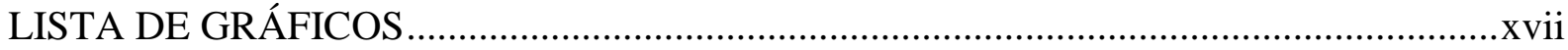

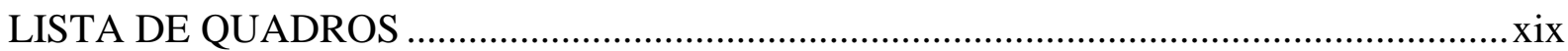

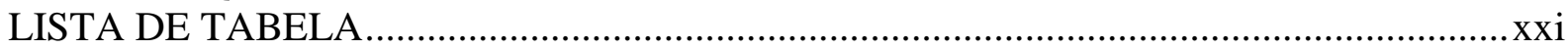

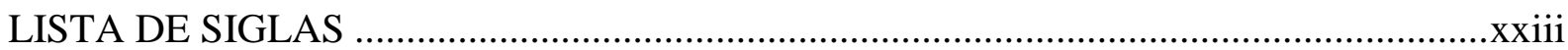

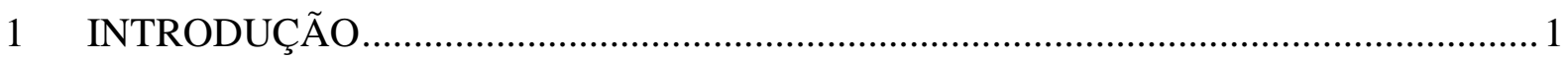

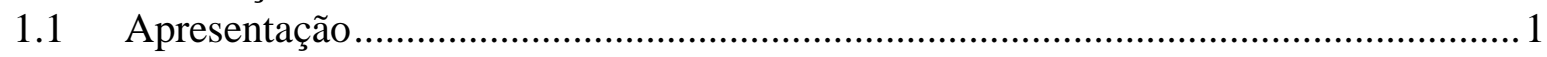

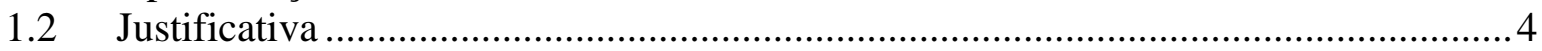

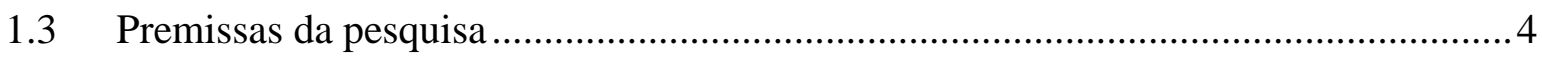

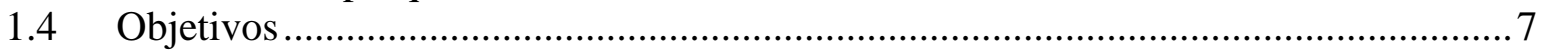

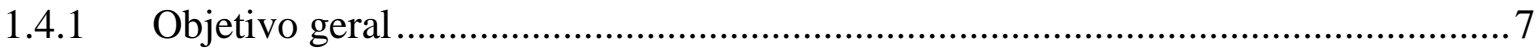

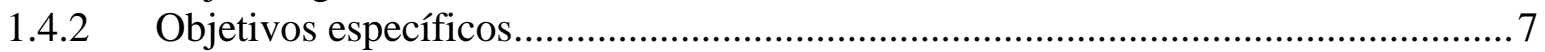

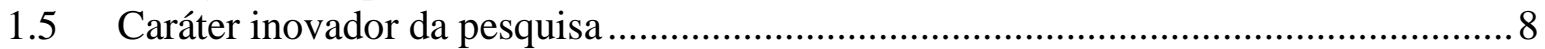

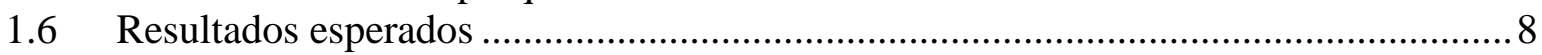

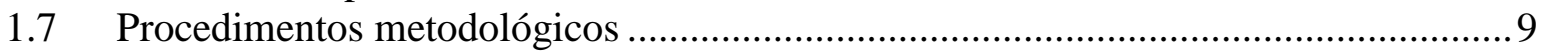

1.8 Estrutura da tese e descrição dos capítulos .......................................................... 11

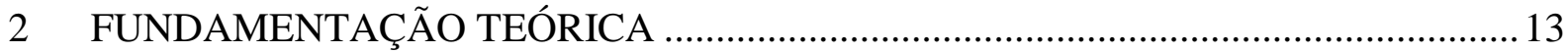

2.1 O design de serviços centrado na jornada do usuário ............................................ 13

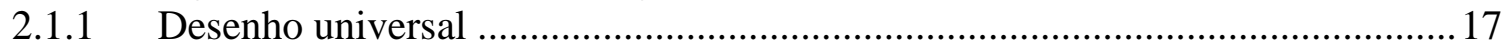

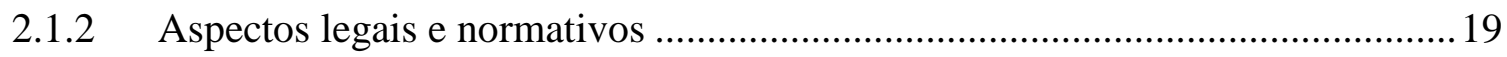

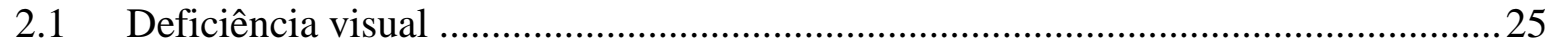

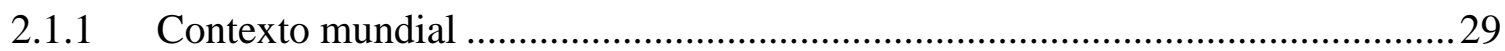

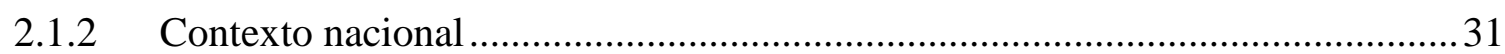

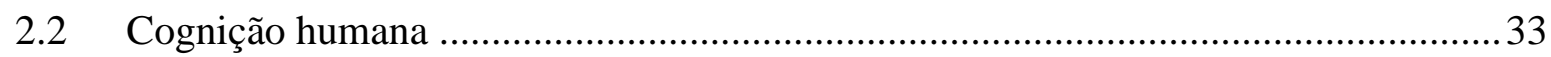

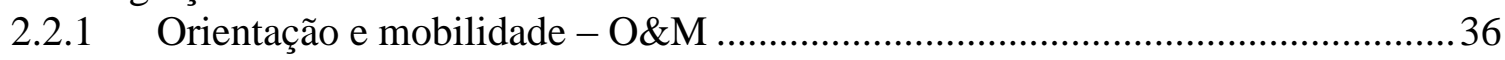

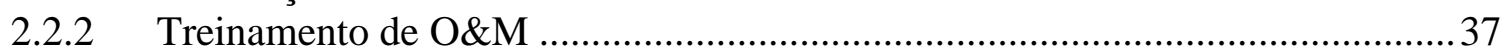

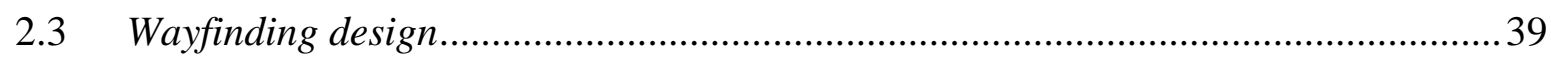

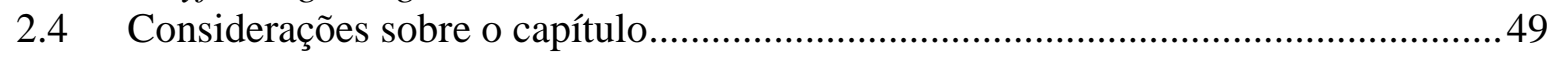

3 O SISTEMA METROFERROVIÁRIO CONTEMPORÂNEO ....................................53

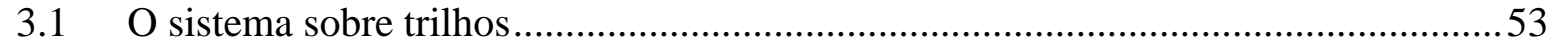

3.2 Os fatores-chave da acessibilidade no sistema metroferroviário ...............................54

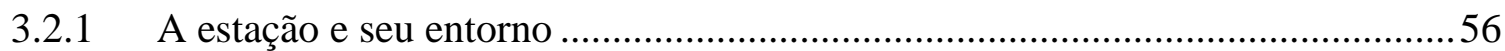

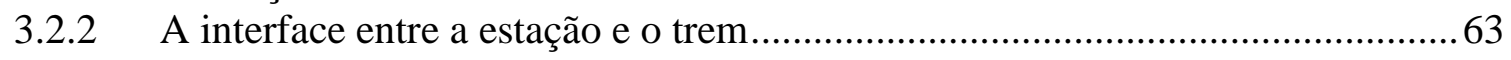

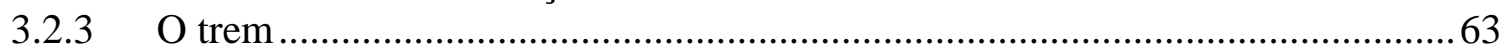

3.2.4 A gestão dos sistemas de informação, comunicação e orientação .......................64

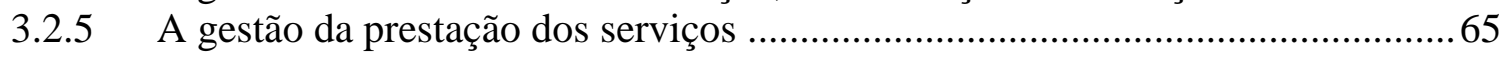

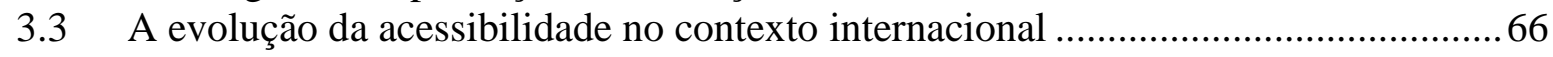

3.4 A rede sobre trilhos na Região Metropolitana de São Paulo .................................... 71

3.5 Os fatores-chave da mobilidade no Metrô de São Paulo ............................................75

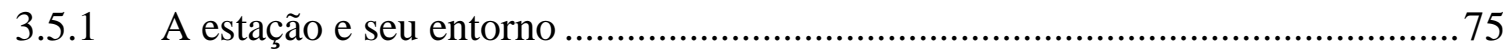

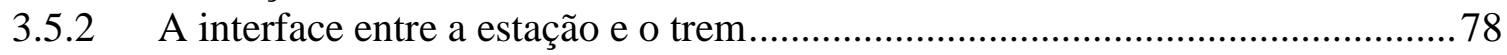




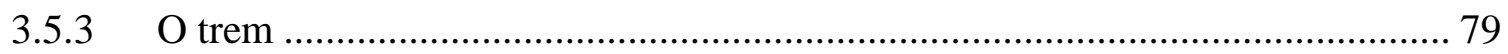

3.5.4 A gestão dos sistemas de informação, comunicação e orientação ....................... 79

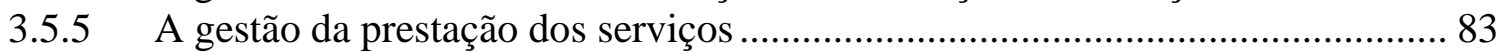

3.6 A evolução da acessibilidade no Metrô de São Paulo................................................ 86

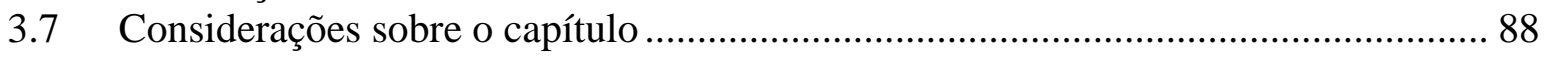

4 DIAGRAMA DE SERVIÇOS DO SISTEMA METROFERROVIÁRIO ...................... 91

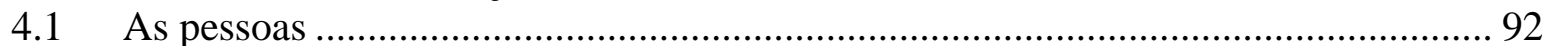

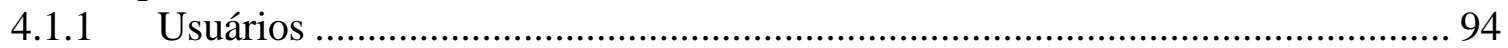

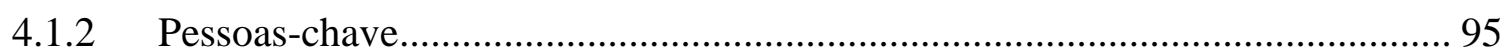

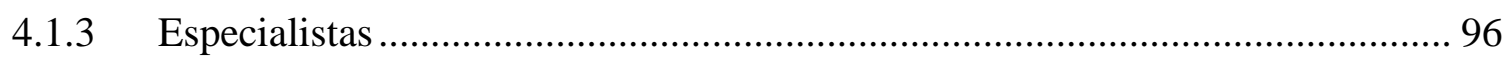

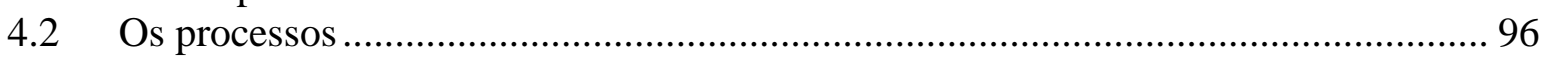

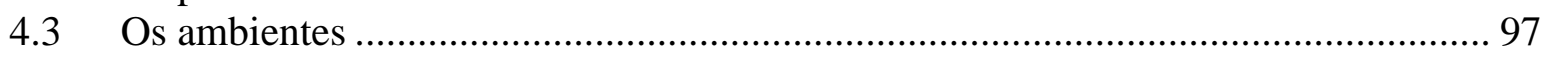

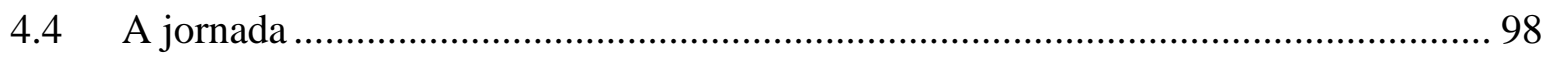

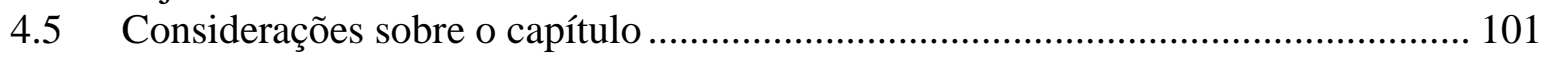

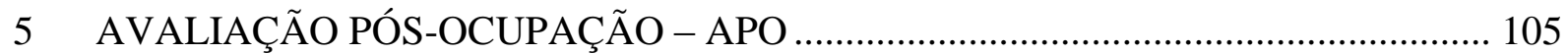

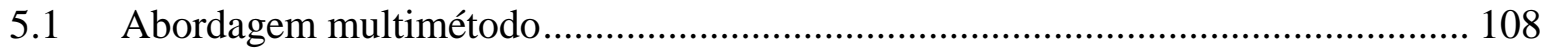

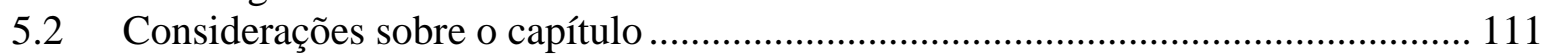

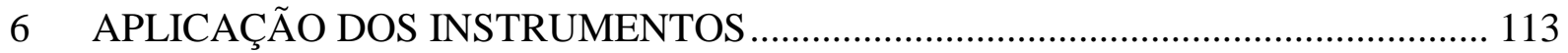

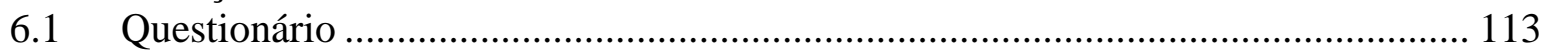

6.1.1 Considerações sobre o instrumento......................................................... 113

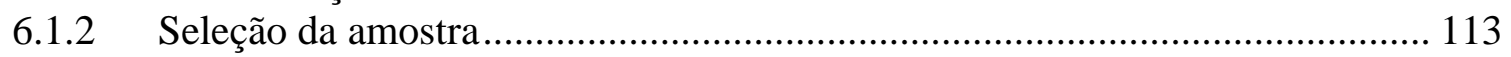

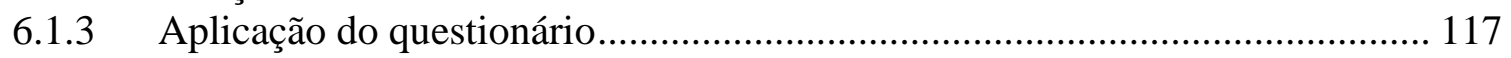

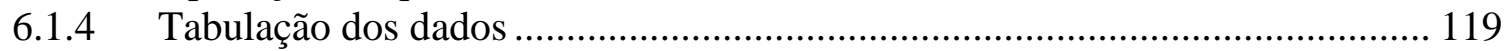

6.1.5 Processamento dos dados - perguntas fechadas ......................................... 120

6.1.6 Processamento dos dados - perguntas abertas ............................................. 129

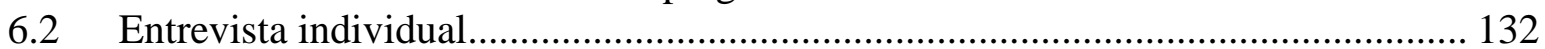

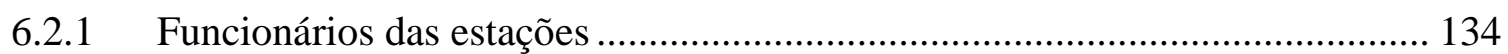

6.2.2 Profissionais que atuam no CCO ............................................................... 137

6.2.3 Profissionais que elaboram normas técnicas de acessibilidade ....................... 138

6.2.4 Professores de orientação e mobilidade ....................................................... 141

6.2.5 Instrutores e elaboradores de treinamento de funcionários e estagiários .......... 143

6.3 Entrevista em grupo........................................................................................ 144

6.3.1 Arquitetos responsáveis pelos projetos das estações ..................................... 145

6.3.2 Engenheiros e designers que elaboram as especificações dos trens ................ 148

6.3.3 Estagiários que auxiliam pessoas com deficiência visual ................................ 149

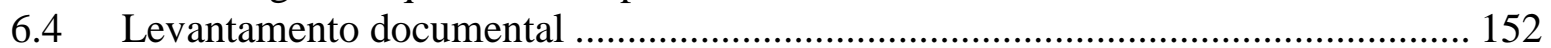

6.4.1 Normas técnicas ABNT e legislação federal .................................................. 152

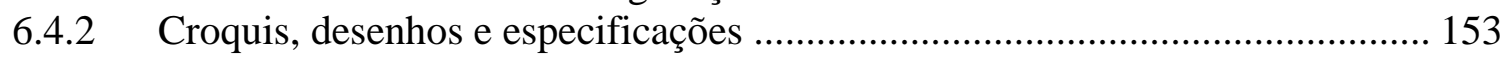

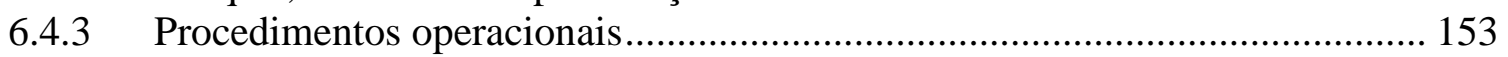

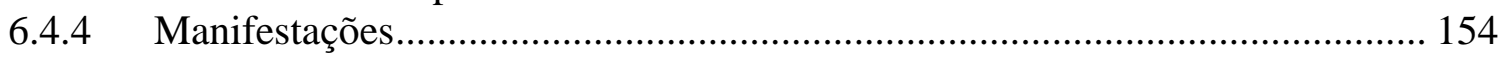

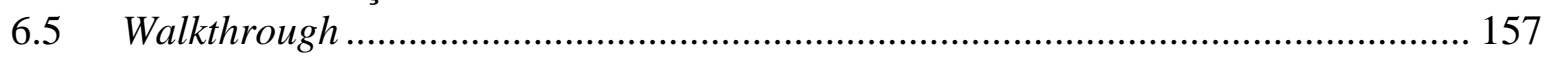

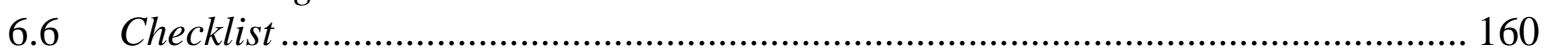

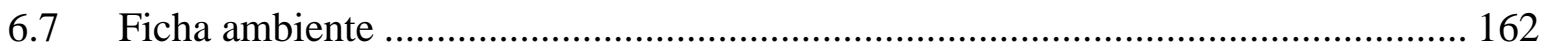

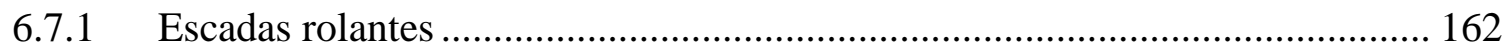

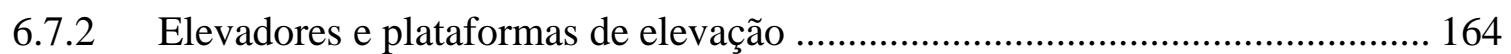

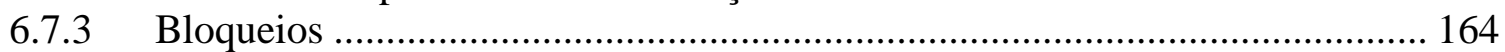




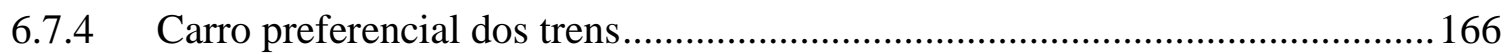

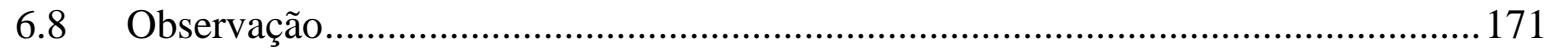

6.8.1 Observação de comportamento ……………………………………………...... 173

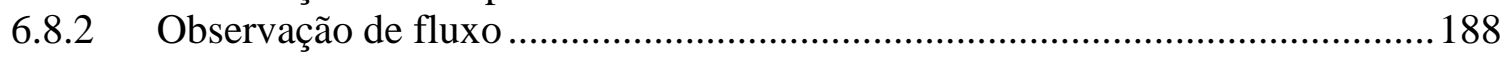

6.8.3 Observação do treinamento de O\&M ..............................................................211

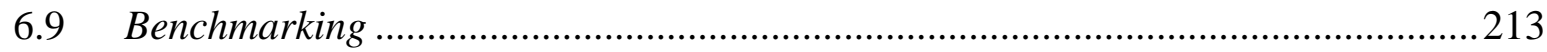

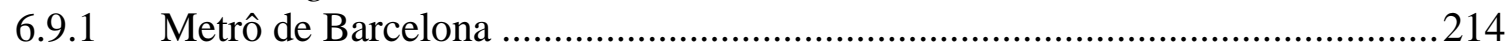

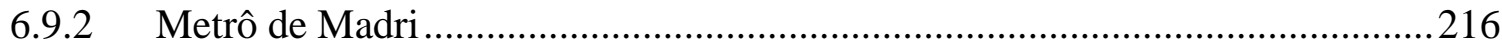

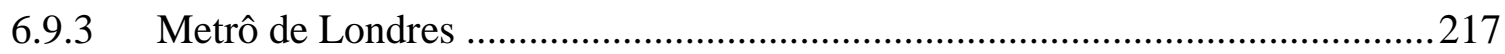

6.9.4 Metrô de Paris........................................................................................... 220

6.9.5 Rede Ferroviária Francesa ...........................................................................22

6.9.6 Metrô de Tóquio .......................................................................................222

6.9.7 Metrô do Rio de Janeiro ………………………………………………......223

6.10 Síntese dos instrumentos aplicados ............................................................22

6.11 Considerações sobre o capítulo ........................................................................229

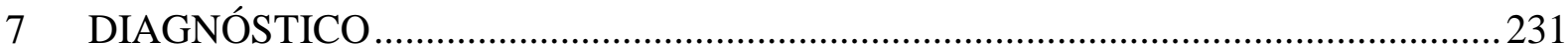

7.1 Etapa 1 - Planejamento do deslocamento.........................................................2232

7.1.1 Métodos e técnicas aplicados .....................................................................232

7.1.2 Melhores Práticas …………………………………................................... 232

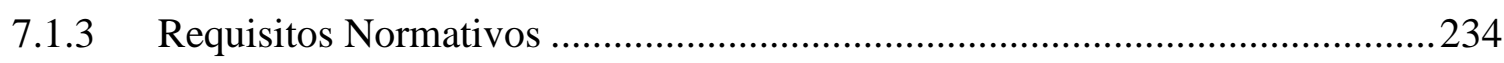

7.1.4 Situação do Metrô de São Paulo........................................................................234

7.1.5 Avaliação pelos usuários .................................................................................237

7.1.6 Avaliação pelas pessoas-chave ......................................................................239

7.1.7 Avaliação pelos especialistas..........................................................................239

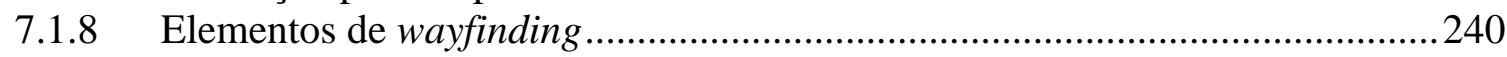

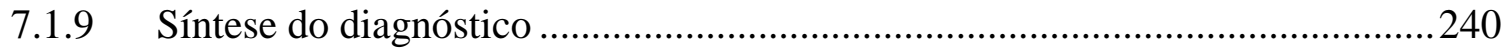

7.2 Etapa 2 - Desembarque do sistema integrado ……………………....................241

7.2.1 Métodos e técnicas aplicados .....................................................................241

7.2.2 Melhores Práticas ..................................................................................... 242

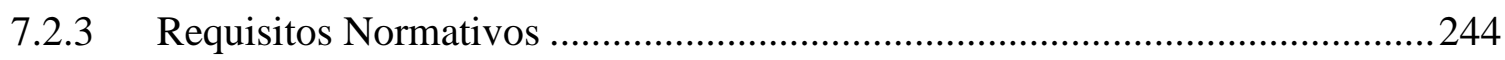

7.2.4 Situação no Metrô de São Paulo......................................................................24

7.2.5 Avaliação pelos usuários .................................................................................24

7.2.6 Avaliação pelas pessoas-chave...................................................................246

7.2.7 Avaliação pelos especialistas..........................................................................248

7.2.8 Elementos de wayfinding ...........................................................................249

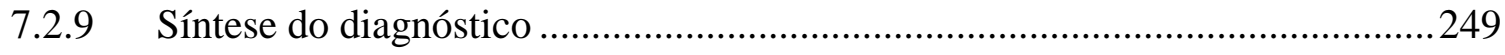

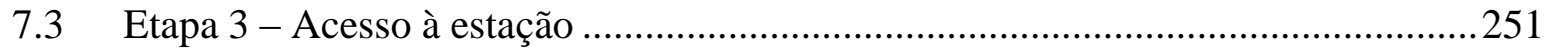

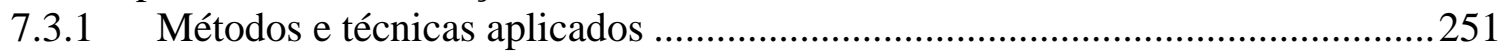

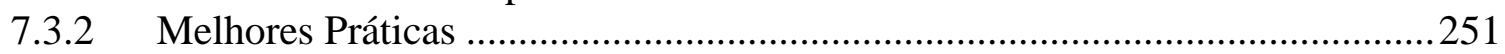

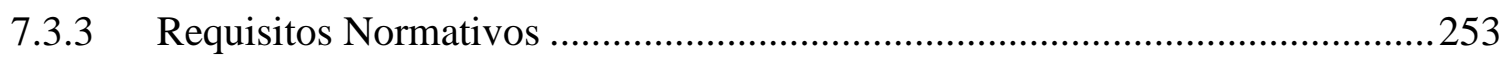

7.3.4 Situação no Metrô de São Paulo......................................................................254

7.3.5 Avaliação pelos usuários ...............................................................................254

7.3.6 Avaliação pelas pessoas-chave .....................................................................25

7.3.7 Avaliação pelos especialistas.........................................................................25

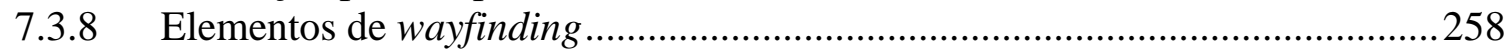

7.3.9 Síntese do diagnóstico ..............................................................................258

7.4 Etapa 4-Circulação vertical entre o acesso e o mezanino ........................................259

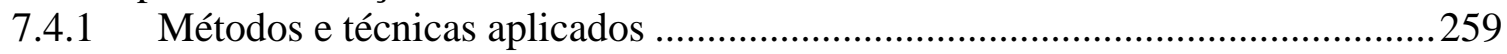


7.4.2 Melhores Práticas ........................................................................................ 260

7.4.3 Requisitos Normativos........................................................................... 260

7.4.4 Avaliação pelos usuários................................................................................. 260

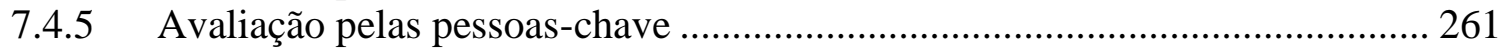

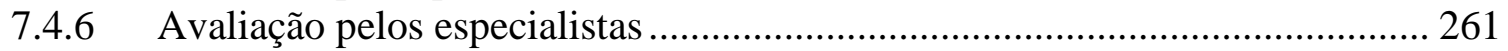

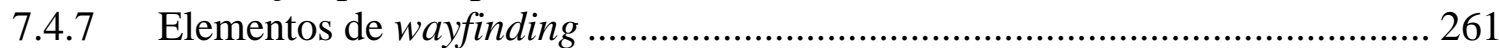

7.4.8 Síntese do diagnóstico................................................................................. 262

7.5 Etapa 5 - Deslocamento no mezanino - área livre …………………………….... 262

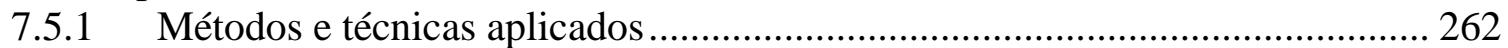

7.5.2 Melhores Práticas ……………………………………………………........ 263

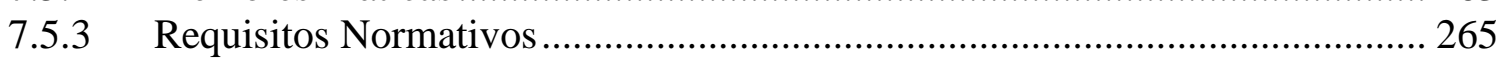

7.5.4 Situação do Metrô de São Paulo ................................................................. 265

7.5.5 Avaliação pelos usuários............................................................................. 266

7.5.6 Avaliação pelas pessoas-chave ...................................................................... 269

7.5.7 Avaliação pelos especialistas ....................................................................... 271

7.5.8 Elementos de wayfinding ........................................................................ 272

7.5.9 Síntese do diagnóstico................................................................................ 273

7.6 Etapa 6 - Aquisição do bilhete..................................................................... 275

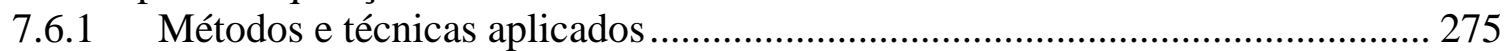

7.6.2 Melhores Práticas ………………………………………………………..... 275

7.6.3 Requisitos Normativos ............................................................................ 276

7.6.4 Situação no Metrô de São Paulo .................................................................. 277

7.6.5 Avaliação pelos usuários............................................................................... 278

7.6.6 Avaliação pelas pessoas-chave .................................................................... 278

7.6.7 Avaliação pelos especialistas ....................................................................... 279

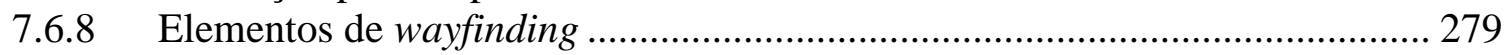

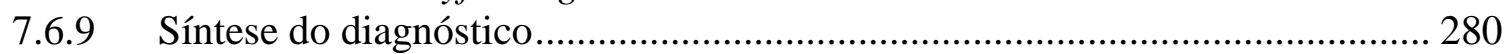

7.7 Etapa 7 - Controle de entrada - Validação do bilhete …………………………….. 280

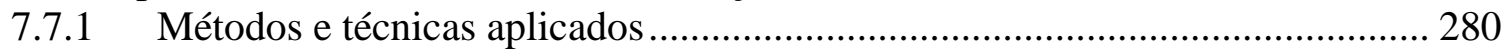

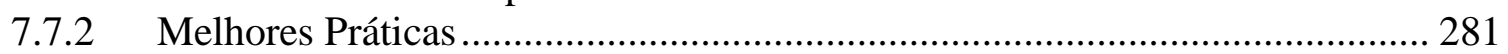

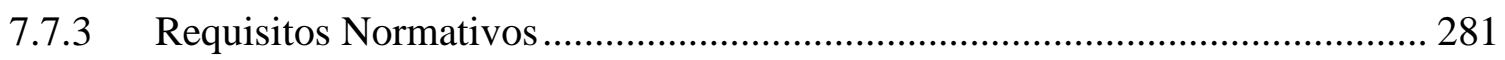

7.7.4 Situação no Metrô de São Paulo .................................................................. 281

7.7.5 Avaliação pelos usuários................................................................................ 283

7.7.6 Avaliação pelas pessoas-chave ..................................................................... 284

7.7.7 Avaliação pelos especialistas ........................................................................ 284

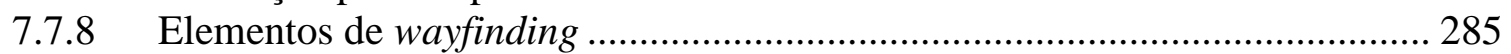

7.7.9 Síntese do diagnóstico................................................................................... 285

7.8 Etapa 8 - Deslocamento no mezanino - área paga e escolha da plataforma ........... 286

7.8.1 Métodos e técnicas aplicados................................................................... 286

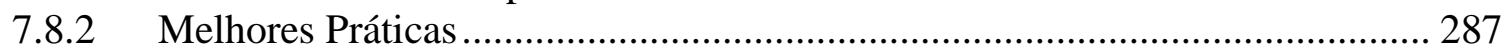

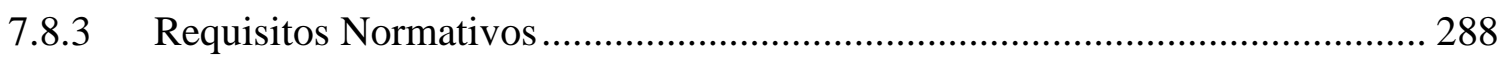

7.8.4 Situação no Metrô de São Paulo ....................................................................... 288

7.8.5 Avaliação pelos usuários........................................................................... 290

7.8.6 Avaliação pelas pessoas-chave ................................................................... 292

7.8.7 Avaliação pelos especialistas .................................................................... 295

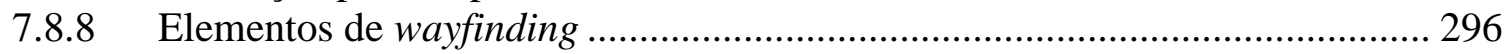

7.8.9 Síntese do diagnóstico................................................................................... 296

7.9 Etapa 9 - Circulação vertical entre o mezanino e as plataformas ............................. 298

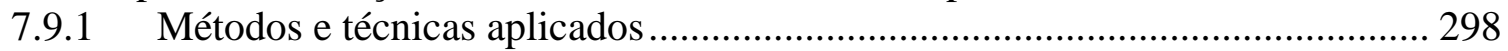




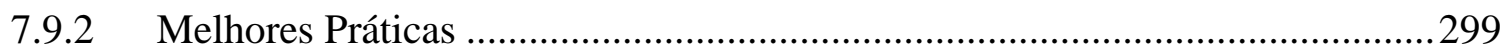

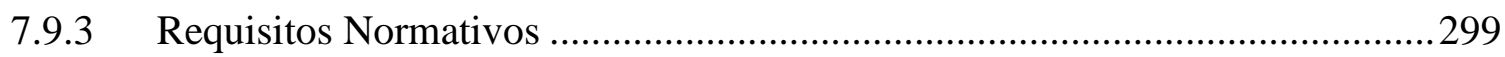

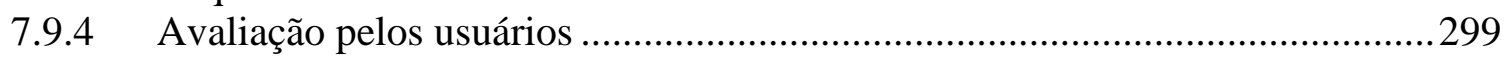

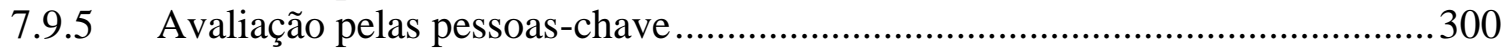

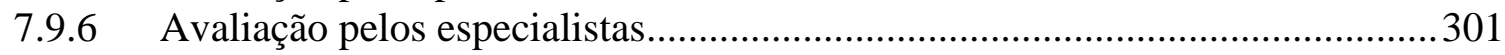

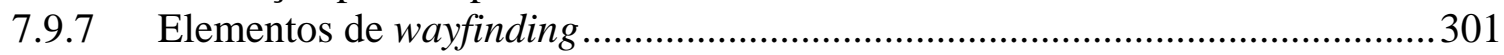

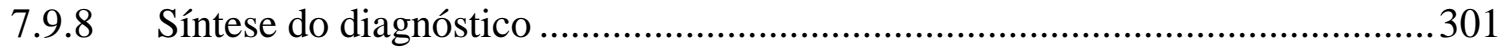

7.10 Etapa 10 - Deslocamento até o local de embarque na plataforma........................302

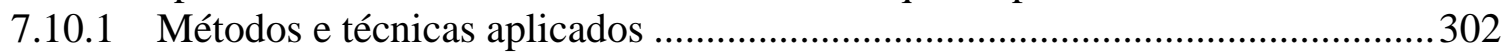

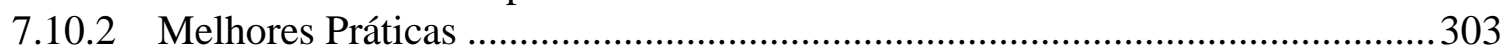

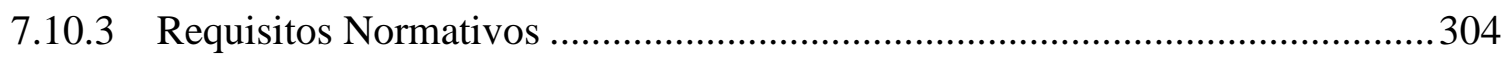

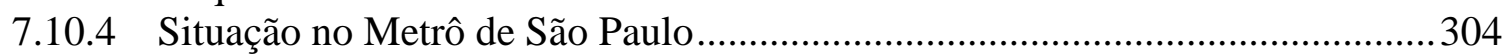

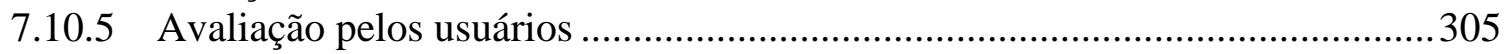

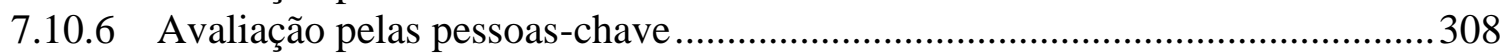

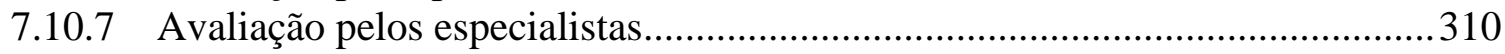

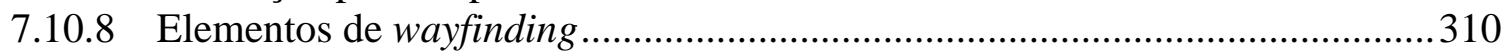

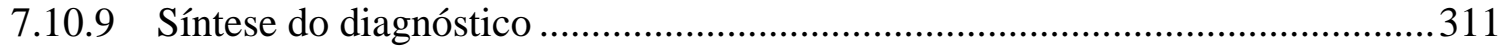

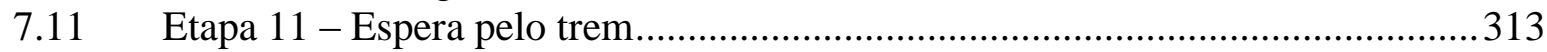

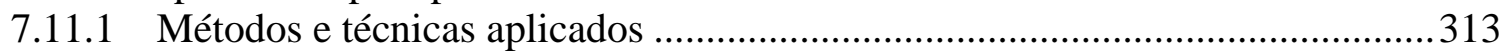

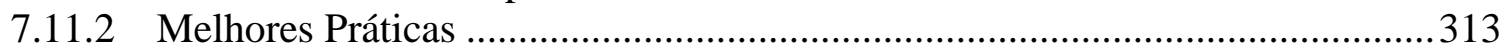

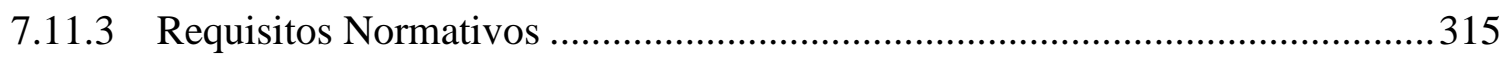

7.11.4 Situação no Metrô de São Paulo.......................................................................... 315

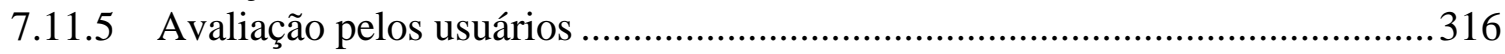

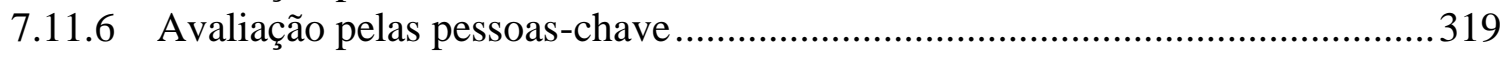

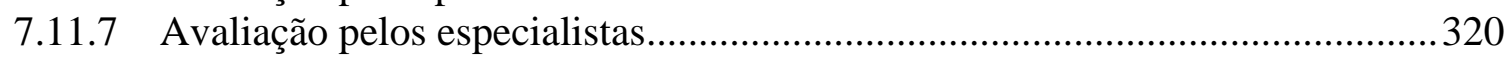

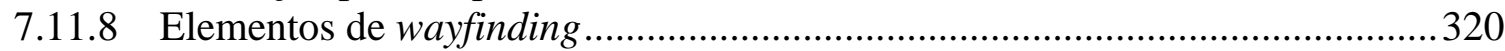

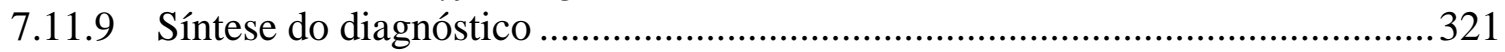

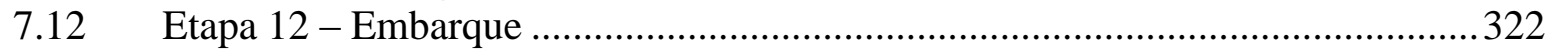

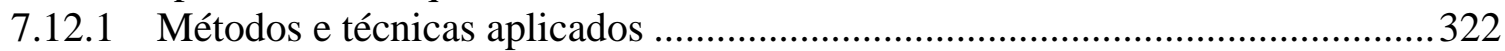

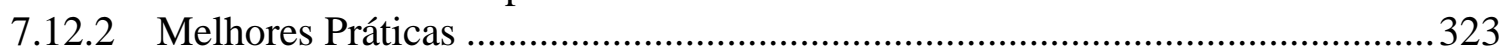

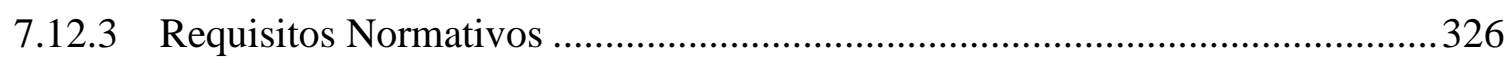

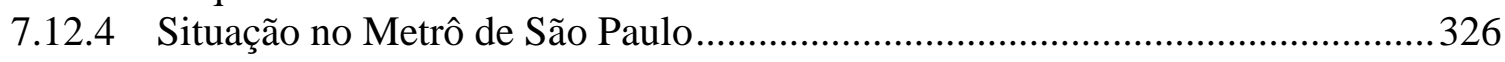

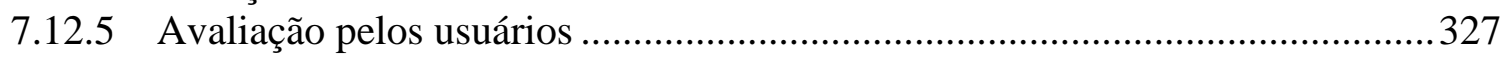

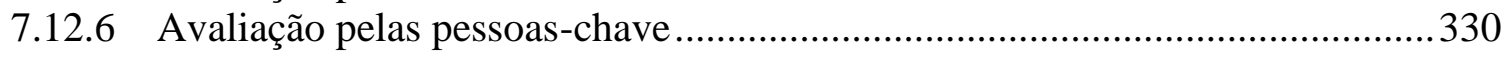

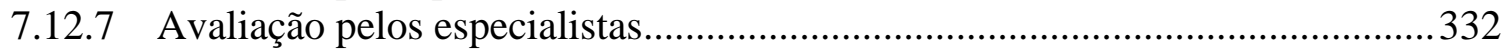

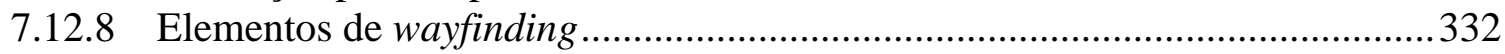

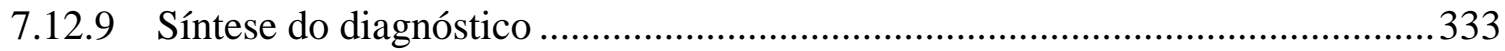

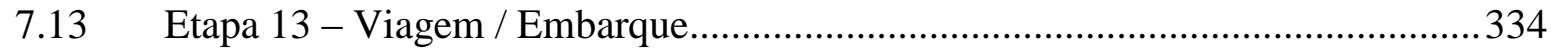

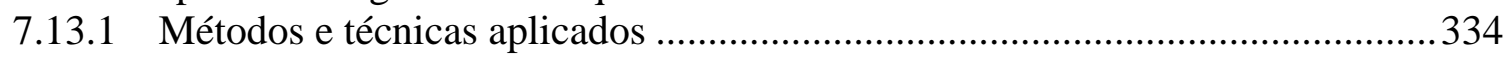

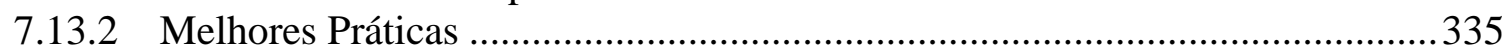

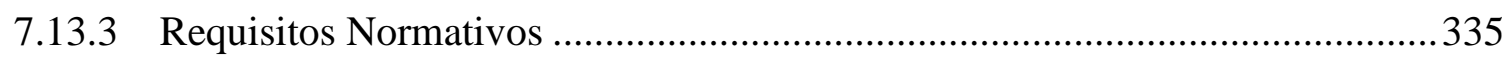

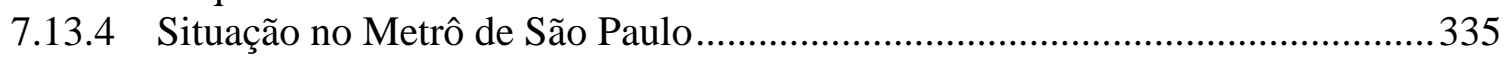

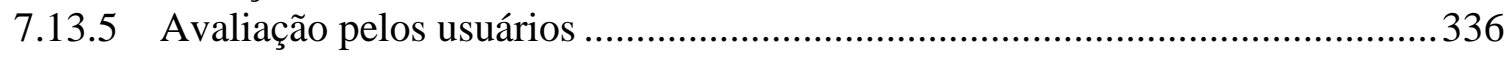

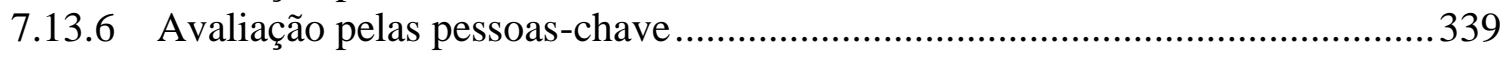

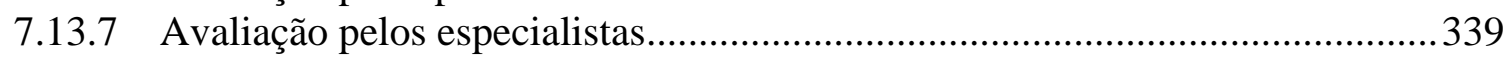

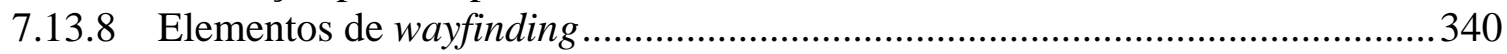

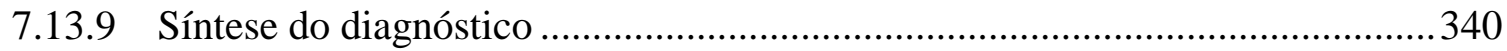

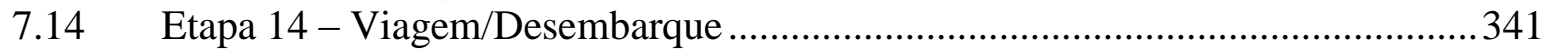

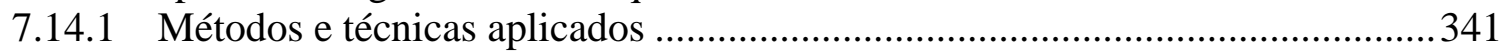




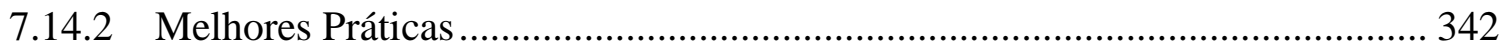

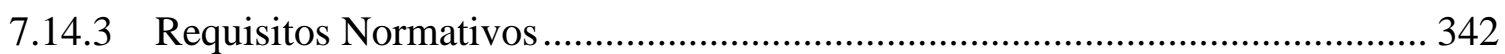

7.14.4 Situação no Metrô de São Paulo …………………………………………….... 343

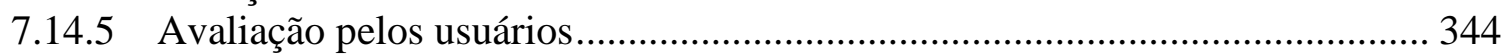

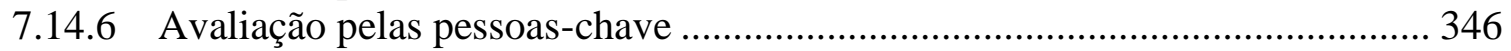

7.14.7 Avaliação pelos especialistas .......................................................................... 346

7.14.8 Elementos de wayfinding ............................................................................. 347

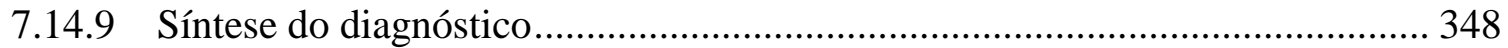

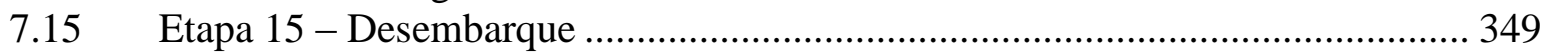

7.15.1 Métodos e técnicas aplicados ...................................................................... 349

7.15.2 Melhores Práticas ………………………………………………………......... 349

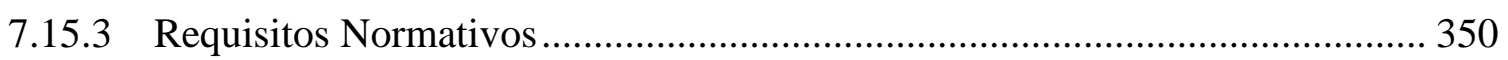

7.15.4 Situação no Metrô de São Paulo ..................................................................... 350

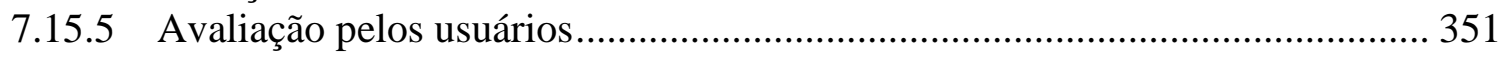

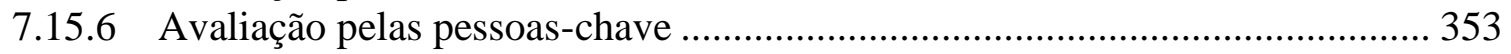

7.15.7 Avaliação pelos especialistas ......................................................................... 355

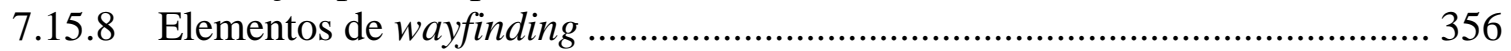

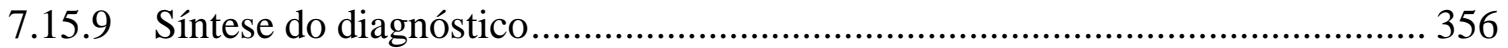

7.16 Etapa 16 - Deslocamento até a saída da plataforma.......................................... 358

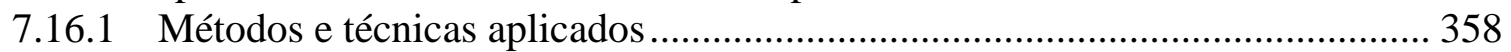

7.16.2 Melhores Práticas ........................................................................................ 358

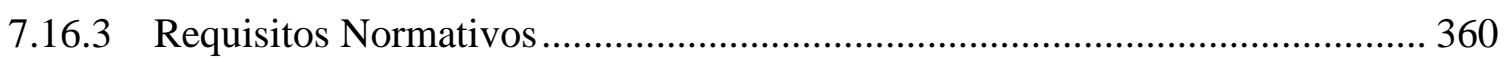

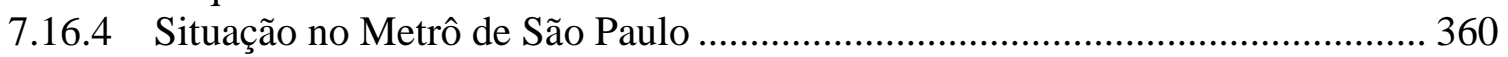

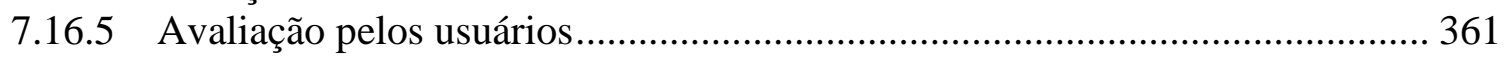

7.16.6 Avaliação pelas pessoas-chave ....................................................................... 364

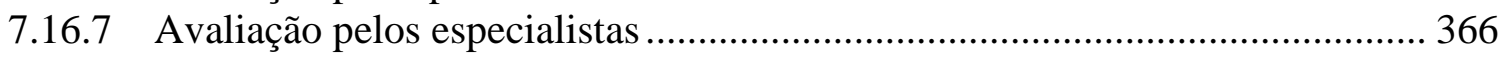

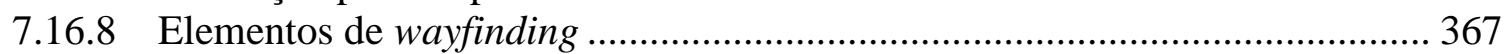

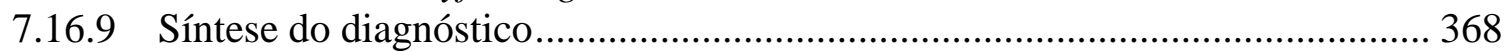

7.17 Etapa 17 - Circulação vertical entre a plataforma e o mezanino ………………... 370

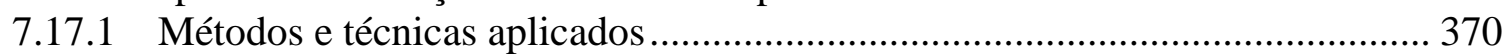

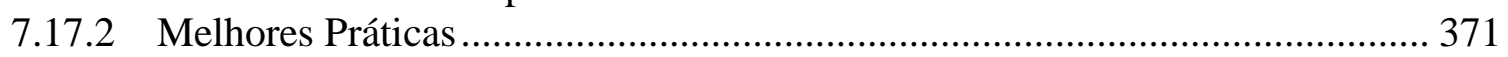

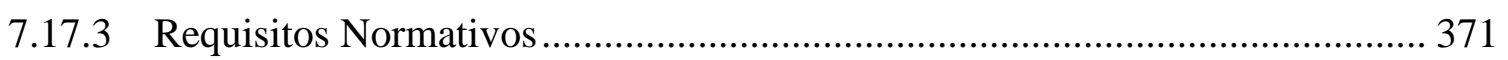

7.17.4 Avaliação pelos usuários................................................................................... 371

7.17.5 Avaliação pelas pessoas-chave ....................................................................... 372

7.17.6 Avaliação pelos especialistas ...................................................................... 372

7.17.7 Elementos de wayfinding ………………………………………………..... 372

7.17.8 Síntese do diagnóstico..................................................................................... 372

7.18 Etapa 18 - Deslocamento no mezanino - área paga............................................. 373

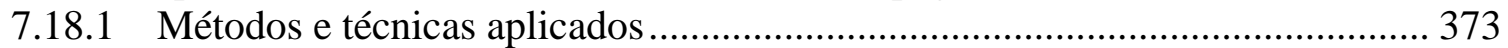

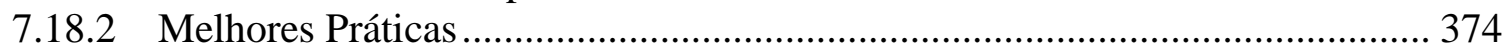

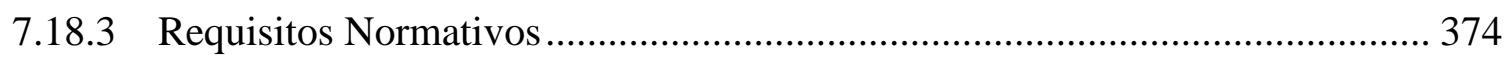

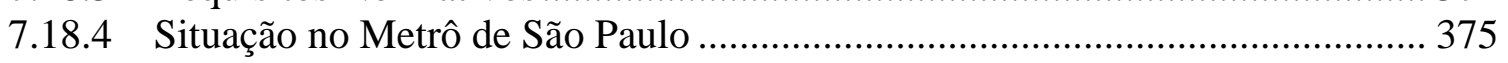

7.18.5 Avaliação pelos usuários...………………………………………………..... 375

7.18.6 Avaliação pelas pessoas-chave ...................................................................... 377

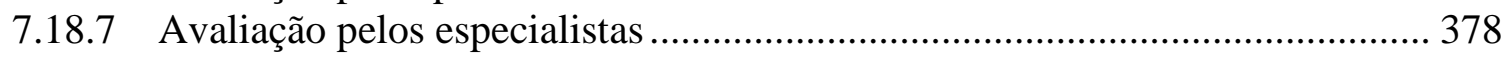

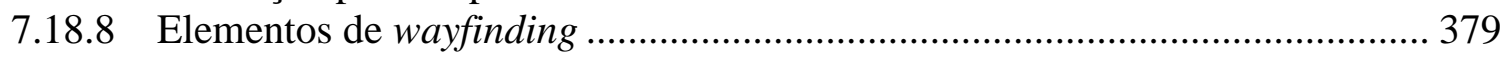

7.18.9 Síntese do diagnóstico................................................................................. 380

7.19 Etapa 19 - Controle de saída ………………….......................................... 381

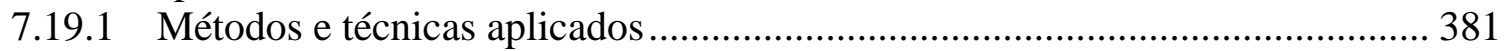




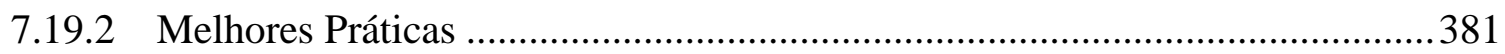

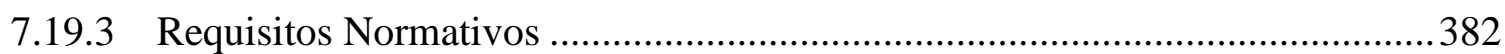

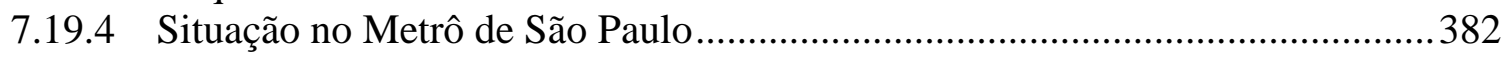

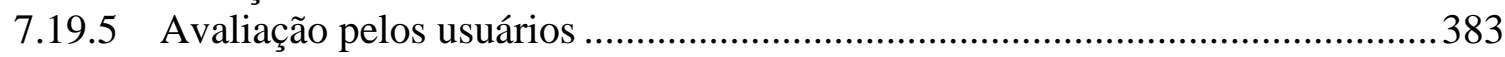

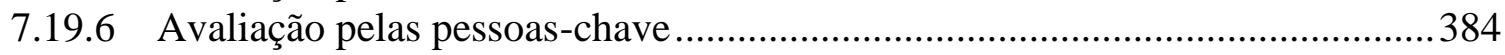

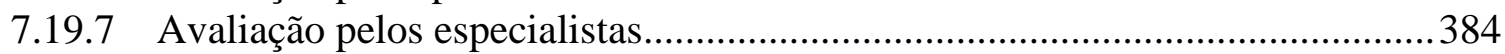

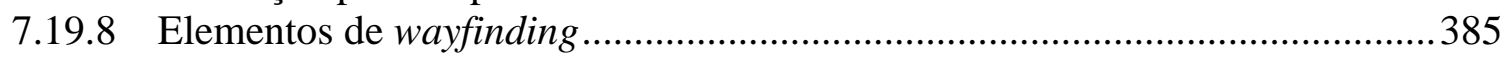

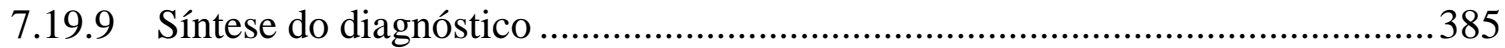

7.20 Etapa 20 - Deslocamento no mezanino - área livre ..............................................386

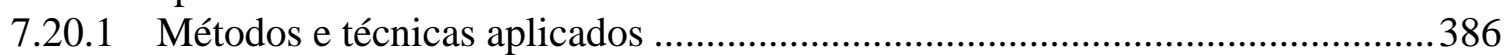

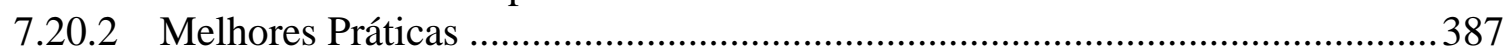

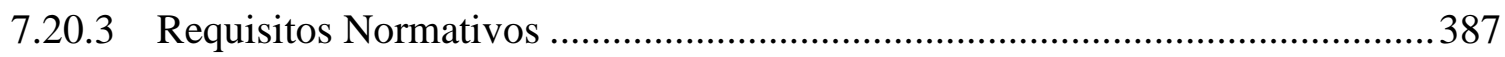

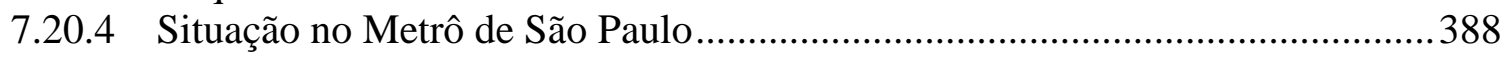

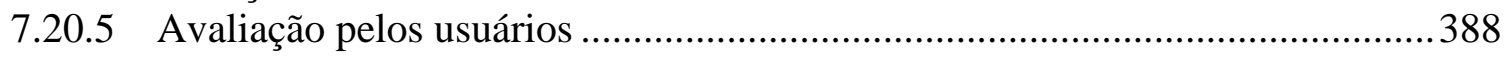

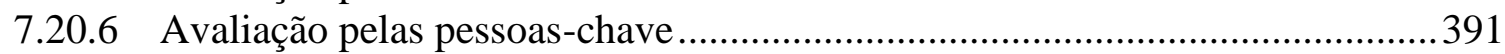

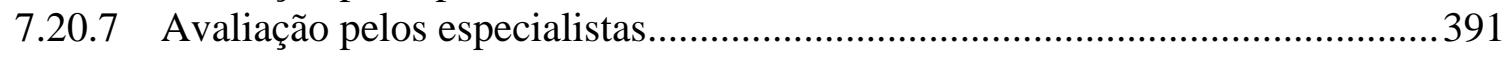

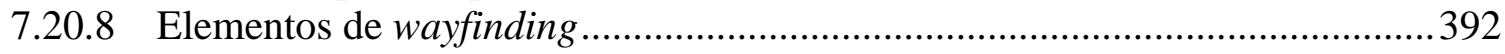

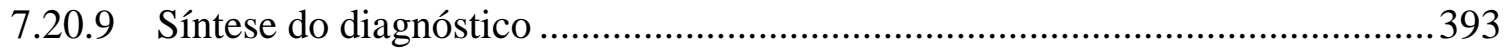

7.21 Etapa 21 - Circulação vertical entre o mezanino e o acesso....................................394

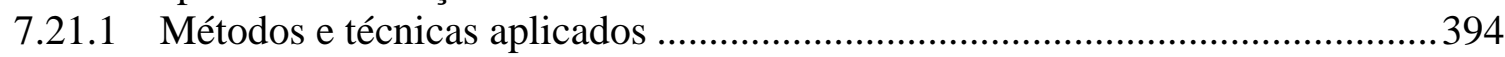

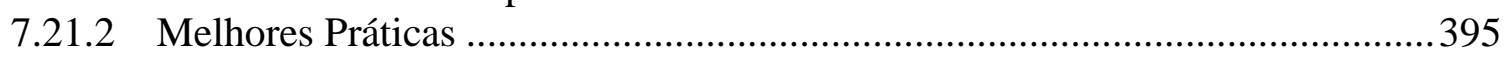

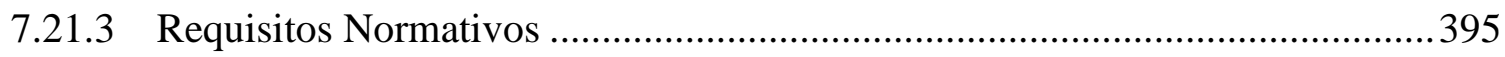

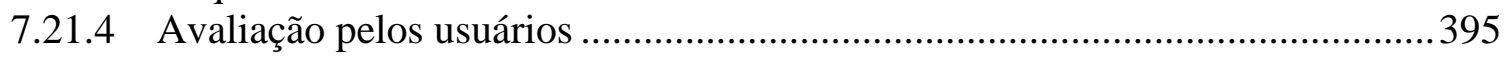

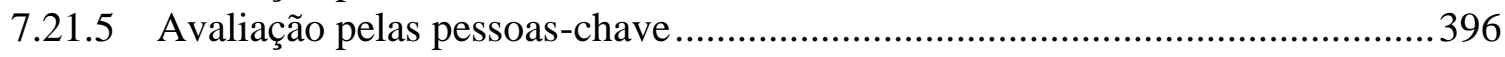

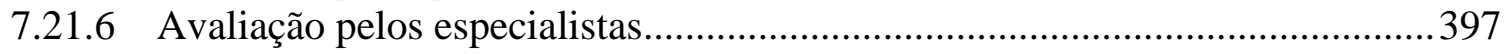

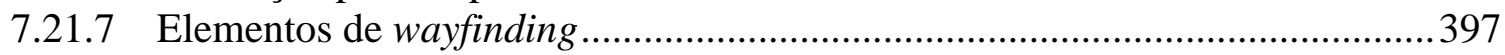

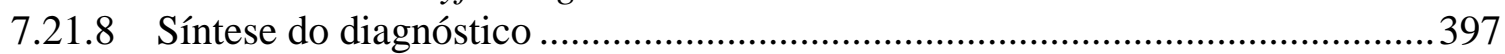

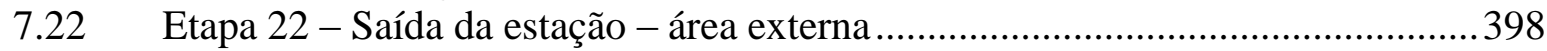

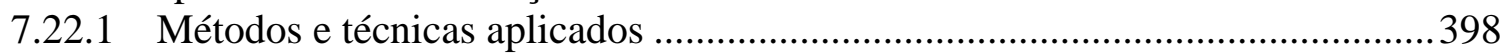

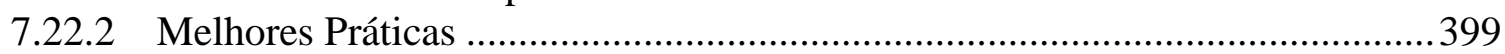

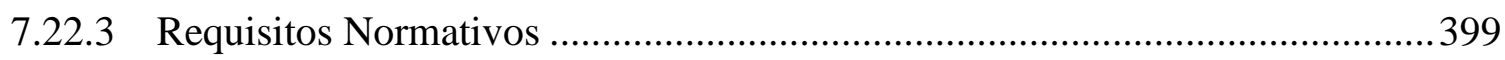

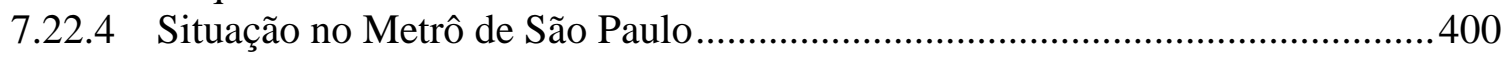

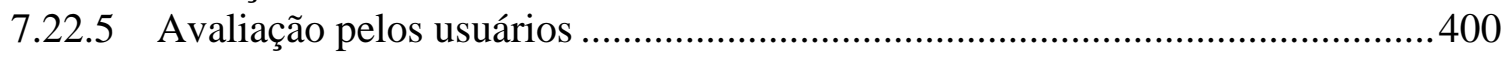

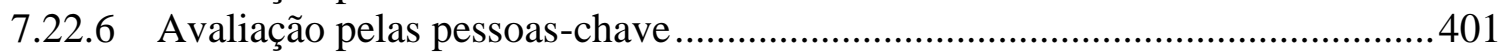

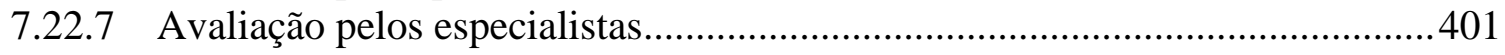

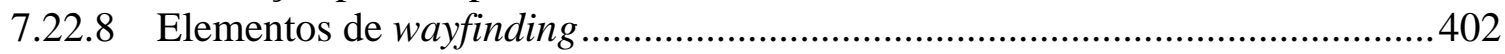

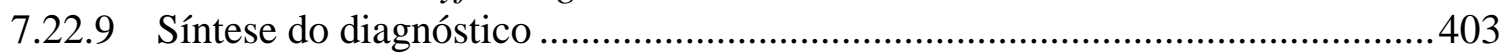

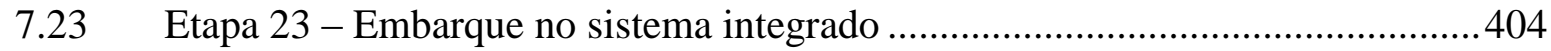

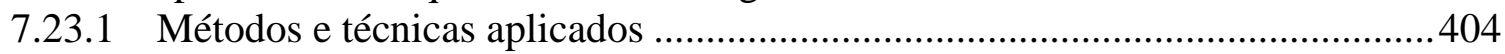

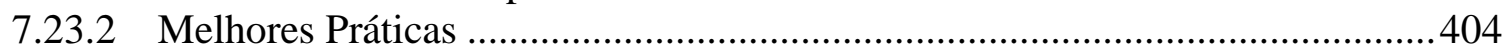

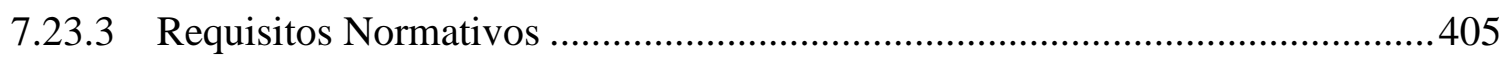

7.23.4 Situação no Metrô de São Paulo...................................................................... 405

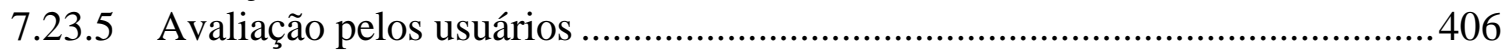

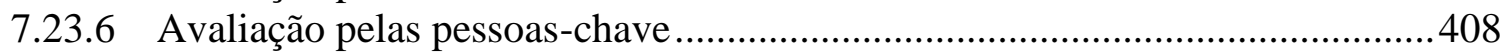

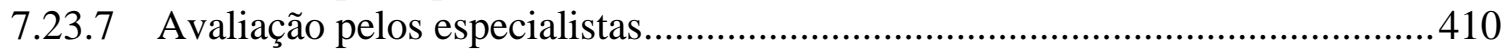

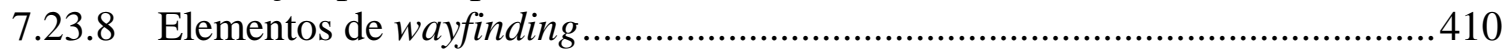

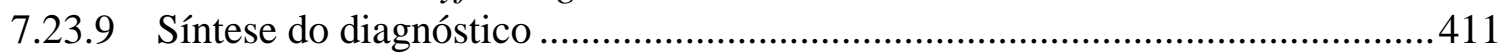

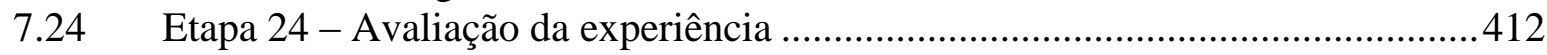

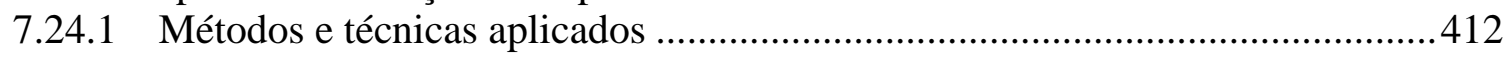




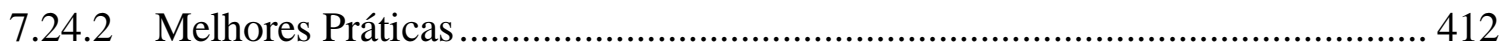

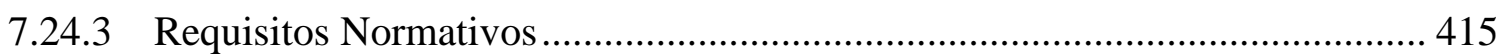

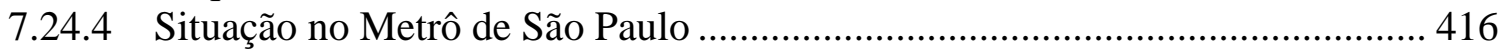

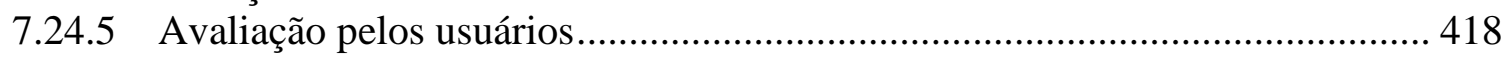

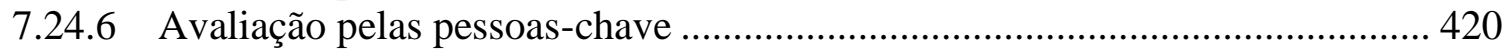

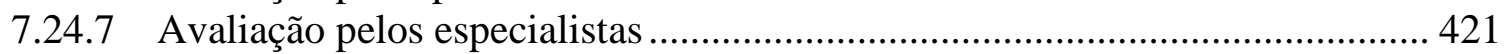

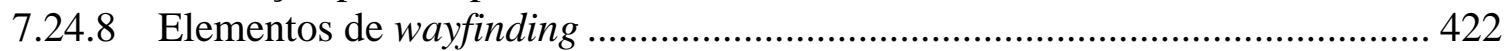

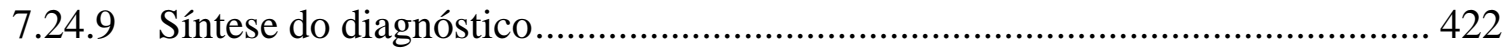

7.25 Etapa 30 - Circulação vertical - sem especificar o local .................................... 423

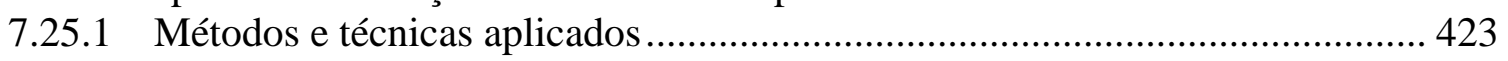

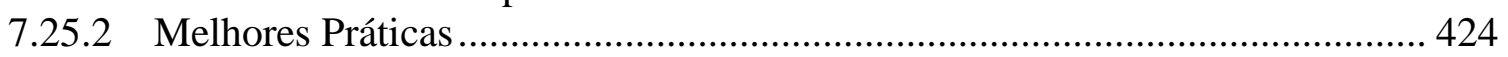

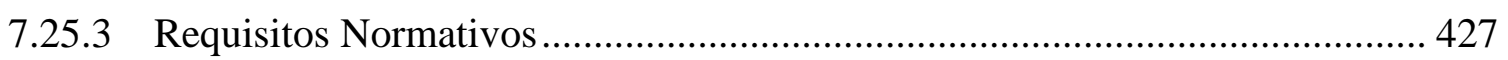

7.25.4 Situação do Metrô de São Paulo .................................................................... 429

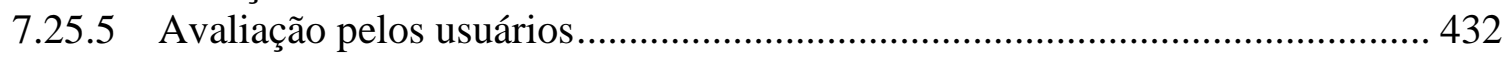

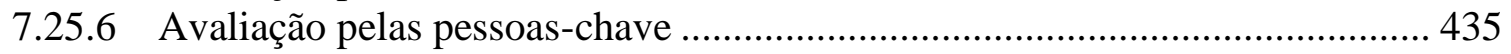

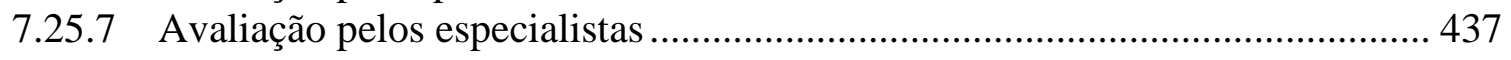

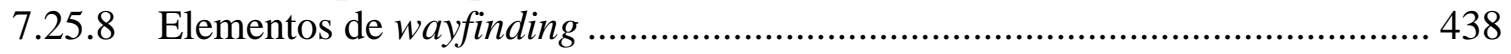

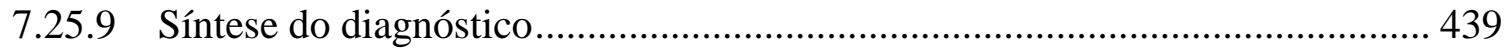

7.26 Etapa 40 - Circulação horizontal na estação - sem especificar o local................ 441

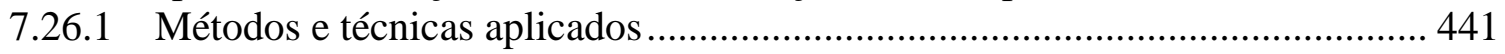

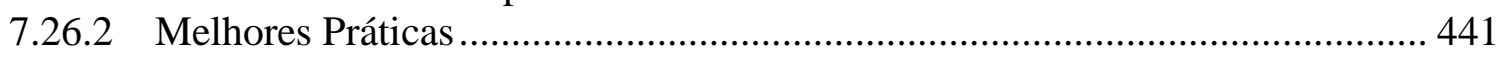

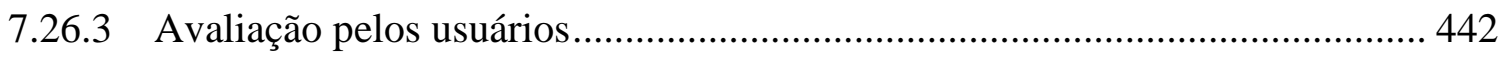

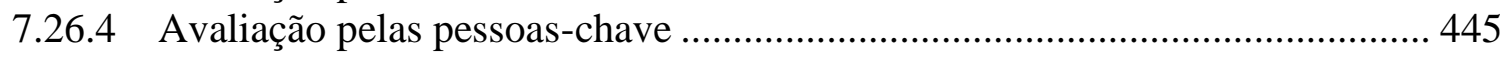

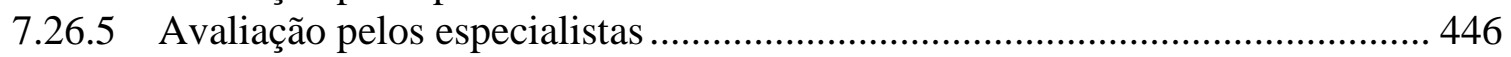

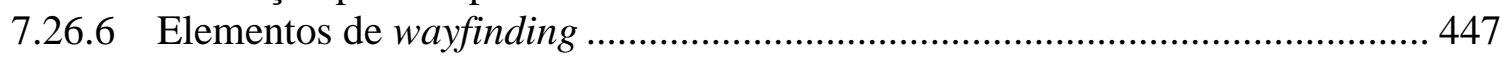

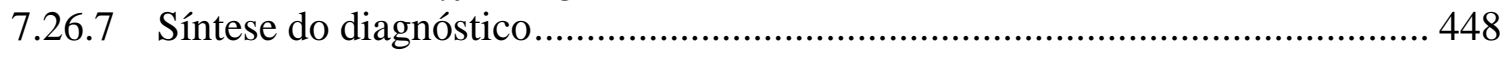

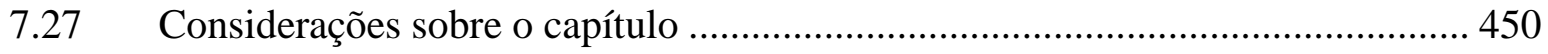

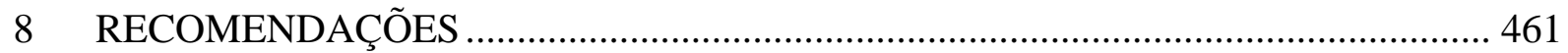

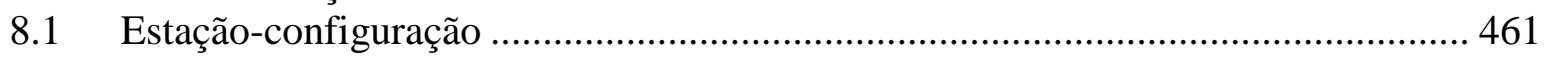

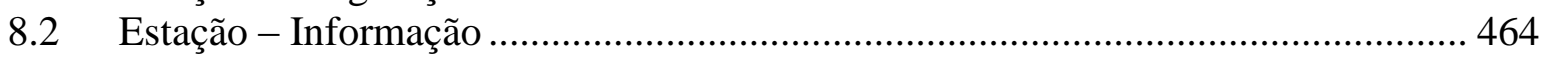

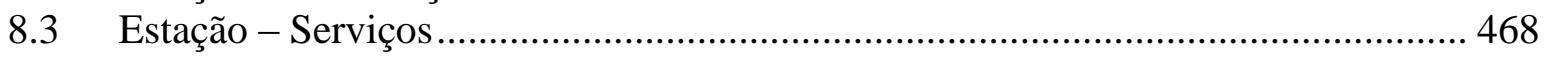

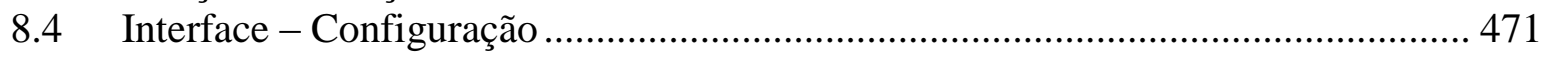

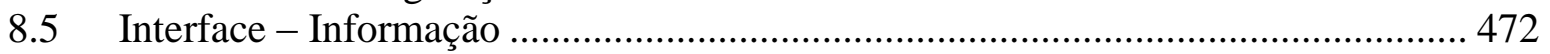

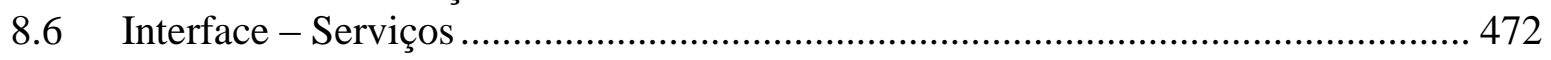

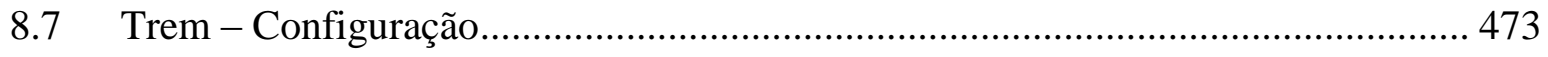

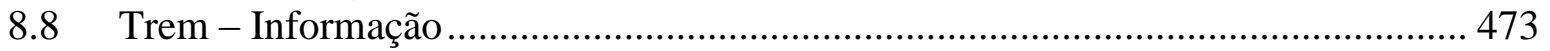

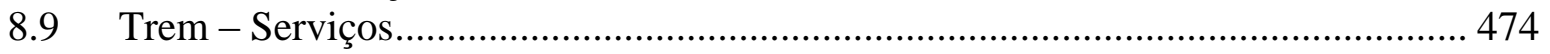

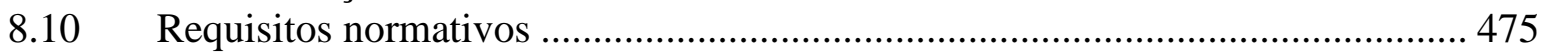

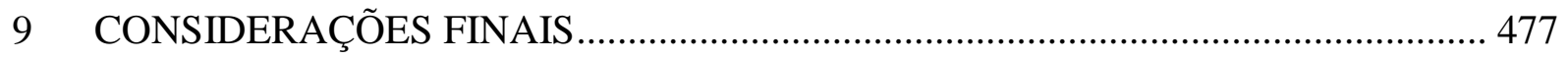

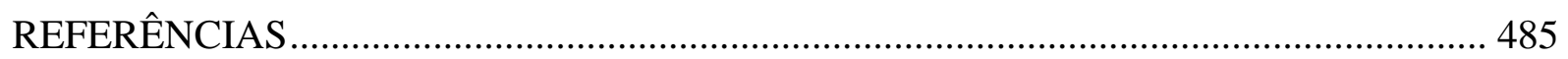

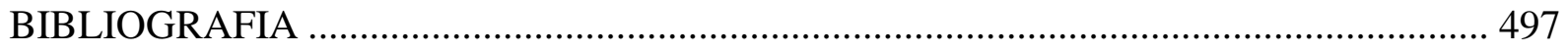

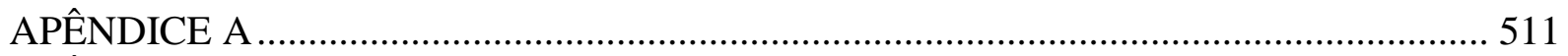

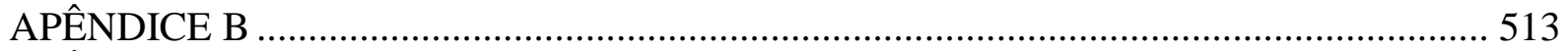

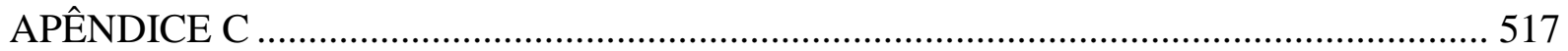


APÊNDICE D 519

APÊNDICE E 521

APÊNDICE F 523

APÊNDICE G 525

APÊNDICE H 527

APENNDICE I 529

APÊNDICE J. 531

APÊNDICE K .533

APÊNDICE L 545

APÊNDICE M 547

APÊNDICE N 
xxxiv 


\section{INTRODUÇÃO}

\subsection{Apresentação}

A mobilidade tem impacto direto na vida das pessoas que moram ou realizam atividades cotidianas nos centros urbanos em função do tempo investido e da qualidade do ambiente onde são realizados os deslocamentos. Por ser uma condição básica para se atingirem outros objetivos, tais como trabalho, moradia, educação, lazer ou saúde, a mobilidade é vista como um direito genérico: um direito que dá acesso a outros direitos (APEL-MULLER; BORTHGARAY, 2012).

A multimodalidade do sistema de transporte integrado - táxi, van, ônibus, metrô, trem implica a compreensão do macroambiente da região metropolitana de acordo com a origem do deslocamento e o destino desejado. A decisão do meio de transporte a ser utilizado envolve aspectos como distância, itinerários, conexões, tempo, custo, facilidades e acessibilidade dos deslocamentos. A contínua mutação da rede resulta das novas integrações ou da ampliação das linhas e tem impacto direto na legibilidade do sistema de transporte metroferroviário, que deve oferecer condições adequadas para proporcionar o deslocamento de todos os cidadãos das regiões metropolitanas.

Os deslocamentos realizados pressupõem também a compreensão de microambientes distintos e complexos em função da diversidade de configuração, equipamentos e sistemas de informação, que impactam a decodificação dos percursos de embarque e desembarque. Os ambientes das estações do sistema metroferroviário, ao contrário de outras edificações de uso público, não se destinam à permanência; são ambientes de passagem.

O cenário dos transportes metropolitanos pressupõe a necessidade de compatibilizar a demanda de passageiros, a diversidade das pessoas (gênero, faixa etária, comportamento, características física e sociocultural, frequência de utilização, habilidade no uso de tecnologias assistivas e de sistemas informatizados, condições de percepção e mobilidade, participação em processos de reabilitação, entre outros), as exigências de segurança (pública, de uso e contra incêndio) e a crescente automação dos componentes e das instalações. 
A complexidade do sistema metroferroviário tem início na definição do traçado da rede e dos métodos construtivos a serem utilizados, de forma a minimizar os impactos urbanos, otimizar os investimentos e compatibilizar os projetos das estações e dos trens com o padrão de serviço a ser ofertado em função da demanda prevista. Os métodos construtivos definem as diferentes tipologias das estações: enquanto externamente busca-se a harmonização dos aspectos arquitetônicos do edifício com o contexto urbano, internamente priorizam-se a funcionalidade e o correto dimensionamento das áreas de circulação desde os acessos até as plataformas (BARBOSA; ORNSTEIN, 2012). Nesta perspectiva, contemplam-se os controles de entrada e saída, as áreas de distribuição e o direcionamento dos percursos horizontais e verticais, fatores essenciais para promover o deslocamento constante de grandes fluxos para embarque e desembarque. Em relação aos trens, a variedade de frotas decorre da evolução da tecnologia, dos requisitos de acessibilidade e do padrão de configuração do interior dos carros à época da especificação e fabricação. Consideram-se, além dos aspectos apresentados, as configurações e os sistemas construtivos das vias e, consequentemente, uma variedade de situações na interface entre o trem e a estação, em cada plataforma, que impacta o embarque e desembarque dos usuários.

A impossibilidade de padronizar soluções implica a existência de referências e de um sistema de informação, de comunicação e de orientação que torne legível, simultaneamente, os macro e os microambientes destinados à mobilidade, e possibilite a orientação dos deslocamentos coletivos em meio às necessidades individuais. Facilitar a percepção e a compreensão dos ambientes é essencial para orientar os deslocamentos, seja em ambientes de uso habitual ou eventual.

Os projetos dos ambientes do sistema metroferroviário devem considerar também os deslocamentos realizados pelas pessoas com deficiência visual. Além da eliminação de obstáculos, deve-se proceder a uma análise espacial para identificar os referenciais válidos que possibilitem a percepção e facilitem a cognição e a compreensão da articulação espacial e do sistema de circulação face à complexidade das instalações e à impossibilidade de padronizar soluções. A leitura positiva do ambiente é condicionada ao serviço oferecido, que, por sua vez, é avaliado pelo aspecto físico de suas instalações. 
A acessibilidade depende não só da estação, do trem e das condições do serviço ofertado, mas também das habilidades dos usuários. Enfim, depende do ambiente, da pessoa, da interrelação entre a pessoa e o ambiente, da inter-relação entre as pessoas e da inter-relação entre os ambientes.

Considerando que os usuários com deficiência visual são coparticipantes do processo de prestação do serviço, pode-se afirmar que a independência nos deslocamentos pressupõe um relacionamento do usuário com deficiência com o ambiente e, simultaneamente, com os demais usuários. Por outro lado, o auxílio nos deslocamentos para embarque ou desembarque pressupõe o relacionamento desse usuário com os funcionários da empresa e, simultaneamente, com os demais usuários.

O relacionamento com a empresa operadora - representada pelos ambientes, funcionários e demais usuários - é complementado pelo envolvimento de especialistas, oriundos das entidades e das instituições da sociedade organizada, para estabelecimento de requisitos legais, normativos e de projeto, bem como dos conteúdos instrucionais dos processos de reabilitação das pessoas com deficiência e dos processos de capacitação dos funcionários das empresas operadoras.

A arquitetura das estações, o design dos trens e o sistema de informação, orientação e comunicação das estações e trens devem compor uma mesma estratégia da empresa, elaborada a partir dos aspectos considerados relevantes e importantes pelo usuário, adaptável às necessidades individuais sem comprometer as necessidades coletivas. As pessoas com deficiência visual dependem da integração, redundância e flexibilidade do sistema de informação e orientação, bem como da comunicação entre os usuários e as empresas dos diferentes modos de transporte. Dessa forma, a gestão do ambiente e do sistema de informação deve estar alinhada com a estratégia do serviço ofertado pela empresa, que deve estar centrada no usuário. 


\subsection{Justificativa}

As ações para adaptar estações e trens do Metrô de São Paulo às condições de acessibilidade tiveram como objetivo facilitar o acesso e o uso por pessoas com deficiência ou com mobilidade reduzida - tais como idosos, gestantes, obesos e pessoas com crianças de colo ou ainda por pessoas que transportam malas ou conduzem carrinhos de bebê (BARBOSA, 2009). Apesar das ações realizadas, o número de auxílios solicitados por pessoas com deficiência visual durante seus deslocamentos diários permanece elevado se comparado às solicitações de pessoas com outros tipos de deficiência. A análise das informações fornecidas pelo Metrô de São Paulo permitiu constatar que, nos índices de monitoramento para embarque ou desembarque realizados pela empresa, predominam os pedidos de auxílio por parte das pessoas com deficiência visual, totalizando, em média, 92,15\% do total de solicitações de auxílio no período entre 2006 e 2013 (CMSP, 2014). Considera-se, portanto, a possibilidade da existência de fatores que impactam, interferem ou até mesmo impedem os deslocamentos independentes das pessoas com deficiência visual nas estações e trens.

Este estudo está focado nos valores, nas ações e nas interações das pessoas com deficiência visual: boas soluções pressupõem o conhecimento técnico e o contato com elas para compreensão das suas necessidades durante os deslocamentos. A seleção de um segmento foi necessária para promover o aprofundamento do conhecimento em relação à acessibilidade do sistema metroferroviário e propor a introdução de novos requisitos que possam ser incorporados às decisões de projeto das estações e trens e ao design do serviço de transporte para possibilitar a sua independência ou para aperfeiçoar o auxílio oferecido.

\subsection{Premissas da pesquisa}

Diante das variáveis apresentadas - impossibilidade de padronizar soluções, complexidade dos projetos, correlação entre a qualidade do serviço e a qualidade dos ambientes, interação entre usuários com deficiência, a empresa operadora e os demais usuários, índice de monitoração -, surgiram as questões que motivaram este estudo:

- Por que o índice de auxílios prestados às pessoas com deficiência visual permanece tão elevado mesmo após efetuada a adaptação das estações e trens?

- Quais são as causas da insatisfação dos usuários com deficiência visual?

- Que fatores interferem ou impedem os seus deslocamentos independentes? 
- Existe algum fator específico que gera insatisfação por parte dos usuários?

- Que elementos podem contribuir para que os deslocamentos sejam realizados de forma independente?

- Existe alguma relação entre a época de construção das estações ou de fabricação dos trens e o atendimento às necessidades das pessoas com deficiência visual?

- As estações e trens mais antigos tendem a atender menos às necessidades das pessoas com deficiência visual?

- As estações e trens novos atendem integralmente essas necessidades?

- Os requisitos estabelecidos nas leis e nas normas técnicas de acessibilidade vigentes foram aplicados no Metrô de São Paulo?

- É possível afirmar que tais requisitos são suficientes para garantir o deslocamento das pessoas com deficiência visual com independência no sistema metroferroviário?

- Quais outros requisitos deveriam ser estabelecidos?

Durante a revisão bibliográfica, observou-se que Juncà (2011) estabeleceu cinco fatores-chave para garantir as condições de acessibilidade nos sistemas de transportes. Quando aplicados ao sistema metroferroviário, esses fatores consistem nas estações, nos trens, na interface tremestação, nos sistemas de informação, comunicação e orientação e na gestão da prestação dos serviços. Contudo, a interdependência entre os ambientes identificados (estação, interface trem-estação e trem) e os temas avaliados (configuração, informação e serviço) sugere a existência de uma matriz com nove fatores que pode ser aplicada à jornada do usuário com deficiência visual no sistema metroferroviário como forma de avaliar as condições de acessibilidade.

A experiência de viagem no sistema metroferroviário resulta da interação pessoa-ambienteprocesso (ZEITHHALM; BITNER, 2003), entre os usuários com deficiência visual e a empresa operadora - representada pelos funcionários e pelos demais usuários, além dos ambientes, serviços e respectivos sistemas de informação, comunicação e orientação. A experiência de viagem pode ser evidenciada no diagrama de serviços (ZEITHAML; BITNER, 2003; FITZSIMMONS; FITZSIMMONS, 2005), permitindo que os elementos, vínculos e evidências coletadas nos relatos dos participantes e nas observações realizadas possam ser 
identificados, caracterizados e classificados ao longo das etapas que compõem a jornada do usuário.

Da mesma forma, segundo Mollerup (2013), o planejamento dos deslocamentos permite a sua subdivisão em seções sequenciais para estabelecer ações específicas - mover-se, buscar informação para subsidiar tal movimento e, em seguida, deslocar-se. Assim, entende-se que a identificação e a caracterização dos elementos de wayfinding, segundo a classificação proposta por Kevin Lynch (1997), podem ser associadas à configuração, ao sistema de informação e aos serviços característicos de cada uma das etapas da jornada do usuário. Tal entendimento facilitaria a análise de ambientes complexos, como é o caso do sistema metroferroviário.

Assim, optou-se por utilizar os métodos e técnicas da Avaliação Pós-Ocupação (APO) para avaliar a adequação da configuração e do sistema de informação das estações e dos trens e, simultaneamente, da estratégia de serviços ofertados pelo Metrô de São Paulo às pessoas com deficiência visual, considerando os fatores-chave da acessibilidade e a visão integrada dos elementos de wayfinding existentes nas diversas etapas da jornada do usuário.

Parte-se da premissa principal de que:

É possível melhorar as condições de acessibilidade das pessoas com deficiência visual a partir de uma visão integrada dos elementos de wayfinding e dos fatores-chave da acessibilidade existentes nas etapas da jornada do usuário do sistema metroferroviário.

Apresentam-se as seguintes premissas secundárias:

- A existência de ambientes complexos e não padronizados - como é o caso das estações e dos trens do sistema metroferroviário - determina e sustenta a adoção da estratégia de wayfinding como forma de auxiliar a percepção do espaço.

- As estações e os trens do sistema metroferroviário devem oferecer condições de acessibilidade para as pessoas com deficiência visual, independentemente da tipologia resultante dos métodos construtivos, do sistema de sinalização, da diversidade tecnológica dos elementos e equipamentos existentes e do período de início de operação. 


\subsection{Objetivos}

\subsubsection{Objetivo geral}

Desenvolver um conjunto de requisitos a partir de uma visão integrada dos elementos de wayfinding e dos fatores-chave de acessibilidade que possam viabilizar deslocamentos independentes por pessoas com deficiência visual no sistema metroferroviário. Esse conjunto de requisitos deve auxiliar a atuação de planejadores, projetistas e tomadores de decisão diante da complexidade dos ambientes e dos sistemas de informação da rede metroferroviária.

\subsubsection{Objetivos específicos}

Entre os objetivos específicos, destacam-se os que se apresentam a seguir:

- Coletar dados primários junto a pessoas com deficiência visual usuárias do serviço a fim de identificar os fatores que interferem ou impedem os deslocamentos das pessoas com deficiência visual com independência.

- Coletar dados comportamentais dos usuários com deficiência visual, relatos das pessoas-chave envolvidas no processo de prestação do serviço e relatos de avaliação de especialistas.

- Comparar os dados coletados junto aos usuários com deficiência visual com os demais dados coletados junto às pessoas-chave e especialistas, bem como com as observações realizadas para elaborar diagnóstico da acessibilidade nas etapas da jornada do usuário do transporte metroferroviário. Essa comparação permitirá identificar pontos positivos e oportunidades de melhoria para proporcionar o uso com independência por pessoas com deficiência visual.

- Sistematizar as informações relacionadas aos requisitos legais e normativos e às boas práticas identificadas em outros sistemas metroferroviários nacionais e internacionais.

- Validar os instrumentos para avaliação da acessibilidade na jornada do usuário do sistema metroferroviário a partir de métodos e técnicas da APO. 


\subsection{Caráter inovador da pesquisa}

Esta tese constitui um trabalho original de pesquisa, pois representa um avanço na área de conhecimento da APO. Cumpre destacar a relevância científica deste estudo, qual seja a aplicação de métodos e técnicas da APO na jornada do usuário do sistema metroferroviário incluindo o percurso de embarque na estação de origem, a viagem e o percurso de desembarque na estação de destino - para identificar os fatores que interferem e impactam os deslocamentos das pessoas com deficiência visual.

Outra inovação desta pesquisa está centrada na proposta de identificação e classificação dos elementos de wayfinding propostos por Lynch (1997) - caminhos, limites, marcadores, nós e marcos - e de associação destes elementos - originalmente aplicados às formas físicas das cidades - à configuração, à informação e aos serviços, segundo as etapas da jornada do usuário, para promover a compreensão dos ambientes construídos, notadamente dos ambientes complexos do sistema metroferroviário.

Por fim, propõe-se a construção de uma matriz para avaliação da acessibilidade no sistema metroferroviário, considerando simultaneamente temas (configuração, informação e serviço) e locais específicos (estação, interface trem-estação e trem) a partir da interpretação dos fatoreschave da acessibilidade nos sistemas de transportes propostos por Juncà (2011).

Ao considerar a jornada do usuário, cabe destacar também a relevância social e econômica do presente estudo. Ao promover a mobilidade das pessoas com deficiência visual segundo sua opção de deslocamento - com independência ou com auxílio -, permite-se que essas pessoas possam ter acesso a outros direitos, individuais e coletivos, promovendo e incentivando a consecução de seus objetivos a partir da sua inclusão na escola, no mercado de trabalho, no acesso aos serviços básicos e, consequentemente, na sociedade, possibilitando a redução das desigualdades sociais.

\subsection{Resultados esperados}

Ao identificar os fatores que impactam e interferem, de forma positiva ou negativa, o deslocamento das pessoas com deficiência visual na rede metroferroviária, busca-se propor recomendações para o desenvolvimento do projeto das instalações e dos serviços oferecidos como forma de melhorar a experiência de utilização e as condições de percepção e cognição 
das pessoas com deficiência visual nas diversas etapas da sua viagem. Entre os resultados esperados, destacam-se os que se seguem:

a) Obtenção de um conjunto de dados primários por meio da aplicação de um instrumento de coleta de dados sobre hábitos de viagem e aspectos positivos e negativos da jornada de pessoas com deficiência visual que utilizam as estações e os trens do Metrô de São Paulo;

b) Obtenção de um conjunto de dados primários sobre o processo de prestação do serviço de transporte metroferroviário, em especial das rotinas de trabalho dos profissionais envolvidos no atendimento às pessoas com deficiência visual;

c) Obtenção de um conjunto de dados primários sobre as diretrizes de projeto dos ambientes metroferroviários, em especial, sobre os requisitos de acessibilidade para as pessoas com deficiência visual;

d) Concepção da matriz para avaliação da acessibilidade do sistema metroferroviário;

e) Identificação e classificação dos elementos do wayfinding como forma de prover acessibilidade para pessoas com deficiência visual no sistema metroferroviário.

A partir de uma estratégia baseada na jornada do usuário nas estações e nos trens operados pelo Metrô na cidade de São Paulo, com diferentes graus de complexidade e condições de acessibilidade, busca-se verificar atitudes, valores e opiniões a respeito da satisfação dos usuários com deficiência visual em relação à configuração das instalações, informações e serviços oferecidos pela Companhia do Metropolitano de São Paulo (CMSP).

Pode-se então realimentar o processo de projeto dos ambientes (estações e trens), de concepção de serviços (procedimentos e atendimentos) e de concepção dos sistemas de informação, comunicação e orientação, como forma de melhorar a experiência de uso do sistema metroferroviário e, consequentemente, a mobilidade das pessoas com deficiência visual.

\subsection{Procedimentos metodológicos}

Considerando que os problemas abordados nesta pesquisa são de natureza interdisciplinar, entendeu-se que o uso de uma abordagem multimétodo proporcionaria uma melhor compreensão sobre o fenômeno da mobilidade das pessoas com deficiência visual em 
ambientes complexos, tais como as estações e trens do sistema metroferroviário. Para Charmaz (2009, p. 32), "determinados problemas de pesquisa indicam a utilização de diversas abordagens combinadas ou em sequência." A utilização de métodos qualitativos e quantitativos pode acontecer nas etapas de coleta, análise ou interpretação de dados ou mesmo em todas elas, possibilitando identificar eventuais relações entre variáveis e realizar generalizações (aspecto da pesquisa quantitativa). Ao mesmo tempo, permite analisar casos concretos em suas particularidades (traço da pesquisa qualitativa). É possível identificar padrões, testar teorias ou hipóteses e fazer revelações a partir de justificativas para os resultados obtidos. (GRAY, 2012)

Conforme afirmam Selltiz et al (1975 p. 59), "o planejamento da pesquisa precisa ser suficientemente flexível de modo a permitir a consideração de muitos aspectos diferentes de um fenômeno". A adoção de uma concepção pragmática ${ }^{1}$, característica da utilização de métodos mistos, enfatiza a preocupação com aplicações e soluções para os problemas apresentados, priorizando o que e como pesquisar. O pragmatismo permite ao pesquisador uma liberdade de escolha dos métodos, das técnicas e dos procedimentos que melhor se ajustem às suas necessidades, estabelecendo um propósito para a combinação de abordagens para coletar e analisar os dados, ou seja, uma base lógica para as razões pelas quais os dados quantitativos e qualitativos precisam ser combinados. Dessa forma, "o pragmatismo abre a porta para múltiplos métodos, diferentes concepções e diferentes suposições, assim como para diferentes formas de coleta e análise de dados" (CRESWELL, 2010 p.35).

Esta pesquisa envolveu a coleta sistemática de uma quantidade significativa de dados primários com o objetivo de descrever, comparar ou explicar conhecimentos, atitudes e comportamentos, utilizando como instrumentos principais questionários, entrevistas, observações estruturadas e identificação de melhores práticas. Foram priorizados aspectos relacionados à padronização a fim de eliminar possíveis erros das ferramentas de coleta de dados.

Os dados secundários coletados e utilizados referem-se, basicamente, à pesquisa bibliográfica sobre as instalações destinadas à mobilidade no sistema metroferroviário e aos aspectos

\footnotetext{
${ }^{1}$ O pragmatismo é uma doutrina filosófica segundo a qual a práxis (ação) é a fonte, o conteúdo, a medida e a meta de todo conhecimento e valor (BUNGE, M. Dicionário de Filosofia. São Paulo: Perspectiva, 2006, p. 291.)
} 
teóricos relacionados à acessibilidade, ao wayfinding, ao design de serviço e ao desenho universal.

\subsection{Estrutura da tese e descrição dos capítulos}

Este trabalho foi estruturado em nove capítulos inter-relacionados, sendo o primeiro capítulo esta introdução; os demais capítulos são estruturados conforme apresentado a seguir:

O segundo capítulo - fundamentação teórica - apresenta os conceitos relacionados ao design de serviço e ao desenho universal, cuja abrangência interdisciplinar centrada na experiência do usuário é complementada pelo embasamento legal e normativo relacionado à deficiência visual, sustentando a adoção da estratégia de wayfinding como forma de auxiliar a percepção do espaço em ambientes complexos e não padronizados, como é o caso das estações e dos trens do sistema metroferroviário.

O terceiro capítulo - o sistema metroferroviário contemporâneo - apresenta os elementos que caracterizam os sistemas sobre trilhos e os fatores-chave da acessibilidade apresentados na literatura internacional, tais como as tipologias das estações - decorrentes das combinações dos diferentes tipos de plataforma -, dos trens - resultantes dos recursos e das tecnologias disponíveis à época de sua especificação e produção -, da interface trem-estação consequência da combinação dos dois fatores anteriores, bem como de fatores intrínsecos à gestão da informação, comunicação e orientação e à gestão da prestação dos serviços. Este capítulo sintetiza ainda a evolução da acessibilidade no contexto internacional e no contexto nacional. Além disso, apresenta as características da rede sobre trilhos na Região Metropolitana de São Paulo (RMSP) e do Metrô de São Paulo, segundo os fatores-chave da acessibilidade.

O quarto capítulo - diagrama de serviços do sistema metroferroviário - apresenta os elementos envolvidos e a sequência de interações realizadas pelo usuário durante a utilização do sistema metroferroviário, sintetizadas na jornada do usuário. São apresentadas as pessoas envolvidas - classificadas como usuários, pessoas-chave e especialistas; os processos conjunto de procedimentos, mecanismos ou roteiros de serviço; as evidências físicas que caracterizam a jornada do usuário. Uma vez representados os elementos, vínculos e evidências relacionados ao serviço, torna-se possível visualizar as inter-relações e interdependências entre pessoas, processos e ambientes. 
O quinto capítulo - Avaliação Pós-Ocupação - apresenta as justificativas para a abordagem qualiquantitativa deste estudo, bem como para a aplicação dos métodos e técnicas da APO para obtenção de múltiplas fontes de evidência com o objetivo de corroborar fatos ou fenômenos a partir da triangulação dos dados coletados.

O sexto capítulo - aplicação dos instrumentos - apresenta as considerações sobre cada um dos instrumentos aplicados, seguidas da descrição do protocolo de aplicação, de registro e de análise dos dados coletados. São apresentados os principais dados obtidos junto ao públicoalvo e aos ambientes, possibilitando melhor compreensão dos relatos realizados pelas pessoas com deficiência visual.

O sétimo capítulo - diagnóstico - apresenta, para cada uma das etapas da jornada do usuário, a sua descrição, os métodos e técnicas aplicados, as melhores práticas identificadas junto a outras empresas operadoras de transporte sobre trilhos nacionais e internacionais, os requisitos normativos estabelecidos pelas normas técnicas nacionais e a situação verificada no Metrô de São Paulo, seguidos da avaliação pelos usuários, pessoas-chave e especialistas. Ao final, são apresentados os elementos de wayfinding associados à configuração, informação e serviços de cada etapa da jornada do usuário. Ao final de cada etapa, apresenta-se a síntese do diagnóstico, associando as descobertas às ideias centrais identificadas e aos pontos-chave da acessibilidade no sistema metroferroviário.

O oitavo capítulo - recomendações - apresenta a síntese das recomendações segundo a matriz de avaliação da acessibilidade das redes de transporte, contendo sugestões de melhorias que podem possibilitar o estabelecimento de novos requisitos de projeto relacionados à configuração, informação e gestão do serviço - seja na edificação, na interface ou no veículo - de forma a auxiliar a tomada de decisão dos projetistas e gestores.

O nono capítulo - considerações finais - destaca a hipótese, verificando sua confirmação ou refutação, bem como o alcance dos objetivos inicialmente propostos. Tais considerações foram fundamentadas no texto da tese, consolidando as informações obtidas ao longo deste estudo para serem comparadas com outras investigações e com a opinião de especialistas no tema. Apresentam-se também as possibilidades de extensão deste trabalho. 


\section{FUNDAMENTAÇÃO TEÓRICA}

\subsection{O design de serviços centrado na jornada do usuário}

Serviços são ações e processos produzidos e consumidos simultaneamente e continuamente por meio da interação direta entre o provedor e o consumidor. Como não são tangíveis, não podem ser padronizados, estocados ou inventariados (ZEITHAML; BITNER, 2003). A simultaneidade entre a produção e o consumo implica a presença do cliente na unidade de produção, ou seja, ele torna-se parte do processo de produção do serviço. Dessa forma, três elementos impactam de forma significativa a percepção da qualidade do serviço prestado: evidência física, pessoas e processo.

Evidência física: ambiente no qual o serviço é executado e onde a empresa interage com o cliente, assim como qualquer componente tangível que facilite o desempenho ou a comunicação do serviço.

Pessoas: todos os agentes humanos que desempenham um papel no processo de execução de um serviço e, nesse sentido, influenciam as percepções do comprador; nominalmente, os funcionários da empresa, o cliente e outros clientes no ambiente de serviço.

Processo: procedimentos, mecanismos e o roteiro efetivo de atividades através dos quais o serviço é executado - os sistemas de execução e prestação dos serviços. (ZEITHAML; BITNER, 2003 p. 41-42).

A satisfação do usuário do serviço de transporte é o resultado da diferença entre a sua expectativa e a sua experiência em relação às evidências físicas do ambiente de serviço, ao relacionamento entre as pessoas - usuários ou funcionários - e à implicação de ambos no processo (Quadro 1). 
Quadro 1 - Evidências do serviço de transporte.

\begin{tabular}{cl}
\hline Aspectos & Elementos \\
\hline Ambiente & $\begin{array}{l}\text { Estações (áreas internas e externas das edificações, áreas de circulação ou de } \\
\text { embarque/desembarque) e trens (meios para a viagem propriamente dita) conferem } \\
\text { tangibilidade aos serviços de transporte. }\end{array}$ \\
\hline Pessoas & $\begin{array}{l}\text { Relação entre os usuários com deficiência e os demais usuários e funcionários; } \\
\text { aparência e atitude dos funcionários de contato - responsáveis pelo auxílio nos } \\
\text { deslocamentos - e comportamento dos demais usuários presentes no processo de } \\
\text { produção e consumo dos serviços. }\end{array}$ \\
\hline
\end{tabular}

Processo Padronização e customização do serviço, incluindo o planejamento, os procedimentos e o roteiro operacional.

Fonte: Elaborado pela pesquisadora, 2012.

O “diagrama de serviços" identifica as evidências físicas (ambiente), as ações dos clientes (pessoas) - seja na linha de frente, entre clientes e funcionários, seja na retaguarda, entre funcionários - e as regras, procedimentos e roteiros de apoio (processos) de um determinado serviço (ZEITHAML; BITNER, 2003; FITZSIMMONS; FITZSIMMONS, 2005). Enquanto a linha de interação representa o ponto de contato entre clientes e funcionários, a linha de visibilidade representa o ponto de separação entre os processos desenvolvidos a partir da interação direta com o cliente e aqueles desenvolvidos fora do seu alcance; a linha de interação interna garante a disponibilidade das instalações e a padronização dos serviços (Figura 1).

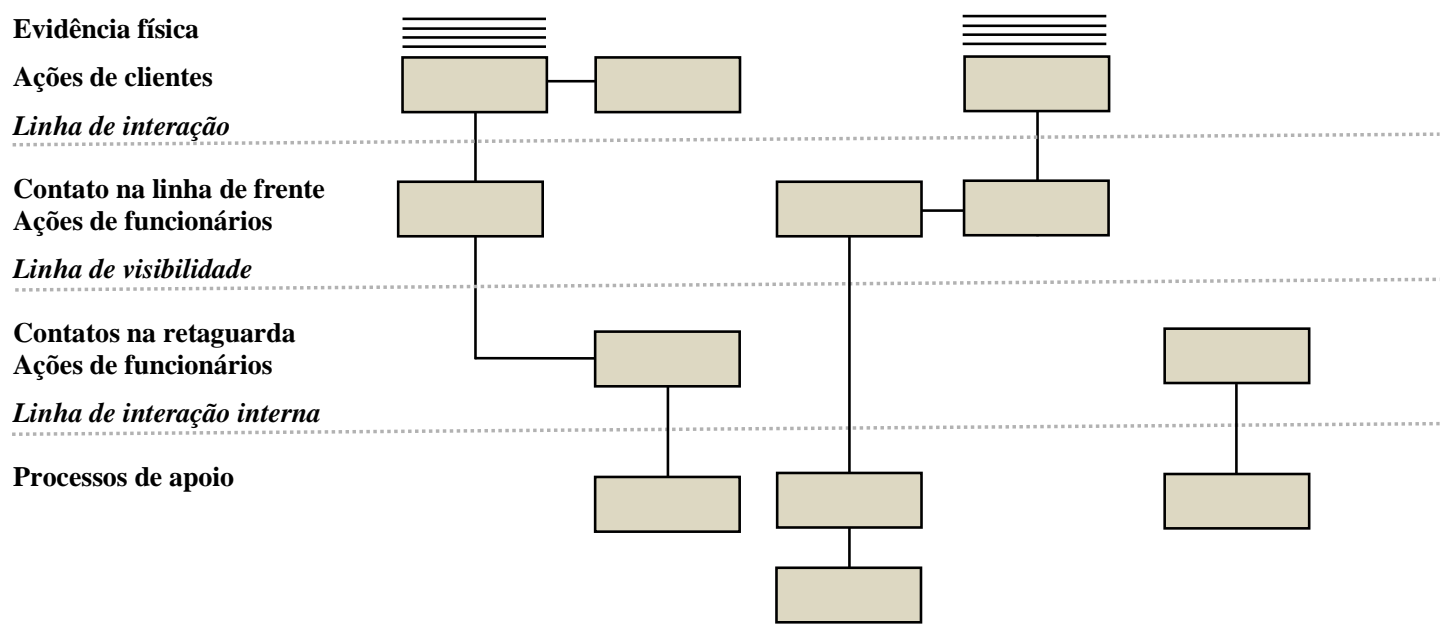

Figura 1 - Componentes do diagrama de serviços Fonte: Zeithaml e Bitner, 2003, p. 194. 
O design de serviços é uma abordagem interdisciplinar que inclui e conecta diferentes áreas do conhecimento, tais como engenharia, tecnologia da informação, arquitetura e psicologia, entre outras (STICKDORN; SCHNEIDER, 2012). A primeira referência a design de serviços é atribuída ao texto de Lynn G. Shostack: "Como desenhar um serviço", publicado em 1982 pelo European Journal of Marketing. Shostack ${ }^{2}$ (1982, apud Viladàs, 2010 p. 30-38) afirma que o serviço, tal como um processo, pode ser representado por elementos, vínculos e evidências, não somente para compreender seu funcionamento, mas também para reorganizar, modelar, testar e replicar.

Numa visão mais holística - e também estratégica -, o serviço deve ser concebido, planejado e idealizado cuidadosamente, em toda sua extensão, tendo em conta as inter-relações entre clientes, provedores e demais partes interessadas, incluindo os aspectos tangíveis e os intangíveis. A jornada do usuário consiste na representação gráfica das etapas de relacionamento do cliente com o serviço, percorridas antes, durante e depois da sua utilização, desde o momento em que se decide pela aquisição de um serviço até sua próxima utilização (VILADÀS, 2010; STICKDORN E SCHNEIDER, 2012; VIANNA ET AL, 2013). Essa técnica, também conhecida como auditoria da experiência do usuário (MARTIN; HANINGTON, 2012), é utilizada quando há necessidade de se ter uma visão abrangente e detalhada para se compreender, simultaneamente, o ciclo completo e cada uma das etapas do relacionamento do usuário com a empresa. Além disso, presta-se a identificar os problemas e as possibilidades de solução, analisar as expectativas, as emoções e o grau de satisfação em cada uma das etapas bem como as intervenções pontuais que poderão impactar essa relação.

Os momentos vivenciados por um passageiro durante a utilização do serviço de transporte oferecido pela empresa operadora são chamados pontos de interação, que, de forma sequenciada, constituem a jornada do usuário do serviço de transporte. As etapas da jornada do usuário são identificadas através dos pontos de contato - presenciais ou virtuais - do cliente com o prestador do serviço. As empresas operadoras do serviço representam esses momentos de forma gráfica com o objetivo de fazer a gestão e adequar seus padrões de serviço (Figuras 2 e 3). No caso específico do serviço metroferroviário, essas etapas estão associadas aos deslocamentos realizados pelos usuários durante o embarque e o desembarque.

\footnotetext{
${ }^{2}$ SHOSTACK, G. L. (1982) How to Design a Service. European Journal of Marketing 16 (1), 49.
} 


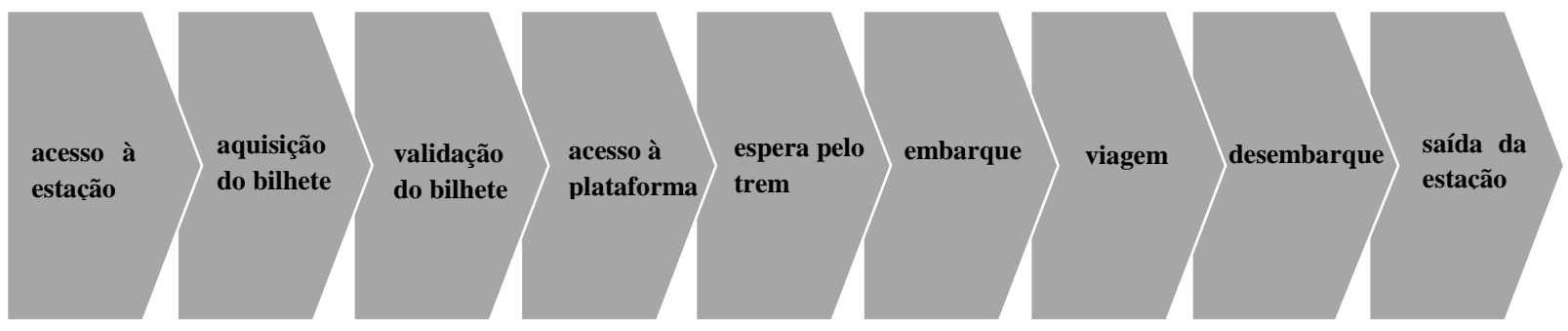

Figura 2 - Ciclo de serviço CPTM.

Fonte: Elaborado pela pesquisadora a partir do Guia de Prestação de Serviço - Trem Metropolitano - CPTM, 2005.

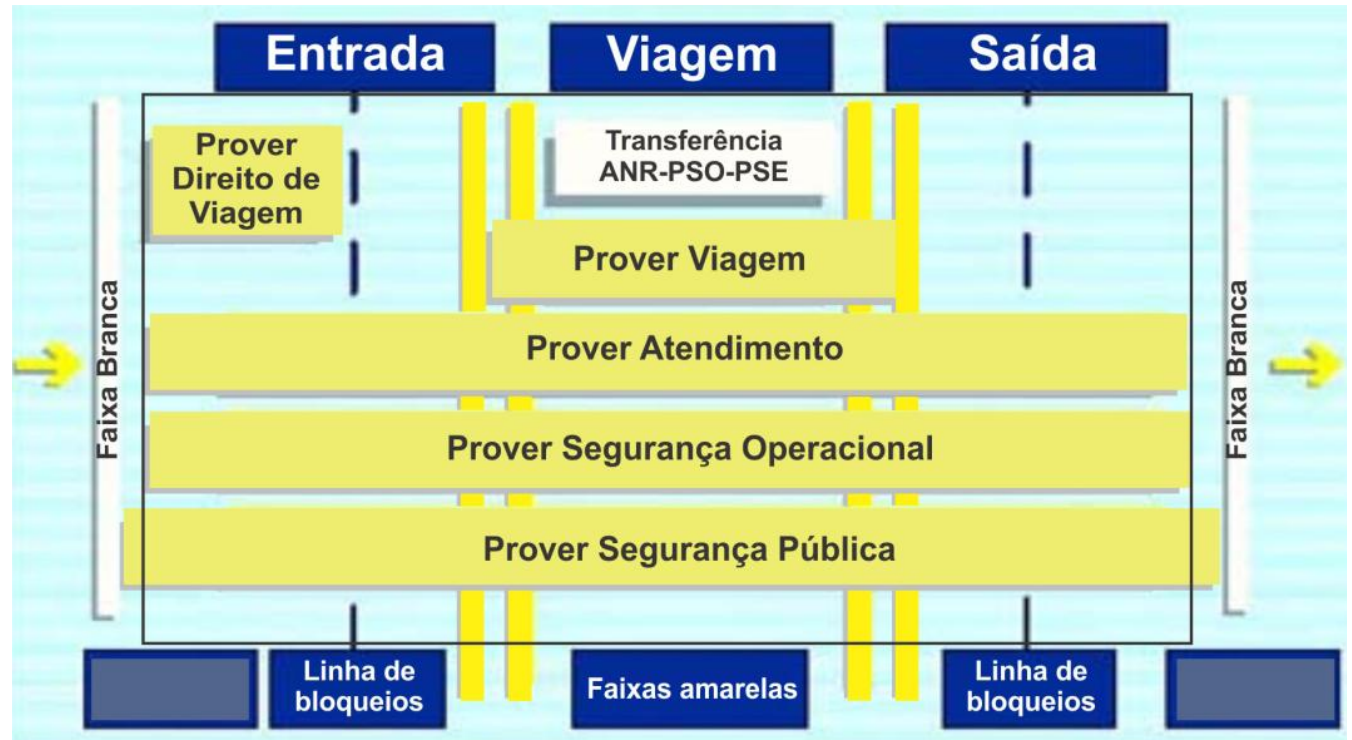

Figura 3 - Ciclo de serviço CMSP.

Fonte:CMSP, 2014 p.128.

A jornada do usuário pode considerar a existência de um determinado segmento de usuários e sua relação com o serviço prestado, possibilitando a criação de soluções específicas, direcionadas para esse segmento, ou uma solução única, que atenda às necessidades desse grupo e dos demais usuários simultaneamente. Devem ser consideradas as expectativas e o grau de satisfação do usuário (HOFFMAN; BATESON, 2003; CORRÊA; CAON, 2002), bem como atendidas as exigências normativas e legais, orientando a concepção e a gestão do serviço e do atendimento preferencial (AENOR, 2011; BRASIL, 2004).

A abordagem metodológica baseada no design de serviços trata os aspectos de complexidade decorrentes da abordagem centrada no usuário, priorizando o ser humano e o cidadão, usuários dos serviços prestados pelas organizações e pelo poder público, respectivamente. Além de permitir maior compreensão da complexidade intrínseca aos serviços públicos, o design de serviços possibilita - a partir do registro do processo, das evidências observadas, dos problemas relatados, das oportunidades identificadas - a criação, a reformulação e a 
implementação de inovações para promover a satisfação do usuário sem ignorar a eficiência requerida pelo prestador de serviço.

A abordagem centrada no ser humano faz de nossas observações fontes poderosas de inspiração, sempre procurando, por meio da empatia, criar soluções para pessoas reais, para problemas concretos, para necessidades humanas percebidas, com base no feedback recebido dos usuários finais e outros stakeholders (KELLEY; KELLEY, 2014). Segundo Maffei ${ }^{3}$ (2005, apud Viladàs, 2010 p. 42), "a inovação dos serviços é realizada através de um exercício exaustivo de observação do usuário: quanto mais grupos e inter-relações se dão em um determinado serviço, mais complicada é sua definição.” A filosofia do design centrado no usuário pressupõe que o usuário conhece suas tarefas, metas e objetivos e, portanto, sabe o que é melhor para si a partir de suas características, limitações e potencialidades. Trata-se de uma filosofia baseada nas necessidades e nos interesses da pessoa que utiliza os ambientes, produtos e serviços, conferindo atenção especial à sua compreensão e fácil utilização, assegurando-se de que o usuário saiba o que deve ser feito e, ao fazê-lo, tenha consciência do que acontecerá (NORMAN, 2006).

\subsubsection{Desenho universal}

O desenho universal é uma diretriz para a concepção de produtos, ambientes e serviços. Consiste em uma combinação de informação, comunicação e política, centrada na experiência do usuário, para ser utilizada por uma gama variada de pessoas, ou seja, tendo "todos" como referência. Essa abordagem integral e inovadora constitui uma diretriz ética e criativa para todos os profissionais responsáveis por tarefas de planejamento urbano, projeto, gestão e administração, bem como para os políticos. Segundo Norman (2008), é um desafio para o qual vale a pena o esforço, pois conceber produtos, ambientes ou serviços para pessoas com deficiência acaba sendo, invariavelmente, melhor para todos. Para tanto, é imprescindível que os profissionais envolvidos no planejamento e projeto tomem consciência da ampla diversidade que compõe a sociedade, não somente relacionada às características antropométricas, como também às diferenças culturais, idiomáticas, religiosas, funcionais, entre outras.

\footnotetext{
${ }^{3}$ MAFFEI, S.; MAGER, B.; SANGIORGI, D. (2005) Innovation through service design. From research and theory to a network of practice. A user's driven perspective., Helsinki: Joining Forces, University of Art and Design, 2005. p.22-24.
} 
Galàn (2011) refere-se à expressão "desenho para todos", que teve sua origem tanto no funcionalismo escandinavo dos anos 1950 como no desenho ergonômico dos anos 1960, assim como nas políticas escandinavas de bem-estar. Essas orientações fundamentam-se no conceito de uma sociedade para todos e no enfoque ideológico de igualdade de oportunidade para pessoas com deficiência preconizado pela Organização das Nações Unidas. O "desenho para todos" é o conceito que tem como base a diversidade humana, a inclusão social e a igualdade, com o objetivo de promover ações para tornar possível a todas as pessoas dispor de igualdade de oportunidades, maximizando o número de usuários que podem lograr êxito ao interagirem com ambientes, produtos ou serviços.

Conceitos similares foram sendo desenvolvidos em outros lugares. Nos Estados Unidos, foi cunhada a expressão "desenho universal”, enquanto o Reino Unido utilizou a designação “desenho inclusivo.” A expressão desenho universal foi utilizada pela primeira vez pelo arquiteto Ronald L. Mace. A Escola de Design da Universidade da Carolina do Norte desenvolveu sete princípios com o intuito de sistematizar os conceitos do desenho universal (Quadro 2), facilitando sua adoção desde a fase inicial do processo de projeto de ambientes, mobiliário, equipamentos e serviços. Além disso, esses princípios maximizaram possibilidades de participação da sociedade bem como minimizaram os custos de adequações posteriores. 
Quadro 2 - Princípios do desenho universal.

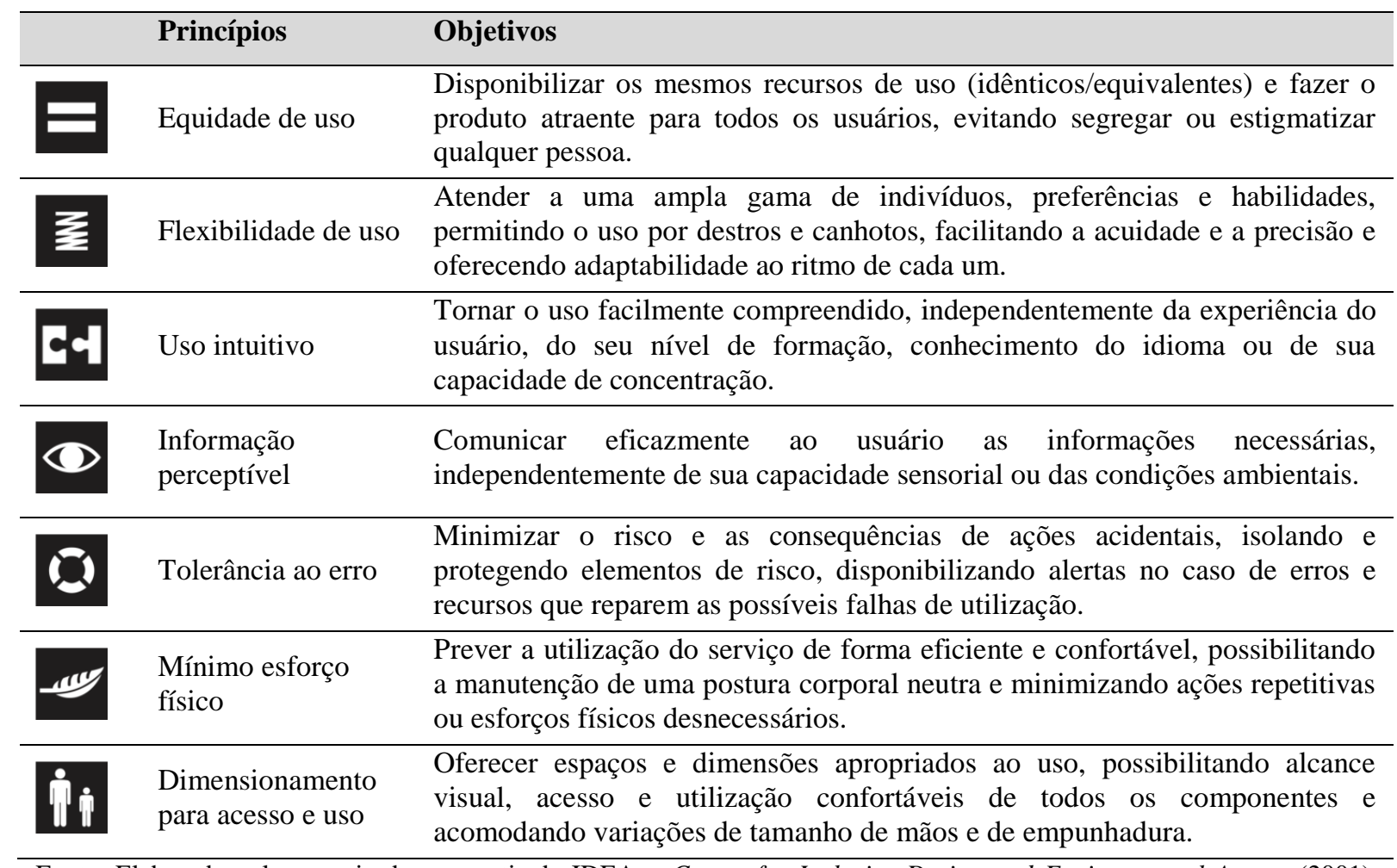

Fonte: Elaborado pela pesquisadora a partir de IDEA - Center for Inclusive Design and Environmental Access (2001) e Cambiaghi (2007).

Estudos acadêmicos, publicações e experiências vêm sendo divulgados ao público, popularizando o benefício do desenho universal para todas as pessoas, em especial para a sociedade em processo de envelhecimento, desmitificando a acessibilidade como benefício exclusivo para pessoas com deficiência (CAMBIAGHI, 2007; SANTOS FILHO, 2010; LOPES; BURJATO, 2010; ORNSTEIN; PRADO; LOPES, 2010).

\subsubsection{Aspectos legais e normativos}

O Decreto Federal n 5.296/2004 definiu a expressão desenho universal da seguinte forma:

[...] concepção de espaços, artefatos e produtos que visam atender simultaneamente todas as pessoas, com diferentes características antropométricas e sensoriais, de forma autônoma, segura e confortável, constituindo-se nos elementos ou soluções que compõem a acessibilidade (BRASIL, 2004).

Nos últimos anos, foram registradas melhorias em todos os âmbitos, inclusive do termo acessibilidade. Inicialmente apresentado como um conceito relacionado à eliminação de barreiras arquitetônicas, como algo físico existente que deveria ser modificado ou eliminado, tal conceito ampliou-se e passou a abranger questões urbanísticas, de transporte e de comunicação. Mais recentemente, a acessibilidade adquiriu o significado de qualidade do 
meio físico onde é possível chegar e circular com segurança, utilizar seus recursos, relacionarse e comunicar-se com o entorno e com as pessoas. Trata-se de melhorar a qualidade de vida de todas as pessoas, em toda a sociedade, em todos os lugares, seja em espaços naturais, nos meios de transporte, nos sistemas de comunicação e informação, em áreas rurais, nas pequenas, médias e grandes cidades.

O Decreto Federal no 6.949/2009 (BRASIL, 2009) promulgou a Convenção Internacional sobre os Direitos das Pessoas com Deficiência e seu Protocolo Facultativo, assinado pelo Brasil e outros 100 países. Assim, o Brasil reconhece e passa a adotar os princípios, definições e obrigações contidas na Convenção, inclusive a definição de pessoas com deficiência:

Pessoas com deficiência são aquelas que têm impedimentos de longo prazo de natureza física, mental, intelectual ou sensorial, os quais, em interação com diversas barreiras, podem obstruir sua participação plena e efetiva na sociedade em igualdades de condições com as demais pessoas (BRASIL, 2009).

Segundo o Decreto Federal n $n^{0}$ 5.296/2004 (BRASIL, 2004), a pessoa com deficiência "possui limitação ou incapacidade para o desempenho de atividade", e a acessibilidade deve proporcionar

condição para utilização, com segurança e autonomia, total ou assistida, dos espaços, mobiliários e equipamentos urbanos, das edificações, dos serviços de transporte e dos dispositivos, sistemas e meios de comunicação e informação, por pessoa com deficiência ou mobilidade reduzida (BRASIL, 2004).

Ainda segundo esse mesmo decreto, as empresas prestadoras de serviços públicos devem “dispensar atendimento prioritário" às pessoas com deficiência ou mobilidade reduzida, caracterizado por seu caráter diferenciado e imediato:

$\S 1^{\underline{o}} \mathrm{O}$ tratamento diferenciado inclui, dentre outros:

I - assentos de uso preferencial sinalizados, espaços e instalações acessíveis;

II - mobiliário de recepção e atendimento obrigatoriamente adaptado à altura e à condição física de pessoas em cadeira de rodas, conforme estabelecido nas normas técnicas de acessibilidade da ABNT;

III - serviços de atendimento para pessoas com deficiência auditiva, prestado por intérpretes ou pessoas capacitadas em Língua Brasileira de Sinais - LIBRAS e no trato com aquelas que não se comuniquem em LIBRAS, e para pessoas surdo-cegas, prestado por guias-intérpretes ou pessoas capacitadas neste tipo de atendimento;

IV - pessoal capacitado para prestar atendimento às pessoas com deficiência visual, mental e múltipla, bem como às pessoas idosas; 
V - disponibilidade de área especial para embarque e desembarque de pessoa portadora de deficiência ou com mobilidade reduzida;

VI - sinalização ambiental para orientação das pessoas referidas no art. 5ㅜㅜㅇ

VII - divulgação, em lugar visível, do direito de atendimento prioritário das pessoas portadoras de deficiência ou com mobilidade reduzida;

VIII - admissão de entrada e permanência de cão-guia ou cão-guia de acompanhamento junto de pessoa portadora de deficiência ou de treinador nos locais dispostos no caput do art. 5ำ bem como nas demais edificações de uso público e naquelas de uso coletivo, mediante apresentação da carteira de vacina atualizada do animal; e

IX - a existência de local de atendimento específico para as pessoas referidas no art. $5^{\circ}$. (BRASIL, 2004).

A evolução da legislação federal, estabelecendo políticas públicas voltadas para os idosos, desde os anos 1990, e para as pessoas com deficiência, desde 2000, vem acompanhada de programas e políticas públicas visando à inclusão social e à eliminação de barreiras no ambiente urbano e nos serviços oferecidos à população, amparada por recomendações estabelecidas pela Associação Brasileira de Normas Técnicas - ABNT.

Pessoas com deficiência dependem mais diretamente das condições de acessibilidade do ambiente para facilitar e tornar mais seguro o uso das instalações e dos serviços oferecidos. Para pessoas com deficiência visual, cabe destacar a importância da padronização de soluções e a possibilidade de customização de modificações, incluindo melhorias opcionais, inovações tecnológicas ou modificações ao longo do tempo, sem custos excessivos.

O princípio da equidade no acesso ao transporte público coletivo e no uso dos espaços públicos de circulação, vias e logradouros, previsto na Lei no 12.587/2012 (BRASIL, 2012), também conhecida como Lei da Mobilidade Urbana, implica o atendimento e a inclusão das pessoas com deficiência ou com mobilidade reduzida em seus deslocamentos para a realização de suas atividades diárias. A acessibilidade é fator essencial para que as cidades sejam viáveis econômica, social e ambientalmente, com impactos positivos na comunidade, a partir de ações sistêmicas e integradas relacionadas ao planejamento dos transportes e ao uso do espaço urbano. A acessibilidade no meio urbano reflete a qualidade de vida de uma sociedade, sendo impactada por diversos fatores: o tratamento físico dado às vias ou aos passeios, a existência de transporte público, a qualidade dos serviços, a tarifa, a sinalização e os sistemas de controle de acesso. É o meio urbano que, atualmente, impõe restrições ou confere autonomia às pessoas durante seus deslocamentos diários (JUNCÁ, 2005). As 
políticas públicas devem reconhecer a diversidade da composição da população e, no caso da mobilidade, as necessidades básicas urbanas (BRASIL, 2004, 2009, 2012; FÁVERO, 2004).

No Brasil, o Decreto Federal $n^{\circ} 5.296 / 2004$ determinou que as empresas de transporte apresentassem planos de adaptação dos sistemas existentes e definiu o horizonte de 2014 para conclusão das intervenções necessárias (BRASIL, 2004). A promoção da acessibilidade nos sistemas de transporte público concentrou-se, inicialmente, no acesso de pessoas em cadeira de rodas aos veículos, fato que impediu uma abordagem adequada e abrangente que atingisse pessoas com outros tipos de deficiência ou mesmo apontasse a necessidade de uma rede integrada e acessível de transporte, concebida a partir das calçadas urbanas e incluindo todos os modos de transporte, de baixa, média e alta capacidade (MINISTÉRIO DAS CIDADES, 2006). A acessibilidade inclui a percepção do usuário quanto às possibilidades de conexão com outros modos de transportes para atingir o destino final. A escolha de uma forma de deslocamento considera, entre diferentes fatores, as condições de deslocamento.

O tema acessibilidade foi por muito tempo tratado exclusivamente na legislação e no conjunto de normas da Associação Brasileira de Normas Técnicas - ABNT -, em especial nas normas relativas à edificação, ao transporte e à comunicação. Os requisitos de acessibilidade vigentes, estabelecidos na legislação e no conjunto de normas da Associação Brasileira de Normas Técnicas - ABNT -, buscam proporcionar autonomia às pessoas com deficiência, conforme ilustram as normas elencadas a seguir:

- NBR 9050 - Acessibilidade a edificações, mobiliário, espaços e equipamentos urbanos - estabelece critérios e parâmetros técnicos a serem observados quando do projeto, construção, instalação e adaptação de edificações, mobiliário, espaços e equipamentos urbanos às condições de acessibilidade (ABNT, 2004);

- NBR 14021 - Transporte - Acessibilidade no sistema de trem urbano ou metropolitano - estabelece os critérios e parâmetros técnicos a serem observados para acessibilidade no sistema de trem urbano ou metropolitano, de acordo com os preceitos do Desenho Universal. (ABNT, 2005);

- NBR 15250 - Acessibilidade em caixa de autoatendimento bancário - fixa os critérios e parâmetros técnicos de acessibilidade a serem observados quando do projeto, construção, instalação e localização de equipamentos destinados à prestação de informações e serviços de autoatendimento bancário. (ABNT, 2005); 
- NBR 15290 - Acessibilidade em comunicação na televisão - estabelece diretrizes gerais a serem observadas para acessibilidade em comunicação por televisão, consideradas as diversas condições de percepção e cognição, com ou sem a ajuda de sistema assistivo ou outro que complemente necessidades individuais (ABNT, 2005);

- NBR 15599 - Acessibilidade - Comunicação na prestação de serviços - apresenta diretrizes gerais a serem observadas para acessibilidade em comunicação na prestação de serviços, consideradas as diversas condições de percepção e cognição, com ou sem a ajuda de tecnologia assistiva ou outra que complemente necessidades individuais (ABNT, 2008);

- NM 313 - Elevadores de passageiros - Elevadores de passageiros - estabelece requisitos de segurança para construção e instalação e requisitos particulares para a acessibilidade das pessoas, incluindo pessoas com deficiência (ABNT, 2007);

- NM 195 - Escadas rolantes e esteiras rolantes - Requisitos de segurança para construção e instalação: estabelece requisitos para instalação e manutenção de escadas e esteiras rolantes (ABNT, 1999).

A NBR 14021 (ABNT, 2005) estabelece os requisitos de configuração e sinalização para as estações e trens dos sistemas urbano e metropolitano e deve ser aplicada tanto para a construção de novos sistemas como para a adequação dos sistemas existentes (Figura 4). O conceito de acessibilidade, quando aplicado aos sistemas de trens urbanos e metropolitanos considera a circulação autônoma e independente do usuário durante os deslocamentos nas estações e trens - ambientes externos e internos. Contudo, em situações de anormalidade, a norma determina a adoção de estratégias pela empresa operadora, de forma a garantir auxílio e proporcionar circulação acompanhada ou assistida em vias e túneis. 


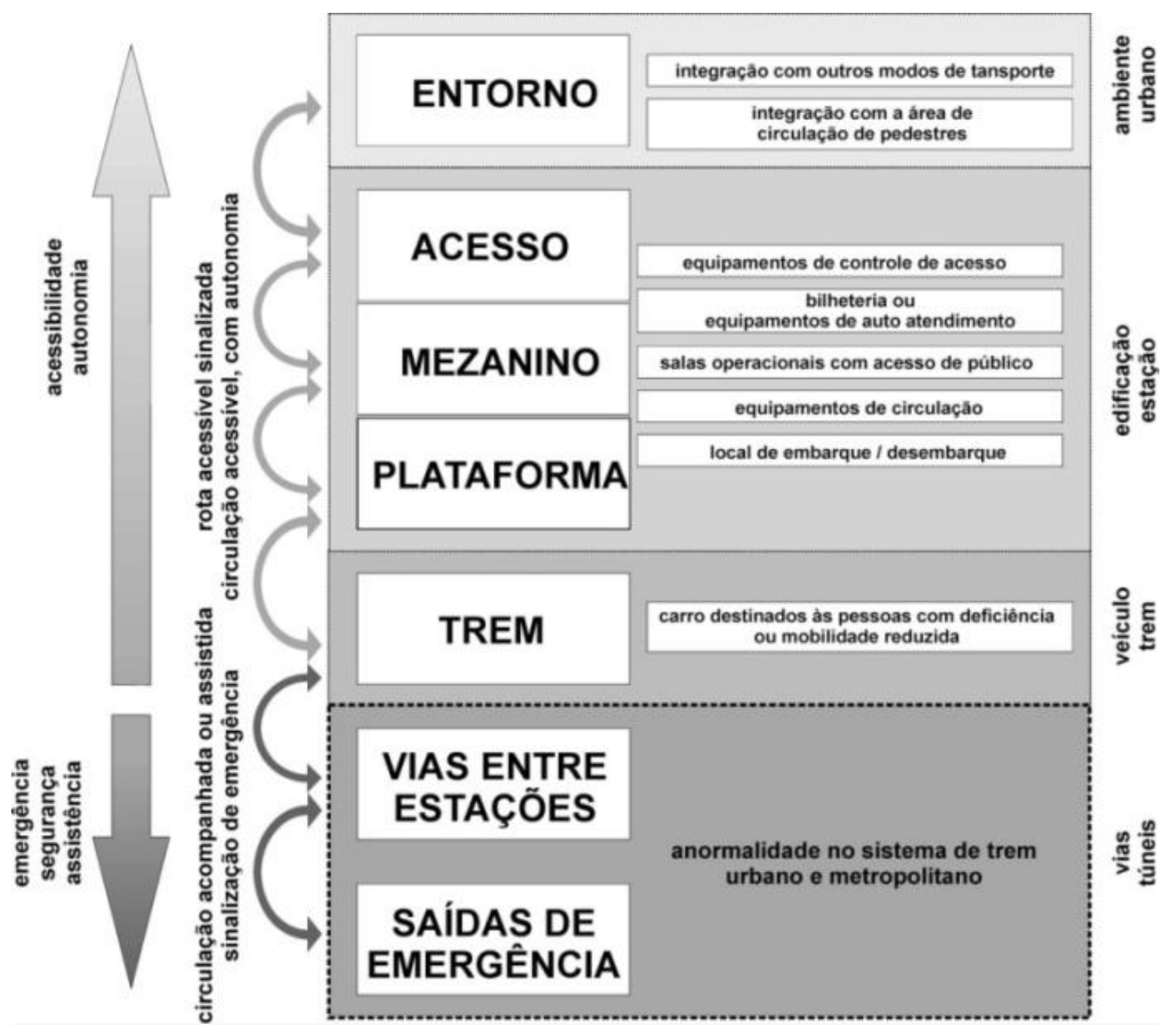

Figura 4 - Conceito de acessibilidade aplicado ao sistema de trens urbanos e metropolitanos. Fonte: BARBOSA, 2006, p.71.

As normas técnicas de acessibilidade nos transportes estabelecem requisitos de acessibilidade para cada um dos modos de transporte, individualmente; porém, não há uma norma específica que estabeleça requisitos para facilitar a conexão intermodal gerando dificuldades adicionais para os profissionais uma vez que,

Do ponto de vista da normatização, isto exige que o conjunto das normas de acessibilidade seja levado em conta, e não as normas isoladamente. Se isto é uma tarefa árdua, deve-se lembrar que o planejamento urbano é um assunto complexo, já de per si exigindo uma grande gama de interdisciplinaridade (SANTOS; BARBOSA, 2012, p.245).

O potencial para a intermodalidade dos transportes requer atenção para a questão da conexão entre os deslocamentos a pé e os diferentes modos de transporte, exigindo uma visão sistêmica para as soluções de acessibilidade propostas para a configuração e a sinalização de calçadas, estacionamentos, elevadores, terminais de transporte e veículos. 


\subsection{Deficiência visual}

A visão consiste na soma de várias funções: acuidade visual (aquilo que se enxerga a determinada distância); campo visual (amplitude da área alcançada pela visão); visão cromática (identificação de cores); percepção de profundidade (estereopsia), entre outras funções. A deficiência visual consiste na perda ou redução da capacidade funcional da visão em ambos os olhos, de origem congênito-hereditária ou adquirida, em caráter definitivo e, portanto, não pode ser melhorada ou corrigida com o uso de lentes, tratamento clínico ou cirúrgico. Por meio da visão, as pessoas estabelecem suas primeiras relações com o ambiente, identificando formas, tamanho, distância, posição e localização dos objetos, unificando, estruturando, organizando e integrando as demais percepções, dando significado às imagens observadas. Contudo,

A formação da imagem visual deriva de uma rede integrada, da qual os olhos são apenas uma parte, envolvendo aspectos fisiológicos, sensórios-motores, perceptivos e emocionais e todo aparelho visual deve estar íntegro, para que a visão se processe normalmente. (SIAULYS, 2006)

A falta da visão na infância acarreta perdas nos seguintes aspectos: vivência de experiências, formação de conceitos, orientação e mobilidade, interação com o ambiente e acesso às informações de alerta ou de perigo. (MACHADO, 2003).

As pessoas com deficiência visual apresentam outras características que as diferenciam entre si. Essas diferenças vão além do grau de dificuldade para enxergar. O nível de autonomia desse segmento pode ser afetado por fatores diversos, entre os quais se destacam o período em que adquiriram a deficiência - no nascimento, na infância, na fase adulta (SAMPAIO; HADDAD; KARA-JOSÉ, 2001; HADDAD, 2012); o acesso a programas de reabilitação (MACHADO, 2003; SIAULYS, 2006; MEC, 2006); a participação em treinamentos de orientação e mobilidade (FELLIPE; FELLIPE, 1997; FELLIPE, 2001; GARCIA, 2003; MASI, 2003; LORA, 2003); o aprendizado do sistema de escrita em Braille; o uso de guia vidente ou cão-guia (CASALS, 2007) e o uso de tecnologias assistivas ou de sistemas informatizados ou eletrônicos (CORDE, 2007; BERSCH, 2008).

A cegueira pode ser definida como a ausência ou a perda total de visão, da capacidade de perceber a luz, a cor e a forma dos objetos. A percepção espacial das pessoas cegas pode ser auxiliada pelo uso dos sentidos perceptivos - audição, paladar, olfato, háptico (tato ativo) e 
orientação $\left(\right.$ GIBSON$^{4}, 1966$ apud DISCHINGER, BINS ELY, 2010) - de forma integrada, facilitando a interação com o ambiente, atribuindo sentidos e significados às novas descobertas.

[...] pessoas com deficiência visual têm sua compreensão espacial baseada na combinação das informações provenientes de seus sistemas perceptivos operantes utilizando, principalmente, o tato exploratório, o movimento orientado e a audição seletiva para identificação de estímulos. Neste processo, a integração das informações oriundas das diversas fontes sensoriais e seu registro temporal consciente é muito importante para a aquisição de significados válidos. (DISCHINGER; BINS ELY, 2010, p.97)

Segundo Molina (2011) o sistema visual recebe e interpreta mais de $80 \%$ dos estímulos do ambiente de forma instantânea e imediata. Dessa forma, para poder interagir com o ambiente as pessoas com deficiência visual necessitam fazer uso de outros sentidos. Isso não implica o desenvolvimento compensatório dos outros sentidos, o que leva comumente à crença de que cegos têm maior audição ou possuem sexto sentido. Os sentidos têm as mesmas características e potencialidades para todas as pessoas; no caso das pessoas com deficiência visual, o canal de informação não é visual, pois o referencial perceptivo utiliza os sentidos remanescentes, e elas recorrem a informações táteis, auditivas, sinestésicas e olfativas com mais frequência para guardar na memória os esquemas de que precisam para construir suas pistas e interagir com o mundo.

\begin{abstract}
A ativação contínua desses sentidos faz com que a pessoa com deficiência visual crie habilidades e desenvolva processos particulares de codificação que formam imagens mentais, que serão ampliadas conforme o grau e a pluralidade de experiências ao longo da vida. São as experiências significativas, contextualizadas, vividas e internalizadas pela pessoa com deficiência visual que formam a imagem mental de que ela necessita. (MOLINA, 2011)
\end{abstract}

Hall (2005) afirma que os receptores remotos - olhos, ouvidos e nariz - se ocupam do exame de objetos distantes, enquanto que os receptores imediatos - tato, pele, músculos e membranas - são usados para examinar o mundo de perto. Comparando a percepção dos espaços tátil e visual, Hall (2005) cita o artista Braque: “O espaço tátil separa o observador dos objetos e o espaço visual separa os objetos uns dos outros."

A audição é o sentido que funciona a longa distância, permitindo à pessoa com deficiência visual a percepção da distância e da profundidade dos ambientes, contribuindo para sua orientação e para o estabelecimento de relações espaciais.

\footnotetext{
${ }^{4}$ GIBSON, James. The senses considered as perceptual systems. Boston: Houhtan Mifflin Company, 1966.
} 


\begin{abstract}
A audição seletiva permite obter informação sobre eventos dinâmicos, tais como atividades humanas, e sobre configurações espaciais, utilizando a técnica de uso pendular da bengala que, através de reflexão sonora, informa sobre a qualidade dos diferentes materiais, a presença de planos verticais/horizontais e suas interrupções (aberturas). Além disso, a audição é o principal canal sensorial para a obtenção de informações espaciais distantes do indivíduo. (DISCHINGER, 2006 ${ }^{5}$, apud DISCHINGER; BINS ELY, 2010 p.97)
\end{abstract}

Segundo Lora (2003), a audição envolve outras quatro funções:

a) ecolocalização - possibilita a aquisição de informações a respeito da dimensão dos ambientes, da presença de objetos, direção dos corredores ou passagens estreitas e outros detalhes cuja percepção varia de pessoa para pessoa;

b) localização dos sons - permite determinar a localização, a distância e a intensidade da fonte sonora, possibilitando a percepção da configuração dos ambientes, a proximidade e altura dos interlocutores, a percepção de cruzamentos ou de sentido de direção dos veículos nas ruas;

c) escuta seletiva - possibilita identificar, discriminar e selecionar um som entre outros emitidos simultaneamente, possibilitando extrair pistas sonoras dos ambientes, identificar os passos e a presença de outras pessoas;

d) sombra sonora - permite identificar uma área de silêncio junto a objetos que interrompam as ondas sonoras, possibilitando perceber a existência de colunas/pilares, paredes, troncos de árvores e veículos estacionados no meio fio, entre outros objetos.

O olfato, assim como a audição, é um sentido de longo alcance que auxilia a localização e identificação de pistas nos ambientes internos - cozinha, sanitários - ou externos - jardins, estabelecimentos comerciais, tais como açougues, padarias, postos de gasolina (LORA, 2003).

O sentido cinestésico permite a percepção e a consciência da posição e da execução dos movimentos do corpo (por exemplo, a elevação do braço até a altura dos ombros ou acima da cabeça) ou a detecção de inclinação (aclives ou declives) ou desníveis na superfície durante os deslocamentos, fatores que auxiliam a orientação. Uma das funções do sentido cinestésico é a memória muscular, que consiste na "repetição de movimentos em uma sequência fixa, que se convertem em movimentos automáticos" (CRATTY 61983 apud LORA, 2003 p.62). Este recurso auxilia subir e descer escadas, deslocar-se em trajetos curtos em ambientes internos,

\footnotetext{
${ }^{5}$ DISCHINGER, M. The Non-Careful Sight. In: DEVLIEGER, P.; RENDERS, F.; FROYEN, H.; WILDIERS, K. Blindness and Multisensorial City. Antwerp: Garant, 2006. p.143-176.

${ }^{6}$ CRATTY, M. B.; SAMS, T. A. The body image of Blind Children. New York: American Foundation for the Blind. Research Bulletin, n. 17, jul. 1983.
} 
possibilitando caminhar e retornar ao ponto de partida sem a necessidade de contar os degraus ou memorizar os passos (LORA, 2003).

Ainda segundo Lora (2003), o sistema háptico, também chamado de tato ativo, consiste na busca intencional de informações táteis, tocando e identificando objetos, transformando-os em pontos de referência. Os receptores térmicos auxiliam a identificar áreas ensolaradas ou sombreadas, fornecendo pistas sobre os ambientes, possibilitando utilizar o sol como referência direcional ao longo do dia ou perceber o movimento ou deslocamento do ar. O uso da bengala longa é, neste caso, uma extensão do dedo indicador para explorar superfícies e objetos.

O tato exploratório permite identificar objetos, formas, relevos e texturas, utilizando as mãos, a bengala e todo o corpo, sendo basicamente próprio-cêntrico. Através do movimento orientado, o indivíduo obtém informações constantes sobre o equilíbrio do corpo no espaço e seus eixos de referência (vertical/horizontal, direita/esquerda, frente/costas), assim como sobre a direção, a distância e o ritmo do movimento em si. (DISCHINGER, 2006, apud DISCHINGER; BINS ELY, 2010 p.97)

O sentido vestibular ou labiríntico permite a percepção dos movimentos rotatórios e lineares em relação à posição vertical do corpo, ou seja, dos movimentos à direita ou à esquerda, exercendo influência significativa no equilíbrio e na orientação (LORA, 2003).

A baixa visão ou visão subnormal consiste numa perda visual severa que não pode ser corrigida por meio de intervenções clínicas ou cirúrgicas ou pelo uso de óculos ou lentes convencionais.

Cada pessoa com baixa visão enxerga de forma diferenciada, de acordo com as alterações que podem ocorrer na função visual - prejuízo na acuidade visual, na visão de cores, no campo visual, na sensibilidade ao contraste, na adaptação à luz. (LARAMARA, s/d $)^{7}$

A utilização do resíduo visual não depende somente da acuidade ou da patologia, mas das possibilidades individuais, que variam desde a capacidade de realização das atividades da vida diária até a leitura e escrita em tinta, com auxílio de recursos especializados ou de tecnologia assistiva. Para Sampaio, Haddad e Kara-José (2001, p.9), a baixa visão é uma "condição intermediária entre a visão normal e a cegueira", consequência de um processo irreversível do sistema visual, prejudicando a realização de determinadas atividades, mesmo com "o uso de correção óptica para erros refracionais." Um dos principais objetivos do tratamento do

\footnotetext{
${ }^{7}$ Disponível em: <http://laramara.org.br/ deficiencia-visual/definicoes $>$. Acesso em: 10 jul. 2012.
} 
paciente com baixa visão é promover maior funcionalidade ou resolução visual, seja por meio da modificação da imagem na retina, de alteração das condições do ambiente ou da utilização de materiais. A avaliação oftalmológica na área da baixa visão inclui pesquisa detalhada de quatro funções visuais (SIAULYS, ORMELEZY, BRIANT, 2010): acuidade visual, visão de cores, sensibilidade ao contraste e campo visual.

Dependendo da extensão do problema no campo visual, a orientação e a mobilidade podem ficar bastante comprometidas. A localização e o tipo de problema influenciam o auxílio e as orientações necessárias a cada paciente. Quando há comprometimento do campo visual inferior, há dificuldade para andar em áreas planas ou inclinadas, em escadas fixas ou rolantes. Em caso de comprometimento do campo visual central, há dificuldade para identificar objetos e textos. Problemas no campo visual periférico podem comprometer a visão espacial e a percepção de obstáculos, dificultando a autonomia nos deslocamentos. Faye (1990 apud SAMPAIO; HADDAD; KARA-JOSÉ, 2001) definiu três perfis de resposta visual a partir da interação entre a doença ocular e a funcionalidade visual: diminuição difusa da resolução visual; problema no campo visual central e problema no campo visual periférico (Figura 5).

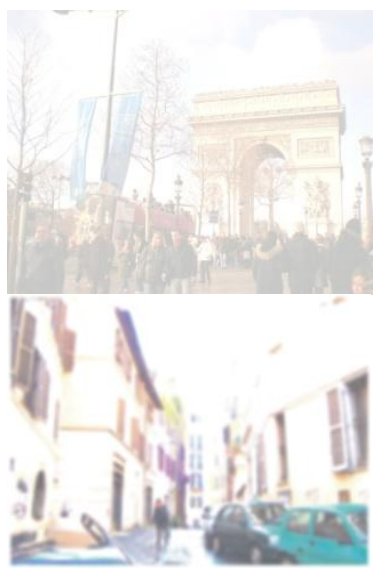

(a)

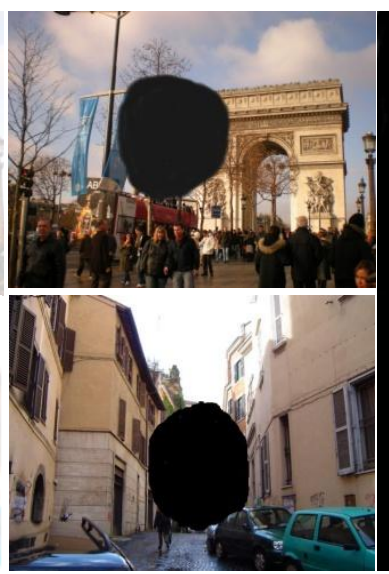

(b)

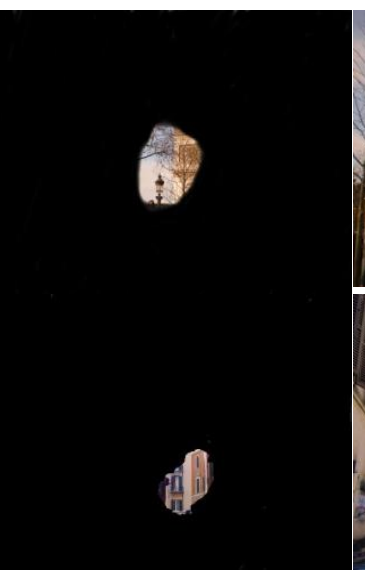

(c)

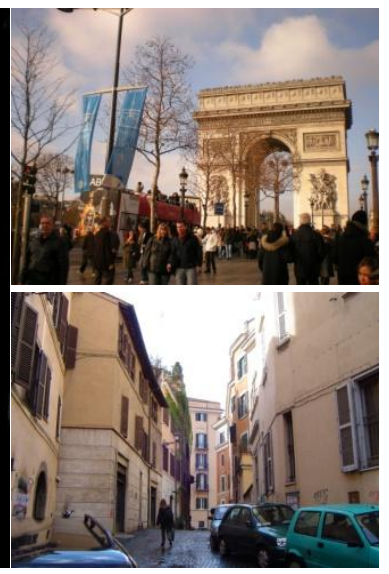

(d)

Figura 5 - Perfis de resposta visual segundo Faye:

(a) simulação da diminuição da transparência dos meios ópticos do globo ocular; (b) simulação do defeito do campo visual central; (c) simulação do defeito do campo visual periférico; (d) imagem original.

Fonte: Haddad, 2012.

\subsubsection{Contexto mundial}

Estima-se que um bilhão de pessoas convivam com alguma forma de deficiência, algo em torno de $15 \%$ da população mundial, e que aproximadamente 200 milhões têm dificuldades funcionais significativas. Existem aproximadamente 285 milhões de pessoas com deficiência 
visual no mundo, sendo 246 milhões com deficiência que varia de leve a moderada e 39 milhões de pessoas cegas (OMS, 2012).

O Relatório Mundial sobre a Deficiência ${ }^{8}$ (OMS, 2012) relata que as pessoas com deficiência apresentam níveis baixos de escolaridade, menor participação econômica, elevada taxa de pobreza e as piores perspectivas de saúde, consequências das condições diferenciadas de acesso a serviços de saúde, educação, emprego, transporte e informação. Essas questões são agravadas nas comunidades mais pobres e indicam que os problemas de saúde podem ser "visíveis ou invisíveis; temporários ou de longo prazo; estáticos, episódicos ou de degeneração; dolorosos ou inconsequentes". Segundo esse relatório, a deficiência é uma questão de saúde pública e exige que sejam implementadas políticas públicas para mitigar e reduzir o impacto na população. Contudo, não se pode inferir que exista uma relação entre a deficiência e a saúde, ao contrário da relação entre a deficiência e a pobreza ou o envelhecimento da população, conforme a seguir:

a) relação saúde-deficiência: fatores contextuais, pessoais ou ambientais, bem como a interação entre inúmeras condições - e não apenas uma condição - contribuirão para a existência de um inter-relacionamento entre a doença e a deficiência.

b) relação pobreza-deficiência: aproximadamente $80 \%$ das pessoas com deficiência moram em países em desenvolvimento, fato que reforça o inter-relacionamento entre esses fatores, pois a deficiência pode aumentar o risco de pobreza, e a pobreza pode aumentar o risco de deficiência;

c) relação envelhecimento da população-deficiência: constata-se que as maiores taxas de incidência de deficiência ocorrem entre pessoas idosas, refletindo o acúmulo de riscos de saúde - doenças crônicas ou não e lesões - durante um período de vida. Nos países onde a renda é maior, há maior expectativa de vida, e, portanto, há predominância de pessoas idosas, que envelhecem à custa de possuir uma deficiência, às vezes incapacitante.

Esse mesmo documento afirma que, apesar da comprovada relação entre a pobreza e a deficiência, poucas ações voltadas à erradicação da pobreza e à promoção do desenvolvimento incluem questões específicas para as pessoas com deficiência. Nos países

\footnotetext{
${ }^{8}$ O Relatório Mundial sobre a Deficiência, publicado pela Organização Mundial da Saúde (2012), apresenta resultados referentes à pesquisa realizada em 51 países, sendo 20 deles com níveis de renda média e alta - entre os quais o Brasil - e 31 países com renda de média a baixa.
} 
em desenvolvimento, observa-se uma taxa maior de deficiência entre crianças até 14 anos e uma expectativa de vida menor. A questão passa a ser um desafio mundial: o crescimento da população nesses países associado à falta de infraestrutura sanitária traz consigo o aumento das doenças crônicas ou infecciosas, agravadas pela falta de intervenção e tratamento. A partir do momento em que as epidemias são controladas, são as doenças crônicas que passam a merecer a atenção dos governantes nas políticas públicas de combate à deficiência.

A deficiência visual não é uniformemente distribuída em todo o mundo e afeta, de forma mais significativa, as regiões menos desenvolvidas: do total de casos de cegueira, 90\% ocorrem nos países emergentes e subdesenvolvidos. Glaucoma, retinopatia diabética, atrofia do nervo ótico, retinose pigmentar e degeneração macular relacionada à idade são as principais causas da cegueira na população adulta. Entre as crianças, as principais causas são glaucoma congênito, retinopatia da prematuridade e toxoplasmose ocular congênita (OMS, 2010 apud HADDAD, 2012). Apesar dos avanços da cirurgia ocorridos em muitos países nas últimas décadas, a catarata permanece como a principal causa de deficiência visual em todas as regiões do mundo, com exceção dos países mais desenvolvidos, onde predominam as deficiências decorrentes do envelhecimento da população.

\subsubsection{Contexto nacional}

Em relação ao contexto nacional, destaca-se que os primeiros censos populacionais no Brasil foram realizados entre 1872 e 1890, tendo sido repetidos, desde então, a cada 10 anos, exceto pelos anos de 1910 e 1930. Esses levantamentos disponibilizam conhecimentos sobre a evolução da distribuição territorial e as principais características socioeconômicas das pessoas e dos seus domicílios. Essas informações são consideradas fundamentais para a definição de políticas e investimentos, públicos ou privados, contribuindo para o planejamento da utilização dos recursos disponíveis (IBGE, 2011).

O Censo 2010 seguiu padrões e orientações internacionais, além de contribuições dadas por especialistas de institutos nacionais de estatística, desenvolvidos e mantidos pela Divisão de Estatísticas da Organização das Nações Unidas - ONU. O Brasil é membro do Grupo de Washington sobre Estatísticas das Pessoas com Deficiência, cujo objetivo é padronizar o levantamento de estatísticas das pessoas com deficiência. Em relação à deficiência visual, o Censo 2010 (IBGE, 2011) verificou se a pessoa tinha dificuldade permanente de enxergar 
(avaliada no quesito sobre o uso de óculos ou lentes de contato, no caso de a pessoa utilizálos), de acordo com a seguinte classificação:

a) não consegue de modo algum - é permanentemente incapaz de enxergar;

b) grande dificuldade - tem grande dificuldade permanente de enxergar, ainda que usando óculos ou lentes de contato;

c) alguma dificuldade - tem alguma dificuldade permanente de enxergar, ainda que usando óculos ou lentes de contato; ou

d) nenhuma dificuldade - ausência de qualquer dificuldade permanente de enxergar, ainda que precisando usar óculos ou lentes de contato.

Segundo resultados divulgados pelo Instituto Brasileiro de Geografia e Estatística - IBGE sobre as pessoas com deficiência visual no Brasil, constatou-se que as que não conseguem enxergar de modo algum têm maior incidência nas faixas etárias de 0-14 anos (2,7\%) e acima de $75 \operatorname{anos}(3,1 \%)$. Além disso, as pessoas que têm alguma dificuldade dividem-se de forma equitativa até os 59 anos. Por último, na faixa etária acima de 60 anos, predominam as pessoas que têm grande dificuldade para enxergar $(50,9 \%)$ - (Tabela 1$)$.

Tabela 1 - Composição da população com deficiência visual segundo faixa etária (em \%).

\begin{tabular}{rrrrrrrrrr}
\hline faixa etária & $\begin{array}{c}\text { não consegue de modo } \\
\text { algum }\end{array}$ & \multicolumn{2}{c}{ grande dificuldade } & \multicolumn{2}{c}{ alguma dificuldade } & \multicolumn{2}{c}{$\begin{array}{c}\text { total de pessoas com } \\
\text { deficiência visual }\end{array}$} \\
\hline $0-14$ anos & 66400 & $2,7 \%$ & 297603 & $12,2 \%$ & 2080352 & $85,1 \%$ & 2444355 & $100 \%$ \\
\hline $15-29$ anos & 114580 & $1,7 \%$ & 834008 & $12,5 \%$ & 5728105 & $85,8 \%$ & 6676693 & $100 \%$ \\
\hline $30-44$ anos & 98498 & $1,4 \%$ & 932168 & $13,7 \%$ & 5769796 & $84,8 \%$ & 6800462 & $100 \%$ \\
\hline $45-59$ anos & 87484 & $0,8 \%$ & 1877712 & $16,2 \%$ & 9637872 & $83,1 \%$ & 11603068 & $100 \%$ \\
\hline $60-74$ anos & 73565 & $1,1 \%$ & 1412230 & $20,5 \%$ & 5388639 & $78,4 \%$ & 6874434 & $100 \%$ \\
\hline$>75$ anos & 90306 & $3,1 \%$ & 898306 & $30,4 \%$ & 1964013 & $66,5 \%$ & 2952625 & $100 \%$ \\
\hline
\end{tabular}

Fonte: Elaborado pela pesquisadora a partir dos dados do IBGE - Censo Demográfico 2010. Características Gerais da População - Resultado da Amostra. Tabela 1.3.1 - População residente, por tipo de deficiência, segundo a situação do domicílio e os grupos de idade. Disponível em: http://www.ibge.gov.br_home/estatistica/populacao/censo2010/ caracteristicas_religiao_deficiencia/caracteristicas_religiao_deficiencia_tab_xls.shtm . Acesso em: 14 jul. 2012.

No Brasil, a principal causa de cegueira é a catarata (opacificação do cristalino), com aproximadamente $40 \%$ dos casos. Em segundo lugar, aparece o glaucoma congênito (aumento de pressão intraocular), com 15\% dos casos, seguido da retinopatia diabética (causadora de edema na retina, na região macular), com 7\% dos casos, e da cegueira na infância, notadamente a retinopatia da prematuridade (exposição de bebês prematuros à aplicação de oxigênio), com $6,4 \%$ dos casos. 
A degeneração macular ${ }^{9}$ relacionada à idade representa $5 \%$ dos casos de cegueira e aparece em quinto lugar, contrariando as estatísticas mundiais, onde aparece em terceiro lugar (RESKINOFF et al., 2004). A prevalência de retinopatia diabética está acima da proporção mundial, consequência do controle inadequado de doenças sistêmicas como a diabetes ou da identificação inadequada de outros problemas oculares, erroneamente classificados como retinopatia diabética (GUEDES, 2007).

\subsection{Cognição humana}

Rogers, Sharp e Preece (2013) apontam a existência de vários tipos de cognição ${ }^{10}$, tais como pensar, lembrar, aprender, sonhar, tomar decisão, ver, ler, escrever e falar, que podem ser isolados ou interdependentes. Vários deles podem estar envolvidos em uma mesma atividade (Quadro 3).

Quadro 3 - Processos cognitivos e implicações no design.

\begin{tabular}{|c|c|c|}
\hline Processos/sentidos & Descrição & Implicações no design \\
\hline $\begin{array}{l}\text { Atenção: visão e } \\
\text { audição }\end{array}$ & $\begin{array}{l}\text { - processo de seleção de uma entre diversas } \\
\text { opções, permitindo estabelecer foco, } \\
\text { priorizar eventos ou informações } \\
\text { relevantes; } \\
\text { - facilitada ou dificultada em função da } \\
\text { clareza do objetivo (saber o que se quer } \\
\text { fazer, aonde se quer chegar) e da forma de } \\
\text { apresentação da informação necessária à } \\
\text { ação (disponibilidade, destaque, } \\
\text { legibilidade, redundância); }\end{array}$ & $\begin{array}{l}\text { - destaque das informações relevantes num } \\
\text { dado momento de realização de tarefas; } \\
\text { - apresentação das informações na ordem } \\
\text { da execução das atividades; } \\
\text { - redução das informações apresentadas; } \\
\text { - simplificação da apresentação das } \\
\text { informações; }\end{array}$ \\
\hline $\begin{array}{l}\text { Percepção: visão, } \\
\text { audição e tato }\end{array}$ & $\begin{array}{l}\text { - processo de captação de uma informação } \\
\text { no ambiente; } \\
\text { - aparentemente simples, envolve processos } \\
\text { complexos como a memória, a atenção e a } \\
\text { linguagem; } \\
\text { - imposição da representação da informação } \\
\text { de forma apropriada para que sejam } \\
\text { facilitados a percepção e o } \\
\text { reconhecimento do seu significado em } \\
\text { diferentes mídias; }\end{array}$ & $\begin{array}{l}\text { - utilização de símbolos que sejam } \\
\text { facilmente associados aos seus } \\
\text { significados; } \\
\text { - clareza da informação sonora (altura e } \\
\text { distinção em relação ao ruído ambiental) } \\
\text { para ser percebido e compreendido; } \\
\text { - contraste entre texto e fundo nas } \\
\text { informações visuais e táteis; } \\
\text { - dimensionamento do texto; } \\
\text { - retorno da informação de forma visual, } \\
\text { tátil ou sonora para que o usuário } \\
\text { reconheça o resultado da sua ação; }\end{array}$ \\
\hline
\end{tabular}

\footnotetext{
${ }^{9}$ Degeneração macular é uma condição médica geral dos adultos mais velhos, que resulta em uma perda de visão no campo visual central devido a danos na retina. Torna difícil ou impossível ler ou reconhecer rostos embora permaneça visão periférica suficiente para permitir outras atividades da vida diária.

${ }^{10}$ Cognição é o processo que leva ao conhecimento. Percepção, exploração, imaginação, raciocínio, crítica e testagem são processos cognitivos. A cognição é estudada pela psicologia cognitiva enquanto que o conhecimento é primordialmente estudado pela epistemologia e pela engenharia do conhecimento. (BUNGE, 2006, p. 61).
} 
Continuação.

\begin{tabular}{ll}
\hline Memória: visão, & - \\
audição, tato e & existentescão sobre acontecimentos pré- \\
olfato. & adequadamente em situações \\
& equivalentes; \\
- & filtragem, codificação e interpretação das \\
& informações percebidas; \\
- & recuperação das informações quando \\
& necessário;
\end{tabular}

- simplificação do procedimento para a realização de tarefas;

- consistência e padronização no posicionamento das informações ou dispositivos de interação, promovendo o reconhecimento em vez da recordação;

- utilização de diferentes formas de classificação ou codificação para auxiliar a busca da informação (categorias, cores, sinais ou símbolos);

\begin{tabular}{ll}
\hline Aprendizado: & - captação das informações a partir de \\
habilidades & opções; \\
individuais & possibilidade de ser otimizado caso sejam \\
& oferecidas alternativas de aprendizagem \\
& ativa (interação exploratória), em vez de \\
& apenas a aprendizagem passiva \\
& (veiculação de instruções em um manual);
\end{tabular}

- projeto de interfaces;

- incentivo à exploração, orientação para a seleção de alternativas e ações no processo de aprendizagem;

- restrição da possibilidade de erros e estabelecimento de uma relação entre conceitos abstratos e representações concretas para facilitar a aprendizagem de informações complexas;

\begin{tabular}{|c|c|c|}
\hline $\begin{array}{l}\text { Leitura, fala e } \\
\text { audição: visão, } \\
\text { tato, audição }\end{array}$ & $\begin{array}{l}\text { - possibilidade de serem afetadas pelas } \\
\text { habilidades individuais, pela } \\
\text { complexidade da tarefa e pela } \\
\text { complexidade do contexto; }\end{array}$ & $\begin{array}{l}\text { - redução da quantidade de opções para } \\
\text { orientar os deslocamentos ou a utilização } \\
\text { de dispositivos ou equipamentos; } \\
\text { - veiculação de informações de forma } \\
\text { redundante - tátil, visual e sonora; } \\
\text { - disponibilização da possibilidade de } \\
\text { ampliação de tamanho do texto ou altura } \\
\text { do som; } \\
\text { - acentuação da entonação das vozes } \\
\text { digitalizadas em função da maior } \\
\text { dificuldade de compreensão dessas em } \\
\text { relação à voz humana; }\end{array}$ \\
\hline $\begin{array}{l}\text { Resolução de } \\
\text { problemas, } \\
\text { planejamento, } \\
\text { raciocínio e } \\
\text { tomada de decisão }\end{array}$ & $\begin{array}{l}\text { - reflexão sobre o que será feito entre as } \\
\text { opções existentes ou o cenário/contexto } \\
\text { apresentados e as consequências de uma } \\
\text { determinada opção; } \\
\text { - processo consciente, solitário ou } \\
\text { compartilhado, com ou sem auxílio de } \\
\text { fontes de consulta; } \\
\text { - suscetibilidade ao grau de conhecimento } \\
\text { ou de experiência individual; }\end{array}$ & $\begin{array}{l}\text { - apoio à tomada de decisão; } \\
\text { - disponibilização de informações } \\
\text { complementares que possam ser acessadas } \\
\text { sempre que necessário; } \\
\text { - utilização de funções simples e fáceis de } \\
\text { lembrar nos dispositivos de interação. }\end{array}$ \\
\hline
\end{tabular}

Fonte: Elaborado pela autora a partir de Rogers, Sharp e Preece, 2013, p. 66-85. 
O mapeamento cognitivo é

uma representação pessoal do espaço ao redor, um constructo mental de um
ambiente que não pode ser visto a partir de um único ponto de observação, mas a
partir da estruturação mental que junta em um todo o que foi percebido em partes, a
partir de uma série de vistas individuais. (ARTHUR; PASSINI, 1992 p.23 -
tradução nossa).

Para Mollerup (2013, p. 24), os mapas cognitivos estão em constante produção, pois a eles são adicionadas informações sobre o ambiente por meio de diferentes recursos: a partir do próprio ambiente, mapas e informações disponibilizadas ou ainda descrições verbais ou de imagens colhidas ao longo da jornada. Os mapas cognitivos são mais precisos e compreensíveis quanto mais informações forem sendo absorvidas; entretanto, podem se tornar imprecisos com o passar do tempo caso informações ou detalhes sejam esquecidos ou se tornem desatualizados. Assim, mapas cognitivos de ambientes de uso frequente são mais precisos do que os de ambientes de uso eventual.

Em relação à cognição espacial, Arthur e Passini (1992) destacam que, além do conhecimento que as pessoas possuem de um determinado cenário e da compreensão das características espaciais de um cenário já descrito em forma de um mapa cognitivo, outros dois aspectos ajudam a fixar sua imagem na memória das pessoas: as características dos edifícios - físicas e não físicas - e os aspectos pessoais - frequência de uso e vínculo emocional. Para encontrar caminhos, os autores consideram a existência de sete tarefas básicas de localização, associando cada uma delas a uma manipulação espacial cognitiva (Quadro 4). As dificuldades encontradas nas tarefas estão relacionadas às características do ambiente, à existência de ambientes não articulados ou à dificuldade de obter ou de entender as informações relevantes a respeito desse ambiente. 
Quadro 4 - Manipulações espacial-cognitivas fundamentais para encontrar caminhos.

\begin{tabular}{|c|c|c|}
\hline Tarefa básica de localização & & Manipulação espacial cognitiva \\
\hline Aprender uma nova rota & $\rightarrow$ & $\begin{array}{l}\text { Memorizar um plano de decisão e/ou desenvolver } \\
\text { um mapa cognitivo }\end{array}$ \\
\hline Voltar ao ponto de origem (retraçar seus passos) & $\rightarrow$ & Inverter o plano de decisão ou a rota mapeada \\
\hline Ligar rotas conhecidas a novas configurações & $\rightarrow$ & $\begin{array}{l}\text { Conectar planos de decisão ou seções de rotas } \\
\text { mapeadas em novas combinações }\end{array}$ \\
\hline $\begin{array}{l}\text { Aprender a rota a partir de um pequeno display } \\
\text { alinhado e fazer a viagem }\end{array}$ & $\rightarrow$ & Fazer uma transferência de escala \\
\hline $\begin{array}{l}\text { Apontar as direções de locais visitados durante a } \\
\text { viagem }\end{array}$ & $\rightarrow$ & Fazer uma triangulação \\
\hline Aprender a rota a partir de um display não-alinhado & $\rightarrow$ & Fazer uma rotação mental \\
\hline Compreender o layout geral de um cenário visitado & $\rightarrow$ & $\begin{array}{l}\text { Identificar o princípio subjacente da organização } \\
\text { espacial }\end{array}$ \\
\hline
\end{tabular}

Fonte: Arthur, P.; Passini, R., 1992, p. 39 - tradução nossa.

A possibilidade de deslocamento independente das pessoas com deficiência visual está sujeita à construção de um mapa cognitivo espacial de seu entorno (FORGUS, 1971; ARTHUR; PASSINI, 1992; BECHTEL, 1997; CARPMAN; GRANT, 2002; OKAMOTO, 2002; IIDA, 2005; FINKEL, 2009; DISCHINGER; BINS ELY, 2010; REIS, 2010). Crianças que nascem com uma deficiência visual - cegueira ou baixa visão - ou adquirem essa condição ainda nos primeiros anos de vida têm severos comprometimentos relacionados à capacidade de se orientar e se movimentar com independência e segurança devido à impossibilidade de usar total ou parcialmente a principal via de entrada: a visão. Por outro lado, o adulto atingido pela deficiência visual tem perdas relacionadas aos aspectos físico, psíquico, social e econômico, sendo que seus efeitos implicam também a reorganização e o estabelecimento de novos esquemas de interação.

\subsubsection{Orientação e mobilidade - O\&M}

Para desenvolver habilidades cognitivas, são ensinados métodos convencionais de navegação às pessoas com deficiência visual, cegas ou com baixa visão, utilizando técnicas de orientação e mobilidade (FELLIPE; FELLIPE, 1997; FELLIPE, 2001; GARCIA, 2003; LORA, 2003; MASI, 2003). 
"Orientação" é a habilidade do indivíduo para perceber o ambiente que o cerca, estabelecendo as relações corporais, espaciais e temporais com esse ambiente. A orientação da pessoa com deficiência visual é alcançada através dos sentidos remanescentes, por meio da utilização da audição, do aparelho vestibular, do tato, da consciência cinestésica, do olfato e da visão residual, nos casos de pessoas portadoras de baixa visão. "Mobilidade" é a capacidade ou estado inato do indivíduo para se mover reagindo a estímulos internos ou externos, em equilíbrio estático ou dinâmico. (FELLIPE; FELLIPE 1997).

Segundo Webster $^{11}$ (1976 apud FELIPPE; FELIPPE, 1997 p.8), a limitação na O\&M é considerada como o mais grave efeito da cegueira sobre o indivíduo. O programa de O\&M para pessoas com deficiência visual tem por objetivo propiciar condições para que elas possam desenvolver sua capacidade de se orientar e se movimentar com independência, segurança, eficiência e adequação, nas mais variadas situações e ambientes, a partir de fatores como idade, interesses, necessidades, experiências e características da deficiência (cegueira congênita ou adquirida, baixa visão ou deficiências associadas). Para Masi (2003), a formação de conceitos espaciais deve considerar os seguintes conceitos de espaço:

a) corporal - construção de conceitos a partir da consciência das posições, direções e distâncias, tendo o próprio corpo como referência;

b) de ação - orientação para a execução de movimentos (próximo, dentro, fora, em cima, embaixo);

c) dos objetos - posição dos objetos em relação à direção e distância da pessoa;

d) geométrico - orientação a partir das experiências concretas, utilizando os conceitos geométricos para a elaboração dos mapas mentais;

e) abstrato - capacidade de uso dos conceitos para elaboração de rotas, mapas e compreensão dos ambientes e das relações entre eles.

\subsubsection{Treinamento de O\&M}

O processo de aprendizagem e treinamento de O\&M é subdividido em etapas que incluem o desenvolvimento de pré-requisitos básicos - cognitivos, psicomotores e emocionais -, além de treinamento dos sentidos remanescentes, como a utilização de visão residual (para pessoas com baixa visão), a interpretação de pistas e o estabelecimento de pontos de referência e o

${ }^{11}$ WEBSTER, R. A concept development program for future mobility training. The New Outlook for the Blind. 1976, p. 175-197. 
relacionamento com o espaço de ação e com objetos significativos do ambiente (FELLIPE; FELLIPE, 1997). O treinamento de O\&M é dividido em etapas:

- $1^{\mathrm{a}}$ etapa - desenvolvimento de pré-requisitos básicos psicomotores: possibilita à pessoa explorar suas potencialidades, incluindo os movimentos básicos fundamentais, as capacidades perceptivas e físicas, as destrezas motoras e a comunicação não verbal. Destaca-se a atenção dada às capacidades perceptivas, que serão posteriormente utilizadas na avaliação inicial dos ambientes, a exemplo do que o vidente faz utilizando a visão. $\mathrm{O}$ conteúdo dessa etapa inclui as capacidades de discriminação cinestésica, visual, auditiva, tátil, olfativa e de coordenação;

- $2^{\text {a }}$ etapa - treinamento dos sentidos remanescentes: prepara para utilização da visão residual - em pessoas com baixa visão -, da audição, do tato e cinestesia e do olfato. Nessa etapa, é realizado o planejamento do programa de treinamento a partir da análise e avaliação dos conhecimentos e vivências experimentadas pelo aluno;

- $3^{\mathbf{a}}$ etapa - habilidades básicas: compreende o aprendizado de técnicas para interação com o ambiente, por meio da capacidade de se orientar e se movimentar com independência e segurança; entre essas técnicas, estão a utilização de guias-videntes, estratégias de autoproteção, desenvolvimento da orientação, técnicas com a bengala longa e com o cãoguia;

- $4^{\text {a }}$ etapa - atividades externas: incluem a aplicação das técnicas anteriormente aprendidas em áreas residenciais e áreas comerciais de pequeno e médio portes, onde se vivenciam áreas com tráfego intenso de pedestres. As últimas etapas são caracterizadas por vivências especiais, típicas do ambiente urbano, como, por exemplo, o uso dos transportes públicos, os testes de reorientação e a avaliação final.

No caso específico dos transportes, o treinamento de O\&M visa a propiciar condições de uso dos procedimentos básicos para viajar de ônibus e de trem, incluindo o deslocamento nos terminais de passageiros, as características das estações e dos trens, os serviços prestados pelas operadoras e os procedimentos pertinentes à viagem em si. Subir ou descer escadas fixas e rampas, bem como a utilização de escadas rolantes e elevadores, exigem procedimentos específicos, aprendidos nesta etapa. (FELLIPE; FELLIPE, 1997). 


\subsection{Wayfinding design}

Wayfinding é a relação dinâmica entre as pessoas e o espaço ou o ambiente por meio da qual os indivíduos se localizam, identificam sua origem e seu destino e desenvolvem um plano de deslocamento entre eles. Esse processo ocorre a partir da capacidade que as pessoas possuem para desenvolver um mapa cognitivo por meio da troca permanente de informações entre os símbolos de orientação e o comportamento dos indivíduos. (ARTHUR; PASSINI, 1992).

O termo wayfinding, ainda que geralmente utilizado como sinônimo de orientação espacial, consiste em um vocábulo que reconhece a necessidade de uma abordagem multidisciplinar, seja de conhecimentos teóricos ou práticos, colocando a pessoa como razão da sua existência uma vez que considera a sua capacidade de relação com o meio ambiente (físico, cultural e social) onde se desenvolve, utilizando as referências e informações do entorno. Dessa forma, pode-se afirmar que o processo de orientação se utiliza de recursos e procedimentos perceptivos, cognitivos e de interação com o ambiente.

Para Mollerup (2013), o processo do wayfinding compreende o planejamento (solução mental) e a execução (solução física), sendo que a etapa de planejamento está subdividida em nove fases intermediárias, e a etapa de execução consiste num processo contínuo de mover, procurar, decidir, mover. A seguir listam-se as fases intermediárias do planejamento no wayfinding:

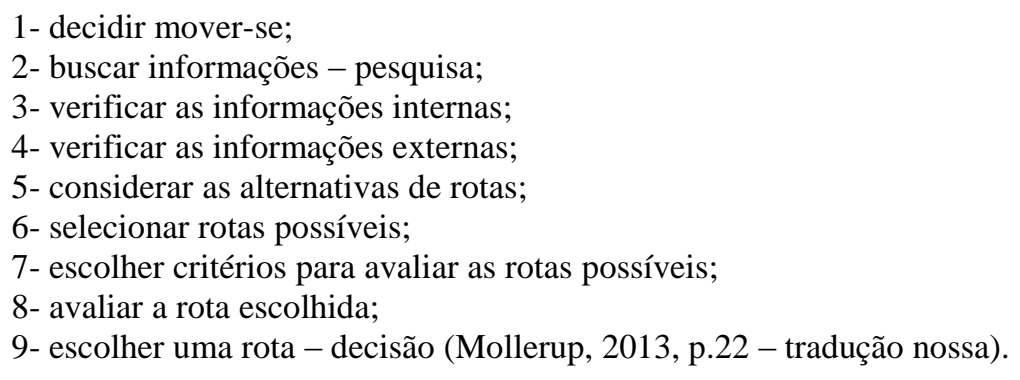

O autor argumenta que todos os deslocamentos são planejados, mais ou menos formalmente, utilizando maior ou menor detalhamento. Tal planejamento pode ser realizado antes do deslocamento, sofrendo ajustes durante o percurso. Segundo ele, normalmente nos planejamos para deslocamentos maiores, seja em distância ou em tempo de percurso, e, quando temos longas jornadas, costumamos subdividi-la em sequências de etapas, que podem ser subdivididas até que se chegue a uma unidade de fácil compreensão, chamada de unidade de planejamento. Planejamentos detalhados não são realizados para todas as situações: algumas 
informações somente podem ser obtidas durante os deslocamentos, a partir da sinalização existente nos ambientes.

O planejamento de um deslocamento requer o estabelecimento de ações em uma determinada sequência, pois "um plano de ação não contém apenas as decisões relevantes, mas reflete a lógica que conecta as decisões com o problema. A mesma lógica conecta as decisões de wayfinding" (ARTHUR; PASSINI, 1992, p.27), abrangendo três etapas inter-relacionadas, a saber:

\footnotetext{
- tomar a decisão e desenvolver um plano de ação;

- executar a decisão, transformando o plano em comportamento adequado no local correto e no espaço;

- processar a informação, entendido em seu sentido genérico abrangendo a percepção e cognição ambiental, que, por sua vez, são responsáveis pela base de informação dos processos relacionados à decisão. (ARTHUR; PASSINI, 1992 p. 25 - tradução nossa).
}

O termo wayfinding foi usado primeiramente por Kevin Lynch, em 1960, no livro “A Imagem da Cidade". Para Lynch (1997), os cinco elementos da imagem urbana que fazem referência a formas físicas - vias, limites, bairros, cruzamentos e pontos marcantes - não aparecem isoladamente, mas sobrepõem-se e interligam-se constantemente. Por conta disso, diferenciam-se na análise como elementos da cidade e reintegram-se no todo na imagem da cidade (LYNCH, 1997; ARTHUR; PASSINI, 1992). Essa classificação tornou-se base dos elementos do wayfinding design (Quadro 5). 
Quadro 5 - Elementos do sistema de wayfinding.

\begin{tabular}{|c|c|}
\hline Elementos & Função \\
\hline $\begin{array}{l}\text { Caminhos ou } \\
\text { circulação }\end{array}$ & Elemento chave de uma organização local ou edifício \\
\hline Marcadores & $\begin{array}{l}\text { Objetos ou características que atuam como pontos de referência e marcam } \\
\text { uma localidade, conferindo-lhe identidade }\end{array}$ \\
\hline Nós & $\begin{array}{l}\text { Pontos de decisão onde se iniciam novos caminhos, com informações para } \\
\text { auxiliar as decisões }\end{array}$ \\
\hline Bordas & Limites entre o início e o término de diferentes áreas \\
\hline Zonas ou distritos & $\begin{array}{l}\text { Regiões internas ou externas com características diferenciadas que } \\
\text { auxiliam a identificação geral do lugar }\end{array}$ \\
\hline
\end{tabular}

Fonte: Elaborado pela pesquisadora a partir de Lynch (1997) e Center for Inclusive Design and Environmental Access IDEA (2010).

Wayfinding é um aspecto muito importante da vida cotidiana e, portanto, parte vital do projeto, podendo mesmo ser considerado um princípio orientado pelas necessidades dos usuários, baseado em fundamentos comportamentais e psicológicos envolvidos no processo de encontrar caminhos. No passado, os ambientes construídos eram relativamente simples e claros; contudo, atualmente, vemos a construção de edifícios complexos, de grandes dimensões. Ambientes acessíveis, eficientes, seguros e espacialmente atrativos devem seguir princípios do processo de localização.

Mollerup (2013) cunhou o termo "wayshowing" como sendo a atividade do profissional que elabora o planejamento e provê a implementação de recursos de sinalização - informação, comunicação, orientação - dos ambientes internos e externos, fazendo uma correlação entre as atividades de escrever e ler; segundo esse autor, o "wayshowing" precede a atividade de "wayfinding".

As características específicas dos ambientes influenciam o processo de orientação espacial das pessoas e o modo como elas encontram seu caminho, fato que é particularmente importante em edifícios complexos ou utilizados por pessoas em curtos períodos de tempo. Via de regra, as pessoas têm sua mobilidade reduzida em ambientes visitados pela primeira vez ou em percursos não habituais (SMITSHUIJZEN, 2007). 
Arthur e Passini (1992) destacam a existência de dois componentes do wayfinding design. O primeiro componente é o planejamento espacial, que está associado às características espaciais de um ambiente - tamanho, organização, sistemas de circulação -, gerando facilidades ou dificuldades de localização para seus usuários. Para facilitar o mapeamento cognitivo, é importante que haja clareza da organização espacial do edifício, com destaque para os acessos, os pontos de interesse e a circulação - horizontal e vertical. Os ambientes precisam ter espaços e cenários interessantes e gratificantes em termos de percepção espacial e ser seguros, acessíveis e eficientes sob a ótica da localização e da facilidade de deslocamento.

O segundo componente do wayfinding design é a comunicação ambiental, que está associada às informações relevantes do ambiente, veiculadas por meio dos elementos arquitetônicos, gráficos e não gráficos, nas formas visual, sonora e tátil. As informações arquitetônicas comunicam a existência e a localização das áreas de interesse enquanto que os elementos gráficos e não gráficos podem aumentar a expressão arquitetônica e indicar sua localização. Os sistemas de informação devem prover as informações necessárias ao longo de um percurso para que seja possível tanto a tomada das decisões como a execução das decisões. A estruturação das informações sobre o edifício - em conformidade com os diagramas de decisão - contribui para a compreensão da organização espacial; essas características podem ser desmembradas em informações referentes ao processo de tomada e de execução da decisão e ao processo de mapeamento cognitivo. A localização das informações deve considerar a sua percepção no ponto de decisão. Para tanto, o projetista deve transferir o diagrama de decisões para a trajetória. O diagrama de decisão é a lógica de combinar conteúdo, localização e características físicas do local - relacionadas à iluminação, demanda e configuração - para o sistema de informação.

Os autores destacam a necessidade de se considerar a interdependência e a inter-relação entre três fatores: a organização espacial, o sistema de circulação e os planos de decisão, sugerindo que tais fatores sejam considerados simultaneamente na fase de projeto de um edifício complexo. Em edifícios existentes, a organização espacial e o sistema de circulação são fatores consolidados que devem ser considerados no processo de entendimento dos diagramas de decisão para que as intervenções promovam a articulação do sistema de circulação, tornando-o legível para os usuários e servindo de base para o sistema de informação. Outros dois aspectos devem ser considerados na comunicação ambiental: a legibilidade (facilidade 
com a qual a informação pode ser percebida) e a inteligibilidade (facilidade com a qual a informação pode ser entendida). As informações devem ser veiculadas de forma linear e sequencial (utilizando placas) ou espacial e global (expondo a organização espacial e o sistema de circulação do edifício). Informações apropriadas orientam e solucionam os problemas de localização da maioria das pessoas que desenvolvem planos de deslocamento semelhantes, mas não excluem a possibilidade de existirem pessoas que tenham preferência ou motivos pessoais para optarem por outras rotas. Para o desenvolvimento do sistema de informação, deve ser analisada cada uma das rotas: as primárias ${ }^{12}$, ou principais, e as demais (secundárias, terciárias). A sobreposição das áreas de informação de diferentes rotas define o local ideal para veiculação das informações. Se o sistema de informação for claro e eficiente para as rotas primárias, determinará a característica de orientação e localização para todo o edifício, destacando-se em relação à orientação das demais rotas - secundárias e terciárias.

Mollerup (2013) aponta a existência de nove estratégias de wayfinding que podem ser descritas como princípios racionais para busca, decisão ou deslocamento, ainda que de forma tácita. Essas estratégias podem ser combinadas ou utilizadas isoladamente em função da sua disponibilidade no ambiente ou do conhecimento prévio de informações sobre o percurso a ser realizado, auxiliando os deslocamentos. São elas:

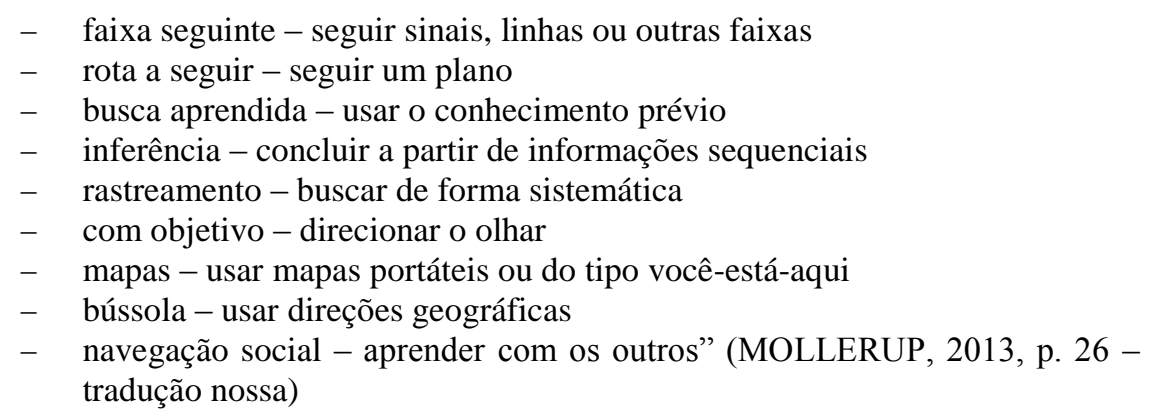

Arthur e Passini (1992) afirmam que os processos de tomada e de execução da decisão são semelhantes entre pessoas sem deficiência e pessoas com deficiência visual, cegas desde o nascimento, e que eventuais diferenças referem-se à etapa de planejamento dos deslocamentos - realizado de forma mais detalhada pelas pessoas com deficiência visual - e à necessidade de maior quantidade de tomadas de decisão ao longo do trajeto, checando referenciais e pontos de informação intermediários, em função da incapacidade para percepção das informações a

\footnotetext{
${ }^{12}$ As rotas primárias incluem a circulação principal entre as entradas ou saídas de um empreendimento e as principais áreas de destino; a circulação entre uma área principal e outra e a circulação dentro de uma área de destino principal. Mesmo em edifícios complexos, as rotas primárias são limitadas em quantidade. (ARTHUR; PASSINI, 1992, p.48)
} 
distância ou dos limites dos grandes espaços. As estratégias utilizadas pelas pessoas videntes e pelas pessoas com deficiência visual são apresentadas a seguir (Quadro 6), sendo ressaltada a similaridade entre elas.

Quadro 6 - Estratégias de wayfinding utilizadas por videntes e pessoas com deficiência visual.

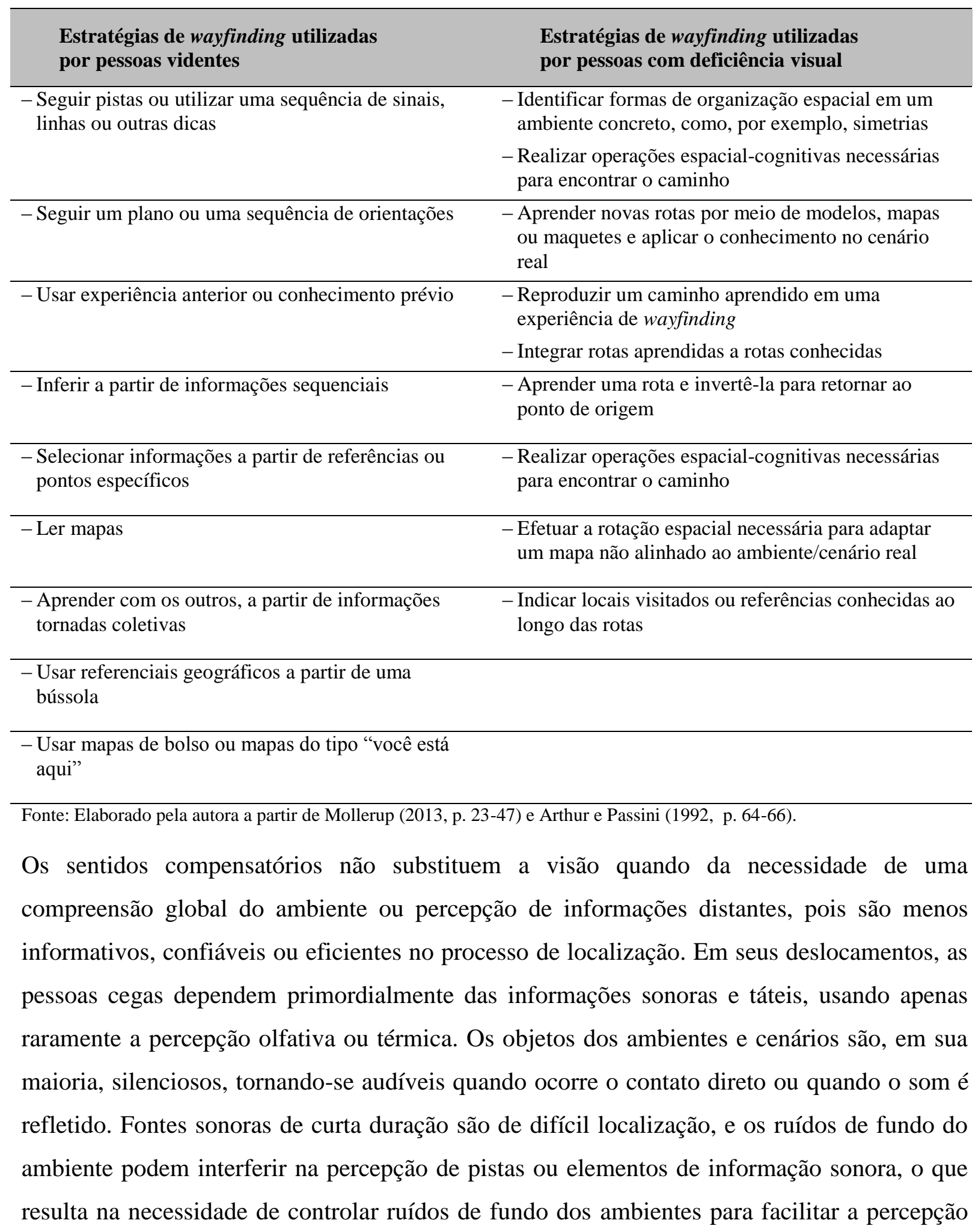


auditiva. Em locais públicos, como, por exemplo, em centros comerciais ou terminais de transporte, o nível do ruído de fundo decorrente da presença e circulação de grande número de pessoas abafa eventuais informações auditivas do ambiente ou do sistema de informação sonora, bem como impede a ecolocalização, desorientando e dificultando o deslocamento em linha reta das pessoas com deficiência visual.

A energia e a atenção despendidas pelas pessoas cegas durante os deslocamentos são imensas, notadamente quando são pessoas mais idosas que se sentem exaustas desempenhando tarefas de localização, seja em ambientes conhecidos ou não. Desse aspecto decorre a necessidade de os projetistas levarem em conta características do projeto que possam facilitar a mobilidade e reduzir riscos de acidentes. Mesmo para as pessoas com baixa visão, que têm comprometida a acuidade do campo visual, há necessidade de adoção de requisitos nos projetos que facilitem a percepção e a compreensão das informações relevantes bem como seu deslocamento, tais como:

a) contrastes de cores e de luminosidade na sinalização;

b) materiais opacos para veicular informações;

c) definições visuais e táteis das rotas de circulação, diferenciando-as das áreas abertas;

d) simultaneidade de informações visuais e não visuais;

e) ambientes bem iluminados, sem contrastes de luminosidade.

Segundo Dischinger e Bins Ely (2010), a percepção pode ser potencializada por meio de elementos ou informações contidas no ambiente, bem como pode ser prejudicada caso seja utilizado excesso de referências, obstáculos ou interferências (ruídos em excesso ou sons muito altos desorientam, confundem e estressam). Assim, a qualidade e a quantidade das informações espaciais são fundamentais no processo de orientação e, portanto, o desenvolvimento de projetos de orientação para pessoas com deficiência visual é uma atividade complexa, que exige análise espacial detalhada para identificar informações que possam auxiliar a localização de atividades, percursos, referenciais e a compreensão das relações espaciais existentes. Nos projetos de ambientes acessíveis para pessoas com baixa visão, devem ser previstas condições adequadas de iluminação, contrastes de cor, nitidez dos contornos e dos limites dos planos verticais e horizontais, eliminando-se a poluição visual e os reflexos. Contudo, nos projetos de ambientes acessíveis para pessoas cegas, devem ser implementados referenciais adicionais que utilizem fontes sensoriais alternativas: 
[...] a presença de deficiências sensoriais requer ainda um maior aprofundamento nas soluções técnicas. No caso de ausência total ou parcial de visão, boas soluções exigem, além do conhecimento teórico, contato direto com usuários com diferentes tipos de deficiência visual para compreender seus processos de percepção e orientação espacial. (DISCHINGER; BINS ELY, 2010, p. 95)

Moreno (2011) propõe a utilização de um modelo conceitual de wayfinding, articulando os elementos básicos do processo de informação e orientação espacial juntamente com o desenho universal, e argumenta que, nesse contexto, "pessoa" e "ambiente" são os pontos de partida para estabelecer uma correlação positiva através da comunicação, informação e orientação, considerando os seguintes aspectos:

a) a partir da pessoa: são abordados os aspectos cognitivos e as diferentes características individuais, a frequência de interação com o ambiente, entendido como espaço de mobilidade;

b) a partir do ambiente: são abordados aspectos de percepção e legibilidade associados aos usos e funções, seja por meio de sua configuração como por meio de informações incorporadas.

O autor enfatiza que os deslocamentos das pessoas estão associados a uma intenção de uso dos espaços - externos ou internos - que se manifesta por meio de rotas ou itinerários que as pessoas percorrem de maneira inconsciente (percursos cotidianos) ou com plena consciência (percursos que demandam exploração, memorização de referências, direções e distâncias). A intenção de criar tipologias de itinerário parte de uma visão global ou de uma concepção espacial em face da impossibilidade ou dificuldade de obtenção de uma imagem do conjunto, como um mapa, contendo as diversas alternativas de deslocamento. Ao contrário de Arthur e Passini (1992), que propõem diferentes tipologias de itinerários a partir de uma visão planialtimétrica (cadarço, gestalt, sistematizado, rede ou padrão repetitivo), Moreno (2011) propõe a realização de estudo a partir da sequência de ações necessárias em cada ambiente com base em tomada de decisão e execução da decisão - e descreve o percurso de embarque em uma estação de metrô com configuração subterrânea, entre o passeio e a plataforma, destacando a existência de pontos de incerteza e, portanto, de tomada de decisão em cada uma das etapas da jornada do usuário. Isso pressupõe que o usuário tenha se informado previamente sobre a estação de embarque (localização) e a estação de desembarque, incluindo a eventual necessidade de conexão entre diferentes linhas, fazendo um planejamento prévio do percurso origem-destino. 
Para Edwards (1997) e Ross (2000), os espaços devem ser amplos e fluídos, adequados ao desempenho de uma estação: espaços livres, de circulação, para espera, filas ou embarque. Espaços amplos podem gerar desorientação dos passageiros; fechamentos obstruem a circulação e a visão e representam custos para segurança, monitoração e manutenção. Os espaços devem proporcionar fluidez aos diferentes percursos, sem conflitos, posicionando as atividades intrínsecas ao funcionamento da estação em ordem lógica à sua utilização. Os fluxos devem ser uniformes ao longo de todo o percurso. Devem-se evitar impedâncias e obstruções e minimizar os percursos de embarque ou saída, com razoável conforto nas áreas de espera.

As estações têm características formais que nos antecipam informações sobre os elementos e os espaços essenciais que as definem: acessos, áreas de distribuição, plataformas, dispostos de forma contínua e sequencial, do início ao término do percurso (EDWARDS, 1997). Nas estações, são promovidas as conexões com outros modos de transporte ou são acrescentados espaços e serviços complementares, agregando usos e atividades.

Considerando que muitas estações são subterrâneas, a iluminação, seja ela natural ou artificial, deve facilitar a identificação do percurso e oferecer segurança, auxiliando a leitura do espaço e da configuração dos ambientes, pontuando saídas e locais de interesse. A iluminação e o ritmo da estrutura colaboram de forma decisiva para a compreensão do espaço e do percurso a ser seguido, seja ele de embarque ou desembarque: vigas, treliças, armações e colunas são utilizadas para dar significado ao interior dos espaços públicos, auxiliando o direcionamento das pessoas para as saídas, áreas de distribuição e plataformas, ou conferindo características que diferenciam uma estação da outra (EDWARDS, 1997; ROSS, 2000).

O plano de ampliação do Metrô de Madrid estabeleceu novas diretrizes para os projetos das estações a partir de 1994, "radicalmente distintos" em relação aos parâmetros vigentes até então. As novas diretrizes preconizaram estações mais amplas, mais ventiladas e plataformas subterrâneas menos profundas (de até 16 metros). Tal decisão, ainda que inicialmente voltada para a redução do custo de escavações e de equipamentos de circulação vertical, proporcionou, sob a ótica da acessibilidade, maior domínio e compreensão do espaço e maior conforto aos passageiros, reduzindo o tempo e as distâncias percorridas nos deslocamentos verticais, horizontais e de conexão (Figuras 6 e 7). 


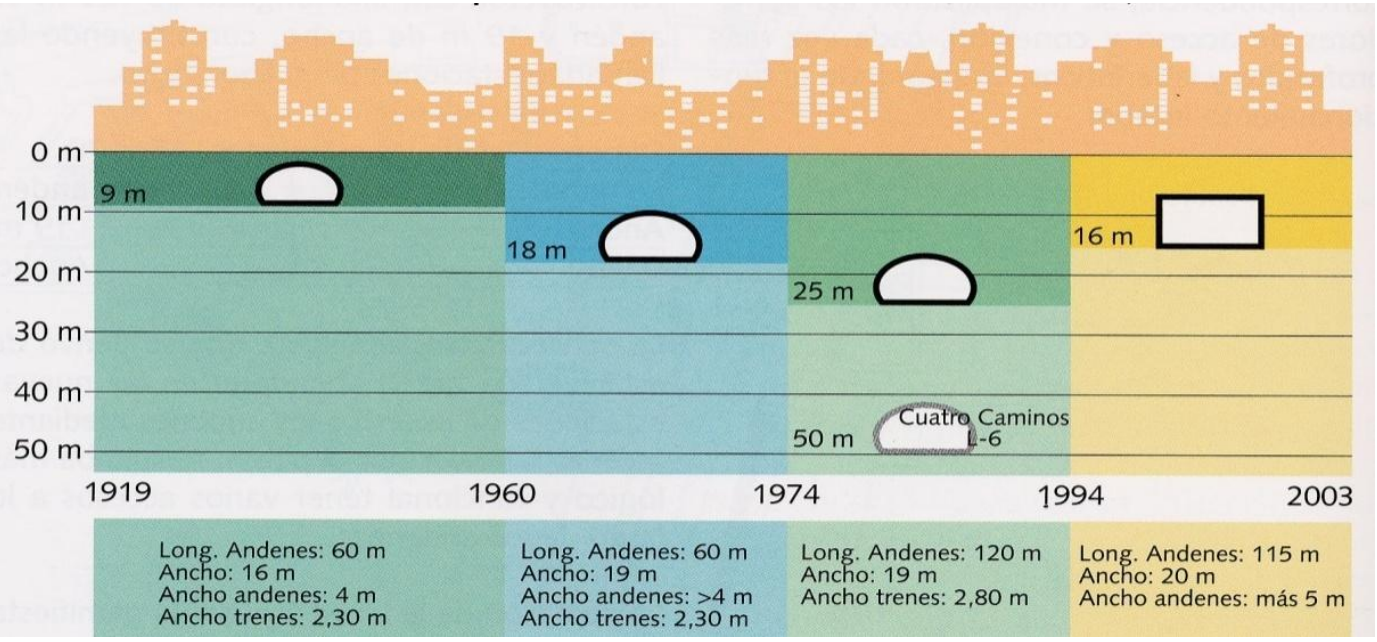

Figura 6 - Evolução da profundidade das estações do Metrô de Madrid - 1919-2003. Fonte: MINTRA, Consejería de Transportes e Infraestructuras, 2007, p. 14.
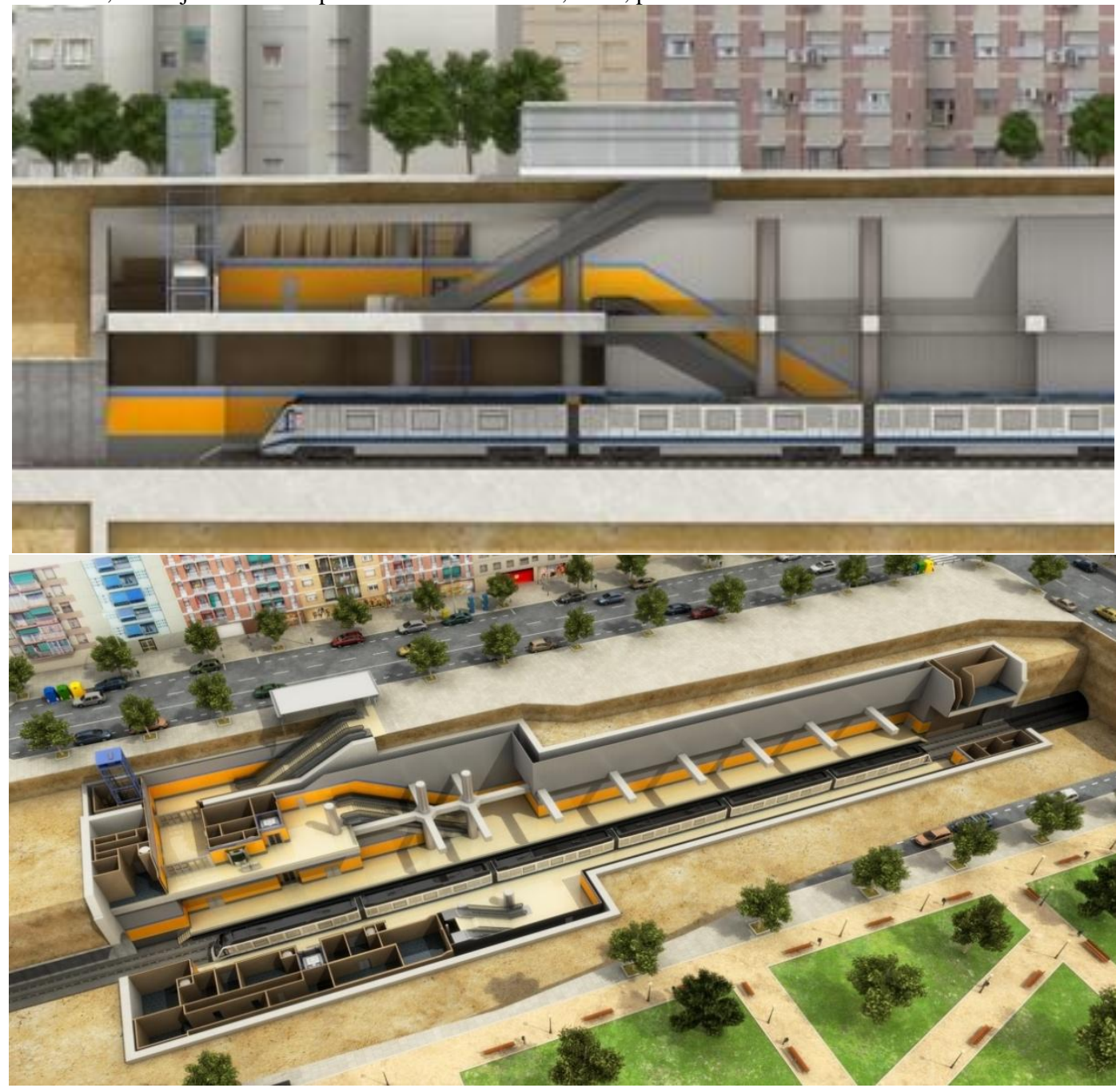

Figura 7 - Critérios de projeto das estações do metrô de Madrid - seção longitudinal e perspectiva. Fonte: Metrô de Madrid, Área de Obra Civil y Estaciones - apresentação realizada em 07/05/2013. 
Teixeira (2013) propôs a elaboração de um esquema para subsidiar o desenvolvimento do projeto de comunicação ambiental e orientar o deslocamento dos usuários nas estações habituais e eventuais no Metrô do Rio de Janeiro (Figura 8).

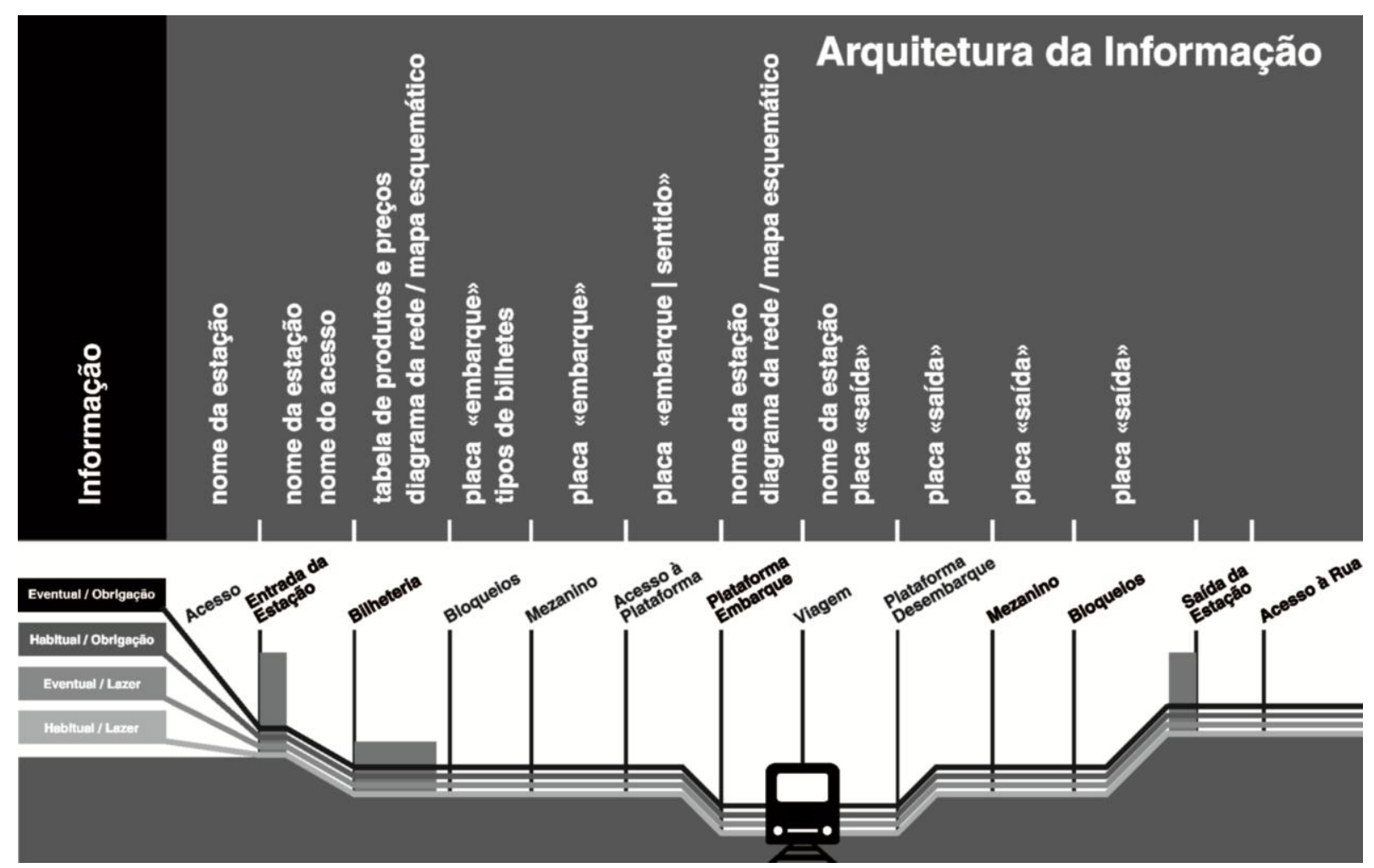

Figura 8 - Arquitetura da informação nas estações do Metrô - RJ.

Fonte: TEIXEIRA, C., 2014. Ambientação das estações do MetrôRio. Apresentação realizada em 28 mar.2014 na FUNDAP.

\subsection{Considerações sobre o capítulo}

A evidência física do serviço de transporte metroferroviário, local onde a empresa interage com seus clientes, é um ambiente complexo, por onde se deslocam milhares de pessoas, com características diversas e objetivos e destinos diversos, simultanea e diariamente. O design de serviços passa pela identificação das necessidades individuais e coletivas de clientes e funcionários, pela avaliação da automatização, customização e padronização de processos relacionados ao atendimento, sejam eles realizados em larga escala ou individualizados. A complexidade intrínseca aos serviços públicos para promover a satisfação dos usuários, das pessoas com deficiência e dos funcionários que atuam e auxiliam os serviços depende intensamente do planejamento espacial e da comunicação ambiental presente nos fatores chave da mobilidade da rede de transporte metroferroviário - estações, trens, interface tremestação, sistemas de informação, comunicação e orientação e gestão e prestação dos serviços. 
Os elementos de wayfinding contribuem para a elaboração do mapa cognitivo sobre o ambiente por meio de diferentes recursos - a partir do próprio ambiente, dos mapas e informações disponibilizadas ou ainda as descrições verbais ou de imagens colhidas ao longo da jornada - sempre considerando a necessidade de percepção, cognição e interação entre o comportamento dos indivíduos e os símbolos de orientação. Essa relação dinâmica (wayfinding) entre as pessoas e o espaço ou ambiente (físico, cultural e social) - por meio da qual as pessoas identificam sua origem, desenvolvem um plano de deslocamento e chegam ao seu objetivo - requer o estabelecimento de ações em uma determinada sequência, conectando as decisões com o problema, seguindo os princípios do processo de localização.

Para facilitar o mapeamento cognitivo das estações, qualquer que seja a sua tipologia, é importante que haja clareza da organização espacial do edifício - com destaque para os acessos, os pontos de interesse e a circulação horizontal e vertical. Também é importante que as informações relevantes do ambiente sejam veiculadas pelos elementos arquitetônicos e por informações táteis, visuais e sonoras simultaneamente, que devem estar presentes nos pontos de decisão ao longo do trajeto para garantir a orientação e possibilitar a tomada e a execução das decisões ao longo de um percurso. A elaboração de mapas cognitivos é mais fácil em ambientes visitados com frequência. Contudo, novos percursos podem ser aprendidos utilizando-se modelos, mapas ou maquetes e aplicando esse conhecimento ao cenário real. A percepção pode ser potencializada pelos elementos e informações do ambiente, mas pode ser prejudicada pelo excesso de referências, obstáculos ou interferências sonoras. Assim, devem ser mantidas as informações e os referenciais que possam auxiliar na localização dos pontos de interesse, na identificação dos percursos e das relações espaciais.

O estudo realizado por Moreno (2011) descrevendo a sequência de decisões e ações necessárias em cada ambiente, segundo cada uma das etapas da jornada do usuário no sistema de transporte considera as decisões e as ações de uma pessoa vidente.

Nesta pesquisa foi proposta a identificação de pré-requisitos e referenciais válidos para os deslocamentos das pessoas com deficiência visual a partir da sequência de decisões e ações necessárias em cada ambiente - com auxílio ou independente - nas diferentes etapas da jornada das pessoas com deficiência visual no sistema metroferroviário. Tais pré-requisitos e referenciais não podem ser vistos de forma isolada, mas podem ser diferenciados para efeito da análise dos elementos que impactam na acessibilidade. Contudo, eles aparecem 
sobrepostos e interligados no mapa cognitivo construído pelos usuários, seja nos deslocamentos independentes ou mediante a solicitação de auxílio.

A identificação dos elementos do wayfinding associada aos fatores-chave facilita a compreensão e a análise dos dados coletados nas entrevistas e questionários aplicados, bem como possibilita o estabelecimento de requisitos de projeto relacionados à configuração, informação e gestão do serviço - seja na edificação, na interface entre a edificação e o veículo ou no veículo - de forma a auxiliar a tomada de decisão dos projetistas e gestores.

Em se tratando de pessoas com deficiência visual - cegas ou baixa visão -, com diferentes problemas potenciais no campo visual e funcionalidades visuais, os aspectos necessários para a construção do mapa cognitivo em ambientes complexos não padronizados e com alto nível de ruído demandam mais atenção, aprendizado, memória, reflexão, percepção e capacidade de resolução de problemas e tomada de decisão durante o processo de encontrar caminhos para embarque, viagem ou saída. Isso ocorre também em deslocamentos habituais ou eventuais, com possibilidade de comprometimento da orientação e da mobilidade, mesmo considerando a familiarização com as instalações, decorrentes dos treinamentos ministrados nas estações e trens.

Assim, compreender as expectativas dos clientes, provedores e demais partes interessadas é importante para que se tenha, simultaneamente, uma visão detalhada de cada uma das etapas da jornada e uma visão abrangente da experiência. Isso possibilita a identificação do grau de satisfação, dos aspectos positivos, dos problemas e das possibilidades de solução, ensejando a adoção de ajustes ou intervenções pontuais para beneficiar a relação entre os usuários finais e o provedor do serviço público. 


\section{O SISTEMA METROFERROVIÁRIO CONTEMPORÂNEO}

O objetivo deste capítulo é apresentar as características do sistema metroferroviário e a evolução dos requisitos de projeto relacionados à acessibilidade nas estações e trens. Faz-se necessária a compreensão do contexto onde se deu o desenvolvimento das tecnologias que permitem, atualmente, a implantação de sistemas metroferroviários acessíveis.

\subsection{O sistema sobre trilhos}

Sistemas sobre trilhos de alta capacidade são estruturadores do sistema de transporte, sendo a eles conectados outros modos de transporte, de baixa ou média capacidade, chamados alimentadores. Além do impacto direto na mobilidade de milhões de pessoas e na redução da poluição atmosférica, os sistemas sobre trilhos geram benefícios sociais e econômicos, contribuem para a revitalização de áreas degradadas, induzem à ocupação de áreas distantes, valorizam os imóveis por onde passam e agilizam os deslocamentos da população.

Os atuais sistemas sobre trilhos - metrôs, trens, trens regionais, veículos leves sobre trilhos, monotrilhos - apresentam características comuns entre si, entre as quais destacam-se a grande capacidade de transporte, o uso de tração elétrica, a existência de via segregada e o emprego de automação dos sistemas de sinalização e operação (ALOUCHE, 2005).

Para Edwards (1997, p.vii-22), a manifestação arquitetônica dos sistemas de transporte sobre trilhos é a estação, uma vez que ela significa, simultaneamente, a "passagem" à rede sobre trilhos e o "ponto da entrada" para as pessoas que entram na cidade. Essa relação entre o sistema de transporte e o contexto urbano confere às estações um significado particular como arquitetura de um dos mais importantes tipos de edifício contemporâneo. A estação de passageiros é um edifício diferenciado e complexo localizado nos centros urbanos, em áreas densamente ocupadas, onde os fluxos de embarque e desembarque não são segregados. As estações têm espaços essenciais que as definem: acessos, áreas de distribuição e plataformas, dispostos de forma contínua e sequencial, do início ao término do percurso de embarque ou desembarque. Nenhuma outra obra de engenharia concentra a escala do movimento humano e a complexidade da função que essas estações desempenham: 


\begin{abstract}
A estação é uma criatura contraditória e diversa, um lugar onde a arquitetura e a tecnologia andam juntas, em uma associação próxima e dramática, com um grande número de pessoas. É esta qualidade que faz da estação de trem um tipo do edifício quase original, certamente um grande desafio aos designers e um dos melhores símbolos das nações civilizadas. (Edwards, 1997, p. 25, tradução nossa)
\end{abstract}

A tecnologia envolvida na implantação, operação e manutenção de túneis e estações, no material rodante, nos sistemas de energia, na sinalização metroferroviária, nas telecomunicações, no telecomando, na comunicação visual e sonora, nos equipamentos complementares (ventilação, climatização, acabamento, proteção contra incêndios, escadas rolantes etc.) vem evoluindo continuamente (ALOUCHE, 2005), assim como aspectos relacionados ao uso de materiais de acabamento não combustíveis ou autoextinguíveis, sustentáveis, duráveis, de fácil manutenção, operação e higienização.

Com o crescimento das redes e da quantidade de estações de conexão entre diferentes linhas, os ambientes foram se tornando cada vez mais complexos, em especial as estações de conexão. Além disso, as empresas passaram a dar maior atenção à questão da informação aos usuários, antes e durante a viagem, tanto nas estações como nos trens, de forma a proporcionar segurança e autonomia nos deslocamentos. Contudo, a orientação para as pessoas com deficiência visual ainda é uma área do conhecimento que necessita ser desenvolvida, equiparando as condições de percepção e cognição.

\title{
3.2 Os fatores-chave da acessibilidade no sistema metroferroviário
}

A complexidade do projeto de um sistema metroferroviário busca minimizar impactos urbanos, otimizar investimentos e compatibilizar o projeto das estações e dos trens com o padrão de serviço a ser ofertado em função da demanda prevista. Enquanto externamente busca-se a harmonização dos aspectos arquitetônicos do edifício com o contexto urbano, internamente busca-se o correto dimensionamento das áreas de circulação desde os acessos até as plataformas, compatibilizando a alta demanda de passageiros, a diversidade das pessoas (faixas etárias, comportamentos, características físicas e socioculturais), as exigências de segurança (pública, de uso e contra incêndio) e a crescente automação de componentes e instalações - processo irreversível que tem como consequência direta uma infinidade e uma diversidade de elementos e equipamentos nas estações e trens. 
A acessibilidade nas redes de transporte deve estar de acordo com os requisitos legais e normativos e, sempre que possível, considerar as boas práticas já sistematizadas em relação aos cinco fatores-chave da acessibilidade: as instalações fixas ou edificações, os veículos, a interface edificações-veículos, os sistemas de informação e a gestão dos serviços. Os fatoreschave aplicados ao sistema metroviário consistem nas estações, nos trens, na interface estação-trem, nos sistemas de informação, comunicação e orientação e na gestão da prestação dos serviços (JUNCÁ, 2005; 2011):

a) a estação e seu entorno - a adaptação das estações existentes ou a construção de novas estações acessíveis consistem no primeiro fator-chave da mobilidade. A funcionalidade dos acessos, das áreas de distribuição e das plataformas, os controles, o direcionamento dos percursos e as mudanças de nível são fatores essenciais para promover o deslocamento constante de grandes fluxos nos percursos de embarque ou desembarque. Devem ser considerados os deslocamentos nas áreas externas à estação, até o local onde estão os pontos de parada dos sistemas de transporte integrados (ônibus, táxis, vans), e também o deslocamento a pé, nas quadras adjacentes, até o local de destino;

b) a interface entre a estação e o trem - é um momento crítico que pode impactar a segurança e a autonomia do usuário, seja para embarque ou desembarque. Nessa etapa, deve-se considerar os aspectos estruturais relacionados à compatibilização entre a edificação (fixa) e o veículo (móvel). Adicionalmente, devem-se considerar os processos de monitoração ou a condição de autonomia e a intensa interação do usuário com deficiência visual com os demais usuários no embarque e desembarque, juntamente com a lotação e os conflitos de fluxo que ocorrem num tempo relativamente curto, contabilizado em segundos, como forma de garantir a continuidade dos serviços e o atendimento à elevada demanda;

c) o trem - a adaptação dos trens existentes ou a aquisição de novos trens consistem no terceiro fator-chave da mobilidade que tem forte impacto na jornada do usuário uma vez que, no interior do trem, a pessoa com deficiência visual depende mais do que nunca da interação com o ambiente, com o serviço prestado e com os demais usuários. Devem-se considerar as condições normais de operação, sem incidentes, ou condições eventuais ou críticas que possam exigir a adoção de estratégias operacionais para 
garantir a chegada dos usuários na estação de destino - situações onde são necessárias ações de contingência para o abandono, a espera por atendimento ou a permanência no interior do veículo até a normalização da situação;

d) a gestão dos sistemas de informação, comunicação e orientação - está relacionada ao uso das tecnologias vigentes à época da construção das estações ou da fabricação dos trens, respectivamente. Os sistemas de informação, comunicação e orientação devem ser coerentes, acessíveis e redundantes, adequados a cada etapa da viagem antes, durante e depois - e ao perfil do usuário - habitual ou eventual. As informações também devem ser veiculadas no formato correto e no momento adequado à sua utilização;

e) a gestão da prestação dos serviços - influencia a decisão pelo uso e impacta, de forma positiva ou negativa, a avaliação do serviço utilizado. A satisfação do usuário resulta da diferença entre a sua expectativa e a sua experiência em relação às evidências físicas do ambiente e do serviço, às informações recebidas, ao relacionamento entre as pessoas - funcionários e demais usuários - e aos procedimentos e processos envolvidos antes, durante e depois da viagem.

\subsubsection{A estação e seu entorno}

O planejamento e a definição do traçado de uma linha de metrô têm início a partir da análise dos deslocamentos de pessoas na cidade, dos principais fluxos e vetores - dados obtidos a partir de pesquisas de origem e destino das viagens. As informações sobre a demanda subsidiam o projeto funcional e o projeto básico, incluindo a quantificação dos equipamentos e dos sistemas, o dimensionamento das estações e dos terminais, a capacidade dos veículos, os intervalos entre trens e o dimensionamento das frotas. Finalizado o traçado da via, são definidos os locais das estações e suas áreas de influência a partir dos polos geradores de demanda. A configuração e o dimensionamento definem níveis de serviço em situações típicas da operação do serviço de transporte, em situações de anormalidade - seja a interrupção ou o maior intervalo na circulação de trens - ou mesmo em situações de emergência, quando há necessidade de evacuação. A configuração das estações resulta de condicionantes técnicas, tais como raios de curvatura, limites de inclinação da via, métodos construtivos, configuração da via permanente, localização dos equipamentos de mudança de 
via $^{13}$, existência de estacionamento de trens entre estações, métodos construtivos e perfil de carregamento da linha ${ }^{14}$, área a ser desapropriada, sistema viário existente e conexão com outros modos de transporte.

As estações que possibilitam a conexão com outros sistemas de transporte público são dimensionadas para garantir segurança nos percursos de embarque, saída e transferência. Como as redes atravessam áreas com características físicas diversas, dificilmente um único método construtivo pode ser utilizado em todo o projeto de uma linha: a alternância de estruturas faz com que as estações tenham características diferentes entre si (BARBOSA;ORNSTEIN, 2012).

A posição e a configuração das plataformas definem as características da estação. Em relação ao desnível, as plataformas podem ser subterrâneas, elevadas ou em superfície. Em relação à configuração, as plataformas podem ser centrais, laterais ou mistas. As diferentes combinações, aliadas ao desnível entre o acesso e a plataforma definem a complexidade da circulação vertical dos usuários no interior das estações. A seguir, são apesentadas as diferentes tipologias relacionadas à posição e configuração das plataformas das estações, destacando os impactos e os aspectos decorrentes para cada situação:

a) plataformas subterrâneas - proporcionam menor impacto na superfície (para carros ou pedestres), geram menor volume de desapropriações e possibilitam a preservação do patrimônio histórico. As edificações têm, em sua maioria, iluminação e ventilação artificiais. Os passageiros descem em direção às plataformas para embarcar; o percurso em direção às saídas é sempre no sentido ascendente (Figura 9).

\footnotetext{
${ }^{13}$ Os equipamentos de mudança de via são responsáveis por permitir a manobra e a passagem dos trens entre as diferentes vias, possibilitando a adoção de diferentes estratégias de operação.

${ }^{14} \mathrm{O}$ perfil de carregamento da linha consiste no conjunto de dados relacionados à demanda de cada uma das estações da linha, que, quando somadas e ponderadas pelos embarques e desembarques realizados, determinam a quantidade de pessoas nos trens e nas plataformas das estações ao longo do período de prestação do serviço.
} 


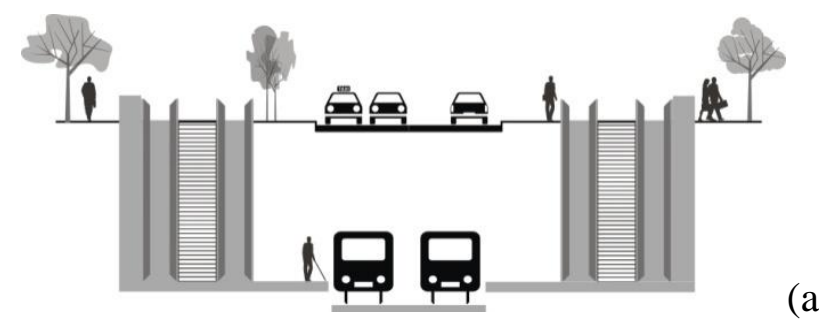

(a)

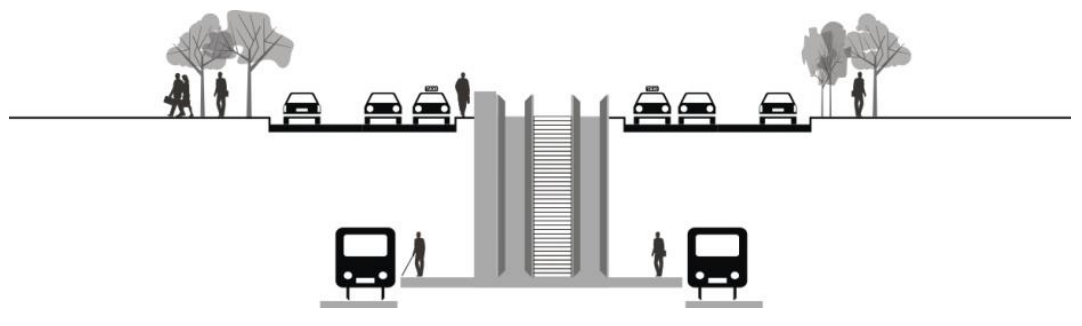

(b)

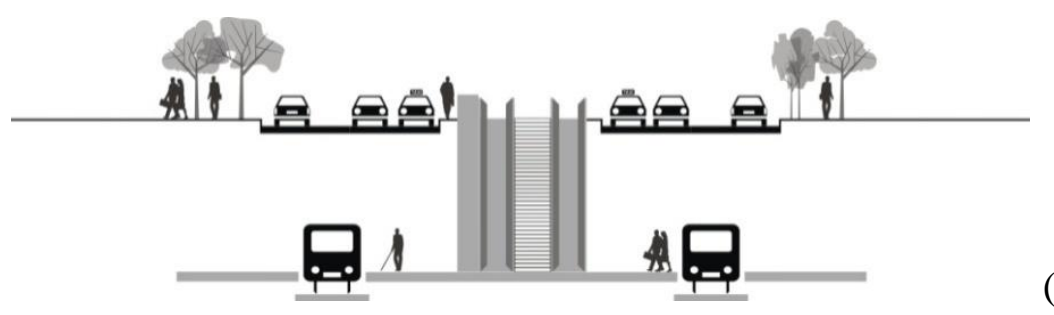

(c)

Figura 9 - Plataforma em estação subterrânea.

Lateral (a), central (b) e mista (c).

Crédito das ilustrações: ALMEIDA, V. J., 2013.

b) plataformas em superfície - segmentam o sistema viário urbano, para carros ou pedestres, sendo indicadas para vazios urbanos ou canteiros centrais de avenidas. As edificações têm possibilidade de iluminação e ventilação naturais. Os passageiros sobem em direção ao mezanino e posteriormente descem em direção às plataformas para embarcar; no desembarque, o percurso é sempre no sentido ascendente em direção ao mezanino e, em seguida, no sentido descendente em direção às saídas, conforme apresentado na Figura 10.

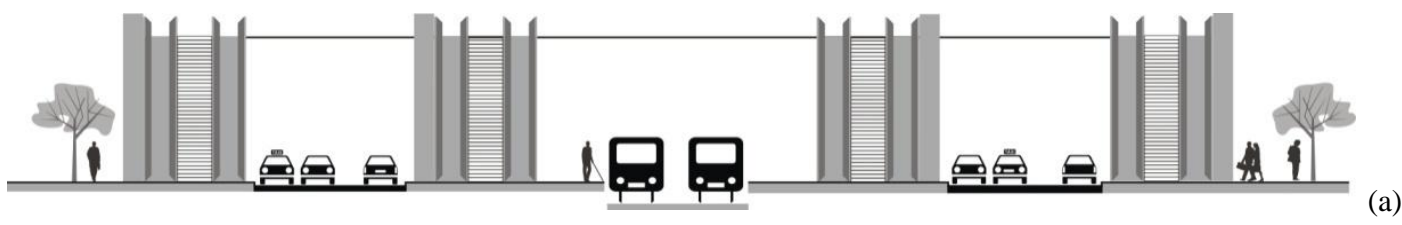


Continuação.

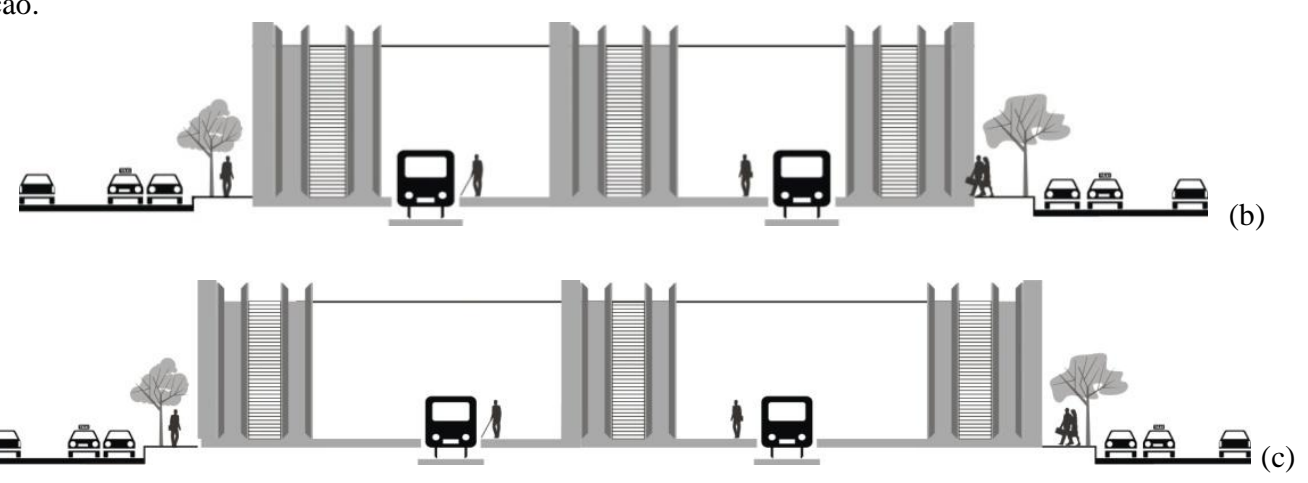

Figura 10 - Plataforma em estação em superfície.

Lateral (a), central (b) e mista (c).

Crédito das ilustrações: ALMEIDA, V. J., 2013.

c) plataformas elevadas - preservam o viário urbano para carros e pedestres, mas causam impacto na paisagem, principalmente nas regiões adensadas. As edificações têm possibilidade de iluminação e ventilação naturais. Nas estações elevadas, os passageiros acessam a estação no mesmo nível das calçadas e posteriormente sobem em direção às plataformas para o embarque; no desembarque, o percurso é sempre no sentido descendente em direção ao mezanino e às saídas (Figura 11).
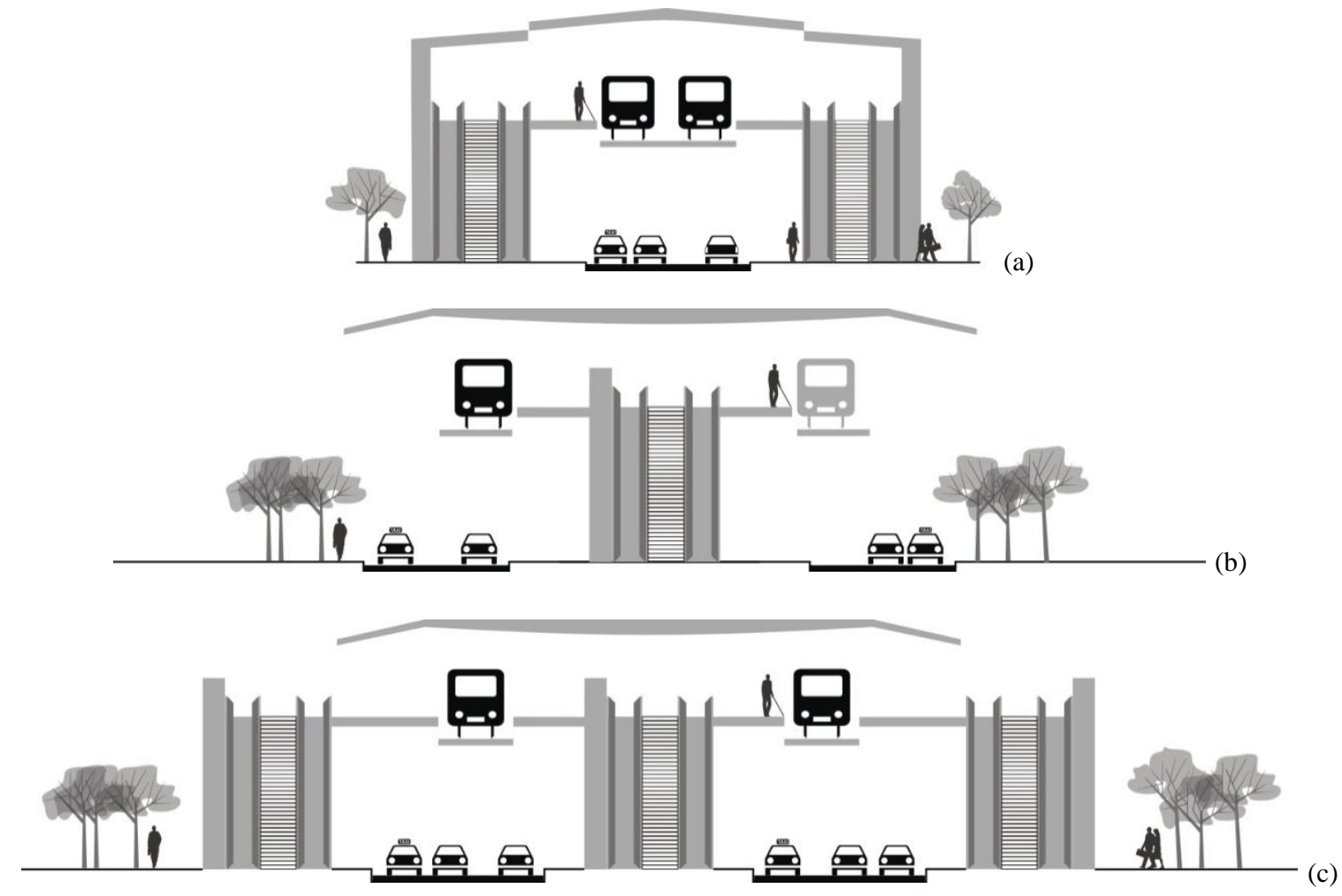

Figura 11 - Plataforma em estação elevada.

Lateral (a), central (b) e mista (c).

Crédito das ilustrações: ALMEIDA, V. J., 2013. 
d) plataforma central - pressupõe fluxos de embarque e desembarque simultâneos na mesma porta do trem; possibilita dimensionar os equipamentos de circulação vertical para atendimento à demanda de duas vias simultaneamente; implica o reforço da sinalização de destino e de embarque uma vez que essas opções são realizadas no nível da plataforma (Figura 12).
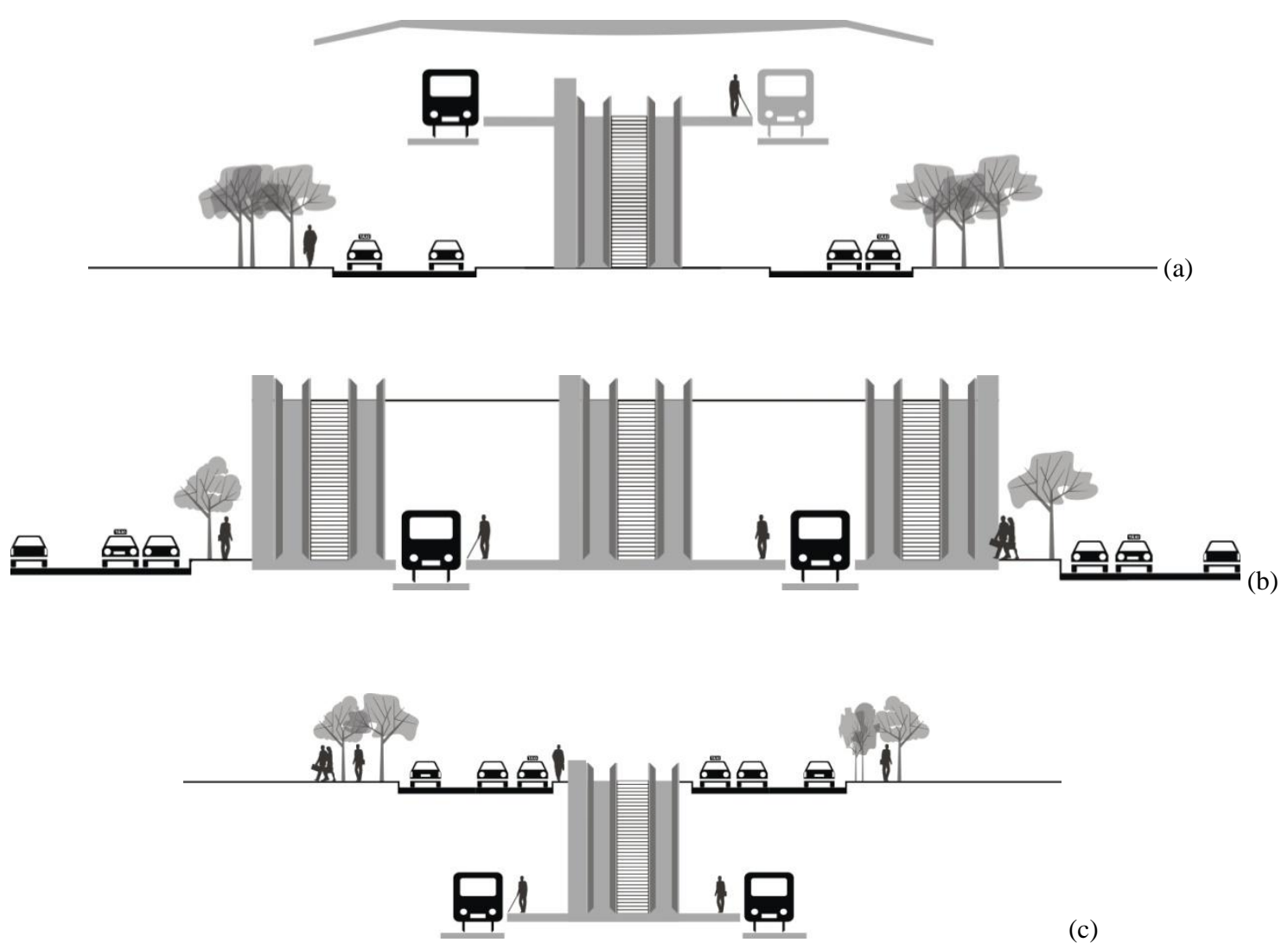

Figura 12 - Plataforma central.

Estação elevada (a), em superfície (b) e subterrânea (c).

Crédito das ilustrações: ALMEIDA, V. J., 2013.

e) plataforma lateral - pressupõe fluxos de deslocamento bidirecionais, com embarque e desembarque simultâneos, na mesma porta do trem; os equipamentos de circulação vertical são dimensionados para atendimento à demanda de uma única plataforma; a sinalização de destino e de embarque é orientadora uma vez que essas opções são realizadas no nível do mezanino (Figura 13). 

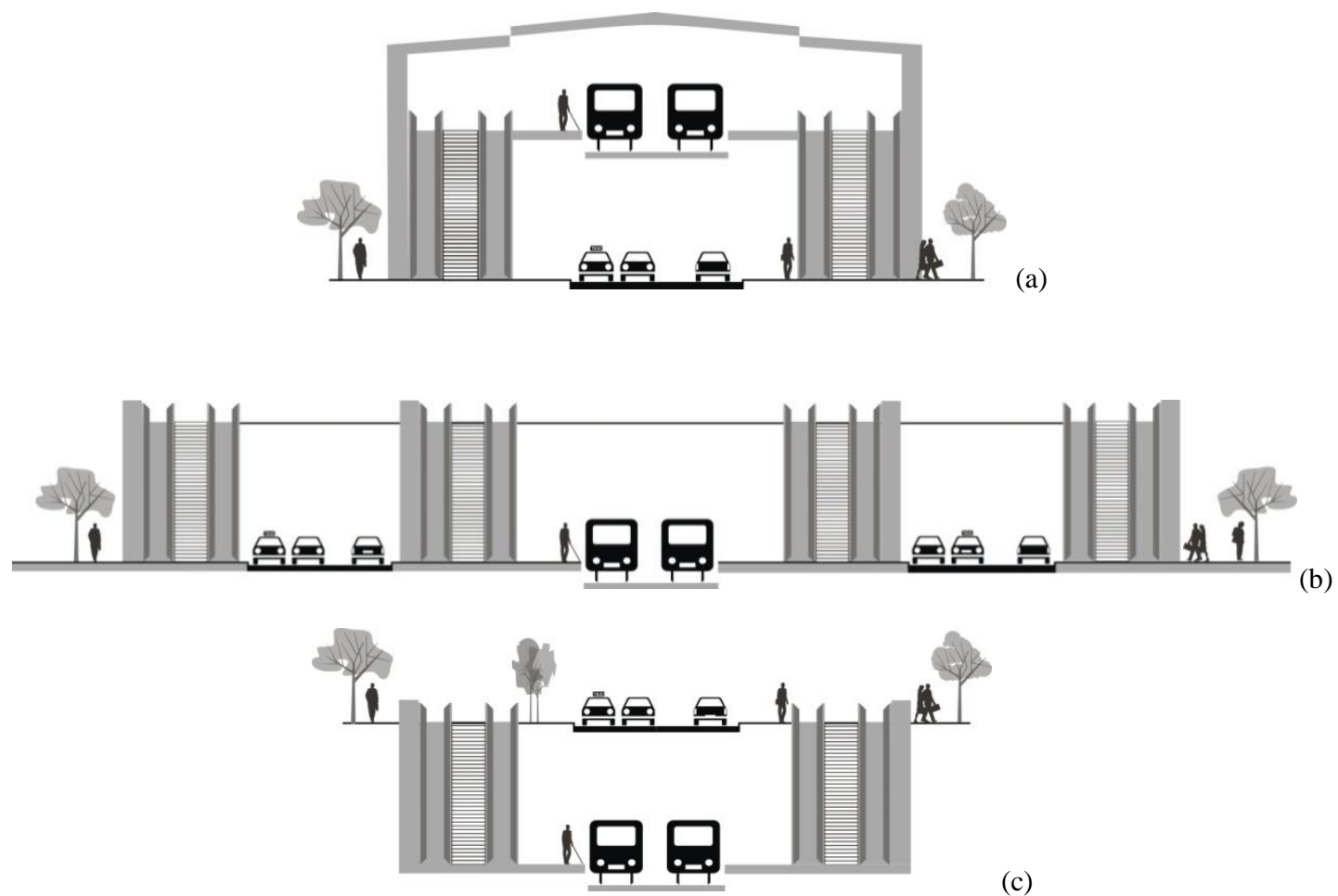

(c)

Figura 13 - Plataforma lateral.

Estação elevada (a), em superfície (b) e subterrânea (c).

Crédito das ilustrações: ALMEIDA, V. J., 2013.

f) plataforma mista - pressupõe fluxos de embarque e desembarque em plataformas distintas e em diferentes portas do trem; os equipamentos de circulação vertical são dimensionados para atendimento à demanda de cada plataforma; a sinalização de destino pode ser direcional (opção de embarque no nível da plataforma), quando o embarque for realizado pela plataforma central, ou de orientação (opção de embarque no nível do mezanino), quando o embarque for realizado pela plataforma lateral, dependendo da estratégia operacional (Figura 14).
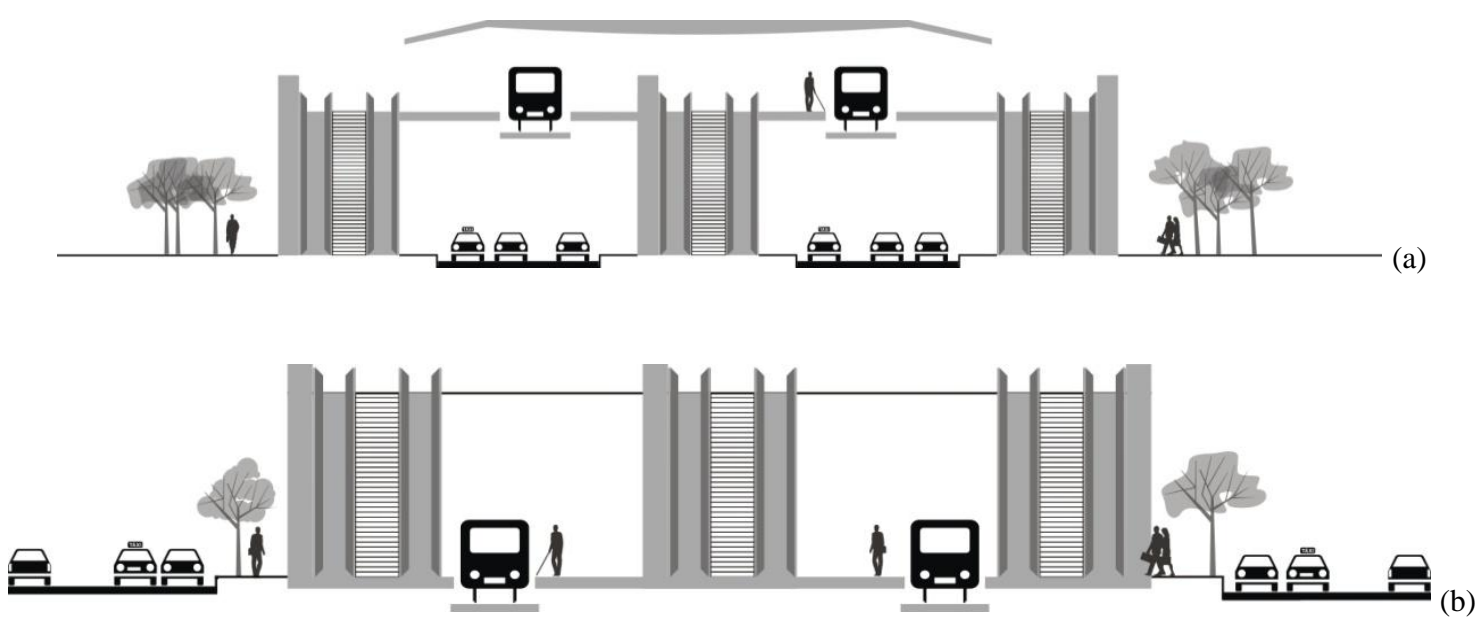
Continuação.

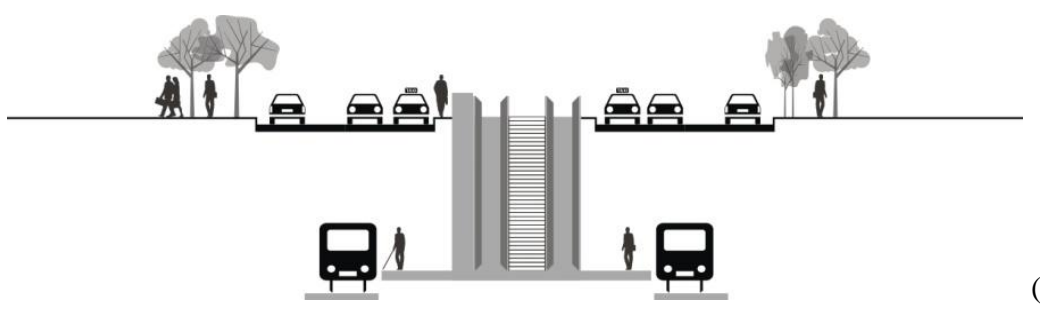

(c)

Figura 14 - Plataforma mista.

Estação elevada (a), em superfície (b) e subterrânea (c).

Crédito das ilustrações: ALMEIDA, V. J., 2013.

Os espaços devem ser otimizados para proporcionar fluidez aos diferentes percursos, sem conflitos, posicionando as atividades intrínsecas ao funcionamento da estação em ordem lógica à sua utilização (EDWARDS, 1997; ROSS; 2000). Os fluxos devem ser uniformes ao longo de todo o percurso, compatibilizando a capacidade de transporte dos trens, das vias, das plataformas e das estações, de forma a evitar eventuais conflitos de fluxo, impedâncias e obstruções. Eventuais alterações nos fluxos podem ser consequência de diferentes percursos (direção ou sentido), velocidades (relacionadas à idade ou habilidades) e hesitações diante das opções para consecução da viagem (BARBOSA; ORNSTEIN, 2012).

Edwards (1997) e Ross (2000) destacam elementos essenciais que auxiliam a legibilidade dos edifícios com programas complexos, colaborando de forma decisiva para a compreensão do espaço e do percurso a ser seguido:

- espaços: são essenciais ao desempenho da estação e devem ser amplos, livres e fluidos, destinados à circulação, espera, filas ou embarque. A visibilidade e a amplitude visual consistem em aspectos de segurança, inibindo crimes e vandalismos. Os fechamentos obstruem a circulação e a visão e representam custos adicionais para segurança e monitoração;

- escala: confere monumentalidade aos ambientes de destaque e escala humana aos corredores de deslocamentos rápidos;

- ritmo da estrutura: dá significado simbólico e estético ao interior dos espaços públicos, conferindo características que diferenciam uma estação da outra e auxiliando o direcionamento das pessoas para as áreas de distribuição e as plataformas; 
- iluminação: natural ou artificial, oferece segurança e facilita a leitura do espaço e a identificação do percurso; orienta os deslocamentos e guia os passageiros de forma mais eficaz do que a sinalização, pontuando saídas e locais de interesse.

A quantidade e o posicionamento dos equipamentos de circulação vertical induzem deslocamentos, organizam e controlam os fluxos de embarque e desembarque nos picos da manhã e da tarde. O sistema de informação inclui a sinalização direcional, a identificação dos ambientes ou serviços oferecidos e dos pontos de interesse, assim como as advertências e as instruções de uso de ambientes, equipamentos e dispositivos.

\subsubsection{A interface entre a estação e o trem}

A configuração da edificação e do material rodante determinam os vãos e os desníveis existentes na interface entre os trens e as plataformas e resulta de condicionantes técnicas das estações, tais como a configuração da via permanente (raios de curvatura, inclinação da via, métodos construtivos em lastro de brita ou em concreto) e a configuração da plataforma (lateral, central, mista).

A configuração da interface também depende de aspectos relacionados ao trem, tais como: comprimento de cada carro; quantidade de carros por composição; quantidade, localização e dimensionamento das portas de embarque e desembarque; desgaste das rodas e dos trilhos; sistema de suspensão e lotação do trem; tolerâncias construtivas da via e da plataforma (GUSTEMS; VALLÈS, 2009). Nas plataformas, a existência ou ausência de proteções, em diferentes alturas, configurações ou modo de funcionamento exercem forte impacto na percepção de segurança pelos usuários. Paralelamente, a existência de sinalização tátil e visual alerta com relação ao perigo iminente e orienta quanto ao posicionamento correto dos usuários que esperam pela chegada do trem.

\subsubsection{O trem}

A configuração dos trens resulta de condicionantes técnicas, tais como carregamento e lotação da linha onde os trens irão circular, e está diretamente relacionada à sua capacidade nominal, definida a partir dos seguintes fatores:

a) largura e comprimento de cada carro;

b) quantidade de carros por composição; 
c) nível de serviço - número de passageiros sentados e em pé por metro quadrado;

d) área ocupada por passageiros sentados;

e) área útil do salão de passageiros ou área ocupada por passageiros em pé.

A padronização, quantidade, localização e dimensionamento das portas, dos assentos comuns e dos assentos preferenciais devem estar associados às facilidades existentes nas plataformas das estações. Eventuais estratégias relacionadas ao embarque preferencial definem a existência e o posicionamento do carro preferencial nas composições.

Os novos trens buscam melhorar o desempenho operacional e atender às novas demandas de segurança e conforto para os passageiros. Os avanços tecnológicos nas áreas de informática e telecomunicação viabilizaram o surgimento de sistemas de sinalização totalmente automáticos, onde a atuação do operador é restrita a casos de anormalidade (TIMÓTEO; FREITAS; GUERRA, 2004). Equipamentos distribuídos estrategicamente ao longo de estações, pátios, vias, ou embarcados garantem a movimentação segura dos trens e incorporam conceitos de operação automática para ações rotineiras, tais como frenagem; controle do tempo de parada, da movimentação dos trens nas plataformas, da velocidade, do percurso entre estações, do rastreamento do trem exibido nas telas de controle; abertura e fechamento das portas do trem e das plataformas. Os recursos de comunicação visual, sonora e de apoio às pessoas no interior dos trens caminham para a disponibilização de sonorização, painéis e sinalizadores luminosos ou sistemas multimídias, utilização de mensagens prégravadas automatizadas para indicação da próxima estação e lado de desembarque, além de mensagens institucionais e comerciais (TAMASHIRO, 2004).

\subsubsection{A gestão dos sistemas de informação, comunicação e orientação}

Informações para os passageiros devem ser precisas, relevantes, suficientes e veiculadas de diferentes maneiras, adaptadas para atender às necessidades dos clientes, tendo em conta as circunstâncias locais. A veiculação de mensagens garante a orientação do fluxo de usuários desde a entrada da estação até as plataformas e destas até as saídas, em situações cotidianas ou de anormalidade e também nas vias - em túnel, em superfície ou vias elevadas -, indicando a rota segura para escape em situações de emergência. As informações sobre horários de funcionamento, interrupções de serviço e mapa da rede são alguns dos fatores que impactam a prestação do serviço de transporte e atendimento às expectativas dos passageiros. No caso de uma rede operada por mais de uma empresa, podem ser veiculadas informações incompletas 
ou conflitantes, impondo aos passageiros fazer o contato para obter a informação necessária, principalmente no caso da necessidade de realizar conexões. Nesse sentido, aprofundar o conhecimento sobre o comportamento e o fluxo dos usuários é essencial para a construção de um eficiente sistema de informações. Para que seja possível uma abordagem orientada para o cliente, torna-se fundamental a colaboração entre as áreas de marketing, de tecnologia da informação e de atendimento ao cliente, envolvidas na prestação de informações.

Griffin (2004, p. 236) sugere a existência de uma hierarquia para veiculação das informações no ambiente metroferroviário, assim estabelecida:

\begin{abstract}
informação prioritária: sinalização direcional, informacional, de orientação e identificação, composta por textos e figuras indicativas das direções, identidade visual dos acessos, localização das bilheterias e equipamentos de venda de bilhetes, localização e identificação das plataformas, localização e identificação das saídas, percursos para abandono da edificação e saídas de emergência;

informação secundária: sinalização de serviços complementares e funções de suporte ao funcionamento do sistema metroviário, composta por mapas e diretórios, mapas dos arredores, tarifas, alertas, orientações de uso, sanitários, telefones, segurança, primeiros socorros, facilidades oferecidas;
\end{abstract}

informação terciária: regulamentações, sinalização de identificação de equipamentos e salas de uso restrito de funcionários, identificação dos ambientes, equipamentos tais como escadas, painéis, elevadores, entre outros. (Griffin, 2004, p.236 - tradução nossa).

Um sistema de informação ideal deve combinar meios tradicionais com sistemas inovadores, de acordo com o lugar, o usuário e o tipo de informação. Independentemente do meio utilizado, as informações veiculadas devem ser completas, corretas, atualizadas, claras, coerentes, de fácil acesso e de fácil compreensão, integradas em um sistema único capaz de fornecer as informações relevantes antes, durante e após a viagem.

\title{
3.2.5 A gestão da prestação dos serviços
}

As evidências físicas, as pessoas e os processos influenciam a decisão pelo uso de um determinado serviço, pois impactam, de forma positiva ou negativa, a avaliação da experiência vivenciada nos deslocamentos. A satisfação do usuário do serviço de transporte é o resultado da diferença entre a sua expectativa e a sua experiência em relação às evidências físicas das estações e dos trens, mas também em relação à interação com os demais usuários e com os funcionários. Nesse sentido, o comportamento dos demais usuários, a aparência e as 
atitudes dos funcionários responsáveis pelo atendimento ou pelo auxílio nos deslocamentos também influenciarão o processo de avaliação.

Os serviços prestados nos sistemas metroferroviários devem considerar a padronização do atendimento, por tratar-se de um serviço de alta capacidade, destinado ao transporte de milhares de passageiros simultaneamente, assim como a customização do atendimento, por tratar-se de um serviço destinado ao transporte de pessoas com diferentes características e necessidades. Tanto a padronização quanto a customização são regidas por procedimentos e roteiros que explicitam o que fazer, quando fazer e como fazer. No caso de uma rede operada por mais de uma empresa, tais procedimentos devem ser coerentes e garantir a continuidade dos serviços prestados.

\subsection{A evolução da acessibilidade no contexto internacional}

Até o início da década de 1990, o tema acessibilidade não era o foco dos planos de modernização dos operadores metroviários. O ponto de inflexão foi impulsionado pelas estatísticas de envelhecimento da população. Na esteira da mobilização da sociedade com temas associados à ética, cidadania, direitos humanos e inclusão social, as organizações começaram a priorizar resultados ambientais, econômicos e sociais adequados para demonstrar sua responsabilidade social. Mais do que o atendimento à legislação cada vez mais exigente, as ações que preconizavam a eliminação de barreiras para as pessoas com deficiência foram apropriadas por todas as pessoas. As premissas de projeto que facilitavam a utilização dos ambientes, produtos e serviços pelas pessoas com deficiência eram úteis para as demais pessoas, possibilitando o uso com autonomia e segurança (BARBOSA; SANTOS, 2010).

A posição oficial da União Internacional dos Transportes Públicos - UITP ${ }^{15}$ em relação ao tema, publicada em 2001, orientava a adoção de ações técnicas, organizacionais e operacionais para garantir a acessibilidade de todas as pessoas. As ações deveriam ser adequadas e aplicáveis aos veículos e à infraestrutura para melhorar a mobilidade e garantir segurança aos passageiros, considerando as condições e situações locais, estabelecendo

\footnotetext{
15 A posição oficial da UITP representa os interesses dos principais intervenientes e reflete a decisão de autoridades de transporte, a indústria e operadores públicos e privados de todos os modos de transporte coletivo de passageiros, totalizando 2000 membros em 80 países.
} 
parcerias das operadoras com o poder público e com a sociedade civil organizada (UITP, 2001). Em relação aos transportes sobre trilhos, três níveis de acessibilidade foram inicialmente definidos, baseados nas dificuldades ou facilidades de uso por pessoas em cadeiras de rodas:

a) acessibilidade independente - condições de acesso sem necessidade de utilização de dispositivos ou serviços para auxiliar o embarque ou o desembarque;

b) acessibilidade com auxílio - condições de acesso mediante utilização de dispositivos ou serviços para auxiliar o embarque ou o desembarque;

c) acessibilidade restrita - condições inadequadas de acesso, sem dispositivos ou serviços para auxiliar o embarque ou o desembarque.

Muitos metrôs têm a exigência legal de prover uma nova infraestrutura de transporte acessível e, simultaneamente, adaptar as instalações antigas: alguns têm recursos para isso, outros não. Construir uma nova linha com estações e trens acessíveis é mais fácil e mais barato do que adaptar estações e trens existentes e, dessa forma, as redes de metrô convivem com linhas mais novas, acessíveis, e com linhas mais antigas, sem acessibilidade, que impõem grandes desafios de engenharia para solução dos problemas. Mais recentemente, foi estabelecido um agrupamento para os sistemas metroferroviários em operação, de acordo com o grau de acessibilidade oferecido:

a) redes já construídas acessíveis ou cujas adaptações já foram concluídas;

b) redes mistas, onde há convivência de linhas antigas, não acessíveis, e linhas mais recentes, acessíveis;

c) redes com um baixo nível global de acessibilidade e/ou significativos desafios de engenharia.

A UITP (UITP, 2009) reconhece que a evolução para o cenário de acesso independente implica a consideração do contexto de sua implementação, ou seja, a existência de diferentes cenários para estações e trens e, consequentemente, para a interface entre ambos:

a) novas estações, novos trens - cenário de expansão da rede;

b) novas estações, trens existentes - cenário de extensão de linhas;

c) estações existentes, novos trens - cenário de incremento da frota; 
d) estações existentes, trens existentes - cenário considerado o mais desafiador, tanto pelas dificuldades técnicas como pelos custos.

Os sistemas de transporte sobre trilhos vêm se mobilizando para promover a adaptação de suas instalações, compartilhando dificuldades, problemas enfrentados e experiências de sucesso. Entre os sistemas internacionais, constatou-se que a adaptação das edificações e veículos, juntamente com a integração entre diferentes modos de transporte, impactaram positivamente a segurança das pessoas e a qualidade do serviço, gerando aumento da receita das empresas operadoras, que atraíram maior quantidade de passageiros fora do horário de pico. Outro impacto positivo foi a redução dos custos operacionais decorrente da diminuição do número de acionamentos dos funcionários para auxílio no embarque ou desembarque e da diminuição da quantidade de acidentes (COMET, 2012).

A estratégia adotada para prover acessibilidade nas estações envolveu a remoção ou minimização dos obstáculos existentes no percurso de embarque e desembarque e a implementação de um caminho alternativo. As operadoras priorizaram as intervenções em estações com elevadas demandas, de conexão com outros modos de transporte ou localizadas junto a polos geradores de fluxo, como hospitais, aeroportos, pontos turísticos e também estações com alta probabilidade de receber pessoas com deficiências.

Na impossibilidade de intervir nas estações, adotou-se uma abordagem multimodal, criandose transportes alternativos acessíveis no mesmo percurso. No caso dos trens, as adaptações implantadas estão relacionadas aos assentos prioritários para pessoas com mobilidade reduzida, ao espaço dedicado a cadeiras de rodas, aos balaústres com cores contrastantes e às informações prestadas aos usuários (sonoras e visuais), indicando a próxima parada e o fechamento das portas, além das informações sobre problemas em casos de anormalidade.

Em relação ao vão e desnível entre a estação e o trem, as adaptações implantadas - em caráter temporário ou definitivo - estão concentradas nas plataformas, seja prolongando a superfície da plataforma (redução do vão), seja elevando a altura em parte da plataforma (redução do desnível).

Embora em menor quantidade, foram feitas adaptações nos trens, em portas específicas, por meio de dispositivos mecânicos acionados mediante solicitação. Nas duas situações, as áreas de embarque preferencial têm sinalização de destaque, orientando os passageiros. 
$\mathrm{Na}$ última análise comparativa sobre acessibilidade em estações e trens (COMET, 2009), foram estabelecidos 45 requisitos de desempenho, visando padronizar a verificação do estágio de adequação dos sistemas metroferroviários. Doze sistemas metroferroviários responderam ao questionário informando o percentual de atendimento aos requisitos avaliados, possibilitando compreender os itens valorizados pelas empresas e o grau de adequação. Do total, 16 requisitos de desempenho relacionam-se à configuração e 29 requisitos relacionamse ao sistema de sinalização em estações e trens (Quadro 7). 
Quadro 7 - Requisitos de desempenho relacionados à acessibilidade em estações e trens.

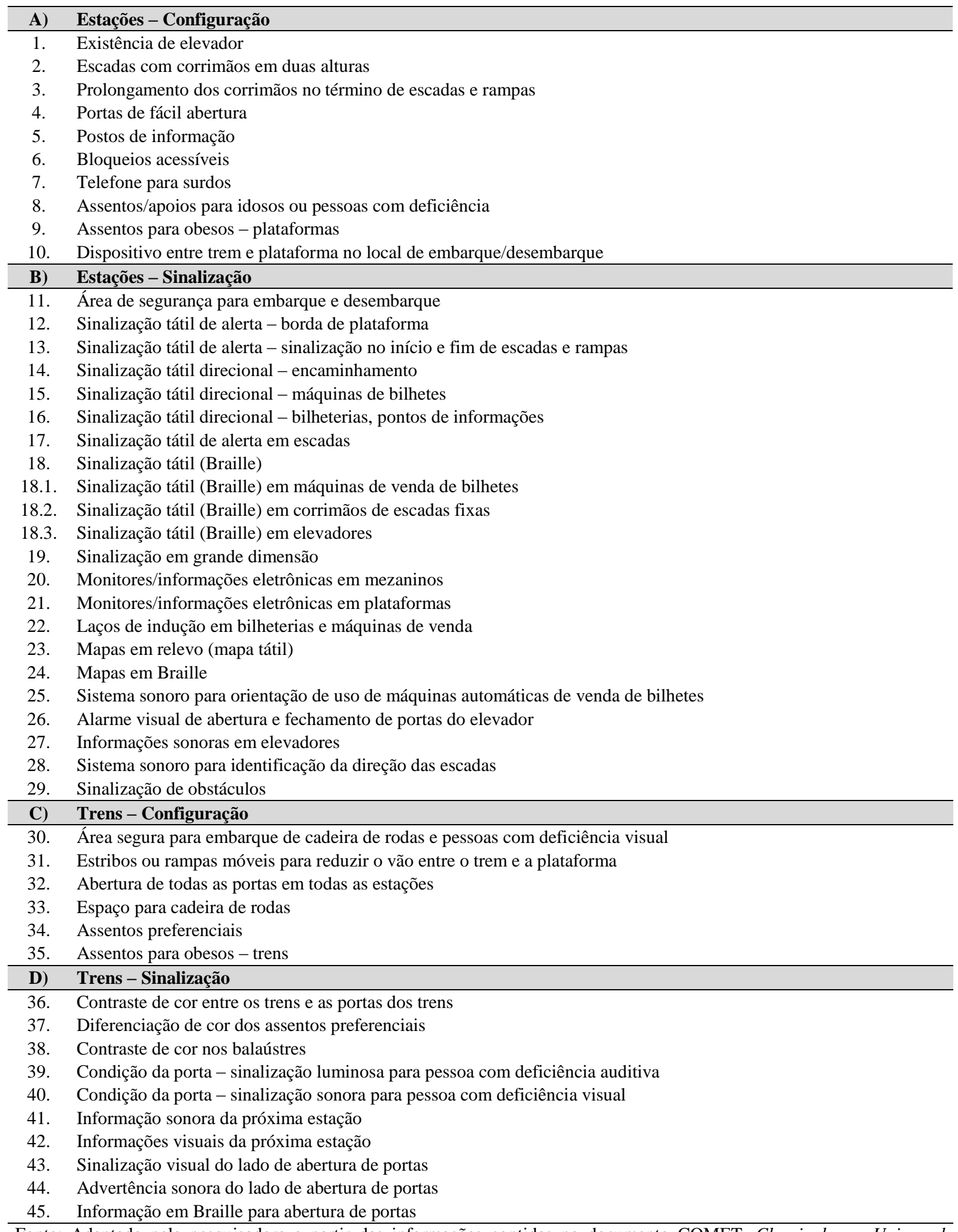

Fonte: Adaptado pela pesquisadora a partir das informações contidas no documento COMET, Clearinghouse Universal Accessibility: Functional Specifications: Level of Progress, 2009. 


\subsection{A rede sobre trilhos na Região Metropolitana de São Paulo}

A Região Metropolitana de São Paulo (RMSP) tem 39 municípios e aproximadamente 20 milhões de habitantes. A rede de transporte metropolitano é gerida pela Secretaria de Estado dos Transportes Metropolitanos e inclui a operação dos ônibus intermunicipais e dos trens em 22 diferentes municípios. A rede sobre trilhos da RMSP é operada por três diferentes empresas: a Companhia do Metropolitano de São Paulo (CMSP), a Companhia Paulista de Trens Metropolitanos (CPTM) e a Via Quatro.

A rede sobre trilhos dispõe de $330 \mathrm{~km}$ de extensão, com 153 estações e 330 trens que transportam, diariamente, em torno de 6,5 milhões de passageiros, número equivalente a $76 \%$ dos deslocamentos metroferroviários no território brasileiro (Anuário Metroferroviário, 2012). A ampliação da rede, seja pela integração com novos modos de transporte seja pela construção de novas linhas pressupõe o aumento das edificações destinadas à conexão de trens regionais e metropolitanos, metrôs, monotrilhos, corredores exclusivos ou expressos de ônibus municipais ou metropolitanos (Figura 15), proporcionando novas opções de deslocamentos e maior mobilidade da população.

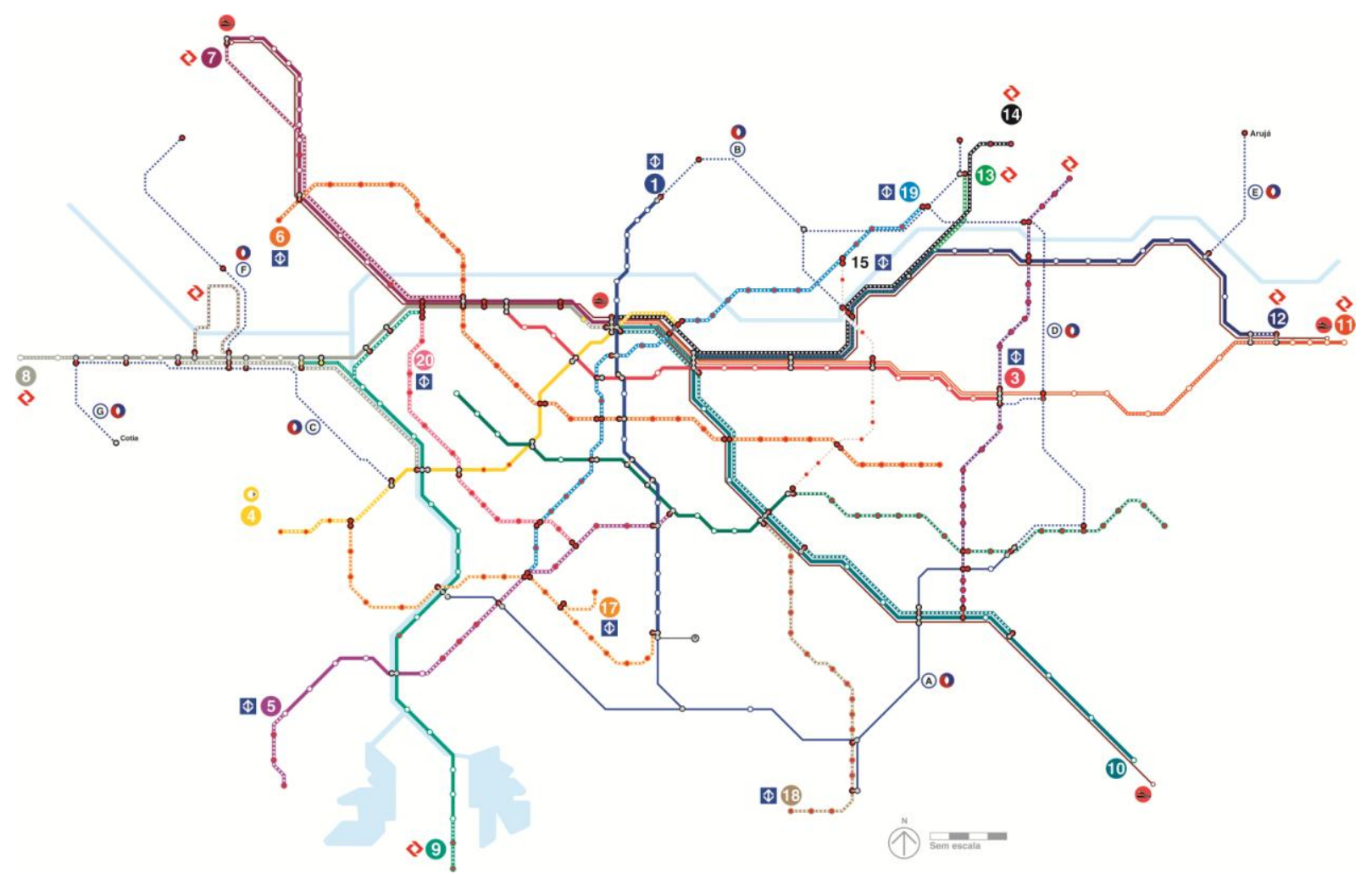

Figura 15 - Transporte Metropolitano RMSP 2030 - ampliação da rede e dos pontos de conexão.

Fonte: Fernandes, J., 2011. Disponível em: 〈http://portal1.antp.net/rep/18cng/ 18cng14pnlt02.pdf>. Acesso em: 12 jan. 2012. 
Com a vigência da NBR 9050 (ABNT, 2004) e da NBR 14021 (ABNT, 2005), os princípios do desenho universal começaram a ser introduzidos como premissas de projetos de estações, terminais urbanos de integração, empreendimentos associados e trens (Figura 16). No campo superior, são indicadas as premissas adotadas nos projetos das estações enquanto que no campo inferior apresenta-se a evolução dos requisitos normativos e/ou legais.

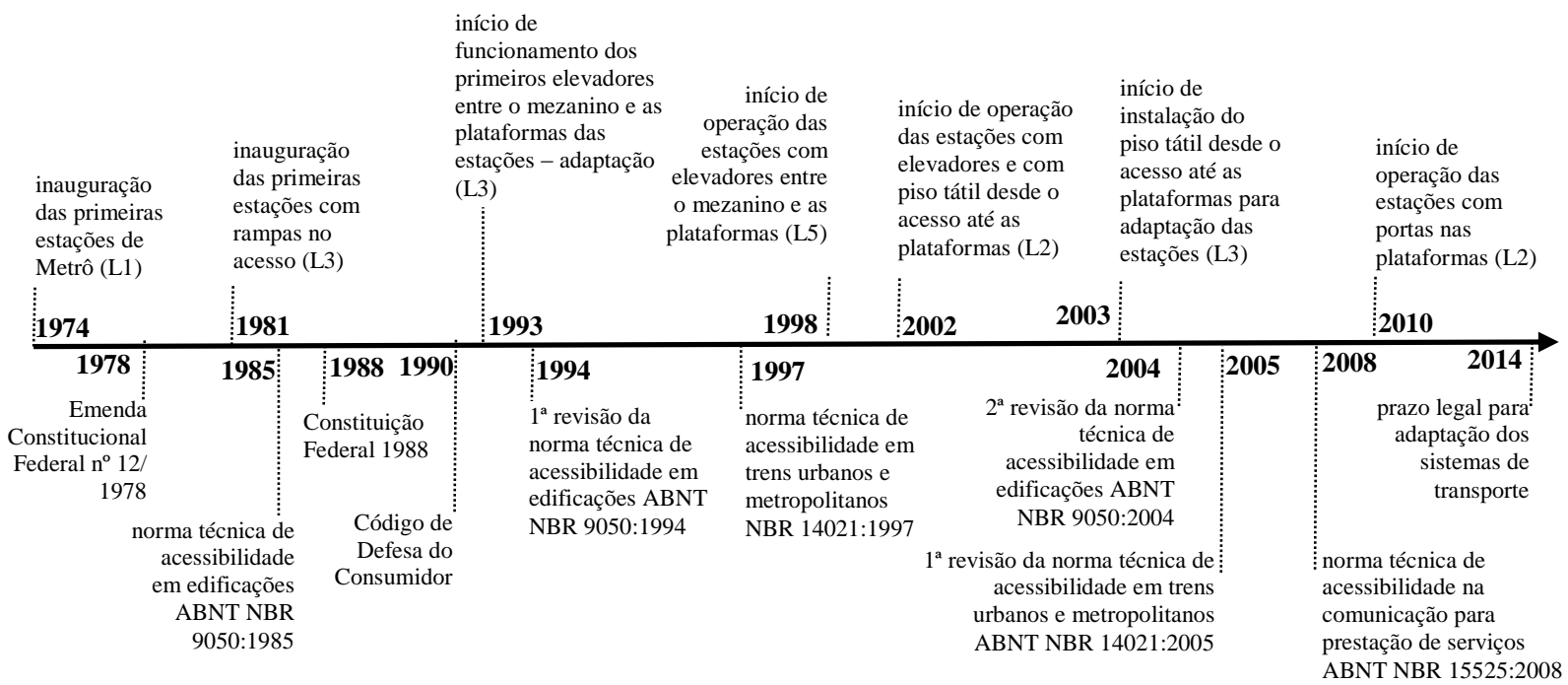

Figura 16 - Evolução das normas técnicas e das premissas de projeto das estações metroviárias. Fonte: Elaborado pela autora a partir de CMSP, 2011.

O movimento em favor da acessibilidade nos transportes começou a ter uma estruturação mais dinâmica na União Internacional dos Transportes Públicos (UITP) e formalizou-se na Associação Nacional de Transportes Públicos (ANTP), dentro da Comissão Metroferroviária, onde foi criada uma comissão de estudo específica para essa finalidade. Durante as reuniões periódicas, além dos aspectos técnicos de adequação das instalações em relação à acessibilidade - estações e trens -, são tratadas questões relacionadas aos benefícios sociais, notadamente à concessão da gratuidade, conforme impactos da legislação vigente em cada estado, e são registradas melhores práticas e ações bem sucedidas relacionadas ao tema.

Em 2002, a ANTP realizou um levantamento entre as empresas operadoras metroferroviárias nacionais com o objetivo de avaliar as condições de acessibilidade existentes, as adaptações implementadas ou previstas nos trens e nos percursos internos e externos das estações, além das políticas de relacionamento com usuários e treinamento de funcionários, considerando a legislação e a regulamentação vigentes. Entre os itens pesquisados e resultados obtidos, destacam-se (a) circulação externa; (b) circulação interna; (c) mobiliário; (d) material rodante; 
(e) via permanente; (f) treinamento de empregados e (g) comunicação e treinamento de usuários.

Os resultados evidenciaram os esforços das empresas no sentido de estudar alternativas para atendimento à legislação, notadamente em relação à adaptação das instalações existentes para permitir o acesso de pessoas com deficiência ou mobilidade reduzida aos sistemas em operação (Gráfico 1). Dos itens atendidos, destacaram-se aqueles com baixo custo de implantação, evidenciando o baixo investimento na questão acessibilidade, em função dos elevados custos de adaptação das instalações existentes e da indisponibilidade de recursos financeiros à época (BARBOSA, 2005). Desde 2002, não foi publicada nenhuma outra pesquisa sobre o tema acessibilidade.

Gráfico 1 - Aspectos avaliados pelos sistemas metroferroviários nacionais.

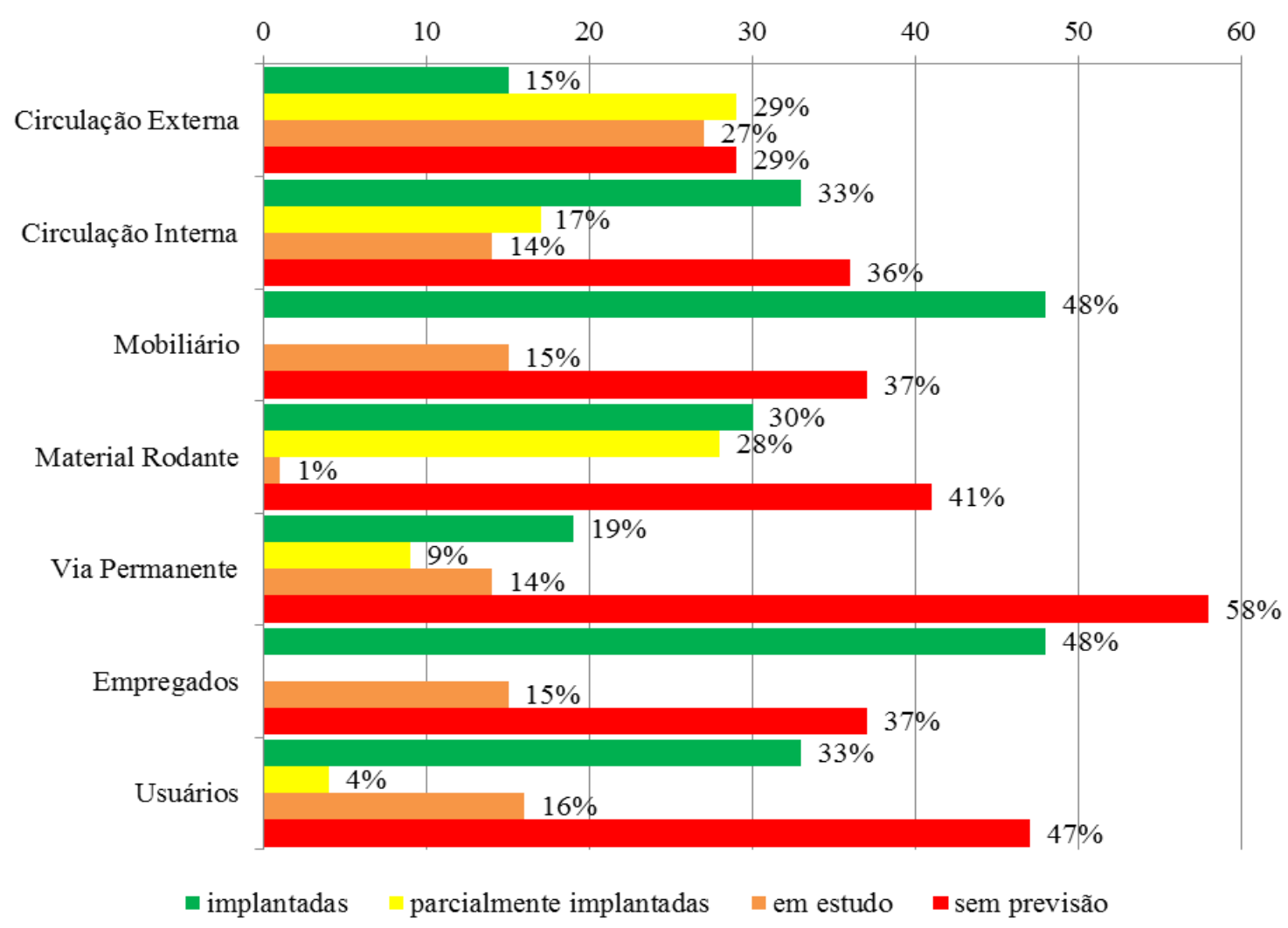

Fonte: Elaborado pela pesquisadora a partir de BARBOSA, 2005 p.59. (2014) 
Construída ao longo dos anos, em diferentes períodos, a rede metroferroviária da RMSP tem instalações com diversas condições de acessibilidade - estações acessíveis, estações adaptadas ou estações não adaptadas, trens acessíveis, trens adaptados ou trens não adaptados -, caracterizando-se como uma rede mista, onde há convivência entre linhas antigas, não acessíveis, e linhas mais recentes, acessíveis, já projetadas e construídas atendendo aos requisitos estabelecidos na legislação, conforme apresentado na Figura 17.

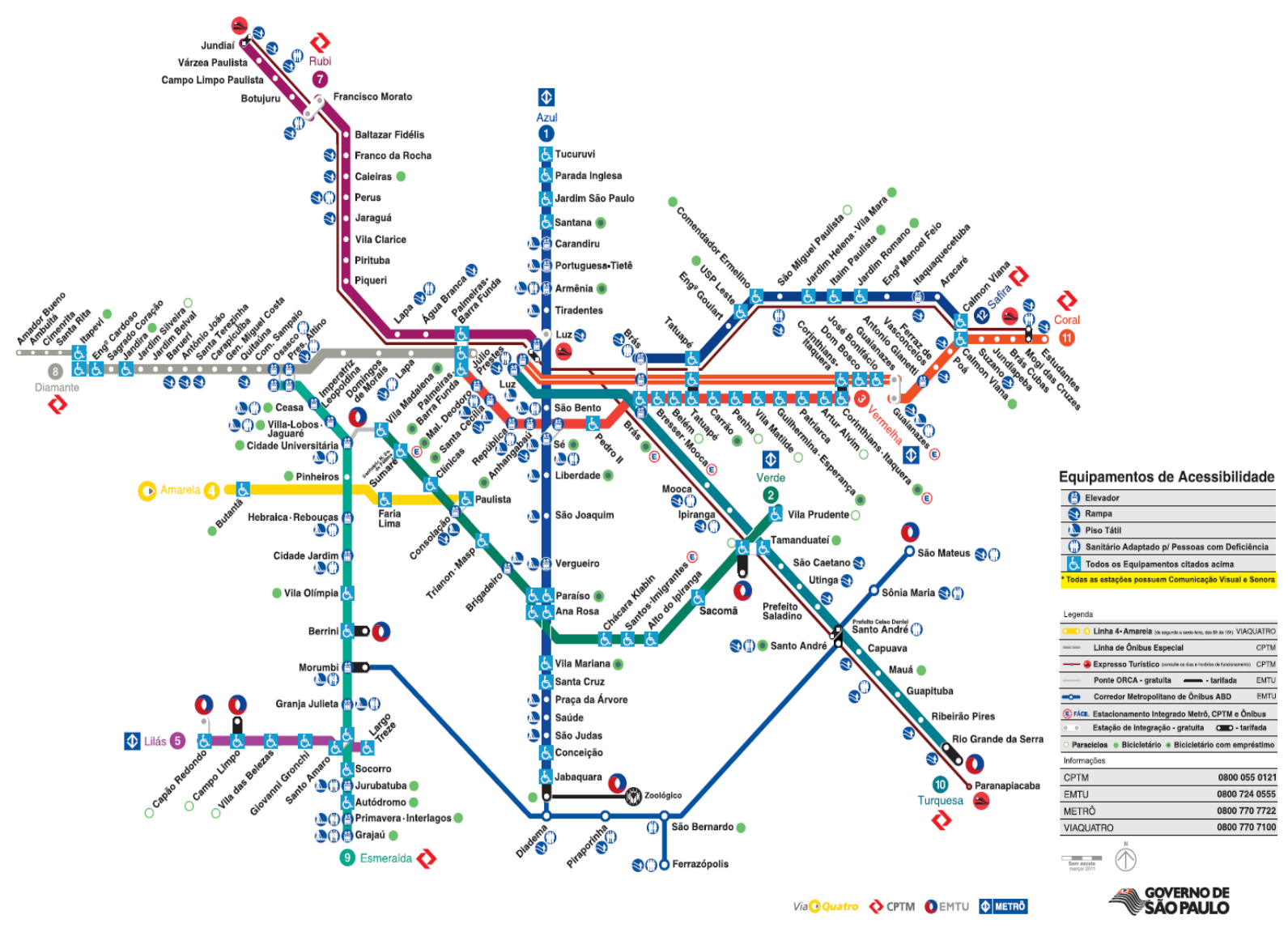

Figura 17 - Equipamentos de Acessibilidade na Rede Metropolitana de Transporte.

Fonte: CMSP, 2011. Disponível em: 〈http://www.metro.sp.gov.br/acessibilidade〉. Acesso em: 04 abr. 2011.

As diretrizes dos projetos das instalações metroviárias seguiram os requisitos da legislação e das normas técnicas vigentes, aperfeiçoados ao longo dos anos. Podemos afirmar, portanto, que as linhas implantadas recentemente possuem mais facilidades de circulação e utilização por pessoas com deficiência ou com mobilidade reduzida. Seguindo as premissas do desenho universal, a construção das novas linhas trouxe consigo inúmeras inovações tecnológicas que permitiram a inclusão de pessoas com deficiência, marcando a história da cidade e introduzindo um novo conceito de prestação de serviço público para a população. 


\subsection{Os fatores-chave da mobilidade no Metrô de São Paulo}

A Companhia do Metropolitano de São Paulo (CMSP) foi criada em 1968, e o início de operação dos serviços ocorreu em 1974, com 6,4 km de extensão. A rede foi ampliada gradativamente ao longo dos anos até atingir sua extensão atual, com 66,2 km, 59 estações e 150 trens (CMSP, 2014). A CMSP é responsável pelo projeto, construção, operação e manutenção das estações e trens.

\subsubsection{A estação e seu entorno}

As estações caracterizam-se como edificações que promovem a transição entre a calçada e o trem, a partir de três ambientes típicos: os acessos, o hall de circulação e controle de acesso (mezanino) e as plataformas. A combinação entre a posição e a configuração das plataformas das estações resulta em 9 tipologias distintas que determinam diferentes fluxos de embarque ou desembarque, impondo deslocamentos horizontais em áreas de circulação ou áreas de acumulação (filas ou espera junto aos bloqueios e plataformas) e deslocamentos verticais, vencidos por meio de elevadores, plataformas horizontais ou inclinadas, escadas rolantes, esteiras, rampas e escadas fixas. Os fluxos e as distâncias - horizontais e verticais - impactam a compreensão do espaço e do trajeto a ser percorrido pelo usuário. Considerando as 59 estações em operação sob responsabilidade do Metrô de São Paulo (Linhas 1-Azul, 2-Verde, 3-Vermelha e 5-Lilás), obtém-se um cenário que explicita a variedade de configuração das estações da rede (Quadro 8). 
Quadro 8 - São Paulo - Quantidade de estações/linhas, segundo a posição e a configuração das plataformas - 2013.

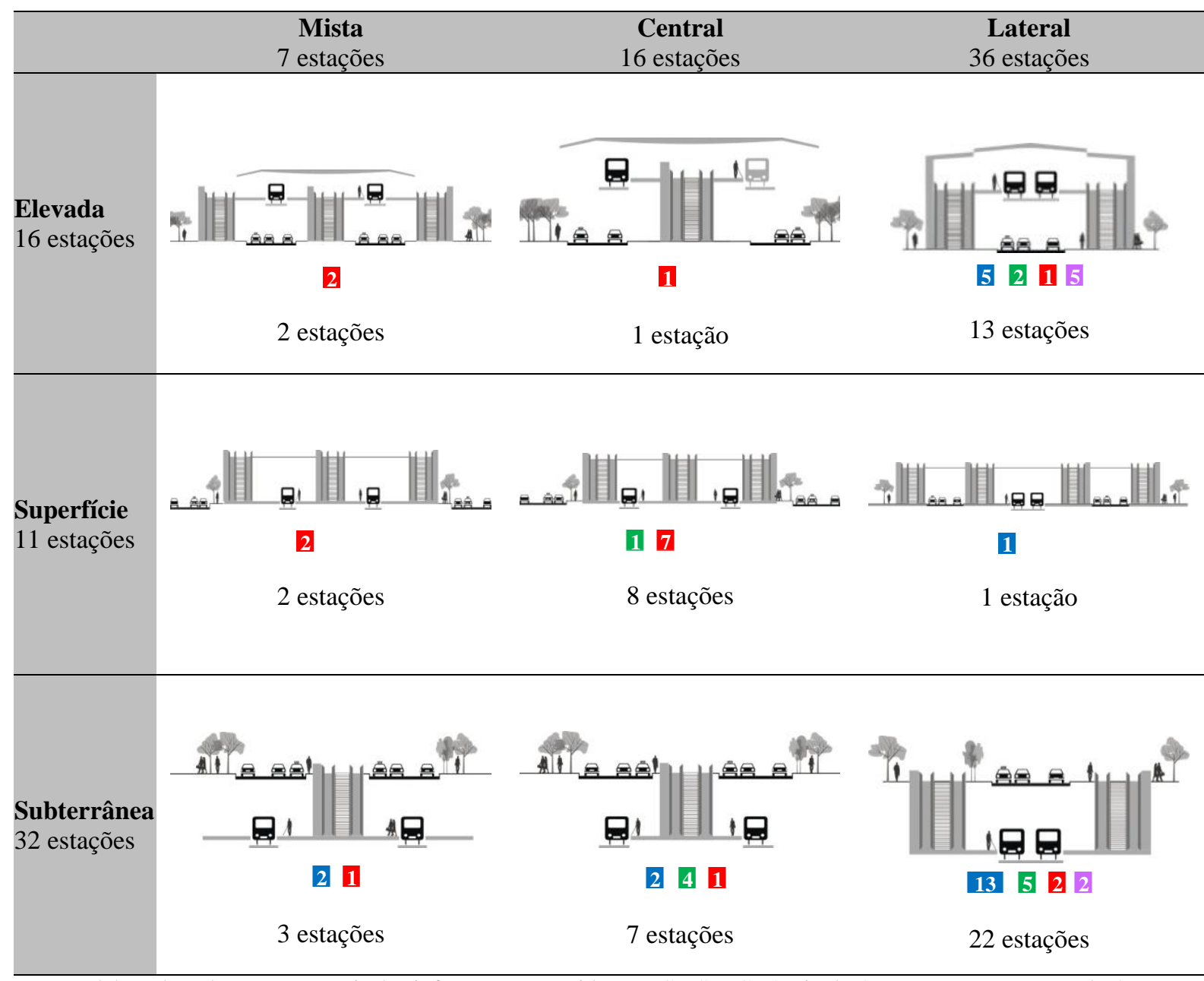

Fonte: Elaborado pela autora a partir das informações contidas em CMSP, Gerência de Operações, Por Dentro da Operação 2013, 2014, p. 45.

Crédito das ilustrações: ALMEIDA, V. J., 2013.

A chegada do usuário é possível a partir de formas diversas: a pé, de bicicleta, táxi, van, ônibus com capacidades diferentes ou de trem. A conexão entre diferentes modos de transporte (trem metropolitano, monotrilho, ônibus intermunicipal, ônibus metropolitano, ônibus municipal, vans ou estacionamentos) e empreendimentos (centros comerciais ou de serviços) implica a construção de infraestrutura adequada para a circulação de pessoas, seja por meio de túneis, passarelas ou corredores (no caso de estruturas conectadas) seja por meio de compartilhamento dos mezaninos/hall de passageiros (no caso de estruturas compartilhadas). O crescimento da rede e a conexão com empreendimentos ou com outros modos de transporte (Tabela 2) resultam em espaços complexos e aspectos diferenciados entre uma estação e outra e implicam mais atenção por parte dos projetistas na orientação dos fluxos. 
Tabela 2 - São Paulo - Quantidade de estações segundo a conexão com outros modos de transporte/empreendimentos $-2013$.

\begin{tabular}{|c|c|c|c|c|c|}
\hline $\begin{array}{l}\text { Conexões com outros modos de } \\
\text { transporte ou empreendimentos }\end{array}$ & $\begin{array}{c}\text { Linha } 1 \text { - } \\
\text { Azul }\end{array}$ & $\begin{array}{c}\text { Linha } 2 \text { - } \\
\text { Verde } \\
\end{array}$ & $\begin{array}{l}\text { Linha } 3 \text { - } \\
\text { Vermelha }\end{array}$ & $\begin{array}{c}\text { Linha } 5 \text { - } \\
\text { Lilás }\end{array}$ & Total \\
\hline Metrô & 3 & 2 & 1 & - & 6 \\
\hline Trem metropolitano & 1 & 1 & 4 & 1 & 7 \\
\hline Monotrilho & - & 1 & - & - & 1 \\
\hline Terminais rodoviários & 2 & - & 1 & - & 3 \\
\hline Ônibus metropolitano & 1 & 1 & - & - & 2 \\
\hline Corredor de ônibus & - & 1 & 1 & - & 2 \\
\hline Terminais urbanos & 6 & 4 & 12 & 3 & 25 \\
\hline Estacionamentos & 3 & 3 & 7 & - & 13 \\
\hline Bicicletários/paraciclos & 5 & 4 & 12 & 3 & 24 \\
\hline Centro comercial & 2 & - & 3 & - & 5 \\
\hline Centro de serviços & - & - & 1 & - & 1 \\
\hline
\end{tabular}

Fonte: Elaborado pela pesquisadora a partir das informações contidas em CMSP, Gerência de Operações, Por Dentro da Operação 2013, 2014, p. 45.

As diferentes demandas (Tabela 3) são consequência do uso e ocupação do solo no entorno das estações, da conexão com outras linhas ou outros modos de transporte ou com empreendimentos existentes.

Tabela 3 - São Paulo - Quantidade de estações segundo a demanda - 2013.

\begin{tabular}{lccccc}
\hline Demanda das estações & $\begin{array}{c}\text { Linha 1 - } \\
\text { Azul }\end{array}$ & $\begin{array}{c}\text { Linha 2 } \\
\text { Verde }\end{array}$ & $\begin{array}{c}\text { Linha 3 - } \\
\text { Vermelha }\end{array}$ & $\begin{array}{c}\text { Linha 5 - } \\
\text { Lilás }\end{array}$ & Rede \\
\hline Alta (> 90.000 entradas ou conexões) & 3 & 2 & 5 & 0 & 10 \\
\hline Média (> 45.000 entradas ou conexões) & 6 & 3 & 5 & 2 & 16 \\
\hline $\begin{array}{l}\text { Baixa (até 45.000 entradas ou } \\
\text { conexões) }\end{array}$ & 12 & 8 & 8 & 5 & 33
\end{tabular}

Fonte: Elaborado pela pesquisadora a partir das informações contidas em CMSP, Gerência de Operações, Por Dentro da Operação 2013, 2014, p. 96.

As estações resultam de diferentes partidos arquitetônicos:

a) linha 1-Azul - as estações tiveram forte caráter subterrâneo, sem relação com o espaço externo, pois não se previa a integração com outros sistemas de transporte. Enquanto no trecho sul predominavam ambientes subterrâneos, cinzas e escuros, no trecho norte predominavam as vias e estações elevadas. Posteriormente, painéis artísticos foram introduzidos em grandes paredes, trazendo a cor para os espaços subterrâneos;

b) linha 3-Vermelha - o partido arquitetônico adotado para os projetos das estações em superfície tem como característica básica a inovação dos materiais empregados nas coberturas, formadas por testeiras e treliças metálicas espaciais, coloridas, resultando em marcos referenciais na paisagem urbana; 
c) linha 2-Verde - as estações são marcadas pela utilização de técnicas construtivas inovadoras e redução de impactos ambientais e urbanísticos decorrentes das obras, com objetivo de minimizar as desapropriações, os transtornos ao trânsito e à circulação de pedestres. A adoção de grandes aberturas entre os diversos níveis da estação possibilitou aos usuários uma visão geral dos espaços projetados. A iluminação padrão deu lugar à iluminação com diferentes faixas de intensidade de luz, buscando valorizar as formas estruturais e os elementos arquitetônicos. Os espaços subterrâneos ganharam revestimentos cerâmicos com cores contrastantes;

d) linha 5-Lilás - caracteriza-se por suas estações elevadas, com acessos a partir de praças e ambientes internos com iluminação e ventilação naturais.

Além das diferentes tipologias decorrentes da configuração e localização das plataformas, da conexão com outros modos de transporte e dos acabamentos utilizados na ambientação das estações, deve ser considerada a diversidade de modelos dos equipamentos existentes, decorrente do projeto, do fabricante/fornecedor e da tecnologia disponível à época em que foram produzidos (Tabela 4).

Tabela 4 - São Paulo - Quantidade de equipamentos típicos de estações - 2013.

\begin{tabular}{lrrrrrr}
\hline $\begin{array}{l}\text { Características dos equipamentos } \\
\text { das estações }\end{array}$ & $\begin{array}{c}\text { Linha 1 } \\
\text { Azul }\end{array}$ & $\begin{array}{c}\text { Linha 2 } \\
\text { Verde }\end{array}$ & $\begin{array}{c}\text { Linha 3 - } \\
\text { Vermelha }\end{array}$ & $\begin{array}{c}\text { Linha 5 - } \\
\text { Lilás }\end{array}$ & Rede \\
\hline Início da operação & $\mathbf{1 9 7 4}$ & $\mathbf{1 9 9 1}$ & $\mathbf{1 9 7 9}$ & $\mathbf{2 0 0 2}$ & - \\
\hline Escadas rolantes (un.) & 206 & 91 & 175 & 54 & $\mathbf{5 2 6}$ \\
\hline Elevadores/plataformas (un.) & 60 & 32 & 24 & 26 & $\mathbf{1 4 2}$ \\
\hline Bloqueios (un.) & 338 & 132 & 216 & 66 & $\mathbf{7 5 2}$ \\
\hline Validadores (un.) & 215 & 141 & 161 & 44 & $\mathbf{5 6 1}$ \\
\hline
\end{tabular}

Fonte: Elaborado pela pesquisadora a partir das informações contidas em CMSP, Gerência de Operações, Por Dentro da Operação 2013, 2014, p. 37.

\subsubsection{A interface entre a estação e o trem}

A interface entre a estação e o trem é afetada pela configuração da via permanente e da plataforma, conforme já apontado anteriormente, e também pela altura do piso do trem. Quando alinhados nas plataformas, os trens das diversas frotas resultam em dimensões variadas para o vão e o desnível entre a edificação e o veículo.

As estações construídas mais recentemente dispõem de portas de plataforma, com o objetivo de "otimizar as operações de embarque, desembarque e a movimentação dos trens nas regiões 
das plataformas, aumentar o nível de segurança dos usuários e impedir o acesso (indevido) às regiões de túneis e vias por pessoas não autorizadas" (CMSP, 2014, p. 90). Nas estações mais antigas e com demanda elevada, foram instalados elementos organizadores de embarque - três modelos diferentes - para organizar os fluxos de embarque e desembarque no momento em que o trem está parado na plataforma (Tabela 5). Os diferentes modelos (curto, longo, embarque) foram desenvolvidos para adequação às dimensões e configuração das plataformas.

Tabela 5 - São Paulo - Quantidade de estações segundo os equipamentos de plataforma.

\begin{tabular}{lccccc}
\hline $\begin{array}{l}\text { Características dos equipamentos e } \\
\text { elementos das plataformas }\end{array}$ & $\begin{array}{c}\text { Linha 1 - } \\
\text { Azul }\end{array}$ & $\begin{array}{c}\text { Linha 2 - } \\
\text { Verde }\end{array}$ & $\begin{array}{c}\text { Linha 3 - } \\
\text { Vermelha }\end{array}$ & $\begin{array}{c}\text { Linha 5 - } \\
\text { Lilás }\end{array}$ & Rede \\
\hline Início da operação & 1974 & 1991 & 1979 & 2002 & - \\
\hline Portas de plataforma (est.) & - & 3 & - & 1 & $\mathbf{4}$ \\
\hline Organizadores de embarque (est.) & 7 & 4 & 10 & 1 & $\mathbf{2 2}$ \\
\hline
\end{tabular}

Fonte: Elaborado pela pesquisadora a partir das informações contidas em CMSP, Gerência de Operações, Por Dentro da Operação 2013, 2014, p. 37 e 91.

\subsubsection{O trem}

Todos os trens são formados por um conjunto de seis carros; cada carro tem quatro portas de cada lado, de forma a possibilitar o embarque e o desembarque em plataformas centrais, laterais e mistas. Internamente, as diferenças são decorrentes da configuração dos assentos, barras de apoio e acabamentos utilizados na ambientação dos carros, resultantes do projeto, do processo de fabricação e da tecnologia disponível à época em que foram produzidos. Os carros líderes de todas as frotas (carro A) são destinados ao atendimento preferencial e possuem condições diferenciadas em relação aos demais carros, seja pela maior quantidade de assentos preferenciais seja pelo local para acomodação do usuário em cadeira de rodas ou pela existência de um assento para obesos. As portas 2 e 7 são destinadas ao embarque e desembarque de pessoas com deficiência visual. Diferentes frotas circulam em uma mesma linha, fazendo com que o usuário nunca saiba em qual trem irá embarcar.

\subsubsection{A gestão dos sistemas de informação, comunicação e orientação}

Antes da viagem, o sítio eletrônico disponibiliza mensagens que informam sobre as opções de trajetos a partir da inserção de informações de origem (estação de embarque) e destino (estação de desembarque), possibilitando o planejamento da viagem com antecedência. $\mathrm{O}$ 
aplicativo "Direto do Metrô"16 informa, em tempo real, as ocorrências operacionais que afetam a circulação dos trens e causam interferências na viagem habitual dos usuários.

Durante a viagem, o sistema de informação, comunicação e orientação - tátil, visual e sonora -, disponível nos ambientes, nos equipamentos de circulação ou nos veículos, auxilia a compreensão do espaço e do trajeto a ser percorrido para consecução da viagem.

Após a viagem, o serviço de atendimento ao cliente possibilita receber, registrar, atuar e responder às manifestações formuladas pelos usuários com deficiência visual junto ao Metrô de São Paulo por meio dos canais de relacionamento disponibilizados pela empresa.

Nas estações, a sinalização visual tem por objetivo identificar, orientar, advertir e proibir. Nas áreas externas, prismas e testeiras junto aos acessos identificam as estações. Nos corredores e passarelas de circulação, assim como nas áreas de distribuição, faixas horizontais laterais longitudinais e transversais orientam os deslocamentos de embarque (plataformas e destinos) e saída (ruas, terminais de integração modal e pontos de interesse nos arredores). A sinalização de funcionamento dos equipamentos é utilizada para orientar o fluxo em escadas rolantes, elevadores, bloqueios e contadores. Nas plataformas, a sinalização cumpre duas funções: identifica a estação para quem está dentro do trem e vai desembarcar e identifica o destino do trem para quem está na plataforma e vai embarcar. Painéis operacionais contendo os mapas da rede e da linha de embarque complementam as informações direcionais. Painéis institucionais e placas com formatos e conteúdos específicos complementam a sinalização de identificação, instrução quanto aos procedimentos seguros para o correto uso dos ambientes e instalações e de advertência sobre eventuais riscos. As mensagens visuais em tempo real, veiculadas em painéis eletrônicos, têm por objetivo informar sobre as estratégias de operação, o horário de abertura e fechamento da estação e de acessos, as condições de operação da linha, a ocorrência de anormalidades, além de informações de orientação e de alertas em geral. Os painéis multimídia instalados nas estações, próximos às linhas de bloqueio e bilheterias e nas plataformas, veiculam informações institucionais e permitem disseminar informações e orientações operacionais sobre o uso do sistema metroviário, de forma padronizada, para todas as estações, ou customizada para estações ou trechos específicos em tempo real, durante a ocorrência de anormalidades.

\footnotetext{
${ }^{16}$ Disponível em: 〈http://www.metro.sp.gov.br>. Acesso em: 04 jan. 2015.
} 
No interior dos trens, os mapas informam as estações ao longo da viagem, destacando as possibilidades de conexão. Painéis eletrônicos informam o deslocamento do trem e o nome da próxima estação. A sinalização luminosa existente junto às portas de embarque e desembarque indica o lado de abertura das portas na próxima estação, quando o trem está em movimento, ou o fechamento iminente das portas, quando o trem está parado na plataforma. Painéis institucionais e placas com formatos e conteúdos específicos complementam a sinalização de identificação, orientam sobre os cuidados no embarque e desembarque, identificam o assento preferencial ou advertem sobre eventuais riscos.

A sinalização tátil compreende o piso tátil direcional e o piso tátil de alerta, as escovas laterais nas escadas rolantes, além de placas com informações em Braille, com formatos e conteúdos específicos, acopladas aos equipamentos e às instalações para identificação, instrução e advertência sobre usos. Os corrimãos centrais e laterais de escadas e rampas são considerados parte da sinalização tátil e complementam a orientação de percurso. A existência de piso tátil nas estações é parte integrante da rota acessível para embarque ou saída das pessoas com deficiência visual durante seus deslocamentos:

a) piso tátil de alerta - na cor azul, instalado junto aos desníveis (degraus, escadas fixas, escadas rolantes, elevadores, rampas), indicativo de mudança de direção (na interseção dos pesos direcionais) ou ainda indicativo de existência de obstáculos aéreos (telefones, arcos, projeção de escadas);

b) piso tátil de alerta - na cor amarela, instalado exclusivamente junto à borda da plataforma, indicando o perigo iminente do desnível entre a plataforma e a via eletrificada;

c) piso tátil direcional - na cor azul, instalado para orientar o percurso entre os acessos e o local de embarque nas plataformas e vice-versa.

A premissa adotada para instalação do piso tátil considerou a entrada e saída das pessoas com deficiência visual entre as áreas externas das estações e as plataformas. No sentido de embarque, a sinalização tátil foi instalada a partir dos diversos acessos até a linha de bloqueios, orientando os fluxos nas escadas fixas e nos elevadores existentes. A partir dos bloqueios, em direção ao local de embarque nas plataformas, o piso tátil orienta os deslocamentos exclusivamente por meio dos elevadores. No sentido de desembarque, o piso tátil orienta o deslocamento desde a área de desembarque preferencial nas plataformas até os 
bloqueios exclusivamente por meio dos elevadores. A partir da linha de bloqueios, em direção às saídas, a sinalização tátil foi instalada de forma a orientar os fluxos de saída por meio das escadas fixas e dos elevadores existentes. Exceto pelo percurso junto aos bloqueios, onde são claramente definidos os percursos de embarque e de saída em função do posicionamento dos equipamentos, nas demais áreas de circulação, a sinalização tátil existente no piso permite o fluxo bidirecional. Por esta razão, o piso é posicionado no eixo das áreas de circulação, notadamente nos corredores dos acessos. Nas plataformas, o piso direcional e de alerta mantêm as pessoas com deficiência visual afastadas das bordas, garantindo sua segurança durante o deslocamento, espera, embarque ou desembarque. Nas rampas e escadas fixas, sempre que possível, o piso tátil é complementado pelo corrimão (central e lateral), instalado de forma a melhor orientar o deslocamento. No interior dos trens, junto aos assentos preferenciais, são disponibilizadas informações táteis indicativas do número do carro, permitindo ao usuário registrar eventuais ocorrências seja por meio de SMS (durante a viagem) ou dos canais de comunicação (antes ou depois da viagem).

A informação sonora compreende as mensagens de audição pública (PA) e designa todas as comunicações sonoras veiculadas para orientação dos usuários sobre os seguintes aspectos: o uso do sistema metrô (serviços oferecidos, normas, proibições, leis); o fluxo nas estações (fechamento ou abertura de acesso, interdição de áreas); as orientações sobre o uso correto das instalações e prevenção de acidentes em escadas rolantes e fixas e portas dos trens; questões comportamentais (transporte de mochilas, embarque preferencial e assentos preferenciais) e segurança pública (atenção aos pertences). As mensagens veiculadas em tempo real servem para orientar e alertar sobre o uso correto das instalações ou informar a ocorrência de anormalidades. Podem ser verbalizadas ou digitalizadas, emitidas de forma centralizada pelo Centro de Controle Operacional - CCO ou de forma local, a partir da Sala de Supervisão Operacional - SSO. Os recursos para emissão de informação sonora permitem a emissão de mensagens em tempo real pelo empregado da estação ou pelo operador do trem, ou de forma automática, por meio de mensagens digitalizadas pré-gravadas. No caso específico dos trens, o alarme sonoro nas portas tem por finalidade informar aos usuários que as portas irão se fechar, advertindo-os de que não se deve embarcar ou desembarcar a partir desse momento. Os equipamentos intercomunicadores e telefones ponto a ponto são utilizados para emissão de mensagens personalizadas, mediante solicitação. 


\subsubsection{A gestão da prestação dos serviços}

Os serviços prestados nas estações consistem nas evidências físicas do ambiente, nas interações entre os usuários e os funcionários "da linha de frente", por meio do atendimento personalizado, ou na padronizado e adoção de estratégias, nas interações na retaguarda, entre funcionários "dos bastidores", bem como nas regras, procedimentos e estratégias adotadas para garantir o atendimento entre estações e a disponibilidade dos equipamentos e das instalações. A relação entre os usuários com deficiência e os demais usuários e funcionários, assim como a aparência e as atitudes dos funcionários de contato - responsáveis pelo auxílio nos deslocamentos - e o comportamento dos demais usuários presentes durante os deslocamentos impactam a percepção do usuário sobre o serviço prestado. Para garantir a qualidade dos serviços, o Metrô de São Paulo atua de forma sistêmica no treinamento dos funcionários, no treinamento das pessoas com deficiência visual e na orientação dos demais usuários.

O treinamento dos funcionários é realizado quando da sua admissão e tem por objetivo sensibilizá-los quanto à diversidade e conscientizá-los sobre o seu papel na inclusão da pessoa com deficiência na sociedade. Os conteúdos, estabelecidos por meio de consenso com entidades de reabilitação, incluem os seguintes assuntos:

a) observação - destaca a forma de deslocamento das pessoas com deficiência - ritmo, hesitação, direção -, indicando a familiaridade ou não com o ambiente, a sua autoconfiança no deslocamento e a necessidade de auxílio;

b) abordagem - ressalta aspectos relacionados à postura para iniciar um contato com o usuário e oferecer ajuda após o cumprimento e a identificação (em caso positivo, conduzir e, em caso negativo, observar à distância);

c) orientação - explicita a importância de informar sobre modificações nas instalações ou equipamentos de uso cotidiano, tais como alteração no sentido das escadas rolantes, interdição de escadas, adoção de estratégias, instalação de novos equipamentos ou mobiliário;

d) condução - orienta quanto à forma de auxílio individual ou em grupo para deslocamento em planos horizontais ou escadas fixas e rolantes, bem como durante o embarque ou desembarque; 
e) monitoração - orienta sobre o contato com o CCO para possibilitar auxílio na estação de desembarque.

O treinamento de O\&M dos usuários com deficiência visual é tão importante quanto o treinamento dos empregados e consiste na capacitação das pessoas com deficiência visual para utilização do sistema metroferroviário. O Metrô de São Paulo facilita o treinamento de O\&M ministrado pelas entidades de reabilitação em suas instalações, liberando o acesso a plataformas não operacionais, ligando e invertendo, quando necessário, as escadas rolantes e posicionando os trens vazios na plataforma de treinamento, possibilitando o contato com as instalações que serão, no futuro, objeto de uso pelas pessoas com deficiência visual. Esse treinamento enfatiza alguns aspectos:

a) na estação, o treinamento inclui a familiarização com as áreas externas (relação da calçada com os acessos, o tráfego, os pontos de ônibus; identificação dos pontos de referência e pistas que facilitem a localização das entradas; percursos de embarque ou saída) e internas (percurso de embarque ou saída entre o acesso e as plataformas; características do mezanino - formato, tamanho, disposição dos recursos de circulação vertical e horizontal, corredores de distribuição e localização dos serviços essenciais -, balcão de informações, bilheterias, linha de bloqueios, sanitários, telefones públicos, bancos de espera e áreas comerciais). Inclui o reconhecimento e a familiarização dos recursos disponíveis, dos percursos e rotas seguras e adequadas para embarque e desembarque, orientações para o relacionamento com os demais usuários nos horários de maior ou menor movimento e avaliação das condições de utilização de forma autônoma ou com auxílio dos funcionários das estações;

b) na interface trem-estação, são reforçadas questões como configuração, extensão e largura, recursos de circulação vertical, faixas de segurança, pontos de referência, pistas e linhas-guia que facilitem o embarque ou o desembarque. A partir dessas informações, são definidos percursos preferenciais para embarque e saída, a partir de pistas e referências ou da utilização de rastreamento de linhas-guias;

c) no trem, externamente, são ressaltados aspectos como o dimensionamento e a configuração dos carros, quantidade e funcionamento automático das portas, o vão entre o trem e a plataforma no local de embarque e desembarque e o vão entre carros; internamente, destacam-se aspectos como dimensionamento, configuração dos apoios 
verticais e horizontais, layout dos assentos e inter-relacionamento entre portas, balaústres e assentos, além do funcionamento de janelas e dispositivos de emergência.

Os procedimentos operacionais consistem em documentos que sustentam a realização de uma atividade ou estratégia de forma padronizada nos diferentes ambientes onde é executada, incluem os seguintes temas:

a) embarque preferencial - orienta a delimitação e a segregação de espaço nas plataformas das estações com maior demanda nos horários de maior movimento, junto à primeira e à segunda porta dos trens, cujo principal objetivo é proporcionar segurança e conforto no momento do embarque nas plataformas. Conscientiza quanto ao direito, assegurado por lei, do embarque preferencial, reservado aos idosos, gestantes, pessoas com deficiência e pessoas com crianças;

b) elevadores preferenciais - orienta a destinação dos equipamentos existentes nas estações para o deslocamento das pessoas com deficiência ou mobilidade reduzida, buscando garantir mais conforto e segurança entre os acessos e as plataformas, seja no embarque ou no desembarque;

c) monitoração - disciplina o auxílio prestado às pessoas com deficiência visual por parte dos funcionários e estagiários das estações e dos operadores de console de passageiros do Centro de Controle Operacional. Os registros dos deslocamentos são processados estatisticamente e utilizados para dimensionar a demanda de usuários com deficiência, possibilitando dimensionar o quadro de empregados para auxílio em cada estação;

d) assentos preferenciais - determinam a destinação de assentos na cor azul claro, para idosos, gestantes, pessoas com deficiência ou com crianças de colo. A quantidade de assentos varia em cada uma das frotas, sendo, no mínimo, 13 e, no máximo, 16 assentos nos carros preferenciais;

e) estratégias em situações cotidianas e de contingência - estabelecem as ações adotadas em situações cotidianas ou de contingências, diretamente relacionadas à presença de pessoas com deficiência nos trens e estações, de forma a orientar o tratamento das ocorrências pelas equipes das estações, dos trens, da segurança e do CCO com relação à eventual necessidade de evacuação ou priorização de alinhamento em plataformas, facilitando o auxílio às pessoas nas estações ou túneis; 
f) emissão de mensagens sonoras - estabelece os critérios para padronizar as mensagens emitidas através do sistema de audição pública das estação e dos trens que orientam os usuários sobre informações operacionais a respeito do uso do sistema metrô e outros modais integrados. As mensagens sonoras podem ser emitidas em tempo real, pré-gravadas ou digitalizadas.

A orientação aos demais usuários tem, entre seus objetivos principais, influenciar o comportamento dos usuários, conscientizar as pessoas sobre o uso correto das estações e trens e estimular a mudança de atitude a partir das orientações disseminadas; indiretamente, facilitam a operação do sistema. As campanhas veiculadas fornecem informações essenciais sobre temas como segurança pública, prevenção de acidentes, cidadania e solidariedade. Em contrapartida, os usuários sugerem novos temas e atribuem à empresa o papel de educação e fomentação de práticas de cidadania. A veiculação das campanhas faz uso de mídias diversificadas - cartazes, banners, folhetos, mensagens sonoras, intervenções artísticas e ações interativas com grupos teatrais; mais recentemente, foram incorporadas novas tecnologias de comunicação, utilizando as redes sociais e mensagens de SMS, proporcionando maior interação, participação e colaboração (MORENO, BRAGA, 2011).

\subsection{A evolução da acessibilidade no Metrô de São Paulo}

Os requisitos de acessibilidade estabelecidos na legislação e nas normas técnicas foram evoluindo e se aperfeiçoando ao longo dos anos. Da mesma forma, as premissas de projeto das estações, dos terminais urbanos de integração e dos empreendimentos associados foram alteradas ao longo dos anos, seja em função das modificações na legislação e nas normas técnicas seja em função das inovações tecnológicas dos sistemas construtivos, das expectativas dos usuários ou das necessidades operacionais. Seguindo essa mesma lógica, os trens tiveram alterações nos requisitos de projeto, notadamente nos sistemas de sinalização e nos equipamentos embarcados.

Acompanhando as tendências dos sistemas metroviários internacionais, as primeiras facilidades implantadas nas estações do Metrô de São Paulo estiveram inicialmente relacionadas ao atendimento de pessoas com deficiência física, notadamente pessoas em cadeira de rodas e, somente depois, adequações voltadas às outras deficiências. Assim, em 1980, passarelas e rampas foram construídas para permitir a transposição das vias e avenidas ao longo da Linha 3 - Vermelha. Em 1993, iniciou-se a instalação dos elevadores nas estações 
(CMSP, 2008). Em 2002, foi instalado o piso tátil em caráter experimental em uma estação, com o objetivo de avaliar os benefícios dessa sinalização para promover o deslocamento das pessoas com deficiência visual com independência. Essa experiência proporcionou o início de treinamento das pessoas com deficiência visual pelas entidades de reabilitação. Em 2003, foram instalados os primeiros telefones de texto para uso por pessoas com deficiência auditiva ou de fala. As diferentes soluções encontradas nas estações são decorrentes das alterações na legislação ou das inovações tecnológicas ocorridas no período, relacionadas aos aspectos construtivos ou aos sistemas de alimentação elétrica, telecomunicações, iluminação, ventilação, circulação vertical, controle de arrecadação e fluxo de passageiros e de segurança:

a) entre 1974 e 1998: necessidade de adaptação para a circulação de pessoas com deficiência física, por meio da instalação de elevadores e plataformas de elevação entre os diferentes desníveis;

b) entre 1998 e 2010: atendimento aos requisitos de acessibilidade para pessoas com deficiência física, uma vez que já dispunham de elevadores facilitando a circulação de pessoas em cadeira de rodas, mas não consideraram os requisitos de acessibilidade para orientar os deslocamentos das pessoas com deficiência visual;

c) antes de 2002: objeto de intervenção para promover a instalação de sinalização tátil de alerta e direcional para orientar os deslocamentos das pessoas com deficiência visual;

d) após 2010: acessíveis para pessoas com deficiência física e sensorial.

Ao longo dos anos, as estações apresentaram diferenças em suas configurações, nos partidos arquitetônicos adotados, nos materiais de acabamento utilizados, nos equipamentos instalados, nos recursos visuais, táteis, sonoros, tecnológicos e de segurança implantados, configurando-se como instalações com diferentes condições de acessibilidade - estações acessíveis ou estações adaptadas -, fato que pressupõe diferenças relacionadas às soluções de acessibilidade que interferem no grau de percepção do planejamento espacial e da comunicação ambiental pelas pessoas com deficiência visual.

Consideram-se "adaptadas" as estações que formam objetos de intervenção para dotar as instalações de condições adequadas de acessibilidade; o termo "acessível" designa as estações construídas de acordo com as normas de acessibilidade vigentes atualmente (Tabela 6). 
Tabela 6 - São Paulo - Acessibilidade das estações - 2013.

\begin{tabular}{lrrrrrr}
\hline Acessibilidade das estações & \multicolumn{2}{c}{$\begin{array}{c}\text { Linha 1 } \\
\text { Azul }\end{array}$} & $\begin{array}{c}\text { Linha 2 } \\
\text { Verde }\end{array}$ & $\begin{array}{c}\text { Linha 3 - } \\
\text { Vermelha }\end{array}$ & $\begin{array}{c}\text { Linha 5 - } \\
\text { Lilás }\end{array}$ & Rede \\
\hline Adaptada & 18 & 4 & 18 & 6 & 46 \\
\hline Acessível & 3 & 9 & - & 1 & 13 \\
\hline
\end{tabular}

Fonte: elaborado pela pesquisadora a partir das informações contidas em: CMSP, Gerência de Operações, Por Dentro da Operação 2013, 2014, p.96.

Em 1989, foram implementados os primeiros assentos preferenciais nos trens, destinados aos idosos, gestantes, pessoas com deficiência ou com crianças de colo. Os carros líderes (carros A) receberam maior quantidade de assentos preferenciais, mantendo a coerência da orientação para embarque das pessoas com deficiência visual na segunda porta do primeiro carro. Em 2002, os trens começaram a ser equipados com sinalização visual associada ao alarme sonoro de fechamento das portas. Foi implantado um local específico para a viagem de pessoas em cadeira de rodas no interior dos trens, alinhado ao local para embarque nas plataformas.

As diversas frotas possuem diferentes condições de acessibilidade, em consequência do período em que foram adquiridas, atendendo aos requisitos de acessibilidade das normas técnicas vigentes à época de sua especificação e sua fabricação. Para os usuários com deficiência visual, destacam-se os aspectos relacionados à configuração - quantidade e localização dos assentos preferenciais e barras e balaústres de apoio - e aos sistemas de informação - existência de recursos para emissão automática de mensagens sonoras.

Modificações, adaptações e adequações nas estações e nos trens tiveram sequência nos anos posteriores, seguindo a legislação federal e as normas técnicas vigentes. Enquanto isso, as novas estações construídas e os trens adquiridos já incorporam os requisitos de acessibilidade desde o projeto, consolidando um processo sistêmico. Como regra geral para as estações e os trens, observa-se que as adaptações são sempre mais caras do que a concepção inicial do projeto, considerando os princípios do desenho universal.

\subsection{Considerações sobre o capítulo}

A acessibilidade das redes de transporte, segundo Juncá (2011), está baseada em cinco fatores-chave, que, quando aplicados ao sistema metroviário, consistem nas estações, nos trens, na interface estação-trem, nos sistemas de informação, comunicação e orientação e na gestão da prestação dos serviços. 
A descrição e a aplicação dos fatores-chave de acessibilidade nos sistemas metroferroviários permitem afirmar a existência de uma relação de interdependência entre os ambientes identificados (estação, interface trem-estação e trem) e os temas avaliados (configuração, informação e serviço).

O crescimento das redes e o avanço da tecnologia trouxeram consigo uma variedade de soluções construtivas para estações e vias, bem como para a fabricação dos trens. Adicionalmente, houve evolução da tecnologia dos equipamentos e elementos característicos dos sistemas metroferroviários (equipamentos de autoatendimento para controle de acesso, circulação vertical, aquisição ou recarga de bilhetes). O aumento da complexidade das estações - em função das opções de conexão com outros modos de transporte ou com empreendimentos -, somado à diversidade e falta de padronização dos ambientes, resultante dos condicionantes de projeto e materiais de acabamento, impõe cuidados adicionais no planejamento espacial e na comunicação ambiental para permitir a construção do mapa cognitivo pelas pessoas com deficiência visual com possibilidade de comprometimento da orientação e da mobilidade, mesmo considerando a familiarização com as instalações a partir de treinamentos de O\&M ministrados nas estações e trens. Via de regra, a adaptação das estações ocorre com maior frequência do que a adaptação dos trens, e essa condição não se mostra diferente nas instalações do Metrô de São Paulo. Contudo, permanece o desafio de conciliar as instalações fixas (estações, plataformas) com as instalações móveis (trens).

Os serviços prestados nos sistemas metroferroviários devem considerar a padronização do atendimento - por se tratar de um serviço de alta capacidade, destinado ao transporte de milhares de passageiros simultaneamente - e a customização do atendimento - por se tratar de um serviço destinado ao transporte de pessoas com diferentes características e necessidades. Nesse contexto, os deslocamentos independentes trazem consigo a necessidade de implementação de uma série de facilidades relacionadas à configuração e às informações sobre o serviço que permitam o planejamento, o deslocamento e a avaliação da experiência. Nesse mesmo contexto, alguns deslocamentos necessitam de apoio adicional por parte dos funcionários, auxiliando e monitorando embarques e desembarques. Nesse sentido, equipamentos e dispositivos que facilitem a comunicação para solicitação de auxílio são elementos fundamentais no processo. Em ambas as situações - independência e auxílio -, a interação com os demais usuários é fundamental para que os deslocamentos sejam realizados com segurança e conforto, sem conflitos ou interferências. 


\section{DIAGRAMA DE SERVIÇOS DO SISTEMA METROFERROVIÁRIO}

Os usuários avaliam sua satisfação ao final da experiência: a disponibilidade e as condições de funcionamento dos equipamentos e das instalações; a disponibilidade e a compreensão do sistema de informação, orientação e comunicação; a disponibilidade e a atenção dos funcionários; o comportamento dos demais usuários; o cumprimento do tempo de espera e do tempo de viagem, entre outros fatores. A sequência de interações realizadas consiste na jornada do usuário e inclui os seguintes aspectos:

a) as ações realizadas pelo usuário com deficiência visual;

b) os contatos realizados com funcionários, demais usuários, equipamentos e instalações;

c) os papéis desempenhados pelos funcionários durante o processo de monitoração dos deslocamentos de pessoas com deficiência ou mobilidade reduzida no Metrô ${ }^{17}$;

d) os processos de apoio (interações e procedimentos);

e) as evidências físicas dos ambientes (configuração, informação).

A elaboração do diagrama de serviços (ZEITHAML; BITNER, 2003; FITZSIMMONS; FITZSIMMONS, 2005) permite identificar em cada etapa da jornada três aspectos considerados relevantes:

a) pessoas: as ações das pessoas com deficiência visual; os relacionamentos entre clientes e funcionários; as ações dos funcionários na linha de frente; os relacionamentos entre funcionários de diferentes áreas na retaguarda;

b) processos: as rotinas, as regras, os procedimentos e os roteiros de serviço, sendo aqui considerados os aspectos de padronização e a customização do serviço, que também proporcionarão aos usuários alguma evidência que será utilizada na avaliação dos serviços prestados;

c) evidências físicas: componentes tangíveis relacionados ao ambiente (configuração, informação/comunicação/orientação) das estações, trens e da interface entre eles.

\footnotetext{
${ }^{17} \mathrm{O}$ processo de monitoração consiste no auxílio dispensado às pessoas com deficiência ou mobilidade reduzida durante seus deslocamentos: um funcionário conduz o usuário desde sua chegada à estação até o local de embarque na plataforma; além disso, informa o Centro de Controle Operacional (CCO) sobre o seu destino, viabilizando auxílio no percurso de desembarque na estação de destino.
} 


\subsection{As pessoas}

Segundo Zeithaml e Bitner (2003), as pessoas envolvidas são aquelas que desempenham um papel no processo de execução de um serviço, incluindo os funcionários da empresa, o usuário com deficiência visual, os demais usuários e outros agentes que exercem influência direta ou indireta na percepção dos usuários. Há uma quantidade significativa de indivíduos que têm participação nas decisões do projeto ou do serviço, chamados stakeholders (partes interessadas), que são afetados pelo resultado final do serviço. A técnica concebida por Mitchell $^{18}$ (1997 apud Curedale 2013, p.151) recomenda utilizar esse recurso para identificar e documentar o grau de influência e interesse, estabelecendo as relações e os objetivos de cada uma das partes interessadas, incluindo o usuário final, o que permite priorizar as reinvindicações e os requisitos, segundo a relevância. O mapeamento dos stakeholders, ou stakeholders mapping, é uma representação visual das pessoas envolvidas em um serviço, cujas inter-relações e motivações devem ser representadas e analisadas, de forma a permitir visualizar as situações complexas relacionadas à prestação dos serviços, com destaque para as interações internas e externas (STICKDORN; SCHNEIDER, 2012).

As pessoas envolvidas (stakeholders) foram classificadas como usuários, pessoas-chave e especialistas, sendo identificados os relacionamentos estabelecidos entre elas (Figura 18). Essas pessoas são definidas a seguir:

a) usuários: são as pessoas com deficiência visual que utilizam o sistema metroviário; devem ser posicionadas no centro, no círculo interno;

b) pessoas-chave: são os profissionais que têm contato direto ou cujas ações impactam diretamente a jornada do usuário com deficiência visual durante seus deslocamentos no sistema metroferroviário; devem ser posicionadas no círculo intermediário;

c) especialistas: são os profissionais que detêm e aplicam conhecimentos sobre o tema acessibilidade no Metrô de São Paulo ou junto às entidades do setor, mas não têm necessariamente contato direto com usuários com deficiência visual; devem ser posicionados no círculo externo.

\footnotetext{
${ }^{18}$ MITCHELL, R. K.; AGLE, B. R.; WOOD, D. J. (1997). Toward a theory of stakeholder identification and salience: defining the principle of who and what really counts. In: Academy of Management Review, 22 (4): 853-888.
} 
Figura 18 - Mapeamento dos stakeholders.

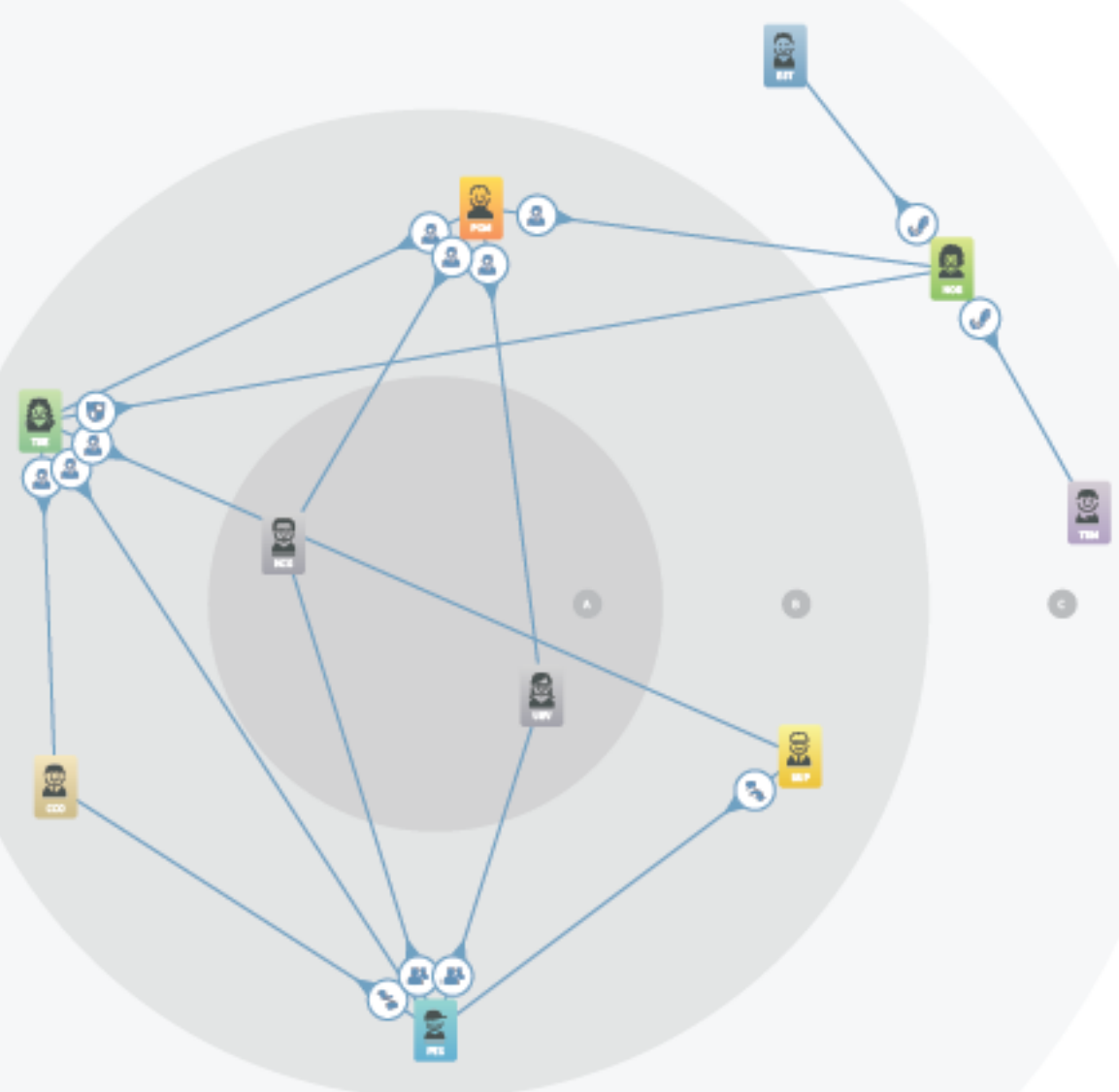

\section{A = Usuários}

B $=$ Pessoas-chave

C = Especialistas

Usuários com deficiência visual - cegos

Funcionários de estação

Usuários com deficiência visual - baixa visão

Funcionários do Centro de

Controle Operacional

Estagiários que auxiliam

pessoas com deficiência visual

Instrutores de treinamento dos

empregados

Professores de orientação e

mobilidade

Fonte: Elaborado pela pesquisadora com auxílio do software Smaply. Disponível em: https://app.smaply.com/projects. Acesso em: 24 mai. 2014. 


\subsubsection{Usuários}

Para efeito desta pesquisa, são considerados "usuários" as pessoas com deficiência visual cegos ou com baixa visão - que fazem uso das estações e trens do metrô de São Paulo em seus deslocamentos. Segundo Juncà (2005), os usuários do sistema de transporte público podem ser segmentados em três grupos, para os quais são necessárias soluções específicas, porém integradas:

pessoas sem dificuldades de mobilidade ou de comunicação - têm condições de utilizar o transporte público - estações e trens - sem qualquer problema. Neste caso, as ações de acessibilidade impactam positivamente sobre os usuários, aumentandolhe as condições de conforto, fornecendo-lhes apoio e comodidade;

pessoas com dificuldades de mobilidade ou de comunicação - somente conseguem utilizar os transportes públicos se estes estiverem totalmente acessíveis. Neste caso, a acessibilidade dos transportes públicos confere novas possibilidades de deslocamento;

pessoas com um grau severo de comprometimento da mobilidade ou da comunicação - não têm condições de utilizar os transportes públicos mesmo que estes estejam totalmente acessíveis. Neste caso, há necessidade de implementação de serviços complementares, porta-a-porta, com atendimento personalizado e prestado por pessoas qualificadas. (JUNCÀ, 2005, p. 214)

As pessoas com deficiência visual apresentam características que as diferenciam entre si que vão além da impossibilidade ou do grau de dificuldade para enxergar. A autonomia pode ser afetada por diversos fatores, entre os quais se destacam o período em que adquiriram a deficiência (no nascimento, na infância, na fase adulta); a participação em programas de reabilitação e treinamento de orientação e mobilidade; a utilização de guia vidente, de cãoguia, de Braille, de tecnologias assistivas ou de sistemas informatizados ou eletrônicos para auxiliar deslocamentos. As ações para adaptar estações e trens às condições de acessibilidade tiveram como objetivo facilitar o acesso e o uso por pessoas com deficiência. Apesar das ações realizadas pelo Metrô de São Paulo, o número de auxílios ou monitoramentos solicitados pelas pessoas com deficiência visual durante seus deslocamentos diários permanece elevado (Tabela 7) em relação ao total de auxílios prestados. 
Tabela 7 - Monitoramentos solicitados no período 2006-2013. (em milhares)

\begin{tabular}{|c|c|c|c|c|c|c|c|c|}
\hline Monitoramento & 2006 & 2007 & 2008 & 2009 & 2010 & 2011 & 2012 & 2013 \\
\hline deficiência física & 9 & 13 & 11 & 16 & 19 & 24 & 25 & 27 \\
\hline deficiência visual & 119 & 136 & 154 & 201 & 230 & 262 & 278 & 287 \\
\hline total & 128 & 149 & 165 & 217 & 249 & 286 & 303 & 309 \\
\hline $\begin{array}{l}\text { participação } \\
\text { deficiência visual } \\
(\text { em \%) }\end{array}$ & 92,96 & 91,27 & 93,33 & 92,62 & 92,36 & 91,60 & 91,74 & 92,88 \\
\hline
\end{tabular}

Fonte: CMSP, 2014b - Relatório Operacional RO2013.

Considera-se, portanto, a possibilidade da existência de fatores que impactam, interferem e até mesmo impedem o uso do transporte com independência pelas pessoas com deficiência visual. Justifica-se, desta forma, a escolha das pessoas com deficiência visual que utilizam o metrô habitualmente, com ou sem auxílio de empregados, guias videntes ou cães-guia.

\subsubsection{Pessoas-chave}

Para efeito desta pesquisa, foram consideradas pessoas-chave os profissionais que têm contato direto ou cujas ações impactam diretamente a jornada do usuário com deficiência visual durante seus deslocamentos no sistema metroferroviário, a saber:

a) professores de orientação e mobilidade - profissionais de reabilitação que atuam junto a diferentes entidades e instituições de reabilitação, responsáveis pelo treinamento e capacitação de pessoas com deficiência visual para que estas possam ter autonomia em seus deslocamentos a partir do aumento da autoconfiança, autoestima e independência, facilitando sua inclusão;

b) instrutores e elaboradores de treinamento de funcionários - profissionais com formação multidisciplinar, responsáveis não só pelo treinamento dos funcionários que atuam em contato direto com os usuários, mas também pelo contato com entidades que realizam treinamento de pessoas com deficiência visual nas estações e trens e pelo estabelecimento de procedimentos padronizados de atendimento aos usuários, de acordo com o perfil e as características individuais;

c) estagiários que auxiliam pessoas com deficiência visual - estudantes do ensino fundamental da rede pública de ensino, maiores de 16 anos, que atuam nas estações prestando atendimento preferencial aos usuários com deficiência visual que solicitam auxílio durante seus deslocamentos; 
d) funcionários do Centro de Controle Operacional - profissionais que atuam junto aos consoles de passageiros de cada uma das linhas e que observam, registram e monitoram os deslocamentos das pessoas com deficiência visual mediante acionamento telefônico efetuado pelos funcionários das estações;

e) funcionários das estações - profissionais responsáveis pela gestão das estratégias de atendimento preferencial nas estações, posicionando as equipes de funcionários e estagiários para auxiliar os usuários com deficiência visual durante o embarque e desembarque.

\subsubsection{Especialistas}

Para efeito desta pesquisa, são considerados especialistas os profissionais que detêm e aplicam conhecimentos sobre o tema acessibilidade no Metrô de São Paulo ou junto às entidades do setor, mas não têm necessariamente contato direto com os usuários com deficiência visual. São eles:

a) profissionais que elaboram ou participam da elaboração de normas técnicas de acessibilidade - profissionais que participam de forma voluntária em conjunto com representantes da sociedade civil e setores organizados - fabricantes ou consumidores de produtos ou de serviços de diferentes comissões de estudo (edificação, transporte, comunicação) - no Comitê Brasileiro de Acessibilidade (CB-40), vinculado à Associação Brasileira de Normas Técnicas - ABNT;

b) profissionais responsáveis pelo projeto das estações - profissionais responsáveis pelo planejamento, especificação, projeto e detalhamento dos ambientes e elementos das estações;

c) profissionais responsáveis pelo projeto dos trens - designers e engenheiros responsáveis pela especificação, projeto e detalhamento dos trens e seus elementos.

\subsection{Os processos}

Segundo Zeithaml e Bitner (2003), a oferta, execução ou operação dos serviços consistem num conjunto de atividades regidas por procedimentos, mecanismos e roteiros. Para efeito desta pesquisa, são identificadas as rotinas que poderiam impactar direta ou indiretamente a percepção dos usuários com deficiência visual durante os deslocamentos na rede 
metroferroviária. Entre os serviços oferecidos, foram objetos de investigação os seguintes processos:

a) treinamento de orientação e mobilidade de pessoas com deficiência visual consiste na capacitação de pessoas com deficiência visual para utilização do sistema metroferroviário mediante treinamento de orientação e mobilidade nas estações e trens de uso habitual, com reconhecimento e familiarização dos recursos disponíveis, dos percursos e rotas seguras e adequadas para embarque e desembarque; inclui também orientações para o relacionamento com os demais usuários nos horários de maior ou menor movimento e a avaliação das condições de utilização de forma autônoma ou com auxílio dos funcionários das estações.

b) treinamento de capacitação dos funcionários - consiste na capacitação dos funcionários e estagiários para prestar auxílio às pessoas com deficiência visual, em função das atividades exercidas em cada posto de trabalho. A coleta de dados deve possibilitar a verificação da relevância dos conteúdos teóricos e práticos ministrados em relação ao desempenho das atividades dos funcionários.

c) procedimentos relacionados ao atendimento preferencial e ao auxílio às pessoas com deficiência visual nas estações - consistem em roteiros de serviço definidos por meio de documentos que sustentam a realização de uma atividade ou estratégia de forma a garantir sua padronização nos diferentes ambientes onde é executada.

\subsection{Os ambientes}

Segundo Zeithaml e Bitner (2003), as evidências físicas consistem nos elementos tangíveis presentes nos ambientes nos quais o serviço é ofertado ou nos locais onde a empresa interage com seus usuários, bem como qualquer elemento ou componente que possa facilitar a execução ou a comunicação do serviço.

As ações visando adequar as redes de transporte às condições de acessibilidade devem considerar a existência de pontos-chave de mobilidade, que devem estar de acordo com os requisitos legais e normativos e, sempre que possível, adotar melhorias em função das boas práticas já sistematizadas: as instalações fixas ou edificações, os veículos, a interface edificações-veículos, os sistemas de informação e a gestão dos serviços (JUNCÀ, 2011).

As evidências físicas relacionadas aos aspectos da configuração, dos sistemas de informação/comunicação/orientação e da gestão da prestação dos serviços nas estações, nos 
trens e na interface trem-estação incluem os equipamentos e os elementos que são objetos de interação com os usuários. Os ambientes característicos dos sistemas metroferroviários foram apresentados e descritos no capítulo 3 - O sistema metroferroviário comtemporâneo.

\subsection{A jornada}

Para efeito desta pesquisa, propõe-se a existência de 24 etapas que compõem a jornada do usuário, incluindo as fases antes, durante e após a viagem no sistema metroferroviário: respectivamente, as fases de planejamento, realização e avaliação do deslocamento. A jornada do usuário desde a origem até o destino final varia em função dos modos de transporte utilizados: a pé, de ônibus, lotação, táxi, carona, metrô, trem, entre outros (Figura 19).

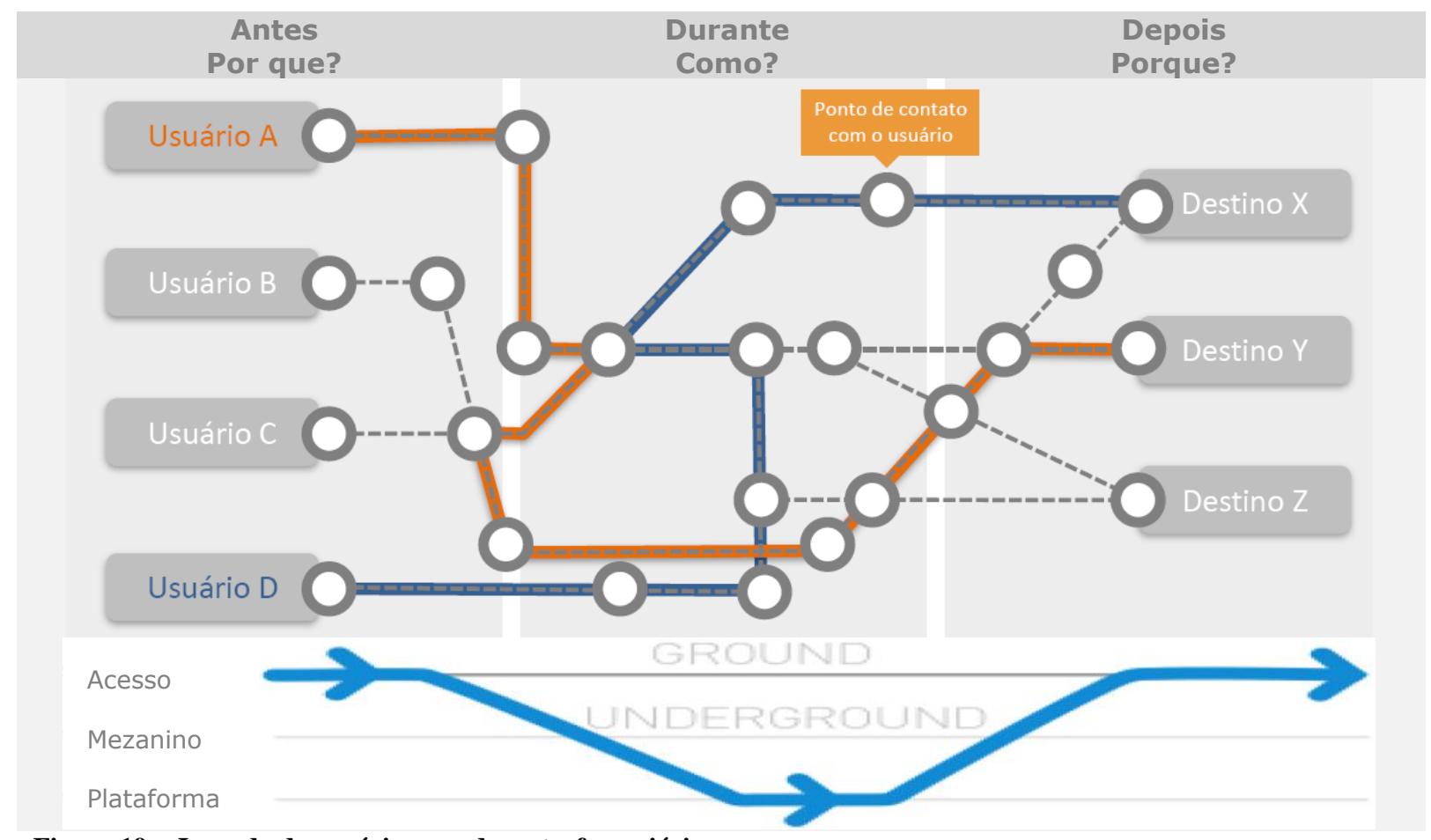

Figura 19 - Jornada do usuário na rede metroferroviária.

Fonte: Teixeira, C. Ambientação das estações do MetrôRio, 2013.

As etapas de planejamento do deslocamento e chegada à estação/desembarque do sistema integrado são consideradas fases precedentes, pois referem-se aos momentos que antecedem a utilização do sistema metroviário. As etapas de embarque no sistema integrado e de avaliação da experiência são consideradas fases subsequentes, pois incluem os momentos que sucedem a utilização do sistema metroviário. As demais etapas - desde o acesso à estação até a saída da estação - abrangem os momentos de utilização do sistema metroviário. Contudo, a jornada do usuário considera todas as etapas, tanto as que antecedem quanto as subsequentes à utilização do sistema metroviário (Quadro 9). 
Quadro 9 - Etapas da jornada do usuário.

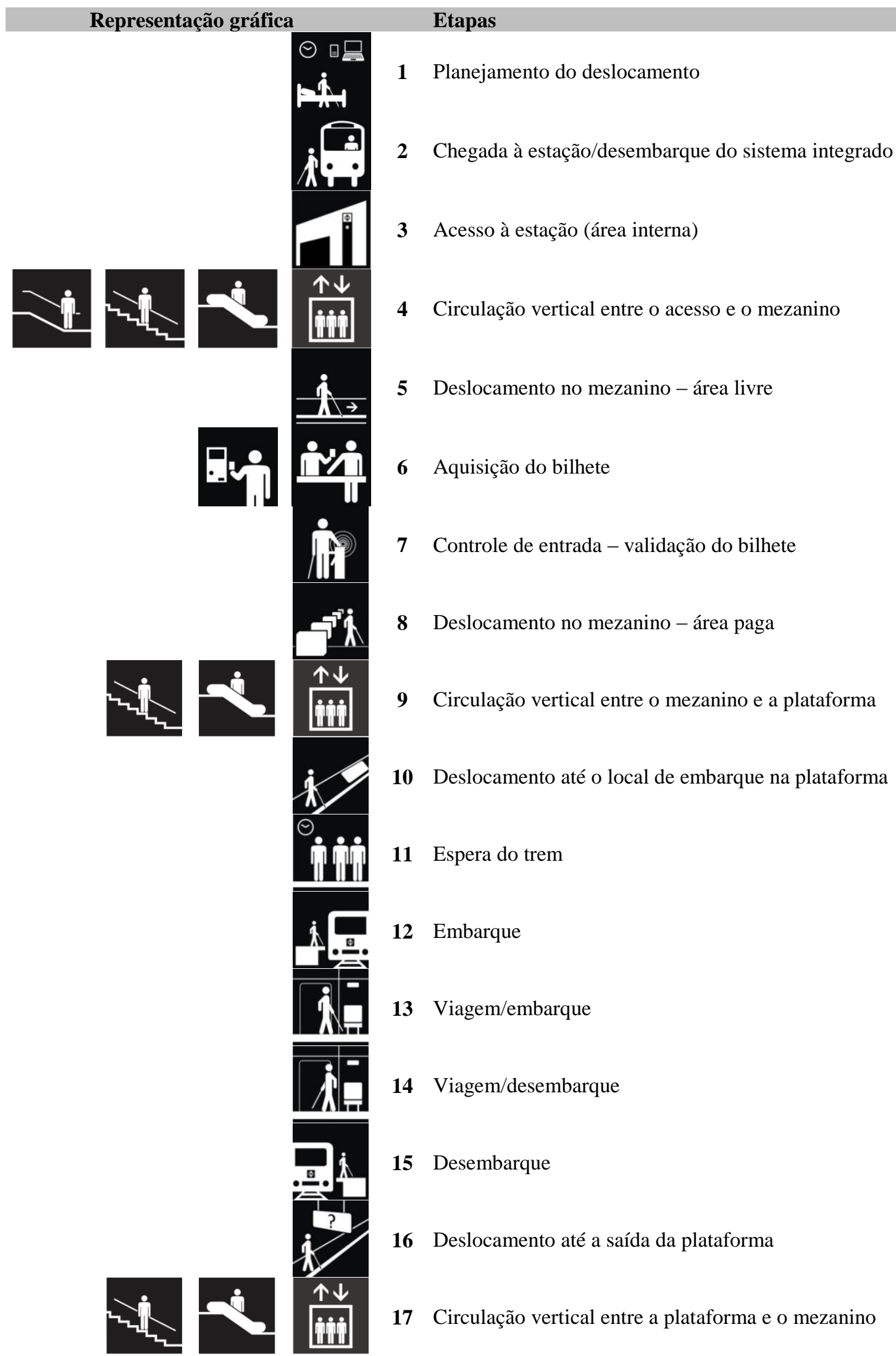




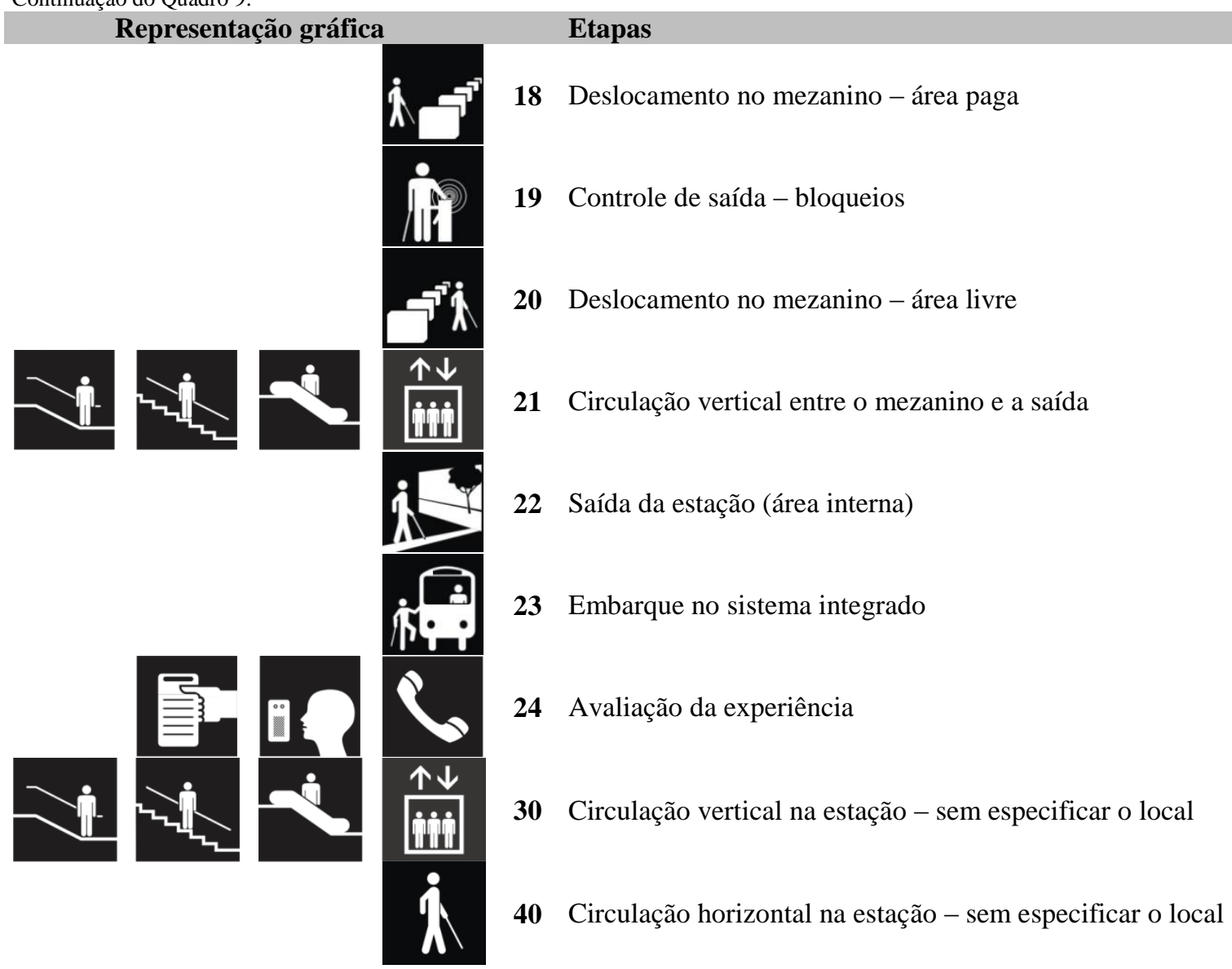

Fonte: Elaborado pela autora.

A elaboração do diagrama de serviços demandou uma reflexão sobre cada uma das etapas da jornada do usuário, incluindo os aspectos relacionados à configuração do ambiente, o respectivo conjunto de informação/comunicação/orientação e os aspectos relacionados à gestão do serviço. Na sequência, foram identificadas as ações dos usuários com deficiência daqueles que poderiam se locomover com independência e daqueles que demandariam auxílio pelos funcionários das estações.

Em seguida, foram identificadas as ações dos funcionários em contato com os usuários chamadas contatos na linha de frente - e as ações dos funcionários em contato com outros funcionários - chamadas contatos na retaguarda. Além disso, foram identificados os processos de apoio, isto é, os roteiros de serviço e procedimentos que definem o padrão de execução dos serviços relacionados à operação e à manutenção dos ambientes e equipamentos das estações e trens (Figura 20). 

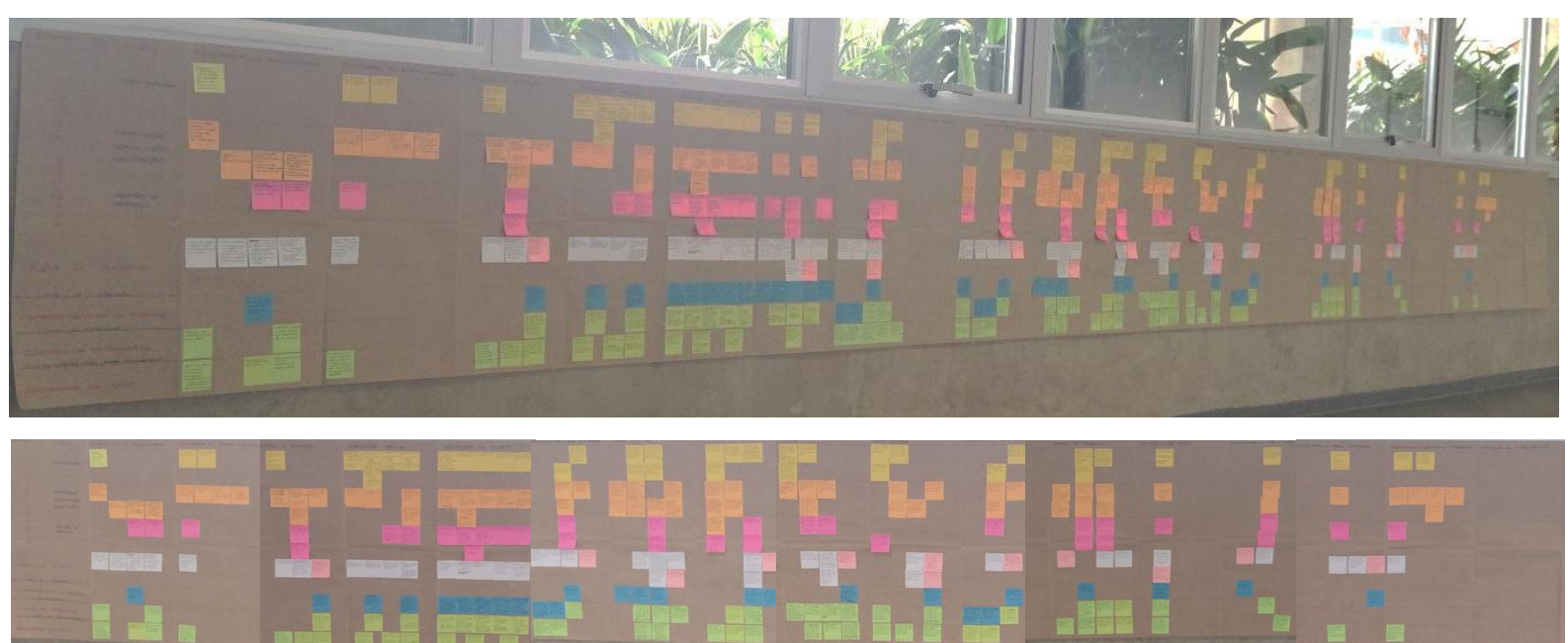

texto Campo 1 - Etapas da jornada do usuário

Campo 2 - Configuração

Campo 3 - Informação/comunicação/orientação

Campo 4 - Gestão do serviço

Campo 5 - Ação do usuário - deslocamento com monitoração

Campo 5 - Ação do usuário - deslocamento com independência

Campo 6 - Contatos na linha de frente (entre usuários e funcionários)

Campo 7 - Contatos na retaguarda (entre funcionários da linha de frente e funcionários da retaguarda)

Campo 8 - Processos de apoio (roteiros de serviço, procedimentos)

Figura 20 - Diagrama de Serviços do Metrô de São Paulo.

Fonte: Elaborado pela pesquisadora em 2012.

A representação dos elementos, vínculos e evidências dos elementos relacionados ao serviço pessoas, processos e ambientes -, tal como um processo, permitiu compreender o seu funcionamento em toda a sua extensão, tendo em conta as inter-relações e a interdependência entre clientes, provedores e demais partes interessadas.

\subsection{Considerações sobre o capítulo}

A complexidade intrínseca aos serviços de transporte para promover a satisfação das pessoas com deficiência depende da inter-relação entre as pessoas, os processos e os ambientes estações, trens, interface trem-estação - seja em relação à sua configuração seja em relação aos sistemas de informação, comunicação e orientação ou em relação à gestão e prestação dos serviços. O projeto de ambientes de prestação de serviço de transporte de alta capacidade pressupõe que muitas das etapas do processo sejam realizadas pelo próprio usuário. Considerando que o desempenho do serviço resulta da interação entre o usuário com deficiência visual e a empresa prestadora do serviço e é coproduzido a partir de uma série de interações, seu resultado depende de todos os entes que participam direta ou indiretamente do 
processo - usuários com deficiência visual, funcionários e demais usuários, pontos de contato existentes nos ambientes onde o serviço é prestado e serviços executados nos bastidores.

Há necessidade de definir ou mesmo de optar pelo uso de diferentes tecnologias nos equipamentos (elevadores, escadas rolantes, bloqueios, trens) ou nas instalações e, simultaneamente, saber quais delas possibilitam independência ou podem gerar alguma restrição em relação ao uso.

Diante do exposto, pensar antecipadamente sobre a experiência do usuário e sobre quais interações devem ser consideradas consiste em uma habilidade necessária, não bastando seguir uma lista de requisitos normativos. Por conseguinte, é importante identificar, entender e analisar as possíveis interações que serão efetuadas entre o usuário e os equipamentos e serviços oferecidos nas diferentes etapas da jornada do usuário, considerando o perfil e as características de cada pessoa, suas habilidades, dificuldades e limitações, o grau de autonomia ou a necessidade de auxílio.

Assim, compreender as relações entre os clientes, os provedores e as demais partes interessadas é importante para que se tenha, simultaneamente, uma visão detalhada de cada uma das etapas da jornada, bem como uma visão abrangente da experiência, a fim de identificar os pontos críticos do processo:

- a elaboração do mapeamento dos stakeholders permitiu visualizar as inter-relações e a interdependência entre as pessoas, os processos e as evidências físicas, conforme preconizado por Zeithaml e Bitner (2003) e Fitzsimmons e Fitzsimmons (2005).

- a identificação dos processos relacionados à jornada do usuário demandou uma análise minuciosa dos procedimentos operacionais que estão direta ou indiretamente relacionados à prestação do serviço metroferroviário.

- a representação dos elementos, vínculos e evidências existentes nas diversas etapas da jornada do usuário, tal como um processo, permitiu compreender a abrangência do inter-relacionamento existentes a partir das ações dos usuários, ações dos funcionários de linha de frete e dos bastidores, as características da configuração dos ambientes, das informações presentes em cada etapa e dos respectivos protocolos de serviço. 
Em se tratando de pessoas com deficiência visual - cegas ou com baixa visão -, é preciso registrar dois perfis diferentes:

- as que aspiram à independência em seus deslocamentos e, por conta disso, necessitam de intervenções para adequação dos ambientes e treinamento de O\&M, além da conscientização dos demais usuários;

- as que aspiram a receber auxílio em seus deslocamentos e, por conta disso, carecem de ações de sensibilização e capacitação dos funcionários, além da conscientização dos demais usuários.

A elaboração do diagrama da jornada possibilitou gerar insumos para subsidiar a elaboração e a aplicação de instrumentos, que será tratada nos próximos capítulos. Esses insumos baseiamse nas interações entre o usuário com deficiência visual e a empresa prestadora do serviço para identificar aspectos positivos e pontos para melhoria. 


\section{AVALIAÇÃO PÓS-OCUPAÇÃO - APO}

Para o desenvolvimento desta tese, optou-se por uma abordagem qualiquantitativa, que permitisse identificar e aprofundar o conhecimento a respeito da relação entre as pessoas com deficiência visual e os ambientes do sistema metroferroviário durante seus deslocamentos. Para tanto, os métodos selecionados para obtenção dos dados deveriam abranger as pessoas envolvidas, os serviços oferecidos e as evidências físicas dos ambientes no Metrô de São Paulo. A opção pela aplicação de métodos e técnicas da Avaliação Pós-Ocupação - APO permitiria avaliar o desempenho funcional de acessibilidade do sistema metroferroviário, considerando, simultaneamente, a ótica de especialistas - para aferição do atendimento às premissas de desempenho dos ambientes, produtos ou serviços tais como a configuração, a comunicação e a sinalização - e de usuários - para aferição do nível de satisfação decorrente da utilização do sistema de transporte.

A APO trata de um conjunto de métodos e técnicas para Avaliação de Desempenho em Uso ${ }^{19}$ (ADU) de edificações e ambientes construídos, considerando, simultaneamente, o ponto de vista dos especialistas e a satisfação dos usuários $^{20}$. A APO busca extrair informações relativas às condições de uso de um determinado ambiente, produto ou serviço tendo como base sua adequação às atividades desenvolvidas pelo usuário para, a partir dessas informações, identificar aspectos positivos (desejáveis) ou negativos (indesejáveis). Dessa forma, esses métodos possibilitam diagnósticos consistentes e completos, que fundamentam recomendações e intervenções para os objetos de estudo e, quando sistematizados, contribuem para a incorporação de novos requisitos em futuros projetos de mesma natureza (ROMERO; ORNSTEIN, 2003).

Define-se assim um ciclo de realimentação da qualidade no processo de projetos, imprescindível para edificações complexas, tais como aeroportos, estações metroferroviárias, hospitais, estádios, centros comerciais ou edifícios construídos em série, como as escolas e os

\footnotetext{
${ }^{19}$ Desempenho é o comportamento em uso de uma edificação e de seus sistemas.

${ }^{20}$ Desde a vigência do Código de Defesa do Consumidor (BRASIL, 1990), que define os direitos e obrigações de consumidores e fornecedores, bem como de empresas construtoras e/ou incorporadoras e, mais recentemente, da ABNT NBR 15575: 2013 (ABNT, 2013), que estabelece e avalia os requisitos e critérios de desempenho que se aplicam às edificações habitacionais, a APO vem sendo gradativamente incorporada às rotinas das empresas construtoras, dos gerentes de facilidades e projetistas preocupados com a qualidade do ambiente construído e também com o atendimento às expectativas dos clientes e dos usuários.
} 
empreendimentos habitacionais (BARBOSA, ORNSTEIN, 2012). A realimentação do processo de projeto a partir do diagnóstico realizado e da validação ou estabelecimento de recomendações para novos projetos possibilita que sejam atendidas as necessidades das pessoas com deficiência visual durante seus deslocamentos na rede metroferroviária.

A satisfação do usuário está relacionada à expectativa e à experiência - emocional ou sensorial - e consiste em aspectos subjetivos - desejáveis ou indesejáveis - e dependentes de fatores interdependentes, tais como o contexto de uso, as interações realizadas com o ambiente ou com os demais usuários, a tecnologia envolvida no processo, o grau de automação dos ambientes, o grau de acessibilidade e o perfil do usuário, incluindo suas habilidades e restrições. Assim,

\footnotetext{
O cotidiano de nossas experiências ambientais é constituído por reações de vários níveis de complexidade, desde as mais instintivas até as bastante sofisticadas, quando processos sensoriais, perceptuais e cognitivos se combinam e até mesmo se confundem (Ittelson, 1973 apud Elali; Pinheiro, 2013, p.22)
}

Segundo Preiser (2005), as experiências na utilização de um mesmo ambiente, produto ou serviço por pessoas com deficiência física, visual, auditiva ou intelectual resultam em contribuições diferenciadas, decorrentes das habilidades e das limitações de cada pessoa durante a interação. A partir das informações obtidas das experiências, positivas ou negativas, projetos e investimentos podem melhor atender às expectativas e satisfazer usuários e investidores. É preciso, portanto, entender a necessidade das pessoas e apresentar uma proposta que signifique uma nova visão sobre o problema relatado.

A participação do usuário e sua interação com o projetista devem ser incentivadas nas diferentes etapas do processo de projeto, cabendo ao profissional diferenciar as experiências individuais das necessidades coletivas, identificando e gerenciando informações que possam contribuir para soluções de qualidade (BERNARDI et al, 2011). Na fase de pré-projeto, contribuições podem ser realizadas por meio da interação entre o projetista e o usuário, que fará sugestões a partir da apresentação de desenhos ou maquetes, permitindo que sejam feitas mudanças incrementais nos projetos. Na fase pós-uso, especialmente nos casos de adaptação ou modificação de ambientes, produtos ou serviços, a solução ideal poderá ser muitas vezes substituída por uma solução viável, em função da existência de condições impeditivas de ordem técnica, econômica ou operacional. Seja na fase de pré-projeto seja na fase de

\footnotetext{
${ }^{21}$ ITTELSON, W. H. Environment and cognition. New York: Seminar, 1973.
} 
avaliação pós-ocupação, as contribuições dos usuários são fundamentais para o sucesso do projeto e também de futuros empreendimentos de mesma natureza. A APO constitui-se então numa "via de estudo privilegiada para [...] promover o diálogo técnico com o projetista e aprofundar a multidisciplinaridade" (COELHO; PEDRO, 2013, p. 318). O autor ressalta ainda que "o aperfeiçoamento da metodologia APO e dos respectivos instrumentos de aplicação constitui uma terceira área de estudo da máxima importância”.

Rheingantz e Pedro (2013) explicam a APO como "um processo de avaliação do ambiente construído que não deve ser interpretado como um método, embora utilize vários métodos provenientes de diferentes áreas do conhecimento". Ela surgiu da necessidade de reunir os conhecimentos até então produzidos sobre as relações entre as pessoas e os ambientes.

Evans (2005) destaca a importância do estudo "científico" das relações entre o "ambiente físico" e o "comportamento humano" na psicologia ambiental e aponta a existência de dois ambientes: um objetivo e outro subjetivo. E justifica da seguinte maneira:

[...] se você está interessado em saber como o ambiente físico objetivo influencia o ambiente subjetivo, você tem que separá-los para poder estudá-los e, certamente, essa é uma área de estudos muito importante: como o ambiente objetivo afeta a nossa percepção. Mas se você usar a sua percepção como ponto de partida, não conseguirá ver essa relação. (EVANS, G. 2005, p. 49)

Os métodos e técnicas utilizados no estudo da relação pessoa-ambiente são selecionados a partir da resposta procurada e do modo de atuação do pesquisador (ELALI; PINHEIRO, 2013). Dessa forma,

[...] nem sempre pessoa (P) e ambiente (A) constituem as variáveis antecedentes e/ou critérios; o foco central dos trabalhos precisa ser a interface entre ambos (P-A). A complexidade de $\mathrm{P}$, de $\mathrm{A}$ e, sobretudo, da interação entre os dois, reflete-se no fato de várias disciplinas [...] investigarem aspectos específicos da relação pessoaambiente. A variedade de formação e de interesses dos pesquisadores envolvidos implica em uma multiplicidade metodológica entre áreas, além da já enfrentada dentro de cada disciplina, de modo que a complexidade da relação pessoa-ambiente salienta as limitações metodológicas de cada uma. (GÜNTHER, ELALI, PINHEIRO, 2008, p. 370)

Partindo das categorias propostas por Proshansky et al. (1970), Günther, Elali e Pinheiro (2008) resumiram os métodos de pesquisa nos estudos pessoa-ambiente a partir do foco do estudo e do tipo da relação:

a) métodos centrados nas pessoas - foco nos atributos das pessoas, em função do ambiente; 
b) métodos centrados no ambiente - foco nas características do ambiente, em função das pessoas;

c) métodos centrados na relação entre a pessoa e o ambiente - foco na interação e transação entre a pessoa e o ambiente.

Para Costa e Elali (2014), a navegação ambiental numa edificação depende da definição de percursos entre o ponto de partida e o ponto de chegada e é influenciada pelas características da pessoa (habilidades, conhecimento, experiência anterior), pelas características do local (aspectos físicos e sistema de informação existente) e, sobretudo, pela interação entre ambos (relação pessoa-ambiente).

Sellitz et al. (1974) ressaltam que os resultados devem atentar para a representatividade do ambiente ou do público-alvo, selecionados de forma que os resultados neles baseados possam refletir a realidade que está sendo investigada.

A necessidade de correspondência entre as prioridades do investigador e as do contexto aponta uma tendência de investigação, mas não de uso e aplicação dos resultados, como um divórcio entre a teoria e a prática. A aplicação, a utilização potencial e a difusão dos resultados devem ser uma preocupação do pesquisador desde o início do projeto (WISENFELD, 2005).

\subsection{Abordagem multimétodo}

Villa (2013) afirma que a adoção de multimétodos - qualitativos e quantitativos - apresentase como uma possibilidade metodológica para a compreensão dos complexos problemas de pesquisa na área do ambiente-comportamento. A abordagem multimétodo (GÜNTHER, ELALI, PINHEIRO, 2008; ELALI, PINHEIRO, 2013) combina métodos e técnicas com os seguintes objetivos:

a) aprofundar as possibilidades de análise do fenômeno estudado;

b) ampliar o repertório de informações do pesquisador durante o processo analítico;

c) complementar e equilibrar as eventuais distorções ou vieses de cada abordagem;

d) possibilitar a elaboração de um diagnóstico consistente, minimizando a existência de lacunas de conhecimento. 
Elali e Pinheiro (2013, p. 22) afirmam que a escolha do método e das técnicas de pesquisa está relacionada aos objetivos da proposta, ao tempo e à tecnologia disponíveis para o processo coleta-sistematização-análise dos dados. A opção metodológica também depende da facilidade de abordagem dos interlocutores e de acesso às informações e à disponibilidade de recursos financeiros e humanos. O conjunto de métodos e técnicas deve ser utilizado e combinado de acordo com os objetivos, os prazos e os recursos humanos e materiais disponíveis a partir das possibilidades e limitações intrínsecas a cada um dos instrumentos com os quais pretende-se trabalhar. Os instrumentos se complementam e podem, portanto, ser considerados mais ou menos adequados ao contexto, ao prazo e à disponibilidade; são as condições que determinam os instrumentos, e não o contrário.

A principal vantagem do uso de múltiplas fontes de evidência é a possibilidade de desenvolvimento de linhas convergentes de investigação, cujas conclusões são mais convincentes e acuradas quando possibilitam corroborar fatos ou fenômenos a partir da triangulação dos dados. Contudo, a utilização de múltiplas fontes de evidência impõe maior carga de trabalho ao pesquisador e torna necessária a sua familiarização com diferentes procedimentos de coleta, análise e interpretação dos dados (YIN, 2010). A abordagem multimétodo exige a integração dos resultados na etapa de análise e assegura uma importante convergência informacional sobre o ambiente em questão, impondo um considerável esforço de síntese (GÜNTHER, ELALI, PINHEIRO, 2008).

A seleção dos instrumentos aplicados nesta pesquisa foi precedida de uma análise das vantagens e desvantagens de cada um deles. O instrumento central foi o questionário aplicado aos usuários com deficiência visual, que permitiu a coleta de dados primários junto às pessoas que utilizam o sistema metroviário de forma habitual. A opção por esse instrumento permitiu, desde o início, assegurar a correta definição do problema sob a ótica das pessoas com deficiência visual, abordando suas necessidades, seus problemas e sua realidade.

Os aspectos abordados nos questionários aplicados aos usuários com deficiência visual deveriam ser objeto de pelo menos um instrumento adicional, aplicado junto às pessoas-chave e especialistas. Tal procedimento possibilitaria a coleta simultânea ou sequencial de dados quantitativos e qualitativos, relacionados aos serviços oferecidos pelo Metrô de São Paulo, o que permitiria uma visão abrangente da situação experimentada pelas pessoas com deficiência 
visual a partir da perspectiva de fontes adicionais, por meio de entrevistas individuais ou em grupo realizadas com pessoas-chave e especialistas.

Os aspectos abordados nos questionários e nas entrevistas foram complementados com dados qualitativos e quantitativos coletados em instrumentos adicionais aplicados nos ambientes do sistema metroferroviário - estações, interface trem-estação e trens, o que favoreceu os seguintes aspectos:

a) obtenção de evidências por meio de pesquisa documental em legislação, normas técnicas, publicações, desenhos, procedimentos operacionais e manifestações dos usuários;

b) elaboração de checklist a partir da análise de desenhos, projetos e normas técnicas;

c) realização de walkthrough nos percursos de embarque e desembarque;

d) elaboração de ficha ambiente;

e) observação de fluxo, de comportamento e de capacitação dos usuários com deficiência visual e dos demais usuários;

f) identificação das melhores práticas (benchmarking) verificadas em outros sistemas de transporte.

Para Sellitz et al. (1974), a etapa de concepção da coleta de dados é o momento em que são introduzidas medidas que impedem o viés e a imprecisão. A elaboração do protocolo consistiu na definição de procedimentos de campo e regras gerais a serem seguidas na coleta de dados das pessoas e da instituição, incluindo o acesso à organização objeto de estudo, aos entrevistados e respondentes, aos recursos materiais necessários à investigação e à programação das atividades relacionadas à disponibilidade das pessoas envolvidas (YIN, 2010). Além de identificar os dados que deveriam ser coletados, o protocolo estabeleceu requisitos para cada um dos instrumentos aplicados, tais como a forma de abordagem, o horário de observação e a forma de registro. Depois de construídos, os instrumentos de coleta de dados foram aplicados em caráter de pré-teste para validação, possibilitando ajustes dos conteúdos ou das condições de aplicação ou de registro.

A análise teve como objetivo organizar os dados de forma a possibilitar o fornecimento de respostas ao problema da investigação. Para proceder à análise das evidências e informações provenientes de cada um dos instrumentos aplicados, foram observados os seguintes passos: 
(a) estabelecimento de categorias; (b) codificação; (c) tabulação e (d) análise estatística dos dados (GIL, 2010).

$\mathrm{Na}$ etapa de interpretação dos resultados, buscou-se conectar os resultados dos dados coletados com as referências teóricas anteriormente obtidas. Para proceder à interpretação dos resultados, foram observados os seguintes passos: (a) avaliação das generalizações; (b) inferência das relações causais e (c) interpretação dos dados (GIL, 2010).

\subsection{Considerações sobre o capítulo}

Neste capítulo foram abordadas as justificativas para adoção de uma abordagem metodológica baseada em multimétodos como forma a possibilitar a compreensão dos complexos problemas de pesquisa na área do ambiente-comportamento a partir de métodos centrados na relação entre a pessoa e o ambiente - cujo foco está na interação - e de métodos centrados no ambiente - considerando o foco de sua utilização por pessoas com deficiência visual.

O desenho do protocolo de coleta, análise e interpretação dos dados será apresentado no próximo capítulo. Por ora, pode-se afirmar que a abordagem multimétodo e a seleção dos instrumentos aplicados deveriam possibilitar a obtenção de dados sobre a sequência e as interações realizadas na jornada do usuário, apresentadas no capítulo anterior, e a comprovação de fatos ou fenômenos a partir da triangulação dos dados, incluindo os seguintes aspectos:

a) as ações realizadas pelo usuário com deficiência visual relacionadas à utilização de equipamentos e instalações;

b) os contatos realizados com demais usuários;

c) os relacionamentos entre usuários e funcionários;

d) os papéis desempenhados pelos funcionários durante o auxílio nos deslocamentos;

e) as ações dos funcionários na linha de frente;

f) os relacionamentos entre funcionários das diferentes áreas, na retaguarda;

g) os processos, as rotinas, as regras, os procedimentos e os roteiros de serviço;

h) as evidências físicas dos ambientes (configuração, informação das estações, dos trens e da interface entre eles.). 
Dessa forma, a abordagem multimétodo possibilitaria a elaboração de diagnósticos consistentes e completos, fundamentando recomendações para os objetos de estudo e, quando sistematizados, possibilitaria eventual incorporação de requisitos normativos em futuras revisões dos textos relacionados à acessibilidade, atendendo as necessidades das pessoas com deficiência visual durante seus deslocamentos na rede metroferroviária, seja pela adequação das instalações como pela adequação dos serviços prestados.

Considerando que as experiências na utilização de um mesmo ambiente, produto ou serviço por pessoas com deficiência resultam em contribuições diferenciadas - face às habilidades e limitações durante a interação ou experiência de uso - (PREISER, 2005), entende-se que a abordagem multimétodo e a triangulação dos dados representou uma oportunidade de corroborar e complementar as informações obtidas a partir de diferentes fontes. Dessa forma, a quantificação dos relatos dos usuários sobre eventuais dificuldades durante as interações permitiria apurar dificuldades comuns às várias pessoas com deficiência visual, portanto mais críticas.

A utilização de múltiplas fontes de evidência impôs uma elevada carga de trabalho nas diferentes fases - coleta, análise e interpretação dos dados (YIN, 2010). Porém, o maior impacto se deu na etapa de análise e interpretação dos dados, onde foi dispendido tempo além do previsto inicialmente, pois exigiu esforço adicional para a integração dos resultados na etapa de análise, de forma que pudesse assegurar a convergência das informações sobre as diferentes etapas da jornada, impondo um considerável esforço de síntese (GÜNTHER, ELALI, PINHEIRO, 2008).

No próximo capítulo, serão apresentados os métodos e as técnicas utilizados para o desenvolvimento desta tese, a partir da justificativa de seleção de cada um dos instrumentos, da explicitação do protocolo de coleta e a forma de análise e interpretação dos dados. 


\section{APLICAÇÃO DOS INSTRUMENTOS}

\subsection{Questionário}

\subsubsection{Considerações sobre o instrumento}

Questionários devem ser utilizados quando o levantamento envolver um número grande de participantes e for necessária "uma abordagem analítica, explorando as relações entre variáveis [...], seguida de entrevistas estruturadas ou observações com uma amostra alvo" (GRAY, 2012, p. 274). Nos questionários, “as pessoas devem responder ao mesmo conjunto de perguntas em uma ordem pré-determinada" (GRAY, 2012, p. 274), na forma escrita, preenchida pelo respondente, ou oral, com abordagem presencial ou por telefone, com um pesquisador anotando as respostas (BELL, 2008; FLICK, 2013). Os questionários "podem ter exclusivamente perguntas fechadas, perguntas abertas ou combinar ambos os tipos de perguntas" (RICHARDSON, 2011, p. 190). Com relação à abordagem por meio de contato telefônico, esta permite o agendamento e oferece comodidade e conforto para o respondente durante a aplicação do instrumento.

\subsubsection{Seleção da amostra}

Segundo Mattar (1999), no processo de seleção de amostras, deve-se atentar para cinco etapas:

- definição do universo ou população da pesquisa;

- identificação dos tipos de amostras e amostragem;

- decisão sobre o tamanho da amostra;

- seleção de procedimento específico para determinação da amostra;

- seleção da amostra a partir das etapas anteriores.

A seguir, cada uma dessas fases será pormenorizada: 


\section{a) Definição do universo ou população}

Considerando que o Metrô de São Paulo não dispunha de dados referentes ao universo dos usuários com deficiência visual que utilizam o sistema, foi necessário estimar a quantidade de pessoas com deficiência visual a partir das informações disponíveis. Para tanto, foram utilizados diferentes registros, entre os quais se destacam:

- total de entrada de passageiros (registro de entradas nos bloqueios);

- total de passageiros transportados (deslocamentos realizados, considerando a utilização de mais de uma linha desde a estação de origem até a estação de destino);

- total de monitorações realizadas (registro de auxílios prestados);

- média semanal de usuários com deficiência visual que utilizam o sistema (total de auxílios prestados às pessoas com deficiência visual).

A primeira questão identificada foi "Como estimar, a partir dos dados de monitoramento das pessoas com deficiência visual, a quantidade total de pessoas com deficiência visual usuárias do sistema metroviário (universo da pesquisa)?" Para proceder à estimativa, foi necessário considerar os seguintes fatores:

- fator de transferência entre linhas: um mesmo usuário utiliza mais de uma linha durante seus deslocamentos desde a estação de origem até a estação de destino;

- frequência de uso do sistema metroviário ao longo do dia: um mesmo usuário realiza mais de uma viagem por dia, ida e volta;

- frequência de uso do sistema metroviário pelas pessoas com deficiência visual: um mesmo usuário realiza mais de uma viagem durante a semana.

Em relação ao fator de transferência entre linhas, foram calculadas as diferenças entre entradas (passagens pagas) e passageiros transportados (deslocamentos nas diferentes linhas, desde a estação de origem até a estação de destino). O total apurado foi de 80,16\% - média de março e maio/2012, meses que historicamente são considerados pelo Metrô de São Paulo como sendo típicos para se proceder cálculos e estudos que estejam relacionados à demanda (Tabela 8), face à quantidade de feriados, dias úteis e hábitos de viagem dos usuários. 
Tabela 8 - Fator de transferência entre linhas.

\begin{tabular}{lrrr}
\hline \multicolumn{1}{c}{ Rede } & \multicolumn{1}{c}{ Entradas } & Passageiros Transportados & Fator de transferência \\
\hline jan-dez/2009 & 706 (milhões) & 975 (milhões) & 0,724102564 \\
\hline jan-dez/2010 & 754 (milhões) & 1.044 (milhões) & 0,722222222 \\
\hline jan-dez/2011 & 811.657 .000 & 1.087 .234 .000 & 0,746533865 \\
\hline jan-dez/2012 & 877.171 .000 & 1.098 .098 .000 & 0,798809395 \\
\hline mar/12 & 80.451 .668 & 100.398 .099 & 0,801326607 \\
\hline mai/12 & 77.682 .877 & 96.877 .776 & 0,801864785 \\
\hline jan-dez/2013 & 888.624 .000 & 1.106 .738 .000 & 0,802921739 \\
\hline Fonte: Elaborado pela autora a partir de CMSP, 2012, p. 91; CMSP, 2012 (93); CMSP, 2013 (p. 93); CMSP, 2014, p. 95.
\end{tabular}

Os dados relativos ao monitoramento das pessoas com deficiência são registrados pelo console de passageiros do Centro de Controle Operacional - CCO toda vez que um auxílio é solicitado em cada uma das estações. Se um usuário vai de uma estação a outra, numa mesma linha, são registrados dois acionamentos: um para auxiliar o embarque, e outro para auxiliar o desembarque. Se um usuário realiza uma viagem que tem início em uma estação de uma linha e tem como destino uma estação de outra linha, são registrados três acionamentos: o primeiro, na estação de embarque; o segundo, na estação de conexão, e o terceiro, na estação de desembarque. Nos meses de março e maio de 2012, foram registrados, em média, 25.179 monitoramentos por mês. Assim, quando aplicado o fator de transferência entre linhas $(80,16 \%)$ à quantidade média de monitoramentos registrados no período (25.179 auxílios), obtém-se o resultado de 20.183 entradas durante um mês. Considerando a frequência de uso ao longo do dia (a ida e a volta), conclui-se que foram realizados 10.092 deslocamentos na rede metroviária por pessoas com deficiência visual.

A frequência de uso do sistema metroviário ao longo do dia está relacionada aos motivos da viagem - trabalhar, estudar, lazer - e implica dois deslocamentos: ida e volta.

A frequência de uso do sistema metroviário por pessoas com deficiência visual está relacionada aos hábitos de viagem. Esse dado foi obtido a partir da questão 5 do questionário, onde foi apurada a quantidade de pessoas que usam o metrô ao longo da semana (Tabela 9). 
Tabela 9 - Frequência de uso do sistema metroviário ao longo da semana.

\begin{tabular}{lr}
\hline $\begin{array}{l}\text { Q5 - Frequência de uso do } \\
\text { sistema metroviário ao longo da } \\
\text { semana }\end{array}$ & $\begin{array}{l}\text { Quantidade de } \\
\text { respondentes }\end{array}$ \\
\hline um dia / semana & 13 \\
\hline dois dias / semana & 24 \\
\hline três dias / semana & 27 \\
\hline quatro dias / semana & 18 \\
\hline cinco dias / semana & 93 \\
\hline seis dias / semana & 32 \\
\hline todos os dias da semana & 28 \\
\hline Total de respondentes & $\mathbf{2 3 5}$ \\
\hline Fonte: Elaborada pela autora a partir do questionário aplicado (Q5).
\end{tabular}

A partir dos dados coletados, conclui-se que cada um dos 235 respondentes realiza, em média, 4,56 viagens por semana, o que totaliza 20,19 viagens ao longo de um mês. Dessa forma, dividindo-se o total de monitoramentos registrados (10.092) pelo número médio de viagens realizadas mensalmente pelos usuários com deficiência visual $(20,19)$, concluiu-se que aproximadamente 500 diferentes pessoas com deficiência visual utilizam o sistema metroviário.

\section{b) Determinação do tamanho da amostra}

Somente foi possível chegar-se a uma conclusão sobre o universo de usuários com deficiência visual que utilizam o sistema metroviário ao longo da aplicação do questionário (questão 5). Dessa forma, ao término do período de aplicação dos 235 questionários, fez-se a avaliação do nível de confiança e da margem de erro obtida para efeito de validação dos dados coletados. Consequentemente, obteve-se um nível de confiança de 95\%, e uma margem de erro de $4,66 \%$, para questões com duas variáveis - sim/não.

\section{c) Identificação dos tipos de amostragem}

Optou-se pelo uso de amostra não probabilística uma vez que "a população toda não está disponível para ser sorteada" (MATTAR, 1999, p. 269). Além disso, a participação foi voluntária, obtida ora por indicação ora por meio de abordagem do usuário na estação, e "a decisão de responder ou não aos questionários cabe exclusivamente aos respondentes, que decidirão, em última análise, se farão ou não parte da amostra" (MATTAR, 1999, p. 269270). Acrescenta-se a isso o fato de não haver preocupação com a representatividade da população uma vez que o objetivo da aplicação do questionário era detectar aspectos positivos 
e identificar pontos para melhoria no sistema metroferroviário a partir da percepção das pessoas com deficiência visual.

\section{d) Seleção de procedimento específico para determinação da amostra}

Conforme já relatado, para seleção dos respondentes, foram utilizadas duas estratégias de amostragem não probabilística:

- seleção não-aleatória, por indicação - cada um dos 15 respondentes do questionário "modelo 1" indicou outro usuário para participar da avaliação. Assim, foram identificados 15 novos potenciais respondentes e, a partir destes, novos contatos foram realizados. Essa técnica, chamada de amostragem bola-de-neve, permite que seja construída uma amostra representativa de um determinado subgrupo através de indicações sucessivas: “O pesquisador identifica um pequeno número de sujeitos, os quais, por sua vez, identificam outros na população" (GRAY, 2012, p. 127). Por meio de indicação e contatos telefônicos, foram aplicados 85 questionários;

- seleção não-aleatória, intencional - os usuários com deficiência visual foram abordados durante seus deslocamentos nas estações, momento em que foram informados dos objetivos da pesquisa e convidados a participar da avaliação: "Neste caso, o pesquisador deliberadamente seleciona os sujeitos em relação a uma ou mais características para ter o que se acredita ser uma amostra representativa" (GRAY, 2012, p. 126). Nos casos em que houve concordância, anotou-se o nome e o telefone, bem como as informações sobre a melhor data e horário para que fosse realizado o contato telefônico. Por meio das abordagens seguidas de contatos telefônicos, foram aplicados 150 questionários.

\subsubsection{Aplicação do questionário}

A aplicação do questionário nos usuários com deficiência visual que utilizam o Metrô de São Paulo de forma habitual - três ou mais vezes por semana, no período entre junho/2011 e junho/2012 - teve por objetivo conhecer o perfil, os hábitos de viagem e sua opinião quanto à legibilidade dos ambientes e os desafios enfrentados na interação com o ambiente, os funcionários e os demais usuários. A aplicação de questionários junto aos usuários com deficiência visual possibilitou identificar aspectos positivos e negativos existentes na relação 
pessoa-ambiente entre as pessoas com deficiência visual e o ambiente das estações e trens do Metrô de São Paulo. Entre os aspectos abordados no questionário, destacam-se os seguintes: o grau de satisfação e as expectativas em relação à configuração, aos sistemas de informação e aos serviços oferecidos nas estações e nos trens, bem como a opinião em relação à priorização das ações focadas no auxílio ou na autonomia dos usuários. Buscou-se ainda identificar os aspectos positivos e negativos enfrentados nos deslocamentos, bem como eventuais sugestões de melhoria.

O questionário modelo "1" - aplicado como pré-teste - continha 55 questões, sendo cinco abertas e 50 fechadas, com base na escala de Likert (com cinco pontos) ou do tipo sim/não. Foi aplicado de forma presencial e individual. O questionário mostrou-se inadequado em função da quantidade excessiva de questões e do tempo necessário à sua aplicação, que variou entre 50 e 60 minutos.

O questionário modelo "2" continha 17 perguntas, sendo 4 abertas - para oportunizar o registro das manifestações dos respondentes - e 13 fechadas, com base na escala de Likert (com cinco pontos), de tipo sim/não ou de múltipla escolha. Esse modelo foi aplicado diretamente ao respondente, individualmente, por telefone.

Após a abordagem na estação e esclarecimento dos propósitos da pesquisa, era realizado o agendamento, mediante concordância do usuário. No dia e horário marcados, era realizado o contato telefônico, iniciando pela identificação da pesquisadora e reforçando o objetivo do contato e da pesquisa. É importante destacar que a pesquisadora sempre foi muito bem acolhida durante o contato telefônico. Acredita-se que esta receptividade se dava, em parte, devido à ansiedade dos respondentes por ter alguém para ouvi-los quanto às suas considerações sobre seus deslocamentos, em parte por ser uma continuidade da abordagem realizada nas estações. Somente três pessoas previamente abordadas nas estações recusaramse a responder o questionário no momento do contato telefônico. A seguir, apresenta-se o roteiro da conversa inicial realizada no contato telefônico:

"Bom dia / Boa tarde / Boa noite. Meu nome é Beatriz. Fizemos contato recentemente, na estação $X$, sobre a possibilidade da sua participação na minha pesquisa acadêmica, junto à uma universidade, cujo tema está relacionado ao deslocamento das pessoas com deficiência visual nas estações e trens do Metrô de São Paulo. Agendamos nossa conversa para hoje... Podemos conversar agora?" 
Ao prosseguir, dava-se início à caracterização do usuário - perfil e hábitos de viagem. Na sequência, a pesquisadora solicitava que fossem relatadas as facilidades e dificuldades observadas em seis das estações mais utilizadas. Essas informações eram registradas em formulários à parte, um para cada estação. Em seguida, a pesquisadora retornava ao questionário principal, cumprindo a leitura das demais questões e avaliando temas como as condições de acessibilidade nas estações e trens e a expectativa e avaliação dos ambientes e da gestão do serviço prestado aos usuários. Ao final, eram solicitadas sugestões para a melhoria do serviço prestado e a indicação de outros usuários para participar da avaliação (Quadro 10). O tempo de aplicação dos questionários "modelo 2" variou entre 20 e 50 minutos $(76,6 \%)$. Casos específicos demoraram acima de 50 minutos $(16,9 \%)$, ou superaram uma hora de duração $(6,5 \%)$, devido à receptividade dos respondentes ou à extensão dos relatos. O questionário "modelo 2" consta do Apêndice A.

Quadro 10 - Temas abordados no questionário "modelo 2".

\begin{tabular}{ll}
\hline Questões & \multicolumn{1}{c}{ Temas } \\
\hline 1 a 4 & Caracterização do usuário - perfil \\
\hline 5 a 10 & Caracterização do usuário - hábitos de viagem \\
\hline 6 & $\begin{array}{l}\text { Planejamento da viagem (etapa que antecede o uso do sistema de transporte); está relacionada, } \\
\text { juntamente com os mapas disponíveis nas estações e trens, à compreensão da rede de transporte }\end{array}$ \\
\hline 9 & Identificação das estações mais utilizadas pelo respondente \\
\hline 10 & $\begin{array}{l}\text { Identificação do uso do sistema de transporte integrado à rede metroviária para avaliar a } \\
\text { acessibilidade das conexões entre diferentes modos de transporte; } \\
\text { relação com o planejamento da viagem (a chegada, o uso e a conexão com outro modo, } \\
\text { sucessivamente, até o destino final da viagem) }\end{array}$ \\
\hline 11,12 e & $\begin{array}{l}\text { Condições de acessibilidade das estações, complementadas pelo questionário do formulário anexo } \\
\text { - facilidades e dificuldades de deslocamento nas 6 (seis) estações utilizadas com maior frequência }\end{array}$ \\
\hline 13 & Condições de acessibilidade do trem \\
\hline 15 e 16 & Expectativas e avaliação da gestão do serviço prestado aos usuários com deficiência visual \\
\hline 17 & $\begin{array}{l}\text { Associação da infraestrutura das estações e dos trens à gestão dos serviços; } \\
\text { solicita que o respondente, a partir de uma visão integrada, aponte sugestões que possam } \\
\text { contribuir para a melhoria do serviço prestado. }\end{array}$ \\
\hline Fonte: Elaborado pela pesquisadora 2011
\end{tabular}

Fonte: Elaborado pela pesquisadora. 2011.

As respostas - das questões fechadas e das questões abertas - foram anotadas no formulário, atentando para transcrever os termos exatos utilizados pelos respondentes durante os relatos (questões abertas).

\subsubsection{Tabulação dos dados}

Todos os questionários foram identificados por números (de "1" a "235"). Foram anotados os horários de início e de término da aplicação do instrumento, conforme data e hora acordadas 
junto ao respondente. A tabulação dos questionários do "modelo 2" foi iniciada pelas perguntas fechadas por meio da codificação das "caselas" (indicadas entre colchetes de " $A$ " a "BE"), seguida do lançamento dos dados nas colunas de uma planilha eletrônica (Microsoft Office Excel) para posterior processamento por meio do software SPSS (Statistical Package for Social Sciences).

A tabulação dos dados das perguntas abertas consistiu na digitação dos textos dos relatos dos respondentes referentes às questões $12,13,14$ e 17, cuidando para identificar seu número no questionário, e do código de classificação do usuário (CG para pessoas cegas e BV para pessoas com baixa visão) nas colunas da planilha eletrônica (Microsoft Office Excel). À direita de cada relato, foram criadas colunas identificadas de CD1 a CD15 para lançamento dos códigos das expressões-chave. Posteriormente, foram inseridas outras 15 colunas, intercaladas, para identificação da etapa da jornada relacionada a cada uma das expressõeschave. Após concluída a codificação, foi realizado o processamento por meio do software SPSS.

\subsubsection{Processamento dos dados - perguntas fechadas}

Responderam o questionário 235 usuários dos sistema metroviário com diferentes idades e graus de deficiência visual. Desse total, 172 respondentes são cegos, e 63 têm baixa visão, correspondendo a 73,2\% e 26,8\% da amostra, respectivamente (Gráfico 2). Os respondentes cegos ou com baixa visão desde o nascimento ou que se tornaram deficientes visuais antes de iniciado o processo de alfabetização somam $38,5 \%$. 
Gráfico 2 - Perfil dos usuários - Deficiência visual.

Questão 2 - A sua deficiência visual é - cego, baixa visão, cego de um olho e baixa visão do outro...

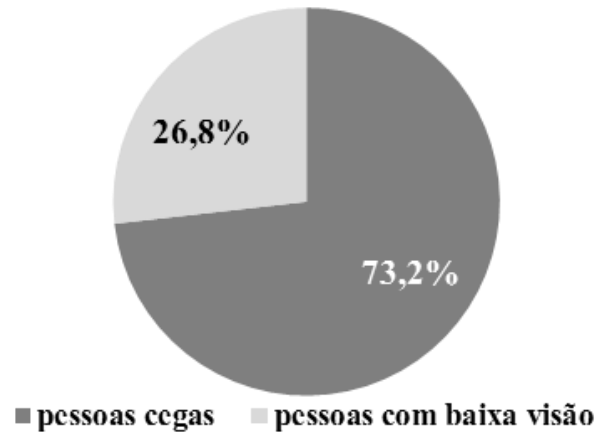

Fonte: Elaborado pela pesquisadora a partir das respostas à Questão 2.

Quanto à escolaridade, 78,7\% têm ensino médio ou superior; 19,1\% têm ensino fundamental ou médio incompleto; apenas $2,2 \%$ são analfabetos. Do total de respondentes, $89,4 \%$ já participaram de treinamentos de orientação e mobilidade (Gráfico 3).

Gráfico 3 - Perfil dos usuários - Participação em treinamento de orientação e mobilidade.

Questão 4 - Já realizou treinamento de orientação e mobilidade?

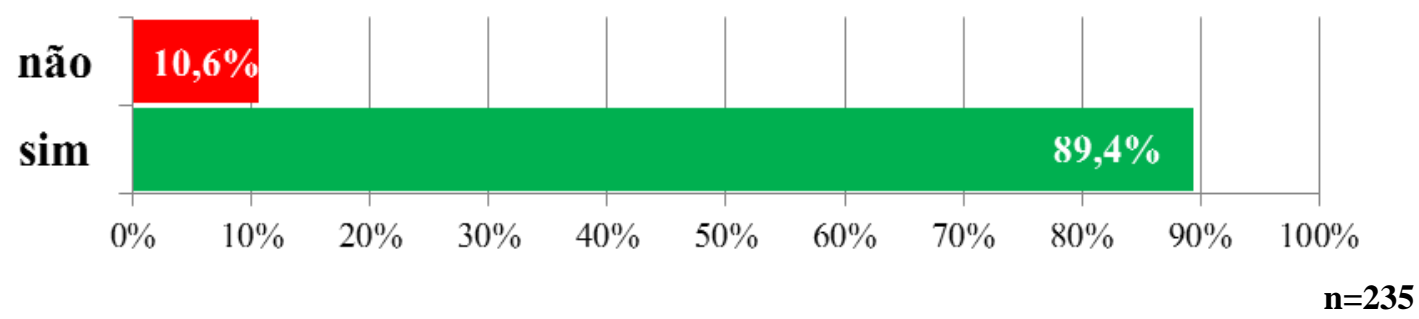

Fonte: Elaborado pela pesquisadora a partir das respostas à Questão 4.

Sobre a frequência de uso, $15,7 \%$ dos respondentes utilizam o metrô esporadicamente enquanto que os outros 84,3\% são usuários habituais (Gráfico 4).

Gráfico 4 - Perfil dos usuários - Frequência de uso do sistema metroviário ao longo da semana.

Questão 5 - Quantos dias da semana o(a) sr(a) costuma usar o metrô?

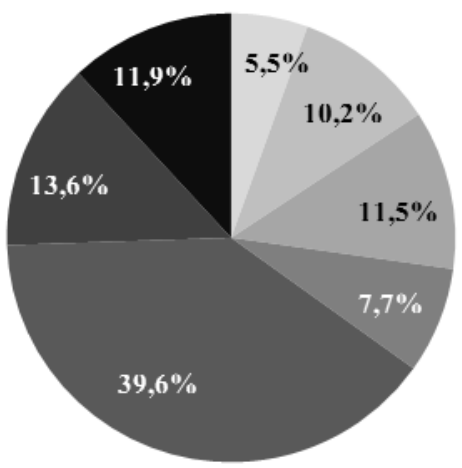

$$
\begin{aligned}
& \text { um dia / semana } \\
& \text { - dois dias / semana } \\
& \text { urês dias / scmana } \\
& \text { quatro dias / semana } \\
& \text { q cinco dias / semana } \\
& \text { - scis dias / semana } \\
& \text { - todos os dias da semana }
\end{aligned}
$$

Fonte: Elaborado pela pesquisadora a partir das respostas à Questão 5. 
Antes de sair de casa, apenas 31,1\% buscam informações sobre os trajetos ou as condições de funcionamento do metrô (Gráfico 5).

Gráfico 5 - Perfil dos usuários - Busca por informações sobre trajeto ou funcionamento.

Questão 6 - Antes de sair, o(a) sr(a) busca informações sobre trajetos ou funcionamento do metrô?

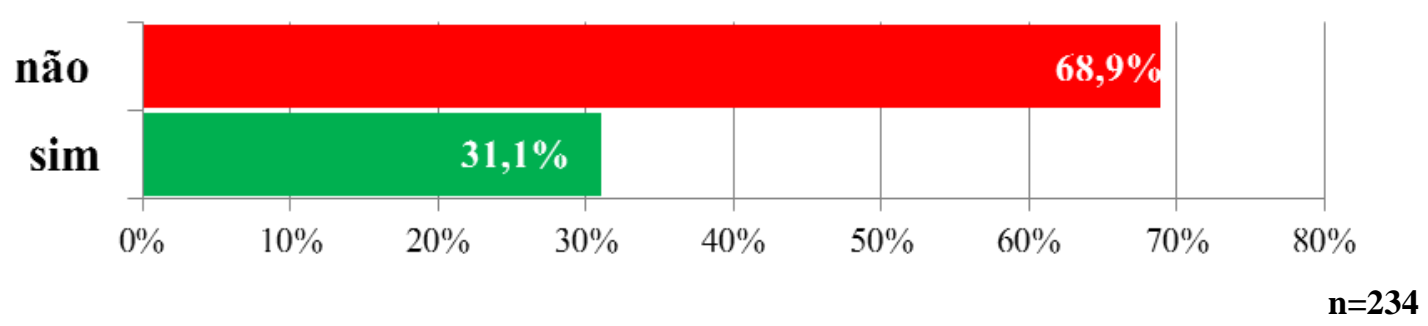

Fonte: Elaborado pela pesquisadora a partir das respostas à Questão 6.

Nos deslocamentos pela cidade, $90,6 \%$ dos respondentes informaram que andam sozinhos; 1,7\% utiliza cão-guia, e 7,2\% são acompanhados por um guia vidente (Gráficos 6 e 7). No metrô, 9,4\% deslocam-se sozinhos, e 90,6\% solicitam o auxílio de empregados da empresa ou de outros usuários.

Gráfico 6 - Perfil dos usuários - Autonomia nos deslocamentos na cidade.

Questão 7 - Em seus deslocamentos, o(a) senhor(a) costuma andar sozinho ou acompanhado?

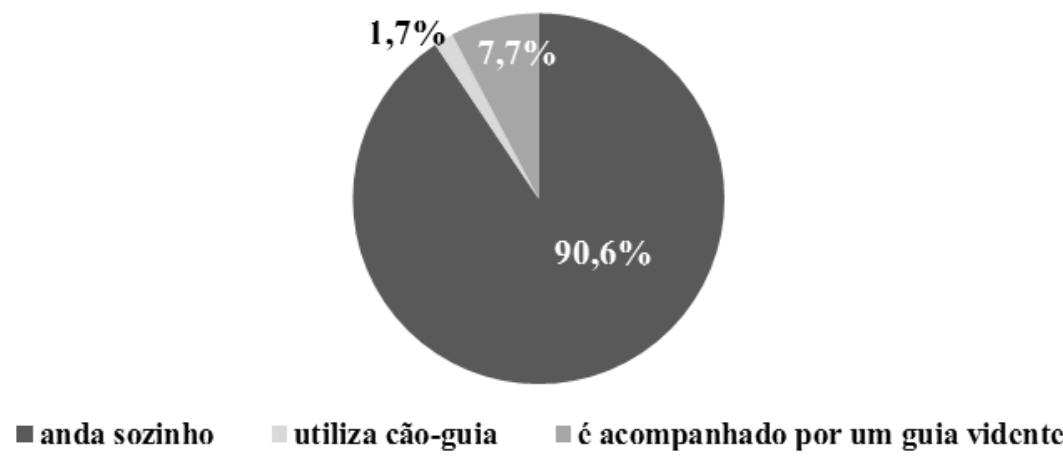

Fonte: Elaborado pela pesquisadora a partir das respostas à Questão 6.

$n=234$

Gráfico 7 - Perfil dos usuários - Autonomia nos deslocamentos no metrô.

Questão 7A - Usa cão-guia ou solicita ajuda de empregados ou outros usuários?

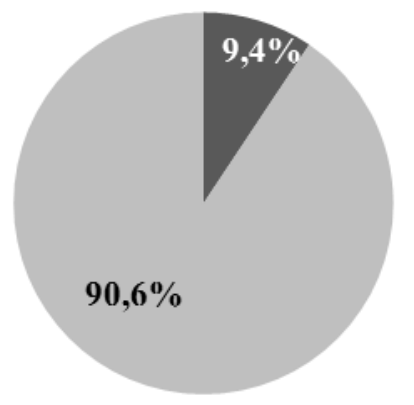

घesloca-se sozinho $\square$ solicita ajuda dos funcionários ou outros usuários

Fonte: Elaborado pela pesquisadora a partir das respostas à Questão 7A. 
A partir desse ponto do questionário, o respondente foi incentivado a falar dos seus deslocamentos, seus hábitos de viagem. As estações mais citadas pelas pessoas com deficiência visual como sendo de utilização frequente foram as seguintes:

- Estação Sé, local de conexão entre as linhas 1-Azul e 3-Vermelha;

- Estações Corinthians-Itaquera e Palmeiras-Barra Funda, na linha 3-Vermelha, locais de conexão entre o Metrô e os trens metropolitanos;

- Estação Santa Cruz, próxima a um centro de reabilitação para pessoas com deficiência visual;

- Estações Paraíso e Ana Rosa, locais de conexão entre as linhas 1-Azul e 2-Verde;

- Estações Tietê e Jabaquara, na linha 1-Azul, locais de conexão com os Terminais Rodoviários;

- Estação Tatuapé, na linha 3-Vermelha, que dispõe de dois empreendimentos comerciais;

- Estação Artur Alvim e Anhangabaú, na linha 3-Vermelha;

- Estação Luz, local de conexão entre as linhas do Metrô, dos trens metropolitanos e a linha de metrô operada pela iniciativa privada.

Na questão seguinte, o respondente foi estimulado a refletir sobre sua jornada, desde o início da sua viagem (a chegada ao Metrô), sobre o uso e a conexão com outros modos de transporte, sucessivamente, até o destino final da viagem. Para tanto, solicitou-se a identificação do uso do sistema de transporte integrado à rede metroviária para avaliar a acessibilidade das conexões entre diferentes modos de transporte. Quanto aos diferentes modos de deslocamento usados para chegar à estação utilizada com maior frequência, destacam-se o ônibus urbano da capital-SP $(29,9 \%)$, o trem metropolitano $(25,6 \%)$ ou ônibus de outros municípios juntamente com o trem (16,2\%). Para sair da estação, destaca-se o deslocamento a pé $(63,1 \%)$, a utilização dos ônibus urbanos da capital-SP $(20,9 \%)$ e o trem $(6,1 \%)$. Verifica-se que a necessidade de uso do transporte integrado é maior no trajeto inicial, antes de chegar à estação. Ao sair da estação do Metrô, com o destino almejado mais próximo, predominam os deslocamentos a pé (Gráfico 8). 
Gráfico 8 - Hábitos de viagem - Uso do transporte integrado.

Questão 10 - Pensando na estação que utiliza com maior frequência, que conduções usa para chegar e para sair da estação?

Para chegar à estação....

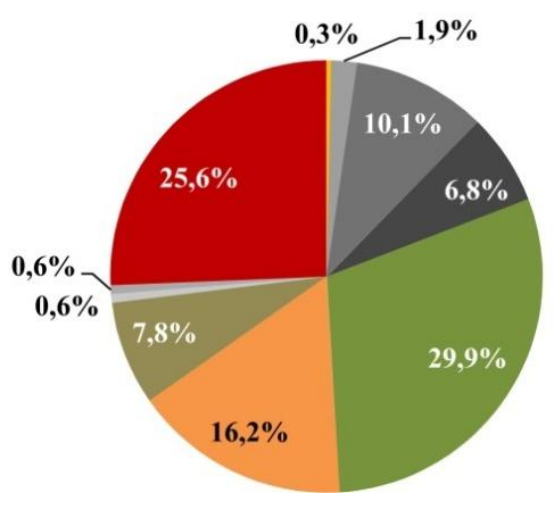

$\mathbf{n}=\mathbf{2 3 5}$

Fonte: Elaborado pela pesquisadora a partir das respostas à Questão 10.
Para sair da estação...

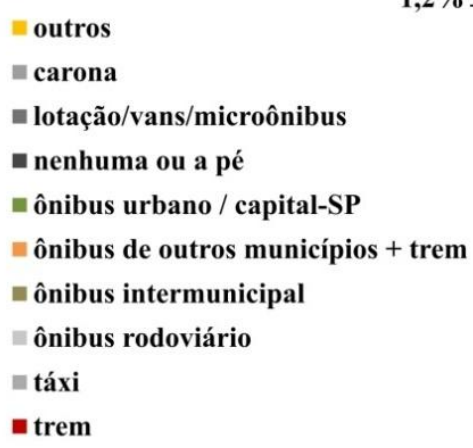

n trem

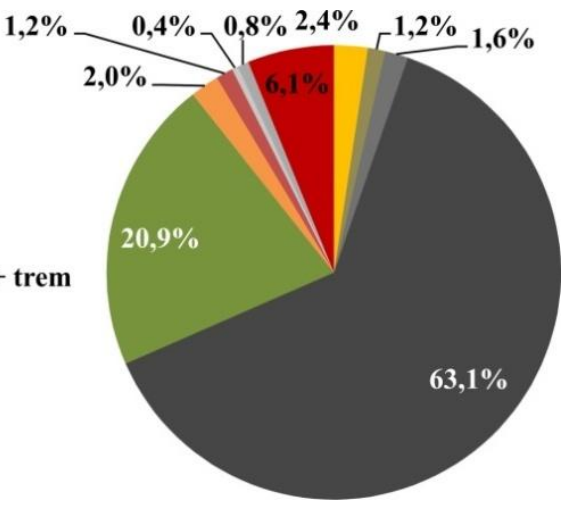

$\mathbf{n}=\mathbf{2 3 2}$

Feita a reflexão sobre sua jornada, as próximas questões tiveram por objetivo identificar as necessidades de deslocamento nas estações e nos trens do metrô. Para tanto, o respondente foi motivado a refletir sobre as condições de acessibilidade das estações, principalmente sobre as adaptações promovidas pelo Metrô. O resultado demonstra que 47,2\% fazem uma avaliação positiva das instalações (totalmente adaptadas ou quase totalmente adaptadas) enquanto que $16,2 \%$ as avaliam negativamente (pouco adaptadas/não estão adaptadas). Uma parcela significativa, que corresponde a $36,6 \%$, é menos crítica e considera as estações "mais ou menos adaptadas" (Gráfico 9).

Gráfico 9 - Condições de acessibilidade das estações - todos os respondentes.

Questão 11 - Pensando apenas nas necessidades dos deficientes visuais, o(a) sr(a) considera que as estações do Metrô estão...

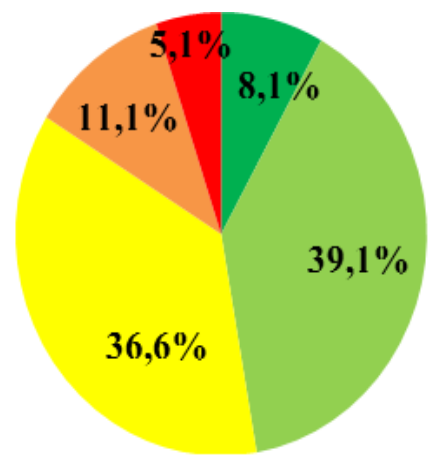

\author{
- totalmente adaptadas \\ quase totalmente adaptadas \\ mais ou menos adaptadas \\ pouco adaptadas \\ não estão adaptadas
}

$\mathbf{n}=\mathbf{2 3 5}$

Fonte: Elaborado pela pesquisadora a partir das respostas à Questão 11. 
Uma segunda estratificação foi processada, considerando a participação dos respondentes em treinamentos de orientação e mobilidade. $\mathrm{O}$ resultado demonstra que, entre os respondentes que participaram de treinamentos de O\&M, 48,6\% fazem uma avaliação positiva das instalações (totalmente adaptadas ou quase totalmente adaptadas) enquanto que 15,7\% avaliam negativamente as instalações (pouco adaptadas/não estão adaptadas), e 35,7\% consideram as estações "mais ou menos adaptadas" (Gráfico 10). Dos usuários que nunca passaram por treinamento de $O \& M$, a parcela que faz uma avaliação positiva das instalações (totalmente adaptadas ou quase totalmente adaptadas), correspondente a $36 \%$, enquanto a parcela que avalia negativamente as instalações (pouco adaptadas/não estão adaptadas), correspondente a $20 \%$. Novamente, uma parcela significativa (44\%) considera as estações "mais ou menos adaptadas".

Gráfico 10 - Condições de acessibilidade das estações - segundo treinamento de O\&M.

Questão 11 - Pensando apenas nas necessidades dos deficientes visuais, o(a) sr(a) considera que as estações do Metrô estão...

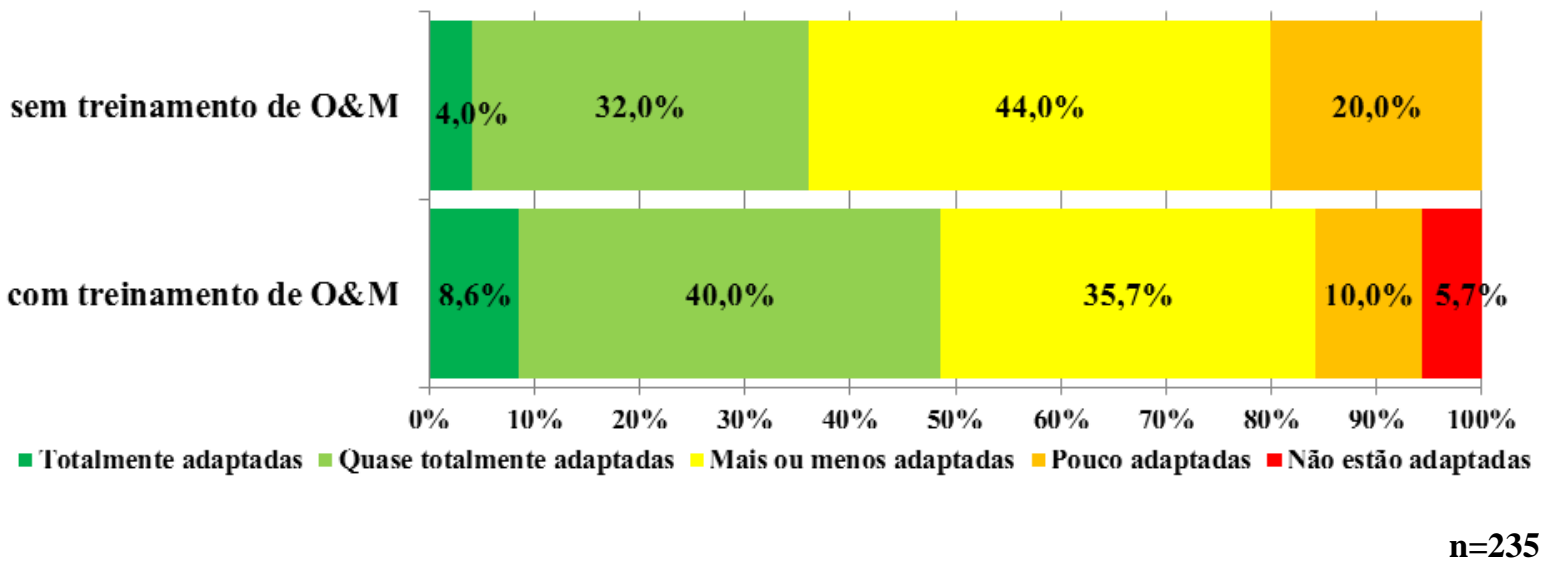

Fonte: Elaborado pela pesquisadora a partir das respostas à Questão 11.

Quando indagados sobre suas necessidades de deslocamento nas estações do metrô e a adequação das condições de acessibilidade das instalações, 67,2\% das pessoas com deficiência visual consideraram que o Metrô não levou em conta suas necessidades (Gráfico $11)$. 
Gráfico 11 - Atendimento às necessidades da pessoa com deficiência visual.

Questão 12 - Em sua opinião, o Metrô considerou todas as necessidades das pessoas com deficiência na adequação das estações?

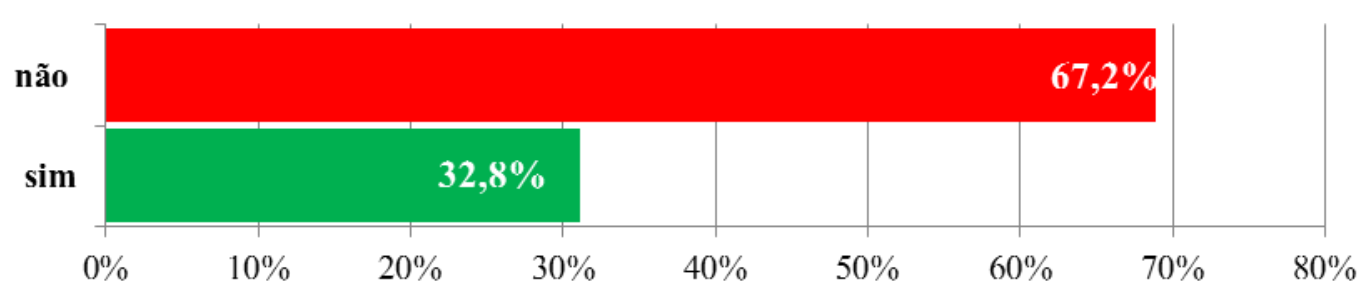

$\mathbf{n}=\mathbf{2 3 5}$

Fonte: Elaborado pela pesquisadora a partir das respostas à Questão 12.

Uma segunda estratificação foi processada, considerando a participação dos respondentes em treinamentos de orientação e mobilidade. O resultado demonstra que 67,6\% dos respondentes que participaram de treinamentos de O\&M consideram que o Metrô não levou em conta as necessidades das pessoas com deficiência visual. Por outro lado, do total de respondentes que não participaram de treinamentos de O\&M, esse índice cai para 64\% (Gráfico 12).

Gráfico 12 - Atendimento às necessidades da pessoa com deficiência visual - segundo treinamento de $0 \& M$. Questão 12 - Em sua opinião, o Metrô considerou todas as necessidades das pessoas com deficiência na adequação das estações?

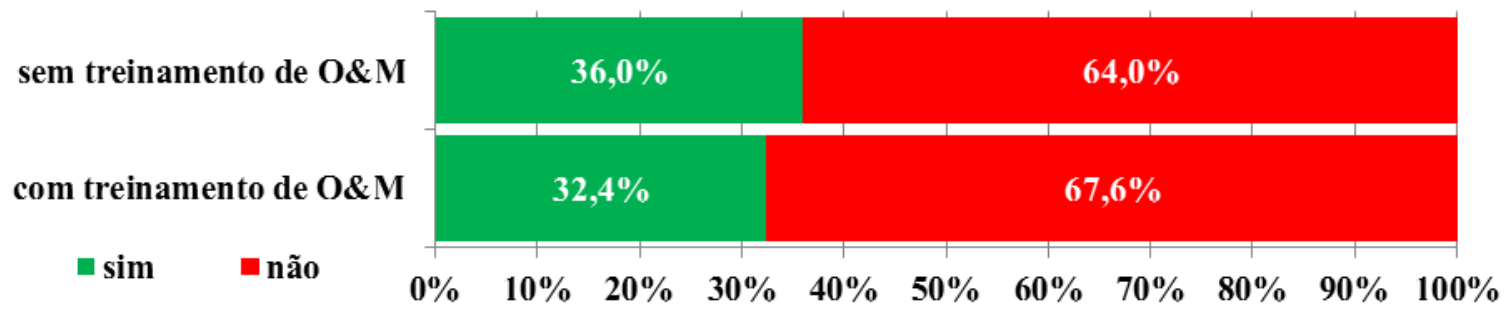

$\mathbf{n}=\mathbf{2 3 5}$

Fonte: Elaborado pela pesquisadora a partir das respostas à Questão 12.

Em relação às ações que devem ser priorizadas, $60 \%$ do total de respondentes entendem que o Metrô deve priorizar a condução das pessoas com deficiência visual por funcionários treinados enquanto que $40 \%$ consideram que o Metrô deve priorizar a adequação das estações. Do total de respondentes que preferem que seja priorizada a condução por empregados treinados, 76,1\% são cegos, e 23,9\% têm baixa visão. Entre os respondentes que preferem que seja priorizada a adequação das estações, 68,5\% são cegos, e 31,5\% têm baixa visão (Gráfico 13). 
Gráfico 13 - Priorização das ações do Metrô.

Questão 15 - Qual dessas ações o Metrô deveria priorizar: adequação das estações ou condução por empregados treinados?

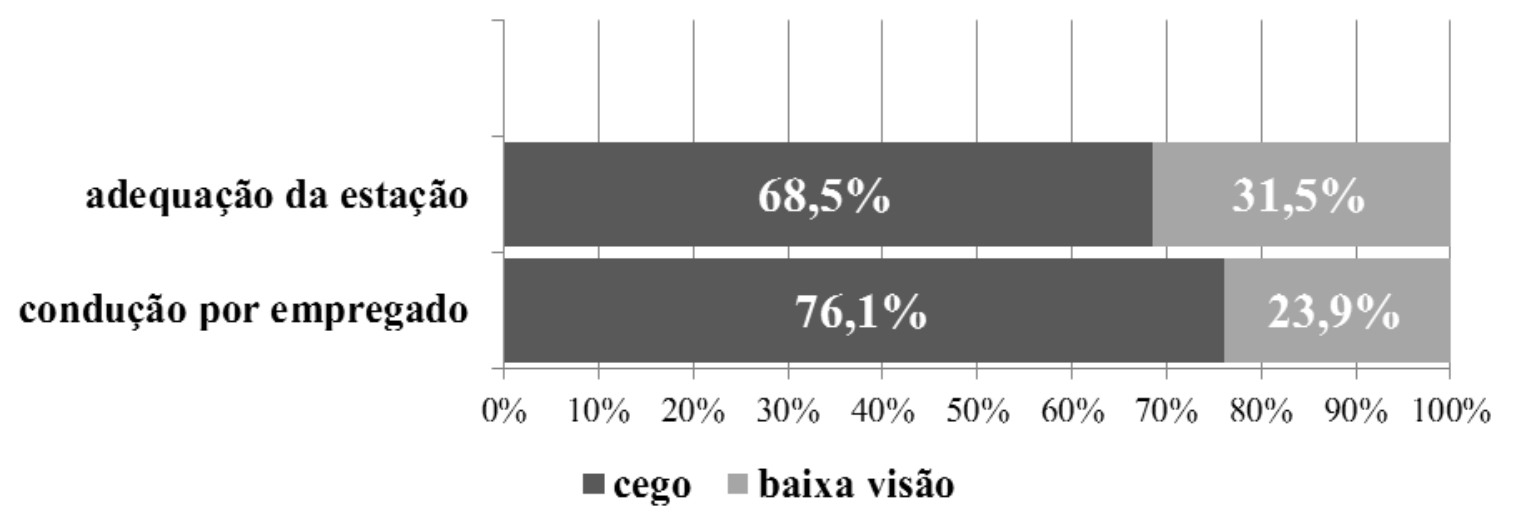

$\mathbf{n}=\mathbf{2 3 0}$

Fonte: Elaborado pela pesquisadora a partir das respostas à Questão 15.

Em relação aos aspectos que interferem negativamente no deslocamento das pessoas com deficiência visual nas estações e trens do metrô, os respondentes, tanto cegos como com baixa visão, consideram que os mais impactantes são a quantidade de empregados, a falta de adequação das instalações e a lotação das estações e trens. A partir da opinião dos usuários, foi possível determinar o grau de interferência destes sete aspectos nos deslocamentos das pessoas com deficiência visual no sistema metroferroviário (Gráfico 14).

Gráfico 14 - Aspectos que interferem no deslocamento das pessoas com deficiência visual.

Questão 16 - Gostaria que o senhor ordenasse do mais importante ao menos importante os aspectos que interferem no deslocamento do deficiente visual nas estações e trens do metrô.

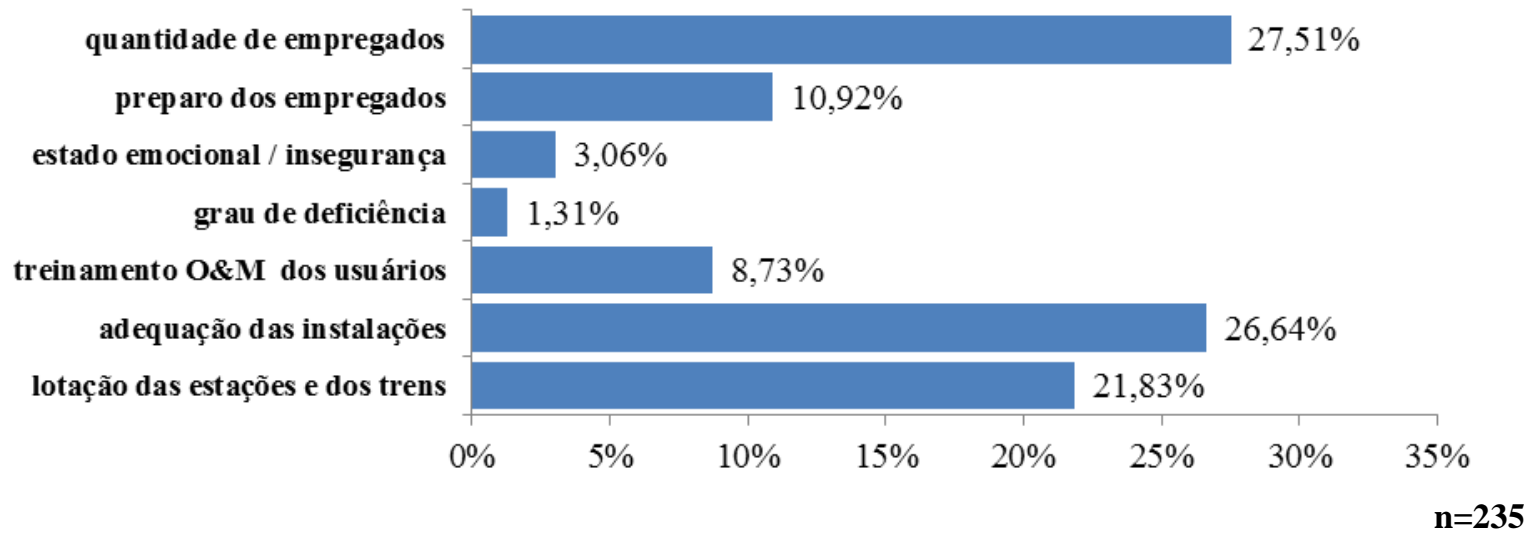

Fonte: Elaborado pela pesquisadora a partir das respostas à Questão 16.

Contudo, a quantidade de empregados é mais impactante para os respondentes cegos $(31,4 \%)$ do que para os respondentes com baixa visão $(16,7 \%)$ enquanto que a lotação das estações e trens afeta mais diretamente as pessoas com baixa visão $(30,0 \%)$ do que as pessoas cegas 
(18,9\%). Na opinião dos respondentes, o grau de deficiência e o estado emocional dos usuários são os aspectos que menos impactam o deslocamento; esses indivíduos atribuem pouca importância a aspectos como o treinamento de orientação e mobilidade dos usuários com deficiência visual e o treinamento dos empregados (Gráfico 15).

Gráfico 15 - Aspectos que interferem no deslocamento das pessoas cegas e com baixa visão.

Questão 16 - Gostaria que o senhor ordenasse do mais importante ao menos importante os aspectos que interferem no deslocamento do deficiente visual nas estações e trens do metrô.

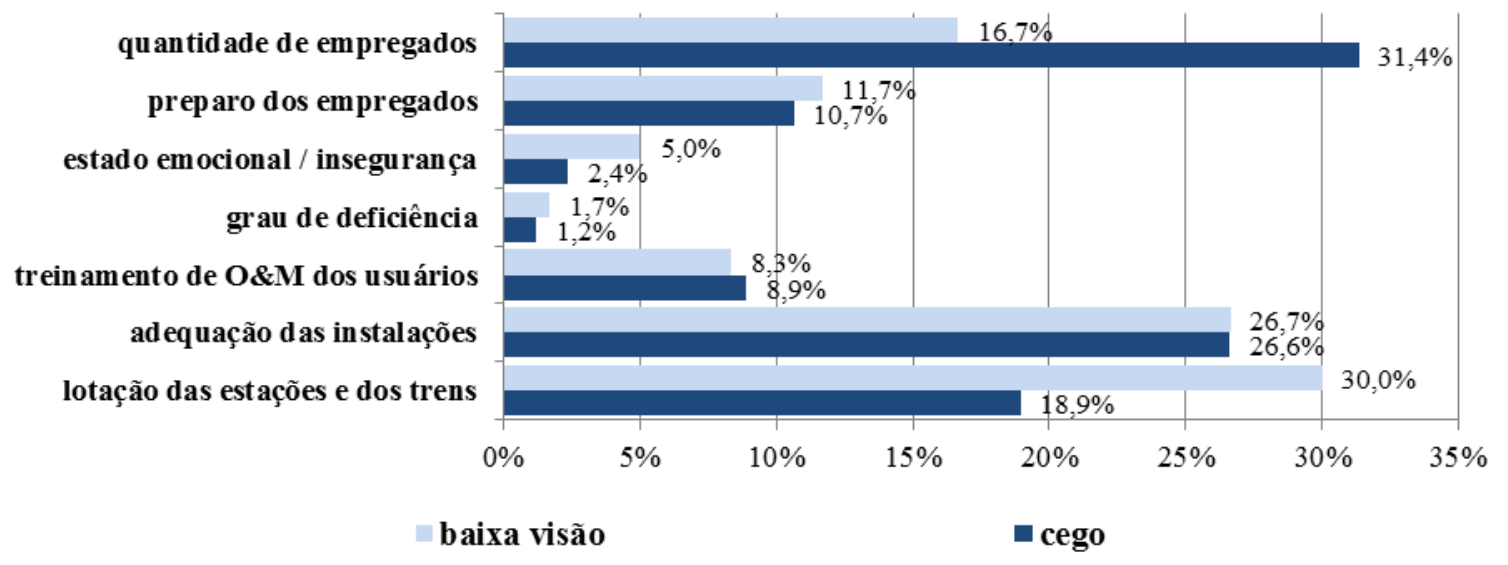

Fonte: Elaborado pela pesquisadora a partir das respostas à Questão 16.

A análise do grau de interferência destes sete aspectos nos deslocamentos das pessoas com deficiência visual no sistema metroferroviário dados permite concluir que:

- os aspectos relacionado às características dos usuários - grau de deficiência, treinamento de O\&M, estado emocional/insegurança - totalizam 13,10\%;

- os aspectos relacionados aos funcionários - quantidade e preparo - totalizam 38,43\%;

- os aspectos relacionados às instalações e aos demais usuários totalizam 48,47\%.

A responsabilidade pelos aspectos relacionados aos funcionários, ao comportamento dos demais usuários e às instalações são atribuídas à empresa prestadora do serviço, totalizando $86,90 \%$ dos aspectos que interferem no deslocamento. Quanto aos aspectos relacionados ao preparo dos usuários com deficiência visual (treinamento de $O \& M$ ) entende-se que estes sejam de responsabilidade compartilhada entre a empresa, as instituições de reabilitação e o usuário com deficiência visual e totalizam $8,73 \%$. Os aspectos relacionados ao grau de deficiência e ao estado emocional do usuário totalizam 4,37\% e não podem ser controlados pela empresa. 


\subsubsection{Processamento dos dados - perguntas abertas}

O processamento dos dados das perguntas abertas consistiu na transcrição, análise, classificação e codificação das respostas a partir da categorização dos fenômenos identificados. As questões abertas apresentadas aos respondentes foram as seguintes:

- Questão 12 - Na sua opinião, o Metrô considerou todas as necessidades das pessoas com deficiência visual na adequação das estações? Se não, o que foi desconsiderado?

- Questão 13 - Pensando nas estações do Metrô em geral, quais as maiores dificuldades enfrentadas no deslocamento? (até 3 menções)

- Questão 14 - Pensando na viagem de trem, quais as maiores dificuldades enfrentadas pelas pessoas com deficiência visual? (até 3 menções)

- Questão 17 - O sr(a) tem alguma sugestão para facilitar o uso das estações ou a viagem de trem pelas pessoas com deficiência visual?

Todas as respostas foram agrupadas uma vez que a análise e a codificação do conteúdo consideraram a identificação da etapa da jornada relacionada a cada uma das expressõeschave para que as informações pudessem ser classificadas segundo o tema (configuração, informação, serviço) e o local (estação, interface trem-estação, trem).

Para fazer com que o conjunto de relatos originados nas questões abertas pudessem representar opiniões coletivas a respeito de um determinado tema - no caso, das etapas da jornada do usuário -, lançou-se mão do Discurso do Sujeito Coletivo, utilizando duas figuras metodológicas sugeridas por Lefevre e Lefevre (2012): a ideia central e as expressões-chave, que são explicitadas a seguir:

A ideia central é um nome ou expressão linguística que revela e descreve da maneira mais sintética e precisa possível o sentido ou os sentidos das expressões-chave de cada um dos discursos analisados e de cada conjunto homogêneo de expressõeschaves (que vai dar nascimento, posteriormente, ao Discurso do Sujeito Coletivo). Neste último caso, a ideia central recebe também o nome de categoria. (LEFEVRE; LEFEVRE, 2012, p. 76)

As expressões-chave são pedaços, ou trechos, ou segmentos, contínuos ou descontínuos, do discurso que devem ser selecionados pelo pesquisador e que revelam a essência do conteúdo do depoimento do depoimento ou do discurso, ou da teoria subjacente. (LEFEVRE; LEFEVRE, 2012 p.73) 
As ideias centrais foram agrupadas segundo sua relação com a configuração, com o sistema de informação, orientação e comunicação ou com a gestão da prestação dos serviços, sendo posteriormente reagrupadas segundo sua localização no sistema metroferroviário - na estação, na interface trem-estação ou no trem. Como já explicitado anteriormente, trata-se de uma adaptação do modelo proposto por Juncà (2011). Foram identificadas 38 ideias centrais, sendo 10 relacionadas à configuração, 10 ao sistema de informação, orientação e comunicação e 18 à gestão e prestação do serviço (Quadro 11). Do total de ideias centrais, 22 estão localizadas na estação; 6 estão localizadas na interface trem-estação e 10 estão localizadas no trem. Todas as ideias centrais foram representadas num diagrama, utilizando o recurso do mapa mental, com auxílio do software iMindMap $8^{22}$, e apresentadas no Apêndice B.

Quadro 11 - Classificação das ideias centrais identificadas nas questões abertas.

\begin{tabular}{l|r|r|r|r}
\hline & \multicolumn{1}{c|}{ Configuração } & \multicolumn{1}{c|}{ Informação } & \multicolumn{1}{c}{ Serviço } & $\begin{array}{c}\text { Total } \\
\text { Ideias centrais }\end{array}$ \\
\hline Estação & $\mathrm{EC}=4$ & $\mathrm{EI}=7$ & $\mathrm{ES}=11$ & 22 \\
\hline Interface trem-estação & $\mathrm{IC}=2$ & $\mathrm{II}=1$ & $\mathrm{IS}=3$ & 10 \\
\hline Trem & $\mathrm{TC}=4$ & $\mathrm{TI}=2$ & $\mathrm{TS}=4$ & 38 \\
\hline $\begin{array}{l}\text { Total } \\
\text { Ideias centrais }\end{array}$ & 10 & 10 & 18 & \\
\hline
\end{tabular}

Fonte: Elaborado pela pesquisadora a partir de JUNCÁ (2011) e da classificação dos relatos dos respondentes.

As 10 ideias centrais classificadas em configuração são apresentadas a seguir (Quadro 12):

Quadro 12 - Classificação das ideias centrais relacionadas à configuração.

\begin{tabular}{|l|l|}
\hline & \multicolumn{1}{c|}{ Configuração } \\
\hline \multirow{2}{*}{ Estação } & - EC1 - independência nos deslocamentos \\
& - EC2 - necessidade de elementos de circulação vertical \\
& - EC3 - condições das instalações existentes \\
& - EC4 - impacto da situação existente na mobilidade \\
\hline \multirow{2}{*}{ Interface trem-estação } & - IC1 - vão e desnível entre o trem e a plataforma \\
& - IC2 - existência de proteção nas plataformas \\
\hline \multirow{3}{*}{ Trem } & - TC1 - barras de apoio \\
& - TC2 - assentos preferenciais \\
& - TC3 - deslocamento do trem \\
& - TC4 - conforto térmico \\
\hline
\end{tabular}

Fonte: Elaborado pela pesquisadora a partir da classificação dos relatos gerados nas respostas às Questões 12, 13,14 e 17.

\footnotetext{
${ }^{22}$ Disponível em: http://thinkbuzan.com/imindmap-8/. Acesso em: 28 dez. 2014.
} 
As 10 ideias centrais classificadas em sistema de informação, comunicação e orientação são apresentadas a seguir (Quadro 13):

Quadro 13 - Classificação das ideias centrais relacionadas ao sistema de informação, comunicação e orientação.

\begin{tabular}{|l|l|}
\hline & \multicolumn{1}{c|}{ Sistema de informação, comunicação e orientação } \\
\hline & - EI1 - piso tátil - contraste tátil e visual \\
& - EI2 - piso tátil - participação no projeto \\
& - EI3 - piso tátil - percurso \\
& - EI4 - informações nos equipamentos \\
Estação & - EI5 - informações para pessoas com deficiência visual antes e depois da viagem \\
& - EI6 - informações para pessoas com deficiência visual durante a viagem ou na \\
& estação \\
\hline \multirow{2}{*}{ Interface trem-estação } & - EI7 - informações para os demais usuários \\
& interface trem-estação \\
\hline \multirow{2}{*}{ Trem } & - TI1 - informação para monitoração \\
& - TI2 - informações para pessoas com deficiência visual durante a viagem no \\
& trem
\end{tabular}

Fonte: Elaborado pela pesquisadora a partir da classificação dos relatos gerados nas respostas às Questões 12, 13,14 e 17.

As 18 ideias centrais classificadas em gestão da prestação de serviço são apresentadas a seguir (Quadro 14):

Quadro 14 - Classificação das ideias centrais relacionadas à gestão e prestação do serviço.

\begin{tabular}{|c|c|}
\hline & Gestão da prestação de serviço \\
\hline Estação & $\begin{array}{l}\text { - ES1 - treinamento dos empregados / estação } \\
\text { - ES2 - atendimento pelos empregados / estação } \\
\text { - ES3 - treinamento dos usuários } \\
\text { - ES4 - comportamento dos demais usuários / estação } \\
\text { - ES5 - obstáculos próximos ao piso tátil } \\
\text { - ES6 - procedimento operacional / estação } \\
\text { - ES7 - lotação nas estações } \\
\text { - ES8 - equipamento de controle de acesso / bloqueios } \\
\text { - ES9 - equipamentos / elevadores } \\
\text { - ES10 - equipamentos / escadas rolantes } \\
\text { - ES11 - equipamentos / intercomunicadores }\end{array}$ \\
\hline Interface trem-estação & $\begin{array}{l}\text { - IS1 - procedimento operacional / interface trem-estação } \\
\text { - IS2 - treinamento dos empregados / interface trem-estação } \\
\text { - IS3 - comportamento dos demais usuários / interface trem-estação }\end{array}$ \\
\hline trem & $\begin{array}{l}\text { - TS1 - treinamento dos empregados / trem } \\
\text { - TS2 - procedimento operacional / trem } \\
\text { - TS3 - comportamento dos demais usuários / trem } \\
\text { - TS4 - lotação dos trens }\end{array}$ \\
\hline
\end{tabular}

Fonte: Elaborado pela pesquisadora a partir da classificação dos relatos gerados nas respostas às Questões 12, 13,14 e 17. 
As ideias centrais identificadas nos relatos dos respondentes serviram de base para a classificação dos relatos coletados nas entrevistas individuais e nas entrevistas em grupo com os especialistas e as pessoas-chave. As mesmas ideias centrais também subsidiaram a análise das informações coletadas nos instrumentos checklist, walkthrough, ficha ambiente, observação de fluxo e observação de comportamento.

Os resultados obtidos a partir dos questionários aplicados serão apresentados no capítulo 7 Diagnóstico.

\subsection{Entrevista individual}

A entrevista é uma das técnicas mais tradicionais para coleta de dados na área das ciências sociais e pressupõe a interação entre o entrevistador e o entrevistado. "A entrevista é a técnica mais adequada para a revelação de informação sobre assuntos complexos [...], para obter informações acerca do que a pessoa sabe, crê ou espera, sente ou deseja, pretende fazer, faz ou fez" (SELLITZ et al., 1974, p. 272-273). É uma conversa entre pessoas para explorar valores, motivação, preferências e atitudes (GRAY, 2012) e obter informações sistemáticas em diferentes áreas do conhecimento com o propósito de compreender a interação pessoaambiente. "Por meio da entrevista obtêm-se informações sobre ambientes físicos, naturais ou construídos, sobre interiores ou exteriores, sobre as ações distintas das pessoas sobre os ambientes e da influência destes ambientes sobre as pessoas" (GÜNTHER I., 2008, p. 70). O sucesso da entrevista não se resume à qualificação e à competência dos pesquisadores, mas relaciona-se à interação entre o pesquisador e o entrevistado. "Uma entrevista continua sendo a conversa gerada diretamente entre duas pessoas em torno das respostas às questões formuladas" (RHEINGANTZ ET AL, 2009, p.71), sendo que a mais comum consiste no envolvimento entre duas pessoas, face a face (GÜNTHER, I., 2008), apesar das novas tecnologias de interação a distância. As entrevistas podem ser de três tipos:

- não estruturadas - listam tópicos a investigar, sem classificá-los;

- semiestruturadas - baseiam-se em uma relação de temas e questões a serem seguidas conforme ordem e referencial, formuladas a partir de observações ou entrevistas informais;

- estruturadas - caracterizam-se por conter questões fechadas, que podem ser exemplificadas por formulários padronizados, inventários ou questionários. 
Foram realizadas 27 entrevistas individuais com especialistas e pessoas-chave no período compreendido entre junho e julho de 2011, abrangendo questões preparadas a partir do perfil, da função, do conhecimento e da experiência dos entrevistados e, consequentemente, da expectativa de resposta sobre os temas abordados. A aplicação do instrumento utilizou-se de diferentes recursos na interação entre a pesquisadora e os entrevistados: entrevistas a distância (on line) e presenciais, com diferentes formas de registro - recebimento de respostas escritas, anotação e/ou gravação para posterior transcrição.

Do total de entrevistas individuais realizadas, 15 foram realizadas de forma presencial, com as pessoas-chave - aquelas que têm contato direto ou cujas ações impactam diretamente a jornada do usuário com deficiência visual durante seus deslocamentos no sistema metroferroviário -, quais sejam os funcionários das estações e os funcionários do centro de controle operacional. A abordagem inicial dos funcionários foi realizada no local de trabalho para esclarecimento dos propósitos da pesquisa. Ato contínuo, foi realizado o agendamento de horário mediante concordância do entrevistado. Durante a entrevista, foram realizadas anotações, gravações e, eventualmente, registros fotográficos, devidamente autorizados pelos funcionários. As anotações e gravações foram transcritas em arquivos de texto (Microsoft Office Word). Foram realizadas entrevistas individuais presenciais com funcionários das estações e com funcionários do CCO.

Doze entrevistas individuais foram realizadas por meio de envio de roteiro de perguntas a pessoas-chave e especialistas. Após a identificação e seleção dos profissionais, foi realizada uma abordagem inicial por telefone ou presencial com cada um deles para esclarecimento dos propósitos da pesquisa. Em seguida, foi enviado o roteiro de perguntas por e-mail com uma sugestão de prazo para devolução. Os roteiros foram recebidos e transcritos em arquivos de texto (Microsoft Office Word). Foram realizadas entrevistas individuais a distância com profissionais que elaboram normas técnicas de acessibilidade, professores de orientação e mobilidade e instrutores e elaboradores de treinamento de funcionários e estagiários. Os protocolos de abordagem, coleta, registro e análise de dados estão apresentados a seguir (Quadro 15): 
Quadro 15 - Entrevistas individuais - protocolo.

\begin{tabular}{|c|c|c|c|c|}
\hline Instrumento & Público-alvo & Abordagem & Registro & Análise \\
\hline \multirow[t]{2}{*}{$\begin{array}{l}\text { Entrevista } \\
\text { individual }\end{array}$} & $\begin{array}{l}\text { - } 15 \text { funcionários } \\
\text { das estações } \\
-3 \text { funcionários do } \\
\text { CCO }\end{array}$ & $\begin{array}{l}\text { - agendamento de } \\
\text { horário } \\
\text { - abordagem } \\
\text { presencial dos } \\
\text { funcionários no } \\
\text { local de trabalho }\end{array}$ & $\begin{array}{l}\text { - anotação e/ou } \\
\text { gravação } \\
\text { - transcrição }\end{array}$ & \multirow{2}{*}{$\begin{array}{l}\text { - transcrição das gravações, anotações e } \\
\text { mensagens recebidas por } e \text {-mail } \\
\text { - organização dos textos } \\
\text { - análise do conteúdo } \\
\text { - identificação de padrões e temas } \\
\text { - codificação das narrativas e relatos } \\
\text { coletados segundo categorias } \\
\text { - modificação das categorias quando } \\
\text { necessário } \\
\text { - identificação de padrões e } \\
\text { inconsistências } \\
\text { - análise dos relatos segundo as ideias } \\
\text { centrais } \\
\text { - interpretações e inferências } \\
\text { - comparação com dados obtidos nos } \\
\text { demais instrumentos }\end{array}$} \\
\hline & $\begin{array}{l}\text { - } 5 \text { profissionais } \\
\text { que elaboram } \\
\text { normas técnicas } \\
\text { de acessibilidade } \\
\text { - } 4 \text { instrutores / } \\
\text { elaboradores de } \\
\text { treinamento de } \\
\text { funcionários } \\
-3 \text { professores de } \\
\text { orientação e } \\
\text { mobilidade }\end{array}$ & $\begin{array}{l}\text { - abordagem } \\
\text { inicial por } \\
\text { telefone } \\
\text { - envio de } \\
\text { perguntas por } e \text { - } \\
\text { mail }\end{array}$ & $\begin{array}{l}\text { - recebimento de } \\
\text { respostas } \\
\text { escritas por } e^{-} \\
\text {mail } \\
\text { - transcrição das } \\
\text { mensagens }\end{array}$ & \\
\hline
\end{tabular}

Fonte: Elaborado pela pesquisadora. (2014).

\subsubsection{Funcionários das estações}

Foram realizadas entrevistas presenciais com funcionários das estações utilizando roteiro estruturado previamente elaborado, com gravação e posterior transcrição dos relatos dos entrevistados. Foram entrevistados 12 funcionários no período compreendido entre 01/06/2011 e 07/03/2013. O registro das informações foi realizado por meio de gravação, com posterior transcrição dos relatos dos entrevistados. O roteiro das entrevistas realizadas consta do Apêndice C. Em relação aos temas abordados, destacam-se os seguintes:

- os aspectos positivos e negativos relacionados ao deslocamento das pessoas com deficiência visual, incluindo a avaliação e o impacto dos fluxos dos demais usuários;

- o preparo dos empregados para auxiliar as pessoas com deficiência visual e para atuar em situações de anormalidade;

- as contribuições da informação integrada (tátil/visual/sonora);

- os aspectos a serem aperfeiçoados.

A entrevista aplicada aos funcionários das estações possibilitou a identificação dos fatores que impactam a gestão dos processos relacionados à gestão do atendimento aos usuários com deficiência visual, à orientação dos estagiários e às estratégias de fluxo em situações de anormalidade nas estações. Entre os aspectos positivos, foram ressaltados tópicos relacionados à configuração das estações. Em relação a esta, foi destacada a facilidade de conexão nas estações com mezaninos compartilhados e em decorrência dos elementos de circulação vertical - como elevadores em todos os acessos nas novas estações e também 
escadas fixas ou rolantes, rampas e elevadores, posicionados estrategicamente próximos uns aos outros, o que facilita a identificação do percurso pelo usuário. Outra facilidade mencionada foi a existência de duas escadas rolantes em cada acesso - para subir e para descer - e a possibilidade de associar a estratégia de embarque preferencial com o posicionamento das escadas rolantes. Quanto ao sistema de informação, foi destacada a existência de piso tátil nas novas estações, proporcionando autonomia à pessoa com deficiência visual.

Quanto aos aspectos negativos, foram destacados os seguintes: a amplitude, a complexidade e a elevada demanda das estações, associadas à falta de capacitação dos usuários com deficiência visual, o que faz com que haja necessidade de auxílio para embarque e desembarque apesar da existência de piso tátil. Tal condição é agravada pela grande distância a ser percorrida entre os bloqueios e os acessos das estações ou terminais integrados, pelo fluxo e contrafluxo de pessoas no mesmo piso tátil direcional e pela proximidade entre o piso tátil direcional e as colunas existentes nas estações. Outro aspecto negativo destacado está relacionado ao posicionamento dos elevadores longe do local de embarque preferencial, impondo a circulação na plataforma. Outro motivo de desaprovação é a falta de escadas rolantes entre mezanino e plataformas em todas as estações. Quanto à ambiência, foi enfatizado o contraste do aspecto visual e dos recursos disponíveis nas estações novas e antigas e a inexistência de faixa de travessia e semáforos junto aos acessos. Sobre o preparo da equipe para agir em situações de anormalidade, é unânime o entendimento de que o treinamento e as orientações contidas nos manuais e procedimentos são suficientes para dar segurança para que cada empregado possa agir corretamente. No caso de eventual anormalidade no trem, foi destacada a necessidade da integração das equipes da estação e do CCO e do auxílio mais efetivo às pessoas com deficiência, mantendo-as em área resguardada até a normalização da situação. Nessa condição, a existência do carro preferencial facilita a atuação das equipes de tráfego e de estação. Foi destacado que é preciso estar sempre de prontidão para garantir a segurança das pessoas com deficiência visual assim como é importante que o serviço de monitoração de embarque e desembarque esteja disponível durante todo o período de prestação de serviço, ainda que a distância. Outro ponto ressaltado foi a necessidade de atenção especial nas conexões entre o sistema de transporte integrado (ônibus urbano, trem metropolitano). Sobre o fluxo, há consenso de que a elevada demanda afeta todas as estações e não somente as estações de conexão, o que impõe um ritmo intenso 
para atendimento às necessidades dos usuários, notadamente às daqueles que fazem uso do sistema em horários de pico para ir e voltar do trabalho e que, portanto, têm pressa como os demais usuários. Foram apontados conflitos nas plataformas, nas escadas, no mezanino: as pessoas param sobre o piso tátil e não respeitam o embarque preferencial. Sobre as contribuições do sistema de informação, foram destacados o prejuízo da compreensão da informação sonora em função do ruído de chegada e saída dos trens nas plataformas; a dificuldade de legibilidade da comunicação visual em função do dimensionamento e contraste dos textos e a dificuldade de uso do Braille por parte das pessoas com deficiência visual. Sobre a sinalização tátil no piso, foi destacada a proximidade do piso tátil com obstáculos corrimãos, lixeiras, extintores, pilares - e a baixa utilização do piso tátil pelas pessoas cegas, havendo a necessidade de maior envolvimento dos empregados para capacitar as pessoas com deficiência visual a utilizar o piso tátil, notadamente nas estações mais novas, com portas nas plataformas. Um aspecto relatado com frequência diz respeito à necessidade de educação dos usuários por meio da veiculação de campanhas ou mensagens sonoras para orientação em relação ao atendimento preferencial, ao embarque preferencial e ao assento preferencial.

Sobre os aspectos a serem aperfeiçoados, destaca-se a necessidade de maior alinhamento entre os supervisores nos vários turnos de trabalho para que haja coerência nas orientações e cobranças em relação às estratégias de atendimento pelos estagiários - posicionamento nos pontos críticos das estações, agilidade no atendimento ou procedimentos nas diferentes situações. Isso é importante devido ao fato de que os estagiários convivem com supervisões de diferentes escalas, ao contrário dos funcionários, que seguem juntos em uma mesma equipe com um mesmo supervisor. Outra questão para melhoria está relacionada à adequação da quantidade de funcionários para agilizar o atendimento às pessoas com deficiência visual, principalmente nas estações com terminal de ônibus urbano, em função do tempo dispendido para auxílio no percurso entre a estação e o terminal. Ainda sobre os empregados, foi destacada a importância da ação efetiva dos empregados abordando os usuários que não respeitam o local de embarque preferencial, que param ou colocam bagagens sobre o piso tátil, dificultando o deslocamento da pessoa com deficiência visual, e que ocupam indevidamente os assentos preferenciais nos trens. Os relatos dos funcionários das estações entrevistados foram codificados segundo categorias, possibilitando a análise do conteúdo e a quantificação das opiniões. 


\subsubsection{Profissionais que atuam no CCO}

Foram realizadas entrevistas presenciais com três profissionais que atuam no console de passageiros do CCO em 01/07/2011. Foi utilizado o roteiro estruturado previamente elaborado. O registro das informações foi realizado por meio de gravação, com posterior transcrição dos relatos dos entrevistados. O roteiro das entrevistas realizadas consta do Apêndice D. Em relação aos temas abordados, destacam-se os principais:

- a descrição do serviço de monitoração das pessoas com deficiência visual;

- o preparo para atuar em situações de anormalidade;

- os aspectos a serem aperfeiçoados.

A entrevista com os funcionários que atuam no CCO possibilitou a identificação dos aspectos relacionados ao registro dos deslocamentos (horário, perfil do usuário, estações e trens de embarque e estações de destino), bem como as ações relacionadas ao atendimento.

O CCO tem como principal objetivo controlar a operação comercial tanto em situações de normalidade como de anormalidade, momento em que são adotadas estratégias para retomar o desempenho das linhas conforme programado. Dessa forma, os dados coletados possibilitaram a compreensão da interdependência das atividades do serviço de monitoração das pessoas com deficiência visual que competem às equipes das estações e às equipes do console de passageiros. O processo de monitoração tem início a partir da solicitação de auxílio pelo usuário com deficiência visual nas estações de embarque e compreende ações coordenadas envolvendo os seguintes aspectos:

- funcionário ou estagiário da estação de origem - realiza a condução do usuário até o local de embarque; comunica-se com o centro de controle por telefone antes do embarque, informando a identificação do trem onde será realizado o embarque, a estação de desembarque e o perfil do usuário (deficiência visual ou física) de forma a garantir auxílio adequado na estação de destino. Em seguida, auxilia o embarque dos usuários nos trens;

- operador do console de passageiros das diferentes linhas - registra os dados do usuário e da estação de destino no sistema de controle, que emite um alarme para o operador três estações antes do trem se aproximar da estação de destino, momento em que o operador entra em contato com a estação informando sobre o desembarque do usuário, seu perfil e 
a identificação do trem. Esses funcionários têm papel fundamental na atuação em situações de anormalidade;

- funcionário da SSO da estação de destino - recebe, por telefone, a informação sobre a chegada do usuário e informa a equipe que irá auxiliar o desembarque e garantir a continuidade do auxílio na estação de destino desde a plataforma até a saída ou embarque no trem em outra linha.

Em relação ao preparo para atuação em situações de anormalidade, os relatos permitiram diferenciar as estratégias adotadas em trens onde há a presença de usuário com deficiência, seja num incidente não programado ou numa evacuação programada. Em ambas as situações, há atuação conjunta das equipes do $\mathrm{CCO}$ e da estação. Entre os aspectos a serem aperfeiçoados, foram destacadas a necessidade de ampliação de ramais nos consoles de passageiros para atendimento às chamadas originadas nas estações e a possibilidade de as equipes das estações inserirem as informações no sistema, que deverá emitir os alarmes na estação de destino automaticamente. Nesse caso, caberia ao CCO apenas decidir as estratégias a serem adotadas em trens onde há a presença de usuários com deficiência. Ressalta-se que, independentemente da manutenção ou substituição dos sistemas existentes ou das estratégias, é possível compreender que a complexidade do processo impossibilita a atuação do usuário e a comunicação direta com a estação de destino/desembarque.

\subsubsection{Profissionais que elaboram normas técnicas de acessibilidade}

Foram aplicadas entrevistas online com profissionais responsáveis pela coordenação dos textos das normas técnicas por meio do envio de questões por e-mail e recebimento de respostas escritas. Foram enviados seis questionários em 08/06/2011, cinco dos quais foram recebidos preenchidos entre os dias 09/06/2011 e 04/07/2011. O roteiro das entrevistas realizadas consta do Apêndice E. Em relação aos temas abordados, destacam-se os listados a seguir:

- importância, características e especificidades das normas técnicas;

- dificuldades para a elaboração dos textos;

- facilidades relacionadas à configuração e sinalização para os passageiros;

- recomendações específicas para pessoas com deficiência visual; 
- segurança e autonomia das pessoas com deficiência visual em ambientes com grandes fluxos de pessoas;

- contribuições da informação integrada (tátil/visual/sonora).

A coleta de dados possibilitou a identificação de recomendações relativas à acessibilidade dos serviços de transporte, que impactam de forma positiva o cotidiano das pessoas com deficiência visual. Isso fica mais visível em aspectos relacionados à mobilidade e à gestão do serviço durante a utilização do sistema metroviário a partir da experiência desses profissionais na elaboração ou coordenação dos trabalhos de redação/aprovação de textos e desenhos técnicos que são a base das normas técnicas.

A entrevista aplicada aos cinco profissionais que coordenam a elaboração de normas técnicas de acessibilidade possibilitou a compreensão das dificuldades enfrentadas para a realização da atividade. Essas normas são elaboradas por um fórum multidisciplinar, do qual participam pessoas com deficiência ou com mobilidade reduzida, profissionais das áreas técnica, biomédica, bem como fornecedores e prestadores de serviços. As Comissões de Estudo (CE) têm como desafio obter o consenso entre representantes da indústria afim e correlata (produtores), do público-alvo (consumidores), dos órgãos de defesa do consumidor, do governo, de entidades de classe, universidades, escolas técnicas e pessoas neutras. Para as normas de acessibilidade, a principal dificuldade hoje enfrentada é constituir e manter ativa uma Comissão de Estudo, com a participação voluntária dos diversos segmentos da sociedade, para alcançar um objetivo comum. A presença de todos é essencial na promoção de debates para se atingirem objetivos eficazes, porém nem sempre todos os envolvidos têm disponibilidade de participar, ou ainda muitos não tomam conhecimento da realização das reuniões. Em um país de dimensões continentais, torna-se mais difícil que essas pessoas consigam viajar para participar voluntariamente de todas as reuniões; assim, o prazo para finalização dos trabalhos se estende, aumentando a expectativa daqueles que tanto necessitam de soluções.

As normas técnicas constituem um registro documentado que possibilita a padronização de conceitos e requisitos para determinado bem ou serviço e que, simultaneamente, enseja revisões ou atualizações periódicas, em conformidade com o desenvolvimento tecnológico e as imposições legais. Ao estabelecer a padronização de conceitos, requisitos, parâmetros e diretrizes para que seja alcançada a acessibilidade, as normas técnicas manifestam sua 
importância: atender e acolher a maior gama possível de capacidades da população. A partir do reconhecimento federal, as normas passam a ser consideradas compulsórias.

A elaboração de normas técnicas de acessibilidade para os sistemas de transporte busca trazer à tona as necessidades dos usuários com deficiência. $\mathrm{Na}$ opinião dos especialistas responsáveis pela elaboração de normas técnicas, as normas de acessibilidade podem contribuir para a segurança e independência de pessoas com deficiência visual em sistemas metroferroviários porque apresentam soluções para o universo de pessoas que utilizam tais sistemas. Essas soluções estão relacionadas à configuração, à sinalização e à iluminação dos ambientes; contudo, é a configuração padronizada ou a padronização de soluções que permite maior agilidade nos deslocamentos. Pessoas com deficiência visual necessitam de referências para orientar seus deslocamentos com independência e segurança.

As referências necessárias para auxiliar a orientação de pessoas com deficiência visual podem ser criadas a partir de estímulos táteis e sonoros, ou ainda visuais, para aqueles que possuem baixa visão, bastando que seja estudada sua aplicação e eficácia. É consenso entre profissionais e estudiosos, além dos próprios usuários, que a soma dessas referências é mais eficaz do que cada uma isoladamente. Portanto, é conveniente que haja redundância para se atingir a diversidade existente dentro do grupo de pessoas com deficiência visual: as informações tátil, visual e sonora são as referências para as pessoas poderem entender como funciona o ambiente, equipamento ou serviço, garantindo-lhes mais segurança e confiança ao utilizá-lo. Nesse sentido, as normas técnicas buscam apresentar os parâmetros mais adequados - de configuração e sinalização - dessas referências. A satisfação pode ser atingida com simples ações de melhoria no sistema de informação. Em relação à sinalização, deve ser clara, objetiva e completa, permitindo que os passageiros alcancem seus destinos no ambiente. Não é possível estabelecer todas as possibilidades de configuração e de sinalização nas normas vigentes devido à abrangência nacional e às diferenças inerentes aos sistemas de transporte metroferroviário, inviabilizando a generalização de soluções que atendam a todas as situações. Normas técnicas não criam tecnologias ainda que o grupo envolvido na sua elaboração busque conhecer tudo o que possa auxiliar as referências. Por esse motivo, normas técnicas por si só não conseguem resolver todos os problemas nesses ambientes, mas contribuem bastante. $\mathrm{O}$ sistema de informação integrada certamente contribui de forma generosa para garantir o uso do transporte, com segurança e autonomia, por todas as pessoas. Quando informa para atingir os recursos sensoriais disponíveis (nem sempre na mesma intensidade e proporção) em cada 
um de nós, acolhe a grande diversidade de capacidades da população, de diferentes faixas etárias, possibilitando que a informação alcance seu alvo e seu objetivo. A informação tátil é acessível a pessoas com déficit de visão, de audição, ou de visão e audição, que disponham de percepção tátil. Recursos táteis possibilitam a captação da mensagem por pessoas com baixavisão, cegas ou surdo-cegas, bem como por ouvintes e videntes. A informação visual apresenta uma variedade de recursos que, combinados, permitem a transmissão da mensagem a pessoas com diferentes características desde que disponham de percepção visual. Pictogramas com texto, por exemplo, transmitem a mensagem a pessoas com surdez, com baixa visão, com ou sem o domínio do português escrito, entre outras. A informação sonora, desde que decodificada, atende a pessoas que disponham de percepção auditiva, inclusive surdo-cegas (com audição residual), cegas e outras. O uso adequado dos recursos táteis, visuais e sonoros, fundamentado no princípio da redundância para transmissão da informação, ensejará mais segurança e autonomia aos usuários.

\subsubsection{Professores de orientação e mobilidade}

Foram aplicadas entrevistas online com profissionais que atuam junto às instituições de reabilitação por meio do envio de questões por e-mail e recebimento de respostas escritas contendo os relatos dos entrevistados. Esses instrumentos buscaram um padrão ou sua inexistência bem como objetivaram a compreensão dos aspectos ressaltados durante os treinamentos realizados nas estações e trens do Metrô de São Paulo. Foram enviados quatro questionários em 08/06/2011, dos quais três foram devolvidos preenchidos entre os dias 09/06/2011 e 17/06/2011. O roteiro das entrevistas realizadas consta do Apêndice F. Em relação aos temas abordados, destacam-se os enumerados a seguir:

- a importância e a forma de realização do treinamento de O\&M para as pessoas com deficiência visual;

- os aspectos enfatizados no treinamento nas estações;

- os aspectos relacionados à memorização dos percursos;

- as dificuldades enfrentadas pelos alunos e pelos instrutores nas estações.

A coleta de dados possibilitou a identificação de fatores que impactam de forma positiva ou negativa a utilização do sistema metroviário e a gestão do serviço durante o treinamento de orientação e mobilidade das pessoas com deficiência visual. 
Os dados coletados junto aos professores de O\&M indicam um consenso quanto à orientação para que o usuário solicite auxílio sempre que não se sentir suficientemente seguro para fazer seu deslocamento com autonomia seja para embarque, conexão entre linhas ou desembarque, já que existem funcionários capacitados para auxiliá-los. Dois dos três entrevistados orientam pessoas com deficiência visual a evitar deslocamentos sozinhas no interior da estação, especialmente no desembarque na plataforma. Eles devem aguardar a chegada de um funcionário e, caso não seja possível obter auxílio, pedir ajuda a uma pessoa que estiver próxima.

Sobre o treinamento de O\&M nas estações, foram destacados os seguinte objetivos:

- familiarização nas estações que são ou serão de uso cotidiano, definindo rotas específicas, mais seguras e adequadas. A título de exemplo, considerem-se os deslocamentos do terminal/ponto de ônibus até a entrada mais próxima da estação; da entrada até a linha de bloqueio no mezanino; da linha de bloqueio até a área de embarque;

- avaliação do desempenho do usuário quanto à manutenção da orientação por meio das pistas e pontos de referência ou das condições de segurança para deslocamento;

- avaliação da interferência e a relação com os demais usuários em horários distintos (pico da manhã, meio da manhã, pico do horário de almoço, meio da tarde, pico do fim da tarde, noite)

- avaliação da pertinência da mobilidade independente, ou da necessidade de auxílio dos funcionários e estagiários do Metrô;

- orientação para aguardar o trem antes do piso de alerta na plataforma, entrar na segunda porta do primeiro carro e sentar-se rapidamente no assento preferencial junto à porta de desembarque, facilitando levantar-se e deslocar-se até a porta preferencial para desembarque, por causa da lotação no interior do trem.

Sobre os pontos para melhoria nas estações, foram obtidas as seguintes informações: os professores de O\&M ressaltaram aspectos relacionados à sinalização tátil, como, por exemplo, a necessidade de maior contraste no relevo/textura entre o piso tátil e o piso de borracha das estações; de ampliação da área sinalizada com piso de alerta nas interseções de percursos; de colocação do piso tátil direcional nos corredores e nas rampas, independentemente da existência de linhas de balizamento naturais; da instalação de piso tátil nas plataformas laterais e não somente nas plataformas centrais. Foram destacados os aspectos relacionados à segurança, como a distância entre o piso direcional e a borda da plataforma nas 
estações com plataformas estreitas ou com elevada demanda (lotação nas plataformas). Sobre a configuração do percurso, foi enfatizada a necessidade de a sinalização tátil orientar percursos para as escadas fixas e rolantes, e não somente para o elevador, bem como a importância de implantar-se a sinalização tátil direcional diagonal, sempre que necessário, evitando o excesso de orientações ortogonais. Os professores de O\&M reforçaram a necessidade de haver opções para os usuários com deficiência visual identificarem quais recursos podem ser mais úteis - mapas táteis ou maquetes (contendo as principais referências da estação, tais como a localização dos acessos, dos bloqueios, as opções de percursos, a localização dos elevadores e das escadas, a configuração e posicionamento das plataformas, os pontos de interesse nos arredores) e a descrição sonora dos percursos de embarque e desembarque em cada uma das estações (disponível na estação ou na internet). Sobre os aspectos de segurança, foi reforçada a necessidade de ampliação dos contrastes visuais de sinalização de alerta nos fechamentos em vidro e a ampliação do nível de iluminação das áreas de circulação no mezanino.

\subsubsection{Instrutores e elaboradores de treinamento de funcionários e estagiários}

Foram aplicadas entrevistas online com profissionais autônomos ou vinculados às instituições que atuam no treinamento dos funcionários ou estagiários responsáveis pelo atendimento às pessoas com deficiência, por meio do envio de roteiro de questões por $e$-mail e recebimento de respostas escritas contendo os relatos, visando verificar a existência de um padrão ou a falta dele. Foram enviados cinco roteiros em 08/06/2011, dos quais quatro foram devolvidos preenchidos entre os dias 12/06/2011 e 11/07/2011. O roteiro das entrevistas realizadas consta do Apêndice G. Em relação aos temas abordados, destacam-se os que se seguem:

- a importância, as características, as especificidades e as dificuldades do treinamento dos funcionários e sua relação com os princípios e valores da empresa;

- os aspectos relacionados à segurança nos deslocamentos da pessoa com deficiência visual;

- o preparo para atuar em situações de anormalidade e os aspectos a serem aperfeiçoados.

A coleta de dados possibilitou a identificação de aspectos relacionados à capacitação dos funcionários para promover o atendimento a pessoas com deficiência visual, incluindo abordagem, condução, auxílio e acompanhamento durante a utilização das estações e trens. 
Em relação aos aspectos de capacitação dos funcionários, a entrevista aplicada aos instrutores possibilitou o acesso a informações relativas aos conteúdos ensinados, aprendidos e interiorizados após o treinamento, tais como as técnicas de abordagem, relacionamento ou oferecimento de auxílio; as técnicas de condução individual ou em grupo. As técnicas arroladas abrangeram o deslocamento em áreas planas ou os deslocamentos verticais - em rampas, escadas fixas ou rolantes - seja para auxiliar o embarque ou o desembarque seja para prestar informações sobre o uso seguro dos recursos disponíveis nas estações e trens. Em relação à segurança nos deslocamentos das pessoas com deficiência visual, foram mencionados os procedimentos vigentes que são ministrados nos treinamentos: auxílio e monitoração dos deslocamentos e aspectos relacionados à lotação ou ao uso do local de embarque preferencial. Quanto às dificuldades, os instrutores afirmaram que as barreiras atitudinais dos funcionários diminuem à medida que passam a interagir com as pessoas com deficiência. Há consenso sobre a necessidade de atenção diferenciada ao primeiro carro do trem, onde estão as pessoas com deficiência ou mobilidade reduzida, bem como sobre as dificuldades no auxílio e embarque/desembarque nos momentos de maior demanda. No caso específico dos estagiários, ressalta-se a necessidade de acompanhamento diário das atividades pelos supervisores orientando e reforçando os aspectos relacionados à disciplina e ao comportamento.

\subsection{Entrevista em grupo}

A entrevista em grupo distingue-se da entrevista individual pela sua natureza e situação social, com maior envolvimento emocional dos participantes. Nessa situação, o entrevistador torna-se catalisador da interação social, estimulando os participantes a falar e a reagir àquilo que outras pessoas no grupo dizem. "Uma sinergia emerge da interação social" (BAUER; GASKELL, 2011, p. 76). Se, por um lado, perde-se no aprofundamento dos temas, por outro lado, ganha-se na interação e motivação dos participantes, pois torna-se possível explorar convergências e divergências.

Foram realizadas entrevistas em grupo com especialistas e pessoas-chave a partir de roteiros semiestruturados, com questões preparadas a partir do perfil e da função dos entrevistados, considerando o conhecimento, a experiência e, consequentemente, a capacidade de resposta sobre os temas abordados. A aplicação do instrumento entrevista em grupo foi realizada de forma presencial, sendo utilizados roteiros semiestruturados durante a interação da 
pesquisadora com os entrevistados. Foram realizadas as seguintes entrevistas em grupo: arquitetos responsáveis pelos projetos das estações, engenheiros responsáveis pelo projeto dos trens e estagiários que auxiliam pessoas com deficiência visual nas estações. O protocolo de abordagem, coleta, registro e análise de dados está apresentado a seguir (Quadro 16):

Quadro 16 - Entrevistas em grupo - protocolo.

\begin{tabular}{|c|c|c|c|c|}
\hline Instrumento & Público-alvo & Abordagem & Registro & Análise \\
\hline $\begin{array}{l}\text { Entrevista } \\
\text { em grupo }\end{array}$ & $\begin{array}{l}-4 \text { arquitetos que } \\
\text { elaboram os projetos } \\
\text { das estações } \\
\text { - } 2 \text { engenheiros e } 1 \\
\text { desenhista industrial } \\
\text { que elaboram os } \\
\text { projetos dos trens } \\
\text { - } 37 \text { estagiários que } \\
\text { auxiliam pessoas com } \\
\text { deficiência visual }\end{array}$ & $\begin{array}{l}\text { - abordagem presencial } \\
\text { dos funcionários no } \\
\text { local de trabalho } \\
\text { - agendamento de } \\
\text { horário }\end{array}$ & $\begin{array}{l}\text { - anotação e/ou } \\
\text { gravação } \\
\text { - transcrição }\end{array}$ & $\begin{array}{l}\text { - transcrição das } \\
\text { gravações, anotações e } \\
\text { mensagens recebidas } \\
\text { por } e \text {-mail } \\
\text { - organização dos textos } \\
\text { - análise do conteúdo } \\
\text { - identificação de } \\
\text { padrões e temas } \\
\text { - codificação das } \\
\text { narrativas e relatos } \\
\text { coletados segundo } \\
\text { categorias } \\
\text { - modificação das } \\
\text { categorias quando } \\
\text { necessário } \\
\text { - identificação de } \\
\text { padrões e } \\
\text { inconsistências } \\
\text { - análise dos relatos } \\
\text { segundo as ideias } \\
\text { centrais } \\
\text { - interpretações e } \\
\text { inferências } \\
\text { - estabelecimento de } \\
\text { relação com } \\
\text { descobertas obtidas } \\
\text { nos demais } \\
\text { instrumentos }\end{array}$ \\
\hline
\end{tabular}

Fonte: Elaborado pela pesquisadora. (2014)

\subsubsection{Arquitetos responsáveis pelos projetos das estações}

Foi realizada uma entrevista em grupo com quatro arquitetos responsáveis pelo estabelecimento das diretrizes de projetos de arquitetura e de acabamento das estações em 13/06/2011. O registro das informações foi realizado por meio de gravação, com posterior transcrição dos relatos dos entrevistados. O roteiro das entrevistas realizadas consta do Apêndice H. Em relação aos temas abordados, destacam-se os seguintes:

- processo de projeto de uma estação;

- requisitos de acessibilidade em termos de configuração e sinalização dos percursos;

- aspectos relacionados à orientação/deslocamento/uso/comunicação e memorização dos percursos no deslocamento das pessoas com deficiência visual nas estações; 
- facilidades futuras, considerando a expansão da rede e as inovações tecnológicas.

A coleta de dados possibilitou a identificação das recomendações legais e requisitos normativos presentes no processo de projeto, os quais impactam de forma positiva o cotidiano das pessoas com deficiência visual, especialmente no que concerne aos aspectos relacionados à configuração e sinalização das estações a partir da experiência desses profissionais durante a elaboração ou coordenação dos projetos de arquitetura.

$\mathrm{Na}$ entrevista aplicada aos profissionais responsáveis pelos projetos de arquitetura, foi destacado o papel das estações de metrô como espaços "de fluxo" e "para fluxo" e não "para funções" uma vez que

Os espaços das estações não são estáticos no sentido da ocupação; ao contrário, são espaços que 'comportam muito mais pessoas' do que efetivamente 'pessoas contidas num espaço', dado que são pessoas em movimento. Isso gera uma relação entre a arquitetura e o tempo; não é o tempo de percepção, mas o tempo de ocupação, que pressupõe um deslocamento constante de pessoas, que geram fluxos e se configuram em situações mutantes de ocupação, ao contrário dos projetos dos ambientes de permanência, que utilizam padrões, referências e situações fixas na concepção do espaço arquitetônico (Relato de arquiteto responsável pelo projeto das estações, 2011).

Em relação à evolução dos projetos, foram destacados os aspectos de configuração das primeiras estações do Metrô de São Paulo, que podem ser consideradas mais funcionais na forma como são apresentadas as estruturas, os pisos, as aberturas e os fechamentos, constituindo-se em espaços mais legíveis pelas pessoas que não têm a visão como canal principal de percepção. Cada etapa do trajeto, assim como cada ambiente, apresenta-se numa sequência lógica, cadenciada:

O ruído externo, o canal de vento do acesso, o ruído abafado ao entrar na estação, um outro nível de ruído dentro da estação, uma outra reverberação por conta dos acabamentos; passando pelos bloqueios, começa um outro canal de vento, do deslocamento dos trens, o ruído reverbera diferente, eu vou me deslocar até a plataforma... (Relato de arquiteto responsável pelo projeto das estações, 2011).

Segundo os arquitetos, a arquitetura das novas estações, com espaços amplos e abertos, busca a transparência nos materiais, considera a entrada de iluminação natural até o nível mais profundo. As novas estações buscam a amplitude e, consequentemente, a percepção do espaço em sua plenitude, e não em suas contenções.

Os vazios transpassam os pavimentos e são transpassados por elementos de circulação... Os ambientes não estão segregados, mas sobrepostos. A transparência 
dos fechamentos e guarda-corpos em vidro amplificam as áreas, proporcionando uma luminosidade muito maior em todo o ambiente, uma vez que a luz natural chega à plataforma. Ganha-se na escala da percepção, não na escala da realidade... Ao contrário das primeiras estações, cujos espaços construídos são 'cheios', ou seja, são referenciais diretos para percepção, os espaços das atuais estações são 'vazios'. (Relato de arquiteto responsável pelo projeto das estações, 2011).

Justamente por isso as referências espaciais ganham outra dimensão: todas as percepções se dispersam, ficam díspares e confusas muitas vezes porque o que se escuta não é o que se vê. A amplitude espacial compromete a percepção e a compreensão do espaço pelas pessoas com deficiência visual uma vez que está mais relacionada à visão do que aos outros sentidos. Os cheiros e os ruídos de balizamento se dispersam, não há penumbra, e existe contraste de iluminação.

As cores dos acabamentos das estações são referenciais basicamente visuais, que as pessoas com deficiência visual não usam; disso decorre a importância da sinalização desses ambientes. Mais do que outros referenciais da edificação, a sinalização tátil no piso é essencial para orientar o fluxo e continua sendo a única alternativa considerada no projeto. Só o Metrô de São Paulo tem um sistema de sinalização tátil implantado nessa escala.

As pessoas precisam reaprender a utilizar as referências, agora no piso. Os percursos foram alterados, e, mesmo as pessoas que já haviam passado por treinamento, devem ser treinadas novamente. A sinalização indica o percurso para os elevadores existentes entre o mezanino e a plataforma, e isso faz com que as pessoas percam a escala do espaço, a percepção dos referenciais da continuidade do percurso, pois mudam de um ambiente com algumas condições para outro ambiente, com outras condições. A escada rolante ou fixa permite ouvir as pessoas em volta, o que possibilita seguir a conversa e o fluxo até a plataforma, enquanto que o elevador não oferece essa condição.

Nos espaços destinados à conexão entre diferentes modos de transporte, o direcionamento de fluxo é feito exclusivamente por meio do piso tátil: não há outros elementos de acabamento ou materiais de revestimento - em paredes, pisos ou forros - que reverberem mais, ou que sejam mais absorventes, para auxiliar. Se os usuários não sabem ler (cego funcional), nos amplos espaços de conexão, não chegam a lugar nenhum, pois não há nada que diferencie o caminho do Metrô do caminho do trem metropolitano, do terminal rodoviário, das alternativas de transporte disponíveis. Espaços de socialização não fazem diferença entre iguais; fala-se de um espaço de especificação, onde cada sistema tenha sua identidade, sua diferença. Não é 
mais a condição massiva, mas a condição individualizada, onde se reconhece que aquela situação espacial é individual e que, entre ela e outra situação individual, deve haver uma junção. Esse é o conceito que tem sido empregado. $\mathrm{O}$ projeto dos espaços destinados à conexão - sejam eles ritos de passagem ou espaços de transição - é extremamente significativo, qualquer que seja a configuração da estação. Nas estações subterrâneas, a amplitude está no espaço percebido, e não no espaço construído: as conectividades intermodais são muito mais claras para quem não enxerga porque são sempre percursos lineares e únicos. Isso é muito mais direcional do que o mezanino das estações amplas ou elevadas, possibilitando a percepção da transição entre uma etapa e outra.

\subsubsection{Engenheiros e designers que elaboram as especificações dos trens}

Foi realizada uma entrevista em grupo com dois engenheiros e um desenhista industrial responsáveis pelo projeto dos trens em 23/07/2012. O registro das informações foi realizado por meio de anotação, com posterior transcrição dos relatos dos entrevistados. O roteiro das entrevistas realizadas consta do Apêndice I. Em relação aos temas abordados, destacam-se os enumerados a seguir:

- evolução dos requisitos de acessibilidade;

- layout dos trens das diferentes frotas;

- inovações tecnológicas.

A coleta de dados possibilitou a identificação de recomendações legais e requisitos normativos presentes no processo de projeto que impactam de forma positiva o cotidiano das pessoas com deficiência visual, especialmente em relação aos aspectos configuração e sinalização dos trens e à interface trem-plataforma a partir da experiência desses profissionais durante a elaboração ou coordenação dos projetos.

$\mathrm{Na}$ entrevista aplicada aos profissionais responsáveis pelos projetos dos trens, foram destacados os aspectos relacionados à concepção, construção e manutenção, que impactam o vão e desnível entre o trem e a plataforma, seja nas vias com fixação direta (trilhos fixados em vigas de concreto sobre lastro de concreto) ou em lastro (trilhos fixados em vigas de concreto sobre lastro de brita). Há consenso de que as tolerâncias previstas nos trilhos, nas rodas dos trens e nas plataformas - seja no projeto, na fabricação ou na manutenção - quando somadas, impactam o valor que resulta no vão entre o trem e a plataforma, além da 
configuração das plataformas em curva.

Em relação aos trens, os profissionais destacaram que muitas melhorias foram implementadas nos novos trens e nos trens modernizados, especialmente em relação ao sistema de informação: foram instalados painéis eletrônicos com informações visuais informando o nome das estações e o lado de desembarque, sincronizados com a emissão automática de mensagens sonoras digitalizadas. Também foram acrescentados mapas eletrônicos informando sobre o deslocamento dos trens ao longo das linhas.

Ainda em relação aos trens, destacam que, em todas as frotas, foi ampliada a quantidade de assentos preferenciais, além de padronizadas a identidade visual e a sinalização indicativa de sua finalidade. Também foram acrescentadas informações nos lados interno e externo, tornando mais explícito o local de embarque preferencial nas duas primeiras portas do trem. Especificamente para pessoas com deficiência visual, houve a instalação de sinalização tátil para identificação do número do carro junto aos quatro assentos preferenciais, facilitando ao usuário informar eventuais problemas durante sua viagem.

Os profissionais destacam os aspectos relacionados à falta de padronização da configuração dos assentos preferenciais e das barras de apoio junto às portas de embarque e desembarque. Também foi ressaltado que é difícil realizar a modificação da localização e da fixação desses elementos em função da estrutura dos trens e da incompatibilidade entre os elementos e mecanismos já instalados, mais especificamente os de abertura e fechamento das portas e os painéis eletrônicos indicativos da movimentação do trem na linha.

\subsubsection{Estagiários que auxiliam pessoas com deficiência visual}

Foram realizadas 14 entrevistas em grupo com um total de 34 estagiários que atuam nas estações nos períodos da manhã e da tarde. As entrevistas foram realizadas no período compreendido entre 01/06/2011 e 15/02/2013, em pequenos grupos com a participação de dois a três estagiários de cada vez a fim de não interferir no atendimento aos usuários. As questões formuladas tiveram como objetivo identificar as principais dificuldades enfrentadas durante o auxílio prestado nas estações do Metrô de São Paulo. O registro das informações foi realizado por meio de anotações, com posterior transcrição dos relatos dos entrevistados. $\mathrm{O}$ roteiro das entrevistas realizadas consta do Apêndice J. Em relação aos temas abordados, destacam-se os mencionados a seguir: 
- perfil dos estagiários e sentimento em relação à tarefa desempenhada;

- identificação dos aspectos positivos e negativos das estações;

- fatores que dificultam a condução/auxílio das pessoas com deficiência visual;

- avaliação do treinamento recebido;

- aspectos a serem aperfeiçoados (atividades ou resultados).

A coleta de dados possibilitou a identificação de aspectos relacionados à capacitação dos estagiários para realizar a abordagem, acompanhamento e monitoração dos usuários com deficiência visual, bem como a outros fatores que impactam a prestação do serviço. Em relação às instalações, foi possível identificar aspectos positivos e negativos existentes nas estações e trens que impactam o deslocamento das pessoas com deficiência visual.

Os relatos dos 34 estagiários entrevistados foram codificados segundo categorias, possibilitando a análise do conteúdo e a quantificação das opiniões. Segundo os estagiários, os usuários com deficiência visual precisam de orientação, entre outros motivos, porque eles têm dificuldade para andar sozinhos $(31,43 \%)$; por uma questão de segurança, para evitar acidentes $(21,43 \%)$ e ainda por causa da falta de atenção e respeito por parte dos demais usuários $(14,29 \%)$ - (Gráfico 16).

Gráfico 16 - Motivos para auxílio às pessoas com deficiência visual.

Pergunta 4 - "Na sua opinião, por que os usuários precisam da sua ajuda?"

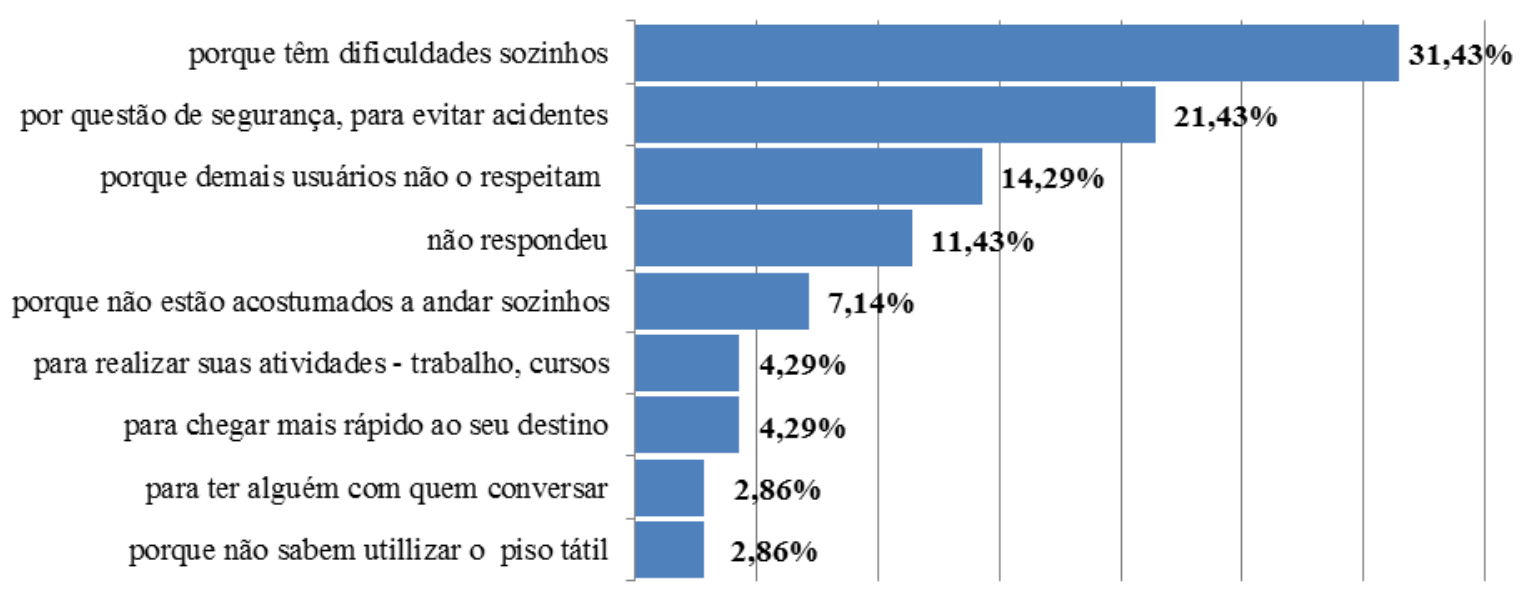

Fonte: Elaborado pela pesquisadora a partir dos relatos dos entrevistados P4 e P5. (2014)

Quando indagados sobre as dificuldades enfrentadas durante o auxílio prestado, destaca-se a convivência com os demais usuários - 79,0\% (Gráfico 17). Sobre as dificuldades enfrentadas nos diferentes percursos, os estagiários fizeram comparações entre os diferentes deslocamentos: 
- o percurso de embarque é o mais difícil $(45,9 \%)$ - as pessoas ficam na frente, não respeitam o embarque preferencial, empurram, não dão passagem; há dificuldade de comunicação com o CCO para informar ao trem onde o usuário será embarcado; existem também os aspectos de segurança relacionados ao vão entre o trem e a plataforma e à lotação;

- a conexão entre linhas também tem suas adversidades $(20,8 \%)$ - dificuldade de utilizar as escadas nos horários de pico; lotação e falta de respeito por parte dos demais usuários, que se interpõem no caminho, não respeitam o embarque preferencial, empurram ou não dão passagem;

- o percurso de desembarque é o menos difícil $(16,7 \%)$ - a ação tem que ser rápida, senão a porta do trem se fecha; existe a lotação, o empurra-empurra; as pessoas param em frente à porta do trem e dificultam a saída do deficiente visual.

Gráfico 17 - Dificuldades enfrentadas pelos estagiários durante a prestação do auxílio.

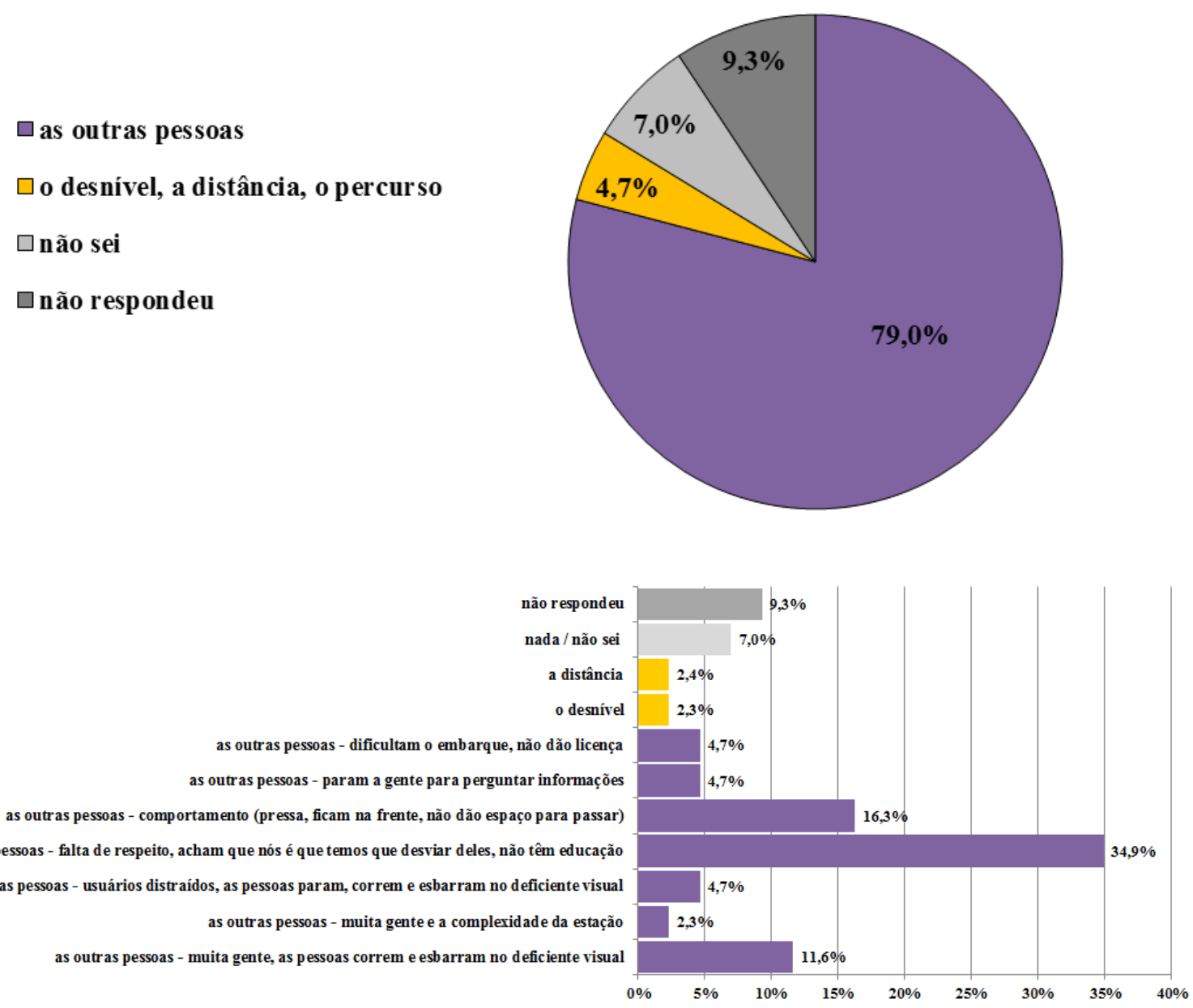

Fonte: Elaborado pela pesquisadora a partir da entrevista aplicada aos estagiários. (2014). 


\subsection{Levantamento documental}

A análise de evidências documentais é utilizada para suplementar informações obtidas por outros métodos e pode, opcionalmente, ter uma abordagem orientada para o problema, investigando diferentes fontes de informação para saber o que já foi abordado sobre o tema da pesquisa (DUFFY, 2008). A realização de levantamento documental teve por objetivo aprofundar os conhecimentos sobre os temas relacionados ao objeto da pesquisa e subsidiar a elaboração dos instrumentos de coleta de dados. Foram considerados os dados contidos nas normas técnicas de acessibilidade e na legislação nacional - considerados documentos públicos -, bem como nos croquis, desenhos e especificações dos equipamentos, estações e trens; nas manifestações dos usuários com deficiência visual e nos procedimentos de serviço adotados pelo Metrô de São Paulo - tidos como documentos de acesso e uso restritos.

\subsubsection{Normas técnicas ABNT e legislação federal}

As normas técnicas da Associação Brasileira de Normas Técnicas (ABNT) têm como objetivo estabelecer padrões que atendam à legislação por meio de consenso entre os fornecedores e os consumidores ou usuários de produtos ou serviços em função do custo-benefício das soluções apresentadas, facilitando a produção, a compatibilização com padrões de mercado, a redução de custos, de erros ou de tempo. As normas técnicas são referenciadas na legislação federal e, assim, passam a ter força de lei. Foram consultadas as normas técnicas relacionadas à acessibilidade, que, direta ou indiretamente, impactam os deslocamentos realizados no sistema metroferroviário. Os critérios de desempenho considerados para avaliação das condições de acessibilidade foram extraídos das informações contidas nas Normas Técnicas de Acessibilidade da ABNT.

A legislação federal, já mencionada no capítulo 2, foi utilizada para justificar a relevância da acessibilidade nos transportes. Destaca-se, para efeito desta pesquisa, a orientação legal para prover acessibilidade nas instalações - assentos de uso preferencial, espaços e instalações acessíveis, sinalização ambiental - e para o serviço prestado pelas empresas de transporte metroferroviário às pessoas com deficiência visual - pessoal capacitado para prestar atendimento; existência de área de embarque e desembarque preferencial; condições de admissão e permanência do cão-guia. 
Os requisitos legais e normativos foram identificados segundo sua relação com as etapas da jornada do usuário, com o objetivo de auxiliar a elaboração do checklist que serviu de roteiro de visita às instalações.

\subsubsection{Croquis, desenhos e especificações}

Croquis, desenhos e especificações de estações, trens e equipamentos do Metrô de São Paulo foram utilizados na elaboração dos instrumentos complementares - walkthrough, observações de fluxo e observações de comportamento - e auxiliaram a interpretação dos relatos efetuados pelos usuários, pessoas-chave e especialistas.

\subsubsection{Procedimentos operacionais}

Os procedimentos operacionais definem os processos de apoio vigentes no Metrô de São Paulo. Foram selecionados documentos relacionados à atuação integrada entre as empresas operadoras dos diferentes modos de transporte nas situações cotidianas ou de anormalidade e os procedimentos que regulamentam as estratégias de comunicação com o usuário nas situações cotidianas ou de anormalidade em estações e trens. Também foram analisados os documentos, legislação e aspectos normativos relacionados ao atendimento preferencial. Atenção especial foi dada à verificação dos procedimentos que regulamentam os serviços de operação e manutenção das instalações e equipamentos (bloqueios, elevadores, escadas rolantes). Todos os requisitos e atividades contidas nos procedimentos operacionais selecionados foram classificados segundo o impacto das suas recomendações em cada uma das etapas da jornada do usuário e auxiliaram a interpretação dos relatos efetuados pelos usuários, pessoas-chave e especialistas.

O embarque preferencial consiste na delimitação e segregação de espaço nas plataformas das estações com maior demanda nos horários de maior movimento, junto à primeira e à segunda porta dos trens, cujo principal objetivo é proporcionar segurança e conforto para os usuários com deficiência no momento do embarque nas plataformas. $\mathrm{O}$ procedimento operacional "estratégias para embarque de usuários preferenciais" está diretamente relacionado às etapas 12 (embarque) e 15 (desembarque). A análise do documento possibilitou verificar o cumprimento da oferta de serviço diferenciado, as condições do local de embarque preferencial, bem como as orientações veiculadas para os usuários preferenciais 
e para os demais usuários, assim como auxiliou a aplicação do instrumento observação de comportamento.

A monitoração consiste no auxílio prestado às pessoas com deficiência visual por parte dos funcionários/estagiários das estações e operadores dos consoles de passageiros do $\mathrm{CCO}$ e constam do procedimento operacional "estratégias para embarque de usuários preferenciais". A análise do documento possibilitou avaliar os requisitos relacionados à comunicação entre os funcionários e estagiários da estação e os funcionários que atuam no console do CCO.

\section{As rotinas de operação e manutenção associadas a equipamentos, elementos ou} ambientes referem-se às atividades realizadas nos bastidores, visando garantir a disponibilização e o funcionamento adequado dos equipamentos, elementos e ambientes das estações e trens. A análise do documento possibilitou avaliar as condições dos elementos e equipamentos típicos do sistema metroferroviário, principalmente em relação à interface de uso pelos usuários com deficiência visual. Foram analisados os documentos relacionados à operação e à manutenção dos elevadores, escadas rolantes e bloqueios. Os requisitos atinentes aos elevadores e escadas rolantes estão relacionados às etapas 4, 9, 17 e 21 (circulação vertical), e os requisitos relacionados aos bloqueios estão relacionados às etapas 7 e 19 (controle de entrada e controle de saída). A análise do documento possibilitou verificar o cumprimento das rotinas de operação e manutenção dos equipamentos, bem como auxiliou a aplicação do instrumento ficha ambiente.

\subsubsection{Manifestações}

No período de janeiro de 2007 a dezembro de 2013, o Serviço de Atendimento ao Cliente (SAC) da Companhia do Metropolitano de São Paulo recebeu 297 manifestações realizadas por pessoas com deficiência visual $(67,34 \%)$, seus acompanhantes $(4,71 \%)$ ou ainda por outros usuários, que se manifestaram em relação a esse segmento $(27,95 \%)$ - (Gráfico 18). 
Gráfico 18 - Origem das manifestações recebidas no período de 2007-2013.

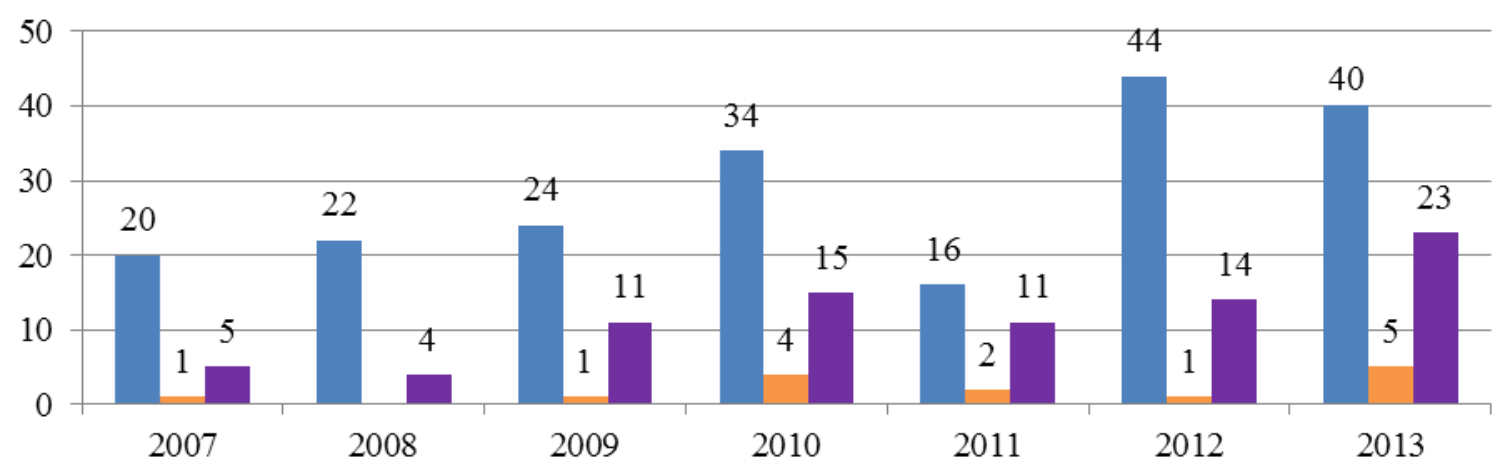

" pessoa com deficiência visual acompanhante alguém que não era usuário ou acompanhante

Fonte: Elaborado pela autora a partir dos dados da CMSP. 2014.

n=297 manifestações

Uma manifestação contém um ou mais relatos, que foram classificados em reclamação $(97,04 \%)$, elogio $(2,44 \%)$ ou solicitação $(0,52 \%)$ - Gráfico 19. Exceto no ano de 2011, o total de reclamações registradas ao longo de sete anos aumentou continuamente - de 55, em 2007, para 117, em 2013.

Gráfico 19 - Reclamações, elogios e solicitações recebidos no período de 2007-2013.

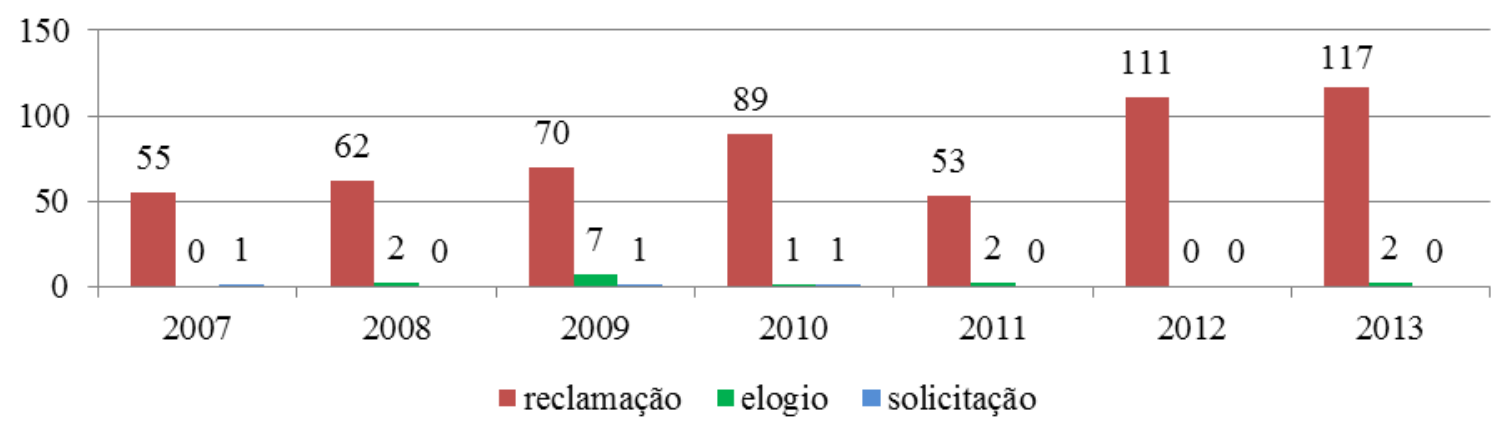

Fonte: Elaborado pela autora a partir dos dados da CMSP. 2014.

$\mathrm{n}=574$ relatos

Do total de 574 relatos, 424 foram realizados por pessoas com deficiência visual ou seus acompanhantes e foram classificados segundo as mesmas ideias centrais identificadas durante a análise das perguntas abertas dos questionários aplicados às pessoas com deficiência visual. Isso possibilitou agrupá-las segundo sua relação com a configuração, com o sistema de informação, orientação e comunicação ou com a gestão da prestação dos serviços. Foram reagrupadas segundo sua localização no sistema metroferroviário - na estação, na interface trem-estação ou no trem. Todas as ideias centrais foram quantificadas. 
Do total de relatos, 94,9\% referem-se à estação, 3,1\%, à interface trem-estação, e 2,0\%, ao trem (Gráfico 20). A maior parte das reclamações está relacionada aos serviços prestados nas estações, totalizando 78,8\%, seguidas pelas informações prestadas nas etações, com 13,0\%. Em seguida, com 3,1\%, apresenta-se igualmente a configuração da estação e o serviço prestado na interface trem-estação. A informação e o serviço prestados nos trens representam $0,9 \%$ do total de relatos, cada um.

Gráfico 20 - Classificação das ideias centrais identificadas nas manifestações dos usuários.

$$
\mid
$$

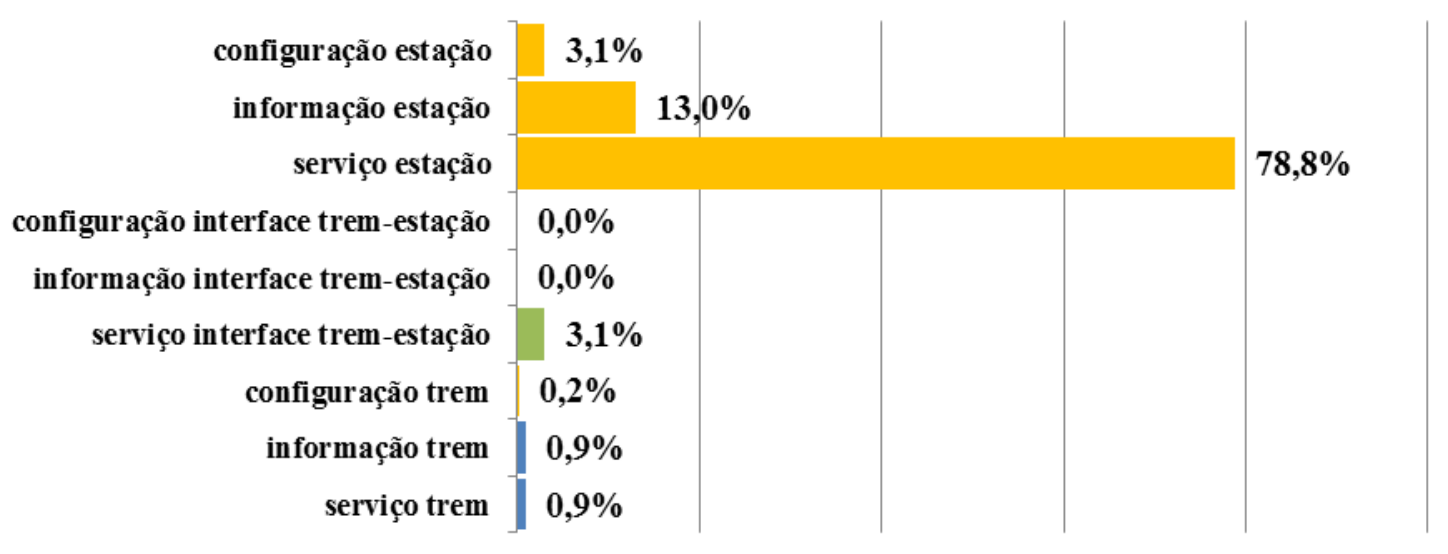

$n=424$ relatos

Fonte: Elaborado pela pesquisadora a partir dos dados coletados no SAC no período de 2007 a 2013.

Quando apresentados segundo os fatores-chave de acessibilidade, nota-se um agravamento dos serviços prestados nas estações nos anos de 2010, 2012 e 2013 (Gráfico 21). No mesmo gráfico é possível constatar que as reclamações relacionadas às informações nas estações tiveram um pico em 2008 - período de início das obras para instalação de sinalização tátil no piso das estações - mas vêm se reduzindo desde então.

Gráfico 21 - Classificação das ideias centrais identificadas nas manifestações dos usuários.

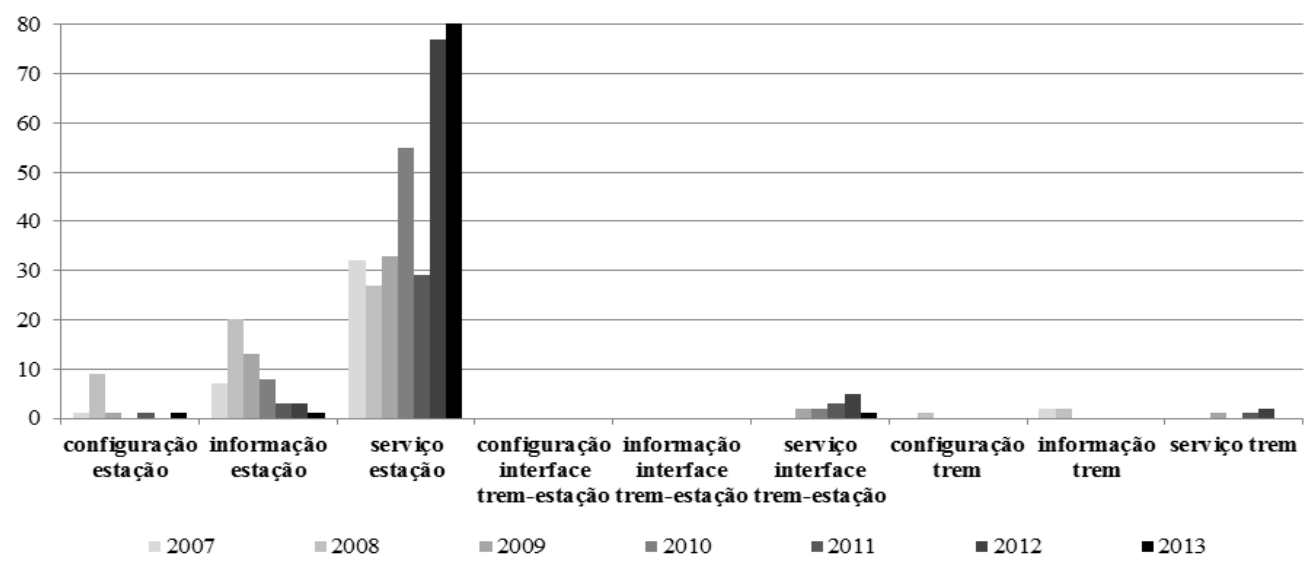

Fonte: Elaborado pela pesquisadora a partir dos dados coletados no SAC no período de 2007 a 2013. 
Considerando que as reclamações sobre os serviços prestados nas estações destacam-se em relação aos demais temas e locais, optou-se por uma análise mais detalhada dos relatos dessas manifestações no período de 2007 a 2013 (Gráfico 22). Aspectos relacionados à melhoria do atendimento pelos empregados das estações somam 50,6\% das reclamações sobre os serviços prestados, com destaque para a falta de empregados para auxílio para embarque e desembarque. Em seguida estão as reclamações sobre a falta de treinamento adequado dos empregados e estagiários das estações $(31,4 \%)$ e a insatisfação em relação aos procedimentos operacionais adotados pela empresa $(8,7 \%)$, notadamente aqueles relacionados à comunicação entre as estações e o $\mathrm{CCO}$ e ao limite de atuação dos empregados e estagiários nas proximidades das estações, que na opinião dos usuários, deveria ser ampliado.

Gráfico 22 - Manifestações recebidas sobre o tema serviço na estação (2007-2013).
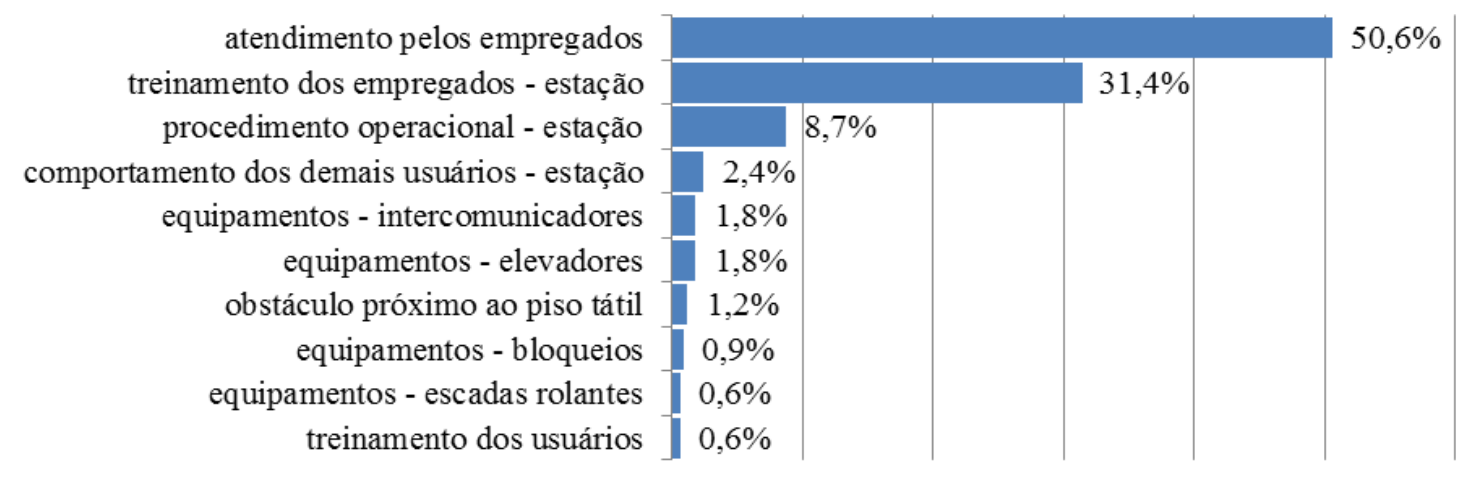

Fonte: Elaborado pela pesquisadora a partir dos dados coletados no SAC no período de 2007 a 2013.(2014)

$\mathrm{n}=424$ relatos

As demais reclamações referem-se ao comportamento dos demais usuários, às constantes falhas nos equipamentos (intercomunicadores, elevadores, bloqueios, escadas rolantes), aos obstáculos existentes próximos ao piso tátil e à falta de treinamento dos usuários com deficiência para utilização dos recursos oferecidos nas estações.

\subsection{Walkthrough}

O walkthrough é um importante instrumento que geralmente precede todos os estudos e levantamentos. Pode ser utilizado de várias maneiras, viabilizando a hierarquização dos aspectos negativos e positivos, que mereceriam estudos mais aprofundados, e facilitando a escolha de técnicas e instrumentos que deveriam ser utilizados. Originário da pesquisa ambiental, este instrumento "consiste em um percurso dialogado, abrangendo todos os ambientes, e combina, simultaneamente, observação, registro fotográfico, desenhos, gravação de áudio ou vídeo e entrevistas, nos quais os aspectos físicos servem para articular as reações 
dos participantes em relação ao ambiente" (RHEINGANTZ et al 2009, p. 23). Esse instrumento possibilita que os observadores se familiarizem com as características da edificação - sua construção, seu estado de conservação e sua forma de utilização -, bem como com aspectos positivos ou falhas e problemas através do percurso por todo o ambiente a ser analisado, servindo para articular as reações dos participantes em relação ao ambiente. É possível realizar, simultaneamente, a análise pelo observador ou grupo de observador, extrair informações das pessoas-chave ou usuários e realizar um levantamento das condições e características do edifício. Esse instrumento subsidia a elaboração de questionários, entrevistas e outras observações mais detalhadas, devendo ser o primeiro instrumento a ser aplicado (SBARRA, 2007).

Os roteiros de walkthrough realizados tiveram por objetivo promover o reconhecimento dos ambientes de circulação internos e externos, bem como os percursos de embarque e desembarque em estações construídas em diferentes períodos, com diferentes demandas e tipologias - segundo a posição e a configuração das plataformas - e condições de acessibilidade - acessível ou adaptada (Quadro 17). Isso facilitou a elaboração dos demais instrumentos e a compreensão dos relatos dos respondentes e entrevistados. Foram observados os aspectos relacionados ao fluxo de usuários nos diferentes períodos do dia; às estratégias de organização e de controle de fluxo adotados nas estações; à organização e uso dos espaços internos e externos; ao sistema de informação existente nas estações com ou sem conexão com outros modos de transporte (com plataformas laterais, centrais e mistas, plataformas elevadas, em superfície e subterrâneas, estações terminais ou de meio de linha). Para melhor compreensão desses aspectos, foram realizados percursos nas seguintes estações: Ana Rosa, Palmeiras-Barra Funda, Sacomã e Tamanduateí (Figuras 21 a 24). 
Quadro 17 - Realização de walkthrough em estações com diferentes tipologias.

\begin{tabular}{|c|c|c|c|c|}
\hline & Ana Rosa & $\begin{array}{l}\text { Palmeiras - } \\
\text { Barra Funda } \\
\end{array}$ & Sacomã & Tamanduateí \\
\hline $\begin{array}{l}\text { Início de } \\
\text { operação }\end{array}$ & $\begin{array}{l}\text { 1975, construção } \\
\text { 1992, ampliação }\end{array}$ & 1988 (reconstrução) & 2010 & 2010 (reconstrução) \\
\hline $\begin{array}{l}\text { Demanda média } \\
\text { de passageiros/ } \\
\text { dia útil }\end{array}$ & $\begin{array}{c}2010 \text { - } 42.000 \text { (média) } \\
2011 \text { - } 193.000 \text { (alta) } \\
2012 \text { - } 175.000 \text { (alta) } \\
2013 \text { - } 183.000 \text { (alta) } \\
\end{array}$ & $\begin{array}{l}2010-208.000 \text { (alta) } \\
2011-205.000 \text { (alta) } \\
2012-199.000 \text { (alta) } \\
2013-198.000 \text { (alta) }\end{array}$ & $\begin{array}{l}2011 \text { - } 30.000 \text { (baixa) } \\
2012 \text { - } 33.000 \text { (média) } \\
2013 \text { - } 34.000 \text { (média) }\end{array}$ & $\begin{array}{l}2010-8.600 \text { (baixa) } \\
2011-34.000 \text { (baixa) } \\
2012-54.000 \text { (média) } \\
2013-58.000 \text { (média) }\end{array}$ \\
\hline $\begin{array}{l}\text { Configuração } \\
\text { da plataforma }\end{array}$ & $\begin{array}{l}\text { subterrânea, central, } \\
\text { com e sem } \\
\text { organizadores de } \\
\text { embarque }\end{array}$ & $\begin{array}{c}\text { em nível, mista, com e } \\
\text { sem organizadores de } \\
\text { embarque }\end{array}$ & $\begin{array}{l}\text { subterrânea, lateral, } \\
\text { com portas de } \\
\text { plataforma }\end{array}$ & $\begin{array}{l}\text { elevada, lateral, com } \\
\text { portas na plataforma }\end{array}$ \\
\hline Acessibilidade & adaptada & adaptada & acessível & acessível \\
\hline Conexão & $\begin{array}{l}\text { Linha } 1 \text { (metrô); } \\
\text { Linha } 2 \text { (metrô); } \\
\text { ônibus urbano; }\end{array}$ & $\begin{array}{l}\text { Linha } 3 \text { (metrô); } \\
\text { Linhas } 7 \text { e } 8 \text { (trem } \\
\text { metropolitano); ônibus } \\
\text { urbano; ônibus } \\
\text { metropolitano; ônibus } \\
\text { rodoviário e turístico; }\end{array}$ & $\begin{array}{l}\text { Linha } 2 \text { (metrô) } \\
\text { corredor de ônibus } \\
\text { urbano (Expresso } \\
\text { Tiradentes) }\end{array}$ & $\begin{array}{l}\text { Linha } 2 \text { (metrô); } \\
\text { Linha } 10 \\
\text { (trem metropolitano); } \\
\text { ônibus metropolitano; }\end{array}$ \\
\hline & $\begin{array}{l}\text { Vila Mariana } \\
\text { o Santa Cruz } \\
\text { OPraça da Árvore }\end{array}$ & 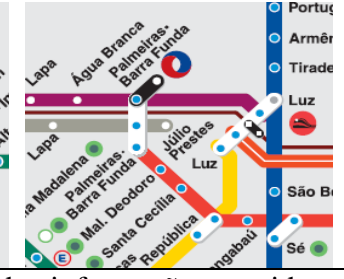 & 8 & $y$ \\
\hline
\end{tabular}

Fonte: Elaborado pela pesquisadora a partir das informações contidas em CMSP, Gerência de Operações, Por Dentro da Operação 2013, 2014, p. 37, 39, 40, 96.
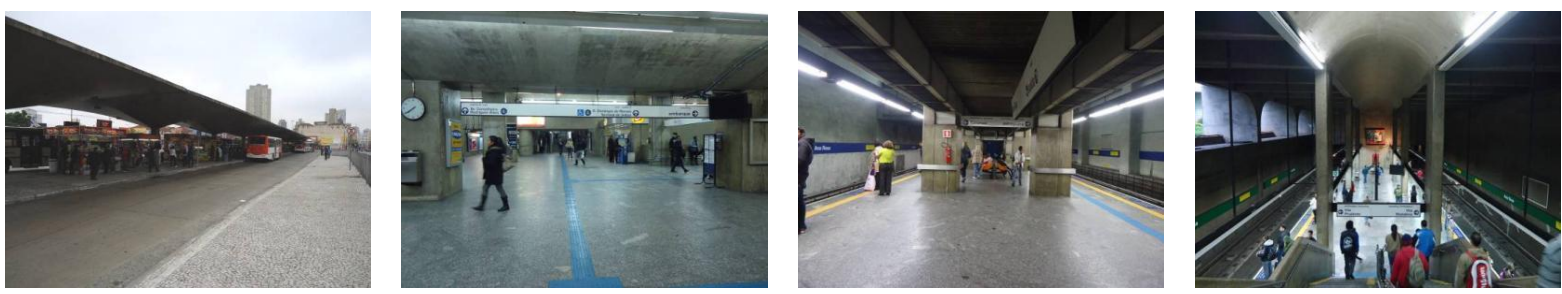

Figura 21 - Estação Ana R
Fonte: Barbosa, M.B., 2011.
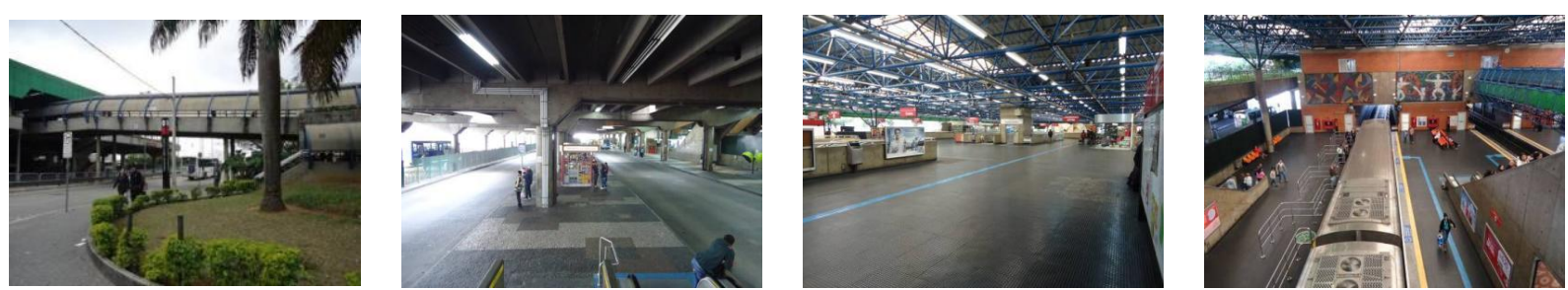

Figura 22 - Estação Palmeiras-Barra Funda - acesso, terminal, mezanino, plataforma. Fonte: Barbosa, M.B., 2011. 

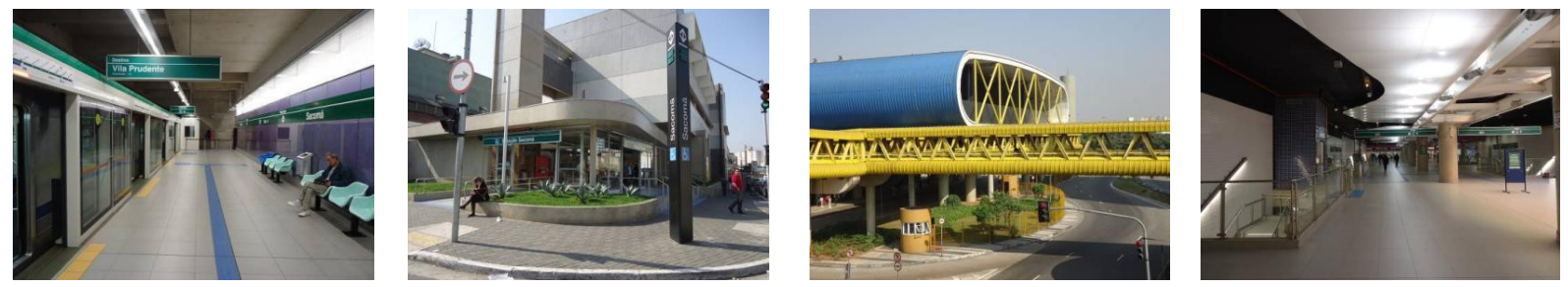

Figura 23 - Estação Sacomã
Crédito: Barbosa, M.B., 2011.
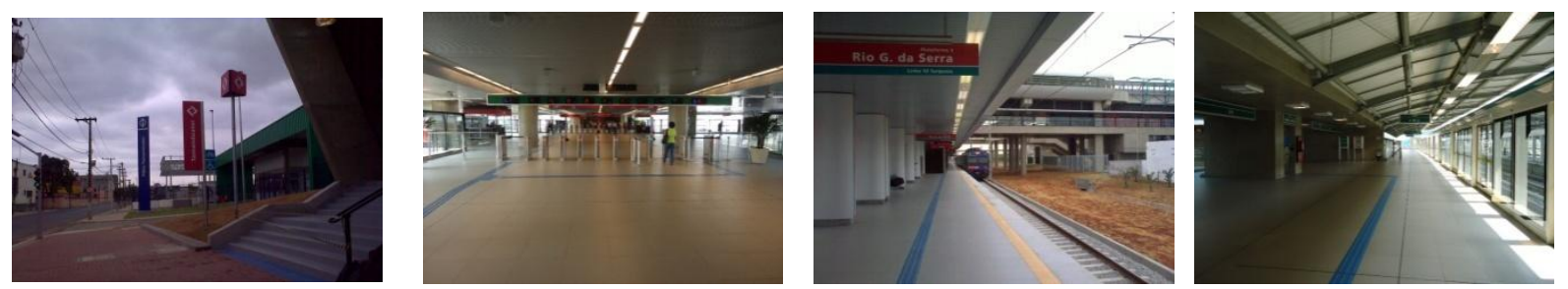

Figura 24 - Estação Tamanduateí - acesso, mezanino, plataformas CPTM e plataforma metrô.

Crédito: Barbosa, M.B., 2011.

\subsection{Checklist}

O checklist é uma ferramenta de auxílio para uso em avaliação de ambientes, elaborada a partir de critérios vigentes em normas e legislação. Pode ser customizado a partir de um roteiro pré-estabelecido, listando e destacando somente os requisitos aplicáveis. Podem ser acrescentados itens relacionados a boas práticas observadas durante consulta a documentos, bibliografias ou visitas técnicas.

As recomendações de acessibilidade estabelecidas pela ABNT foram analisadas e comparadas com os critérios para avaliação das condições de acessibilidade estabelecidos por outros metrôs de diferentes países para identificar ações voltadas à adequação das instalações de trens e estações visando promover a acessibilidade no transporte. O documento elaborado pela Consejería de Transporte e Infraestrutura, órgão vinculado ao Departamento de Infraestrutura de Transporte em Madrid (MINTRA, 2006) concentra os requisitos relacionados ao desenho universal utilizados para avaliação das instalações de diversas redes metroferroviárias a partir das informações prestadas pelas empresas operadoras: integração com a paisagem e com o ambiente; entorno (meio ambiente urbano; entradas e saídas no nível da rua); fluxo vertical de pedestres; rotas horizontais; acabamento das superfícies; plataformas; mobiliário urbano; iluminação; sinalização de informação; condições de evacuação/saídas de emergência; comunicação; trens. 
O checklist elaborado considerou os requisitos e as exigências legais e normativas, bem como as boas práticas identificadas junto a outros sistemas metroferroviários nacionais e internacionais, classificando-os quanto à sua origem e ordenando-os segundo as etapas da jornada do usuário. O modelo do checklist consta no Apêndice $\mathrm{K}$. Os itens do checklist foram classificados em 24 grupos, apresentados a seguir:

a) desembarque do sistema de transporte integrado;

b) acesso à estação;

c) aquisição do bilhete;

d) validação do bilhete;

e) acesso à plataforma;

f) espera pelo trem;

g) embarque;

h) viagem, interior do trem;

i) desembarque;

j) saída da estação;

k) embarque no sistema de transporte integrado;

1) circulação vertical;

m)rampas e escadas fixas;

n) escadas rolantes

o) esteiras rolantes;

p) elevadores;

q) plataformas inclinadas;

r) circulação horizontal;

s) sinalização horizontal;

t) sinalização de emergência;

u) mobiliário;

v) iluminação;

w) comunicação;

x) informação.

Esse levantamento mostrou-se muito significativo quanto ao cenário do ambiente de serviço. $\mathrm{Na}$ maioria dos requisitos e recomendações, estão explícitas as necessidades do ambiente; porém, poucas referências são feitas às pessoas - além dos parâmetros antropométricos - ou às inter-relações entre pessoas, entre essas e os ambientes ou entre ambientes. 


\subsection{Ficha ambiente}

A ficha dos ambientes é um instrumento que facilita a ação de levantamento de campo a partir de um modelo de avaliação que se utiliza de registro gráfico, fotográfico e escrito, complementando e auxiliando a coleta de dados técnicos e as características físicas do ambiente e seus elementos, bem como o entendimento das observações realizadas no ambiente. As fichas podem ser complementadas com informações colhidas durante o walkthrough.

O ambiente dos sistemas metroferroviários impõe uma relação constante dos usuários com equipamentos de autoatendimento - escadas rolantes, elevadores, plataformas de elevação, bloqueios, trens. Esse instrumento foi concebido de forma bastante concisa para auxiliar o registro das informações sobre os aspectos técnicos e funcionais relacionados à configuração e aos sistemas de informação dos equipamentos, a partir do modelo proposto no Guide to Post Occupancy Evaluation (UNIVERSITY OF WESTMINSTER, 2006). A ficha foi previamente formatada, contendo espaço para a identificação do equipamento avaliado; espaço para inserção de croqui e/ou registros fotográficos e para anotação de eventuais observações.

A aplicação desse instrumento possibilitou observarem-se aspectos relacionados à padronização de soluções para, posteriormente, confrontar os dados com os relatos sobre os aspectos positivos ou negativos apontados pelas pessoas com deficiência visual que responderam ao questionário. A utilização desse instrumento permitiu a compreensão das considerações realizadas pelos respondentes. O modelo da ficha ambiente elaborada consta do Apêndice L.

\subsubsection{Escadas rolantes}

O Metrô de São Paulo dispõe de 526 escadas rolantes, que foram instaladas de acordo com o início da operação das estações, por diferentes fornecedores (Otis, Thyssen-Krüpp, Villares). Com a evolução da tecnologia ao longo dos anos, um mesmo fabricante forneceu escadas rolantes que dispõem de configuração e sinalização diferentes. Portanto, pode-se afirmar que existem diferentes modelos de escadas rolantes ao longo de uma mesma linha ou mesmo numa única estação. 
As escadas rolantes foram avaliadas quanto à padronização da localização da informação sobre o sentido de funcionamento e à existência de sinalização de alerta nos degraus. Observou-se a inexistência de um padrão de sinalização nos equipamentos (Figura 25). Sobre a sinalização tátil e visual dos degraus, constatou-se a existência/ausência dos seguintes itens:

- sinalização tátil e visual nos limites da superfície, nos degraus ou no limite entre a parte fixa e a parte móvel (pente);

- sinalização visual no limite da parte fixa da escada rolante.
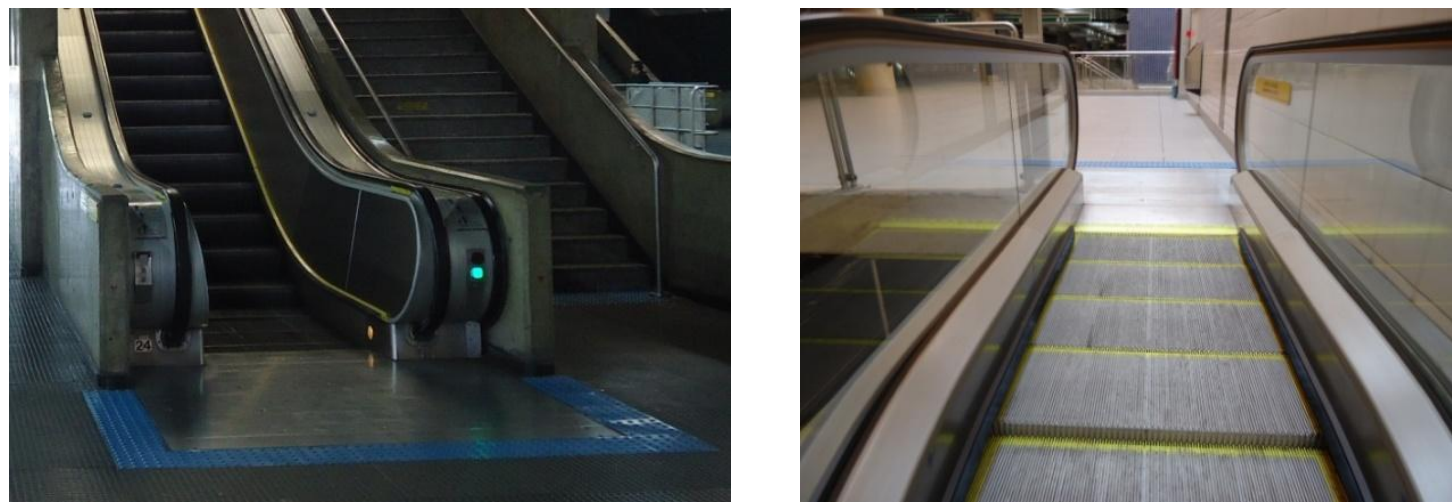

Figura 25 - São Paulo - Sinalização tátil e visual nos degraus das escadas rolantes. Fonte: BARBOSA, M. B., 2011.

Observou-se que os equipamentos mais antigos têm a sinalização indicativa de sentido na própria estrutura enquanto que os equipamentos instalados recentemente dispõem de sinalização em estrutura independente. A sinalização orienta fluxos (luz verde) e contrafluxos (luz vermelha) e pode ser percebida por pessoas com baixa visão (Figura 26).
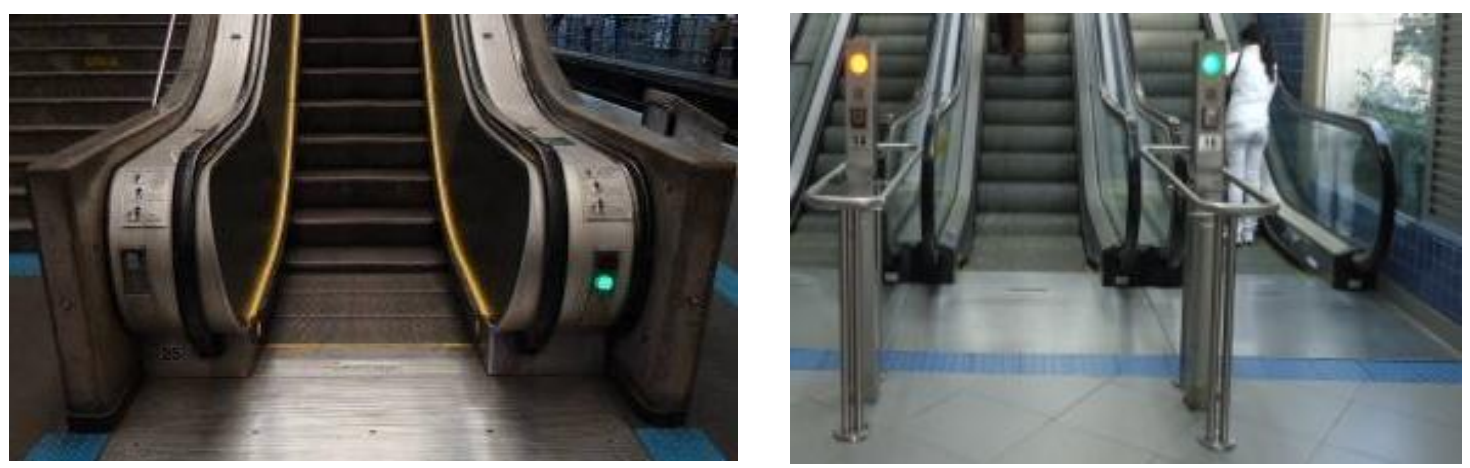

Figura 26 - São Paulo - Sinalização visual do sentido de deslocamento das escadas rolantes. Fonte: BARBOSA, M. B., 2011.

As escadas rolantes caracterizam-se por serem equipamentos de fluxo unidirecional, ao contrário das escadas fixas e elevadores. As escadas rolantes podem ser instaladas isoladamente ou associadas a escadas fixas ou outras escadas rolantes (Figura 27). O conjunto 
de circulação vertical existente nos acessos e plataformas oferece diferentes possibilidades em função da combinação dos recursos (somente subir; somente descer; subir e descer).

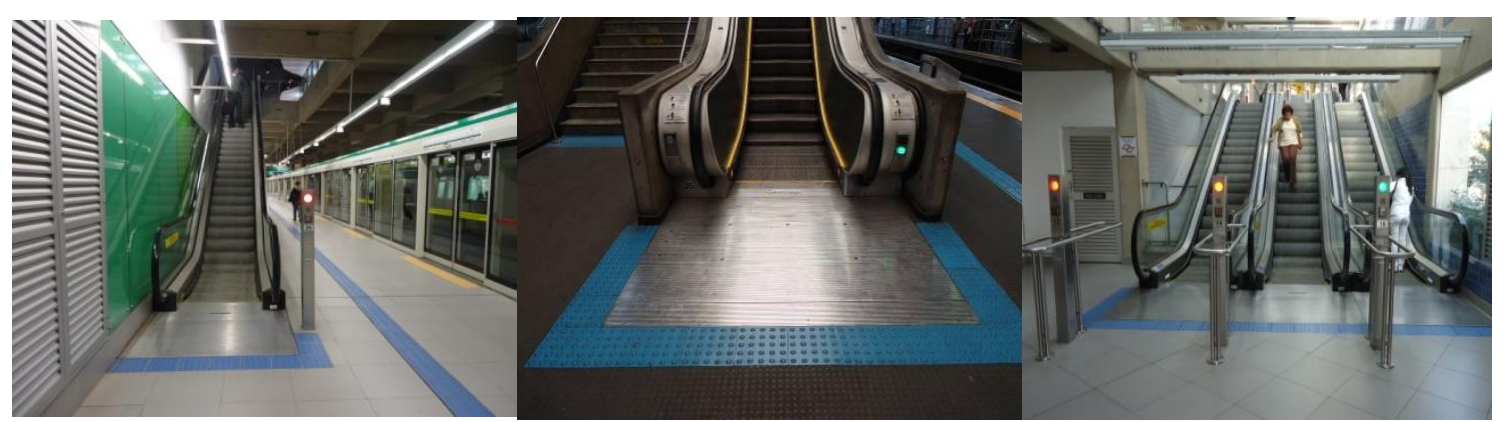

Figura 27 - São Paulo - Escada rolante isolada ou em conjunto com outras escadas. Fonte: BARBOSA, M. B., 2011.

Em relação ao fluxo, foi constatado que algumas escadas rolantes têm seu sentido de funcionamento invertido ao longo do dia, principalmente nos horários de pico da manhã ou da tarde, em função da demanda de embarque ou de desembarque.

\subsubsection{Elevadores e plataformas de elevação}

O Metrô de São Paulo dispõe de 142 elevadores e plataformas de elevação. Os diferentes modelos de elevadores e plataformas de elevação foram avaliados quanto à padronização da configuração, dos comandos e das informações táteis e visuais disponíveis interna e externamente, de forma a contextualizar os requisitos normativos e a rotina de uso dos equipamentos existentes nos acessos (interligando o acesso e o mezanino) e nas plataformas (interligando a plataforma e o mezanino).

Possibilitam a transposição de desníveis, com conforto e autonomia, especialmente por pessoas em cadeiras de rodas ou com restrição de mobilidade. A sinalização é fundamental para auxiliar e orientar o uso dos equipamentos e orienta quanto ao uso preferencial dos equipamentos por pessoas com deficiência, idosos, pessoas com criança de colo ou com carrinhos de bebê. A sinalização tátil, em Braille, é dirigida às pessoas com deficiência visual; a sinalização visual, em textos e figuras, é dirigida aos demais usuários. A existência de intercomunicador facilita a solicitação de auxílio ou instruções sobre a utilização das botoeiras internas, em função do percurso desejado;

\subsubsection{Bloqueios}

O Metrô de São Paulo dispõe de 789 bloqueios. Existem bloqueios com torniquetes e bloqueios com portas de vidro, com ou sem dispositivo para leitura de cartões magnéticos 
(Figuras 28 e 29). Os bloqueios existentes nas estações foram avaliados em relação à sua configuração e sinalização de forma a contextualizar os requisitos normativos às rotinas de uso nos mezaninos das estações. Os diferentes modelos de bloqueios foram avaliados quanto à localização dos elementos de leitura de bilhete/cartão magnético. Em relação à sinalização, os bloqueios foram avaliados quanto à padronização da localização da informação sobre o sentido de funcionamento (entrada/saída) nos diferentes horários ao longo do dia. Todos os equipamentos possuem fenda para inserção de bilhete magnético, mas somente parte dos bloqueios dispõe de dispositivo para leitura de cartões. Esses dispositivos ficam posicionados na face superior do equipamento, ora alinhados com a face frontal ora centralizados sobre o equipamento, ora destacados do corpo do equipamento, ora incorporados ao equipamento.

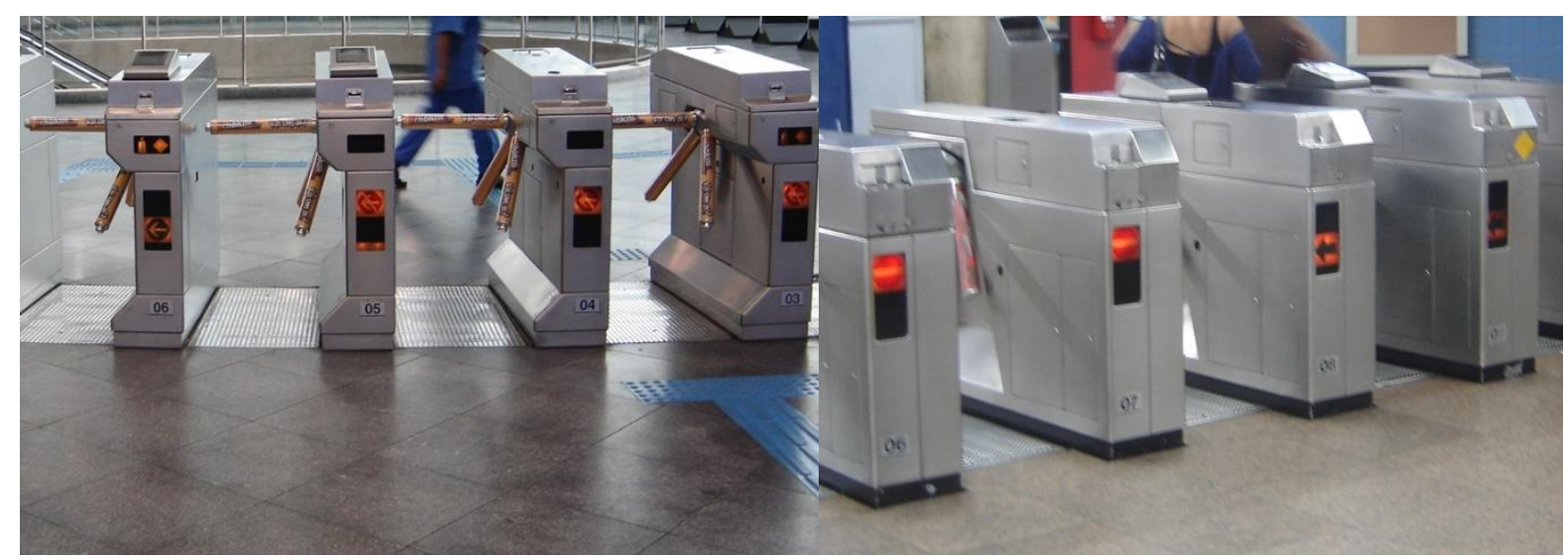

Figura 28 - São Paulo: bloqueios com diferentes dispositivos para leitura de cartões. Fonte: Elaborado pela pesquisadora a partir de desenho fornecido pela CMSP.

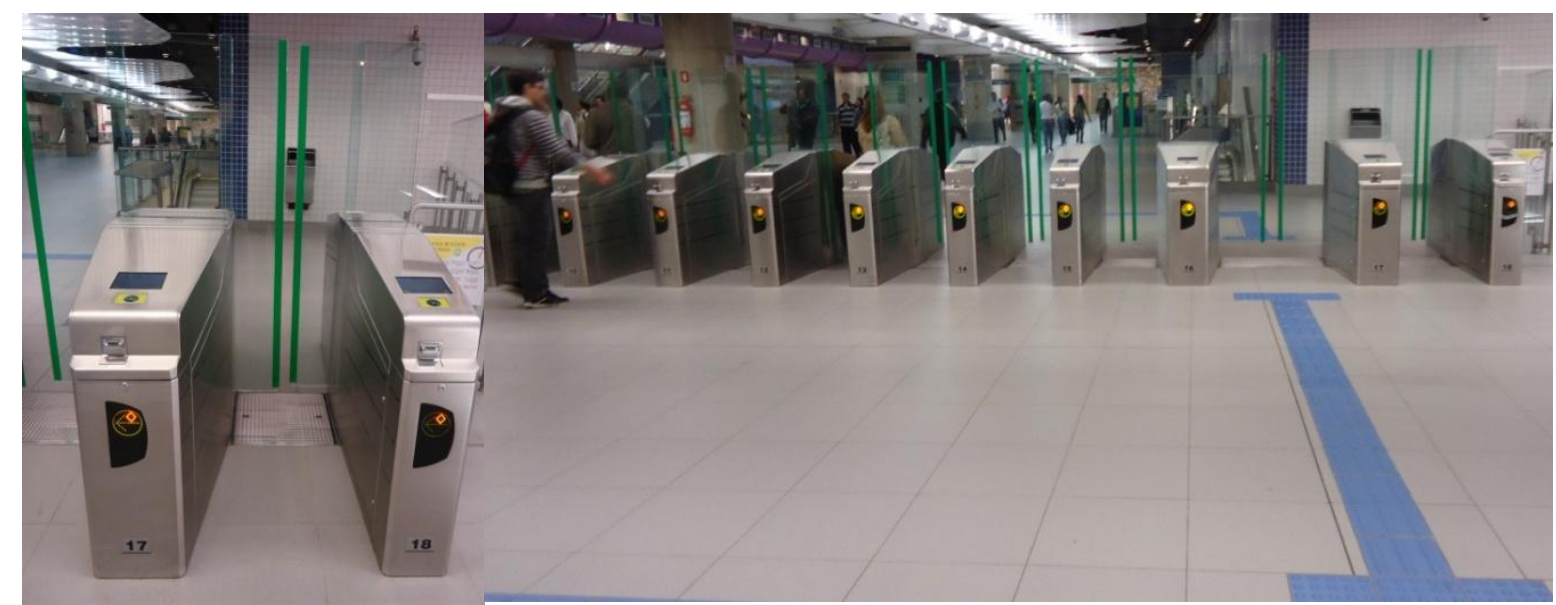

Figura 29 - São Paulo: bloqueios com porta de vidro. Fonte: BARBOSA, M. B., 2011. 


\subsubsection{Carro preferencial dos trens}

O Metrô de São Paulo dispõe de 11 frotas e 300 carros preferenciais. Os carros preferenciais estão localizados nas duas extremidades de cada um dos 150 trens. Os carros A (carros líderes ou primeiros carros da composição) são destinados ao embarque preferencial das diferentes frotas. Foram observados quanto aos recursos de informação, comunicação e orientação, além da configuração, localização e dimensionamento dos assentos preferenciais, posicionamento e configuração dos balaústres e dos apoios horizontais e verticais junto às portas de embarque e desembarque.

Em relação aos trens, foram selecionados os desenhos do carro-líder dos trens das diversas frotas que circulam nas diferentes linhas. Contudo, não foi possível identificar a frota objeto do comentário a partir dos relatos dos respondentes. Da mesma forma, na entrevista com os especialistas, os assuntos abordados foram mais genéricos, não se atendo a detalhes específicos de cada uma das frotas. Apesar da similaridade, as diferentes frotas possuem localização e dimensionamento de assentos preferenciais e configuração de apoios diferentes entre si, dificultando sua compreensão pelos usuários com deficiência visual.

Na Linha 1 - Azul -, circulam os trens das frotas A/B, H, I e J, conforme apresentado na Tabela 10 e nas Figuras de 30 a 33. 
Tabela 10 - Configuração do carro líder nas diferentes frotas da Linha 1 - Azul

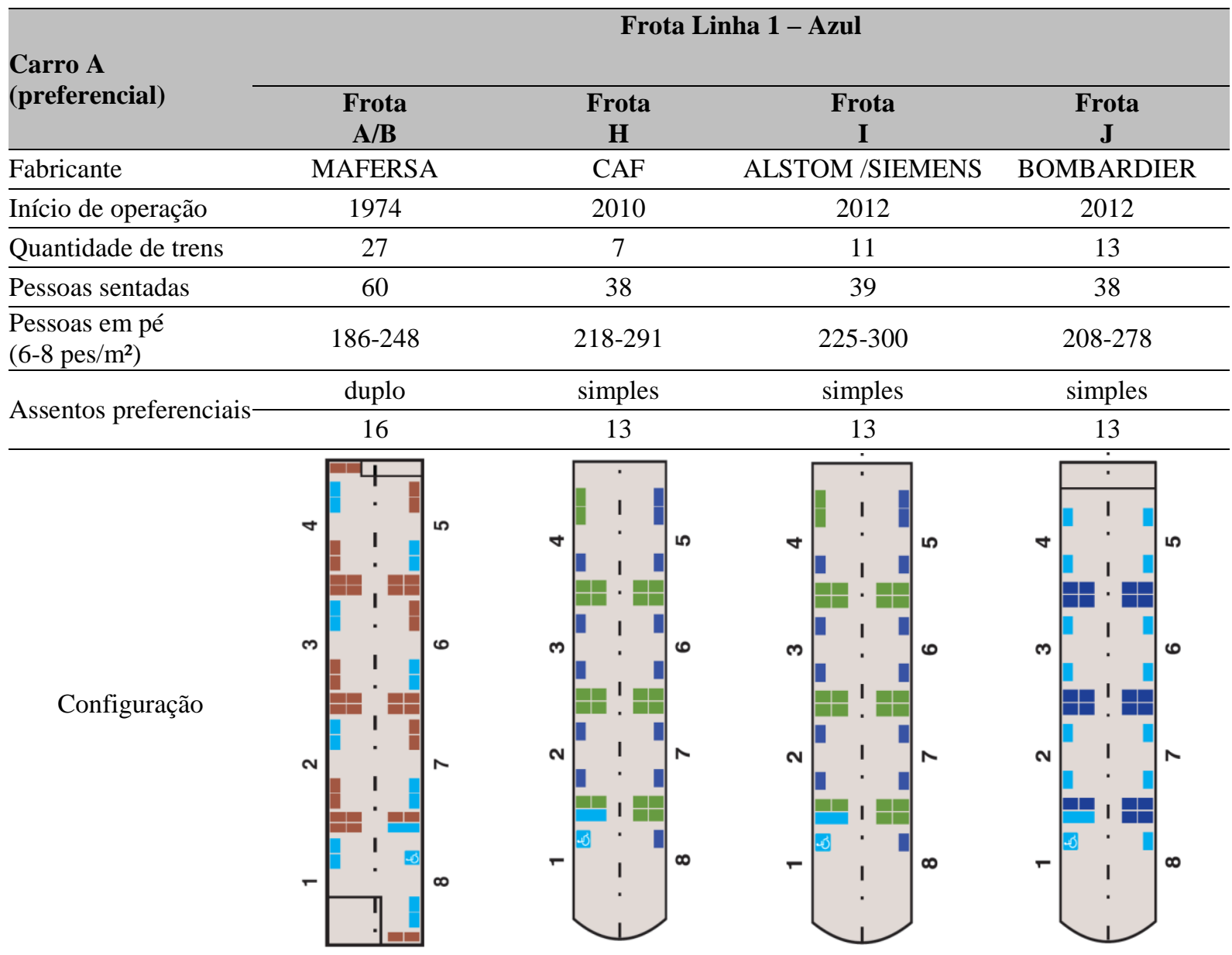

Fonte: Elaborado pela pesquisadora a partir das informações contidas em CMSP, Gerência de Operações, Por Dentro da Operação 2013, 2014, p. 51-69 e desenhos fornecidos pela CMSP.

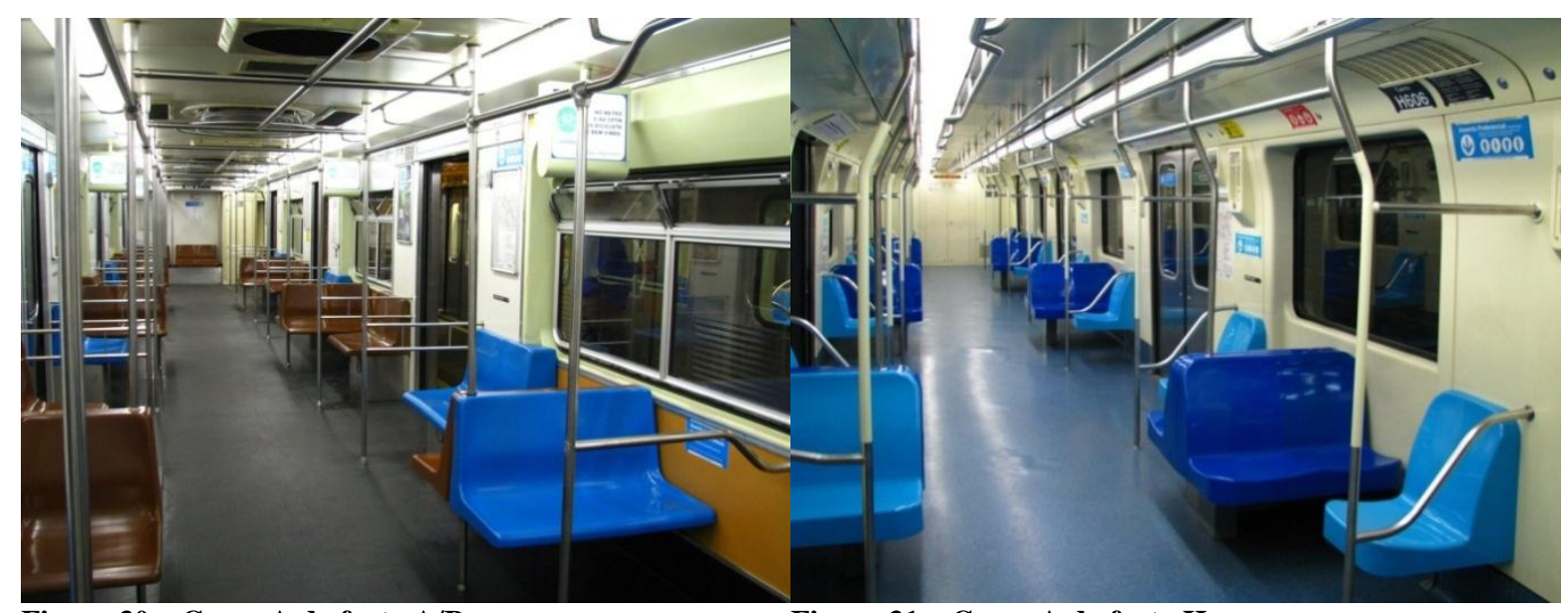

Figura 30 - Carro A da frota A/B.

Fonte: ZAITSU, B. T., 2014.
Figura 31 - Carro A da frota $H$

Fonte: ZAITSU, B. T., 2014. 


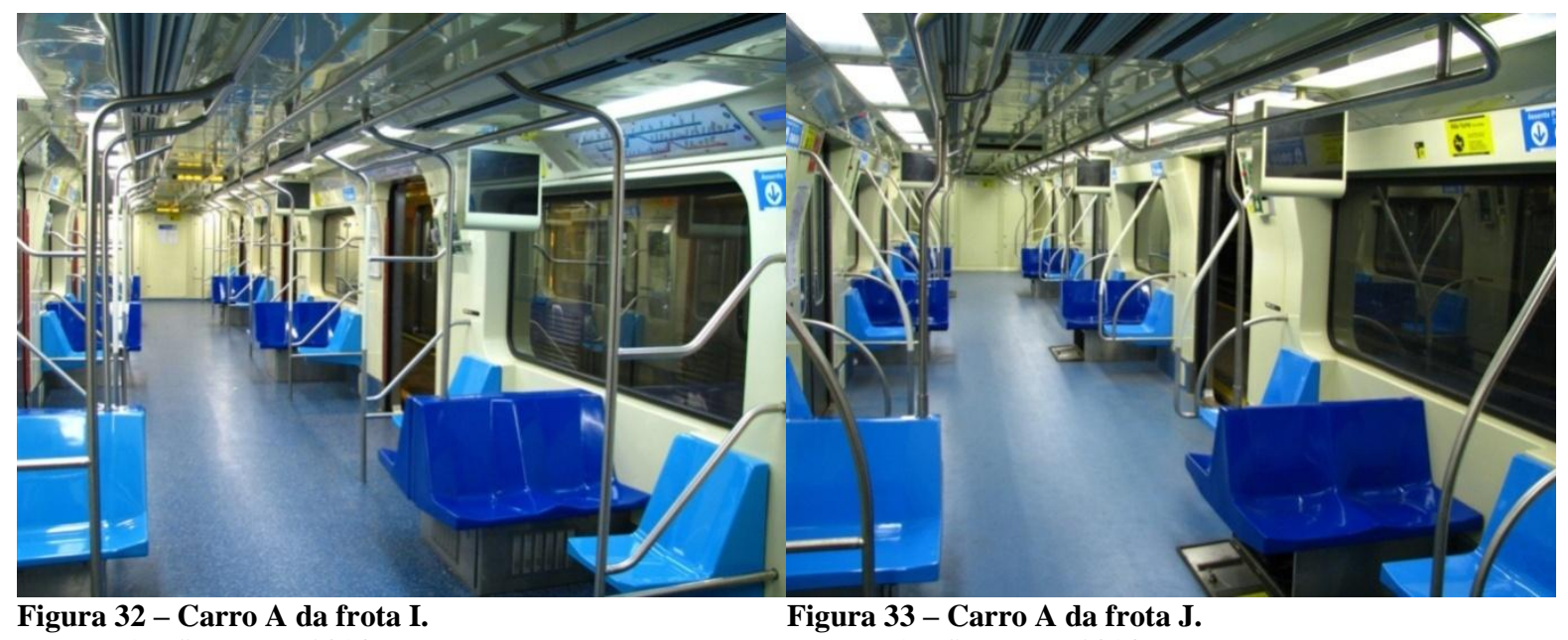

Fonte: ZAITSU, B. T., 2014.

Fonte: ZAITSU, B. T., 2014.

Na Linha 3 - Vermelha -, circulam os trens das frotas C/D, H, K e L, conforme apresentado na Tabela 11 e nas Figuras de 34 a 37.

Tabela 11 - Configuração do carro líder nas diferentes frotas da Linha 3 - Vermelha.

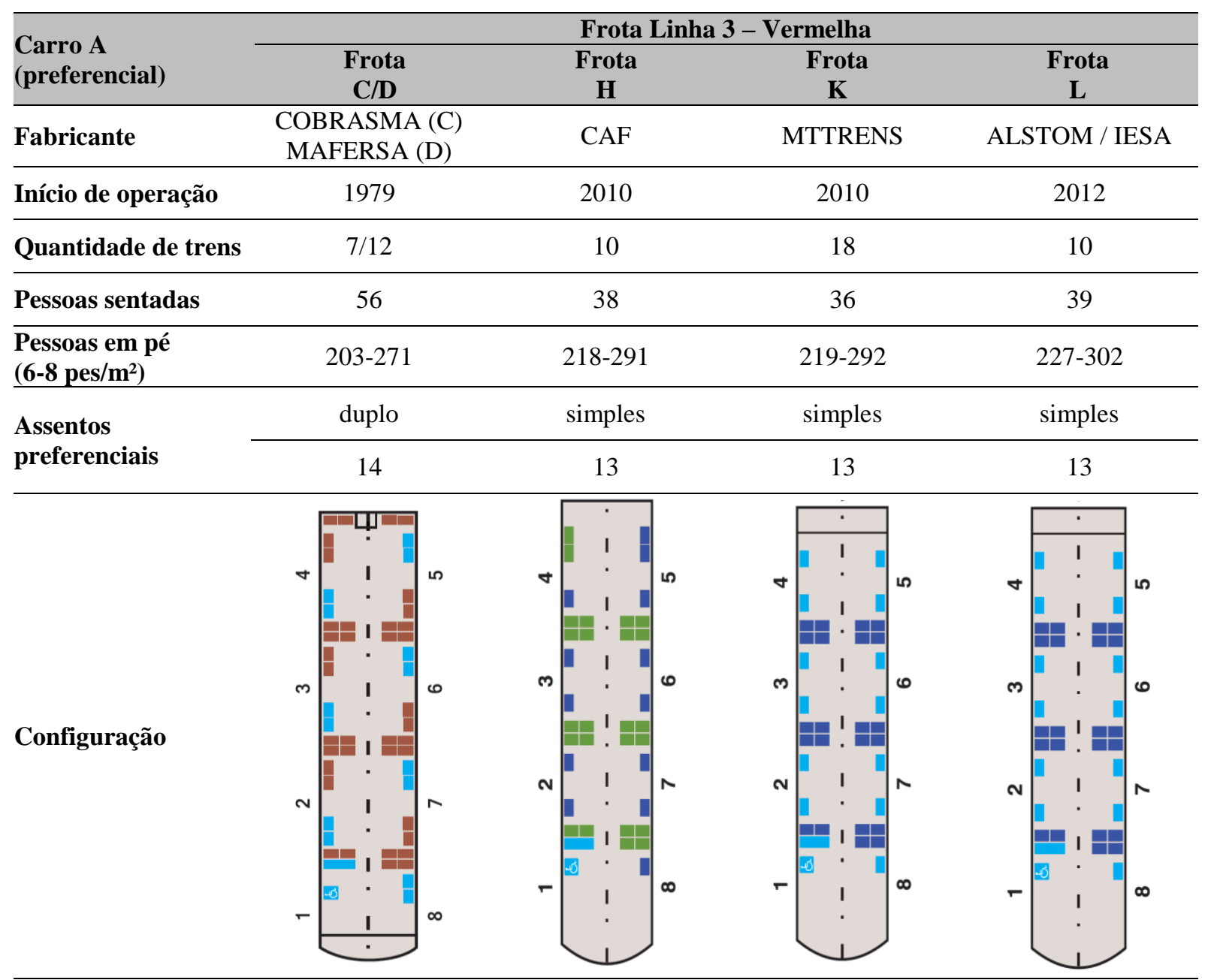

Fonte: Elaborado pela pesquisadora a partir das informações contidas em CMSP, Gerência de Operações, Por Dentro da Operação 2013, 2014, p. 51-69 e desenhos fornecidos pela CMSP. 


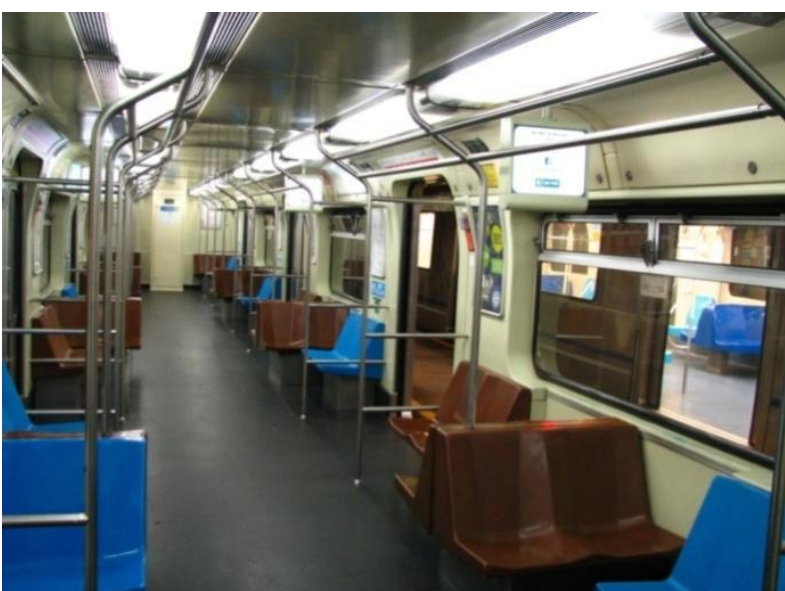

Figura 34 - Carro A da frota C/D.

Fonte: ZAITSU, B.T., 2014.

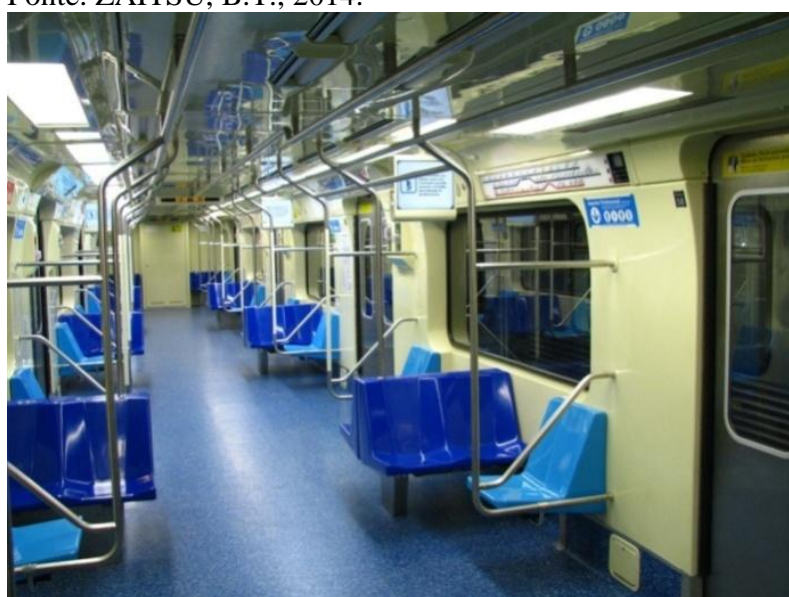

Figura 36 - Carro A da frota $\mathrm{K}$.

Fonte: ZAITSU, B.T., 2014.

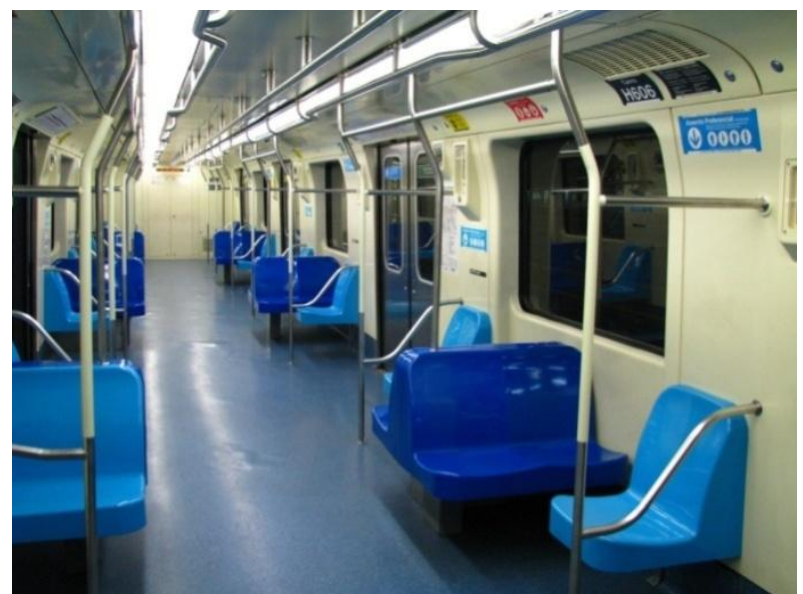

Figura 35 - Carro A da frota $H$.

Fonte: ZAITSU, B.T., 2014

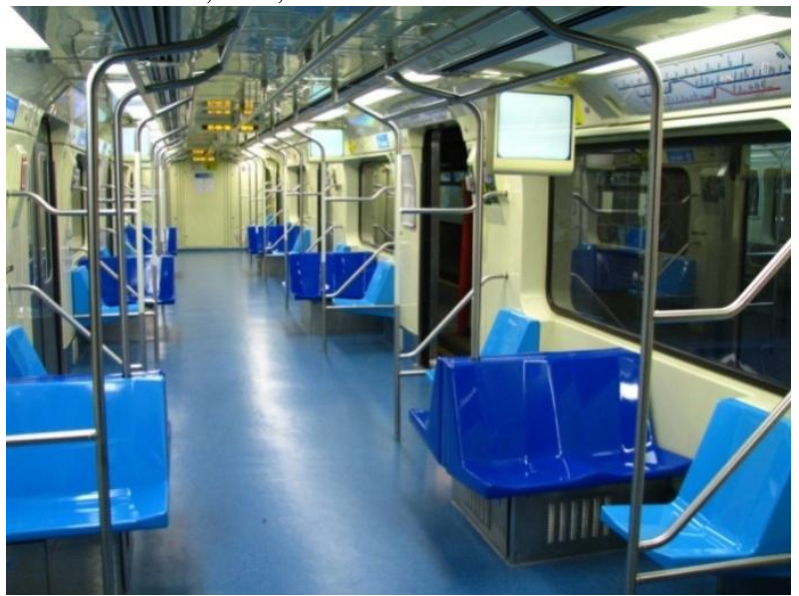

Figura 37 - Carro A da frota $L$. Fonte: ZAITSU, B.T., 2014.

Na Linha 2 - Verde -, circulam os trens das frotas E e G. Na Linha 5 - Lilás -, circulam os trens da frota F, conforme apresentado na Tabela 12 e nas Figuras de 38 a 40. 
Tabela 12 - Configuração do carro líder nas diferentes frotas das Linhas 2 - Verde e 5 - Lilás.

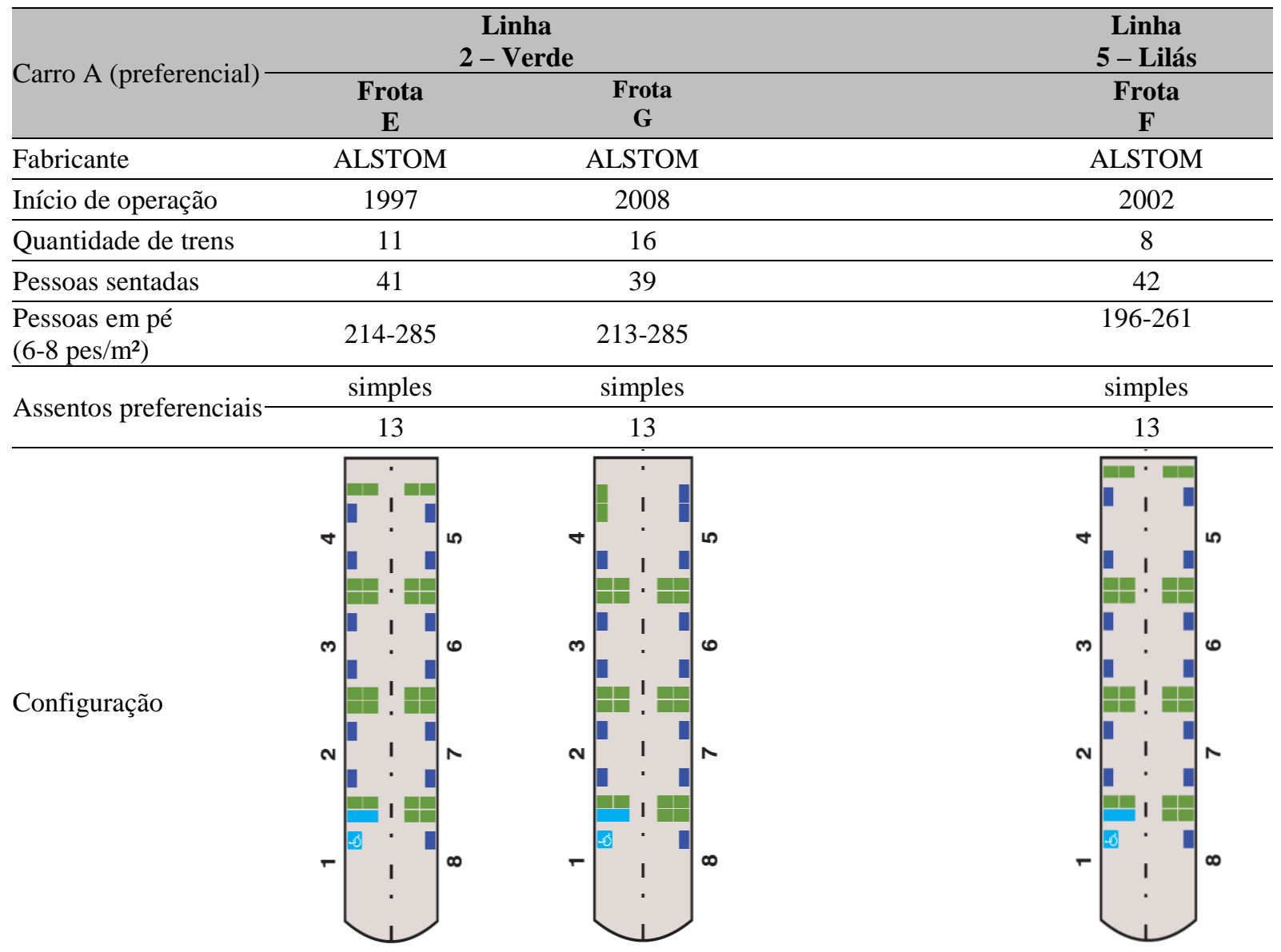

Fonte: Elaborado pela pesquisadora a partir das informações contidas em CMSP, Gerência de Operações, Por Dentro da Operação 2013, 2014, p. 51-69 e desenhos fornecidos pela CMSP.

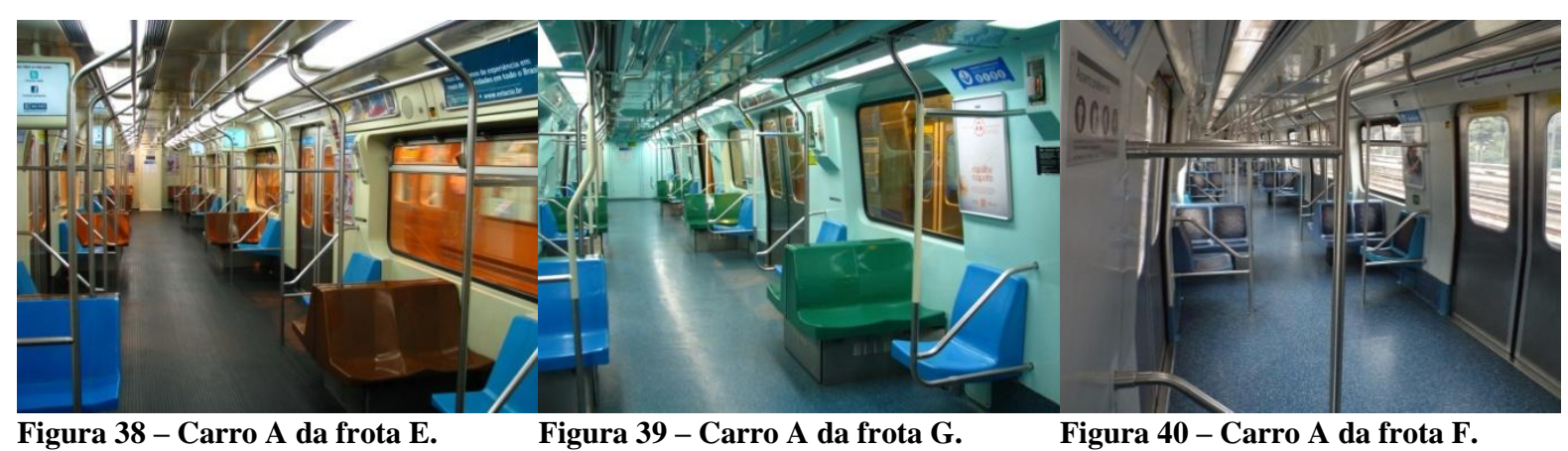
Fonte: ZAITSU, B.T., 2014.

Os recursos de informação visual - mapas de linha estáticos, mapas de linha dinâmicos, painéis eletrônicos e monitores multimídia, sinalização de fechamento de portas e lado de desembarque - variam entre as diversas frotas, conforme apresentado na Tabela 13. 
Tabela 13 - Características dos trens da frota metroviária.

\begin{tabular}{|c|c|c|c|c|c|c|c|c|c|c|c|}
\hline \multirow{2}{*}{$\begin{array}{l}\text { Características dos } \\
\text { trens }\end{array}$} & \multicolumn{4}{|c|}{$\begin{array}{c}\text { Linha } \\
1-\text { Azul }\end{array}$} & \multicolumn{2}{|c|}{$\begin{array}{c}\text { Linha } \\
2-\text { Verde }\end{array}$} & \multicolumn{4}{|c|}{$\begin{array}{c}\text { Linha } \\
\text { 3-Vermelha }\end{array}$} & \multirow{2}{*}{$\begin{array}{c}\text { Linha } \\
5- \\
\text { Lilás } \\
\text { Frota } \\
\text { F } \\
\end{array}$} \\
\hline & $\begin{array}{c}\text { Frota } \\
\text { A/B } \\
\end{array}$ & $\begin{array}{c}\text { Frota } \\
\text { H }\end{array}$ & $\begin{array}{c}\text { Frota } \\
\text { I }\end{array}$ & $\begin{array}{c}\text { Frota } \\
\mathbf{J}\end{array}$ & $\begin{array}{c}\text { Frota } \\
\text { E }\end{array}$ & $\begin{array}{c}\text { Frota } \\
\text { G }\end{array}$ & $\begin{array}{c}\text { Frota } \\
\text { C/D }\end{array}$ & $\begin{array}{c}\text { Frota } \\
\text { H }\end{array}$ & $\begin{array}{c}\text { Frota } \\
\text { K } \\
\end{array}$ & $\begin{array}{c}\text { Frota } \\
\text { L }\end{array}$ & \\
\hline Início de operação & 1974 & 2010 & 2012 & 2012 & 1997 & 2008 & 1979 & 2010 & 2010 & 2012 & 2002 \\
\hline Quantidade de trens & 27 & 7 & 11 & 13 & 11 & 16 & $7 / 12$ & 10 & 18 & 10 & 8 \\
\hline Mapa de linha estático & 48 & - & - & - & 48 & 24 & 48 & - & - & - & 48 \\
\hline Mapa de linha dinâmico & - & 24 & 48 & 48 & - & - & - & 24 & 48 & 48 & - \\
\hline Painel eletrônico & - & 12 & 24 & 24 & - & - & - & 12 & 24 & 24 & 12 \\
\hline Monitor multimídia & 24 & - & 24 & 24 & 24 & 24 & 24 & 24 & 24 & 24 & - \\
\hline $\begin{array}{l}\text { Sinalização de } \\
\text { fechamento de portas }\end{array}$ & sonora & $\begin{array}{c}\text { sonora/ } \\
\text { visual }\end{array}$ & $\begin{array}{l}\text { sonora/ } \\
\text { visual }\end{array}$ & $\begin{array}{l}\text { sonora/ } \\
\text { visual }\end{array}$ & $\begin{array}{l}\text { sonora/ } \\
\text { visual }\end{array}$ & $\begin{array}{l}\text { sonora/ } \\
\text { visual }\end{array}$ & sonora & $\begin{array}{c}\text { sonora/ } \\
\text { visual }\end{array}$ & $\begin{array}{l}\text { sonora/ } \\
\text { visual }\end{array}$ & $\begin{array}{l}\text { sonora/ } \\
\text { visual }\end{array}$ & $\begin{array}{c}\text { sonora/ } \\
\text { visual }\end{array}$ \\
\hline $\begin{array}{l}\text { Sinalização do lado de } \\
\text { desembarque }\end{array}$ & - & visual & visual & visual & visual & visual & - & visual & visual & visual & visual \\
\hline Mensagens sonoras & tanual & $\begin{array}{l}\text { auto- } \\
\text { mática }\end{array}$ & $\begin{array}{l}\text { auto- } \\
\text { mática }\end{array}$ & $\begin{array}{l}\text { auto- } \\
\text { mática }\end{array}$ & $\begin{array}{l}\text { auto- } \\
\text { mática }\end{array}$ & $\begin{array}{l}\text { auto- } \\
\text { mática }\end{array}$ & nual & $\begin{array}{l}\text { auto- } \\
\text { mática }\end{array}$ & $\begin{array}{l}\text { auto- } \\
\text { mática }\end{array}$ & $\begin{array}{l}\text { auto- } \\
\text { mática }\end{array}$ & \\
\hline
\end{tabular}

Fonte: Elaborado pela pesquisadora a partir das informações contidas em CMSP, Gerência de Operações, Por Dentro da Operação - 2013, CMSP, 2014, p. 51-69.

\subsection{Observação}

Para REIS \& LAY (1994), o método de observação consiste em uma avaliação visual do ambiente construído, sendo o método mais apropriado para detectar o que acontece e como funciona (ou não) um determinado espaço/edificação. Segundo os autores, os dados obtidos a partir de observações geram subsídios para a avaliação de elementos de desempenho técnico, funcional e comportamental. Dessa forma, "as observações têm como objetivo gerar dados sobre as atividades realizadas (como e o que as pessoas fazem), regularidades de comportamento (frequência de uso de espaços) e oportunidades e restrições de uso proporcionadas pelo projeto".

“Os métodos de observação se dirigem, fundamentalmente, para a descrição e compreensão do comportamento tal qual este ocorre naturalmente" (SELLITZ et al., 1974 p. 265). A observação pode "ser utilizada de maneira exploratória, a fim de conseguir intuições que mais tarde serão verificadas com outras técnicas" (SELLITZ et al., 1974, p. 228) e possibilita registrar situações simultaneamente com sua ocorrência espontânea, sendo, contudo, limitada 
à duração dos acontecimentos, necessitando que sejam definidos previamente os seguintes aspectos: (a) o que observar; (b) como registrar; (c) quais processos utilizar para garantir a exatidão da observação; (d) qual a relação entre o observador e a situação observada; (e) os participantes; (f) a situação; (g) o objetivo; (h) o comportamento social; (i) a frequência e a duração (SELLITZ et al., 1974; FLICK, 2009; GIL, 2010; GRAY, 2012).

Depois de construídos, os instrumentos de coleta de dados foram aplicados em caráter de préteste em uma estação para validação, possibilitando efetuar ajustes do instrumento, seja dos conteúdos, da forma de abordagem, do horário de observação, da forma de registro ou das condições de aplicação. As observações foram realizadas em diferentes períodos (Quadro 18).

Quadro 18 - Atividades de campo - Observações.

\begin{tabular}{|c|c|c|c|c|c|c|}
\hline \multirow[b]{2}{*}{ Estação } & \multicolumn{2}{|c|}{ Pico manhã } & \multicolumn{2}{|c|}{ Pico intermediário } & \multicolumn{2}{|c|}{ Pico tarde } \\
\hline & Data & $\begin{array}{c}\text { Horário } \\
\text { início/término }\end{array}$ & Data & $\begin{array}{c}\text { Horário } \\
\text { início/término }\end{array}$ & Data & $\begin{array}{c}\text { Horário } \\
\text { início/término }\end{array}$ \\
\hline \multirow{3}{*}{ Ana Rosa (pré-teste) } & $12 / 05 / 2011$ & $7 \mathrm{~h} 00 / 8 \mathrm{~h} 30$ & $31 / 05 / 2011$ & $12 \mathrm{~h} 00 / 13 \mathrm{~h} 30$ & $16 / 05 / 2011$ & $18 \mathrm{~h} 00 / 19 \mathrm{~h} 30$ \\
\hline & & & & & $30 / 05 / 2011$ & $18 \mathrm{~h} 00 / 19 \mathrm{~h} 30$ \\
\hline & & & & & 01/06/2011 & $18 \mathrm{~h} 00 / 19 \mathrm{~h} 30$ \\
\hline \multirow{4}{*}{ Ana Rosa } & $01 / 03 / 2012$ & 7h00/9h00 & $02 / 03 / 2012$ & $11 \mathrm{~h} 45 / 14 \mathrm{~h} 30$ & $28 / 02 / 2012$ & $16 \mathrm{~h} 30 / 19 \mathrm{~h} 00$ \\
\hline & $05 / 03 / 2012$ & $7 \mathrm{~h} 00 / 10 \mathrm{~h} 30$ & $05 / 03 / 2012$ & $11 \mathrm{~h} 30 / 13 \mathrm{~h} 00$ & 06/03/2012 & $16 \mathrm{~h} 30 / 19 \mathrm{~h} 00$ \\
\hline & & & 07/03/2012 & $11 \mathrm{~h} 45 / 14 \mathrm{~h} 45$ & 13/03/2012 & 17h30/19h30 \\
\hline & & & & & $07 / 05 / 2013$ & 17h00/19h00 \\
\hline \multirow{6}{*}{ Palmeiras-Barra Funda } & $15 / 08 / 2011$ & $8 \mathrm{~h} 30 / 9 \mathrm{~h} 30$ & $15 / 08 / 2011$ & $12 \mathrm{~h} 00 / 13 \mathrm{~h} 00$ & $15 / 08 / 2011$ & $18 \mathrm{~h} 00 / 19 \mathrm{~h} 00$ \\
\hline & & & $17 / 08 / 2011$ & $11 \mathrm{~h} 45 / 13 \mathrm{~h} 30$ & $17 / 08 / 2011$ & 17h30/19h30 \\
\hline & $20 / 03 / 2012$ & 7h30/9h30 & $15 / 03 / 2012$ & $11 \mathrm{~h} 00 / 13 \mathrm{~h} 00$ & 20/03/2012 & 17h00/19h50 \\
\hline & $22 / 03 / 2012$ & $6 \mathrm{~h} 30 / 9 \mathrm{~h} 30$ & $19 / 03 / 2012$ & 10h30/14h00 & $22 / 03 / 2012$ & 17h00/19h30 \\
\hline & $26 / 03 / 2012$ & $6 \mathrm{~h} 30 / 10 \mathrm{~h} 00$ & & & $26 / 03 / 2012$ & $16 \mathrm{~h} 00 / 20 \mathrm{~h} 00$ \\
\hline & $27 / 03 / 2012$ & $6 \mathrm{~h} 20 / 10 \mathrm{~h} 00$ & & & & \\
\hline \multirow{2}{*}{ Sacomã } & $10 / 08 / 2011$ & 7h40/9h00 & $10 / 08 / 2011$ & $11 \mathrm{~h} 30 / 13 \mathrm{~h} 40$ & 08/08/2011 & 18h00/19h30 \\
\hline & $25 / 08 / 2011$ & 7h30/10h00 & $22 / 08 / 2011$ & $12 \mathrm{~h} 50 / 14 \mathrm{~h} 30$ & $22 / 08 / 2011$ & 17h30/19h30 \\
\hline \multirow{3}{*}{ Tamanduateí } & $27 / 02 / 2012$ & 7h00/9h00 & $27 / 02 / 2012$ & $11 \mathrm{~h} 30 / 13 \mathrm{~h} 30$ & $27 / 02 / 2012$ & 17h00/19h00 \\
\hline & $28 / 02 / 2012$ & $6 \mathrm{~h} 30 / 9 \mathrm{~h} 00$ & $13 / 03 / 2012$ & $11 \mathrm{~h} 30 / 14 \mathrm{~h} 30$ & $19 / 03 / 2012$ & $17 \mathrm{~h} 00 / 19 \mathrm{~h} 30$ \\
\hline & $19 / 03 / 2012$ & $6 \mathrm{~h} 30 / 9 \mathrm{~h} 00$ & & & & \\
\hline Vila Prudente & $18 / 06 / 2011$ & $11 \mathrm{~h} 30 / 13 \mathrm{~h} 30$ & $16 / 06 / 2011$ & $15 h 30 / 16 h 30$ & & \\
\hline Vila Madalena & $18 / 06 / 2011$ & $9 \mathrm{~h} 00 / 11 \mathrm{~h} 00$ & $16 / 06 / 2011$ & $14 \mathrm{~h} 00 / 15 \mathrm{~h} 00$ & & \\
\hline
\end{tabular}

Fonte: Elaborado pela pesquisadora a partir dos registros de campo. (2013)

O período de observação nas estações incluiu a realização de observação de comportamento no local de embarque e desembarque, a observação de fluxo no mezanino, bem como a observação dos acompanhamentos dos treinamentos de orientação e mobilidade. 


\subsubsection{Observação de comportamento}

Segundo Ittelson, Rivlin \& Prochansky ${ }^{23}$ (1970 apud PINHEIRO, ELALI e FERNANDES, 2008), o mapeamento comportamental é um instrumento empírico que corresponde à representação gráfica das localizações e comportamentos das pessoas no espaço, possibilitando a análise crítica dessas atividades e sua comparação com aquelas que estavam planejadas para o local. Os autores recomendam que, para que sejam obtidos resultados pertinentes, a utilização do mapa comportamental deve ser acompanhada dos seguintes itens:

- diagrama representando a área observada;

- definição clara dos comportamentos observados;

- horário ou esquema das vezes que deve ocorrer a observação;

- procedimento sistemático de observação, que inclua codificação e contagem, de modo a minimizar a dificuldade de registro das observações.

Rheingantz et al (2009) esclarece que esse instrumento é muito útil para identificar usos, arranjos espaciais ou layouts, fluxos e relações espaciais observados ou ainda para indicar graficamente as interações, os movimentos e a distribuição das pessoas, seja relativamente a espaço ou tempo que permanecem no ambiente considerado. Para tanto, sugere que sejam utilizadas as seguintes técnicas de registro:

- observação direta e registro em diagramas, indicativos da localização e movimento das pessoas no ambiente;

- fotografias com lapso de tempo;

- gravação em vídeo ou câmera digital.

Para Sommer \& Sommer $^{24}$ (1987 apud PINHEIRO, ELALI e FERNANDES, 2008), a técnica pode estar "centrada no lugar" - quando o estudo é focado na ambiente, de maneira que as pessoas que passam por ele são observadas nesse momento - ou 'centrada na pessoa' quando o foco de estudo está nas pessoas, seus percursos e modo de utilização do espaço. No mapeamento centrado no lugar, os dados coletados são traduzidos em representações gráficas

23 ITTELSON, W. H., RIVLIN, L. G. \& PROSHANSKY, H. M. The use of behavioral maps in environmental psychology: man and his physical setting. Nova York: Holt, Rinehart \& Winston, 1970, p. 658-668.

${ }^{24}$ SOMMER, B. B., \& SOMMER, R. A practical guide to behavioral research, tool and techniques, Nova York: Oxford University Press, 1997. 
nas quais os diversos tipos de comportamento dos usuários são relacionados a seções específicas do espaço.

A observação do comportamento das pessoas nas áreas de embarque preferencial foi programada para ser realizada de forma presencial, nos horários de maior movimento, no início da manhã e no final da tarde, visando registrar aspectos relacionados ao embarque ou desembarque dos usuários com deficiência visual, em especial o auxílio prestado pelos funcionários/estagiários e o comportamento dos demais usuários. O tempo para aplicação do instrumento nas plataformas variou entre dois e cinco minutos, em função da chegada dos trens, provocando o acúmulo de usuários no sentido de embarque. Para aplicação desse instrumento, foram selecionadas quatro estações:

- estação Ana Rosa - estação intermediária, de conexão entre as linhas 1-Azul e 2Verde - dispõe de duas plataformas centrais que atendem a quatro diferentes destinos, com embarque e desembarque simultâneos (quatro locais de observação);

- estação Palmeiras-Barra Funda - estação terminal da Linha 3-Vermelha, de conexão com o trem metropolitano - dispõe de uma plataforma mista que atende a um único destino, com plataformas exclusivas para embarque ou desembarque (quatro locais de observação);

- estação Sacomã - estação intermediária da Linha 2-Verde - dispõe de duas plataformas laterais que atendem a dois diferentes destinos, com embarque e desembarque simultâneos (dois locais de observação);

- estação Tamanduateí - estação intermediária da Linha 2-Verde, de conexão com o trem metropolitano - dispõe de duas plataformas laterais que atendem a dois diferentes destinos com embarque e desembarque simultâneos (dois locais de observação).

Foram preparadas fichas para anotação dos comportamentos dos usuários, contendo as seguintes especificações: (a) campos para anotação da data e do horário de início e término da observação e tempo de duração da observação; (b) local, estação e plataforma, identificação das fotos relacionadas à observação; (c) representação dos comportamentos e conflitos predominantes, tais como quantidade de pessoas (com deficiência visual, preferencial, comum) para embarque e desembarque na área destinada ao embarque preferencial; (e) indicação da existência de estratégia de embarque preferencial; (f) existência ou não de 
pessoas para auxílio - usuário com deficiência visual sozinho ou acompanhado por estagiário, funcionário ou outro usuário; (g) espaço para inserção de registros fotográficos. O modelo da ficha de observação elaborada consta do Apêndice M.

Dessa forma, a primeira etapa da análise teve como objetivo organizar os dados coletados e realizar a transcrição dos registros em uma tabela, classificando as observações realizadas em cada local de embarque ou desembarque preferencial segundo diferentes parâmetros: embarque ou desembarque; com auxílio ou sem auxílio; com ou sem conflito com os demais usuários. Os conflitos observados foram transcritos, identificando-se os registros fotográficos referentes a cada um deles. As transcrições e registros foram comparados com os relatos dos usuários, obtidos no instrumento questionário, e com os relatos dos estagiários, obtidos no instrumento entrevista, a fim de estabelecer uma relação entre os achados por meio de observação e as descobertas obtidas nos demais instrumentos.

Constata-se que todos os locais de embarque preferencial nas plataformas - e nos trens - são ocupados indevidamente pelos demais usuários, o que dificulta o auxílio pelos funcionários ou estagiários, seja para embarque ou desembarque de pessoas com deficiência visual, apesar da existência de comunicação visual (Figura 41). Além da identificação visual, são emitidas mensagens sonoras reforçando a orientação para que os demais usuários respeitem o local de embarque preferencial.

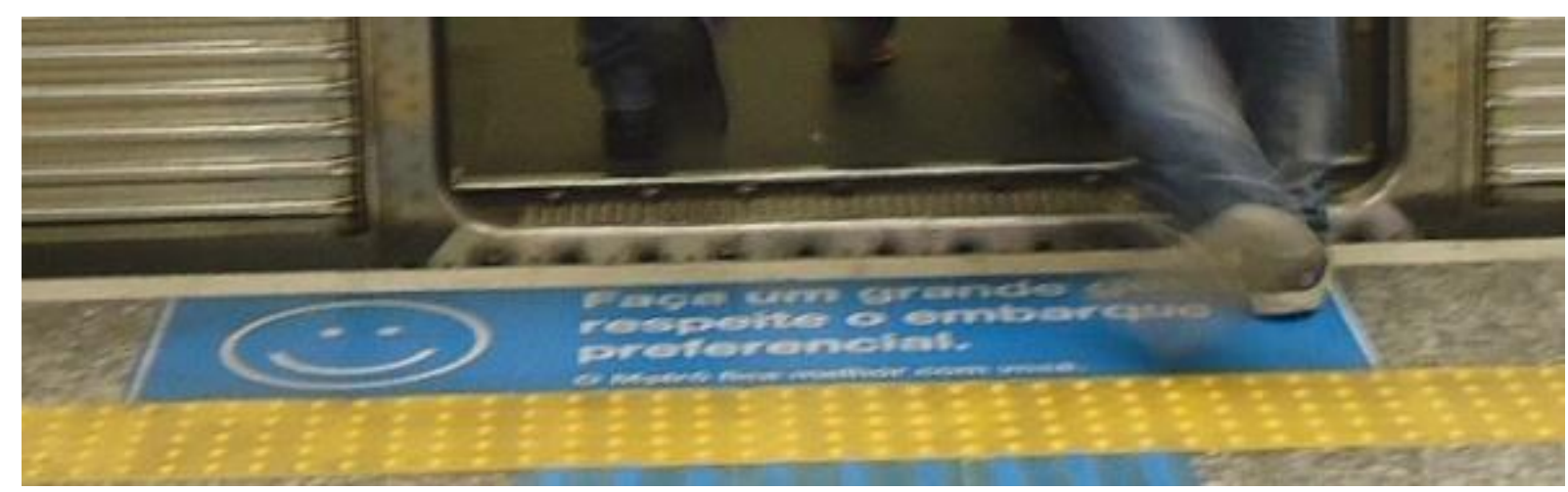

Figura 41 - São Paulo/Ana Rosa - sinalização indicativa do embarque preferencial.

Fonte: BARBOSA, M. B., 2011.

Segundo levantamento realizado pelo Metrô-SP (CMSP, 2014) a respeito da visão do usuário sobre o comportamento dos demais usuários durante a utilização do sistema metroviário, as atitudes mais desrespeitosas, que mais incomodam, ocorrem no momento do embarque ou do desembarque são as seguintes: a desconsideração do público preferencial - idosos, pessoas 
com deficiência, gestantes -; o empurra-empurra no embarque e desembarque; a permanência junto às portas do trem, atrapalhando o embarque e o desembarque.

O mesmo levantamento indica que os comportamentos que ocorrem com mais frequência nas plataformas são os seguintes: correr para pegar o trem (85\%); ficar na porta, impedindo a entrada ou saída de outros usuários do trem (81\%); ultrapassar a faixa amarela (74\%); furar a fila no hora do embarque (70\%); não esperar os usuários desembarcarem para somente depois embarcar $(70 \%)$.

A estação Ana Rosa é uma estação de conexão entre duas linhas que dispõe de duas plataformas centrais, com diferentes destinos: Jabaquara e Tucuruvi, na Linha 1-Azul, e Vila Madalena e Vila Prudente, na Linha 2-Verde (Figura 42). O tempo de parada padrão do trem nas plataformas é de 30 segundos - nos sentidos Tucuruvi e Vila Madalena - e de 25 segundos - nos sentidos Jabaquara e Vila Prudente - para embarque e desembarque simultâneos. As plataformas não têm portas de proteção; a plataforma da Linha 2-Verde, sentido Vila Madalena, dispõe de elementos organizadores de embarque.
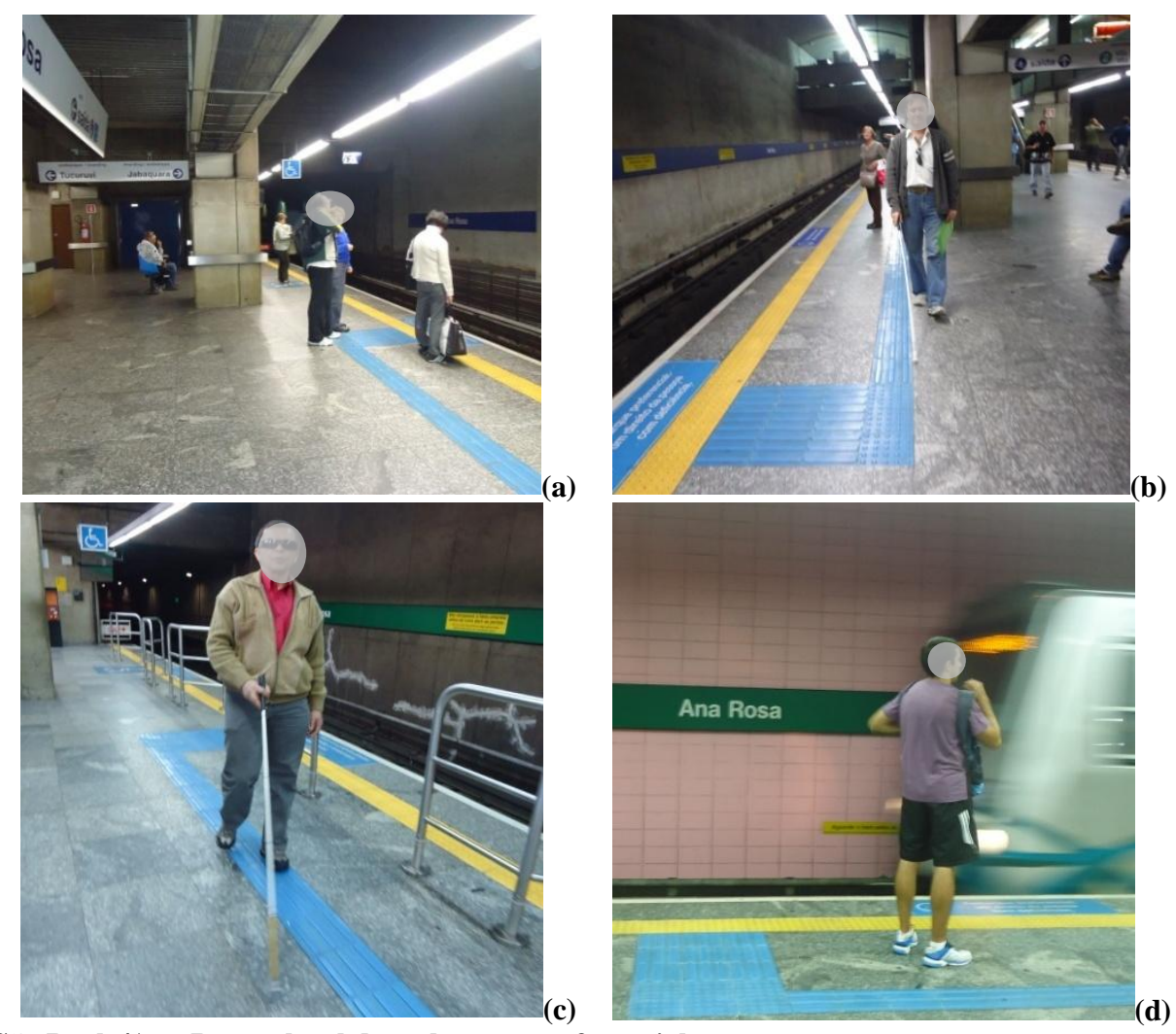

Figura 42 - São Paulo/Ana Rosa - local de embarque preferencial.

sentido (a) Jabaquara; (b) Tucuruvi; (c) Vila Madalena; (d) Vila Prudente

Fonte: BARBOSA, M.B., 2011. 
Foram realizadas 413 observações de comportamentos nas quatro plataformas da estação, das quais 46 foram realizadas após a implantação do embarque preferencial na plataforma sentido Vila Madalena. Outras quatro observações ocorreram com a presença de pessoas com deficiência visual.

A estratégia de embarque preferencial foi implantada em maio de 2013 na plataforma da Linha 2-Verde, sentido Vila Madalena, no pico da tarde, das $17 \mathrm{~h}$ às $19 \mathrm{~h}$, em todas as portas do carro líder. Antes da implantação da estratégia de embarque preferencial, a identificação do usuário e o auxílio prestado pelos funcionários e estagiários eram dificultados pela permanência indevida de pessoas no local de embarque preferencial e também no interior dos trens, junto à porta de embarque/desembarque preferencial (Figura 43). Após a implantação da estratégia, a identificação e o auxílio foram facilitados (Figura 44).
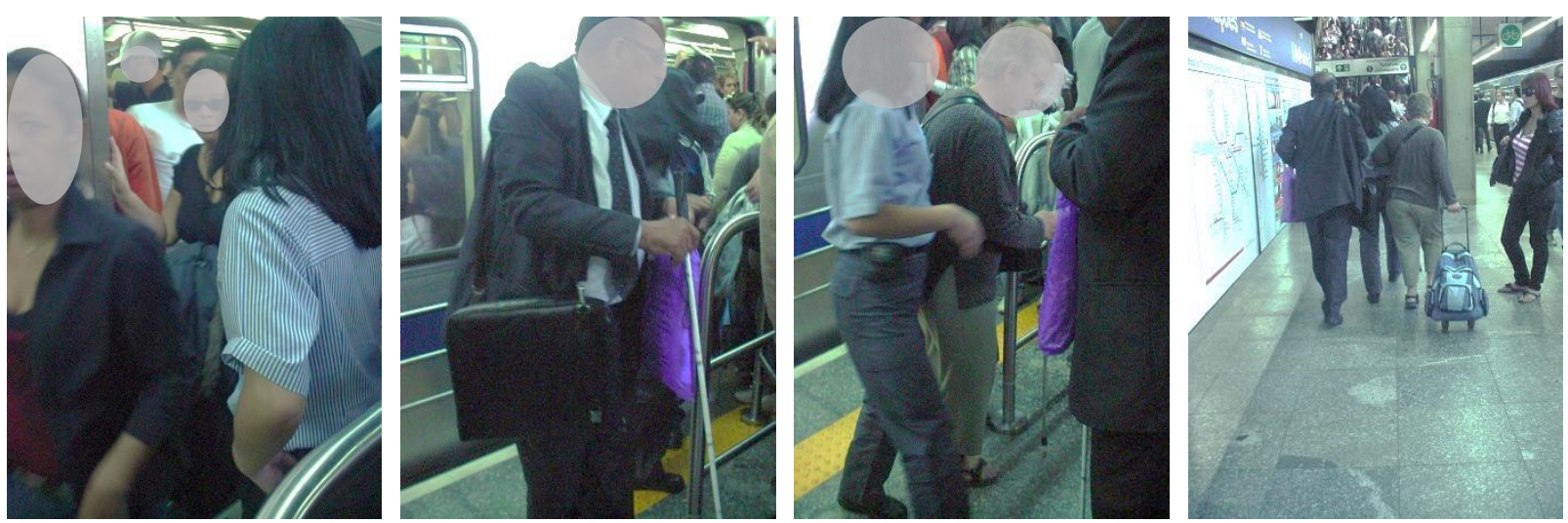

Figura 43 - São Paulo/Ana Rosa - Auxílio antes da estratégia de embarque preferencial. Fonte: BARBOSA, M. B., 2011.
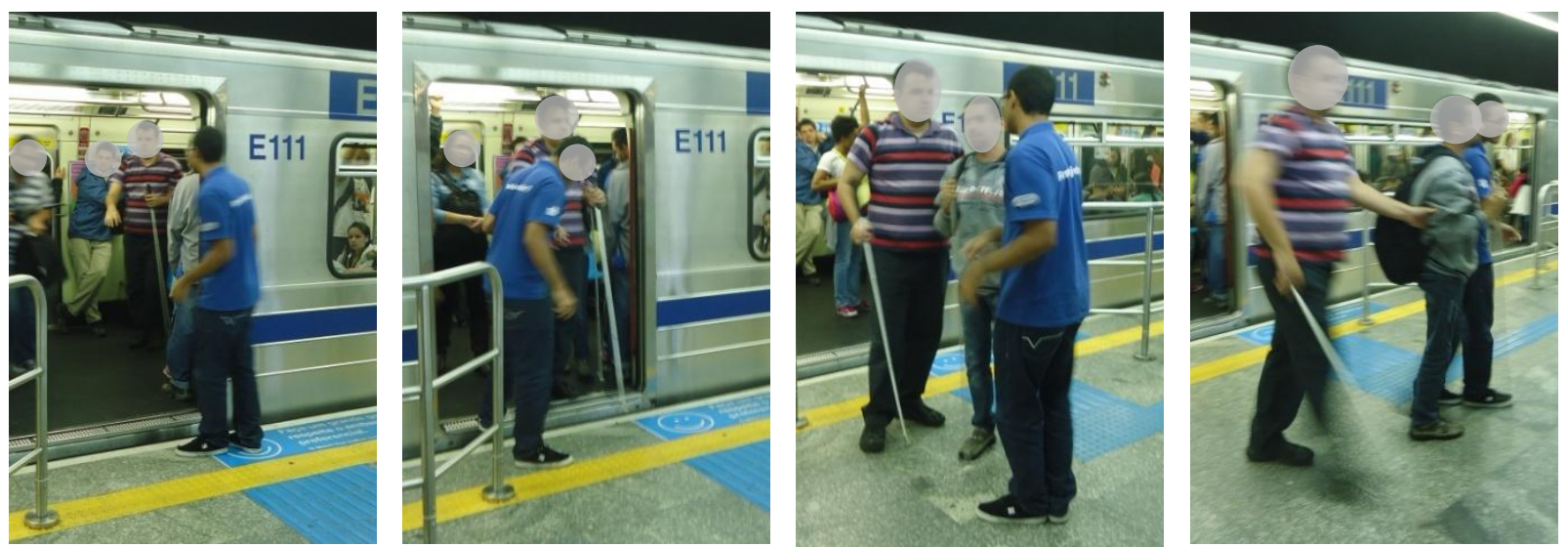

Figura 44 - São Paulo/Ana Rosa - Auxílio após a estratégia de embarque preferencial. Fonte: BARBOSA, M. B., 2013. 
Do total de observações de comportamentos nas quatro plataformas da estação, foi possível registrar o embarque de pessoas com deficiência visual em 32 observações e o desembarque de pessoas com deficiência visual em 27 (Tabela 14). Do total de 59 observações de embarque e desembarque de pessoas com deficiência visual, 19 foram classificadas como críticas, em função da existência de conflitos com os demais usuários, sendo sete no embarque e 12 no desembarque de pessoas com deficiência visual.

Tabela 14 - Embarque/desembarque preferencial na estação Ana Rosa.

\begin{tabular}{|c|c|c|c|c|c|c|c|c|}
\hline \multirow{3}{*}{ Plataforma } & \multicolumn{4}{|c|}{ Embarque } & \multicolumn{4}{|c|}{ Desembarque } \\
\hline & \multicolumn{2}{|c|}{$\begin{array}{c}\text { com } \\
\text { auxílio }\end{array}$} & \multicolumn{2}{|c|}{$\begin{array}{c}\text { com } \\
\text { independência }\end{array}$} & \multicolumn{2}{|c|}{$\begin{array}{c}\text { com } \\
\text { auxílio }\end{array}$} & \multicolumn{2}{|c|}{$\begin{array}{c}\text { com } \\
\text { independência }\end{array}$} \\
\hline & total & crítico & total & crítico & total & crítico & total & crítico \\
\hline Jabaquara & 11 & 0 & 0 & 0 & 3 & 1 & 1 & 0 \\
\hline Tucuruvi & 7 & 3 & 3 & 0 & 3 & 1 & 0 & 0 \\
\hline Vila Madalena & 1 & 0 & 1 & 1 & 9 & 4 & 3 & 0 \\
\hline Vila Prudente & 9 & 3 & 0 & 0 & 7 & 5 & 1 & 1 \\
\hline Total & 28 & 6 & 4 & 1 & 22 & 11 & 5 & 1 \\
\hline
\end{tabular}

Fonte: Elaborado pela pesquisadora a partir das observações de comportamento no local de embarque preferencial.

Como exemplo da situação vivenciada em uma das observações realizadas, muitas vezes o estagiário é obrigado a permanecer na borda da plataforma e aguardar a chegada do próximo trem para conseguir auxiliar o embarque do usuário (Figura 45). Simultaneamente, o CCO deve ser avisado quanto à identificação do trem e destino do usuário com deficiência visual. 


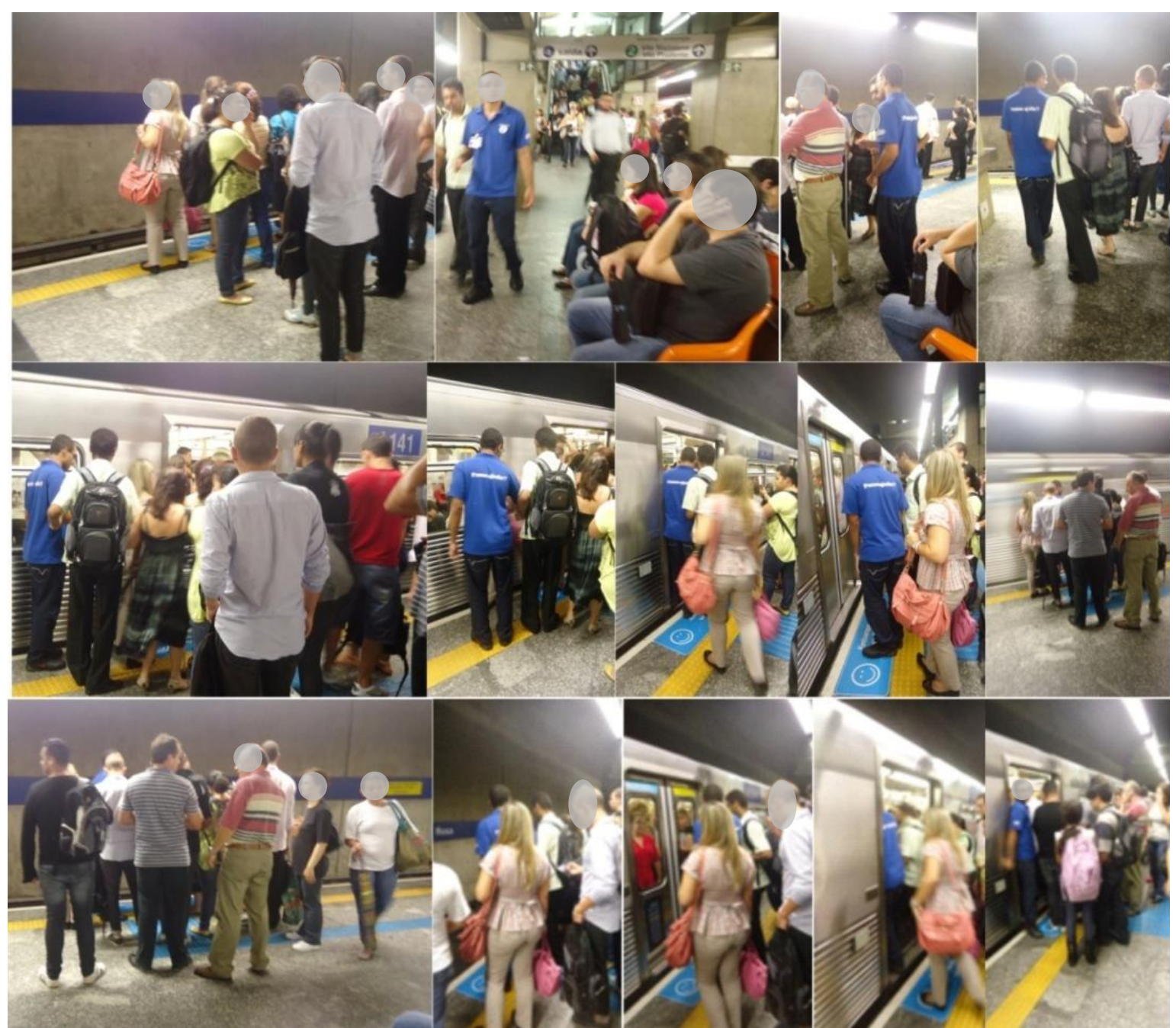

Figura 45 - São Paulo/Ana Rosa - Permanência indevida dos demais usuários no local de embarque preferencial. Fonte: BARBOSA, M. B., 2011.

Cabe salientar que existem ainda conflitos entre os usuários devido à ansiedade daqueles que estão dentro do trem e querem desembarcar antes que a porta se feche ou devido à pressa daqueles que estão na plataforma e querem embarcar. Para quem está dentro do trem, não desembarcar na estação desejada implica desembarcar na estação seguinte e embarcar em um outro trem no sentido contrário, muitas vezes implicando um deslocamento adicional até o mezanino para mudar de plataforma, o que pode levar até 12 minutos. Para quem está na plataforma, não embarcar implica esperar e tentar novamente o embarque no próximo trem, o que pode levar até três minutos.

A estação Palmeiras-Barra Funda é uma estação terminal da Linha 3-Vermelha, de conexão com o trem metropolitano, que dispõe de plataformas mistas - duas plataformas centrais e duas plataformas laterais, com um único destino: Corinthians-Itaquera. O tempo de parada padrão do trem nas plataformas é de 30 segundos. 
As plataformas não têm portas de proteção; apenas a plataforma de embarque lateral, sentido Corinthians-Itaquera, dispõe de elementos organizadores de embarque. Por ser uma estação terminal, as manobras do trem para continuidade do serviço são realizadas nesse local. Tais manobras podem acontecer antes ou depois da plataforma da estação.

Quando são realizadas depois da estação, o trem chega à estação pela via 1, abre as portas dos dois lados para permitir o desembarque dos usuários que estão dentro do trem em duas plataformas (central-1 e lateral-1), segue para a zona de manobra e retorna pela via 2, momento em que se dá o embarque dos usuários da estação a partir de duas diferentes plataformas (central-2 e lateral-2). Nesse caso, há um único fluxo, ora de embarque ora de desembarque.

Quando as manobras são realizadas antes da estação, o trem chega pela via 2, abre as portas de um lado para permitir o desembarque dos usuários que estão dentro do trem em uma plataforma (central-2) e, em seguida, abre a porta do outro lado (lateral-2) para permitir o embarque dos usuários que estão na estação nas duas plataformas (central-2 e lateral-2) (Figura 46).

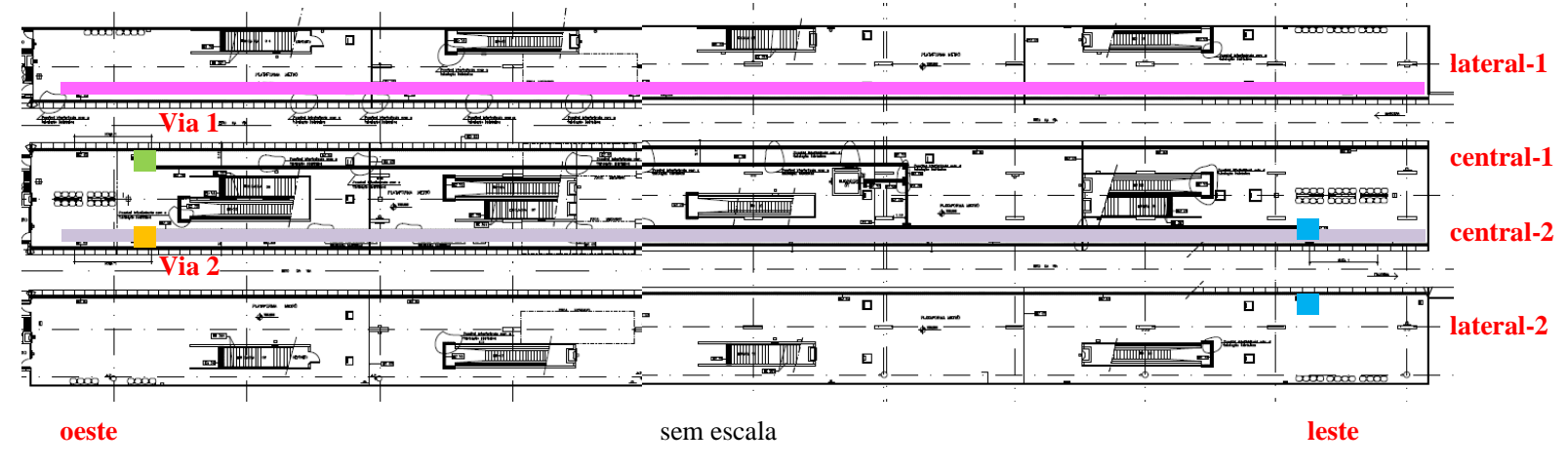

Manobra do trem antes da plataforma

Manobra do trem depois da plataforma

desembarque dos demais usuários

desembarque preferencial

embarque preferencial

desembarque dos demais usuários

desembarque preferencial

embarque preferencial

Figura 46 - São Paulo - Plataforma mista para embarque e desembarque. Fonte: Elaborado pela pesquisadora a partir de desenho fornecido pela CMSP.

O desembarque preferencial é realizado na extremidade oeste, na plataforma central-1 (Figura 47). O embarque preferencial é realizado na extremidade leste, nas plataformas central-2 e lateral-2 (Figura 48). A estratégia de embarque preferencial nas plataformas central-2 e lateral-2 foi implantada em 2007, das 6h às 9h (pico da manhã) e das $16 \mathrm{~h}$ às 19h30min (pico da tarde), em todas as portas do carro líder. 


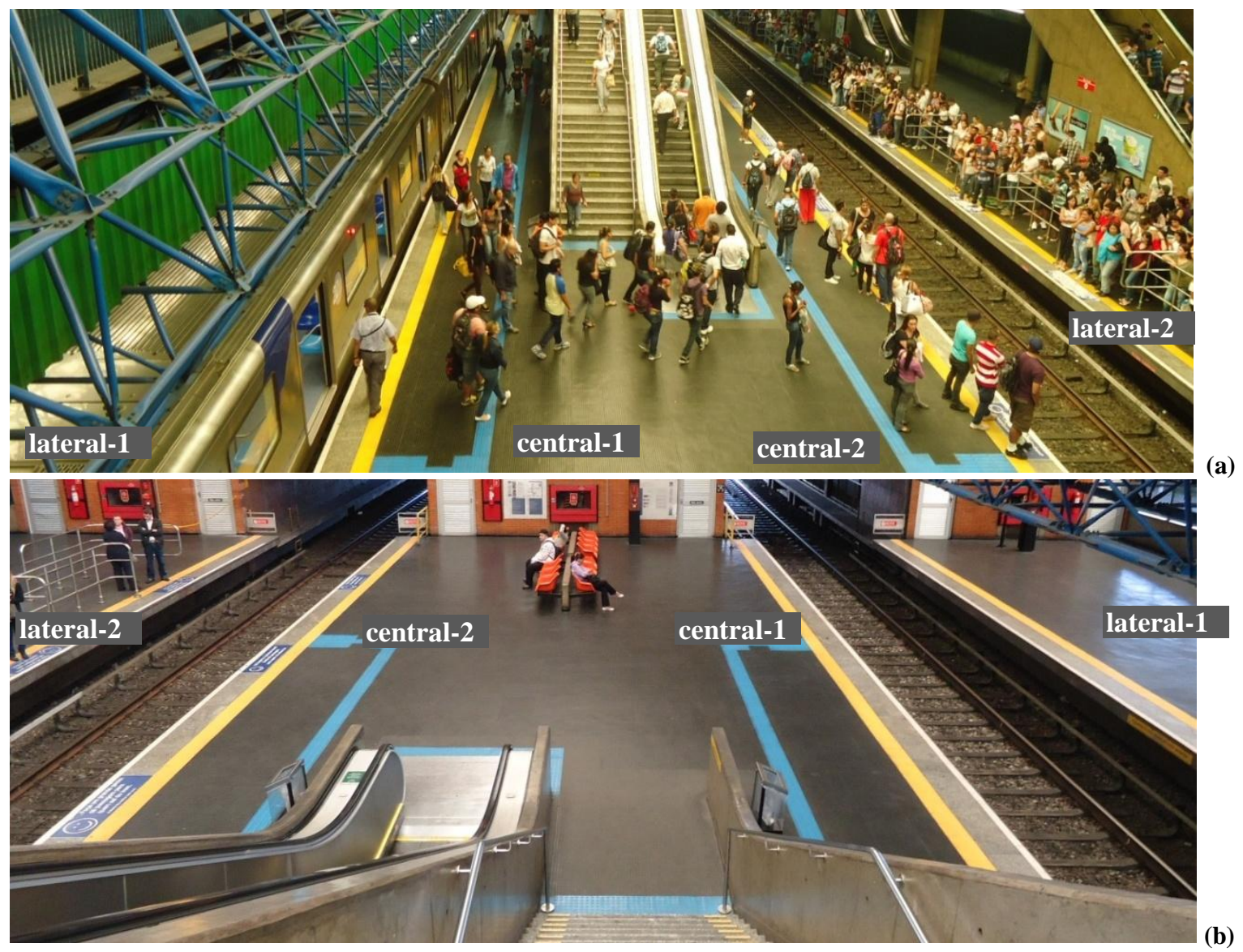

Figura 47 - São Paulo/Palmeiras-Barra Funda - locais de desembarque preferencial

Plataforma central-1 e central-2 - lado oeste (a e b).

Fonte: BARBOSA, M. B., 2013.
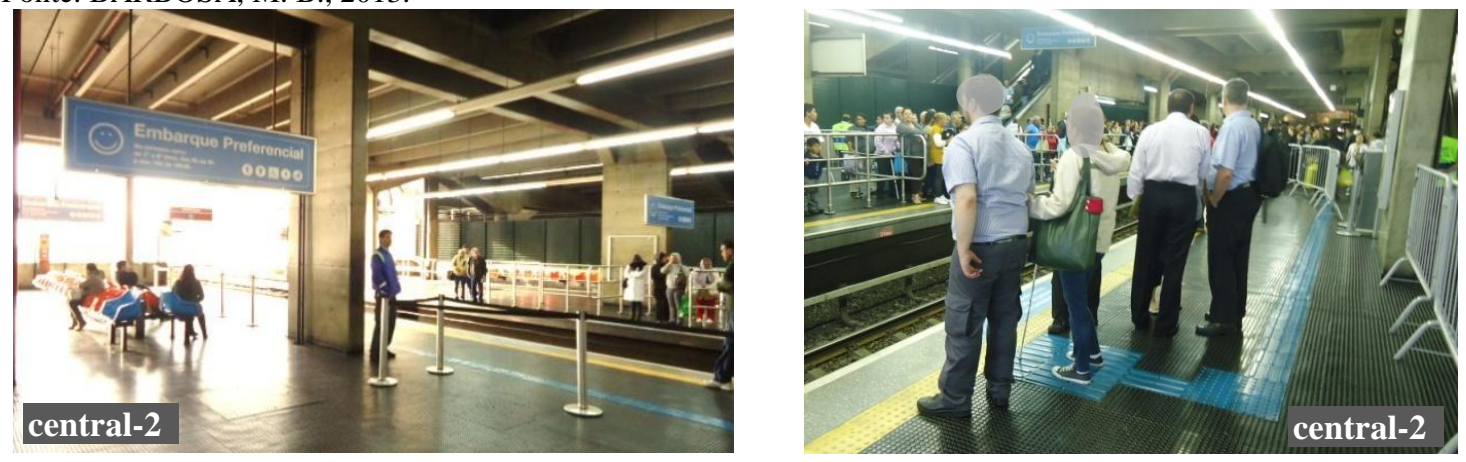

(b)
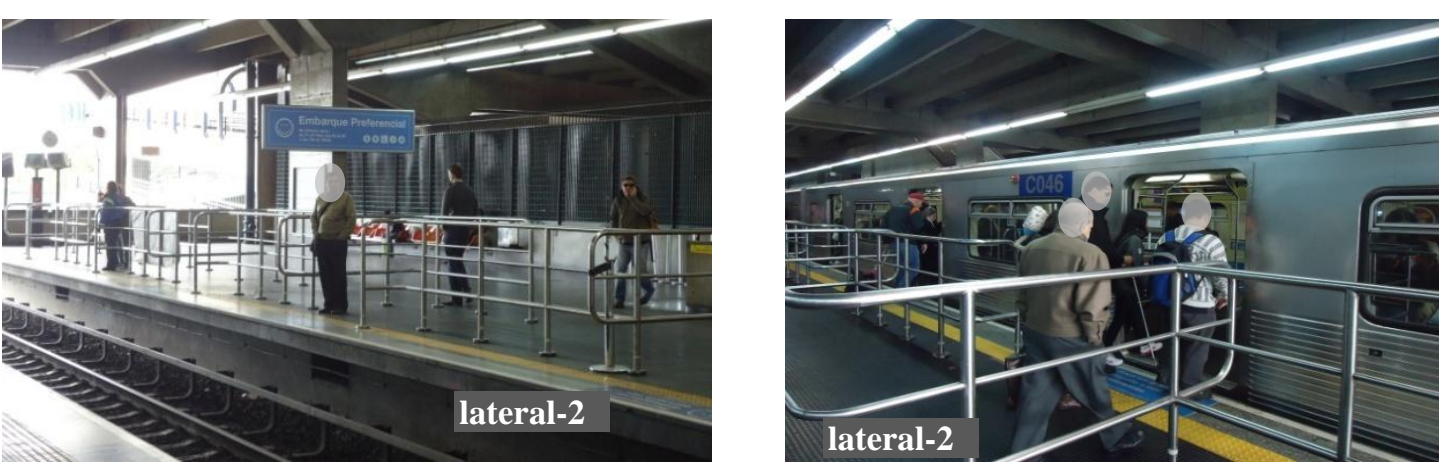

Figura 48 - São Paulo/Palmeiras-Barra Funda - locais de embarque preferencial Plataforma central-2 (c) e lateral-2 (d).

Fonte: BARBOSA, M. B., 2013. 
Foram realizadas 313 observações de comportamentos nas quatro plataformas da estação, sendo possível registrar o embarque de pessoas com deficiência visual em 40 observações, e o desembarque de pessoas com deficiência visual em 47 dessas observações (Tabela 15). Do total de 87 observações de embarque e desembarque de pessoas com deficiência visual, 43 foram classificadas como críticas em função da existência de conflitos com os demais usuários ou por causa da estratégia de manobra dos trens, sendo 15 no embarque e 28 no desembarque de pessoas com deficiência visual.

Tabela 15 - Embarque/desembarque preferencial na estação Palmeiras-Barra Funda.

\begin{tabular}{|c|c|c|c|c|c|c|c|c|}
\hline \multirow{3}{*}{ Plataforma } & \multicolumn{4}{|c|}{ Embarque } & \multicolumn{4}{|c|}{ Desembarque } \\
\hline & \multicolumn{2}{|c|}{$\begin{array}{c}\text { Com } \\
\text { auxílio }\end{array}$} & \multicolumn{2}{|c|}{$\begin{array}{c}\text { Com } \\
\text { independência }\end{array}$} & \multicolumn{2}{|c|}{$\begin{array}{c}\text { Com } \\
\text { auxílio }\end{array}$} & \multicolumn{2}{|c|}{$\begin{array}{c}\text { Com } \\
\text { independência }\end{array}$} \\
\hline & total & crítico & total & crítico & total & crítico & total & crítico \\
\hline lateral-2 & 22 & 10 & 6 & 2 & 0 & 0 & 0 & 0 \\
\hline central-2 & 7 & 2 & 5 & 1 & 2 & 2 & 0 & 0 \\
\hline central-1 & 0 & 0 & 0 & 0 & 32 & 17 & 10 & 6 \\
\hline lateral-1 & 0 & 0 & 0 & 0 & 1 & 1 & 2 & 2 \\
\hline Total & 29 & 12 & 11 & 3 & 35 & 20 & 12 & 8 \\
\hline
\end{tabular}

Fonte: Elaborado pela pesquisadora a partir das observações de comportamentos no local de embarque preferencial.

Como exemplo de situações críticas vivenciadas durante as observações realizadas, destaquese o desembarque indevido do usuário com deficiência visual na plataforma lateral-1 quando a manobra do trem é realizada depois da estação -, obrigando o estagiário ou funcionário a atravessar o trem para prestar auxílio (Figura 49).
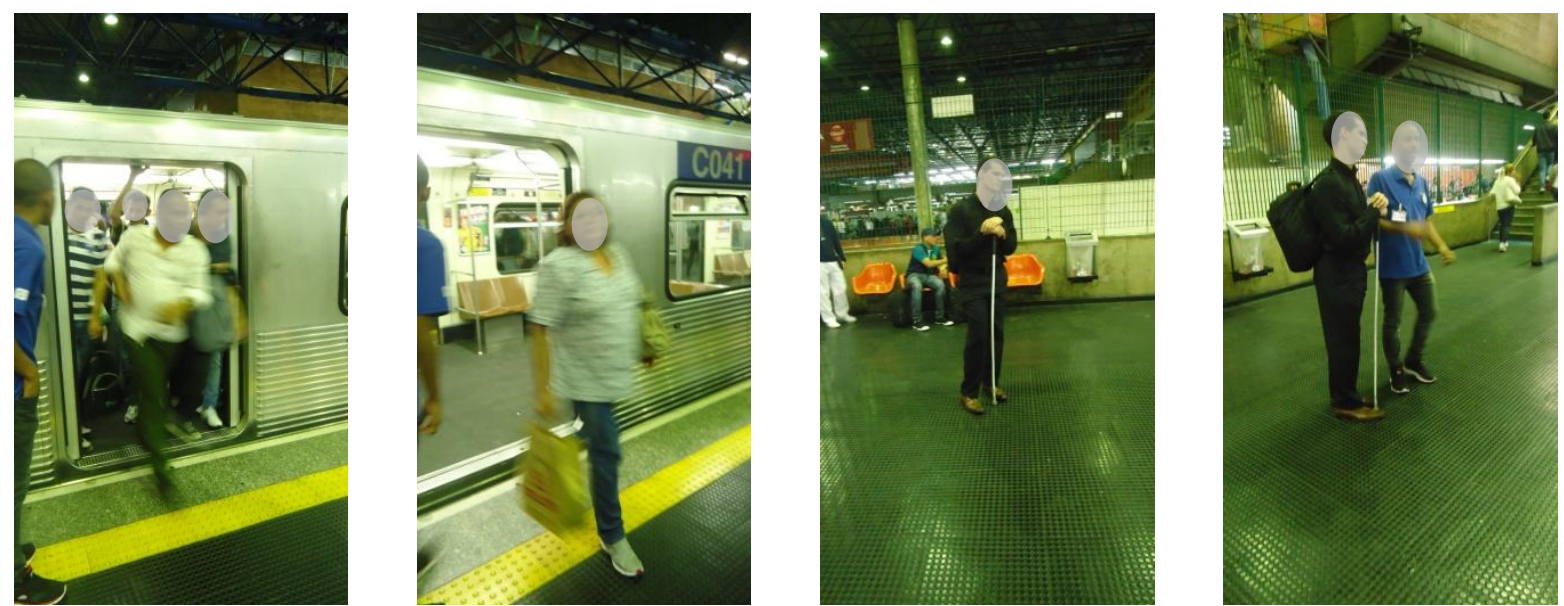

Figura 49 - São Paulo/Palmeiras-Barra Funda - Desembarque na plataforma lateral-1. Fonte: BARBOSA, M. B., 2011.

Outra situação crítica acontece no desembarque realizado na plataforma central-2, quando a manobra do trem é realizada antes da estação. O usuário com deficiência visual, acostumado ao desembarque na porta esquerda do trem, posiciona-se junto à porta fechada do trem, 
obrigando o estagiário ou funcionário a entrar no trem para prestar auxílio em meio ao desembarque e ao embarque dos demais usuários, conforme demonstra a Figura 50.
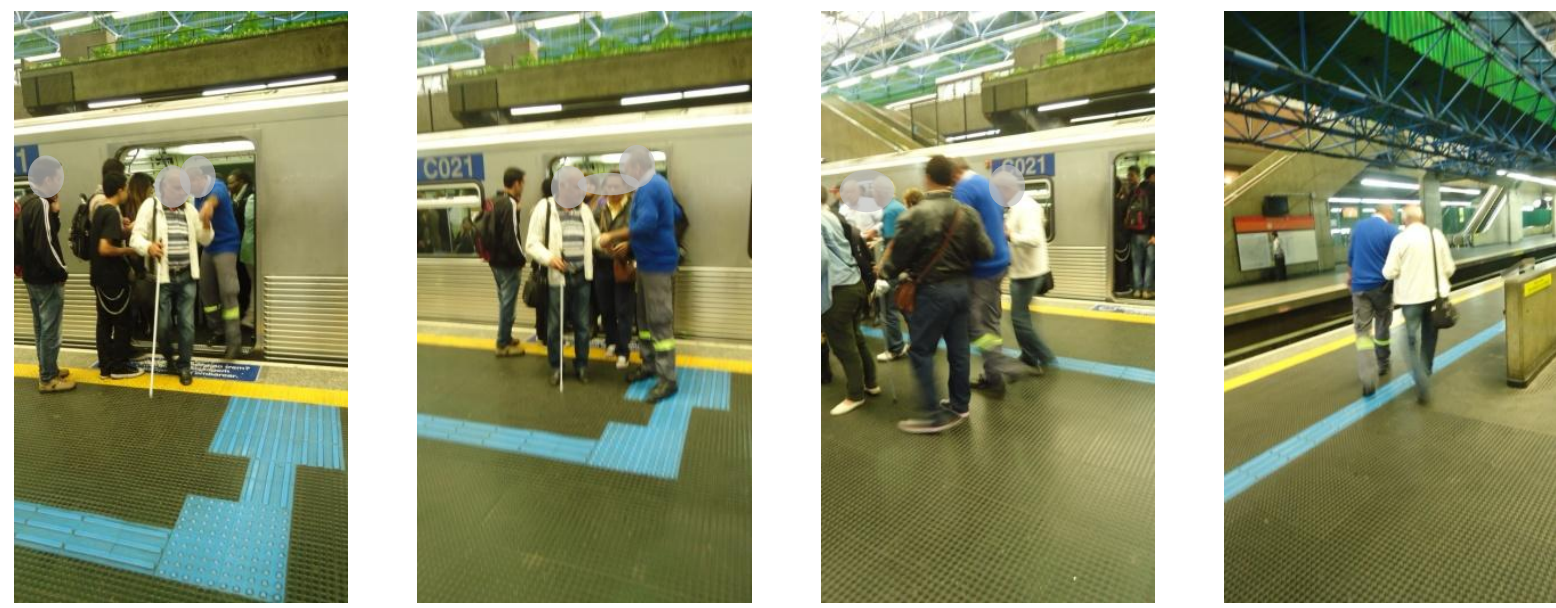

Figura 50 - São Paulo/Palmeiras-Barra Funda - Desembarque na plataforma central-2. Fonte: BARBOSA, M. B., 2011.

Ainda como situação crítica de desembarque, é digno de nota o tempo de espera por atendimento, pois a pessoa com deficiência desembarca, e o estagiário ou funcionário não está à sua espera. Nessa situação, muitos aceitam ajuda de outros usuários, ainda que desconhecidos (Figura 51); outros aguardam a chegada de funcionários ou estagiários.
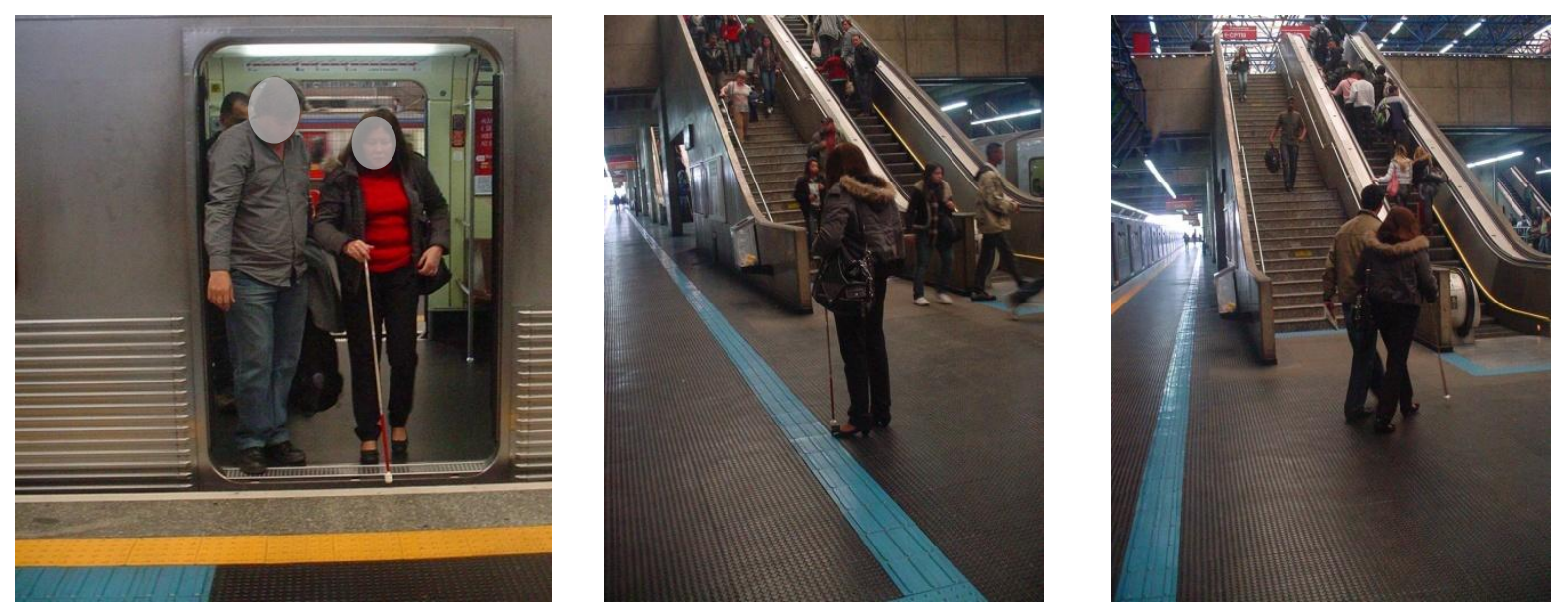

Figura 51 - São Paulo/Palmeiras-Barra Funda - Desembarque na plataforma central-1.

Fonte: BARBOSA, M. B., 2011.

Com relação ao embarque, evidenciou-se, assim como em outras estações, a dificuldade no auxílio prestado pelos estagiários e funcionários devido à presença de outros usuários no local de embarque preferencial. A dificuldade deveu-se, em grande parte, pelo posicionamento indevido dos demais usuários no local preferencial (Figura 52). 

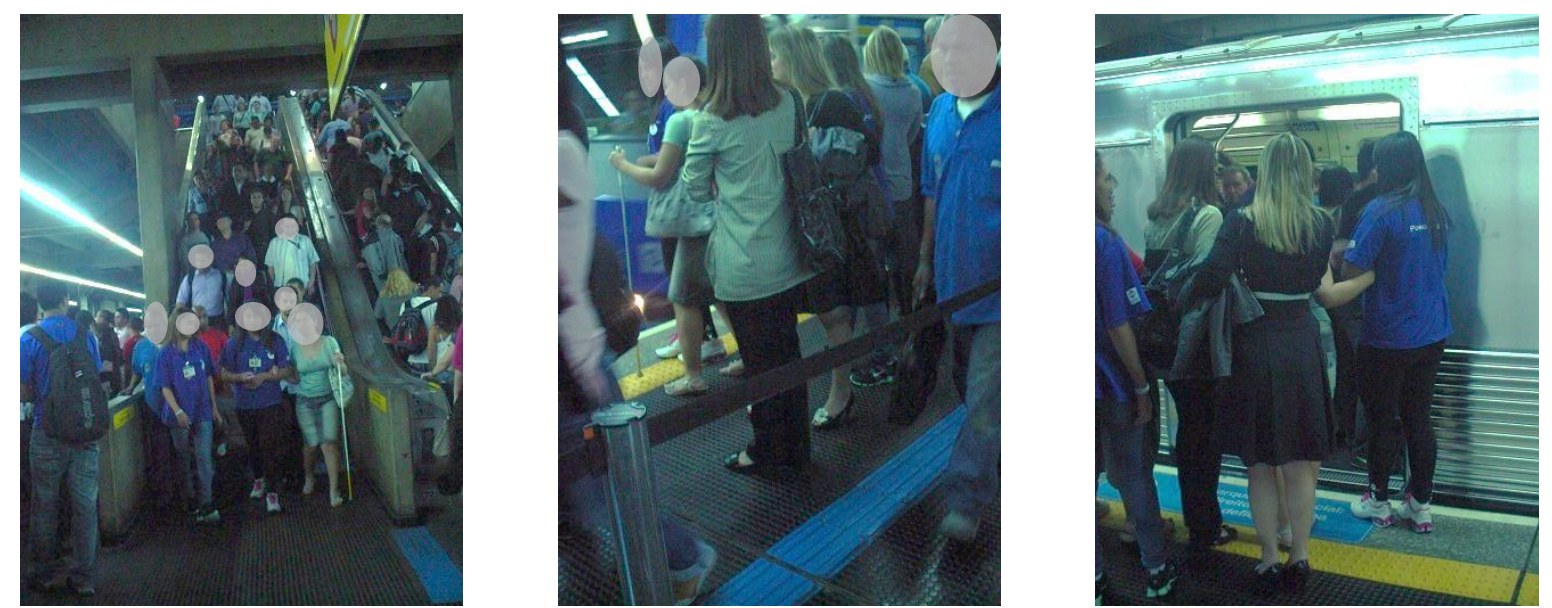

Figura 52 - São Paulo/Palmeiras-Barra Funda - Embarque com auxílio na plataforma central-2.

Fonte: BARBOSA, M. B., 2011.

Apesar disso, há que se registrar também o êxito de alguns usuários, que, de forma independente, embarcam em meio aos demais usuários preferenciais (Figura 53).
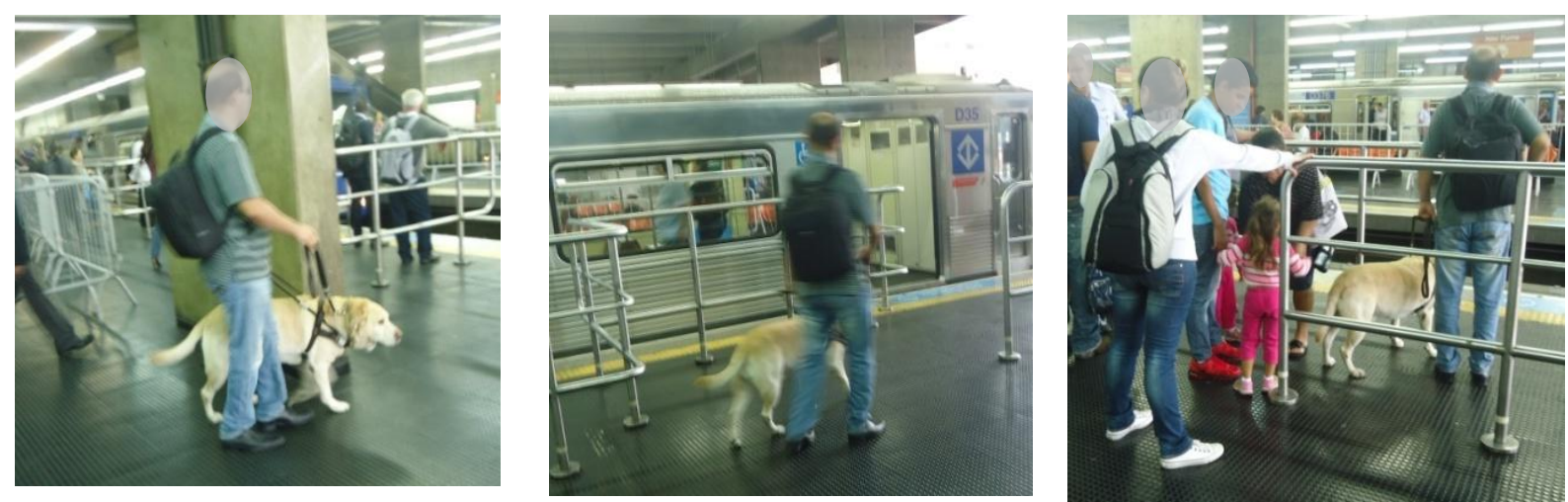

Figura 53 - São Paulo/Palmeiras-Barra Funda - Embarque independente na plataforma lateral-2. Fonte: BARBOSA, M. B., 2013.

A estação Sacomã é uma estação intermediária da Linha 2-Verde que dispõe de plataformas laterais com destino a Vila Madalena e Vila Prudente. O tempo de parada padrão do trem nas plataformas é de 15 segundos - sentido Vila Madalena - e de 30 segundos - sentido Vila Prudente - para embarque e desembarque simultâneos. As plataformas têm portas de proteção. Não há estratégia de embarque preferencial nessa estação.

Foram realizadas 128 observações de comportamentos nas duas plataformas da estação Sacomã, sendo possível registrar o embarque de pessoas com deficiência visual em 10 oportunidades, bem como o desembarque de pessoas com deficiência visual em 9 ocasiões (Tabela 16). Do total de 19 observações de embarque e desembarque de pessoas com deficiência visual, 4 foram classificadas como críticas em função da existência de conflitos com os demais usuários, sendo 2 no embarque e 2 no desembarque de pessoas com deficiência visual. 
Tabela 16 - Embarque/desembarque preferencial na estação Sacomã.

\begin{tabular}{|c|c|c|c|c|c|c|c|c|}
\hline \multirow{3}{*}{ Plataforma } & \multicolumn{4}{|c|}{ Embarque } & \multicolumn{4}{|c|}{ Desembarque } \\
\hline & \multicolumn{2}{|c|}{$\begin{array}{c}\text { com } \\
\text { auxílio }\end{array}$} & \multicolumn{2}{|c|}{$\begin{array}{c}\text { com } \\
\text { independência }\end{array}$} & \multicolumn{2}{|c|}{$\begin{array}{c}\text { com } \\
\text { auxílio }\end{array}$} & \multicolumn{2}{|c|}{$\begin{array}{c}\text { com } \\
\text { independência }\end{array}$} \\
\hline & total & crítico & total & crítico & total & crítico & total & crítico \\
\hline Vila Madalena & 8 & 1 & 2 & 1 & 1 & 0 & 0 & 0 \\
\hline Vila Prudente & 0 & 0 & 0 & 0 & 6 & 2 & 2 & 0 \\
\hline Total & 8 & 1 & 2 & 1 & 7 & 2 & 2 & 0 \\
\hline
\end{tabular}

Fonte: Elaborado pela pesquisadora a partir das observações de comportamentos no local de embarque preferencial.

Como exemplo das situações críticas vivenciadas durante as observações realizadas, tem-se a presença indevida de outros usuários nos locais de embarque preferencial, tanto na plataforma como no interior do trem (Figura 54).

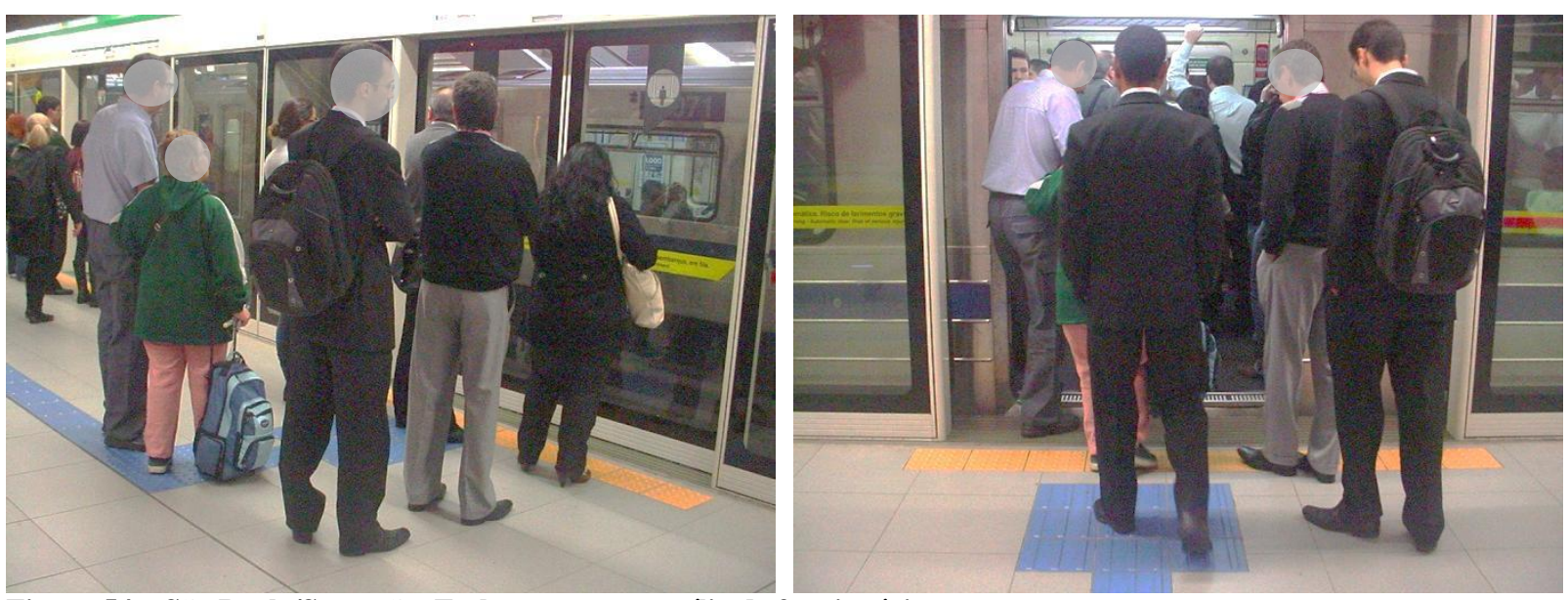

Figura 54 - São Paulo/Sacomã - Embarque com auxílio de funcionário Fonte: BARBOSA, M. B., 2011.

Em função da demanda moderada ao longo do dia, foram presenciadas situações de deslocamento e embarque com independência (Figura 55).
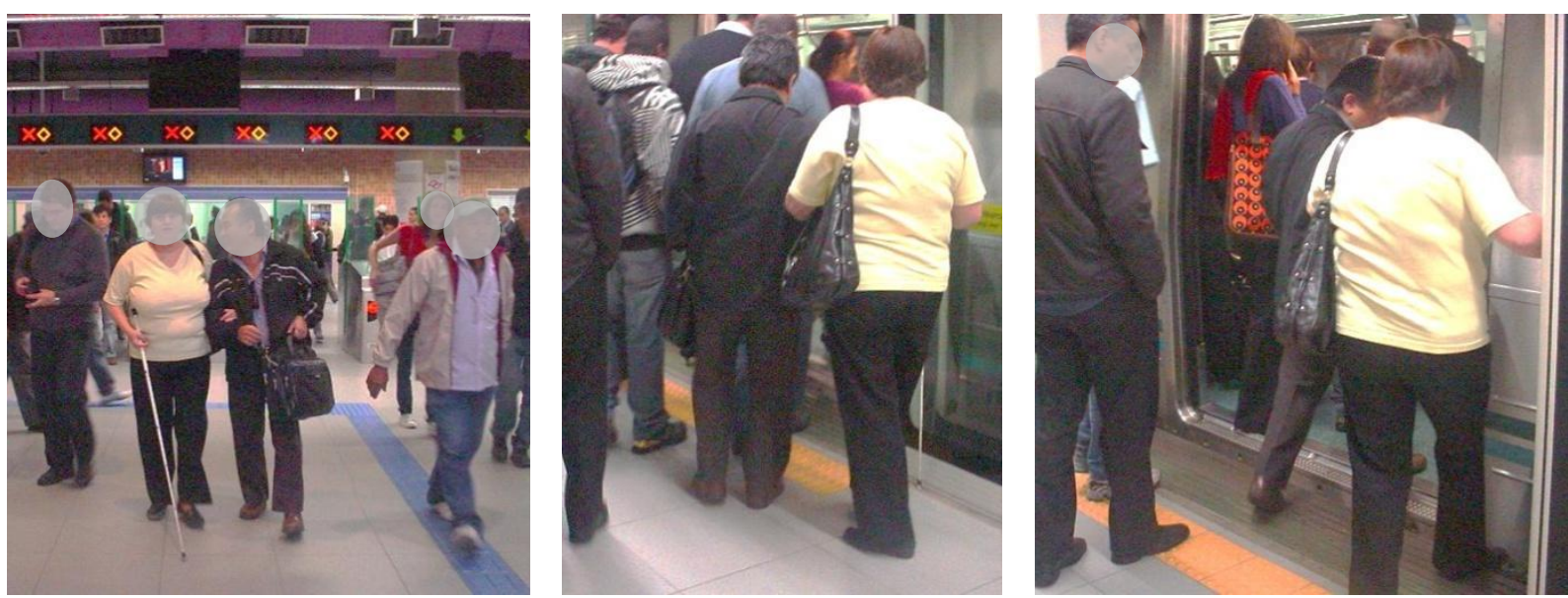

Figura 55 - São Paulo/Sacomã - Embarque com auxílio de acompanhante. Fonte: BARBOSA, M. B., 2011. 
A estação Tamanduateí é uma estação intermediária da Linha 2-Verde e dispõe de plataformas laterais com destino a Vila Madalena e Vila Prudente. O tempo de parada padrão do trem nas plataformas é de 15 segundos - sentido Vila Madalena - e de 30 segundos sentido Vila Prudente - para embarque e desembarque simultâneos. As plataformas têm portas de proteção. Não há estratégia de embarque preferencial nessa estação.

Foram realizadas 35 observações de comportamentos nas duas plataformas da estação Tamanduateí, sendo possível registrar o embarque de pessoas com deficiência visual em quatro observações e o desembarque de pessoas com deficiência visual em seis dessas observações, conforme Tabela 17. Do total de 10 observações de embarque e desembarque de pessoas com deficiência visual, três foram classificadas como críticas, em função da existência de conflitos com os demais usuários, sendo uma no embarque e duas no desembarque de pessoas com deficiência visual.

Tabela 17 - Embarque/desembarque preferencial na estação Tamanduateí.

\begin{tabular}{|c|c|c|c|c|c|c|c|c|}
\hline \multirow{3}{*}{ Plataforma } & \multicolumn{4}{|c|}{ Embarque } & \multicolumn{4}{|c|}{ Desembarque } \\
\hline & \multicolumn{2}{|c|}{$\begin{array}{c}\text { Com } \\
\text { auxílio }\end{array}$} & \multicolumn{2}{|c|}{$\begin{array}{c}\text { Com } \\
\text { independência }\end{array}$} & \multicolumn{2}{|c|}{$\begin{array}{c}\text { Com } \\
\text { auxílio }\end{array}$} & \multicolumn{2}{|c|}{$\begin{array}{c}\text { Com } \\
\text { independência } \\
\end{array}$} \\
\hline & total & crítico & total & crítico & total & crítico & total & crítico \\
\hline Vila Madalena & 2 & 0 & 2 & 1 & 0 & 0 & 0 & 0 \\
\hline Vila Prudente & 0 & 0 & 0 & 0 & 4 & 2 & 2 & 0 \\
\hline Total & 2 & 0 & 2 & 1 & 4 & 2 & 2 & 0 \\
\hline
\end{tabular}

Fonte: Elaborado pela pesquisadora a partir das observações de comportamento no local de embarque preferencial.

Como exemplo das situações críticas vivenciadas durante as observações realizadas, mencione-se a presença indevida de usuários nos locais de embarque preferencial tanto na plataforma como no interior do trem (Figuras 56 e 57). Em função da demanda moderada ao longo do dia, não há conflito de embarque ou desembarque.
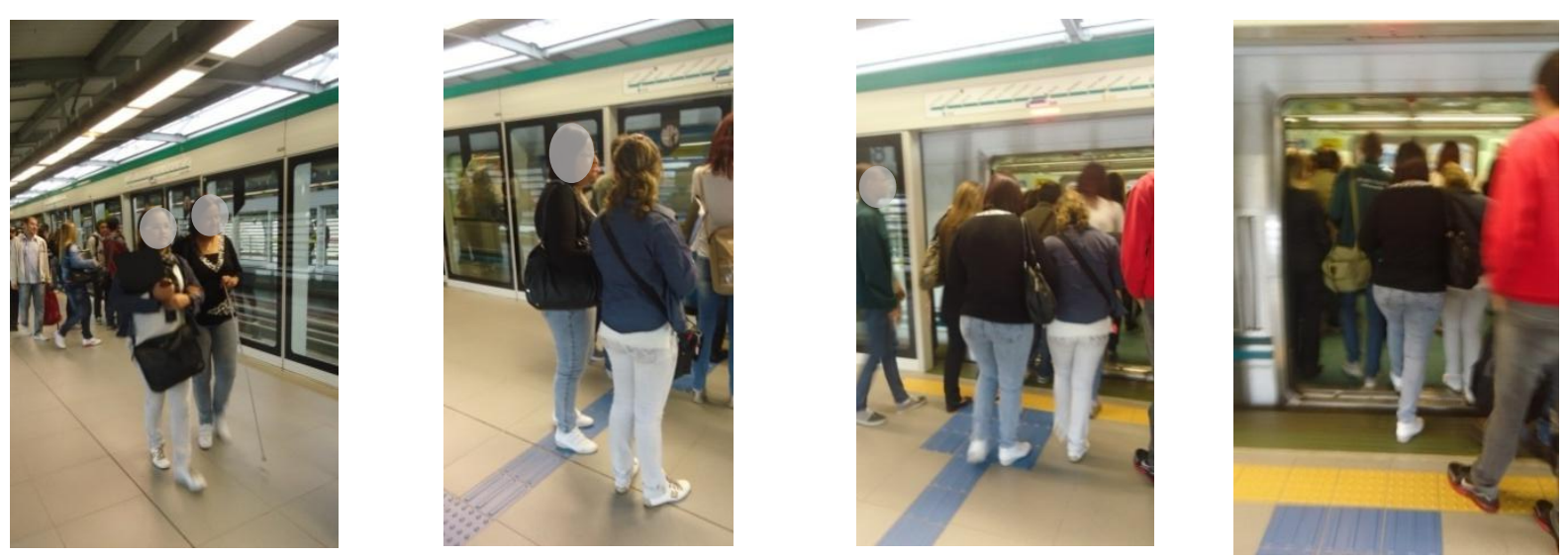

Figura 56 - São Paulo/Tamanduateí - Embarque com auxílio de estagiário.

Fonte: BARBOSA, M. B., 2011. 

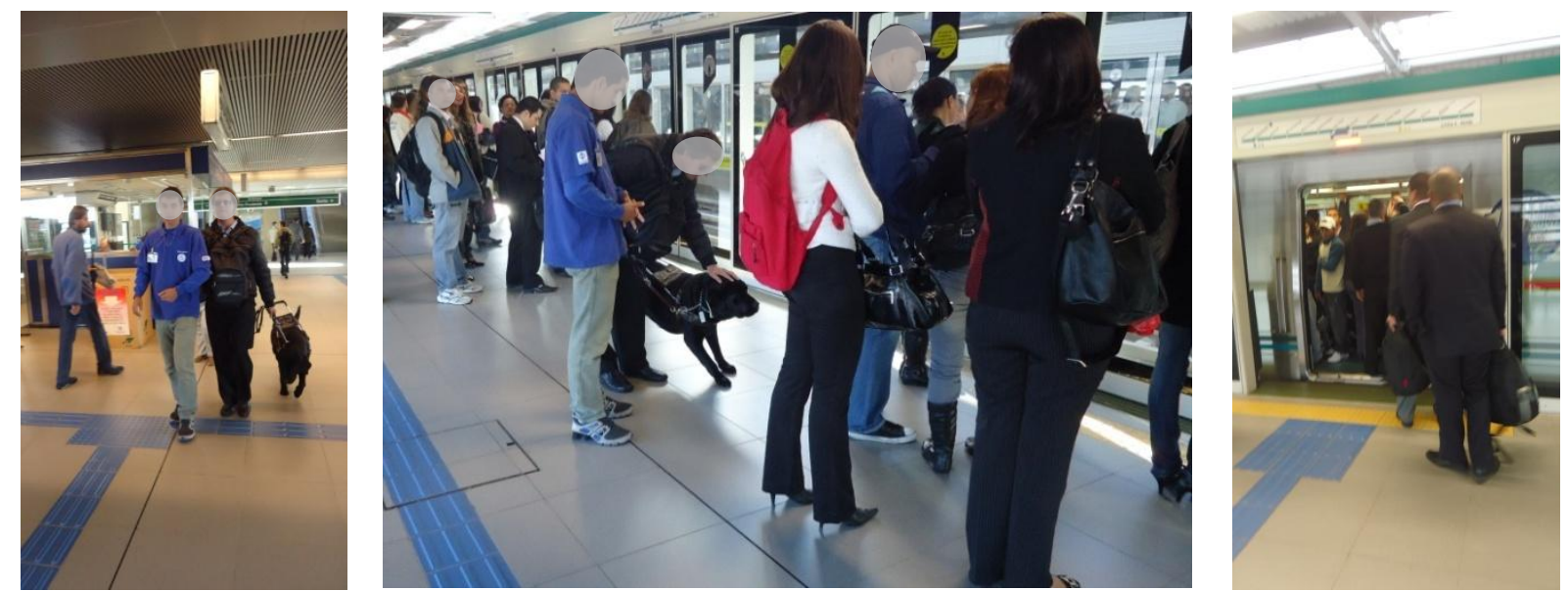

Figura 57 - São Paulo/Tamanduateí - Embarque de usuário e cão-guia com auxílio de estagiário. Fonte: BARBOSA, M. B., 2011.

As observações de comportamento realizadas nos locais de embarque e desembarque preferencial mostraram que vários fatores interferem e impactam essa etapa da viagem, sendo os mais significativos a lotação nas plataformas e nos trens; a existência de fluxos bidirecionais de embarque e desembarque simultâneos (plataformas centrais ou laterais) ou fluxos unidirecionais de embarque ou desembarque alternados (plataformas mistas); a presença e o comportamento dos demais usuários, preferenciais ou não; a postura dos estagiários e funcionários diante das ocorrências, seja em relação ao $\mathrm{CCO}$, à pessoa com deficiência visual ou aos demais usuários, no sentido de garantir o embarque e o desembarque com segurança. Nesse sentido, o ambiente existente - a configuração e a sinalização das plataformas - tem impacto nessa etapa quando associadas ao serviço prestado - sejam as estratégias de embarque preferencial ou de manobra dos trens (no caso das estações terminais).

Mais do que o ambiente, o comportamento dos demais usuários é decisivo para garantir a segurança das pessoas com deficiência visual: os comportamentos desrespeitosos são atribuídos às pessoas e não ao serviço oferecido, ainda que seja considerado o aspecto da lotação das plataformas. Tais comportamentos desrespeitosos às pessoas e às regras estabelecidas pela operadora do serviço, tidos como consequência do estilo de vida conturbado e estressante, levam à intolerância entre as pessoas, ao individualismo nos espaços públicos e equipamentos coletivos, à preferência pelas conexões virtuais em relação às interações pessoais e à ausência de vínculos - seja com as pessoas ou com os ambientes. 


\subsubsection{Observação de fluxo}

Fluxos são percursos-padrão utilizados pelos usuários, que se repetem no tempo e no espaço, nos ambientes internos e externos. A representação gráfica dos fluxos é denominada de mapa de fluxo. Por meio desse instrumento, podem-se analisar os diversos fluxos quanto à sua origem, frequência, usuários, maneira como ocorrem (organizados ou não) e intercorrências, tais como podem-se citar:

- pontos de cruzamento de fluxos, com possibilidade de conflitos;

- obstáculos no percurso;

- incompatibilidade de fluxos em um mesmo percurso.

A vantagem desse instrumento é sua elaboração em tempo real. Por outro lado, tem como desvantagem a necessidade de diferentes observadores, num amplo período de tempo e restritos à área a ser observada. Em sua aplicação, deve-se estabelecer com clareza seus limites, tanto em relação aos períodos de tempo em que se realizam as observações, como na demarcação das áreas a serem observadas e aos grupos de usuários a que se referem.

A observação de fluxo no mezanino - área paga - foi programada para ser realizada de forma presencial nos horários de maior movimento (início da manhã, meio do dia e final da tarde), visando registrar aspectos relacionados aos deslocamentos dos usuários com deficiência visual, em especial o auxílio prestado pelos funcionários/estagiários e o comportamento dos demais usuários, as estratégias de organização de fluxos junto às escadas fixas e rolantes e bloqueios de entrada/saída.

Tal escolha foi motivada pelo conhecimento prévio da existência de conflitos na circulação nesses locais, relatados pelos supervisores e estagiários das estações nas entrevistas e pelos usuários nos questionários aplicados. A observação dos fluxos no mezanino possibilitou identificar também as rotas acessíveis utilizadas para embarque preferencial, os comportamentos predominantes e o percurso de embarque, desembarque e conexão dos usuários com deficiência visual, auxiliados pelos estagiários ou com autonomia, momentos em que foram feitas anotações sobre as circulações horizontais e verticais, os fluxos predominantes e eventuais gargalos. 
No instrumento elaborado, destacam-se as informações sobre a demanda, a anotação da data e do horário de início e término da observação, os desenhos em escala/croquis representativos das áreas observadas, onde foram registrados (a) os espaços institucionais, comerciais, culturais ou de serviços; (b) o piso tátil de orientação para pessoas com deficiência visual; (c) os demais elementos intrínsecos ao serviço metroferroviário. A contagem do número de pessoas em cada sentido ou local não era objetivo final ou principal. As observações do mezanino foram realizadas em dez minutos, em função do intervalo entre trens e do tempo necessário para o deslocamento dos usuários entre as plataformas e o mezanino e vice-versa.

Foram padronizadas as legendas e a simbologia de representação, utilizando codificação em cores para indicar (a) fluxos predominantes para embarque, desembarque e transferência/conexão entre cada uma das linhas existentes; (b) fluxos dos usuários com deficiência visual, com e sem acompanhamento de empregados; (c) identificação de pontos de cruzamento e de conflitos de fluxo; (d) incompatibilidade de fluxos e de gargalos; (e) identificação de estratégias de contorno em cada local, elementos ou pessoas alocadas para orientação do fluxo; (f) existência de obstáculos na rota acessível. O modelo da ficha de observação elaborada consta do Apêndice N.

A primeira etapa da análise teve como objetivo organizar os dados coletados e realizar a transcrição dos registros em uma tabela, classificando as observações realizadas segundo padrões e temas que pudessem ser organizados em categorias - trajetos realizados; auxílio ou independência; eventuais conflitos com os demais usuários. Os trajetos foram codificados, facilitando a interpretação das observações e registros fotográficos referentes a cada um deles. As transcrições e registros foram comparados com os relatos dos usuários, obtidos no instrumento questionário, com os relatos dos estagiários, obtidos no instrumento entrevista a fim de estabelecer uma relação entre os achados por meio de observação e as descobertas obtidas nos demais instrumentos.

A estação Ana Rosa é uma estação intermediária que dispõe de um único mezanino para circulação de pessoas para embarque ou desembarque nas Linhas 1-Azul ou Linha 2-Verde ou conexão entre elas, conforme apresentado na Figura 58. Entre o mezanino e a plataforma da Linha 1-Azul, existem duas escadas fixas (EF01 e EF04), três escadas rolantes (ER20, ER21 e ER22) e um elevador (EL01). Entre o mezanino e a plataforma da Linha 2-Verde, existem três escadas fixas (EF05, EF06 e EF07) e um elevador (EL02). 


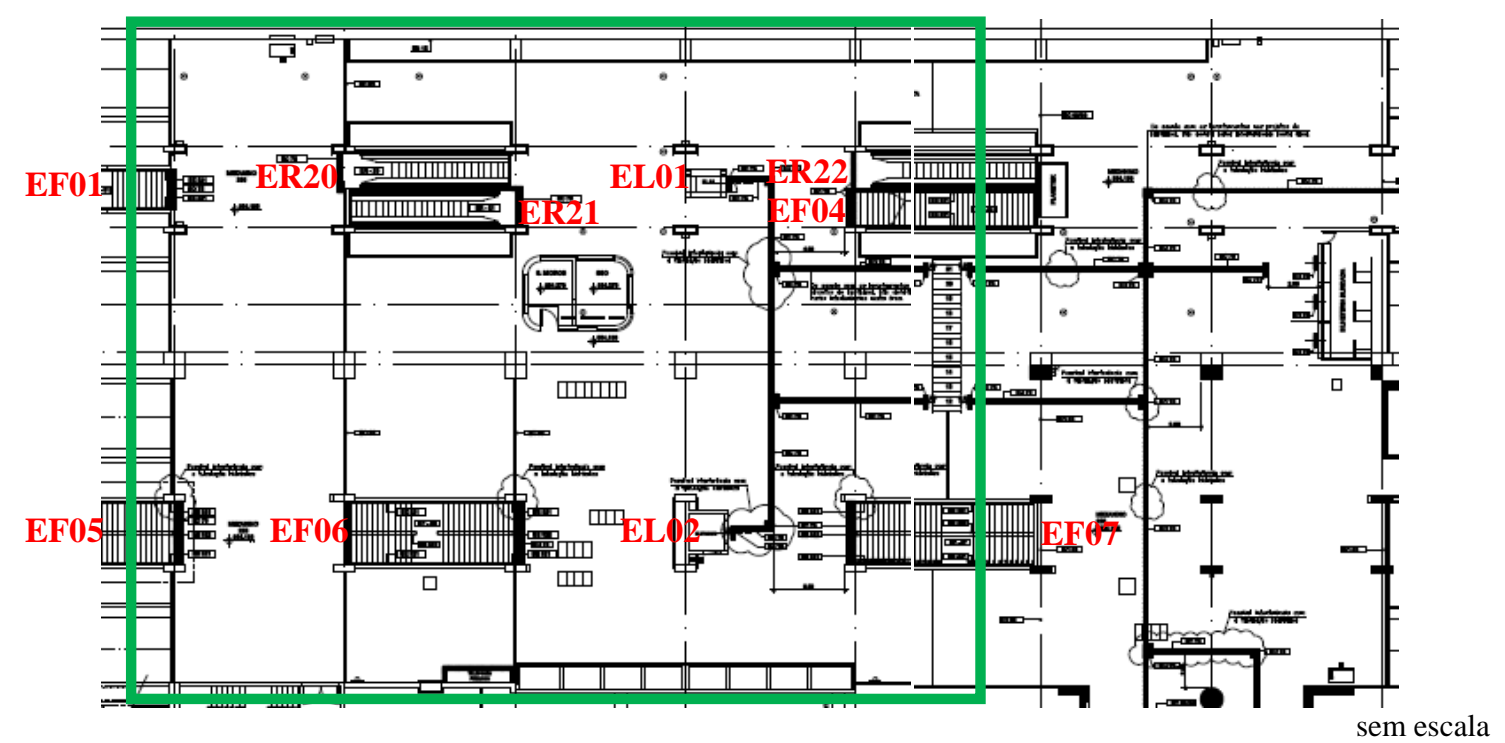

Figura 58 - São Paulo/Ana Rosa: Mezanino da área paga.

Fonte: Elaborado pela pesquisadora a partir de desenho fornecido pela CMSP. (2014)

Para minimizar os conflitos e organizar os fluxos, são colocados elementos direcionadores junto às escadas fixas, conforme apresentado na Figura 59.
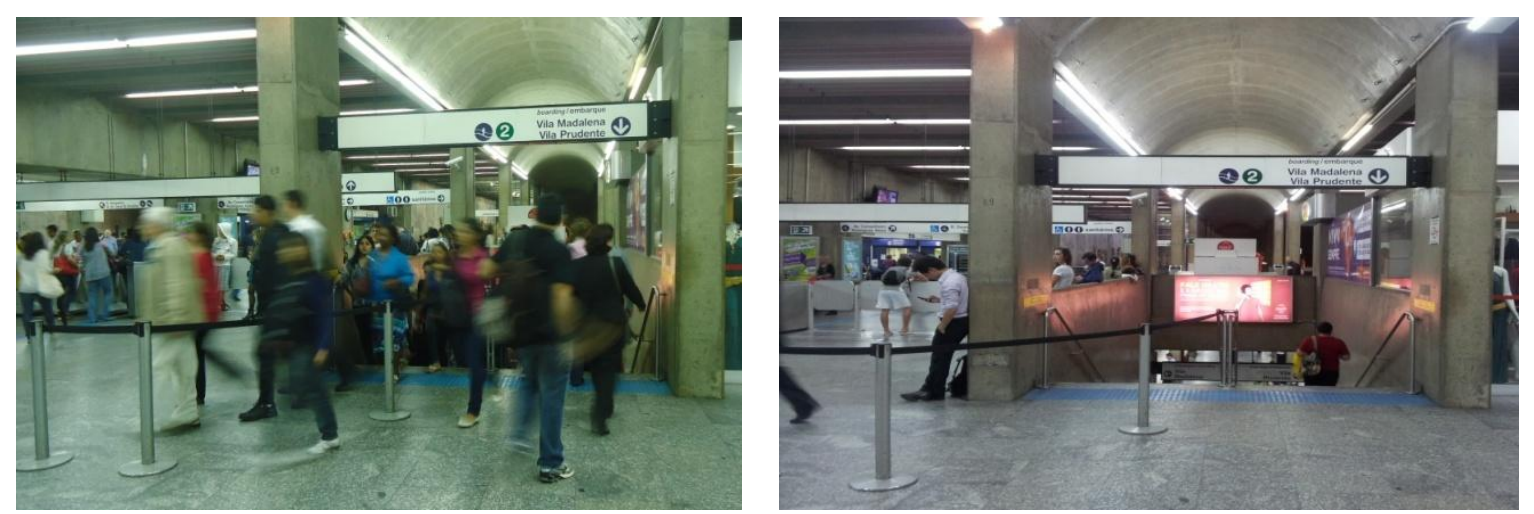

Figura 59 - São Paulo/Ana Rosa: Elementos orientadores de fluxo junto às escadas fixas. Fonte: BARBOSA, M. B., 2011.

Existe uma única linha de bloqueio junto ao acesso, e nove diferentes fluxos para embarque ou saída na área paga do mezanino. Em relação às conexões entre as Linhas 1-Azul e 2Verde, foram identificados outros oito diferentes fluxos. No total, foram identificados 17 diferentes fluxos no mezanino da área paga, conforme ilustra a Figura 60. 


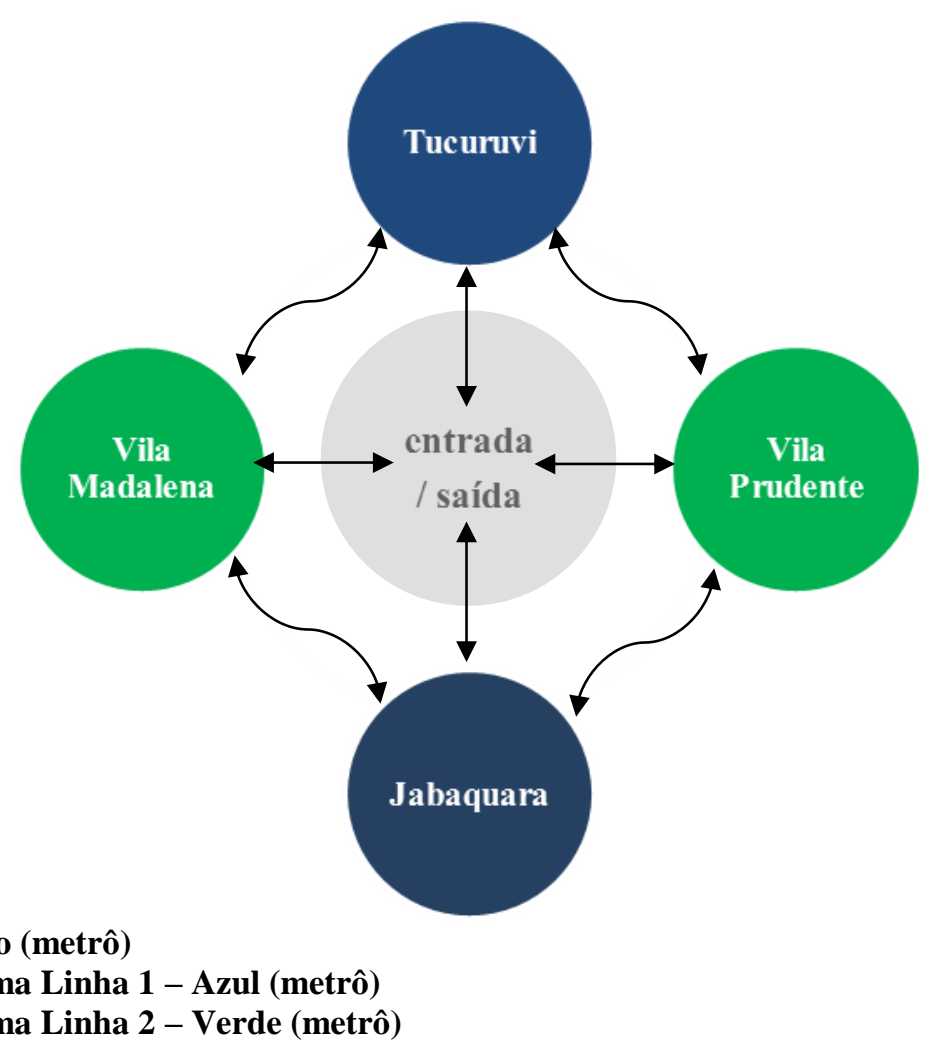

Figura 60 - São Paulo/Ana Rosa: Esquema de fluxos. Fonte: Elaborado pela pesquisadora. (2014)

Foi observada a existência de conflitos entre os fluxos de embarque, saída e conexão exatamente em frente aos bloqueios, em todos os períodos - no pico da manhã, no pico intermediário e no pico da tarde. O fluxo intenso de usuários sobre o piso tátil no mezanino da área paga dificulta sua utilização por pessoas com deficiência visual (Figura 61).
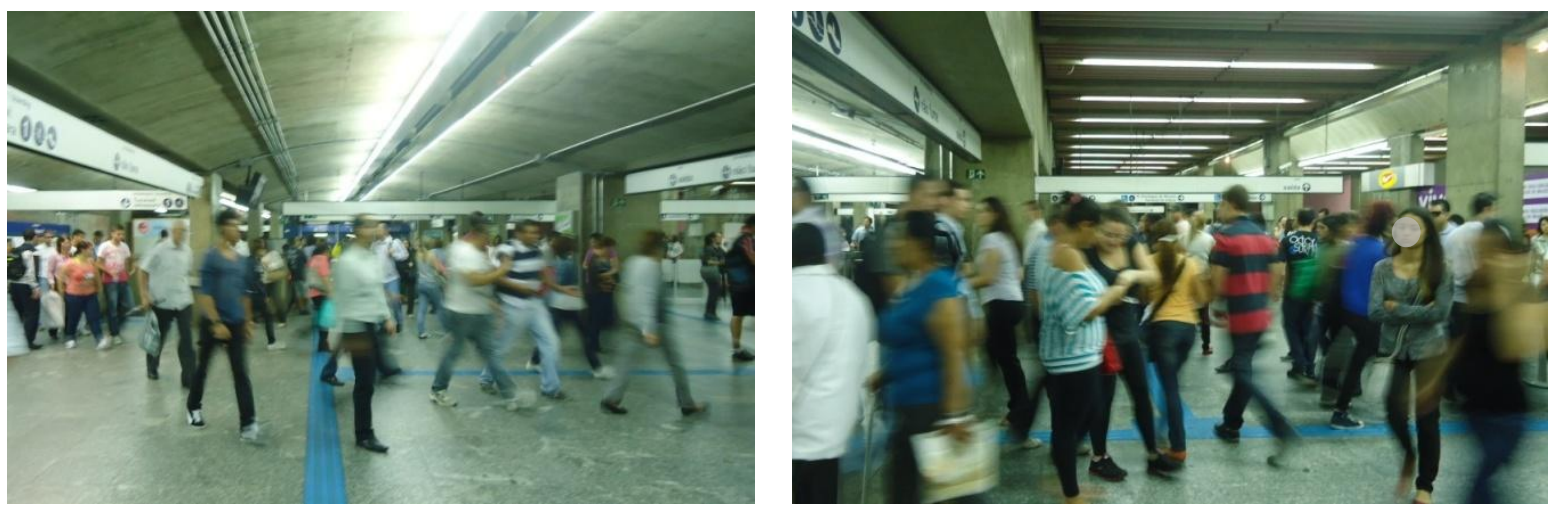

Figura 61 - São Paulo/Ana Rosa: Conflito entre fluxos de embarque, saída e conexão entre linhas. Fonte: BARBOSA, M. B., 2011.

Durante as observações realizadas, não foi constatada a utilização dos elevadores pelas pessoas com deficiência visual, sozinhas ou acompanhadas por estagiários ou funcionários, seja para embarque, desembarque ou conexão entre linhas. 
Os estagiários e funcionários que auxiliam pessoas com deficiência visual costumam fazer os seguintes trajetos:

\section{Para conexão da Linha 1-Azul para a Linha 2-Verde:}

- Trajeto A - vindo da Linha 1-Azul, sentido Jabaquara, sobem a ER22 ou a EF04 e atravessam o mezanino, em meio ao conflito de fluxo, e descem a EF05 para embarque na Linha 2-Verde, sentido Vila Madalena;

- Trajeto B - vindo da Linha 1-Azul, sentido Jabaquara, sobem a ER22 ou a EF04 e caminham em frente ao bloqueio, em meio ao conflito de fluxo, e descem a EF07 para embarque na Linha 2-Verde, sentido Vila Prudente;

- Trajeto C - vindo da Linha 1-Azul, sentido Tucuruvi, sobem a EF01, caminham nos fundos do mezanino e descem a EF05 para embarque na Linha 2-Verde, sentido Vila Madalena;

- Trajeto D - vindo da Linha 1-Azul, sentido Tucuruvi, sobem a ER20 ou a EF01 e atravessam todo o mezanino, em meio ao conflito de fluxos, e descem a EF07 para embarque na Linha 2-Verde, sentido Vila Prudente.

Para conexão entre a Linha 2-Verde e a Linha 1-Azul:

- Trajeto E - vindo da Linha 2-Verde, sentido Vila Madalena, sobem a EF05 e atravessam o mezanino, em meio ao conflito de fluxo, e descem a EF04 ou a ER21 para embarque na Linha 1-Azul, sentido Jabaquara;

- Trajeto F - vindo da Linha 2-Verde, sentido Vila Madalena, sobem a EF05 e caminham nos fundos do mezanino, em meio ao conflito de fluxo, e descem a EF01 ou a ER21 para embarque na Linha 1-Azul, sentido Tucuruvi;

- Trajeto G - vindo da Linha 2-Verde, sentido Vila Prudente, sobem a EF07 e caminham em frente ao bloqueio, em meio ao conflito de fluxo, e descem a EF04 ou a ER21 para embarque na Linha 1-Azul, sentido Jabaquara;

- Trajeto H - vindo da Linha 2-Verde, sentido Vila Prudente, sobem a EF07, caminham em frente ao bloqueio, em meio ao conflito de fluxo, e descem a EF01 ou a ER21 para embarque na Linha 1-Azul, sentido Tucuruvi.

\section{Para desembarque:}

- Trajeto I - vindo da Linha 1-Azul, sentido Jabaquara, sobem a ER22 ou a EF04 e caminham em frente aos bloqueios, em meio ao conflito de fluxo, até chegar ao bloqueio de saída; 
- Trajeto J - vindo da Linha 1-Azul, sentido Tucuruvi, sobem a EF01 e atravessam todo o mezanino, em meio ao conflito de fluxos, até chegar ao bloqueio de saída;

- Trajeto K - vindo da Linha 2-Verde, sentido Vila Prudente, sobem a EF07 e andam um pequeno trecho do mezanino até chegar ao bloqueio de saída;

- Trajeto L - vindos da Linha 2-Verde, sentido Vila Madalena, sobem a EF05 e atravessam todo o mezanino, em meio ao conflito de fluxos, até chegar ao bloqueio de saída.

Para embarque:

- Trajeto M - viram à direita e descem a EF04 ou a ER21 para embarque na Linha 1Azul, sentido Jabaquara;

- Trajeto $\mathbf{N}$ - atravessam o mezanino, em meio ao conflito de fluxo, e descem a EF01 ou a ER21 para embarque na Linha 1-Azul, sentido Tucuruvi;

- Trajeto $\mathbf{O}$ - atravessam o mezanino, em meio ao conflito de fluxo, e descem a EF05 para embarque na Linha 2-Verde, sentido Vila Madalena;

- Trajeto $\mathbf{P}$ - atravessam o mezanino, em meio ao conflito de fluxo, e descem a EF06 para embarque na Linha 2-Verde, sentido Vila Madalena;

- Trajeto Q - viram à esquerda e descem a EF07 para embarque na Linha 2-Verde, sentido Vila Prudente.

Foram registrados 35 deslocamentos de pessoas com deficiência visual em diferentes horários, sendo 8 deslocamentos com independência e 27 com auxílio dos estagiários e funcionários, percorrendo diferentes trajetos (Quadro 19 e Figuras de 62 a 63).

Quadro 19 - Deslocamentos e trajetos realizados na estação Ana Rosa

\begin{tabular}{lcc}
\hline Observações & $\begin{array}{c}\text { Deslocamentos } \\
\text { independentes }\end{array}$ & $\begin{array}{c}\text { Deslocamentos } \\
\text { com auxílio }\end{array}$ \\
\hline Pico manhã & Trajetos B, G, J, L, P, & Trajetos B, C,D, E, G, L \\
\hline Pico intermediário & Trajeto G & $\begin{array}{c}\text { Trajetos A, B, C, D, E, } \\
\text { F, G, G, I, J, K, L }\end{array}$ \\
\hline Pico tarde & Trajetos I, P & $\begin{array}{c}\text { Trajetos A, B, C, D, E, } \\
\text { F, G, G, I }\end{array}$ \\
\hline
\end{tabular}



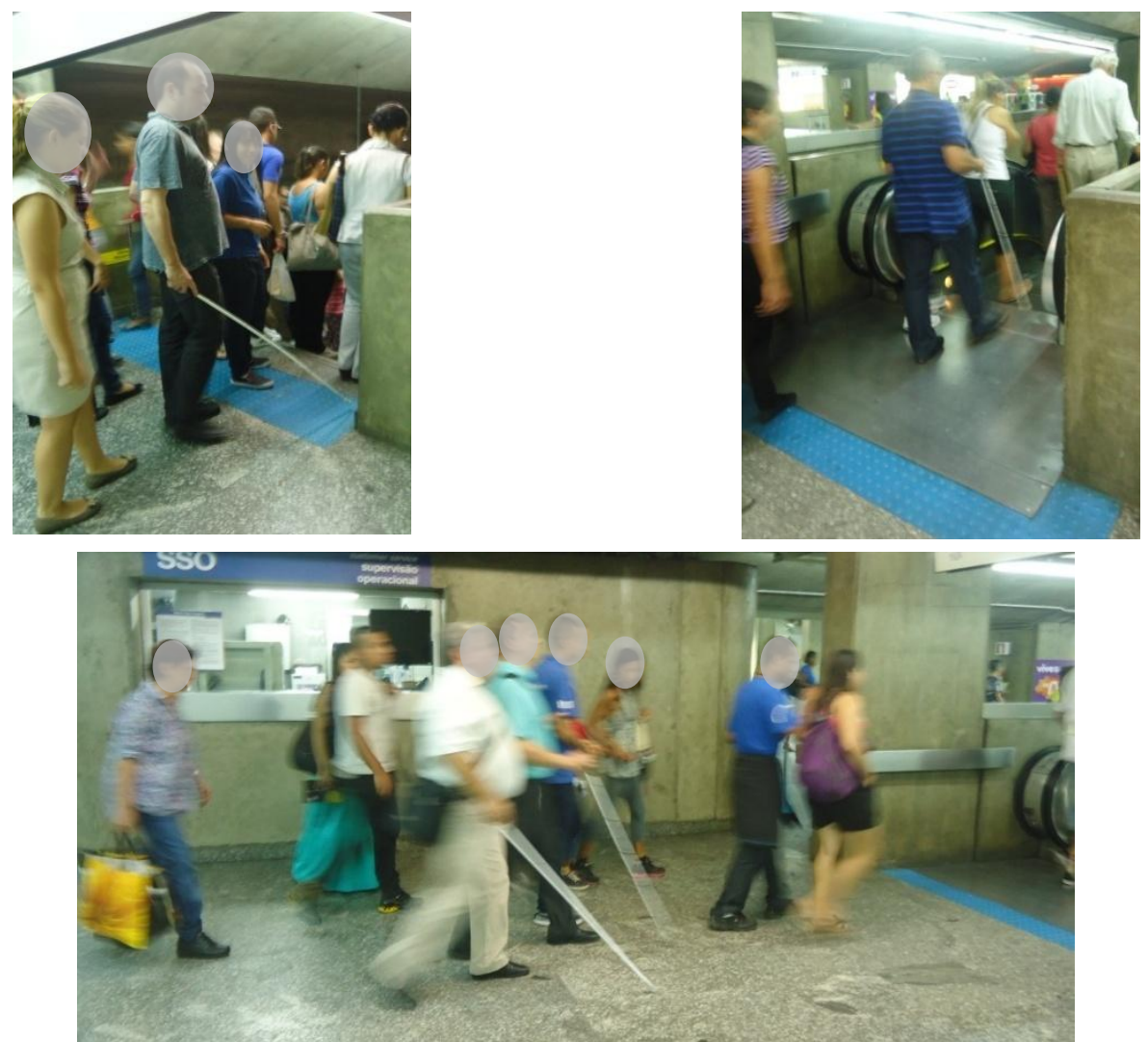

Figura 62 - São Paulo/Ana Rosa: Deslocamentos com auxílio.

Fonte: BARBOSA, M. B., 2011.
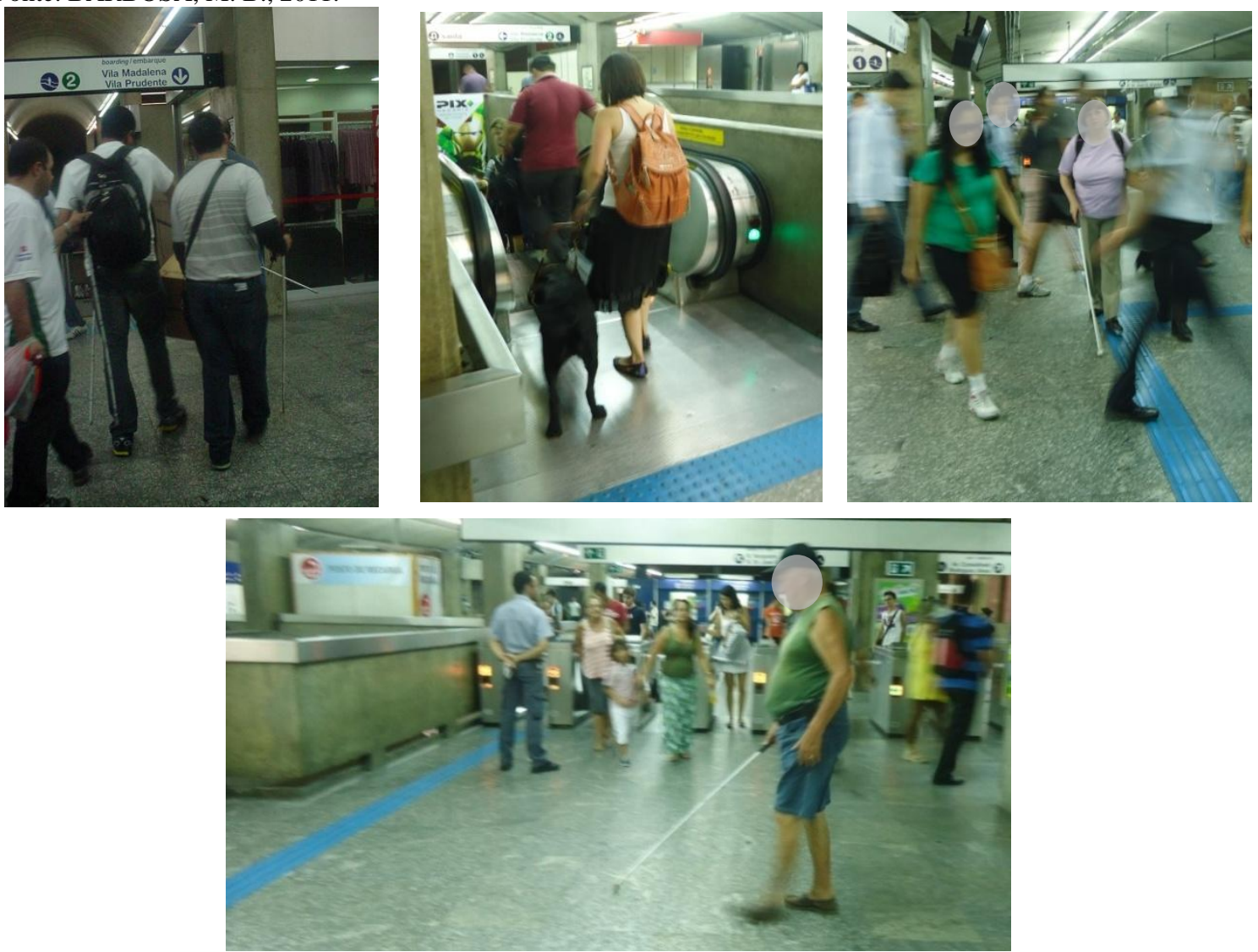

Figura 63 - São Paulo/Ana Rosa: Deslocamentos com independência.

Fonte: BARBOSA, M. B., 2011. 
A estação Palmeiras-Barra Funda é uma estação terminal que dispõe de um mezanino para circulação de pessoas para embarque ou desembarque da Linha 3-Vermelha ou para conexão entre o metrô e o trem metropolitano. Entre o mezanino e a plataforma da Linha 3-Vermelha, existem sete escadas fixas, oito escadas rolantes e um elevador (Figura 64).

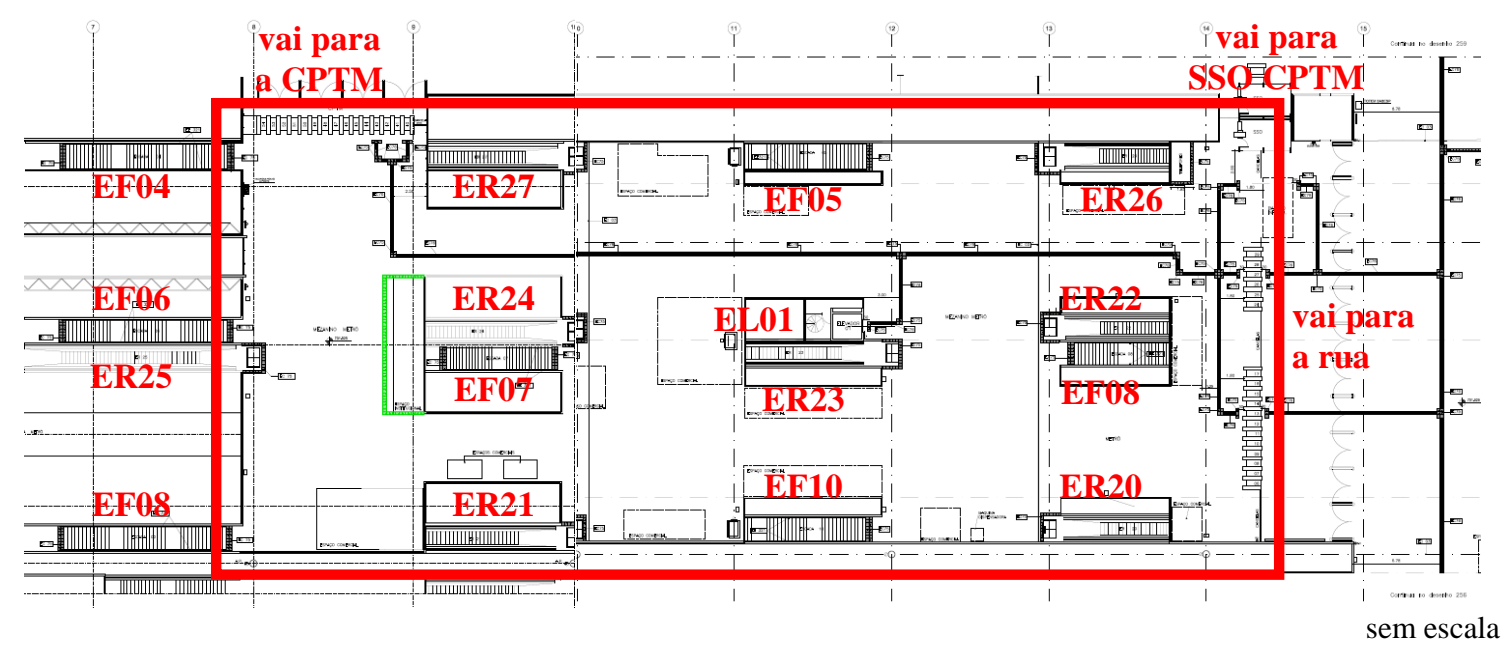

Figura 64 - São Paulo/Palmeiras-Barra Funda: Mezanino área paga

Fonte: Elaborado pela pesquisadora a partir de desenho fornecido pela CMSP. (2014)

Existem duas linhas de bloqueios, sendo uma de entrada/saída junto à passarela de acesso e outra na transferência entre o metrô e o trem metropolitano. Por conta disso, existem diferentes fluxos na área paga do mezanino:

- entrada para embarque no metrô, sentido Corinthians-Itaquera ou desembarque do metrô para a rua, utilizando a linha de bloqueios da passarela;

- conexão entre o trem metropolitano e o metrô, com embarque sentido CorinthiansItaquera, ou conexão entre o metrô e as linhas da CPTM, utilizando a linha de bloqueios da transferência.

Foram identificados diferentes fluxos no mezanino do metrô (Figura 65). Outros fluxos ocorrem no mezanino da CPTM e estão relacionados ao embarque, desembarque e conexão entre as linhas de trem metropolitano. 

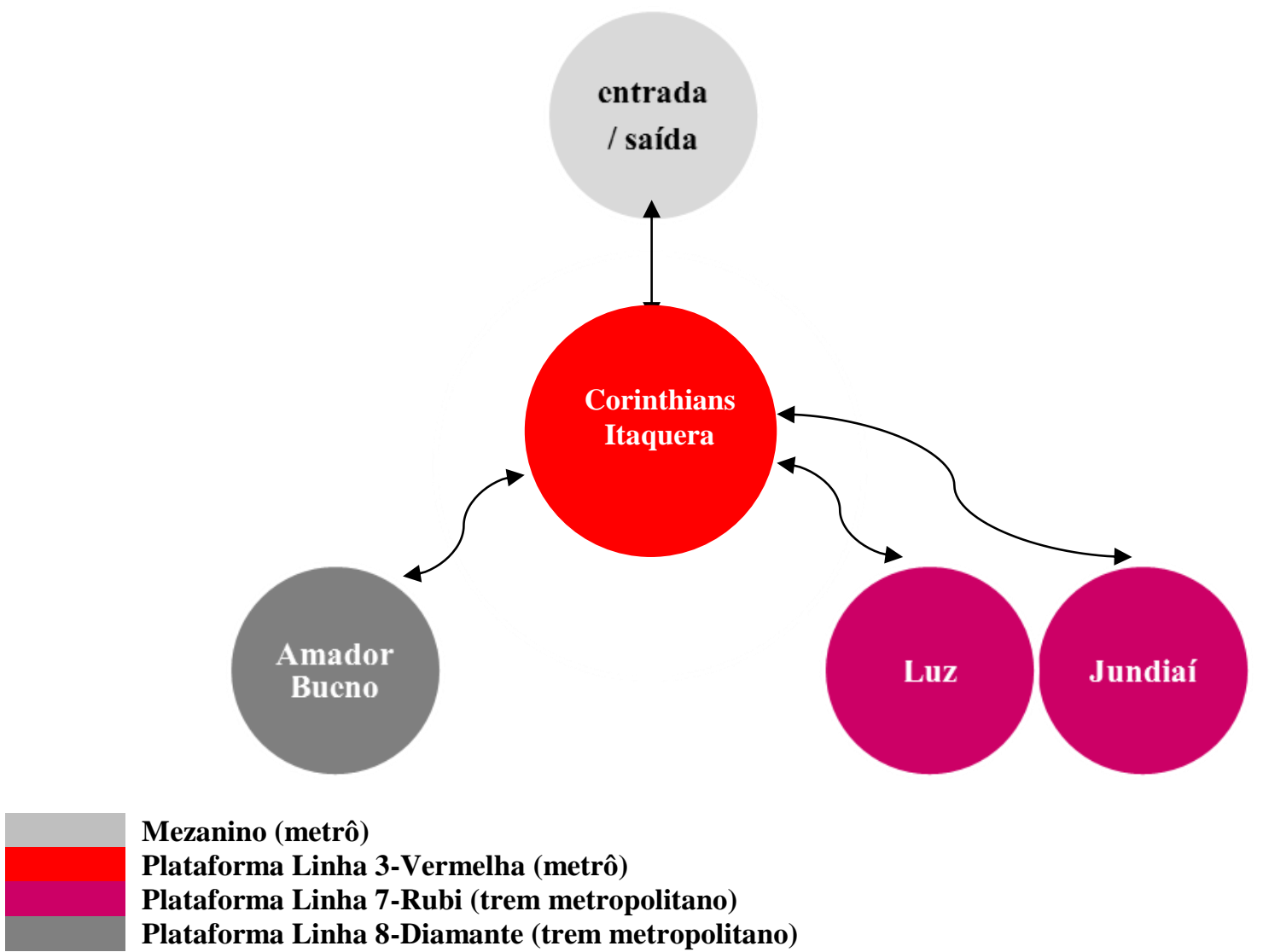

\section{Mezanino (metrô)}

Plataforma Linha 3-Vermelha (metrô)

Plataforma Linha 7-Rubi (trem metropolitano)

Plataforma Linha 8-Diamante (trem metropolitano)

Figura 65 - São Paulo/Palmeiras-Barra Funda: Esquema de fluxos.

Fonte: Elaborado pela pesquisadora. (2014)

A linha de bloqueio junto à passarela é utilizada predominantemente pelos usuários que embarcam no sentido Corinthians-Itaquera. A sinalização tátil em frente aos bloqueios de entrada e saída da estação orienta o percurso até a SSO ou o elevador para embarque e tem sua utilização prejudicada pelo fluxo intenso de usuários que circulam sobre o piso tátil, dificultando seu uso por pessoas com deficiência visual, conforme apresentado na Figura 66. Em função da lotação, as pessoas têm dificuldade em perceber a bengala das pessoas com deficiência e, por vezes, tropeçam nela. Algumas pessoas com deficiência visual usam o piso tátil da estação para ir do bloqueio à SSO para solicitar auxílio dos funcionários para embarcar. Às vezes os estagiários seguem por esse piso tátil para embarcar pessoas com deficiência visual. Tais situações ocorrem tanto no pico da manhã, ao meio dia ou no pico da tarde. 

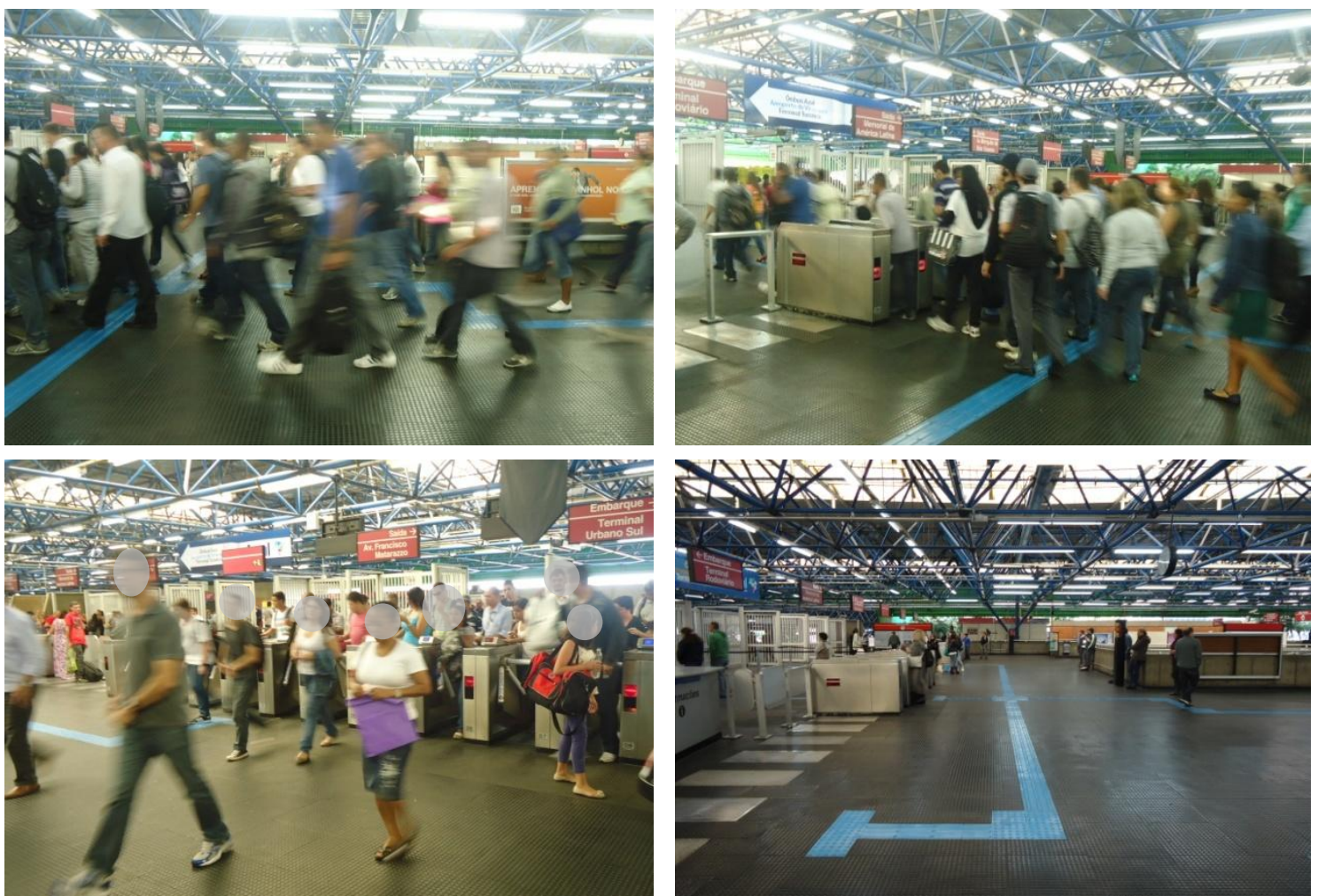

Figura 66 - São Paulo/Palmeiras-Barra Funda: Fluxo junto aos bloqueios da passarela.

Fonte: BARBOSA, M. B., 2011.

A linha de bloqueio da transferência é utilizada predominantemente para conexão entre o metrô e o trem. A quantidade de bloqueios posicionados para embarque no trem ou para embarque no metrô varia ao longo do dia, de acordo com o fluxo. A sinalização tátil no piso em frente aos bloqueios de transferência orienta o percurso até a SSO ou até o elevador para embarque. Tem sua utilização prejudicada pelo fluxo intenso de usuários que circulam sobre o piso tátil, dificultando seu uso por pessoas com deficiência visual, conforme apresentado nas Figuras 67 e 68.
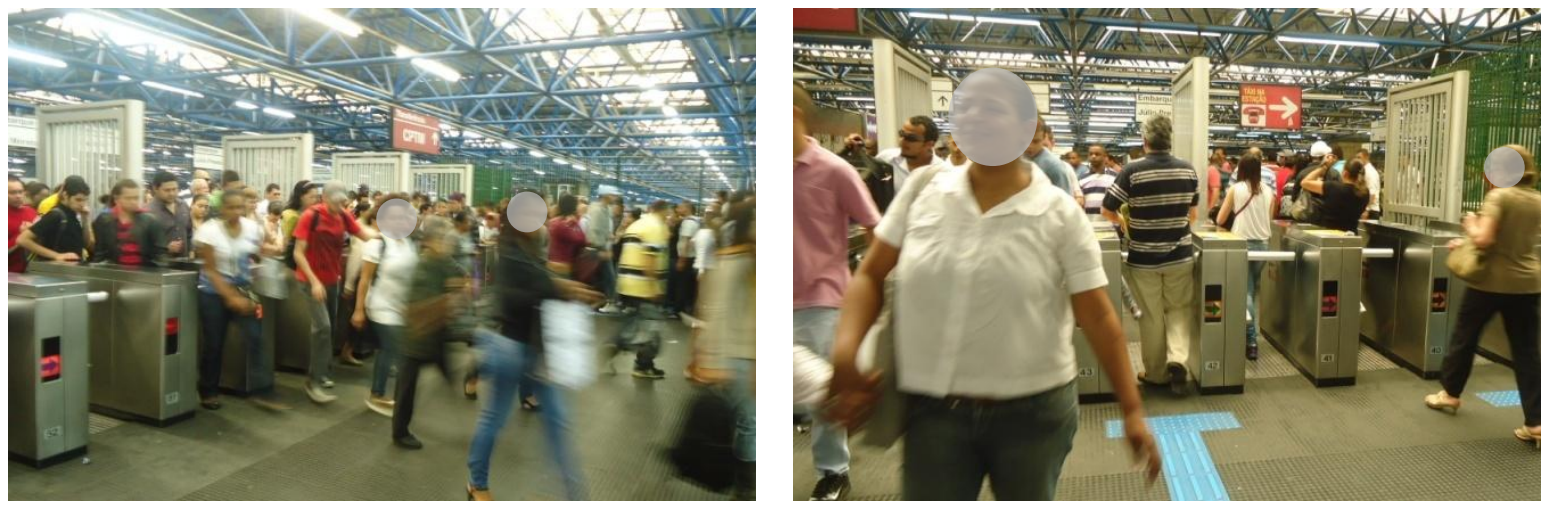

Figura 67 - São Paulo/Palmeiras-Barra Funda: Fluxo junto aos bloqueios de transferência. Fonte: BARBOSA, M. B., 2011. 

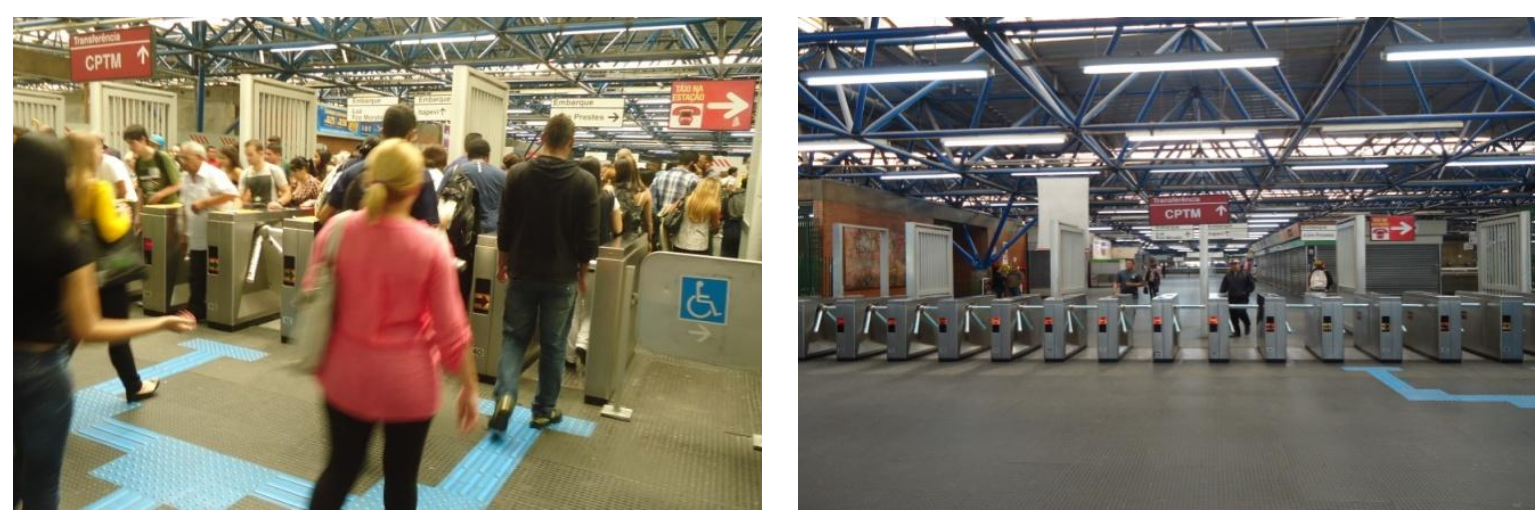

Figura 68 - São Paulo/Palmeiras-Barra Funda: Fluxo junto aos bloqueios de transferência. Fonte: BARBOSA, M. B., 2011.

Foram identificados sete trajetos no mezanino área paga:

Para conexão da Linha 3-Vermelha do metrô para a CPTM:

- Trajeto A - para conexão com o trem metropolitano, sobem a ER25/ER24/ER23 e deslocam-se no mezanino até a SSO da CPTM para dar continuidade ao atendimento pelo funcionário da CPTM;

Para conexão da CPTM para a Linha 3-Vermelha do metrô:

- Trajeto B - vindo da CPTM para embarque na Linha 3-Vermelha, descem a ER20 e deslocam-se até o local do embarque preferencial na plataforma lateral;

- Trajeto C - vindo da CPTM para embarque na Linha 3-Vermelha, descem a EF08 ou o EL01 e deslocam-se até o local do embarque preferencial na plataforma central;

\section{Para desembarque:}

- Trajeto D - para desembarque vindo da Linha 3-Vermelha, sobem a ER25/ER24/ER23 e deslocam-se no mezanino até a linha de bloqueios e, em seguida, para a saída desejada;

- Trajeto E - para desembarque vindo da Linha 3-Vermelha, sobem a ER26 e deslocam-se no mezanino até a linha de bloqueios e, em seguida, para a saída desejada;

Para embarque:

- Trajeto F - vindo da rua para embarque na Linha 3-Vermelha, descem a ER20 e deslocam-se até o local do embarque preferencial na plataforma lateral;

- Trajeto G - vindo da rua para embarque na Linha 3-Vermelha, descem a EF08 ou o EL01 e deslocam-se até o local do embarque preferencial na plataforma central. 
Foram registrados 24 deslocamentos de pessoas com deficiência visual em diferentes horários, sendo seis deslocamentos com independência e 18 com auxílio dos estagiários e funcionários, percorrendo diferentes trajetos (Quadro 20 e Figuras de 69 a 72).

Quadro 20 - Deslocamentos e trajetos realizados na estação Palmeiras-Barra Funda.

\begin{tabular}{lcc}
\hline \multicolumn{1}{c}{ Observações } & $\begin{array}{c}\text { Deslocamentos } \\
\text { independentes }\end{array}$ & $\begin{array}{c}\text { Deslocamentos } \\
\text { com auxílio }\end{array}$ \\
\hline Pico manhã & trajetos D, E & trajetos A, A, B, D, D, F \\
\hline Pico intermediário & trajetos A, B & trajetos A, A, B, D, D, F \\
\hline Pico tarde & trajetos C, G & trajetos A, C, C, D, F, G, \\
\hline
\end{tabular}
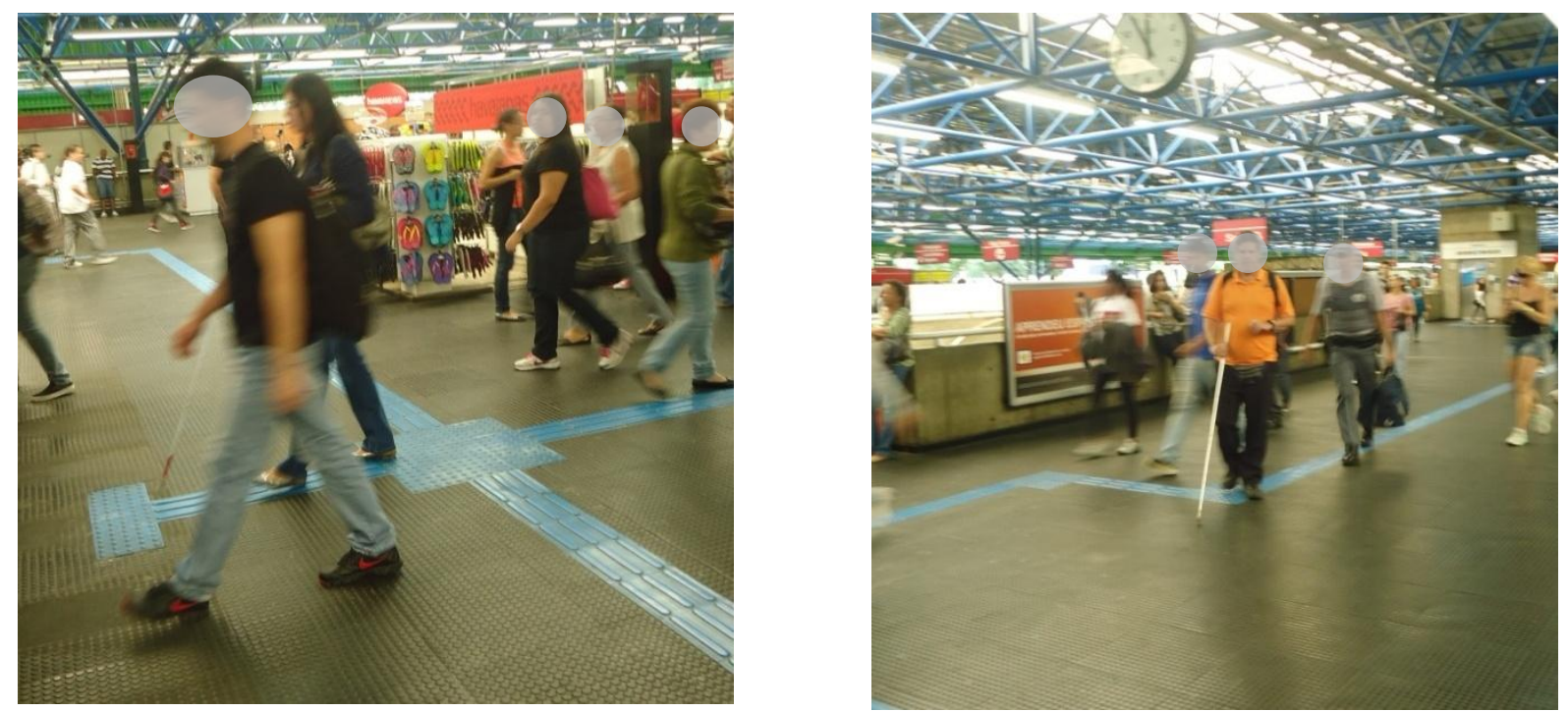

Figura 69 - São Paulo/Palmeiras-Barra Funda: Fluxos e deslocamento com independência.

Fonte: BARBOSA, M. B., 2011.
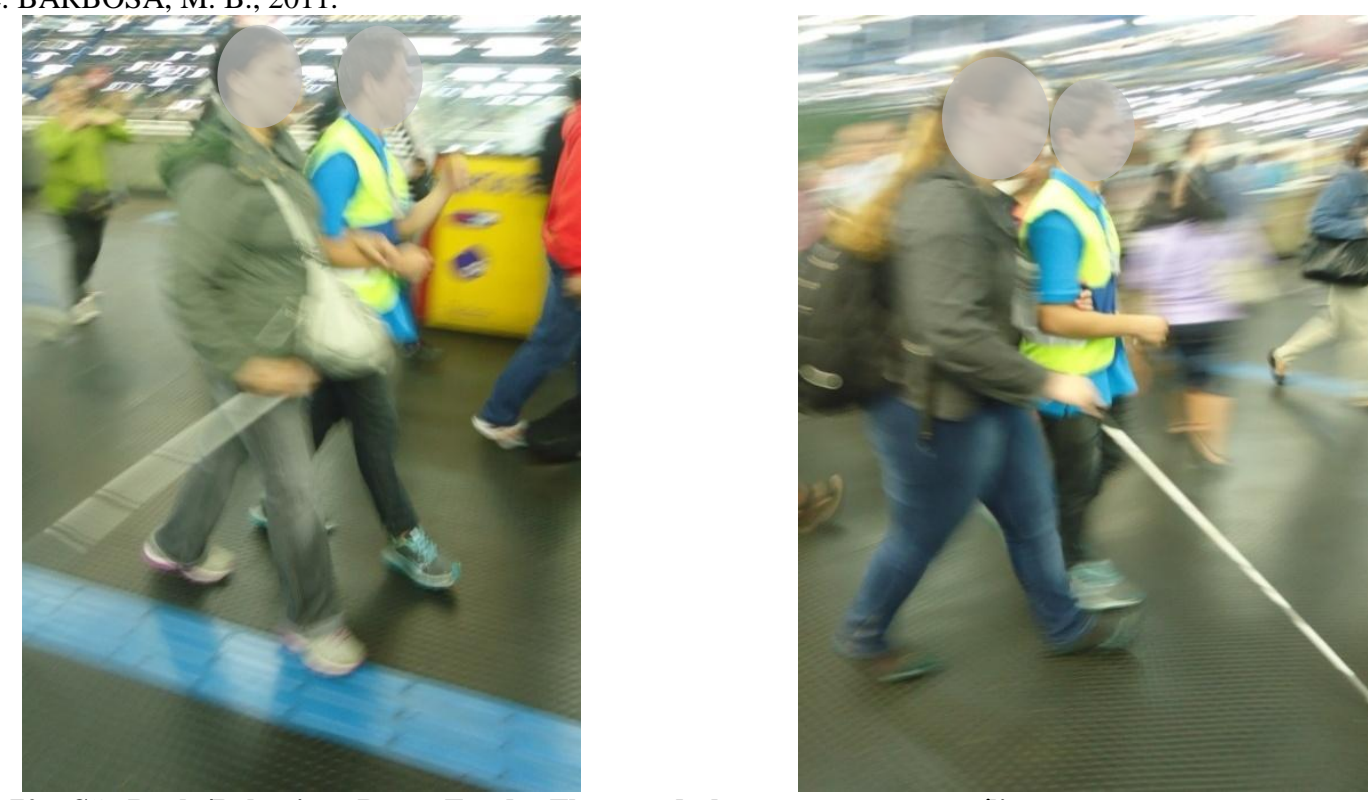

Figura 70 - São Paulo/Palmeiras-Barra Funda: Fluxos e deslocamentos com auxílio.

Fonte: BARBOSA, M. B., 2011. 


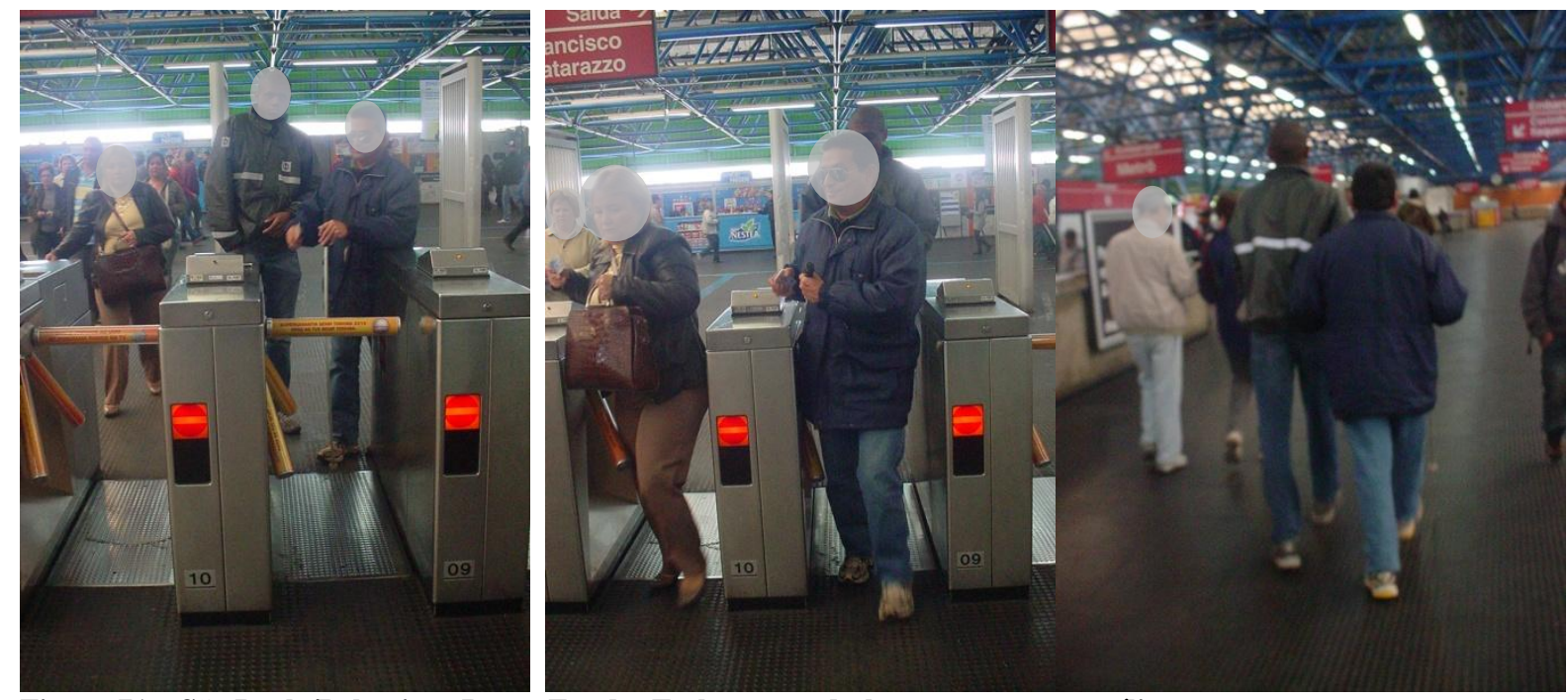

Figura 71 - São Paulo/Palmeiras-Barra Funda: Embarque e deslocamento com auxílio.

Fonte: BARBOSA, M. B., 2011.
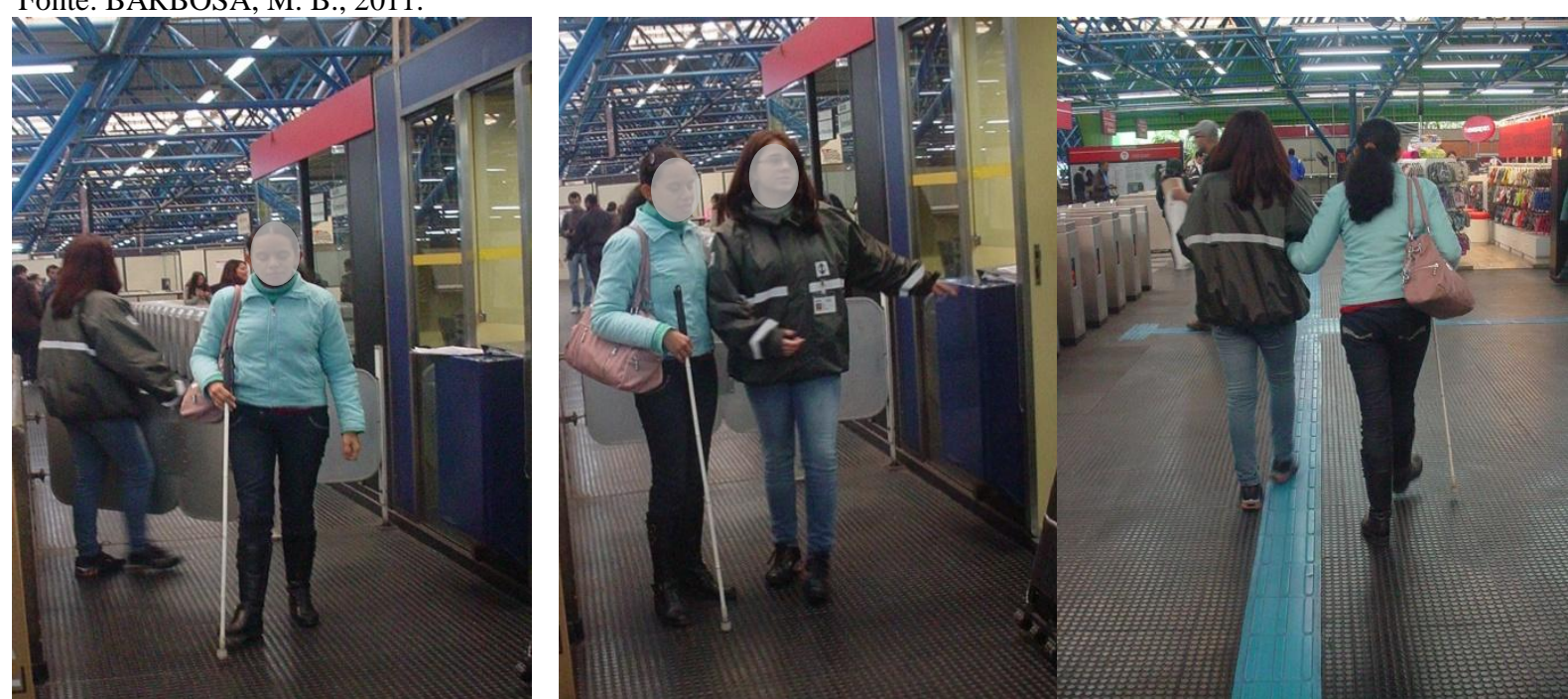

Figura 72 - São Paulo/Palmeiras-Barra Funda: Conexão e deslocamento com auxílio. Fonte: BARBOSA, M. B., 2011.

A estação Sacomã é uma estação intermediária que dispõe de um mezanino para circulação de pessoas para embarque ou desembarque da Linha 2-Verde. Entre o mezanino e cada uma das plataformas laterais, existem duas escadas fixas (EF04 a EF07), três escadas rolantes (ER31 a ER36) e um elevador (EL03 e EL04), conforme Figura 73. 


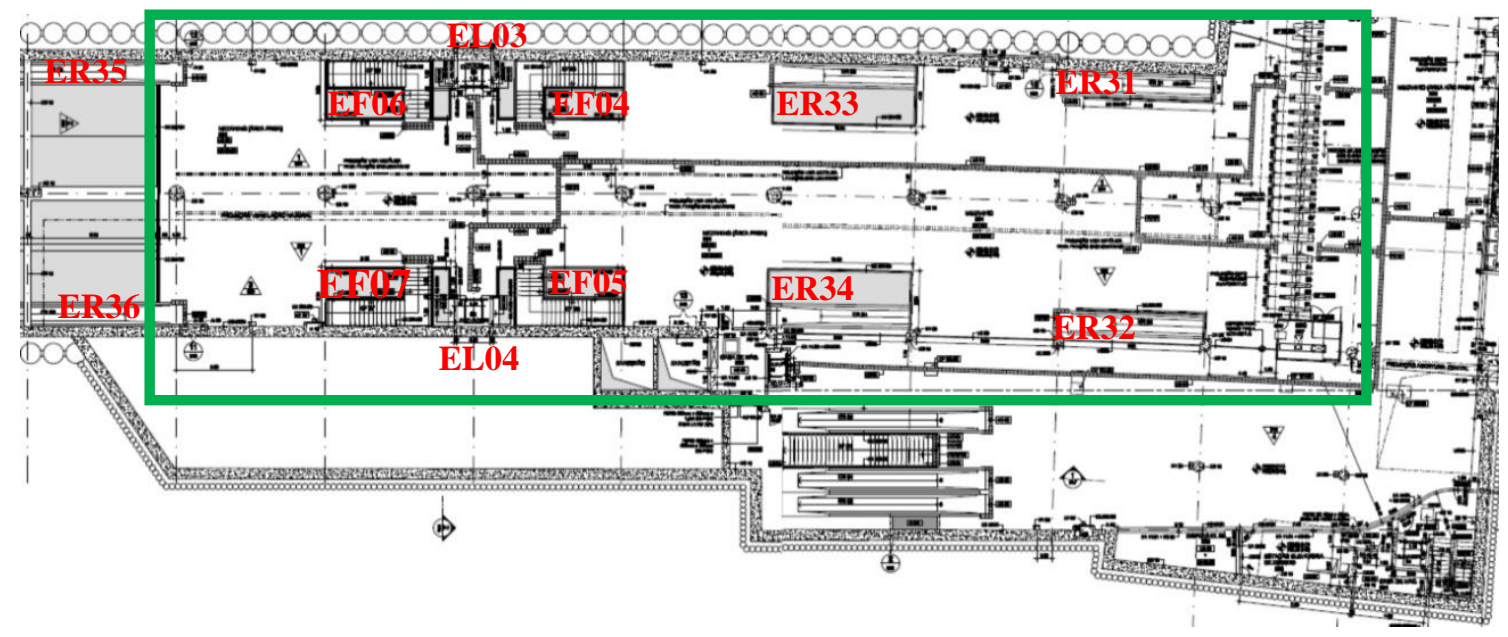

Figura 73 - São Paulo/Sacomã: Mezanino área paga.

(sem escala)

Fonte: Elaborado pela pesquisadora a partir de desenho fornecido pela CMSP. (2014)

Há uma única linha de bloqueios, junto à circulação do acesso, e quatro diferentes fluxos para embarque, no sentido Vila Prudente ou Vila Madalena, e para saída (Figura 74).

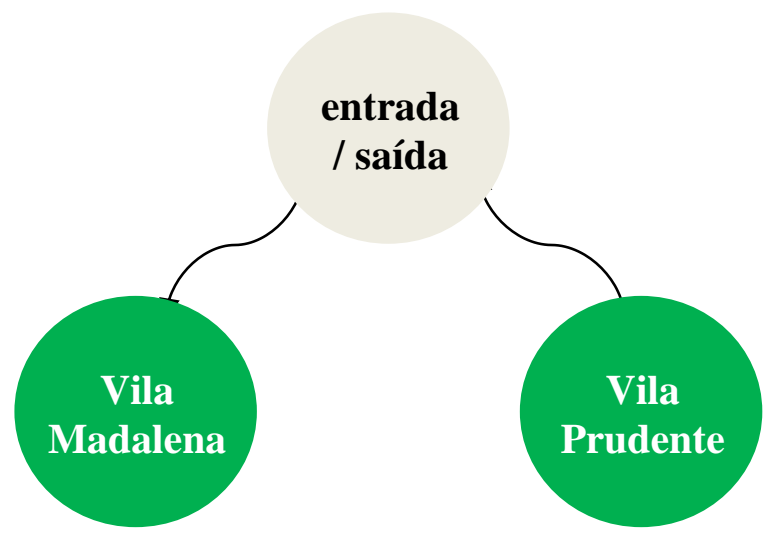

\section{Mezanino \\ Plataforma Linha 2-Verde (metrô)}

Figura 74 - São Paulo/Sacomã: Esquema de Fluxos. Fonte: Elaborado pela pesquisadora. (2014)

A sinalização tátil em frente aos bloqueios de entrada e saída da estação orienta o percurso até os elevadores de embarque. Entretanto, tem sua utilização prejudicada pela proximidade com os bloqueios e pelo intenso fluxo de usuários sobre o piso tátil, dificultando o uso independente pelas pessoas com deficiência visual, conforme apresentado nas Figuras 75 e 76. 

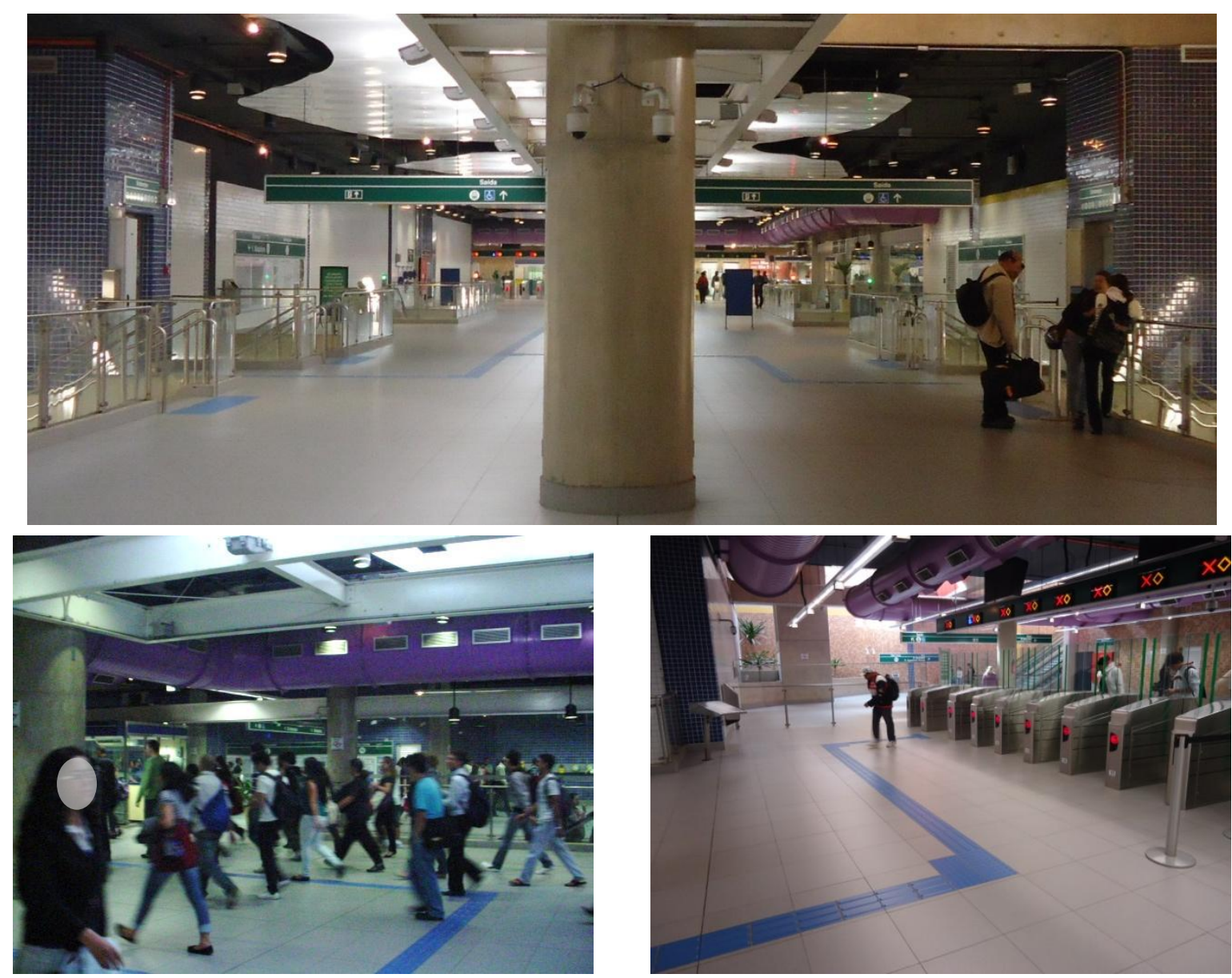

Figura 76 - São Paulo/Sacomã: Fluxo junto ao bloqueio do mezanino da área paga. Fonte: BARBOSA, M. B., 2011.

No pico da manhã, prevalece o fluxo de embarque. Os usuários utilizam em sua maioria as escadas rolantes próximas aos bloqueios, mas alguns usuários descem pelas escadas fixas ou pela rolante localizadas no fundo do mezanino. Há cruzamento de fluxos de embarque e desembarque próximo à ER31 para embarque sentido Vila Madalena. Ao meio dia e à noite, prevalece o fluxo de desembarque, em sua maioria proveniente da plataforma sentido Vila Prudente. Ainda assim, há fluxos de embarque e desembarque próximos à ER31 para embarque sentido Vila Madalena e também junto à ER32 para embarque sentido Vila Prudente. No mezanino da área paga, percebe-se que, durante o auxílio prestado, estagiários e funcionários não seguem o piso tátil por causa do fluxo de usuários, que cruzam por cima dele, bloqueando a passagem das pessoas com deficiência visual.

Os estagiários e funcionários que auxiliam as pessoas com deficiência visual costumam fazer os seguintes trajetos: 
Para desembarque:

- Trajeto A - desembarcam da plataforma sentido Vila Madalena, sobem a ER31 ou a EF06 e deslocam-se pelo piso tátil do mezanino até os bloqueios de saída;

- Trajeto B - desembarcam da plataforma sentido Vila Prudente, sobem a ER32 ou a EF05 e deslocam-se pelo piso tátil do mezanino até os bloqueios de saída;

Para embarque:

- Trajeto C - deslocam-se pelo piso tátil do mezanino e descem a ER33 ou EF06 seguindo até o embarque sentido Vila Madalena. Ao meio dia, é utilizada a ER35 para descer para o embarque sentido Vila Madalena; entretanto, nos demais períodos, essa escada rolante fica posicionada para subir;

- Trajeto D - deslocam-se pelo piso tátil do mezanino e descem a ER34 ou EF05, seguindo até o embarque sentido Vila Prudente. Algumas pessoas seguem pelo piso tátil até a ER33, do lado direito, e saem do piso tátil em direção à ER34, do lado esquerdo, para embarcar no sentido Vila Prudente. Outras seguem no contrafluxo, sem piso tátil, até a ER34.

Foram registrados dez deslocamentos de pessoas com deficiência visual em diferentes horários, todos com auxílio dos estagiários e funcionários, percorrendo diferentes trajetos, conforme demonstram o Quadro 19 e a Figura 76.

Quadro 21 - Deslocamentos e trajetos realizados na estação Ana Rosa

\begin{tabular}{lcc}
\hline \multicolumn{1}{c}{ Observações } & $\begin{array}{c}\text { Deslocamentos } \\
\text { independentes }\end{array}$ & $\begin{array}{c}\text { Deslocamentos } \\
\text { com auxílio }\end{array}$ \\
\hline Pico manhã & --- & --- \\
\hline Pico intermediário & --- & trajetos A, B, C, D, D \\
\hline Pico tarde & --- & trajetos A, B, C, D, D \\
\hline
\end{tabular}



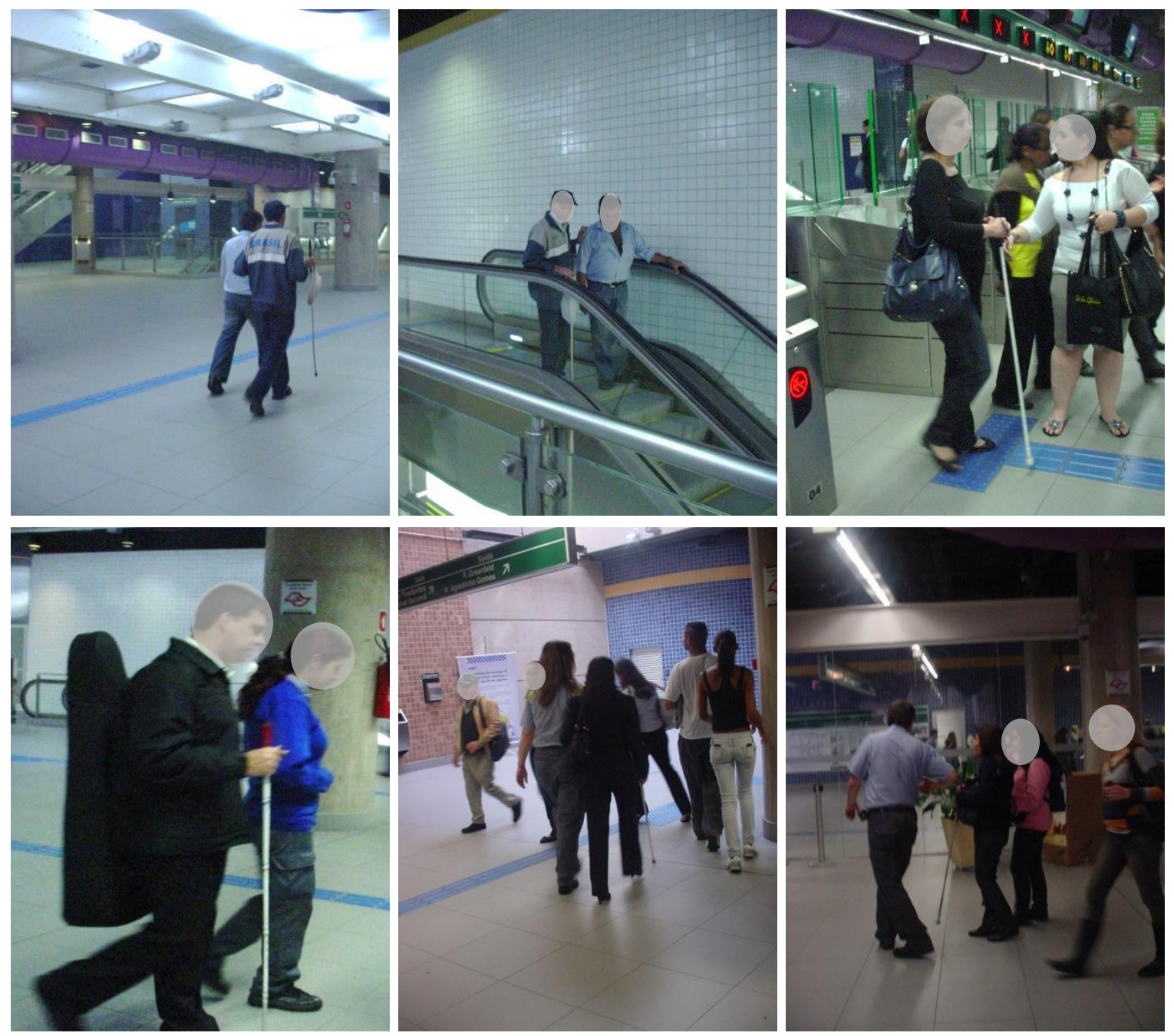

Figura 76 - São Paulo/Sacomã: Fluxos e deslocamento com auxílio. Fonte: BARBOSA, M. B., 2011.

Durante os períodos em que foram realizadas observações, não foi constatada a utilização dos elevadores pelas pessoas com deficiência visual, sozinhas ou acompanhadas por estagiários ou funcionários, seja para embarque, desembarque ou conexão entre linhas. Observou-se que alguns deslocamentos que utilizam a sinalização tátil no piso são realizados no contrafluxo. Há necessidade de instalação de sinalização tátil interligando as duas plataformas, de forma independente, desde os bloqueios de entrada/saída. 
A estação Tamanduateí é uma estação intermediária que dispõe de um mezanino para circulação de pessoas para embarque ou desembarque da Linha 2-Verde ou para conexão entre o metrô e o trem metropolitano. Entre o mezanino e cada uma das plataformas laterais da Linha 2-Verde, existem duas escadas fixas (EF06 a EF09), duas escadas rolantes (ER20 a ER23) e um elevador (EL03 e EL04) - (Figuras 77 e 78).

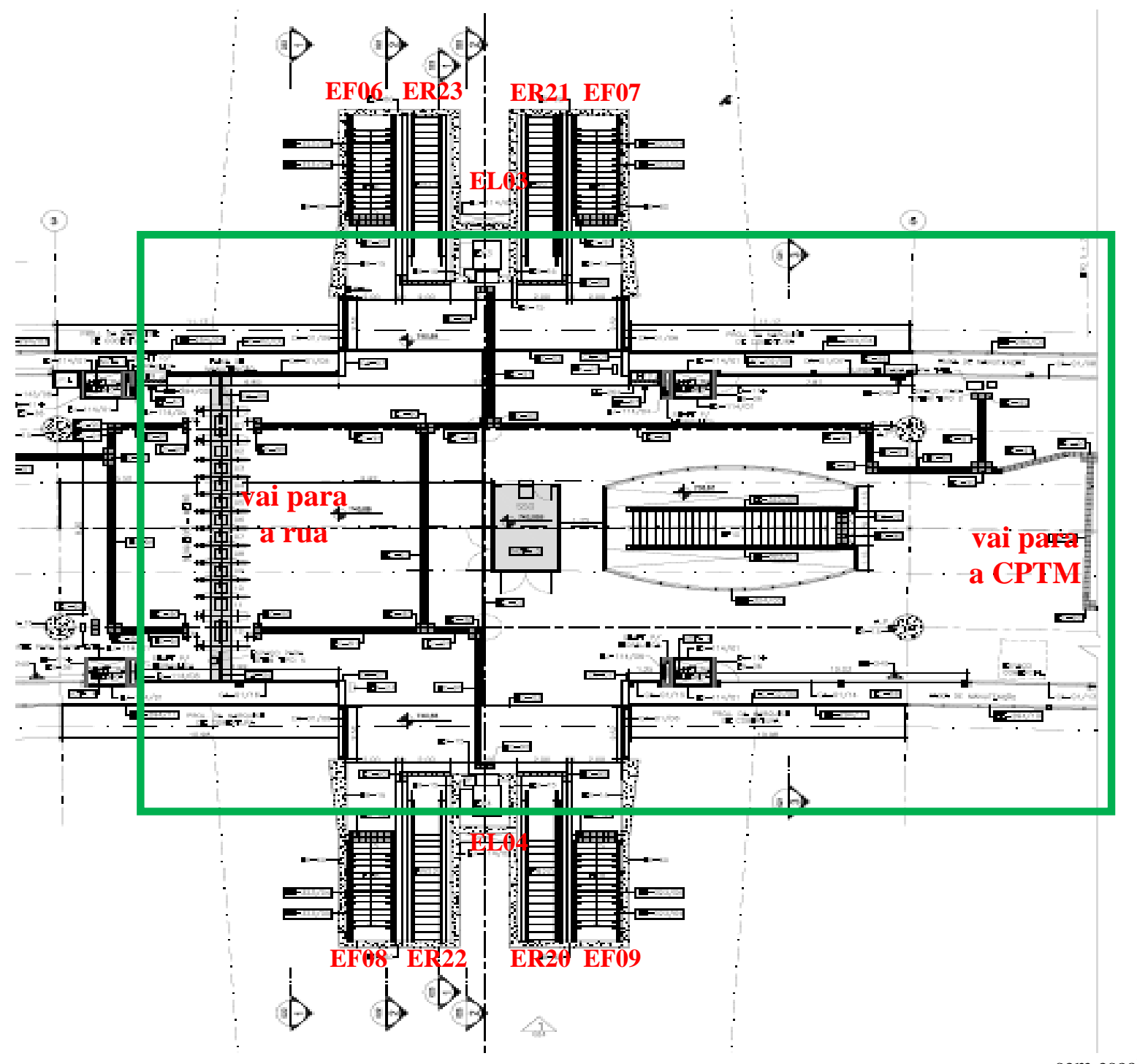

Figura 77 - São Paulo/Tamanduateí: Mezanino da área paga.

Fonte: Elaborado pela pesquisadora a partir de desenho fornecido pela CMSP. (2014) 

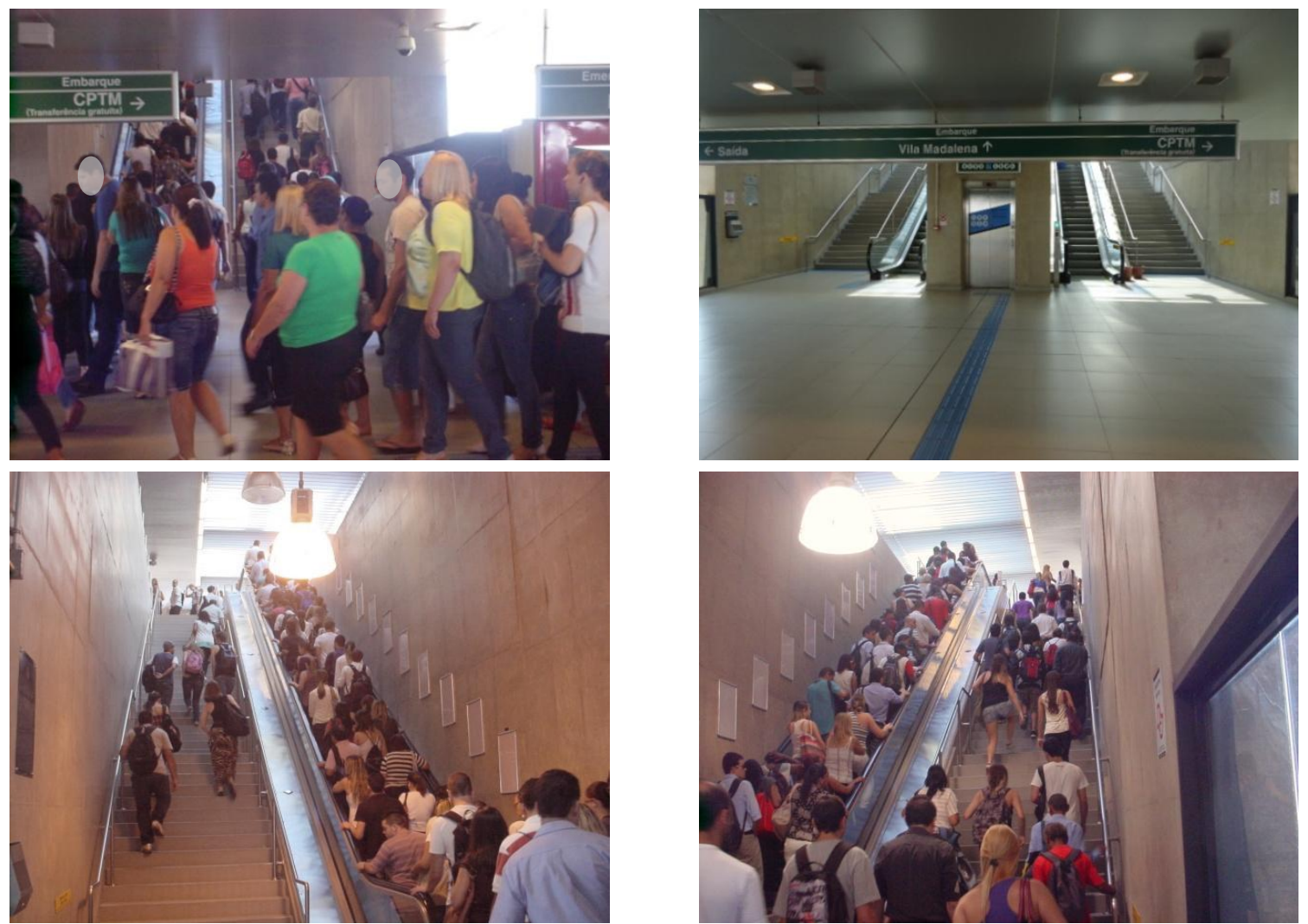

Figura 78 - São Paulo/Tamanduateí: Elementos de circulação vertical - embarque Vila Madalena. Fonte: BARBOSA, M. B., 2011.

Existem duas linhas de bloqueios, sendo uma de entrada/saída junto à passarela do acesso e outra na transferência entre o metrô e o trem metropolitano. Por conta disso, existem diferentes fluxos na área paga do mezanino:

- entrada para embarque no metrô, sentido Vila Prudente ou Vila Madalena, ou desembarque do metrô para a rua, utilizando a linha de bloqueios da passarela (Figura 79);

- conexão entre o trem metropolitano e o metrô, utilizando a linha de contadores da transferência (Figura 80).
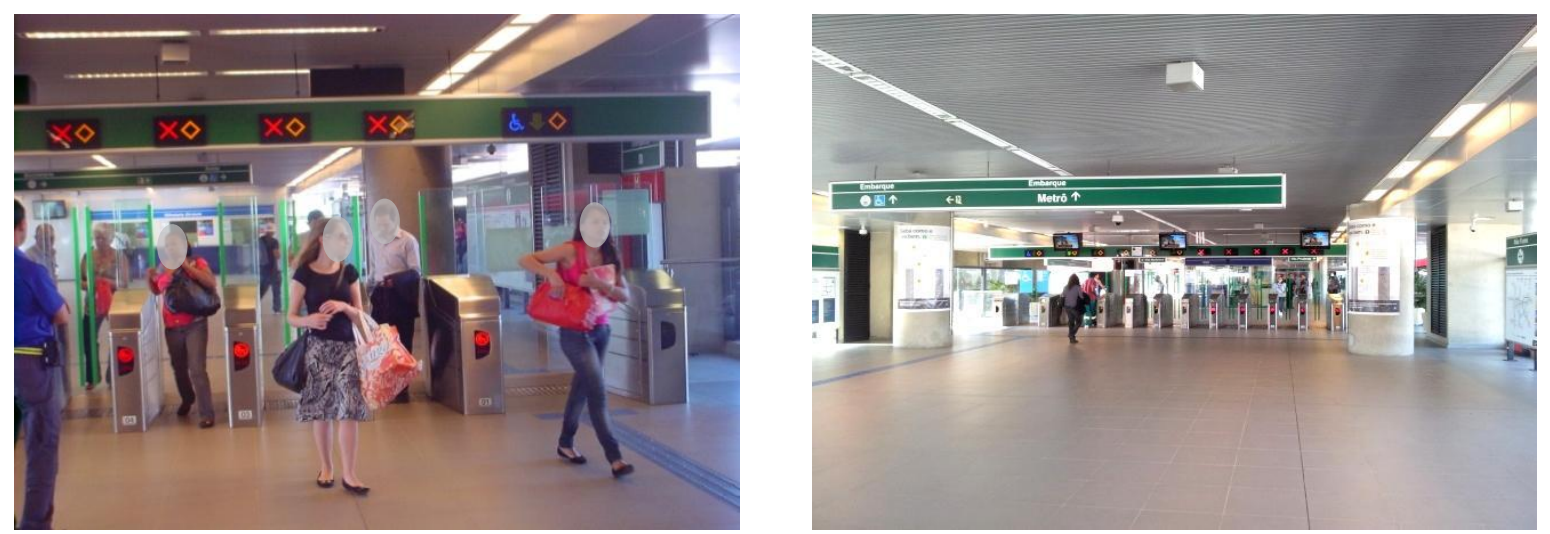

Figura 79 - São Paulo/Tamanduateí: Fluxo de embarque na linha de bloqueios da passarela.

Fonte: BARBOSA, M. B., 2013. 

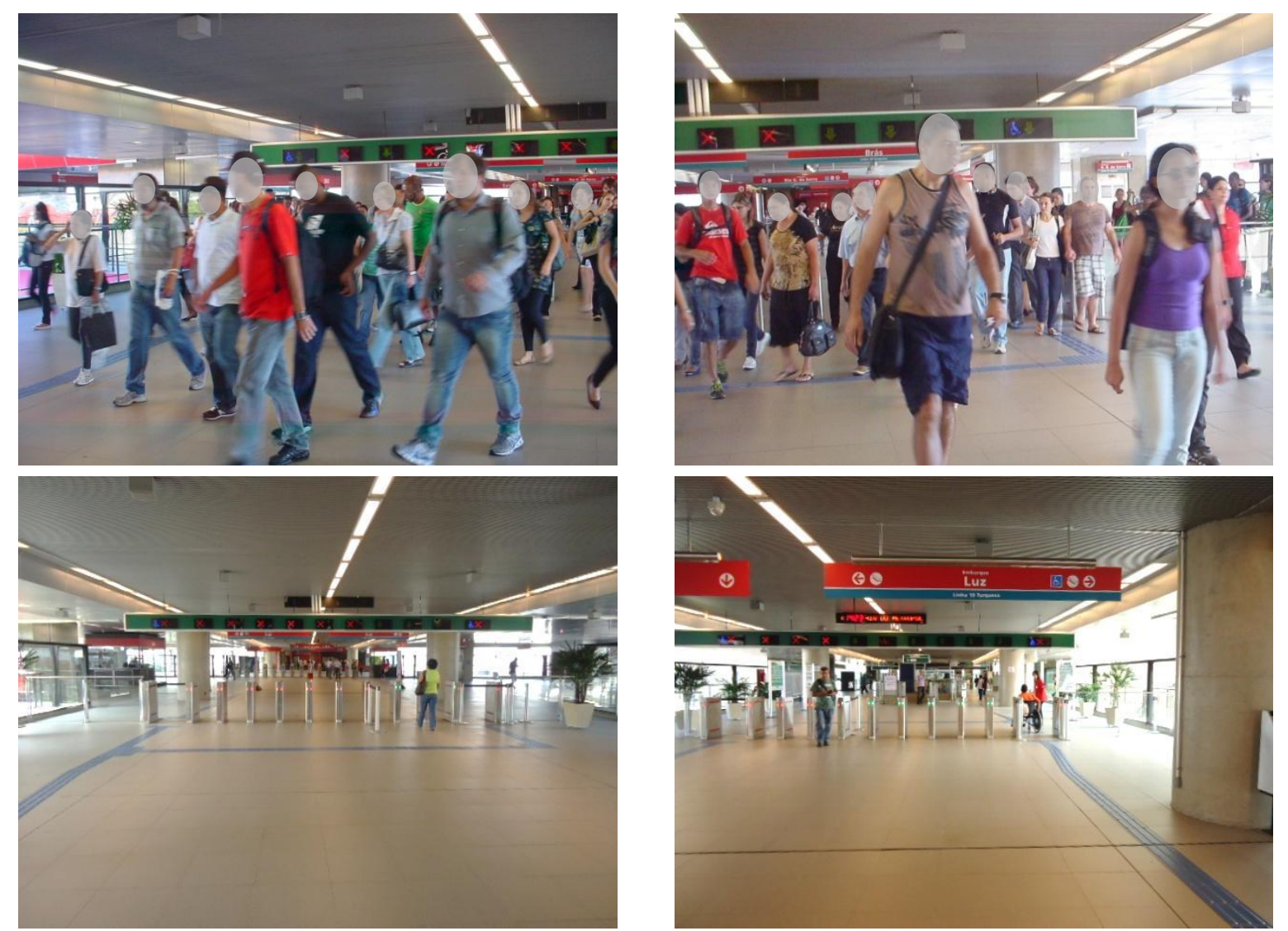

Figura 80 - São Paulo/Tamanduateí: Fluxo de transferência do trem metropolitano para o Metrô. Fonte: BARBOSA, M. B., 2013.

No período da manhã, o fluxo de usuários que vêm dos arredores para embarcar nessa estação é bem pequeno, e prevalece o fluxo de conexão vindo do trem metropolitano para embarque no sentido Vila Madalena. Ao meio dia, há um fluxo grande de usuários que vêm da plataforma no sentido Vila Prudente para fazer a transferência para o trem metropolitano. À noite, o fluxo de desembarque para as imediações é proveniente da plataforma no sentido Vila Prudente, mas também, nesse período, prevalece a conexão para o trem metropolitano.

Foram identificados diferentes fluxos no mezanino do metrô, conforme apresentado na Figura 81. Outros fluxos ocorrem no mezanino do trem metropolitano e estão relacionados ao embarque e desembarque das linhas de trem metropolitano. 


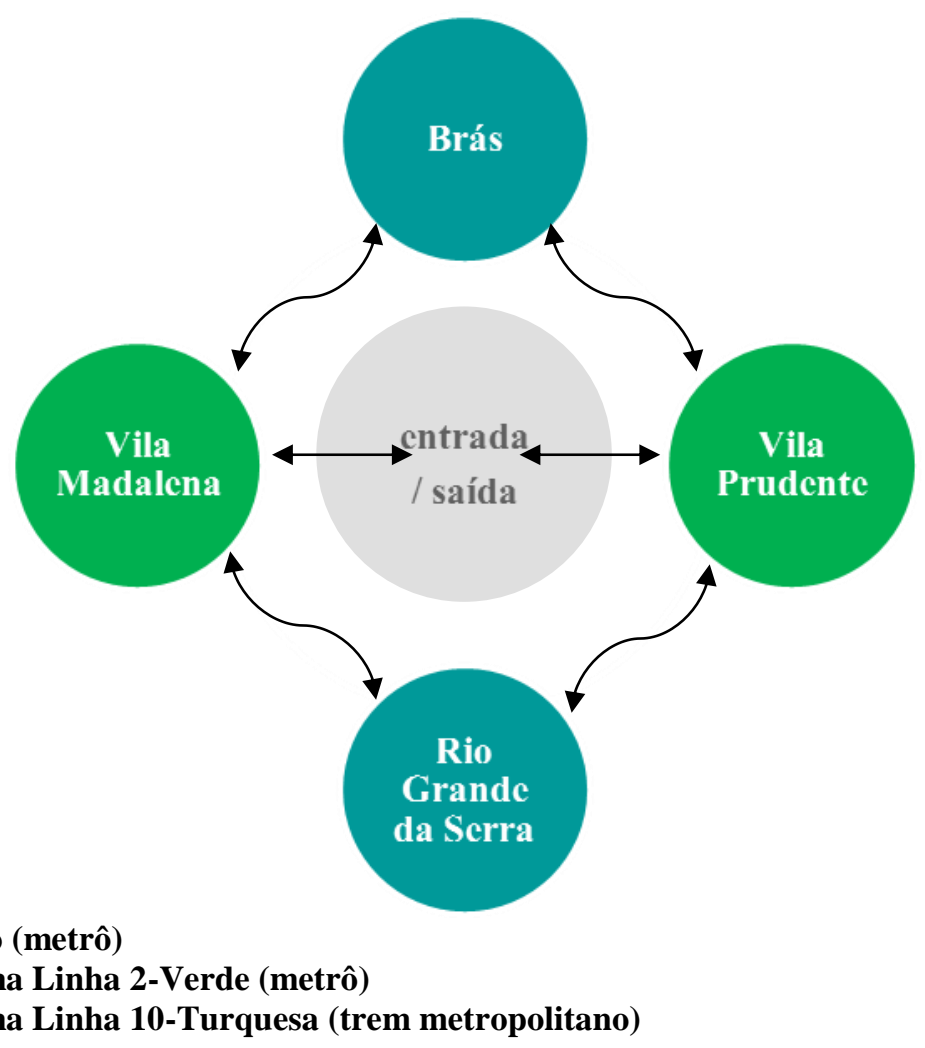

Figura 81 - São Paulo/Tamanduateí: Esquema de fluxos.

Fonte: Elaborado pela pesquisadora. (2014)

No mezanino da área paga, percebe-se que, durante o auxílio prestado, os estagiários e funcionários não seguem o piso tátil por causa do fluxo de usuários, que o atravessam por cima, bloqueando a passagem das pessoas com deficiência visual. Os estagiários e funcionários que auxiliam pessoas com deficiência visual costumam fazer os seguintes trajetos:

Para conexão da Linha 2-Verde do Metrô para a Linha 10-Turquesa da CPTM:

- Trajeto A - desembarcam do metrô no sentido Vila Madalena, descem a ER23 ou EF06 e deslocam-se pelo piso tátil do mezanino, no contrafluxo, até os contadores de transferência para o trem metropolitano;

- Trajeto B - desembarcam do metrô no sentido Vila Prudente, descem a ER20 ou EF09 e deslocam-se no mezanino sem piso tátil, no mesmo fluxo dos demais usuários, até os contadores de transferência para o trem metropolitano;

Para conexão da Linha 10-Turquesa da CPTM para a Linha 2-Verde do Metrô:

- Trajeto $\mathbf{C}$ - vindo do trem metropolitano, passam pelos contadores de transferência para o Metrô e deslocam-se pelo piso tátil do mezanino, no mesmo fluxo dos demais usuários, e sobem a ER21 ou EF07 até o embarque no sentido Vila Madalena; 
- Trajeto D - vindo do trem metropolitano, passam pelos contadores de transferência para o Metrô e deslocam-se no mezanino sem piso tátil, no mesmo fluxo dos demais usuários, e sobem a ER22 ou EF08 até o embarque no sentido Vila Prudente;

Para desembarque:

- Trajeto E - desembarcam do metrô no sentido Vila Madalena, descem a ER23 ou EF06 e deslocam-se pelo piso tátil do mezanino até os bloqueios de saída;

- Trajeto F - desembarcam do metrô no sentido Vila Prudente, descem a ER20 ou EF09 e deslocam-se pelo piso tátil do mezanino até os bloqueios de saída;

Para embarque:

- Trajeto G - vindo da rua para embarque na Linha 2-Verde, deslocam-se pelo piso tátil do mezanino e sobem a ER21 ou EF07, seguindo até o embarque no sentido Vila Madalena. No pico da manhã, é utilizada a ER23 para embarcar; porém, nos demais períodos, essa escada rolante fica posicionada para descer;

- Trajeto H - vindo da rua para embarque na Linha 2-Verde, deslocam-se pelo piso tátil do mezanino e sobem a ER22 ou EF08, seguindo até o embarque no sentido Vila Prudente.

Foram registrados sete deslocamentos de pessoas com deficiência visual em diferentes horários, sendo dois deslocamentos com independência e cinco com auxílio dos estagiários e funcionários, percorrendo diferentes trajetos (Quadro 22).

Quadro 22 - Deslocamentos e trajetos realizados na estação Tamanduateí.

\begin{tabular}{lcc}
\hline \multicolumn{1}{c}{ Observações } & $\begin{array}{c}\text { Deslocamentos } \\
\text { independentes }\end{array}$ & $\begin{array}{c}\text { Deslocamentos } \\
\text { com auxílio }\end{array}$ \\
\hline Pico manhã & trajeto C & trajetos C, G \\
\hline Pico intermediário & --- & trajeto C \\
\hline Pico tarde & trajeto A & trajetos A, C \\
\hline
\end{tabular}

Durante os períodos em que foram realizadas observações, não foi constatada a utilização dos elevadores pelas pessoas com deficiência visual, sozinhas ou acompanhadas por estagiários ou funcionários, seja para embarque, desembarque ou conexão entre linhas. Observou-se que os deslocamentos que utilizam a sinalização tátil no piso são realizados no contrafluxo. Há necessidade de instalação de sinalização tátil interligando as duas plataformas, de forma independente, desde os contadores da transferência. 
As observações de fluxo realizadas nos mezaninos área paga das estações mostraram que vários fatores interferem e impactam essa etapa da viagem, sendo os mais significativos a configuração e a localização dos elementos de circulação vertical; a existência de fluxos bidirecionais de embarque e desembarque simultâneos, além dos fluxos de conexão; a presença e o comportamento dos demais usuários; a lotação; as condições para realização de deslocamentos com segurança; a colocação de elemento orientadores ou direcionadores de fluxo. Nesse sentido, o ambiente existente - a configuração, a localização e a sinalização dos mezaninos - tem impacto nessa etapa quando associadas ao serviço prestado.

No mezanino área paga, a localização da sinalização tátil no piso, orientando os deslocamentos exclusivamente entre os bloqueios e os elementos de circulação vertical elevadores ou plataformas de elevação - garante que os fluxos sejam bidirecionais. Contudo, inviabilizam os deslocamentos para embarque por meio das escadas fixas, fazendo com que os usuários com deficiência visual utilizem estratégias para se orientar e identificar a localização das escadas para a plataforma. No sentido contrário, de desembarque, os usuários que usam as escadas chegam ao mezanino sem referenciais para ir até os bloqueios.

A existência de elementos orientadores ou direcionadores de fluxo próximo à sinalização tátil no piso - principalmente junto às escadas fixas e rolantes - interferem nos deslocamentos. Tanto quanto o ambiente, o comportamento dos demais usuários é decisivo para garantir a segurança das pessoas com deficiência visual: os comportamentos desrespeitosos são atribuídos às pessoas, em função da lotação dos mezaninos e da permanência dos demais usuários - ou seus pertences - sobre o piso tátil. Tais comportamentos desrespeitosos às pessoas e às regras estabelecidas pela operadora do serviço levam à intolerância entre as pessoas, ao individualismo nos espaços públicos e equipamentos coletivos.

Contudo, destaca-se a quantidade de trajetos possíveis nos mezaninos, seja em função dos fluxos de embarque, desembarque ou conexão entre diferentes linhas que devem ser memorizados pelos usuários com deficiência visual para que possam efetuar seus deslocamentos para consecução de seus objetivos. A impossibilidade de padronização da configuração das estações - foram identificadas nove tipologias básicas, apresentadas em 3.5.1 -, agravada pela impossibilidade de padronização da localização dos elementos de circulação vertical, faz com que os deslocamentos independentes sejam ainda mais desafiadores. 


\subsubsection{Observação do treinamento de O\&M}

Durante a realização desta pesquisa, houve duas oportunidades para observação do treinamento de O\&M para pessoas com deficiência visual nas estações e trens, visando a utilização de escadas rolantes, o deslocamento na plataforma e o reconhecimento das configurações interna e externa do trem. Os treinamentos foram realizados com diferentes públicos (crianças, adolescentes e adultos) nos dias 16 e 18/06/2011 nas estações Vila Madalena e Vila Prudente.

As observações realizadas foram objetos de anotação e registro fotográfico e permitiram confrontar e validar os dados coletados nas entrevistas realizadas com professores de O\&M e nos questionários aplicados às pessoas com deficiência visual. Foi possível relacionar as descobertas obtidas na observação do treinamento de O\&M e as observadas nos demais instrumentos.

Nos treinamentos de O\&M para utilização das escadas rolantes, as pessoas cegas foram orientadas a se aproximar desses equipamentos a partir de pistas ambientais (informações auditivas, vibração do pavimento e piso diferenciado) e contatar os lados da escada com a bengala. Segundo Felippe e Felippe (1997), o sentido de deslocamento das escadas é percebido quando a pessoa toca e sente o movimento do corrimão; com a ponteira da bengala, ela localiza e sente o movimento dos degraus. Em seguida, firma-se ao corrimão e dá um passo em direção aos degraus, sem hesitação. Já na escada, mantém um pé em cada degrau para manter o equilíbrio. A percepção do término da escada dá-se de forma cinestésica, pelo nivelamento dos degraus e do corrimão. Nesse momento, a pessoa dá um passo à frente, afastando-se da escada rolante (Figura 82). Os treinamentos de O\&M para utilização da sinalização tátil de piso são realizados pelas entidades de reabilitação nas estações do Metrô de São Paulo, visando agilizar a capacitação de um contingente maior de usuários (Figuras de 83 a 85$)$. 


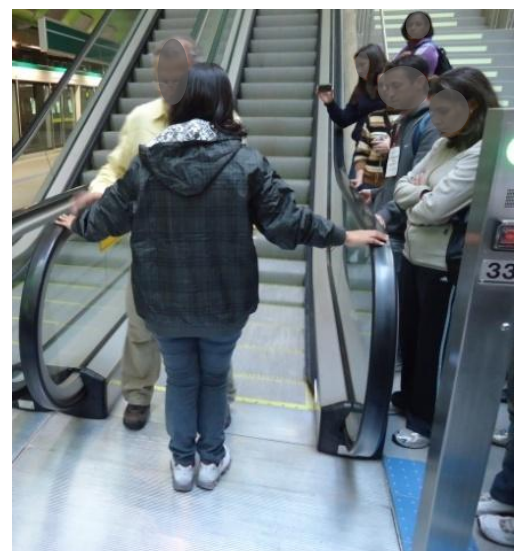

Figura 82 - Reconhecimento e utilização da escada rolante. Fonte: BARBOSA, M. B., 2011.

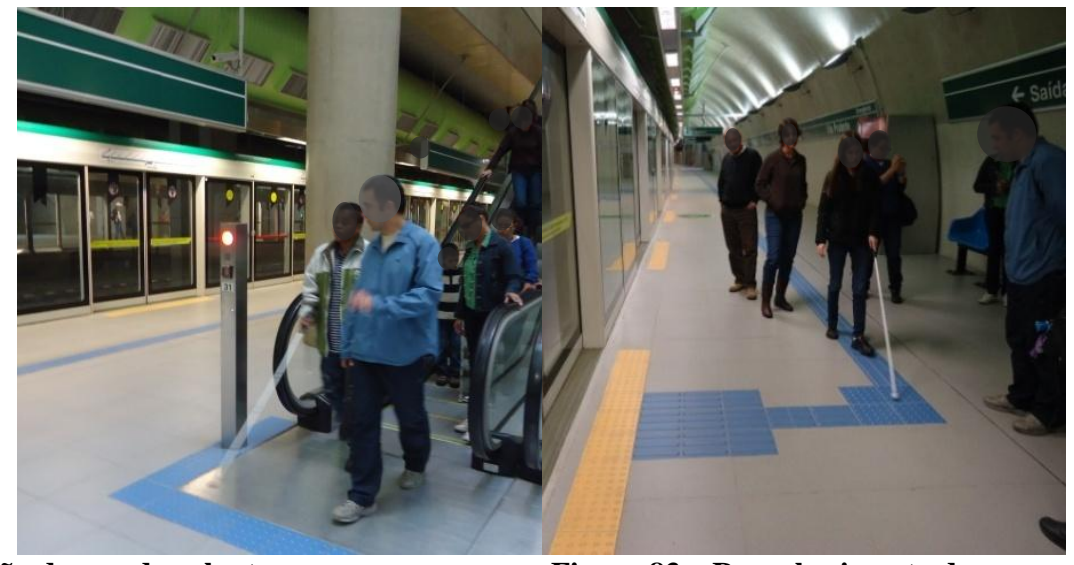

Figura 83 - Reconhecimento do percurso de embarque.

Fonte: BARBOSA, M. B., 2011.

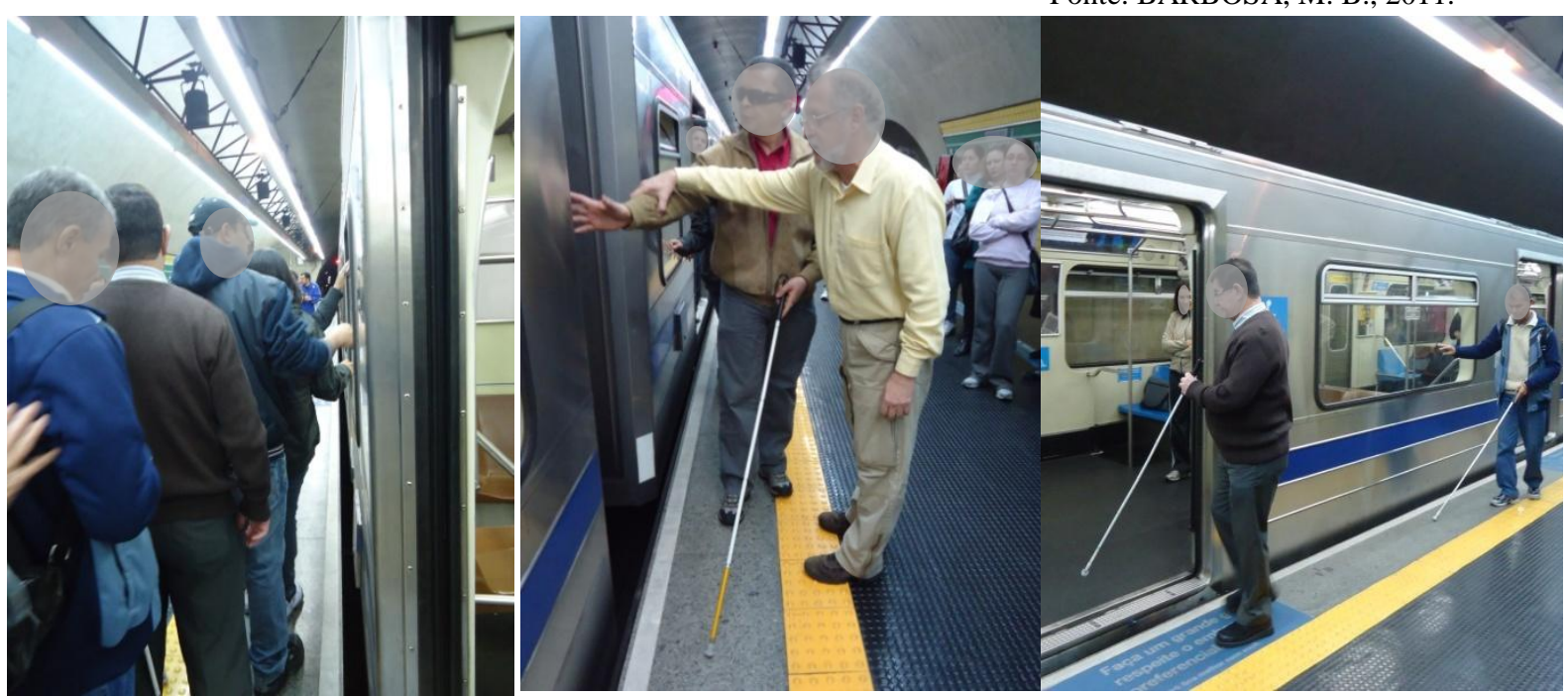

Figura 84 - Reconhecimento do dimensionamento e da configuração externa do trem.

Fonte: BARBOSA, M. B., 2011.

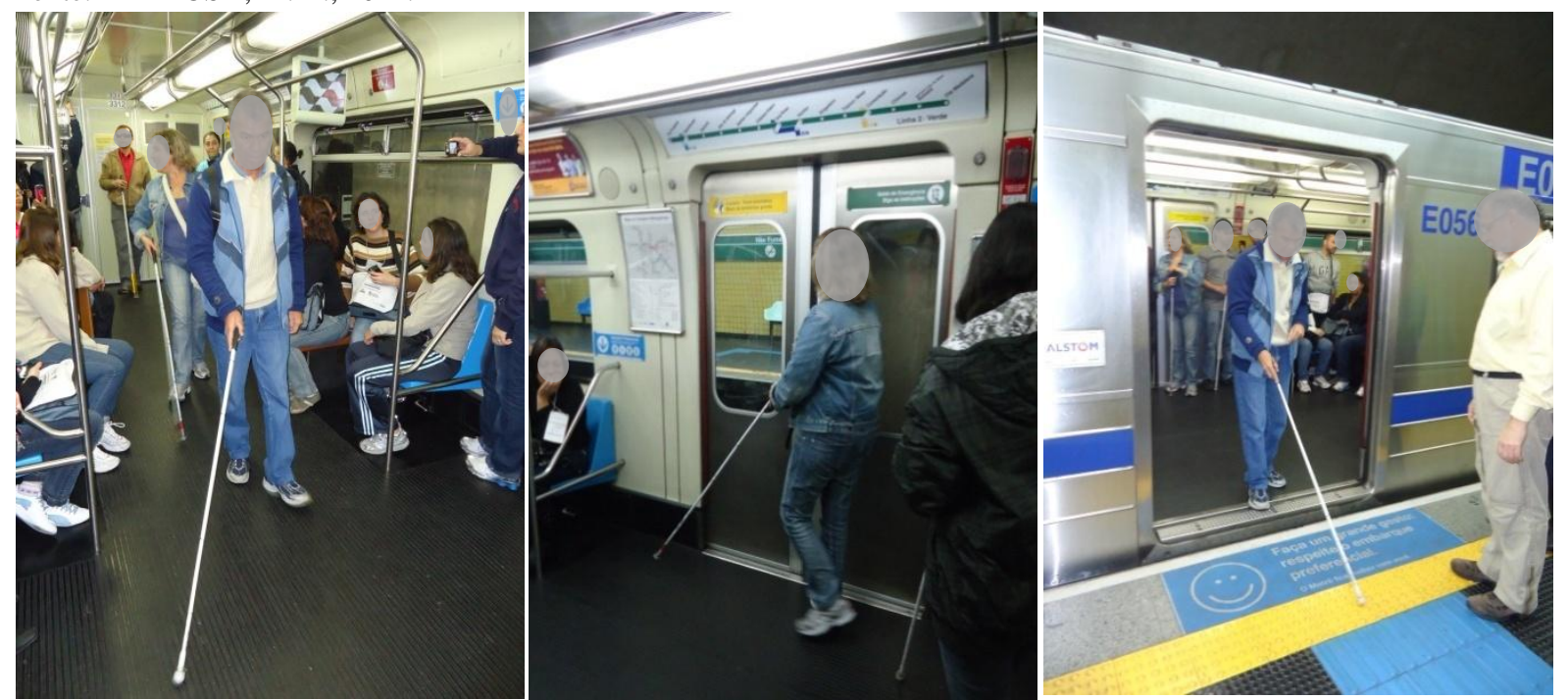

Figura 85 - Reconhecimento do dimensionamento e da configuração interna do trem.

Fonte: BARBOSA, M. B., 2011. 


\subsection{Benchmarking}

Benchmarking é um processo sistemático e contínuo para avaliação de produtos, serviços e procedimentos, visando ao reconhecimento de melhores práticas entre empresas ou produtos similares, considerados paradigmas. Tal processo permite inovação e aprendizado por meio de troca de informações.

O projeto de benchmarking entre metrôs nasceu na reunião do Comitê de Direção da União Internacional dos Transportes Públicos - UITP, em maio de 1982, quando alguns metrôs concordaram em elaborar, em conjunto, um estudo comparativo de seus desempenhos, identificando paradigmas de excelência nos seus procedimentos e nas suas práticas. Os estudos vêm sendo confiados ao Railway Technology Strategy Center (RTSC), da Universidade de Londres $^{25}$. No caso específico dos metrôs ${ }^{26}$, são utilizadas técnicas de investigação aplicadas continuamente entre empresas de transporte metroferroviário com características similares. Atualmente, três grupos de metrôs estão envolvidos em processos de benchmarking com objetivo de identificar ações estruturadas que possam levar a desempenhos superiores: COMET - Community of Metros; NOVA - Group of Metros; e ISBERG - International Suburban Rail Benchmarking Group. Cada um dos grupos tem, em média, 16 participantes, que se reúnem periodicamente e trocam informações entre si.

A organização dos 45 requisitos de desempenho relacionados à configuração e sinalização das estações e dos trens já mencionados e apresentados no Quadro 7, permitiu identificar quais aspectos vêm sendo valorizados e priorizados pelas empresas operadoras metroferroviárias internacionais.

Os dados sobre o processo de adaptação das redes existentes, as ações implementadas e o grau de acessibilidade alcançado possibilitaram a seleção de cinco redes pertencentes aos grupos Comet e Nova para realização de visitas técnicas. O foco principal das visitas técnicas foi identificar soluções relacionadas à configuração e sinalização e verificar a concretização dos novos requisitos de acessibilidade nas estações e trens construídos, fabricados ou adaptados recentemente, considerando ainda o tratamento dado à interface trem-estação.

\footnotetext{
${ }^{25}$ Disponível em: http://cometandnova.org/background. Acesso em: 17 jan. 2011.

${ }^{26} \mathrm{O}$ sucesso do estudo se fundamenta na confiança total entre os membros para que se possa estabelecer e discutir, com total realismo, os dados e resultados de todos, sem receio de que algum participante possa revelar dados obtidos de outros. Foi então decidido, entre os membros do CoMET, um acordo de confidencialidade [...] os resultados de algum estudo, se citados ou revelados fora do grupo, não podem conter referência aos nomes dos metrôs envolvidos.
} 


\subsubsection{Metrô de Barcelona}

A visita à rede de transportes de Barcelona foi realizada no período de 14 a 21/04/2011. O metrô de Barcelona iniciou sua operação em 1924 e foi um dos primeiros metrôs a iniciar obras para acessibilidade nas estações e trens, por conta das olimpíadas e paraolimpíadas, realizadas simultaneamente, pela primeira vez, em 1992 naquela cidade (JUNCÀ, 1992). O metrô de Barcelona tem 101,8 km de rede e 117 estações distribuídas em oito linhas, por onde circulam 136 trens nos horários de maior demanda, com um intervalo médio de 164 segundos. Essa rede é responsável pelo transporte de 1,16 milhões de passageiros por dia. Os trens pertencem a oito frotas diferentes. As estações possuem um total de 596 escadas rolantes e 384 elevadores. ${ }^{27}$

A visita foi organizada pela Unidade de Infraestrutura e Via da TMB - Transports Metropolitans de Barcelona -, possibilitando conhecer o plano de acessibilidade (aspectos já implantados e em desenvolvimento), incluindo dificuldades, parcerias e ações de êxito. Foram realizadas visitas às estações padrão, adaptadas, e às novas estações com automação total, acessíveis (Figuras 86 a 88). Também foi possível observar critérios de projeto de sinalização e comunicação das diferentes estações, bem como estratégias de operação das linhas.
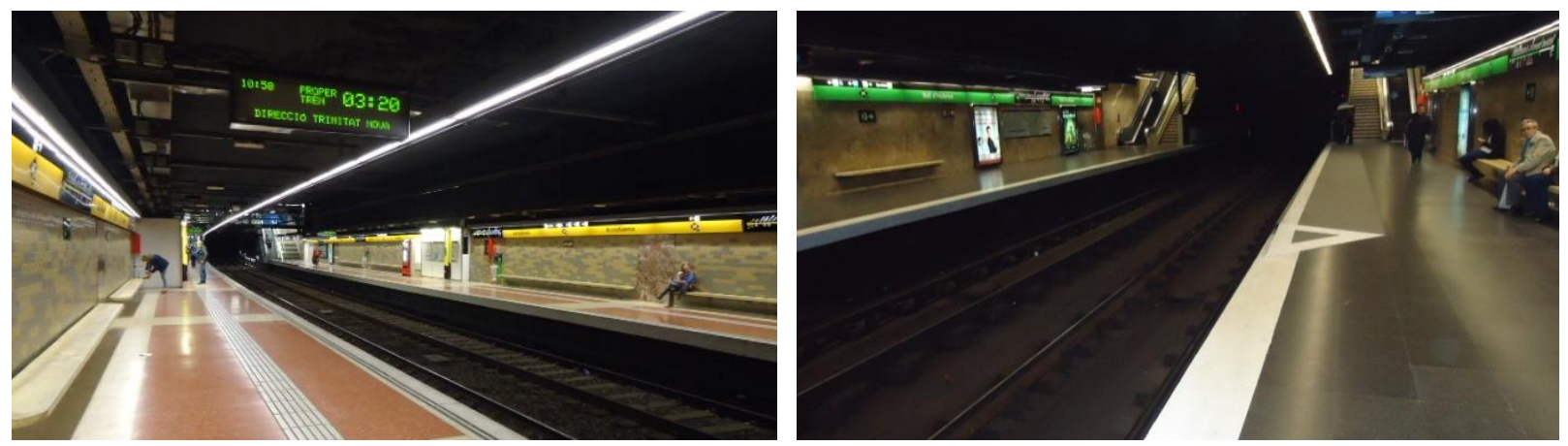

Figura 86 - Barcelona - Sinalização tátil até o local de embarque preferencial nas estações antigas. Fonte: BARBOSA, M. B., 2011.

\footnotetext{
${ }^{27}$ Munõz, S.C. Plan de Accesibilidad de las Infraestructuras Existentes. Apresentação realizada durante a visita ao Metrô de Barcelona em 19/04/2011.
} 


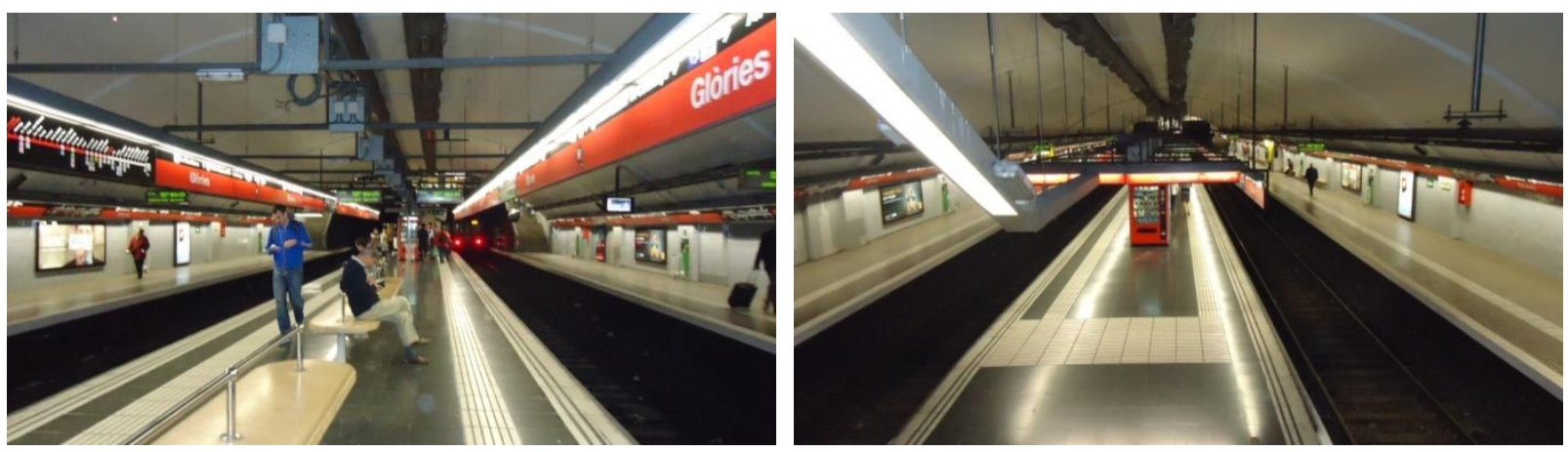

Figura 87 - Barcelona - Sinalização tátil até o embarque preferencial - estações modernizadas. Fonte: BARBOSA, M. B., 2011.
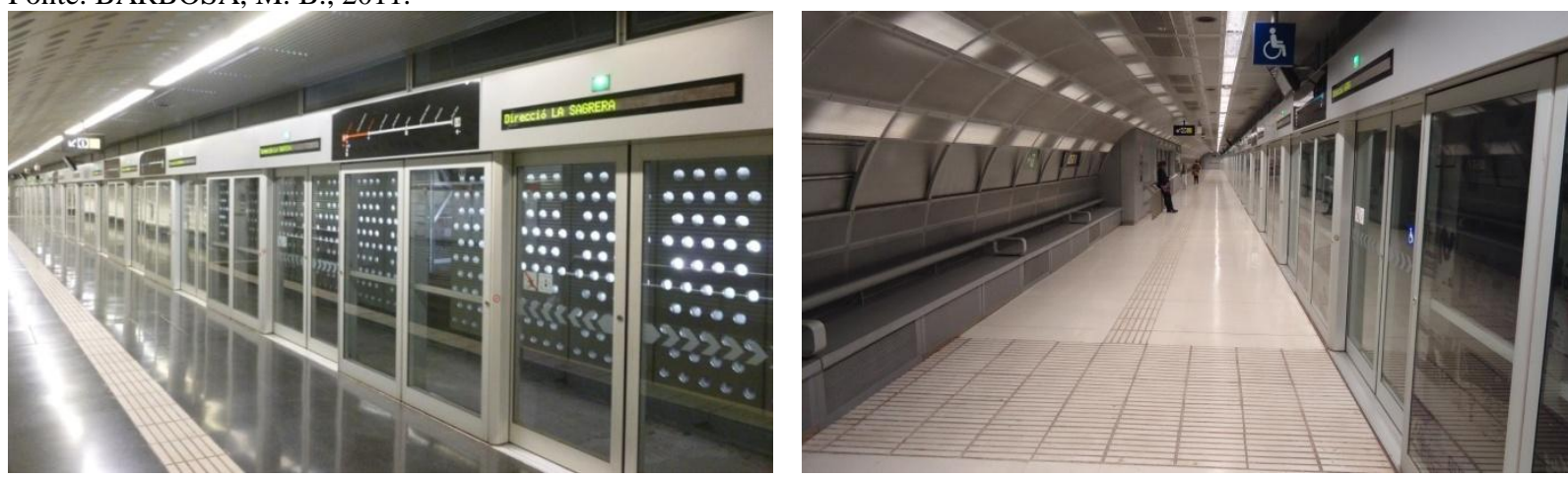

Figura 88 - Barcelona - Sinalização tátil até o embarque preferencial - estações automáticas.

Fonte: BARBOSA, M. B., 2011.

Foi realizada uma visita ao Centro de Controle Operacional (CCM) da rede metroviária, local de onde, além do controle da circulação dos trens, controle dos intervalos entre trens, ajuste da oferta e da demanda em tempo real, gerenciamento dos trabalhos noturnos e dos equipamentos de segurança das estações (coordenação dos incidentes e emergências), partem as mensagens sonoras e visuais dos painéis eletrônicos existentes nas estações e trens que alimentam os canais de informação internos e externos (Figura 89).
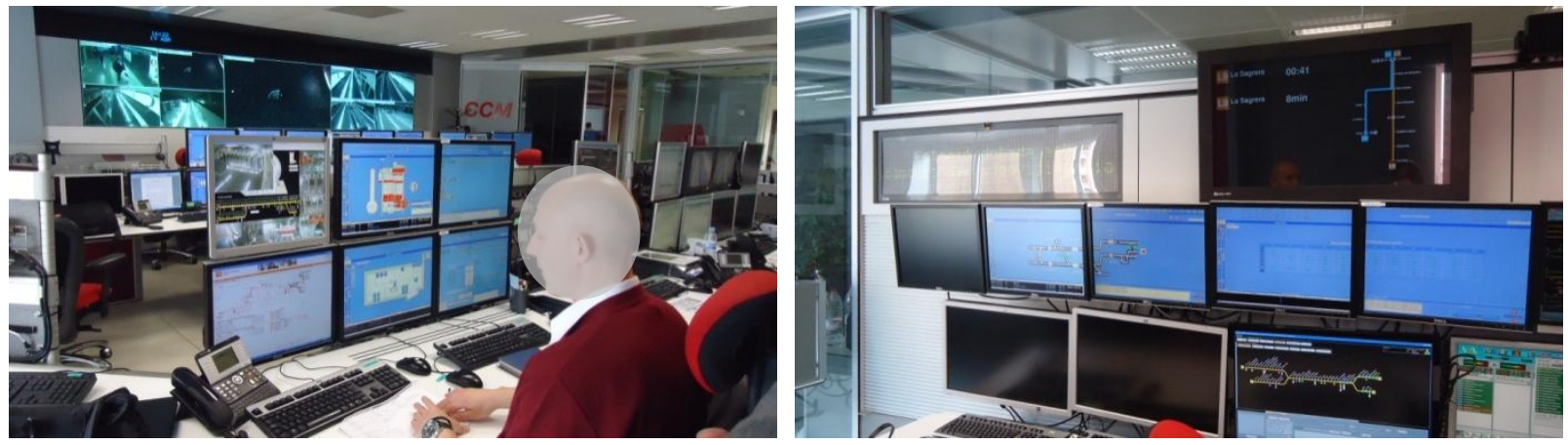

Figura 89 - Barcelona - Centro de Controle do Metrô de Barcelona.

Fonte: BARBOSA, M. B., 2011.

O supervisor do CCM gerencia todos os recursos para garantir o serviço regular e para agir com eficiência e eficácia máximas diante de qualquer incidente. $\mathrm{O}$ centro é responsável pela operação das linhas 1, 2, 3, 4 e 5 (convencionais) e das linhas 9, 10 e 11 (automáticas). 


\subsubsection{Metrô de Madri}

A visita à rede de transporte de Madri foi realizada no período de 23 a 30/05/2013. O metrô de Madri iniciou sua operação em 1919 e atualmente tem 293 km de rede e 300 estações distribuídas em 14 linhas, por onde circulam 301 trens nos horários de maior demanda, com intervalo médio de 150 segundos, responsáveis pelo transporte de 1,92 milhão de passageiros por dia. As estações possuem 1.729 escadas rolantes e 508 elevadores. Uma das características marcantes da rede do metrô de Madri é a conectividade: 23 estações têm conexão com a rede de trens metropolitanos, regionais e de longo percurso; 24 estações fazem conexão com o sistema de ônibus interurbanos, e duas estações, com aeroportos. Pelo menos 41 estações servem a duas ou mais linhas de metrô, e a maioria das estações está conectada à rede de ônibus urbanos. ${ }^{28} \mathrm{~A}$ visita foi organizada pelo Departamento de Projetos Especiais do Metro de Madrid S.A. e possibilitou conhecer o plano de acessibilidade - os aspectos já implantados e aqueles em desenvolvimento. Foram realizadas visitas às estações padrão, adaptadas, e às novas estações com automação total, acessíveis, onde foi possível observar os critérios de projeto de sinalização e informação das diferentes estações (Figuras 90 e 91).

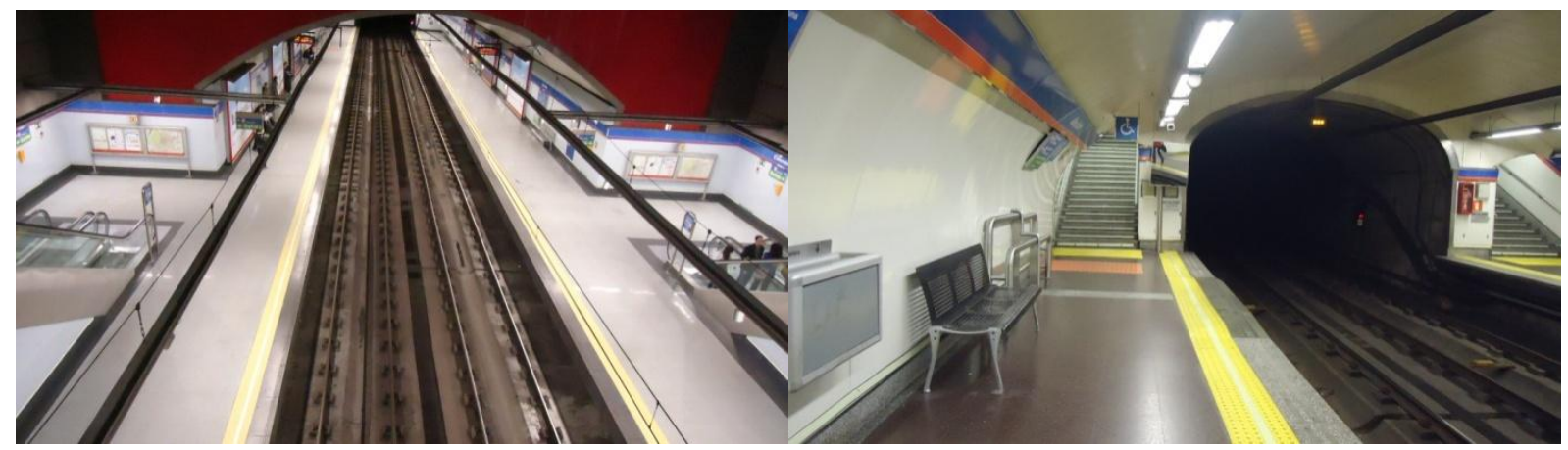

Figura 90 - Madri - Adaptação e sinalização tátil do local de embarque preferencial nas estações antigas. Fonte: BARBOSA, M. B., 2013.

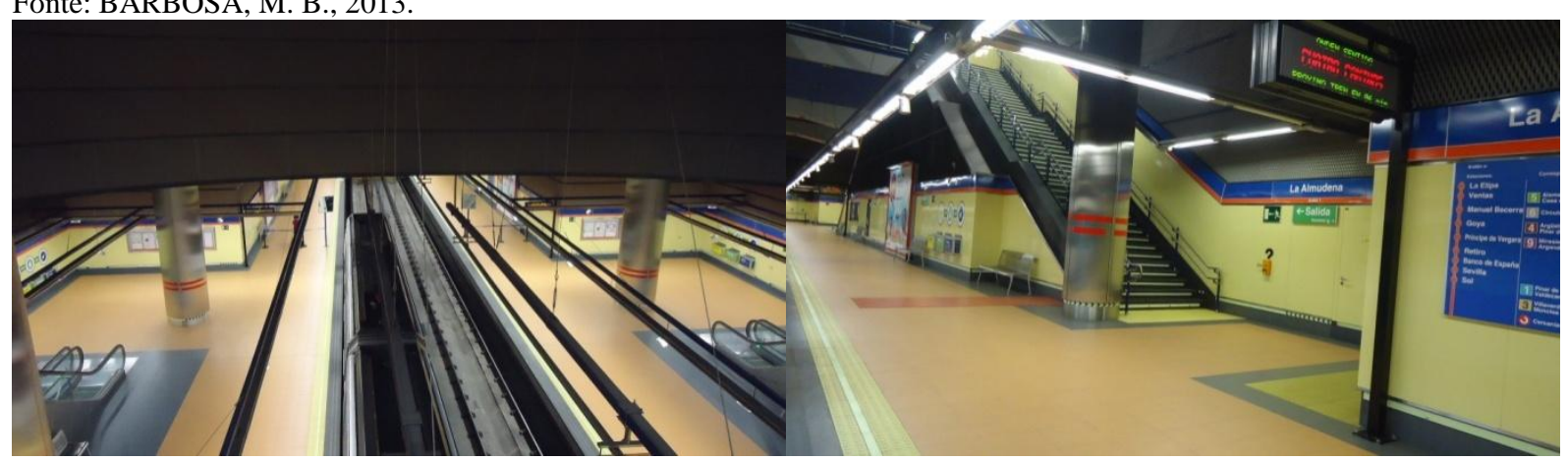

Figura 91 - Madri - Configuração e sinalização tátil do local de embarque preferencial nas estações acessíveis. Fonte: BARBOSA, M. B., 2013.

\footnotetext{
${ }^{28}$ González, V. R. Modelo de Movilidad de la Región de Madrid. Apresentação realizada durante a visita ao
} Metrô de Madri em 29/05/2013. 
Foi realizada uma visita à estação La Almudena, da Linha 2 da rede metroviária, para constatação do atendimento aos requisitos de acessibilidade nas novas estações. Em relação aos trens, foram apresentados os requisitos de acessibilidade para fabricação ou modernização dos trens das diferentes frotas. Um trem permaneceu estacionado na plataforma dessa estação para que fossem explicados os recursos de acessibilidade em funcionamento na interface trem-estação e no interior dos carros, conforme ilustram as Figuras 92 e 93.

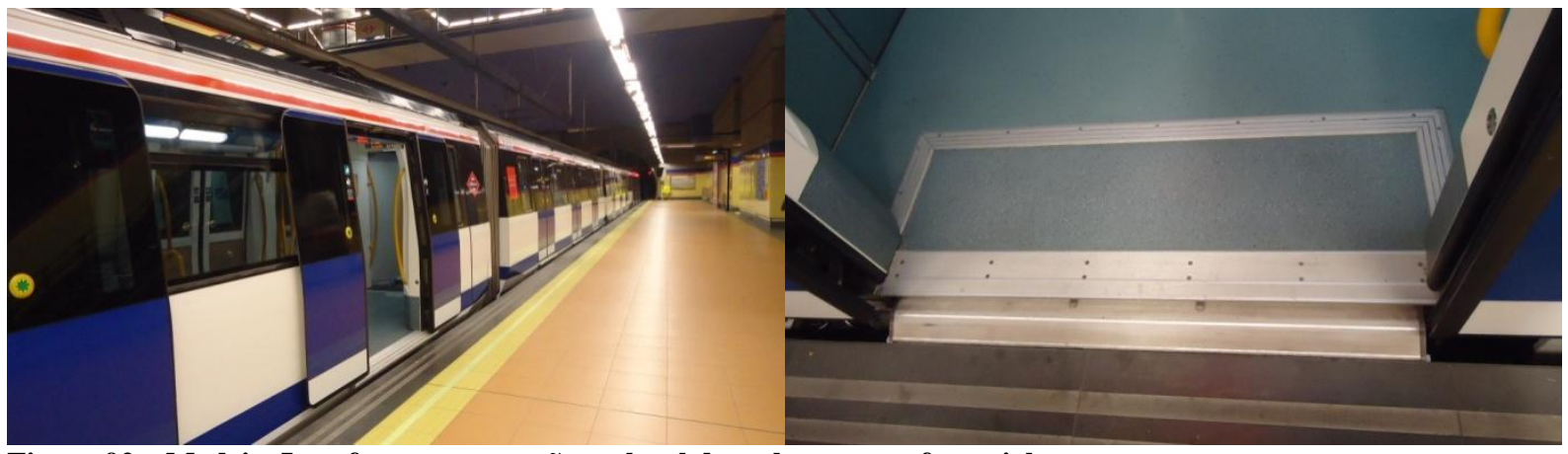

Figura 92 - Madri - Interface trem-estação no local de embarque preferencial.

Fonte: BARBOSA, M. B., 2013.
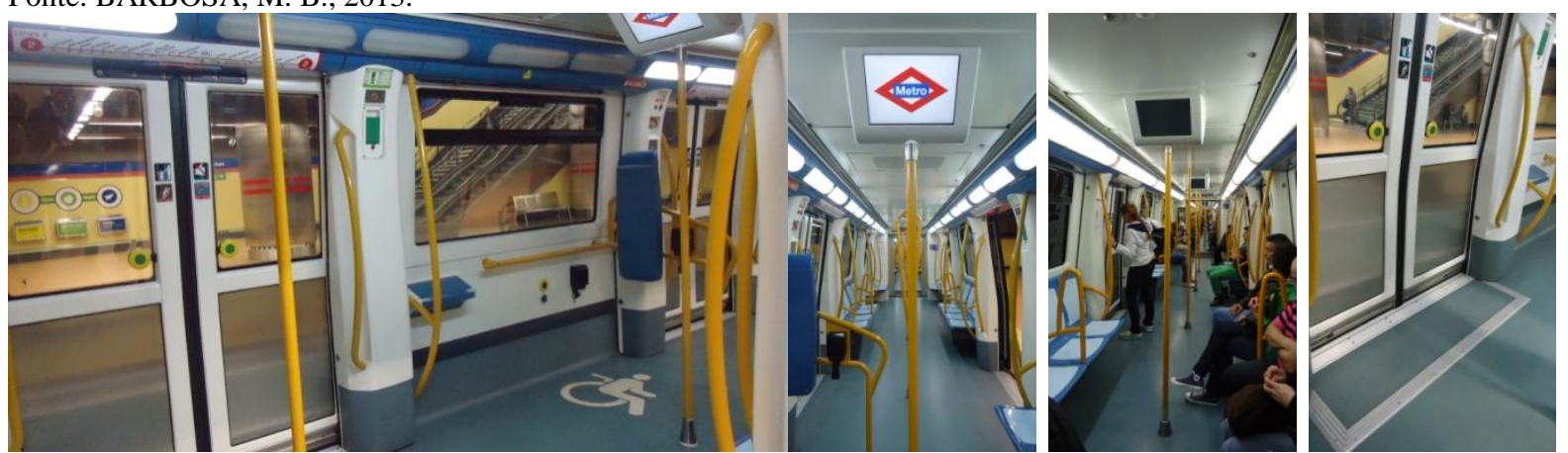

Figura 93 - Madri - Recursos de acessibilidade no interior dos trens. Fonte: BARBOSA, M. B., 2013.

Na rede metroviária de Madri, constatou-se que a nova diretriz de projeto de arquitetura das estações - menor profundidade -, além de facilitar o deslocamento, simplifica a compreensão da configuração das estações e, consequentemente, dos percursos.

\subsubsection{Metrô de Londres}

A visita à rede de transporte de Londres foi realizada no período de 13 a 20/05/2013. O metrô de Londres foi o primeiro metrô a ser implantado, em 1863. Ao completar 150 anos, vem gradativamente investindo esforços para modernizar suas instalações, adequando-se às novas demandas e tecnologias, incluindo obras de adaptação para dotar estações e trens de condições de acessibilidade por conta do legado das olimpíadas e paraolimpíadas, realizadas em 2012. O metrô de Londres tem 439 km de rede e 270 estações distribuídas em 10 linhas, 
por onde circulam 532 trens nos horários de maior demanda, com intervalo médio de 150 segundos, responsáveis pelo transporte de 3,98 milhões de passageiros por dia. Os trens pertencem a 10 diferentes frotas. As estações possuem 442 escadas rolantes e 174 elevadores. $^{29}$

A visita foi organizada pelo Departamento de Comunicação Corporativa e pela equipe de Acessibilidade e inclusão do London Underground Limited - LUL, possibilitando conhecer o plano de modernização das estações, os critérios de acessibilidade adotados para a adaptação das instalações - aspectos já implantados e em desenvolvimento. Foram realizadas visitas às estações em processo de modernização ou já modernizadas (estações Paddington e Farringdon), bem como às estações com automação total, acessíveis, onde foi possível observar os requisitos de projeto implantados (Figuras de 94 a 96).
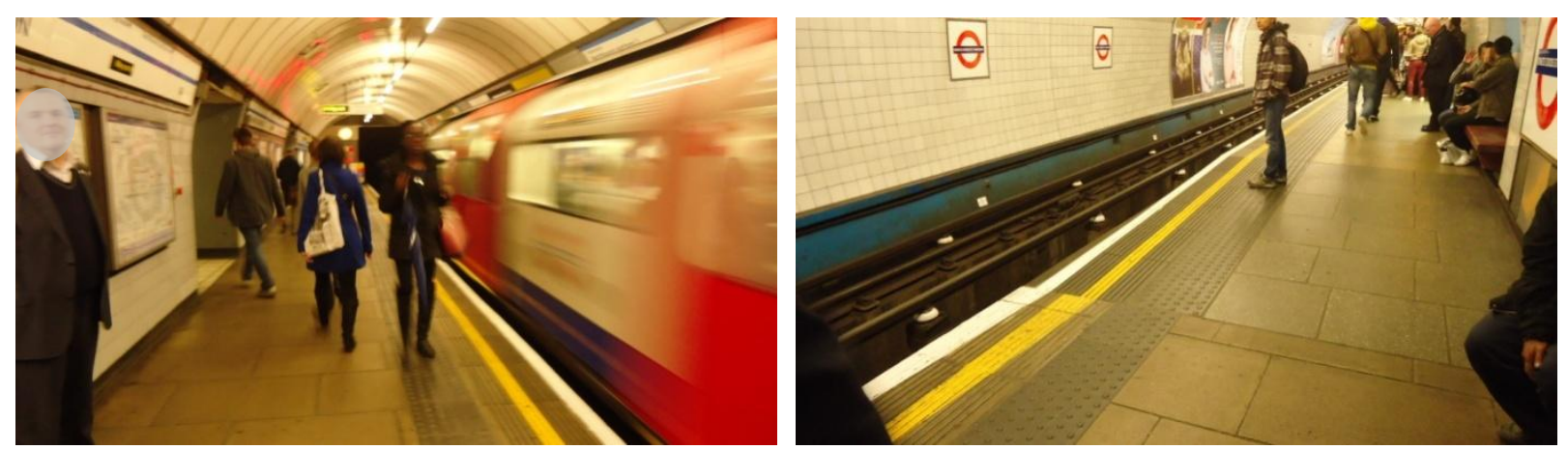

Figura 94 - Londres - Plataforma das estações antigas. Fonte: BARBOSA, M. B., 2013.
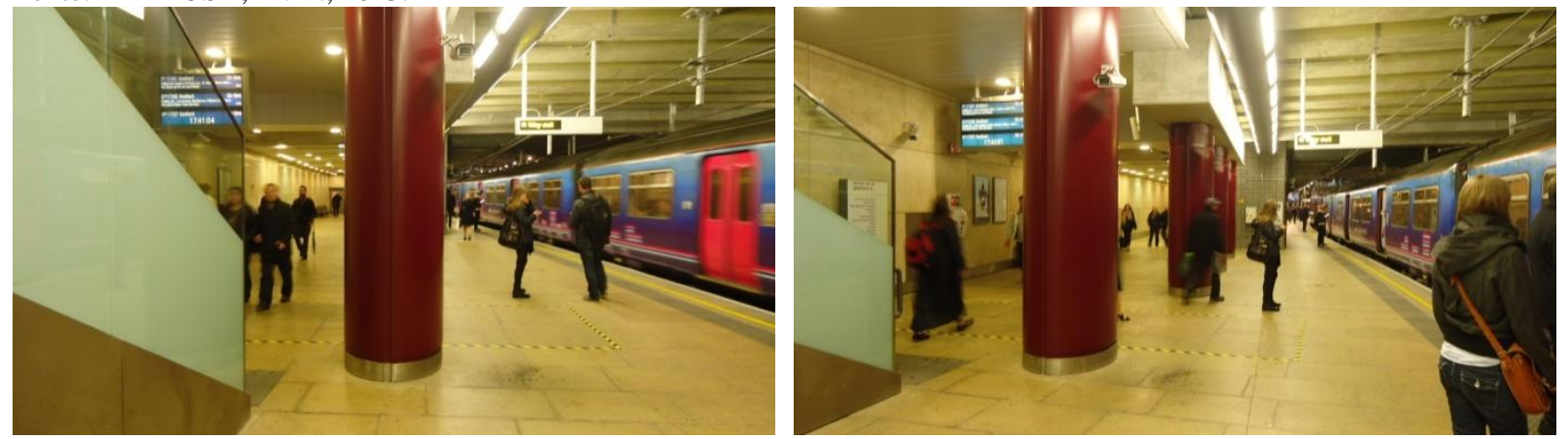

Figura 95 - Londres - Plataforma das estações modernizadas. Fonte: BARBOSA, M. B., 2013.

\footnotetext{
${ }^{29}$ Hetherington, L; Teichler, S., Customer Information and Accessibility on Tube. Apresentação realizada durante a visita ao Metrô de Londres em 15/05/2013.
} 

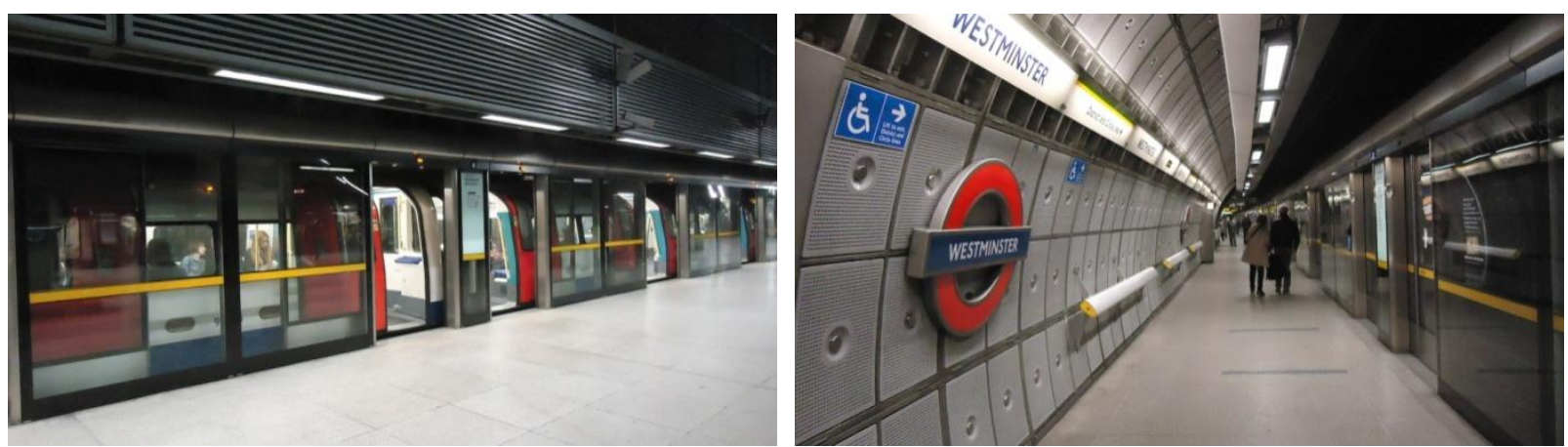

Figura 96 - Londres - Plataforma das estações acessíveis. Fonte: BARBOSA, M. B., 2013.

Houve ainda uma explanação sobre os serviços prestados pelos funcionários que auxiliam pessoas com deficiência visual durante o embarque e o desembarque, cujo treinamento e programas de requalificação são realizados em Centros de Excelência - estações Stratford, London Bridge, Green Park, King's Cross, St. Pancras e Westminster -, em parceria com instituições de reabilitação, como forma de promover a capacitação de usuários e funcionários simultaneamente.

Um fator que se destacou no processo de adaptação das estações e trens do Metrô de Londres foi o processo de consulta pública para priorização das ações relacionadas à adaptação da infraestrutura dos trens e das estações, que envolveu apresentação das ações e custos envolvidos para que a população opinasse sobre o plano de adequação, considerando o orçamento e seus impactos frente à complexidade das intervenções e aos prazos necessários para compatibilizar a acessibilidade e a preservação do patrimônio histórico que as estações representam.

Também foi objeto da visita o novo sistema de sinalização integrado com a sinalização urbana (Legible London ${ }^{30}$ ) e as informações veiculadas para pessoas com deficiência visual para facilitar o planejamento e os deslocamentos, por meio da distribuição de folhetos com letras e figuras ampliadas ou disponibilizadas no sítio eletrônico.

\footnotetext{
${ }^{30}$ Legible London (Londres Legível) é parte de um programa integrado de informações de transporte para o centro de Londres que auxilia as pessoas a planejarem e executarem suas jornadas independentemente do meio de transporte que escolherem (BEST, K. 2012, p. 56); inclui um sistema padronizado de mapas veiculados de forma física e virtual.
} 


\subsubsection{Metrô de Paris}

A visita à rede de transporte de Paris foi realizada em 21/05/2013. O metrô de Paris foi implantado em 1900 e tem um audacioso projeto para modernizar suas instalações, adequando-se às novas demandas e tecnologias. A rede de metrô tem 214,5 km de rede e 300 estações distribuídas ao longo de 14 linhas, por onde circulam 811 trens nos horários de maior demanda, com intervalo médio de 110 segundos, responsáveis pelo transporte de cinco milhões de passageiros por dia. Os trens pertencem a oito diferentes frotas e as composições podem ser de três a seis carros. As estações possuem 520 escadas rolantes e 74 elevadores.

A visita técnica foi organizada pela Régie Autonome des Transports Parisiens- RATP, incluindo estações e trens, com o objetivo de aprofundar as questões relacionadas à implantação de um sistema de orientação dos deslocamentos nas estações baseado em sinalização tátil no piso e orientações sonoras integradas (RATP, 2010).

O programa de modernização do Metrô de Paris priorizou a reforma das estações de forma a torná-las mais confortáveis (por meio da instalação de 200 novas escadas rolantes), iluminadas e, quando possível, acessíveis uma vez que a legislação não obriga o metrô a adaptar as estações e trens às condições de acessibilidade, exceto nas novas estações. Entre as melhorias propostas, destaca-se o processo de instalação de portas de plataformas nas estações antigas, concluído em 16\% das estações (Figuras 97 e 98).

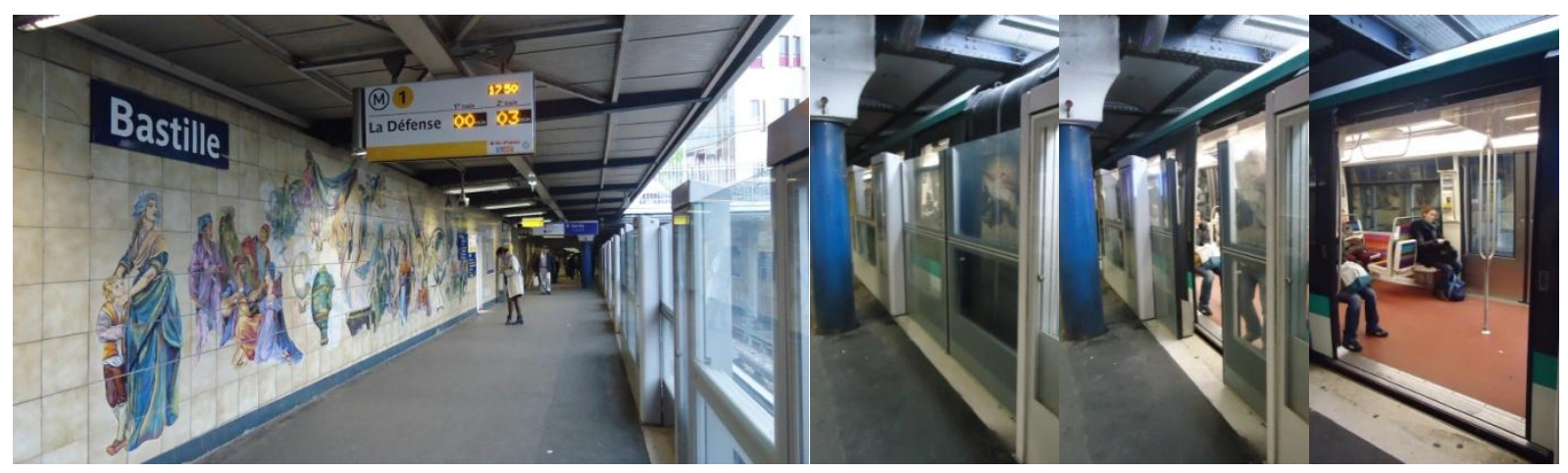

Figura 97 - Paris/estação Bastille - Portas de plataforma das estações modernizadas.

Fonte: BARBOSA, M. B., 2013. 


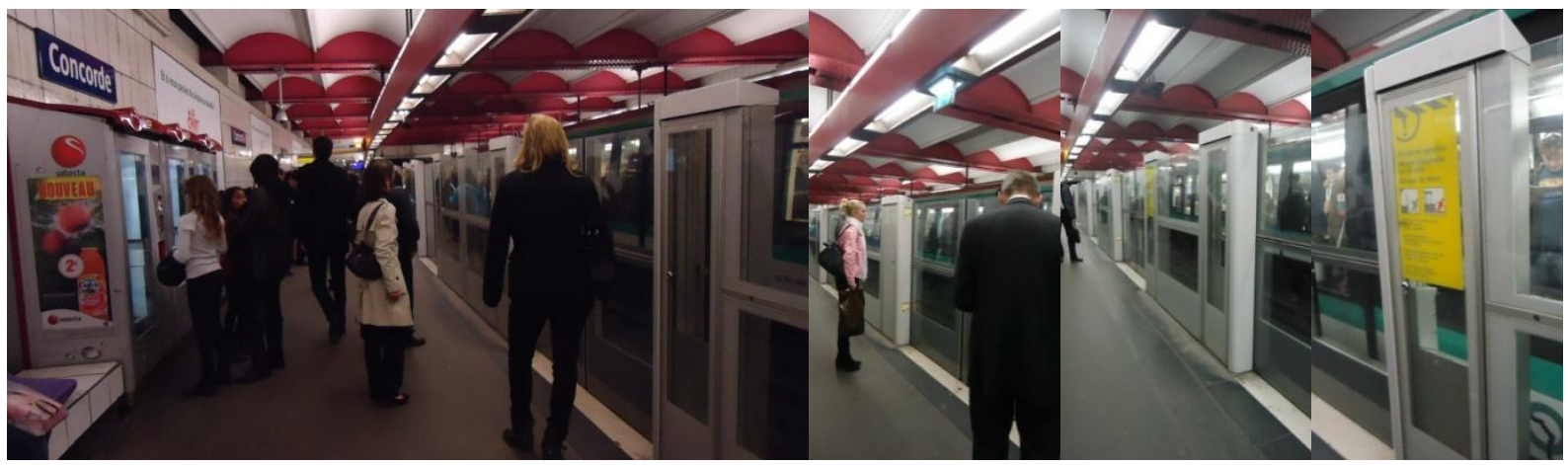

Figura 98 - Paris/estação Concorde - Portas de plataforma das estações modernizadas. Fonte: BARBOSA, M. B., 2013.

Destaca-se ainda a implantação de um novo sistema de informação denominado "Blue Eyes", que tem por objetivo de orientar o deslocamento das pessoas com deficiência visual.

\subsubsection{Rede Ferroviária Francesa}

A visita à sede da rede ferroviária francesa foi realizada em 22/05/2013. A visita foi organizada pela Délégation à l'accessibilité et aux voyageurs handicapés, área responsável pela implantação do programa de acessibilidade da Société Nationale des Chemins de Fer Français - SNCF, incluindo estações e trens, com o objetivo de aprofundar as questões relacionadas à implantação de um sistema de orientação dos deslocamentos nas estações baseado em sinalização tátil no piso e orientações sonoras integradas (Figura 99). A visita técnica foi realizada na estação Montparnasse, utilizada como laboratório para avaliação pela população.

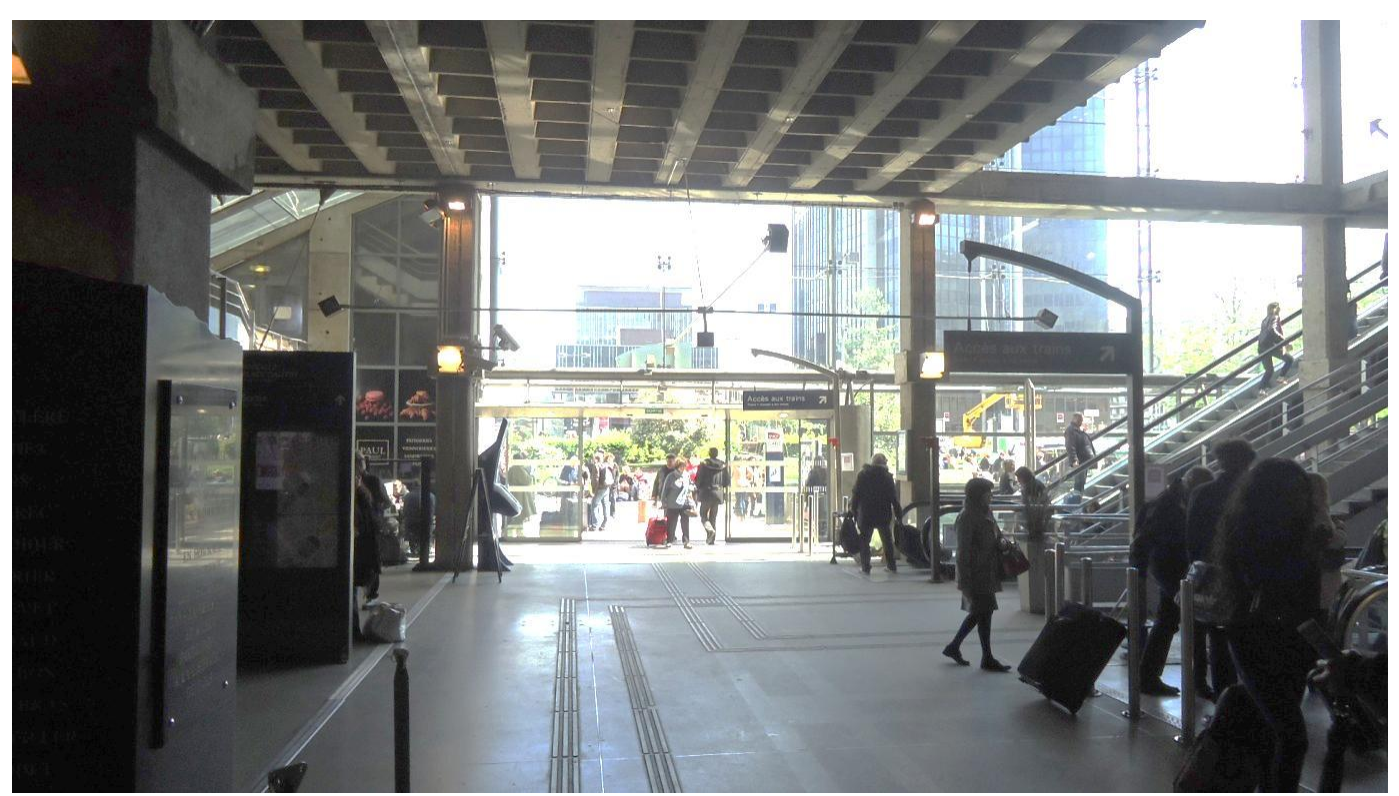

Figura 99 - Paris - Sinalização integrada (tátil e sonora) do mezanino da estação.

Fonte: BARBOSA, M. B., 2013. 


\subsubsection{Metrô de Tóquio}

É importante destacar que, mesmo antes do início desta tese, o envolvimento profissional da pesquisadora com o tema da inclusão no transporte impunha atenção às questões relativas às boas práticas de acessibilidade nas redes metroferroviárias. Assim, a participação no curso “Colloquium on Urban Public Transport”, promovido pela Japan International Cooperation Agency (JICA) e realizado no Japão no período compreendido entre maio e julho de 2002, possibilitou conhecer linhas, estações e trens do Metrô de Tóquio. Apesar do tempo decorrido desde a visita técnica ao sistema metroviário de Tóquio, destaca-se que os requisitos de sinalização tátil no piso daquele sistema inspiraram a definição dos requisitos estabelecidos na ABNT NBR 14021:2005.

Durante as visitas realizadas ao sistema metroviário de Tóquio, destaca-se a existência de sinalização tátil direcional e de alerta nos percursos realizados entre os acessos e as plataformas (Figura 100).
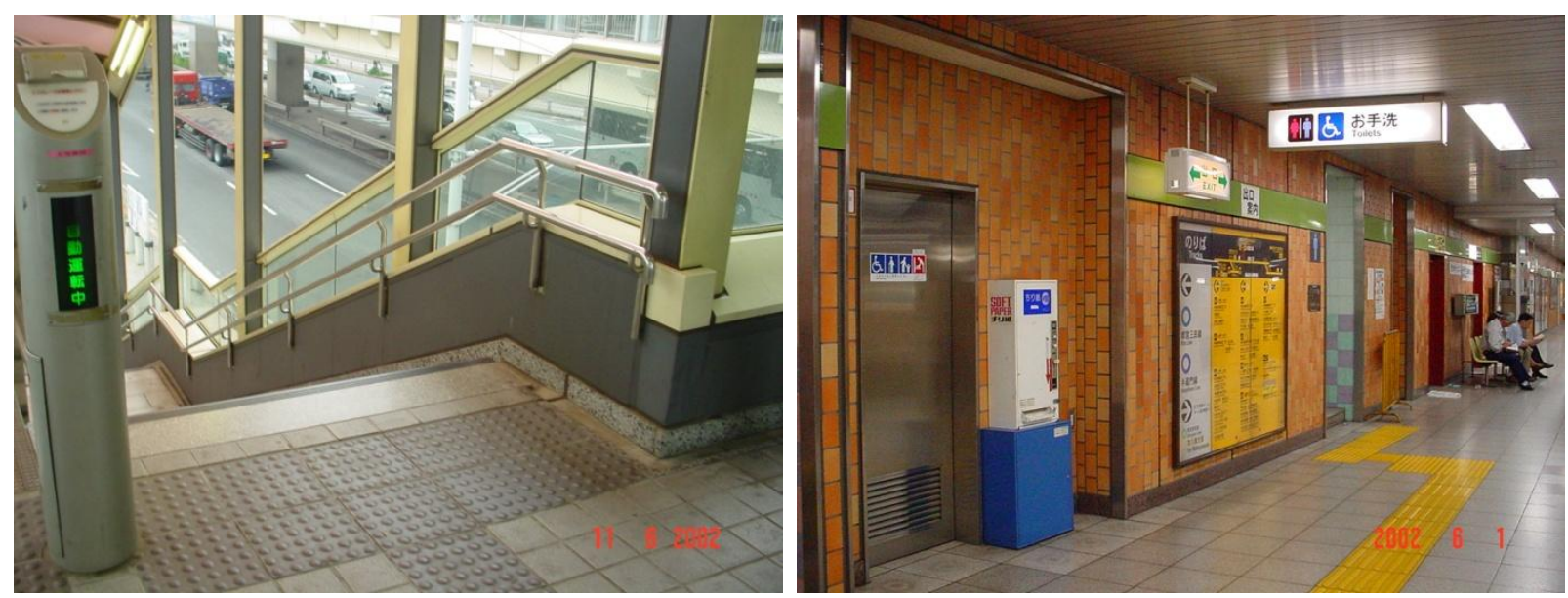

Figura 100 - Tóquio - Sinalização do mezanino da estação. Fonte: BARBOSA, M. B., 2002.

As plataformas cuja configuração em curva oferecem riscos adicionais em função do vão resultante entre o trem e a plataforma recebem sinalização especial, luminosa, para alertar os usuários durante o embarque e desembarque (Figura 101). 

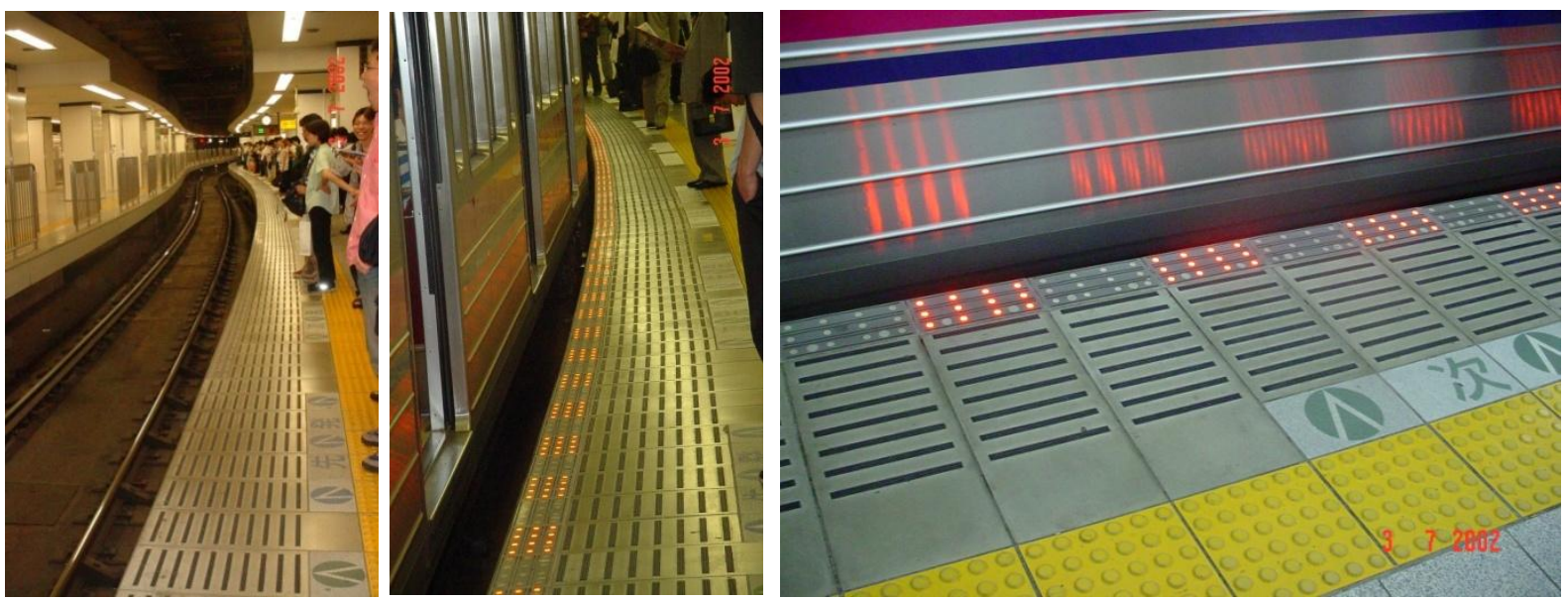

Figura 101 - Tóquio - Sinalização da plataforma da estação em curva.

Fonte: BARBOSA, M. B., 2002.

\subsubsection{Metrô do Rio de Janeiro}

Entre os sistemas metroferroviários nacionais selecionados para a realização de visitas técnicas, foi escolhida a rede do metrô do Rio de Janeiro devido ao fato de ter sido um sistema metroviário construído no mesmo período que o Metrô de São Paulo. Por esse motivo, enfrentou os mesmos desafios em relação às necessidades de adequação à legislação e aos requisitos normativos nesses anos, embora sua demanda seja infinitamente menor.

A visita ao Metrô do Rio de Janeiro foi realizada no período de 01 a 05/11/2011. O Metrorio foi inaugurado em 1979, mas sua expansão teve início em 1997, quando o direito de explorar o serviço metroviário da cidade do Rio de Janeiro foi concedido à iniciativa privada. A extensão da rede é de 40,9km, com 35 estações distribuídas ao longo de duas linhas, por onde circulam 32 trens nos horários de maior demanda, com intervalo médio de 137 segundos. Esses trens são responsáveis pelo transporte de aproximadamente 669,4 mil passageiros por $\operatorname{dia}^{31}$. Os trens pertencem a três diferentes frotas. As estações possuem 125 escadas rolantes e 47 elevadores.

A visita foi organizada pelo Departamento de Planejamento e Controle, possibilitando conhecer o plano de modernização das estações e trens, bem como do Centro de Controle. O programa de modernização do Metrorio incluiu a instalação de elevadores, de sinalização tátil no piso e de mapas táteis de orientação dos deslocamentos das pessoas com deficiência nas estações (Figuras 102 e 103).

\footnotetext{
${ }^{31}$ RANGEL, V. "Sejam bem vindos ao Metrorio do século XXI". Apresentação realizada durante a visita ao Metrô do Rio de Janeiro em 01/11/2011.
} 

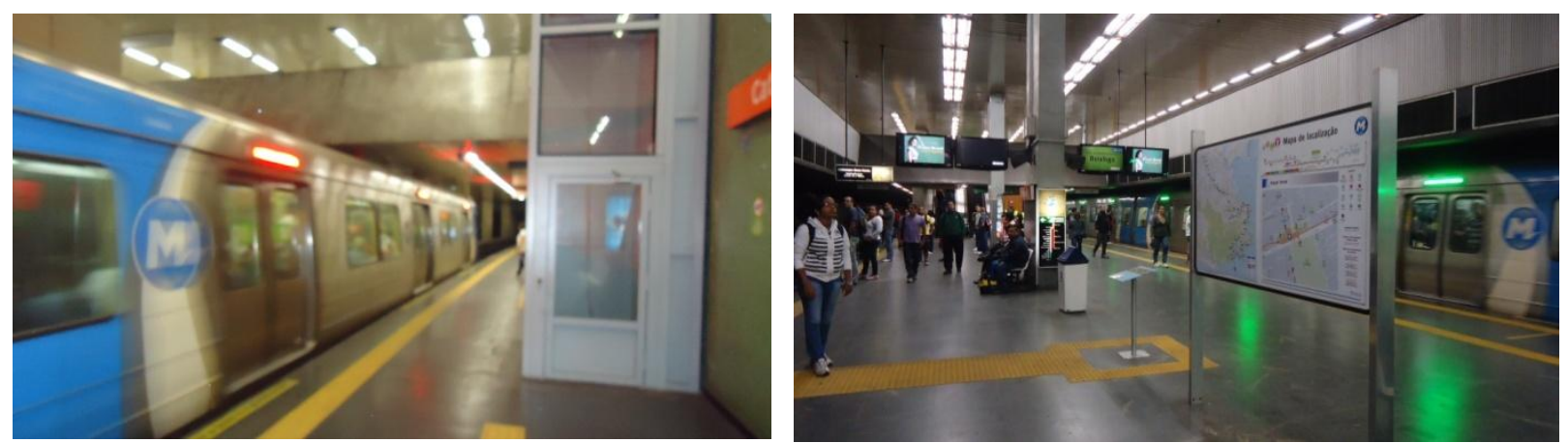

Figura 102 - Rio de Janeiro - Plataforma das estações modernizadas. Fonte: BARBOSA, M. B., 2011.
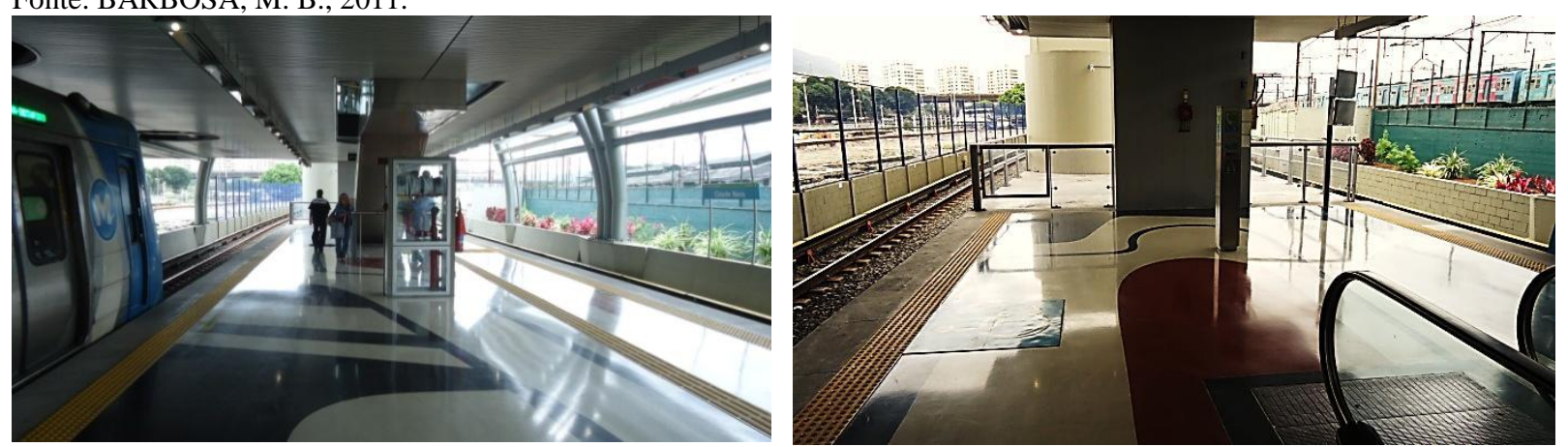

Figura 103 - Rio de Janeiro - Plataforma das estações acessíveis.

Fonte: BARBOSA, M. B., 2011.

Um fator que se destacou durante a visita às estações foi a intensiva comunicação visual de orientação dos comportamentos desejáveis dos usuários, desde a orientação do embarque e desembarque nas plataformas das estações até o uso seguro das escadas, conforme exemplificado nas Figuras 104 e 105. Um outro fator que diferencia o Metrorio das demais empresas operadoras é a sinalização tátil direcional para os elementos de circulação vertical: enquanto as outras empresas privilegiam a indicação de elevadores e escadas fixas (circulação bidirecional), o Metrorio orienta a circulação vertical para as escadas fixas e rolantes (Figura 106).
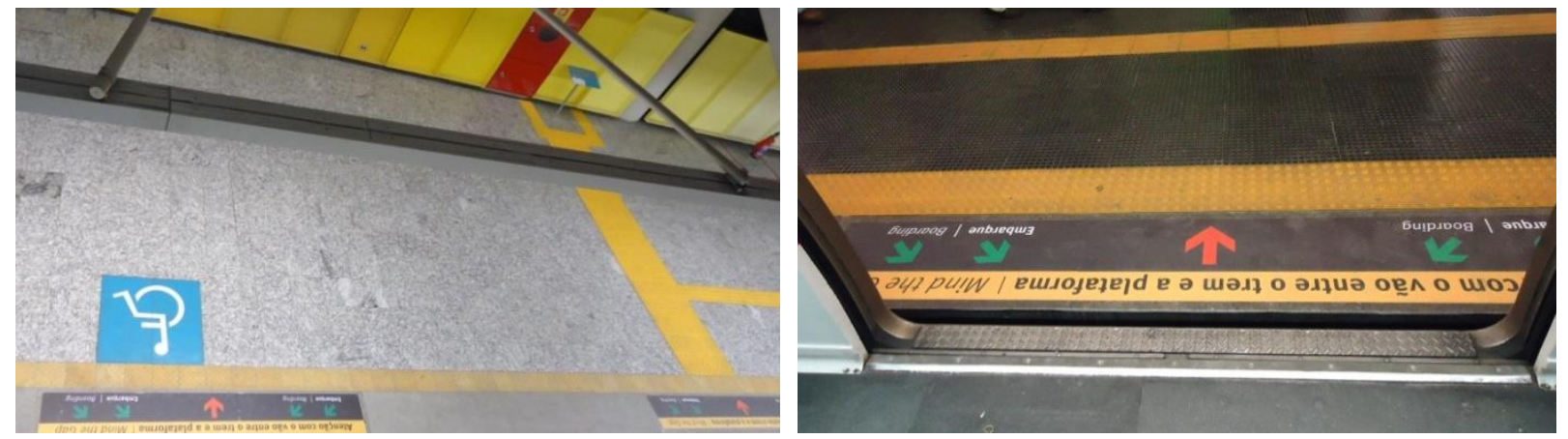

Figura 104 - Rio de Janeiro - Sinalização de embarque e desembarque a partir da plataforma e do trem. Fonte: BARBOSA, M. B., 2011. 


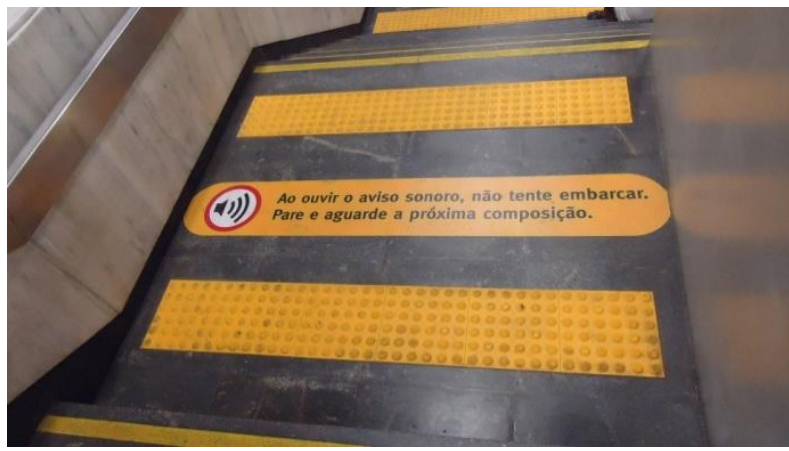

Figura 105 - Rio de Janeiro - Sinalização de segurança nas escadas fixas.

Fonte: BARBOSA, M. B., 2011.

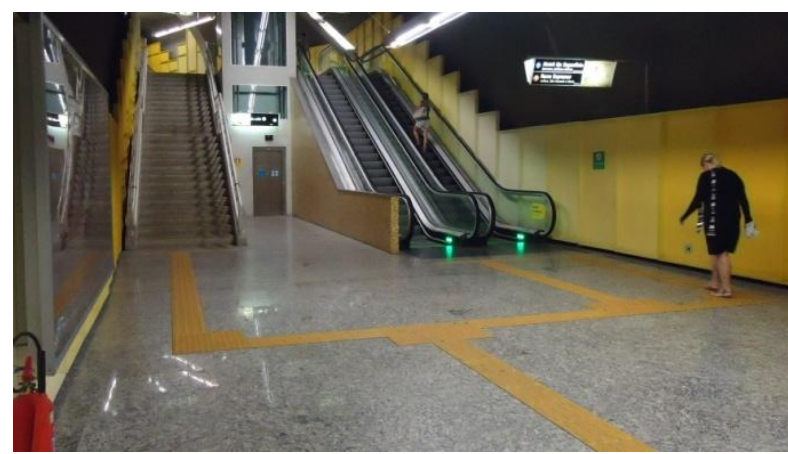

Figura 106 - Rio de Janeiro - Sinalização tátil no piso para conjunto de equipamentos de circulação vertical. Fonte: BARBOSA, M. B., 2011.

\subsection{Síntese dos instrumentos aplicados}

A seguir será apresentada a síntese dos instrumentos aplicados, detalhando, o público-alvo usuários com deficiência visual, pessoas-chave e especialistas -, os ambientes - estação, interface trem-estação e trem -, bem como os objetivos pretendidos em cada instrumento, visando a obtenção de dados quantitativos e qualitativos e de evidências que permitissem uma visão abrangente da situação experimentada pelas pessoas com deficiência visual (Quadro 23). A seleção dos instrumentos aplicados nesta pesquisa foi precedida de uma análise das vantagens e desvantagens de cada um deles e do estabelecimento de procedimentos de campo e regras gerais a serem seguidas na coleta de dados para a compreensão da interação pessoaambiente. 
Quadro 23 - Instrumentos aplicados, ambientes, públicos-alvo e objetivos.

\begin{tabular}{|c|c|c|}
\hline Instrumento & $\begin{array}{l}\text { Ambiente / } \\
\text { Público-alvo } \\
\end{array}$ & Objetivos \\
\hline Questionário & $\begin{array}{l}235 \text { pessoas com } \\
\text { deficiência visual }\end{array}$ & $\begin{array}{l}\text { - hábitos de viagem } \\
\text { - planejamento da viagem (etapa que antecede o uso do sistema de } \\
\text { transporte); está relacionada, juntamente com os mapas disponíveis nas } \\
\text { estações e trens, à compreensão da rede de transporte, objeto de estudo } \\
\text { posterior } \\
\text { - identificação das estações utilizadas pelo respondente } \\
\text { - identificação do uso do sistema de transporte integrado à rede } \\
\text { metroviária para avaliar a acessibilidade das conexões entre diferentes } \\
\text { modos de transporte, relacionada ao planejamento da viagem (a chegada, } \\
\text { o uso e a conexão com outro modo, sucessivamente, até atingir o destino } \\
\text { final da viagem) } \\
\text { - condições de acessibilidade das estações } \\
\text { - condições de acessibilidade do trem } \\
\text { - expectativa e avaliação da gestão do serviço prestado aos usuários } \\
\text { - associa a infraestrutura das estações e dos trens à gestão dos serviços, } \\
\text { solicitando que o respondente, a partir de uma visão integrada, aponte } \\
\text { melhorias que possam contribuir para a melhoria do serviço prestado }\end{array}$ \\
\hline \multirow{4}{*}{$\begin{array}{l}\text { Entrevista } \\
\text { individual }\end{array}$} & $\begin{array}{l}5 \text { profissionais } \\
\text { que elaboram as } \\
\text { normas técnicas } \\
\text { de acessibilidade } \\
\text { da ABNT }\end{array}$ & $\begin{array}{l}\text { - importância, características e especificidades das normas técnicas de } \\
\text { acessibilidade, incluindo as dificuldades para a elaboração dos textos } \\
\text { - facilidades relacionadas à configuração e sinalização para os passageiros } \\
\text { - recomendações para pessoas com deficiência visual } \\
\text { - segurança e autonomia das pessoas com deficiência visual em ambientes } \\
\text { com grandes fluxos de pessoas } \\
\text { - contribuições da informação integrada (tátil/visual/sonora) }\end{array}$ \\
\hline & $\begin{array}{l}5 \text { professores de } \\
\text { orientação e } \\
\text { mobilidade }\end{array}$ & $\begin{array}{l}\text { - importância e forma de realização do treinamento de orientação e } \\
\text { mobilidade para as pessoas com deficiência visual } \\
\text { - aspectos enfatizados no treinamento nas estações } \\
\text { - aspectos relacionados à memorização dos percursos } \\
\text { - dificuldades enfrentadas pelos alunos e pelos instrutores nas estações } \\
\text { estudos de caso }\end{array}$ \\
\hline & $\begin{array}{l}3 \text { instrutores/ } \\
\text { elaboradores de } \\
\text { treinamento de } \\
\text { funcionários }\end{array}$ & $\begin{array}{l}\text { - importância, características, especificidades e dificuldades do } \\
\text { treinamento dos empregados e sua relação com os princípios e valores } \\
\text { da empresa } \\
\text { - aspectos relacionados à segurança nos deslocamentos da pessoa com } \\
\text { deficiência visual } \\
\text { - preparo para atuar em situações de anormalidade } \\
\text { - contribuições do sistema de informação }\end{array}$ \\
\hline & $\begin{array}{l}12 \text { supervisores } \\
\text { das estações }\end{array}$ & $\begin{array}{l}\text { - aspectos positivos e negativos existentes na estação para o deslocamento } \\
\text { das pessoas com deficiência visual, incluindo a avaliação e o impacto } \\
\text { dos fluxos dos demais usuários } \\
\text { - preparo dos empregados para auxiliar pessoas com deficiência visual e } \\
\text { para atuar em situações de anormalidade } \\
\text { contribuições da informação integrada (tátil/visual/sonora) } \\
\text { - aspectos a serem aperfeiçoados }\end{array}$ \\
\hline
\end{tabular}


Continuação.

37 estagiários que - perfil dos estagiários (idade, experiência)

auxiliam pessoas - sentimento em relação à tarefa desempenhada

com deficiência

- identificação dos aspectos positivos e negativos das estações

visual

- fatores ou locais que dificultam a condução/auxílio das pessoas com deficiência visual

- avaliação do treinamento recebido

- aspectos a serem aperfeiçoados (atividades ou resultados)

$\begin{gathered}\text { Entrevista } \\ \text { grupo }\end{gathered}$
8

- processo de projeto de uma estação

- requisitos de acessibilidade em termos de configuração e sinalização dos percursos

- aspectos relacionados à orientação/deslocamento/uso/comunicação e memorização dos percursos no deslocamento das pessoas com deficiência visual nas estações

- facilidades futuras, considerando a expansão da rede e as inovações tecnológicas

\begin{tabular}{ll}
\hline $\begin{array}{l}\text { 5 engenheiros/ } \\
\text { designers dos } \\
\text { trens }\end{array}$ & $\begin{array}{l}\text { - evolução dos requisitos de acessibilidade } \\
- \text { layout dos trens das diferentes frotas } \\
\text { - inovações tecnológicas }\end{array}$ \\
\hline normas técnicas & - NBR 9050:2004 - Acessibilidade a edificações, mobiliário, espaços e
\end{tabular}
equipamentos urbanos

- NBR 14021:2005 - Transporte - Acessibilidade no sistema de trens urbano ou metropolitano

- NBR 15599:2008 - Acessibilidade - Comunicação na prestação de serviços

- NBR 15250:2005 - Acessibilidade em caixa de autoatendimento bancário

- NBR 313:2007 - Elevadores de passageiros; requisitos de segurança para construção e instalação; requisitos particulares para acessibilidade das pessoas, incluindo pessoas com deficiência

- NBR 195:1999 - Escadas rolantes e esteiras rolantes; requisitos de segurança para construção e instalação

\begin{tabular}{cll}
$\begin{array}{c}\text { Pesquisa } \\
\text { documental }\end{array}$ & $\begin{array}{l}\text { desenhos de } \\
\text { estações }\end{array}$ & $\begin{array}{l}\text { - Estações de conexão Ana Rosa, Tamanduateí, Palmeiras-Barra Funda, } \\
\text { Paraíso, Sé, República } \\
\end{array}$ \\
\cline { 2 - 3 } & & -Estações Santa Cruz, Sacomã \\
\hline desenhos de trens & - Frotas A/B, C/D, E, F, G, H, I, J, K e L
\end{tabular}

procedimentos - Integração entre os modos de transporte - situações cotidianas ou de operacionais anormalidade

- Comunicação com o usuário por meio de mensagens sonoras padronizadas, emitidas nas estações e trens, seja nas situações cotidianas ou situações de anormalidade

- Serviços relacionados ao atendimento preferencial

- Estratégias adotadas em caso de anormalidade nas estações e nos trens

- Operação e manutenção das instalações e equipamentos (bloqueios, elevadores, escadas rolantes)

297 manifestações - Manifestações feitas por usuários com deficiência visual, seus enviadas ao SAC acompanhantes e demais usuários 
Continuação.

\begin{tabular}{|c|c|c|}
\hline $\begin{array}{c}\text { Walkthrough } \\
\text { \& checklist }\end{array}$ & $\begin{array}{l}\text { acesso, mezanino, } \\
\text { plataforma }\end{array}$ & $\begin{array}{l}\text { - Compreensão dos percursos de embarque e desembarque nas estações } \\
\text { Ana Rosa, Palmeiras-Barra Funda, Sacomã e Tamanduateí }\end{array}$ \\
\hline & $\begin{array}{l}\text { estação, interface } \\
\text { e trem }\end{array}$ & $\begin{array}{l}\text { - Verificação dos recursos disponíveis nas estações Ana Rosa, Palmeiras- } \\
\text { Barra Funda, Sacomã e Tamanduateí } \\
\text { - Frotas A/B, C/D, E, F, G, H, I, J, K e L }\end{array}$ \\
\hline \multirow{4}{*}{$\begin{array}{l}\text { Ficha } \\
\text { ambiente }\end{array}$} & $\begin{array}{l}\text { escadas fixas, } \\
\text { escadas rolantes }\end{array}$ & $\begin{array}{l}\text { - Identificação das características e dos recursos de sinalização existentes } \\
\text { nos conjuntos de escadas fixas e escadas rolantes }\end{array}$ \\
\hline & elevadores & $\begin{array}{l}\text { - Identificação das características e dos recursos de sinalização existentes } \\
\text { nos elevadores e plataformas elevatórias }\end{array}$ \\
\hline & bloqueios & $\begin{array}{l}\text { - Identificação das características e dos recursos de sinalização existentes } \\
\text { no tripé tradicional e bloqueios com portas de vidro }\end{array}$ \\
\hline & carro preferencial & $\begin{array}{l}\text { - Identificação das características de configuração e dos recursos de } \\
\text { sinalização existentes nas frotas A, C, D, E, F, G, H, I, J, K e L }\end{array}$ \\
\hline $\begin{array}{l}\text { Observação - } \\
\text { mapa de } \\
\text { fluxo }\end{array}$ & $\begin{array}{l}\text { mezanino - área } \\
\text { paga }\end{array}$ & $\begin{array}{l}\text { - Estação Ana Rosa - pico manhã, pico intermediário e pico tarde } \\
\text { - Estação Palmeiras-Barra Funda - pico manhã, pico intermediário e pico } \\
\text { tarde } \\
\text { - Estação Sacomã - pico manhã, pico intermediário e pico tarde } \\
\text { - Estação Tamanduateí - pico manhã, pico intermediário e pico tarde }\end{array}$ \\
\hline $\begin{array}{l}\text { Observação- } \\
\text { mapa de } \\
\text { comporta- } \\
\text { mento }\end{array}$ & $\begin{array}{l}\text { áreas de } \\
\text { embarque } \\
\text { preferencial; }\end{array}$ & $\begin{array}{l}\text { - Estação Ana Rosa - pico manhã e pico tarde } \\
\text { - Estação Palmeiras-Barra Funda - pico manhã e pico tarde } \\
\text { - Estação Sacomã - pico manhã e pico tarde } \\
\text { - Estação Tamanduateí - pico manhã e pico tarde }\end{array}$ \\
\hline $\begin{array}{l}\text { Observação - } \\
\text { treinamento } \\
\quad \text { O\&M }\end{array}$ & $\begin{array}{l}\text { treinamento de } \\
\text { orientação e } \\
\text { mobilidade nas } \\
\text { estações e trens }\end{array}$ & $\begin{array}{l}\text { - Estação Vila Madalena } \\
\text { - Estação Vila Prudente }\end{array}$ \\
\hline $\begin{array}{l}\text { Benchmarking } \\
\qquad \begin{array}{|l|l|}\text { A } & \text { B } \\
\text { C } & \text { D } \\
\end{array}\end{array}$ & $\begin{array}{l}\text { comparação com } \\
\text { requisitos e } \\
\text { práticas } \\
\text { evidenciados em } \\
\text { outros sistemas de } \\
\text { transportes }\end{array}$ & $\begin{array}{l}\text { - Sistemas metroferroviários nacionais } \\
\text { - Rio de Janeiro } \\
\text { - Sistemas metroferroviários internacionais } \\
\text { - Barcelona (TMB) } \\
\text { - Madri (Madrid S.A) } \\
\text { - Londres (LUL) } \\
\text { - Paris (RATP e SNCF) } \\
\text { - Tóquio }\end{array}$ \\
\hline
\end{tabular}

Fonte: Elaborado pela pesquisadora. (2014) 


\subsection{Considerações sobre o capítulo}

A definição do objeto e dos objetivos antecedeu o momento de escolha do conjunto de instrumentos, método e técnicas a serem aplicados. Contudo, determinadas alterações foram realizadas durante o desenvolvimento da pesquisa em função das possibilidades e das limitações intrínsecas a cada um dos instrumentos com os quais se trabalhou.

Os métodos e técnicas da APO foram combinados e utilizados de acordo com os objetivos da pesquisa, os prazos definidos e os recursos humanos e financeiros envolvidos. $\mathrm{O}$ planejamento para utilização dos instrumentos considerou o tempo necessário à elaboração e aplicação de cada um deles, porém subestimou o tempo necessário para a transcrição dos dados coletados e análise das informações.

A combinação dos instrumentos aplicados aos usuários, pessoas-chave e especialistas questionários, entrevistas, entrevistas em grupo - e dos instrumentos aplicados aos diferentes ambientes - walkthrough, checklist, ficha ambiente, observação - possibilitou a obtenção de informações sobre cada uma das etapas da jornada do usuário, incluindo os aspectos relacionados à configuração do ambiente, o respectivo conjunto de informação/comunicação/ orientação e os aspectos relacionados à gestão do serviço bem como permitiu uma maior compreensão dos relatos realizados pelas pessoas com deficiência visual durante a aplicação dos questionários. Os instrumentos se complementaram e, portanto, é possível destacar a importância de cada um deles para compreender da complexidade das relações entre as pessoas e os ambientes desta pesquisa.

Os questionários e as entrevistas permitiram identificar os aspectos positivos e os pontos críticos sob a ótica dos usuários e das demais partes interessadas, a partir de diferentes perspectivas sobre o tema e de uma visão detalhada de cada uma das etapas da jornada e uma visão abrangente da experiência. A triangulação dos dados obtidos a partir de diferentes fontes - usuários, pessoas-chave e especialistas - e dos dados obtidos sobre os diversos ambientes serão apresentados no próximo capítulo, consolidando as informações detalhadas sobre cada uma das etapas da jornada do usuário, bem como uma visão abrangente da experiência, a fim de identificar os pontos críticos do processo. 


\section{DIAGNÓSTICO}

Este capítulo apresenta a descrição de cada uma das etapas da jornada do usuário, seguida da apresentação dos métodos e técnicas aplicados, as melhores práticas identificadas junto a outras empresas operadoras de transporte sobre trilhos nacionais e internacionais, os requisitos normativos estabelecidos pelas normas técnicas ABNT e a situação verificada no Metrô de São Paulo.

Na sequência, apresenta-se a avaliação dos usuários, conforme a quantidade de relatos registrados em relação às ideias centrais de cada etapa da jornada. Os relatos dos respondentes referem-se à configuração, à informação e aos serviços característicos de cada ambiente estação, interface trem-estação, trem -, resultando numa matriz com nove fatores-chave para avaliação da acessibilidade de cada etapa. A quantidade de respondentes e de relatos definiu o grau de criticidade de cada etapa. Os relatos das pessoas com deficiência visual foram classificados e agrupados em um texto característico de cada etapa, usando a técnica do Discurso do Sujeito Coletivo.

Foram identificados os aspectos positivos e os pontos para melhoria apontados pelas pessoaschave e pelos especialistas, que ora corroboram, ora complementam, ora somam diferentes perspectivas relacionadas a cada uma das etapas da jornada do usuário com deficiência visual no sistema metroferroviário.

A partir dos relatos dos respondentes, foram identificados e caracterizados os elementos de wayfinding de cada etapa. Apresenta-se então a síntese do diagnóstico da etapa, elaborado a partir do cruzamento dos dados coletados junto aos usuários, às pessoas-chave e aos especialistas considerando também as constatações feitas a partir dos demais métodos e técnicas aplicados.

No final deste capítulo, apresenta-se uma síntese de todas as etapas da jornada do usuário, destacando-se os aspectos críticos segundo o local e o tema avaliado, bem como o grau de criticidade das ideias centrais segundo a ótica dos usuários com deficiência visual. 


\subsection{Etapa 1 - Planejamento do deslocamento}

Nesta etapa, o usuário busca as informações disponíveis para realizar o planejamento da viagem - itinerários dos diferentes modos de transporte que serão utilizados desde a origem até o destino final, pontos de conexão, tempo de viagem, custo do deslocamento, entre outras. Além disso, busca treinamento específico de O\&M para os deslocamentos nas estações habituais. Para a consecução de uma viagem na rede metroferroviária, o usuário define a estação de embarque e a estação de desembarque, bem como as possíveis conexões ao longo do percurso.

\subsubsection{Métodos e técnicas aplicados}

Os métodos e técnicas utilizados para coleta de dados nesta etapa foram apresentados no item 6.10 - Síntese dos instrumentos aplicados - e consistiram em:

a) melhores práticas identificadas em outros sistemas metroferroviários;

b) pesquisa documental (normas técnicas ABNT vigentes, procedimentos operacionais e informações disponibilizadas aos usuários pelo Metrô de São Paulo - folhetos, mapas, sítio eletrônico);

c) questionário aplicado em pessoas com deficiência visual - questão 6;

d) entrevista com professores de orientação e mobilidade;

e) entrevista com profissionais responsáveis pela elaboração de normas técnicas;

f) observação de treinamento de O\&M.

As formas de análise e interpretação dos dados coletados foram apresentadas no Capítulo 6 Aplicação dos instrumentos.

\subsubsection{Melhores Práticas}

Entre as melhores práticas observadas, destaca-se a Transport for London - TFL, empresa responsável pelo transporte na região metropolitana de Londres, que distribui mapas com texto ampliado, com impressão nas opções colorida ou em preto e branco, como forma de auxiliar o planejamento da viagem por pessoas com baixa visão (Figura 107). Em outro mapa (Figura 108), a TFL informa a distância (com letras - A, B ou C) e o desnível (com cores vermelha, amarela ou verde) do vão entre o trem e a plataforma, caracterizando cada uma das estações da rede de transporte sobre trilhos por meio da combinação de letra e cor. 


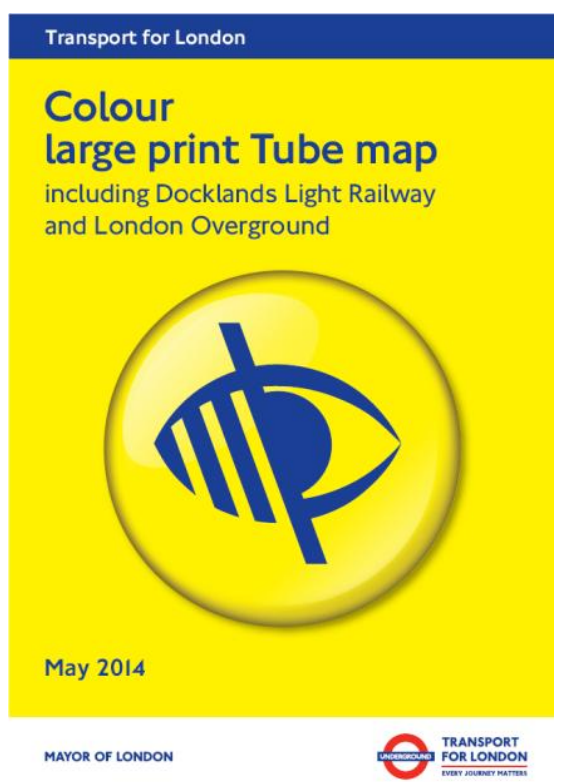

\section{Transport for London}

\section{Black and white} large print Tube map

including Docklands Light Railway and London Overground

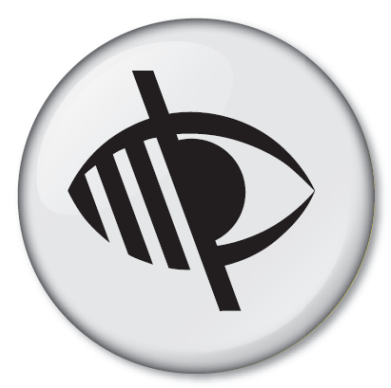

May 2014

MAYOR OF LONDON

Figura 107 - Londres - Mapa da rede - fonte ampliada, versões colorida e preto e branco.

Fonte: Transport for London. Disponível em: https://tfl.gov.uk/forms/12387.aspx. Acesso em: 02 ago. 2014
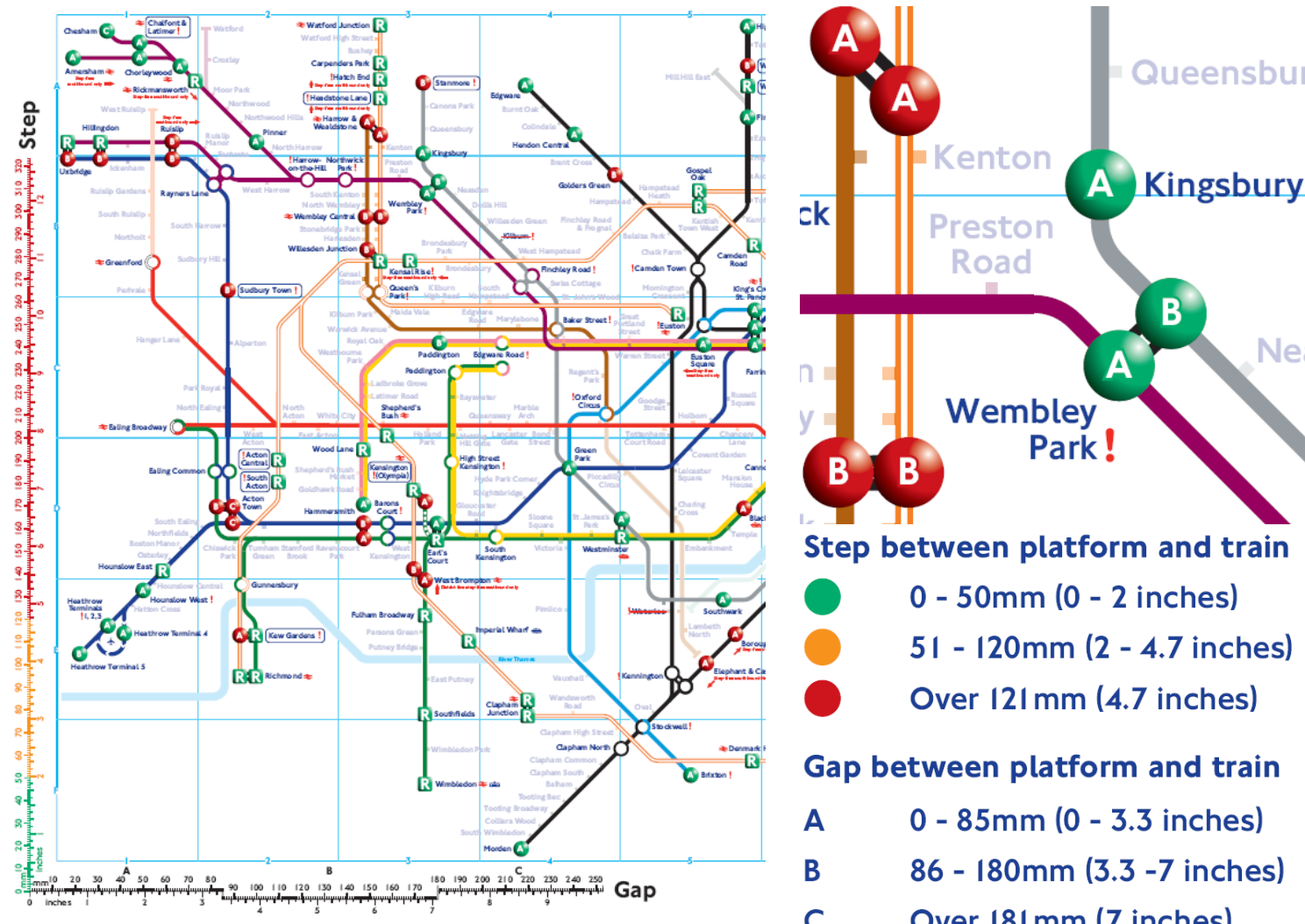

Gap between platform and train
A $\quad 0-85 \mathrm{~mm}(0-3.3$ inches $)$
B $\quad 86-180 \mathrm{~mm}(3.3-7$ inches $)$
C Over $181 \mathrm{~mm}$ (7 inches)

Figura 108 - Londres - Mapa, gabarito e detalhes do vão e do desnível em cada estação.

Fonte: Transport for London. Disponível em: https://tfl.gov.uk/forms/12387.aspx. Acesso em: 02 ago. 2014

As informações veiculadas em mapas e folhetos são disponibilizadas no sítio eletrônico da TFL, onde também é possível realizar as seguintes ações: 
- baixar um arquivo contendo informações sonoras que descrevem as linhas da rede do transporte metropolitano, as possibilidades de conexão entre linhas e as facilidades existentes em cada uma das estações;

- utilizar um sistema roteador para o planejamento dos deslocamentos a partir da inserção das informações de origem, destino e restrições do usuário, obtendo orientações sobre o percurso a ser realizado, as conexões e o tempo estimado de deslocamento.

No Metrô de Brasília, destaca-se a existência do mapa tátil da rede, disponibilizado nas estações, que orienta o planejamento dos deslocamentos (Figura 109).
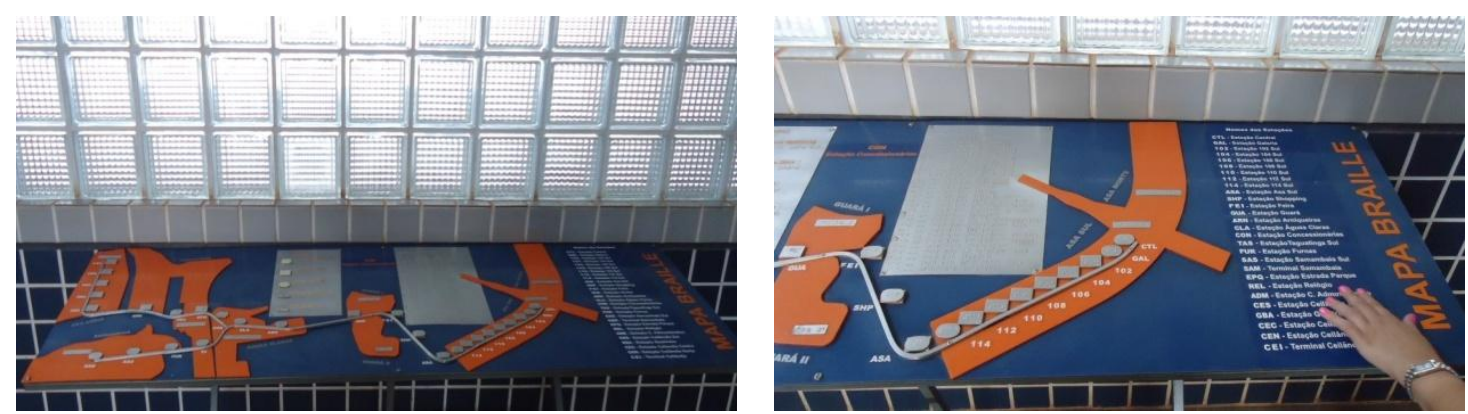

Figura 109 - Brasília - Mapa tátil da rede de transporte metroviário.

Fonte: BARBOSA, M.B., 2011.

\subsubsection{Requisitos Normativos}

Com relação aos requisitos normativos, a ABNT NBR 15.599:2008 estabelece que todo serviço de atendimento ao consumidor deve fornecer informações e esclarecimentos por meio de diferentes recursos, considerando a possibilidade de utilização dos serviços com independência por pessoas com deficiência visual.

As informações veiculadas pelas empresas operadoras sobre a condição de operação dos serviços devem ser disponibilizadas e atualizadas por meio de folhetos, sítios eletrônicos ou telefone.

\subsubsection{Situação do Metrô de São Paulo}

O Metrô de São Paulo disponibiliza informações sobre os serviços prestados na rede de transporte metropolitano e sobre a acessibilidade das suas instalações por meio de diferentes canais de comunicação com os usuários, com destaque para os seguintes: 
a) atendimento pessoal - pelos funcionários que atuam em todas as estações, nos balcões de informação existentes nas estações com maior demanda e na Central de Serviços da estação Sé;

b) atendimento telefônico - discagem gratuita para a central de informações 0800 (Figura 110), e intercomunicadores disponibilizados em todas as estações;

c) atendimento eletrônico - sítio eletrônico, SMS, redes sociais, aplicativo Direto do Metrô - que informa as condições de circulação dos trens em tempo real (Figura 111), simulador de trajetos - que informa as alternativas de percurso e o tempo estimado de deslocamento entre duas estações (Figura 112);

d) atendimento escrito - por meio de resposta às cartas enviadas pelo correio ou pela "caixa de sugestões" disponibilizada em todas as estações

e) folhetos - distribuição de impressos nas estações, contendo o mapa de acessibilidade da rede de transporte na versão impressa (Figuras 113 e 114).

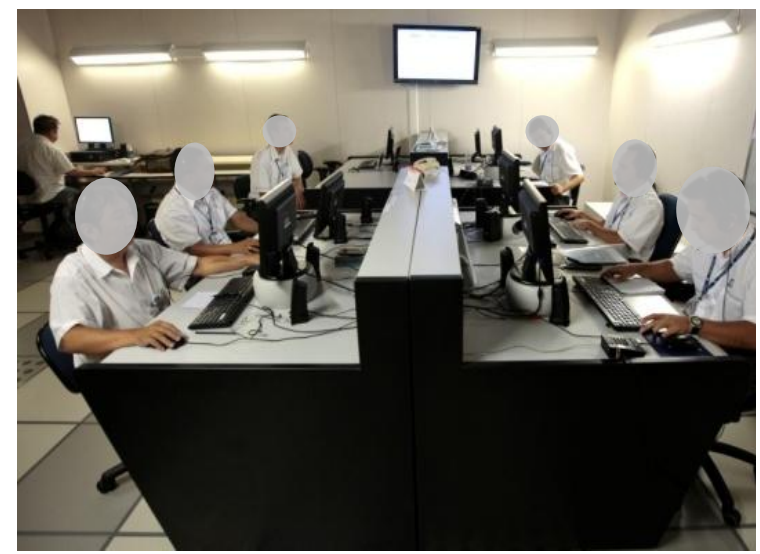

Figura 110 - São Paulo - Central de Informações. Fonte: BARBOSA, M.B., 2013.
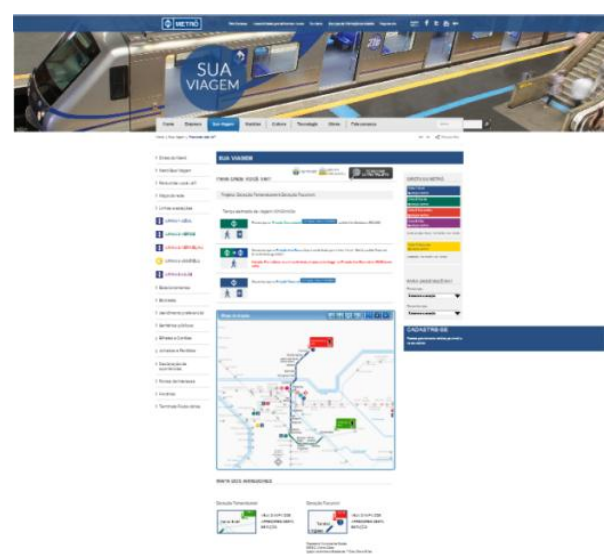

\section{SUA VIAGEM}

DIRETO DO METRÔ

(1) Linha 1-Azul Operaçäo Normal

(1) Linha 2-Verde Operaçäo Normal

(1) Linha 3-Vermelha Operaçäo Normal

(1)

Operaçäo Normal

Metrô de São Paulo, 04/01/2015 às 10 h42

( ) Linha 4-Amarela O Operação Normal

ViaQuatro, 04/01/2015 às 10 h42

Figura 111 - São Paulo - Direto do Metrô Fonte: Metrô-SP. Disponível em: www.metro.sp.gov.br. Acesso em: 04 jan. 2015.

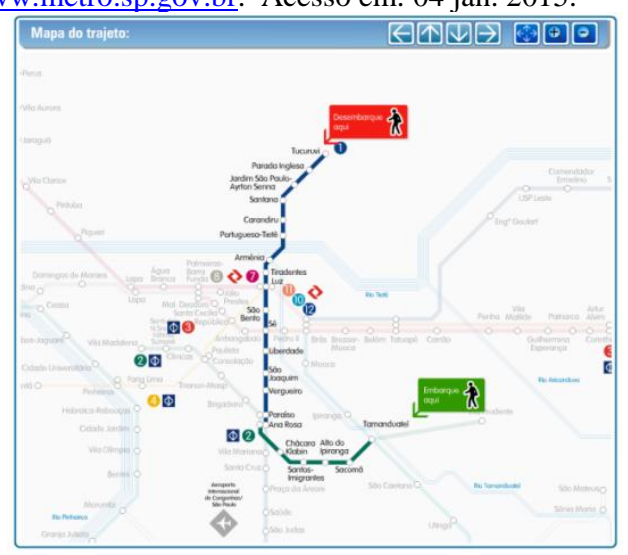

Figura 112 - São Paulo - Simulador de trajeto - tela do sítio eletrônico do Metrô de São Paulo. Fonte: CMSP. Disponível em: http://www.metro.sp.gov.br/sua-viagem/trajeto/trajeto.aspx?origemId=201\& destinoId=8. Acesso em: 15 out. 2014. 


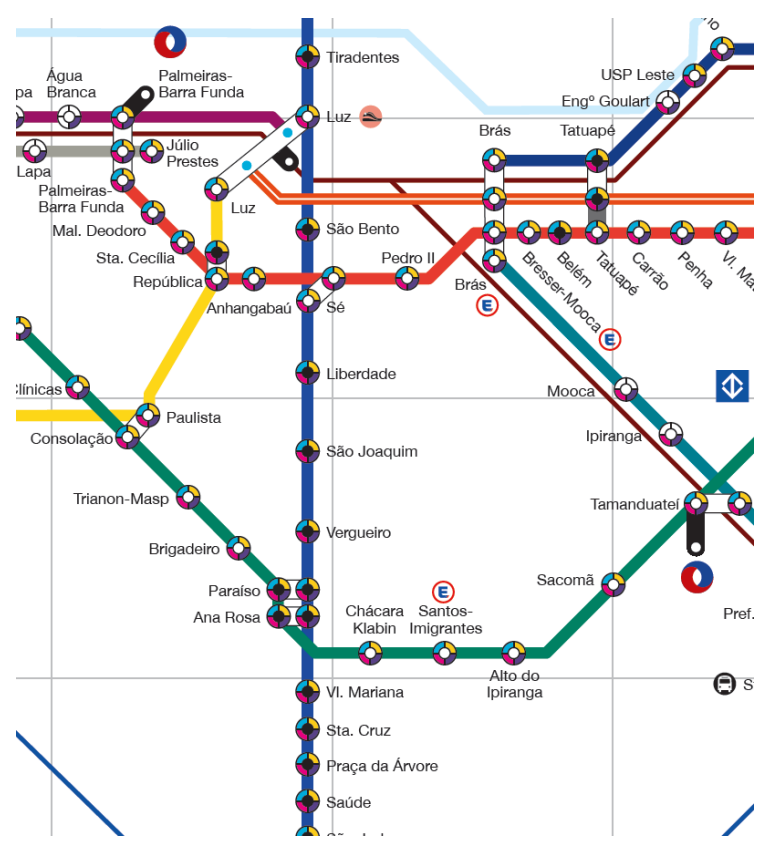

EQUIPAMENTOS DE ACESSIBILIDADE

Cada desenho indica um tipo de equipamento existente

na estação ou terminal.

(1) Elevador

(8) Sanitário adaptado

(-) Rampa

(-) Piso tátil

(P) Plataforma elevatória

As combinações de desenhos mostram todos os

equipamentos existentes na estação marcada.

(2) Elevador + Sanitário adaptado

(-) Elevador + Piso tátil

(2) Elevador + Rampa + Sanitário adaptado

(2) Elevador + Piso tátil + Sanitário adaptado

Rampa + Sanitário adaptado

Rampa + Piso tátil + Sanitário adaptado

(2) Elevador + Piso tátil + Rampa + Sanitário adaptado

Todos os equipamentos de acessibilidade

Todas as estações possuem comunicação visual e sonora

Figura 113 - São Paulo - Mapa do Transporte Metropolitano - Condições de acessibilidade das estações STM.

Fonte: Acessibilidade - Mapa do Transporte Metropolitano - Secretaria dos Transportes Metropolitanos - STM.

Folheto distribuído em 2013.

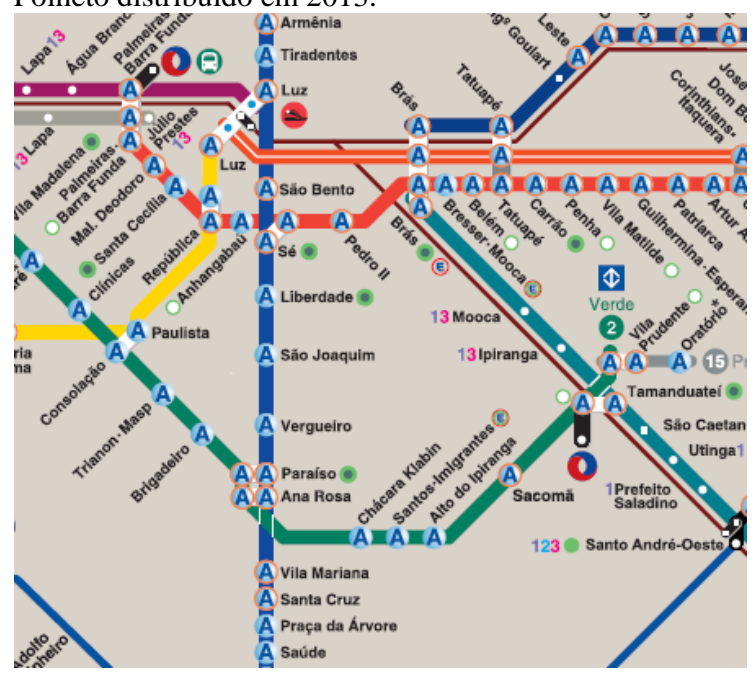

\section{Equipamentos de Acessibilidade}

\begin{tabular}{ll}
\hline Estação com elevador \\
\hline 1 & Rampa \\
\hline 2 & Piso Tátil \\
\hline 3 & Sanitário Adaptado PCD \\
\hline A & Todos os Equipamentos citados acima \\
\hline * Todas as estações possuem Comunicação Visual e Sonora \\
Sanitário Público
\end{tabular}

Figura 114 - São Paulo - Mapa do Transporte Metropolitano - Condições de acessibilidade das estações.

Fonte: Acessibilidade - Mapa do Transporte Metropolitano - Companhia do Metropolitano de São Paulo - Metrô.

Disponível em: http://www.metro.sp.gov.br/pdf/acessibilidade/mapa-acessibilidade.pdf. Acesso em: 04 jan. 2015

Além das informações disponibilizadas pelo Metrô de São Paulo, as estações de rádio e as redes sociais divulgam as condições de operação das diferentes linhas, permitindo o planejamento e a previsão de estratégias pelos usuários para efetuar os deslocamentos desejados. 
A empresa viabiliza, mediante agendamento, a realização de visitas guiadas às suas instalações por meio do "Programa de Visitas ${ }^{32, ", ~ c o m ~ d i f e r e n t e s ~ r o t e i r o s, ~ o b j e t i v o s ~ e ~ p u ́ b l i c o-~}$ alvo. O roteiro "Acessibilidade no Metrô" acontece uma vez por semana, com duração de duas horas e é destinado às pessoas com deficiência com idade superior a 12 anos, atendidas por instituições ou associações de reabilitação. O programa possibilita aos participantes conhecer os detalhes da acessibilidade das instalações e dos equipamentos disponíveis nas estações e nos trens, bem como o funcionamento do sistema metroviário.

\subsubsection{Avaliação pelos usuários}

De um total de 235 respondentes, 73 usuários com deficiência visual - dos quais 49 cegos e 24 pessoas com baixa visão - informaram que buscam informações sobre os trajetos ou sobre o funcionamento do Metrô antes de sair de casa. Destes, apenas 17,8\% buscam informações nos canais oficiais da empresa (Central de Informações, sítio eletrônico, Direto do Metrô), enquanto $11 \%$ recorrem a outras empresas operadoras de transporte (SPTrans), e outros 5,5\% contam com amigos ou familiares. A maioria dos respondentes $(65,7 \%)$ afirmou buscar outros recursos para obter informações sobre os trajetos ou sobre o funcionamento do Metrô (Gráfico 23).

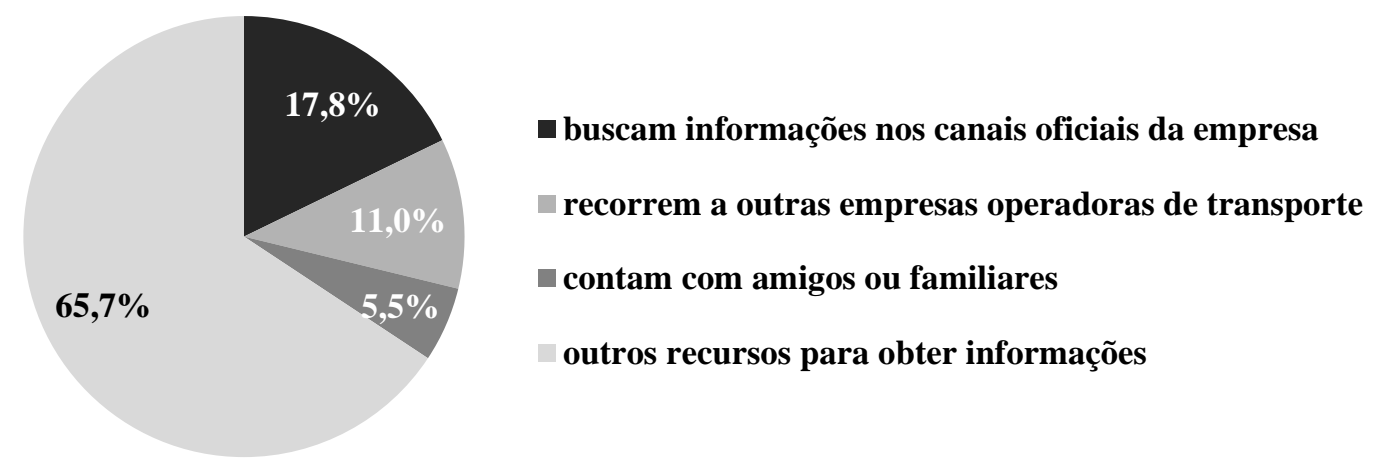

Gráfico 23 - Fonte de informação para o planejamento do deslocamento.

Fonte: Elaborado pela pesquisadora a partir das respostas à Questão 6 do questionário.

Na etapa de planejamento do deslocamento, 55 usuários com deficiência visual - dos quais 39 são cegos e 16 têm baixa visão - relataram seu descontentamento em relação à estação $(100,0 \%)$. Foram registrados 81 relatos sobre esta etapa da jornada, o que representa 3,0\% do total de relatos registrados para todas as etapas da jornada do usuário. Os relatos estão

\footnotetext{
${ }^{32}$ Programa de Visitas do Metrô de São Paulo. Disponível em: http://www.metro.sp.gov.br/ metro/programavisitas.aspx. Acesso em: 04 jan. 2015.
} 
relacionados, em sua maioria, ao serviço prestado nas estações $(77,8 \%)$, e também às informações para planejamento dos deslocamentos $(22,2 \%)$ - (Tabela 18).

Tabela 18 - Matriz de avaliação da etapa 1 - Planejamento do deslocamento.

(\% em relação ao total de relatos registrados nesta etapa)

\begin{tabular}{l|r|r|r|r}
\hline & $\begin{array}{c}\text { Configuração } \\
\text { \% }\end{array}$ & $\begin{array}{c}\text { Informação } \\
\text { \% }\end{array}$ & $\begin{array}{c}\text { Serviço } \\
\text { \% }\end{array}$ & $\begin{array}{c}\text { Total } \\
\%\end{array}$ \\
\hline Estação & $\mathbf{0 , 0}$ & (EI) 22,2 & (ES) $\mathbf{7 7 , 8}$ & $\mathbf{1 0 0 , 0}$ \\
\hline Interface Trem-Estação & $\mathbf{0 , 0}$ & $\mathbf{0 , 0}$ & $\mathbf{0 , 0}$ & $\mathbf{0 , 0 0}$ \\
\hline Trem & $\mathbf{0 , 0}$ & $\mathbf{0 , 0}$ & $\mathbf{0 , 0}$ & $\mathbf{0 , 0 0}$ \\
\hline Total & $\mathbf{0 , 0}$ & $\mathbf{2 2 , 2}$ & $\mathbf{7 7 , 8}$ & $\mathbf{1 0 0 , 0}$ \\
\hline
\end{tabular}

“Acho importante eu ser treinado para conhecer e saber usar o piso tátil em todas as estações, para poder ter mais autonomia e me locomover sozinho. Esse treinamento poderia ser feito pelos empregados das estações em parceria com instituições de deficientes visuais. Por exemplo, quando eu chegasse a uma estação que não conheço o empregado poderia ir me explicando a disposição dos equipamentos - a rampa está à esquerda, o elevador está na sua lateral direita, a bilheteria à sua frente. O empregado deveria ir junto, descrevendo a estação... Porque eu preciso saber, preciso conhecer o trajeto, para saber aonde o piso tátil vai dar... Para eu me deslocar nas estações eu precisaria ter um caderno com as informações e desenhos em alto relevo de todas as estações, mostrando as entradas, escadas, bloqueio, plataformas, dimensão do trem, enfim toda a disposição das estações. Eu poderia também receber folhetos com as alterações das estações e mapas das linhas e estações em braile ou descritas com som para ser acessado no computador... Eu poderia ir ouvindo no celular como me locomover nesta estação. Gostaria que houvesse informação na internet sobre as alterações nos atendimentos preferenciais prestados nas estações, nem todo mundo sabe que tem empregado nas estações para ajudar..." (Discurso do Sujeito Coletivo - Etapa 1)

Os principais problemas relatados pelos usuários na etapa de planejamento do deslocamento são apresentados, de forma hierarquizada (Gráfico 24), conforme número de relatos registrados.

Gráfico 24 - Avaliação da etapa 1 - Planejamento do deslocamento pelos usuários (\% em relação ao total de relatos registrados nesta etapa)

treinamento dos usuários

informações para a pessoa com deficiência visual antes e depois da viagem

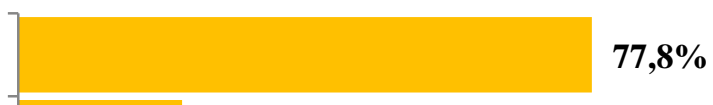

$22,2 \%$ 
Os problemas relatados estão relacionados às seguintes ideias centrais:

a) treinamento dos usuários (ES3) - falta de treinamento prévio dos usuários para aprender a usar o piso tátil;

b) informações para a pessoa com deficiência visual - antes e depois da viagem (EI5) - faltam informações sobre atendimento preferencial, gratuidade e acessibilidade aos interessados por meio de folhetos com orientações em Braille ou informação sonora para a pessoa com deficiência visual saber utilizar as estações.

\subsubsection{Avaliação pelas pessoas-chave}

Os professores de orientação e mobilidade relataram que a falta de treinamento dos usuários (ES3) tem impacto direto na independência dos deslocamentos das pessoas com deficiência, em especial no que concerne às vivências para uso de elevadores ou escadas rolantes e à familiarização com os diferentes modos de transporte ou com o meio urbano. Técnicas de autoproteção, utilização do guia vidente, rastreamento com bengala longa por meio de toque ou deslize são igualmente importantes para que as pessoas com deficiência visual possam adaptar-se à diversidade e à complexidade das situações cotidianas. Programas de capacitação customizados permitem, por um lado, a familiarização com percursos que serão cotidianos utilizando-se o conjunto de informações para a pessoa com deficiência visual - estação (EI6), pistas e referências disponíveis nos ambientes e, por outro, a avaliação da pertinência da independência ou da necessidade de auxílio. A compreensão dos percursos que serão realizados pode ser ampliada com o auxílio de informações para a pessoa com deficiência visual - antes e depois da viagem (EI5), tais como as descrições sonoras disponibilizadas na internet, contendo as principais referências dos percursos de embarque e de desembarque em cada estação, permitindo informações em igualdade de condições com os demais usuários.

\subsubsection{Avaliação pelos especialistas}

Os profissionais responsáveis pela elaboração de normas técnicas de acessibilidade ressaltam as dificuldades enfrentadas para constituir e manter ativa uma Comissão de Estudo - CE com a participação voluntária dos diversos segmentos da sociedade, em especial das pessoas com deficiência. Essa participação é essencial para a promoção de debates para se atingirem objetivos eficazes, que possam ser traduzidos em requisitos de projeto, seja de ambientes, de informações ou de serviços adequados às necessidades das pessoas com deficiência visual. 


\subsubsection{Elementos de wayfinding}

Os dados coletados permitem afirmar que todos os elementos de wayfinding - marcadores, caminhos, nós, zonas e bordas - devem estar presentes nesta etapa, (Quadro 24). Ao mesmo tempo, tais elementos devem compor e ser ressaltados nas informações veiculadas, especialmente quando da elaboração de materiais táteis, visuais e sonoros voltados para a descrição da rede de transporte e das estações para informar as pessoas com deficiência antes da viagem, de forma a facilitar a percepção e a compreensão dos trajetos na etapa de planejamento dos deslocamentos.

Quadro 24 - Elementos de wayfinding da Etapa 1 - Planejamento do deslocamento.

\begin{tabular}{|c|c|c|c|}
\hline $\begin{array}{l}\text { Elementos de } \\
\text { wayfinding }\end{array}$ & Configuração & Informação & Serviço \\
\hline Marcadores & \multirow{3}{*}{$\begin{array}{l}\text { - elementos de } \\
\text { wayfinding presentes de } \\
\text { forma integrada }\end{array}$} & \multirow{3}{*}{$\begin{array}{l}\text { - existência de } \\
\text { sinalização integrada } \\
\text { sobre os diferentes } \\
\text { modos de transporte }\end{array}$} & \multirow{3}{*}{$\begin{array}{l}\text { - veiculação das } \\
\text { informações completas } \\
\text { para os usuários }\end{array}$} \\
\hline $\begin{array}{l}\text { Caminhos } \\
\text { Nós } \\
\text { Bordas }\end{array}$ & & & \\
\hline Zonas & & & \\
\hline
\end{tabular}

Fonte: Elaborado pela pesquisadora.

\subsubsection{Síntese do diagnóstico}

Na etapa 1 - Planejamento do deslocamento, foram identificadas recursos que devem ser oferecidos previamente pelas empresas operadoras dos sistemas metroferroviários para auxiliar as pessoas com deficiência visual a estabelecer estratégias antes de empreender seus deslocamentos, entre os quais destacam-se:

a) informações para a pessoa com deficiência visual - antes e depois da viagem (EI5) - veicular informações e esclarecimentos sobre o atendimento preferencial, a gratuidade, a acessibilidade e as condições de operação dos serviços (disponibilizados, distribuídos e atualizados por meio de folhetos, sítios eletrônicos, atendimento pelo telefone, estações de rádio e redes sociais). Outro tipo de informação compreende o detalhamento da rede de transporte metroferroviário (mapa impresso da rede, com informações visuais em texto ampliado; mapa da rede com informações táteis; folhetos com orientações em Braille; arquivo sonoro contendo a descrição das linhas da rede do 
transporte metropolitano e a descrição das principais referências dos percursos de embarque e desembarque disponibilizada na internet; sistema roteador para orientar o percurso a ser realizado, informando as conexões e o tempo estimado de deslocamento);

b) informações para a pessoa com deficiência visual - estação (EI6) - veicular, nas estações, informações sobre a configuração da rede de transporte metroferroviário e das estações (mapa da rede com informações táteis, sonoras e visuais em texto ampliado; folhetos com orientações em Braille; informações táteis, sonoras e visuais com descrição das principais referências dos percursos de embarque e de desembarque);

c) treinamento dos usuários (ES3) - promover maior integração entre as instituições de reabilitação e as empresas operadoras dos sistemas metroferroviários com o objetivo de promover treinamento específico de orientação e mobilidade nas estações para que as pessoas com deficiência visual possam utilizá-las com independência.

\subsection{Etapa 2 - Desembarque do sistema integrado}

Nesta etapa, o usuário desloca-se a pé a partir dos arredores ou dos diferentes modos de transporte integrados - ônibus, lotação, táxi, carona - até o acesso da estação.

\subsubsection{Métodos e técnicas aplicados}

Os métodos e técnicas utilizados para coleta de dados nesta etapa foram apresentados no item 6.10 - Síntese dos instrumentos aplicados - e consistiram em:

a) melhores práticas identificadas em outros sistemas metroferroviários;

b) pesquisa documental (normas técnicas ABNT vigentes, desenhos, procedimentos operacionais);

c) checklist dos recursos disponíveis e walkthrough realizado nas estações para compreensão do percurso de embarque;

d) questionário aplicado em pessoas com deficiência visual - questão 10;

e) entrevista com empregados das estações;

f) entrevista com estagiários que auxiliam pessoas com deficiência visual;

g) entrevista com professores de orientação e mobilidade;

h) entrevista com profissionais responsáveis pelos projetos das estações; 
i) entrevista com profissionais responsáveis pela elaboração de normas técnicas.

As formas de análise e interpretação dos dados coletados foram apresentadas no Capítulo 6 Aplicação dos instrumentos.

\subsubsection{Melhores Práticas}

Entre as melhores práticas, destacam-se as novas estações do Metrô de Madri, que dispõem de sinalização tátil no percurso entre os pontos de parada de ônibus e os acessos, proporcionando a percepção da rota de embarque (Figura 115). Nos acessos das estações, que devem ser facilmente reconhecidos e integrados com o sistema de sinalização urbana e com os sistemas de transporte urbano, predominam fechamentos em vidro e estrutura em aço, conferindo segurança e harmonização da edificação com a paisagem. Os acessos contêm sinalização de identificação da estação e da linha, de acessibilidade da estação e da condição de operação da rede metroferroviária (Figura 116).
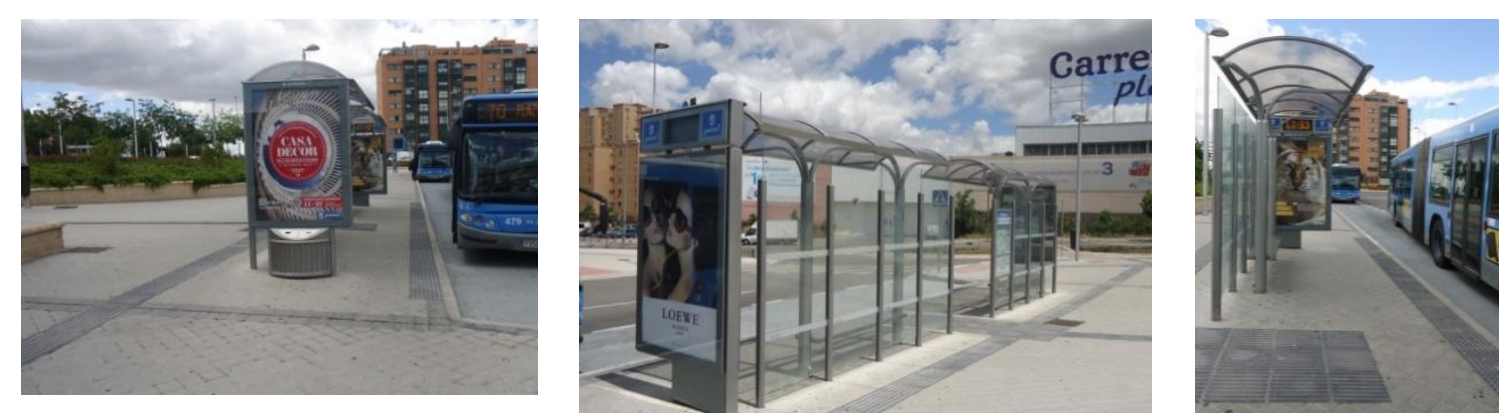

Figura 115 - Madri - Sinalização tátil direcional entre o ponto de parada de ônibus e o acesso da estação. Fonte: BARBOSA, M.B., 2013.

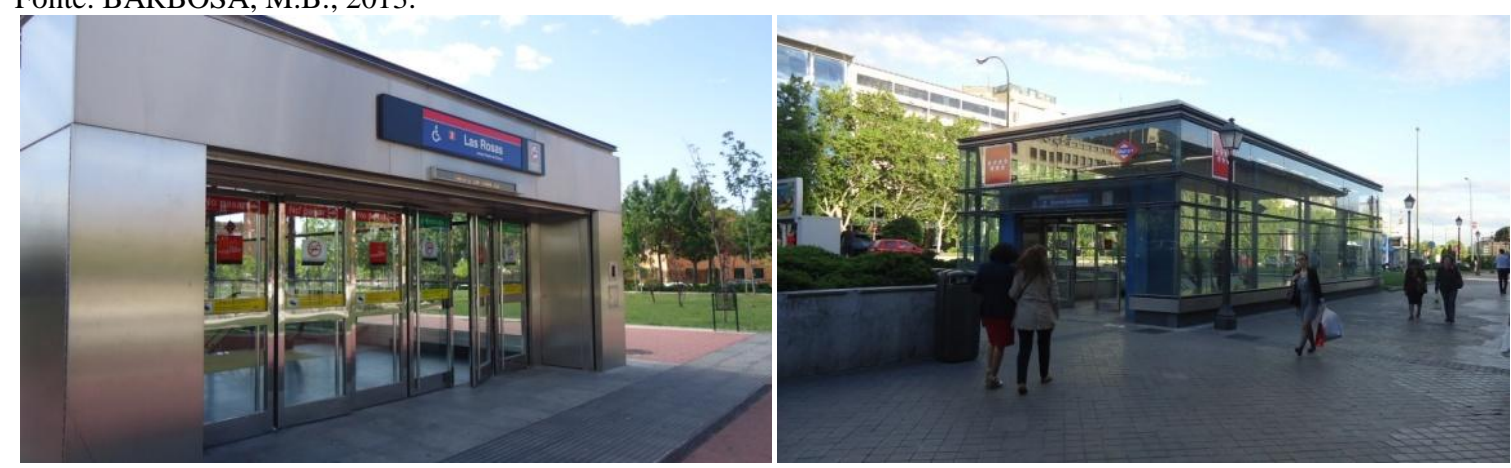

Figura 116 - Madri - Aspecto visual e sinalização dos acessos das estações

Fonte: BARBOSA, M.B., 2013.

Outro exemplo de melhores práticas é a sinalização de acesso às estações do Metrô de Hong Kong, que são integradas com o sistema de sinalização urbana, onde predominam fechamentos em vidro e estrutura em aço, o que confere segurança e harmonização da edificação com a paisagem. Cada acesso é identificado por uma letra que aparece nos mapas 
táteis informando a configuração das áreas internas da estação e a configuração do entorno, indicando a localização e posicionamento de cada acesso. Indicações em relevo contendo o nome da estação e da linha são posicionadas nos acessos das estações. Alarmes de baixa intensidade junto à porta de acesso auxiliam a identificação da localização do acesso da estação (Figuras 117 e 118)
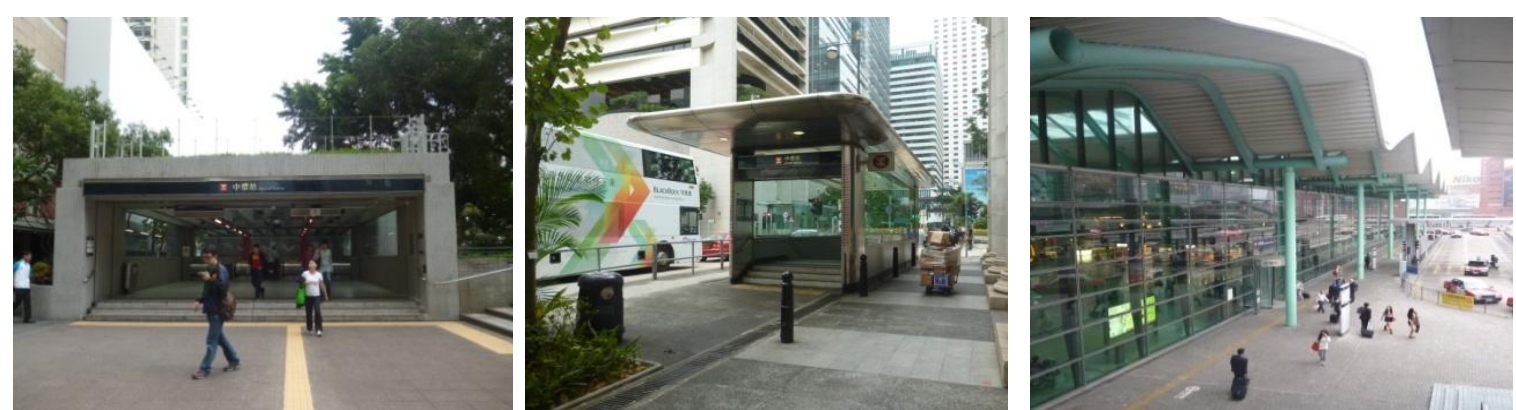

Figura 117 - Hong Kong - Aspecto visual e piso tátil nos acessos das estações. Crédito: Pontes, F.M., 2012.
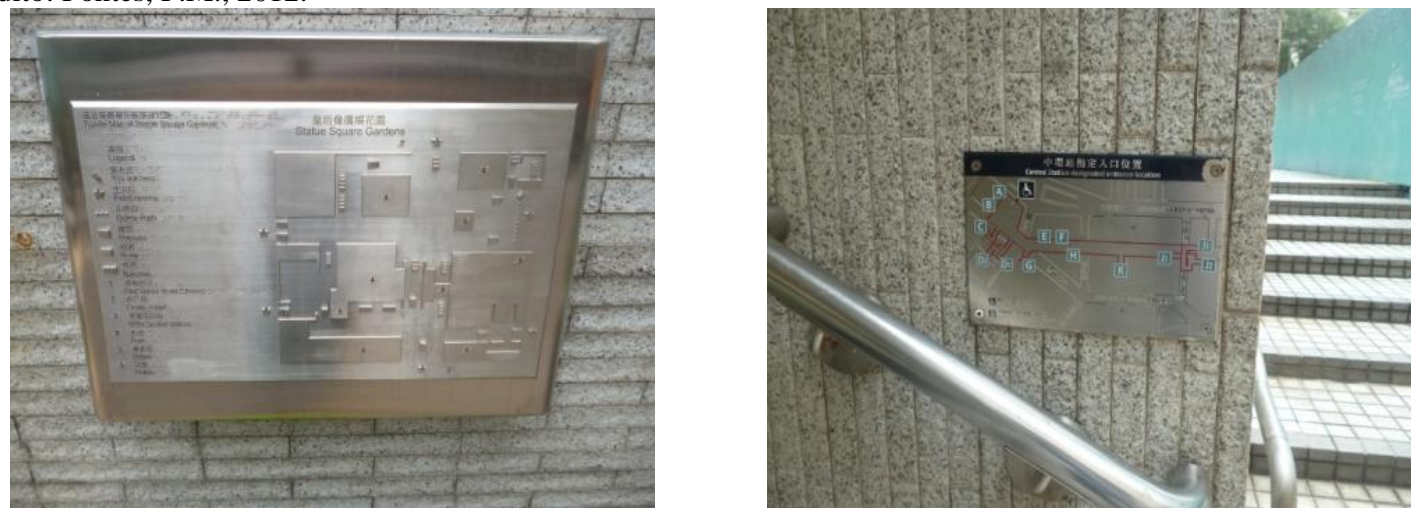

Figura 118 - Hong Kong - Mapa tátil nos acessos das estações.

Crédito: Pontes, F.M., 2012.

Nos acessos das estações do Metrô de Tóquio há intensa iluminação, facilitando sua identificação no período noturno (Figura 119). A sinalização tátil no piso referente à localização do acesso está integrada à sinalização tátil no piso dos passeios públicos, (Figura 120).
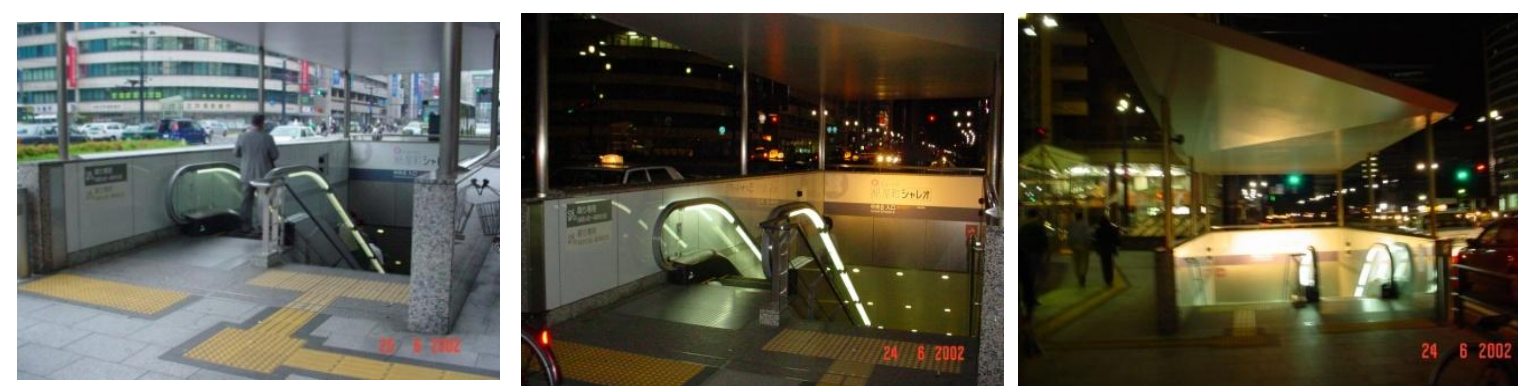

Figura 119 - Tóquio - Sinalização dos acessos das estações. Fonte: BARBOSA, M.B., 2002. 


\subsubsection{Requisitos Normativos}

Com relação aos requisitos normativos, a ABNT NBR 9050:2004 estabelece a necessidade de existência de uma rota acessível e de sinalização tátil direcional em áreas de circulação, indicando o caminho a ser percorrido em espaços amplos. A ABNT NBR 14021:2005 estabelece a necessidade de existência de equipamento intercomunicador para possibilitar a solicitação de auxílio pelo usuário, bem como a necessidade de sinalização específica para identificar o acesso, contendo as seguintes informações:

a) nome da estação e da(s) linha(s);

b) horário de funcionamento da estação e do acesso;

c) identificação do acesso, através de número, letra ou nome.

\subsubsection{Situação no Metrô de São Paulo}

No Metrô de São Paulo, pontos de parada de ônibus municipais, metropolitanos, intermunicipais e de fretamento estão localizados no sistema viário, junto aos acessos, e nos terminais de ônibus urbanos e rodoviários integrados às estações (Figuras 120 e 121). Não existe sinalização tátil orientando o percurso de embarque entre os pontos de parada - seja no viário ou nos terminais - e os acessos das estações.
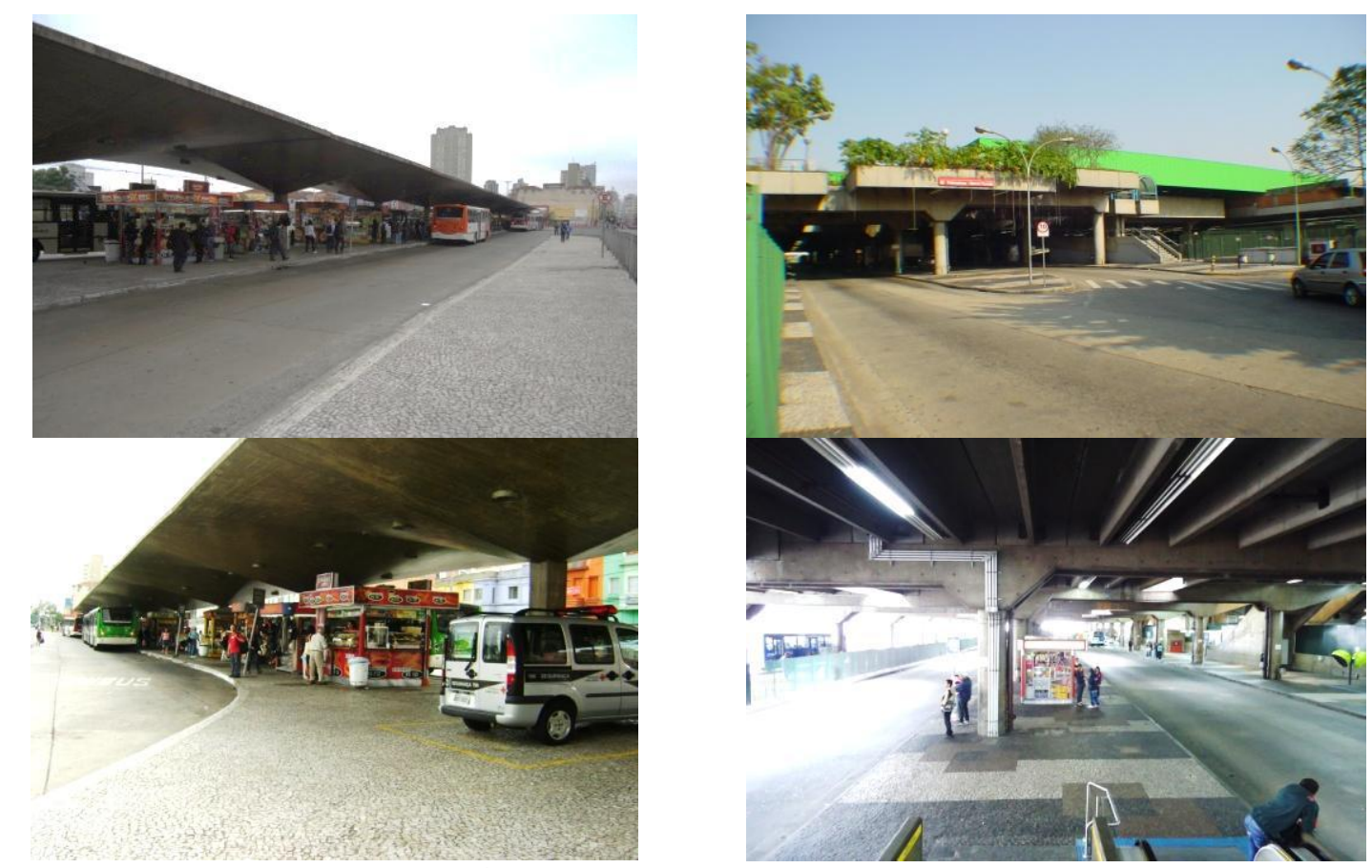

Figura 120 - São Paulo - Terminal de ônibus urbano. Fonte: BARBOSA, M.B., 2013. 

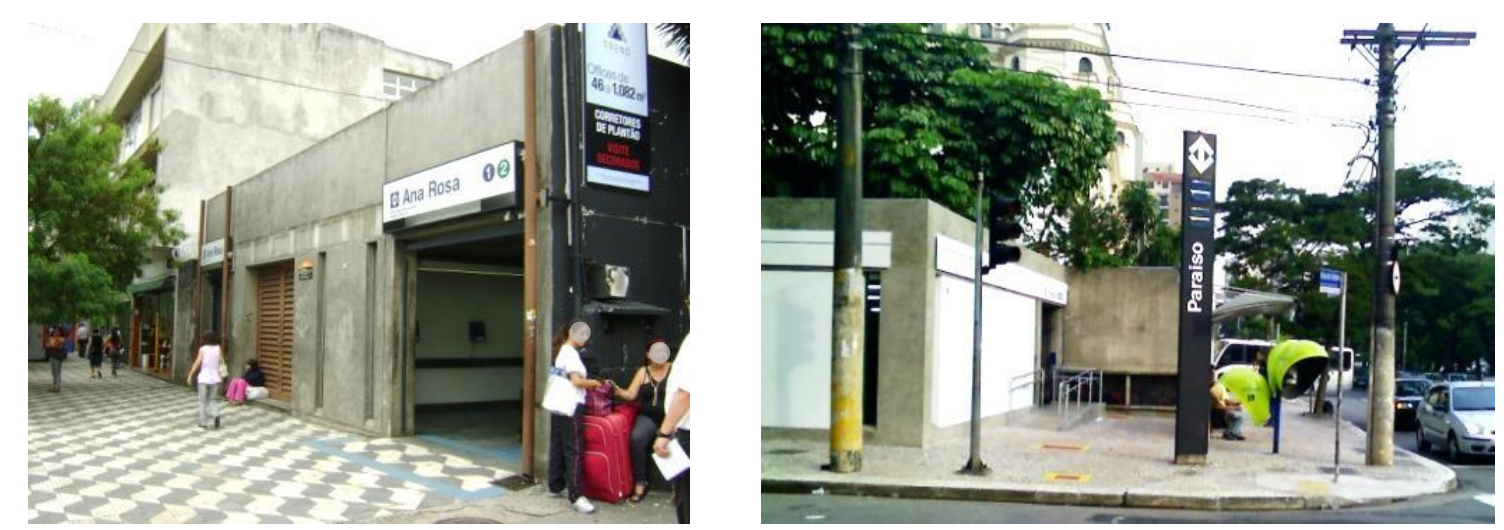

Figura 121 - São Paulo - Ponto de parada no passeio público.

Fonte: BARBOSA, M.B., 2013.

\subsubsection{Avaliação pelos usuários}

Na etapa de desembarque do sistema integrado, 21 usuários com deficiência visual - dos quais 16 pessoas são cegas e cinco pessoas têm baixa visão - manifestaram seu descontentamento em relação à estação (100\%). Foram registrados 28 relatos, o que representa $1,0 \%$ do total de relatos registrados para todas as etapas da jornada do usuário. Os relatos estão relacionados, em sua maioria, à disponibilidade de informações nas estações (75,0\%), mas também referem-se à configuração da estação (14,3\%) para facilitar o desembarque do usuário do sistema integrado e o acesso aos serviços prestados $(10,7 \%)-$ (Tabela 19).

Tabela 19 - Matriz de avaliação da etapa 2 - Desembarque do sistema integrado.

(\% em relação ao total de relatos registrados nesta etapa)

\begin{tabular}{l|r|r|r|r}
\hline & \multicolumn{1}{c|}{$\begin{array}{c}\text { Configuração } \\
\text { \% }\end{array}$} & $\begin{array}{c}\text { Informação } \\
\text { \% }\end{array}$ & $\begin{array}{c}\text { Serviço } \\
\text { \% }\end{array}$ & $\begin{array}{c}\text { Total } \\
\%\end{array}$ \\
\hline Estação & (EC) $\mathbf{1 4 , 3}$ & (EI) $\mathbf{7 5 , 0}$ & (ES) $\mathbf{1 0 , 7}$ & $\mathbf{1 0 0 , 0}$ \\
\hline Interface Trem-Estação & $\mathbf{0 , 0}$ & $\mathbf{0 , 0}$ & $\mathbf{0 , 0}$ & $\mathbf{0 , 0}$ \\
\hline Trem & $\mathbf{0 , 0}$ & $\mathbf{0 , 0}$ & $\mathbf{0 , 0}$ & $\mathbf{0 , 0}$ \\
\hline Total & $\mathbf{1 4 , 3}$ & $\mathbf{7 5 , 0}$ & $\mathbf{1 0 , 7}$ & $\mathbf{1 0 0 , 0}$ \\
\hline
\end{tabular}

"Quando estou chegando na estação, não tem piso tátil entre os pontos de ônibus ou terminais de ônibus e o acesso da estação. Para mim também é importante que tenha piso tátil na calçada, para indicar que cheguei na estação do metrô. Deveria ter guias táteis nas calçadas indicando a entrada da estação ou a escada do metrô para eu não passar batido... Para chegar nas estações eu enfrento vários obstáculos como calçadas estreitas, camelôs, barracas de lanches próximas ao piso tátil, postes, lixeiras...é difícil de andar nos horários de pico! Eu acho que precisa melhorar o entorno das estações, colocar faixas de travessia e semáforos sonoros, colocar os pontos de ônibus mais próximos, para que eu possa chegar mais fácil. Outro ponto importante é melhorar o atendimento entre as diferentes operadoras. Quando faço a transferência passo na mão de três empregados, sendo que apenas um poderia fazer 
esta condução. Além disso, acho que é preciso aumentar o número de empregados no terminal de ônibus para auxiliar o deslocamento até a estação". (Discurso do Sujeito Coletivo - Etapa 2)

Os principais problemas relatados pelos usuários na etapa desembarque do sistema integrado são apresentados, de forma hierarquizada, conforme o número de relatos registrados (Gráfico 25).

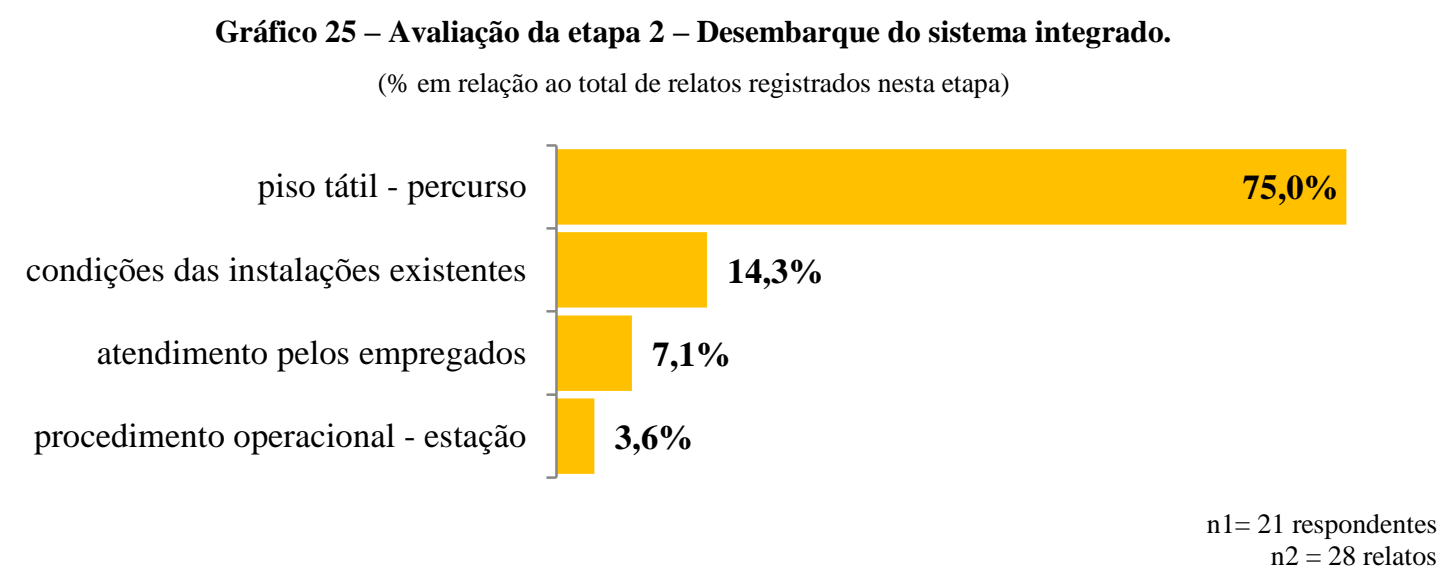

Os problemas relatados estão relacionados às seguintes ideias centrais:

a) piso tátil - percurso (EI3) - dificuldade de compreensão sobre o caminho e destaca que o piso tátil foi instalado próximo de obstáculos existentes na edificação e não orienta para todos os equipamentos e serviços oferecidos;

b) condições das instalações existentes (EC3) - más condições existentes nos arredores das estações;

c) atendimento pelos empregados (ES2) - falta de assistência e auxílio no percurso entre o desembarque do sistema de ônibus integrado e a chegada à estação;

d) procedimento operacional - estação (ES6) - necessidade de adequação dos procedimentos vigentes face à demora do atendimento pelos empregados do Metrô quando das transferências vindas da CPTM, da Via Quatro ou dos deslocamentos no entorno das estações.

\subsubsection{Avaliação pelas pessoas-chave}

Os empregados das estações relataram como fator negativo, nas condições das instalações existentes (EC3), a distância entre os pontos de parada ou dos terminais de ônibus urbanos e os acessos da estação, fato que interfere na prestação do auxílio pelos empregados (Figuras 122 e 123). Nos horários de maior movimento, a lotação das estações (ES7) impacta o 
deslocamento com independência das pessoas com deficiência visual. Também é considerada negativa a inexistência de semáforos ou faixas de travessia junto aos acessos das estações.

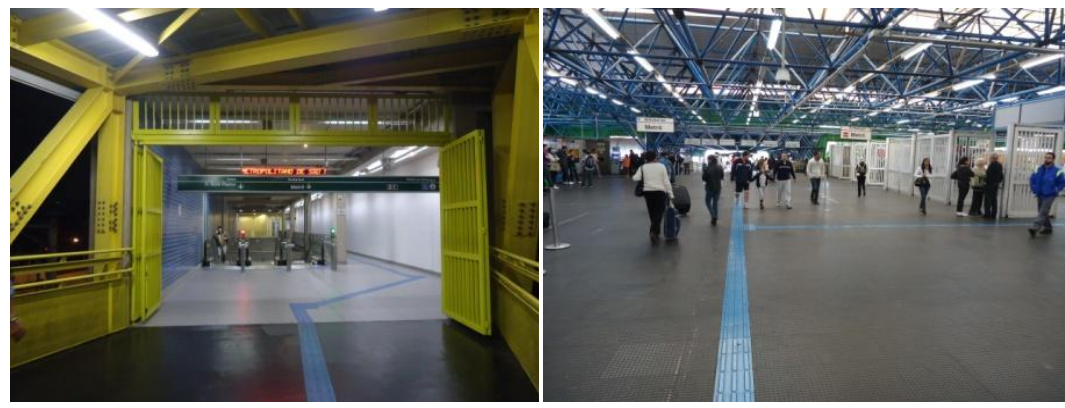

Figura 122 - São Paulo - Distância entre os terminais de ônibus urbanos e o mezanino.

Fonte: BARBOSA, M.B., 2011.

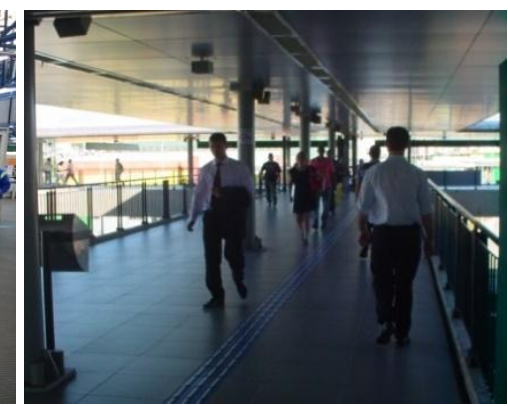

Figura 123- São Paulo - Distância entre o acesso e o mezanino. Fonte: BARBOSA, M.B., 2011.

Sobre o atendimento prestado pelas operadoras dos trens e dos ônibus municipais, metropolitanos ou intermunicipais, os empregados das estações destacaram a afinidade entre as equipes e a avaliação positiva do procedimento operacional - estação (ES6), que estabelece os limites de atuação, cabendo a cada uma das equipes auxiliar os deslocamentos até a Sala de Supervisão Operacional - SSO - da outra operadora para que as equipes deem continuidade ao atendimento. Em relação às informações para a pessoa com deficiência visual - estação (EI6), eles destacaram a inexistência de intercomunicadores nos terminais de ônibus urbanos, o que impossibilita à pessoa com deficiência visual solicitar auxílio para os empregados do Metrô.

Os estagiários relataram a dificuldade de auxiliar as pessoas com deficiência nos ambientes onde se dá o desembarque do sistema integrado - pontos de parada em terminais urbanos ou sistema viário - em função das condições das instalações existentes (EC3). Destaquem-se, entre essas condições, os obstáculos, o mobiliário e os equipamentos ao longo do caminho, a falta de infraestrutura adequada dos arredores das estações, tais como a ausência de faixas de travessia com semáforos sonoros e a iluminação inadequada no período noturno, gerando sensação de insegurança para que as pessoas com deficiência possam empreender deslocamentos com independência. Também foram relatadas dificuldades no auxílio prestado decorrentes da lotação das estações (ES7) e do comportamento dos demais usuários estação (ES4), que ora estão parados, ora estão desatentos, ora não respeitam o deslocamento preferencial da pessoa com deficiência visual e do estagiário, obrigando-os a desviarem seu caminho em todas essas situações. 
Os professores de orientação e mobilidade relataram que a ausência de uma faixa de transição traz dificuldades para identificação do piso tátil - contraste tátil e visual (EI1) em relação ao piso utilizado na pavimentação dos passeios públicos. Destaquem-se os pisos com textura, tais como mosaicos portugueses, blocos intertravados, entre outros acabamentos (Figura 124). Em relação ao piso tátil - percurso (EI3), criticaram o dimensionamento insuficiente da sinalização tátil de alerta nas interseções entre pisos direcionais, dificultando a percepção quanto às mudanças de direção. Criticaram ainda o fato de a sinalização não considerar ou ser igual ao percurso dos demais usuários, o que pode gerar eventuais conflitos de fluxo. Para melhor compreensão do percurso realizado até a estação pode ser ampliada com o auxílio de mapas táteis e descrições sonoras contendo as principais referências urbanas e a localização dos acessos das estações, permitindo informações em igualdade de condições com os demais usuários.
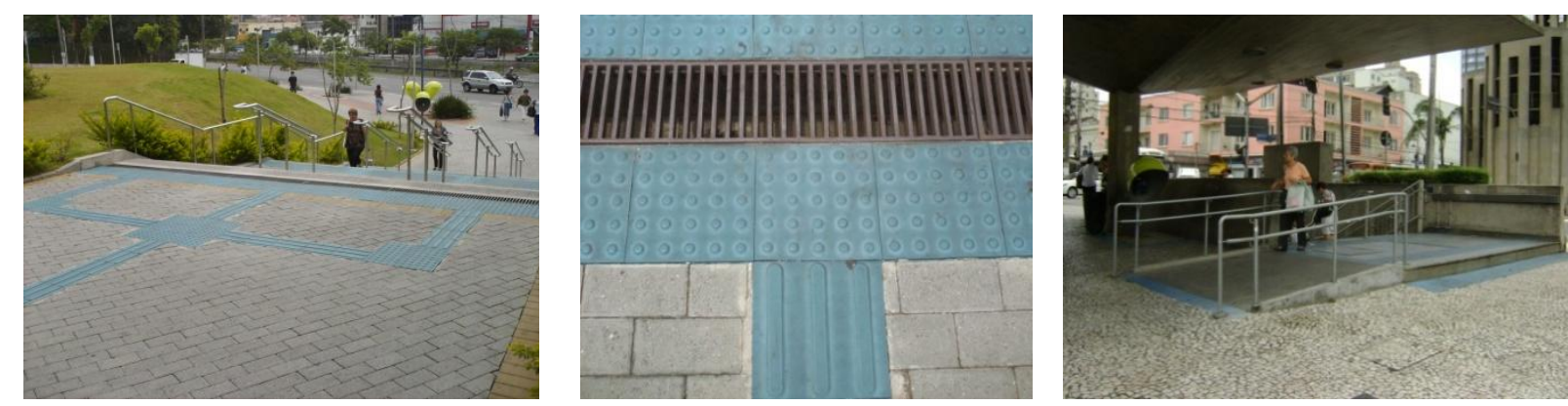

Figura 124 - São Paulo - Contraste tátil e visual entre o piso tátil e o piso intertravado ou com o mosaico português. Fonte: BARBOSA, M.B., 2011.

\subsubsection{Avaliação pelos especialistas}

$\mathrm{Na}$ etapa de desembarque do sistema integrado, os profissionais responsáveis pelos projetos das estações relataram que o direcionamento de fluxo nos espaços destinados à conexão entre diferentes modos de transporte é feito exclusivamente por meio do piso tátil - percurso (EI3) uma vez que não são utilizados elementos de acabamento ou materiais de revestimento diferenciados, seja em paredes, piso ou forros, que reverberem mais ou que sejam mais absorventes, para auxiliar os deslocamentos. Quanto às informações para a pessoa com deficiência visual - estação (EI6), esses especialistas ressaltam que não há nada que diferencie o caminho do Metrô do caminho da CPTM, do terminal rodoviário, das alternativas de transporte disponíveis: todas as informações são veiculadas por meio de textos informativos. Em relação às condições das instalações existentes (EC3), afirmam que os espaços destinados à conexão são entendidos como espaços de socialização e, portanto, não se 
diferenciam para referenciar os diversos modos de transporte, apesar de serem extremamente significativos, qualquer que seja a configuração da estação.

Os profissionais responsáveis pela elaboração de normas técnicas de acessibilidade ressaltam a inexistência de requisitos específicos relacionados à configuração ou à sinalização dos ambientes para definição da rota acessível entre diferentes modos de transporte.

\subsubsection{Elementos de wayfinding}

Os dados coletados permitem afirmar que os elementos de wayfinding característicos desta etapa são: marcadores e caminhos (Quadro 25). Tais elementos devem ser destacados dos demais elementos da paisagem ou do ambiente. As informações táteis, visuais e sonoras dos elementos de wayfinding devem-se sobressair em relação às demais informações para facilitar a percepção e a compreensão dos percursos a partir dos diferentes sistemas integrados de transporte até o acesso da estação.

Quadro 25 - Elementos de wayfinding da Etapa 2 - Desembarque do sistema integrado.

\begin{tabular}{|c|c|c|c|}
\hline $\begin{array}{l}\text { Elementos de } \\
\text { wayfinding }\end{array}$ & Configuração & Informação & Serviço \\
\hline Marcador & - acesso da estação & $\begin{array}{l}\text { - sinalização tátil/visual/ } \\
\text { sonora para identificação } \\
\text { da localização do acesso }\end{array}$ & $\begin{array}{c}\text { - intercomunicador para } \\
\text { solicitação de auxílio }\end{array}$ \\
\hline Caminho & $\begin{array}{l}\text { - percurso entre o transporte } \\
\text { integrado e o acesso da } \\
\text { estação }\end{array}$ & $\begin{array}{c}\text { - sinalização tátil/ visual } \\
\text { para identificação do } \\
\text { percurso de integração }\end{array}$ & $\begin{array}{l}\text { - integração com outros } \\
\text { modos de transporte } \\
\text { (ônibus, vans, táxis) }\end{array}$ \\
\hline
\end{tabular}

Fonte: Elaborado pela pesquisadora.

\subsubsection{Síntese do diagnóstico}

Na etapa 2 - Desembarque do sistema integrado -, foram identificados aspectos que devem ser tratados pelas empresas operadoras dos sistemas metroferroviários para auxiliar pessoas com deficiência visual a estabelecer estratégias para empreender seus deslocamentos, especificados a seguir:

a) condições das instalações existentes (EC3) - zelar pelas condições adequadas de segurança e manutenção nos arredores das estações; manter as áreas de circulação e calçadas livres de obstáculos como mobiliário, equipamentos, ambulantes; reduzir as distâncias entre os postos de parada e terminais urbanos e os acessos das estações; instalar semáforos sonoros e faixas de travessia de pedestres; incluir requisitos de 
projeto relacionados à configuração dos ambientes nas normas técnicas de acessibilidade para definição da rota acessível entre diferentes modos de transporte;

b) piso tátil - contraste tátil e visual (EI1) - melhorar o contraste entre a sinalização tátil e o piso utilizado na pavimentação dos passeios públicos e dos terminais de ônibus urbanos;

c) piso tátil - percurso (EI3) - remanejar piso tátil instalado próximo de obstáculos existentes na edificação (colunas, pilares); instalar sinalização tátil no piso orientando o percurso para todos os equipamentos e serviços oferecidos; considerar, sempre que possível, o mesmo percurso dos demais usuários; redimensionar a sinalização de alerta nas interseções entre pisos direcionais; melhorar a compreensão sobre o caminho, por meio de mapas táteis ou descrições sonoras, permitindo informação em igualdade de condições com os demais usuários;

d) informações para a pessoa com deficiência visual - estação (EI6) - instalar intercomunicadores nos terminais de ônibus urbanos; diferenciar o ambiente e os caminhos que levam ao Metrô a partir dos demais serviços ou transportes integrados nas estações de conexão, por meio de materiais de acabamento / revestimento ou sistemas de informação; incluir requisitos de projeto relacionados à sinalização dos ambientes nas normas técnicas de acessibilidade para definição da rota acessível entre diferentes modos de transporte;

e) atendimento pelos empregados (ES2) - prover auxílio no percurso entre o desembarque do sistema de ônibus integrado e a chegada à estação; agilizar o auxílio prestado pelos empregados / estagiários;

f) comportamento dos demais usuários - estação (ES4) - promover campanhas para orientar os demais usuários a não permanecerem parados ou não colocarem bagagens sobre o piso tátil, a prestarem atenção e respeitarem o deslocamento preferencial das pessoas com deficiência visual e seus acompanhantes;

g) procedimento operacional - estação (ES6) - adequar os procedimentos vigentes para agilizar o atendimento pelos empregados do Metrô quando das transferências originadas nas outras operadoras, ou mesmo nos arredores das estações;

h) lotação das estações (ES7) - organizar os fluxos para reduzir os impactos da demanda elevada de passageiros no deslocamento das pessoas com deficiência visual com independência. 


\subsection{Etapa 3 - Acesso à estação}

Nesta etapa, o usuário entra na estação e dirige-se aos elementos de circulação vertical rampas, escadas fixas, escadas rolantes ou elevadores.

\subsubsection{Métodos e técnicas aplicados}

Os métodos e técnicas utilizados para coleta de dados nesta etapa foram apresentados no item 6.10 - Síntese dos instrumentos aplicados - e consistiram em:

a) melhores práticas identificadas em outros sistemas metroferroviários;

b) pesquisa documental (normas técnicas ABNT vigentes, desenhos, procedimentos operacionais);

c) checklist dos recursos disponíveis e walkthrough realizado nas estações para compreensão do percurso de embarque;

d) questionário aplicado às pessoas com deficiência visual - questões 12, 13 e 17;

e) entrevista com empregados das estações;

f) entrevista com estagiários que auxiliam pessoas com deficiência visual;

g) entrevista com professores de orientação e mobilidade;

h) entrevista com profissionais responsáveis pelos projetos das estações;

i) entrevista com profissionais responsáveis pela elaboração de normas técnicas.

As formas de análise e interpretação dos dados coletados foram apresentadas no Capítulo 6 Aplicação dos instrumentos.

\subsubsection{Melhores Práticas}

Entre as melhores práticas, destacam-se os acessos das estações de trem operadas pela SNCF em Paris (Figura 125), que dispõem de sinalização sonora associada à sinalização tátil no piso. As mensagens sonoras de orientação e de localização são veiculadas a partir de antenas que funcionam como balizas e emitem informações diretamente para dispositivos utilizados pelos usuários com deficiência visual, de acordo com seus deslocamentos. 


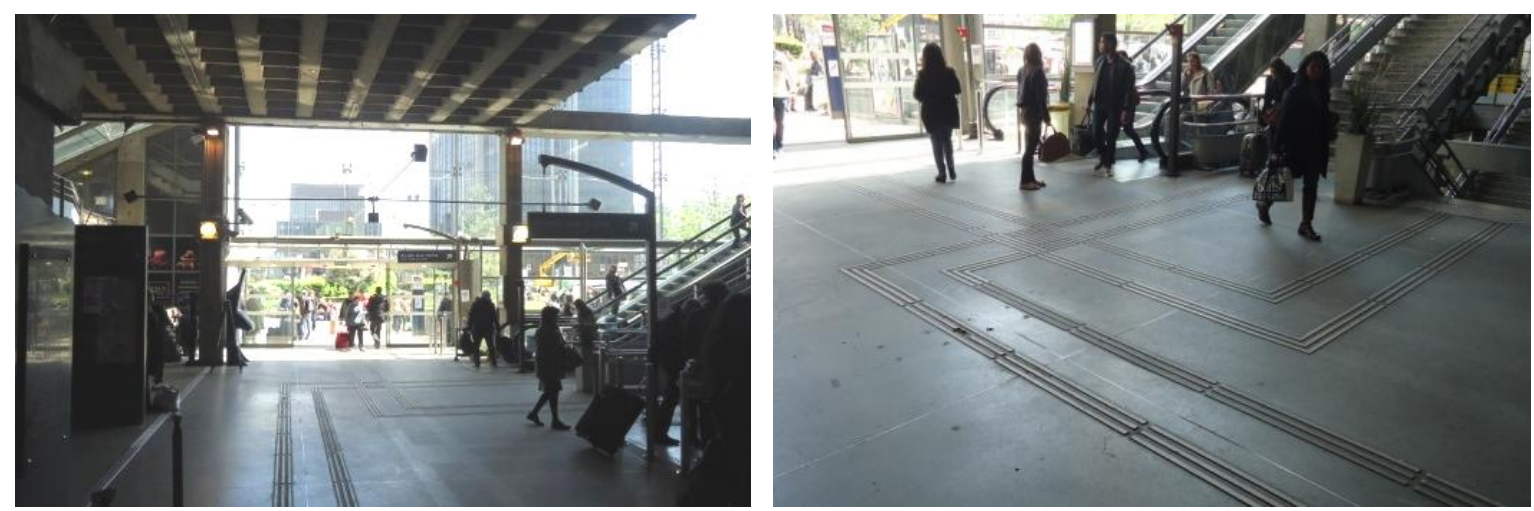

Figura 125 - Paris - Acesso das estações de trem operadas pela SNCF.

Fonte: BARBOSA, M.B., 2013.

No Metrô do Rio de Janeiro, destaca-se a existência de dois modelos de mapas táteis disponibilizados nas estações. O primeiro deles, localizado nas paredes junto aos acessos, orienta o planejamento dos deslocamentos de embarque a partir do posicionamento do usuário ("você está aqui") e da localização dos demais mapas táteis existentes na estação (Figura 126). Esse mapa tátil contém as seguintes informações: o nome da estação, a configuração dos acessos e ruas do entorno, a localização dos elementos de circulação vertical - elevadores, escadas fixas e rolantes -, dos equipamentos de controle de acesso e dos sanitários. O mapa indica a configuração do percurso por meio dos pisos direcionais e de alerta em cada pavimento da estação. Todas as referências são explicadas em uma legenda posicionada ao lado do desenho em relevo. As informações táteis são veiculadas por meio de caracteres em relevo e texto em Braille na cor branca sobre fundo azul escuro.

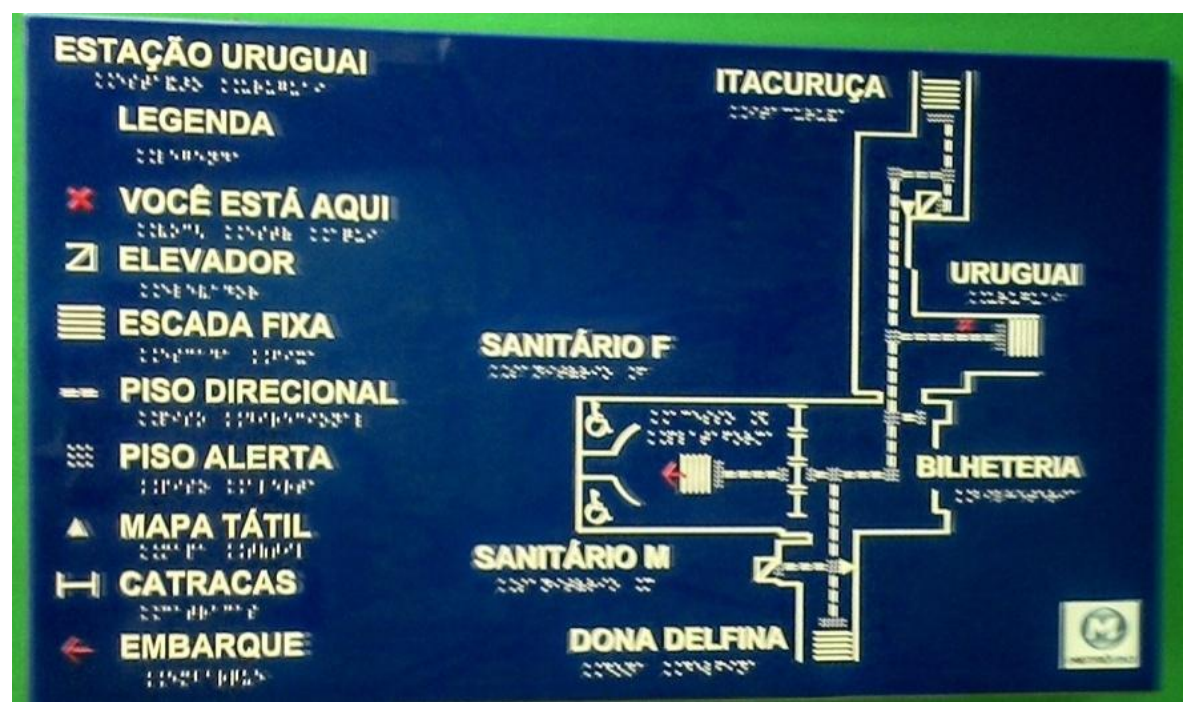

Figura 126 - Rio de Janeiro - Configuração dos acessos e detalhe do mapa tátil da estação. Fonte: BARBOSA, M.B., 2011.

O segundo modelo de mapa tátil contém as seguintes informações: o nome da estação, a configuração dos acessos, a localização dos elementos de circulação vertical - elevadores, 
escadas fixas e rolantes - e dos equipamentos de controle de acesso. As escadas rolantes e elevadores são representados por meio de linhas em relevo na cor preta. As escadas fixas são representadas por placas na cor cinza com textura em baixo relevo (Figura 127). O mapa indica a configuração do percurso por meio de pisos táteis em cada pavimento da estação, sem distinção entre pisos direcionais e pisos de alerta, ambos representados pela cor amarela. Todas as referências são explicadas em uma legenda posicionada ao lado ou abaixo da representação gráfica. As informações táteis são veiculadas por meio de texto em Braille, produzido em esfera de aço. Caracteres em relevo são utilizados para informar o nome da estação. O mapa contém uma referência ao posicionamento do usuário ("você está aquil"), indicado por meio de uma esfera em aço.
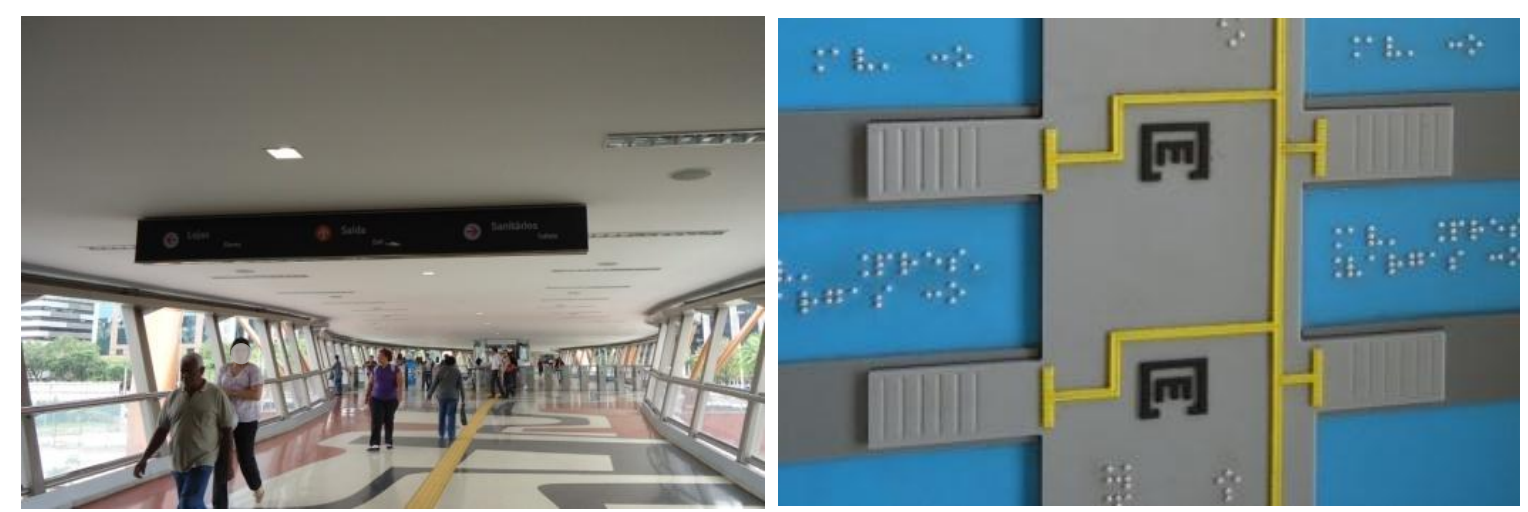

Figura 127 - Rio de Janeiro - Configuração dos acessos e detalhe do mapa tátil da estação. Fonte: BARBOSA, M.B., 2011.

\subsubsection{Requisitos Normativos}

Com relação aos requisitos normativos, a ABNT NBR 15.599:2008 estabelece a necessidade de existência de mapas táteis nos acessos, contendo a descrição do espaço utilizado pelo público e de sinalização tátil orientando a circulação de embarque. A ABNT NBR 14.021:2005 estabelece a necessidade de pelo menos uma entrada acessível e a existência de sinalização visual e tátil no lado externo de todos os acessos, contendo:

a) nome da estação e da(s) linha(s) a que pertence;

b) horário de funcionamento da estação e do acesso;

c) identificação do acesso, através de número, letra ou nome;

d) existência de equipamento intercomunicador nos pavimentos atendidos pelo elevador, possibilitando a solicitação de auxílio pelo usuário. 


\subsubsection{Situação no Metrô de São Paulo}

No Metrô de São Paulo, devido à diversidade de configuração das estações, esta etapa apresenta-se de diferentes maneiras: as áreas de acomodação e os elementos de circulação podem estar inseridos em edificações posicionadas no alinhamento dos lotes ou mesmo localizados em calçadas ou praças. Os acessos são identificados com prismas e testeiras que indicam as linhas às quais pertence a estação, o horário de funcionamento e a condição de normalidade ou anormalidade da operação (Figuras 128 e 129).
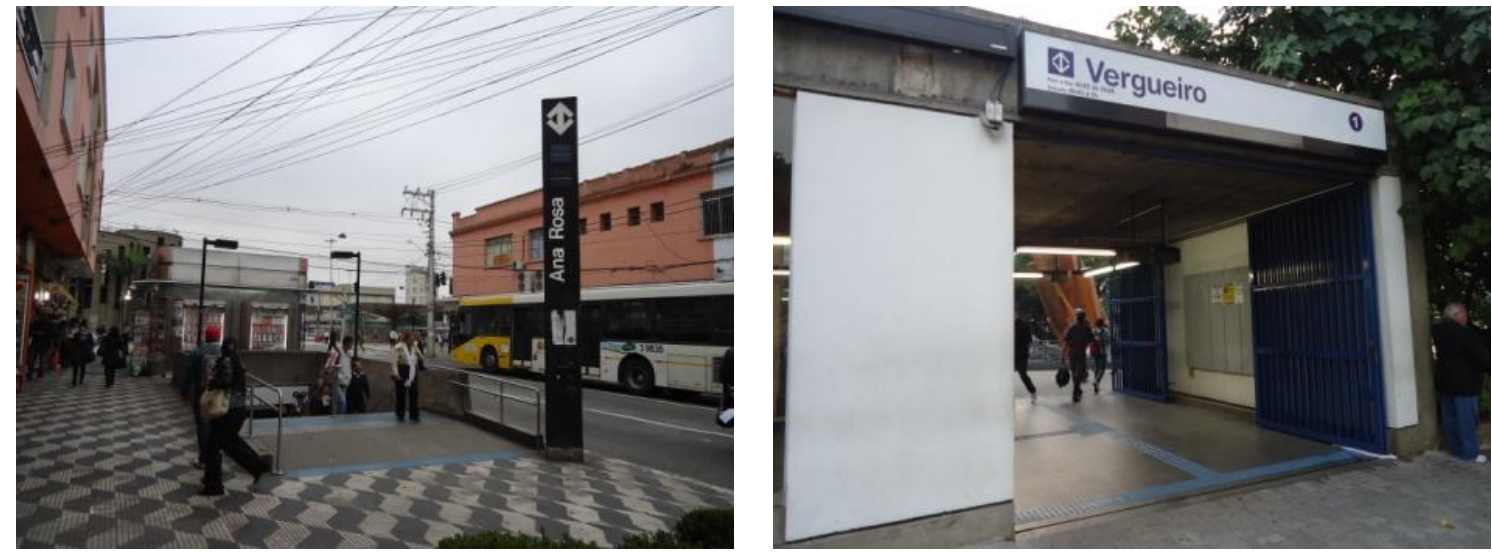

Figura 128 - São Paulo - Acessos das estações localizados no passeio público e no alinhamento do lote. Fonte: BARBOSA, M.B., 2011.
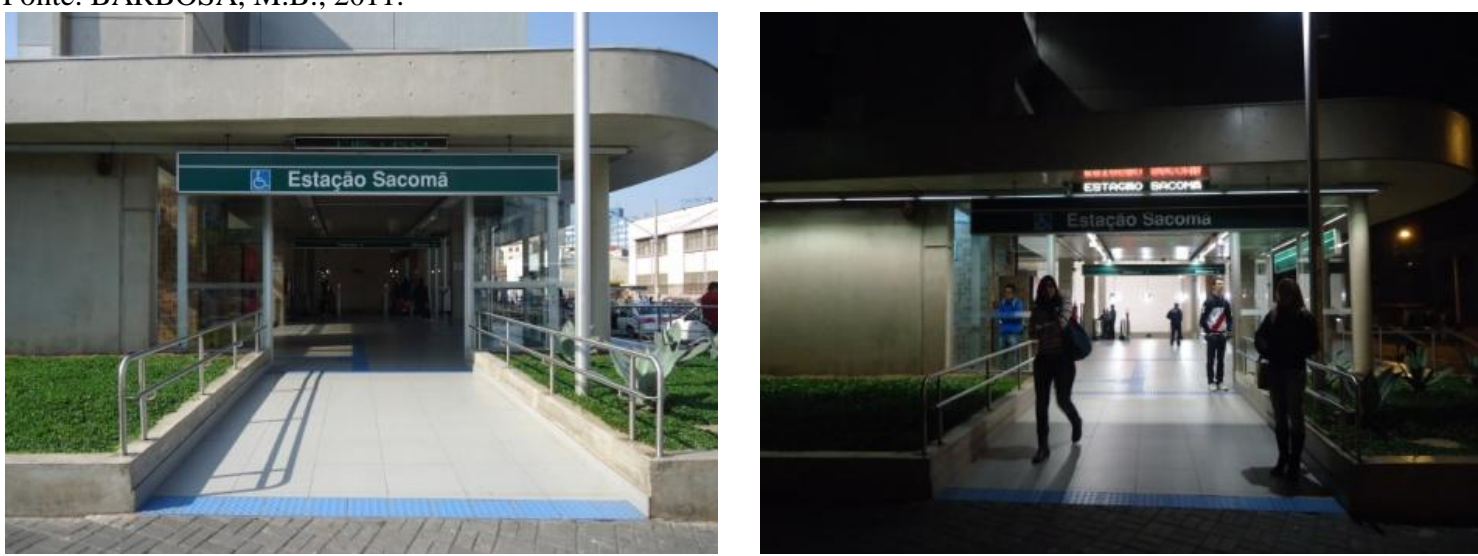

Figura 129 - São Paulo - Vista geral do acesso nos períodos diurno e noturno. Fonte: BARBOSA, M.B., 2011.

\subsubsection{Avaliação pelos usuários}

Na etapa de acesso à estação, oito usuários com deficiência visual - dos quais seis pessoas são cegas e duas pessoas têm baixa visão - manifestaram seu descontentamento em relação à estação (100\%). Foram registrados 13 relatos, o que representa $0,5 \%$ do total de relatos registrados para todas as etapas da jornada do usuário. Os relatos estão relacionados, em sua maioria, à disponibilidade de informações nas estações $(76,9 \%)$, mas também são dirigidos à 
configuração da estação para facilitar o desembarque do usuário do sistema integrado $(15,4 \%)$ e aos serviços prestados $(7,7 \%)$.

\begin{abstract}
"Em algumas estações fica difícil para eu entrar porque não tem piso tátil que leve da rua para as escadas da entrada. Tem estação próxima de shopping que não tem piso tátil que leve para a escada do metrô e também não tem linha guia que leve da calçada até a escada rolante. Facilitaria também se na entrada da estação tivesse intercomunicador para eu chamar um empregado para me auxiliar - porque os empregados ficam no bloqueio. Sinto dificuldade em estações que não tem acesso nos dois lados da rua, porque o empregado não pode me ajudar a atravessar a avenida. Tem algumas situações que tornam o meu deslocamento mais complicado, por exemplo, na época do Natal, colocam vasos e árvores de natal no meio do caminho e eu não consigo me orientar, necessitando, portanto, do auxílio de algum usuário. E ainda têm as pessoas que colocam malas, mochilas e sacolas no piso tátil.” (Discurso do Sujeito Coletivo - Etapa 3)
\end{abstract}

Os principais problemas relatados pelos usuários na etapa de acesso à estação estão relacionados às seguintes ideias centrais:

a) piso tátil - percurso (EI3) - falta de piso tátil no deslocamento para as escadas fixas e rolantes ou para os serviços disponibilizados nas estações;

b) condições das instalações existentes (EC3) - inexistência de acesso em ambos os lados de avenidas movimentadas e a localização do mobiliário ou dos equipamentos existentes nos percursos;

c) informações para a pessoa com deficiência visual - estação (EI6) - falta de intercomunicador na estação, dificultando a solicitação de auxílio quando da chegada à estação;

d) comportamento dos demais usuários - estação (ES4) - mau comportamento dos demais usuários nas estações, dificultando o deslocamento nos acessos.

\title{
7.3.6 Avaliação pelas pessoas-chave
}

Os empregados das estações relataram como fator negativo das condições das instalações existentes (EC3) o dimensionamento dos corredores de acesso e das áreas de conexão entre linhas, fato que impacta o deslocamento com independência das pessoas com deficiência visual nos horários de maior movimento em função do fluxo intenso de usuários (Figura 130). 

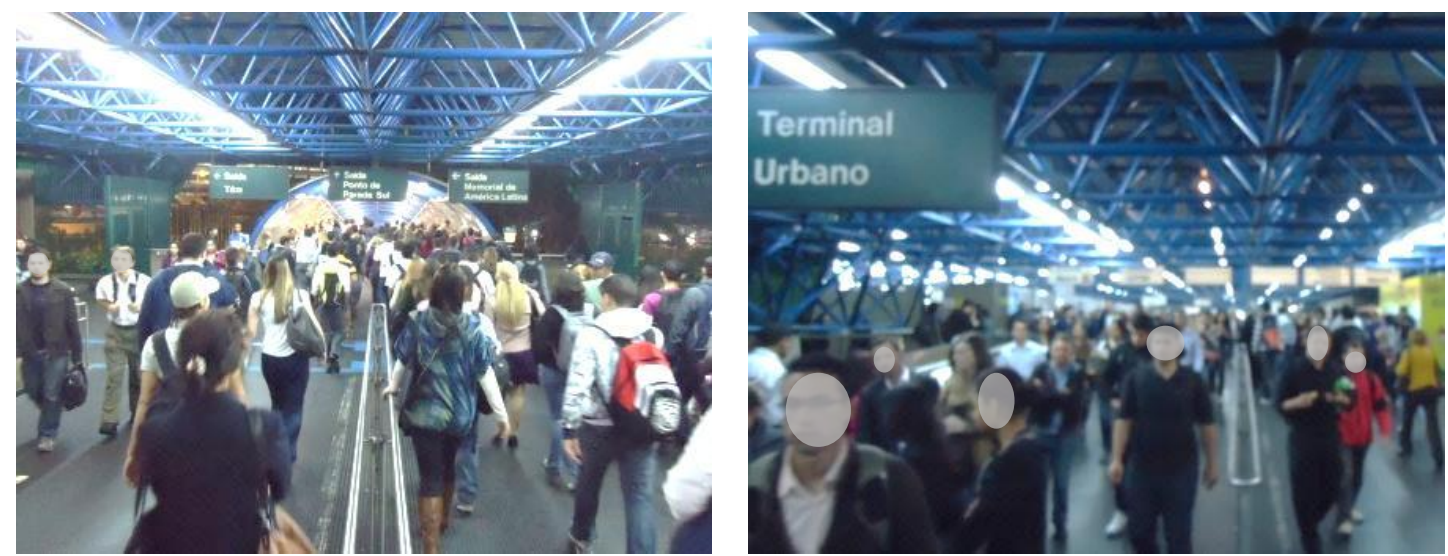

Figura 130 - São Paulo - Dimensionamento dos corredores de acesso. Fonte: BARBOSA, M.B., 2011.

Em relação à configuração dos acessos, destaca-se como fator negativo das condições das instalações existentes (EC3) a inexistência de rampas ou elevadores em todos os acessos notadamente nas estações mais antigas - ou a dificuldade de localização dos elevadores devido ao seu posicionamento em relação às escadas fixas e rolantes, prejudicando a compreensão dos percursos (Figura 131).
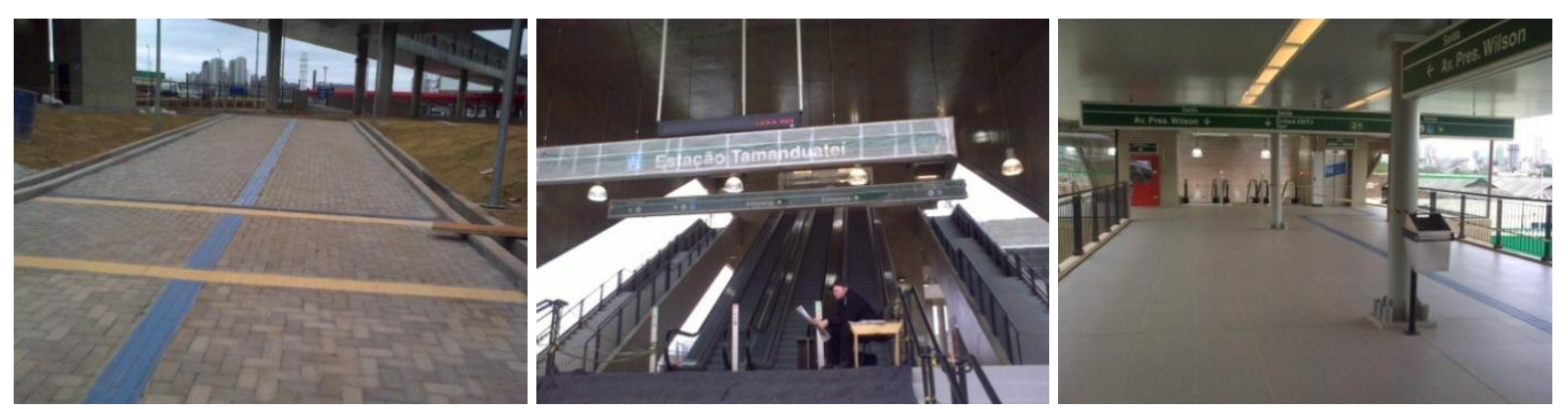

Figura 131 - São Paulo - Localização e percurso para os elevadores. Fonte: BARBOSA, M.B., 2011.

Os estagiários relataram a dificuldade de auxiliar pessoas com deficiência junto aos acessos da estação em função da lotação das estações (ES7) e do comportamento dos demais usuários - estação (ES4), que ora estão parados, ora estão desatentos, ora não respeitam o deslocamento preferencial da pessoa com deficiência visual e do estagiário, obrigando-os a desviarem seu caminho em todas essas situações.

Nos programas de capacitação, os professores de orientação e mobilidade sugerem que, na ausência dos empregados ou estagiários no momento da chegada à estação, as pessoas com deficiência visual solicitem auxílio caso não se sintam seguras para empreender seu percurso de embarque com independência. Em relação ao piso existente eles relataram dificuldades para identificar o piso tátil - contraste tátil e visual (EI1), notadamente nas estações que têm piso emborrachado, com pastilhas em relevo, devido à ausência de uma faixa de 
transição. Em relação ao piso tátil - percurso (EI3), há críticas ao dimensionamento insuficiente da sinalização tátil de alerta nas interseções entre pisos direcionais - o que dificulta a percepção das mudanças de direção - e ao fato de a sinalização não considerar ou coincidir com o percurso dos demais usuários - o que pode gerar eventuais conflitos de fluxo. A utilização de pisos diagonais ou em curvas pouco acentuadas pode resultar em maior funcionalidade do que percursos ortogonais; a eliminação de alguns pisos instalados nos acessos pode aumentar a legibilidade do espaço (Figuras 132 e 133). A compreensão do percurso realizado no mezanino pode ser ampliada com o auxílio de mapas táteis e descrições sonoras contendo as referências principais das estações, permitindo informações em igualdade de condições com os demais usuários.

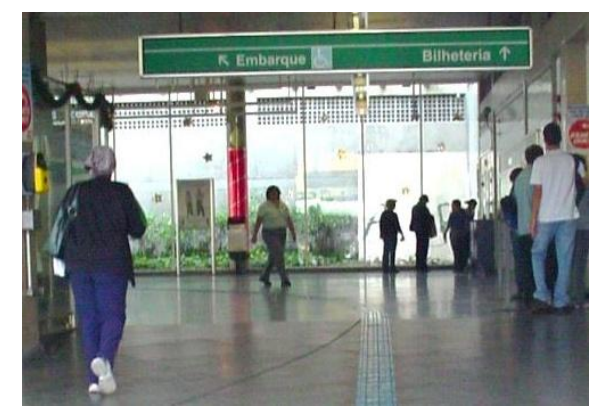

Figura 132 - São Paulo - Percurso em curvas em substituição aos percursos ortogonais.

Fonte: BARBOSA, M.B., 2011.

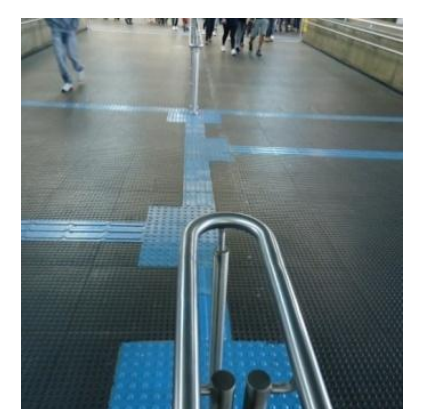

Figura 133 - São Paulo - Excesso de sinalização nos acessos. Fonte: BARBOSA, M.B., 2011.

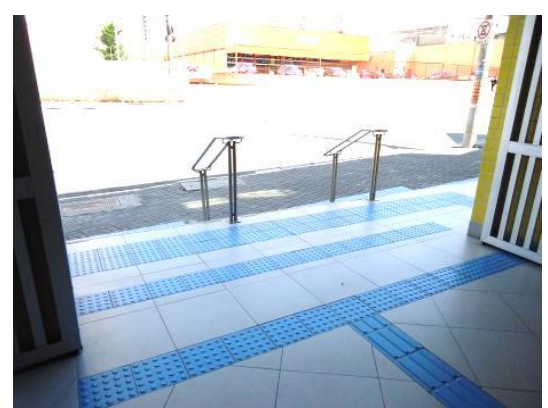

\subsubsection{Avaliação pelos especialistas}

Os profissionais responsáveis pelos projetos das estações relataram que o direcionamento de fluxo no acesso às estações é feito exclusivamente por meio do piso tátil - percurso (EI3) uma vez que não são utilizados elementos de acabamento ou materiais de revestimento diferenciados - que reverberem mais ou que sejam mais absorventes - seja em paredes, piso ou forros, para auxiliar os deslocamentos.

Os profissionais responsáveis pela elaboração de normas técnicas relataram que as normas de acessibilidade contribuem para prover segurança, autonomia e agilidade nos deslocamentos por meio de soluções padronizadas relacionadas à configuração, sinalização e iluminação dos ambientes característicos do sistema metroferroviário. Entre as soluções que podem contribuir para a segurança e independência dos usuários nos deslocamentos, em função das condições das instalações existentes (EC3), estão as recomendações para melhoria dos textos normativos vigentes, destacando o estabelecimento de condições adequadas para execução de 
obras e serviços, garantindo uma rota acessível para embarque e a existência de contraste entre pisos, paredes, portas, corrimãos e painéis de informação da estação. As informações para a pessoa com deficiência visual - estação (EI6) devem ser claras, objetivas e completas, além de redundantes, para que as orientações operacionais e institucionais sobre os serviços ofertados (comércio, exposições, espaços institucionais) possam contribuir para que os usuários alcancem seus destinos com segurança.

\subsubsection{Elementos de wayfinding}

Os dados coletados permitem afirmar que o elemento característico de wayfinding desta etapa é o caminho (Quadro 26). O acesso da estação deve ser provido de sinalização tátil, visual e sonora, específica e característica, de forma a auxiliar sua identificação por pessoas com deficiência visual e sobressair-se em relação aos demais elementos e informações do ambiente para facilitar a percepção e a compreensão dos percursos desde o acesso da estação até os elementos de circulação vertical.

Quadro 26 - Elemento de wayfinding da Etapa 3 - Acesso à estação.

\begin{tabular}{c|c|c|c}
\hline $\begin{array}{c}\text { Elementos de } \\
\text { wayfinding }\end{array}$ & Configuração & Informação & Serviço \\
\hline Caminho & $\begin{array}{l}\text { - percurso entre o acesso } \\
\text { da estação e os } \\
\text { elementos de circulação } \\
\text { vertical }\end{array}$ & $\begin{array}{l}\text { - sinalização tátil/visual/ } \\
\text { sonora sobre a } \\
\text { configuração do } \\
\text { percurso }\end{array}$ & $\begin{array}{l}\text { - treinamento dos } \\
\text { usuários } \\
\text { - auxílio no deslocamento }\end{array}$ \\
\hline
\end{tabular}

Fonte: Elaborado pela pesquisadora.

\subsubsection{Síntese do diagnóstico}

Na etapa 3 - Acesso à estação -, foram identificados aspectos que devem ser tratados pelas empresas operadoras dos sistemas metroferroviários para auxiliar pessoas com deficiência visual a estabelecer estratégias para empreender seus deslocamentos, descritos a seguir:

a) condições das instalações existentes (EC3) - prever acessos em ambos os lados de avenidas movimentadas; remanejar mobiliário e equipamentos existentes próximos ao piso tátil; instalar rampas ou elevadores em todos os acessos; utilizar elementos de acabamento ou materiais de revestimento diferenciados - que reverberem mais ou que sejam mais absorventes em paredes, piso ou forros; instalar revestimento de cor contrastante com o piso, paredes, portas, corrimãos e painéis de informação da 
estação; estabelecer condições adequadas para garantir uma rota acessível durante a execução de obras e serviços para embarque;

b) contraste tátil e visual do piso tátil (EI1) - melhorar o contraste tátil entre a sinalização tátil e o piso emborrachado utilizado no revestimento das estações;

c) piso tátil - percurso (EI3) - orientar o deslocamento para as escadas fixas e rolantes e para os serviços disponibilizados nas estações; redimensionar a sinalização de alerta nas interseções entre pisos direcionais; considerar, sempre que possível, igualdade com o percurso dos demais usuários; instalar pisos diagonais ou em curvas pouco acentuadas para aumentar a funcionalidade dos percursos; eliminar excesso de pisos táteis instalados nos acessos para aumentar a legibilidade;

d) informações para a pessoa com deficiência visual - estação (EI6) - instalar intercomunicador no acesso para facilitar a solicitação de auxílio; instalar informações institucionais e orientações operacionais claras, objetivas, completas e redundantes sobre os serviços ofertados;

e) comportamento dos demais usuários - estação (ES4) - promover campanhas para orientar o comportamento dos demais usuários nas estações para prestarem atenção e respeitarem o deslocamento preferencial de pessoas com deficiência visual e seus acompanhantes e para facilitar o deslocamento nos acessos;

f) lotação das estações (ES7) - organizar o fluxo de usuários nos corredores, facilitando o deslocamento independente de pessoas com deficiência visual nos horários de maior movimento.

\subsection{Etapa 4 - Circulação vertical entre o acesso e o mezanino}

Nesta etapa, o usuário utiliza os elementos de circulação vertical para dirigir-se ao mezanino. Entre os elementos de circulação vertical disponibilizados, destacam-se as rampas, as escadas fixas, as escadas rolantes, as plataformas de elevação inclinada e os elevadores.

\subsubsection{Métodos e técnicas aplicados}

Os métodos e técnicas utilizados para coleta de dados nesta etapa foram apresentados no item 6.10 - Síntese dos instrumentos aplicados - e consistiram em:

a) melhores práticas identificadas em outros sistemas metroferroviários; 
b) pesquisa documental (normas técnicas ABNT vigentes, desenhos, procedimentos operacionais);

c) checklist dos recursos disponíveis e walkthrough realizado nas estações para compreensão do percurso de embarque;

d) ficha ambiente das escadas rolantes, elevadores e plataformas de elevação;

e) questionário aplicado às pessoas com deficiência visual - questões 12, 13 e 17;

f) entrevista com empregados das estações;

g) entrevista com estagiários que auxiliam pessoas com deficiência visual;

h) entrevista com professores de orientação e mobilidade;

i) entrevista com profissionais responsáveis pelo treinamento dos empregados;

j) entrevista com profissionais responsáveis pelos projetos das estações;

k) entrevista com profissionais responsáveis pela elaboração de normas técnicas.

As formas de análise e interpretação dos dados coletados foram apresentadas no Capítulo 6 Aplicação dos instrumentos.

\subsubsection{Melhores Práticas}

Devem ser consideradas as melhores práticas apresentadas no item 7.25.2.

\subsubsection{Requisitos Normativos}

Devem ser considerados os requisitos normativos apresentados no item 7.25.3.

\subsubsection{Avaliação pelos usuários}

Na etapa de circulação vertical entre o acesso e o mezanino, dois usuários cegos manifestaram seu descontentamento em relação à configuração da estação (100\%). Foram registrados quatro relatos, o que representa $0,1 \%$ do total de relatos registrados para todas as etapas da jornada do usuário.

"Eu percebo que nas estações mais antigas, por exemplo, na Linha Norte-Sul, não houve a preocupação com os deficientes visuais: sinto falta de elevadores e escadas rolantes até a rua. Eles melhoraram alguma coisa, mas não é como as estações da Paulista, com elevadores que vão até a rua..." (Discurso do Sujeito Coletivo - Etapa 4) 
Os problemas relatados pelos usuários estão relacionados às seguintes ideias centrais:

a) instalação de elementos de circulação vertical (EC2) - falta de elevadores, escadas rolantes ou rampas em todos os acessos de todas as estações;

b) condições das instalações existentes (EC3) - existência de problemas na configuração dos acessos das estações, inviabilizando a instalação de equipamentos de circulação vertical.

\subsubsection{Avaliação pelas pessoas-chave}

Os empregados das estações relataram como fator negativo das condições das instalações existentes (EC3) a inexistência de escadas rolantes e elevadores em todos os acessos, especialmente nas estações antigas (Figura 134).
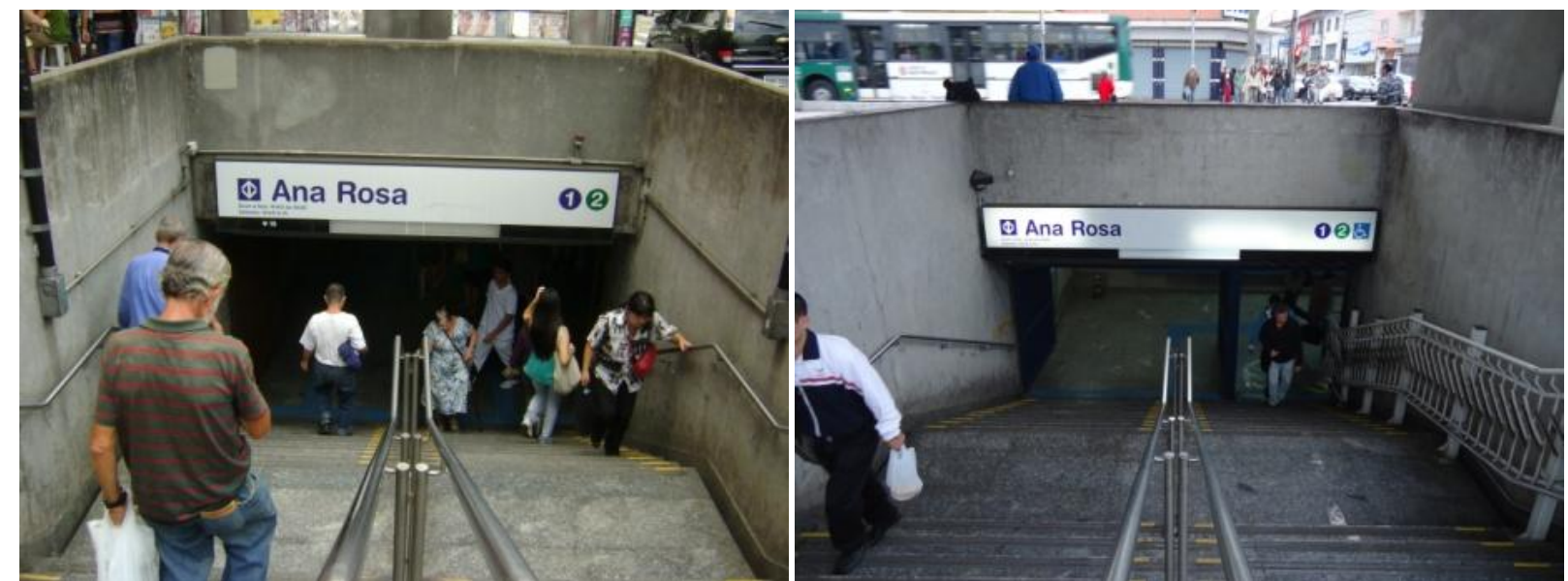

Figura 134 - São Paulo - Escadas fixas como único recurso de circulação vertical no acesso. Fonte: BARBOSA, M.B., 2011.

\subsubsection{Avaliação pelos especialistas}

Os profissionais responsáveis pelos projetos das estações relataram que a existência de piso tátil - percurso (EI3) somente junto aos elevadores dificulta a percepção da escala e dos referenciais da estação. Quando os deslocamentos se dão por meio de escadas fixas ou rolantes, permitem ao usuário seguir os referenciais do ambiente e compreender a continuidade do percurso entre a plataforma e o mezanino.

\subsubsection{Elementos de wayfinding}

Devem ser considerados os elementos de wayfinding mencionados no item 7.25.8. 


\subsubsection{Síntese do diagnóstico}

Na etapa 4 - Circulação vertical entre o acesso e o mezanino -, foram identificados aspectos que devem ser tratados pelas empresas operadoras dos sistemas metroferroviários para auxiliar pessoas com deficiência visual a estabelecerem estratégias para empreender seus deslocamentos, especificados a seguir:

a) instalação de elementos de circulação vertical (EC2) - instalar elevadores, escadas rolantes ou rampas em todos os acessos de todas as estações, especialmente nas estações antigas;

b) condições das instalações existentes (EC3) - viabilizar a instalação de equipamentos de circulação vertical;

c) piso tátil - percurso (EI3) - orientar os deslocamentos simultaneamente por meio dos elevadores e das escadas para que as pessoas com deficiência visual não percam a escala do espaço e a percepção dos referenciais da continuidade do percurso entre os diferentes ambientes;

d) treinamento dos empregados - estação (ES1) - capacitar os empregados para que tenham desenvoltura ao oferecer ajuda para condução individual ou em grupo em planos horizontais, rampas, escadas rolantes, escadas fixas e elevadores.

\subsection{Etapa 5 - Deslocamento no mezanino - área livre}

Esta etapa consiste no deslocamento do usuário entre os equipamentos de circulação vertical e as bilheterias, ou diretamente para os elementos de controle de acesso.

\subsubsection{Métodos e técnicas aplicados}

Os métodos e técnicas utilizados para coleta de dados nesta etapa foram apresentados no item 6.10 - Síntese dos instrumentos aplicados - e consistiram em:

a) melhores práticas identificadas em outros sistemas metroferroviários;

b) pesquisa documental (normas técnicas $\mathrm{ABNT}$ vigentes, desenhos, procedimentos operacionais);

c) checklist dos recursos disponíveis e walkthrough realizado nas estações para compreensão do percurso de embarque;

d) questionário aplicado em pessoas com deficiência visual - questões 12, 13 e 17; 
e) entrevista com empregados das estações;

f) entrevista com profissionais responsáveis pelo treinamento dos empregados;

g) entrevista com estagiários que auxiliam pessoas com deficiência visual;

h) entrevista com professores de orientação e mobilidade;

i) entrevista com profissionais responsáveis pelos projetos das estações;

j) entrevista com profissionais responsáveis pela elaboração de normas técnicas.

As formas de análise e interpretação dos dados coletados foram apresentadas no Capítulo 6 Aplicação dos instrumentos.

\subsubsection{Melhores Práticas}

Entre as melhores práticas, destacam-se as estações de trem operadas pela SNCF, em Paris, dispõem de sinalização tátil no piso, complementada por sinalização sonora veiculada a partir de antenas que funcionam como balizas e emitem informações diretamente para dispositivos utilizados pelos usuários com deficiência visual, de acordo com seus deslocamentos. Junto à sinalização tátil no piso foram colocados adesivos orientando os demais usuários quanto à sua finalidade (Figuras 137 a 137).
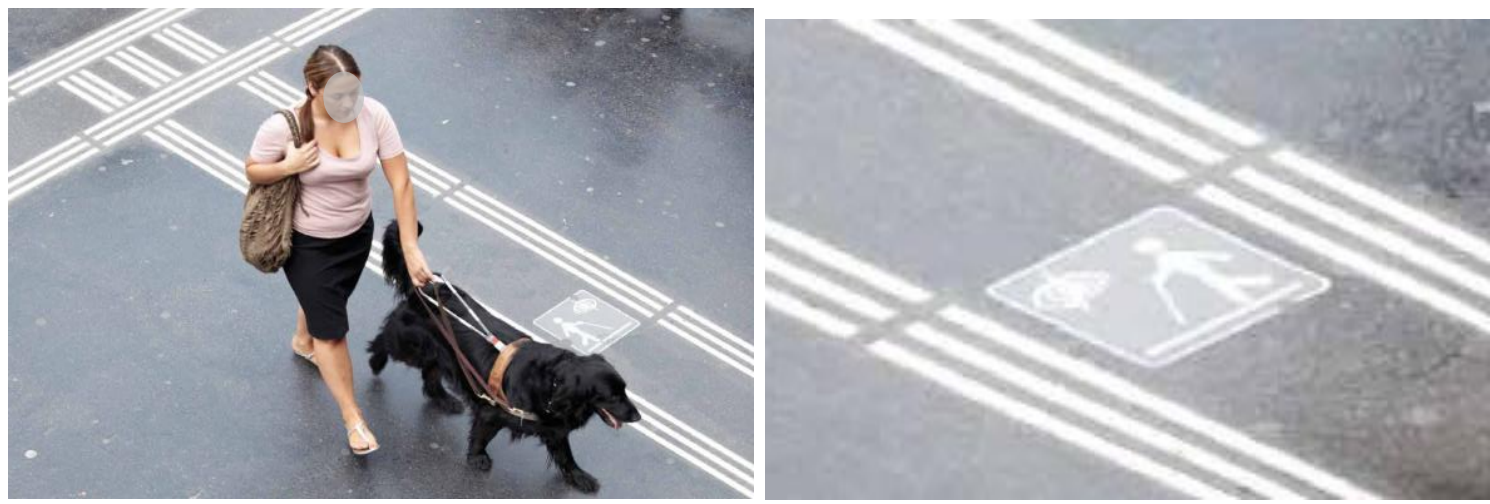

Figura 135 - Paris - Sinalização tátil complementada por sinalização visual indicativa da sua finalidade Fonte: SNCF, 2011, p. 56. 


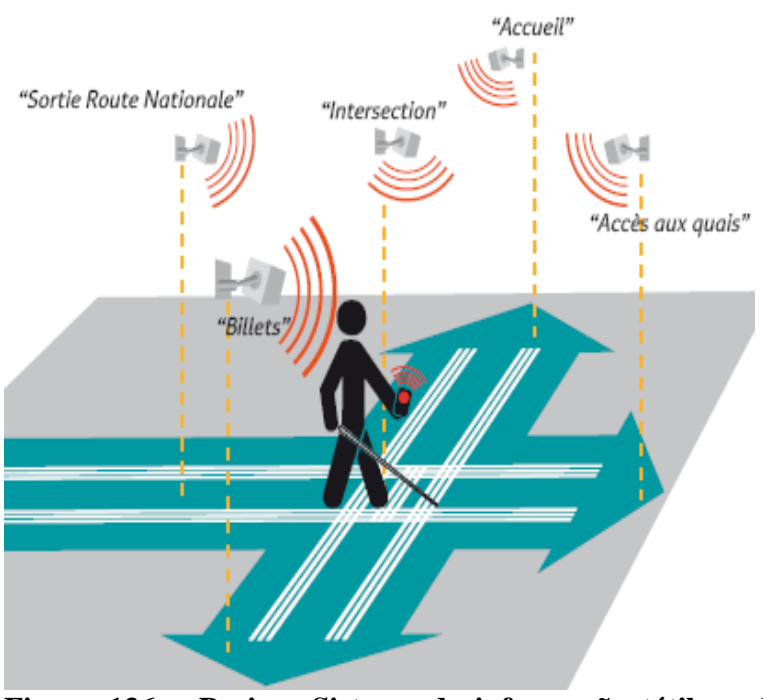

Figura 136 - Paris - Sistema de informação tátil e sonora dos percursos.

Fonte: SNCF, 2011,p. 65.

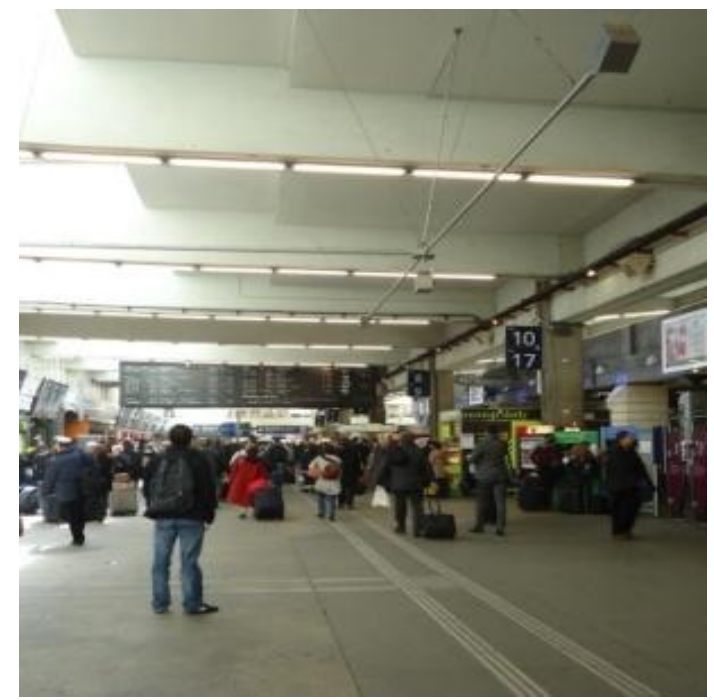

Figura 137 - Paris - Sinalização tátil associada à informação sonora.

Fonte: BARBOSA, M.B., 2013.

O Metrô de Madri tem como requisitos de projeto a existência de contraste visual entre superfícies - pisos, fechamentos laterais, mobiliário, corrimãos, placas de informação e equipamentos - para facilitar a legibilidade e a compreensão dos ambientes e a existência de piso tátil direcional para orientar deslocamentos (Figura 138).

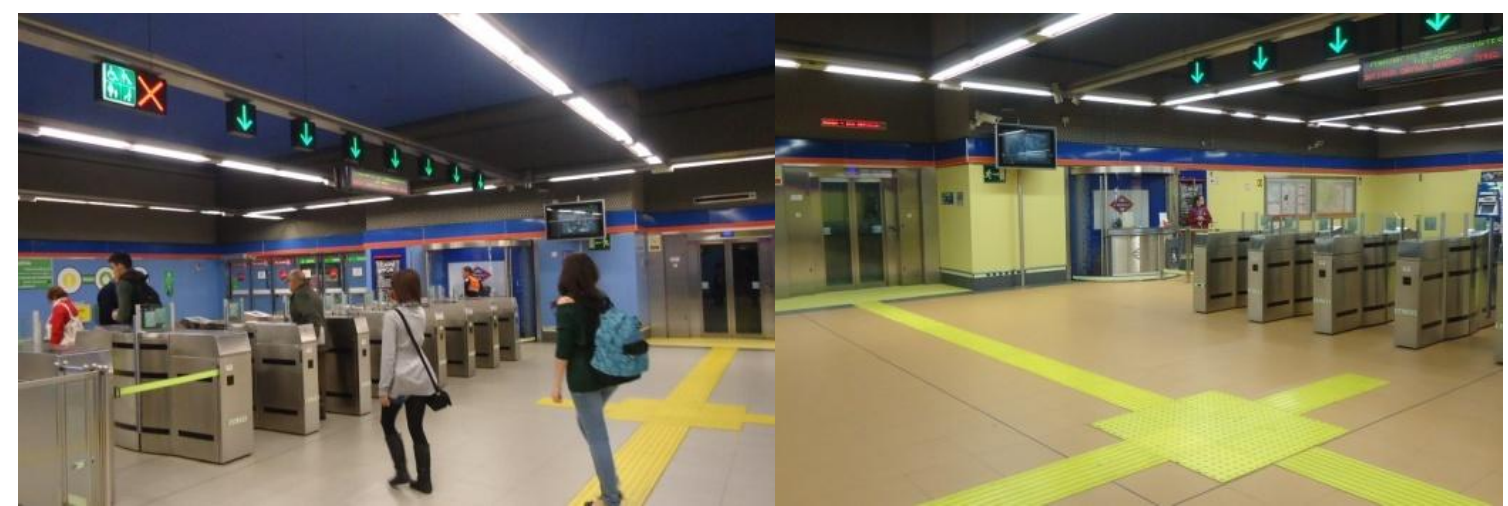

Figura 138 - Madri - Contraste dos elementos de acabamento e sinalização tátil do percurso. Fonte: BARBOSA, M.B., 2013.

O Metrô do Rio de Janeiro dispõe de mapas e pisos táteis que informam os percursos entre os acessos e as áreas de interesse (Figura 139). 

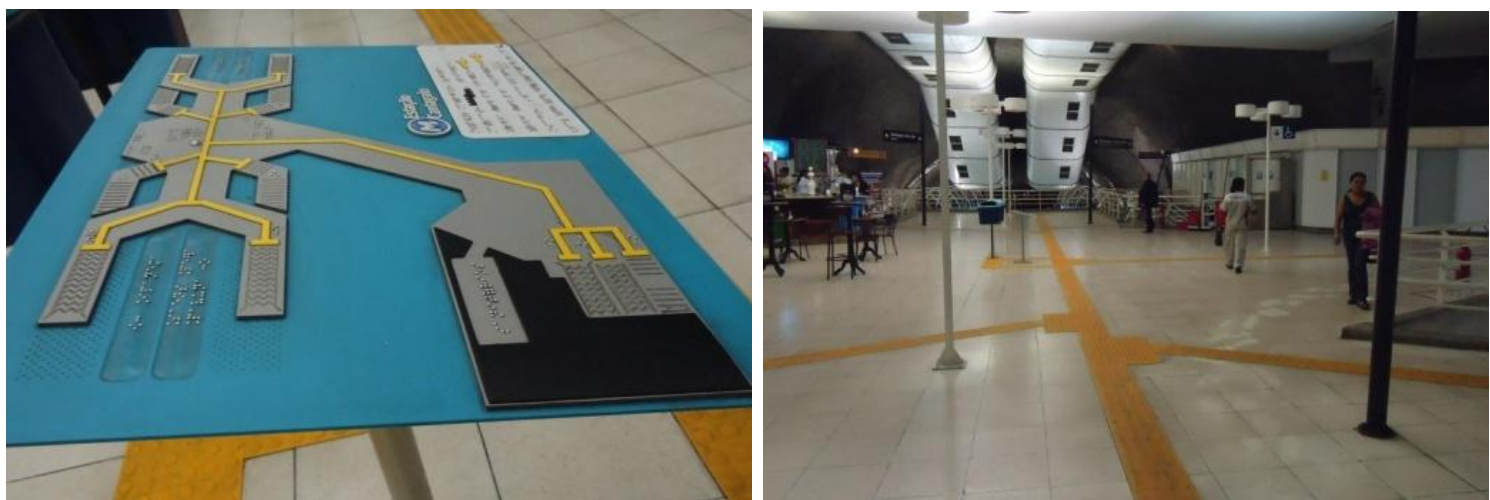

Figura 139 - Rio de Janeiro - Mapa e sinalização tátil direcional no piso indicando diferentes percursos. Fonte: BARBOSA, M.B., 2011.

\subsubsection{Requisitos Normativos}

Com relação aos requisitos normativos, a ABNT NBR 14.021:2005 determina a existência de rota acessível entre os acessos e os equipamentos de controle de acesso, bilheterias e equipamentos de autoatendimento, salas com acesso de público e elementos de circulação vertical. A sinalização de circulação de embarque deve utilizar a palavra “embarque”. Não há recomendação para instalação de piso tátil direcional para orientar percursos.

\subsubsection{Situação do Metrô de São Paulo}

No Metrô de São Paulo, os percursos entre todos os acessos e o mezanino dispõem de piso tátil direcional posicionado no eixo das áreas de circulação como parte integrante da rota acessível, fato que permite o fluxo bidirecional para embarque ou saída das pessoas com deficiência visual durante seus deslocamentos (Figura 140). As interseções entre os diferentes percursos são sinalizadas com piso tátil de alerta. Não existem mapas táteis orientando a localização de pontos de interesse (bilheterias, bloqueios, serviços complementares). 

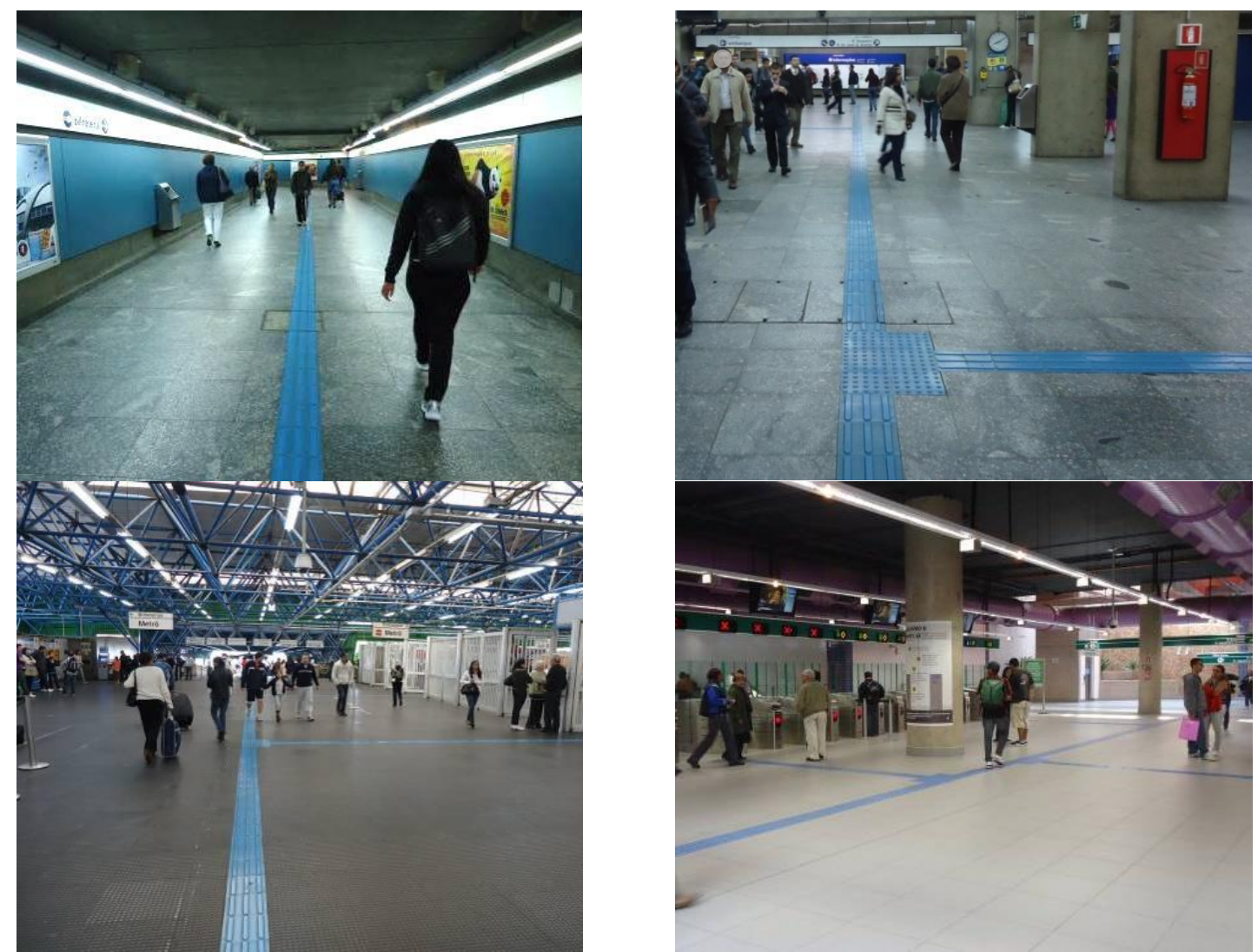

Figura 140 - São Paulo - Áreas de circulação no mezanino - área livre. Fonte: BARBOSA, M.B., 2011.

\subsubsection{Avaliação pelos usuários}

Na etapa de deslocamento no mezanino - área livre, 58 usuários com deficiência visual - dos quais 40 pessoas são cegas e 18 pessoas têm baixa visão - manifestaram seu descontentamento em relação à estação $(100,0 \%)$. Foram registrados 104 relatos, o que representa 3,9\% do total de relatos registrados para todas as etapas da jornada do usuário. Os relatos estão relacionados, em sua maioria, à disponibilidade de informações nas estações $(82,7 \%)$ e também à configuração da estação para facilitar o deslocamento no mezanino $(9,6 \%)$ e aos serviços prestados $(7,7 \%)$ - (Tabela 20$)$. 
Tabela 20 - Matriz de avaliação da etapa 5 - Deslocamento no mezanino - área livre.

(\% em relação ao total de relatos registrados nesta etapa)

\begin{tabular}{l|r|r|r|r}
\hline & \multicolumn{2}{|c|}{$\begin{array}{c}\text { Configuração } \\
\text { \% }\end{array}$} & $\begin{array}{c}\text { Informação } \\
\text { \% }\end{array}$ & \multicolumn{2}{c|}{$\begin{array}{c}\text { Serviço } \\
\text { Total } \\
\%\end{array}$} \\
\hline Estação & (EC) $\mathbf{9 , 6}$ & (EI) 82,7 & (ES) $\mathbf{7 , 7}$ & $\mathbf{1 0 0 , 0}$ \\
\hline Interface Trem-Estação & $\mathbf{0 , 0}$ & $\mathbf{0 , 0}$ & $\mathbf{0 , 0}$ & $\mathbf{0 , 0}$ \\
\hline Trem & $\mathbf{0 , 0}$ & $\mathbf{0 , 0}$ & $\mathbf{0 , 0}$ & $\mathbf{0 , 0}$ \\
\hline Total & $\mathbf{9 , 6}$ & $\mathbf{8 2 , 7}$ & $\mathbf{7 , 7}$ & $\mathbf{1 0 0 , 0}$ \\
\hline
\end{tabular}

"Eu sinto dificuldade para chegar até o bloqueio porque algumas estações não têm piso tátil desde a rua até o bloqueio. Muitas vezes as estações são acessíveis para sair, mas não para entrar porque não tem demarcações nos bloqueios... Precisa ter empregados na parte externa do bloqueio para me auxiliar no embarque. Isso faz diferença para mim. Para mim também não fica claro, na entrada, para onde está indo o piso tátil, não tem nenhuma informação se existe uma encruzilhada ou se existem várias faixas guias saindo do mesmo lugar. Para mim, ficaria mais fácil se nas encruzilhadas tivessem algo suspenso, com indicações em braile ou alto relevo. Acho que deveriam colocar o básico: piso tátil indo para a escada fixa ou rolante e para o bloqueio... Eu acho fundamental o piso tátil levar para as escadas rolantes... O piso tátil também não me ajuda diferenciar as operadoras, se está indo para uma ou para outra... Se o piso tátil ficasse na lateral e tivesse mão e contramão - em vez de ficar no meio do corredor -, eu poderia me apoiar na parede e não trombar com outro deficiente... Em muitas estações, o piso tátil faz com que eu trombe com outros usuários nos bloqueios e bilheterias. Tem estação onde os dois pisos táteis que vêm da rua terminam no centro do fluxo, nos bloqueios de saída e não no bloqueio de entrada. Outras coisas que me atrapalham muito: colocar os direcionadores de fila em cima do piso tátil; deixar a fila dos bloqueios, das maquininhas de bilhetes ou de livros em cima do piso tátil. Nas estações que são muito grandes, por ter muita gente, eu fico atrapalhado ao usar o piso tátil... Em algumas estações os pisos táteis deveriam estar afastados de obstáculos como colunas. Tem estações que o bloqueio está bem próximo da coluna; e eu preciso de alguma indicação quando este tipo de coisa acontece... Por isso eu acho que deveriam ter consultado os deficientes visuais antes de definir o local para colocar o piso tátil, onde sinalizar os desvios ou fazer a marcação dos destinos... Para mim, não adianta ter piso tátil se não sei para onde ele está me levando. Sei que existem tecnologias - que não são caras - que poderiam ser colocadas no piso tátil para que eu pudesse acessar o celular e saber qual o trajeto que preciso fazer para chegar ao meu destino. Para minha orientação seria muito útil ter sinalização sonora ou mapa tátil sobre o percurso... Poderia ter, por exemplo, um mural em Braille ou um mapa da estação para eu poder circular dentro da estação..." (Discurso do Sujeito Coletivo - Etapa 5)

Os principais problemas relatados pelos usuários na etapa de deslocamento no mezanino área livre - são apresentados de forma hierarquizada conforme número de relatos registrados (Gráfico 26). 
Gráfico 26 - Avaliação da etapa 5 - Deslocamento no mezanino - área livre.

(\% em relação ao total de relatos registrados nesta etapa)

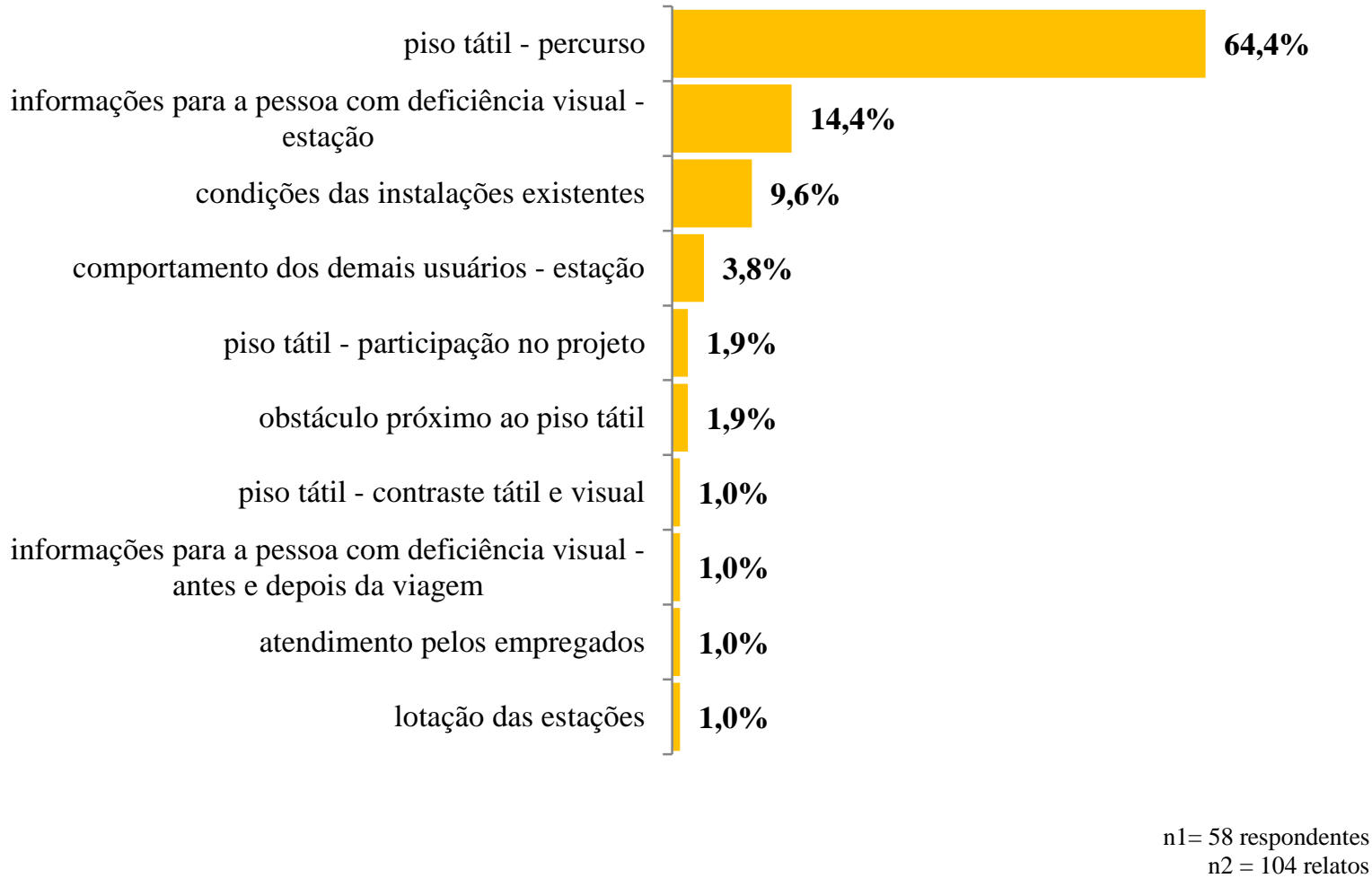

Os problemas relatados estão relacionados às seguintes ideias centrais:

a) piso tátil - percurso (EI3) - não leva para todos os equipamentos e serviços oferecidos na estação, não considera e nem é igual ao fluxo dos demais usuários, não direciona para as escadas rolantes e muitas vezes acabar no corrimão central das rampas. Há dificuldade de compreensão do caminho, o piso tátil está próximo de obstáculos da edificação;

b) informações para a pessoa com deficiência visual - estação (EI6) -inexistência de informação tátil, visual ou sonora sobre a configuração e os percursos realizados na estação; dimensões inadequadas e falta de contraste das informações visuais;

c) condições das instalações existentes (EC3) - problemas no posicionamento do mobiliário ou localização dos equipamentos e falta de segurança no interior das estações;

d) comportamento dos demais usuários - estação (ES4) - mau comportamento ou comportamento indevido dos demais usuários na estação; 
e) piso tátil - participação no projeto (EI2) - descontentamento pelo fato de os usuários ficarem alheios às decisões que definiram as premissas para instalação do piso tátil nas estações;

f) obstáculo próximo ao piso tátil (ES5) - posicionamento inadequado dos direcionadores de fila próximo ou mesmo sobre o piso tátil pelos próprios empregados das estações;

g) piso tátil - contraste tátil e visual (EI1) - inexistência de piso tátil diferenciado para orientar a localização do embarque nas estações de conexão;

h) informações para a pessoa com deficiência visual antes ou depois da viagem (EI5) - falta de folhetos com orientações em Braille ou ausência de informação sonora para a pessoa com deficiência visual saber utilizar as estações;

i) atendimento pelos empregados (ES2) - inexistência de empregados ou estagiários posicionados antes dos bloqueios para auxiliar o embarque;

j) lotação das estações (ES7) - dificuldade de utilização do piso tátil em função da intensa circulação de usuários nas estações.

\subsubsection{Avaliação pelas pessoas-chave}

Os empregados das estações relataram como fator negativo das condições das instalações existentes (EC3) a distância entre os equipamentos de circulação vertical dos acessos rampas, escadas, elevadores - e os bloqueios, dificultando a compreensão do ambiente e do percurso por pessoas com deficiência visual, principalmente nos horários de maior movimento.

Os profissionais responsáveis pelo treinamento de empregados destacaram, entre os temas abordados no programa de capacitação e treinamento dos empregados - estação (ES1), a abordagem e a comunicação adequadas, o oferecimento de ajuda com técnicas apropriadas e as orientações para condução individual ou em grupo em planos horizontais, utilizando o piso tátil. Tais conteúdos permitem que os empregados tenham desenvoltura no momento do primeiro contato e durante todo o período de atendimento.

Apesar da realização de treinamento dos empregados - estação (ES1), os estagiários relataram a dificuldade de abordar, identificar-se e oferecer auxílio, com receio de que sua iniciativa possa ser mal recebida pela pessoa com deficiência visual quando de sua aproximação junto à linha de bloqueios. Há receio ainda de que a pessoa com deficiência 
visual possa chocar-se com um usuário andando em sentido contrário durante o auxílio, em função da lotação das estações (ES7) decorrente do deslocamento simultâneo de um grande número de pessoas para entrada e saída e do comportamento dos demais usuários - estação (ES4), que muitas vezes andam distraídos ou olhando para baixo e, em outras vezes, não respeitam o deslocamento preferencial da pessoa com deficiência visual e do estagiário, obrigando-os a desviarem seu caminho para não esbarrarem em alguém e, eventualmente, se machucarem.

Os professores de orientação e mobilidade relataram que a ausência de uma faixa de transição traz dificuldades para identificar o piso tátil - contraste tátil e visual (EI1) em relação ao piso existente, notadamente nas estações que têm piso emborrachado com pastilhas em relevo. Em relação ao piso tátil - percurso (EI3), há críticas ao dimensionamento insuficiente da sinalização tátil de alerta nas interseções entre pisos direcionais - o que dificulta a percepção quanto às mudanças de direção - e ao fato de a sinalização não considerar ou coincidir com o percurso dos demais usuários - o que pode gerar eventuais conflitos de fluxo. A utilização de pisos diagonais ou em curvas pouco acentuadas pode resultar maior funcionalidade do que a de percursos ortogonais (Figuras 141 e 142).
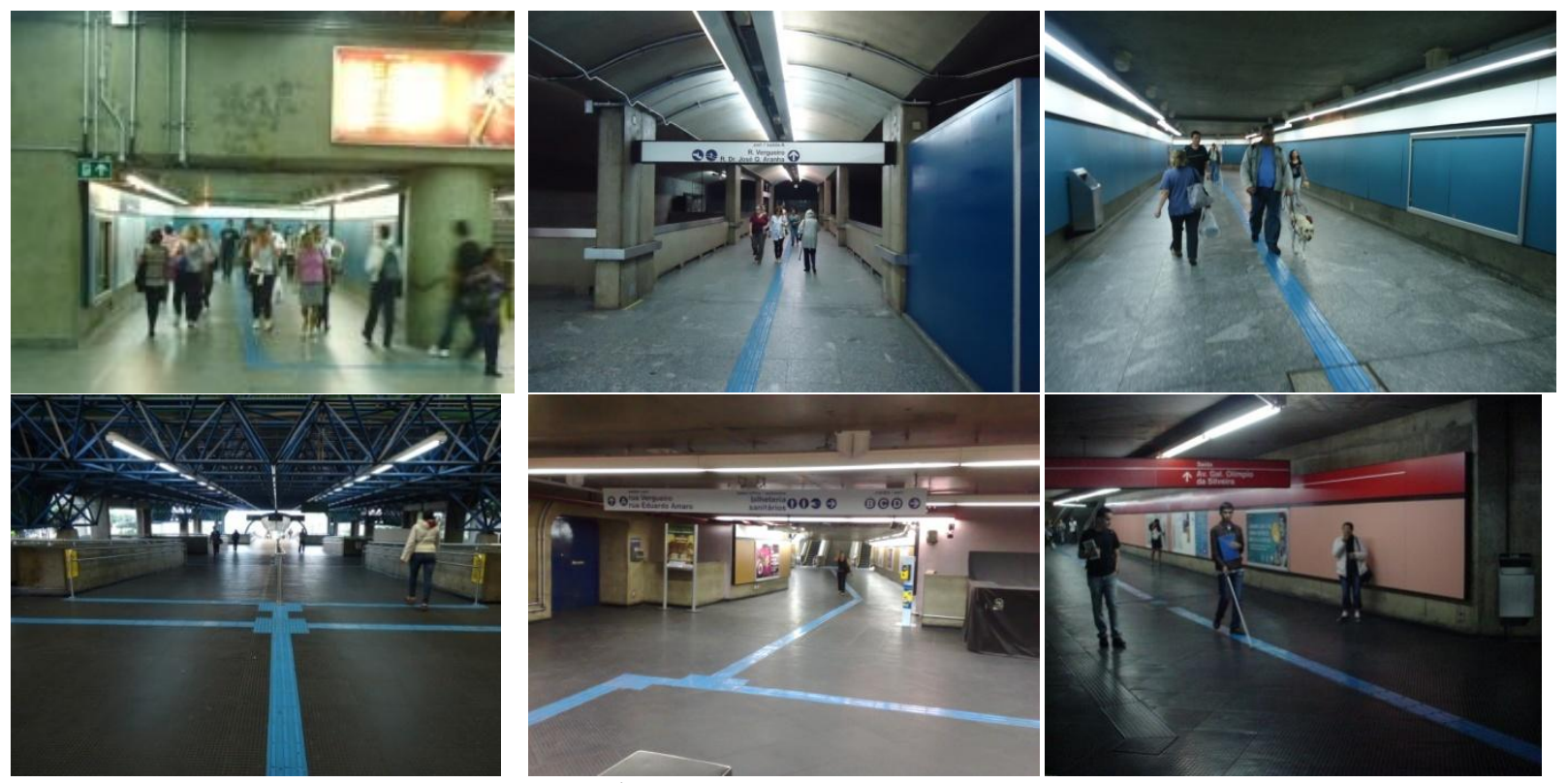

Figura 141 - São Paulo - Localização do piso tátil direcional no eixo dos corredores de acesso atende ao fluxo e ao contrafluxo.

Fonte: BARBOSA, M.B., 2011. 

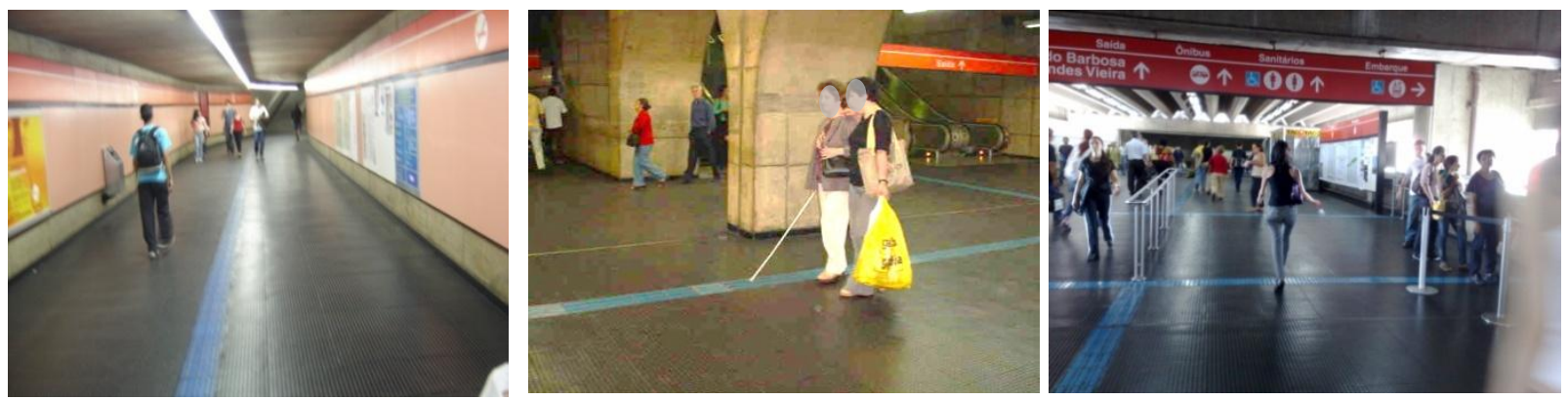

Figura 142 - São Paulo - Falta de contraste tátil em estações com piso emborrachado. Fonte: BARBOSA, M.B., 2011.

A compreensão do percurso realizado no mezanino pode ser ampliada com a instalação de informações para a pessoa com deficiência visual - estação (EI6), por meio de mapas táteis ou descrições sonoras contendo as referências principais das estações, permitindo informações em igualdade de condições com os demais usuários. Outro recurso, segundo os professores de orientação e mobilidade, é seguir o percurso do piso tátil durante a prestação de auxílio a pessoas com deficiência visual, fato que deve ser abordado no programa de capacitação e treinamento dos empregados - estação (ES1).

\subsubsection{Avaliação pelos especialistas}

Os profissionais responsáveis pelos projetos das estações destacaram as condições das instalações existentes (EC3), em especial as diferenças entre os ambientes resultantes dos projetos da primeira geração de estação - espaços segregados, iluminados artificialmente, contidos em fechamentos, com guardacorpo em concreto - e das estações recentemente construídas - espaços abertos e sobrepostos, com iluminação natural, amplos, com guardacorpo em vidro - notadamente com relação à percepção dos espaços. Quanto aos espaços de conexão entre diferentes modos de transporte, devem ser significativos e providos de ritos de passagem ou de transição, qualquer que seja a configuração da estação, facilitando a sua percepção e compreensão. Com relação às informações para a pessoa com deficiência visual - estação (EI6), destacaram os amplos espaços de conexão e a inexistência de diferenciação da sinalização dos percursos de acesso ao Metrô, à CPTM, aos terminais rodoviários ou a outros modos integrados e as condições que diferenciem os ambientes dos diferentes modos de transportes. Em todas as situações, a sinalização tátil no piso continua sendo a única alternativa considerada na fase de projeto.

Os profissionais responsáveis pela elaboração de normas técnicas relataram que soluções padronizadas relacionadas à configuração, sinalização e iluminação dos ambientes 
característicos do sistema metroferroviário contribuem para prover segurança, autonomia e agilidade nos deslocamentos. Entre as soluções que podem contribuir para a segurança e independência dos deslocamentos em função das condições das instalações existentes (EC3), estão recomendações para melhoria dos textos normativos vigentes, destacando o estabelecimento de condições adequadas para execução de obras e serviços, garantindo uma rota acessível para embarque e a existência de contraste entre piso, paredes, portas, corrimãos e painéis de informação da estação. As informações para a pessoa com deficiência visual estação (EI6) devem ser claras, objetivas e completas, além de redundantes, para que as orientações operacionais e institucionais sobre os serviços ofertados (comércio, exposições, espaços institucionais) possam contribuir para que os passageiros alcancem seus destinos com segurança. As referências necessárias para orientar os deslocamentos das pessoas com deficiência visual podem ser criadas a partir de estímulos táteis e sonoros, ou mesmo visuais, desde que adequados aos parâmetros que possibilitem sua percepção por pessoas com baixa visão. Para que sejam mais eficientes e atinjam a diversidade de pessoas com deficiência visual, tais referências devem ser redundantes e integradas uma vez que a soma dessas referências é mais eficaz do que cada uma isoladamente.

\subsubsection{Elementos de wayfinding}

Os dados coletados permitem afirmar que os elementos de wayfinding característicos desta etapa são os seguintes: marcadores, caminhos, nós e zonas (Quadro 27). Os elementos de wayfinding - marcadores, caminhos, nós, zonas - devem ser providos de uma configuração e sinalização tátil/visual/sonora de forma a auxiliar sua identificação por pessoas com deficiência visual, bem como devem-se sobressair em relação aos demais elementos e informações do ambiente para facilitar sua percepção. Ao mesmo tempo, tais elementos devem constar e ser ressaltados nas informações veiculadas, especialmente quando da elaboração dos materiais táteis, visuais e sonoros voltados à descrição do ambiente das estações, facilitando a compreensão dos percursos desde os elementos de circulação vertical até os elementos de controle de acesso. 
Quadro 27 - Elementos de wayfinding da Etapa 5 - Mezanino - área livre.

\begin{tabular}{|c|c|c|c|}
\hline $\begin{array}{l}\text { Elementos de } \\
\text { wayfinding }\end{array}$ & Configuração & Informação & Serviço \\
\hline Marcadores & $\begin{array}{l}\text { - elementos de circulação } \\
\text { vertical } \\
\text { - bilheterias ou máquinas } \\
\text { de autoatendimento } \\
\text { - bloqueios }\end{array}$ & $\begin{array}{l}\text { - sinalização } \\
\text { tátil/visual/sonora dos } \\
\text { equipamentos e } \\
\text { elementos }\end{array}$ & - treinamento dos usuários \\
\hline Caminhos & $\begin{array}{l}\text { - percursos entre os } \\
\text { elementos de circulação } \\
\text { vertical e os bloqueios, } \\
\text { bilheterias ou máquinas } \\
\text { de autoatendimento } \\
\text { - interseções entre os } \\
\text { diferentes percursos } \\
\text { vindos dos acessos }\end{array}$ & $\begin{array}{l}\text { - sinalização tátil/visual das } \\
\text { opções de percurso }\end{array}$ & $\begin{array}{l}\text { - treinamento dos usuários } \\
\text { - auxílio no deslocamento }\end{array}$ \\
\hline Nós & $\begin{array}{l}\text { - interseção entre percursos } \\
\text { vindos dos diferentes } \\
\text { acessos }\end{array}$ & $\begin{array}{l}\text { - sinalização tátil/visual das } \\
\text { opções de percurso }\end{array}$ & $\begin{array}{l}\text { - treinamento dos usuários } \\
\text { - auxílio no deslocamento }\end{array}$ \\
\hline Zonas & $\begin{array}{l}\text { - superfície da área de } \\
\text { circulação no mezanino } \\
\text { - área livre }\end{array}$ & $\begin{array}{l}\text { - contraste visual entre } \\
\text { equipamentos da estação } \\
\text { e superfícies horizontais e } \\
\text { verticais }\end{array}$ & $\begin{array}{l}\text { - treinamento dos usuários } \\
\text { - auxílio no deslocamento } \\
\text { - gestão de fluxos }\end{array}$ \\
\hline
\end{tabular}

Fonte: Elaborado pela pesquisadora.

\subsubsection{Síntese do diagnóstico}

Na etapa 5 - Deslocamento no mezanino área livre -, foram identificados aspectos que devem ser tratados pelas empresas operadoras dos sistemas metroferroviários para auxiliar pessoas com deficiência visual a estabelecer estratégias para empreender seus deslocamentos:

a) condições das instalações existentes (EC3) - posicionar mobiliário e equipamentos preservando as áreas de circulação; prover segurança no interior das estações; minimizar as distâncias entre a circulação vertical e os bloqueios, facilitando a compreensão do ambiente e do percurso; dotar os ambientes construídos em diferentes épocas de recursos que facilitem a percepção e compreensão dos percursos; diferenciar os ambientes dos vários modos de transporte integrado por meio de ritos de passagem ou de transição, facilitando a sua percepção e compreensão; estabelecer os requisitos e as condições adequadas para execução de obras e serviços na rota acessível; prover contraste entre piso, paredes, portas, corrimãos e painéis de informação da estação;

b) piso tátil - contraste tátil e visual (EI1) - instalar piso tátil diferenciado para orientar a localização do embarque nas estações de conexão; acrescentar uma faixa lisa junto ao piso tátil nas estações que têm piso emborrachado com pastilhas em relevo; 
c) piso tátil - participação no projeto (EI2) - envolver / consultar usuários antes de definir premissas de instalação do piso tátil nas estações;

d) piso tátil - percurso (EI3) - instalar piso tátil em todos os equipamentos e serviços oferecidos na estação; considerar ou ser igual ao fluxo dos demais usuários; direcionar para as escadas rolantes; evitar terminar no corrimão central das rampas; melhorar a compreensão sobre o caminho; manter distanciamento do piso tátil em relação aos obstáculos existentes na edificação; aumentar a área de sinalização tátil de alerta nas interseções entre pisos direcionais; utilizar pisos táteis com percursos diagonais ou em curva em substituição aos percursos ortogonais;

e) informações para a pessoa com deficiência visual antes ou depois da viagem (EI5) - disponibilizar folhetos com orientações em Braille ou informação sonora para a pessoa com deficiência visual saber utilizar as estações;

f) informações para a pessoa com deficiência visual - estação (EI6) - prover informações e orientações operacionais e institucionais sobre os serviços ofertados (comércio, exposições, espaços institucionais); essas devem ser claras, objetivas, completas, redundantes; disponibilizar informação tátil, visual ou sonora sobre a configuração e os percursos realizados na estação; aumentar o contraste e as dimensões das informações visuais; instalar mapas táteis ou descrições sonoras com as referências principais das estações, permitindo informações em igualdade de condições com os demais usuários; diferenciar a sinalização dos percursos de acesso aos trens metropolitanos, aos terminais rodoviários ou a outros modos integrados;

g) treinamento dos empregados - estação (ES1) - incluir abordagem e comunicação adequadas, oferecimento de ajuda com técnicas apropriadas e condução de indivíduos ou grupos em planos horizontais utilizando o piso tátil nos programas de capacitação para que o empregado tenha desenvoltura no atendimento;

h) atendimento pelos empregados (ES2) - prover empregados posicionados antes dos bloqueios para auxiliar o embarque;

i) comportamento dos demais usuários - estação (ES4) - promover campanhas para orientar o comportamento dos demais usuários nas estações para que estejam atentos e respeitem o deslocamento preferencial da pessoa com deficiência visual e do estagiário;

j) obstáculo próximo ao piso tátil (ES5) - posicionar os direcionadores de fila a uma distância segura do piso tátil; 
k) lotação das estações (ES7) - organizar o fluxo de usuários nas estações, nos horários de maior movimento, facilitando o deslocamento das pessoas com deficiência visual, seja de forma independente ou com auxílio.

\subsection{Etapa 6 - Aquisição do bilhete}

Nesta etapa, o usuário adquire o bilhete ou efetua o carregamento do cartão de viagem para realizar o seu deslocamento.

\subsubsection{Métodos e técnicas aplicados}

a) melhores práticas identificadas em outros sistemas metroferroviários;

b) pesquisa documental (normas técnicas ABNT vigentes, desenhos, procedimentos operacionais);

c) checklist dos recursos disponíveis e walkthrough realizado nas estações para compreensão do percurso de embarque;

d) questionário aplicado a pessoas com deficiência visual - questão 8;

e) entrevista com empregados das estações;

f) entrevista com profissionais responsáveis pela elaboração de normas técnicas.

As formas de análise e interpretação dos dados coletados foram apresentadas no Capítulo 6 Aplicação dos instrumentos.

\subsubsection{Melhores Práticas}

Dentre as melhores práticas, destacam-se os equipamentos de autoatendimento existentes no Metrô de Barcelona e no Metrô de Madri, que dispõem de telas com orientações por meio de texto ampliado, associado a informações e orientações sonoras para auxiliar o uso do equipamento. O percurso e o posicionamento adequado para uso dos equipamentos, posicionados lado a lado, são orientados por meio de piso tátil (Figuras 143 e 144) 

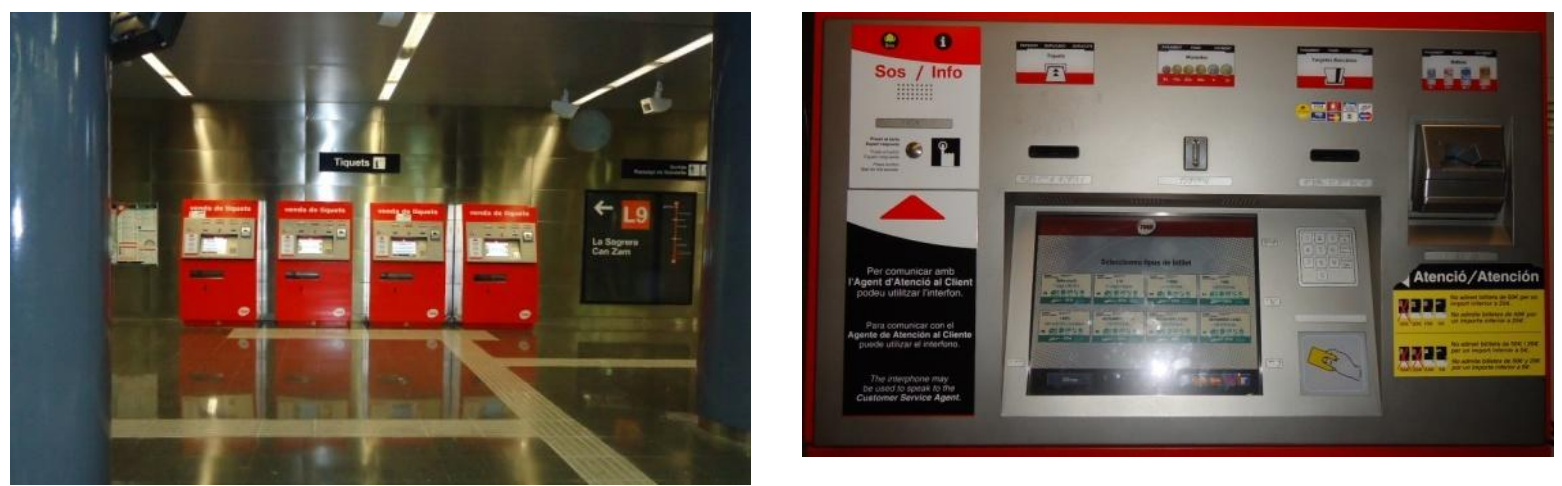

Figura 143 - Barcelona - Máquinas de autoatendimento para aquisição de bilhetes. Fonte: BARBOSA, M.B., 2011.
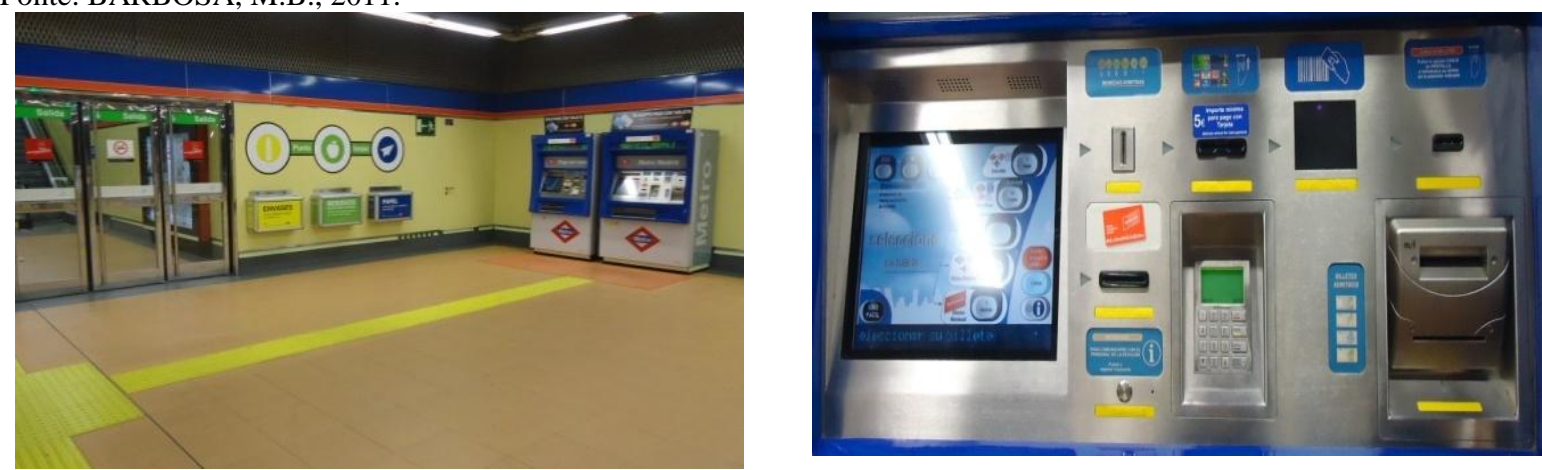

Figura 144 - Madri - Máquinas de autoatendimento para aquisição de bilhetes.

Fonte: BARBOSA, M.B., 2011.

No Metrô do Rio de Janeiro, as máquinas de autoatendimento dispõem de recursos sonoros e visuais, em diferentes idiomas, para orientação das ações necessárias para aquisição de bilhetes (Figura 145).
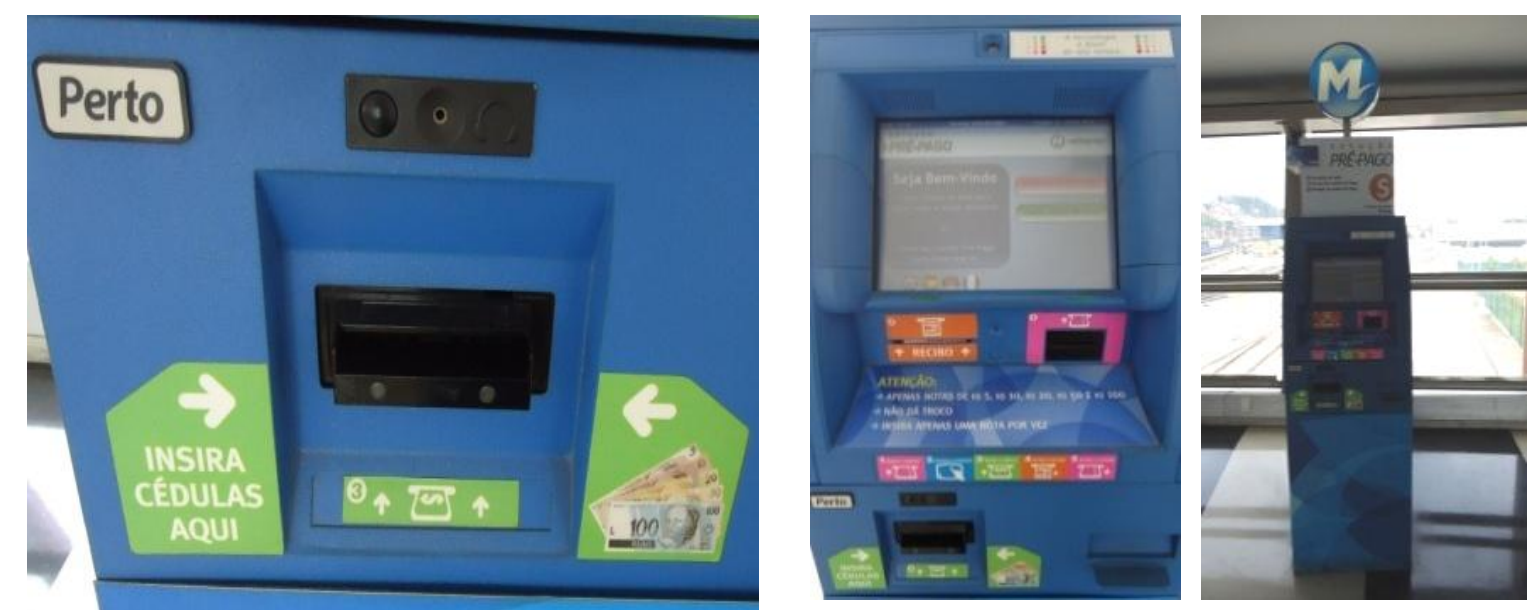

Figura 145 - Rio de Janeiro - Máquinas de autoatendimento para aquisição de bilhetes. Fonte: BARBOSA, M.B., 2011.

\subsubsection{Requisitos Normativos}

Com relação aos requisitos normativos, a ABNT NBR 14021:2005 determina que a informação sobre bilhetes e tarifas seja feita de forma visual e sonora e que informações sobre 
o atendimento e uso preferencial de equipamentos e serviços oferecidos sejam disponibilizadas de forma visual. As características e requisitos dos equipamentos e dispositivos de autoatendimento são definidas em ABNT NBR 15520:2005.

\subsubsection{Situação no Metrô de São Paulo}

No Metrô de São Paulo, a aquisição de bilhetes ou o carregamento de cartões de viagem podem ser realizados em diferentes locais, por meio de atendimento pessoal nas bilheterias próprias ou terceirizadas - ou de autoatendimento por meio de equipamentos existentes nas estações. É importante destacar que há legislação específica, vigente ${ }^{33}$, que isenta parte das pessoas com deficiência do pagamento de tarifa e, dessa forma, apenas uma parcela dos usuários adquire o bilhete nas estações. A gratuidade é concedida a pessoas com deficiência cuja gravidade comprometa sua capacidade de trabalho. As demais pessoas necessitam de adquirir o bilhete de viagem nas bilheterias, equipamentos de autoatendimento ou recarga de bilhete. As informações sobre o atendimento preferencial, os bilhetes e as tarifas, assim como as instruções de uso dos equipamentos de autoatendimento e de recarga são disponibilizadas apenas de forma visual (Figuras 146 e 147).

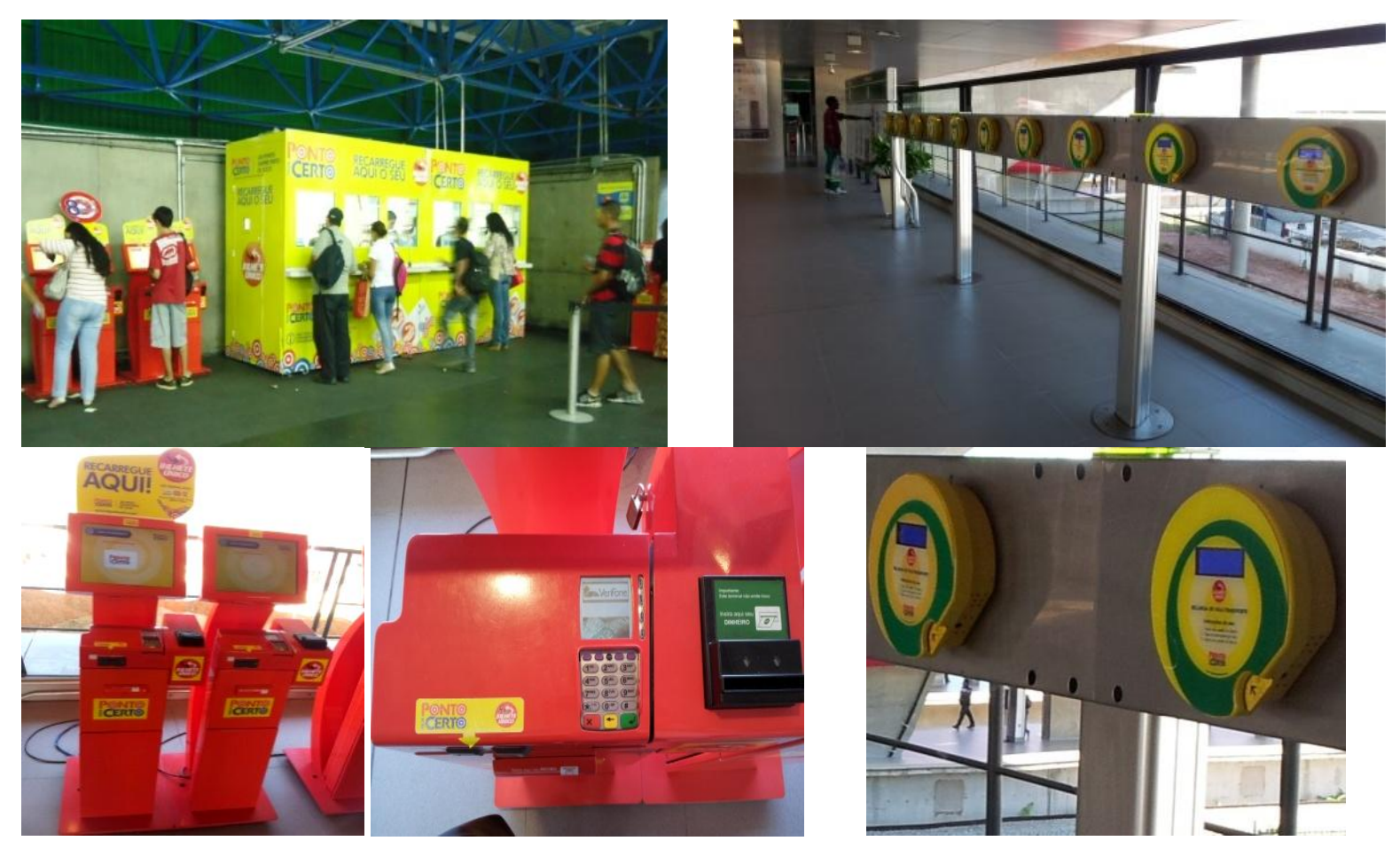

Figura 146 - São Paulo - Sinalização e configuração das bilheterias terceirizadas e dos equipamentos de autoatendimento.

Fonte: BARBOSA, M.B., 2011.

${ }^{33}$ Resolução Conjunta SS/STM n ${ }^{\circ} 03$, de 09 de junho de 2004, que disciplina a concessão de isenção do pagamento de tarifas de transporte coletivo regular em região metropolitana às pessoas com deficiência cuja gravidade comprometa sua capacidade de trabalho, bem como aos menores de 16 (dezesseis) anos, com deficiência. 

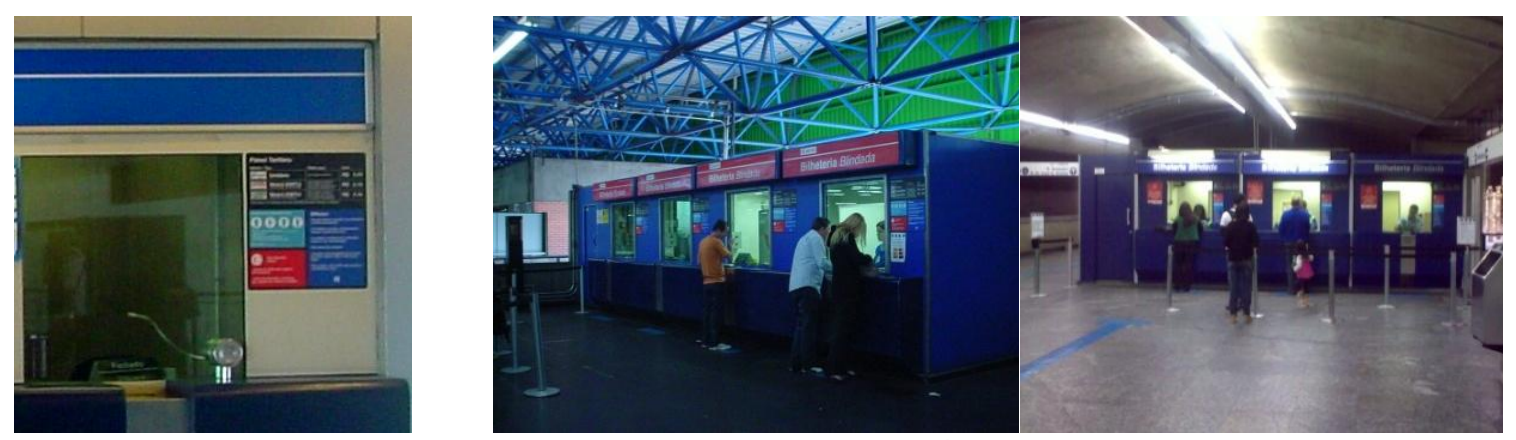

Figura 147 - São Paulo - Sinalização e configuração das bilheterias Metrô.

Fonte: BARBOSA, M.B., 2011.

A sinalização tátil no piso é realizada apenas para as bilheterias do Metrô, não orientando os deslocamentos para os serviços terceirizados, máquinas de autoatendimento ou de recarga de bilhetes.

\subsubsection{Avaliação pelos usuários}

Na etapa de aquisição do bilhete, três usuários com deficiência visual - todos eles cegos manifestaram seu descontentamento em relação à estação (100\%). Foram registrados apenas três relatos, o que representa $0,1 \%$ do total de relatos registrados para todas as etapas da jornada do usuário. Os relatos estão relacionados aos serviços prestados (100\%).

Eu acho que deveria ter apenas um único bilhete para permitir o uso dos trens e dos ônibus, assim eu não precisaria levar vários bilhetes. E também deveriam facilitar a renovação do bilhete para quem é deficiente permanente, porque demoram até 20 dias para renovar. E enquanto isto eu fico sem o bilhete. (Discurso do Sujeito Coletivo - Etapa 6)

Os principais problemas relatados pelos usuários na etapa de aquisição do bilhete estão relacionados à ideia chave de alteração no procedimento operacional - estação (ES6), que impede o acesso de pessoas com deficiência cujo bilhete esteja expirado, apesar da visível deficiência do usuário. A reclamação está direcionada, na verdade, à burocracia para aquisição ou validação do bilhete especial e à inexistência de um bilhete que possa ser utilizado, simultaneamente, em todos os sistemas da rede de transporte (ônibus, trem metropolitano, metrô, ônibus metropolitano e ônibus municipal).

\subsubsection{Avaliação pelas pessoas-chave}

Os empregados das estações relataram que não há registro de problemas relacionados à aquisição dos bilhetes nas bilheterias uma vez que as pessoas com deficiência visual chegam 
às estações portando o Bilhete Especial, conforme procedimento operacional - estação (ES6).

\subsubsection{Avaliação pelos especialistas}

Os profissionais responsáveis pela elaboração de normas técnicas relataram que as normas de acessibilidade contribuem para prover segurança, autonomia e agilidade nos deslocamentos por meio de soluções padronizadas relacionadas à configuração, sinalização e iluminação dos elementos, equipamentos e dispositivos. Entre as soluções que podem contribuir para a segurança e a independência dos deslocamentos em função das condições das instalações existentes (EC3), foram feitas recomendações para melhoria dos textos normativos vigentes, destacando-se as seguintes:

a) a existência de acessibilidade do sistema de bilhetagem, como, por exemplo, o retorno sonoro nos dispositivos de carregamento de créditos de viagem;

b) a realização de obras/reformas parciais ou totais para execução de obras ou serviços garantindo rota acessível para embarque/desembarque;

c) o contraste entre o piso, as paredes e os equipamentos.

\subsubsection{Elementos de wayfinding}

Os dados coletados permitem afirmar que os elementos de wayfinding característicos desta etapa são os seguintes: marcadores e caminhos (Quadro 28).

Quadro 28 - Elementos de wayfinding da Etapa 6 - Aquisição do bilhete.

\begin{tabular}{|c|c|c|c|}
\hline $\begin{array}{l}\text { Elementos de } \\
\text { wayfinding }\end{array}$ & Configuração & Informação & Serviço \\
\hline Marcadores & $\begin{array}{l}\text { - localização das } \\
\text { bilheterias e máquinas de } \\
\text { autoatendimento }\end{array}$ & $\begin{array}{l}\text { - sinalização das } \\
\text { bilheterias e máquinas de } \\
\text { autoatendimento }\end{array}$ & $\begin{array}{l}\text { - treinamento dos usuários } \\
\text { - auxílio no deslocamento }\end{array}$ \\
\hline Caminhos & $\begin{array}{l}\text { - percurso até as } \\
\text { bilheterias e máquinas de } \\
\text { autoatendimento }\end{array}$ & $\begin{array}{l}\text { - sinalização tátil/visual do } \\
\text { percurso até as } \\
\text { bilheterias e máquinas de } \\
\text { autoatendimento }\end{array}$ & $\begin{array}{l}\text { - treinamento dos usuários } \\
\text { - auxílio no deslocamento }\end{array}$ \\
\hline
\end{tabular}

Fonte: Elaborado pela pesquisadora. 


\subsubsection{Síntese do diagnóstico}

Na etapa 6 - aquisição do bilhete -, foram identificados aspectos que devem ser tratados pelas empresas operadoras dos sistemas metroferroviários para auxiliar pessoas com deficiência visual a estabelecer estratégias para empreender seus deslocamentos:

a) procedimento operacional - estação (ES6) - facilitar a concessão ou renovação do bilhete especial; implantar um bilhete que possa ser utilizado em todos a rede de transporte simultaneamente;

b) condições das instalações existentes (EC3) - dotar as máquinas de autoatendimento de condições adequadas de acessibilidade; estabelecer os requisitos e as condições adequadas para execução de obras e serviços na rota acessível; prover contraste entre piso, paredes, portas, corrimãos e painéis de informação da estação.

\subsection{Etapa 7 - Controle de entrada - Validação do bilhete}

Nesta etapa, o usuário ultrapassa os bloqueios, mediante validação do seu bilhete ou cartão.

\subsubsection{Métodos e técnicas aplicados}

Os métodos e técnicas utilizados para coleta de dados nesta etapa foram apresentados no item 6.10 - Síntese dos instrumentos aplicados - e consistiram em:

a) melhores práticas identificadas em outros sistemas metroferroviários;

b) pesquisa documental (normas técnicas ABNT vigentes, desenhos, procedimentos operacionais);

c) checklist dos recursos disponíveis e walkthrough realizado nas estações para compreensão do percurso de embarque;

d) questionário aplicado a pessoas com deficiência visual - questões 12, 13 e 17;

e) entrevista com professores de orientação e mobilidade;

f) entrevista com profissionais responsáveis pela elaboração de normas técnicas.

As formas de análise e interpretação dos dados coletados foram apresentadas no Capítulo 6 Aplicação dos instrumentos. 


\subsubsection{Melhores Práticas}

Entre as melhores práticas, destaca-se o Metrô de Madri, que dispõe de equipamento para auxílio dos usuários posicionado junto à linha de bloqueios para orientar ou dirimir eventuais dúvidas dos usuários, além de sinalização tátil e visual indicativa da localização do bilhete de entrada (Figura 148).
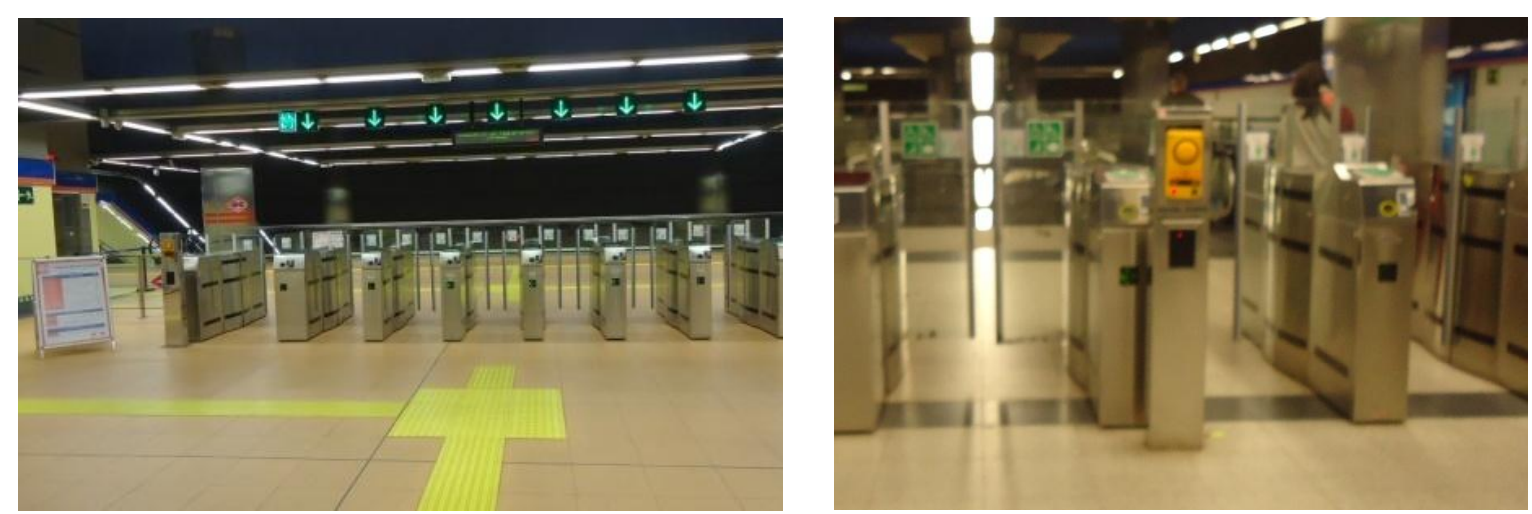

Figura 148 - Madri - Equipamentos de controle de acesso e dispositivo para auxílio. Fonte: BARBOSA, M.B., 2013.

\subsubsection{Requisitos Normativos}

Com relação aos requisitos normativos, a ABNT NBR 14.021:2005 estabelece a necessidade de existência de piso tátil direcional desde as entradas da estação até o bloqueio identificado para o embarque preferencial, informando o posicionamento do usuário para sua utilização. As sinalizações de uso para embarque ou saída, de exclusividade de uso e tipo de bilhete ou cartão devem ser posicionadas sobre o equipamento, que deve dispor de sinalização visual e tátil indicando o local para inserção ou posicionamento dos bilhetes e cartões bem como de informação visual e sonora sobre a quantidade de créditos restantes no bilhete ou cartão. $\mathrm{Na}$ área livre do mezanino, próximo aos equipamentos de controle de acesso, deve haver informação tátil indicando as linhas e a sequência das estações, destacando a estação onde o usuário se encontra e as estações de transferência.

\subsubsection{Situação no Metrô de São Paulo}

No Metrô de São Paulo, os equipamentos de controle de acesso dispõem de fendas para inserção de bilhetes e dispositivos para a leitura de cartões magnéticos. O bloqueio da passagem se dá por meio de tripés ou portas de vidro (Figuras 149 e 150). As novas estações dispõem de painéis de informação indicando o fluxo - embarque, saída ou uso preferencial posicionados sobre os equipamentos de controle de acesso enquanto nas demais estações tal 
informação está posicionada exclusivamente nos equipamentos. Nenhum dos equipamentos dispõe de recursos sonoros para informar os créditos disponíveis nos bilhetes ou cartões.
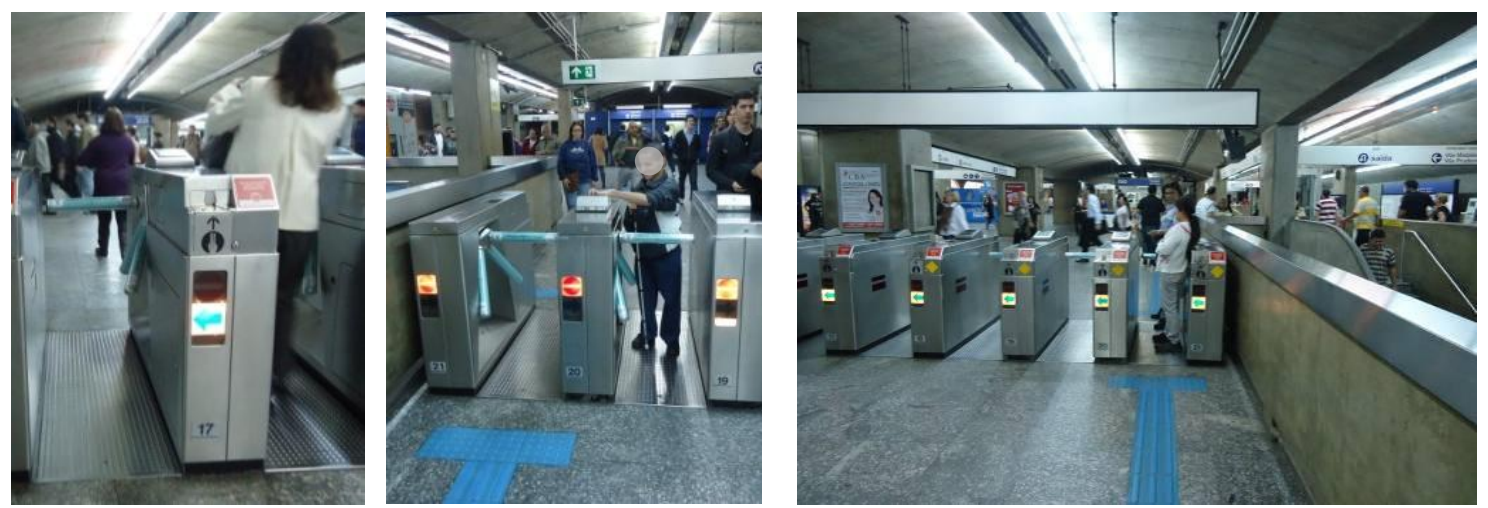

Figura 149 - São Paulo - Equipamentos de controle de acesso com torniquetes.

Fonte: BARBOSA, M.B., 2011.
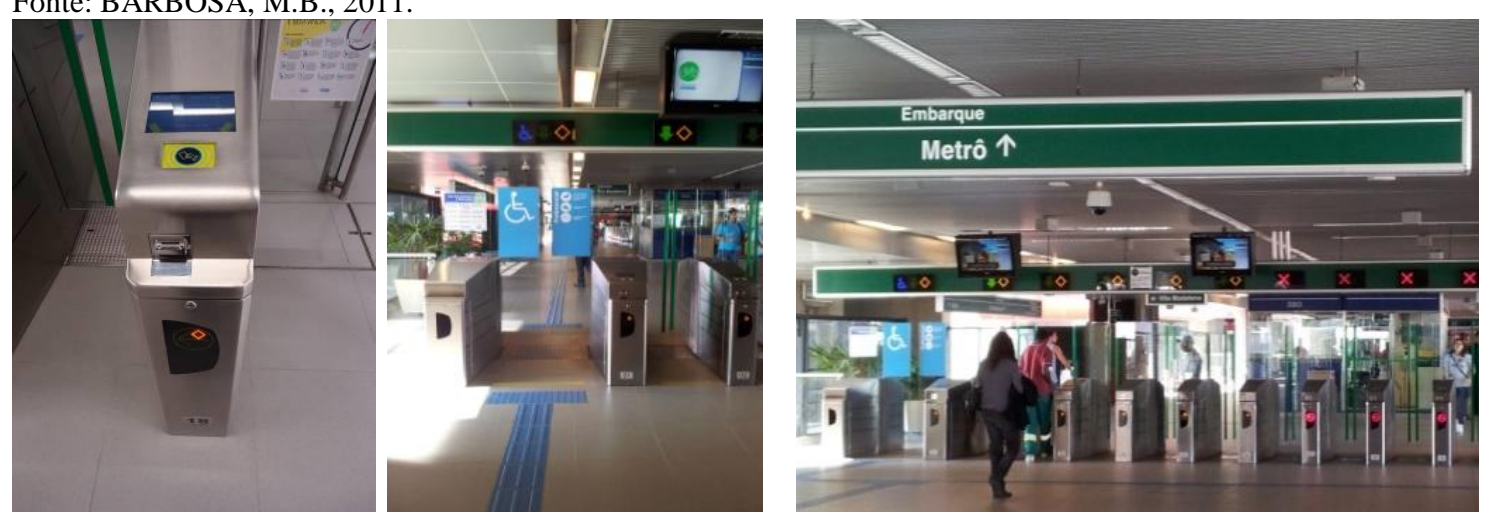

Figura 150 - São Paulo - Equipamentos de controle de acesso com portas de vidro.

Fonte: BARBOSA, M.B., 2011.

Nas estações de conexão entre diferentes empresas, contadores fazem a contabilização da quantidade de usuários que se transferem de um sistema para outro, sem bloquear a circulação (Figura 151).

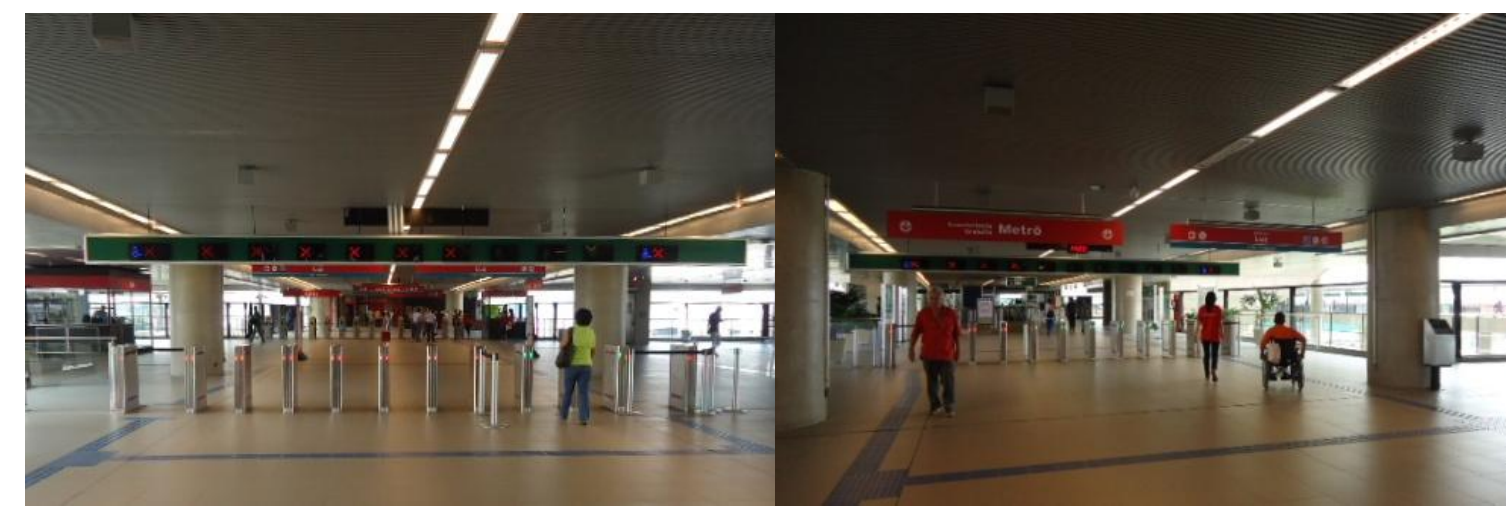

Figura 151 - São Paulo - Equipamentos de contagem de acesso.

Fonte: BARBOSA, M.B., 2011. 


\subsubsection{Avaliação pelos usuários}

Na etapa de controle de entrada - validação do bilhete, 10 usuários com deficiência visual dos quais seis pessoas são cegas e quatro pessoas têm baixa visão - manifestaram seu descontentamento em relação à estação (100\%). Foram registrados 12 relatos, o que representa $0,4 \%$ do total de relatos registrados para todas as etapas da jornada do usuário. Os relatos estão relacionados, em sua maioria, à disponibilidade de informações nas estações $(41,7 \%)$ e aos serviços prestados $(33,3 \%)$, mas também são dirigidos à configuração da estação para facilitar a validação do bilhete $(25,0 \%)$.

\footnotetext{
"Em minha opinião deveria ter sinalização em Braille ou informação sonora para eu saber qual é o bloqueio para entrar e qual é o bloqueio para sair. Também acho que deveria ter um alarme - principalmente nos bloqueios com porta de vidro - porque muitas vezes eles abrem e fecham rapidamente. Um dia, para não me machucar, eu tive que segurar a porta com o braço. Os bloqueios antigos deveriam ser substituídos pelos de porta, porque é mais fácil de eu passar sem enroscar a bolsa... Para mim, ficaria mais fácil se tivesse um bloqueio para embarque exclusivo, só para pessoas especiais." (Discurso do Sujeito Coletivo - Etapa 7)
}

Os principais problemas relatados pelos usuários na etapa de validação do bilhete são apresentados de forma hierarquizada conforme número de relatos registrados e estão relacionados às seguintes ideias centrais:

a) informações nos equipamentos (EI4) - falta de informação tátil, visual e sonora nos bloqueios preferenciais;

b) situação existente dificulta a mobilidade (EC4) - subdimensionamento dos bloqueios de tripé ou contadores existentes, que, por serem estreitos, dificultam a mobilidade;

c) equipamento de controle de acesso - bloqueios (ES8) - insegurança durante a passagem pelos bloqueios cujas portas de vidro fecham-se sobre as pessoas;

d) condições das instalações existentes (EC3) - quantidade insuficiente de bloqueios disponibilizados ou mal posicionados conforme o fluxo das estações;

e) comportamento dos demais usuários - estação (ES4) - comportamento indevido dos demais usuários em relação ao uso do bloqueio preferencial face à inexistência de bloqueio exclusivo;

f) obstáculo próximo ao piso tátil (ES5) - posicionamento inadequado dos direcionadores de fila próximo ou mesmo sobre o piso tátil pelos próprios empregados das estações. 


\subsubsection{Avaliação pelas pessoas-chave}

Os professores de orientação e mobilidade destacaram a importância das informações nos equipamentos (EI4) e relataram que a sinalização tátil direcional junto aos elementos de controle de acesso pode, ainda que temporariamente, ficar incoerente com bloqueios que estejam desligados, em manutenção ou sem dispositivo de leitura de cartões (Figura 152).

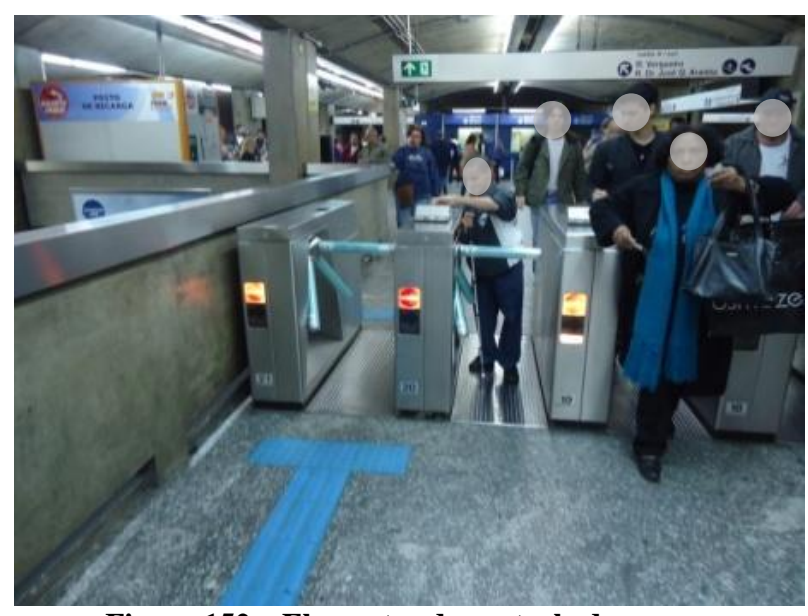

Figura 152 - Elementos de controle de acesso. Fonte: BARBOSA, M.B., 2011.

\subsubsection{Avaliação pelos especialistas}

Os profissionais responsáveis pela elaboração de normas técnicas relataram que as normas de acessibilidade contribuem para prover segurança, autonomia e agilidade nos deslocamentos por meio de soluções padronizadas relacionadas à configuração, sinalização e iluminação dos elementos, equipamentos e dispositivos. Entre as soluções que podem contribuir para a segurança e a independência dos deslocamentos em função das condições das instalações existentes (EC3) e das informações nos equipamentos (EI4), foram feitas recomendações para melhoria dos textos normativos vigentes, destacando-se as seguintes:

a) a instalação de bloqueios/catracas acessíveis e eliminação das cancelas como equipamentos de controle de acesso;

b) a existência de acessibilidade do sistema de bilhetagem, como, por exemplo, o retorno sonoro nos bloqueios acessíveis para informar sobre a liberação da passagem e o saldo de viagens nos cartões;

c) as condições para execução de serviços, realização de obras e reformas parciais ou totais, garantindo a existência de rota acessível para embarque/desembarque;

d) o contraste entre o piso, as paredes e os equipamentos. 


\subsubsection{Elementos de wayfinding}

Os dados coletados permitem afirmar que os elementos de wayfinding característicos desta etapa são os seguintes: marcadores e caminhos (Quadro 29). Os elementos de wayfinding marcadores e caminhos - devem ser providos de configuração e sinalização tátil/visual/sonora de forma a facilitar sua identificação por pessoas com deficiência visual e sobressair-se em relação aos demais elementos e informações do ambiente para facilitar sua percepção. Ao mesmo tempo, tais elementos devem constar e ser ressaltados nas informações veiculadas, especialmente quando da elaboração dos materiais táteis, visuais e sonoros voltados à descrição do ambiente das estações, facilitando a compreensão dos percursos desde os elementos de circulação vertical até os elementos de controle de acesso.

Quadro 29 - Elementos de wayfinding da Etapa 7 - Controle de entrada - validação do bilhete.

\begin{tabular}{|c|c|c|c|}
\hline $\begin{array}{l}\text { Elementos de } \\
\text { wayfinding }\end{array}$ & Configuração & Informação & Serviço \\
\hline Marcadores & $\begin{array}{l}\text { - localização dos } \\
\text { equipamentos de controle } \\
\text { de acesso }\end{array}$ & $\begin{array}{l}\text { - contraste visual entre } \\
\text { equipamentos e cenário } \\
\text { da estação } \\
\text { - sinalização tátil, visual e } \\
\text { sonora sobre o } \\
\text { funcionamento do } \\
\text { equipamento }\end{array}$ & $\begin{array}{l}\text { - gestão de filas } \\
\text { - atendimento preferencial }\end{array}$ \\
\hline Caminhos & $\begin{array}{l}\text { - percurso até os } \\
\text { equipamentos de controle } \\
\text { de acesso }\end{array}$ & $\begin{array}{l}\text { - sinalização tátil/visual do } \\
\text { percurso até os } \\
\text { equipamentos de controle } \\
\text { de acesso }\end{array}$ & $\begin{array}{l}\text { - treinamento dos usuários } \\
\text { - auxílio no deslocamento }\end{array}$ \\
\hline
\end{tabular}

Fonte: Elaborado pela pesquisadora.

\subsubsection{Síntese do diagnóstico}

Na etapa 7 - controle de entrada/ validação do bilhete -, foram identificados aspectos que devem ser tratados pelas empresas operadoras dos sistemas metroferroviários para auxiliar pessoas com deficiência visual a estabelecer estratégias para empreender seus deslocamentos, descritos a seguir:

a) condições das instalações existentes (EC3) - disponibilizar bloqueios em quantidade e localização adequadas, conforme a demanda e o fluxo das estações; substituir as cancelas existentes por bloqueios; garantir contraste entre o piso, as paredes e os equipamentos; garantir condições adequadas para a execução de serviços, realização de obras e reformas parciais ou totais, garantindo a existência de rota acessível para embarque/desembarque; 
b) situação existente dificulta a mobilidade (EC4) - dimensionar os bloqueios de tripé e os contadores existentes para facilitar a mobilidade;

c) informações nos equipamentos (EI4) - implementar informação tátil, visual e sonora nos bloqueios preferenciais; implementar retorno sonoro para informar sobre a liberação da passagem e o saldo de viagens nos cartões; instalar sinalização tátil no piso direcionando fluxo para bloqueios que estejam ligados, em operação ou que disponham de dispositivo de leitura de cartões;

d) comportamento dos demais usuários - estação (ES4) - promover campanhas para orientar o comportamento dos demais usuários nas estações, para que respeitem o uso do bloqueio preferencial face à inexistência de bloqueio exclusivo;

e) obstáculo próximo ao piso tátil (ES5) - posicionar os direcionadores de fila a uma distância segura do piso tátil;

f) equipamento de controle de acesso - bloqueios (ES8) - implementar dispositivo de segurança para impedir o fechamento das portas de vidro sobre as pessoas durante a passagem pelos bloqueios.

\subsection{Etapa 8 - Deslocamento no mezanino - área paga e escolha da plataforma}

Nesta etapa, o usuário inicia seu deslocamento em direção às plataformas e opta pelos equipamentos de circulação vertical que o conduzirá até a plataforma de embarque, de acordo com o destino desejado. Em algumas situações, cabe ao usuário, nesta etapa, optar por diferentes operadoras de transporte sobre trilhos ou diferentes linhas de metrô ou de trem.

\subsubsection{Métodos e técnicas aplicados}

Os métodos e técnicas utilizados para coleta de dados nesta etapa foram apresentados no item 6.10 - Síntese dos instrumentos aplicados - e consistiram em:

a) melhores práticas identificadas em outros sistemas metroferroviários;

b) pesquisa documental (normas técnicas $\mathrm{ABNT}$ vigentes, desenhos, procedimentos operacionais);

c) checklist dos recursos disponíveis e walkthrough realizado nas estações para compreensão do percurso de embarque;

d) questionário aplicado a pessoas com deficiência visual - questões 12, 13 e 17;

e) entrevista com empregados das estações; 
f) entrevista com estagiários que auxiliam pessoas com deficiência visual;

g) entrevista com professores de orientação e mobilidade;

h) entrevista com profissionais responsáveis pelos projetos das estações.

As formas de análise e interpretação dos dados coletados foram apresentadas no Capítulo 6 Aplicação dos instrumentos.

\subsubsection{Melhores Práticas}

Entre as melhores práticas, destacam-se o Metrô de Madri, que tem como requisitos de projeto a existência de contraste visual entre superfícies - pisos, fechamentos laterais, mobiliário, corrimãos, placas de informação e equipamentos para facilitar a legibilidade e a compreensão dos espaços e ambientes - e a existência de piso tátil direcional para orientar os deslocamentos (Figura 153).
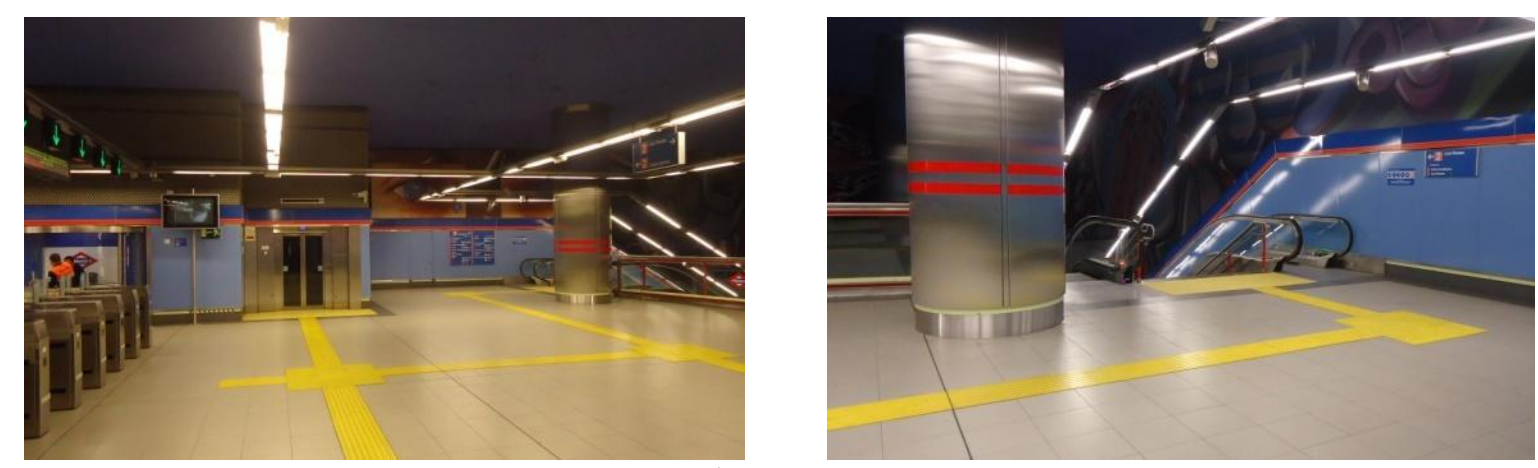

Figura 153 - Madri - Contraste visual e sinalização tátil direcional indicativa do percurso de embarque. Fonte: BARBOSA, M.B., 2013.

O Metrô de Hong Kong e o Metrô do Rio de Janeiro dispõem de mapas e pisos táteis que informam os percursos entre os equipamentos de controle de acesso e os elementos de circulação vertical (Figuras 154 e 155).
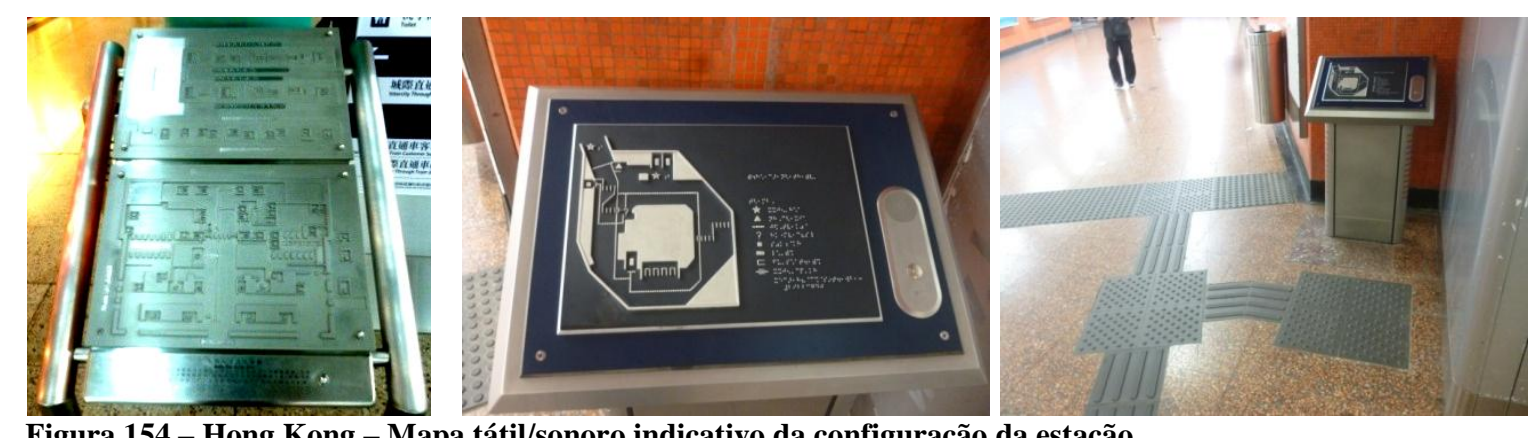

Figura 154 - Hong Kong - Mapa tátil/sonoro indicativo da configuração da estação.

Crédito: PONTES, F.M., 2012. 

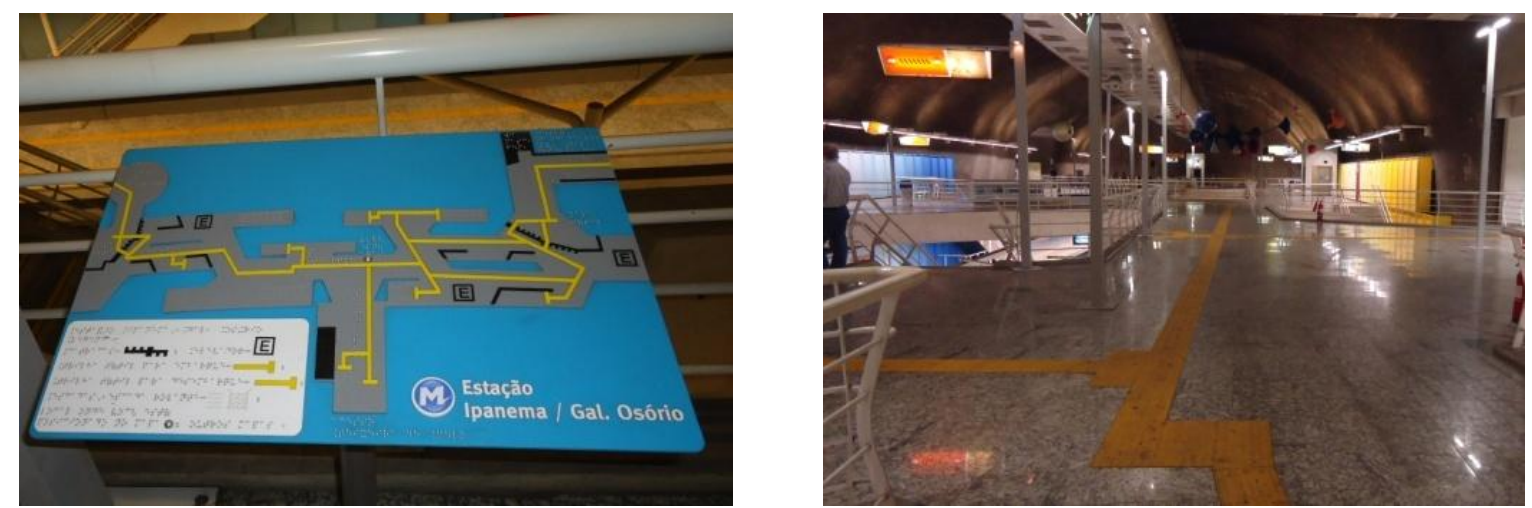

Figura 155 - Rio de Janeiro - Mapa e sinalização tátil direcional do percurso de embarque. Fonte: BARBOSA, M.B., 2011.

\subsubsection{Requisitos Normativos}

Com relação aos requisitos normativos, a ABNT NBR 14.021:2005 determina a existência de rota acessível para embarque nas plataformas, utilizando a palavra "embarque". Não há recomendação para instalação de piso tátil direcional para orientar os percursos até o local de embarque. A mesma norma determina a identificação das plataformas por meio de letras, números ou nomes. A ABNT NBR 15.599:2008 determina a existência de informação visual, sonora e tátil para informar linhas e destinos em cada uma das plataformas.

\subsubsection{Situação no Metrô de São Paulo}

No Metrô de São Paulo, o percurso no mezanino - área paga - dispõe de piso tátil para orientar os percursos de embarque, entre os equipamentos de controle de acesso e o elevador de acesso às plataformas (Figura 156). Em geral, nos horários de maior demanda, o deslocamento nessa área é difícil face à intensidade de fluxo, notadamente junto às escadas fixas e rolantes, locais em que são adotadas estratégias para organizar os fluxos, direcionar os deslocamentos e minimizar conflitos e acidentes (Figura 157).
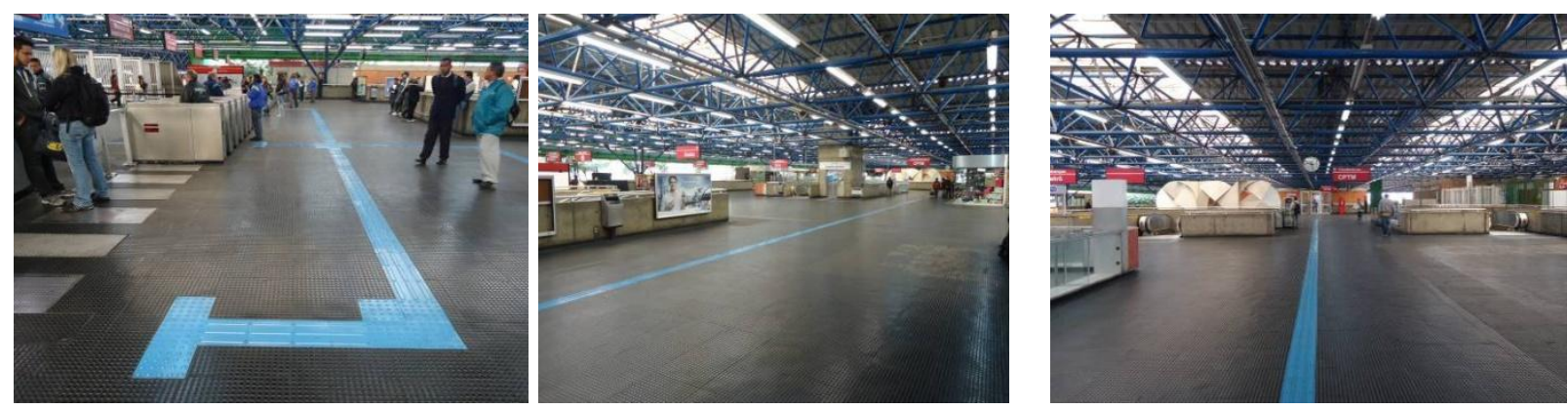

Figura 156 - São Paulo - Circulação no mezanino - área paga Fonte: BARBOSA, M.B., 2011. 

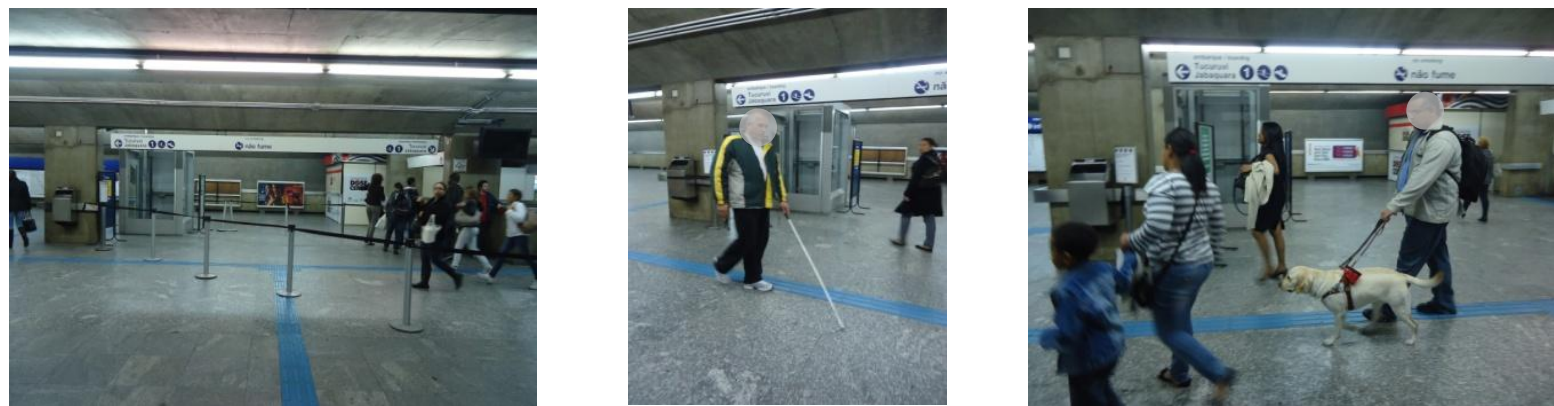

Figura 157 - São Paulo - Circulação no mezanino - estratégias para organizar fluxos.

Fonte: BARBOSA, M.B., 2011.

O percurso até os elevadores que levam às plataformas de embarque dispõe de sinalização com piso tátil. Nas estações com plataforma lateral ou mista, a opção de embarque se dá no nível do mezanino; nas estações com plataforma central, a opção de embarque se dá no nível da plataforma (Figuras 158 e 159). Nas estações de conexão, a decisão pela linha ou pelo destino pode ser tomada no mezanino ou na plataforma, dependendo da configuração da estação.

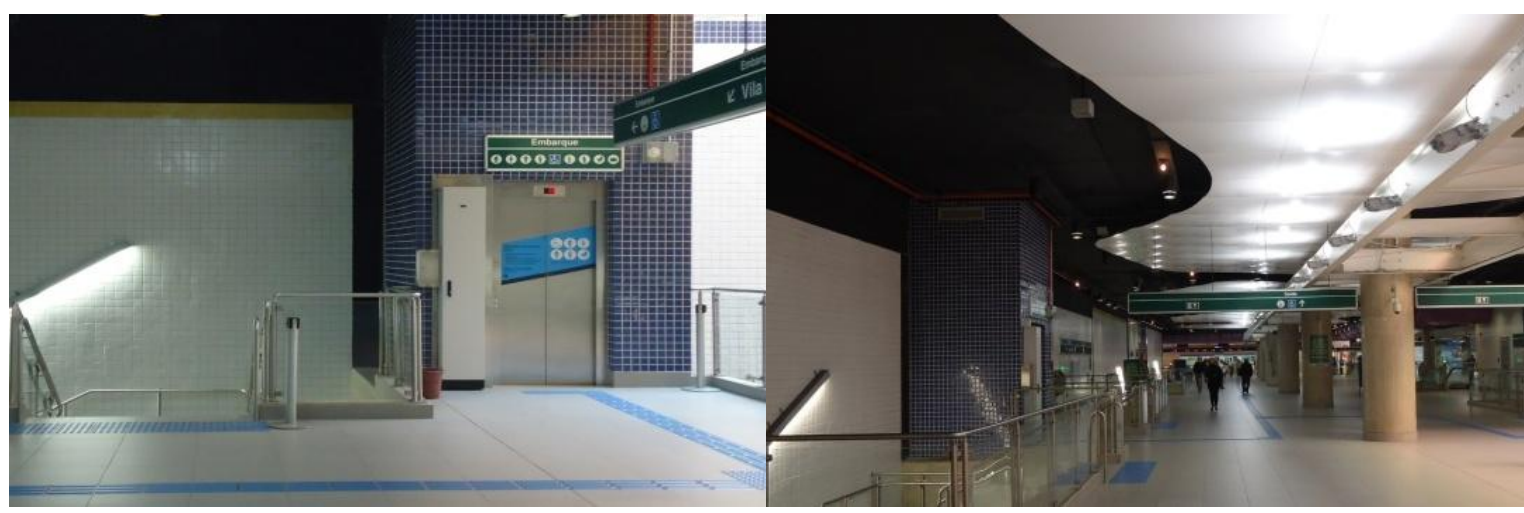

Figura 158 - São Paulo - Sinalização de embarque do mezanino para plataforma lateral. Fonte: BARBOSA, M.B., 2011.
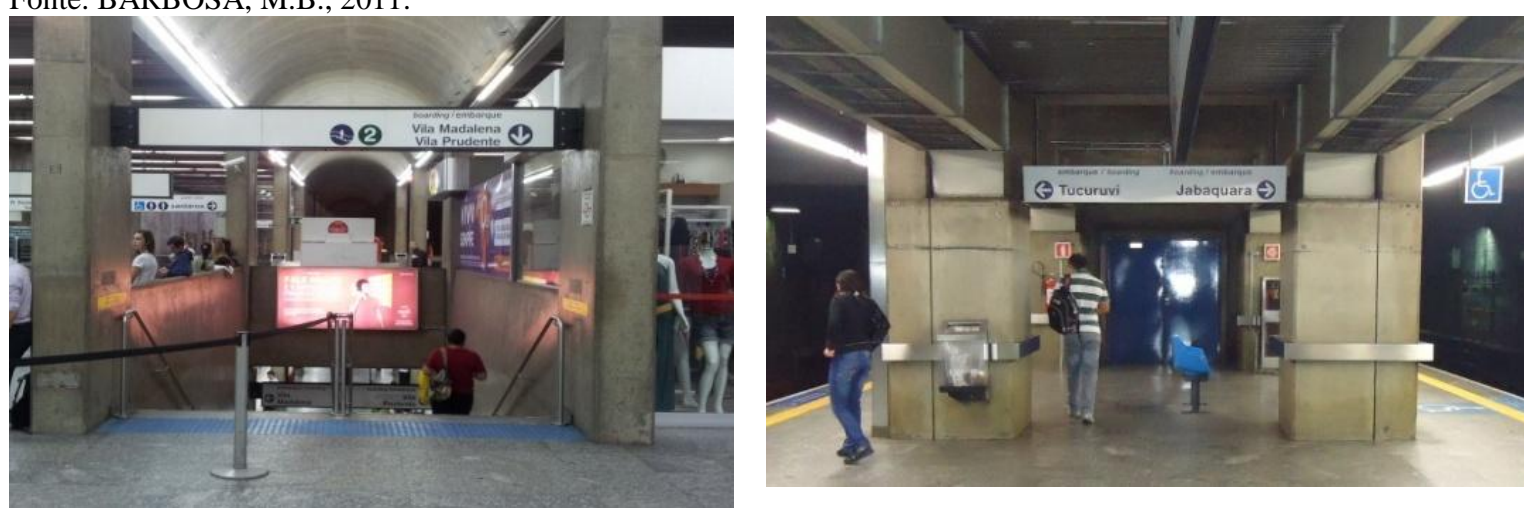

Figura 159 - São Paulo - Sinalização de embarque do mezanino para plataforma central.

Fonte: BARBOSA, M.B., 2011. 


\title{
7.8.5 Avaliação pelos usuários
}

$\mathrm{Na}$ etapa de deslocamento no mezanino - área paga -, 76 usuários com deficiência visual dos quais 49 pessoas são cegas e 27 pessoas têm baixa visão - manifestaram seu descontentamento em relação à estação (100\%). Foram registrados 110 relatos, o que representa $4,1 \%$ do total de relatos registrados para todas as etapas da jornada do usuário. Os relatos estão relacionados, em sua maioria, aos serviços prestados $(64,5 \%)$ e à disponibilidade de informações nas estações $(29,1 \%)$ bem como à configuração da estação para facilitar o deslocamento no mezanino $(6,4 \%)$ - (Tabela 21$)$.

Tabela 21 - Matriz de avaliação da etapa 8 - Deslocamento no mezanino - área paga.

(\% em relação ao total de relatos registrados nesta etapa)

\begin{tabular}{|c|c|c|c|c|}
\hline & $\underset{\%}{\text { Configuração }}$ & $\begin{array}{c}\text { Informação } \\
\%\end{array}$ & $\begin{array}{c}\text { Serviço } \\
\%\end{array}$ & $\begin{array}{c}\text { Total } \\
\%\end{array}$ \\
\hline Estação & (EC) 6,4 & (EI) 29,1 & (ES) 64,5 & 100,0 \\
\hline Interface Trem-Estação & $\mathbf{0 , 0}$ & $\mathbf{0 , 0}$ & $\mathbf{0 , 0}$ & $\mathbf{0 , 0}$ \\
\hline Trem & $\mathbf{0 , 0}$ & $\mathbf{0 , 0}$ & $\mathbf{0 , 0}$ & $\mathbf{0 , 0}$ \\
\hline Total & 6,4 & 29,1 & 64,5 & 100,0 \\
\hline
\end{tabular}

\begin{abstract}
"Na minha opinião deveriam treinar melhor os empregados, seja para nos ajudar nas estações seja para nos atender mais rápido no embarque e no desembarque. É comum eu ter que ficar esperando muito tempo alguém para me auxiliar na estação. Estou chegando sempre atrasado e meu chefe já me chamou a atenção. Nos finais de semana é pior ainda... Para eu me locomover melhor nas estações precisaria ter informação sonora ao longo do percurso no meu celular, para eu localizar os bloqueios, as escadas e o elevador. Enfim, as mesmas informações que têm em mapas, deveriam ter em forma de áudio... Acho que não adianta colocar o piso tátil, sem informar para onde estou indo. Os destinos do trem deveriam também estar indicados próximos das escadas, com setas indicativas para o lado correto. Em algumas estações o piso tátil não leva para onde eu quero ir: deveria ter piso tátil para todas as escadas rolantes próximas do local de embarque no trem. Acho também que não foi considerado o fluxo das outras pessoas: quando as mudanças de direção no piso tátil são de 90 graus, provocam esbarrões entre as pessoas. Além disso, fica para mim difícil me virar sozinho no metrô se os outros usuários não me respeitam, se me empurram... Para eu poder entender o caminho, principalmente nas estações grandes, a linha guia deveria ser reta, com as indicações e menos desvios, sem zigue-zague... Não sei se adianta ter o piso tátil como é hoje. Muitas vezes eles colocam objetos sobre o piso tátil, colocam painéis e suportes para direcionar as filas. Tem algumas estações que são muito escuras. Para mim, que tenho baixa visão, precisaria melhorar a iluminação das estações para poder me orientar melhor. Também é bom deixarem o piso sempre fosco porque o brilho reflete as luzes e atrapalha." (Discurso do Sujeito Coletivo - Etapa 8)
\end{abstract}

Os principais problemas relatados pelos usuários na etapa de deslocamento no mezanino área paga - são apresentados de forma hierarquizada, conforme o número de relatos registrados (Gráfico 27). 
Gráfico 27 - Avaliação da etapa 8 - Deslocamento no mezanino - área paga.

(\% em relação ao total de relatos registrados nesta etapa)

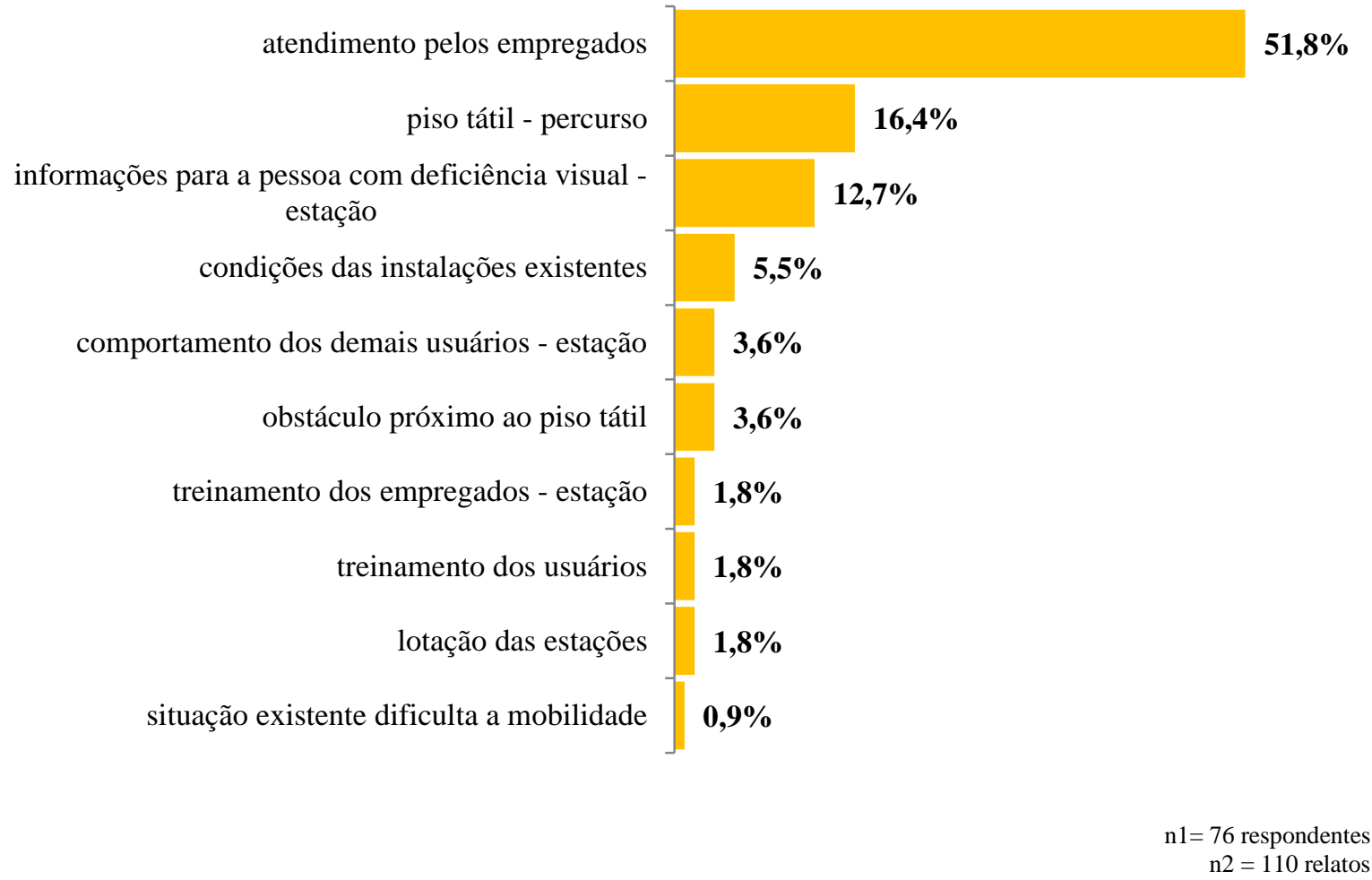

Os problemas relatados estão relacionados às seguintes ideias centrais:

a) atendimento pelos empregados (ES2) - descontentamento quanto ao tempo de espera para auxílio nos deslocamentos face à inexistência ou insuficiência de empregados ou estagiários nas estações;

b) informações para a pessoa com deficiência visual - estação (EI6) -inexistência de informação tátil, visual ou sonora sobre a configuração e os percursos realizados na estação e a falta de contraste ou dimensões inadequadas das informações visuais;

c) piso tátil - percurso (EI3) - dificuldade de compreensão sobre o caminho, bem como aponta a proximidade do piso tátil em relação aos obstáculos da edificação e destaca o fato de o piso tátil não levar para todos os equipamentos e serviços oferecidos na estação, de não considerar ou ser igual ao fluxo dos demais usuários e de não direcionar para as escadas rolantes e fixas;

d) condições das instalações existentes (EC3) - baixa iluminação dos ambientes e a configuração das estações em função da dimensão e complexidade;

e) comportamento dos demais usuários (ES4) - falta de respeito dos outros usuários durante os deslocamentos nas estações com maior demanda; 
f) obstáculo próximo ao piso tátil (ES5) - posicionamento inadequado dos direcionadores de fila próximo ou mesmo sobre o piso tátil pelos próprios empregados das estações;

g) treinamento dos empregados - estação (ES1) - insatisfação em relação ao atendimento prestado pelos empregados das estações;

h) lotação das estações (ES7) - revela conflitos e cruzamentos de fluxo de embarque e desembarque simultâneos nos horários de maior movimento;

i) situação existente dificulta a mobilidade (EC4) - dificuldade de deslocamento decorrente de obras ou alterações de fluxo nas estações.

\subsubsection{Avaliação pelas pessoas-chave}

Os empregados das estações consideraram negativo o percurso do piso tátil (EI3) em função da proximidade da sinalização tátil direcional perpendicular com os bloqueios, pois dificultam sua utilização por pessoas com deficiência visual, notadamente nos horários de maior demanda (Figura 160).
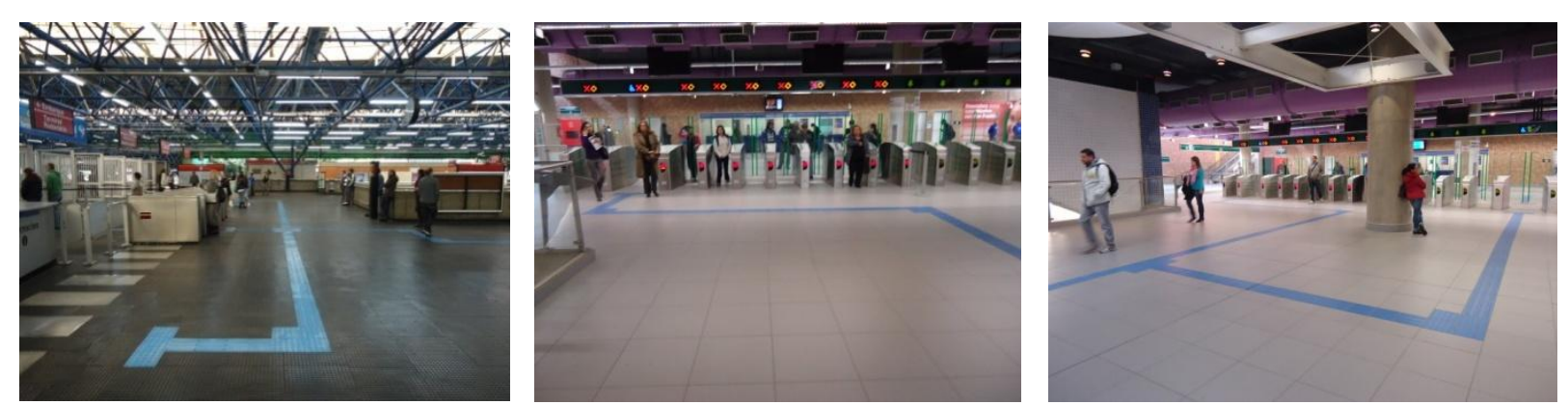

Figura 160 - São Paulo - Proximidade entre o piso tátil direcional e a linha de bloqueios. Fonte: BARBOSA, M.B., 2011.

Outros aspectos relacionados ao percurso do piso tátil (EI3) são a instalação do piso próximo a obstáculos - colunas, pilares - e a existência de uma sinalização única para embarque e desembarque (sem considerar mão e contramão), dificultando tanto o deslocamento independente como o auxílio prestado pelos empregados, principalmente nos horários de maior demanda (Figura 161). 


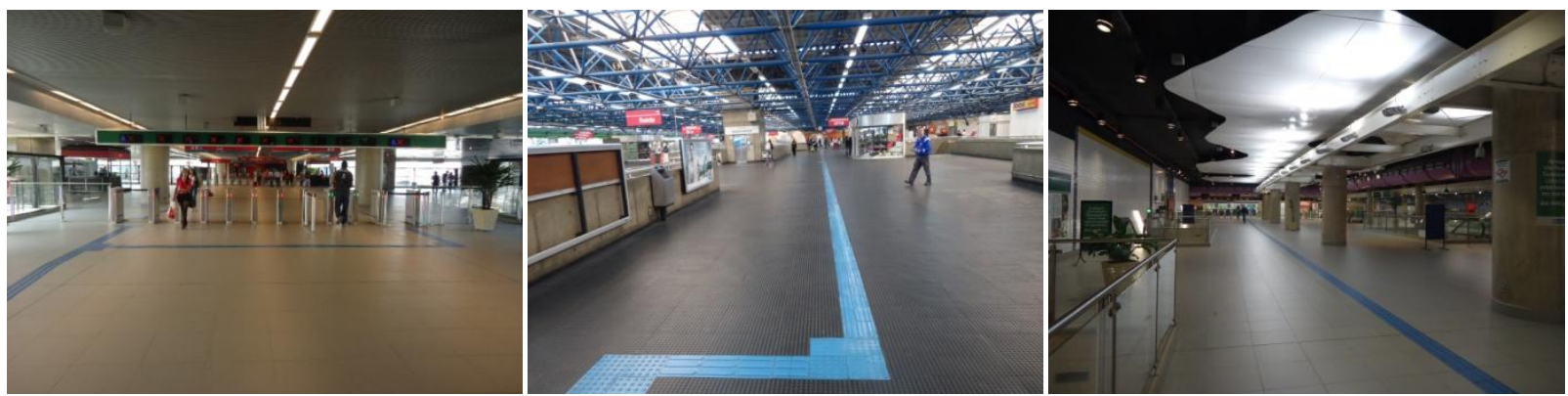

Figura 161 - São Paulo - Sinalização tátil direcional instalada para fluxos simultâneos de embarque e desembarque. Fonte: BARBOSA, M.B., 2011.

Os empregados das estações destacam a lotação das estações (ES7) e os conflitos e cruzamentos de fluxo principalmente junto às escadas das estações de conexão entre diferentes linhas, que são agravados pela chegada simultânea de trens e pela inexistência de escadas rolantes (Figura 162).
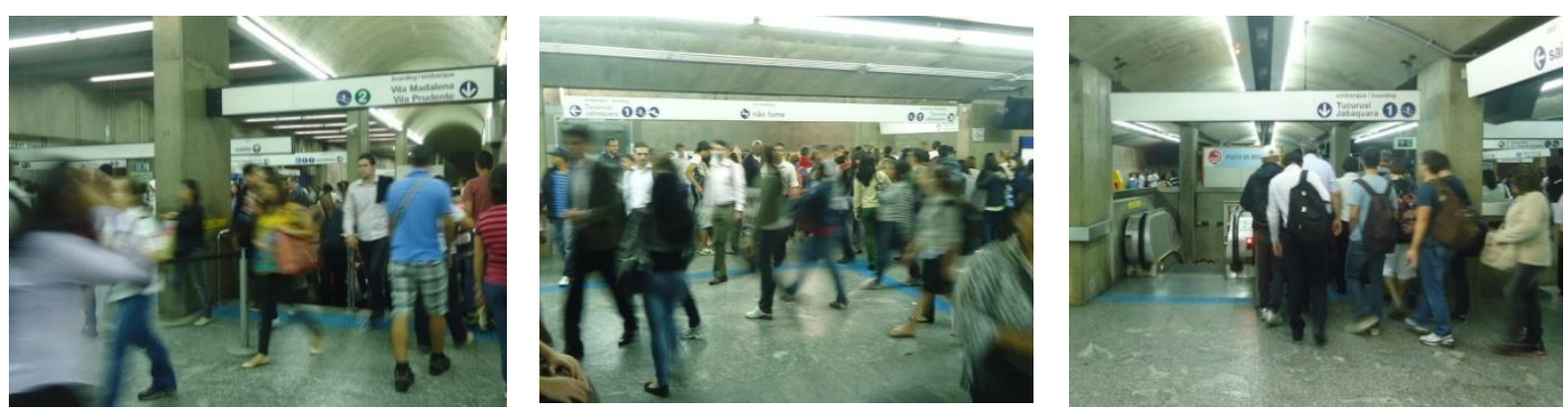

Figura 162 - São Paulo - Lotação, conflitos e cruzamentos de fluxo no mezanino. Fonte: BARBOSA, M.B., 2011.

Em relação às condições das instalações existentes (EC3), a proximidade entre os bloqueios e os elementos de circulação vertical e destes para o local de embarque preferencial é considerado um fator positivo para o deslocamento independente ou mesmo para o auxílio prestado às pessoas com deficiência visual. Da mesma forma, a proximidade entre os elevadores e escadas para acesso à plataforma facilita a compreensão do percurso para embarque (Figura 163).
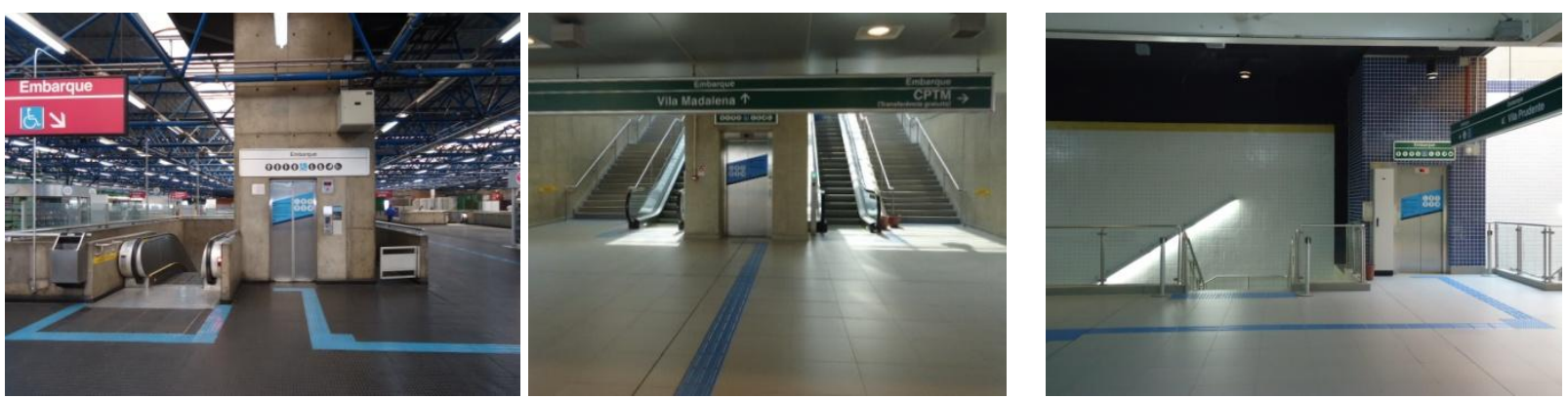

Figura 163 - São Paulo - Elevador associado às escadas fixas e rolantes para acesso à plataforma. Fonte: BARBOSA, M.B., 2011. 
Os estagiários relataram que a dificuldade de compreensão do piso tátil - percurso (EI3) de embarque e a pressa para chegar ao destino correto mobilizam a solicitação de auxílio pelas pessoas com deficiência. Foram destacadas as dificuldades para auxílio à pessoa com deficiência visual em função da lotação das estações (ES7) decorrente do deslocamento simultâneo de um grande número de pessoas para embarque e desembarque, do comportamento dos demais usuários - estação (ES4), que muitas vezes andam distraídos ou olhando para baixo e, em outras ocasiões, não respeitam o deslocamento preferencial da pessoa com deficiência visual e do estagiário, obrigando-os a desviarem seu caminho para não esbarrarem em alguém e, eventualmente, se machucarem. Os estagiários relataram ainda a dificuldade de uso independente da sinalização tátil no piso em função da lotação das estações (ES7) e do mau comportamento dos usuários (ES4), que param ou circulam sobre o piso tátil e não dão preferência ao deslocamento da pessoa com deficiência visual.

Os professores de orientação e mobilidade relataram que a ausência de uma faixa de transição traz dificuldades para identificar o piso tátil - contraste tátil e visual (EI1) em relação ao piso existente, notadamente nas estações que têm piso emborrachado com pastilhas em relevo. Em relação ao piso tátil - percurso (EI3), há críticas ao dimensionamento insuficiente da sinalização tátil de alerta nas interseções entre pisos direcionais - o que dificulta a percepção quanto às mudanças de direção - e ao fato de a sinalização não considerar ou ser igual ao percurso dos demais usuários - o que pode gerar eventuais conflitos de fluxo. A utilização de pisos diagonais ou em curvas pouco acentuadas pode resultar maior funcionalidade do que a de percursos ortogonais. De mesma forma, o encaminhamento para escadas fixas e rolantes pode incentivar a utilização da sinalização uma vez que as pessoas com deficiência visual que participam dos treinamentos de orientação e mobilidade preferem usar este equipamento em vez do elevador. Sobre as informações nos equipamentos (EI4), destacaram o subdimensionamento da sinalização visual de alerta - faixas contrastantes nas portas de vidro - também insuficiente para alertar pessoas com baixa visão (Figura 164). A compreensão do percurso realizado no mezanino - área paga - pode ser ampliada com o auxílio de informações para a pessoa com deficiência visual - estação (EI6) por meio de mapas táteis e descrições sonoras contendo as referências principais das estações, permitindo informações em igualdade de condições com os demais usuários. 

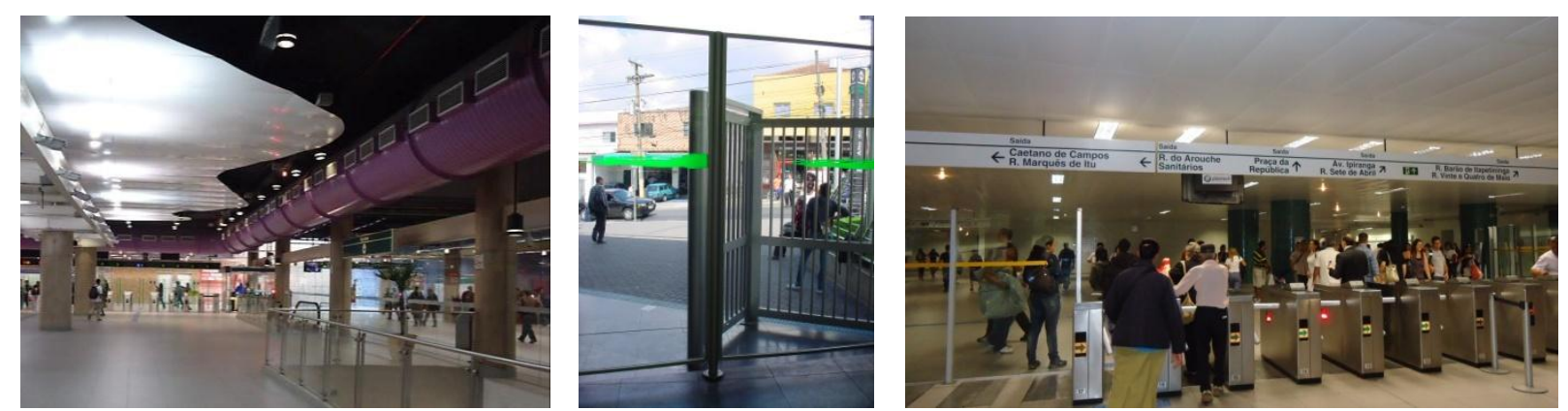

Figura 164 - São Paulo - Sinalização de alerta insuficiente em fechamentos de vidro. Fonte: BARBOSA, M.B., 2011.

Outro recurso, segundo os professores de orientação e mobilidade, é seguir o percurso do piso tátil durante a prestação de auxílio às pessoas com deficiência visual, fato que deve ser abordado no programa de capacitação e treinamento dos empregados - estação (ES1).

\subsubsection{Avaliação pelos especialistas}

Os profissionais responsáveis pelos projetos das estações relataram que as soluções padronizadas relacionadas às condições das instalações existentes (EC3), tais como configuração, sinalização e iluminação dos ambientes característicos do sistema metroferroviário contribuem para prover segurança, autonomia e agilidade nos deslocamentos. Entre as soluções que podem contribuir para a segurança e a independência dos deslocamentos em função das condições das instalações existentes (EC3), foram feitas recomendações para melhoria dos textos normativos vigentes, destacando o estabelecimento de condições adequadas para execução de obras e serviços, garantindo uma rota acessível para embarque e a existência de contraste entre piso, paredes, portas, corrimãos e painéis de informação da estação. As informações para a pessoa com deficiência visual - estação (EI6) devem ser claras, objetivas e completas, além de redundantes, para que as orientações operacionais e institucionais sobre os serviços ofertados (comércio, exposições, espaços institucionais) possam contribuir para que os passageiros alcancem seus destinos com segurança. As referências necessárias para orientar os deslocamentos das pessoas com deficiência visual podem ser criadas a partir de estímulos táteis e sonoros, ou mesmo visuais, desde que adequadas aos parâmetros que possibilitem sua percepção por pessoas com baixa visão. Uma vez que a soma dessas referências é mais eficaz do que cada uma isoladamente, para serem mais eficientes e atingirem a diversidade existente no segmento de pessoas com deficiência visual, tais referências devem ser redundantes e integradas. 


\subsubsection{Elementos de wayfinding}

Os dados coletados permitem afirmar que os elementos de wayfinding característicos desta etapa são os seguintes: nós e zonas (Quadro 30). Os elementos de wayfinding - caminhos, nós, zonas - devem ser providos de uma configuração e sinalização tátil, visual e sonora de forma a auxiliar sua identificação por pessoas com deficiência visual e sobressair-se em relação aos demais elementos e informações do ambiente para facilitar sua percepção. Ao mesmo tempo, tais elementos devem estar presentes e ser ressaltados nas informações veiculadas, especialmente quando da elaboração dos materiais táteis, visuais e sonoros voltados à descrição do ambiente das estações, facilitando a compreensão dos percursos desde os elementos de controle de acesso até os elementos de circulação vertical.

Quadro 30 - Elementos de wayfinding da etapa 8 - Deslocamento no mezanino - área paga.

\begin{tabular}{|c|c|c|c|}
\hline Elementos de wayfinding & Configuração & Informação & Serviço \\
\hline Caminhos & $\begin{array}{l}\text { - percurso de saída ou } \\
\text { conexão }\end{array}$ & $\begin{array}{l}\text { - sinalização } \\
\text { tátil/visual/sonora da } \\
\text { configuração do } \\
\text { percurso }\end{array}$ & $\begin{array}{l}\text { - treinamento dos } \\
\text { usuários } \\
\text { - auxílio no } \\
\text { deslocamento }\end{array}$ \\
\hline Nós & $\begin{array}{l}\text { - interseção entre } \\
\text { percursos de embarque } \\
\text { para diferentes } \\
\text { plataformas }\end{array}$ & $\begin{array}{l}\text { - sinalização tátil/visual } \\
\text { das opções de percurso }\end{array}$ & $\begin{array}{l}\text { - treinamento dos } \\
\text { usuários } \\
\text { - auxílio no } \\
\text { deslocamento } \\
\end{array}$ \\
\hline Zonas & $\begin{array}{l}\text { - superfície da área de } \\
\text { circulação no } \\
\text { mezanino-área paga }\end{array}$ & $\begin{array}{l}\text { - contraste visual entre } \\
\text { superfícies horizontais, } \\
\text { verticais e } \\
\text { equipamentos da } \\
\text { estação }\end{array}$ & $\begin{array}{l}\text { - treinamento dos } \\
\text { usuários } \\
\text { - auxílio no } \\
\text { deslocamento } \\
\text { - gestão de fluxos }\end{array}$ \\
\hline
\end{tabular}

Fonte: Elaborado pela pesquisadora.

\subsubsection{Síntese do diagnóstico}

Na etapa 8 - Deslocamento no mezanino - área paga -, foram identificados aspectos que devem ser tratados pelas empresas operadoras dos sistemas metroferroviários para auxiliar pessoas com deficiência visual a estabelecerem estratégias para empreender seus deslocamentos, descritas a seguir:

a) condições das instalações existentes (EC3) - iluminar adequadamente os ambientes; dispor os ambientes e elementos em função da dimensão e complexidade das estações; instalar os elementos de circulação vertical - elevadores e escadas, fixas e rolantes próximos aos bloqueios e ao local de embarque preferencial; dar preferência às soluções padronizadas de configuração, sinalização e iluminação dos ambientes 
característicos do sistema metroferroviário; estabelecer condições adequadas para execução de obras e serviços, garantindo uma rota acessível para embarque; prover contraste entre pisos, paredes, portas, corrimãos e painéis de informação da estação;

b) situação existente dificulta a mobilidade (EC4) - estabelecer os requisitos e as condições adequadas para execução de obras e serviços na rota acessível para embarque; informar eventuais alterações de fluxo;

c) piso tátil - contraste tátil e visual (EI1) - instalar faixa de transição junto ao piso existente para facilitar a identificação do piso tátil nas estações que têm piso emborrachado com pastilhas em relevo;

d) piso tátil - percurso (EI3) - melhorar a compreensão sobre o caminho; manter distanciamento do piso tátil em relação aos obstáculos existentes na edificação; instalar piso tátil em todos os equipamentos e serviços oferecidos na estação; considerar a possibilidade de igualdade com o fluxo dos demais usuários; orientar o percurso para as escadas fixas e rolantes; prever distanciamento adequado entre a sinalização tátil direcional perpendicular e os bloqueios; manter distanciamento do piso tátil em relação aos obstáculos existentes na edificação; instalar sinalização tátil direcional específica para fluxo e contrafluxo, sendo uma para embarque e outra para desembarque; aumentar a área de sinalização tátil de alerta nas interseções entre pisos direcionais; utilizar pisos táteis com percursos diagonais ou em curva em substituição aos percursos ortogonais;

e) informações nos equipamentos (EI4) - dimensionar a sinalização visual de alerta nas portas de vidro para alertar pessoas com baixa visão;

f) informações para a pessoa com deficiência visual - estação (EI6) -disponibilizar informação visual, tátil e sonora e mapas sobre a configuração e principais referências das estações, localização e percursos a serem realizados até os equipamentos de circulação vertical; aumentar o contraste de cor e as dimensões das informações visuais nas placas de sinalização; prover informações e orientações operacionais e institucionais sobre os serviços ofertados (comércio, exposições, espaços institucionais) que sejam claras, objetivas, completas, redundantes; disponibilizar informação tátil, visual ou sonora sobre a configuração e os percursos realizados na estação;

g) treinamento dos empregados - estação (ES1) - incluir abordagem e comunicação adequadas, oferecimento de ajuda com técnicas apropriadas e condução de indivíduos 
ou grupos em planos horizontais utilizando o piso tátil nos programas de capacitação para que o empregado tenha desenvoltura no atendimento; seguir o percurso do piso tátil durante a prestação de auxílio às pessoas com deficiência visual;

h) atendimento pelos empregados (ES2) - dimensionar o quadro de empregados e estagiários de acordo com a demanda para minimizar o tempo de espera para auxílio nos deslocamentos;

i) treinamento dos usuários (ES3) - prover treinamento para os usuários saberem utilizar o piso tátil existente nas estações;

j) comportamento dos demais usuários (ES4) - promover campanhas para orientar o comportamento dos demais usuários nas estações para respeitar, desviar e prestar atenção no deslocamento preferencial da pessoa com deficiência visual sem esbarrar ou machucar;

k) obstáculo próximo ao piso tátil (ES5) - posicionar os direcionadores de fila a uma distância segura do piso tátil;

1) lotação das estações (ES7) - orientar os fluxos de embarque e desembarque simultâneos junto às escadas nas estações de conexão.

\subsection{Etapa 9 - Circulação vertical entre o mezanino e as plataformas}

Nesta etapa, o usuário utiliza os elementos de circulação vertical para dirigir-se às plataformas. Entre os elementos de circulação vertical disponibilizados, destacam-se os seguintes: as escadas fixas, as escadas rolantes, as plataformas de elevação vertical e os elevadores.

\subsubsection{Métodos e técnicas aplicados}

Os métodos e técnicas utilizados para coleta de dados nesta etapa foram apresentados no item 6.10 - Síntese dos instrumentos aplicados - e consistiram em:

1) melhores práticas identificadas em outros sistemas metroferroviários;

m) pesquisa documental (normas técnicas ABNT vigentes, desenhos, procedimentos operacionais);

n) checklist dos recursos disponíveis e walkthrough realizado nas estações para compreensão do percurso de embarque;

o) ficha ambiente das escadas rolantes, elevadores e plataformas de elevação; 
p) questionário aplicado às pessoas com deficiência visual - questões 12, 13 e 17;

q) entrevista com empregados das estações;

r) entrevista com estagiários que auxiliam pessoas com deficiência visual;

s) entrevista com professores de orientação e mobilidade;

t) entrevista com profissionais responsáveis pelo treinamento dos empregados;

u) entrevista com profissionais responsáveis pelos projetos das estações;

v) entrevista com profissionais responsáveis pela elaboração de normas técnicas.

As formas de análise e interpretação dos dados coletados foram apresentadas no Capítulo 6 Aplicação dos instrumentos.

\subsubsection{Melhores Práticas}

Devem ser consideradas as melhores práticas apresentadas no 7.25.2, relativos ao percurso entre o mezanino e a plataforma.

\subsubsection{Requisitos Normativos}

Devem ser considerados os requisitos normativos apresentados no item 7.25.3.

\subsubsection{Avaliação pelos usuários}

Na etapa de circulação vertical entre o mezanino e a plataforma, 8 usuários com deficiência visual - dos quais 6 pessoas são cegas e 2 pessoas têm baixa visão - manifestaram seu descontentamento em relação à estação (100\%). Foram registrados 10 relatos, o que representa $0,4 \%$ do total de relatos registrados para todas as etapas da jornada do usuário. Os relatos estão relacionados, em sua maioria, à disponibilidade de informações nas estações (90,0\%), mas também referem-se à configuração da estação para facilitar a circulação vertical entre o mezanino e a plataforma $(10,0 \%)$.

\footnotetext{
"Eu gostaria de fazer sugestões para ter maior autonomia nas estações. Penso que deveria haver escadas rolantes ou elevadores dos dois lados da plataforma, o que não acontece atualmente. Quando ando pelas estações percebo que as plataformas têm escadas rolantes só de um lado e do outro têm escada fixa... Tem estações que nem escada rolante tem... Outro problema é a falta de informações visuais, táteis e sonoras para que eu possa ter uma ideia sobre a configuração e o percurso nas estações, principalmente nas maiores, onde fica mais difícil minha circulação. Por isso, nas estações grandes, nem sempre dá pra eu andar sozinho... Finalizando, considero que seria importante fazer adequações nas estações para facilitar a minha circulação ou dos outros deficientes visuais. Coisas simples - como colocar as escadas rolantes ou instalar mais elevador próximo ao vagão preferencial - melhorariam bastante a acessibilidade.” (Discurso do Sujeito Coletivo - Etapa 9)
} 
Os problemas relatados pelos usuários estão relacionados às seguintes ideias centrais:

a) instalação de elementos de circulação vertical (EC2) - falta de escadas rolantes em todas as plataformas;

b) condições das instalações existentes (EC3) - problemas nas condições de segurança e na configuração das estações;

c) informações para a pessoa com deficiência visual - estação (EI6) - insuficiência de informação tátil, visual e sonora sobre a configuração das estações e o percurso durante os deslocamentos.

\subsubsection{Avaliação pelas pessoas-chave}

Os empregados das estações consideram necessária a instalação de elementos de circulação vertical (EC2), notadamente escadas rolantes, entre o mezanino e a plataforma, em todas as estações (Figura 165). Também relataram a importância da localização dos equipamentos de circulação vertical no centro da plataforma, de forma a distribuir de maneira equitativa a concentração de pessoas ao longo das plataformas e equilibrar as distâncias para embarque e desembarque (Figura 166).
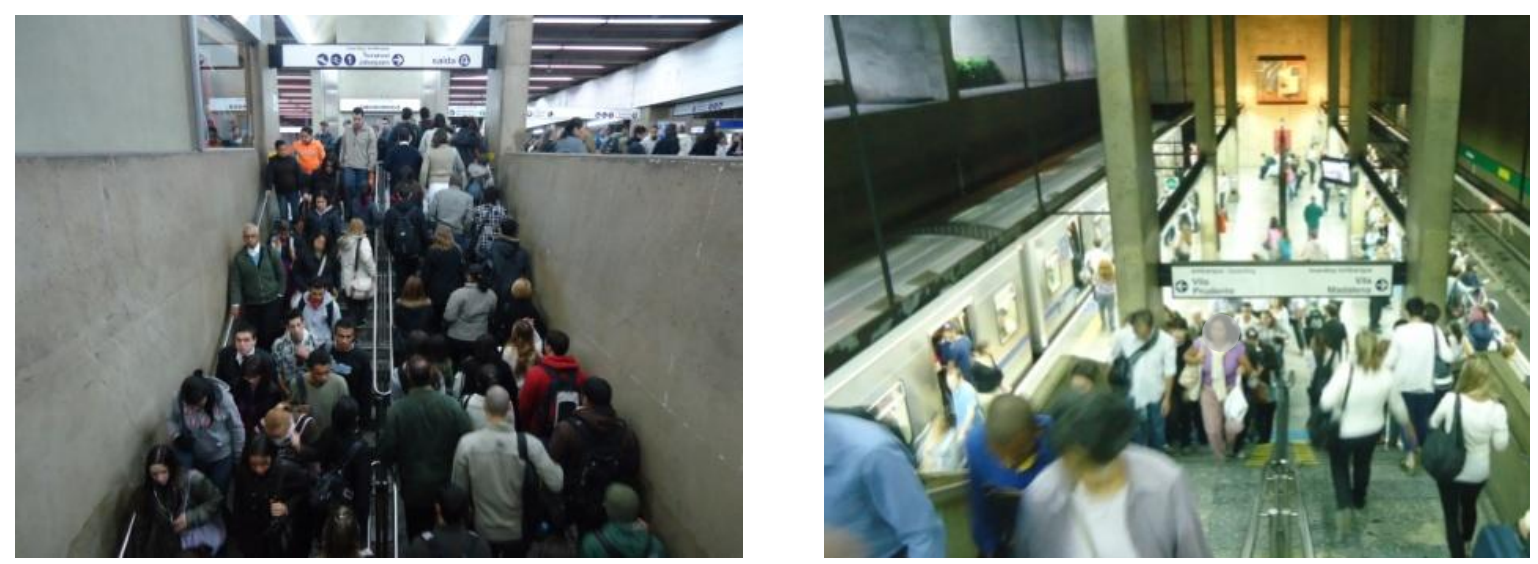

Figura 165 - São Paulo - Inexistência de escadas rolantes na plataforma da Linha 2 - Verde. Fonte: BARBOSA, M.B., 2011. 

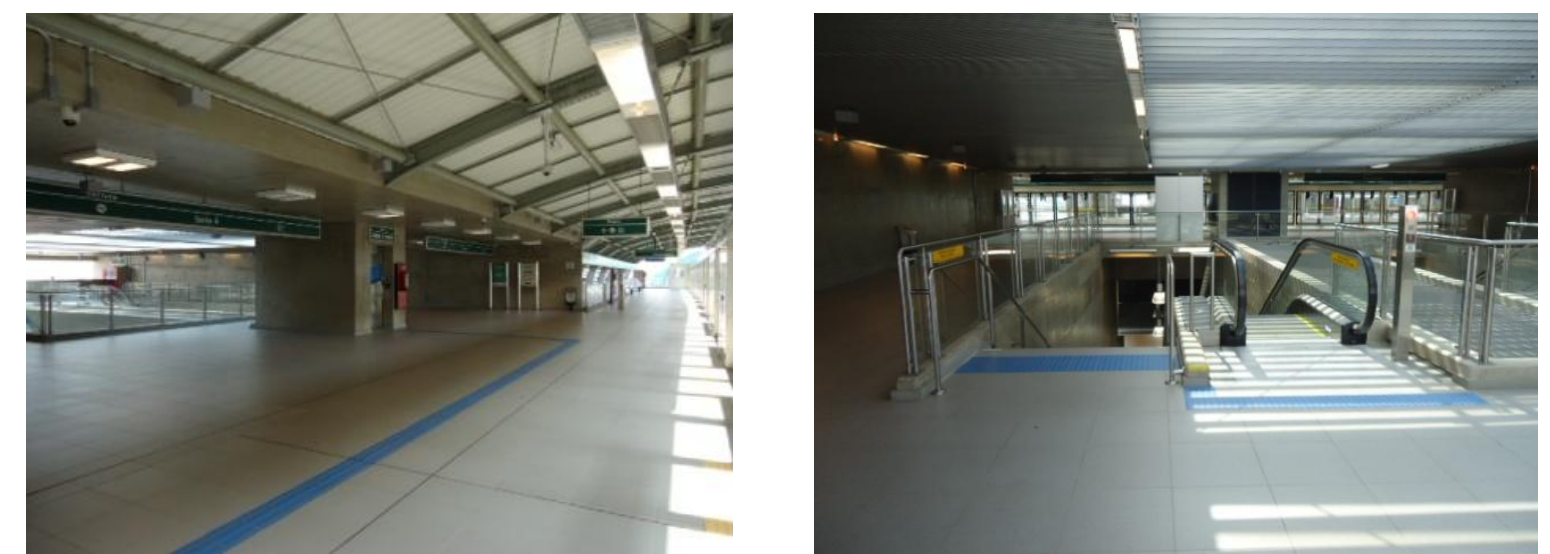

Figura 166 - São Paulo - elevador e escadas fixas e rolantes no centro da plataforma Fonte: BARBOSA, M.B., 2011.

Os estagiários relataram que as pessoas com deficiência visual demonstram preferência pelo uso das escadas rolantes em relação às escadas fixas, mas raramente pedem para usar o elevador, exceto se têm algum problema de mobilidade. Os deslocamentos nas escadas fixas e rolantes são afetados pela lotação das estações (ES7) e pelo comportamento dos demais usuários - estação (ES4), que, em função da pressa ou de comportamentos individualistas, esbarram ou empurram as pessoas com deficiência e o estagiário. A escolha da escada é, em sua maioria, determinada pela proximidade em relação ao local de embarque uma vez que as pessoas com deficiência preferem andar em distâncias maiores no mezanino e não na plataforma.

\subsubsection{Avaliação pelos especialistas}

Os profissionais responsáveis pelos projetos das estações relataram que a existência de piso tátil - percurso (EI3) somente junto aos elevadores dificulta a percepção da escala e dos referenciais da estação. Quando os deslocamentos se dão por meio das escadas fixas ou rolantes, permitem ao usuário seguir os referenciais do ambiente e compreender a continuidade do percurso entre a plataforma e o mezanino.

\subsubsection{Elementos de wayfinding}

Devem ser considerados os elementos de wayfinding mencionados no item 7.25.8.

\subsubsection{Síntese do diagnóstico}

Na etapa 9 - Circulação vertical entre o mezanino e a plataforma -, foram identificados aspectos que devem ser tratados pelas empresas operadoras dos sistemas metroferroviários 
para auxiliar as pessoas com deficiência visual a estabelecer estratégias para empreender seus deslocamentos, descritos a seguir:

a) instalação de elementos de circulação vertical (EC2) - instalar escadas rolantes e elevadores entre o mezanino e as plataformas, em todas as estações;

b) condições das instalações existentes (EC3) - melhorar as condições de segurança e a configuração das estações;

c) piso tátil - percurso (EI3) - orientar os deslocamentos por meio da sinalização tátil de piso para os elevadores e as escadas simultaneamente, possibilitando opção de percurso segundo a preferência do usuário;

d) informações nos equipamentos (EI4) - melhorar as informações nos elevadores, escadas rolantes, intercomunicadores; padronizar as botoeiras dos elevadores para facilitar a utilização dos elevadores; reduzir a diversidade de comandos dos equipamentos;

e) informações para a pessoa com deficiência visual - estação (EI6) - disponibilizar informação tátil, visual e sonora sobre a configuração das estações e os percursos para utilização dos equipamentos de circulação vertical;

f) lotação das estações (ES7) - organizar o fluxo de pessoas junto às escadas fixas e rolantes para disciplinar o comportamento dos usuários e melhorar as condições de segurança;

g) comportamento dos demais usuários - estação (ES4) - promover campanhas para orientar os demais usuários a não esbarrar ou empurrar as pessoas com deficiência visual e seus acompanhantes.

\subsection{Etapa 10 - Deslocamento até o local de embarque na plataforma}

Nesta etapa, o usuário desloca-se na plataforma, entre os elementos de circulação vertical e a área de embarque preferencial.

\subsubsection{Métodos e técnicas aplicados}

Os métodos e técnicas utilizados para coleta de dados nesta etapa foram apresentados no item 6.10 - Síntese dos instrumentos aplicados - e consistiram em: 
a) melhores práticas identificadas em outros sistemas metroferroviários;

b) pesquisa documental (normas técnicas ABNT vigentes, desenhos, procedimentos operacionais);

c) checklist dos recursos disponíveis e walkthrough realizado nas estações para compreensão do percurso de embarque;

d) questionário aplicado em pessoas com deficiência visual - questões 12, 13 e 17;

e) entrevista com empregados das estações;

f) entrevista com profissionais responsáveis pelo treinamento dos empregados;

g) entrevista com estagiários que auxiliam pessoas com deficiência visual;

h) entrevista com professores de orientação e mobilidade.

As formas de análise e interpretação dos dados coletados foram apresentadas no Capítulo 6 Aplicação dos instrumentos.

\subsubsection{Melhores Práticas}

Entre as melhores práticas, destacam-se as estações do Metrô de Barcelona, que tem como requisitos de projeto, a existência de contraste visual entre superfícies para facilitar a legibilidade e a compreensão dos espaços e ambientes e de piso tátil direcional para orientar os deslocamentos (Figura 167). As novas estações dispõem de portas nas plataformas, aumentando as condições de segurança nos deslocamentos e na espera pelo trem.
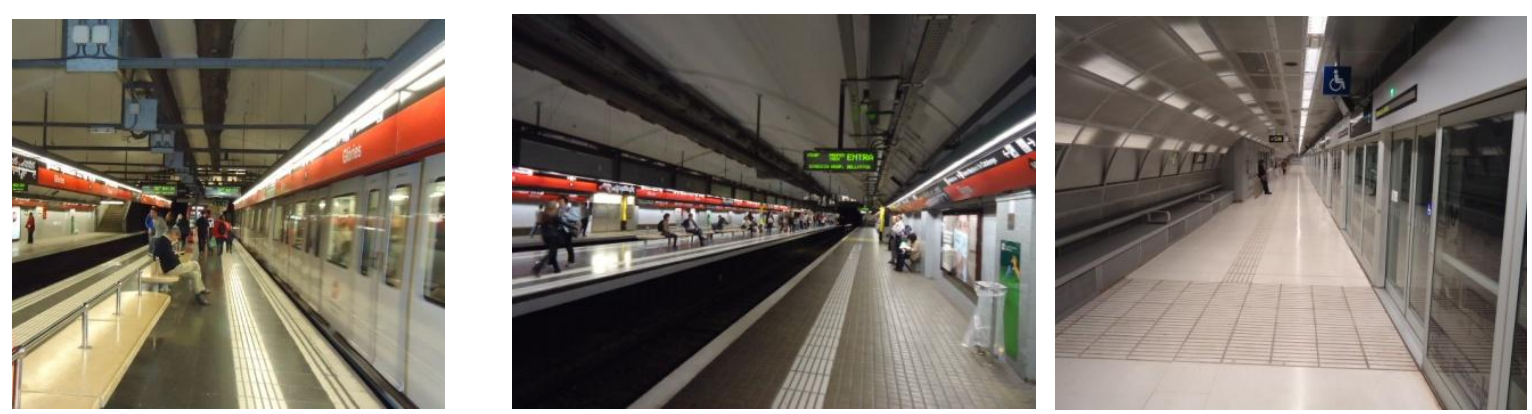

Figura 167 - Barcelona - Sinalização do percurso nas plataformas central e lateral, com e sem porta de plataforma. Fonte: BARBOSA, M.B., 2011.

Nas estações do Metrô de Tóquio, as plataformas centrais dispõem de portas em cor contrastante e identificação com números. Painéis eletrônicos informam o tempo para chegada dos próximos trens (Figura 168). 

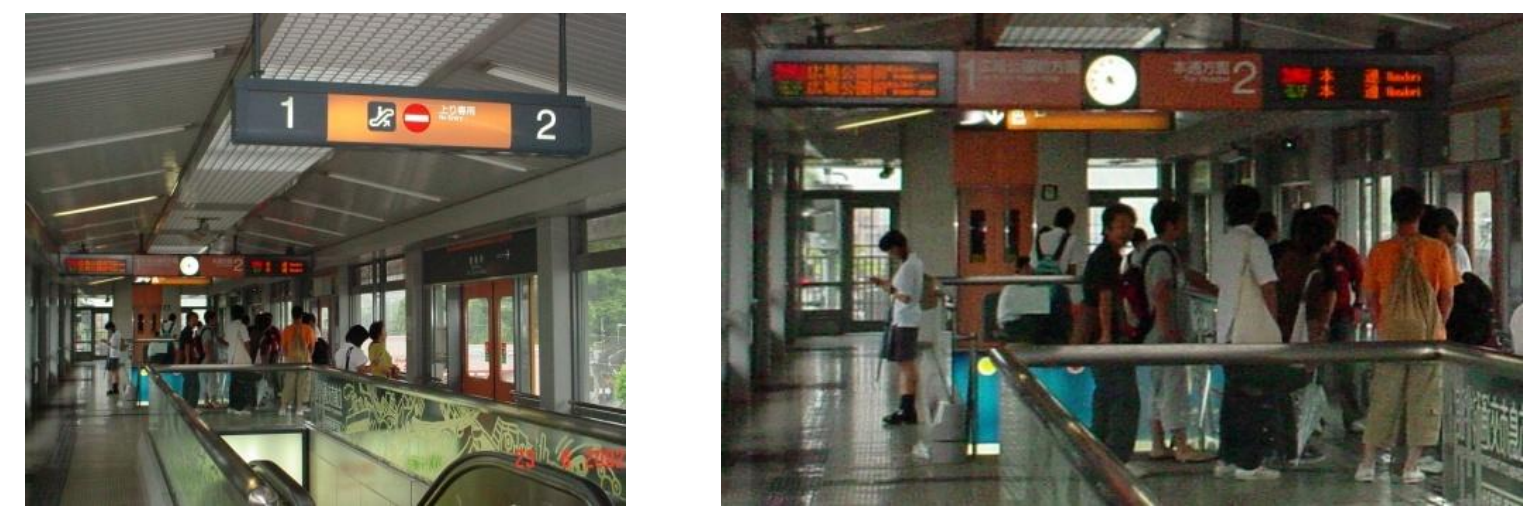

Figura 168 - Tóquio - Sinalização da plataforma central.

Fonte: BARBOSA, M.B., 2013.

\subsubsection{Requisitos Normativos}

Com relação aos requisitos normativos, a ABNT NBR 14021:2005 determina a necessidade de rota acessível até o local para embarque preferencial para pessoas com deficiência, identificada por meio de sinalização tátil e visual de piso e sinalização suspensa indicativa do embarque preferencial alinhada com o espaço reservado dentro do trem. As plataformas devem ser identificadas por meio de letras, números ou nomes e, para garantir a segurança durante o deslocamento ou a espera pelo trem, devem ter sinalização visual e piso tátil de alerta na borda, junto à via.

\subsubsection{Situação no Metrô de São Paulo}

O Metrô de São Paulo estabeleceu que a circulação vertical das pessoas com deficiência entre o mezanino e a plataforma deve ser realizada exclusivamente por meio dos elevadores, que permitem fluxo bidirecional. O percurso entre o elevador e o local de embarque preferencial é sinalizado com piso tátil direcional, qualquer que seja a tipologia da plataforma - central, lateral ou mista (Figura 169 a 172). O local de embarque preferencial das pessoas com deficiência visual está alinhado com a segunda porta do carro líder do trem.

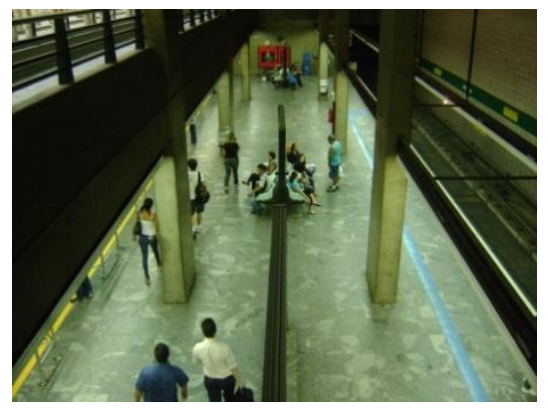

(a)

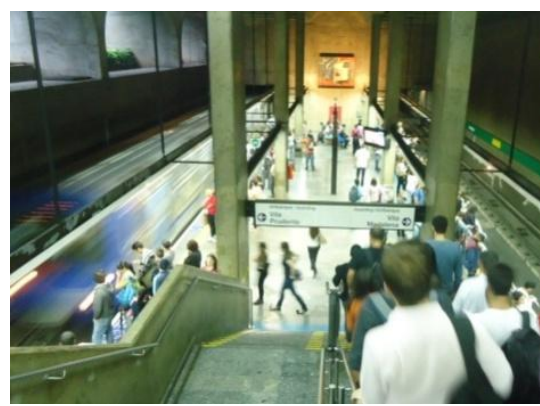

(b)

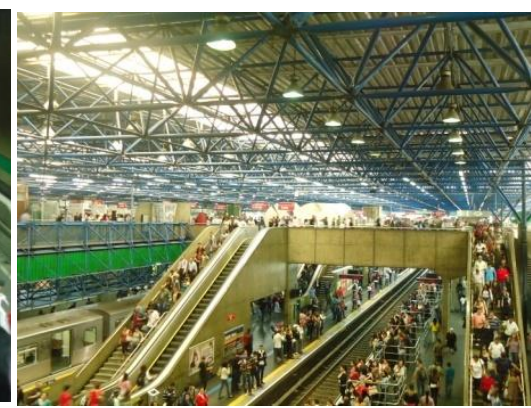

(c)

Figura 169 - São Paulo - Plataformas centrais (a, b) e mistas (c).

Fonte: BARBOSA, M.B., 2011. 

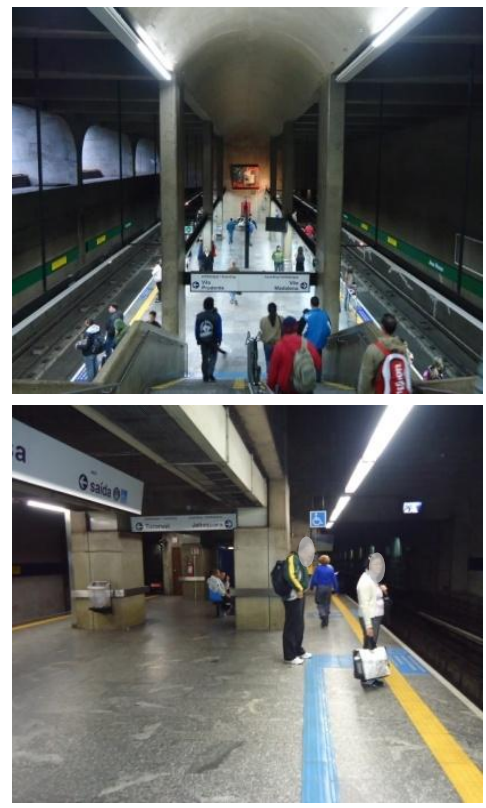

Figura 170 - São Paulo - Vista geral e sinalização da plataforma central. Fonte: BARBOSA, M.B., 2011.

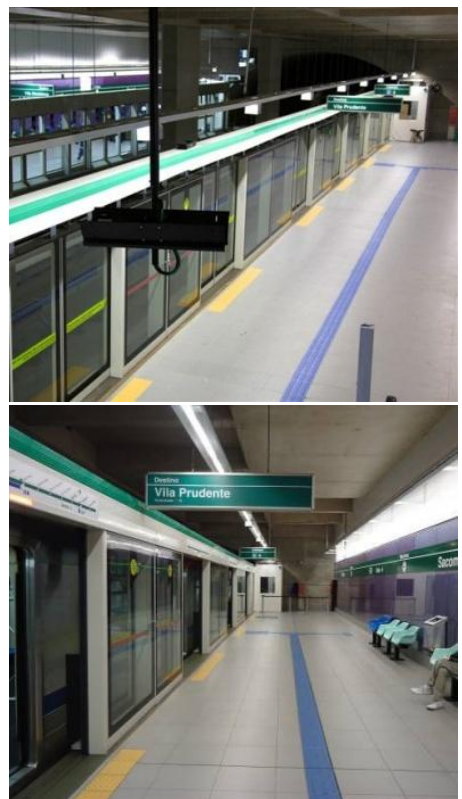

Figura 171 - São Paulo - Vista geral e sinalização da plataforma lateral. Fonte: BARBOSA, M.B., 2011.

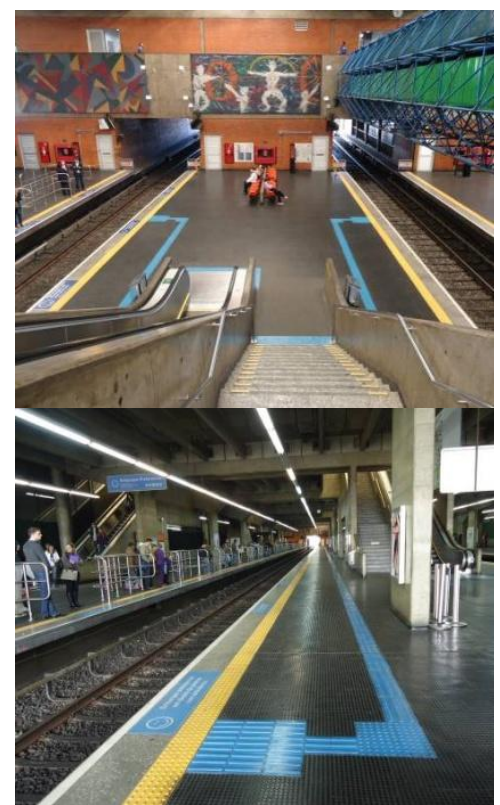

Figura 172 - São Paulo - Vista geral e sinalização da plataforma mista. Fonte: BARBOSA, M.B., 2011.

\subsubsection{Avaliação pelos usuários}

Na etapa de deslocamento até o local de embarque, 69 usuários com deficiência visual - dos quais 59 pessoas são cegas e 10 pessoas têm baixa visão - manifestaram seu descontentamento em relação à estação $(73 \%)$ e à interface trem-estação (26,2\%). Foram registrados 139 relatos, o que representa 5,2\% do total de relatos registrados para todas as etapas da jornada do usuário. Os relatos estão relacionados, em sua maioria, à disponibilidade de informações nas estações $(38,8 \%)$, mas também são dirigidos à configuração da interface trem-estação $(24,5 \%)$ e da estação $(20,9 \%)$, como também aos serviços prestados na estação $(15,1 \%)$ para facilitar o deslocamento até o local de embarque (Tabela 22).

Tabela 22 - Matriz de avaliação da etapa 10 - Deslocamento até o local de embarque.

(\% em relação ao total de relatos registrados nesta etapa)

\begin{tabular}{l|r|r|r|r}
\hline & \multicolumn{1}{|c|}{$\begin{array}{c}\text { Configuração } \\
\text { \% }\end{array}$} & $\begin{array}{c}\text { Informação } \\
\text { \% }\end{array}$ & $\begin{array}{c}\text { Serviço } \\
\%\end{array}$ & $\begin{array}{c}\text { Total } \\
\%\end{array}$ \\
\hline Estação & (EC) 20,9 & (EI) $\mathbf{3 8 , 8}$ & (ES) 15,1 & $\mathbf{7 4 , 8}$ \\
\hline Interface Trem-Estação & (IC) 24,5 & (II) $\mathbf{0 , 7}$ & $\mathbf{0 , 0}$ & $\mathbf{2 5 , 2}$ \\
\hline Trem & $\mathbf{0 , 0}$ & $\mathbf{0 , 0}$ & $\mathbf{0 , 0}$ & $\mathbf{0 , 0 0}$ \\
\hline Total & $\mathbf{4 5 , 4}$ & $\mathbf{3 9 , 5}$ & $\mathbf{1 5 , 1}$ & $\mathbf{1 0 0 , 0}$ \\
\hline
\end{tabular}

"Eu considero importante ter uma barreira entre a plataforma e a via que, para minha segurança, fosse alguma coisa que eu percebesse ou que evitasse que eu caísse na via... Não gosto quando a estação tem plataforma central. Nessas estações eu peço a ajuda de empregado porque eu fico sem referência: não tenho uma parede para me guiar e a minha audição também fica prejudicada, porque capta muita coisa ao mesmo tempo... Acho que em algumas 
estações colocaram o piso tátil muito na beirada da plataforma, quando ele deveria estar mais próximo da parede. Seria mais seguro para mim se colocassem as escadas rolantes e os elevadores próximos do vagão preferencial: isso evitaria que eu tivesse que andar toda a plataforma que, no horário de pico, fica muito lotada... Deveria ter piso tátil levando para as escadas rolantes, isto me deixaria mais seguro porque minha maior insegurança é quando estou na plataforma... Tem estações que tenho que andar toda a plataforma para embarcar no primeiro vagão. Acho que o piso tátil deveria percorrer toda a plataforma, para que eu tivesse opção de embarcar em outro vagão ou outras portas do trem, no meio e no final também... Acho que é preciso modificar o piso tátil próximo dos obstáculos, - paredes, hidrantes e colunas - para que não ocorram acidentes... Minha opinião: é importante diferenciar mais a cor do piso tátil do piso normal... Não sei como isso pode ser feito. Outro problema que eu enfrento é quando a estação está lotada: não tenho como andar no piso tátil porque as pessoas ficam em cima dele e eu trombo nelas. Fora isso, as pessoas deixam malas ou pacotes no piso tátil e eu tenho que ficar me desviando e, neste vai e volta, eu perco a referência. Acho que deveriam falar nos alto-falantes, fazer campanhas para explicar para as outras pessoas para que serve o piso tátil, para que elas deixem o caminho livre... A acessibilidade para o deficiente visual recente está na informação sonora e não no Braille... Faltam também placas com letras grandes e um mapa da linha e das estações na plataforma para que pessoas como eu, que tenho baixa visão - possam ter informação... Sinto falta de um treinamento para eu usar o piso tátil, pois nas estações que não conheço fica difícil me locomover." (Discurso do Sujeito Coletivo - Etapa 10)

Os principais problemas relatados pelos usuários na etapa de deslocamento até o local de embarque são apresentados de forma hierarquizada, conforme número de relatos registrados (Gráfico 28).

Gráfico 28 - Avaliação da etapa 10 - Deslocamento até o local de embarque.

(\% em relação ao total de relatos registrados nesta etapa)

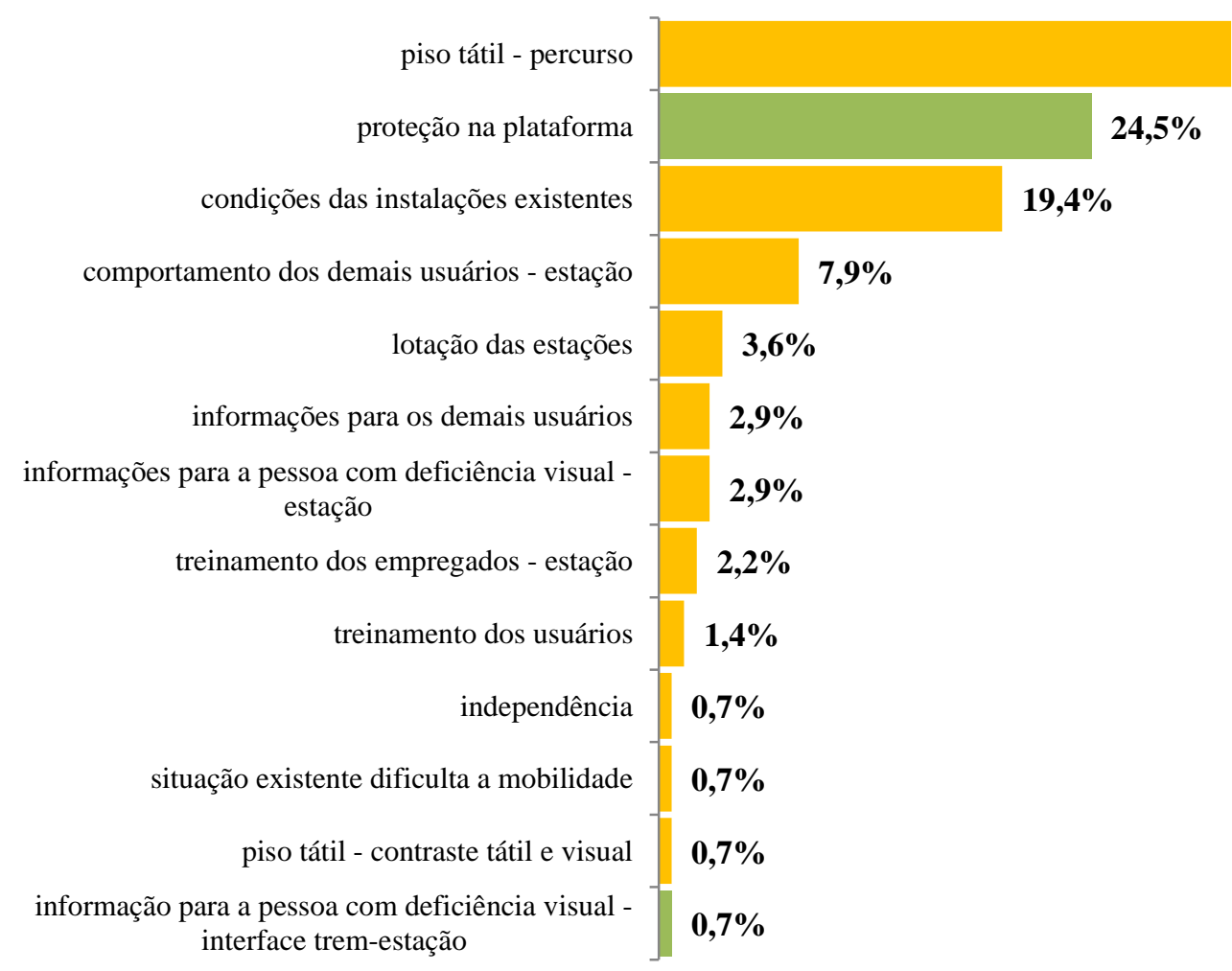


Os problemas relatados estão relacionados às seguintes ideias centrais:

a) piso tátil - percurso (EI3) - refere-se ao fato de o piso tátil não direcionar para todos os equipamentos e serviços oferecidos na estação e ser inadequado no percurso na plataforma, além de apontar a proximidade do piso tátil em relação aos obstáculos da edificação;

b) proteção na plataforma (IC2) - relata a inexistência de barreiras ou portas nas plataformas em todas as estações;

c) condições das instalações existentes (EC3) - refere-se à existência de problemas na configuração das estações, nas condições de segurança e na localização do mobiliário e dos equipamentos;

d) comportamento dos demais usuários - estação (ES4) - relata o comportamento indevido dos demais usuários em relação à permanência sobre o piso tátil, dificultando o deslocamento das pessoas com deficiência visual até o local de embarque;

e) lotação das estações (ES7) - dificuldade de utilização do piso tátil em função da intensa circulação de usuários nas estações;

f) informações para os demais usuários (EI7) - falta de orientação para os demais usuários quanto à finalidade do piso tátil e sobre o embarque preferencial;

g) informações para a pessoa com deficiência visual - estação (EI6) -inexistência de informação tátil, visual ou sonora sobre a configuração e os percursos realizados na estação e a falta de contraste ou as dimensões inadequadas das informações visuais;

h) treinamento dos empregados - estação (ES1) - insatisfação em relação ao treinamento realizado pelos estagiários e a preferência pelo atendimento realizado pelos empregados;

i) treinamento dos usuários (ES3) - falta de treinamento dos usuários para utilizar o piso tátil disponível nas estações;

j) independência (EC1) - falta de padronização das plataformas das estações (sempre plataforma lateral), fato que dificulta a adoção de estratégias de contorno para deslocamentos independentes;

k) situação existente dificulta a mobilidade (EC4) - existência de obras nas estações que alteram as condições de circulação e por vezes dificultam os deslocamentos;

1) piso tátil - contraste tátil e visual (EI1) - insuficiência de contraste das cores e dos relevos do piso tátil; 
m) informações para a pessoa com deficiência visual - interface trem-estação (II1) falta de sinalização do local de embarque e o dimensionamento insuficiente da faixa tátil de alerta.

\subsubsection{Avaliação pelas pessoas-chave}

Na etapa de deslocamento até o local de embarque, os empregados das estações destacaram as condições das instalações existentes (EC3) e consideraram que a configuração das plataformas centrais ou mistas (central + lateral) pode gerar maior insegurança para os usuários ou maior possibilidade de acidentes (Figura 173), em função da falta de proteção ou de referências edificadas para balizamento durante o deslocamento.

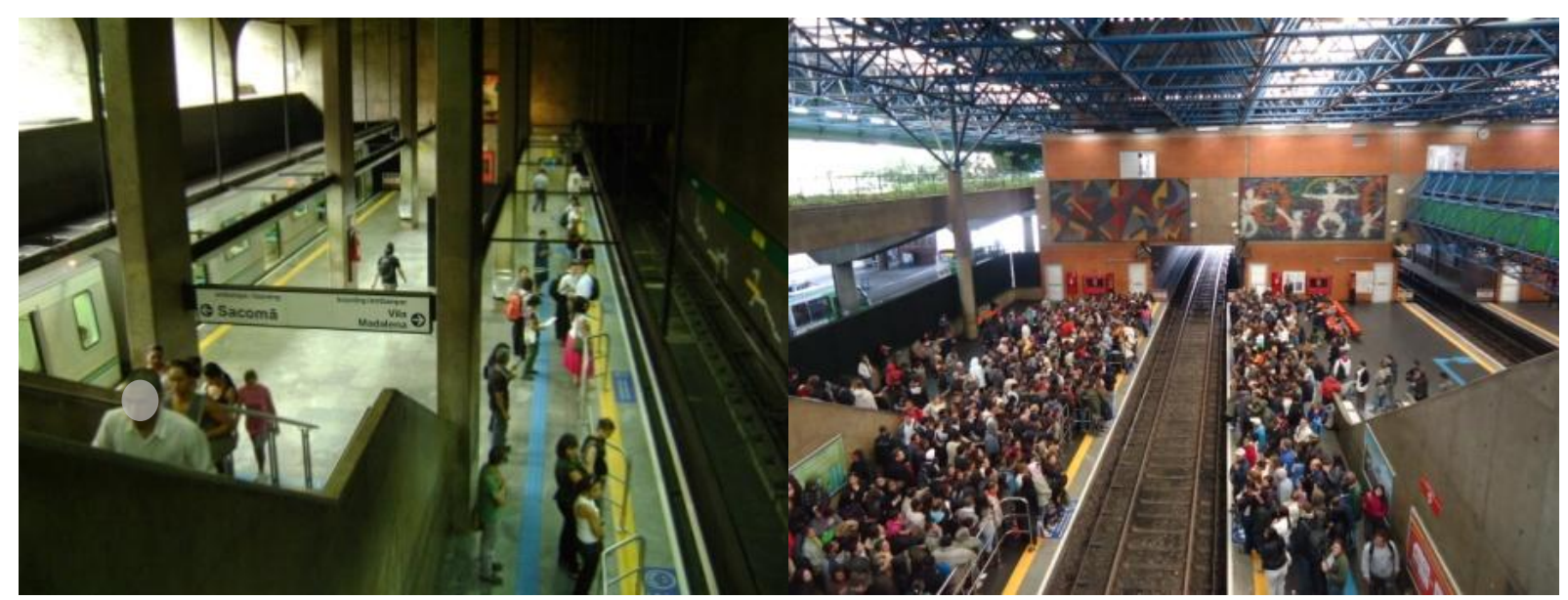

Figura 173 - São Paulo - Largura insuficiente e lotação das plataformas. Fonte: BARBOSA, M.B., 2011.

Há consenso de que as condições das instalações existentes (EC3), notadamente a largura insuficiente das plataformas frente à lotação das estações (ES7) e o mau comportamento dos demais usuários (ES4), geram conflitos e cruzamentos de fluxo, agravando a condição existente.

Quando tal condição está associada à falta de proteção nas plataformas (IC2), pode gerar insegurança nos usuários com deficiência visual. Os empregados das estações consideram essencial a instalação de portas de plataformas para que sejam garantidas as condições de segurança das pessoas com deficiência visual (Figura 174). 

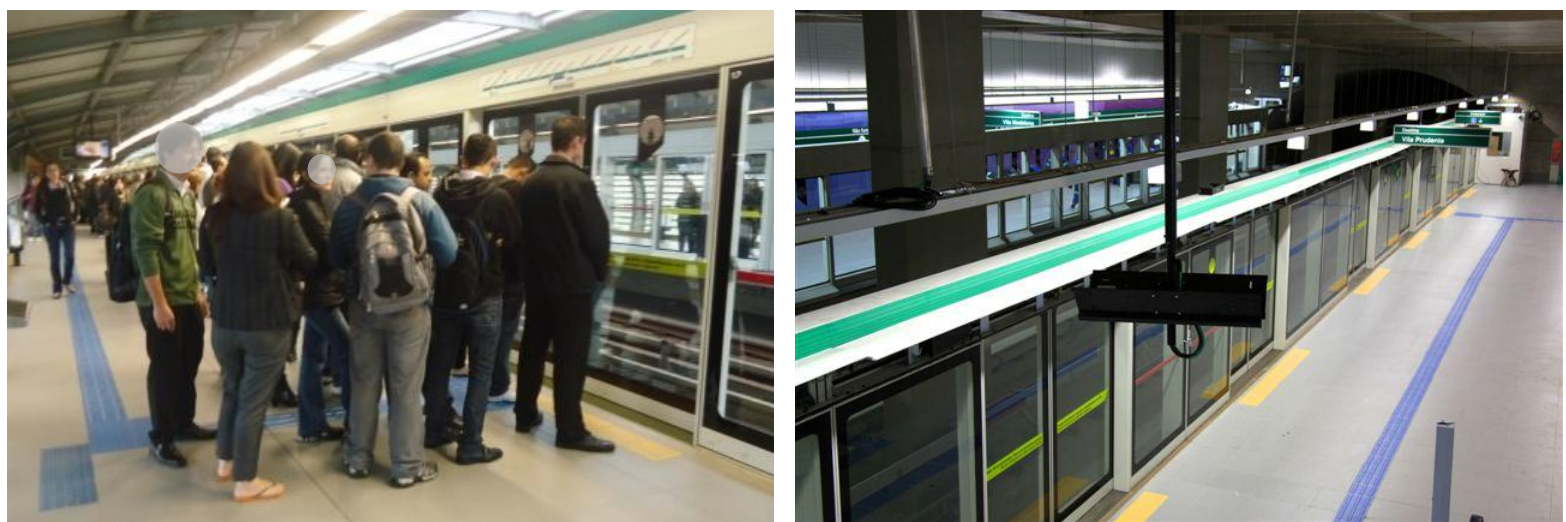

Figura 174 - São Paulo - Porta de proteção na plataforma lateral. Fonte: BARBOSA, M.B., 2011.

Os estagiários relataram que a apreensão durante o uso da sinalização tátil no piso é decorrente da dificuldade de compreensão do piso tátil - percurso (EI3), especialmente da falta de percepção das mudanças de direção, fato que pode causar acidentes. Os estagiários destacaram o cumprimento do procedimento operacional - interface (IS1), que estabelece o embarque no primeiro carro, mesmo que isso contrarie o desejo das pessoas com deficiência visual. Como em outras áreas da estação, são destacadas dificuldades relacionadas à prestação de auxílio às pessoas com deficiência visual em função da lotação das estações (ES7) e do mau comportamento dos usuários (ES4), que param ou circulam sobre o piso tátil e não dão preferência ao deslocamento da pessoa com deficiência visual.

Os professores de orientação e mobilidade relataram que a ausência de uma faixa de transição traz dificuldades para identificar o piso tátil - contraste tátil e visual (EI1) em relação ao piso existente, notadamente nas estações que têm piso emborrachado com pastilhas em relevo. Em relação ao piso tátil - percurso (EI3), há críticas ao dimensionamento insuficiente da sinalização tátil de alerta nas interseções entre pisos direcionais - o que dificulta a percepção quanto às mudanças de direção -, à proximidade da sinalização direcional em relação à borda da plataforma e à inexistência de sinalização direcional nas plataformas laterais das estações com plataformas mistas. Entende-se que o fato de a sinalização existir somente a partir do elevador, desconsiderando percursos a partir das escadas fixas e rolantes, ou seja, por não considerar ou ser igual ao percurso dos demais usuários, pode gerar eventuais conflitos de fluxo e ser um fator inibidor do uso da sinalização tátil no piso. Isso se justifica pelo fato de que as pessoas com deficiência visual que participam dos treinamentos de orientação e mobilidade preferem usar escadas que cheguem próximas ao local de embarque preferencial. Quanto às condições das instalações existentes (EC3), foi destacada a insuficiência de iluminação em algumas plataformas, constituindo-se em um risco para pessoas com baixa 
visão. Sobre as informações nos equipamentos (EI4), destacaram o subdimensionamento das faixas contrastantes nas portas de vidro, insuficientes para alertar pessoas com baixa visão. Quanto às informações para a pessoa com deficiência visual - estação (EI6), ressaltaram que a compreensão do percurso realizado na plataforma pode ser ampliada com o auxílio de mapas táteis e descrições sonoras contendo as referências principais das estações, permitindo informações em igualdade de condições com os demais usuários.

\subsubsection{Avaliação pelos especialistas}

Os profissionais responsáveis pela elaboração de normas técnicas relataram que soluções padronizadas relacionadas à configuração, sinalização e iluminação dos ambientes característicos do sistema metroferroviário contribuem para prover segurança, autonomia e agilidade nos deslocamentos. Entre as soluções que podem contribuir para a segurança e a independência dos deslocamentos em função das condições das instalações existentes (EC3), foram feitas recomendações para melhoria dos textos normativos vigentes, destacando o estabelecimento de condições adequadas para execução de obras e serviços, garantindo uma rota acessível para embarque e a existência de contraste entre pisos, paredes, pilares e painéis de informação da estação. As informações para a pessoa com deficiência visual - estação (EI6) devem ser claras, objetivas e completas, além de redundantes, para que as orientações operacionais e institucionais sobre os serviços ofertados (comércio, exposições e espaços institucionais) possam contribuir para que os passageiros alcancem seus destinos com segurança. As referências necessárias para orientar os deslocamentos das pessoas com deficiência visual podem ser criadas a partir de estímulos táteis e sonoros, ou mesmo visuais, desde que adequados aos parâmetros que possibilitem sua percepção por pessoas com baixa visão. Tais referências devem ser redundantes e integradas, uma vez que a soma dessas referências é mais eficaz do que cada uma isoladamente, para atingir a diversidade existente no segmento de pessoas com deficiência visual.

\subsubsection{Elementos de wayfinding}

Os dados coletados permitem afirmar que os elementos de wayfinding característicos desta etapa são os seguintes: caminhos e limites (Quadro 31). Os elementos de wayfinding caminhos e limites - devem ter configuração adequada e ser providos de sinalização tátil/visual/sonora, de forma a auxiliar sua identificação pelas pessoas com deficiência visual e sobressair-se em relação aos demais elementos e informações do ambiente para facilitar sua 
percepção. Ao mesmo tempo, tais elementos devem estar presentes e ser ressaltados nas informações veiculadas, especialmente quando da elaboração dos materiais táteis, visuais e sonoros voltados à descrição do ambiente das estações, resultando em melhor compreensão dos percursos desde os elementos de circulação vertical até o local de embarque.

Quadro 31 - Elementos de wayfinding da Etapa 10 - Deslocamento até o local de embarque na plataforma.

\begin{tabular}{|c|c|c|c|}
\hline $\begin{array}{l}\text { Elementos de } \\
\text { wayfinding }\end{array}$ & Configuração & Informação & Serviço \\
\hline Caminhos & $\begin{array}{l}\text { - percurso entre a } \\
\text { circulação vertical e o } \\
\text { local de embarque na } \\
\text { plataforma }\end{array}$ & $\begin{array}{l}\text { - tátil, sonora e visual sobre } \\
\text { a configuração e o } \\
\text { percurso, considerando a } \\
\text { opção de destino }\end{array}$ & $\begin{array}{l}\text { - treinamento dos usuários } \\
\text { - funcionários para auxiliar } \\
\text { no deslocamento }\end{array}$ \\
\hline Limites & $\begin{array}{l}\text { - limite da plataforma } \\
\text { - portas de fechamento da } \\
\text { plataforma }\end{array}$ & $\begin{array}{l}\text { - sinalização tátil/visual da } \\
\text { borda da plataforma }\end{array}$ & $\begin{array}{l}\text { - campanhas sobre o } \\
\text { atendimento preferencial } \\
\text { - gestão do embarque } \\
\text { preferencial }\end{array}$ \\
\hline
\end{tabular}

Fonte: Elaborado pela pesquisadora.

\subsubsection{Síntese do diagnóstico}

Na etapa 10 - Deslocamento até o local de embarque -, foram identificados aspectos que devem ser tratados pelas empresas operadoras dos sistemas metroferroviários para auxiliar as pessoas com deficiência visual a estabelecer estratégias para empreender seus deslocamentos:

a) independência (EC1) - padronizar as plataformas das estações para facilitar a adoção de estratégias de contorno para deslocamentos independentes; promover a aprendizagem de estratégias de contorno;

b) condições das instalações existentes (EC3) - evitar plataformas centrais e mistas; dimensionar as plataformas em função da demanda; manter as áreas de circulação livres de obstáculos como mobiliário e equipamentos; estabelecer condições adequadas para execução de obras e serviços; ampliar a sensação de segurança por meio da instalação de câmeras de monitoração; garantir uma rota acessível para embarque; prever contraste entre piso, paredes, pilares e painéis de informação da estação; garantir nível de iluminação adequado;

c) situação existente dificulta a mobilidade (EC4) - estabelecer condições adequadas para execução de obras e serviços; facilitar e garantir condições adequadas de circulação;

d) piso tátil - contraste tátil e visual (EI1) - aumentar o contraste das cores e dos relevos do piso tátil; 
e) piso tátil - percurso (EI3) - melhorar a compreensão do percurso; aumentar a área de sinalização tátil de alerta nas interseções entre pisos direcionais; instalar piso tátil direcional em todos os equipamentos e serviços oferecidos na estação; manter distanciamento do piso tátil em relação aos obstáculos existentes (colunas, pilares); manter distanciamento do piso tátil direcional em relação à borda da plataforma; instalar sinalização direcional nas plataformas laterais das estações com plataformas mistas; considerar a possibilidade de ser igual ao percurso dos demais usuários para evitar conflitos de fluxo e incentivar o seu uso; direcionar para as escadas fixas e rolantes próximas do local de embarque; melhorar a compreensão sobre o caminho;

f) informações nos equipamentos (EI4) - instalar faixas contrastantes nas portas de vidro com dimensões adequadas às pessoas com baixa visão;

g) informações para a pessoa com deficiência visual - estação (EI6) - prover mapas táteis, informações e descrições sonoras para orientar os percursos, permitindo informações em igualdade de condições com os demais usuários; aumentar o contraste e as dimensões das informações visuais; prover informações e orientações operacionais e institucionais sobre os serviços ofertados (comércio, exposições, espaços institucionais) que sejam claras, objetivas, completas, redundantes; criar referências e estímulos táteis, visuais e sonoros integrados que possibilitem sua percepção por pessoas com baixa visão;

h) informações para os demais usuários (EI7) - promover campanhas para orientar os demais usuários sobre a finalidade do piso tátil; promover campanhas para orientar os demais usuários sobre o embarque preferencial;

i) treinamento dos empregados - estação (ES1) - padronizar atendimento pelos estagiários e empregados;

j) treinamento dos usuários (ES3) - treinar os usuários para utilização do piso tátil;

k) comportamento dos demais usuários - estação (ES4) - promover campanhas para orientar os demais usuários a não andar ou permanecer sobre piso tátil, atentar para o deslocamento preferencial durante a prestação de auxílio às pessoas com deficiência visual;

1) lotação das estações (ES7) - organizar o fluxo de usuários nas plataformas para evitar conflitos e cruzamentos de fluxo e facilitar a prestação de auxílio pelos estagiários;

m) proteção na plataforma (IC2) - instalar barreiras ou portas de plataforma em todas as estações, especialmente nas estações mais lotadas; 
n) informações para a pessoa com deficiência visual - interface trem-estação (II1) sinalizar o local de embarque preferencial; aumentar o contraste e as dimensões das informações visuais existentes nas plataformas;

o) procedimento operacional - interface (IS1) - orientar usuários sobre a importância do embarque no primeiro carro.

\subsection{Etapa 11 - Espera pelo trem}

Nesta etapa, o usuário permanece na área de embarque preferencial e aguarda a chegada do trem.

\subsubsection{Métodos e técnicas aplicados}

Os métodos e técnicas utilizados para coleta de dados nesta etapa foram apresentados no item 6.10 - Síntese dos instrumentos aplicados - e consistiram em:

a) melhores práticas identificadas em outros sistemas metroferroviários;

b) pesquisa documental (normas técnicas ABNT vigentes, desenhos, procedimentos operacionais);

c) checklist dos recursos disponíveis e walkthrough realizado nas estações para compreensão da condição de espera pelo trem;

d) questionário aplicado em pessoas com deficiência visual - questões 12, 13 e 17;

e) entrevista com empregados das estações;

f) entrevista com profissionais responsáveis pelo treinamento dos empregados;

g) entrevista com estagiários que auxiliam as pessoas com deficiência visual;

h) entrevista com professores de orientação e mobilidade.

As formas de análise e interpretação dos dados coletados foram apresentadas no Capítulo 6 Aplicação dos instrumentos.

\subsubsection{Melhores Práticas}

Entre as melhores práticas, destacam-se as estações de Tóquio, que dispõem de portas de embarque em cor contrastante com o fechamento da plataforma e de maior intensidade de iluminação, além de sinalização visual de identificação da linha, do sentido do trem e das próximas estações da linha, bem como de alarme sonoro e visual indicativo do fechamento 
das portas. As plataformas dispõem de sinalização retroiluminada para indicar rotas de fuga (Figura 175).
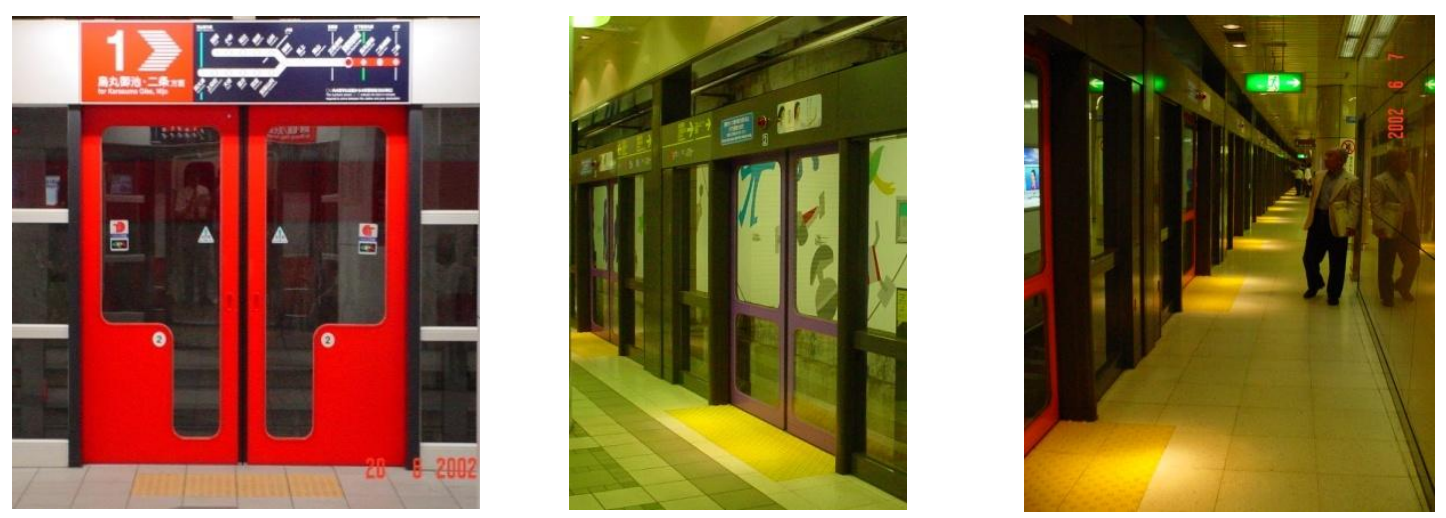

Figura 175 - Tóquio - Plataforma de embarque.

Fonte: BARBOSA, M.B., 2013.

As estações do Metrô de Barcelona dispõem de piso tátil direcional, que orienta os deslocamentos na plataforma até a área de embarque preferencial, localizada junto ao carro líder (Figura 176). Os trens do Metrô de Londres têm portas em cor contrastante em relação à superfície externa dos carros, facilitando a sua identificação, além de faixas contrastantes para sinalização da borda da plataforma e de sua extremidade, alertando quanto ao vão entre a plataforma e o trem (Figura 177).

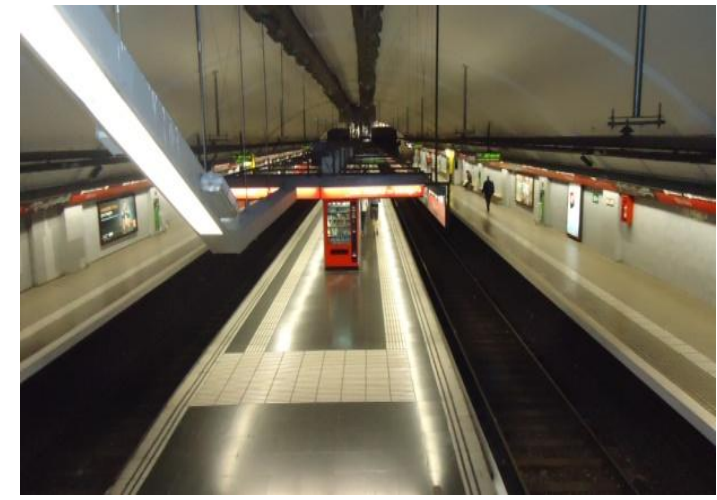

Figura 176 - Barcelona - Sinalização do local de embarque preferencial em plataformas mista e lateral. trem.

Fonte: BARBOSA, M.B., 2011.

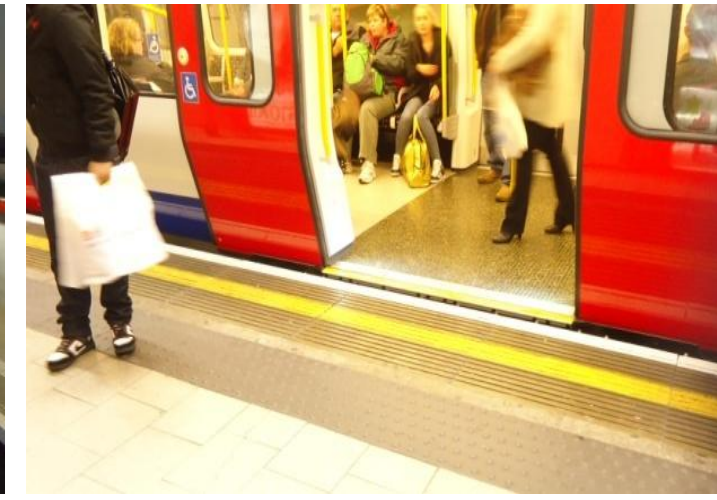

Figura 177 - Londres - Contraste visual das portas do Fonte: BARBOSA, M.B., 2013.

As novas estações do Metrô de Madrid não têm piso tátil direcional para orientar os deslocamentos na plataforma até a área de embarque preferencial. A faixa tátil incorpora sinalização fotoluminescente - para maior segurança em situações de emergência - e borda antiderrapante para evitar escorregões durante o embarque e desembarque na plataforma (Figura 178). 


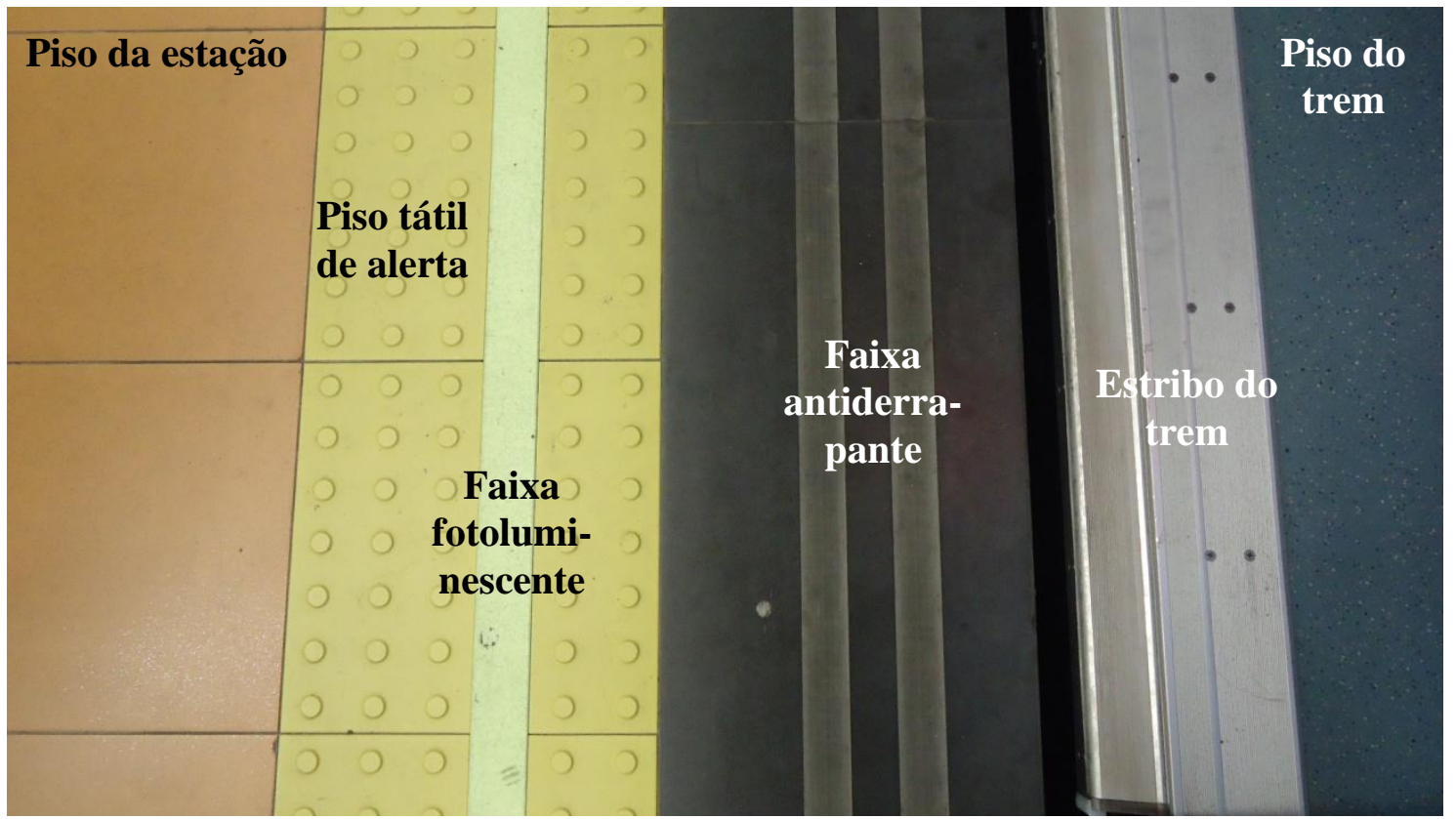

Figura 178 - Madri - Piso tátil com sinalização fotoluminescente e borda antiderrapante na plataforma. Fonte: BARBOSA, M.B., 2011.

\subsubsection{Requisitos Normativos}

Com relação aos requisitos normativos, a ABNT NBR 14021:2005 determina a identificação do local de embarque preferencial - sinalização tátil e visual no piso, alinhada com a sinalização visual suspensa e com o carro preferencial - bem como a existência de sinalização visual e tátil de alerta, com cor e textura contrastantes, na borda de plataforma. Para auxiliar o deslocamento, deve haver informação permanente indicando a linha e a estação onde o usuário se encontra e as estações de transferência.

\subsubsection{Situação no Metrô de São Paulo}

No Metrô de São Paulo, o local de embarque preferencial para as pessoas com deficiência visual está posicionado junto à segunda porta do primeiro carro do trem. As plataformas de todas as estações têm sinalização tátil e visual identificando o local de embarque preferencial (Figura 179). Em algumas estações, são implementadas estratégias segregando uma área destinada ao embarque preferencial ${ }^{34}$ - para idosos, pessoas com deficiência ou com crianças de colo, idosos, obesos, gestantes e pessoas com restrição de mobilidade, nas estações e horários de maior movimento, especificamente em 19 estações e 19 plataformas no período da manhã, entre 6 h e 9h, e em 12 estações e 15 plataformas no período da tarde, entre 16h e 19h.

\footnotetext{
${ }^{34}$ Disponível em: http://www.metro.sp.gov.br/pdf/acessibilidade/atendimento-preferencial.pdf. Acesso em: 24 nov. 2013.
} 
Algumas estações com elevada demanda dispõem de elementos organizadores de embarque. As estações construídas mais recentemente dispõem de portas de plataforma.
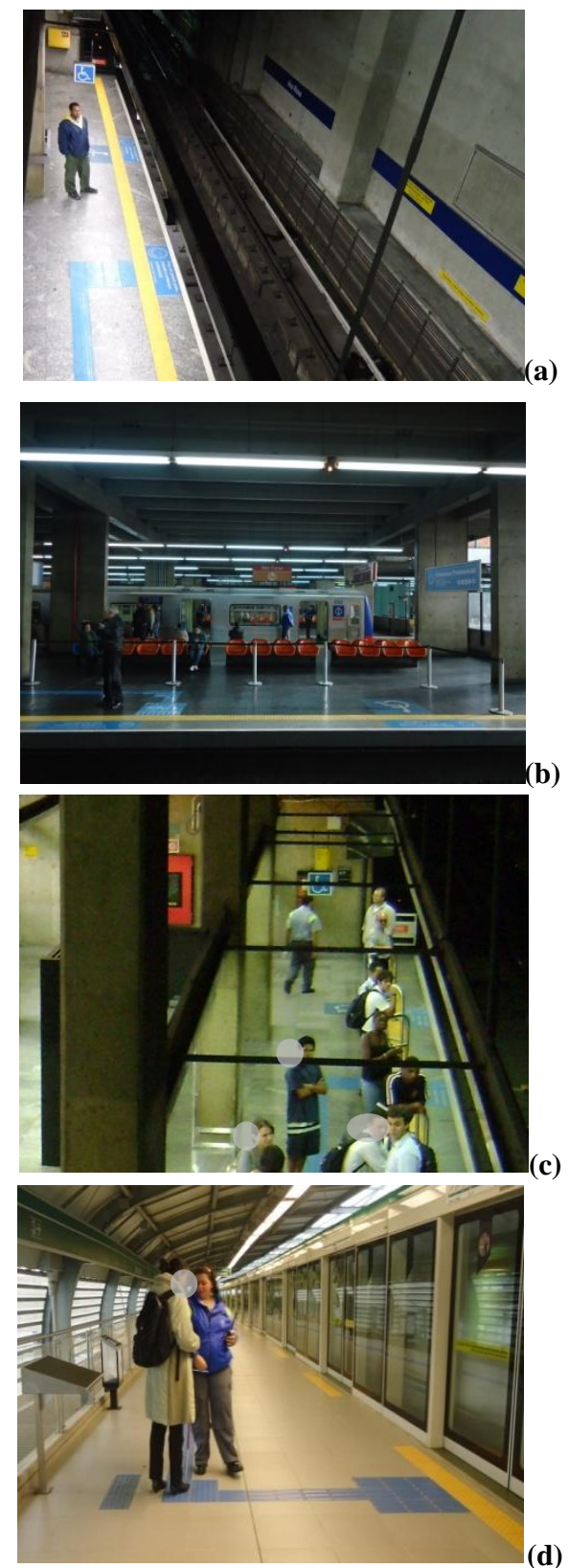
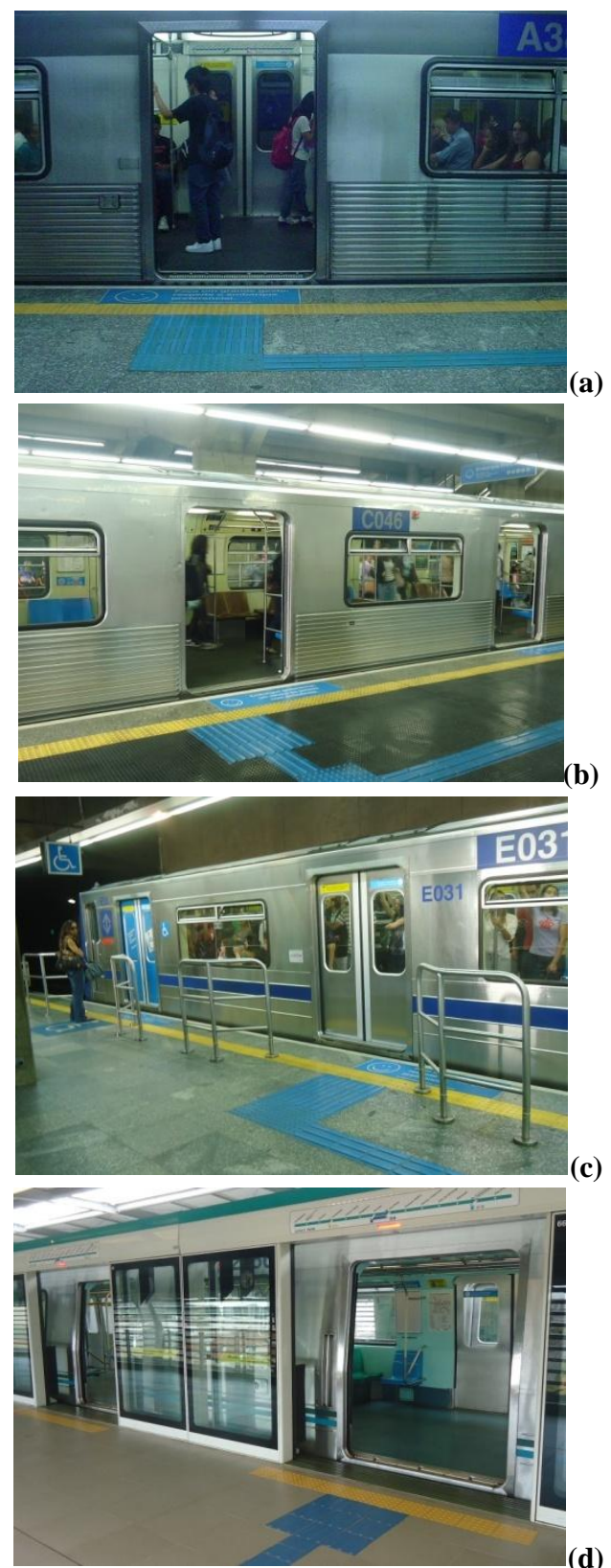

Figura 179 - São Paulo - Local de embarque preferencial.

Plataforma sem proteção (a), em área segregada (b), com elemento orientador de embarque (c) e com porta de plataforma (d).

Fonte: BARBOSA, M.B., 2011.

\subsubsection{Avaliação pelos usuários}

Na etapa de espera pelo trem, 51 usuários com deficiência visual - dos quais 36 pessoas são cegas e 15 pessoas têm baixa visão - manifestaram seu descontentamento em relação à estação $(74,3 \%)$ e à interface trem-estação $(25,7 \%)$. Foram registrados 74 relatos, o que 
representa $2,8 \%$ do total de relatos registrados para todas as etapas da jornada do usuário. Os relatos estão relacionados, em sua maioria, aos serviços prestados na estação $(59,5 \%)$ e à interface entre o trem e a estação (20,3\%), mas também referem-se à disponibilidade de informações nas estações $(8,1 \%)$ e à interface entre o trem e a plataforma $(5,4 \%)$, bem como à configuração da estação $(6,8 \%)$ para prover segurança enquanto se espera pelo trem (Tabela 23).

Tabela 23 - Matriz de avaliação da etapa 11 - Espera pelo trem.

(\% em relação ao total de relatos registrados nesta etapa)

\begin{tabular}{l|r|r|r|r}
\hline & $\begin{array}{c}\text { Configuração } \\
\%\end{array}$ & $\begin{array}{c}\text { Informação } \\
\%\end{array}$ & $\begin{array}{c}\text { Serviço } \\
\%\end{array}$ \\
\hline Estação & (EC) $\mathbf{6 , 8}$ & (EI) 8,1 & (ES) 59,4 & (II) 5,4 \\
\hline Interface Trem-Estação & $\mathbf{0 , 0}$ & $\mathbf{0 , 0}$ & $\mathbf{2 5 , 7}$ \\
\hline Trem & $\mathbf{0 , 0}$ & $\mathbf{1 3 , 5}$ & $\mathbf{0 , 0}$ \\
\hline Total & $\mathbf{6 , 8}$ & $\mathbf{1 0 0 , 0}$ \\
\hline
\end{tabular}

"Eu acho que é importante controlar melhor o uso do vagão preferencial, deixar passar somente quem precisa e, ao mesmo tempo, fazer com que os deficientes entendam que é importante embarcar no primeiro vagão porque fica mais fácil receber ajuda se houver algum problema com o trem. Todos precisam respeitar as regras de segurança. Por isso eu entendo que não deveriam deixar o usuário comum entrar nesse vagão e deveriam fazer campanhas constantes para os outros usuários respeitarem o embarque preferencial. Eu considero necessário ampliar o embarque preferencial: acho que ele deveria acontecer em todas as estações no horário de pico, e no primeiro carro inteiro. Já ouvi usuários que não querem embarcar no $1^{\circ}$ vagão e gostariam de escolher o vagão porque facilita o desembarque próximo à escada (rolante ou fixa) na saída, no desembarque, principalmente à noite, quando não tem empregado para ajudar. Também já ouvi outros deficientes visuais falarem que perdem o trem porque tem que andar toda a plataforma para poder embarcar no primeiro carro e muitas vezes, já estão atrasados para seus compromissos. Gostaria de ter um cartão para que eu pudesse usar o telefone dos empregados e avisar a SSO que estou aguardando ajuda na plataforma. Deveria ter câmeras na plataforma para que o empregado viesse ao meu encontro quando me visse desembarcando. Acho que os interfones estão sempre quebrados... Para que eu possa ter as mesmas condições dos outros usuários, preciso receber informações sonoras, que me avisem quando o trem está atrasado, quando vai passar direto pela estação ou quando está chegando na plataforma, como é feito na Europa... Acho importante diferenciar mais a faixa amarela de alerta. Como eu ando com o cão guia, ficaria mais fácil se tivesse piso tátil na área de embarque do cadeirante.” (Discurso do Sujeito Coletivo - Etapa 11)

Os principais problemas relatados pelos usuários na etapa de espera pelo trem são apresentados de forma hierarquizada, conforme o número de relatos registrados (Gráfico 29). 
Gráfico 29 - Avaliação da etapa 11 - Espera pelo trem.

(\% em relação ao total de relatos registrados nesta etapa)

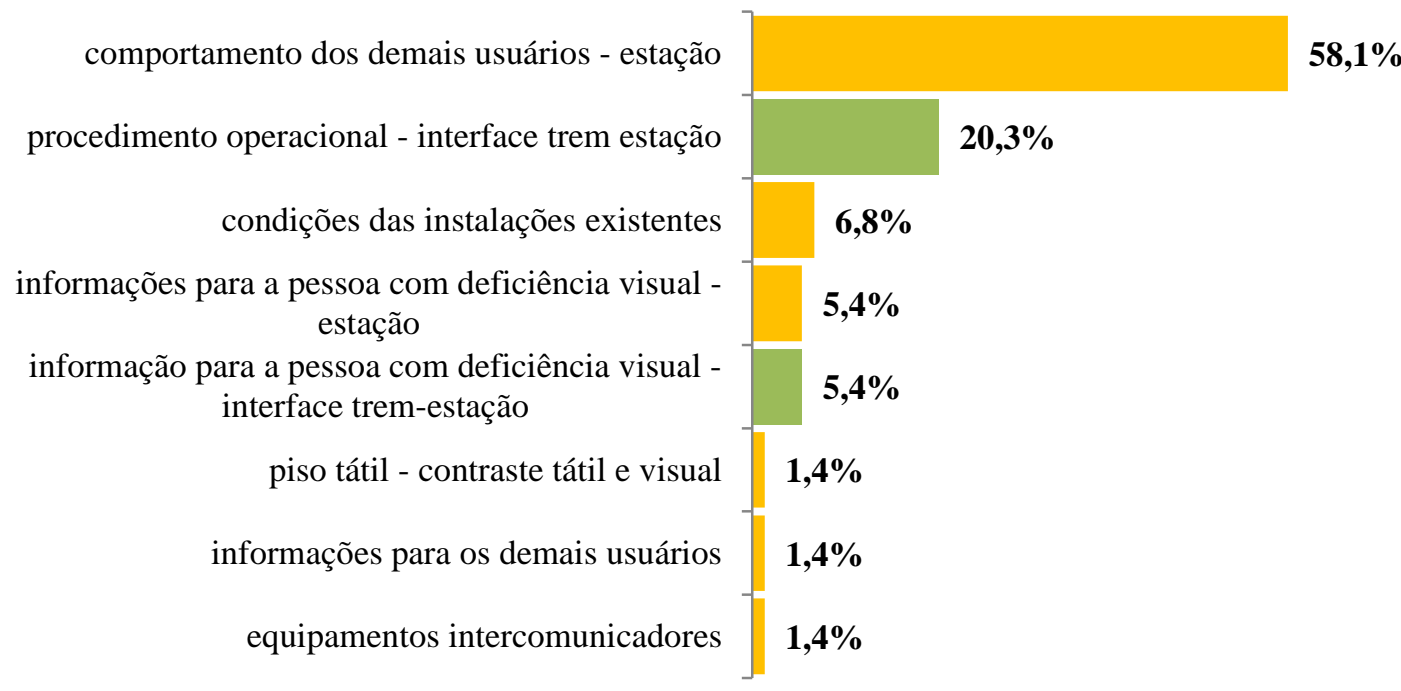

$\mathrm{n} 1=52$ respondentes $\mathrm{n} 2=74$ relatos

Os problemas relatados estão relacionados às seguintes ideias centrais:

a) comportamento dos demais usuários - estação (ES4) - falta de controle de acesso às áreas de embarque ou de atendimento preferencial;

b) procedimento operacional - interface trem-estação (IS1) - descontentamento em relação à obrigatoriedade de embarque no primeiro carro;

c) condições das instalações existentes (EC3) - falta de condições de segurança na plataforma das estações;

d) informações para a pessoa com deficiência visual - estação (EI6) - inexistência de informações sonoras e intercomunicadores nas plataformas;

e) informações para a pessoa com deficiência visual - interface trem-estação (II1) falta de sinalização do local de embarque e o dimensionamento insuficiente da faixa tátil de alerta;

f) piso tátil - contraste tátil e visual (EI1) - falta de diferenciação entre a textura do piso tátil de alerta na borda da plataforma e nas escadas;

g) informações para os demais usuários (EI7) - inexistência de orientações para os usuários sobre a finalidade do piso tátil ou sobre o embarque preferencial;

h) equipamentos intercomunicadores (ES11) - inoperância de totem intercomunicador. 


\subsubsection{Avaliação pelas pessoas-chave}

$\mathrm{Na}$ etapa de espera pelo trem, os empregados das estações relataram como positivo o procedimento operacional - interface trem-estação (IS1), quanto à obrigatoriedade de embarque no primeiro carro (Figura 180), pois, em caso de anormalidade ou emergência, o usuário tem auxílio do operador do trem e prioridade de atendimento pelas equipes de resgate. Em relação ao piso tátil - percurso (EI3), os empregados das estações relataram a importância da informação tátil de alerta na borda da plataforma ou da emissão de mensagens sonoras, orientando quanto ao perigo da proximidade da via e garantindo a segurança da pessoa com deficiência visual e dos demais usuários.
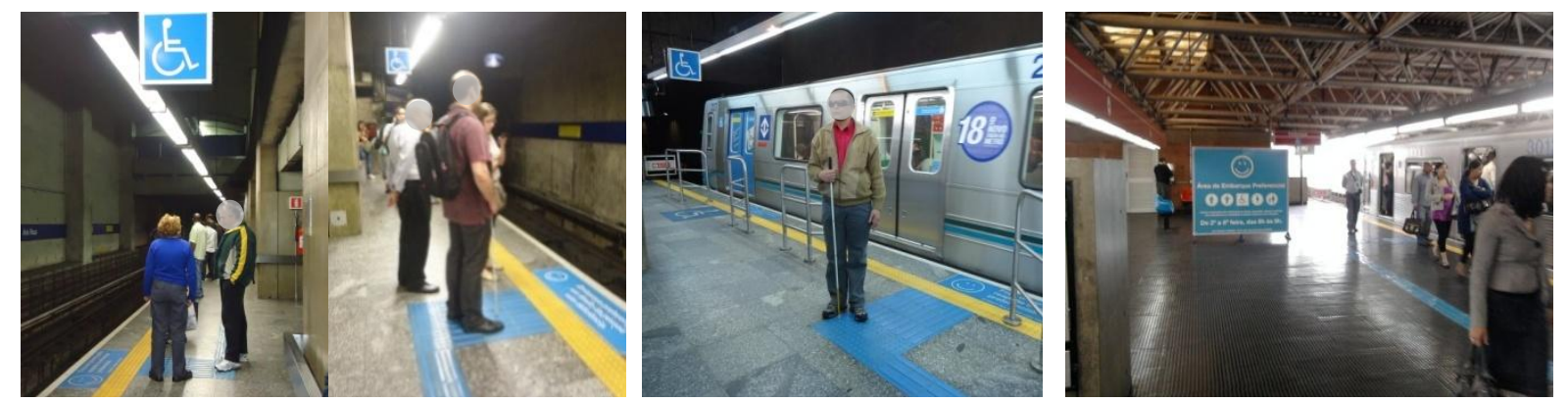

Figura 180 - São Paulo - Local de embarque preferencial.

Fonte: BARBOSA, M.B., 2011.

Os professores de orientação e mobilidade destacam o procedimento operacional interface trem-estação (IS1) entre os temas abordados no programa de capacitação das pessoas com deficiência visual e a importância da utilização do carro líder e do embarque na segunda porta do trem, especialmente para evitar incidentes durante a viagem, em ocorrências imprevistas ou anormalidades.

Os empregados das estações destacam a necessidade de realização de campanhas para melhorar o comportamento dos demais usuários - estação (ES4), especialmente em relação ao respeito do embarque preferencial (Figura 181). Os estagiários apontam o comportamento dos demais usuários - estação (ES4), em especial o desrespeito por parte das pessoas que utilizam indevidamente o local de embarque preferencial, dificultando o embarque da pessoa com deficiência visual, mesmo com auxílio. 

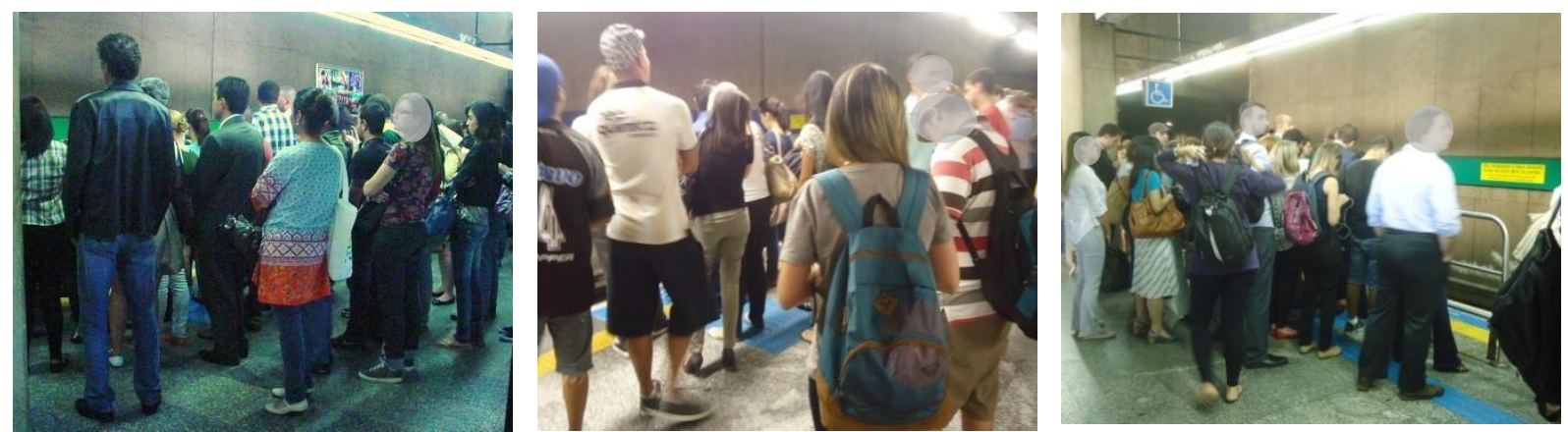

Figura 181 - São Paulo - Permanência indevida dos demais usuários no local de embarque preferencial. Fonte: BARBOSA, M.B., 2011.

\subsubsection{Avaliação pelos especialistas}

Os profissionais responsáveis pela elaboração de normas técnicas relataram que soluções padronizadas relacionadas à configuração, sinalização e iluminação dos ambientes característicos do sistema metroferroviário contribuem para prover segurança, autonomia e agilidade nos deslocamentos. Entre as soluções que podem contribuir para a segurança e independência dos deslocamentos em função das condições das instalações existentes (EC3), foram feitas recomendações para melhoria dos textos normativos vigentes, destacando o estabelecimento de condições adequadas para execução de obras e serviços, garantindo uma rota acessível para embarque e a existência de contraste entre pisos, paredes e painéis de informação da estação. As informações para a pessoa com deficiência visual - estação (EI6) devem ser claras, objetivas e completas, além de redundantes, para que as orientações operacionais e institucionais sobre os serviços ofertados (anormalidade na circulação de trens, atrasos e outras ocorrências) possam contribuir para que os passageiros alcancem seus destinos com segurança. As referências necessárias para orientar os deslocamentos das pessoas com deficiência visual podem ser criadas a partir de estímulos táteis e sonoros, ou mesmo visuais, desde que adequados aos parâmetros que possibilitem sua percepção por pessoas com baixa visão. Uma vez que a soma dessas referências é mais eficaz do que cada uma isoladamente para atingir a diversidade existente no segmento de pessoas com deficiência visual, tais referências devem ser redundantes e integradas.

\subsubsection{Elementos de wayfinding}

Os elementos de wayfinding característicos desta etapa são os seguintes: marcador, limite e zona (Quadro 32). Os elementos de wayfinding - marcadores, bordas e zonas - devem ter configuração adequada e ser providos de sinalização tátil /visual/sonora, de forma a auxiliar sua identificação pelas pessoas com deficiência visual e sobressair-se em relação aos demais 
elementos e informações do ambiente para facilitar sua percepção. Ao mesmo tempo, tais elementos devem estar presentes e ser ressaltados nas informações veiculadas, especialmente quando da elaboração dos materiais táteis, visuais e sonoros.

Quadro 32 - Elementos de wayfinding da Etapa 11 - Espera pelo trem.

\begin{tabular}{c|c|c|c}
\hline $\begin{array}{c}\text { Elementos de } \\
\text { wayfinding }\end{array}$ & \multicolumn{1}{c|}{ Configuração } & Informação & Serviço \\
\hline Marcadores & $\begin{array}{l}\text { - local de embarque } \\
\text { preferencial }\end{array}$ & $\begin{array}{l}\text { - sinalização tátil e visual } \\
\text { do local de embarque } \\
\text { preferencial }\end{array}$ & $\begin{array}{c}\text { - controle de acesso à área } \\
\text { de embarque preferencial }\end{array}$ \\
\hline Bordas & $\begin{array}{l}\text { - portas de fechamento da } \\
\text { plataforma } \\
\text { - direcionadores de fluxo } \\
\text { para isolar/demarcar a } \\
\text { área de embarque } \\
\text { preferencial }\end{array}$ & $\begin{array}{l}\text { - sinalização tátil de alerta } \\
\text { nas bordas das } \\
\text { plataformas } \\
\text { informação visual } \\
\text { orientando a espera pelo } \\
\text { trem em local seguro } \\
\text { (antes da faixa amarela) }\end{array}$ & $\begin{array}{l}\text { - organização, montagem e } \\
\text { desmontagem dos } \\
\text { elementos para isolar a } \\
\text { área de embarque } \\
\text { preferencial }\end{array}$ \\
\hline Zonas & $\begin{array}{l}\text { - área destinada ao } \\
\text { embarque preferencial }\end{array}$ & $\begin{array}{l}\text {-informação sonora e } \\
\text { visual orientando sobre as } \\
\text { estratégias de embarque } \\
\text { preferencial }\end{array}$ & $\begin{array}{l}\text { - gestão do embarque } \\
\text { preferencial }\end{array}$ \\
\hline
\end{tabular}

Fonte: Elaborado pela pesquisadora.

\subsubsection{Síntese do diagnóstico}

Na etapa 11 - Espera pelo trem -, foram identificados aspectos que devem ser tratados pelas empresas operadoras dos sistemas metroferroviários para auxiliar pessoas com deficiência visual a estabelecer estratégias para empreender seus deslocamentos, descritos a seguir:

a) condições das instalações existentes (EC3) - aumentar as condições de segurança na plataforma; estabelecer condições adequadas para execução de obras e serviços; garantir uma rota acessível para embarque; prever contraste entre pisos, paredes, pilares e painéis de informação da estação; garantir nível de iluminação adequado;

b) piso tátil - contraste tátil e visual (EI1) - aumentar o contraste das cores e dos relevos do piso tátil;

c) piso tátil - percurso (EI3) - destacar a informação tátil de alerta na borda da plataforma; emitir mensagens sonoras sobre a proximidade da via;

d) informações para a pessoa com deficiência visual - estação (EI6) - prover informações sonoras e intercomunicadores nas plataformas; prover informações e orientações operacionais claras, objetivas e completas, além de redundantes, para que as orientações operacionais sobre os serviços ofertados (anormalidade na circulação de 
trens, atrasos, ocorrências) sejam compreendidas; criar referências e estímulos táteis, visuais e sonoros integrados que possibilitem sua percepção por pessoas com baixa visão;

e) informações para os demais usuários (EI7) - promover campanhas para orientar os demais usuários sobre a finalidade do piso tátil; promover campanhas para orientar os demais usuários sobre o embarque preferencial;

f) comportamento dos demais usuários - estação (ES4) - controlar o acesso às áreas de embarque ou de atendimento preferencial; promover campanhas para orientar os demais usuários sobre o local de embarque preferencial, facilitando o embarque da pessoa com deficiência visual, mesmo com auxílio;

g) equipamentos intercomunicadores (ES11) - manter intercomunicadores em condições de operação e uso;

h) informações para a pessoa com deficiência visual - interface trem-estação (II1) sinalizar o local de embarque preferencial; aumentar o contraste e as dimensões das informações visuais existentes nas plataformas;

i) procedimento operacional - interface trem-estação (IS1) - orientar usuários sobre a importância do embarque no primeiro carro face ao auxílio imediato do operador do trem e prioridade de atendimento pelas equipes de resgate durante incidentes, ocorrências imprevistas ou anormalidades.

\subsection{Etapa 12 - Embarque}

Nessa etapa, o usuário desloca-se da plataforma da estação em direção ao interior do trem.

\subsubsection{Métodos e técnicas aplicados}

Os métodos e técnicas utilizados para coleta de dados nesta etapa foram apresentados no item 6.10 - Síntese dos instrumentos aplicados - e consistiram em:
a) melhores práticas identificadas em outros sistemas metroferroviários;
b) pesquisa documental (normas técnicas ABNT vigentes, procedimentos operacionais);
c) checklist dos recursos disponíveis e walkthrough realizado nas estações para compreensão do percurso de embarque;
d) questionário aplicado às pessoas com deficiência visual - questões 12, 13, 14 e 17;
e) entrevista com empregados das estações; 
f) entrevista com profissionais responsáveis pelo treinamento dos empregados;

g) entrevista com os estagiários que auxiliam os usuários com deficiência visual;

h) entrevista com operadores do Centro de Controle Operacional;

i) entrevista com os profissionais responsáveis pelo projeto dos trens;

j) entrevista com profissionais responsáveis pela elaboração de normas técnicas.

As formas de análise e interpretação dos dados coletados foram apresentadas no Capítulo 6 Aplicação dos instrumentos.

\subsubsection{Melhores Práticas}

Entre as melhores práticas, destaca-se o Metrô de Madri, que está implantando um dispositivo nos trens para reduzir o vão e o desnível entre o trem e as plataformas, acionado pelo condutor quando da chegada dos trens às estações (Figura 182).
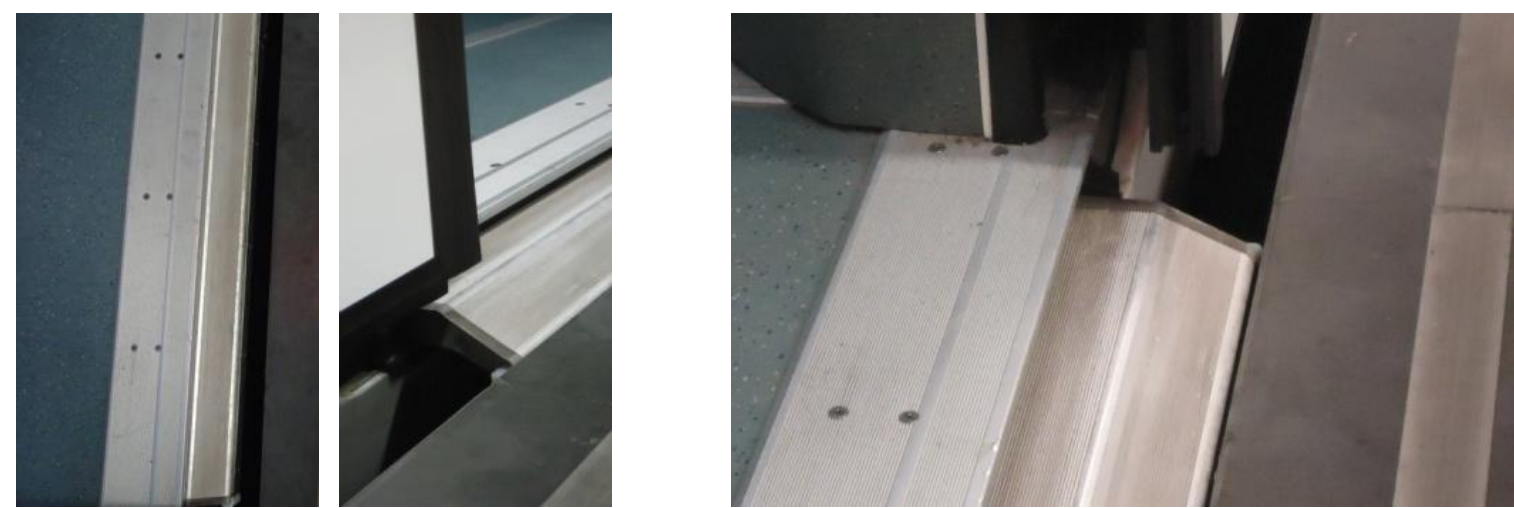

Figura 182 - Madri - Dispositivo para reduzir o vão e desnível entre o trem e a plataforma. Fonte: BARBOSA, M.B., 2013.

Em Barcelona foi desenvolvido um estudo para definir índices aceitáveis de vão e desnível entre os trens e as plataformas, notadamente para pessoas em cadeira de rodas, resultado de parceria entre a Disputació Barcelona, a Transports Metropolitans de Barcelona - TMB e a Ferrocarrils de la Generalitat de Catalunya - FGC. Como produto final, gerou-se uma régua/gráfico que informa o percentual de usuários em cadeira de rodas atendidos em função do vão e desnível existentes na plataforma de cada estação (Figura 183). Observa-se que aproximadamente $95 \%$ das pessoas conseguem embarcar com autonomia quando o vão tem até $62 \mathrm{~mm}$ e desnível de até $22 \mathrm{~mm}$. Esse índice é reduzido para 50\% quando o vão é de 92 mm e o desnível é de $45 \mathrm{~mm}$ e, para $10 \%$, quando o vão é de $12 \mathrm{~mm}$ e o desnível é de 65 $\mathrm{mm}$. 


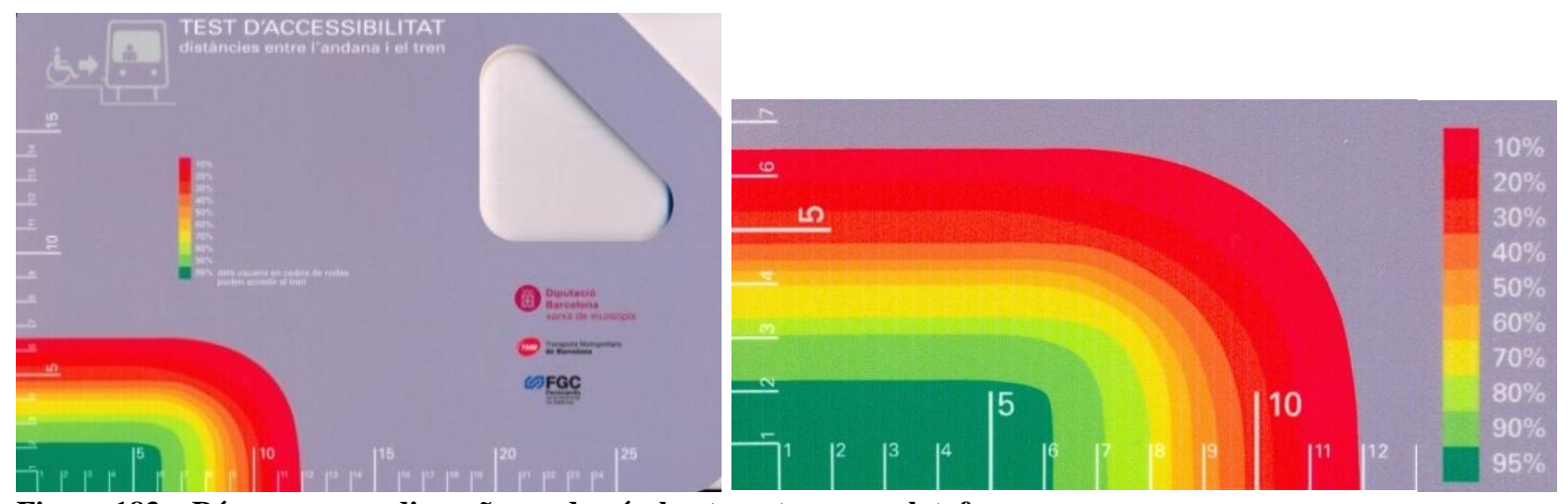

Figura 183 - Régua para medir o vão e o desnível entre o trem e a plataforma.

Fonte: Dispositivo produzido pela Disputació de Barcelona.

Para reduzir o vão e o desnível existentes entre o trem e a plataforma, soluções podem ser implementadas nos trens ou nas plataformas ou em ambos. A CPTM implementou um estribo nas portas (Figura 184).O Metrô de Madri promoveu a adequação parcial de um trecho da plataforma (Figura 185).

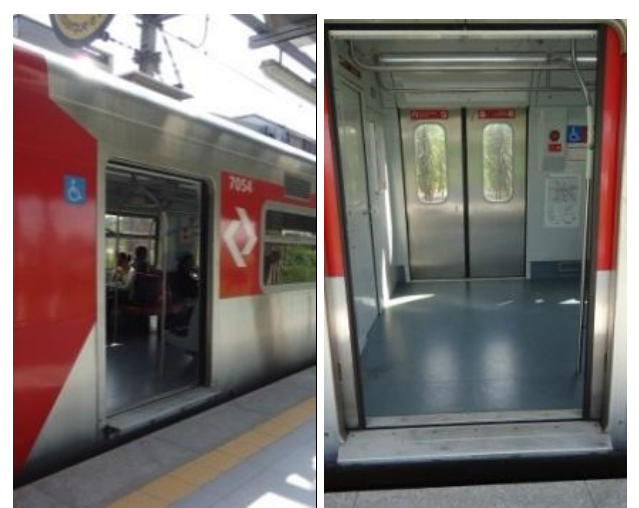

Figura 184 - São Paulo - CPTM - Estribo para eliminação do vão entre o trem e a plataforma.

Fonte: BARBOSA, M.B., 2011

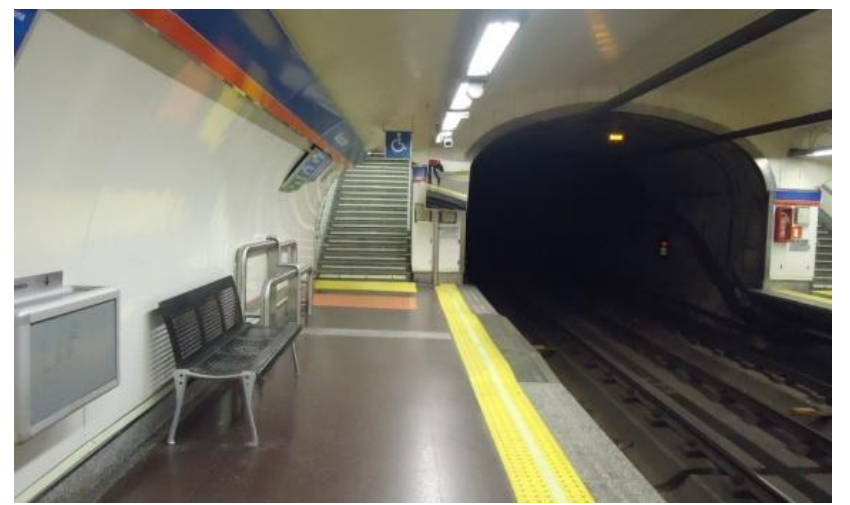

Figura 185 - Madri - Rampa para eliminação do desnível entre o trem e a plataforma.

Fonte: BARBOSA, M.B. , 2013.

O Metrô de Londres elevou o nível de um setor da plataforma, nivelando com o piso do trem, nos locais onde diferentes frotas permitem tal intervenção (Figuras 186 e 187). O Metrô do Japão instalou sinalização luminosa intermitente nas plataformas curvas e sob os trens, alertando para o vão existente (Figura 188). 


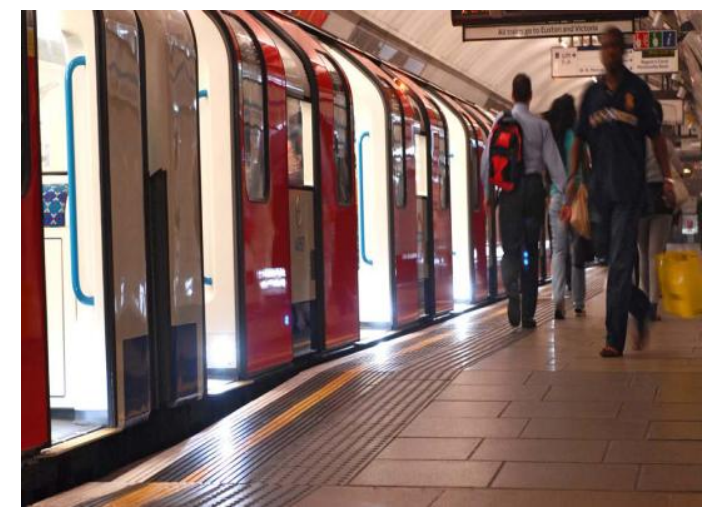

Figura 186 - Londres - Eliminação do desnível entre o trem e a plataforma.

Fonte: Transport for London. Taking forward the Mayor's Transport Strategy Accessibility Implementation Plan. p.88, 2012.

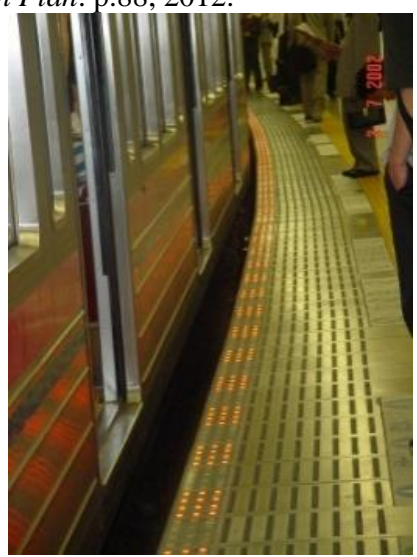

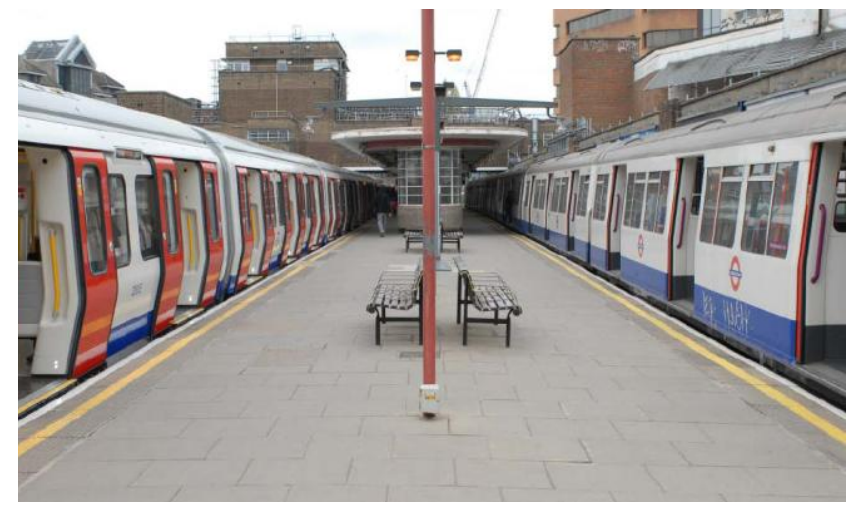

Figura 187 - Londres - Diferentes frotas em uma mesma plataforma.

Fonte: Transport for London. Taking forward the Mayor's Transport Strategy Accessibility Implementation Plan. p.88, 2012.

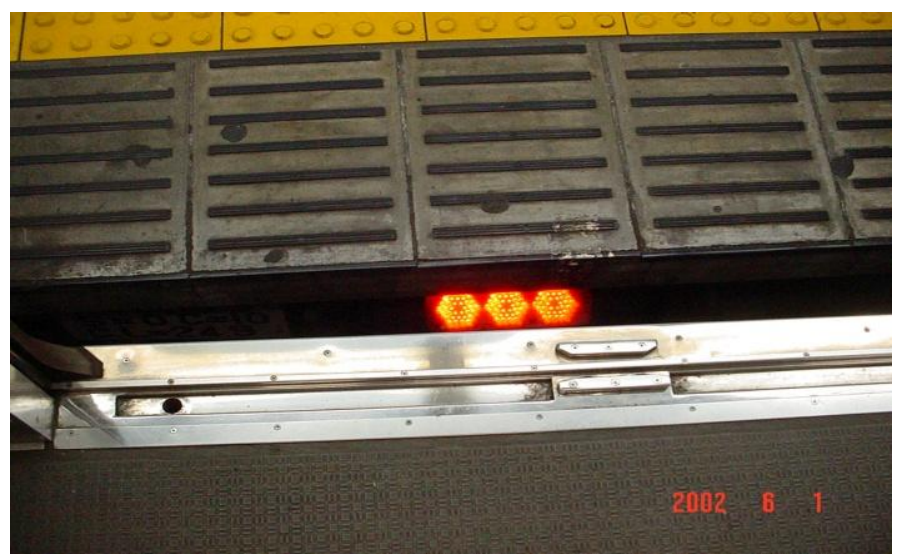

Figura 188 - Tóquio - Sinalização do vão entre o trem e a plataforma.

Fonte: BARBOSA, M.B., 2013.

Para alertar quanto à existência de vão entre os carros dos trens, são utilizadas diferentes estratégias. Nas frotas antigas, o Metrô de Hong Kong dispõe de barras horizontais em diferentes alturas (Figura 189) enquanto que o Metrô de Londres têm anteparos contínuos (Figura 190).

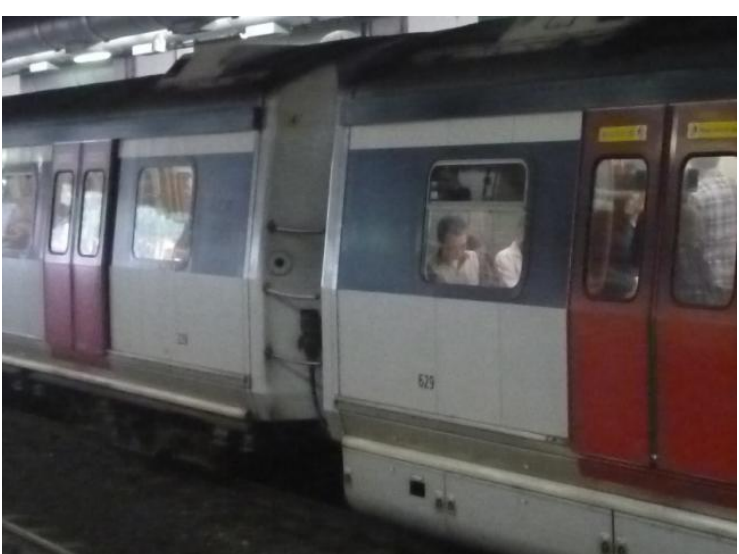

Figura 189 - Hong Kong - Barras horizontais entre carros nas frotas antigas.

Crédito: PONTES, F.M. , 2012

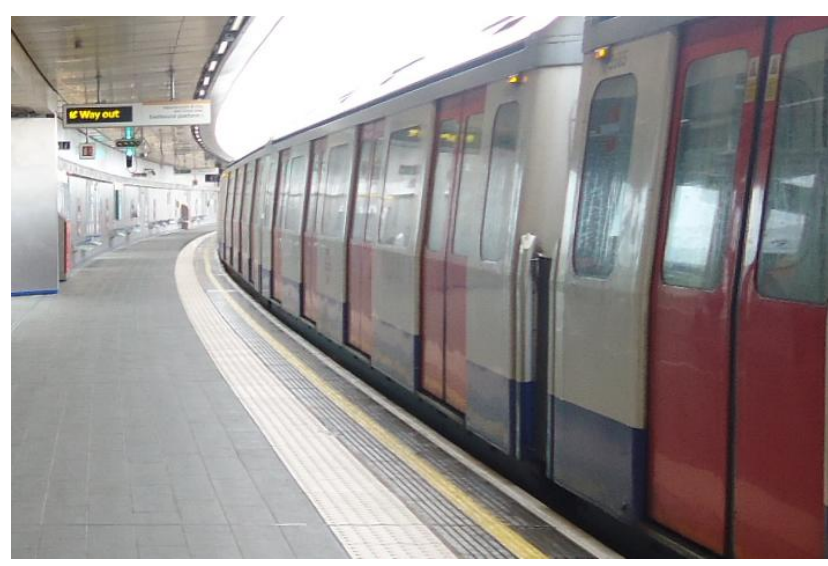

Figura 190 - Londres - Fechamento entre carros nas frotas antigas.

Fonte: BARBOSA, M.B., 2013 
Nas novas frotas dos Metrôs de Madri e Barcelona, os vãos entre carros são complementados com superfície flexível contínua em cor contrastante que funciona como anteparo e confere maior segurança aos usuários com deficiência visual, especialmente nos trens com salão de passageiros contínuo (Figuras 191 e 192).

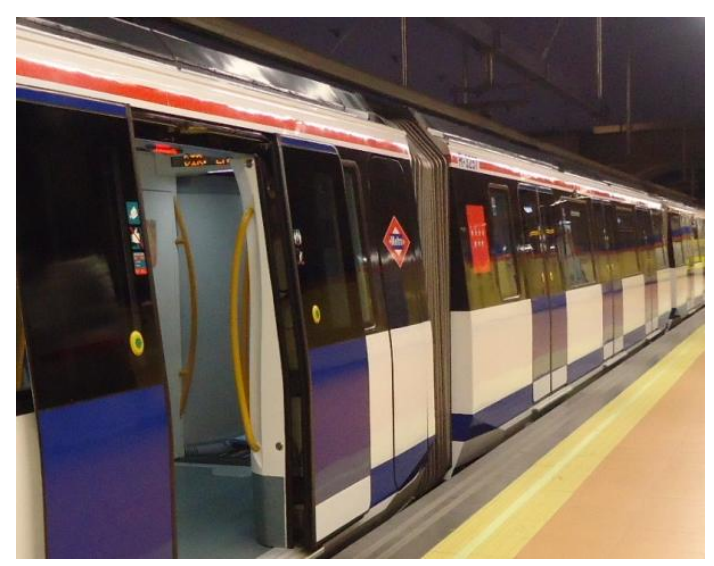

Figura 191 - Madri - Fechamento entre carros. Fonte: BARBOSA, M.B., 2013

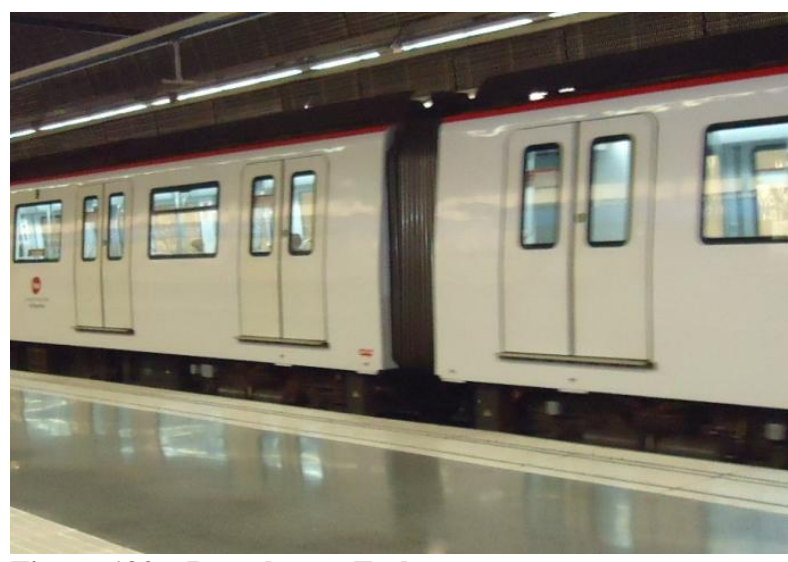

Figura 192 - Barcelona - Fechamento entre carros. Fonte: BARBOSA, M.B., 2011

\subsubsection{Requisitos Normativos}

Com relação aos requisitos normativos para a estação, a ABNT NBR 14.021:2005 estabelece a necessidade de sinalização visual e tátil de alerta distando no mínimo $50 \mathrm{~cm}$ da borda da plataforma, em toda a sua extensão ou na projeção das portas, de forma a orientar quanto à localização da via. Também determina a existência de informação visual e sonora alertando quanto ao vão ou desnível entre o trem e a plataforma, quando o vão supera $10 \mathrm{~cm}$, ou quando o desnível supera $8 \mathrm{~cm}$. Quanto aos requisitos normativos para o trem, a ABNT NBR 14.021:2005 estabelece a sinalização de identificação da porta de embarque preferencial na lateral do carro, a informação visual sobre o destino do trem, além de alarme sonoro e visual para informar sobre o fechamento das portas. Não há requisitos que estabeleçam a necessidade de eliminação do vão entre carros.

\subsubsection{Situação no Metrô de São Paulo}

No Metrô de São Paulo, o vão e o desnível entre o trem e a plataforma são afetados pela configuração da plataforma (reta ou em curva), pela estrutura da via (em concreto ou em lastro de brita) e pelo modelo do trem. Trens de diferentes frotas causam diferentes desníveis e pontos de parada junto ao local de embarque preferencial. Plataformas curvas e vias em lastro de brita geram maiores vãos e desníveis entre os trens e as plataformas. Para sinalizar a 
existência do vão, foram instaladas faixas brancas antiderrapantes na borda da plataforma. Para reduzir os vãos, foram instaladas chapas em polipropileno nas bordas das plataformas, alinhadas às portas dos trens nos locais mais críticos. A questão do desnível, verificada apenas nas frotas novas, ainda não foi solucionada (Figura 193).

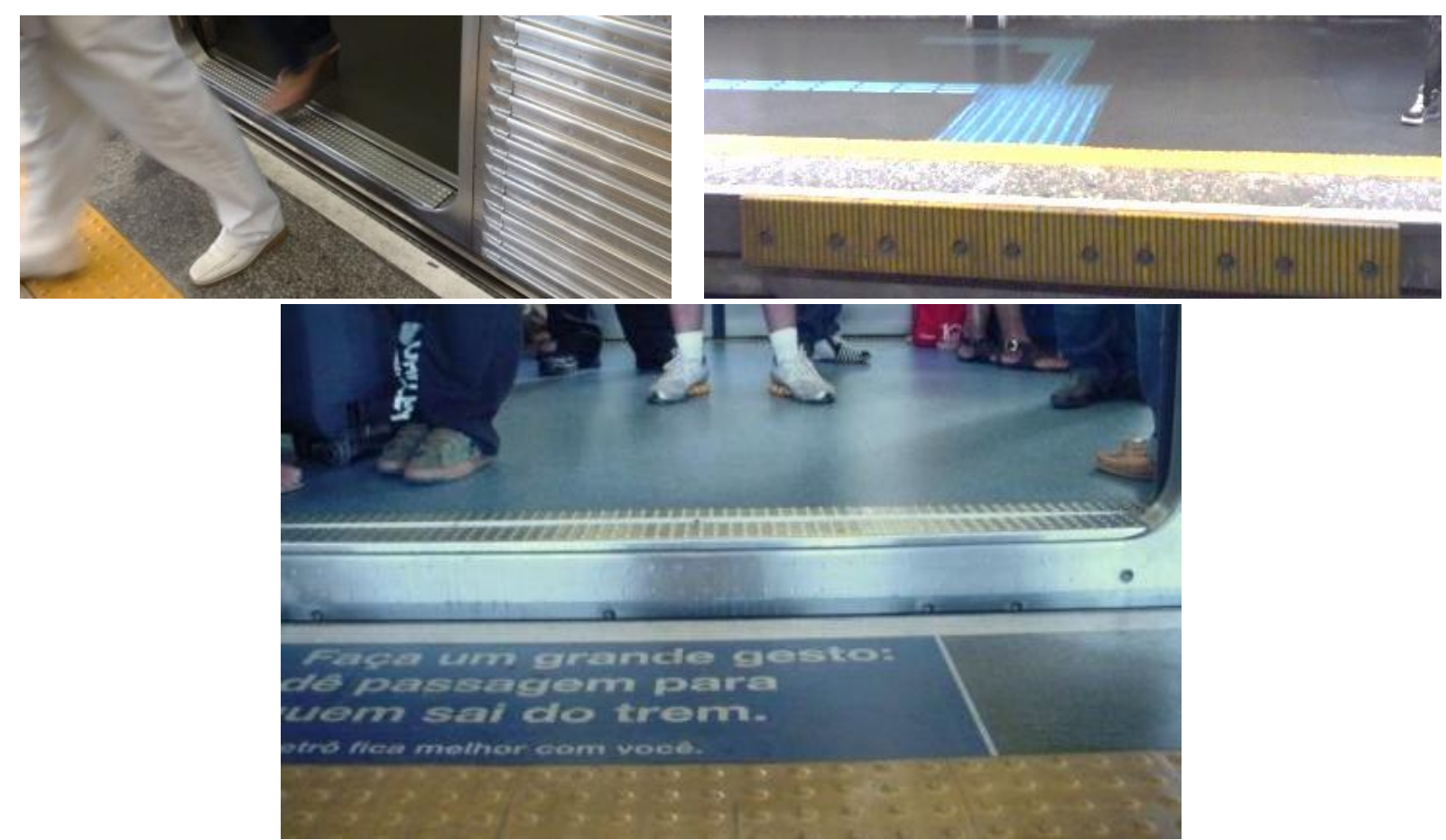

Figura 193 - São Paulo - Vão e desnível entre o trem e a plataforma. Fonte: BARBOSA, M.B., 2011.

Todas as frotas têm configuração padrão: todos os trens têm seis carros e, portanto, têm o mesmo comprimento e as plataformas têm a dimensão padronizada de acordo com o comprimento do trem. Todos os carros têm quatro portas de cada lado. Em todas as frotas o carro líder é destinado ao uso preferencial.

\subsubsection{Avaliação pelos usuários}

Na etapa de embarque, 57 usuários com deficiência visual - dos quais 43 pessoas são cegas e 14 pessoas têm baixa visão - manifestaram seu descontentamento em relação à interface tremestação $(81,1 \%)$, à estação $(12,2 \%)$ e ao trem $(6,7 \%)$, Foram registrados 90 relatos, o que representa $3,4 \%$ do total de relatos registrados para todas as etapas da jornada do usuário. Os relatos estão relacionados, em sua maioria, aos serviços prestados na interface trem-estação $(54,4 \%)$ e à configuração da interface trem-estação $(26,7 \%)$, mas também referem-se à configuração da estação (26,7\%), e aos serviços prestado nas estações $(8,9 \%)$ e no trem $(6,7 \%)$ para prover segurança durante o embarque (Tabela 24$).$ 
Tabela 24 - Matriz de avaliação da etapa 12 - Embarque.

(\% em relação ao total de relatos registrados nesta etapa)

\begin{tabular}{|c|c|c|c|c|}
\hline & $\begin{array}{c}\text { Configuração } \\
\%\end{array}$ & $\begin{array}{c}\text { Informação } \\
\%\end{array}$ & $\begin{array}{c}\text { Serviço } \\
\%\end{array}$ & $\begin{array}{c}\text { Total } \\
\%\end{array}$ \\
\hline Estação & (EC) 3,3 & $\mathbf{0 , 0}$ & (ES) 8,9 & 12,2 \\
\hline Interface Trem-Estação & (IC) 26,7 & $\mathbf{0 , 0}$ & (IS) 54,4 & 81,1 \\
\hline Trem & $\mathbf{0 , 0}$ & $\mathbf{0 , 0}$ & (TS) 6,7 & 6,7 \\
\hline Total & 30,0 & $\mathbf{0 , 0}$ & $\mathbf{7 0 , 0}$ & 100,0 \\
\hline
\end{tabular}

"Não gosto quando a estação tem uma só plataforma porque os usuários não respeitam o local de embarque do deficiente visual, aí vira um empurra-empurra. Há muito desrespeito por parte das pessoas: eu sou empurrado, chutam a minha bengala, elas esquecem que têm deficientes, idosos e não abrem espaço para eu embarcar, acham ruim quando eu passo na frente delas, mesmo quando estou acompanhada de um PET... Eu acho que todos os empregados têm treinamento, só que muitas vezes eles não praticam: quando me ajudam entrar no trem, não me levam até a barra de ferro para eu me segurar... e eu me desequilibro quando o trem anda. Algumas vezes também me embarcam na $1^{\mathrm{a}}$ porta, dos cadeirantes, e eu fico perdido porque não encontro as barras de ferro. E também não me avisam se tem lugar vazio para eu sentar quando me deixam dentro do trem. $\mathrm{O}$ funcionário deveria sempre me colocar próximo à barra de ferro e dizer se tem lugar vazio ou não... Outra situação problemática para mim é o tamanho do vão entre o trem e a plataforma. Em muitas estações o vão é muito grande e também tem desnível entre o trem e a plataforma. No meio da multidão, fico com medo de cair ou enfiar o pé no vão. Precisam dar um jeito de diminuir ou tampar esse vão. Eu fico com medo de tropeçar e encaixar o pé no vão entre a plataforma e o trem no meio da multidão. Quando o trem está lotado fica difícil para eu embarcar. Já aconteceu de me prensarem e de eu quase cair no vão. No horário de pico, sempre tem muita gente, é quase impossível eu entrar no trem, que fica superlotado... Tenho que esperar todo mundo descer e às vezes a campainha toca e não dá tempo para eu entrar no trem. O PET deveria me colocar do lado que vou desembarcar. Isso poderia ser resolvido se todas as estações tivessem plataformas diferentes para embarque e desembarque, mas isso não foi pensado nem no começo e nem agora. Todas as estações deveriam ter aqueles ferros, como na Sé, pois isto facilita eu achar a porta do trem. Mas quando o trem para fora de lugar, a grade da plataforma vira um obstáculo. Quando acontece do trem não parar no lugar do piso de alerta, tenho que ficar procurando com a bengala e tem pessoas entrando e saindo do trem. Se não tenho ajuda do empregado ou de um usuário posso acabar batendo no trem". (Discurso do Sujeito Coletivo - Etapa 12)

Os principais problemas relatados pelos usuários na etapa de embarque são apresentados de forma hierarquizada conforme número de relatos registrados (Gráfico 30). 
Gráfico 30 - Avaliação da etapa 12 - Embarque.

(\% em relação ao total de relatos registrados nesta etapa)

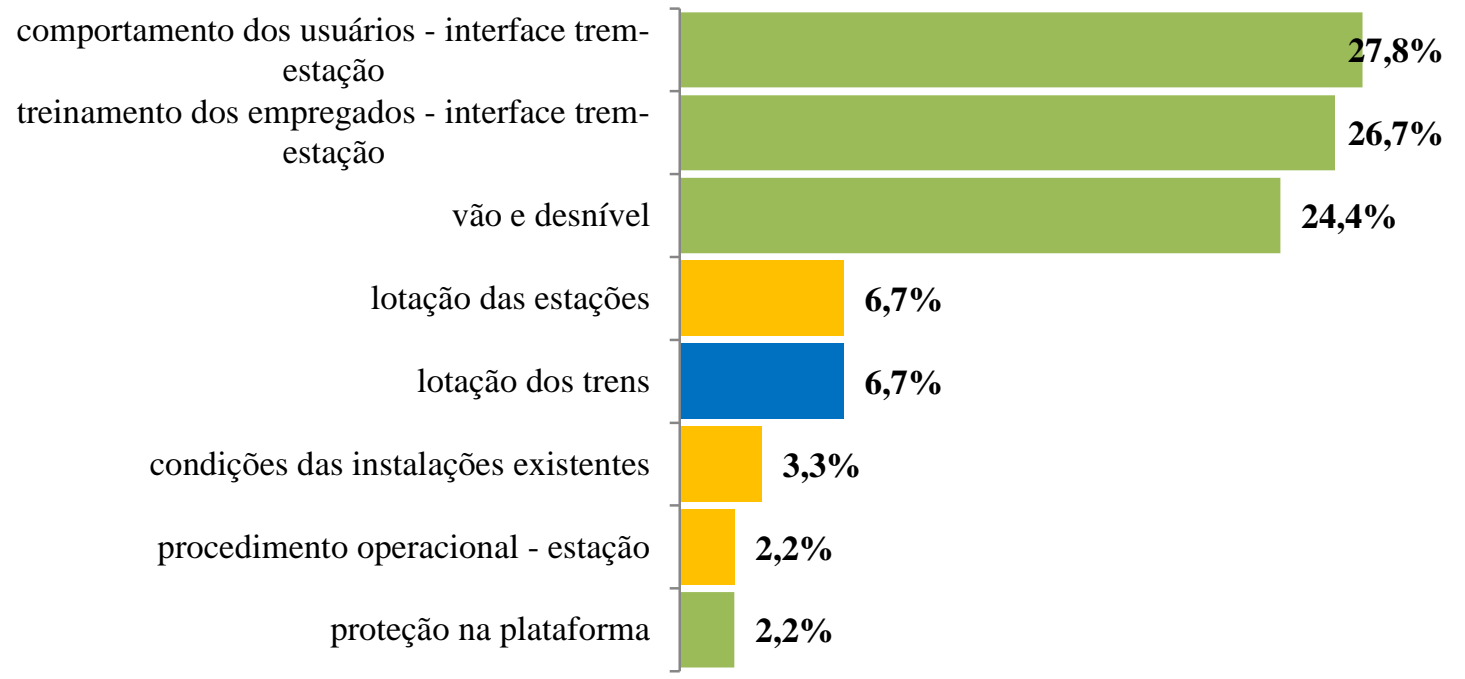

$\mathrm{n} 1=57$ respondentes $\mathrm{n} 2=90$ relatos

Os problemas relatados estão relacionados às seguintes ideias centrais:

a) comportamento dos usuários - interface trem-estação (IS3) - mau comportamento dos usuários para embarcar ou desembarcar;

b) treinamento dos empregados - interface trem-estação (IS2) - descontentamento em relação ao atendimento recebido para embarque, uma vez que os empregados não colocam a mão do usuário nas barras de apoio dos trens;

c) vão e desnível (IC1) - existência de vão e desnível entre a plataforma e o trem e falta de alinhamento entre a sinalização tátil da plataforma e a porta do trem, gerando insegurança no momento do embarque;

d) lotação das estações (ES7) - descontentamento e insegurança resultantes da lotação das plataformas;

e) lotação dos trens (TS4) - dificuldade de embarcar ou desembarcar em função da lotação dos trens e insuficiência de trens para atender à demanda das estações;

f) condições das instalações existentes (EC3) - configuração da maioria das estações impõe o embarque e o desembarque simultâneo pela mesma plataforma;

g) procedimento operacional - estação (ES6) - dificuldade de embarque pela plataforma central nas estações com plataforma mista, no contra fluxo dos demais usuários; 
h) proteção na plataforma (IC2) - falta de elementos direcionadores de embarque em todas as plataformas, dificultando o embarque.

\subsubsection{Avaliação pelas pessoas-chave}

Os empregados das estações relataram a dificuldade de comunicação com o CCO para viabilizar a monitoração (TI1) que possibilita o acompanhamento para embarque, a notificação do Centro de Controle para monitorar o deslocamento entre a estação de embarque e de destino e a presença de um empregado na plataforma para auxiliar o desembarque (Figuras 194 e 195). No horário de maior demanda, os telefones de contato ficam ocupados; por vezes, o usuário já está na estação de desembarque quando o contato é concluído.
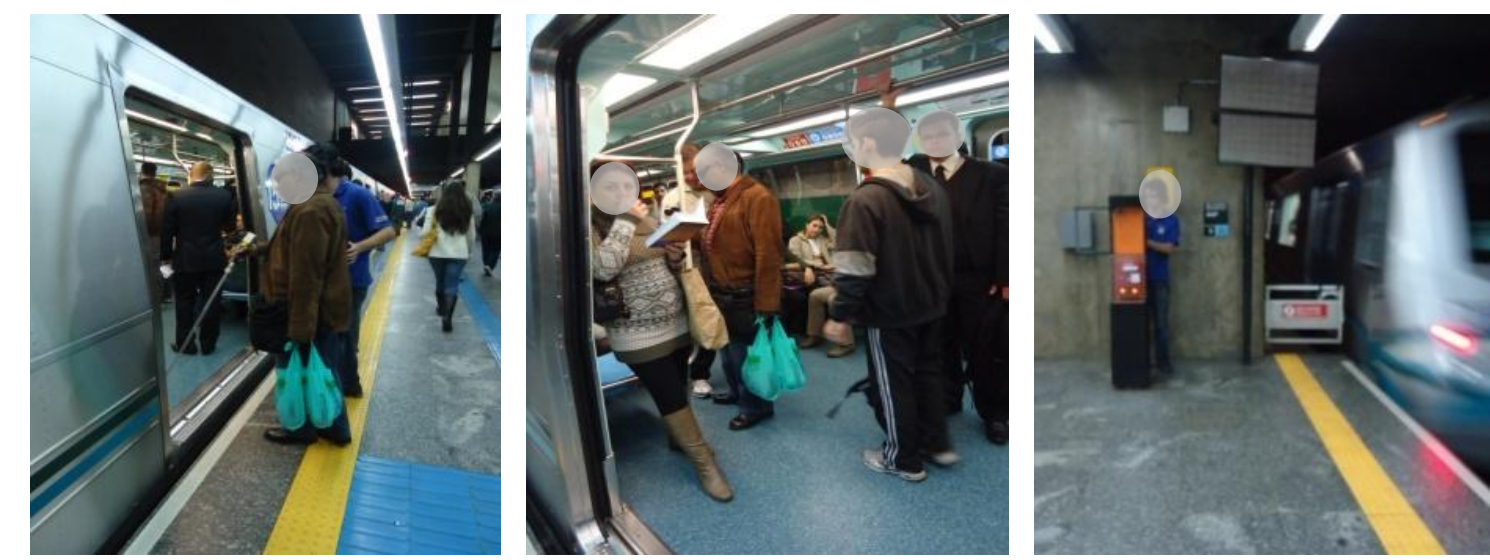

Figura 194 - São Paulo - Monitoração do deslocamento de embarque pelo atendente. Fonte: BARBOSA, M.B., 2011.
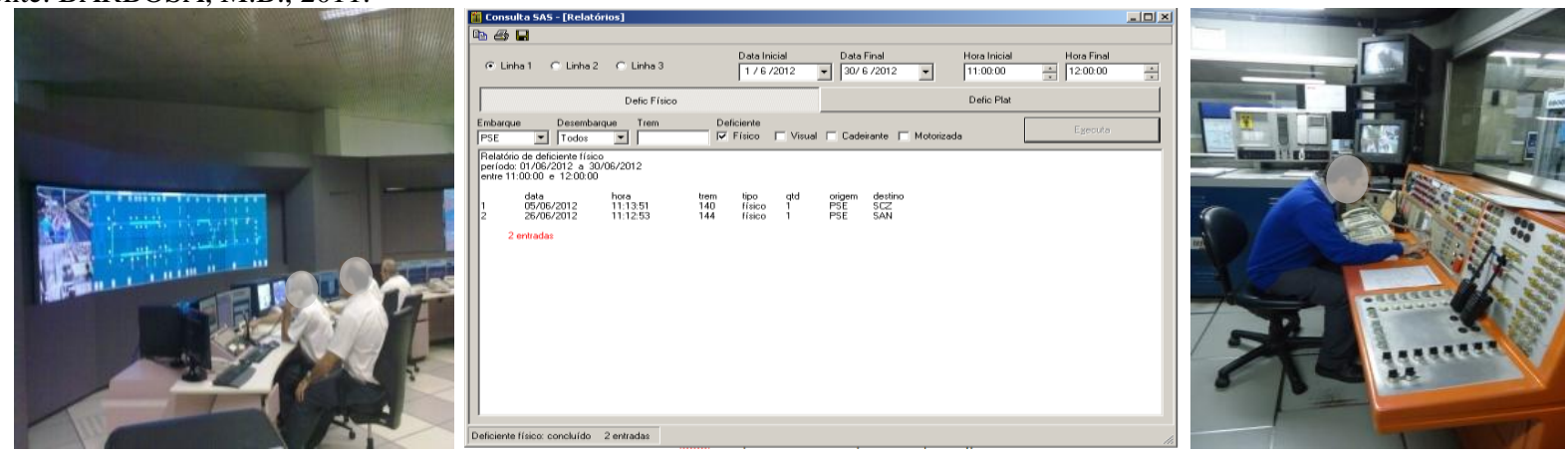

Figura 195 - São Paulo - Monitoração do deslocamento pelo CCO e pela SSO.

Fonte: BARBOSA, M.B., 2011.

Os profissionais responsáveis pelo treinamento dos empregados destacam, entre os temas abordados no programa de capacitação, o treinamento dos empregados - interface tremestação (IS2) para oferecimento de ajuda com técnicas apropriadas e orientações para condução individual ou em grupo durante o embarque. 
Os estagiários relataram o mau comportamento dos demais usuários - interface tremestação (IS3), destacando o desrespeito vivenciado durante o embarque, em função da lotação da plataforma, da pressa e das atitudes individualistas por parte dos usuários que permanecem indevidamente nos locais destinados ao embarque preferencial. Além disso, no momento em que o trem abre as portas, os usuários desembarcam sem prestar atenção nas pessoas com deficiência que estão na plataforma. Os estagiários relataram ainda a apreensão durante o embarque decorrente da existência do vão e desnível (IC1) entre o trem e a plataforma. O aspecto mais crítico está relacionado à efetiva monitoração (TI1), face à dificuldade de comunicação com o CCO, pois os telefones ficam permanentemente ocupados, aumentando o tempo necessário para conclusão do atendimento. Os estagiários destacam as estratégias utilizadas e as ações tomadas a partir da solicitação de auxílio para embarque, descritas a seguir:

a) nos destinos distantes até duas estações, pode-se ligar direto para a estação de desembarque;

b) nos destinos distantes até cinco estações, deve-se conseguir contato com o CCO antes de auxiliar o embarque;

c) nos destinos com distâncias superiores a seis estações, pode-se auxiliar o embarque a avisar o CCO em seguida.

Os operadores do CCO relataram que a dificuldade de comunicação para monitoração (TI1) é decorrente do processo uma vez que, para cada passageiro transportado, são necessárias duas ligações, congestionando as linhas e dificultando a comunicação com as estações. Foi destacada a importância do registro de embarque das pessoas com deficiência visual nos trens para orientar a adoção das estratégias pelas estações ou pelo CCO que impliquem a evacuação do trem na estação, evitando-se a adoção de estratégia em trens que tenham pessoas com deficiência a bordo; quando não é possível evitar, são tomados cuidados específicos junto às equipes das estações. Em caso de anormalidade com um trem, como no caso de haver necessidade de evacuação do trem no trecho entre estações por motivo de falha, são deslocados empregados para auxiliar, acompanhar e orientar a saída. O tratamento estatístico aplicado aos registros do perfil dos usuários e respectivos deslocamentos possibilita ainda o redimensionamento do quadro de funcionários em função da concentração de auxílios em estações ou horários específicos. 


\subsubsection{Avaliação pelos especialistas}

Os profissionais responsáveis pelos projetos dos trens relataram aspectos relacionados à concepção, construção e manutenção que impactam o vão e desnível (IC1) entre o trem e a plataforma. Entre os aspectos relatados, destacam-se as tolerâncias previstas na instalação e na manutenção da via (fixação direta ou em lastro), dos trilhos e das rodas do trem, bem como as tolerâncias de construção das plataformas e de fabricação dos trens.

Os profissionais responsáveis pela elaboração de normas técnicas destacaram as recomendações para melhoria dos textos normativos vigentes, destacando a redução do vão e desnível (IC1) entre o trem e a plataforma bem como a melhoria do acesso às informações para a pessoa com deficiência visual - plataforma (II1) por meio da implementação de contraste de cor entre a porta do trem e a caixa do trem, destacando o local de embarque.

\subsubsection{Elementos de wayfinding}

Os elementos de wayfinding característicos desta etapa são os seguintes: marcador, nós e zona (Quadro 33). Esses elementos devem ser providos de configuração adequada bem como de sinalização tátil/visual/sonora integrada de forma a facilitar sua identificação pelas pessoas com deficiência visual e sobressair-se em relação aos demais elementos e informações do ambiente para facilitar sua percepção. Ao mesmo tempo, devem estar presentes e ser ressaltadas informações táteis, visuais e sonoras integradas, especialmente quando da elaboração dos materiais voltados à descrição do ambiente das estações, facilitando a compreensão do local de embarque. 
Quadro 33 - Elementos de wayfinding da Etapa 12 - Embarque.

\begin{tabular}{|c|c|c|c|}
\hline $\begin{array}{l}\text { Elementos de } \\
\text { wayfinding }\end{array}$ & Configuração & Informação & Serviço \\
\hline Marcadores & $\begin{array}{l}\text { - portas de embarque } \\
\text { preferencial }\end{array}$ & $\begin{array}{l}\text { - contraste visual entre o } \\
\text { trem e a porta do trem }\end{array}$ & $\begin{array}{l}\text { - parada do trem no local } \\
\text { correto na plataforma } \\
\text { - veiculação de campanhas } \\
\text { sobre a porta de } \\
\text { embarque preferencial } \\
\text { nos trens }\end{array}$ \\
\hline Nós & $\begin{array}{l}\text { - fluxo de embarque e } \\
\text { desembarque }\end{array}$ & $\begin{array}{l}\text { - sinalização sonora/visual } \\
\text { sobre segurança no } \\
\text { embarque }\end{array}$ & $\begin{array}{l}\text { - tempo de abertura e } \\
\text { fechamento das portas do } \\
\text { trem }\end{array}$ \\
\hline Zonas & $\begin{array}{l}\text { - distância e desnível entre } \\
\text { os pisos da plataforma e } \\
\text { do trem }\end{array}$ & $\begin{array}{l}\text { - sinalização sonora/visual } \\
\text { sobre o desnível entre } \\
\text { trem e plataforma } \\
\text { - sinalização sonora/visual } \\
\text { sobre o fechamento das } \\
\text { portas }\end{array}$ & $\begin{array}{l}\text { - funcionários para auxiliar } \\
\text { o embarque preferencial }\end{array}$ \\
\hline
\end{tabular}

Fonte: Elaborado pela pesquisadora.

\subsubsection{Síntese do diagnóstico}

Na etapa 12 - Embarque -, foram identificados aspectos que devem ser tratados pelas empresas operadoras dos sistemas metroferroviários para auxiliar pessoas com deficiência visual a estabelecer estratégias para empreender seus deslocamentos, descritos a seguir:

a) condições das instalações existentes (EC3) - prever plataformas mistas nas estações com demanda elevada para possibilitar embarque e desembarque em portas distintas do trem; minimizar o vão e o desnível entre o trem e a plataforma; prover sinalização sonora da localização das portas do trem nas plataformas; disponibilizar informação visual, tátil e sonora sobre a configuração e as principais referências das estações;

b) procedimento operacional - estação (ES6) - fazer o mesmo percurso dos demais usuários para embarque, evitando embarcar no contrafluxo;

c) lotação das estações (ES7) - fazer a gestão do fluxo para reduzir a lotação nas plataformas;

d) vão e desnível (IC1) - eliminar e minimizar o vão e o desnível existentes entre a plataforma e o trem; alinhar a sinalização tátil da plataforma à porta de embarque no trem; eliminar e minimizar o vão e o desnível existentes entre a plataforma e o trem; atentar para as tolerâncias de projeto, fabricação/construção e manutenção das vias, dos trilhos, das rodas dos trens, dos trens e das plataformas das estações; 
e) proteção na plataforma (IC2) - instalar elementos direcionadores de embarque em todas as plataformas;

f) informações para a pessoa com deficiência visual - plataforma (II1) implementar contraste na cor entre a porta do trem e a caixa do trem;

g) treinamento dos empregados - interface trem-estação (IS2) - oferecer ajuda utilizando técnicas apropriadas para auxiliar o embarque; colocar a mão do usuário nas barras de apoio dos trens; padronizar o procedimento para auxílio durante o embarque;

h) comportamento dos usuários - interface trem-estação (IS3) - promover campanhas para orientar e conscientizar os demais usuários da plataforma a não permanecer no local destinado ao embarque preferencial; sensibilizar as pessoas que desembarcam a estarem atentas às pessoas com deficiência que estão na plataforma;

i) monitoração (TI1) - agilizar a comunicação entre as estações e o CCO; dimensionar adequadamente a quantidade de linhas telefônicas e postos de trabalho dedicados para atender/efetuar contato com as estações;

j) lotação dos trens (TS4) - fazer a gestão do fluxo para reduzir a lotação dos trens; adequar o número de trens para atender à demanda das estações.

\subsection{Etapa 13 - Viagem / Embarque}

Nesta etapa, o usuário entra no trem e desloca-se até um dos assentos preferenciais disponibilizados.

\subsubsection{Métodos e técnicas aplicados}

Os métodos e técnicas utilizados para coleta de dados nesta etapa foram apresentados no item 6.10 - Síntese dos instrumentos aplicados - e consistiram em:
a) melhores práticas identificadas em outros sistemas metroferroviários;
b) pesquisa documental (normas técnicas ABNT vigentes, procedimentos operacionais);
c) análise de informações disponibilizadas pelo Metrô de São Paulo (folhetos, sítio eletrônico);
d) questionário aplicado a pessoas com deficiência visual - questões 14 e 17;
e) entrevista com professores de orientação e mobilidade;
f) entrevista com profissionais responsáveis pelo projeto dos trens;
g) entrevista com profissionais responsáveis pela elaboração de normas técnicas. 
As formas de análise e interpretação dos dados coletados foram apresentadas no Capítulo 6 Aplicação dos instrumentos.

\subsubsection{Melhores Práticas}

Entre as melhores práticas, destaca-se o Metrô de Barcelona, que dispõe de assentos preferenciais localizados junto à porta de embarque preferencial, ambos sinalizados quanto ao seu uso (Figura 196). Ainda em Barcelona, destaca-se a sinalização identificativa da destinação do assento preferencial à pessoa cega acompanhada de cão guia no sistema ônibus (Figura 197).

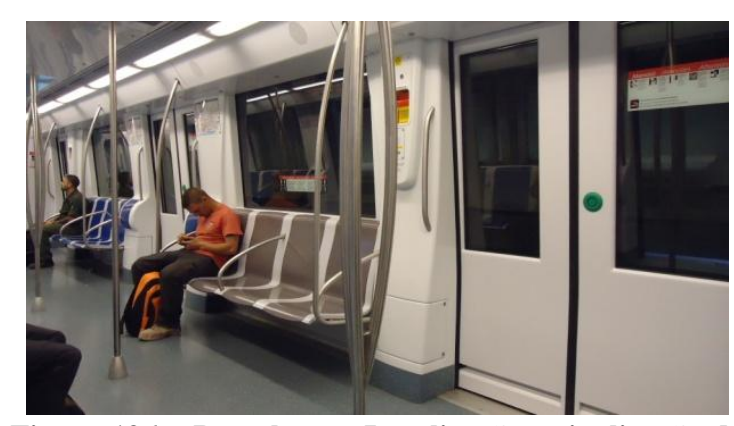

Figura 196 - Barcelona - Localização e sinalização do assento preferencial.

Fonte: BARBOSA, M.B., 2011.

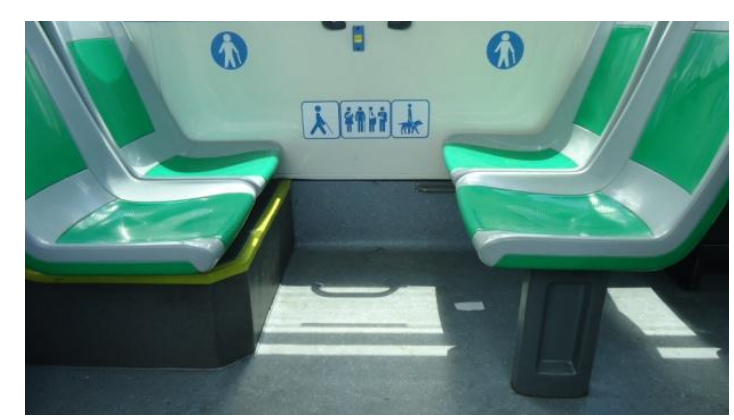

Figura 197 - Madri - Configuração e sinalização do assento preferencial para pessoas com cão-guia no sistema ônibus.

Fonte: BARBOSA, M.B., 2013.

\subsubsection{Requisitos Normativos}

Com relação aos requisitos normativos, a ABNT NBR 14021:2005 determina a necessidade de sinalização visual indicativa da finalidade dos assentos preferenciais e a sinalização tátil com caracteres em relevo e Braille, contendo informações sobre o número do carro ou trem. Há necessidade de alarme visual e sonoro indicativo do fechamento das portas.

\subsubsection{Situação no Metrô de São Paulo}

No Metrô de São Paulo, as diferentes frotas têm configuração e sinalização interna dos carros diferentes entre si. Nas frotas A/B e C/D, ao lado de cada porta de embarque preferencial para pessoas com deficiência visual existe um assento duplo, totalizando quatro assentos. Nos trens das frotas E, F, G, H, I, J, K, L, existem assentos simples nos lados direito e esquerdo de cada porta, totalizando quatro assentos. Todos os assentos preferenciais são de cor azul claro e estão identificados com sinalização visual. As frotas A/B e C/D dispõem de balaústres horizontais junto aos assentos e às portas, oferecendo apoio durante o embarque. As demais 
frotas dispõem de balaústres inclinados nesses locais, dificultando o apoio durante o embarque (Figura 198). Nenhuma das frotas dispõe de balaústre horizontal junto ao teto para auxiliar o deslocamento entre a porta de embarque e o assento preferencial posicionado no lado oposto. Não há local específico destinado ou sinalizado para o usuário com deficiência visual acomodar-se juntamente com o seu cão-guia (Figura 199). Os trens dispõem de alarme sonoro em todos os carros e alarme visual no carro preferencial, indicando o fechamento das portas.
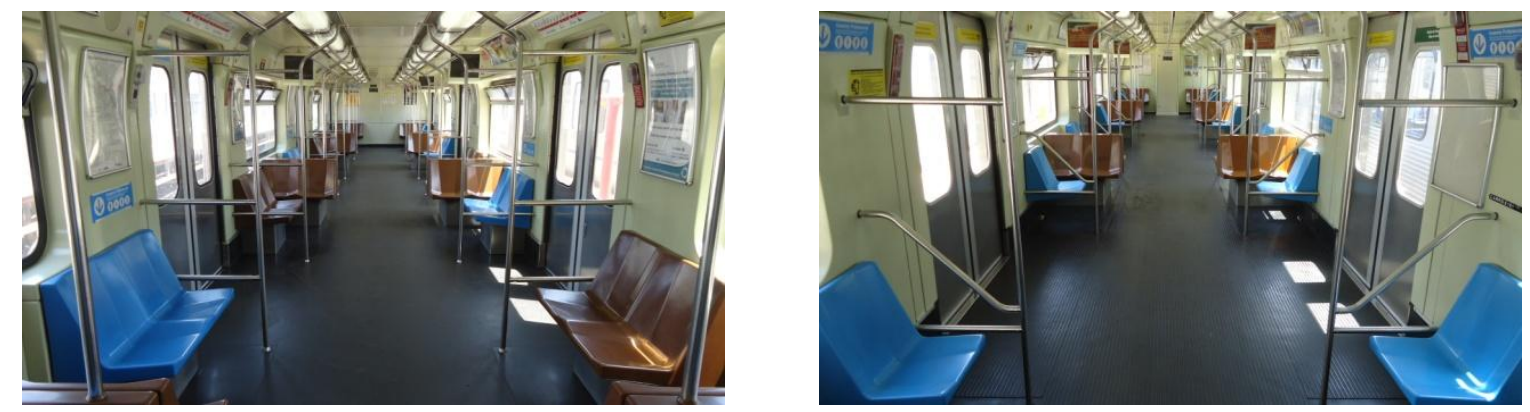

Figura 198 - São Paulo - Configuração da barra de apoio junto às portas em diferentes frotas. Fonte: BARBOSA, M.B., 2011.
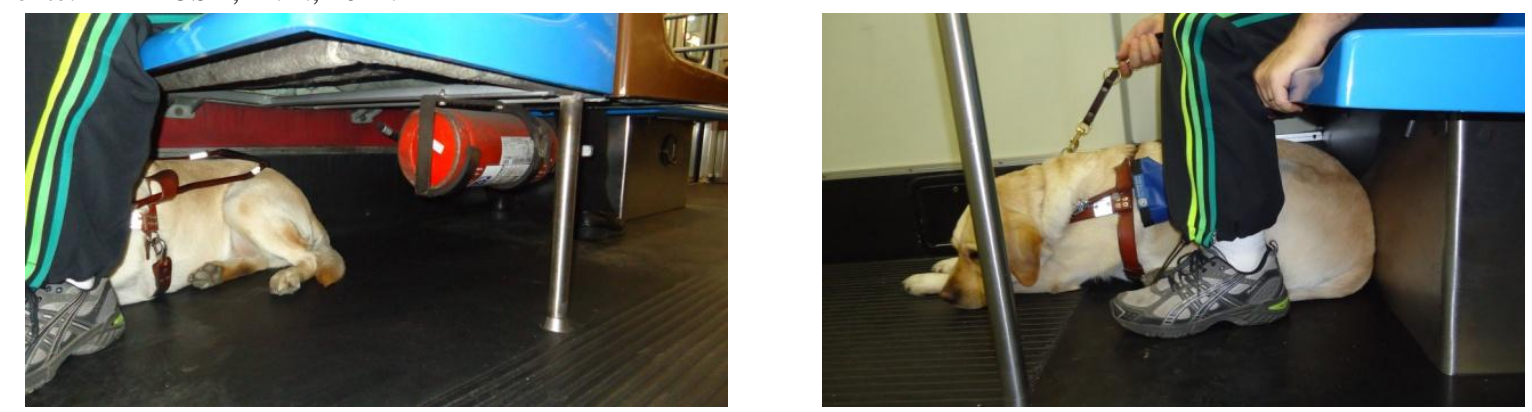

Figura 199 - São Paulo - Acomodação do cão-guia sob o assento do trem. Fonte: BARBOSA, M.B., 2011.

\subsubsection{Avaliação pelos usuários}

Na etapa de viagem-embarque, 124 usuários com deficiência visual - dos quais 88 pessoas são cegas e 36 têm baixa visão - manifestaram seu descontentamento em relação ao trem $(98,1 \%)$, à estação $(1,5 \%)$ e à interface trem-estação $(0,4 \%)$. Foram registrados 261 relatos, o que representa $10,0 \%$ do total de relatos registrados para todas as etapas da jornada do usuário. Os relatos estão relacionados, em sua maioria, aos serviços prestados no trem $(74,4 \%)$ e à configuração do trem $(23,3 \%)$, mas também são dirigidos aos serviços prestados na interface trem-estação $(0,4 \%)$ e à configuração da estação $(1,5 \%)$ para prover segurança durante a viagem (Tabela 25). 
Tabela 25 - Matriz de avaliação da etapa 13 - Viagem / Embarque.

(\% em relação ao total de relatos registrados nesta etapa)

\begin{tabular}{|c|c|c|c|c|}
\hline $9 \sqrt{\square}$ & $\underset{\%}{\text { Configuração }}$ & $\begin{array}{c}\text { Informação } \\
\%\end{array}$ & $\begin{array}{c}\text { Serviço } \\
\%\end{array}$ & $\begin{array}{c}\text { Total } \\
\%\end{array}$ \\
\hline Estação & (EC) 1,5 & $\mathbf{0 , 0}$ & $\mathbf{0 , 0}$ & 1,5 \\
\hline Interface Trem-Estação & $\mathbf{0 , 0}$ & $\mathbf{0 , 0}$ & (IS) 0,4 & 0,4 \\
\hline Trem & (TC) 23,3 & (TI) 0,4 & (TS) 74,4 & 98,1 \\
\hline Total & 24,8 & 0,4 & 74,8 & 100,0 \\
\hline
\end{tabular}

"Eu acho muito difícil viajar no trem: as pessoas nem sempre respeitam os assentos preferenciais, nos horários de pico elas correm na frente dos deficientes para sentar ou fingem que estão dormindo, só para não dar lugar. Se alguém pede para sentar, há discussão e eu fico constrangido. Já vi gente falar: 'Por que não fica em casa? É cego, mas não aleijado'. Às vezes o usuário sai do banco preferencial e não avisa... Eu acho que as três primeiras portas deveriam ser para o deficiente: somente assim eu poderia me sentar ou conseguiria segurar no ferro, pois o usuário comum não deixa a gente segurar. Falando em apoio, uma frota é diferente da outra, umas têm dois ferros e apoio logo na entrada do trem, outras são diferentes, só têm um ferro e não têm apoio na entrada e nem no meio do corredor. Se o trem está muito cheio, não tenho onde segurar, e fico solto no meio da multidão. Quando eu sento do lado que vou descer, tenho que ficar tateando para ver onde está a barra ou apoiar nos outros usuários, principalmente se o trem está lotado. Deveriam sempre informar que o primeiro vagão é prioridade de deficientes e idosos, além de fazer apelo sobre os assentos preferenciais pelo alto falante. Precisaria ter um vagão só para deficientes, porque quando eu entro já está lotado e tem poucos bancos para eu sentar. Esqueceram que já somos muitos. Não dá para embarcar e nem para desembarcar, é difícil se mexer lá dentro. Acho que precisa ter mais bancos especiais e deveriam ser padronizados em todos os trens, pois em uma linha fica de um lado, na outra linha fica de outro lado. Para eu saber qual é o banco especial, ele precisaria ter uma textura diferente, não adianta nada ter uma cor diferente. Eu que uso cão guia, sinto falta de um espaço para ele ficar. O banco precisaria ser mais alto, para o cão se encaixar embaixo." (Discurso do Sujeito Coletivo - Etapa 13)

Os principais problemas relatados pelos usuários na etapa viagem/embarque são apresentados no Gráfico 31, de forma hierarquizada conforme número de relatos registrados. 
Gráfico 31 - Avaliação da etapa 13 - Viagem / Embarque.

(\% em relação ao total de relatos registrados nesta etapa)

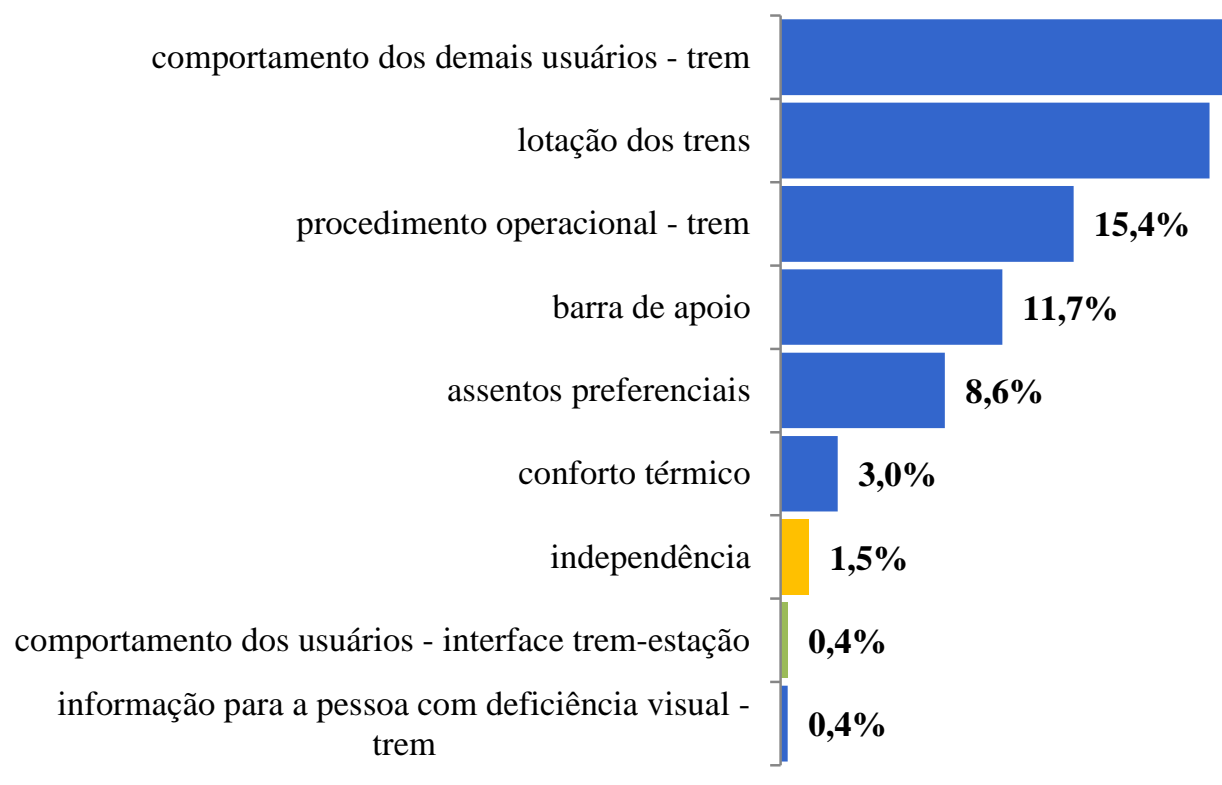

$\mathrm{n} 1=124$ respondentes $\mathrm{n} 2=266$ relatos

Os problemas relatados estão relacionados às seguintes ideias centrais:

a) comportamento dos demais usuários - trem (TS3) - mau comportamento dos usuários no interior dos trens e uso indevido dos assentos preferenciais;

b) lotação dos trens (TS4) - falta de controle do uso dos carros preferenciais;

c) procedimento operacional - trem (TS2) - inexistência de um carro exclusivo para uso preferencial e de orientação aos demais usuários sobre o uso dos carros preferenciais;

d) barra de apoio (TC1) - inexistência ou falta de padronização das barras de apoio no interior dos trens nas diferentes frotas, dificultando o embarque e o deslocamento até o assento preferencial;

e) assentos preferenciais (TC2) - insuficiência de assentos preferenciais e falta de padronização na configuração e na localização dos assentos preferenciais nas diferentes frotas;

f) conforto térmico (TC4) - falta de ventilação - quando o trem para no túnel - e baixa temperatura do ar condicionado;

g) independência (EC1) - necessidade de adoção de estratégias de contorno para facilitar o embarque e desembarque; 
h) comportamento dos usuários - interface trem-estação (IS3) - mau comportamento dos usuários para embarcar ou desembarcar, empurrando as pessoas;

i) informação para a pessoa com deficiência visual - trem (TI2) - falta de piso tátil no interior do trem para orientar o percurso entre as portas de embarque e o assento preferencial.

\subsubsection{Avaliação pelas pessoas-chave}

Os professores de orientação e mobilidade relataram que orientam as pessoas com deficiência a sentar-se tão logo entrem no trem, preferencialmente próximo à porta de desembarque, e destacaram a importância da informação para a pessoa com deficiência visual - trem (TI2), ou seja, a emissão de mensagens sonoras para incentivar o respeito aos assentos preferenciais, para não incomodar o cão-guia e para não permanecer parado ou colocar carrinhos, bagagens ou sacolas junto às portas.

\subsubsection{Avaliação pelos especialistas}

Os profissionais responsáveis pelos projetos dos trens relataram que a modificação da configuração das barras de apoio (TC1) horizontais junto ao teto e às portas preferenciais nas frotas existentes implica a análise estrutural dos carros e a compatibilização entre os elementos e mecanismos já instalados e o sistema de fixação das barras de apoio face ao esforço exercido sobre elas.

Os profissionais responsáveis pela elaboração das normas técnicas relataram que as soluções padronizadas relacionadas à configuração e sinalização dos trens contribuem para prover segurança durante o embarque e a viagem. Entre as soluções que podem contribuir para a segurança e a independência dos deslocamentos, estão recomendações para melhoria dos textos normativos vigentes, destacando aspectos relacionados ao interior dos trens, descritos a seguir:

a) padronização da configuração e da localização dos assentos preferenciais (TC2);

b) padronização da configuração do local para acomodação do cão-guia com sua respectiva sinalização identificadora nas laterais e no piso do assento preferencial (TC2); 
c) padronização da configuração das barras de apoio (TC1) transversais no teto e junto às portas preferenciais;

d) estabelecimento de contraste de cor e textura entre os elementos de acabamento (pisos, assentos, portas, revestimentos) para ampliar a informação para a pessoa com deficiência visual - trem (TI2).

\subsubsection{Elementos de wayfinding}

Os elementos de wayfinding característicos desta etapa são os marcadores e caminhos, (Quadro 34). Esses elementos devem ser providos de configuração adequada bem como de sinalização tátil/visual/sonora integrada de forma a auxiliar sua identificação pelas pessoas com deficiência visual e sobressair-se em relação aos demais elementos e informações do ambiente para facilitar sua percepção. Ao mesmo tempo, tais elementos devem estar presentes e ser ressaltados nas informações veiculadas, especialmente quando da elaboração dos materiais táteis, visuais e sonoros voltados à descrição do interior dos trens, facilitando a compreensão do ambiente e do percurso desde a porta do trem até o assento preferencial.

Quadro 34 - Elementos de wayfinding da Etapa 13 - Viagem / embarque.

\begin{tabular}{|c|c|c|c|}
\hline $\begin{array}{l}\text { Elementos de } \\
\text { wayfinding }\end{array}$ & Configuração & Informação & Serviço \\
\hline Marcadores & - assentos preferenciais & $\begin{array}{l}\text { - contraste visual entre a } \\
\text { superfície do assento } \\
\text { preferencial e a superfície } \\
\text { do trem; } \\
\text { - identificação dos assentos } \\
\text { preferenciais }\end{array}$ & $\begin{array}{l}\text { - campanhas sobre o uso do } \\
\text { assento preferencial }\end{array}$ \\
\hline Caminhos & - barras de apoio & $\begin{array}{l}\text { - contraste visual das } \\
\text { barras de apoio } \\
\text { - sinalização sonora/visual } \\
\text { sobre segurança no } \\
\text { embarque } \\
\text { - informação sonora da } \\
\text { próxima estação }\end{array}$ & $\begin{array}{l}\text { - campanhas sobre o uso } \\
\text { preferencial do } 1^{\circ} \text { carro }\end{array}$ \\
\hline
\end{tabular}

\subsubsection{Síntese do diagnóstico}

Na etapa 13 - Viagem/Embarque -, foram identificados aspectos que devem ser tratados pelas empresas operadoras dos sistemas metroferroviários para auxiliar pessoas com deficiência visual a estabelecer estratégias para empreender seus deslocamentos, descritos a seguir: 
a) treinamento dos usuários (ES3) - orientar os usuários para sentar-se tão logo entrem no trem, preferencialmente próximo à porta de desembarque;

b) independência (EC1) - promover a aprendizagem de estratégias de contorno, como a utilização dos assentos próximos à porta de desembarque;

c) comportamento dos usuários - interface trem-estação (IS3) - promover campanhas para orientar e conscientizar os demais usuários para respeitar o embarque preferencial e não empurrar pessoas com deficiência;

d) barra de apoio (TC1) - padronizar e adequar a configuração e localização das barras de apoio no interior dos trens nas diferentes frotas;

e) assentos preferenciais (TC2) - adequar a quantidade e padronizar a configuração e a localização dos assentos preferenciais nas diferentes frotas; adequar a configuração e a sinalização do assento preferencial para indicar o uso por pessoas com cão-guia;

f) conforto térmico (TC4) - garantir o funcionamento da ventilação e do ar condicionado quando o trem estiver parado no túnel;

e) informação para a pessoa com deficiência visual - trem (TI2) - instalar revestimento tátil para orientar o percurso entre as portas de embarque e o assento preferencial; emitir mensagens sonoras para incentivar o respeito aos assentos preferenciais, bem como para não incomodar o cão-guia e não permanecer parado ou colocar carrinhos, bagagens ou sacolas junto às portas; estabelecer contraste de cor e textura entre os elementos de acabamento;

g) procedimento operacional - trem (TS2) - implementar um carro exclusivo para uso preferencial; orientar os demais usuários sobre o uso dos carros preferenciais;

h) comportamento dos demais usuários - trem (TS3) - promover campanhas para orientar e conscientizar os demais usuários sobre o uso dos assentos preferenciais;

i) lotação dos trens (TS4) - controlar o acesso aos carros preferenciais.

\subsection{Etapa 14 - Viagem/Desembarque}

Nesta etapa, o usuário levanta-se de um dos assentos preferenciais e dirige-se à porta do trem para desembarcar.

\subsubsection{Métodos e técnicas aplicados}

Os métodos e técnicas utilizados para coleta de dados nesta etapa foram apresentados no item 6.10 - Síntese dos instrumentos aplicados - e consistiram em: 
a) melhores práticas identificadas em outros sistemas metroferroviários;

b) pesquisa documental (normas técnicas ABNT vigentes, procedimentos operacionais);

c) análise de informações disponibilizadas pelo Metrô de São Paulo (folhetos, sítio eletrônico);

d) questionário aplicado a pessoas com deficiência visual - questões 14 e 17;

e) entrevista com professores de orientação e mobilidade;

f) entrevista com profissionais responsáveis pelo projeto dos trens;

g) entrevista com profissionais responsáveis pela elaboração de normas técnicas.

As formas de análise e interpretação dos dados coletados foram apresentadas no Capítulo 6 Aplicação dos instrumentos.

\subsubsection{Melhores Práticas}

Entre as melhores práticas, destaca-se o Metrô de Madri, cujos trens dispõem de barras de apoio verticais em cores contrastantes em relação aos fechamentos laterais e assentos com altura livre sob os quais o cão-guia pode acomodar-se com segurança (Figura 200). No Metrô de Londres, o piso no interior dos trens dispõe de contraste tátil e visual junto às portas, facilitando sua identificação (Figura 201). Ambos os sistemas dispõem somente de balaústres verticais.

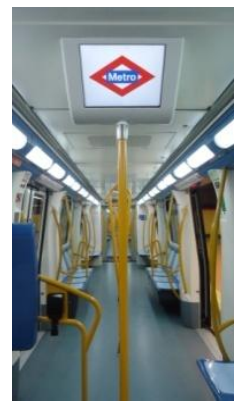

Figura 200 - Madri - Contraste visual das barras de apoio verticais e altura livre dos assentos para acomodação do cão guia.

Fonte: BARBOSA, M.B., 2013.

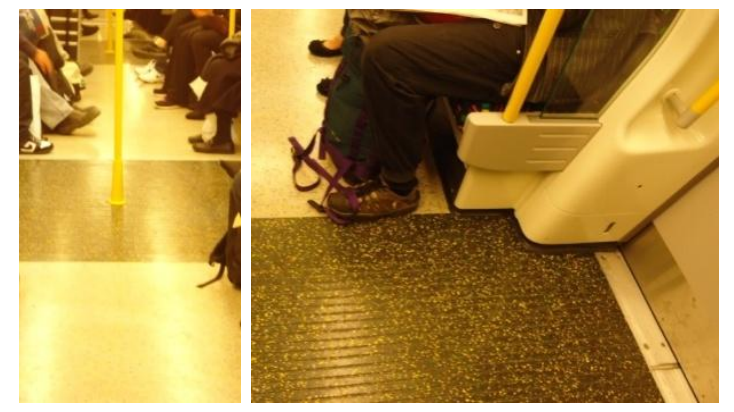

Figura 201 - Londres - Contraste tátil e visual do piso no interior dos trens, junto às portas. Fonte: BARBOSA, M.B., 2013.

\subsubsection{Requisitos Normativos}

Com relação aos requisitos normativos, a ABNT NBR 14.021:2005 determina que haja informação visual permanente na parte interna do trem, próximo às portas, contendo o nome e a sequência das estações, destacando as estações de transferência. A norma determina também a existência de dispositivos de sinalização visual e sonora para informar eventual 
anormalidade na circulação de trens, a estação em que o trem está, a próxima estação e o lado de desembarque. Também há necessidade de dispositivo para solicitar auxílio em situação de emergência.

\subsubsection{Situação no Metrô de São Paulo}

No Metrô de São Paulo, todos os trens dispõem de informações visuais indicativas da linha onde o trem está circulando: em todas as frotas existe informação por meio de mapas impressos. Nas frotas F, H, I, J, K, L, a informação é dinâmica, por meio de painel eletrônico, indicando as estações já atendidas. As informações sonoras sobre o nome da próxima estação e o lado de desembarque são sempre veiculadas, seja pelo condutor - frotas antigas A/B e C/D - seja por meio de mensagens digitalizadas pré-gravadas - novas frotas E, F, G, H, I, J, K e L. O lado de abertura das portas é indicado simultaneamente por meio de alarme visual intermitente nas frotas F, G, H, I, J, K e L. A configuração das barras de apoio e balaústres é diferente: as novas frotas dispõem de balaústre longitudinal ao longo do carro para auxiliar a distribuição dos usuários nos corredores longe das portas. Porém, nenhuma das frotas dispõe de balaústre transversal no interior do carro para auxiliar o deslocamento entre o assento preferencial e a porta de desembarque preferencial. As frotas antigas - A/B e C/D - dispõem de balaústres horizontais junto às portas, oferecendo apoio durante o desembarque (Figura 202).
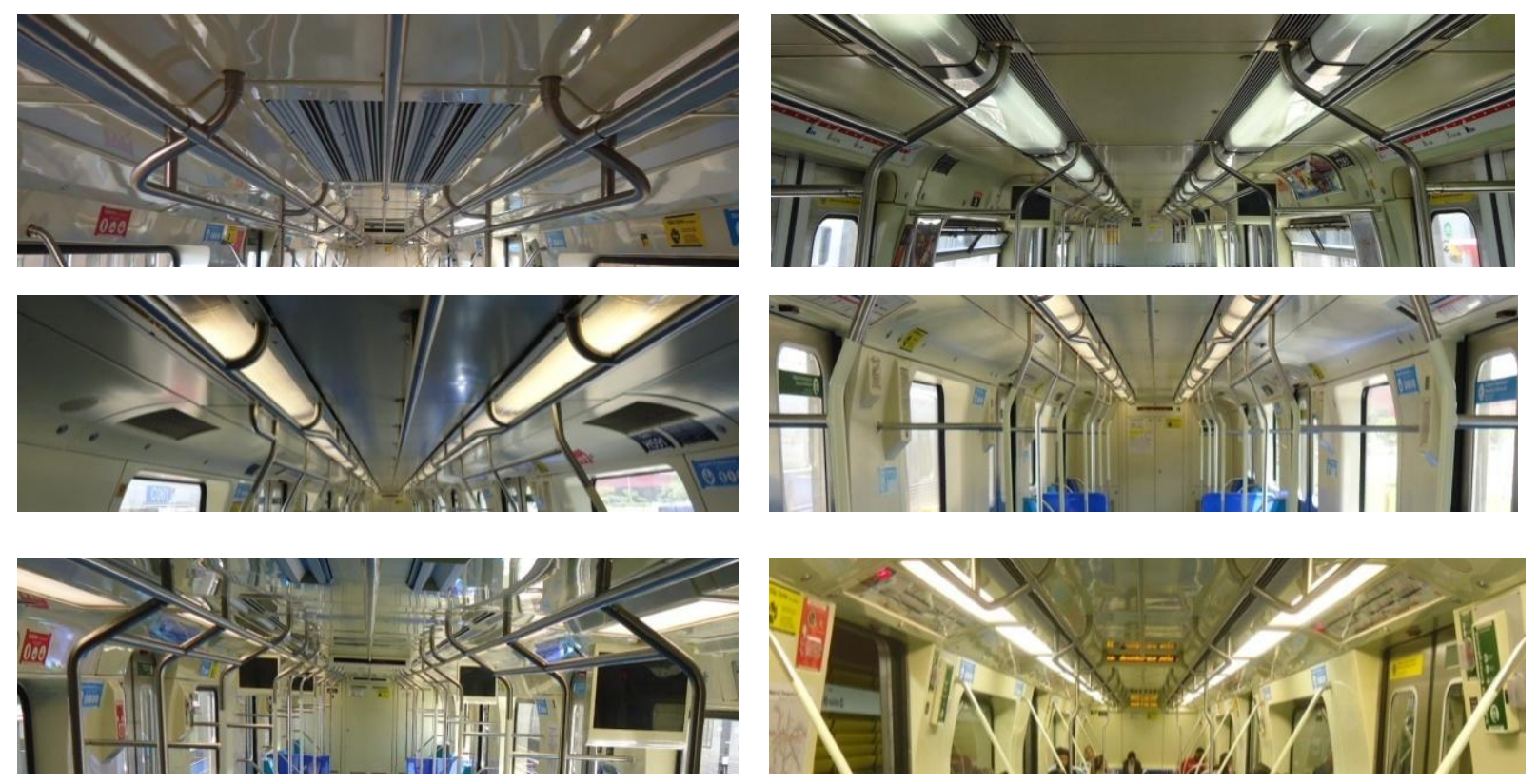

Figura 202 - São Paulo - Configuração das barras de apoio e balaústres nas diferentes frotas. Fonte: BARBOSA, M.B., 2011. 


\subsubsection{Avaliação pelos usuários}

Na etapa de viagem/desembarque, 114 usuários com deficiência visual - dos quais 87 pessoas são cegas e 27 têm baixa visão - manifestaram seu descontentamento em relação ao trem $(98,4 \%)$ e à estação (1,6\%). Foram registrados 261 relatos, o que representa 9,8\% do total de relatos registrados para todas as etapas da jornada do usuário. Os relatos estão relacionados, em sua maioria, às informações prestadas no trem $(83,1 \%)$, aos serviços prestados no trem $(12,6 \%)$ e à configuração do trem $(2,7 \%)$, mas também referem-se às informações prestadas na estação $(1,1 \%)$ e aos serviços prestados na estação $(0,4 \%)$ para prover segurança durante a viagem (Tabela 26).

Tabela 26 - Matriz de avaliação da etapa 14 - Viagem/Desembarque.

(\% em relação ao total de relatos registrados nesta etapa)

\begin{tabular}{l|r|r|r|r|}
\hline & $\begin{array}{c}\text { Configuração } \\
(\%)\end{array}$ & $\begin{array}{c}\text { Informação } \\
(\%)\end{array}$ & $\begin{array}{c}\text { Serviço } \\
(\%)\end{array}$ & \multicolumn{2}{c|}{$\begin{array}{c}\text { Total } \\
\text { (\%) }\end{array}$} \\
\hline Estação & $\mathbf{0 , 0}$ & (EI) $\mathbf{1 , 1}$ & $\mathbf{( E S ) ~} \mathbf{0 , 4}$ & $\mathbf{1 , 5}$ \\
\hline Interface Trem-Estação & $\mathbf{0 , 0}$ & $\mathbf{0 , 0}$ & $\mathbf{0 , 0}$ & $\mathbf{9 8 , 5}$ \\
\hline Trem & (TC) 2,7 & (TI) 83,1 & (TS) 12,6 & $\mathbf{1 0 0 , 0}$ \\
\hline Total & $\mathbf{2 , 7}$ & $\mathbf{8 4 , 3}$ & $\mathbf{1 3 , 0}$ & $\mathrm{n}=261$ relatos \\
\hline
\end{tabular}

"Eu acho que é preciso melhorar a qualidade do som do alto falante para eu não ter que perguntar para outro usuário qual é a próxima estação. Às vezes o som está muito baixo, às vezes falha e não dá para entender. Precisa melhorar a manutenção dos alto falantes e dar treinamento para os operadores melhorarem sua dicção. Melhoraria muito para mim se tivesse um sistema no bluetooth para eu me cadastrar e receber informações do horário do ônibus e do trem, o nome das estações e das linhas, pois assim poderia programar o GPS do celular para avisar quando estivesse chegando na estação que vou descer. Quando o operador fala a próxima estação logo que o trem sai fica mais difícil de ouvir por causa do barulho, mudou faz pouco tempo... Para mim também fica difícil quando o operador do trem não fala o nome da próxima estação. Às vezes ele esquece e eu tenho que perguntar para outro usuário. A informação do lado do desembarque também é importante porque quando o trem abre as duas portas, eu não sei para que lado sair. Os funcionários deveriam ser sensibilizados para as necessidades dos deficientes visuais... Como eu já disse me ajudaria muito se todas as estações tivessem plataforma diferente para embarque e desembarque: quando o trem está muito lotado e eu estou sentado, tenho que me levantar antes, senão não consigo desembarcar. As freadas dos trens novos me causam desequilíbrio. Preciso que tenha mais informação em braile dentro do trem, o mapa das estações, os procedimentos em caso de evacuação dos trens, o local do botão de emergência... Eu que tenho baixa visão tenho dificuldade em ler as placas das estações e dos trens, acho que as letras poderiam ser maiores." (Discurso do Sujeito Coletivo - Etapa 14)

Os principais problemas relatados pelos usuários na etapa de viagem/desembarque são apresentados de forma hierarquizada, conforme o número de relatos registrados (Gráfico 32). 
Gráfico 32 - Avaliação da etapa 14 - Viagem / Desembarque.

(\% em relação ao total de relatos registrados nesta etapa)

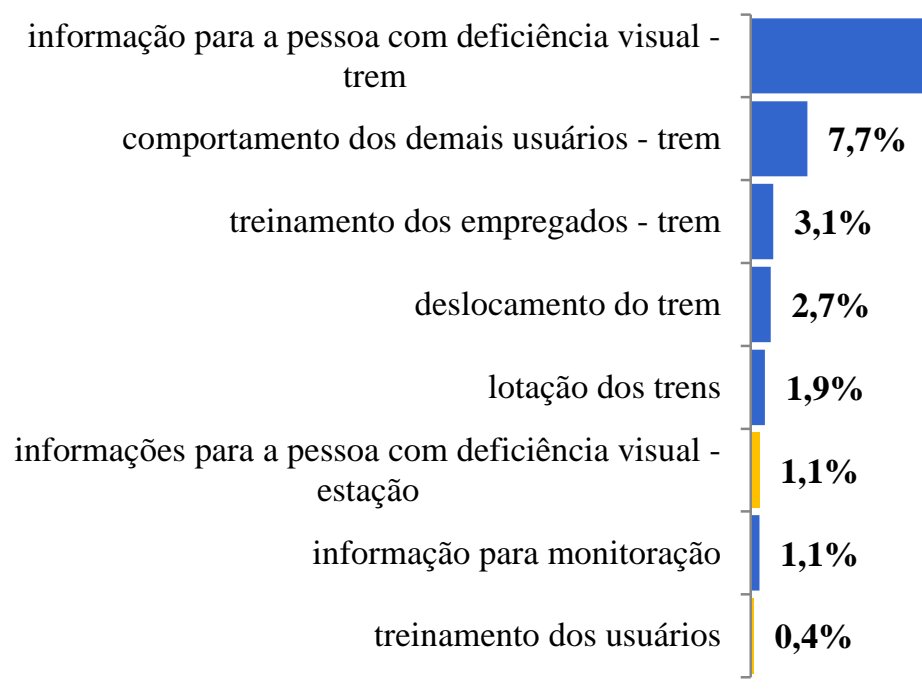

$\mathrm{n} 1=114$ respondentes $\mathrm{n} 2=261$ relatos

Os problemas relatados estão relacionados às seguintes ideias centrais:

a) informações para a pessoa com deficiência visual - trem (TI2) - falta de sinalização tátil no interior do trem, seja por meio de mapas, orientações ou instruções de uso dos dispositivos de emergência;

b) comportamento dos demais usuários - trem (TS3) - dificuldades encontradas para desembarcar em função do comportamento inadequado e pouco solidário das pessoas (paradas na porta ou no caminho, ouvindo som alto);

c) treinamento dos empregados - trem (TS1) - má qualidade da dicção e da entonação dos operadores de trem durante a emissão de mensagens sonoras;

d) deslocamento do trem (TC3) - insegurança causada pelas frenagens bruscas dos trens;

e) informações para a pessoa com deficiência visual - estação (EI6) subdimensionamento dos textos utilizados nos mapas, insuficientes para legibilidade;

f) informação para monitoração (TI1) - insatisfação quanto à falta de um serviço de comunicação direta entre o usuário cego e a estação de destino para informar seu desembarque, agilizando o auxílio;

g) treinamento dos usuários (ES3) - falta de conhecimento sobre como proceder em situações de emergência; 
h) lotação dos trens (TS4) - dificuldade de deslocamento e desembarque quando o trem está lotado.

\subsubsection{Avaliação pelas pessoas-chave}

Os professores de orientação e mobilidade relataram que, durante o treinamento dos usuários (ES3), orientam as pessoas com deficiência a prepararem-se para o desembarque tão logo seja anunciada a estação de destino e a esperarem o trem "quase parar" para então se levantarem. Não se aconselha aguardar a parada total uma vez que a lotação do trem (TS4) pode dificultar o percurso de desembarque.

Os estagiários relataram o mau comportamento dos demais usuários - estação (ES4), mais especificamente o desrespeito vivenciado no momento do desembarque, em função da lotação ou da pressa, das pessoas que param ou colocam malas junto às portas do trem.

Os professores de orientação e mobilidade relataram a importância da informação para a pessoa com deficiência visual - trem (TI2), ou seja, da emissão de mensagens sonoras sobre a próxima estação e sobre o lado de desembarque para orientar o deslocamento no trem e permitir que o usuário se prepare para o desembarque.

\subsubsection{Avaliação pelos especialistas}

Os profissionais responsáveis pelos projetos dos trens relataram que a adequação da configuração dos balaústres horizontais junto ao teto e às portas preferenciais nas frotas existentes implica a análise estrutural dos carros e a compatibilização entre os elementos e mecanismos já instalados e o sistema de fixação dos balaústres face ao esforço exercido sobre eles.

Os profissionais responsáveis pela elaboração das normas técnicas relataram que as soluções padronizadas relacionadas à configuração e sinalização dos trens contribuem para prover segurança durante a viagem e o desembarque. Entre as soluções que podem contribuir para a segurança e a independência dos deslocamentos, foram feitas recomendações para melhoria dos textos normativos vigentes, destacando aspectos relacionados ao interior dos trens, descritos a seguir:

a) padronização da configuração e da localização dos assentos preferenciais (TC2); 
b) padronização da configuração das barras de apoio (TC1) transversais no teto e junto às portas preferenciais;

c) definição dos requisitos e padronização das características dos painéis eletrônicos, dos mapas dinâmicos e da informação sonora para proporcionar informação para a pessoa com deficiência visual - trem (TI2);

d) estabelecimento de contraste de cor e textura entre os elementos de acabamento (pisos, assentos, portas, revestimentos) para ampliar a informação para a pessoa com deficiência visual - trem (TI2).

As referências necessárias para orientar os deslocamentos das pessoas com deficiência visual podem ser criadas a partir de estímulos táteis e sonoros, ou mesmo visuais, desde que redundantes, integrados e adequados aos parâmetros que possibilitem sua percepção por pessoas com baixa visão.

\subsubsection{Elementos de wayfinding}

Os elementos de wayfinding característicos desta etapa são os marcadores e caminhos, (Quadro 35). Esses elementos devem ser providos de configuração adequada bem como de sinalização tátil/visual/sonora integrada de forma a auxiliar sua identificação pelas pessoas com deficiência visual e sobressair-se em relação aos demais elementos e informações do ambiente para auxiliar sua percepção. Ao mesmo tempo, tais elementos devem estar presentes e ser ressaltados nas informações veiculadas, especialmente quando da elaboração dos materiais táteis, visuais e sonoros voltados à descrição do ambiente dos trens, facilitando a compreensão do ambiente e do percurso desde o assento preferencial até a porta do trem.

Quadro 35 - Elementos de wayfinding da Etapa 14 - Viagem/desembarque.

\begin{tabular}{c|c|c|c}
\hline \multicolumn{1}{c|}{$\begin{array}{c}\text { Elementos de } \\
\text { wayfinding }\end{array}$} & Configuração & Informação & Serviço \\
\hline Marcadores & $\begin{array}{l}\text { - assentos preferenciais } \\
\text { - portas de desembarque } \\
\text { preferencial }\end{array}$ & $\begin{array}{l}\text { - contraste visual entre a } \\
\text { superfície interna e a porta } \\
\text { do trem }\end{array}$ & $\begin{array}{c}\text { - campanhas sobre a porta } \\
\text { de desembarque } \\
\text { preferencial }\end{array}$ \\
\hline Caminhos & - barras de apoio & $\begin{array}{l}\text { - contraste visual entre as } \\
\text { superfícies e as barras de } \\
\text { apoio } \\
\text { - informação sonora sobre a } \\
\text { próxima estação/o lado de } \\
\text { desembarque/o } \\
\text { deslocamento }\end{array}$ & $\begin{array}{c}\text { - campanhas sobre o uso } \\
\text { preferencial do } 1^{\circ} \text { carro }\end{array}$ \\
\hline
\end{tabular}

Fonte: Elaborado pela pesquisadora. 


\subsubsection{Síntese do diagnóstico}

Na etapa 14 - Viagem/Desembarque -, foram identificados aspectos que devem ser tratados pelas empresas operadoras dos sistemas metroferroviários para auxiliar as pessoas com deficiência visual a estabelecer estratégias para empreender seus deslocamentos:

a) informações para a pessoa com deficiência visual - estação (EI6) - aumentar a dimensão e contraste dos textos utilizados nos mapas para melhor legibilidade;

b) treinamento dos usuários (ES3) - capacitar as pessoas com deficiência sobre como proceder em situações de emergência; orientar as pessoas com deficiência a se prepararem para o desembarque tão logo seja anunciada a estação de destino e a esperarem o trem "quase parar" para então se levantarem;

c) barras de apoio (TC1) - padronizar a configuração das barras transversais no teto e junto às portas preferenciais;

d) assentos preferenciais (TC2) - padronizar a configuração e a localização dos assentos preferenciais;

e) deslocamento do trem (TC3) - evitar frenagens bruscas dos trens;

f) informação para monitoração (TI1) - implementar um serviço de comunicação direta entre o usuário cego e a estação de destino para informar seu desembarque;

g) informações para a pessoa com deficiência visual - trem (TI2) - instalar sinalização tátil no interior do trem (mapas, orientações ou instruções de uso dos dispositivos de emergência); definir requisitos e padronizar as características dos painéis eletrônicos, dos mapas dinâmicos e da informação sonora; estabelecer contraste de cor e textura entre os elementos de acabamento;

h) treinamento dos empregados - trem (TS1) - capacitar os operadores de trem em relação à dicção e entonação durante a emissão de mensagens sonoras;

i) comportamento dos demais usuários - trem (TS3) - promover campanhas para orientar e conscientizar os demais usuários para terem um comportamento respeitoso e solidário para desembarcar, para não pararem junto à porta ou no caminho e não ouvirem música em volume elevado;

j) lotação dos trens (TS4) - fazer a gestão de fluxo e controlar a lotação no interior dos trens para facilitar o percurso de desembarque. 


\subsection{Etapa 15 - Desembarque}

Nesta etapa, o usuário passa do trem à plataforma da estação.

\subsubsection{Métodos e técnicas aplicados}

Os métodos e técnicas utilizados para coleta de dados nesta etapa foram apresentados no item 6.10 - Síntese dos instrumentos aplicados - e consistiram em:

a) melhores práticas identificadas em outros sistemas metroferroviários;

b) pesquisa documental (normas técnicas ABNT vigentes, procedimentos operacionais);

c) checklist dos recursos disponíveis e walkthrough realizado nas estações para compreensão do percurso de desembarque;

d) questionário aplicado às pessoas com deficiência visual - questões 12, 13, 14 e 17;

e) entrevista com empregados das estações;

f) entrevista com profissionais responsáveis pelo treinamento dos empregados;

g) entrevista com os estagiários que auxiliam usuários com deficiência visual;

h) entrevista com operadores do Centro de Controle Operacional;

i) entrevista com profissionais responsáveis pelo projeto dos trens;

j) entrevista com profissionais responsáveis pela elaboração de normas técnicas.

As formas de análise e interpretação dos dados coletados foram apresentadas no Capítulo 6 Aplicação dos instrumentos.

\subsubsection{Melhores Práticas}

Entre as melhores práticas, destacam-se o Metrô de Madri, cujos trens têm dispositivo para reduzir o vão e desnível entre o trem e a plataforma (Figura 203), e o Metrô de Londres, que dispõe de desenho representativo de cada estação nas plataformas da Linha Victoria, facilitando sua identificação por pessoas com deficiência cognitiva (Figura 204). 


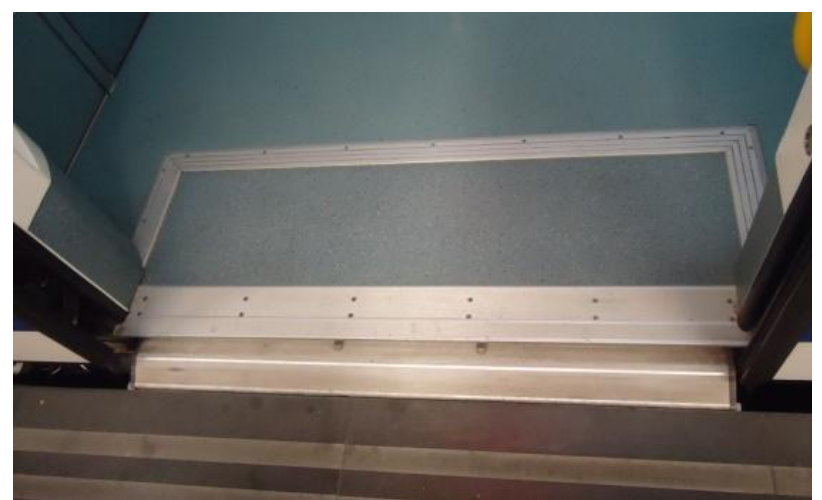

Figura 203 - Madri - Dispositivo no trem para reduzir vão e desnível entre o trem e a plataforma.

Fonte: BARBOSA, M.B., 2013.

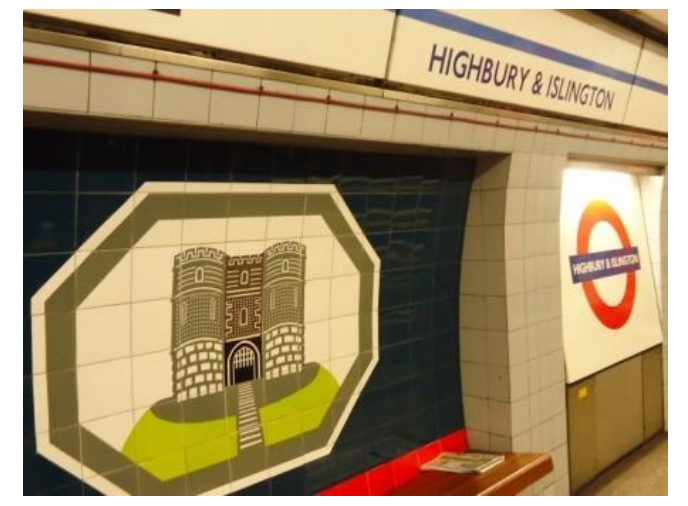

Figura 204 - Londres - Símbolo de identificação na plataforma da estação.

Fonte: BARBOSA, M.B., 2013.

\subsubsection{Requisitos Normativos}

Assim como no embarque, os requisitos normativos para a estação estabelecidos pela ABNT NBR 14.021:2005 são a sinalização visual e tátil de alerta distando de, no mínimo, $50 \mathrm{~cm}$ da borda da plataforma, em toda a sua extensão ou na projeção das portas, e informação visual e sonora alertando quanto à localização da plataforma. A norma determina a existência de identificação da estação visível para a maioria dos usuários que estão dentro do trem, em qualquer dos carros, estejam sentados ou em pé. Além disso, determina a existência de um símbolo de identificação para cada estação, localizado nas plataformas, próximo ou visível a partir do local de desembarque para a pessoa com deficiência ou com mobilidade reduzida. Quanto aos requisitos normativos para o trem, a ABNT NBR 14.021:2005 estabelece a existência de alarme sonoro e visual para informar sobre o fechamento das portas.

\subsubsection{Situação no Metrô de São Paulo}

No Metrô de São Paulo, para reduzir o vão e o desnível entre o trem e a plataforma junto ao local de desembarque preferencial, foram instaladas chapas em polipropileno nas bordas das plataformas, alinhadas às portas dos trens. Os vãos existentes são decorrentes da configuração da plataforma (reta ou em curva), da estrutura da via (em concreto ou em lastro de brita) ou dos diferentes modelos de trens/frotas. No interior dos trens são emitidas mensagens sonoras informando sobre a existência de vão entre o trem e a plataforma antes da chegada às estações em curva (Figura 205). 


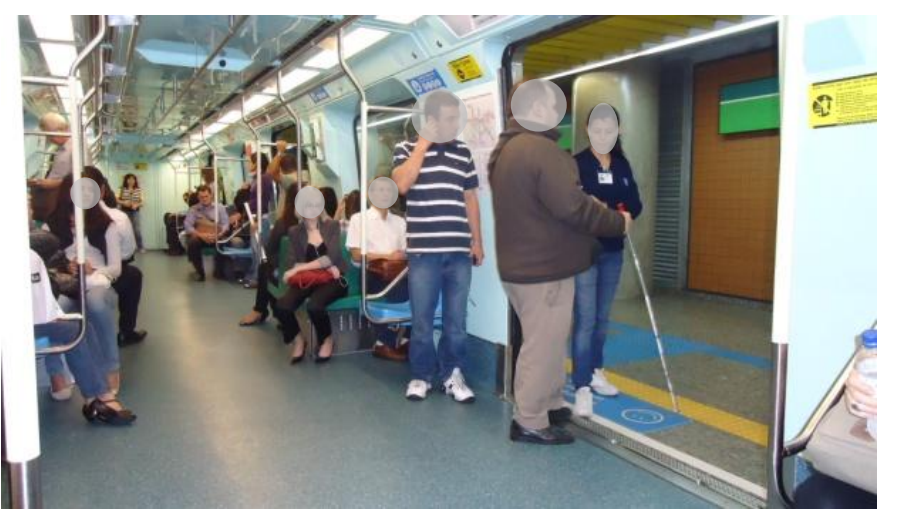

Figura 205 - São Paulo - Sinalização do local de parada e dos vãos e desníveis entre o trem e a plataforma. Fonte: BARBOSA, M.B., 2011.

\subsubsection{Avaliação pelos usuários}

Na etapa de desembarque, 72 usuários com deficiência visual - dos quais 55 pessoas são cegas e 17 pessoas têm baixa visão - manifestaram seu descontentamento em relação à estação $(68,1 \%)$, à interface trem-estação $(26,7 \%)$ e ao trem $(5,2 \%)$. Foram registrados 116 relatos, o que representa $4,3 \%$ do total de relatos registrados para todas as etapas da jornada do usuário. Os relatos estão relacionados, em sua maioria, aos serviços prestados na estação $(50,0 \%)$ e na interface trem-estação $(16,4 \%)$, às informações na estação $(11,2 \%)$ e à configuração da interface trem-estação $(10,3 \%)$, mas também referem-se à configuração da estação $(6,9 \%)$ e às informações no trem $(5,2 \%)$ para prover segurança durante o desembarque (Tabela 27).

Tabela 27 - Matriz de avaliação da etapa 15 - Desembarque.

(\% em relação ao total de relatos registrados nesta etapa)

\begin{tabular}{|c|c|c|c|c|}
\hline & $\underset{\%}{\text { Configuração }}$ & $\begin{array}{c}\text { Informação } \\
\%\end{array}$ & $\begin{array}{c}\text { Serviço } \\
\%\end{array}$ & $\begin{array}{c}\text { Total } \\
\%\end{array}$ \\
\hline Estação & (EC) 6,9 & (EI) 11,2 & (ES) 50,0 & 68,1 \\
\hline Interface Trem-Estação & (IC) 10,3 & $\mathbf{0 , 0}$ & (IS) 16,4 & 26,7 \\
\hline Trem & $\mathbf{0 , 0}$ & (TI) 5,2 & $\mathbf{0 , 0}$ & 5,2 \\
\hline Total & 17,2 & 16,4 & 66,4 & 100,0 \\
\hline
\end{tabular}

"Acho importante melhorar a comunicação entre as estações para avisar do meu desembarque. Hoje o funcionário precisa ligar para uma central, mas nem sempre a informação chega na estação onde vou desembarcar, porque não tem empregado me esperando quando eu chego. Isso poderia evitar que eu esperasse tanto o empregado para me auxiliar no desembarque. Essa espera já fez com que eu me machucasse... porque quando desembarquei não tinha nenhum empregado para me ajudar no horário de pico. O estagiário também deveria estar mais preparado para ajudar na plataforma. Facilitaria bastante se tivesse um intercomunicador na plataforma das estações próximo à porta do trem porque aí eu mesmo poderia avisar quando desembarcasse. E deveria ter mais totens espalhados na estação para eu chamar um empregado. Os que existem nem sempre estão funcionando e eu até hoje não entendi direito como ele funciona, mesmo com a ajudada de um empregado. Poderia ter um cartão de uso exclusivo do deficiente para que eu pudesse usar o telefone que ele usa para avisar a central, também me ajudaria, principalmente à noite. Em alguns locais da estação poderia ter uma 


\begin{abstract}
sirene para eu apertar e saber onde estou e para onde devo ir... Para eu me sentir mais seguro no desembarque precisaria ter mais câmeras varrendo toda a plataforma, para que o empregado da SSO me visse perdido ou em um local mais afastado. Isso ajudaria muito à noite que não tem muito empregado para me ajudar... O tamanho dos vãos nas plataformas não é o mesmo em todas as estações e, em algumas, forma um desnível entre o trem e a plataforma e isto pode me causar acidentes, se eu não estiver atento. Acho que deveriam dar um jeito de tampar esse vão para que eu me sinta mais seguro. Melhoraria a minha segurança se as estações tivessem plataformas diferentes para embarque e desembarque, aí eu não precisaria descer do trem, como acontece em algumas estações, para os outros usuários conseguirem desembarcar. Quando o trem está muito cheio já fui empurrado para fora e me machuquei. O pessoal não respeita o desembarque, eu tento descer e eles não deixam. Às vezes, na hora do desembarque, as pessoas passam com tudo, já levaram até a minha bengala." (Discurso do Sujeito Coletivo - Etapa 15)
\end{abstract}

Os principais problemas relatados pelos usuários na etapa de desembarque são apresentados de forma hierarquizada, conforme o número de relatos registrados (Gráfico 33).

\title{
Gráfico 33 - Avaliação da etapa 15 - Desembarque
}

(\% em relação ao total de relatos registrados nesta etapa)

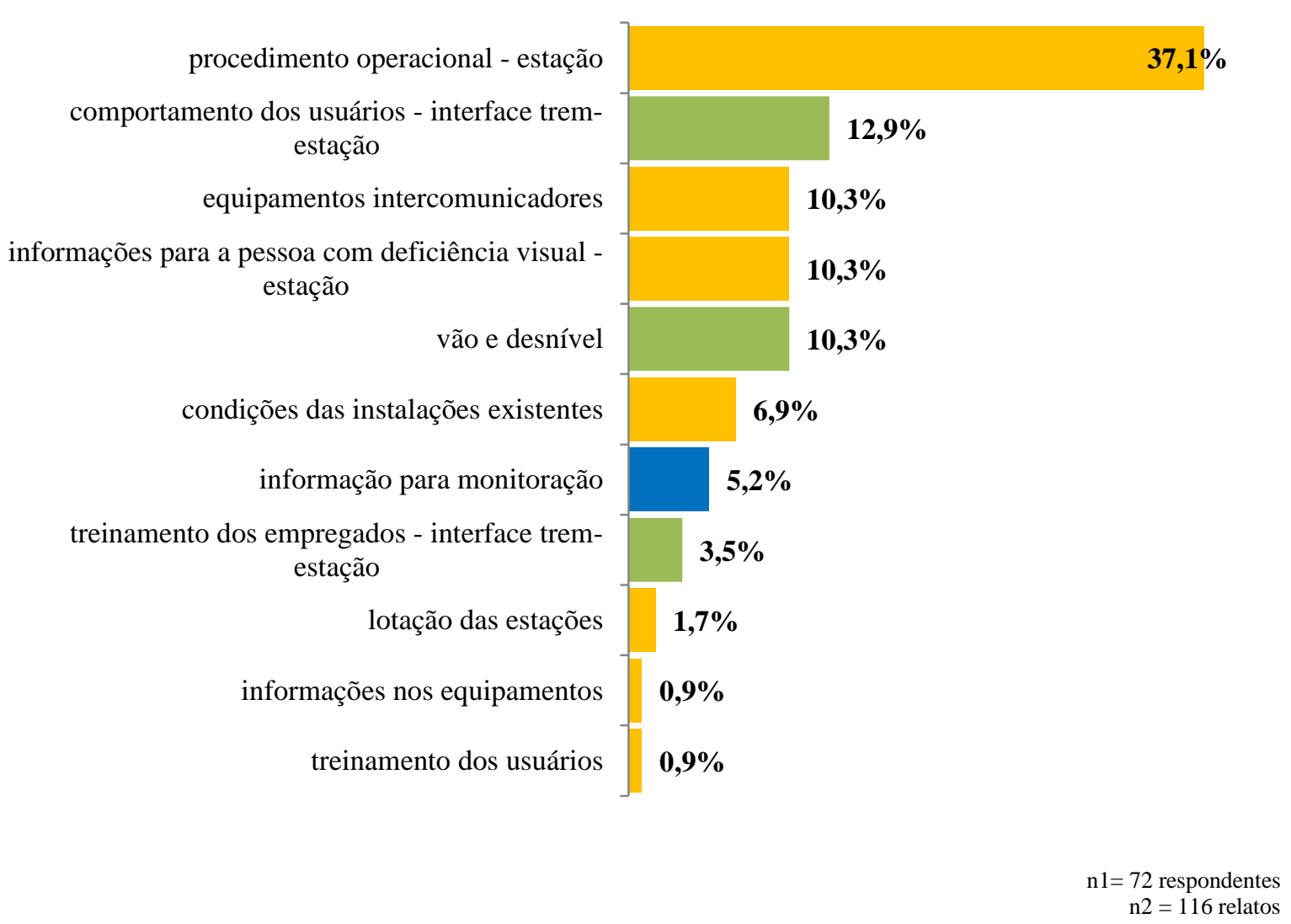

Os problemas relatados estão relacionados às seguintes ideias centrais:

a) procedimento operacional - estação (ES6) - relata a insatisfação em relação à comunicação entre as estações e o centro de controle, o que leva à ausência de empregados na plataforma da estação de desembarque; 
b) comportamento dos usuários - interface trem-estação (IS3) - relata o mau comportamento dos demais usuários para desembarcar, em função da lotação ou da pressa;

c) equipamentos intercomunicadores (ES11) - relata a inoperância dos intercomunicadores, dificultando a solicitação de auxílio no desembarque;

d) informações para a pessoa com deficiência visual - estação (EI6) - critica a falta de intercomunicador nas plataformas, dificultando a solicitação de auxílio no desembarque;

e) vão e desnível (IC1) - critica o vão e o desnível existentes entre a plataforma e o trem, gerando insegurança no momento do desembarque;

f) condições das instalações existentes (EC3) - refere-se à sensação de insegurança gerada pela ausência de câmeras de monitoração e à insatisfação em relação à configuração das plataformas (laterais ou centrais), que impõem que o embarque e o desembarque sejam feitos por uma única porta do trem, gerando conflitos;

g) informação para monitoração (TI1) - relata a insatisfação em relação à inexistência de comunicação direta entre as estações para facilitar o auxílio no desembarque;

h) treinamento dos empregados - interface trem-estação (IS2) - refere-se à insatisfação com a falta de auxílio dos empregados durante o desembarque;

i) lotação das estações (ES7) - refere-se à lotação das plataformas e à presença de usuários em frente à porta do trem, dificultando o desembarque;

j) informações nos equipamentos (EI4) - refere-se à inexistência ou inadequação das informações e orientações tátil e visual para utilização do intercomunicador;

k) treinamento dos usuários (ES3) - critica a falta de orientação para aprender a utilizar os recursos disponíveis nas estações, com destaque para o intercomunicador.

\subsubsection{Avaliação pelas pessoas-chave}

Os empregados das estações relataram o recebimento de informação para monitoração (TI1) do Centro de Controle, deslocando um empregado da linha de bloqueio para o local de desembarque na plataforma para auxiliar o desembarque. Alguns supervisores estão testando uma nova estratégia, mantendo um estagiário na plataforma, para garantir maior prontidão no atendimento da pessoa com deficiência visual até o seu local de destino - seja para conexão com outra linha de metrô, com o trem ou o ônibus ou para saída da estação. 
Os profissionais responsáveis pelo treinamento dos empregados destacam, entre os temas abordados no programa de capacitação, o treinamento dos empregados - interface tremestação (IS2) para oferecimento de ajuda com técnicas apropriadas e orientações para condução individual ou em grupo, durante o desembarque (Figuras 206 a 209).
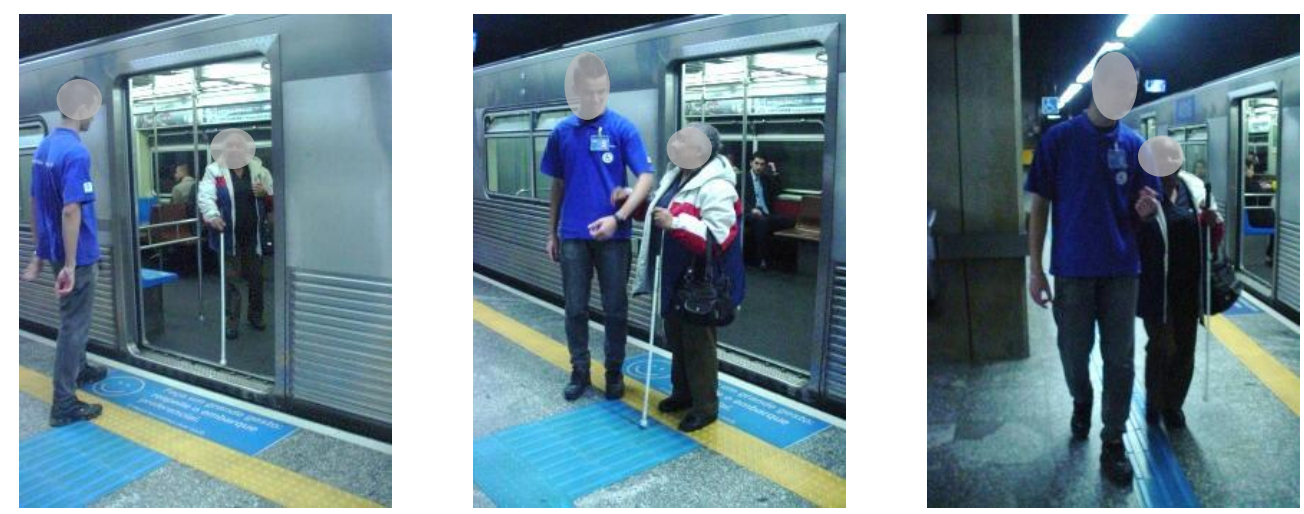

Figura 206 - São Paulo - Monitoração de desembarque.
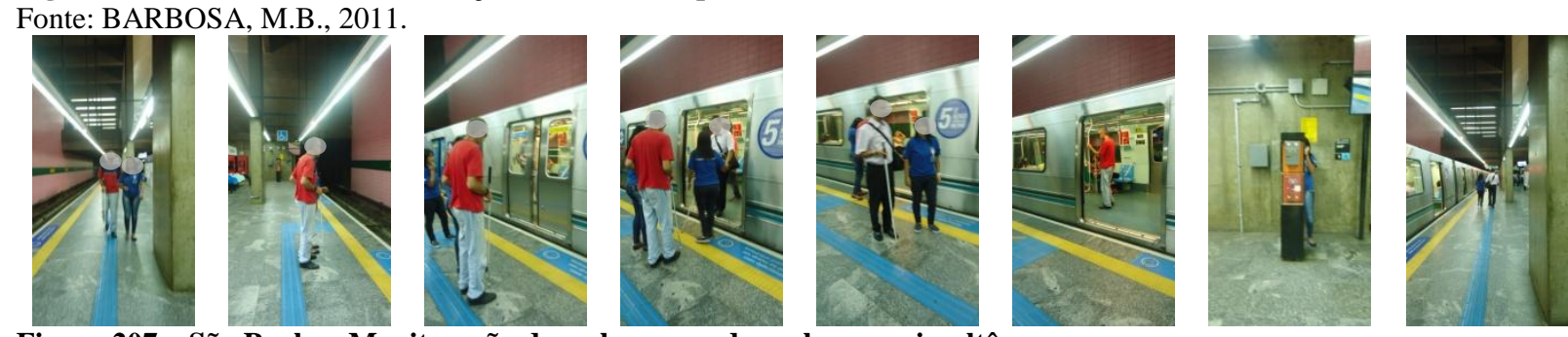

Fonte: BARBOSA, M.B., 2011
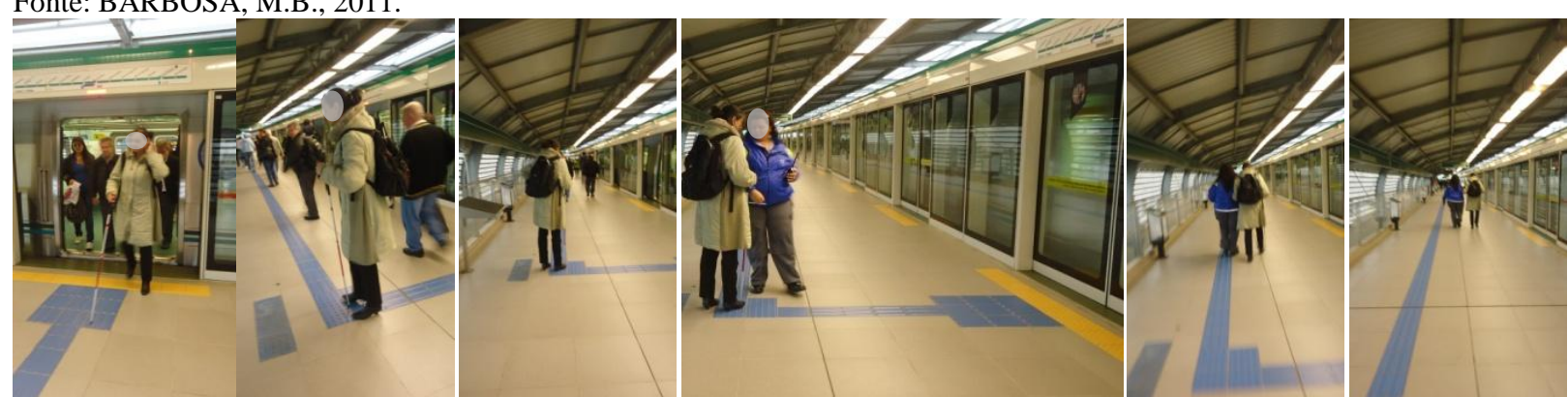

Figura 208 - São Paulo - Monitoração de desembarque em estação com porta de plataforma.

Fonte: BARBOSA, M.B., 2011.

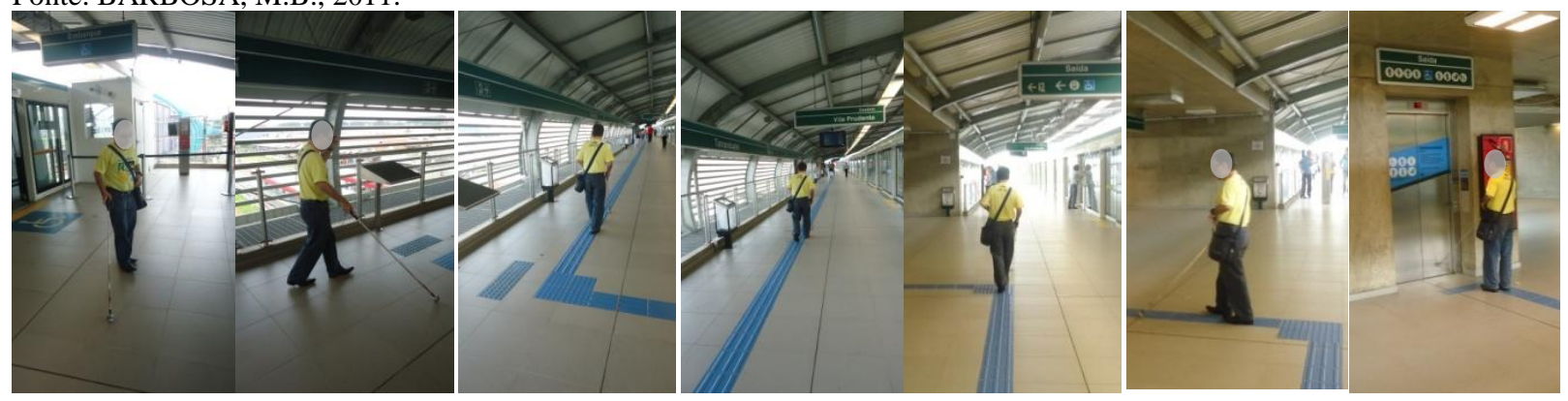

Figura 209 - São Paulo - Deslocamento com independência em estação com porta de plataforma.

Fonte: BARBOSA, M.B., 2011.

Os estagiários relataram o mau comportamento dos demais usuários - interface trem-

estação (IS3) e destacaram o desrespeito vivenciado durante o desembarque em função da 
pressa dos usuários comuns, que estão nos locais destinados ao embarque preferencial: no momento em que o trem abre as portas, os usuários forçam o embarque sem prestar atenção às pessoas com deficiência que estão desembarcando. Os estagiários destacam ainda a dificuldade de localizar a pessoa com deficiência visual no momento do desembarque, em função da lotação do trem (TS4), do comportamento do usuário - trem (TS3) e do desrespeito ao embarque e desembarque preferencial (TS2), fatores que prejudicam o atendimento prestado (Figura 210). Outro aspecto da etapa de desembarque está relacionado à existência de vão e desnível (IC1) entre o trem e a plataforma, fato que gera insegurança pelo medo de pisar no vão e cair na via.

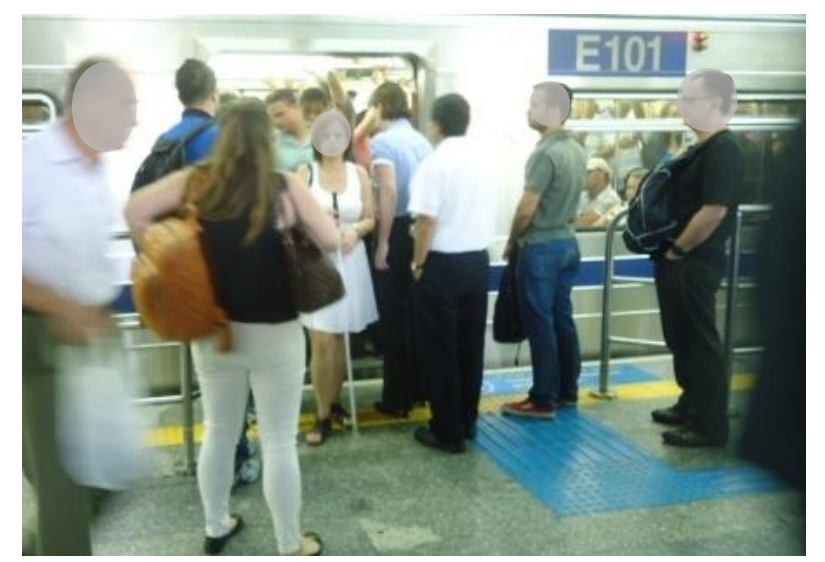

Figura 210 - São Paulo - Desrespeito do desembarque preferencial. Fonte: BARBOSA, M.B., 2011.

Entre os temas abordados no programa de capacitação, os profissionais responsáveis pelo treinamento dos usuários (ES3) destacam que, na ausência dos estagiários na plataforma, os usuários devem desembarcar e aguardar sua chegada caso não se sintam seguros para empreender seu percurso de saída com independência.

\subsubsection{Avaliação pelos especialistas}

Os profissionais responsáveis pelos projetos dos trens relataram aspectos relacionados à concepção, construção e manutenção que impactam no vão e desnível (IC1) entre o trem e a plataforma. Entre os aspectos relatados, destacam-se os seguintes: as tolerâncias previstas na instalação e na manutenção das vias (fixação direta ou em lastro), dos trilhos e das rodas do trem, bem como na construção das plataformas e na fabricação dos trens.

Os profissionais responsáveis pela elaboração de normas técnicas destacaram as recomendações para melhoria dos textos normativos vigentes, ressaltando a redução do vão e 
desnível (IC1) entre o trem e a plataforma bem como a sinalização sonora da localização das portas do trem nas plataformas.

\subsubsection{Elementos de wayfinding}

Os elementos de wayfinding característicos desta etapa são o marcador e a zona (Quadro 36). Esses elementos devem ser providos de configuração adequada bem como de sinalização tátil/visual/sonora integrada de forma a facilitar sua identificação por pessoas com deficiência visual e sobressair-se em relação aos demais elementos e informações do ambiente para facilitar sua percepção. Ao mesmo tempo, devem-se colocar e ressaltar as informações táteis, visuais e sonoros integradas, especialmente quando da elaboração dos materiais voltados à descrição do ambiente das estações, facilitando a compreensão dos elementos de circulação vertical.

Quadro 36 - Elementos de wayfinding da Etapa 15 - Desembarque.

\begin{tabular}{l|l|l|c}
\multicolumn{1}{c|}{$\begin{array}{c}\text { Elementos de } \\
\text { wayfinding }\end{array}$} & \multicolumn{1}{c|}{ Configuração } & Informação & Serviço \\
\hline Marcadores & - local de desembarque & $\begin{array}{c}\text { - sinalização do local de } \\
\text { espera para auxílio }\end{array}$ & $\begin{array}{c}\text { - intercomunicador para } \\
\text { solicitação de auxílio }\end{array}$ \\
\hline Zona & $\begin{array}{l}\text { - distância e desnível entre o } \\
\text { piso da plataforma e o piso } \\
\text { do trem }\end{array}$ & $\begin{array}{c}\text { - sinalização tátil/visual sobre } \\
\text { o vão e desnível entre trem e } \\
\text { plataforma }\end{array}$ & $\begin{array}{c}\text { - funcionários aguardando } \\
\text { para auxiliar o desembarque }\end{array}$ \\
\hline
\end{tabular}

Fonte: Elaborado pela pesquisadora.

\subsubsection{Síntese do diagnóstico}

Na etapa 15 - Desembarque -, foram identificados aspectos que devem ser tratados pelas empresas operadoras dos sistemas metroferroviários para auxiliar pessoas com deficiência visual a estabelecer estratégias para empreender seus deslocamentos, descritos a seguir:

a) condições das instalações existentes (EC3) - instalar câmeras de monitoração nas plataformas; prever plataformas mistas nas estações com demanda elevada para possibilitar embarque e desembarque em portas distintas do trem;

b) informações nos equipamentos (EI4) - instalar informação tátil e visual para utilização do intercomunicador; 
c) informações para a pessoa com deficiência visual - estação (EI6) - instalar intercomunicador nas plataformas; disponibilizar informações institucionais e orientações operacionais claras, objetivas, completas e redundantes sobre os serviços ofertados;

d) treinamento dos usuários (ES3) - capacitar usuários para que saibam utilizar os recursos disponíveis nas estações; orientar usuários quanto ao funcionamento do intercomunicador; orientar os usuários a aguardar a chegada do empregado da estação caso não se sintam seguros para empreender seu deslocamento com independência;

e) procedimento operacional - estação (ES6) - garantir a comunicação adequada entre as estações e o centro de controle; garantir a presença de empregados na plataforma da estação de desembarque;

f) lotação das estações (ES7) - fazer a gestão do fluxo para reduzir a lotação nas plataformas; impedir a permanência de usuários em frente à porta durante o desembarque;

g) equipamentos intercomunicadores (ES11) - manter os intercomunicadores em condições de operação e uso; possibilitar a solicitação de auxílio;

h) vão e desnível (IC1) - eliminar e minimizar o vão e o desnível existentes entre a plataforma e o trem; atentar para as tolerâncias de projeto, fabricação/construção e manutenção das vias, dos trilhos, das rodas dos trens, dos trens e das plataformas das estações;

i) treinamento dos empregados - interface trem-estação (IS2) - oferecer ajuda com técnicas apropriadas durante o desembarque;

j) comportamento dos usuários - interface trem-estação (IS3) - promover campanhas para orientar e conscientizar os demais usuários a respeitar o desembarque preferencial e não forçar o embarque simultâneo;

k) informação para monitoração (TI1) - possibilitar a comunicação direta entre as estações; agilizar o auxílio no desembarque;

1) embarque e desembarque preferencial (TS2) - fazer a gestão de fluxo nas plataformas para facilitar o embarque e o desembarque preferencial;

m) comportamento do usuário - trem (TS3) - promover campanhas para orientar e conscientizar os demais usuários no interior do trem a respeitar o embarque preferencial e não forçar o desembarque simultâneo; 
n) lotação do trem (TS4) - fazer a gestão de fluxo nas plataformas para facilitar a localização da pessoa com deficiência visual no momento do desembarque.

\subsection{Etapa 16 - Deslocamento até a saída da plataforma}

Nesta etapa, o usuário desloca-se na plataforma, entre a área de embarque preferencial e a circulação vertical. Em algumas situações, cabe ao usuário, nesta etapa, optar por diferentes saídas ou fazer a conexão com outras linhas de metrô ou de trem.

\subsubsection{Métodos e técnicas aplicados}

a) melhores práticas identificadas em outros sistemas metroferroviários;

b) pesquisa documental (normas técnicas ABNT vigentes, desenhos, procedimentos operacionais);

c) checklist dos recursos disponíveis e walkthrough realizado nas estações para compreensão do percurso de desembarque;

d) questionário aplicado a pessoas com deficiência visual - questões 12, 13 e 17;

e) entrevista com empregados das estações;

f) entrevista com profissionais responsáveis pelo treinamento dos empregados;

g) entrevista com estagiários que auxiliam pessoas com deficiência visual;

h) entrevista com professores de orientação e mobilidade.

As formas de análise e interpretação dos dados coletados foram apresentadas no Capítulo 6 Aplicação dos instrumentos.

\subsubsection{Melhores Práticas}

Entre as melhores práticas, destacam-se os mapas táteis existentes nas plataformas, que auxiliam os deslocamentos de desembarque, seja para saída ou para conexão com outras linhas ou modos de transporte. No Metrô de Madri, destaca-se o mapa tátil fixado sobre uma superfície inclinada, contendo informações sonoras e orientações sobre os diferentes percursos em função do destino dos usuários, seja o desembarque para saída ou para conexão com outras linhas de trem ou de metrô (Figura 211). 

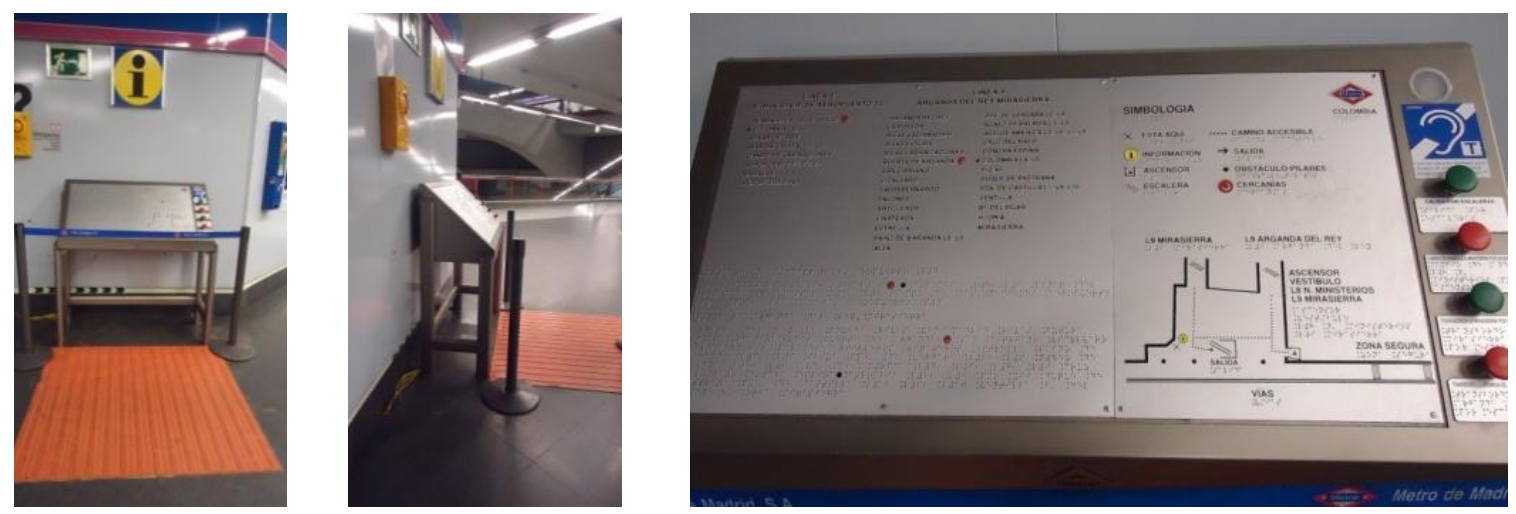

Figura 211 - Madri - Mapa tátil na plataforma. Fonte: BARBOSA, M.B., 2013.

No Metrô do Rio de Janeiro, destaca-se a existência de um mapa tátil disponibilizado nas plataformas, cujo objetivo é orientar o planejamento dos deslocamentos de desembarque nas estações, incluindo percursos feitos por meio de escadas rolantes ou de elevadores (Figura 212). O mapa tátil contém as seguintes informações: o nome da estação, a configuração das plataformas, a localização dos elementos de circulação vertical - elevadores, escadas fixas e rolantes. As escadas rolantes e os elevadores são representados por meio de linhas em relevo na cor preta. As escadas fixas são representadas por placas na cor cinza com textura em baixo relevo. A configuração do percurso por meio de pisos táteis não faz distinção entre pisos direcionais e pisos de alerta, sendo ambos representados por uma linha na cor amarela. Todas as referências são explicadas em uma legenda posicionada ao lado ou abaixo da representação gráfica. As informações táteis são veiculadas por meio de texto em Braille, produzido em esfera de aço. Caracteres em relevo são utilizados para informar o nome da estação. O mapa contém uma referência ao posicionamento do usuário ("você está aqui"), indicado por meio de uma esfera em aço.
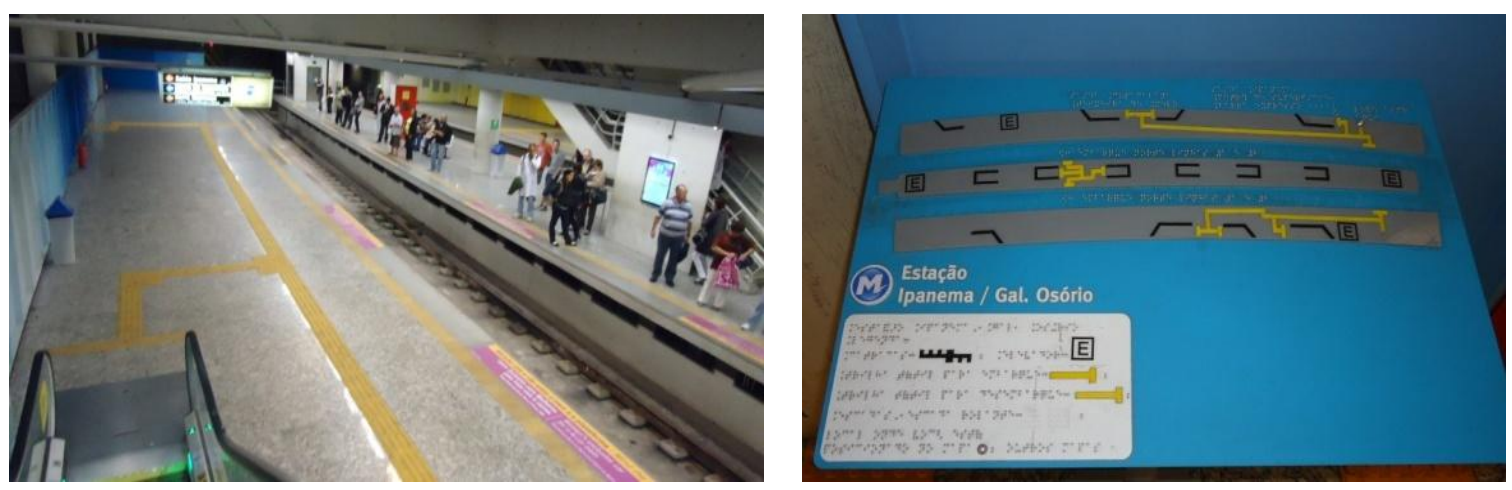

Figura 212 - Rio de Janeiro - Mapa tátil na plataforma. Fonte: BARBOSA, M.B., 2011. 
Ainda em relação às melhores práticas, destacam-se os dispositivos intercomunicadores ofertados pelas operadoras nas plataformas dos metrôs de Londres, Barcelona e Madri, que possibilitam solicitar informação ou auxílio, ou mesmo acionar equipes, em situações de emergência (Figura 213).
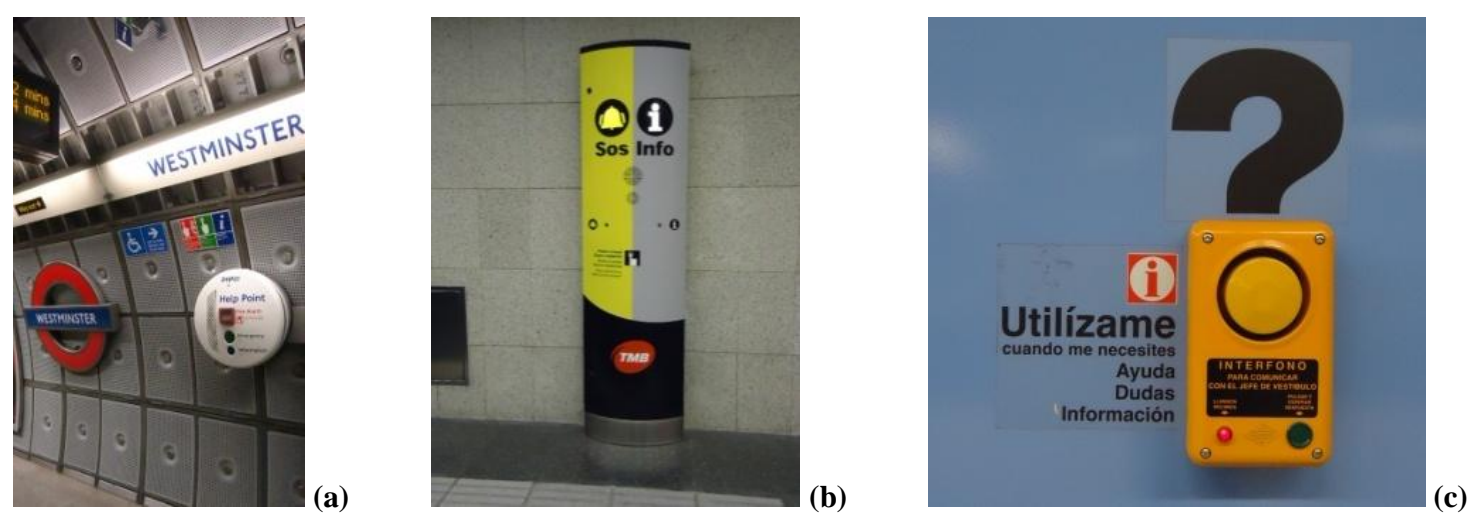

Figura 213 - Londres, Barcelona e Madri - Intercomunicadores nas plataformas. Fonte: BARBOSA, M.B., 2013, 2011 e 2013, respectivamente.

\subsubsection{Requisitos Normativos}

Com relação aos requisitos normativos, a ABNT NBR 14.021:2005 determina a existência de dispositivo para solicitação de auxílio sinalizado com o Símbolo Internacional de Acesso e de sinalização visual e tátil identificando a localização da circulação vertical de saída e a proximidade com a borda da plataforma para garantir segurança no deslocamento.

\subsubsection{Situação no Metrô de São Paulo}

No Metrô de São Paulo, as plataformas dispõem de piso tátil entre o local de desembarque e os elevadores para saída ou conexão com outros modos de transporte. A localização dos elevadores depende da existência de prumada vertical entre as plataformas e os mezaninos das estações e, portanto, não há padronização em relação ao seu posicionamento na plataforma (Figura 214). 


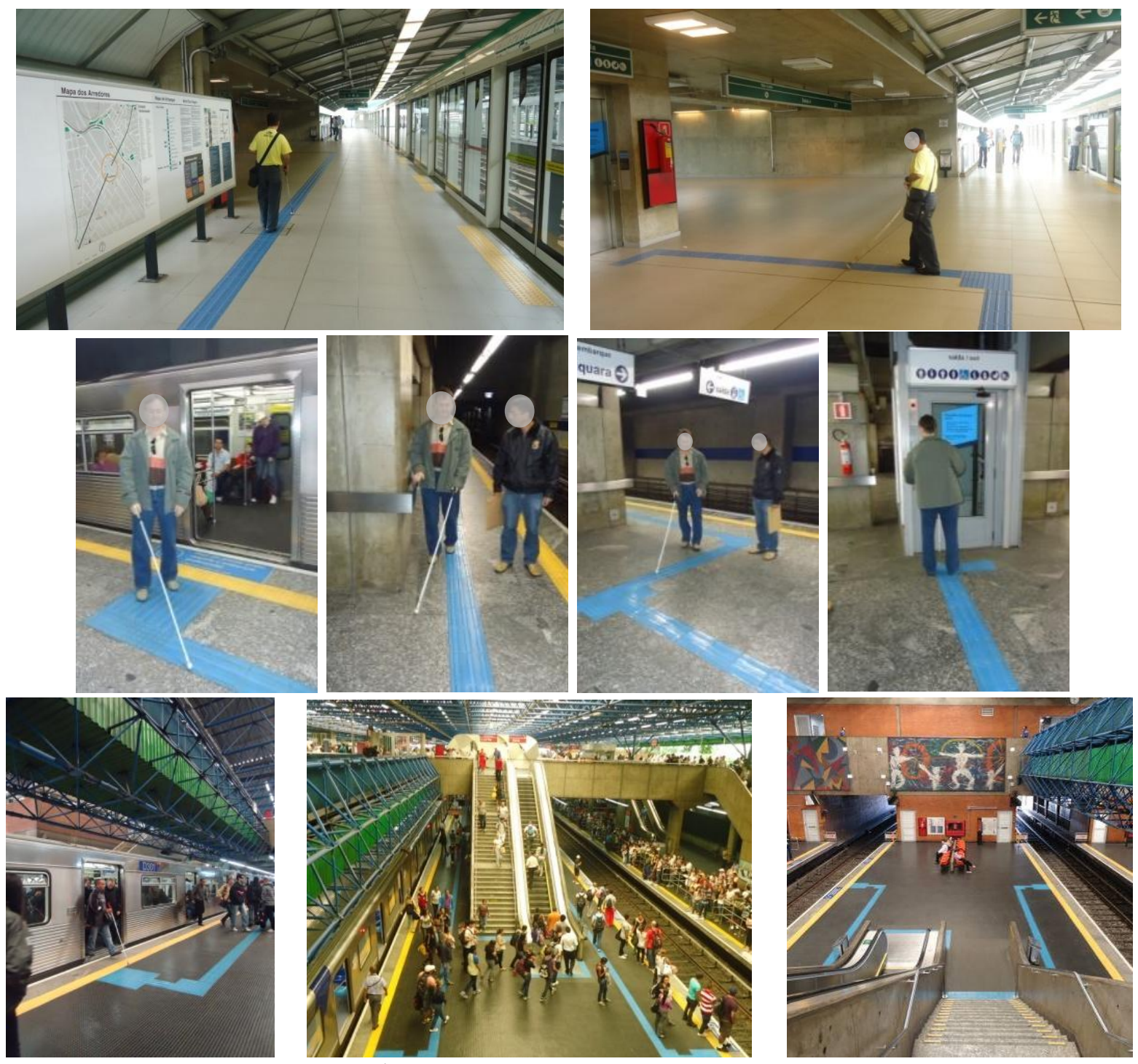

Figura 214 - São Paulo - Sinalização tátil das plataformas no percurso entre o local de desembarque e o elevador. Fonte: BARBOSA, M.B., 2011.

\subsubsection{Avaliação pelos usuários}

Na etapa de deslocamento até a saída da plataforma, 163 usuários com deficiência visual dos quais 125 pessoas são cegas e 38 têm baixa visão - manifestaram seu descontentamento em relação à estação $(90,3 \%)$ e à interface trem-estação $(9,7 \%)$. Foram registrados 361 relatos, o que representa $13,5 \%$ do total de relatos registrados para todas as etapas da jornada do usuário. Os relatos estão relacionados, em sua maioria, aos serviços prestados na estação $(61,5 \%)$, às informações disponibilizadas na estação (17,5\%) e à configuração da estação $(11,4 \%)$, mas também referem-se à configuração da interface trem-estação $(9,4 \%)$ e às informações veiculadas na interface trem-estação $(0,3 \%)$ para prover segurança durante o deslocamento até a saída da plataforma (Tabela 28). 
Tabela 28 - Matriz de avaliação da etapa 16 - Deslocamento até a saída da plataforma.

(\% em relação ao total de relatos registrados nesta etapa)

\begin{tabular}{l|r|r|r|r}
\hline & $\begin{array}{c}\text { Configuração } \\
\%\end{array}$ & $\begin{array}{c}\text { Informação } \\
\%\end{array}$ & $\begin{array}{c}\text { Serviço } \\
\%\end{array}$ & $\begin{array}{c}\text { Total } \\
\%\end{array}$ \\
\hline Estação & (EC) 11,4 & (EI) 17,5 & (ES) $\mathbf{6 1 , 5}$ & $\mathbf{9 0 , 3}$ \\
\hline Interface Trem-Estação & (IC) $\mathbf{9 , 4}$ & (II) 0,3 & $\mathbf{0 , 0}$ & $\mathbf{9 , 7}$ \\
\hline Trem & $\mathbf{0 , 0}$ & $\mathbf{0 , 0}$ & $\mathbf{0 , 0}$ & $\mathbf{0 , 0}$ \\
\hline Total & $\mathbf{2 0 , 8}$ & $\mathbf{1 7 , 7}$ & $\mathbf{6 1 , 5}$ & n=361 relatos \\
\hline
\end{tabular}
como outros usuários: tenho horário para cumprir. Quando chego na estação e o empregado não está lá para me ajudar, eu tento ir sozinho. Quando conheço a estação, tudo bem; mas quando não conheço, eu me perco... isso é desesperador. Acho importante colocar mais empregados para ajudar os deficientes no desembarque. Para eu me deslocar mais fácil é preciso colocar as escadas e os elevadores próximos ao vagão preferencial, para eu não ter que andar muito na plataforma; nas escadas deveria ter informações para onde eu devo ir; seria bom se houvesse plataformas diferentes para embarcar e desembarcar. Quando a plataforma é central fico com medo de cair na outra via porque não tem paredes para eu me guiar. Quando a estação está muito lotada, as pessoas empurram... Aí fica complicado andar sozinho... e nem sempre tem empregado para me ajudar. Se as estações tivessem duas plataformas, eu até me arriscaria ir sozinho pelo piso tátil até as escadas rolantes. Ajudaria muito se o piso tátil me levasse direto para todas as escadas porque eu não uso elevador... Ele dá muitas voltas, então não me arrisco porque posso cair na via. A plataforma é o local que me sinto mais inseguro porque tem muita gente com pressa, tropeçam em mim e na minha bengala. Ao longo do percurso do piso tátil, tem lugares onde não tem muito espaço para eu passar, fica difícil andar sozinho, pois corro o risco de cair na via. Nos espaços que estão debaixo das escadas têm ferros e eu preciso ir rente à parede. Em algumas estações fica difícil usar o piso tátil porque muitas vezes têm obstáculos próximos e posso trombar ou bater o braço... Às vezes o piso tátil me leva para pilastras, bancos nas plataformas, cestos de lixo, etc. Enfim, para eu me sentir mais seguro na plataforma, deveria ter barreiras em todas as estações para impedir que eu caísse na via - paredes, portas de vidro, barras de ferro e muretas com abertura somente no local do desembarque. Ainda pensando na minha segurança, seria importante o piso tátil estar mais distante da faixa amarela, mais próximo da parede. Isso evitaria que outras pessoas andassem ou ficassem paradas nele. Para melhorar a minha acessibilidade, poderia ter piso tátil ao longo da plataforma, permitindo que eu embarque em outros vagões e não somente no $1^{\circ}$. Além disso, na transferência de uma linha para outra o piso tátil deveria ligar um embarque ao outro. Têm estações que não percebo que tem o piso tátil na plataforma na transferência de uma linha para outra, que faça esta ligação... Outra coisa importante para mim, que tenho baixa visão, seria melhorar a cor das placas: a cor da letra e fundo da placa precisaria ser bem contrastante. Precisa também melhorar a informação sonora nas plataformas por meio da qual eu pudesse saber o posicionamento dos elevadores e do piso tátil. Deveria ter um equipamento, uma câmera que o empregado pudesse ver o deficiente e orientá-lo por meio de um áudio instalado nos letreiros... Levando em conta todas essas dificuldades que a estação oferece para eu andar sozinho, seria importante que sempre eu encontrasse rapidamente um empregado para me ajudar no meu percurso, não dá para ficar sempre esperando de 10 a 15 minutos, nem sempre avisam a estação que eu irei desembarcar. Precisaria treinar melhor os empregados e programar melhor o tempo de viagem para que eu não tenha que esperar muito." (Discurso do Sujeito Coletivo - Etapa 16)

Os principais problemas relatados pelos usuários na etapa de deslocamento até a saída da plataforma, de forma hierarquizada conforme número de relatos registrados (Gráfico 34): 
Gráfico 34 - Avaliação da etapa 16 - Deslocamento até a saída da plataforma.

(\% em relação ao total de relatos registrados nesta etapa)

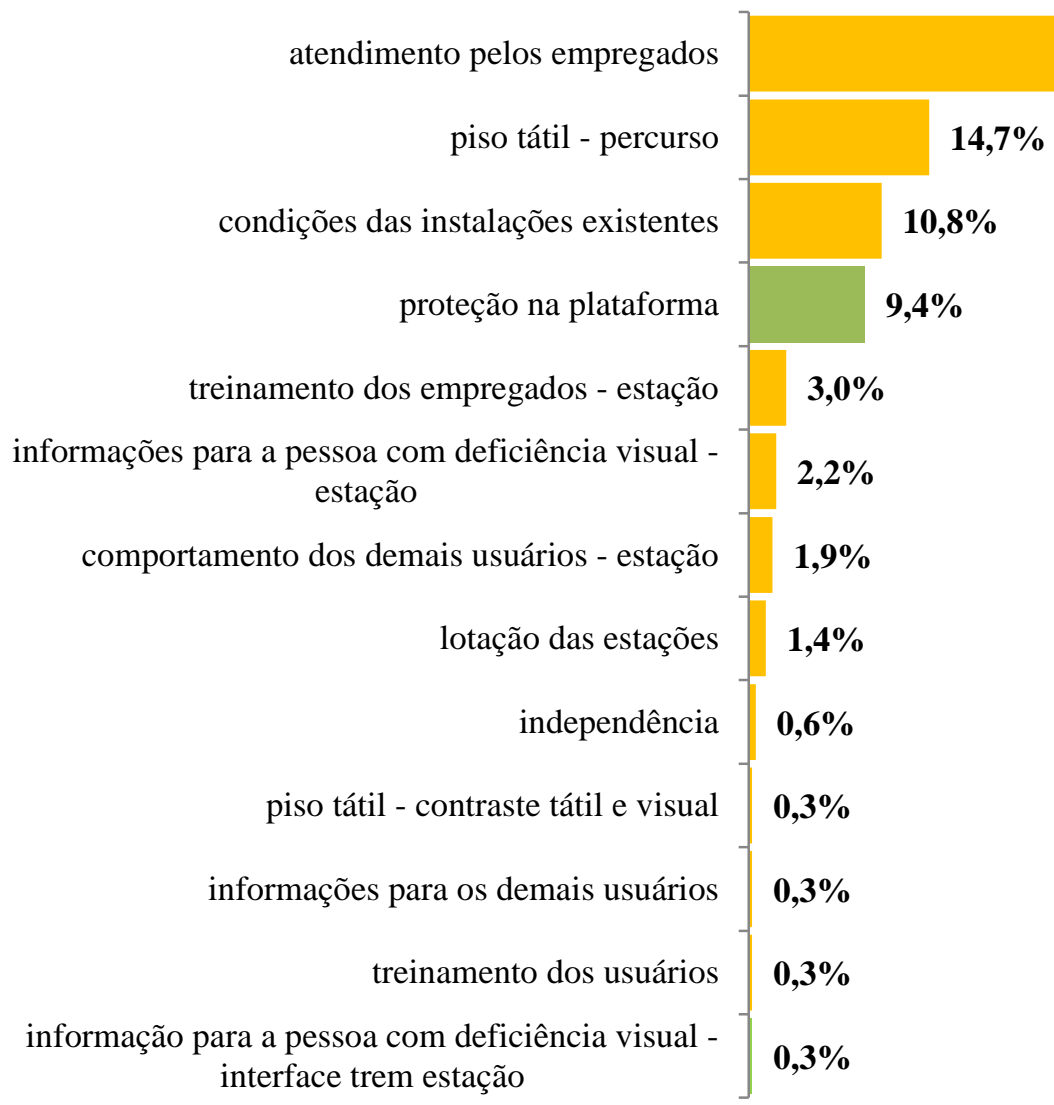

$\mathrm{n} 1=163$ respondentes $\mathrm{n} 2=361$ relatos

Os problemas relatados estão relacionados às seguintes ideias centrais:

a) atendimento pelos empregados (ES2) - ausência de empregados no momento do desembarque e ao elevado tempo de espera para auxílio;

b) piso tátil - percurso (EI3) - insegurança gerada pela proximidade entre o piso tátil e a borda da plataforma ou outros obstáculos existentes (colunas, pilares); destaca que o piso tátil não leva para todos os equipamentos e serviços oferecidos e relata a dificuldade de compreensão sobre o caminho, que não é igual ao fluxo dos demais usuários e não direciona para as escadas fixas e rolantes;

c) condições das instalações existentes (EC3) - distância entre o local de desembarque preferencial e o elevador e à sensação de insegurança gerada pela ausência de câmeras de monitoração; 
d) proteção na plataforma (IC2) - falta de barreiras ou de portas de plataforma em todas as estações, especialmente nas estações com plataforma central;

e) treinamento dos empregados - estação (ES1) - elevado tempo de espera para obter auxílio pelos empregados e declara a preferência pelo atendimento realizado pelos empregados mais bem preparados das estações;

f) informações para a pessoa com deficiência visual - estação (EI6) subdimensionamento das informações visuais (contraste, tamanho da letra) e das placas de sinalização, dificultando sua legibilidade pelas pessoas com baixa visão e inexistência de informação sonora nas plataformas para orientar os percursos;

g) comportamento dos demais usuários - estação (ES4) - mau comportamento dos usuários na estação, que ora permanecem sobre o piso tátil ora esbarram e tropeçam na bengala da pessoa com deficiência visual, desorientando e dificultando seu deslocamento na plataforma;

h) lotação das estações (ES7) - dificuldade de utilização do piso tátil devido à aglomeração de pessoas na plataforma;

i) independência (EC1) - utilização de estratégias de contorno, como a utilização das paredes nas plataformas laterais;

j) piso tátil - contraste tátil e visual (EI1) - falta de diferenciação no contraste tátil para indicar diferentes destinos;

k) informações para os demais usuários (EI7) - insatisfação pela inexistência ou insuficiência de campanhas para orientar os demais usuários sobre a finalidade do piso tátil e sobre o embarque preferencial;

1) treinamento dos usuários (ES3) - falta de treinamento para utilização do piso tátil;

m) informações para a pessoa com deficiência visual - interface trem-estação (II1) insuficiência do contraste visual na sinalização existente nas plataformas.

\subsubsection{Avaliação pelas pessoas-chave}

Os empregados das estações destacaram as condições das instalações existentes (EC3) e consideraram que a localização do elevador no meio da plataforma central torna-o equidistante dos locais de embarque e desembarque nas duas plataformas, facilitando o deslocamento. Também é considerada positiva a localização das escadas rolantes próximas ao local de embarque preferencial, facilitando o auxílio para embarque e desembarque (Figuras 215 e 216). 


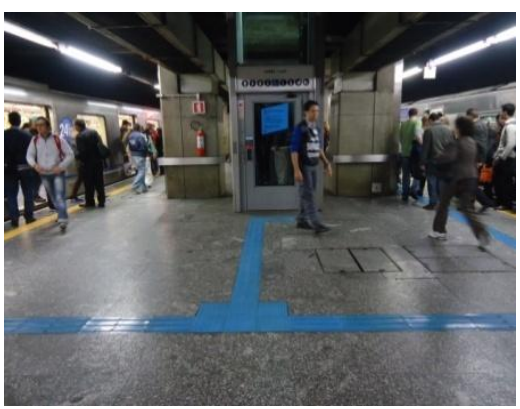

Figura 215 - São Paulo - Elevador na plataforma central.

Fonte: BARBOSA, M.B., 2011.
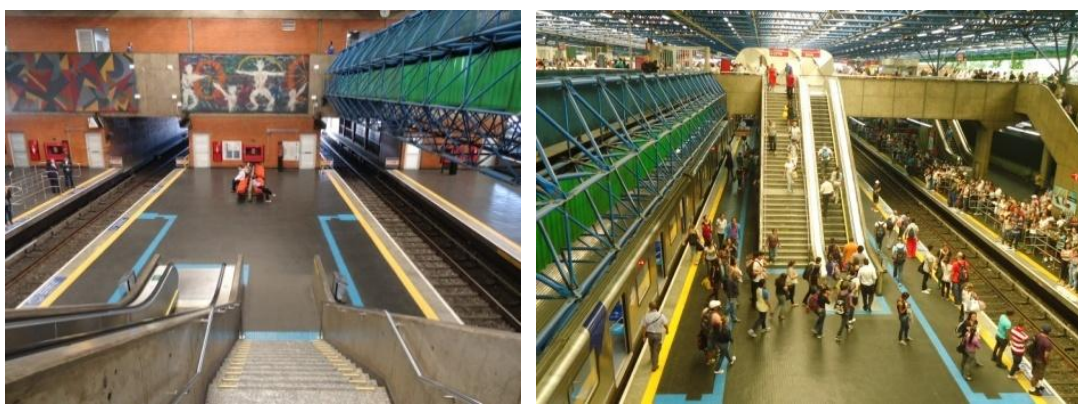

Figura 216 - São Paulo - Local de desembarque próximo à escada rolante. Fonte: BARBOSA, M.B., 2011.

As condições das instalações existentes (EC3), notadamente a largura insuficiente das plataformas, a localização do piso tátil - percurso (EI3) junto a obstáculos existentes, a lotação das estações (ES7) e o mau comportamento dos demais usuários (ES4) geram conflitos de fluxo. Quando tal condição está associada à falta de proteção nas plataformas (IC2), a chegada simultânea de trens na plataforma central pode gerar a sensação de insegurança nos usuários com deficiência visual, conforme Figura 217.
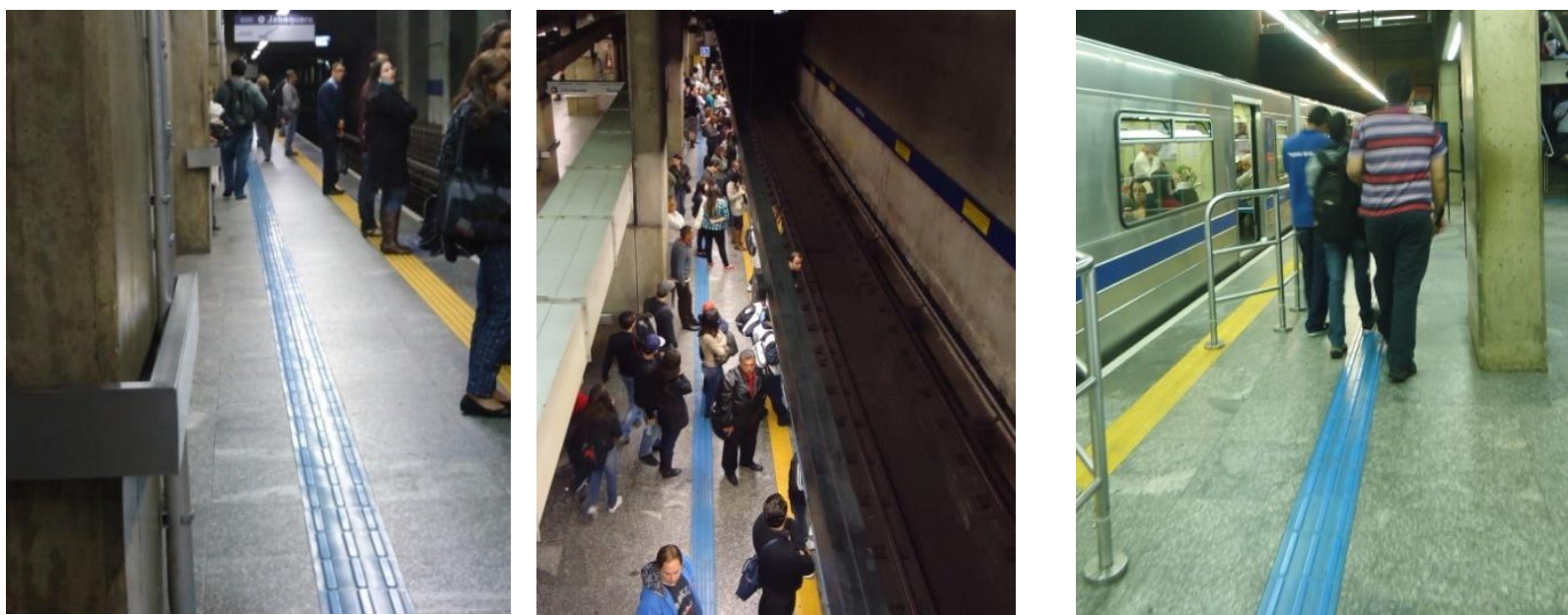

Figura 217 - São Paulo - Lotação, obstáculos e conflitos de fluxo na plataforma. Fonte: BARBOSA, M.B., 2011.

Em relação ao piso tátil - percurso (EI3), os empregados das estações relataram que a informação tátil de alerta na borda da plataforma orienta quanto ao perigo da proximidade da via, garantindo a segurança da pessoa com deficiência visual. Além disso, são veiculadas informações para a pessoa com deficiência visual - estação (EI6) por meio da emissão de mensagens sonoras orientando todos os usuários a não ultrapassar a faixa de alerta amarela.

Os estagiários relataram que a apreensão durante o uso da sinalização tátil no piso é decorrente da dificuldade de compreensão do piso tátil - percurso (EI3), especialmente por causa da falta de percepção das mudanças de direção, fato que pode causar acidentes. Como 
em outras áreas da estação, são destacadas dificuldades relacionadas à prestação de auxílio às pessoas com deficiência visual em função da lotação das estações (ES7) e do comportamento dos usuários (ES4), que param ou circulam sobre o piso tátil e não dão preferência ao deslocamento da pessoa com deficiência visual.

Os professores de orientação e mobilidade relataram que a ausência de uma faixa de transição traz dificuldades para identificar o piso tátil - contraste tátil e visual (EI1) em relação ao piso existente, notadamente nas estações que têm piso emborrachado com pastilhas em relevo. Em relação ao piso tátil - percurso (EI3), há críticas à proximidade da sinalização direcional em relação à borda da plataforma, à inexistência de sinalização direcional nas plataformas laterais das estações com plataformas mistas e ao dimensionamento insuficiente da sinalização tátil de alerta nas interseções entre pisos direcionais - o que dificulta a percepção das mudanças de direção. Entende-se que o fato de a sinalização tátil no piso existir somente para o elevador pode gerar conflitos de fluxo e ser um fator inibidor deste recurso, uma vez que desconsidera as alternativas de percurso oferecida aos demais usuários - as escadas fixas e rolantes. As pessoas com deficiência visual que participam dos treinamentos de orientação e mobilidade declararam preferência para usar as escadas próximas ao local de desembarque preferencial. Quanto às condições das instalações existentes (EC3), foi destacada a insuficiência de iluminação em algumas plataformas, constituindo riscos para pessoas com baixa visão. Sobre as informações nos equipamentos (EI4), destacaram o subdimensionamento das faixas contrastantes nas portas de vidro, insuficiente para alertar pessoas com baixa visão. Quanto às informações para as pessoas com deficiência visual estação (EI6), ressaltaram que a compreensão do percurso realizado na plataforma pode ser ampliada com o auxílio de mapas táteis e descrições sonoras contendo as referências principais das estações, permitindo informações em igualdade de condições com os demais usuários.

\subsubsection{Avaliação pelos especialistas}

Os profissionais responsáveis pela elaboração de normas técnicas relataram que soluções padronizadas relacionadas à configuração, sinalização e iluminação dos ambientes característicos do sistema metroferroviário contribuem para prover segurança, autonomia e agilidade nos deslocamentos. Entre as soluções que podem contribuir para a segurança e a independência dos deslocamentos em função das condições das instalações existentes 
(EC3), estão recomendações para melhoria dos textos normativos vigentes, destacando o estabelecimento de condições adequadas para execução de obras e serviços, garantindo uma rota acessível para embarque e a existência de contraste de cores entre pisos, paredes, pilares e painéis de informação da estação (Figura 218).

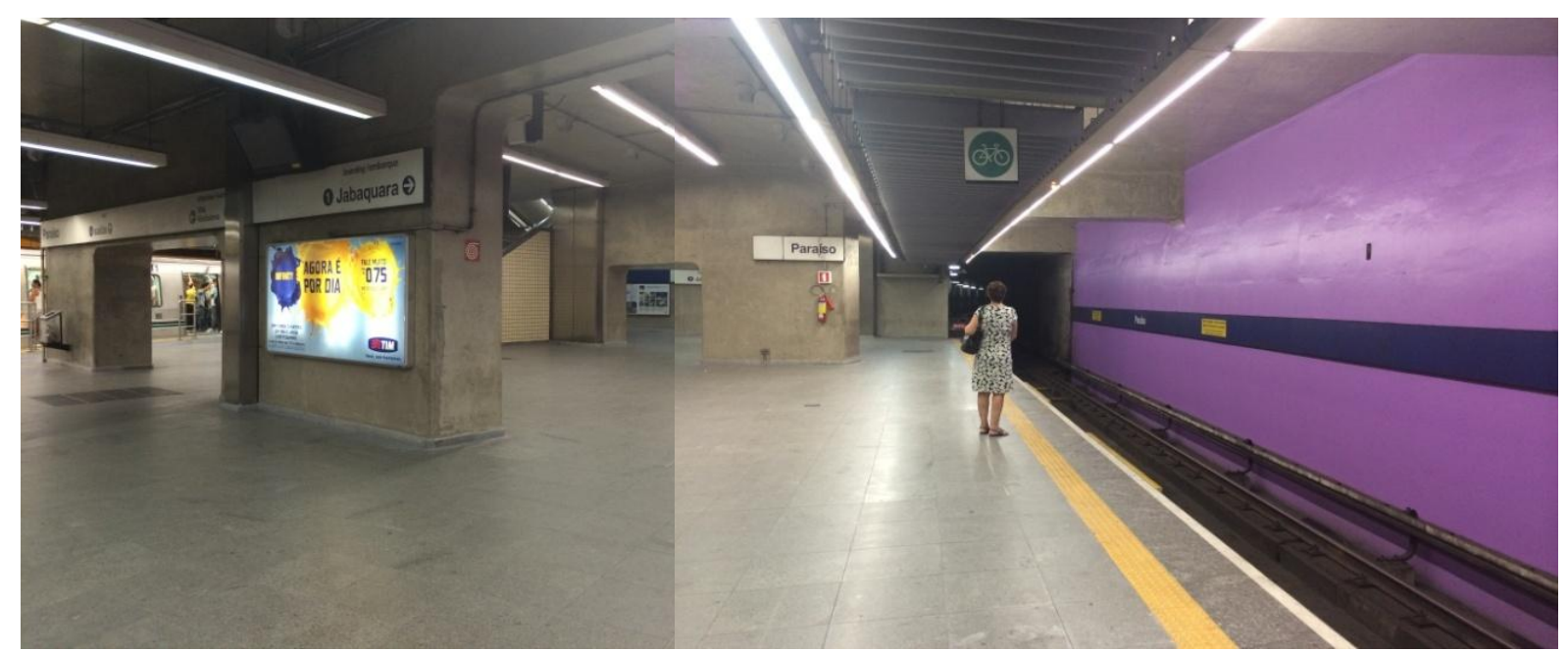

Figura 218 - São Paulo - Falta de contraste de cores entre piso e pilares. Destaque da cor dos painéis e da parede da via.

Fonte: BARBOSA, M.B., 2011.

Ainda segundo os profissionais responsáveis pela elaboração de normas técnicas, as informações para a pessoa com deficiência visual - estação (EI6) devem ser claras, objetivas e completas, além de redundantes, para que as orientações operacionais e institucionais sobre os serviços ofertados (comércio, exposições, espaços institucionais) possam contribuir para que os passageiros alcancem seus destinos com segurança. As referências necessárias para orientar os deslocamentos das pessoas com deficiência visual podem ser criadas a partir de estímulos táteis e sonoros, ou mesmo visuais, desde que adequados aos parâmetros que possibilitem sua percepção por pessoas com baixa visão. Uma vez que a soma dessas referências é mais eficaz do que cada uma isoladamente, para serem mais eficientes e atingirem a diversidade existente no segmento de pessoas com deficiência visual, tais referências devem ser redundantes e integradas.

\subsubsection{Elementos de wayfinding}

Os dados coletados permitem afirmar que os elementos de wayfinding característicos desta etapa são os seguintes: caminho e limite (Quadro 37). Esses elementos devem ser providos de configuração adequada bem como de sinalização tátil/visual/sonora integrada de forma a facilitar sua identificação por pessoas com deficiência visual e sobressair-se em relação aos 
demais elementos e informações do ambiente para facilitar sua percepção. Ao mesmo tempo, tais elementos devem constar e ser ressaltados nas informações veiculadas, especialmente quando da elaboração dos materiais táteis, visuais e sonoros voltados à descrição do ambiente das estações, resultando na melhor compreensão dos percursos desde o local de desembarque até os elementos de circulação vertical, seja para saída ou para conexão com outras linhas.

Quadro 37 - Elementos de wayfinding da Etapa 16 - Deslocamento até a saída da plataforma.

\begin{tabular}{|c|c|c|c|}
\hline $\begin{array}{l}\text { Elementos de } \\
\text { wayfinding }\end{array}$ & Configuração & Informação & Serviço \\
\hline Caminhos & $\begin{array}{l}\text { - percurso entre o local de } \\
\text { desembarque e a } \\
\text { circulação vertical para } \\
\text { saída ou conexão }\end{array}$ & $\begin{array}{l}\text { - tátil, sonora e visual sobre } \\
\text { a configuração e o } \\
\text { percurso, considerando as } \\
\text { opções de saída ou de } \\
\text { conexão }\end{array}$ & $\begin{array}{l}\text { - treinamento dos usuários } \\
\text { - funcionários para auxiliar } \\
\text { no deslocamento }\end{array}$ \\
\hline Limites & $\begin{array}{l}\text { - limite da plataforma } \\
\text { - portas de fechamento da } \\
\text { plataforma; }\end{array}$ & $\begin{array}{l}\text { - sinalização tátil/visual da } \\
\text { borda da plataforma }\end{array}$ & $\begin{array}{l}\text { - gestão do desembarque } \\
\text { preferencial }\end{array}$ \\
\hline
\end{tabular}

Fonte: Elaborado pela pesquisadora.

\subsubsection{Síntese do diagnóstico}

Na etapa 16 - Deslocamento até a saída da plataforma -, foram identificados aspectos que devem ser tratados pelas empresas operadoras dos sistemas metroferroviários para auxiliar pessoas com deficiência visual a estabelecer estratégias para empreender seus deslocamentos:

a) independência (EC1) - promover a aprendizagem de estratégias de contorno, como a utilização das paredes nas plataformas laterais;

b) condições das instalações existentes (EC3) - minimizar a distância entre o local de desembarque preferencial e o elevador ou as escadas rolantes; localizar o elevador no meio da plataforma central, tornando-o equidistante do local de embarque e desembarque nas duas plataformas; ampliar a sensação de segurança por meio da instalação de câmeras de monitoração; prover largura adequada das plataformas; prover iluminação adequada nas plataformas; estabelecer condições adequadas para execução de obras e serviços; garantir uma rota acessível para embarque; garantir contraste entre pisos, paredes e painéis de informação;

c) piso tátil - contraste tátil e visual (EI1) - instalar piso tátil diferenciado para indicar diferentes destinos; acrescentar uma faixa lisa junto ao piso tátil nas estações que têm piso emborrachado com pastilhas em relevo; 
d) piso tátil - percurso (EI3) - manter distanciamento do piso tátil direcional em relação à borda da plataforma; manter distanciamento do piso tátil em relação aos obstáculos existentes (colunas, pilares); instalar piso tátil de alerta junto à borda da plataforma; instalar piso tátil direcional nas plataformas laterais das estações com plataformas mistas; instalar piso tátil direcional em todos os equipamentos e serviços oferecidos na estação; direcionar para as escadas fixas e rolantes; melhorar a compreensão sobre o caminho; aumentar a área de sinalização tátil de alerta nas interseções entre pisos direcionais;

e) informações nos equipamentos (EI4) - instalar faixas contrastantes nas portas de vidro com dimensões adequadas às pessoas com baixa visão;

f) informações para a pessoa com deficiência visual - estação (EI6) - aumentar o contraste e as dimensões das informações visuais; prover mapas táteis, informações e descrições sonoras para orientar os percursos, permitindo informações em igualdade de condições com os demais usuários; emitir mensagens sonoras para que os usuários não ultrapassem a faixa amarela de alerta; prover informações e orientações operacionais e institucionais sobre os serviços ofertados (comércio, exposições, espaços institucionais) de maneira clara, objetiva, completa e redundante; criar referências e estímulos táteis, visuais e sonoros integrados que possibilitem sua percepção por pessoas com baixa visão;

g) informações para os demais usuários (EI7) - promover campanhas para orientar os demais usuários sobre a finalidade do piso tátil; promover campanhas para orientar os demais usuários sobre o embarque preferencial;

h) treinamento dos empregados - estação (ES1) - minimizar o tempo de espera para obter auxílio; padronizar atendimento pelos empregados;

i) atendimento pelos empregados (ES2) - disponibilizar empregados no momento do desembarque; minimizar o tempo de espera para auxílio;

j) treinamento dos usuários (ES3) - treinar os usuários para utilização do piso tátil;

k) comportamento dos demais usuários - estação (ES4) - promover campanhas para orientar os demais usuários a não andar ou permanecer sobre o piso tátil, atentando para o deslocamento preferencial das pessoas com deficiência visual e evitando esbarrar ou tropeçar na bengala; 
1) lotação das estações (ES7) - organizar o fluxo de usuários nas plataformas para facilitar a utilização do piso tátil com independência e o auxílio prestado pelos empregados;

m) proteção na plataforma (IC2) - instalar barreiras ou portas de plataforma em todas as estações, especialmente naquelas com plataforma central;

n) informações para a pessoa com deficiência visual - interface trem-estação (II1) aumentar o contraste e as dimensões das informações visuais existentes nas plataformas.

\subsection{Etapa 17 - Circulação vertical entre a plataforma e o mezanino}

Nesta etapa, o usuário utiliza os elementos de circulação vertical para dirigir-se às plataformas. Entre os elementos de circulação vertical disponibilizados, destacam-se as escadas fixas, as escadas rolantes, as plataformas de elevação vertical e os elevadores.

\subsubsection{Métodos e técnicas aplicados}

Os métodos e técnicas utilizados para coleta de dados nesta etapa foram apresentados no item 6.10 - Síntese dos instrumentos aplicados - e consistiram em:

a) melhores práticas identificadas em outros sistemas metroferroviários;

b) pesquisa documental (normas técnicas ABNT vigentes, desenhos, procedimentos operacionais);

c) checklist dos recursos disponíveis e walkthrough realizado nas estações para compreensão do percurso de embarque;

d) ficha ambiente das escadas rolantes, elevadores e plataformas de elevação;

e) questionário aplicado às pessoas com deficiência visual - questões 12, 13 e 17;

f) entrevista com empregados das estações;

g) entrevista com estagiários que auxiliam pessoas com deficiência visual;

h) entrevista com professores de orientação e mobilidade;

i) entrevista com profissionais responsáveis pelo treinamento dos empregados;

j) entrevista com profissionais responsáveis pelos projetos das estações;

k) entrevista com profissionais responsáveis pela elaboração de normas técnicas. 
As formas de análise e interpretação dos dados coletados foram apresentadas no Capítulo 6 Aplicação dos instrumentos.

\subsubsection{Melhores Práticas}

Devem ser consideradas as melhores práticas apresentadas no 7.25.2, relativos ao percurso entre o mezanino e a plataforma.

\subsubsection{Requisitos Normativos}

Devem ser considerados os requisitos normativos apresentados no item 7.25.3.

\subsubsection{Avaliação pelos usuários}

Na etapa de circulação vertical entre a plataforma e o mezanino, oito usuários com deficiência visual - dos quais cinco pessoas são cegas e três pessoas têm baixa visão - manifestaram seu descontentamento em relação à estação $(100,0 \%)$. Foram registrados 10 relatos, o que representa $0,4 \%$ do total de relatos registrados para todas as etapas da jornada do usuário. Os relatos estão relacionados, em sua maioria, à configuração $(80,0 \%)$ e às informações prestadas na estação $(20,0 \%)$ para facilitar a circulação vertical entre a plataforma e o mezanino.

\footnotetext{
"Na minha opinião as escadas rolantes ou elevadores deveriam estar nos dois lados da plataforma, o que não acontece atualmente. Quando ando pelas estações percebo que as plataformas têm escadas rolantes só de um lado e do outro têm escada fixa... Tem estações que nem escada rolante tem... Em algumas estações aéreas, em cima de viadutos, só tem escada fixa entre a plataforma e a saída... Quando chego nessas estações tenho que descer as escadas - sozinho ou com auxílio dos outros usuários - para poder ir até a linha de bloqueio, que é onde tem funcionários para me auxiliar. Outro problema é a falta de informações visuais, táteis e sonoras para que eu possa ter uma ideia sobre a configuração e o percurso nas estações, principalmente nas maiores, onde fica mais difícil minha circulação. Por isso, nas estações grandes, nem sempre dá pra eu andar sozinho... Finalizando, considero que seria importante fazer adequações nas estações para facilitar a minha circulação ou dos outros deficientes visuais. Coisas simples - como colocar vagão preferencial próximo às escadas rolantes ou instalar mais elevadores - melhorariam bastante a acessibilidade." (Discurso do Sujeito Coletivo - Etapa 17)
}

Os problemas relatados pelos usuários estão relacionados às seguintes ideias centrais:

a) instalação de elementos de circulação vertical (EC2) - critica a inexistência de escadas rolantes em ambos os lados das plataformas das estações;

b) condições das instalações existentes (EC3) - refere-se à distância entre o local de desembarque preferencial e o elevador;

c) informações nos equipamentos (EI4) - relata a falta de informações táteis ou sonoras nas escadas rolantes, indicando o sentido de movimento; 
d) informações para a pessoa com deficiência visual - estação (EI6) - relata a inexistência de informação visual, sonora ou tátil sobre configurações e percursos nas estações.

\subsubsection{Avaliação pelas pessoas-chave}

Na etapa de circulação vertical entre a plataforma e o mezanino, devem ser considerados os relatos efetuados pelos empregados das estações e pelos estagiários que auxiliam os deslocamentos das pessoas com deficiência visual em relação à instalação de elementos de circulação vertical (EC2), à lotação das estações (ES7) e ao comportamento dos demais usuários - estação (ES4), já registrados no item 7.9.5, relativos ao percurso entre o mezanino e a plataforma.

\subsubsection{Avaliação pelos especialistas}

Na etapa de circulação vertical entre a plataforma e o trem devem ser considerados os relatos efetuados pelos profissionais responsáveis pelos projetos das estações em relação ao piso tátil - percurso (EI3), já registrados no item 7.9.6, relativos ao percurso entre o mezanino e a plataforma.

\subsubsection{Elementos de wayfinding}

Devem ser considerados os elementos de wayfinding mencionados no item 7.25.8.

\subsubsection{Síntese do diagnóstico}

Na etapa 17 - Circulação vertical entre a plataforma e o mezanino -, foram identificados aspectos que devem ser tratados pelas empresas operadoras dos sistemas metroferroviários para auxiliar pessoas com deficiência visual a estabelecer estratégias para empreender seus deslocamentos:

a) instalação de elementos de circulação vertical (EC2) - instalar escadas rolantes e elevadores entre as plataformas e o mezanino, em todas as estações;

b) condições das instalações existentes (EC3) - melhorar as condições de segurança e a configuração das estações; 
c) piso tátil - percurso (EI3) - orientar os deslocamentos por meio da sinalização tátil de piso para os elevadores e as escadas simultaneamente, possibilitando opção de percurso segundo a preferência do usuário;

d) informações nos equipamentos (EI4) - instalar informações táteis ou sonoras nas escadas rolantes, indicando o sentido de movimento; melhorar as informações nos elevadores, escadas rolantes, intercomunicadores; padronizar as botoeiras dos elevadores para facilitar a utilização dos elevadores; reduzir a diversidade de comandos dos equipamentos;

e) informações para a pessoa com deficiência visual - estação (EI6) - disponibilizar informação tátil, visual e sonora sobre a configuração das estações e os percursos para utilização dos equipamentos de circulação vertical;

f) lotação das estações (ES7) - organizar o fluxo de pessoas junto às escadas fixas e rolantes para disciplinar o comportamento dos usuários e melhorar as condições de segurança;

g) comportamento dos demais usuários - estação (ES4) - promover campanhas para orientar os demais usuários a não esbarrar ou empurrar as pessoas com deficiência visual e seus acompanhantes.

\subsection{Etapa 18 - Deslocamento no mezanino - área paga}

Nesta etapa, o usuário desloca-se em direção aos bloqueios de saída ou em direção à conexão com outras linhas de metrô ou de trem, em função do destino desejado.

\subsubsection{Métodos e técnicas aplicados}

Os métodos e técnicas utilizados para coleta de dados nesta etapa foram apresentados no item 6.10 - Síntese dos instrumentos aplicados - e consistiram em:

a) melhores práticas identificadas em outros sistemas metroferroviários;

b) pesquisa documental (normas técnicas ABNT vigentes, desenhos, procedimentos operacionais);

c) checklist dos recursos disponíveis e walkthrough realizado nas estações para compreensão do percurso de embarque;

d) questionário aplicado a pessoas com deficiência visual - questões 12, 13 e 17;

e) entrevista com empregados das estações; 
f) entrevista com profissionais responsáveis pelo treinamento dos empregados;

g) entrevista com estagiários que auxiliam pessoas com deficiência visual;

h) entrevista com professores de orientação e mobilidade;

i) entrevista com profissionais responsáveis pelos projetos das estações.

\subsubsection{Melhores Práticas}

Entre as melhores práticas, destaca-se o Metrô de Madri, que tem como requisitos de projeto a existência de contraste visual entre superfícies - pisos, fechamentos laterais, mobiliário, corrimãos, placas de informação e equipamentos para facilitar a legibilidade e a compreensão dos espaços e ambientes - e a existência de piso tátil direcional para orientar os deslocamentos (Figura 219).
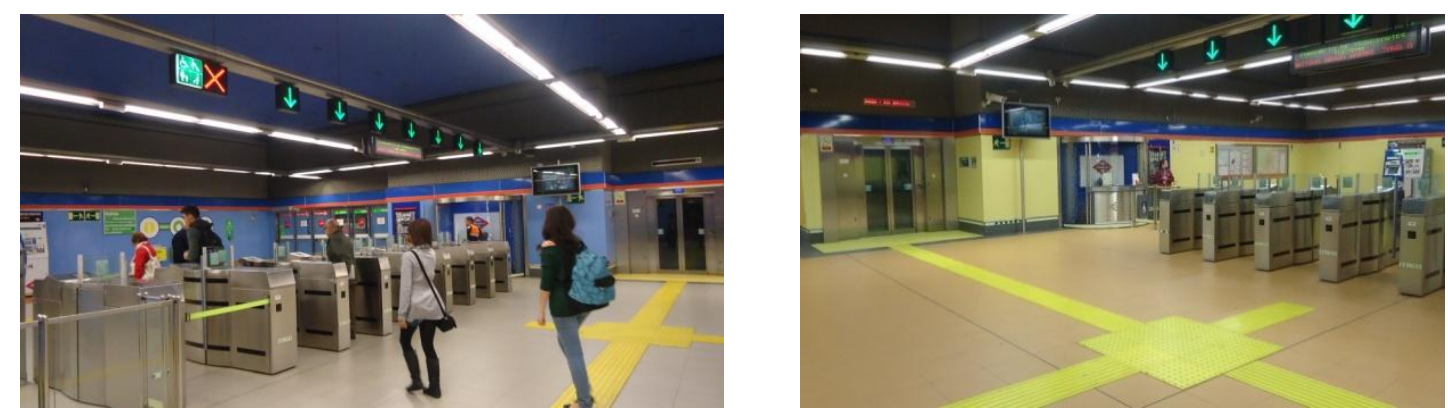

Figura 219 - Madri - Contraste visual e sinalização tátil direcional indicativa do percurso de saída. Fonte: BARBOSA, M.B., 2013.

O Metrô do Rio de Janeiro dispõe de mapas e pisos táteis que informam os percursos entre os elementos de circulação vertical e os equipamentos de controle de acesso (Figura 220).
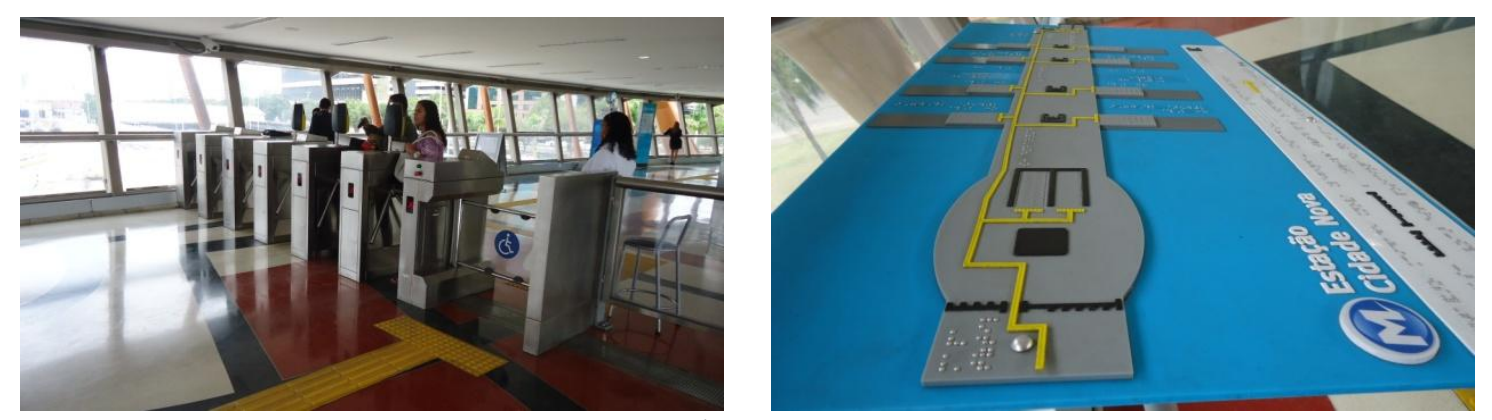

Figura 220 - Rio de Janeiro - Mapa e sinalização tátil direcional indicativa do percurso de desembarque. Fonte: BARBOSA, M.B., 2011.

\subsubsection{Requisitos Normativos}

Com relação aos requisitos normativos, a ABNT NBR 14.021:2005 determina a orientação do percurso de saída utilizando a palavra "saída" e a sinalização das áreas essenciais da estação. Não há indicação quanto à expressão a ser utilizada para conexão entre diferentes modos de 
transporte. A ABNT NBR 15.599:2008 determina a existência de sinalização de alerta e sinalização direcional para deslocamento até a saída.

\subsubsection{Situação no Metrô de São Paulo}

No Metrô de São Paulo, o deslocamento no mezanino - área paga conta com piso tátil para orientar o percurso de desembarque desde o elevador até o equipamento de controle de saída (Figura 221). Conflitos de fluxo entre usuários que desembarcam e usuários que embarcam podem ocorrer nos horários de maior demanda, momento em que são adotadas estratégias para organizar e direcionar os deslocamentos e minimizar conflitos e acidentes.

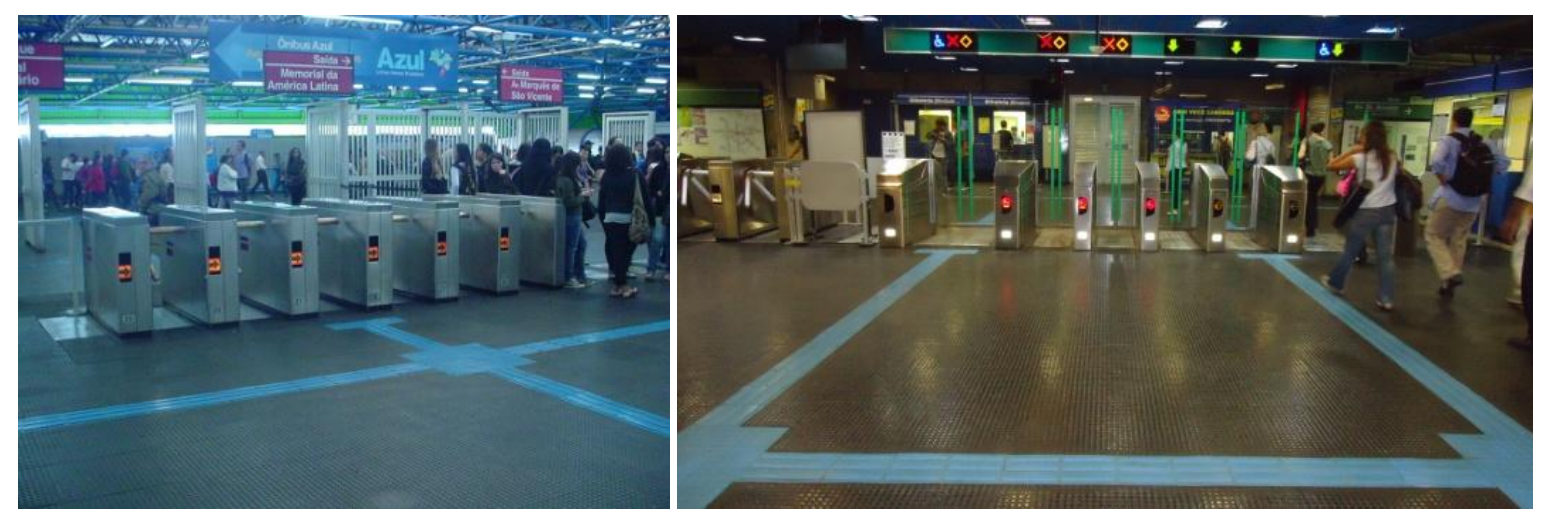

Figura 221 - São Paulo - Sinalização tátil no percurso entre o elevador e os equipamentos de controle de saída. Fonte: BARBOSA, M.B., 2011.

\subsubsection{Avaliação pelos usuários}

Na etapa de deslocamento no mezanino - área paga, 25 usuários com deficiência visual - dos quais 14 pessoas são cegas e 11 pessoas têm baixa visão - manifestaram seu descontentamento em relação à estação $(100,0 \%)$. Foram registrados 39 relatos, o que representa $1,5 \%$ do total de relatos registrados para todas as etapas da jornada do usuário. Os relatos estão relacionados, em sua maioria, às informações prestadas na estação $(94,8 \%)$, mas também referem-se aos serviços $(2,6 \%)$ e à configuração da estação $(2,6 \%)$ para facilitar o deslocamento no mezanino - área paga (Tabela 29). 
Tabela 29 - Matriz de avaliação da etapa 18 - Deslocamento no mezanino - área paga.

(\% em relação ao total de relatos registrados nesta etapa)

\begin{tabular}{l|r|r|r|r|}
\hline & \multicolumn{1}{|c|}{$\begin{array}{c}\text { Configuração } \\
(\%)\end{array}$} & $\begin{array}{c}\text { Informação } \\
(\%)\end{array}$ & $\begin{array}{c}\text { Serviço } \\
(\%)\end{array}$ & \multicolumn{2}{|c|}{$\begin{array}{c}\text { Total } \\
\text { (\%) }\end{array}$} \\
\hline Estação & (EC) 2,6 & (EI) 94,8 & (ES) 2,6 & $\mathbf{1 0 0 , 0}$ \\
\hline Interface Trem-Estação & $\mathbf{0 , 0}$ & $\mathbf{0 , 0}$ & $\mathbf{0 , 0}$ & $\mathbf{0 , 0}$ \\
\hline Trem & $\mathbf{0 , 0}$ & $\mathbf{0 , 0}$ & $\mathbf{0 , 0}$ & $\mathbf{0 , 0}$ \\
\hline Total & $\mathbf{2 , 6}$ & $\mathbf{9 4 , 8}$ & $\mathbf{2 , 6}$ & $\mathbf{1 0 0 , 0}$ \\
\hline
\end{tabular}

"Eu sinto falta de um piso tátil que me leve direto das escadas rolantes e fixas para o bloqueio e para a SSO. Tem estações que o piso tátil dá muitas voltas e eu não consigo chegar até os bloqueios... e aí eu preciso pedir ajuda. Deveriam simplificar as faixas guias, colocar o básico, não deveria dar tantas voltas, assim como na Paulista que é reto. Eu às vezes penso que estou indo para o bloqueio e não estou indo para lugar nenhum, não tem nenhuma sinalização para informar para onde estou indo. Quando tem piso tátil que leva para o bloqueio, ele está no meio do fluxo dos outros usuários e aí eu sempre trombo com os outros... Poderiam instalar sinalizadores eletrônicos, tecnologia barata, para me indicar os caminhos. Também deveria ter uma sirene que se eu apertasse pudesse saber em que local da estação estou e qual o sentido que devo tomar para chegar até onde quero ir.” (Discurso do Sujeito Coletivo - Etapa 18)

Os principais problemas relatados pelos usuários na etapa de deslocamento no mezanino área paga são apresentados de forma hierarquizada conforme o número de relatos registrados (Gráfico 35).

Gráfico 35 - Avaliação da etapa 18 - Deslocamento no mezanino - área paga.

(\% em relação ao total de relatos registrados nesta etapa)

piso tátil - percurso

informações para a pessoa com deficiência visual -

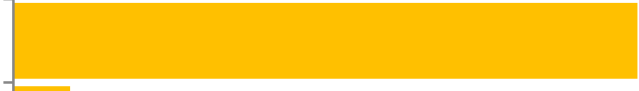

$84,6 \%$

$$
\begin{array}{c|r}
\begin{array}{c}
\text { ara a pessoa com deficiência visual - } \\
\text { estação }
\end{array} & \mathbf{7 , 7 \%} \\
\begin{array}{c}
\text { condições das instalações existentes } \\
\text { informações nos equipamentos }
\end{array} & \mathbf{2 , 6 \%} \\
\hline \begin{array}{l}
\mathbf{2 , 6 \%} \\
\text { obstáculo próximo ao piso tátil }
\end{array} & \mathbf{2 , 6 \%}
\end{array}
$$

$\mathrm{n} 1=25$ respondentes $\mathrm{n} 2=39$ relatos

Os relatos estão relacionados às seguintes ideias centrais:

a) piso tátil - percurso (EI3) - refere-se ao fato de o piso tátil não levar para todos os equipamentos e serviços oferecidos na estação, à dificuldade de compreensão sobre o caminho, bem como aponta a proximidade do piso tátil em relação aos obstáculos da edificação e destaca o fato de o piso tátil não considerar ou ser igual ao fluxo dos demais usuários e não direcionar para as escadas rolantes e fixas; 
b) informações para a pessoa com deficiência visual - estação (EI6) - critica a falta de informação sonora sobre a configuração e os percursos nas estações;

c) condições das instalações existentes (EC3) - refere-se à necessidade de alterações na configuração das estações, notadamente em relação à quantidade de bloqueios de saída;

d) informações nos equipamento (EI4) - refere-se à falta de informações táteis ou sonoras indicando a localização dos bloqueios preferenciais de saída;

e) obstáculo próximo ao piso tátil (ES5) - destaca a existência de direcionadores de fila e painéis informativos sobre o piso tátil, que se tornam obstáculos.

\subsubsection{Avaliação pelas pessoas-chave}

Os empregados das estações destacaram os aspectos relacionados à lotação das estações (ES7) devido à elevada demanda, causando conflitos e cruzamentos de fluxo no mezanino área paga, principalmente próximo às escadas de acesso às plataformas. A disposição das escadas rolantes existentes é muitas vezes considerada incompatível com os fluxos de embarque e desembarque e torna os deslocamentos no mezanino complexos, o que exige a montagem de elementos orientadores de fluxo nos horários de maior movimento, por vezes configurando-se como obstáculos próximos ao piso tátil (ES5) - (Figura 222).
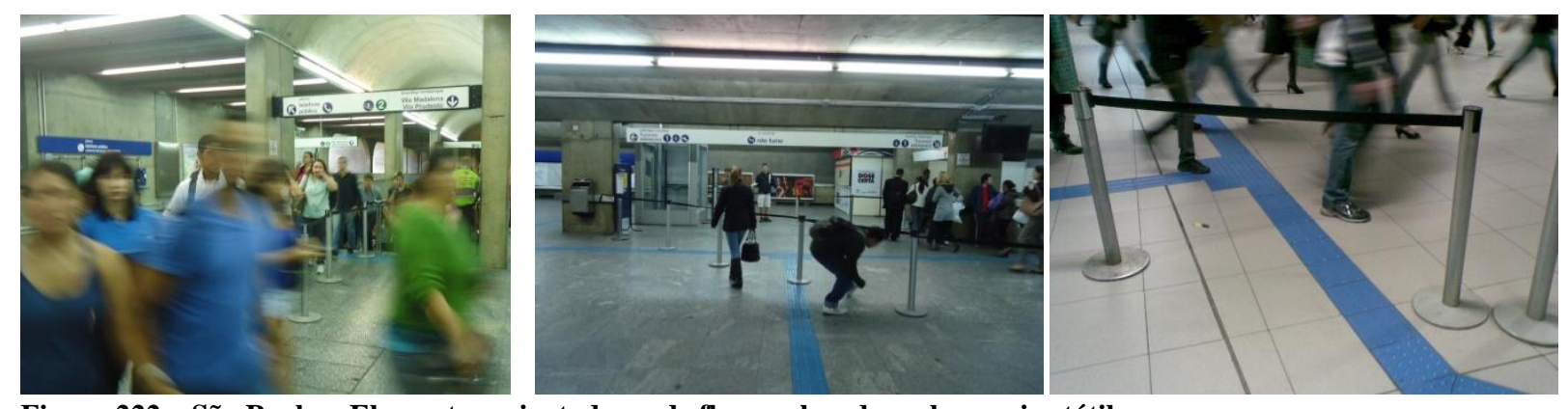

Figura 222 - São Paulo - Elementos orientadores de fluxo colocados sobre o piso tátil. Fonte: BARBOSA, M.B., 2013.

Os estagiários relataram que a dificuldade de compreensão do piso tátil - percurso (EI3) de desembarque e a pressa para encontrar a saída correta mobiliza a solicitação de auxílio pelas pessoas com deficiência. Também são destacadas dificuldades para uso independente da sinalização tátil no piso em função da lotação das estações (ES7) e do mau comportamento dos usuários (ES4), que param ou circulam sobre o piso tátil e não dão preferência ao deslocamento da pessoa com deficiência visual. Eles relataram ainda a dificuldade de auxiliar a pessoa com deficiência visual em função da lotação das estações (ES7), decorrente do 
deslocamento simultâneo de um grande número de pessoas para embarque e desembarque, do comportamento dos demais usuários - estação (ES4), que muitas vezes andam distraídos ou olhando para baixo e, em outras vezes, não respeitam o deslocamento preferencial da pessoa com deficiência visual e do estagiário, obrigando-os a desviarem seu caminho para não esbarrar em ninguém e, eventualmente, se machucar.

Os professores de orientação e mobilidade relataram que a ausência de uma faixa de transição traz dificuldades para identificar o piso tátil - contraste tátil e visual (EI1) em relação ao piso existente, notadamente nas estações que têm piso emborrachado com pastilhas em relevo. Em relação ao piso tátil - percurso (EI3), há críticas ao dimensionamento insuficiente da sinalização tátil de alerta nas interseções entre pisos direcionais - o que dificulta a percepção quanto às mudanças de direção - e ao fato de a sinalização não considerar ou ser igual ao percurso dos demais usuários - o que pode gerar eventuais conflitos de fluxo. A utilização de pisos diagonais ou em curvas pouco acentuadas pode resultar maior funcionalidade do que percursos ortogonais. A compreensão do percurso realizado no mezanino - área paga pode ser ampliada com o auxílio de informações para a pessoa com deficiência visual - estação (EI6) por meio de mapas táteis e descrições sonoras contendo as referências principais das estações, permitindo informações em igualdade de condições com os demais usuários. Outro recurso, segundo os professores de orientação e mobilidade, é seguir o percurso do piso tátil durante a prestação de auxílio às pessoas com deficiência visual, fato que deve ser abordado no programa de capacitação e treinamento dos empregados - estação (ES1).

\subsubsection{Avaliação pelos especialistas}

Os profissionais responsáveis pelos projetos das estações relataram que as soluções padronizadas relacionadas à configuração, sinalização e iluminação dos ambientes característicos do sistema metroferroviário contribuem para prover segurança, autonomia e agilidade nos deslocamentos. Entre as soluções que podem contribuir para a segurança e a independência dos deslocamentos em função das condições das instalações existentes (EC3), estão recomendações para melhoria dos textos normativos vigentes, destacando o estabelecimento de condições adequadas para execução de obras e serviços, garantindo uma rota acessível para embarque e a existência de contraste entre piso, paredes, portas, corrimãos e painéis de informação da estação. As informações para a pessoa com deficiência visual estação (EI6) devem ser claras, objetivas e completas, além de redundantes, para que as 
orientações operacionais e institucionais sobre os serviços ofertados (comércio, exposições, espaços institucionais) possam contribuir para que os passageiros alcancem seus destinos com segurança. As referências necessárias para orientar os deslocamentos das pessoas com deficiência visual podem ser criadas a partir de estímulos táteis e sonoros, ou mesmo visuais, desde que adequados aos parâmetros que possibilitem sua percepção por pessoas com baixa visão. Uma vez que a soma dessas referências é mais eficaz do que cada uma isoladamente, para serem mais eficientes e atingirem a diversidade existente no segmento de pessoas com deficiência visual, tais referências devem ser redundantes e integradas.

\subsubsection{Elementos de wayfinding}

Os dados coletados permitem afirmar que os elementos de wayfinding característicos desta etapa são os seguintes: caminhos, nós e zonas (Quadro 38). Esses elementos devem ser providos de configuração adequada bem como de sinalização tátil/visual/sonora integrada de forma a facilitar sua identificação por pessoas com deficiência visual e sobressair-se em relação aos demais elementos e informações do ambiente para auxiliar sua percepção. Ao mesmo tempo, tais elementos devem constar e ser ressaltados nas informações veiculadas, especialmente quando da elaboração dos materiais táteis, visuais e sonoros voltados à descrição do ambiente das estações, resultando na melhor compreensão dos percursos desde os elementos de circulação vertical até os elementos de controle de acesso.

Quadro 38 - Elementos de wayfinding da Etapa 18 - Deslocamento no mezanino - área paga.

\begin{tabular}{|c|c|c|c|}
\hline $\begin{array}{l}\text { Elementos de } \\
\text { wayfinding }\end{array}$ & Configuração & Informação & Serviço \\
\hline Caminhos & $\begin{array}{l}\text { - percurso de saída ou } \\
\text { conexão }\end{array}$ & $\begin{array}{l}\text { - sinalização } \\
\text { tátil/visual/sonora da } \\
\text { configuração do percurso }\end{array}$ & $\begin{array}{l}\text { - treinamento dos usuários } \\
\text { - auxílio no deslocamento }\end{array}$ \\
\hline Nós & $\begin{array}{l}\text { - interseção entre } \\
\text { percursos de saída e de } \\
\text { conexão entre linhas }\end{array}$ & $\begin{array}{l}\text { - sinalização tátil/visual } \\
\text { das opções de percurso }\end{array}$ & $\begin{array}{l}\text { - treinamento dos usuários } \\
\text { - auxílio no deslocamento }\end{array}$ \\
\hline Zonas & $\begin{array}{l}\text { - superfície da área de } \\
\text { circulação no mezanino } \\
\text { - área paga }\end{array}$ & $\begin{array}{l}\text { - contraste visual entre } \\
\text { superfícies horizontais, } \\
\text { verticais e equipamentos } \\
\text { da estação }\end{array}$ & $\begin{array}{l}\text { - treinamento dos usuários } \\
\text { - auxílio no deslocamento } \\
\text { - gestão de fluxos }\end{array}$ \\
\hline
\end{tabular}

Fonte: Elaborado pela pesquisadora. 


\subsubsection{Síntese do diagnóstico}

Na etapa 18 - Deslocamento no mezanino - área paga -, foram identificados aspectos que devem ser tratados pelas empresas operadoras dos sistemas metroferroviários para auxiliar pessoas com deficiência visual a estabelecer estratégias para empreender seus deslocamentos:

a) condições das instalações existentes (EC3) - adequar a quantidade de bloqueios de saída; dar preferência às soluções padronizadas de configuração, sinalização e iluminação dos ambientes característicos do sistema metroferroviário; estabelecer condições adequadas para execução de obras e serviços, garantindo uma rota acessível para embarque; prover contraste entre pisos, paredes, portas, corrimãos e painéis de informação da estação;

b) piso tátil - contraste tátil e visual (EI1) - instalar faixa de transição junto ao piso existente para facilitar a identificação do piso tátil nas estações que têm piso emborrachado com pastilhas em relevo;

c) piso tátil - percurso (EI3) - instalar piso tátil em todos os equipamentos e serviços oferecidos na estação; melhorar a compreensão sobre o caminho e encontrar a saída correta; manter distanciamento do piso tátil em relação aos obstáculos existentes na edificação; considerar ou ser igual ao fluxo dos demais usuários; direcionar para as escadas rolantes e fixas; aumentar a área de sinalização tátil de alerta nas interseções entre pisos direcionais; utilizar pisos táteis com percursos diagonais ou em curva em substituição aos percursos ortogonais;

d) informações nos equipamento (EI4) - instalar informações táteis ou sonoras indicando a localização dos bloqueios preferenciais de saída;

e) informações para a pessoa com deficiência visual - estação (EI6) - disponibilizar informação visual, tátil e sonora e mapas sobre a configuração e principais referências das estações, localização e percursos a serem realizados até os bloqueios de saída; prover informações e orientações operacionais e institucionais sobre os serviços ofertados (comércio, exposições, espaços institucionais) de maneira clara, objetiva, completa e redundante; disponibilizar informação tátil, visual ou sonora sobre a configuração e os percursos realizados na estação;

f) treinamento dos empregados - estação (ES1) - seguir o percurso do piso tátil durante a prestação de auxílio às pessoas com deficiência visual; 
g) comportamento dos usuários (ES4) - promover campanhas para orientar o comportamento dos demais usuários nas estações, para prestar atenção, respeitar, desviar e dar preferência ao deslocamento da pessoa com deficiência visual, sem esbarrar ou machucar ninguém e parar ou circular sobre o piso tátil;

h) obstáculo próximo ao piso tátil (ES5) - posicionar os direcionadores de fila a uma distância segura do piso tátil;

i) lotação das estações (ES7) - organizar conflitos e cruzamentos de fluxo de embarque e desembarque simultâneos nos horários de maior movimento.

\subsection{Etapa 19 - Controle de saída}

Nesta etapa, o usuário passa pelos bloqueios sem necessidade de utilizar um bilhete ou cartão.

\subsubsection{Métodos e técnicas aplicados}

Os métodos e técnicas utilizados para coleta de dados nesta etapa foram apresentados no item 6.10 - Síntese dos instrumentos aplicados - e consistiram em:

a) melhores práticas identificadas em outros sistemas metroferroviários;

b) pesquisa documental (normas técnicas ABNT vigentes, desenhos, procedimentos operacionais);

c) checklist dos recursos disponíveis e walkthrough realizado nas estações para compreensão do percurso de embarque;

d) questionário aplicado às pessoas com deficiência visual - questões 12, 13 e 17;

e) entrevista com professores de orientação e mobilidade;

f) entrevista com profissionais responsáveis pela elaboração de normas técnicas.

As formas de análise e interpretação dos dados coletados foram apresentadas no Capítulo 6 Aplicação dos instrumentos.

\subsubsection{Melhores Práticas}

Entre as melhores práticas, destaca-se o Metrô de Madri, que dispõe de sinalização luminosa suspensa posicionada sobre a linha de bloqueios para orientar os fluxos (Figura 223). O Metrô de Barcelona dispõe de sinalização tátil no piso e sinalização suspensa indicativa do bloqueio preferencial (Figura 224). 


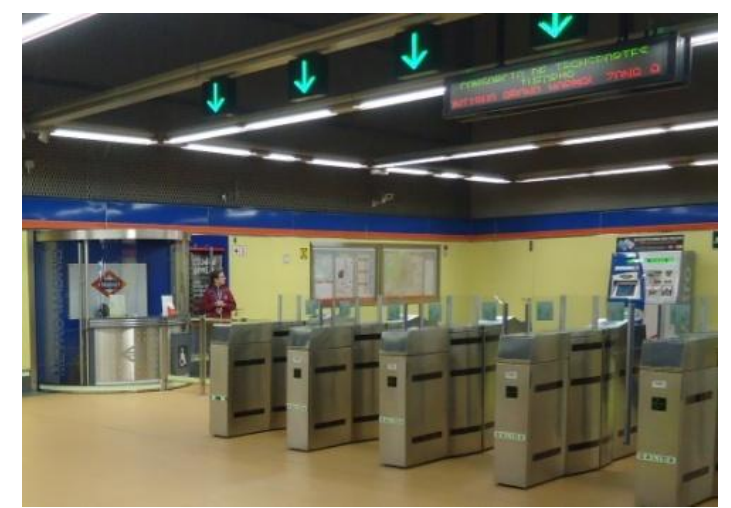

Figura 223 - Madri - Sinalização suspensa sobre os equipamentos de controle de saída. Fonte: BARBOSA, M.B., 2013.

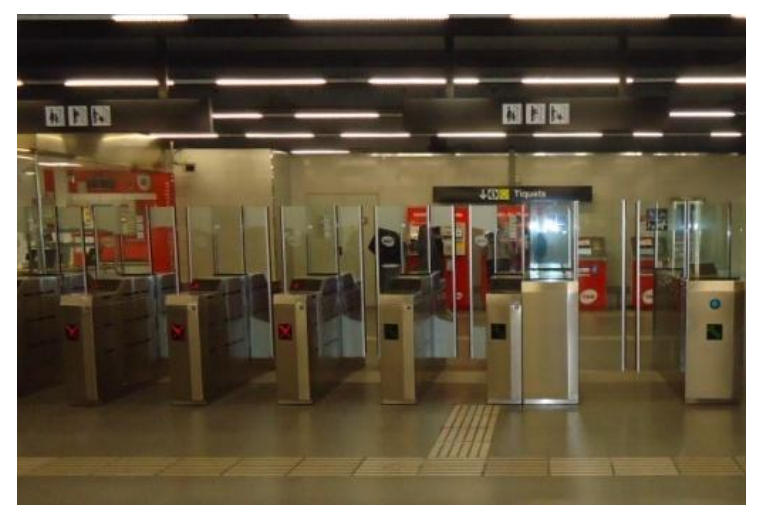

Figura 224 - Barcelona - Sinalização suspensa sobre os equipamentos de uso preferencial. Fonte: BARBOSA, M.B., 2011.

\subsubsection{Requisitos Normativos}

Com relação aos requisitos normativos, a ABNT NBR 14.021:2005 recomenda que os equipamentos de controle de saída sejam sinalizados quanto ao uso preferencial, por meio de sinalização suspensa posicionada sobre os equipamentos e, quanto ao posicionamento para utilização do equipamento de controle de saída pelo usuário com deficiência visual, por meio de sinalização tátil no piso.

\subsubsection{Situação no Metrô de São Paulo}

No Metrô de São Paulo, os equipamentos de controle de saída dispõem de sinalização indicativa do fluxo - embarque ou desembarque - no próprio equipamento; nas estações mais recentemente construídas, essa sinalização é redundante, suspensa sobre os equipamentos. A sinalização tátil direcional orienta o percurso e o posicionamento do usuário com deficiência visual junto ao bloqueio de saída (Figura 225). Nas estações que permitem a conexão com os trens metropolitanos, equipamentos de controle de fluxo e contadores são posicionados no limite da área de atuação de cada empresa. Esses equipamentos dispõem de sinalização indicativa do fluxo no próprio equipamento e em painéis suspensos (nas estações mais novas), além de piso tátil direcional indicativo do percurso (Figura 226). 

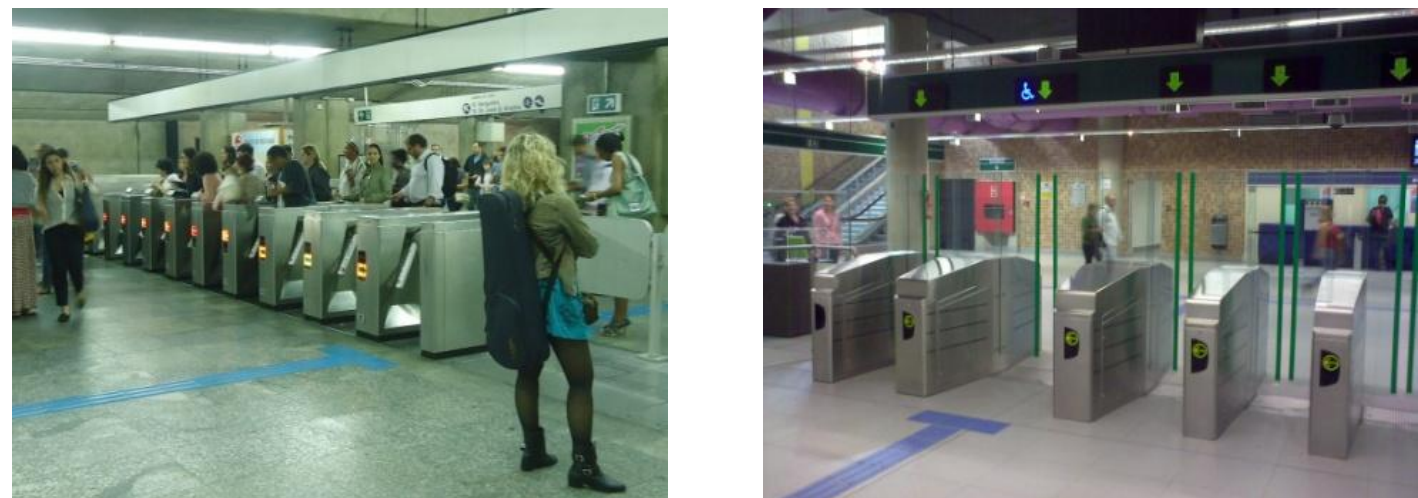

Figura 225 - São Paulo - Sinalização visual (suspensa e no equipamento) e tátil indicativa do percurso de saída.

Fonte: BARBOSA, M.B., 2011.
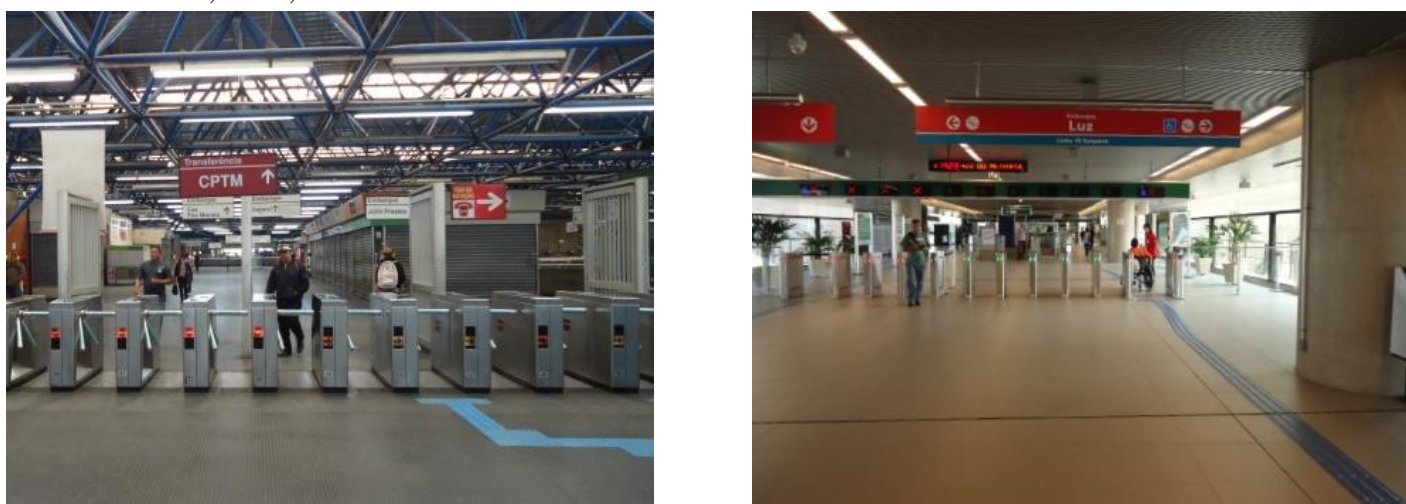

Figura 226 - São Paulo - Sinalização visual (suspensa e no equipamento) e tátil indicativa do percurso de conexão.

Fonte: BARBOSA, M.B., 2011.

\subsubsection{Avaliação pelos usuários}

Na etapa de controle de saída, quatro usuários com deficiência visual - dos quais duas pessoas são cegas e duas pessoas têm baixa visão - manifestaram seu descontentamento em relação à estação $(100,0 \%)$. Foram registrados quatro relatos, o que representa $0,1 \%$ do total de relatos registrados para todas as etapas da jornada do usuário. Os relatos estão relacionados à configuração da estação $(50,0 \%)$ e às informações prestadas na estação $(50,0 \%)$ para facilitar o controle de saída.

"É importante para mim que os bloqueios sinalizem, em braile ou de forma sonora, o sentido de entrada e de saída. Em algumas estações precisaria ter mais bloqueios disponíveis para sair. Todos os bloqueios deveriam ter portas de vidro... Às vezes a estação coloca painéis em cima do piso tátil, complicando ainda mais o meu percurso." (Discurso do Sujeito Coletivo Etapa 19)

Os principais problemas relatados pelos usuários na etapa de controle de saída são apresentados de forma hierarquizada, conforme o número de relatos registrados. Os problemas relatados estão relacionados às seguintes ideias centrais: 
a) informações nos equipamentos (EI4) - refere-se à falta de informações táteis e sonoras nos bloqueios preferenciais de saída;

b) condições das instalações existentes (EC3) - refere-se à falta de bloqueios de saída localizados em pontos estratégicos das estações;

c) situação existente dificulta a mobilidade (EC4) - destaca a existência de bloqueios de tripé e contadores estreitos, que dificultam a mobilidade.

\subsubsection{Avaliação pelas pessoas-chave}

Na etapa de validação do bilhete, os professores de orientação e mobilidade destacaram a importância das informações nos equipamentos (EI4) e relataram que a sinalização tátil direcional junto aos elementos de saída pode, ainda que temporariamente, ficar incoerente com bloqueios e contadores que estejam desligados ou em manutenção (Figura 227).
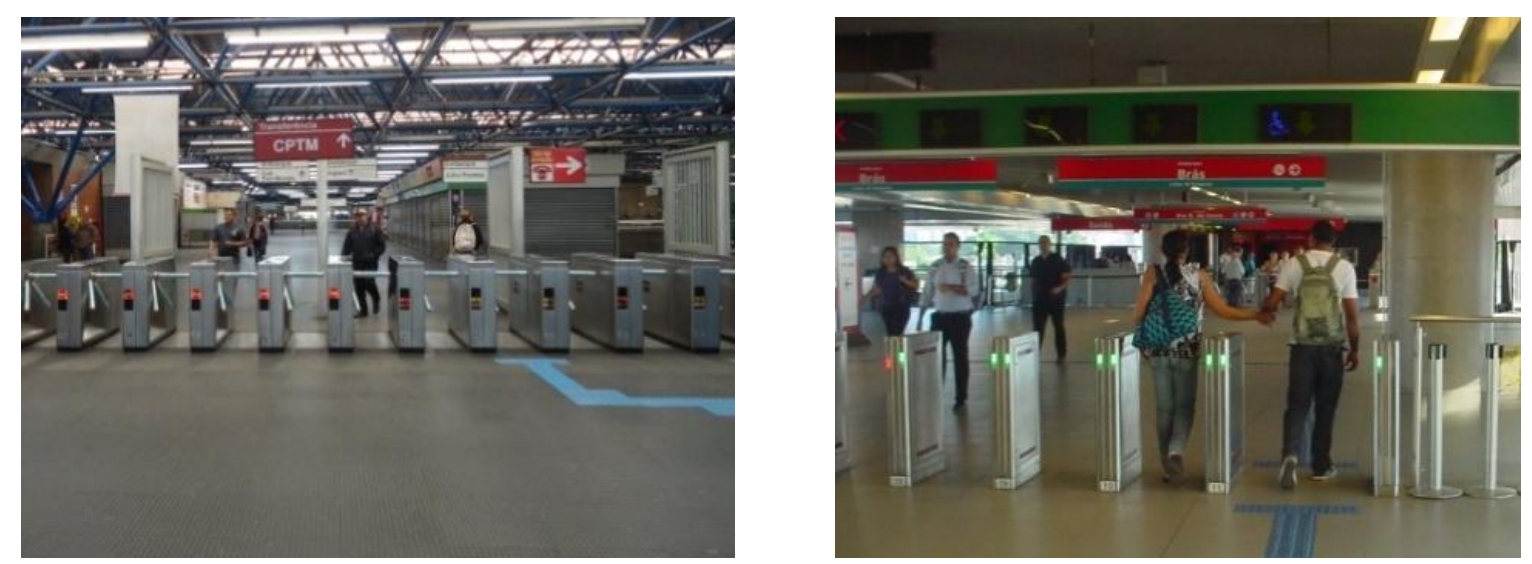

Figura 227 - São Paulo - Elementos de controle de saída (a) ou de transferência (b,c). Fonte: BARBOSA, M.B., 2011.

\subsubsection{Avaliação pelos especialistas}

Os profissionais responsáveis pela elaboração de normas técnicas relataram que as normas de acessibilidade contribuem para prover segurança, autonomia e agilidade nos deslocamentos por meio de soluções padronizadas relacionadas à configuração, sinalização e iluminação dos elementos, equipamentos e dispositivos. Entre as soluções que podem contribuir para a segurança e a independência dos deslocamentos em função das condições das instalações existentes (EC3), foram feitas recomendações para melhoria dos textos normativos vigentes, destacando-se as seguintes:

a) a instalação de bloqueios/catracas acessíveis e eliminação das cancelas como equipamento de controle de acesso; 
b) a existência de acessibilidade do sistema de bilhetagem, como, por exemplo, o retorno sonoro nos bloqueios acessíveis;

c) as condições para execução de obras e serviços: realização de obras/reformas parciais ou totais deve garantir rota acessível para embarque/desembarque;

d) o contraste entre o piso, as paredes e os equipamentos.

\subsubsection{Elementos de wayfinding}

Os dados coletados permitem afirmar que os elementos de wayfinding característicos desta etapa são os seguintes: caminho e limite (Quadro 39). Esses elementos devem ser providos de configuração adequada bem como de sinalização tátil/visual/sonora integrada de forma a auxiliar sua identificação pelas pessoas com deficiência visual e sobressair-se em relação aos demais elementos e informações do ambiente para facilitar sua percepção. Ao mesmo tempo, tais elementos devem estar presentes e ser ressaltados nas informações veiculadas, especialmente quando da elaboração dos materiais táteis, visuais e sonoros voltados à descrição do ambiente das estações, facilitando a compreensão dos percursos desde os elementos de circulação vertical até os elementos de controle de acesso.

Quadro 39 - Elementos de wayfinding da Etapa 19 - Controle de saída

\begin{tabular}{|c|c|c|c|}
\hline $\begin{array}{l}\text { Elementos de } \\
\text { wayfinding }\end{array}$ & Configuração & Informação & Serviço \\
\hline & $\begin{array}{l}\text { - localização dos } \\
\text { equipamentos de controle } \\
\text { de saída/contadores de } \\
\text { conexão }\end{array}$ & $\begin{array}{l}\text { - contraste visual entre } \\
\text { equipamentos e cenário da } \\
\text { estação } \\
\text { - sinalização tátil e visual } \\
\text { sobre o funcionamento do } \\
\text { equipamento }\end{array}$ & - atendimento preferencial \\
\hline & $\begin{array}{l}\text { - percurso até os } \\
\text { equipamentos de controle } \\
\text { de saída } \\
\text { - percurso até os contadores } \\
\text { - equipamentos de controle } \\
\text { de conexão }\end{array}$ & $\begin{array}{l}\text { - sinalização tátil/visual do } \\
\text { percurso até os } \\
\text { equipamentos de controle } \\
\text { de saída/contadores de } \\
\text { conexão }\end{array}$ & $\begin{array}{l}\text { - treinamento dos usuários } \\
\text { - auxílio no deslocamento }\end{array}$ \\
\hline
\end{tabular}

Fonte: Elaborado pela pesquisadora.

\subsubsection{Síntese do diagnóstico}

Na etapa 19 - Controle de saída -, foram identificados aspectos que devem ser tratados pelas empresas operadoras dos sistemas metroferroviários para auxiliar pessoas com deficiência visual a estabelecer estratégias para empreender seus deslocamentos: 
a) condições das instalações existentes (EC3) - disponibilizar bloqueios de saída localizados em pontos estratégicos das estações; substituir as cancelas existentes por bloqueios; garantir contraste entre o piso, as paredes e os equipamentos; garantir condições adequadas para a execução de serviços, realização de obras e reformas parciais ou totais, garantindo a existência de rota acessível para embarque/desembarque;

b) situação existente dificulta a mobilidade (EC4) - dimensionar os bloqueios de tripé e os contadores existentes para facilitar a mobilidade;

c) informações nos equipamentos (EI4) - implementar informação tátil, visual e sonora nos bloqueios preferenciais; implementar retorno sonoro para informar sobre a liberação da passagem; instalar sinalização tátil no piso, direcionando o fluxo para bloqueios ou contadores que estejam operacionais.

\subsection{Etapa 20 - Deslocamento no mezanino - área livre}

Nesta etapa, o usuário inicia seu deslocamento no mezanino - área livre - e opta pela circulação vertical que o levará até a saída em função do destino desejado. Em algumas situações, cabe ao usuário, nesta etapa, optar por diferentes saídas em função da integração com linhas de ônibus nos terminais urbanos ou nos pontos de parada.

\subsubsection{Métodos e técnicas aplicados}

Os métodos e técnicas utilizados para coleta de dados nesta etapa foram apresentados no item 6.10 - Síntese dos instrumentos aplicados - e consistiram em:

a) identificação de melhores práticas em outros sistemas metroferroviários;

b) pesquisa documental (normas técnicas ABNT vigentes, desenhos, procedimentos operacionais);

c) checklist dos recursos disponíveis e walkthrough realizado nas estações para compreensão do percurso de saída;

d) questionário aplicado às pessoas com deficiência visual - questões 12, 13 e 17;

e) entrevista com estagiários que auxiliam pessoas com deficiência visual;

f) entrevista com professores de orientação e mobilidade;

g) entrevista com profissionais responsáveis pelos projetos das estações. 
As formas de análise e interpretação dos dados coletados foram apresentadas no Capítulo 6 Aplicação dos instrumentos.

\subsubsection{Melhores Práticas}

Entre as melhores práticas, destaca-se o Metrô de Hong Kong, que dispõe de piso tátil direcional indicando os percursos de saída, garantindo o contraste visual com o piso adjacente e sinalização retroiluminada indicativa das rotas de fuga/saídas de emergência (Figura 228).
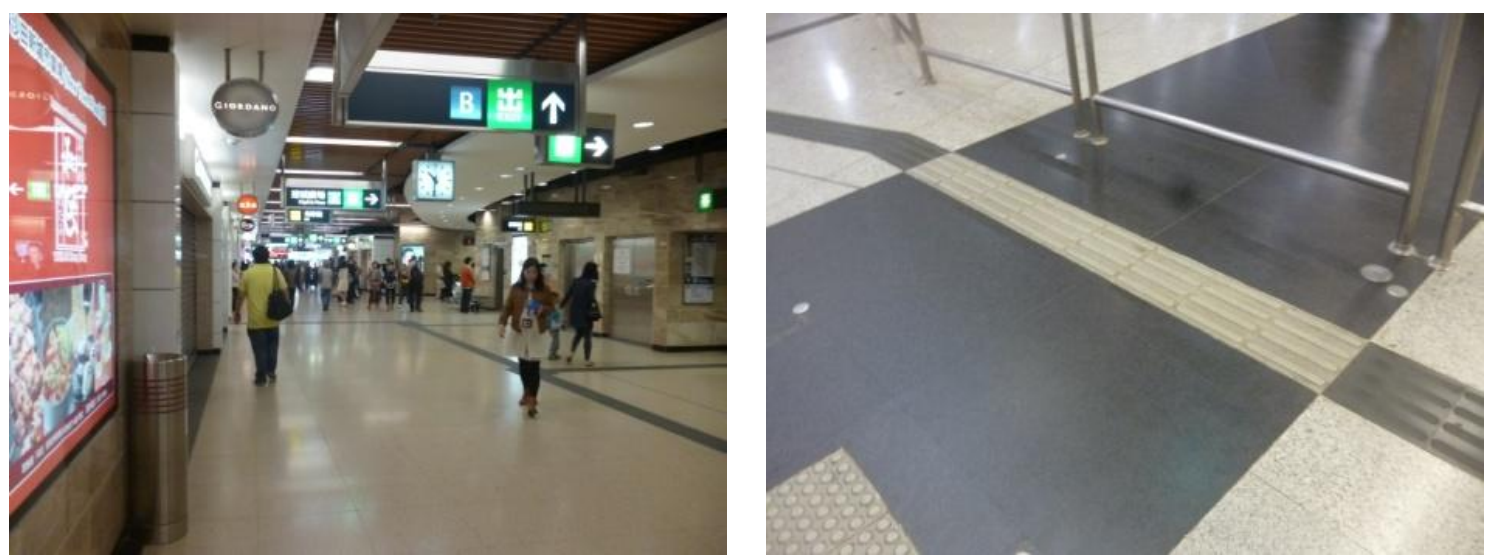

Figura 228 - Hong Kong - Piso tátil direcional com cores contrastantes. Crédito: PONTES, F.M., 2012.

O Metrô do Rio de Janeiro dispõe de mapa tátil em plano inclinado indicando a localização dos acessos e das respectivas ruas no entorno das estações (Figura 229).
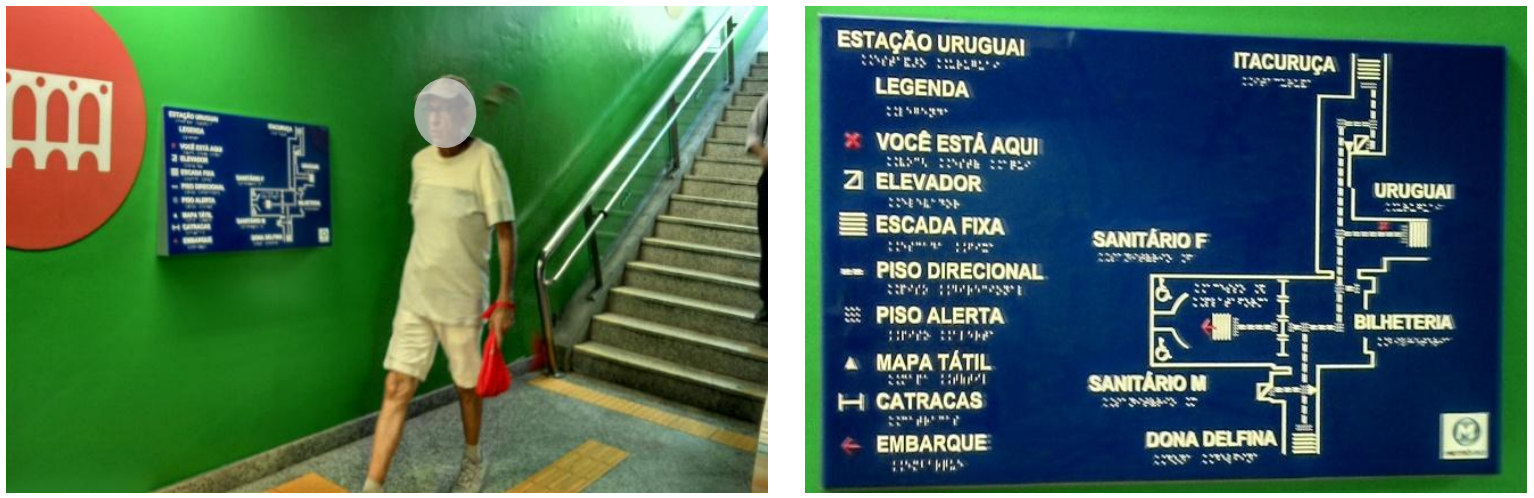

Figura 229 - Rio de Janeiro - Mapa tátil indicativo das ruas do entorno das estações.

Crédito: SILVA, R., 2014.

\subsubsection{Requisitos Normativos}

Com relação aos requisitos normativos, a ABNT NBR 14.021:2005 estabelece que a circulação para saída deve dispor de rota acessível sinalizada, indicando as saídas, os modos de transporte integrados e os locais de interesse no entorno, utilizando a palavra "saída". A ABNT NBR 9050:2004 estabelece que as rotas de fuga e saídas de emergência devem ser sinalizadas com informações visuais e sonoras e também estabelece a necessidade de 
instalação de piso tátil direcional quando da ausência ou descontinuidade de linha-guia identificável, como guia de caminhamento em ambientes internos ou externos, ou quando houver caminhos preferenciais de circulação.

\subsubsection{Situação no Metrô de São Paulo}

No Metrô de São Paulo, o deslocamento no mezanino - área livre dispõe de piso tátil direcional para orientar o percurso de desembarque desde os equipamentos de controle de saída até a saída propriamente dita, posicionada no eixo dos corredores e áreas de circulação. A nova sinalização visual - implantada em parte das estações - incorpora a identificação da saída por meio de letra associada às ruas do entorno e a indicação do tipo de equipamento de circulação vertical associado a cada saída. A sinalização visual de saída de emergência/rota de fuga utiliza as mesmas estruturas de suporte (Figura 230).
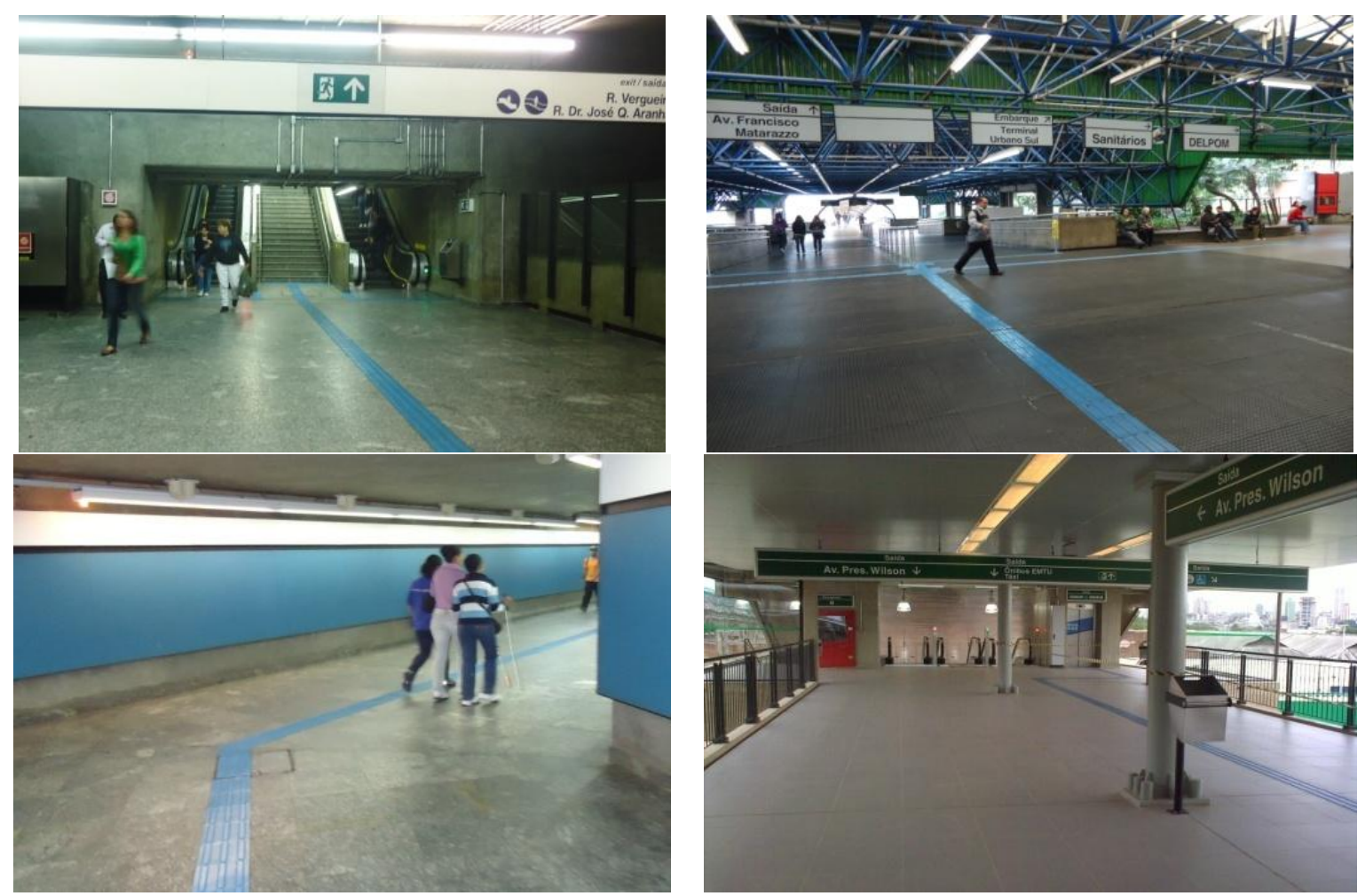

Figura 230 - São Paulo - Sinalização tátil e visual indicativa do percurso de saída. Fonte: BARBOSA, M.B., 2011.

\subsubsection{Avaliação pelos usuários}

Na etapa de deslocamento no mezanino - área livre, 35 usuários com deficiência visual - dos quais 24 pessoas são cegas e 11 pessoas têm baixa visão - manifestaram seu descontentamento em relação à estação $(100,0 \%)$. Foram registrados 52 relatos, o que 
representa $1,9 \%$ do total de relatos registrados para todas as etapas da jornada do usuário. Os relatos estão, em sua maioria, relacionados às informações prestadas na estação $(92,4 \%)$, mas também referem-se à configuração da estação $(3,8 \%)$ e aos serviços prestados na estação $(3,8 \%)$ para facilitar o deslocamento no mezanino - área livre (Tabela 30$)$.

Tabela 30 - Matriz de avaliação da etapa 20 - Deslocamento no mezanino - área livre.

(\% em relação ao total de relatos registrados nesta etapa)

\begin{tabular}{|c|c|c|c|c|}
\hline & $\underset{\%}{\text { Configuração }}$ & $\begin{array}{c}\text { Informação } \\
\%\end{array}$ & $\begin{array}{c}\text { Serviço } \\
\%\end{array}$ & $\begin{array}{c}\text { Total } \\
\%\end{array}$ \\
\hline Estação & (EC)3,8 & (EI) 92,4 & (ES) 3,8 & 100,0 \\
\hline Interface Trem-Estação & $\mathbf{0 , 0}$ & $\mathbf{0 , 0}$ & $\mathbf{0 , 0}$ & $\mathbf{0 , 0}$ \\
\hline Trem & $\mathbf{0 , 0}$ & $\mathbf{0 , 0}$ & $\mathbf{0 , 0}$ & $\mathbf{0 , 0}$ \\
\hline Total \% & 3,8 & 92,4 & 3,8 & 100,0 \\
\hline
\end{tabular}

"Eu sinto falta de uma sinalização melhor das saídas das estações, fica difícil decorar a direção das saídas de todas as estações que utilizo. Seria muito importante que em todas estações houvesse uma maquete para que eu pudesse compreender melhor o seu desenho, ou que tivesse um mapa em braile indicando aonde vão dar as saídas e as ruas que ficam próximas às estações, um mapa com o desenho do piso tátil. Outra alternativa é colocar sinalizadores eletrônicos ou sensores infravermelhos para me enviar sinais, por meio de um equipamento, indicando os caminhos e as saídas, por exemplo, vire à esquerda para ir à rodoviária, à direita para o terminal urbano... Para que eu pudesse me locomover sozinho, o piso tátil também poderia ser mais simples e direto, levando do bloqueio para a saída da estação. Eles têm muitas ramificações, às vezes não chega até a saída... Em algumas estações tem o piso tátil com tantas ramificações que eu não sei nunca para onde está indo. Algumas estações não têm piso tátil dos bloqueios para as escadas de saída. Às vezes o piso tátil que sai do bloqueio dá no meio do fluxo dos outros usuários e aí ocorrem trombadas, deveria estar fora deste fluxo. Quando fica no meio de um corredor, precisaria ter mão e contramão, para evitar trombadas: o ideal seria estar sempre na lateral. Em algumas estações, o piso tátil me leva para algum obstáculos ou acaba em um corrimão... Para melhorar a acessibilidade, as estações precisam melhorar as informações visuais. Tenho dificuldade de ler as placas porque ficam em lugares altos e as letras deveriam ser maiores e mais contrastantes com o fundo das placas..." (Discurso do Sujeito Coletivo - Etapa 20)

Os principais problemas relatados pelos usuários na etapa deslocamento no mezanino - área livre são apresentados de forma hierarquizada, conforme o número de relatos registrados (Gráfico 36). 
Gráfico 36 - Avaliação da etapa 20 - Deslocamento no mezanino - área livre.

(\% em relação ao total de relatos registrados nesta etapa)

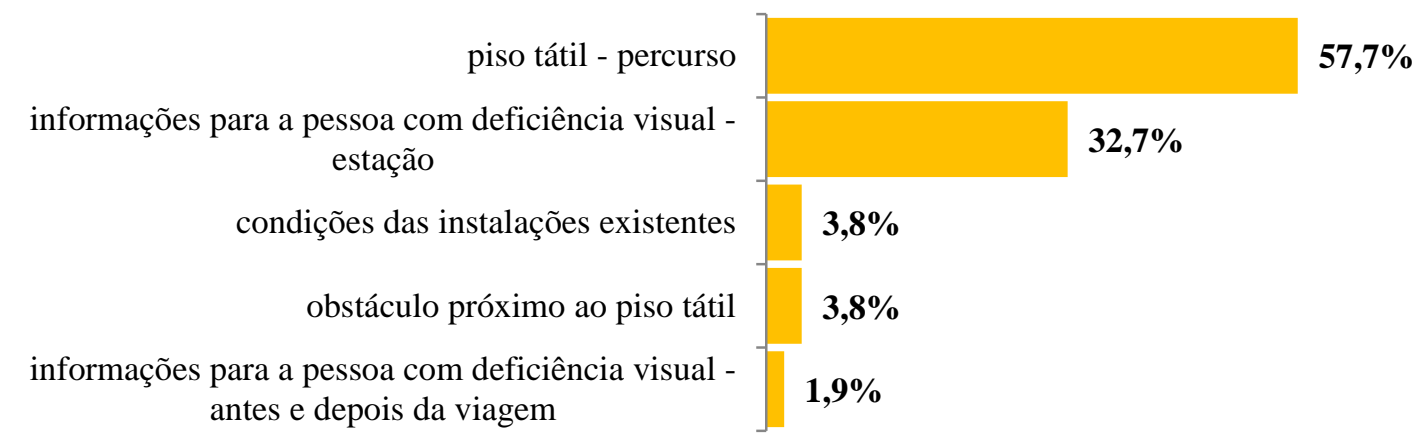

$\mathrm{n} 1=35$ respondentes $\mathrm{n} 2=52$ relatos

Os relatos estão relacionados às seguintes ideias centrais:

a) piso tátil - percurso (EI3) - relata a insatisfação decorrente do piso tátil não considerar ou ser igual ao fluxo dos demais usuários e não orientar o percurso para as escadas fixas e rolantes ou não levar para todos os equipamentos e serviços oferecidos na estação. Destaca a dificuldade de compreensão do caminho e aponta a proximidade do piso tátil em relação aos obstáculos da edificação - pilares, paredes e corrimãos;

b) informações para a pessoa com deficiência visual - estação (EI6) - refere-se à inexistência de informação sonora e tátil e de mapas sobre a configuração das estações, os percursos a serem realizados e a localização das saídas e das ruas do entorno. Relata, ainda, a dificuldade de legibilidade das informações visuais em função da insuficiência do contraste de cor e do tamanho das letras nas placas de sinalização e da inexistência de folhetos com orientações em Braille ou informações sonoras para o deficiente visual saber usar a estação;

c) condições das instalações existentes (EC3) - refere-se à insatisfação em relação ao dimensionamento dos corredores das estações, com a demanda elevada e com as condições de segurança das estações;

d) obstáculo próximo ao piso tátil (ES5) - relata a existência de direcionador de fila próximo ao piso tátil direcional, dificultando o deslocamento;

e) informações para a pessoa com deficiência visual - antes e depois da viagem (EI5) - refere-se à falta de folhetos ou manuais com informações sobre a configuração da estação e das ruas do entorno. 


\subsubsection{Avaliação pelas pessoas-chave}

Os estagiários relataram a dificuldade para auxiliar a pessoa com deficiência visual em função da lotação das estações (ES7), decorrente do deslocamento simultâneo de um grande número de pessoas para entrada e saída, do comportamento dos demais usuários - estação (ES4), que muitas vezes andam distraídos ou olhando para baixo e, em outras vezes, não respeitam o deslocamento preferencial da pessoa com deficiência visual e do estagiário, obrigando-os a desviarem seu caminho para não esbarrarem em ninguém e, eventualmente, se machucarem.

Os professores de orientação e mobilidade relataram que a ausência de uma faixa de transição traz dificuldades para identificar o piso tátil - contraste tátil e visual (EI1) em relação ao piso existente, notadamente nas estações que têm piso emborrachado com pastilhas em relevo. Em relação ao piso tátil - percurso (EI3), há críticas ao dimensionamento insuficiente da sinalização tátil de alerta nas interseções entre pisos direcionais - o que dificulta a percepção quanto às mudanças de direção - e ao fato de a sinalização não considerar ou ser igual ao percurso dos demais usuários - o que pode gerar eventuais conflitos de fluxo. A utilização de pisos diagonais ou em curvas pouco acentuadas pode resultar em maior funcionalidade do que percursos ortogonais. A compreensão do percurso realizado no mezanino pode ser ampliada com a instalação de informações para a pessoa com deficiência visual - estação (EI6) por meio de mapas táteis ou descrições sonoras, contendo as referências principais das estações, disponibilizando informações em igualdade de condições com os demais usuários. Outro recurso, segundo os professores de orientação e mobilidade, é seguir o percurso do piso tátil durante a prestação de auxílio às pessoas com deficiência visual, fato que deve ser abordado no programa de capacitação e treinamento dos empregados - estação (ES1).

\subsubsection{Avaliação pelos especialistas}

Os profissionais responsáveis pelos projetos das estações relataram que as soluções padronizadas relacionadas à configuração, sinalização e iluminação dos ambientes característicos do sistema metroferroviário contribuem para prover segurança, autonomia e agilidade nos deslocamentos. Entre as soluções que podem contribuir para a segurança e a independência dos deslocamentos em função das condições das instalações existentes (EC3) estão recomendações para a melhoria dos textos normativos vigentes, destacando o estabelecimento de condições adequadas para execução de obras e serviços, garantindo uma rota acessível para embarque e a existência de contraste entre pisos, paredes, portas, 
corrimãos e painéis de informação da estação. As informações para a pessoa com deficiência visual - estação (EI6) devem ser claras, objetivas e completas, além de redundantes, para que as orientações operacionais e institucionais sobre os serviços ofertados (comércio, exposições, espaços institucionais) possam contribuir para que os passageiros alcancem seus destinos com segurança. As referências necessárias para orientar os deslocamentos das pessoas com deficiência visual podem ser criadas a partir de estímulos táteis e sonoros, ou mesmo visuais, desde que adequados aos parâmetros que possibilitem sua percepção por pessoas com baixa visão. Uma vez que a soma dessas referências é mais eficaz do que cada uma isoladamente, para serem mais eficientes e atingir à diversidade existente no segmento de pessoas com deficiência visual, tais referências devem ser redundantes e integradas.

\subsubsection{Elementos de wayfinding}

Os dados coletados permitem afirmar que os elementos de wayfinding característicos desta etapa são os seguintes: marcadores, caminhos, nós e zonas (Quadro 40). Esses elementos devem ser providos de configuração adequada bem como de sinalização tátil/visual/sonora integrada de forma a auxiliar sua identificação pelas pessoas com deficiência visual e sobressair-se em relação aos demais elementos e informações do ambiente para facilitar sua percepção. Ao mesmo tempo, tais elementos devem constar e ser ressaltados nas informações veiculadas, especialmente quando da elaboração dos materiais táteis, visuais e sonoros voltados à descrição do ambiente das estações, resultando em melhor compreensão dos percursos de saída, desde os elementos de controle de saída até os elementos de circulação vertical. 
Quadro 40 - Elementos de wayfinding da Etapa 20 - Deslocamento no mezanino - área livre.

\begin{tabular}{|c|c|c|c|}
\hline $\begin{array}{l}\text { Elementos de } \\
\text { wayfinding }\end{array}$ & Configuração & Informação & Serviço \\
\hline Marcadores & $\begin{array}{l}\text { - elementos de circulação } \\
\text { vertical } \\
\text { - bloqueios }\end{array}$ & $\begin{array}{l}\text { - sinalização } \\
\text { tátil/visual/sonora dos } \\
\text { equipamentos e } \\
\text { elementos }\end{array}$ & - treinamento dos usuários \\
\hline Caminhos & $\begin{array}{l}\text { - percursos até os elementos } \\
\text { de circulação vertical para } \\
\text { as saídas }\end{array}$ & $\begin{array}{l}\text { - sinalização tátil/visual/ } \\
\text { sonora da configuração do } \\
\text { percurso }\end{array}$ & $\begin{array}{l}\text { - treinamento dos usuários } \\
\text { - auxílio no deslocamento }\end{array}$ \\
\hline Nós & $\begin{array}{l}\text { - interseção entre percursos } \\
\text { para diferentes saídas }\end{array}$ & $\begin{array}{l}\text { - sinalização tátil/visual das } \\
\text { opções de percurso }\end{array}$ & $\begin{array}{l}\text { - treinamento dos usuários } \\
\text { - auxílio no deslocamento }\end{array}$ \\
\hline Zonas & $\begin{array}{l}\text { - superfície da área de } \\
\text { circulação no mezanino - } \\
\text { área livre }\end{array}$ & $\begin{array}{l}\text { - contraste visual entre } \\
\text { superfícies horizontais, } \\
\text { verticais e equipamentos } \\
\text { da estação }\end{array}$ & $\begin{array}{l}\text { - treinamento dos usuários } \\
\text { - auxílio no deslocamento }\end{array}$ \\
\hline
\end{tabular}

Fonte: Elaborado pela pesquisadora.

\subsubsection{Síntese do diagnóstico}

Na etapa 20 - Deslocamento até a saída -, foram identificados aspectos que devem ser tratados pelas empresas operadoras dos sistemas metroferroviários para auxiliar as pessoas com deficiência visual a estabelecer estratégias para empreender seus deslocamentos:

a) condições das instalações existentes (EC3) - dimensionar os corredores das estações de acordo com os fluxos e a demanda; prover condições adequadas de segurança das estações; estabelecer os requisitos e as condições adequadas para execução de obras e serviços na rota acessível para saída; prover contraste entre pisos, paredes, portas, corrimãos e painéis de informação da estação;

b) piso tátil - contraste tátil e visual (EI1) - acrescentar uma faixa lisa junto ao piso tátil nas estações que têm piso emborrachado com pastilhas em relevo;

c) piso tátil - percurso (EI3) - instalar piso tátil em todos os equipamentos e serviços oferecidos na estação; considerar ou ser igual ao fluxo dos demais usuários; orientar o percurso para as escadas fixas e rolantes; melhorar a compreensão sobre o caminho; manter distanciamento do piso tátil em relação aos obstáculos existentes na edificação; aumentar a área de sinalização tátil de alerta nas interseções entre pisos direcionais; utilizar pisos táteis com percursos diagonais ou em curva em substituição aos percursos ortogonais; 
d) informações para a pessoa com deficiência visual - antes e depois da viagem (EI5) - distribuir folhetos ou manuais com informações sobre a configuração da estação e das ruas do entorno;

e) informações para a pessoa com deficiência visual - estação (EI6) - disponibilizar informação visual, tátil e sonora e mapas sobre a configuração das estações, a localização e os percursos a serem realizados até as saídas, as ruas do entorno; aumentar o contraste de cor e as dimensões das informações visuais nas placas de sinalização; prover informações e orientações operacionais e institucionais sobre os serviços ofertados (comércio, exposições, espaços institucionais) de maneira clara, objetiva, completa e redundante; disponibilizar informação tátil, visual ou sonora sobre a configuração e os percursos realizados na estação;

f) comportamento dos demais usuários - estação (ES4) - promover campanhas para orientar o comportamento dos demais usuários nas estações para que estejam atentos e respeitem o deslocamento preferencial da pessoa com deficiência visual e do estagiário;

g) obstáculo próximo ao piso tátil (ES5) - posicionar os direcionadores de fila a uma distância segura do piso tátil;

h) lotação das estações (ES7) - organizar o fluxo decorrente do deslocamento simultâneo de um grande número de pessoas para entrada e saída, nos horários de maior movimento, facilitando o deslocamento das pessoas com deficiência visual, seja com independência ou com auxílio.

\subsection{Etapa 21 - Circulação vertical entre o mezanino e o acesso}

Nesta etapa, o usuário utiliza os elementos de circulação vertical para sair da estação. Entre os elementos de circulação vertical disponibilizados, destacam-se as rampas, as escadas fixas, as escadas rolantes, as plataformas de elevação inclinada e os elevadores.

\subsubsection{Métodos e técnicas aplicados}

Os métodos e técnicas utilizados para coleta de dados nesta etapa foram apresentados no item 6.10 - Síntese dos instrumentos aplicados - e consistiram em:

1) melhores práticas identificadas em outros sistemas metroferroviários; 
m) pesquisa documental (normas técnicas ABNT vigentes, desenhos, procedimentos operacionais);

n) checklist dos recursos disponíveis e walkthrough realizado nas estações para compreensão do percurso de embarque;

o) ficha ambiente das escadas rolantes, elevadores e plataformas de elevação;

p) questionário aplicado às pessoas com deficiência visual - questões 12, 13 e 17;

q) entrevista com empregados das estações;

r) entrevista com estagiários que auxiliam pessoas com deficiência visual;

s) entrevista com professores de orientação e mobilidade;

t) entrevista com profissionais responsáveis pelo treinamento dos empregados;

u) entrevista com profissionais responsáveis pelos projetos das estações;

v) entrevista com profissionais responsáveis pela elaboração de normas técnicas.

As formas de análise e interpretação dos dados coletados foram apresentadas no Capítulo 6 Aplicação dos instrumentos.

\subsubsection{Melhores Práticas}

Devem ser consideradas as melhores práticas apresentadas no 7.25.2, relativos ao percurso entre o mezanino e a plataforma.

\subsubsection{Requisitos Normativos}

Devem ser considerados os requisitos normativos apresentados no item 7.25.3.

\subsubsection{Avaliação pelos usuários}

$\mathrm{Na}$ etapa de circulação vertical entre o mezanino e o acesso, 12 usuários com deficiência visual - dos quais 9 pessoas são cegas e três pessoas têm baixa visão - manifestaram seu descontentamento em relação à estação (100,0\%). Foram registrados 20 relatos, o que representa $0,7 \%$ do total de relatos registrados para todas as etapas da jornada do usuário. Os relatos estão, em sua maioria, relacionadas à configuração da estação $(80,0 \%)$, mas também referem-se às informações prestadas na estação $(15,0 \%)$ e aos serviços disponibilizados na estação $(5,0 \%)$ para facilitar a circulação vertical entre o mezanino e o acesso. 


\begin{abstract}
"Eu penso que deveriam instalar escadas rolantes e elevadores em todos os acessos das estações, pois grande parte das estações tem escada rolante em apenas um lado dos acessos e do outro só tem escada fixa, cansa muito. No início o projeto foi feito sem pensar no deficiente visual e fizeram as saídas sem escadas rolantes e elevadores. Tem estações que não tem piso tátil nas rampas. Em outras, ele vai dar em frente a uma escada rolante que está descendo, fazendo com que eu trombe com os usuários que vêm em sentido contrário." (Discurso do Sujeito Coletivo - Etapa 21)
\end{abstract}

Os problemas relatados pelos usuários estão relacionados às seguintes ideias centrais:

a) instalação de elementos de circulação vertical (EC2) - refere-se à inexistência de escadas rolantes e de elevadores em todos os acessos de todas as estações;

b) informações nos equipamentos (EI4) - refere-se à falta de piso tátil ao longo das rampas;

c) condições das instalações existentes (EC3) - refere-se à insatisfação com algumas estações cuja configuração impede a instalação de elevadores e escadas rolantes;

d) piso tátil - percurso (EI3) - relata a insatisfação em função de o piso tátil não considerar ou não ser igual ao fluxo natural dos demais usuários;

e) equipamentos - escadas rolantes (ES10) - relata a insatisfação em relação às escadas rolantes posicionadas no sentido de descida e à necessidade de uso de escada fixa para subir.

\title{
7.21.5 Avaliação pelas pessoas-chave
}

Na etapa de circulação vertical entre a plataforma e o mezanino, devem ser considerados os relatos efetuados pelos empregados das estações sobre as condições das instalações existentes (EC3), já registrados no item 7.4.5.

Os professores de orientação e mobilidade destacam, entre as informações nos equipamentos (EI4), a existência de faixas refletivas nos espelhos dos degraus das escadas fixas nas novas estações, fato que proporciona maior funcionalidade da sinalização (Figura 231). 

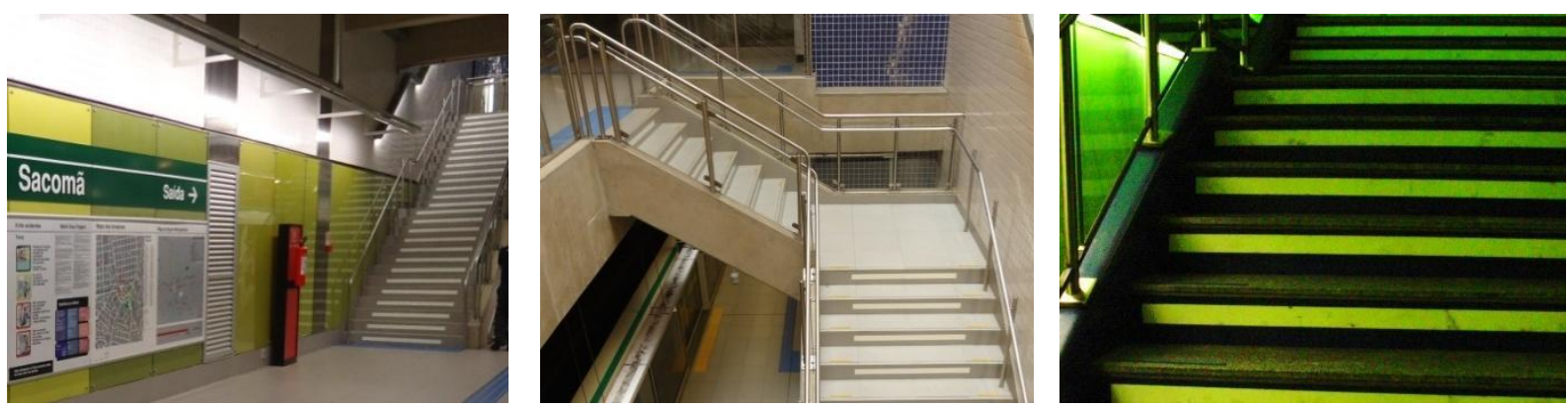

Figura 231 - São Paulo - Sinalização de alerta nos espelhos dos degraus. Fonte: BARBOSA, M.B., 2011.

\subsubsection{Avaliação pelos especialistas}

$\mathrm{Na}$ etapa de circulação vertical entre a plataforma e o mezanino, devem ser considerados os relatos efetuados pelos profissionais responsáveis pelos projetos das estações em relação ao piso tátil - percurso (EI3), já registrados no item 7.4.6.

\subsubsection{Elementos de wayfinding}

Devem ser considerados os elementos de wayfinding do item 7.25.8.

\subsubsection{Síntese do diagnóstico}

Na etapa 21 - Circulação vertical entre o mezanino e o acesso -, foram identificados aspectos que devem ser tratados pelas empresas operadoras dos sistemas metroferroviários para auxiliar as pessoas com deficiência visual a estabelecer estratégias para empreender seus deslocamentos:

a) instalação de elementos de circulação vertical (EC2) - instalar elevadores, escadas rolantes ou rampas em todos os acessos de todas as estações, especialmente nas estações antigas;

b) condições das instalações existentes (EC3) - viabilizar a instalação de equipamentos de circulação vertical, notadamente de escadas rolantes;

c) piso tátil - percurso (EI3) - considerar, sempre que possível, o mesmo percurso dos demais usuários; orientar os deslocamentos simultaneamente por meio dos elevadores e das escadas para que as pessoas com deficiência visual não percam a escala do espaço e a percepção dos referenciais da continuidade do percurso entre os diferentes ambientes; 
f) informações nos equipamentos (EI4) - instalar piso tátil ao longo das rampas; instalar faixas refletivas nos espelhos dos degraus das escadas fixas;

d) treinamento dos empregados - estação (ES1) - capacitar os empregados para que tenham desenvoltura ao oferecer ajuda para condução individual ou em grupo de usuários em planos horizontais, rampas, escadas rolantes, escadas fixas e elevadores;

e) equipamentos - escadas rolantes (ES10) - nos locais que dispõem de uma única escada rolante, priorizar o posicionamento para subir.

\subsection{Etapa 22 - Saída da estação - área externa}

Nesta etapa, o usuário desloca-se entre os elementos de circulação vertical e a saída da estação.

\subsubsection{Métodos e técnicas aplicados}

Os métodos e técnicas utilizados para coleta de dados nesta etapa foram apresentados no item 6.10 - Síntese dos instrumentos aplicados - e consistiram em:

a) melhores práticas identificadas em outros sistemas metroferroviários;

b) pesquisa documental (normas técnicas ABNT vigentes, desenhos, procedimentos operacionais);

c) checklist dos recursos disponíveis e walkthrough realizado nas estações para compreensão do percurso de embarque;

d) questionário aplicado a pessoas com deficiência visual - questão 10;

e) entrevista com empregados das estações;

f) entrevista com estagiários que auxiliam pessoas com deficiência visual;

g) entrevista com professores de orientação e mobilidade;

h) entrevista com profissionais responsáveis pelos projetos das estações;

i) entrevista com profissionais responsáveis pela elaboração de normas técnicas.

As formas de análise e interpretação dos dados coletados foram apresentadas no Capítulo 6 Aplicação dos instrumentos. 


\subsubsection{Melhores Práticas}

Entre as melhores práticas, destaca-se o Metrô de Barcelona, há preocupação quanto à ordenação das travessias em áreas consolidadas e de grande fluxo de travessia de pedestres junto aos acessos das estações (Figura 232).
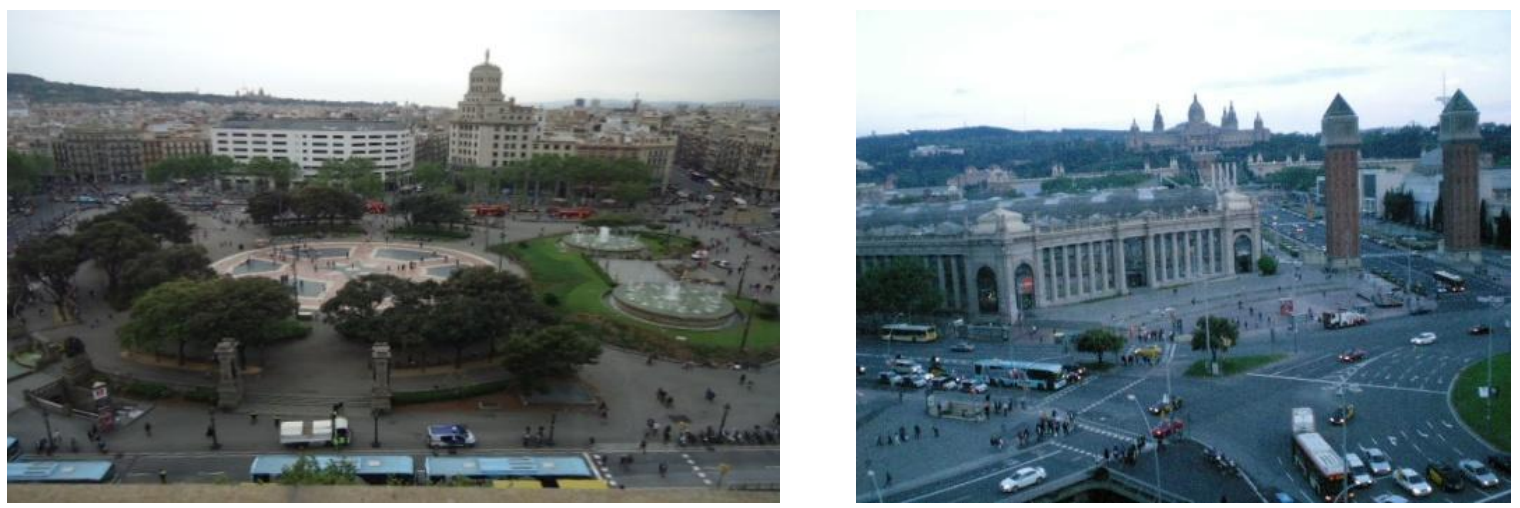

Figura 232 - Barcelona - Urbanização no entorno dos acessos em áreas consolidadas. Fonte: BARBOSA, M.B., 2011.

O Metrô de Madri usa a expansão da rede para induzir a ocupação ordenada de áreas periféricas, aumentando o adensamento populacional e implantando infraestrutura urbana comércio, serviços, escola - juntamente com praças, parques e passeios públicos dotados de iluminação pública, semáforos e faixas de travessia junto aos acessos das novas estações (Figura 233).
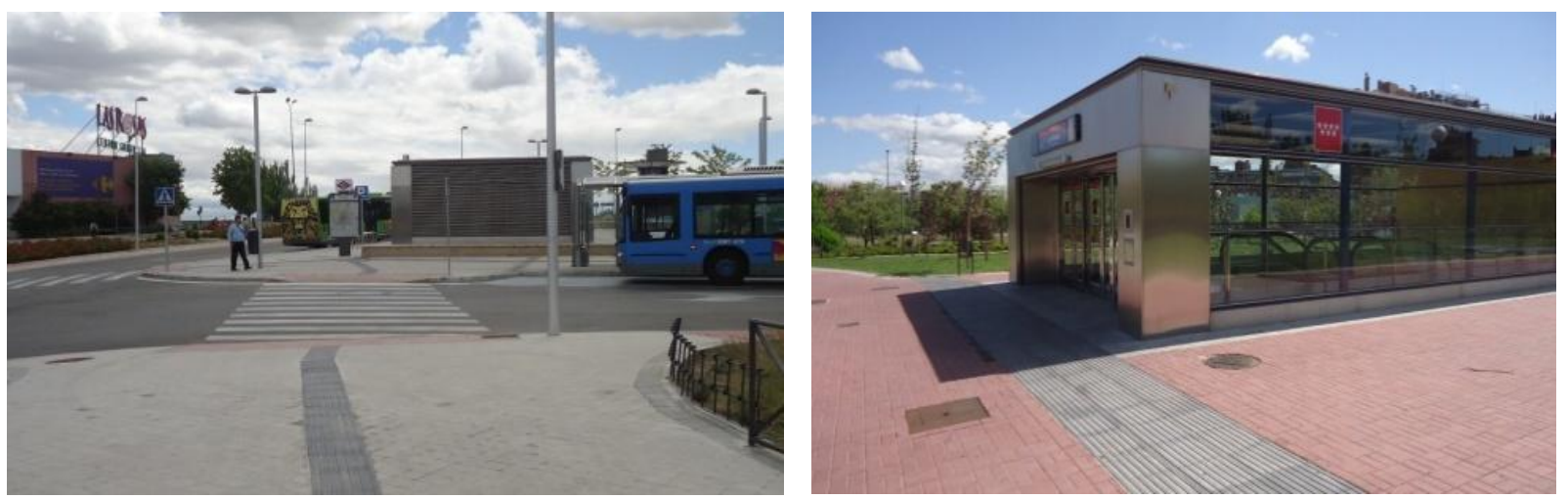

Figura 233 - Madri - Urbanização no entorno dos acessos - expansão da rede. Fonte: BARBOSA, M.B., 2013.

\subsubsection{Requisitos Normativos}

Com relação aos requisitos normativos, a ABNT NBR 9050:2004 estabelece a existência de uma rota acessível entre a saída da estação e o entorno, viabilizando a utilização do transporte integrado. Estabelece ainda que as calçadas, passeios e vias exclusivas de pedestres devem 
incorporar uma faixa livre com largura mínima de 1,50m e ser rebaixadas junto às travessias de pedestres sinalizadas, com ou sem faixa, com ou sem semáforo, e sempre que houver foco de pedestres.

\subsubsection{Situação no Metrô de São Paulo}

No Metrô de São Paulo, o processo de reurbanização do entorno ocorre no momento de construção das estações: praças, passeios, faixas de travessia de pedestres, semáforos e rebaixamentos de calçada são implantados juntamente com calçamento e pavimentação adequados (Figura 234).
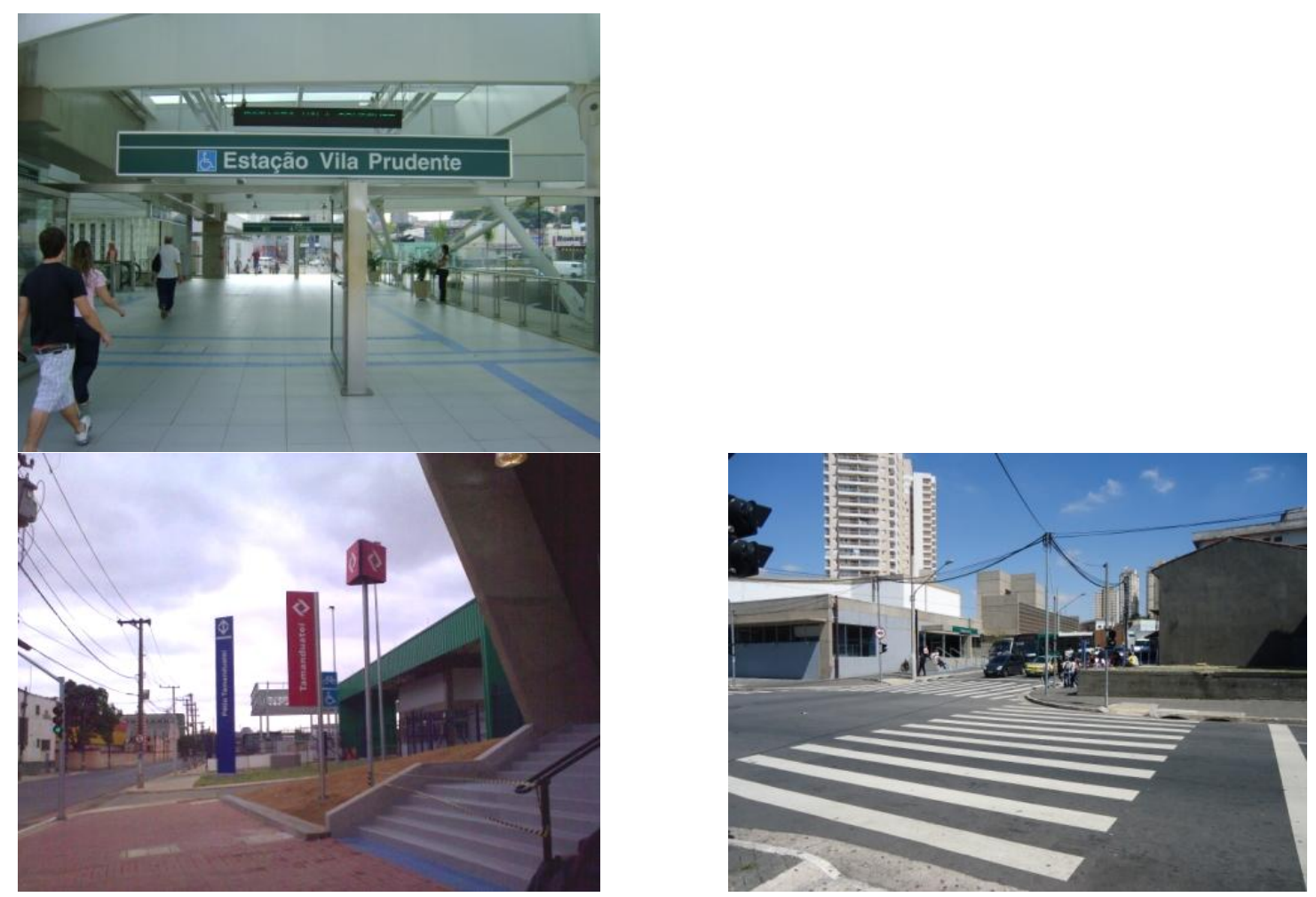

Figura 234 - São Paulo - Urbanização no entorno dos acessos das estações.

Fonte: BARBOSA, M.B., 2011.

\subsubsection{Avaliação pelos usuários}

Na etapa de saída da estação - área externa, 6 usuários com deficiência visual - dos quais 5 pessoas são cegas e 1 pessoa tem baixa visão - manifestaram seu descontentamento em relação à estação $(100,0 \%)$. Foram registrados 8 relatos, o que representa $0,3 \%$ do total de relatos registrados para todas as etapas da jornada do usuário. Os relatos estão, em sua maioria, relacionadas aos serviços prestados na estação $(62,5 \%)$, mas também referem-se à 
configuração da estação $(25,0 \%)$ e às informações prestadas na estação $(12,5 \%)$ para facilitar a saída da estação para a área externa.

\footnotetext{
"Percebo que nem todas as estações têm acesso nos dois lados da avenida: tem funcionários que me ajudam para atravessar e tem outros que não. E todos os empregados deveriam me ajudar a atravessar a avenida sempre que eu precisasse, deveria ser uma regra única. As barracas existentes nas calçadas, na saída de algumas estações, me deixam desorientado. Outro problema é que o piso tátil me leva para o meio do fluxo na saída da estação... Tem funcionário que não presta atenção no que eu falo e me leva para um destino diferente do que eu preciso..." (Discurso do Sujeito Coletivo - Etapa 22)
}

Os principais problemas relatados pelos usuários na etapa de saída da estação - área externa estão relacionados às seguintes ideias centrais:

a) procedimento operacional - estação (ES6) - refere-se à insatisfação em relação ao limite de atuação para auxílio no entorno das estações;

b) condições das instalações existentes (EC3) - relata a inexistência de acessos em ambos os lados de avenidas movimentadas, impondo travessias, e a existência de barracas/comércio em áreas próximas aos acessos, desorientando os deslocamentos no entorno das estações;

c) piso tátil - percurso (EI3) - refere-se ao descontentamento quanto ao encaminhamento do piso tátil para o corrimão central de escadas e rampas;

d) treinamento dos empregados - estação (ES1) - relata a desatenção dos estagiários que auxiliam os deslocamentos no momento em que são informadas as saídas desejadas.

\subsubsection{Avaliação pelas pessoas-chave}

Os estagiários relataram a dificuldade de auxiliar as pessoas com deficiência em função das condições das instalações existentes (EC3), em especial dos obstáculos, mobiliário e equipamentos existentes ao longo do caminho, da falta de infraestrutura adequada dos arredores das estações, tais como faixas de travessia com semáforos sonoros e de iluminação inadequada no período noturno, gerando sensação de insegurança para que as pessoas com deficiência possam empreender deslocamentos com independência.

\subsubsection{Avaliação pelos especialistas}

Os profissionais responsáveis pelos projetos das estações relataram que o direcionamento de fluxo no acesso às estações é feito exclusivamente por meio do piso tátil e sugeriram 
alterações nas condições das instalações existentes (EC3) uma vez que não são utilizados elementos de acabamento ou materiais de revestimento diferenciados - que reverberam mais ou são mais absorventes - seja em paredes, pisos ou forros, para auxiliar os deslocamentos.

Os profissionais responsáveis pela elaboração de normas técnicas relataram que as normas de acessibilidade contribuem para prover segurança, autonomia e agilidade nos deslocamentos por meio de soluções padronizadas relacionadas à configuração, sinalização e iluminação dos ambientes característicos do sistema metroferroviário. Entre as soluções que podem contribuir para a segurança e a independência dos deslocamentos em função das condições das instalações existentes (EC3) estão as recomendações para melhoria dos textos normativos vigentes, destacando o estabelecimento de condições adequadas para execução de obras e serviços, garantindo uma rota acessível para embarque e a existência de contraste entre pisos, paredes, portas, corrimãos e painéis de informação da estação. As informações para a pessoa com deficiência visual - estação (EI6) devem ser claras, objetivas e completas, além de redundantes, para que as orientações operacionais e institucionais sobre os serviços ofertados (comércio, exposições, espaços institucionais) possam contribuir para que os passageiros alcancem seus destinos com segurança.

\subsubsection{Elementos de wayfinding}

Os dados coletados permitem afirmar que os elementos de wayfinding característicos da etapa saída da estação é o caminho (Quadro 41). Esse elemento deve ser provido de configuração adequada bem como de sinalização tátil/visual/sonora integrada de forma a auxiliar sua identificação por pessoas com deficiência visual e sobressair-se em relação aos demais elementos e informações do ambiente para facilitar sua percepção. Ao mesmo tempo, tais elementos devem estar presentes e ser ressaltados nas informações veiculadas, especialmente quando da elaboração dos materiais táteis, visuais e sonoros voltados à descrição do ambiente das estações, resultando em melhor compreensão dos percursos de saída desde os elementos de circulação vertical até a saída da estação, na área externa. 
Quadro 41 - Elementos de wayfinding da Etapa 22 - Saída da estação - área externa.

\begin{tabular}{|c|c|c|c|}
\hline $\begin{array}{l}\text { Elementos de } \\
\text { wayfinding }\end{array}$ & Configuração & Informação & Serviço \\
\hline & $\begin{array}{l}\text { - percurso entre os } \\
\text { elementos de circulação } \\
\text { vertical e a saída da } \\
\text { estação }\end{array}$ & $\begin{array}{l}\text { - sinalização } \\
\text { tátil/visual/sonora sobre a } \\
\text { configuração do percurso } \\
\text { de saída em relação ao } \\
\text { entorno }\end{array}$ & $\begin{array}{l}\text { - treinamento dos usuários } \\
\text { - auxílio no deslocamento }\end{array}$ \\
\hline
\end{tabular}

Fonte: Elaborado pela pesquisadora.

\subsubsection{Síntese do diagnóstico}

Na etapa 22 - Saída da estação - área externa, foram identificados aspectos que devem ser tratados pelas empresas operadoras dos sistemas metroferroviários para auxiliar as pessoas com deficiência visual a estabelecer estratégias para empreender seus deslocamentos:

a) condições das instalações existentes (EC3) - prever acessos em ambos os lados de avenidas movimentadas; eliminar barracas/comércio em áreas próximas aos acessos; estabelecer condições adequadas para execução de obras e serviços, garantindo uma rota acessível para embarque; garantir a existência de contraste entre pisos, paredes, pilares, portas, corrimãos e painéis de informação da estação; eliminar obstáculos, mobiliário e equipamentos existentes ao longo do caminho; prover infraestrutura adequada nos arredores das estações (faixas de travessia, semáforos sonoros, iluminação no período noturno); utilizar elementos de acabamento ou materiais de revestimento diferenciados - que reverberem mais ou que sejam mais absorventes seja em paredes, piso ou forros, para auxiliar os deslocamentos;

b) piso tátil - percurso (EI3) - padronizar a sinalização direcional junto ao corrimão lateral das escadas e rampas;

c) informações para a pessoa com deficiência visual - estação (EI6) - fornecer informações e orientações operacionais e institucionais claras, objetivas, completas e redundantes sobre os serviços ofertados (comércio, exposições, espaços institucionais);

d) treinamento dos empregados - estação (ES1) - orientar/capacitar estagiários para atentar para auxiliar adequadamente o usuário no deslocamento para a saída desejada;

e) procedimento operacional - estação (ES6) - ampliar o limite de atuação para auxílio no entorno das estações. 


\subsection{Etapa 23 - Embarque no sistema integrado}

Nesta etapa, o usuário desloca-se em direção à área externa ou aos terminais de ônibus integrados, entre o acesso da estação e os diferentes modos de locomoção - a pé, de ônibus, lotação, táxi, carona.

\subsubsection{Métodos e técnicas aplicados}

Os métodos e técnicas utilizados para coleta de dados nesta etapa foram apresentados no item 6.10 - Síntese dos instrumentos aplicados - e consistiram em:

a) melhores práticas identificadas em outros sistemas metroferroviários;

b) pesquisa documental (normas técnicas ABNT vigentes, desenhos, procedimentos operacionais);

c) checklist dos recursos disponíveis e walkthrough realizado nas estações para compreensão do percurso de desembarque;

d) questionário aplicado às pessoas com deficiência visual - questão 10;

e) entrevista com empregados das estações;

f) entrevista com estagiários que auxiliam pessoas com deficiência visual;

g) entrevista com professores de orientação e mobilidade;

h) entrevista com profissionais responsáveis pelos projetos das estações;

i) entrevista com profissionais responsáveis pela elaboração de normas técnicas.

As formas de análise e interpretação dos dados coletados foram apresentadas no Capítulo 6 Aplicação dos instrumentos.

\subsubsection{Melhores Práticas}

Entre as melhores práticas, destaca-se a cidade de Jaú, que implantou, em 2010, um sistema de sinalização eletrônica para facilitar o uso do transporte público pelas pessoas com deficiência visual, por meio de um dispositivo que permite a comunicação entre motorista do veículo e usuário (Figura 235). O dispositivo emite informação sonora ao passageiro deficiente visual sobre as opções de linhas disponíveis, a chegada do veículo e a localização da porta de embarque. Após a escolha da linha pelo usuário, o dispositivo emite ondas de baixa frequência, e o receptor instalado no veículo alerta o motorista de que uma pessoa com deficiência visual está no próximo ponto, permitindo que o condutor faça uma parada mais 
precisa e atenciosa. Quando o ônibus para, um alto-falante instalado na porta de embarque avisa à pessoa que o ônibus já está no local.
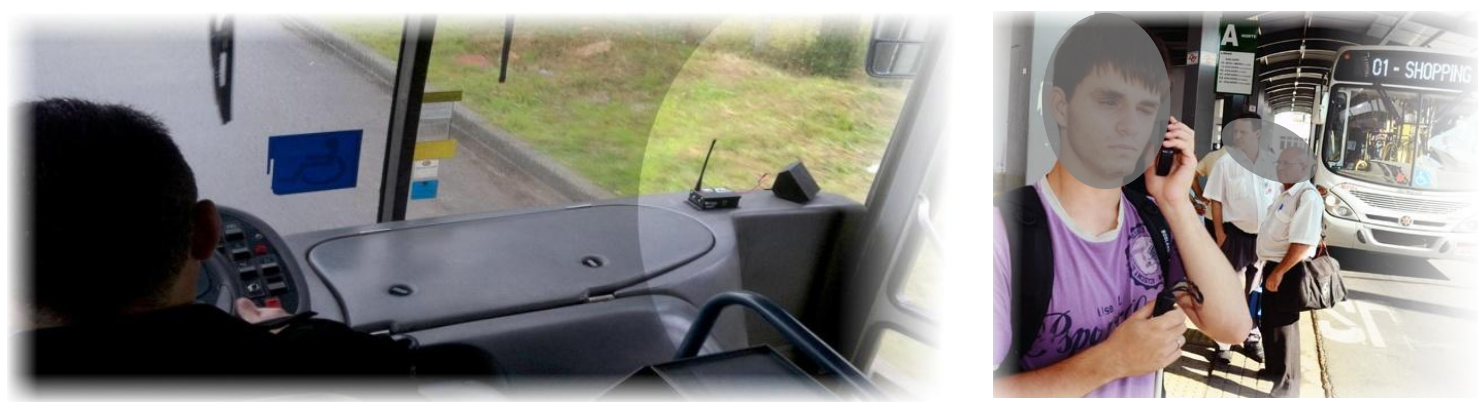

Figura 235 - Jaú - Dispositivo de comunicação entre motorista e usuário de ônibus.

Fonte: disponível em: http://www.onibusacessivel.com.br/ComoFunciona.php. Acesso em: 10 set. 2014.

\subsubsection{Requisitos Normativos}

Com relação aos requisitos normativos, a ABNT NBR 15.599:2008 estabelece a necessidade de rota acessível sinalizada até o ponto de parada, bem como a necessidade de prever informação tátil, visual e sonora que inclua a identificação, o destino e o itinerário das linhas que passam em cada um dos pontos de parada ou nos terminais urbanos.

\subsubsection{Situação no Metrô de São Paulo}

No Metrô de São Paulo, a sinalização tátil direcional termina na soleira dos acessos ou nas escadas fixas e rolantes e não interliga o acesso da estação ou a circulação vertical com os pontos de parada de ônibus nas calçadas ou nos terminais urbanos (Figuras 236 e 237).
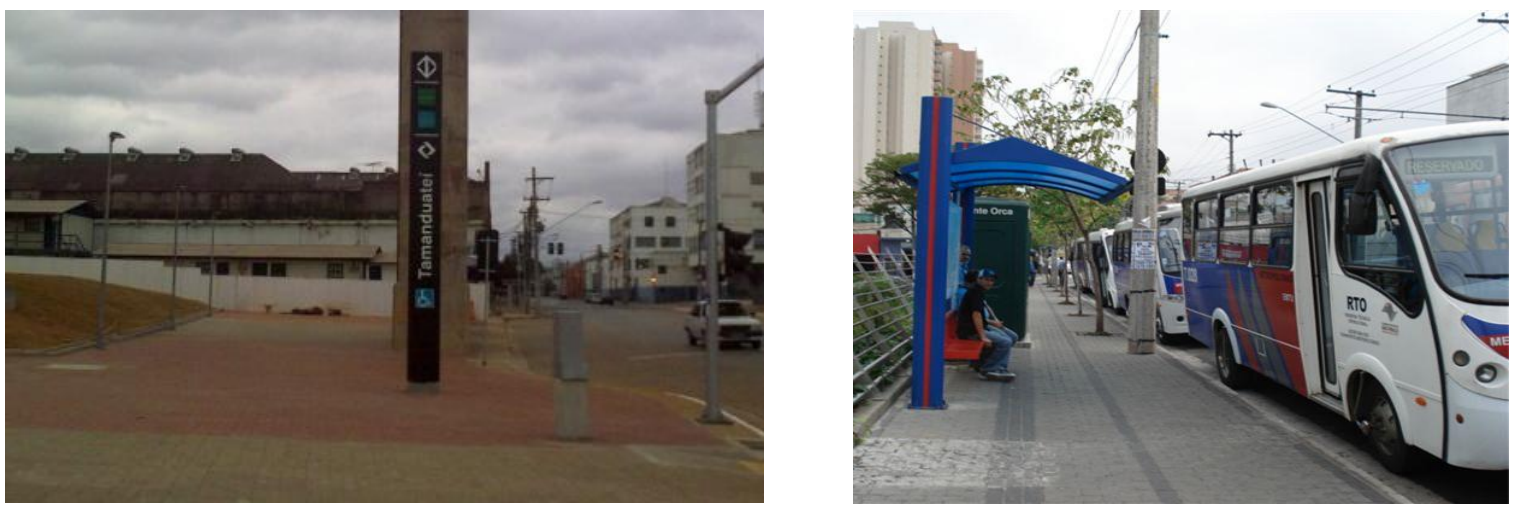

Figura 236 - São Paulo - Pontos de parada de ônibus nas calçadas. Fonte: BARBOSA, M.B., 2011. 

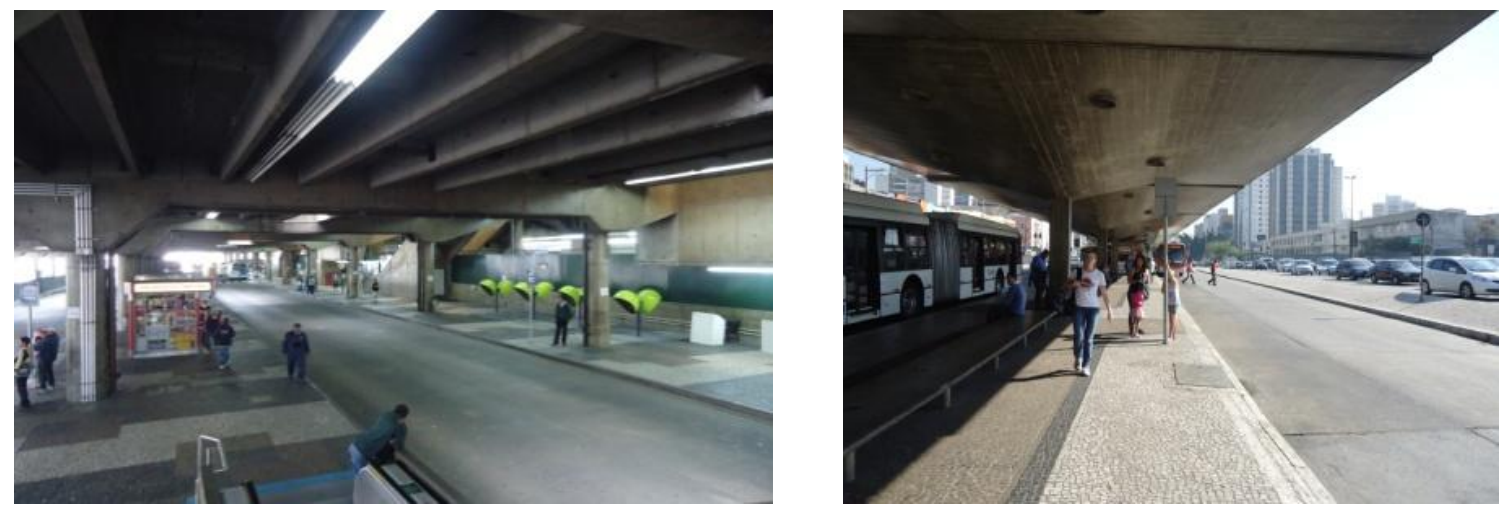

Figura 237 - São Paulo - Pontos de parada de ônibus nos terminais urbanos.

Fonte: BARBOSA, M.B., 2011.

\subsubsection{Avaliação pelos usuários}

Na etapa de embarque no sistema integrado, 17 usuários com deficiência visual - dos quais 12 pessoas são cegas e cinco pessoas têm baixa visão - manifestaram seu descontentamento em relação à estação (100,0\%). Foram registrados 28 relatos, o que representa 1,0\% do total de relatos registrados para todas as etapas da jornada do usuário. Os relatos estão, em sua maioria, relacionados às informações $(57,1 \%)$ e aos serviços prestados na estação $(39,3 \%)$, mas também referem-se à configuração das estações $(3,6 \%)$ para facilitar o embarque no sistema integrado (Tabela 31).

Tabela 31 - Matriz de avaliação da etapa 23 - Embarque no sistema integrado.

(\% em relação ao total de relatos registrados nesta etapa)

\begin{tabular}{|c|c|c|c|c|}
\hline & $\begin{array}{c}\text { Configuração } \\
(\%)\end{array}$ & $\begin{array}{c}\text { Informação } \\
(\%)\end{array}$ & $\begin{array}{c}\text { Serviço } \\
(\%)\end{array}$ & $\begin{array}{c}\text { Total } \\
(\%)\end{array}$ \\
\hline Estação & (EC) 3,6 & (EI) 57,1 & (ES) 39,3 & 100,0 \\
\hline Interface Trem-Estação & $\mathbf{0 , 0}$ & $\mathbf{0 , 0}$ & $\mathbf{0 , 0}$ & $\mathbf{0 , 0}$ \\
\hline Trem & $\mathbf{0 , 0}$ & $\mathbf{0 , 0}$ & $\mathbf{0 , 0}$ & 0,0 \\
\hline Total & 3,6 & 57,1 & 39,3 & 100,0 \\
\hline
\end{tabular}

"Percebo que nem sempre tem funcionários para me ajudar a chegar até o terminal. Deveria ter piso tátil que me levasse da estação direto para o terminal, sem dar muitas voltas ou dificultar a minha orientação. Nem sempre o piso tátil corre toda a plataforma, não leva para todos os pontos de ônibus e nem para os orelhões. Quando o Terminal tem várias plataformas fica mais difícil memorizar o ponto de ônibus: o conceito de ilha é mais fácil para o meu cão memorizar. Tem Terminal com barracas de alimentação próximas do piso tátil e eu sempre trombo com alguns usuários que estão comendo nestes locais. É importante melhorar a infraestrutura das saídas das estações como o calçamento para que eu possa me deslocar com mais segurança... Na transferência entre estações, os direcionadores de fila estão em cima do piso tátil... Tem empregado que até me leva até o ponto de ônibus, mas às vezes me deixa no sentido contrário ao que desejo ir, dizem que só podem ir até a linha branca do acesso... Acho que os empregados precisam de treinamento para que tenham o bom senso. Isso ajudaria 
muito. Os jovens cidadãos também não são bem preparados, eles não conhecem as linhas de ônibus que saem das estações, apesar de terem boa vontade." (Discurso do Sujeito Coletivo Etapa 23)

Os principais problemas relatados pelos usuários na etapa embarque no sistema integrado são apresentados de forma hierarquizada, conforme número de relatos registrados (Gráfico 37).

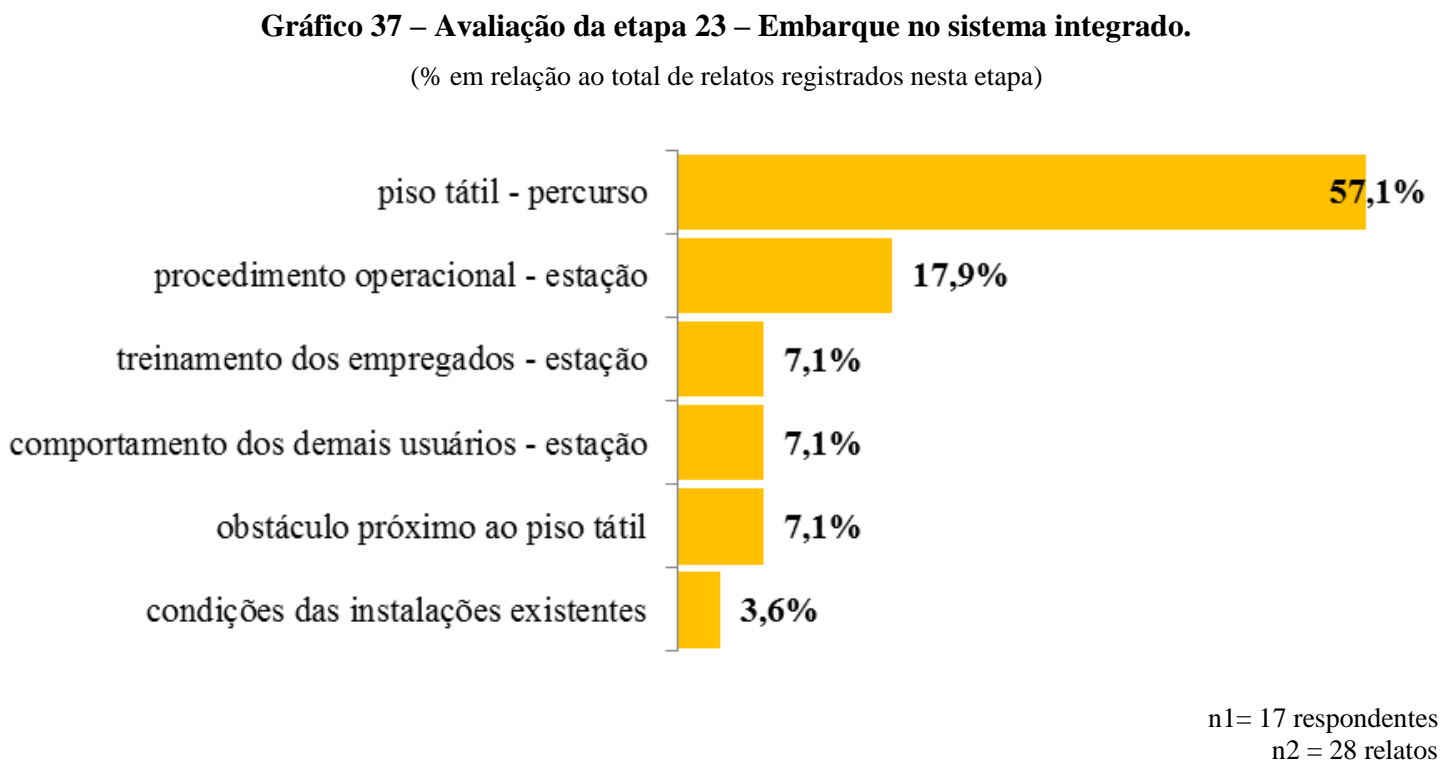

Os problemas relatados estão relacionados às seguintes ideias centrais:

a) piso tátil - percurso (EI3) - destaca a insatisfação decorrente pelo fato de o piso tátil não levar para todas as baias, pontos de parada de ônibus e balcões de informação e aponta as dificuldades decorrentes da falta de compreensão do caminho nas estações de conexão e da proximidade do piso tátil em relação aos quiosques e lojas existentes nos terminais urbanos e rodoviários;

b) procedimento operacional - estação (ES6) - refere-se à insatisfação em relação ao tempo de espera para atendimento entre diferentes operadoras e à atuação dos empregados que não auxiliam o embarque no sistema integrado;

c) treinamento dos empregados - estação (ES1) - revela o descontentamento em relação ao atendimento prestado pelos funcionários e estagiários, que desconhecem os pontos de referência e as linhas integradas no entorno das estações;

d) comportamento dos demais usuários - estação (ES4) - refere-se ao mau comportamento dos usuários que andam na "contramão" e dificultam o deslocamento das pessoas com deficiência visual; 
e) obstáculo próximo ao piso tátil (ES5) - relata a existência de direcionador de fila próximo ao piso tátil direcional, dificultando o deslocamento;

f) condições das instalações existentes (EC3) - relata a insatisfação em relação às más condições das calçadas no entorno das estações.

\subsubsection{Avaliação pelas pessoas-chave}

$\mathrm{Na}$ etapa de embarque no sistema integrado, os empregados das estações relataram como fator negativo das condições das instalações existentes (EC3) a complexidade e a distância do percurso entre o mezanino da estação e os terminais de ônibus urbanos ou os pontos de parada, que, somadas ao fluxo intenso de usuários nos horários de maior movimento, impactam o deslocamento com independência das pessoas com deficiência visual e interferem na prestação de auxílio pelos empregados (Figuras 238 e 239). Os pontos de parada, sejam aqueles existentes nos terminais urbanos ou no sistema viário, atrasam o retorno do funcionário ao posto de trabalho, prejudicando o atendimento aos demais usuários.

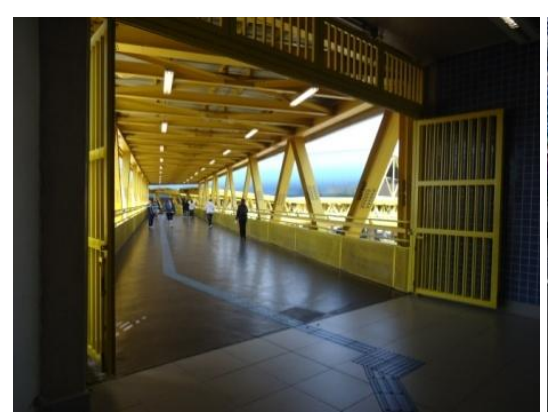

Figura 238 - São Paulo - Complexidade e distância entre o mezanino e os terminais de ônibus urbanos e pontos de parada. Fonte: BARBOSA, M.B., 2011.

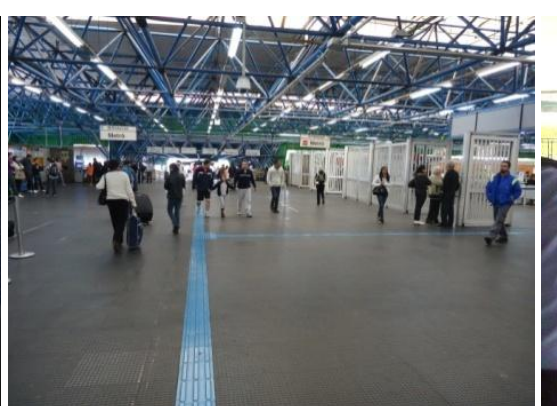

Figura 239 - São Paulo - distância entre o mezanino e o acesso. Fonte: BARBOSA, M.B., 2011.

Os estagiários destacaram as ações tomadas a partir da solicitação de auxílio para embarque no sistema integrado, cumprindo o procedimento operacional - estação (ES6). Eles conduzem o usuário:

a) até a conexão com outros modos de transporte, tais como ônibus rodoviários ou trens metropolitanos - nesse caso, o atendimento é concluído pela equipe da SOCICAM, da CPTM, ou da Via Quatro, respectivamente;

b) até o ponto de parada no sistema viário ou no terminal de ônibus urbano; caso o ônibus esteja no ponto, auxiliam o embarque ou, se o ônibus não estiver no local, deixam o usuário no ponto de parada correto;

c) até a rua desejada e auxiliam a travessia de ruas e avenidas nos arredores;

d) até a "faixa branca" no limite identificado junto à saída da estação. 
Os estagiários relataram a dificuldade de auxiliar as pessoas com deficiência no percurso para embarque no sistema integrado - pontos de parada em terminais urbanos ou sistema viário - em função das condições das instalações existentes (EC3), em especial dos obstáculos, mobiliário e equipamentos ao longo do caminho, gerando sensação de insegurança para que as pessoas com deficiência possam empreender deslocamentos com independência (Figuras 240 e 241). Apesar da ciência das regras relacionadas aos limites de atuação, muitos relataram que "vão além do limite de atuação" por uma questão de compaixão, respeito, gentileza e cidadania, sem a consciência de que tal atitude resulta em um tempo maior de atendimento e, consequentemente, na espera maior por atendimento pelo próximo usuário.

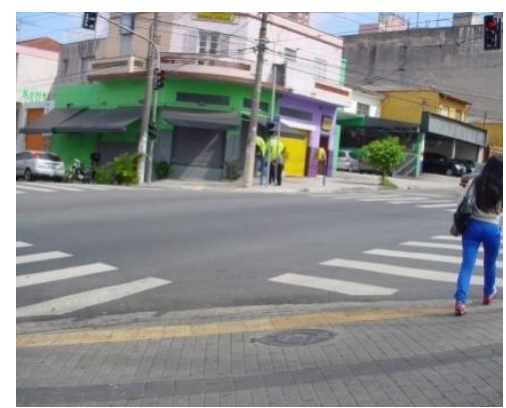

Figura 240 - São Paulo inexistência de acesso do outro lado da rua.

Fonte: BARBOSA, M.B., 2011.
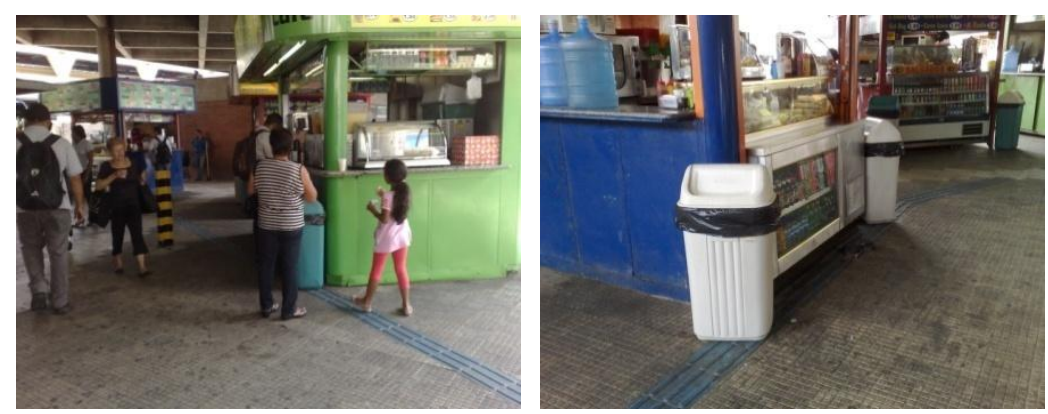

Figura 241 - São Paulo - Quiosques e mobiliário sobre o piso tátil. Fonte: BARBOSA, M.B., 2011.

Os professores de orientação e mobilidade relataram que a ausência de uma faixa de transição traz dificuldades para identificar o piso tátil - contraste tátil e visual (EI1) em relação ao piso utilizado na pavimentação dos passeios públicos, notadamente de pisos em relevo, pedras portuguesas, blocos intertravados e outros acabamentos. Em relação ao piso tátil - percurso (EI3), há críticas ao dimensionamento insuficiente da sinalização tátil de alerta nas interseções entre pisos direcionais - o que dificulta a percepção quanto às mudanças de direção - e ao fato de a sinalização não considerar ou ser igual ao percurso dos demais usuários - o que pode gerar eventuais conflitos de fluxo. A compreensão do percurso realizado até os destinos próximos pode ser ampliada com o auxílio de mapas táteis e descrições sonoras contendo as principais referências urbanas dos arredores, permitindo acesso a informações em igualdade de condições com os demais usuários. 


\subsubsection{Avaliação pelos especialistas}

Os profissionais responsáveis pelos projetos das estações relataram que o direcionamento de fluxo nos espaços destinados à conexão entre diferentes modos de transporte é feito exclusivamente por meio do piso tátil - percurso (EI3) uma vez que não são utilizados elementos de acabamento ou materiais de revestimento diferenciados - que reverberam mais ou são mais absorventes - seja em paredes, pisos ou forros, para auxiliar os deslocamentos. Quanto às informações para a pessoa com deficiência visual - estação (EI6), ressaltaram que não há nada que diferencie o caminho do Metrô do caminho da CPTM, do terminal rodoviário e das alternativas de transporte disponíveis. Todas as informações são veiculadas por meio de textos informativos. Em relação às condições das instalações existentes (EC3), afirmaram que os espaços destinados à conexão são entendidos como espaços de socialização e, portanto, não se diferenciam para referenciar os diversos modos de transporte apesar de serem extremamente significativos, qualquer que seja a configuração da estação.

Os profissionais responsáveis pela elaboração de normas técnicas de acessibilidade ressaltam a falta de menção a requisitos específicos de projeto relacionados à configuração ou à sinalização dos ambientes para definição da rota acessível entre diferentes modos de transporte.

\subsubsection{Elementos de wayfinding}

Os dados coletados permitem afirmar que os elementos de wayfinding característicos desta etapa são os seguintes: marcadores e caminhos (Quadro 42). Esses elementos devem ser providos de configuração adequada bem como de sinalização tátil/visual/sonora integrada de forma a auxiliar sua identificação por pessoas com deficiência visual e sobressair-se em relação aos demais elementos e informações do ambiente para facilitar sua percepção e a compreensão dos percursos a partir da saída da estação até os diferentes sistemas integrados de transporte. O percurso de conexão entre os diferentes modos de transporte integrado deve ser provido de sinalização tátil/visual/sonora específica. 
Quadro 42 - Elementos de wayfinding da Etapa 23 - Embarque no sistema integrado.

\begin{tabular}{c|l|l|c}
\hline $\begin{array}{c}\text { Elementos de } \\
\text { wayfinding }\end{array}$ & \multicolumn{1}{|c|}{ Configuração } & Sinalização & Serviço \\
\hline & - saída da estação & $\begin{array}{l}\text { - sinalização } \\
\text { tátil/visual/sonora para } \\
\text { identificação da } \\
\text { localização da saída }\end{array}$ & $\begin{array}{l}\text { - treinamento dos usuários } \\
- \text { auxílio no deslocamento }\end{array}$ \\
\hline & $\begin{array}{l}\text { - percurso entre o transporte } \\
\text { integrado e o acesso da } \\
\text { estação }\end{array}$ & $\begin{array}{l}\text { - sinalização tátil/visual para } \\
\text { identificação do percurso } \\
\text { de integração }\end{array}$ & $\begin{array}{l}\text { - integração com outros } \\
\text { modos de transporte } \\
\text { (ônibus, vans, táxis) }\end{array}$ \\
\hline
\end{tabular}

Fonte: Elaborado pela pesquisadora.

\subsubsection{Síntese do diagnóstico}

Na etapa 23 - Embarque no sistema integrado -, foram identificados aspectos que devem ser tratados pelas empresas operadoras dos sistemas metroferroviários para auxiliar pessoas com deficiência visual a estabelecer estratégias para empreender seus deslocamentos:

a) condições das instalações existentes (EC3) - manter calçadas no entorno das estações em bom estado;

b) piso tátil - percurso (EI3) - instalar sinalização tátil no piso orientando o percurso para todas as baias, pontos de parada de ônibus e balcões de informação; melhorar a compreensão sobre o caminho nas estações de conexão, permitindo informação em igualdade de condições com os demais usuários; remanejar piso tátil instalado próximo a quiosques e lojas existentes nos terminais urbanos e rodoviários;

c) treinamento dos empregados - estação (ES1) - capacitar funcionários e estagiários em relação aos pontos de referência e às linhas integradas no entorno das estações;

a) comportamento dos demais usuários - estação (ES4) - promover campanhas para orientar os demais usuários a não andar na "contramão" e facilitar o deslocamento preferencial das pessoas com deficiência visual;

d) obstáculo próximo ao piso tátil (ES5) - posicionar os direcionadores de fila a uma distância segura do piso tátil;

e) procedimento operacional - estação (ES6) - disponibilizar empregados ou estagiários para atendimento entre diferentes operadoras no momento do embarque para minimizar o tempo de espera para auxílio. 


\subsection{Etapa 24 - Avaliação da experiência}

Nesta etapa, o usuário faz uma reflexão comparando suas expectativas prévias com a avaliação das situações vivenciadas durante os deslocamentos. Quando a experiência da viagem supera a expectativa, gera um sentimento de satisfação. Ao contrário, quando a experiência de viagem está aquém da expectativa, reflete-se na insatisfação do usuário que, muitas vezes, exterioriza seu sentimento na esperança de que providências sejam tomadas para que a situação se reverta em uma experiência positiva na próxima oportunidade.

\subsubsection{Métodos e técnicas aplicados}

Os métodos e técnicas utilizados para coleta de dados nesta etapa foram apresentados no item 6.10 - Síntese dos instrumentos aplicados - e consistiram em:
a) identificação de melhores práticas em outros sistemas metroferroviários;
b) pesquisa documental (normas técnicas ABNT vigentes, procedimentos operacionais);
c) análise de informações disponibilizadas pelo Metrô de São Paulo (folhetos, sítio eletrônico);
d) questionário aplicado às pessoas com deficiência visual - questões 14 e 17;
e) entrevista com professores de orientação e mobilidade;
f) entrevista com os profissionais responsáveis pelo projeto dos trens;
g) entrevista com profissionais responsáveis pela elaboração de normas técnicas.

As formas de análise e interpretação dos dados coletados foram apresentadas no Capítulo 6 Aplicação dos instrumentos.

\subsubsection{Melhores Práticas}

Entre as melhores práticas, destaca-se a experiência da SNCF em Paris (SNCF, 2011). A diversidade das estações e trens levou a SNCF a trocar informações com várias associações de pessoas com deficiência e, posteriormente, ensejou a necessidade de testar soluções de acessibilidade e de realizar uma ampla consulta pública das propostas de adequação para aprovação prévia pelas pessoas com deficiência e com mobilidade reduzida (Figura 242). A partir de um experimento em grande escala (laboratório de estação), pessoas com deficiência foram capazes de testar durante vários meses diversos dispositivos e instalações colocadas na gare Montparnasse em Paris. Um total de 964 pessoas com deficiência, 600 viajantes e 140 
empregados da SNCF foram entrevistados. Os resultados desta pesquisa possibilitaram colher sugestões para melhoria da acessibilidade. Alguns equipamentos foram imediatamente incorporados aos projetos enquanto aguardavam um trabalho conjunto com os representantes das associações para alcançar soluções eficazes.
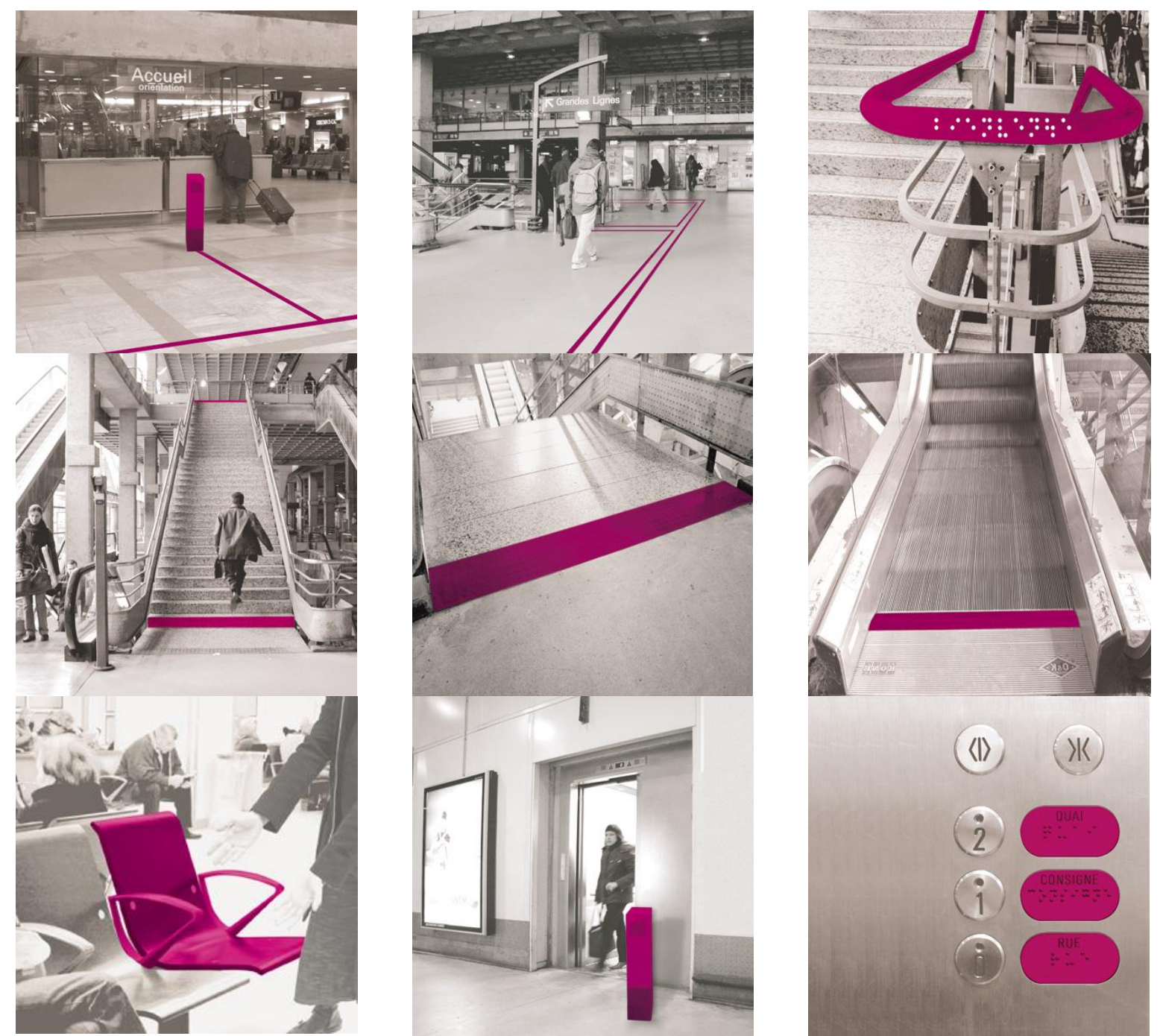

Figura 242 - Paris - Consulta pública às pessoas com deficiência para avaliação dos protótipos de estação e trem. Fonte: SNCF. Gare Laboratoire d'Accessibilité - Montparnasse, 2006 p. 11-12. Disponível em: $\langle$ http://www.accessibilite.sncf.com/IMG/pdf/dossier_presse_gare_labo_resultats.pdf $>$. Acesso em: 28 jun. 2011.

Em Londres, no ano de 2007, as pessoas com deficiência responderam ao questionário integrante da pesquisa Unlocking London for All, onde puderam opinar sobre os serviços, as ações e a priorização dos investimentos previstos, conforme formulários disponibilizado (Figura 243). O objetivo da TFL era melhorar o design das estações e serviços; rever políticas, práticas e procedimentos para as pessoas com deficiência; garantir instalações acessíveis por meio da instalação de sinalização tátil; melhorar a interface entre o trem e a plataforma; aumentar o número de estações sem barreiras entre a rua e a plataforma. 


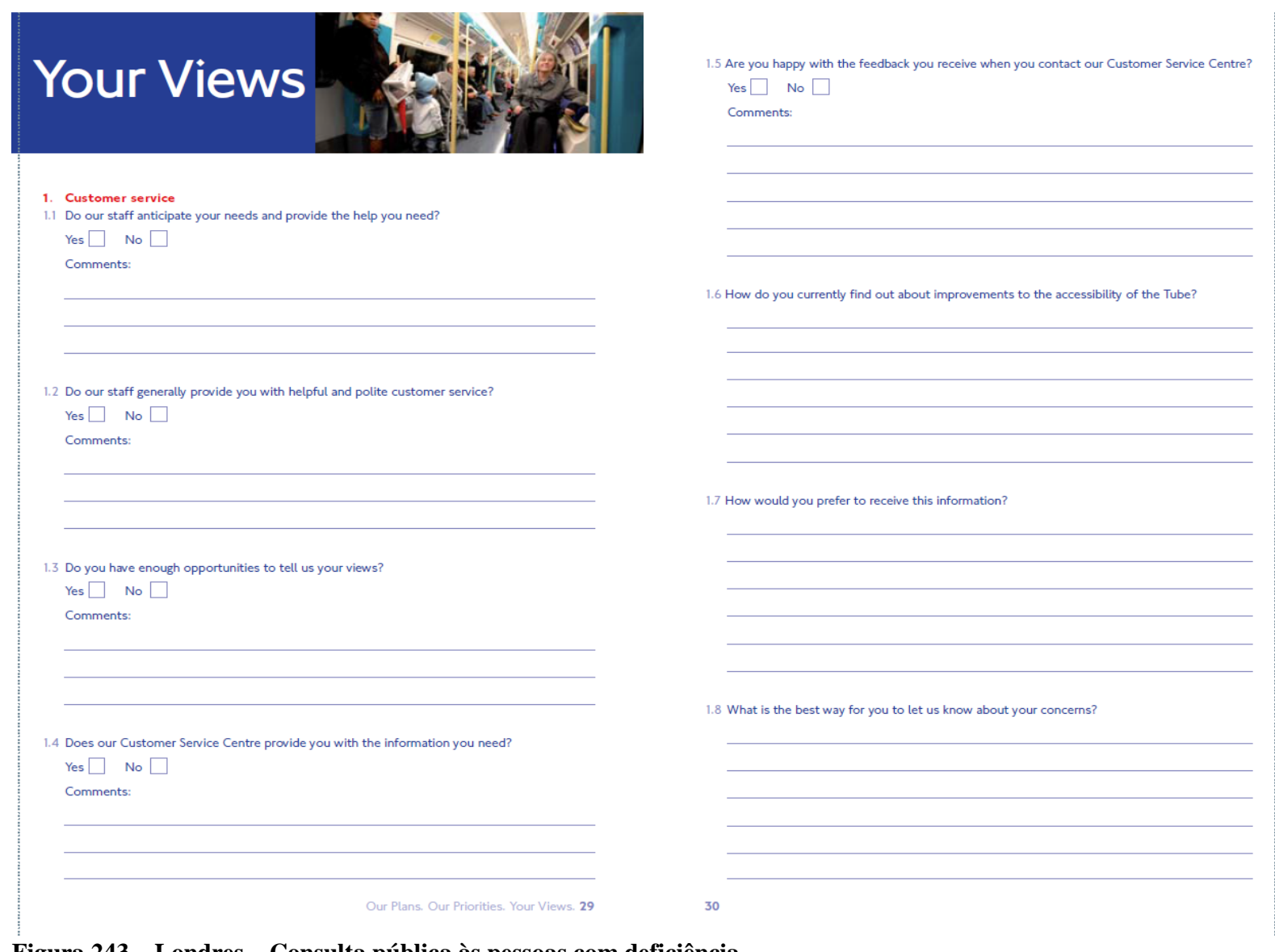

Figura 243 - Londres - Consulta pública às pessoas com deficiência.

Fonte: TFL. London Underground: Towards an Accessible Tube. Our plans. Our priorities. Your views. 2007 p. $46-47$. Disponível em: http://travability.info/london/underground/Accessible-Tube-Large-Print-2.pdf . Acesso em: 25 jul. 2011.

A decisão sobre o direcionamento dos investimentos deveria considerar os seguintes aspectos:

- estações localizadas na área central, onde há maior demanda e maior interesse de viagens, ou estações mais utilizadas por pessoas com deficiência;

- desníveis entre a calçada e a rua ou o vão e desnível entre o trem e a plataforma;

- eliminação das barreiras nas estações existentes ou a expansão da rede.

Além das pesquisas e avaliações realizadas pontualmente para colher informações específicas, as operadoras de transporte disponibilizam pontos de contato para que os usuários possam registrar ocorrências, sugestões ou reclamações sobre os serviços ou sobre as instalações. Esses recursos permitem contato direto com atendentes especializados, orientando deslocamentos, sanando dúvidas ou auxiliando no caso eventuais ocorrências e emergências. Em Barcelona, Londres destacam-se os intercomunicadores instalados em todas as estações (Figuras 244 e 245). No Metrô do Rio de Janeiro, também foram instalados intercomunicadores nas plataformas, visando à prestação de informação e auxílio nos deslocamentos (Figura 246). 


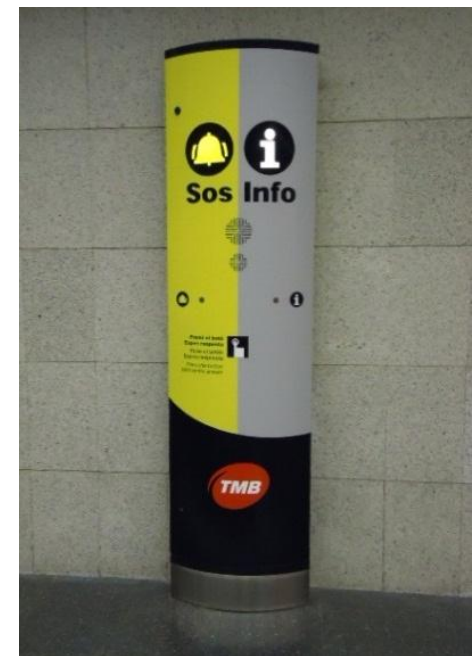

Figura 244 - Barcelona Intercomunicador nas estações. Fonte: BARBOSA, M.B., 2011.

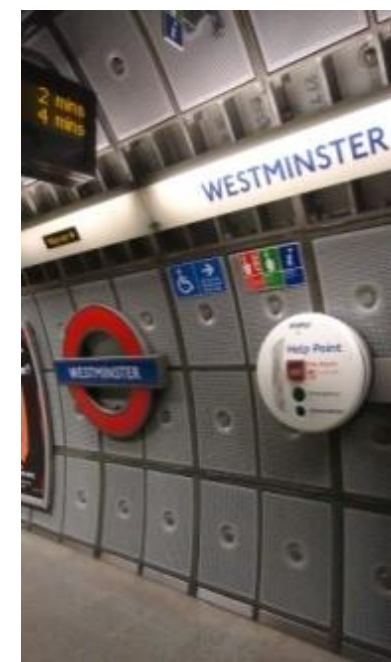

Figura 245 - Londres Intercomunicador nas estações. Fonte: BARBOSA, M.B., 2013.

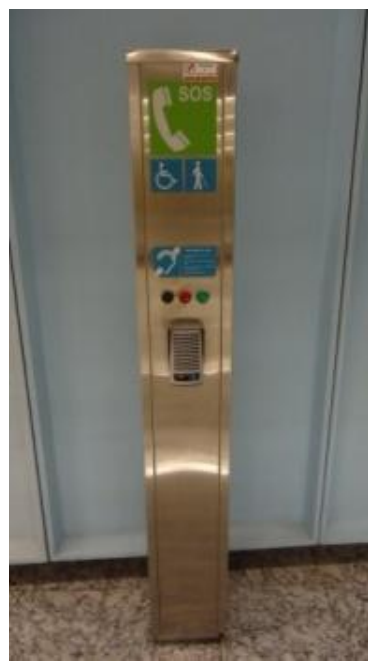

Figura 246 - Rio de Janeiro Intercomunicador nas estações. Fonte: BARBOSA, M.B., 2011.

\subsubsection{Requisitos Normativos}

Com relação aos requisitos normativos, a ABNT NBR 15.599:2008 determina que, nos serviços de atendimento ao público, as empresas prestadoras de serviço devem oferecer diferentes meios de comunicação, simultaneamente, por meio de telefone, equipamentos de autoatendimento, internet, correio, fax ou telefone para surdos seja para reclamação, consultas, solicitações, esclarecimentos ou sugestões. No caso de formulários colocados à disposição dos usuários, os mesmos devem oferecer recursos específicos para pessoas com deficiência visual - cegas ou com baixa visão - seja por meio de recurso do "tipo ampliado", no caso de formulários impressos, seja em formato que possa ser processado por sistemas de leitura e ampliação de tela, no caso dos formatos digitais. A mesma norma determina ainda que os serviços de atendimento via internet devem ter formato digital que permita seu processamento por meio de sistemas de leitura e ampliação de tela. Quando o atendimento se der por meio de contato telefônico, os atendentes devem estar capacitados e aptos para fornecer informações e esclarecimentos para pessoas com deficiência visual. Para nortear a comunicação entre os prestadores e os usuários dos serviços, a ABNT NBR 15.599 esclarece que a captação e a troca de mensagens devem atentar para o público-alvo e para a escolha adequada dos recursos de comunicação, tomando sempre o cuidado para utilizar o princípio da redundância, ou seja, para não restringir o contato a uma única forma de comunicação, pois a combinação de diferentes tipos - tátil, visual e sonora - possibilita atender a pessoas com diferentes necessidades e capacidades. 


\subsubsection{Situação no Metrô de São Paulo}

Ao longo dos anos de 2000 e 2001, o Metrô de São Paulo viabilizou, juntamente com o Conselho Estadual para Assuntos das Pessoas com Deficiências - CEAPPD, uma série de visitas para que fossem apontados problemas ou dificuldades encontradas no dia a dia durante os deslocamentos em todas as estações da rede (Figura 247). Esse programa resultou no registro das contribuições dos participantes, que, posteriormente, foram objeto de priorização e de intervenções por parte da CMSP. As questões foram tratadas sob quatro focos:

- atendimento às solicitações emergenciais relatadas durante as visitas;

- incorporação de novas exigências nas normas técnicas de acessibilidade relacionadas às edificações e ao sistema de trens metropolitanos;

- elaboração de um plano de adequação das instalações metroviárias às normas técnicas - "Programa de Acessibilidade do Metrô de São Paulo";

- integração das ações com os outros modos de transporte vinculados à Secretaria de Transportes Metropolitanos - STM.
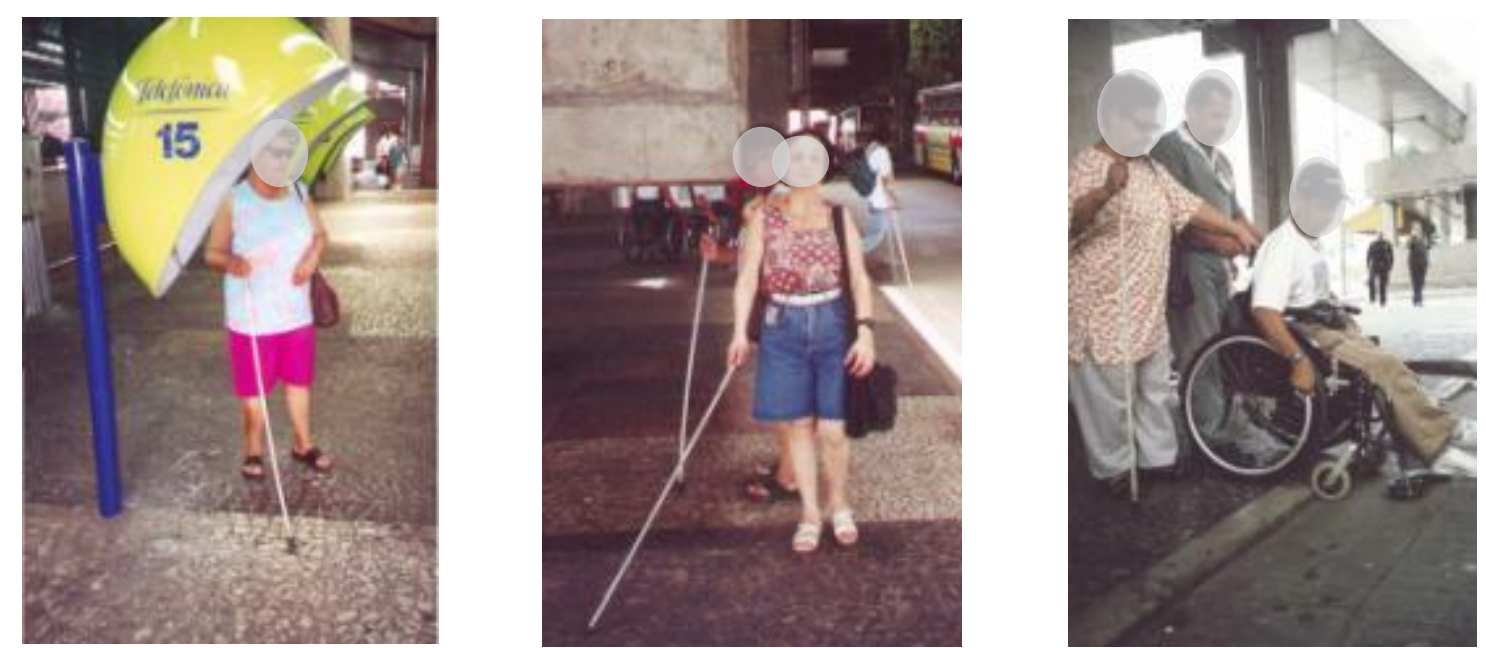

Figura 247 - São Paulo - Visita técnica às estações juntamente com pessoas com deficiência. Fonte: BARBOSA, M.B., 2002.

Paralelamente, no ano de 2003, foram instalados pisos táteis nas estações Vergueiro, Marechal Deodoro e Sé, com o objetivo de promover uma avaliação técnica (quanto aos materiais utilizados e ao sistema de fixação) e de usabilidade (quanto aos encaminhamentos, pontos de mudança de direção, entre outros). As organizações responsáveis pelos treinamentos de orientação e mobilidade (Laramara e Fundação Dorina Nowill) promoveram a avaliação das estações pelas pessoas com deficiência visual (Figura 248). 

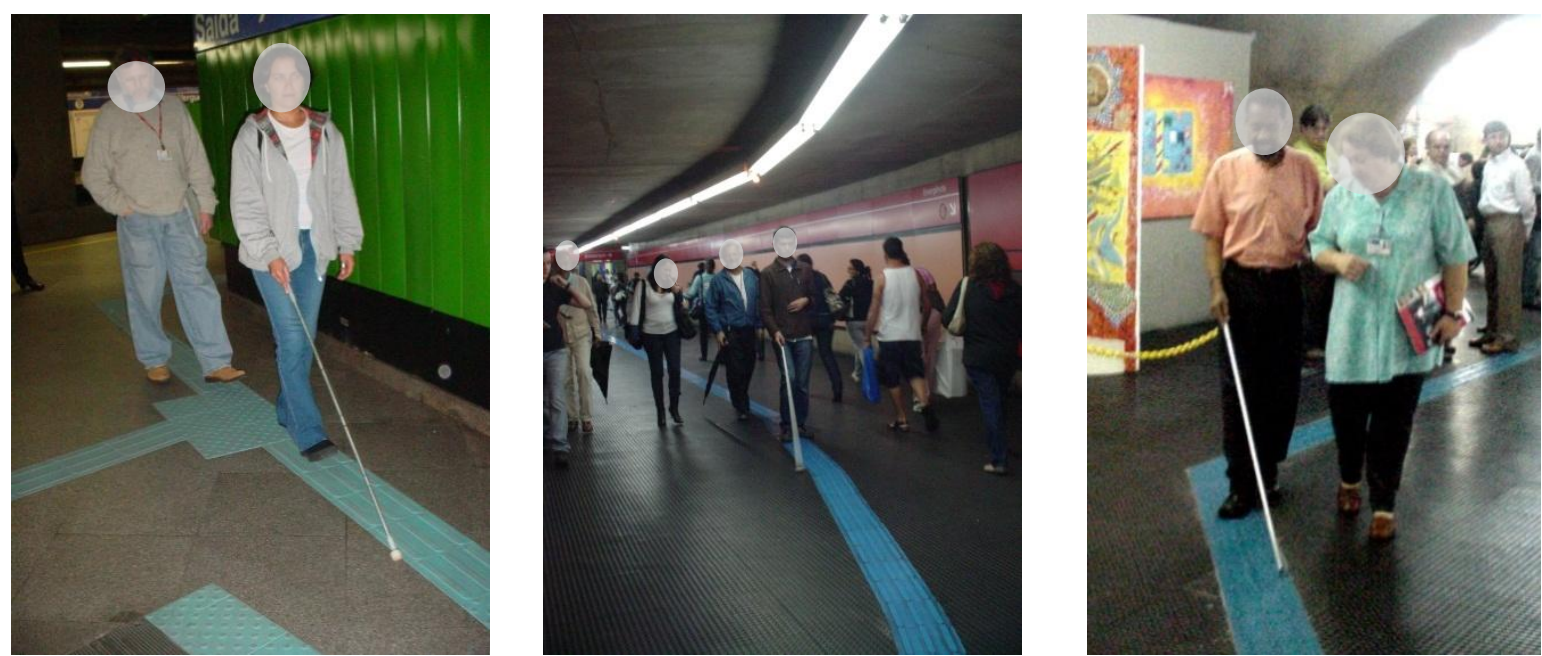

Figura 249 - São Paulo - Avaliação do piso tátil pelas pessoas com deficiência visual.

Fonte: BARBOSA, M.B., 2004.

Em maio e junho de 2009, após a conclusão da instalação do piso tátil em parte das estações, o Metrô de São Paulo promoveu uma consulta para medir o conhecimento, uso e aprovação por parte dos usuários com deficiência visual em 8 estações. De um total de 357 respondentes, $64 \%$ afirmaram que, ao utilizar as estações, sempre solicitam ajuda do empregado, e 10\% nunca solicitam auxílio; os demais afirmaram solicitar auxílio às vezes. Quando indagados sobre a sinalização tátil instalada no piso das estações, $90 \%$ deles afirmaram conhecer esse recurso de sinalização do percurso, enquanto que $77 \%$ disseram já terem tentado utilizá-lo, e $74 \%$ declararam terem conhecimento da instalação do piso em todas as estações. Do total de entrevistados, 57\% afirmaram sentir dificuldades para utilizar o piso tátil no Metrô, seja para entender a direção a seguir ou pelo fato de o piso não orientar o percurso desejado pelo usuário (Gráfico 38).

Gráfico 38 - Avaliação do piso tátil pelas pessoas com deficiência visual.

(\% em relação ao total de relatos registrados nesta etapa)

sentiu dificuldades em usar o piso tátil do metrô?

sabe que o Metrô está instalando pisos táteis em todas as estações?

já usou o piso tátil?

conhece o piso tátil?

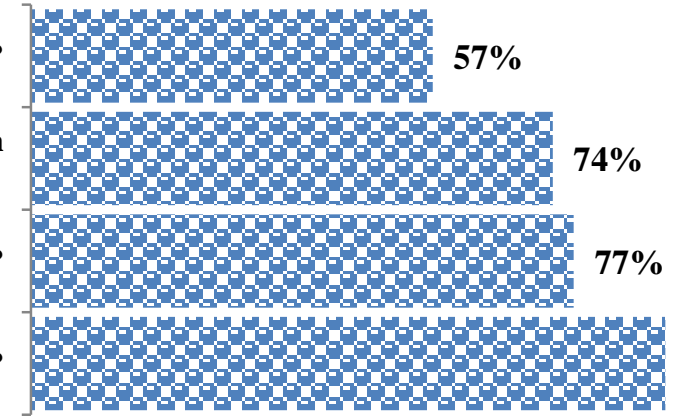

$90 \%$ 
Além da realização de pesquisas, o Metrô de São Paulo abriu diferentes canais de comunicação com os usuários (Figura 250), com destaque para o atendimento pessoal, telefônico, eletrônico ou por escrito. Os canais de comunicação permitem que sejam solicitadas informações e orientações, ou mesmo que sejam registradas manifestações relacionadas às experiências de uso do sistema metroferroviário, possibilitando elogios, críticas ou sugestões de mudanças em função das situações vivenciadas.
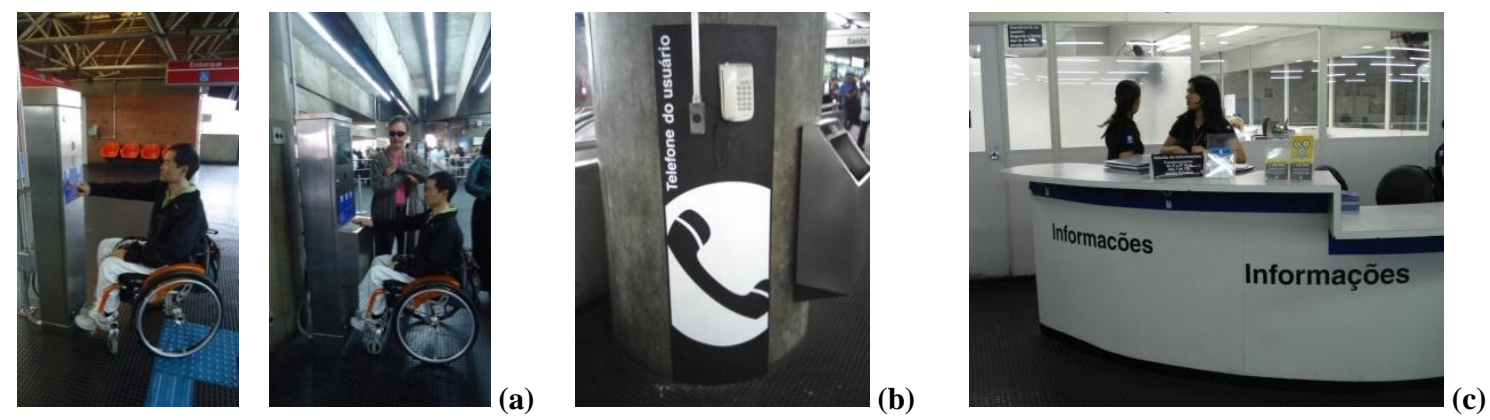

Figura 250 - São Paulo - Meios de comunicação disponibilizados nas estações.

- Intercomunicador (a), Telefone do usuário (b) e Balcão de Informações (c).

Fonte: BARBOSA, M.B., 2011.

\subsubsection{Avaliação pelos usuários}

Na etapa de avaliação da experiência, 140 usuários com deficiência visual - dos quais 107 pessoas são cegas e 33 pessoas têm baixa visão - manifestaram seu descontentamento em relação à estação $(97,9 \%)$ e ao trem $(2,1 \%)$. Foram registrados 291 relatos, o que representa $10,9 \%$ do total de relatos registrados para todas as etapas da jornada do usuário. Os relatos estão, em sua maioria, relacionados aos serviços prestados na estação $(69,4 \%)$ e às informações prestadas na estação $(28,5 \%)$, mas também são dirigidos aos serviços prestados nos trens $(2,1 \%)$, conforme apresentado na Tabela 32 .

Tabela 32 - Matriz de avaliação da etapa 24 - Avaliação da experiência.

(\% em relação ao total de relatos registrados nesta etapa)

\begin{tabular}{l|r|r|r|r}
\hline & $\begin{array}{c}\text { Configuração } \\
(\%)\end{array}$ & $\begin{array}{c}\text { Informação } \\
(\%)\end{array}$ & $\begin{array}{c}\text { Serviço } \\
(\%)\end{array}$ & $\begin{array}{c}\text { Total } \\
(\%)\end{array}$ \\
\hline Estação & $\mathbf{0 , 0}$ & (EI) 28,5 & (ES) $\mathbf{6 9 , 4}$ & $\mathbf{9 7 , 9}$ \\
\hline Interface Trem-Estação & $\mathbf{0 , 0}$ & $\mathbf{0 , 0}$ & $\mathbf{0 , 0}$ & $\mathbf{0 , 0}$ \\
\hline Trem & $\mathbf{0 , 0}$ & $\mathbf{0 , 0}$ & (TS) 2,1 & $\mathbf{2 , 1}$ \\
\hline Total & $\mathbf{0 , 0}$ & $\mathbf{2 8 , 5}$ & $\mathbf{7 1 , 5 \%}$ & $\mathrm{100,0}$ \\
\hline
\end{tabular}


"Nos horários de pico eu me sinto mais seguro com a ajuda de um empregado devido à grande quantidade de usuários. E não tem empregado em quantidade suficiente nas estações para auxiliar no meu deslocamento e, por conta disso, tenho que ficar muito tempo aguardando pela ajuda, e tenho horário a cumprir. Precisa ter mais empregados nas estações de transferência. No final de semana é pior porque não tem nem estagiário. Após o horário dos estagiários deveria ter um efetivo suficiente para atender em cada estação, para que eu pudesse me deslocar com mais rapidez. Antes a quantidade de deficientes visuais era pequena e tudo funcionava igual a um relógio, mas agora têm muitos deficientes e precisa aumentar também a quantidade de empregados para fazer este serviço. Se eles tivessem intercomunicadores facilitaria para que um avisasse ou outro quando eu chegasse na estação... Raramente, eu encontro um empregado quando desembarco na plataforma. Aí preciso aceitar ajuda de um usuário... Com relação ao atendimento dos estagiários, eu me sinto inseguro: eles não dão o braço quando me conduzem, às vezes me puxam pela bengala, andam muito rápido, não respeitam o nosso ritmo, fazem pouco caso e não aceitam as dicas que eu dou, parece que estão ali só pelo dinheiro. Posso ajudar a formar os jovens atendentes, usando a minha experiência no metrô. Eles precisam perguntar se quero andar mais rápido ou mais devagar, se forem muito rápido eu posso me machucar. Às vezes eles me tratam como um bichinho e precisam saber que estão na estação para trabalhar e não para brincar, eles precisam procurar saber o que precisamos e não fazer o que eles querem. Acho que é necessário, na verdade, selecionar melhor os estagiários. Este programa é bom e deve continuar porque me ajuda a embarcar e desembarcar, mas é preciso controlar os estagiários e punir aqueles que faltam porque eles sobrecarregam os que são mais responsáveis. Depois que colocaram o piso tátil eles pensam que não precisamos mais deles e muitas vezes até se escondem para não oferecer ajuda. Os funcionários precisa receber mais treinamento, saber que precisam me dar o braço ou ombro, conforme o caso. É importante colocar que eu acho humilhante ser conduzido em trenzinho, além do que, o último da fila corre o risco de se acidentar... Quanto aos empregados nos trens, eu acredito que tenham treinamento, mas nem sempre praticam. Às vezes não dizem o nome da próxima estação e é importante que eles sejam mais preparados, para que eu possa calcular o tempo que vou levar para desembarcar e para que eu não tenha que esperar tanto. O Metrô poderia ter feito uma consulta aos deficientes visuais antes de colocar o piso: sobre qual o tipo de guia é melhor, sobre levar para a escada rolante... Eu prefiro usar a escada rolante, ou pelo menos ter esta opção... Eu poderia ter ido até as estações para avaliar o piso, para ver se está colocado corretamente, se está levando para onde eu e os outros queremos ir, se está de acordo com a necessidade de todos os deficientes visuais, com baixa visão, como eu, ou os que sempre foram cegos. Infelizmente, eu e os outros deficientes não fomos consultados e eu acho que o piso foi colocado aleatoriamente. Acho que poderiam ter consultado a Laramara, associação que treina e conhece as necessidades da pessoa com deficiência visual para orientar quanto à função do piso tátil e dos elevadores, saber como usar esses recursos. Precisa ter campanhas voltadas para o respeito do piso tátil e do cão guia pelo usuário comum: orientar para não andar sobre o piso tátil, não ficar parado nele, não brincar com o cão guia e respeitar o embarque preferencial." (Discurso do Sujeito Coletivo - etapa 24)

Os principais problemas relatados pelos usuários na etapa de avaliação da experiência são apresentados no de forma hierarquizada, conforme número de relatos registrados (Gráfico 39). 
Gráfico 39 - Avaliação da etapa 24 - Avaliação da experiência.

(\% em relação ao total de relatos registrados nesta etapa)

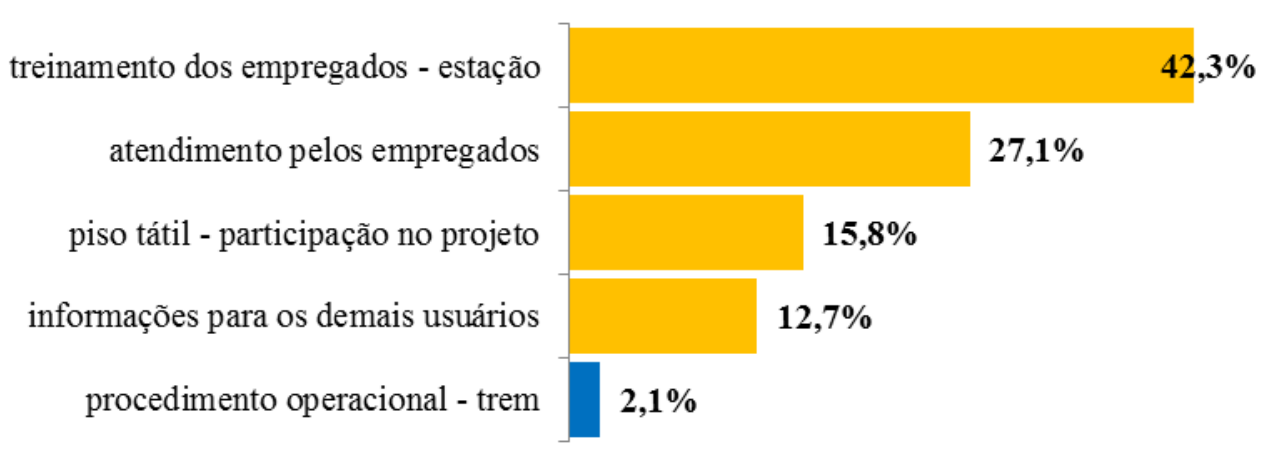

$\mathrm{n} 1=140$ respondentes $\mathrm{n} 2=291$ relatos

Os problemas relatados estão relacionados às seguintes ideias centrais:

a) treinamento dos empregados - estação (ES1) - refere-se ao mau atendimento pelos empregados e estagiários, à falta de cortesia e desrespeito ao ritmo de deslocamento e ao livre arbítrio do usuário quanto ao auxílio prestado, levando à preferência pelo atendimento pelos empregados;

b) atendimento pelos empregados (ES2) - refere-se à falta de empregados, elevando o tempo de espera para atendimento;

c) piso tátil - participação no projeto (EI2) - relata a insatisfação pela falta de consulta às pessoas com deficiência visual para implantação da sinalização tátil nas estações;

d) informações para os demais usuários (EI7) - refere-se à falta de orientação e conscientização dos demais usuários sobre a finalidade do piso tátil direcional, inibindo a permanência de pessoas, objetos ou sacolas sobre a sinalização;

e) procedimento operacional - trem (TS2) - refere-se à destinação exclusiva do primeiro carro para pessoas que têm direito ao atendimento preferencial.

\subsubsection{Avaliação pelas pessoas-chave}

Em relação ao atendimento pelos empregados (ES2), os empregados das estações destacam que o treinamento recebido é suficiente para o desempenho da função; contudo, sabem que os usuários reclamam do tempo de espera para atendimento, fato que atribuem ao quadro insuficiente de empregados, ao crescimento da demanda e às distâncias percorridas durante o auxílio no desembarque, pois o empregado vai até o ponto de parada ou até o terminal de ônibus urbano, aumentando o tempo dispendido no atendimento (Figura 251). A proximidade 
com centros de reabilitação, a maior oferta de empregos - para cumprimento da lei de cotas e a existência de polos educacionais contribuem para uma demanda elevada de pessoas com deficiência visual nas estações, nos mesmos horários que as demais pessoas utilizam o sistema metroviário.
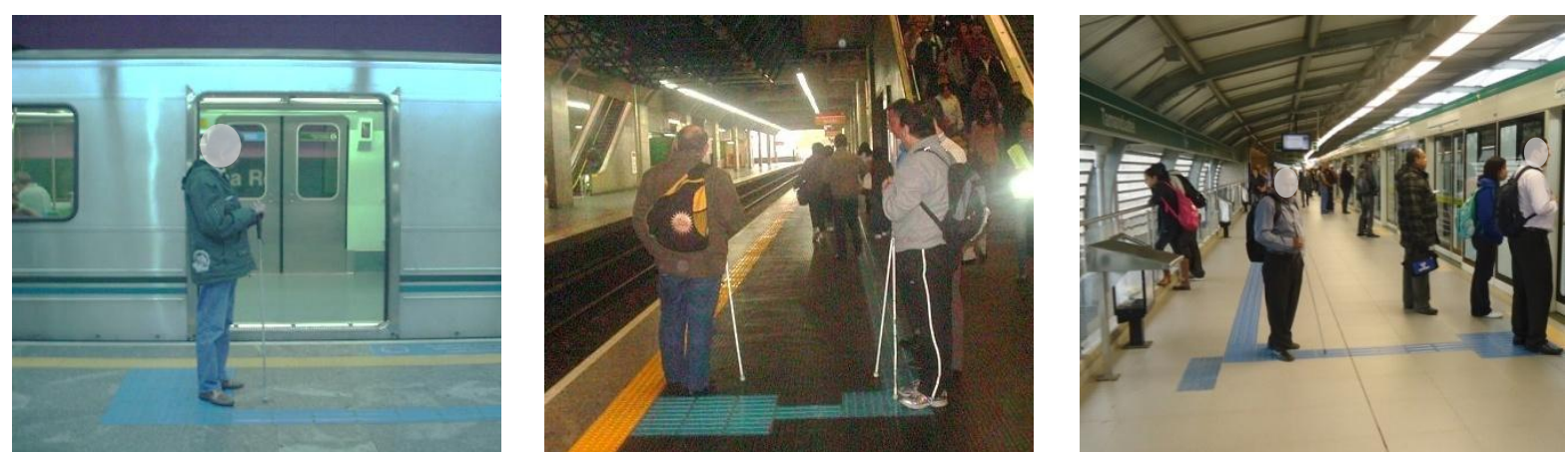

Figura 251 - São Paulo - Usuários aguardam a chegada de auxílio para desembarque. Fonte: BARBOSA, M.B., 2011.

\subsubsection{Avaliação pelos especialistas}

Os responsáveis pelos projetos das estações relataram que o direcionamento de fluxo nos espaços destinados à conexão entre diferentes modos de transporte é feito exclusivamente por meio do piso tátil - percurso (EI3) uma vez que não são utilizados elementos de acabamento ou materiais de revestimento diferenciados - que reverberem mais ou que sejam mais absorventes - seja em paredes, piso ou forros, para auxiliar os deslocamentos. Quanto às informações para a pessoa com deficiência visual - estação (EI6), ressaltaram que não há nada que diferencie o caminho do Metrô do caminho da CPTM, do terminal rodoviário e das alternativas de transporte disponíveis; todas as informações são veiculadas por meio de textos informativos. Em relação às condições das instalações existentes (EC3), afirmam que os espaços destinados à conexão são entendidos como espaços de socialização e, portanto, não se diferenciam para referenciar os diversos modos de transporte apesar de serem extremamente significativos, qualquer que seja a configuração da estação.

Os profissionais responsáveis pela elaboração de normas técnicas de acessibilidade ressaltam a inexistência de requisitos de acessibilidade específicos para os espaços de conexão visando à adequação das condições das instalações existentes (EC3). 


\subsubsection{Elementos de wayfinding}

Os dados coletados permitem afirmar que todos os elementos de wayfinding - marcadores, caminhos, nós, zonas e bordas - devem estar presentes nesta etapa (Quadro 43) e devem ser destacados dos demais elementos da paisagem ou do ambiente. As informações táteis, visuais e sonoras veiculadas devem sobressair em relação às demais informações para auxiliar a percepção e a compreensão e facilitar sua identificação pelas pessoas com deficiência visual.

Quadro 43 - Elementos de wayfinding da Etapa 24 - Avaliação da experiência.

\begin{tabular}{|c|c|c|c|}
\hline $\begin{array}{l}\text { Elementos de } \\
\text { wayfinding }\end{array}$ & Configuração & Informação & Serviço \\
\hline $\begin{array}{l}\text { Marcadores } \\
\text { Caminhos }\end{array}$ & \multirow[t]{4}{*}{$\begin{array}{l}\text { - elementos de wayfinding } \\
\text { presentes de forma } \\
\text { integrada }\end{array}$} & \multirow[t]{4}{*}{$\begin{array}{l}\text { - informação sobre os } \\
\text { canais de comunicação } \\
\text { existentes para registro da } \\
\text { avaliação da experiência }\end{array}$} & \multirow[t]{4}{*}{$\begin{array}{l}\text { - disponibilidade de canais } \\
\text { de comunicação para } \\
\text { registro da avaliação da } \\
\text { experiência }\end{array}$} \\
\hline Nós & & & \\
\hline Bordas & & & \\
\hline Zonas & & & \\
\hline
\end{tabular}

Fonte: Elaborado pela pesquisadora.

\subsubsection{Síntese do diagnóstico}

Na etapa 24 - Avaliação da experiência -, foram identificados aspectos que devem ser tratados pelas empresas operadoras dos sistemas metroferroviários para auxiliar as pessoas com deficiência visual a estabelecer estratégias para empreender seus deslocamentos:

a) condições das instalações existentes (EC3) - diferenciar os espaços destinados aos diversos modos de transporte; estabelecer requisitos de acessibilidade específicos para os espaços de conexão

b) piso tátil - participação no projeto (EI2) - promover a participação/consulta às pessoas com deficiência visual para implantação da sinalização tátil nas estações;

c) piso tátil - percurso (EI3) - orientar deslocamentos em todos os espaços de conexão;

d) informações para a pessoa com deficiência visual - estação (EI6) - diferenciar o caminho do Metrô dos demais sistemas integrados (CPTM, terminal rodoviário, entre outros) utilizando acabamentos ou materiais de revestimento diferenciados; 
e) informações para os demais usuários (EI7) - informar os demais usuários sobre a finalidade do piso tátil direcional e sobre o embarque preferencial;

f) treinamento dos empregados - estação (ES1) - respeitar o ritmo de deslocamento dos usuários; aceitar o livre arbítrio sobre uso de escadas das estações e carros dos trens;

g) atendimento pelos empregados (ES2) - minimizar o tempo de espera para atendimento;

h) procedimento operacional - trem (TS2) - destinar o primeiro carro do trem para uso exclusivo de pessoas com deficiência.

\subsection{Etapa 30 - Circulação vertical - sem especificar o local}

Refere-se ao deslocamento vertical de embarque ou de desembarque dos usuários entre os acessos, os mezaninos e as plataformas, envolvendo diferentes etapas da jornada do usuário, a saber: circulação vertical entre o acesso e o mezanino (etapas 4 e 21), circulação vertical entre o mezanino e a plataforma (etapas 9 e 17). Foram classificadas nessa condição em função de o usuário ter manifestado seu descontentamento em relação ao deslocamento vertical na estação, sem ter especificado o local ou etapa onde tal problema era vivenciado.

\subsubsection{Métodos e técnicas aplicados}

Os métodos e técnicas utilizados para coleta de dados nesta etapa foram apresentados no item 6.10 - Síntese dos instrumentos aplicados - e consistiram em:

a) identificação de melhores práticas em outros sistemas metroferroviários;

b) pesquisa documental (normas técnicas ABNT vigentes, desenhos, procedimentos operacionais);

c) checklist dos recursos disponíveis e walkthrough realizado nas estações para compreensão do percurso de embarque;

d) ficha ambiente dos elementos de circulação vertical;

e) questionário aplicado às pessoas com deficiência visual - questões 12, 13 e 17;

f) entrevista com empregados das estações;

g) entrevista com estagiários que auxiliam as pessoas com deficiência visual;

h) entrevista com professores de orientação e mobilidade;

i) entrevista com profissionais responsáveis pelo treinamento dos empregados; 
j) entrevista com profissionais responsáveis pelos projetos das estações;

k) entrevista com profissionais responsáveis pela elaboração de normas técnicas.

As formas de análise e interpretação dos dados coletados foram apresentadas no Capítulo 6 Aplicação dos instrumentos.

\subsubsection{Melhores Práticas}

No Metrô de Madri, há uma diretriz de projeto para o posicionamento dos elevadores, das escadas fixas e das escadas rolantes nas novas estações de forma a facilitar a percepção e compreensão sobre os deslocamentos (Figura 252). Essas orientações são descritas a seguir:
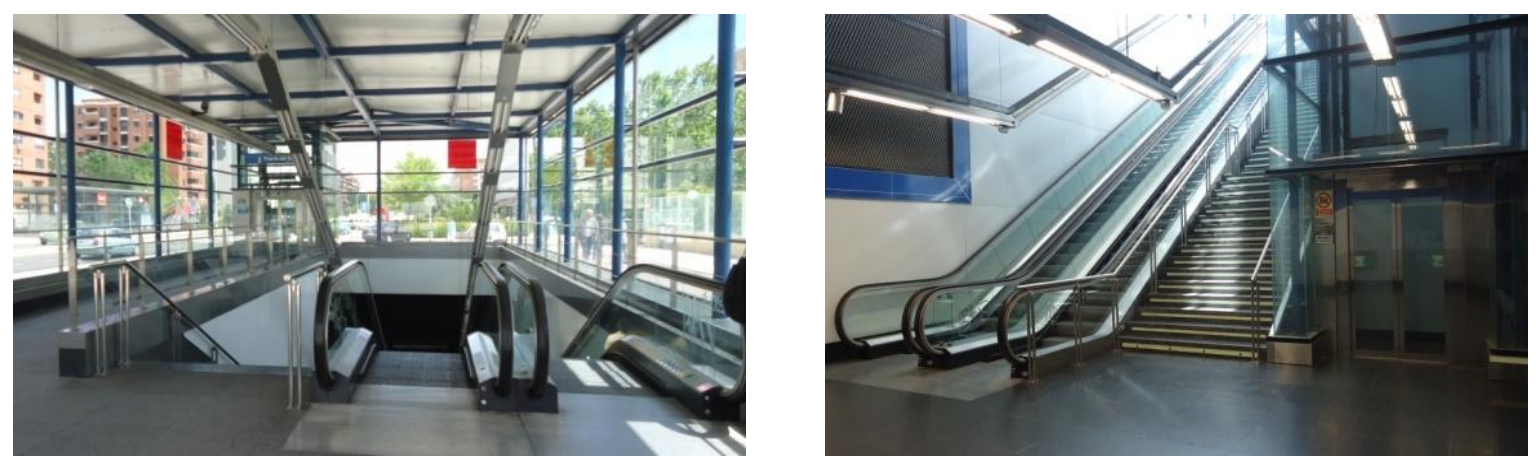

Figura 252 - Madri - Acesso com escadas fixas, escadas rolantes e elevadores integrados. Fonte: BARBOSA, M.B., 2013.

a) rampas: nas novas estações do Metrô de Londres, predominam corrimãos em cor contrastante em relação à superfície da parede, destacando o percurso a ser realizado (Figura 253). No Metrô de Porto Alegre, além do corrimão em cor contrastante, foi incorporada a sinalização de fluxo no acabamento do piso da rampa, orientando os deslocamentos (Figura 254).

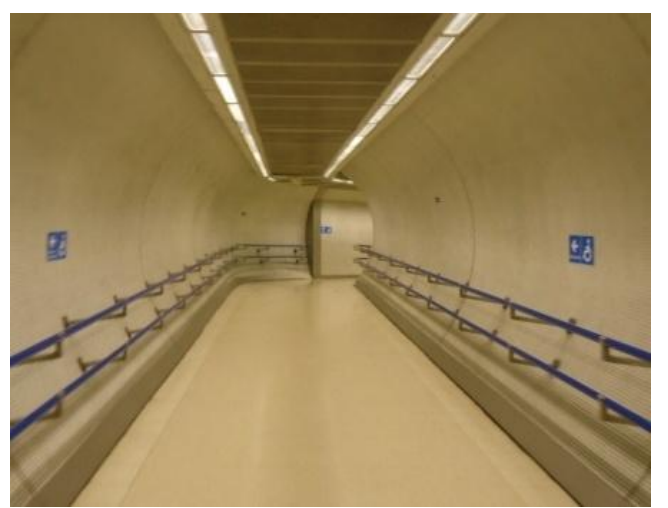

Figura 253 - Londres - Rampa com corrimão lateral em cor contrastante em relação à parede.

Fonte: BARBOSA, M.B., 2013.

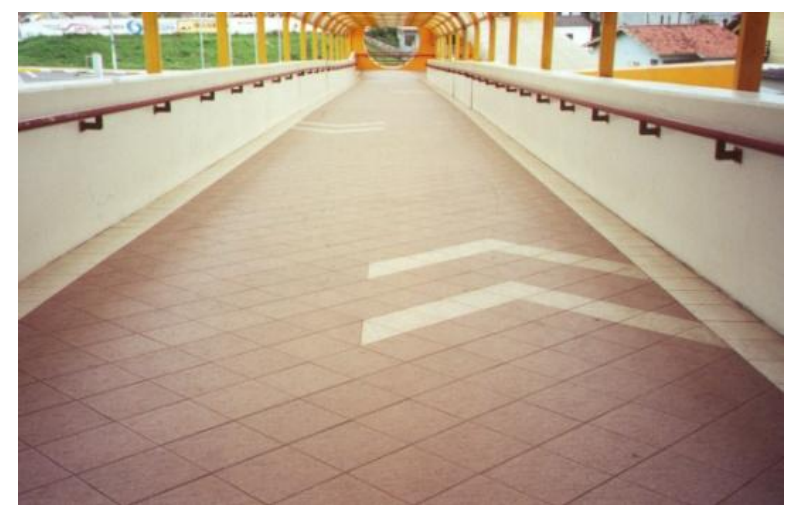

Figura 254 - Porto Alegre - Sinalização de fluxo em rampa de acesso/saída. Fonte: BARBOSA, M.B., 2007. 
b) escadas fixas: as novas estações do Metrô de Tóquio e de Londres dispõem de corrimãos em duas alturas e em cor contrastante em relação ao material de acabamento do entorno e sinalização tátil de alerta no piso nos patamares superior e inferior (Figuras 255 e 256). Nas novas estações do Metrô de Madri, o suporte dos corrimãos, em duas alturas, tem cor contrastante e sinalização tátil posicionada na geratriz inferior do corrimão superior, com o objetivo de evitar o vandalismo e minimizar o desgaste da sinalização (Figura 257). As estações de trem em Paris também dispõem de sinalização tátil indicativa do percurso no corrimão das escadas fixas (Figura 258).

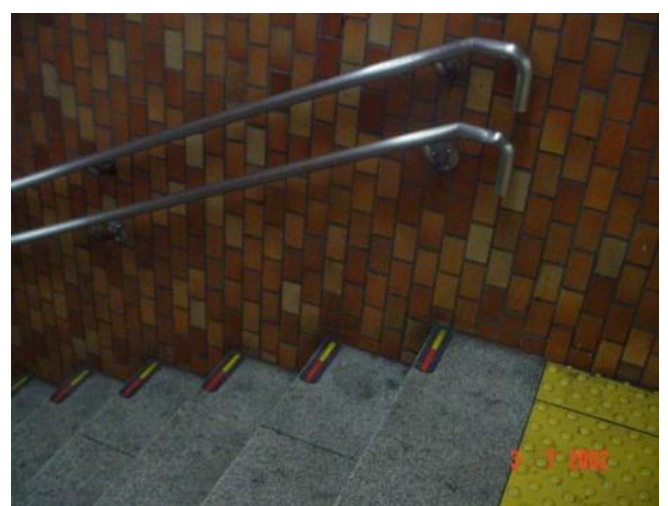

Figura 255 - Tóquio - Escada fixa - corrimão duplo, sinalização visual e tátil.

Fonte: BARBOSA, M.B., 2013.

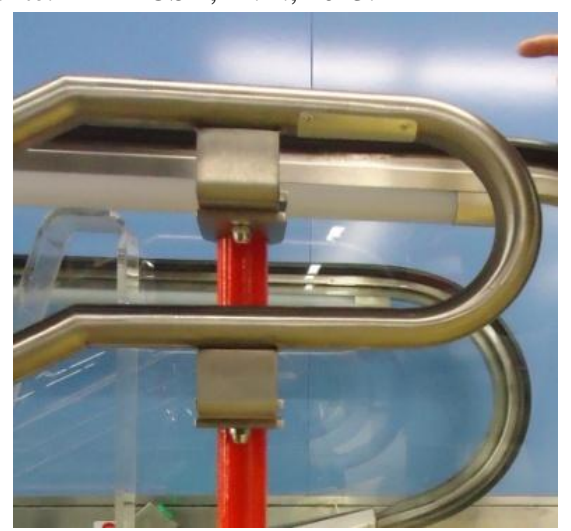

Figura 257 - Madri - Suporte com contraste visual e sinalização tátil no corrimão.

Fonte: BARBOSA, M.B., 2013.

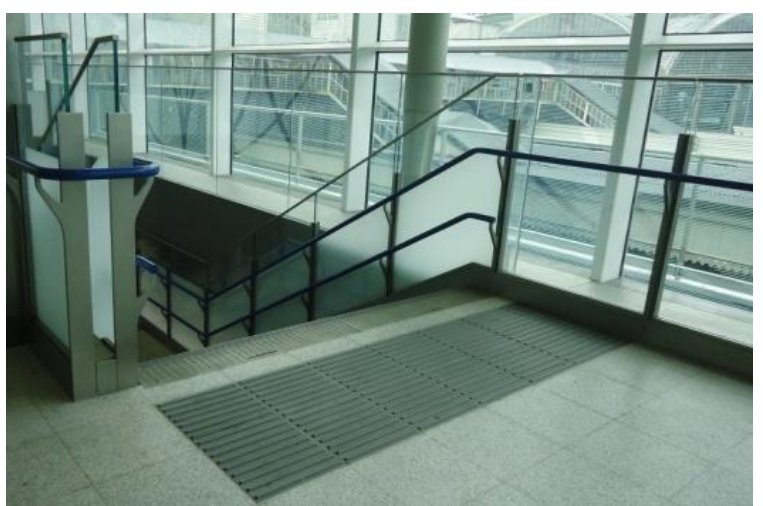

Figura 256 - Londres - Escada fixa - corrimão em cor contrastante, sinalização tátil.

Fonte: BARBOSA, M.B., 2013.

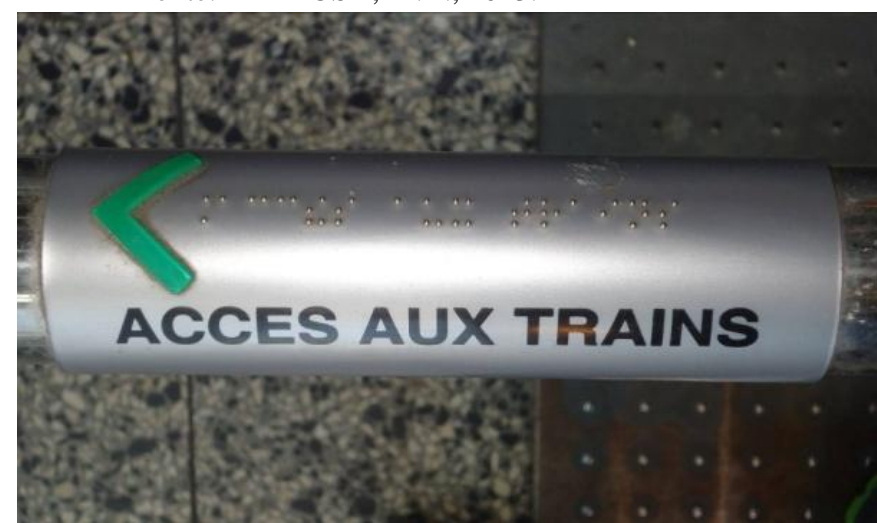

Figura 258 - Paris - Sinalização tátil no corrimão.

Fonte: BARBOSA, M.B., 2013.

c) escadas rolantes: o Metrô de Hong Kong dispõe de barreira de segurança identificável visualmente para informar quando os equipamentos estão interditados ou fora de uso. A sinalização indicativa do sentido de deslocamento é informada junto com a comunicação visual direcional (Figura 259). No Metrô de Barcelona, destaca-se a iluminação do corrimão da escada rolante, que permite melhor visualização do desnível e do percurso (Figura 260). Em Madri, o contraste visual do fechamento lateral da escada rolante facilita a identificação da sua localização (Figura 261). No 
Rio de Janeiro, foi instalado piso tátil direcional orientando o deslocamento das pessoas com deficiência visual para utilização das escadas rolantes, contrariando as orientações contidas nos manuais ou praticadas por outros metrôs internacionais (Figura 262).
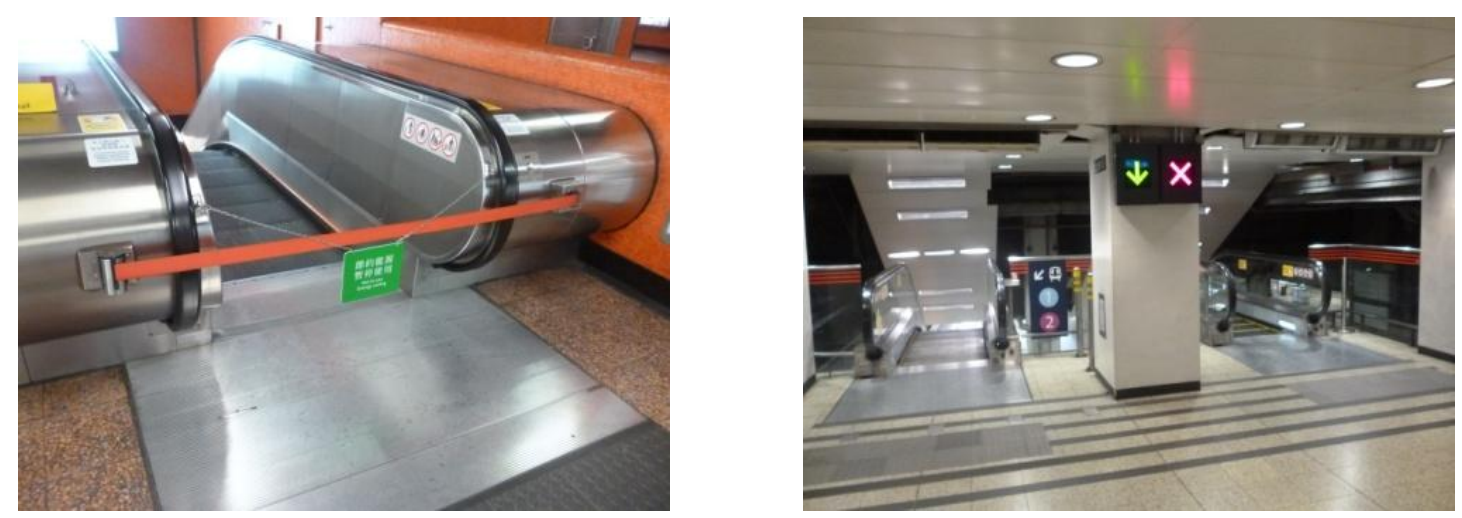

Figura 259 - Hong Kong - Barreira de segurança e indicação do sentido de deslocamento da escada rolante. Crédito: PONTES, F.M., 2012.

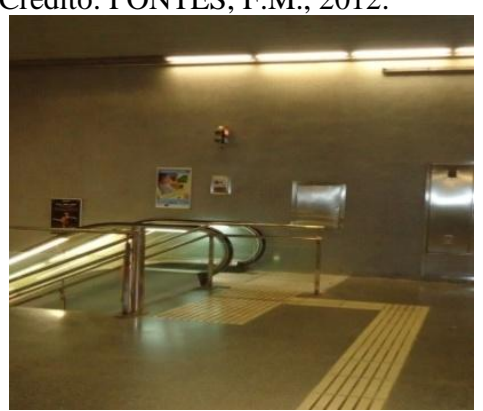

Figura 260 - Barcelona - Escada rolante iluminada.

Fonte: BARBOSA, M.B., 2011.

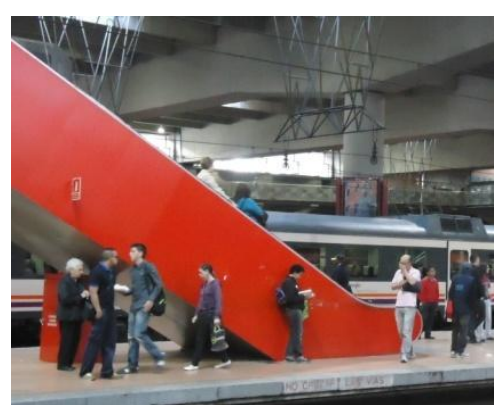

Figura 261 - Madri - Escada rolante em cor contrastante. Fonte: BARBOSA, M.B., 2013.

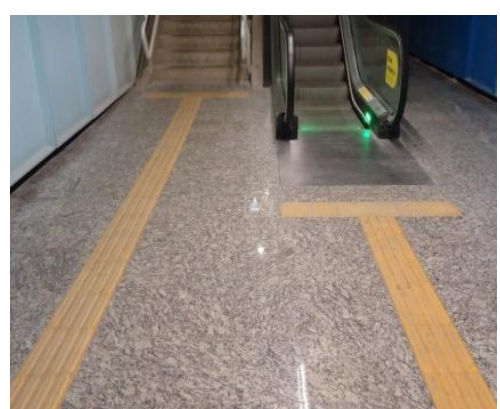

Figura 262 - Rio de Janeiro - Piso tátil para escada rolante.

Fonte: BARBOSA, M.B., 2011.

d) elevadores: o Metrô de Londres utiliza uma cor contrastante no batente dos elevadores para facilitar sua percepção e sua localização por pessoas com baixa visão. A existência de portas ou acabamentos em vidro - total ou parcial - contribui para a segurança na utilização do equipamento. A adoção de letras para identificação dos equipamentos e de cores para identificação das linhas em esquemas gráficos informam sobre os diferentes pavimentos atendidos pelos elevadores de uma mesma estação (Figura 263). O Metrô de Hong Kong incorporou a identificação das linhas atendidas nas botoeiras do elevador, com indicações complementares em Braille (Figura 264). Outro destaque é o Metrô de Madri, que dispõe de sinalização sonora e visual indicativa de abertura e fechamento das portas e que desenvolveu um novo padrão de sinalização para as botoeiras internas e externas, com texto em tipologia ampliada, cor contrastante e relevo, além de sinalização em Braille (Figura 265) associada à informação sonora. Quando o equipamento abre a porta na plataforma, há informação 
sonora sobre o número da linha e a direção do trem. Também em relação às botoeiras, o Metrô de Barcelona incorporou o código de cor identificativa das linhas nas testeiras e nas botoeiras dos equipamentos existentes nas estações de integração (Figura 266).

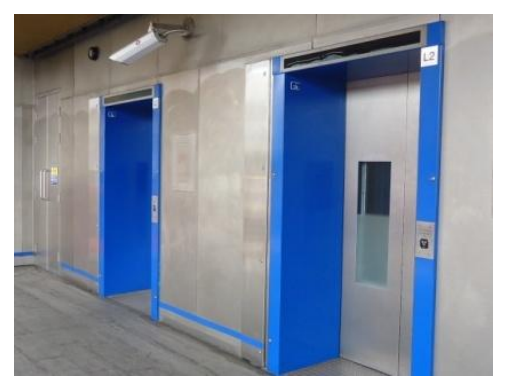

Figura 263 - Londres - Contraste visual no elevador e esquema gráfico indicativo dos percursos.

Fonte: BARBOSA, M.B., 2013.
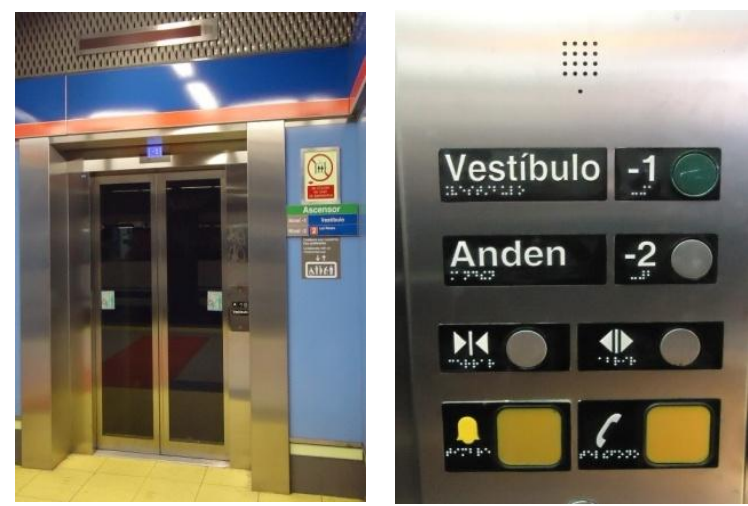

Figura 265 - Madri - Botoeiras em cor contrastante indicativas dos diferentes pavimentos.

Fonte: BARBOSA, M.B., 2013.

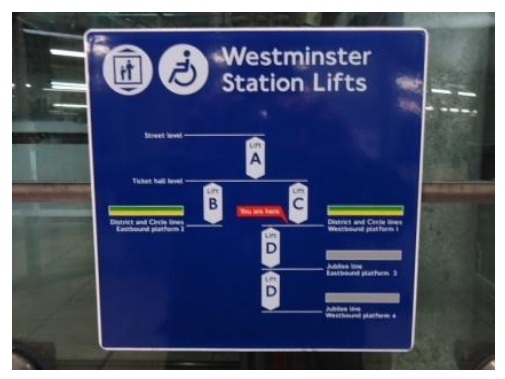

Figura 264 - Hong Kong - Botoeiras indicativas dos diferentes pavimentos.

Crédito: PONTES, F.M., 2012.
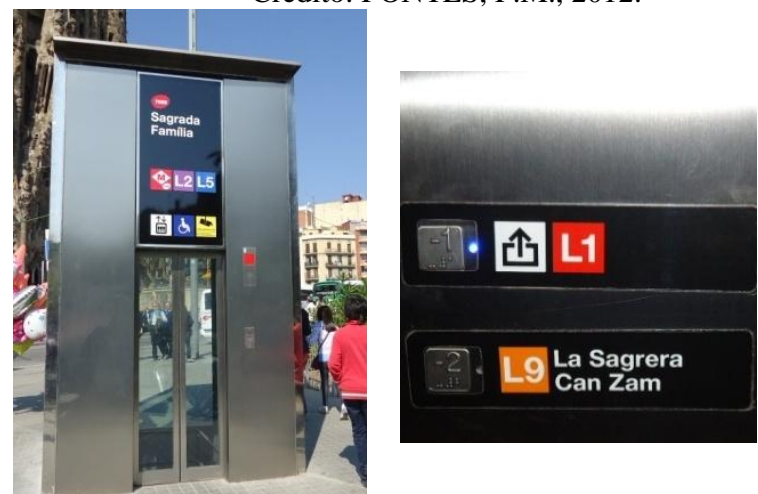

Figura 266 - Barcelona - Botoeiras indicativas das linhas nas estações de integração. Fonte: BARBOSA, M.B., 2011.

\subsubsection{Requisitos Normativos}

Cada um dos elementos de circulação vertical tem requisitos normativos específicos. Contudo, a ABNT NBR 9050:2004 estabelece que as informações visual e tátil devem indicar a existência e a localização dos equipamentos de circulação vertical. Essas especificações são descritas a seguir:

a) rampas - a ABNT NBR 9050:2004 determina a instalação de piso tátil de alerta perpendicularmente ao sentido de deslocamento no início e término de rampas e recomenda que os corrimãos sejam sinalizados por meio de anel com textura contrastante com a superfície do corrimão e sinalização em Braille, informando sobre os pavimentos atendidos;

b) escadas fixas - a ABNT NBR 9050:2004 determina que as escadas fixas devem ter degraus com superfície ou faixa antiderrapante e sinalização visual em cor contrastante posicionada na lateral dos degraus, na projeção dos corrimãos. Em 
relação à sinalização, a norma determina a instalação de piso tátil de alerta perpendicularmente ao sentido de deslocamento no início e no término das escadas fixas e recomenda que os corrimãos sejam sinalizados por meio de anel com textura contrastante com a superfície do corrimão e sinalização em Braille, informando sobre os pavimentos atendidos;

c) escadas rolantes - a ABNT NBR 14021:2005 determina a necessidade de sinalização visual de alerta na cor amarela, nas extremidades dos degraus, sinalização tátil de alerta em cor contrastante com o piso do entorno instalada perpendicularmente ao sentido de deslocamento no início e no término dos equipamentos, além de sinalização de orientação sobre o movimento, instruções de uso, indicação da posição para embarque e pavimentos atendidos pelo equipamento;

d) elevadores - a ABNT NM 313:2007 determina a existência de dispositivos de operação, botoeiras e sistemas de informação; orientação com alarmes visuais e luminosos, complementados por avisos sonoros. Externamente, nos pavimentos, alarmes visuais e sonoros devem informar a chegada e o sentido de deslocamento do elevador. Internamente, na cabine, devem ser previstas botoeiras internas com indicações em Braille - no próprio botão ou abaixo dele - associadas a caracteres e símbolos em relevo em cores claras em fundo escuro, localizados à esquerda, informação visual e sonora do pavimento desejado, além de intercomunicador e alarme de emergência sonoro e visual (na cor amarela). Elaborada para edificações verticalizadas, o sistema de sinalização de pavimentos determina que a informação dos pavimentos seja realizada por meio de números, sendo zero para o nível da rua, números negativos para pisos no subsolo e números positivos para os pavimentos acima do solo;

e) plataformas de elevação vertical - a ABNT NBR 15655-1:2009 determina que tais plataformas possam vencer desníveis de até $4 \mathrm{~m}$ e devam ser providas de portas com acionamento manual autônomo, estável na posição aberta. O acionamento para movimentação da plataforma de elevação deve ser realizado por meio de pressão contínua em botões de pressão convencionais, joysticks ou dispositivos similares, sem alterar a velocidade de deslocamento. Informações e instruções de operação devem ser disponibilizadas por meio de etiquetas contendo legendas e símbolos. Onde necessário, devem ser incorporadas informações táteis e sonoras. 


\subsubsection{Situação do Metrô de São Paulo}

No Metrô de São Paulo, o projeto das novas estações busca, sempre que possível, posicionar os elevadores junto ao conjunto das escadas fixas e rolantes, facilitando a compreensão dos deslocamentos, conforme Figura 267. As situações são descritas a seguir:
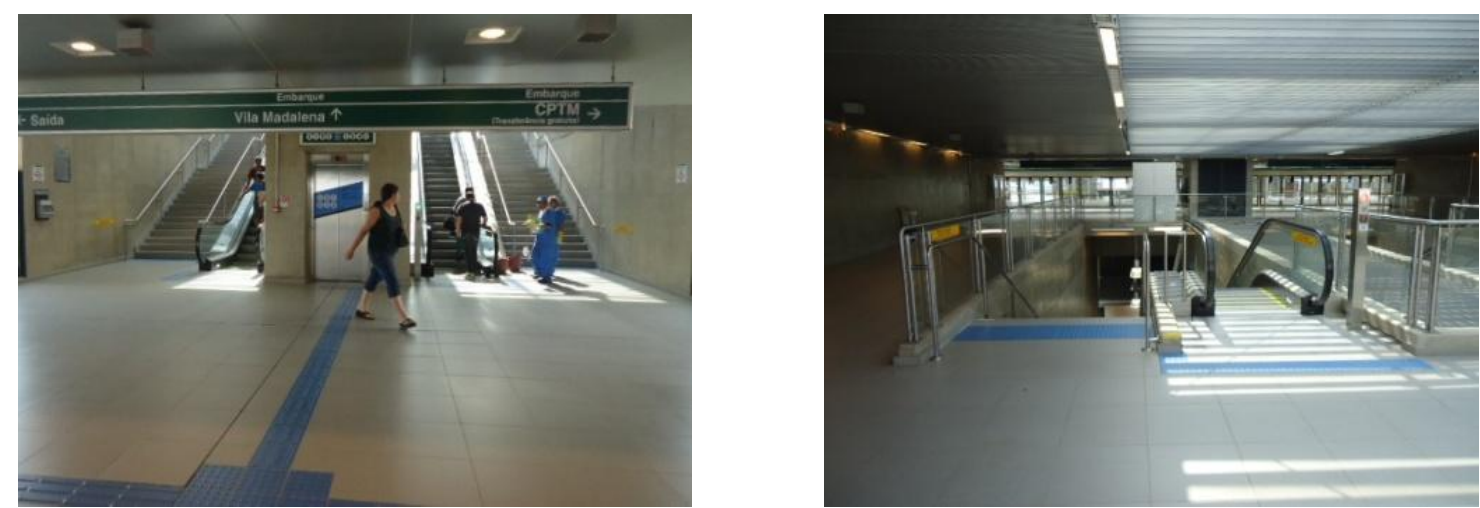

Figura 267 - São Paulo - Mezanino com escadas fixas, escadas rolantes e elevadores integrados. Fonte: BARBOSA, M.B., 2011.

a) rampas - as rampas dispõem de corrimãos laterais e centrais em duas alturas, além de sinalização tátil de alerta nos patamares superior, intermediário e inferior, em cor contrastante em relação ao piso adjacente (Figura 268). Os corrimãos, em aço inox, têm baixo contraste visual com superfícies vazadas ou com o acabamento em concreto. Não existem anéis ou sinalização em Braille informando os pavimentos atendidos.
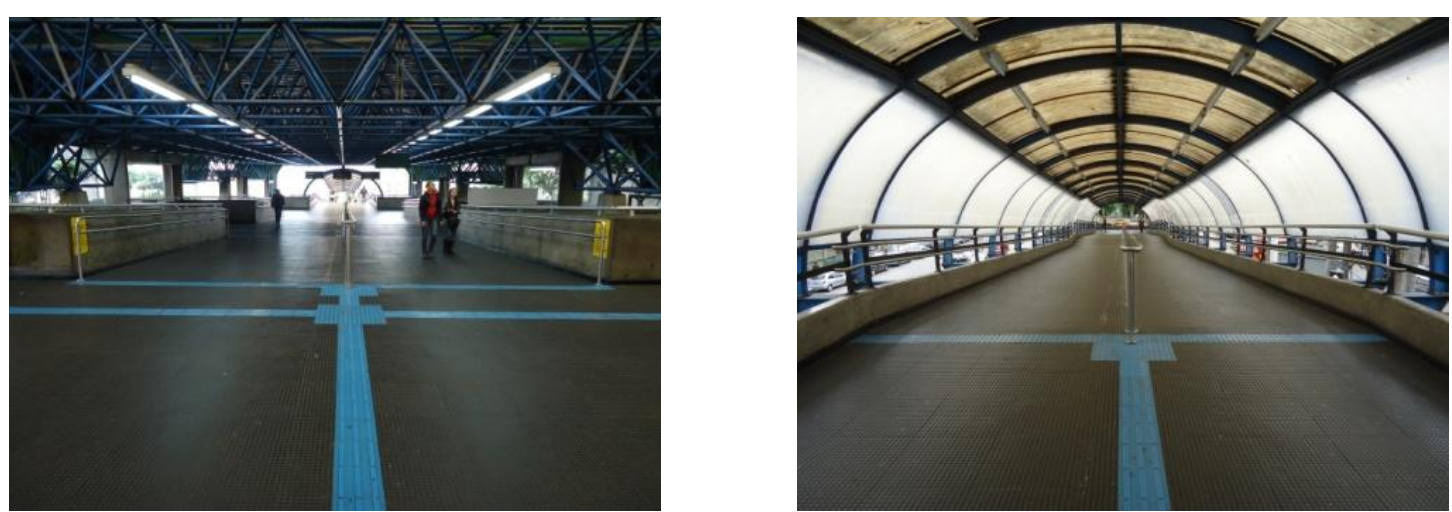

Figura 268 - São Paulo - Rampa com corrimãos lateral e central e sinalização tátil no piso.

Fonte: BARBOSA, M.B., 2011.

b) escadas fixas - as escadas dispõem de corrimãos laterais e centrais instalados a $0,92 \mathrm{~m}$ de altura, sinalização visual na lateral dos degraus e sinalização tátil de alerta nos patamares superior e inferior, em cor contrastante em relação ao piso adjacente. O piso tátil direcional existente nos acessos orienta o fluxo para as escadas fixas e elevadores, uma vez que ambos permitem fluxo bidirecional. Os corrimãos, em aço inox, têm 
baixo contraste visual com superfícies vazadas ou com acabamento em concreto; ao contrário, quando as paredes laterais são coloridas, há maior contraste visual entre o acabamento do corrimão e o acabamento da parede (Figura 269).

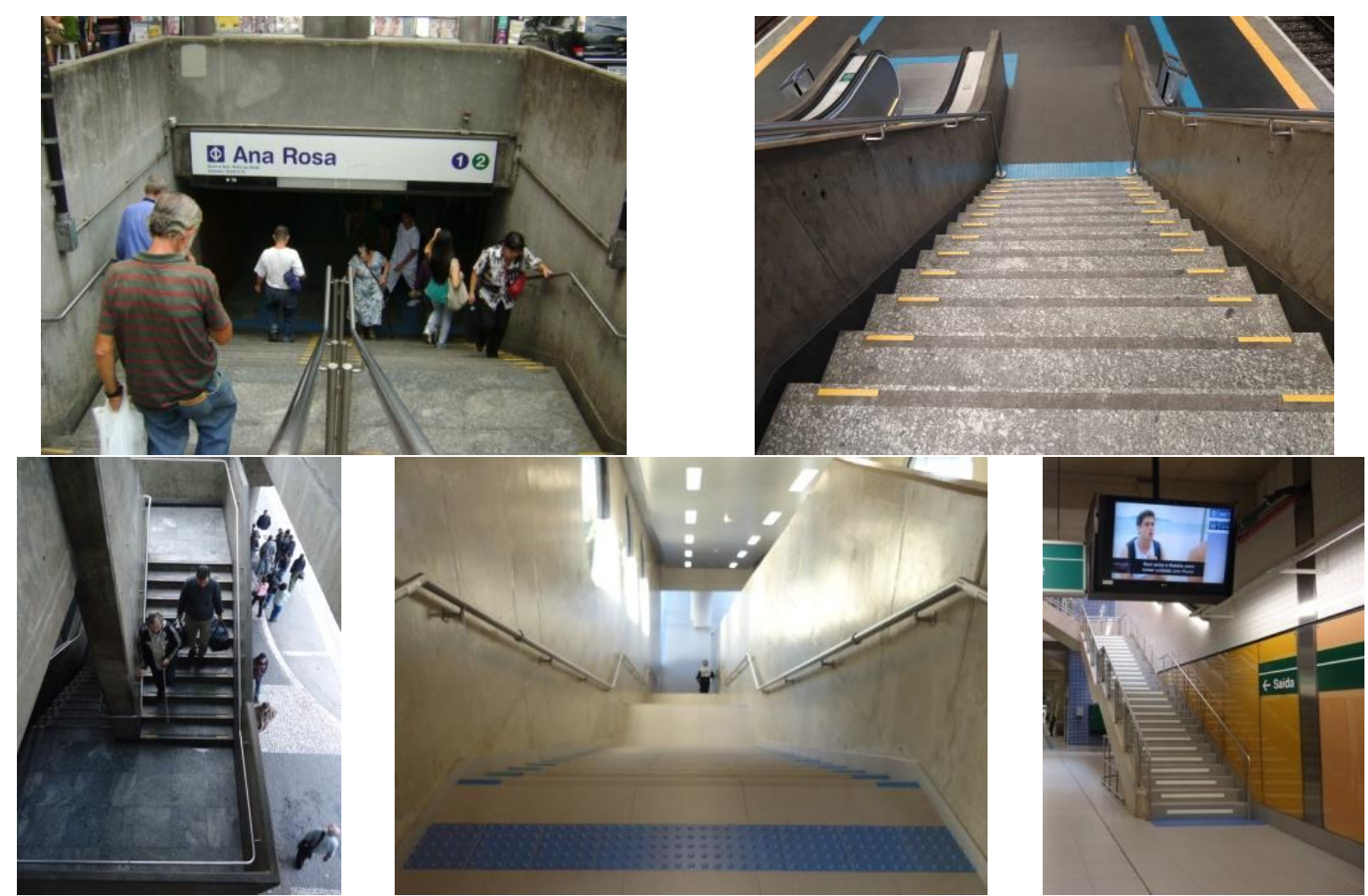

Figura 269 - São Paulo - Escada fixa com corrimão lateral e central, além de sinalização visual e tátil no piso. Fonte: BARBOSA, M.B., 2011.

c) escadas rolantes - dispõem de sinalização tátil nos pavimentos e orientações de uso no equipamento. As novas escadas dispõem ainda de sinalização luminosa indicativa do sentido de deslocamento e de sinalização próxima aos degraus de extremidade, informando o término da escada, conforme apresentado nas (Figuras 270 e 271). Para conferir maior segurança aos usuários no uso das escadas rolantes, foram implementados os seguintes elementos:

- corrimãos/elementos de apoio para possibilitar maior equilíbrio para os usuários na transição entre a parte fixa e a parte móvel, ao entrar ou sair da escada;

- sinalização visual em cor contrastante destacando os limites entre as superfícies fixas e em movimento, além dos limites dos degraus;

- sinalização tátil na lateral dos degraus. 

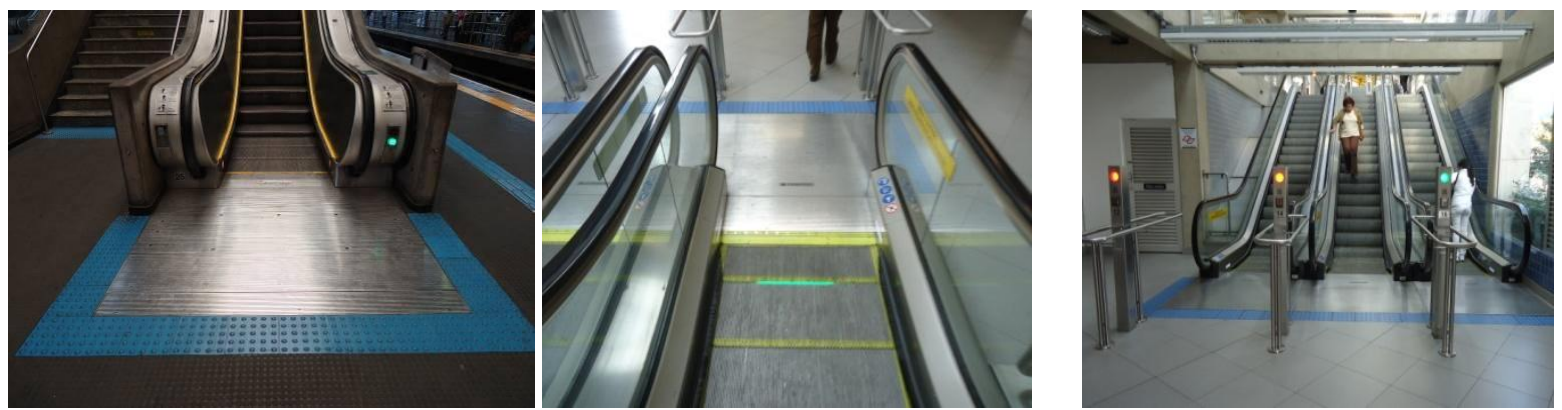

Figura 270 - São Paulo - Escada rolante com sinalização tátil de alerta e sinalização visual indicativa do sentido de deslocamento.

Fonte: BARBOSA, M.B., 2011.
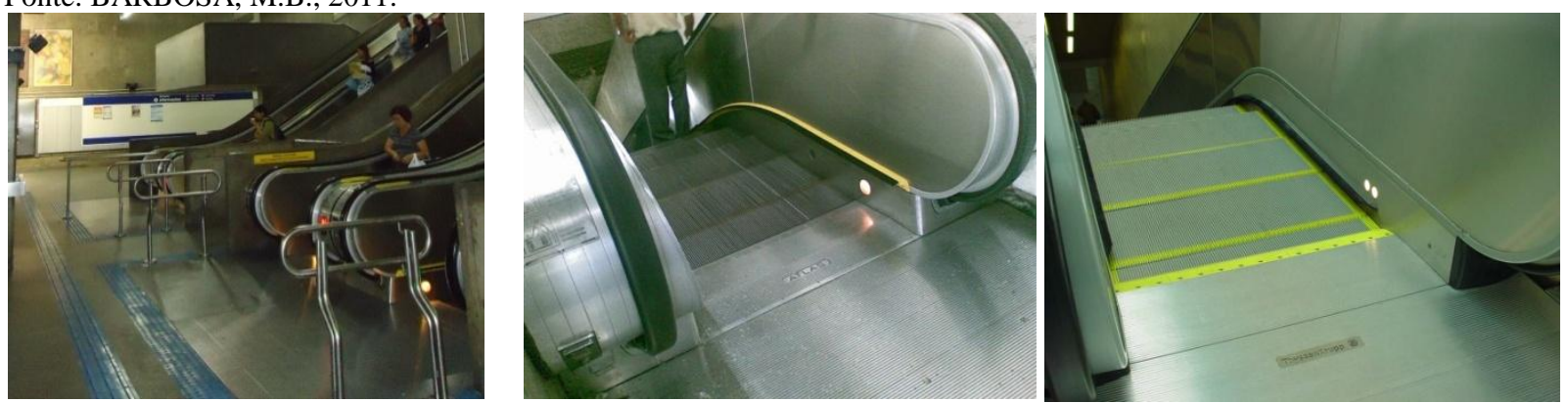

Figura 271 - São Paulo - Escada rolante - elementos de apoio ou reforço de sinalização. Fonte: BARBOSA, M.B., 2011.

d) elevadores - o Metrô de São Paulo dispõe de elevadores de equipamentos com diferentes modelos e, consequentemente, com diferentes formas de acionamento externo e interno em função da tecnologia disponível no período no qual foram adquiridos e instalados. As botoeiras internas dispõem de texto e relevo e sinalização em Braille. Interna e externamente, um intercomunicador possibilita a solicitação de auxílio pelo usuário (Figura 272).
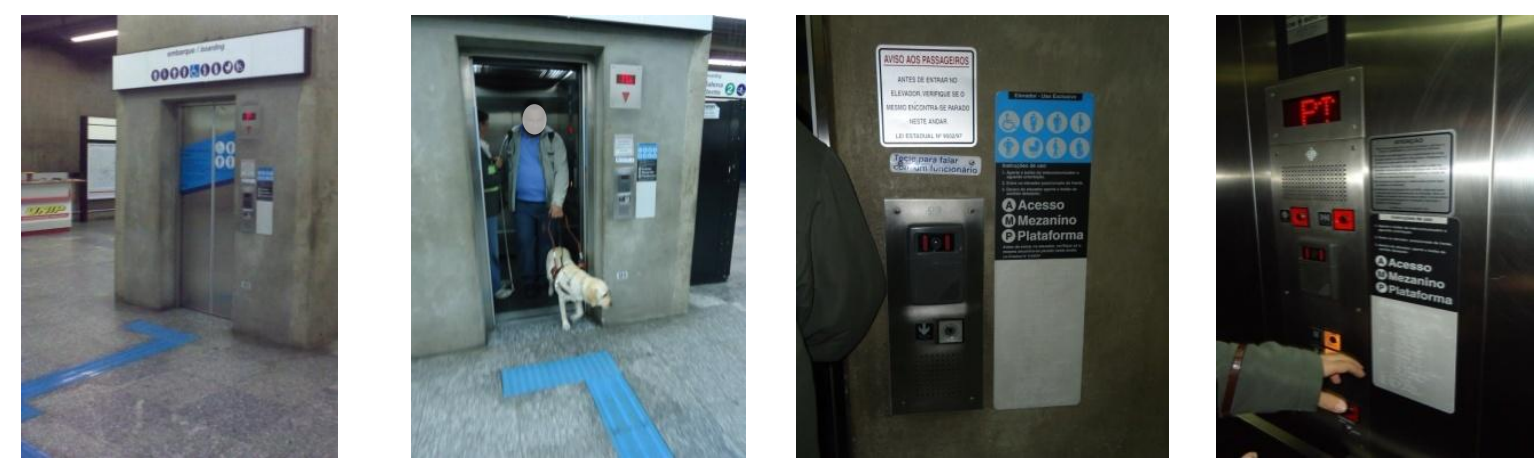

Figura 272 - São Paulo - Sinalização externa e interna dos elevadores.

Fonte: BARBOSA, M.B., 2011.

e) plataformas de elevação vertical - algumas estações dispõem de plataformas verticais que possibilitam a circulação vertical; o acionamento é realizado por meio de uma alavanca que deve ser mantida pressionada até que o equipamento chegue ao pavimento desejado (Figura 273). Externamente, o piso tátil direcional existente 
direciona o fluxo para os elevadores e plataformas verticais, além das escadas fixas, uma vez que todos eles permitem fluxo bidirecional.
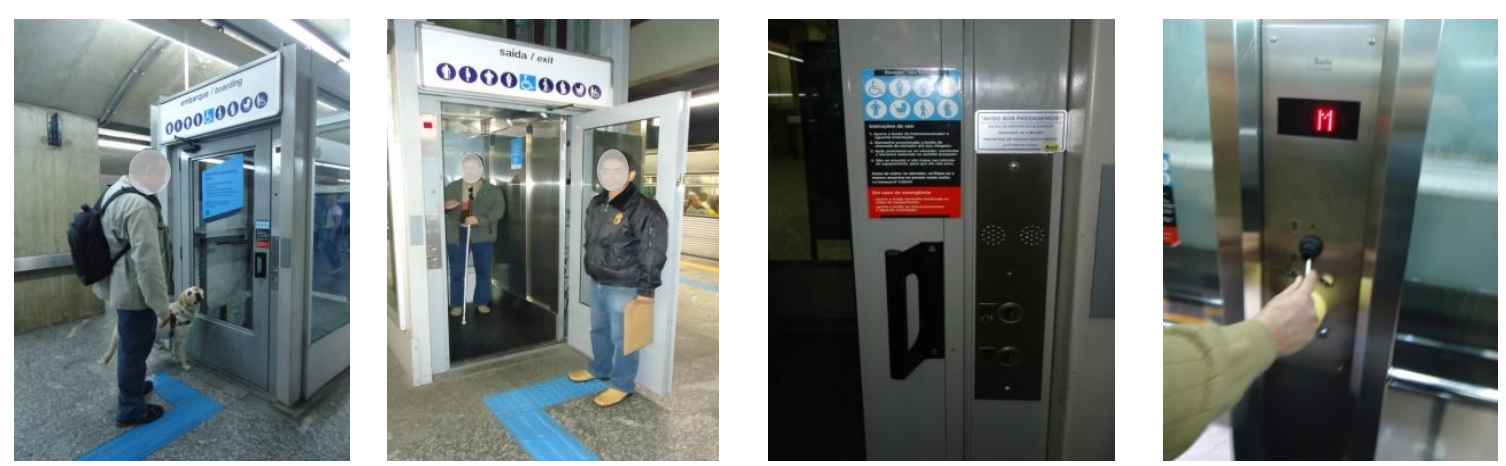

Figura 273 - São Paulo - Sinalização externa e interna das plataformas de elevação. Fonte: BARBOSA, M.B., 2011.

\subsubsection{Avaliação pelos usuários}

Sobre a circulação vertical - sem especificar o local, 64 usuários com deficiência visual - dos quais 42 pessoas são cegas e 22 têm baixa visão - manifestaram seu descontentamento em relação à estação $(100,0 \%)$. Foram registrados 121 relatos, o que representa 4,5\% do total de relatos registrados para todas as etapas da jornada do usuário. Os relatos estão relacionados aos serviços $(36,7 \%)$, às informações $(32,4 \%)$ e à configuração da estação $(30,9 \%)$ - (Tabela $33)$.

Tabela 33 - Matriz de avaliação da etapa 30 - Circulação Vertical - sem especificar o local.

(\% em relação ao total de relatos registrados nesta etapa)

\begin{tabular}{|c|c|c|c|c|}
\hline 工 & $\begin{array}{c}\text { Configuração } \\
(\%)\end{array}$ & $\begin{array}{c}\text { Informação } \\
(\%)\end{array}$ & $\begin{array}{c}\text { Serviço } \\
(\%)\end{array}$ & $\begin{array}{c}\text { Total } \\
(\%)\end{array}$ \\
\hline Estação & (EC) 30,9 & (EI) 32,4 & (ES) 36,7 & 100,0 \\
\hline Interface Trem-Estação & $\mathbf{0 , 0}$ & $\mathbf{0 , 0}$ & $\mathbf{0 , 0}$ & $\mathbf{0 , 0}$ \\
\hline Trem & $\mathbf{0 , 0}$ & $\mathbf{0 , 0}$ & $\mathbf{0 , 0}$ & $\mathbf{0 , 0}$ \\
\hline Total & 30,9 & 32,4 & 36,7 & 100,0 \\
\hline
\end{tabular}

"Eu sinto falta de uma sinalização melhor nos elevadores, os botões não deveriam ser afundados, mas sim saltados com a letra "D" para descer e "S" para subir. Preciso de informação sonora avisando que eu cheguei no andar desejado, porque ainda não uso o braile. A informação em braile, quando existir, deve estar na altura do peito e não abaixo... porque todo mundo leva a mão nesta posição. Acho que os elevadores precisariam ter informações sobre as plataformas e as linhas, em todas as estações, indicando plataforma e saídas. Os elevadores deveriam levar para todos os pavimentos - às vezes eles não levam direto para os bloqueios ou plataformas. Os elevadores são muitos lentos e demoram muito para fechar as porta; e precisariam ter feixe de luz na altura do cão guia para não prendê-lo. As escadas rolantes também deveriam ter informações sonoras ou em braile informando se ela está subindo ou descendo. Melhoraria minha acessibilidade se tivessem escadas rolantes dos dois lados da plataforma, em todas as estações. Minha opinião, que tenho baixa 
visão, é que a faixa de alerta das escadas fixas precisa ser mais larga para eu enxergar... Para eu chegar às estações - ou mesmo sair delas - é melhor ter rampas do que escadas fixas, porque os elevadores quebram sempre. É importante que eu seja respeitado quanto ao equipamento que quero usar: elevador ou escada rolante. Quando o empregado me conduz pela escada rolante, ele quer me colocar na sua frente quando o correto é eu ficar atrás; eles também querem pegar no meu braço quando o certo é o contrário; muitos empregados andam muito rápido e eu tenho que acompanhar o ritmo dele e nem sempre consigo. Sinto falta de treinamento para usar as estações, sei que o piso tátil me direciona para o elevador, mas fico perdido sem saber onde estou. Também não me sinto preparado para usar os elevadores, fico confuso. Para mim é complicado usar as estações em horários de pico, quando as escadas rolantes estão paradas ou invertidas. Acho a plataforma de elevação muito ruim, inadequada quanto ao tamanho, tem que manter a botoeira apertada para chamar, a alavanca acionada para subir e para descer... Os usuários não me respeitam, eles esbarram em mim, querem passar na minha frente e não respeitam o sentido do fluxo. Não dá para andar na estação sem os estagiários. Além disso, não respeitam o uso dos elevadores. Deveria ter um ascensorista que permitisse a entrada apenas dos que têm direito..." (Discurso do Sujeito Coletivo - Etapa 30 - Circulação vertical, sem especificar o local)

Os principais problemas relatados pelos usuários em relação à circulação vertical - sem especificar o local são apresentados de forma hierarquizada, conforme o número de relatos registrados (Gráfico 40). 
Gráfico 40 - Avaliação da circulação vertical - sem especificar o local.

(\% em relação ao total de relatos registrados nesta etapa)

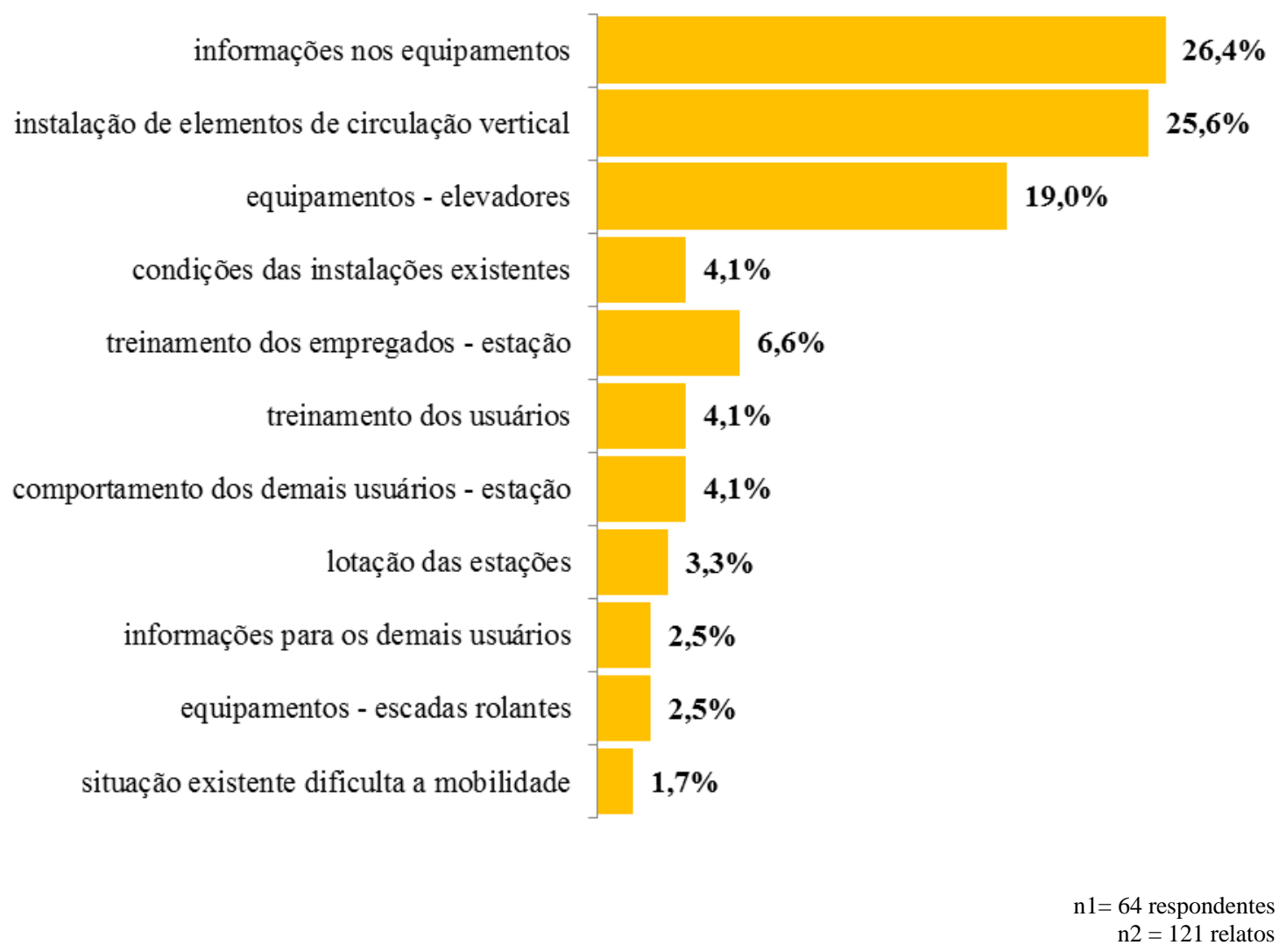

Os problemas relatados estão relacionados às seguintes ideias centrais:

a) informações nos equipamentos (EI4) - relata a inexistência de orientações sonoras e a inadequação da sinalização tátil nos elevadores e a inexistência de informações sonoras e táteis nas escadas rolantes;

b) instalação de elementos de circulação vertical (EC2) - refere-se à falta de elevadores em todos os acessos e de escadas rolantes em todos os lados das plataformas;

c) equipamentos - elevadores (ES9) - refere-se à demora para abrir ou fechar a porta e liberar o equipamento, à demora para consertar o equipamento quando da ocorrência de falhas, ao uso indevido do elevador pelos demais usuários e à falta de detector de presença na altura do cão-guia;

d) condições das instalações existentes (EC3) - refere-se à disposição das escadas rolantes nas estações, que não favorece a compreensão do percurso; 
e) treinamento dos empregados - estação (ES1) - relata a insatisfação em relação à realização de percursos pelo elevador durante o auxílio para deslocamento e ao posicionamento para utilização das escadas rolantes;

f) treinamento dos usuários (ES3) - relata a falta de treinamento dos usuários sobre como proceder para utilizar os elevadores;

g) comportamento dos demais usuários - estação (ES4) - refere-se ao mau comportamento dos usuários na estação, que empurram ou andam na contramão nas escadas;

h) lotação das estações (ES7) - relata a insatisfação em relação à lotação das estações, dificultando os deslocamentos nas escadas fixas e rolantes;

i) informações para os demais usuários (EI7) - refere-se à falta de orientação para os usuários no que tange à utilização das escadas (subir por um lado e descer por outro) para evitar conflitos e acidentes;

j) equipamentos - escadas rolantes (ES10) - refere-se à insatisfação com o desligamento ou com a inversão das escadas rolantes, dificultando a circulação;

k) situação existente dificulta a mobilidade (EC4) - refere-se à dificuldade de utilização das plataformas de elevação existentes nas estações.

\subsubsection{Avaliação pelas pessoas-chave}

Em relação às informações nos equipamentos (EI4), os empregados das estações destacaram que, apesar da orientação visual e tátil disponível nos elevadores e plataformas de elevação, as pessoas com deficiência preferem utilizar o interfone para solicitar informações sobre os equipamentos. A demora e a falta de informação sonora durante o deslocamento causam insatisfação nos usuários, que pressionam insistentemente os intercomunicadores e as botoeiras de chamada. Há muita dificuldade para utilização das plataformas de elevação, pois o usuário não mantém pressionada a alavanca que movimenta o equipamento. Apesar de promoverem, mediante solicitação, o treinamento sobre os recursos disponíveis (ES3), em especial sobre as diferenças de acionamento entre os elevadores e as plataformas de elevação, muitas pessoas esquecem que a porta do elevador abre sozinha, que a porta da plataforma de elevação precisa ser puxada ou empurrada; que a botoeira do elevador deve ser pressionada uma única vez e que a alavanca da plataforma de elevação deve ser mantida acionada. Devido ao uso inadequado - excesso de bagagem, acionamento indevido de dispositivos -, há um 
constante acionamento de atividades para manutenção dos equipamentos - elevadores (ES9).

$\mathrm{Na}$ opinião dos empregados das estações, as informações nos equipamentos (EI4) que são disponibilizadas na forma tátil, visual ou sonora estão bem especificadas. Contudo, a falta de treinamento dos usuários (ES3) e a falta de alfabetização em Braille dificultam a utilização dos dispositivos onde existe esse recurso. Os empregados das estações destacaram a veiculação de informações para a pessoa com deficiência visual - estação (EI6) por meio da emissão de mensagens sonoras, que orientam os usuários a segurar o corrimão das escadas fixas e rolantes. Contudo, ressaltaram a necessidade de realização de campanhas para melhorar o comportamento dos demais usuários - estação (ES4), especialmente em relação ao respeito do atendimento preferencial.

Os profissionais responsáveis pelo programa de capacitação destacaram, entre os temas abordados no treinamento dos empregados - estação (ES1), o oferecimento de ajuda com técnicas apropriadas e orientações para condução individual ou em grupo em planos horizontais, rampas, escadas rolantes, escadas fixas e elevadores. Tais conteúdos permitem que os empregados tenham desenvoltura durante todo o período de atendimento.

Os estagiários relataram que as pessoas com deficiência visual demonstram preferência pelo uso de escadas rolantes, uma vez que este equipamento não demanda esforço, é mais cômodo, mais confortável, dá mais segurança, não tem contrafluxo, é mais rápido, não fica em manutenção, é mais seguro do que o elevador ou a escada fixa e os demais usuários não esbarram ou empurram, além de ser posicionada mais próximo do local de embarque. Em relação aos demais equipamentos, foram feitas as seguintes considerações:

a) escada fixa - tem menos usuários nos horários de pico é mais rápido do que o elevador, os demais usuários esbarram e empurram tornando-a menos segura do que a escada rolante;

b) elevador - é uma opção quando há problema de mobilidade; está sempre em manutenção; o deslocamento é demorado, e a porta demora para fechar, além de ser longe;

c) plataforma de elevação vertical - a alavanca de acionamento é de difícil manuseio.

Durante o atendimento pelos empregados (ES2), os estagiários perguntam às pessoas com deficiência visual sobre sua preferência no deslocamento, especialmente quando não os 
conhecem, quando não são usuários habituais, quando são idosos ou quando há dois tipos de escadas. O questionamento quanto à preferência não é realizado se o usuário declara sua preferência no momento da abordagem, ou quando se trata de um usuário habitual e o estagiário já o conhece. Alguns estagiários não perguntam a preferência do usuário e o conduzem segundo sua própria preferência - ora por escada fixa ora por escada rolante.

Os professores de orientação e mobilidade destacaram, entre as informações nos equipamentos (EI4), a existência de faixas refletivas nos espelhos dos degraus das escadas fixas nas novas estações, fato que proporciona maior funcionalidade da sinalização, notadamente para pessoas com baixa visão (Figura 274).
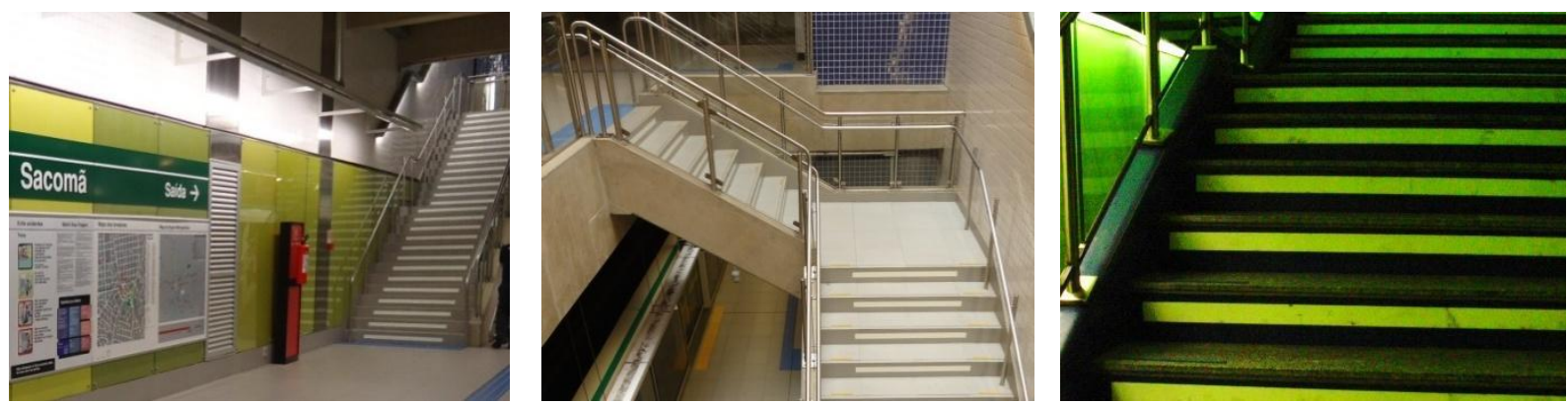

Figura 274 - São Paulo - Sinalização visual de alerta nos espelhos dos degraus. Fonte: BARBOSA, M.B., 2011.

\subsubsection{Avaliação pelos especialistas}

Sobre a circulação vertical - sem especificar o local, os profissionais responsáveis pelos projetos das estações relataram que o fato de o piso tátil - percurso (EI3) orientar os deslocamentos exclusivamente por meio dos elevadores faz com que as pessoas com deficiência visual percam a escala do espaço e a percepção dos referenciais da continuidade do percurso entre ambientes com diferentes condições, fato que não acontece quando tais deslocamentos se dão por meio de escadas fixas ou rolantes, que permitem ao usuário seguir os referenciais do ambiente, como as vozes das pessoas em volta.

Os profissionais responsáveis pela elaboração de normas técnicas relataram a importância de soluções padronizadas relacionadas à configuração, sinalização e iluminação dos elementos e equipamentos característicos do sistema metroferroviário. Entre as soluções que podem contribuir para a segurança e a independência dos deslocamentos em função das condições das instalações existentes (EC3), estão as recomendações para melhoria dos textos normativos vigentes, destacando-se a instalação de elevadores e escadas rolantes entre o 
mezanino e todos os acessos da estação, a melhoria das informações nos equipamentos (EI4) elevadores, escadas rolantes, intercomunicadores, com destaque para a padronização de botoeiras dos elevadores uma vez que há dificuldade de utilização dos elevadores em função da diversidade de comandos dos equipamentos ou da existência de mais de um elevador servindo a diferentes plataformas ou da existência de elevadores com mais de duas paradas. Também foram ressaltadas as condições para veiculação de informações para a pessoa com deficiência visual - estação (EI6), que devem ser claras, objetivas e completas, além de redundantes, para que possam contribuir para que os passageiros alcancem seus destinos com segurança. As referências necessárias para orientar os deslocamentos das pessoas com deficiência visual podem ser criadas a partir de estímulos táteis e sonoros, ou mesmo visuais, desde que adequados aos parâmetros que possibilitem sua percepção por pessoas com baixa visão. Uma vez que a soma dessas referências é mais eficaz do que cada uma isoladamente, para serem mais eficientes e atingirem a diversidade de pessoas com deficiência visual, tais referências devem ser redundantes e integradas.

\subsubsection{Elementos de wayfinding}

Os dados coletados permitem afirmar que os elementos de wayfinding característicos desta etapa são os marcadores e caminhos (Quadro 44). Esses elementos devem ser providos de configuração adequada bem como de sinalização tátil/visual/sonora integrada de forma a facilitar sua identificação por pessoas com deficiência visual e sobressair-se em relação aos demais elementos e informações do ambiente para facilitar sua percepção. Ao mesmo tempo, devem estar presentes e ser ressaltados nas informações veiculadas, especialmente quando da elaboração dos materiais táteis, visuais e sonoros voltados à descrição do ambiente das estações, facilitando a compreensão dos elementos de circulação vertical. 
Quadro 44 - Elementos de wayfinding da Etapa 30 - Circulação vertical.

\begin{tabular}{|c|c|c|c|}
\hline $\begin{array}{l}\text { Elementos de } \\
\text { wayfinding }\end{array}$ & Configuração & Informação & Serviço \\
\hline Marcador & $\begin{array}{l}\text { - localização dos elementos } \\
\text { de circulação vertical } \\
\text { - patamares dos pavimentos } \\
\text { atendidos }\end{array}$ & $\begin{array}{l}\text { - sinalização } \\
\text { tátil/visual/sonora dos } \\
\text { pavimentos atendidos } \\
\text { - sinalização tátil de alerta } \\
\text { dos patamares }\end{array}$ & $\begin{array}{l}\text { - equipamento disponível } \\
\text { - intercomunicador nos } \\
\text { patamares }\end{array}$ \\
\hline Caminho & $\begin{array}{l}\text { - fluxo bidirecional } \\
\text { simultâneo nas escadas } \\
\text { fixas e rampas } \\
\text { - fluxo bidirecional } \\
\text { alternado nos elevadores } \\
\text { - fluxo unidirecional nas } \\
\text { escadas rolantes }\end{array}$ & $\begin{array}{l}\text { - sinalização visual na } \\
\text { lateral dos degraus } \\
\text { - sinalização do sentido de } \\
\text { fluxo das escadas rolantes } \\
\text { - informação sonora sobre } \\
\text { o deslocamento dos } \\
\text { elevadores }\end{array}$ & $\begin{array}{l}\text { - intercomunicador nos } \\
\text { elevadores (área interna) } \\
\text { - treinamento dos usuários } \\
\text { - auxílio no deslocamento }\end{array}$ \\
\hline
\end{tabular}

Fonte: Elaborado pela pesquisadora.

\subsubsection{Síntese do diagnóstico}

Na circulação vertical - sem especificar o local -, foram identificados aspectos que devem ser tratados pelas empresas operadoras dos sistemas metroferroviários para auxiliar pessoas com deficiência visual a estabelecer estratégias para empreender seus deslocamentos:

a) instalação de elementos de circulação vertical (EC2) - disponibilizar elevadores em todos os acessos; disponibilizar escadas rolantes nos dois lados das plataformas;

b) condições das instalações existentes (EC3) - facilitar a compreensão do percurso a partir da localização das escadas rolantes; prover soluções padronizadas relacionadas à configuração, sinalização e iluminação dos elementos e equipamentos do sistema metroferroviário; instalar elevadores e escadas rolantes entre o mezanino e todos os acessos entre o mezanino e as plataformas da estação;

c) situação existente dificulta a mobilidade (EC4) - facilitar a utilização das plataformas de elevação existentes nas estações;

d) piso tátil - percurso (EI3) - orientar os deslocamentos por meio de elevadores, escadas fixas ou rolantes;

e) informações nos equipamentos (EI4) - disponibilizar orientações visuais, sonoras e táteis nos elevadores, plataformas de elevação, escadas rolantes e intercomunicadores; prover informação sonora durante o deslocamento dos equipamentos; prover informações sobre a utilização dos dispositivos de acionamentos dos equipamentos; instalar faixas refletivas nos espelhos dos degraus das escadas fixas; padronizar os dispositivos de comando dos elevadores; 
f) informações para a pessoa com deficiência visual - estação (EI6) - veicular mensagens sonoras orientando sobre a utilização do corrimão das escadas fixas e rolantes; disponibilizar informações claras, objetivas, completas, integradas e redundantes a partir de estímulos visuais, táteis e sonoros;

g) informações para os demais usuários (EI7) - prover orientação para os usuários sobre a utilização das escadas (subir por um lado e descer por outro) para evitar conflitos e acidentes;

h) treinamento dos empregados - estação (ES1) - respeitar o livre arbítrio e a opção de uso dos elementos de circulação vertical durante o auxílio nos deslocamentos; melhorar a orientação quanto ao posicionamento para auxílio durante utilização das escadas rolantes; oferecer ajuda com técnicas apropriadas durante a condução individual ou em grupo em planos horizontais, rampas, escadas rolantes, escadas fixas e elevadores para que os empregados tenham desenvoltura durante o atendimento;

i) atendimento pelos empregados (ES2) - perguntar a preferência do usuário em relação ao uso de escadas fixas, rolantes ou elevadores durante o deslocamento;

j) treinamento dos usuários (ES3) - treinar os usuários para utilização dos elevadores e plataformas de elevação, em especial sobre as diferenças de acionamento dos dispositivos desses equipamentos; acrescentar informações/orientações além das já existentes em Braille;

k) comportamento dos demais usuários - estação (ES4) - promover campanhas para orientar o comportamento dos demais usuários nas estações para prestar atenção e respeitar o atendimento e o deslocamento preferencial das pessoas com deficiência visual sem empurrar ou andar na contramão nas escadas;

1) lotação das estações (ES7) - organizar o fluxo de usuários nas escadas fixas e rolantes facilitando o deslocamento com independência das pessoas com deficiência visual nos horários de maior movimento;

m) equipamentos - elevadores (ES9) - agilizar a abertura e o fechamento das portas, a liberação do equipamento, a manutenção do equipamento quando da ocorrência de falhas; instalar detector de presença na altura do cão-guia; disciplinar o uso do elevador pelos demais usuários; disciplinar o transporte de bagagem; minimizar o uso ou o acionamento indevidos, que resultam em manutenção excessiva;

n) equipamentos - escadas rolantes (ES10) - evitar o desligamento ou a inversão das escadas rolantes, facilitando a compreensão do percurso de circulação. 


\subsection{Etapa 40 - Circulação horizontal na estação - sem especificar o local}

Refere-se ao deslocamento dos usuários nos acessos, mezaninos e plataformas, envolvendo diferentes etapas da jornada do usuário, a saber: acesso à estação (etapa 3), deslocamento no mezanino área livre (etapas 5 e 20), no mezanino área paga (etapas 8 e 18), até o local de embarque (etapa 10), até a saída da plataforma (etapa 16) e até a saída da estação (etapa 22). Em algumas situações, cabe ao usuário optar por diferentes plataformas, diferentes saídas ou fazer a conexão com outras linhas de metrô ou de trem. Foram classificadas nessa condição situações em que o usuário manifestou seu descontentamento em relação ao deslocamento na estação, sem ter especificado o local ou etapa onde tal problema foi vivenciado.

\subsubsection{Métodos e técnicas aplicados}

Os métodos e técnicas utilizados para coleta de dados foram apresentados no item 6.10 Síntese dos instrumentos aplicados - e consistiram em:

a) identificação de melhores práticas em outros sistemas metroferroviários;

b) pesquisa documental (normas técnicas ABNT vigentes, desenhos, procedimentos operacionais);

c) checklist dos recursos disponíveis e walkthrough realizado nas estações para compreensão dos percursos de embarque e desembaque;

d) questionário aplicado a pessoas com deficiência visual - questões 12, 13 e 17;

e) entrevista com empregados das estações;

f) entrevista com estagiários que auxiliam pessoas com deficiência visual;

g) entrevista com professores de orientação e mobilidade;

h) entrevista com profissionais responsáveis pelos projetos das estações;

i) entrevista com profissionais responsáveis pela elaboração de normas técnicas.

As formas de análise e interpretação dos dados coletados foram apresentadas no Capítulo 6 Aplicação dos instrumentos.

\subsubsection{Melhores Práticas}

As melhores práticas verificadas para auxiliar os deslocamentos horizontais nas estações foram relatadas nos itens 7.3, 7.5, 7.8, 7.10, 7.16, 7.18, 7.20 e 7.22 e estão relacionadas à 
disponibilização de informação tátil, sonora e visual para facilitar a compreensão dos percursos de embarque e desembarque e auxiliar os deslocamentos.

\subsubsection{Avaliação pelos usuários}

Sobre o deslocamento horizontal na estação - sem especificar o local, 145 usuários com deficiência visual - dos quais 111 pessoas são cegas e 34 pessoas têm baixa visão manifestaram seu descontentamento em relação à estação (100,0\%). Foram registrados 425 relatos, o que representa $15,9 \%$ do total de relatos registrados para todas as etapas da jornada do usuário. Os relatos estão, em sua maioria, relacionadas às informações prestadas na estação $(79,1 \%)$, mas também referem-se aos serviços prestados na estação $(16,8 \%)$ e à configuração da estação $(4,1 \%)$ - (Tabela 34).

Tabela 34 - Matriz de avaliação da etapa 40 - Circulação horizontal na estação - sem especificar o local.

(\% em relação ao total de relatos registrados nesta etapa)

\begin{tabular}{l|r|r|r|r}
\hline & $\begin{array}{c}\text { Configuração } \\
\text { \% }\end{array}$ & $\begin{array}{c}\text { Informação } \\
\%\end{array}$ & $\begin{array}{c}\text { Serviço } \\
\%\end{array}$ & $\begin{array}{c}\text { Total } \\
\%\end{array}$ \\
\hline Estação & (EC) $\mathbf{4 , 1}$ & (EI) 79,1 & (ES) $\mathbf{1 6 , 8}$ & $\mathbf{1 0 0 , 0}$ \\
\hline Interface Trem-Estação & $\mathbf{0 , 0}$ & $\mathbf{0 , 0}$ & $\mathbf{0 , 0}$ & $\mathbf{0 , 0 0}$ \\
\hline Trem & $\mathbf{0 , 0}$ & $\mathbf{0 , 0}$ & $\mathbf{0 , 0}$ & $\mathbf{0 , 0 0}$ \\
\hline Total & $\mathbf{4 , 1}$ & $\mathbf{7 9 , 1}$ & $\mathbf{1 6 , 8}$ & $\mathbf{1 0 0 , 0}$ \\
\hline
\end{tabular}

"Eu não sei usar o piso tátil, não entendo para onde ele está levando e, como tem muitas ramificações, fico mais perdido. Ele deve ir de forma mais reta para o bloqueio, o embarque preferencial e a saída... Para eu poder usar o piso tátil com autonomia precisaria ter sinalizações indicando se o piso está levando para escada fixa, para o bloqueio ou para o elevador. Muitas vezes acabam em um piso de alerta - mas não dá para saber o que vem a seguir - ou acaba pela metade, sem indicar se eu tenho que ir para direita ou para esquerda. $O$ piso tátil não está ajudando em nada. O piso tátil tem que levar para escada rolante e não apenas para a escada fixa ou para o elevador porque o percurso é menor. E também é uma forma de tratar o deficiente visual como um usuário comum. Enfim, precisa percorrer toda a estação porque, na verdade, ele não leva para onde preciso ir e como tem as ramificações sem sinalização para onde está indo, ou acaba em algum lugar que não me atende, eu não consigo me locomover sozinho, fica difícil decorar o trajeto. Eu que tenho baixa visão tenho dificuldade de enxergar o piso tátil porque a cor é pouco contrastante com a do piso. Ele precisa ser mais largo para ficar mais fácil de não perder a direção. Tem estações que quando eu bato a bengala, não consigo captá-lo, pois a vibração difere pouco da do piso comum. A sua canalização precisaria segurar melhor a ponta da bengala, deveria ser como um trilho de trem para a bengala deslizar livremente e não ficar presa nas emendas. O alto relevo do piso tátil pode me levar a torcer o pé, se eu pisar em cima dele. É necessário adequar o piso tátil em todas as estações, colocar aonde não tem e não acabar de repente como acontece em muitos locais e, no caso das escadas, não terminar no corrimão central porque eu 
posso me machucar. Em algumas estações, o piso tátil me leva para alguns obstáculos - como colunas e muretas ou paredes - e eu fico perdido. Outro problema que encontro é que na sua colocação não foi considerado o fluxo normal das pessoas: quando eu uso o piso tátil, eu esbarro em outros usuários. Os desvios do piso tátil são de 90 graus e atravessa o fluxo normal das pessoas. Para que eu possa usar o piso tátil, ele precisaria ser padronizado em todas as estações. Em cada estação ele está colocado de um jeito: às vezes em um piso, está no meio da escada e quando ela termina, no outro piso, está diferente... aí fica difícil. Seria melhor se tivesse corrimãos que eu pudesse usar para me locomover na estação ou se tivesse um mapa em braile que descrevesse toda a configuração das estações. São coisas que me ajudariam bastante... Mas para quem ficou cego mais recentemente, a informação sonora é mais importante. Além desses pontos que melhorariam a minha acessibilidade, o desrespeito dos outros usuários complica ainda mais a minha vida. O povo é muito ignorante e por isso não dá para andar sem auxílio. Os usuários me empurram e trombam em mim, chutam a minha bengala, pisam e ficam parados em cima do piso tátil. Nas estações mais movimentadas o desrespeito é maior. O Metrô precisa orientar os usuários comuns para que respeitem os deficientes visuais, não usando o piso tátil, não embarcando na área preferencial, enfim, não usando os equipamentos destinados as pessoas com deficiência." (Discurso do Sujeito Coletivo - Etapa 40 - Circulação Horizontal, sem especificar o local)

Os principais problemas relatados pelos usuários em relação ao deslocamento na estação sem especificar o local - são apresentados no Gráfico 41, de forma hierarquizada, conforme número de relatos registrados.

Gráfico 41 - Avaliação do deslocamento horizontal na estação - sem especificar o local.

(\% em relação ao total de relatos registrados nesta etapa)

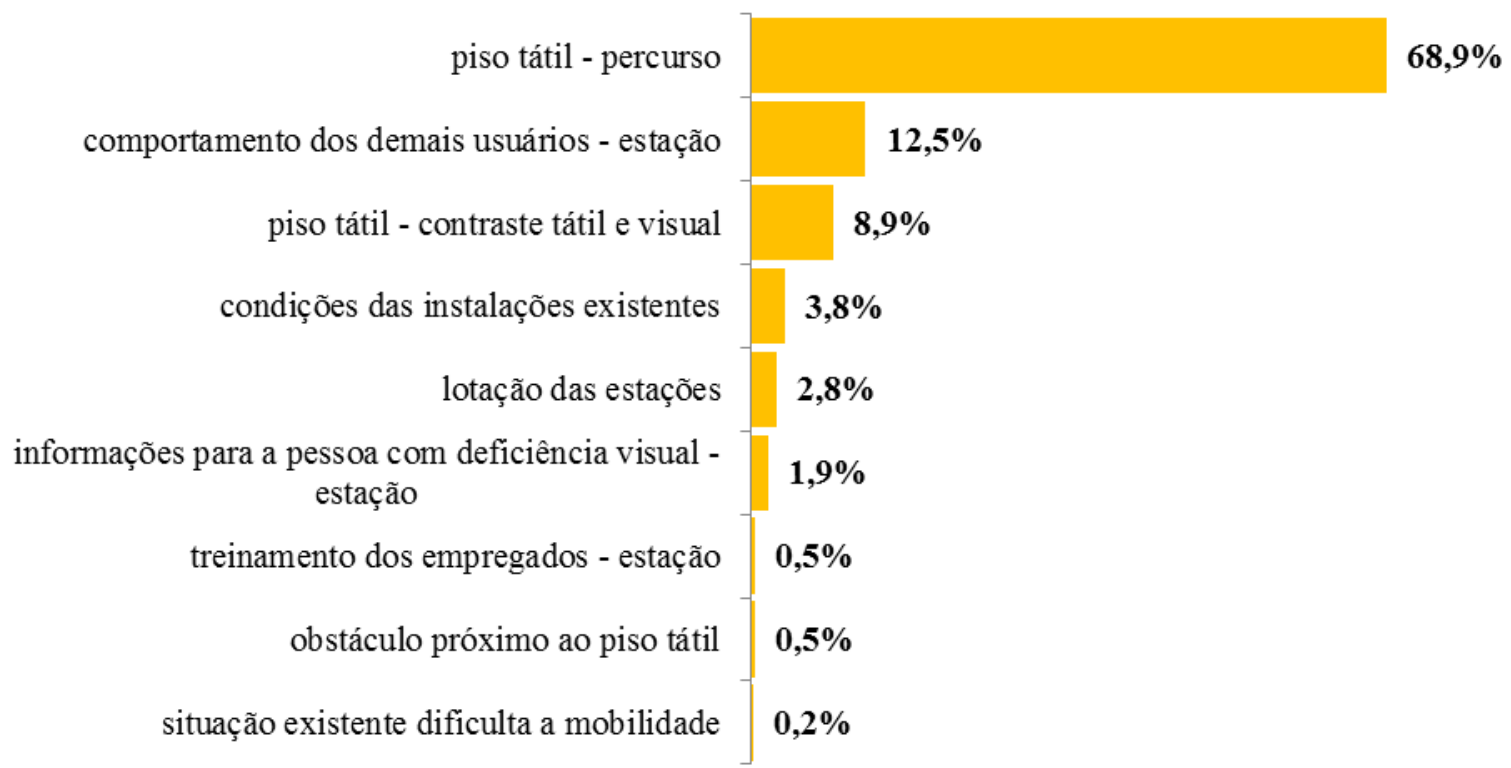

$\mathrm{n} 1=145$ respondentes $\mathrm{n} 2=425$ relatos 
Os problemas relatados estão relacionados às seguintes ideias centrais:

a) piso tátil - percurso (EI3) - relata a insatisfação decorrente de o piso tátil não orientar o percurso para as escadas fixas e rolantes, não levar para todos os equipamentos e serviços oferecidos na estação e não considerar ou ser igual ao fluxo dos demais usuários. Destaca a dificuldade de compreensão do caminho e das mudanças de direção e a proximidade do piso tátil em relação aos obstáculos da edificação - pilares, paredes. Reclama do fato de a sinalização tátil junto às escadas e rampas direcionar ora para o corrimão central ora para o lateral, confundindo o usuário;

b) comportamento dos demais usuários - estação (ES4) - refere-se ao mau comportamento do usuário na estação, sempre com pressa, empurrando e tropeçando nas bengalas ou obstruindo a passagem;

c) piso tátil - contraste tátil e visual (EI1) - refere-se à falta de contraste entre o piso tátil, o piso da estação e os obstáculos, à largura insuficiente da sinalização direcional e à inadequação do material emborrachado, dificultando o deslizamento da bengala;

d) condições das instalações existentes (EC3) - refere-se à falta de padronização da configuração das estações, dificultando a compreensão e memorização dos percursos. Relata a existência de mobiliário suspenso (lixeiras), que dificulta a detecção com a bengala e a ausência de câmeras de monitoramento para auxílio imediato pelos empregados. Destaca a inexistência de sanitários e ar condicionado nas estações.

e) lotação das estações (ES7) - relata a dificuldade de utilização do piso tátil em função da lotação das estações;

f) informações para a pessoa com deficiência visual - estação (EI6) - relata a falta de mapas táteis com descrição sonora, a falta de informações sonoras ao longo do trajeto, orientando sobre a configuração e os percursos e a inexistência de contraste dos obstáculos. Ressalta a insuficiência do contraste e das dimensões das informações visuais;

g) treinamento dos empregados - estação (ES1) - refere-se à necessidade de auxílio dos empregados em função da complexidade das estações;

h) obstáculo próximo ao piso tátil (ES5) - refere-se ao posicionamento inadequado dos direcionadores de fila próximo ou mesmo sobre o piso tátil pelos próprios empregados das estações; 
i) situação existente dificulta a mobilidade (EC4) - refere-se à execução de obras na estação, obstruindo ou interrompendo a sinalização do piso tátil.

\subsubsection{Avaliação pelas pessoas-chave}

Sobre o deslocamento horizontal na estação - sem especificar o local, os empregados das estações destacam a lotação das estações (ES7), gerando conflitos e cruzamentos de fluxo, principalmente junto às escadas das estações de conexão entre diferentes linhas. Tais conflitos são agravados pela chegada simultânea de trens e pela inexistência de escadas rolantes. Sobre o comportamento dos demais usuários da estação (ES4), os empregados das estações enfatizam a necessidade de promover campanhas de conscientização, de forma a orientá-los quanto à finalidade do piso tátil e quanto ao respeito do atendimento preferencial.

Na opinião dos empregados das estações, as informações nos equipamentos (EI4), que são disponibilizadas na forma tátil, visual ou sonora, estão bem especificadas. São veiculadas informações para a pessoa com deficiência visual - estação (EI6) por meio da emissão de mensagens sonoras, orientando-as a não ultrapassar a faixa de alerta amarela na plataforma. Contudo, a falta de treinamento dos usuários (ES3) e a falta de alfabetização em Braille dificultam a utilização dos dispositivos existentes nas estações (bloqueios, interfones, intercomunicadores).

Os empregados das estações consideraram que o índice de utilização do piso tátil é muito baixo. Entretanto, entendem que a garantia de segurança nos deslocamentos somente se dará a partir da instalação das portas nas plataformas, condição na qual os empregados e estagiários poderão, gradativamente, promover o treinamento dos usuários (ES3) para que ganhem confiança e tenham independência em seus deslocamentos. Para tanto, sugerem a realização do treinamento dos usuários nos finais de semana, em uma estação pré-determinada, com horário pré-agendado.

Os estagiários relataram o mau comportamento dos demais usuários - estação (ES4), mais especificamente em relação ao desrespeito vivenciado durante os deslocamentos pela estação em função da lotação, da pressa, da distração e das atitudes individualistas por parte dos usuários, que, mesmo sem querer, esbarram, machucam, tropeçam e danificam as bengalas dos usuários com deficiência visual. O deslocamento com auxílio dos estagiários ou dos empregados é visto como garantia de segurança por causa da lotação e da falta de atenção por 
parte dos demais usuários, que acabam esbarrando e, às vezes, machucando as pessoas com deficiência visual.

\subsubsection{Avaliação pelos especialistas}

Os profissionais responsáveis pelos projetos das estações relataram que projetam espaços para fluxos e que, portanto, se configuram em situações mutantes de ocupação, decorrentes do deslocamento constante de pessoas. Sobre as condições das instalações existentes (EC3), destacam que a evolução das premissas de projeto resultou em ambientes diversificados: confinados ou abertos, segregados ou sobrepostos, com fechamentos e contenções com muretas ou vidros, mais legíveis ou menos legíveis, respectivamente. Espaços amplos impõem a existência de informações para a pessoa com deficiência visual - estação (EI6) por meio de sinalização complementar - tátil, visual, sonora. Por sua vez, a sinalização com piso tátil - percurso (EI3) na escala implantada no Metrô de São Paulo implica treinamento dos usuários (ES3), mesmo daqueles que já passaram por programas de capacitação em O\&M, para reaprender a utilizar a nova referência, uma vez que os percursos foram alterados.

Ainda em relação às condições das instalações existentes (EC3), os profissionais responsáveis pela elaboração das normas técnicas relataram que as soluções padronizadas relacionadas à configuração, sinalização e iluminação dos ambientes característicos do sistema metroferroviário contribuem para prover segurança, autonomia e agilidade nos deslocamentos. Entre as soluções que podem contribuir para a segurança e a independência dos deslocamentos em função das condições das instalações existentes (EC3), estão as recomendações para melhoria dos textos normativos vigentes, destacando o estabelecimento de condições adequadas para execução de obras e serviços, garantindo uma rota acessível para embarque e a existência de contraste entre pisos, paredes, portas, corrimãos e painéis de informação da estação. As informações para a pessoa com deficiência visual - estação (EI6) devem ser claras, objetivas e completas, além de redundantes, para que as orientações operacionais e institucionais sobre os serviços ofertados (comércio, exposições, espaços institucionais) possam contribuir para que os passageiros alcancem seus destinos com segurança. As referências necessárias para orientar os deslocamentos das pessoas com deficiência visual podem ser criadas a partir de estímulos táteis e sonoros, ou mesmo visuais, desde que adequados aos parâmetros que possibilitem sua percepção por pessoas com baixa visão. Uma vez que a soma dessas referências é mais eficaz do que cada uma isoladamente, 
para serem mais eficientes e atingirem a diversidade existente no segmento de pessoas com deficiência visual, tais referências devem ser redundantes e integradas.

\subsubsection{Elementos de wayfinding}

Os dados coletados permitem afirmar que os elementos de wayfinding característicos da circulação horizontal - sem especificar o local - são os seguintes: caminhos, limites, marcadores, nós e zonas (Quadro 45). Esses elementos devem ser providos de configuração adequada bem como de sinalização tátil/visual/sonora integrada de forma a facilitar sua identificação por pessoas com deficiência visual e sobressair-se em relação aos demais elementos e informações do ambiente para facilitar sua percepção.

Quadro 45 - Elementos de wayfinding da Etapa 40 - Circulação horizontal.

\begin{tabular}{|c|c|c|c|}
\hline $\begin{array}{l}\text { Elementos } \\
\text { de } \\
\text { wayfinding }\end{array}$ & Configuração & Informação & Serviço \\
\hline Caminhos & $\begin{array}{l}\text { Percurso entre } \\
\text { - o acesso da estação e os } \\
\text { elementos de circulação } \\
\text { vertical } \\
\text { - os elementos de circulação } \\
\text { vertical e os bloqueios, } \\
\text { bilheterias ou máquinas de } \\
\text { autoatendimento } \\
\text { - os bloqueios e os elementos } \\
\text { de circulação vertical } \\
\text { - os elementos de circulação } \\
\text { vertical e o local de } \\
\text { embarque na plataforma } \\
\text { - o local de desembarque e a } \\
\text { circulação vertical para } \\
\text { saída ou conexão } \\
\text { - os elementos de circulação } \\
\text { vertical e os bloqueios de } \\
\text { saída; } \\
\text { - os bloqueios de saída e os } \\
\text { elementos de circulação } \\
\text { vertical } \\
\text { - os elementos de circulação } \\
\text { vertical e a saída da estação } \\
\end{array}$ & $\begin{array}{l}\text { - tátil, sonora e visual sobre a } \\
\text { configuração e o percurso, } \\
\text { considerando a opção de } \\
\text { destino, as opções de saída } \\
\text { ou de conexão, o percurso } \\
\text { de saída em relação ao } \\
\text { entorno }\end{array}$ & $\begin{array}{l}\text { - treinamento dos usuários } \\
\text { - funcionários para auxiliar o } \\
\text { deslocamento }\end{array}$ \\
\hline Limites & $\begin{array}{l}\text { - limite da plataforma } \\
\text { - portas de fechamento da } \\
\text { plataforma }\end{array}$ & $\begin{array}{l}\text { - sinalização tátil/visual da } \\
\text { borda da plataforma }\end{array}$ & $\begin{array}{l}\text { - gestão do desembarque } \\
\text { preferencial } \\
\text { - campanhas sobre o } \\
\text { atendimento preferencial }\end{array}$ \\
\hline Marcadores & $\begin{array}{l}\text { - elementos de circulação } \\
\text { vertical } \\
\text { - bilheterias ou máquinas de } \\
\text { autoatendimento } \\
\text { - bloqueios }\end{array}$ & $\begin{array}{l}\text { - sinalização } \\
\text { tátil/visual/sonora dos } \\
\text { equipamentos e elementos }\end{array}$ & - treinamento dos usuários \\
\hline
\end{tabular}


Continuação.

\begin{tabular}{|c|c|c|c|}
\hline Nós & $\begin{array}{l}\text { Intersecção entre percursos: } \\
\text { - a partir de diferentes acessos } \\
\text { - a partir da conexão entre } \\
\text { diferentes linhas } \\
\text { - de embarque para diferentes } \\
\text { plataformas } \\
\text { - para conexão entre linhas } \\
\text { - para diferentes saídas }\end{array}$ & $\begin{array}{l}\text { - sinalização tátil/visual das } \\
\text { opções de percurso }\end{array}$ & $\begin{array}{l}\text { - treinamento dos usuários } \\
\text { - auxílio no deslocamento }\end{array}$ \\
\hline Zonas & $\begin{array}{l}\text { - superfície da área de } \\
\text { circulação no mezanino - } \\
\text { área paga } \\
\text { - superfície da área de } \\
\text { circulação no mezanino - } \\
\text { área livre; }\end{array}$ & $\begin{array}{l}\text { - contraste visual entre } \\
\text { superfícies horizontais, } \\
\text { verticais e equipamentos da } \\
\text { estação }\end{array}$ & $\begin{array}{l}\text { - treinamento dos usuários } \\
\text { - auxílio no deslocamento } \\
\text { - gestão de fluxos }\end{array}$ \\
\hline
\end{tabular}

Fonte: Elaborado pela pesquisadora.

\subsubsection{Síntese do diagnóstico}

Na circulação horizontal - sem especificar o local, foram identificados aspectos que devem ser tratados pelas empresas operadoras dos sistemas metroferroviários para auxiliar pessoas com deficiência visual a estabelecer estratégias para empreender seus deslocamentos:

a) condições das instalações existentes (EC3) - padronizar a configuração das estações, facilitando a compreensão e memorização dos percursos; evitar a instalação de mobiliário suspenso (lixeiras), difícil de detectar com a bengala de rastreamento; instalar câmeras de monitoramento para agilizar o auxílio pelos empregados; prover sanitários; instalar ar condicionado nas estações; privilegiar ambientes mais legíveis - confinados/segregados, com muretas ou vidros; padronizar a configuração, sinalização e iluminação dos ambientes; estabelecer condições adequadas para execução de obras e serviços; garantir uma rota acessível para embarque; garantir contraste entre pisos, paredes e painéis de informação;

b) situação existente dificulta a mobilidade (EC4) - refere-se à execução de obras na estação, obstruindo ou interrompendo a sinalização do piso tátil;

c) piso tátil - contraste tátil e visual (EI1) - garantir contraste entre o piso tátil e o piso da estação; redimensionar a largura da sinalização direcional; evitar a utilização de material emborrachado por dificultar o deslizamento da bengala;

d) piso tátil - percurso (EI3) - direcionar para as escadas fixas e rolantes; instalar piso tátil direcional em todos os equipamentos e serviços oferecidos na estação; considerar ou ser igual ao fluxo dos demais usuários; melhorar a compreensão 
sobre o caminho; aumentar a área de sinalização tátil de alerta nas interseções entre pisos direcionais; manter distanciamento do piso tátil em relação aos obstáculos existentes (colunas, pilares, paredes); padronizar a sinalização direcional junto ao corrimão das escadas; instalar portas nas plataformas para garantir a segurança nos deslocamentos;

e) informações nos equipamentos (EI4) - instalar informação tátil, visual ou sonora nos equipamentos e dispositivos acionados pelos usuários;

f) informações para a pessoa com deficiência visual - estação (EI6) - prover mapas táteis, informações e descrições sonoras para orientar os percursos, permitindo informações em igualdade de condições com os demais usuários; instalar sinalização complementar - tátil, visual, sonora - em espaços amplos; privilegiar informações com caracteres em relevo em substituição ao Braille nos dispositivos e equipamentos; prover informações e orientações operacionais e institucionais claras, objetivas, completas e redundantes sobre os serviços ofertados (comércio, exposições, espaços institucionais); garantir contraste visual dos obstáculos, equipamentos, mobiliário; aumentar o contraste e as dimensões das informações visuais; emitir mensagens sonoras para usuários não ultrapassarem a faixa amarela de alerta; criar referências e estímulos táteis, visuais e sonoras integrados que possibilitem sua percepção por pessoas com baixa visão;

g) treinamento dos empregados - estação (ES1) - treinar os empregados em função da complexidade das estações;

h) treinamento dos usuários (ES3) - treinar os usuários para utilização do piso tátil; oferecer treinamento pelos empregados e estagiários em estações em datas e horários pré-agendados após a instalação das portas nas plataformas; viabilizar programas de capacitação para utilizar novas referências quando os percursos forem alterados;

i) comportamento dos demais usuários - estação (ES4) - promover campanhas de conscientização de forma a orientá-los a não andar ou permanecer sobre o piso tátil, não empurrar, não esbarrar ou tropeçar na bengala dos usuários com deficiência visual, e atentar e respeitar o atendimento e o deslocamento preferencial e facilitar o deslocamento das pessoas com deficiência visual, seja com independência ou com auxílio; 
j) obstáculo próximo ao piso tátil (ES5) - posicionar os direcionadores de fila a uma distância segura do piso tátil;

k) lotação das estações (ES7) - organizar o fluxo de usuários nas estações, nos horários de maior movimento, principalmente junto às escadas das estações de conexão entre diferentes linhas.

\subsection{Considerações sobre o capítulo}

Este capítulo apresentou o diagnóstico de cada uma das etapas da jornada do usuário. Foram inicialmente apresentados os métodos e técnicas utilizados para elaboração do diagnóstico de cada uma das etapas. Em seguida foram apresentadas as melhores práticas em uso por outros sistemas metroferroviários, possibilitando conhecer formas de solucionar as dificuldades das pessoas com deficiência visual específicas dessa etapa. Na sequência, destacam-se os requisitos normativos aplicáveis a partir das recomendações vigentes. A situação existente no Metrô de São Paulo vem em seguida, ilustrando situações e cenas presenciadas pela pesquisadora durante a aplicação dos instrumentos nas estações bem como procedimentos vigentes no Metrô de São Paulo. Apresenta-se, então, os dados coletados a partir dos instrumentos aplicados nos usuários, pessoas-chave, especialistas e ambientes do sistema metroferroviário, já classificados em função da matriz de avaliação da acessibilidade e das ideias centrais identificadas. Os elementos de wayfinding - identificados a partir das informações apresentadas - são relatados na sequência, classificados segundo a matriz de avaliação da acessibilidade. A final de cada etapa, apresenta-se uma síntese do diagnóstico.

O questionário aplicado nos usuários com deficiência visual possibilitou identificar a percepção da qualidade do serviço ofertado pelo Metrô de São Paulo e, consequentemente, os pontos para melhoria relacionados ao ambiente, às pessoas e aos processos envolvidos na experiência do usuário durante seus deslocamentos no sistema metroferroviário.

O questionário aplicado nos usuários com deficiência visual também possibilitou identificar quais são os pontos que impactam de forma negativa na percepção do usuário. Os resultados refletem os pontos críticos identificados pelos usuários. A análise dos resultados obtidos em cada etapa permite afirmar que há maior descontentamento nas etapas relacionadas ao deslocamento na estação $(72,7 \%)$, seguida pelas etapas que ocorrem no interior do trem $(20,1 \%)$ e, por último, representando menor descontentamento, as etapas que ocorrem na interface trem-estação $(7,2 \%)$. Em relação aos temas pesquisados, observa-se que o maior 
descontentamento está relacionado à gestão do serviço prestado $(43,9 \%)$ seguido pelo descontentamento em relação à gestão das informações. A configuração das instalações concentra o menor descontentamento por parte dos usuários. - (Gráfico 42).

Gráfico 42 - Aspectos críticos apontados pelos usuários com deficiência visual.

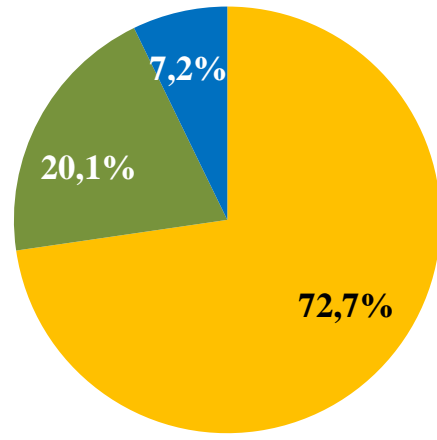

$\square$ estação $\square$ interface trem-estação $\square$ trem

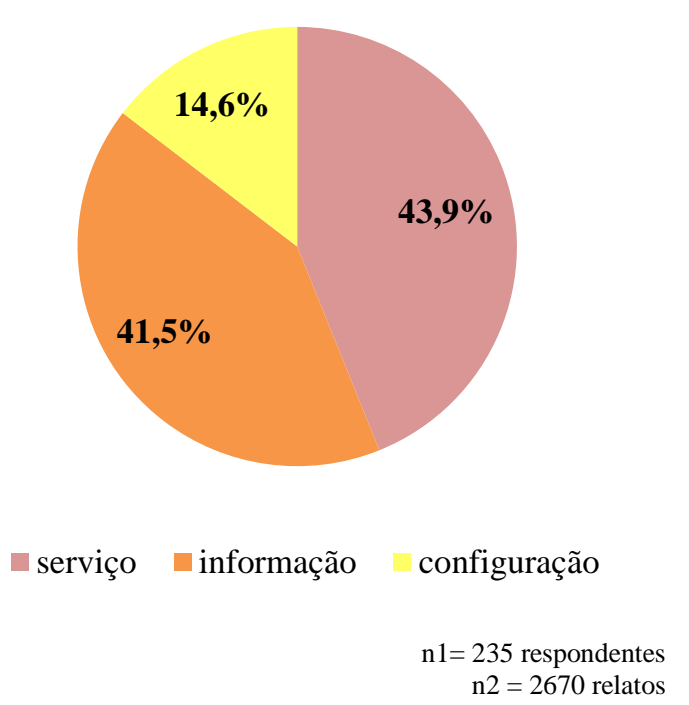

$\mathrm{n} 2=2670$ relatos

Fonte: Elaborado pela pesquisadora a partir dos relatos dos usuários coletados nas questões Q12, Q13, Q14 e Q17

A seguir, são apresentadas informações de todas as etapas, segundo avaliação realizada pelos usuários, permitindo comparação dos valores obtidos (Gráfico 43) Na estação, o descontentamento em relação à circulação vertical representa $6,1 \%$ do total de relatos, enquanto que os deslocamentos horizontais impactam em $46,8 \%$ das avaliações negativas. A avaliação mais crítica ocorre nos deslocamentos realizados na plataforma, entre os elementos de circulação vertical e a área de embarque $(5,2 \%)$ ou entre o desembarque e os elementos de circulação vertical $(13,5 \%)$, totalizando $18,7 \%$ dos relatos registrados. Os deslocamentos no mezanino - área livre e área paga - representam 11,4\% das avaliações negativas, sendo maior o descontentamento relacionado ao deslocamento no momento do embarque $(8,0 \%)$ do que no desembarque $(3,4 \%)$. Na interface trem-estação, o descontentamento em relação à etapa do desembarque $(4,3 \%)$ é maior que na etapa de embarque $(3,4 \%)$. No trem, o descontentamento em relação à etapa viagem-embarque $(10,0 \%)$ é ligeiramente maior do que na etapa viagemdesembarque $(9,8 \%)$. 
Gráfico 43 - Avaliação das etapas da jornada do usuário pelas pessoas com deficiência visual.

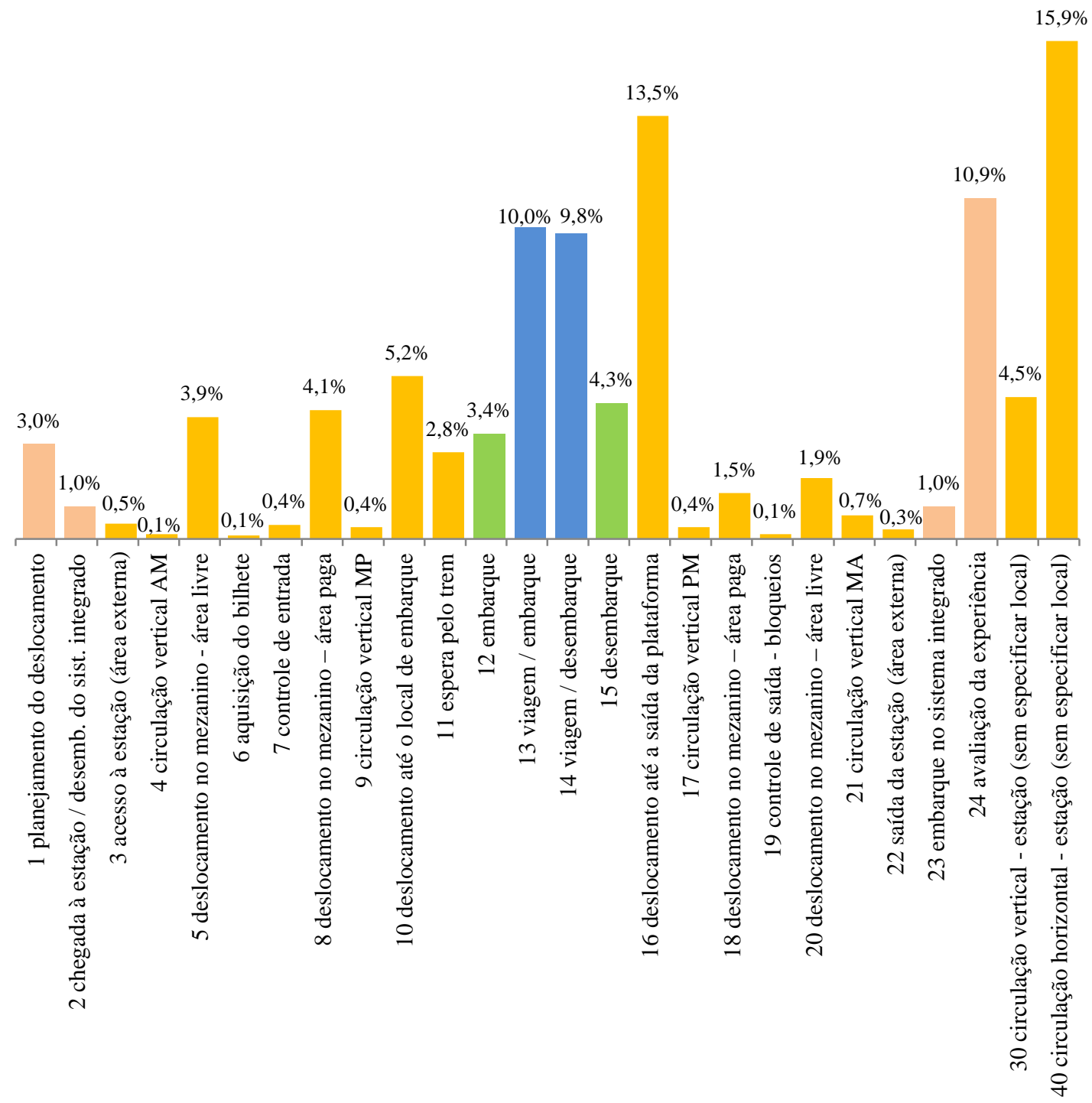

\footnotetext{
$\square$ planejamento / avaliação da experiência estação

interface trem-estação

trem
}

$\mathrm{n} 1=235$ respondentes $\mathrm{n} 2=2670$ relatos

Fonte: Elaborado pela pesquisadora a partir dos relatos dos usuários coletados nas questões Q12, Q13, Q14 e Q17.

A análise dos resultados obtidos em cada etapa permite afirmar que os maiores descontentamentos referentes às ideias centrais relacionadas à estação ora impactam - e possivelmente inibem - a independência, ora impactam o auxílio recebido durante os deslocamentos. Entre as ideias centrais com avaliação mais crítica que impactam na independência destacam-se a sinalização tátil do piso nos percursos $(21,9 \%)$, as condições das instalações existentes $(5,2 \%)$, o comportamento dos demais usuários $(4,9 \%)$, as informações para a pessoa com deficiência visual na estação $(3,4 \%)$ e o treinamento dos usuários $(2,8 \%)$. Entre as ideias centrais com avaliação mais crítica que impactam no auxílio recebido nos 
deslocamentos destacam-se o atendimento realizado pelos empregados $(12,6 \%)$ e o treinamento dos empregados (5,7\%). Entre as ideias centrais com avaliação mais crítica na interface trem-estação destacam-se a falta de proteção na plataforma (2,6\%), o comportamento dos usuários $(1,5 \%)$ e o vão e desnível entre o trem e a plataforma $(1,3 \%)$. No trem, destacam-se a falta de informações para a pessoa com deficiência visual $(8,1 \%)$, o comportamento dos demais usuários $(4,4)$, a lotação dos trens $(2,7 \%)$ e o desrespeito ao embarque/desembarque preferencial (1,8\%)- (Gráfico 44).

Gráfico 44 - Grau de criticidade das ideias centrais segundo as pessoas com deficiência visual.

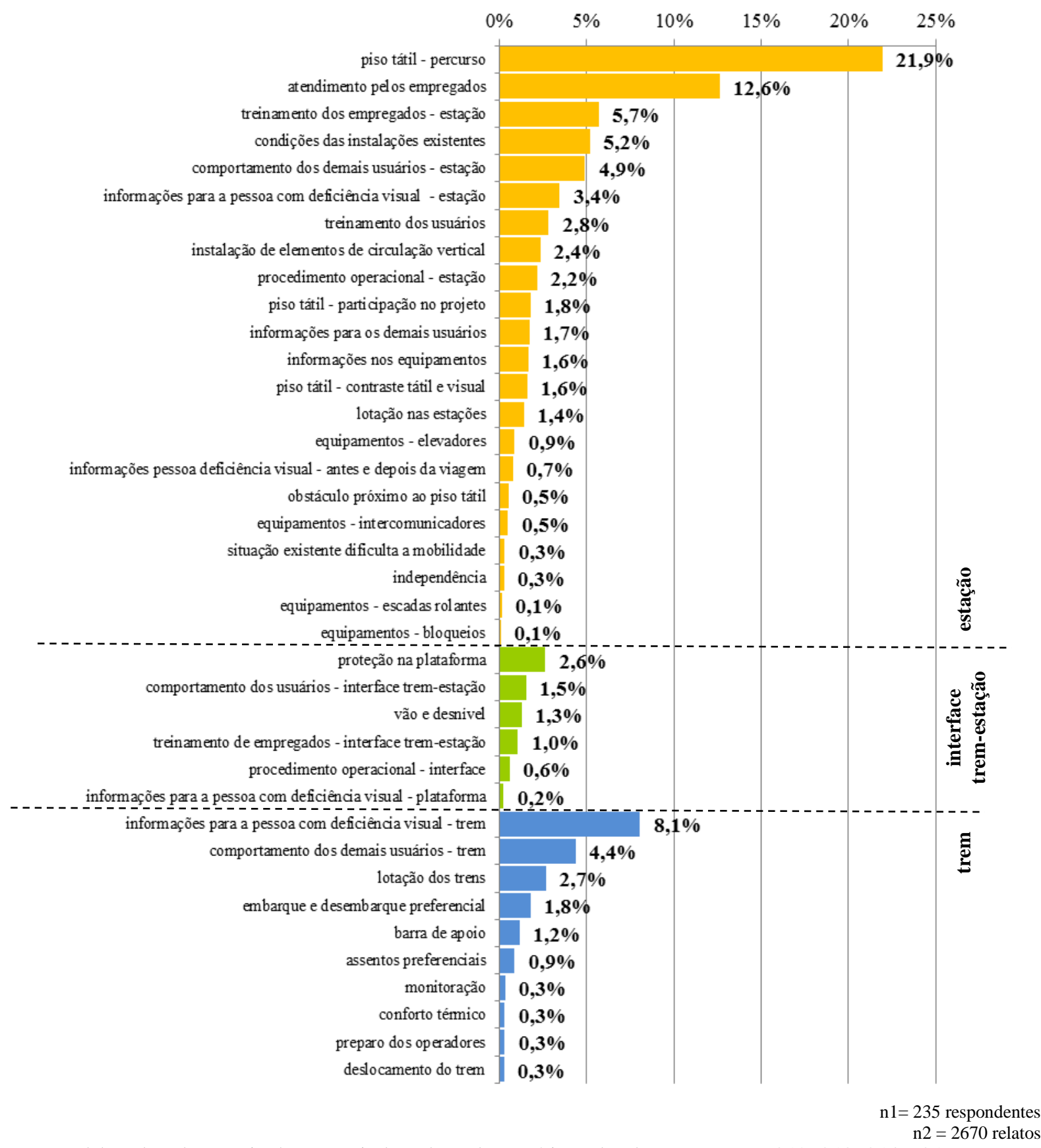

Fonte: Elaborado pela pesquisadora a partir dos relatos dos usuários coletados nas questões Q12, Q13, Q14 e Q17 
A análise dos dados coletados a partir dos relatos dos usuários com deficiência visual permite afirmar a existência de seis fatores que contribuem para que o índice de auxílios prestados nas estações permaneça elevado, mesmo após a adaptação das instalações. Quando somados, tais fatores representam $40,8 \%$ do total de relatos de descontentamento e estão relacionados somente à estação e à interface trem-estação, uma vez que o usuário não é acompanhado durante a viagem:

- o percurso a ser realizado com auxílio da sinalização tátil no piso $(21,9 \%)$;

- as condições das instalações existentes $(5,2 \%)$;

- o comportamento dos demais usuários na estação (4,9\%);

- a insuficiência ou inadequação das informações para a pessoa com deficiência visual na estação $(3,4 \%)$;

- falta de treinamento dos usuários $(2,8 \%)$;

- inexistência de proteção na plataforma $(2,6 \%)$.

Quanto ao percurso a ser realizado com auxílio da sinalização tátil no piso, existe uma percepção que esse recurso não leva aos locais desejados ou aos equipamentos e serviços existentes nas estações. Adicionalmente, há um consenso que é preciso melhorar a compreensão sobre o caminho e a percepção sobre as mudanças de direção. Outro aspecto está relacionado ao fato de ser um percurso à margem dos deslocamentos realizados pelos demais usuários, caracterizado pela existência de uma sinalização tátil no piso que considera premissas de implantação que não favorecem a compreensão dos percursos - seja à medida que privilegia os deslocamentos ortogonais - muitas vezes cruzando os fluxos predominantes - seja quando induz à utilização dos elevadores em vez das escadas fixas ou rolantes. Por fim, a proximidade com os obstáculos da edificação e com a borda da plataforma gera insegurança nos deslocamentos independentes.

Em relação à s condições das instalações existentes, a insatisfação está relacionada às distâncias percorridas e à falta de padronização das estações, notadamente em relação à localização dos elementos de circulação vertical e à configuração das plataformas, principalmente a plataforma central.

Sobre o comportamento dos demais usuários nas estações, destacam-se os aspectos relacionados à falta de respeito ao deslocamento - colocam bagagens ou permanecem parados 
sobre o piso tátil, tropeçam na bengala, empurram nas escadas fixas e rolantes - e ao embarque e desembarque preferenciais - permanecem no local destinado ao embarque preferencial, colocam bagagens ou permanecem parados junto às portas dos trens, empurram durante o embarque e o desembarque. Em parte, a falta de consideração está relacionada ao desconhecimento quanto à finalidade do piso tátil. Contudo, as atitudes e os comportamentos individualistas nas estações, notadamente no local embarque e de desembarque, nos horários de pico manhã e tarde, não pode ser interpretado como desconhecimento, uma vez que existe sinalização quase ostensiva nas plataformas e nos trens alertando quanto à sua finalidade: embarque e desembarque preferencial. A desconsideração está relacionada a atitudes e comportamentos cristalizados, tornando necessária uma abordagem de impacto. É importante chamar a atenção não só dos usuários beneficiados, mas da população em geral, visto que este problema atinge toda a sociedade, em quaisquer serviços de atendimento ao público ou meios de transporte coletivos. Campanhas devem enfatizar e estimular o público beneficiado a assumir uma atitude mais ativa na busca de seus direitos, não esperando que o outro atenda às suas necessidades. Por outro lado, deve ser estimulado o comportamento cidadão, o respeito e a necessidade de humanização do ambiente coletivo, apelando para a solidariedade e civilidade envolvidas neste ato de cidadania junto ao público em geral. O público mais jovem é o maior foco de resistência no respeito aos assentos preferenciais, cabendo, portanto, apelos especialmente direcionados a esse grupo.

Quanto à insuficiência ou inadequação das informações existentes durante a viagem, refere-se à falta de informação integrada e redundante - tátil, visual e sonora - que possa facilitar a compreensão dos percursos, agravada pela falta de padronização das instalações.

Sobre a falta de treinamento dos usuários, apesar da elevada participação em treinamentos de orientação e mobilidade, poucos são aqueles que aprenderam a usar os recursos atualmente disponíveis nas estações: as pessoas com deficiência visual receberam treinamentos em diferentes épocas de suas vidas, na maioria das vezes em data anterior à implementação dos recursos de acessibilidade, utilizando como referências elementos distintos e não sistematizados ou padronizados. A avaliação positiva das instalações existentes é maior pelas pessoas com deficiência visual que têm treinamento de O\&M $(48,6 \%)$ quando comparada às pessoas que não passaram por treinamento de O\&M (36,0\%), reforçando a necessidade de corresponsabilidade da empresa operadora incentivando a promoção dessa capacitação. 
Quando analisada sob a ótica da localização, a insatisfação tem destaque nos deslocamentos efetuados nas plataformas $(13,6 \%)$ As causas da insatisfação dos usuários com deficiência visual podem ser explicadas, de forma específica, para os dois diferentes perfis: os que prezam o auxílio e aqueles que almejam a independência.

Para os usuários que almejam a independência, a insatisfação está relacionada à inexistência de proteção nas plataformas - portas ou elementos direcionadores -, agravada pela diversidade de configuração, que gera insegurança nos deslocamentos, principalmente no percurso até a saída da plataforma. A elevada distância entre o elevador ou as escadas e o local de embarque e desembarque pressupõe um deslocamento nas plataformas, local onde há percepção de insegurança quanto ao medo de cair na via. Nesse caso, além da questão da distância a ser percorrida, há um descontentamento adicional em relação aos demais usuários, que permanecem parados ou colocam objetos sobre a sinalização tátil no piso, obrigando a pessoa com deficiência visual a se desviar, o que causa desorientação. Dessa forma, entendese que há oportunidades de melhoria para proporcionar independência nos deslocamentos com independência. A seguir são apresentados alguns elementos poderiam auxiliar tais deslocamentos:

- na estação - alterar a sinalização tátil do piso, possibilitando a utilização das escadas rolantes e fixas bem como de todos os equipamentos e serviços oferecidos na estação; instalar mais equipamentos de circulação vertical - notadamente elevadores e escadas rolantes; assumir o treinamento de O\&M para as pessoas com deficiência visual; intensificar as campanhas de orientação junto aos demais usuários para que estes não permaneçam parados sobre o piso tátil, não coloquem malas ou outros obstáculos sobre a sinalização;

- na interface trem-estação- instalar portas em todas as plataformas para prover segurança no momento de espera pelo trem; reduzir o vão e desnível entre o trem e a plataforma facilitando os deslocamentos de embarque e desembarque;

- no trem - ampliar a quantidade e padronizar a localização dos assentos preferenciais; determinar o uso exclusivo do carro preferencial pelas pessoas com deficiência ou mobilidade reduzida, de forma a garantir mais conforto e respeito aos assentos preferenciais. 
Para os usuários que almejam o auxílio nos deslocamentos, a insatisfação está relacionada ao serviço de atendimento e decorre da demora para obter auxílio, principalmente no momento do desembarque, quando não há empregado à sua espera e o usuário se vê obrigado a permanecer sozinho até a chegada de um funcionário para auxiliar seu deslocamento até a saída da plataforma. Nesse caso, o tempo percebido é muito superior ao tempo real. A percepção do tempo resulta do número de trens que passam no local enquanto ele aguarda a chegada do funcionário. Os dados coletados junto aos usuários com deficiência visual indicam que há oportunidade de melhorias no serviço de auxílio prestado nos deslocamentos:

- na estação - ter mais funcionários para auxiliar os deslocamentos, notadamente o desembarque e ampliar o auxílio na área de entorno das estações;

- na interface trem-estação - melhorar o treinamento dos empregados e estagiários, principalmente no momento do embarque, colocando a mão do usuário sobre as barras de apoio existentes no interior do trem; intensificar estratégias e campanhas para garantir o embarque preferencial nas plataformas;

- no trem - veicular informações sobre a próxima estação e lado de desembarque.

A seguir são apresentados os elementos do wayfinding associados aos identificados em cada etapa da jornada do usuário, classificados segundo os fatores-chave da acessibilidade no sistema metroferroviário (Quadros 46 a 48). 
Quadro 46 - Elementos de wayfinding na estação.

\begin{tabular}{|c|c|c|}
\hline configuração & sinalização & serviço \\
\hline $\begin{array}{l}\text { - acesso da estação } \\
\text { - elementos de circulação } \\
\text { vertical } \\
\text { - bloqueios } \\
\text { - localização das bilheterias e } \\
\text { máquinas de autoatendimento } \\
\text { - localização dos equipamentos } \\
\text { de controle de acesso } \\
\text { - localização dos elementos de } \\
\text { circulação vertical } \\
\text { - patamares dos pavimentos } \\
\text { atendidos pelos equipamentos } \\
\text { de circulação vertical } \\
\text { - saída da estação }\end{array}$ & $\begin{array}{l}\text { - existência de sinalização } \\
\text { integrada sobre os diferentes } \\
\text { modos de transporte } \\
\text { - sinalização tátil/visual/sonora } \\
\text { para identificação da } \\
\text { localização do acesso, dos } \\
\text { equipamentos, dos elementos } \\
\text { de circulação vertical, das } \\
\text { bilheterias e máquinas de } \\
\text { autoatendimento } \\
\text { - sinalização tátil/visual/sonora } \\
\text { sobre o funcionamento dos } \\
\text { equipamentos } \\
\text { - contraste visual entre os } \\
\text { equipamentos e o cenário da } \\
\text { estação } \\
\text { - sinalização tátil/visual/sonora } \\
\text { dos pavimentos atendidos } \\
\text { - sinalização tátil de alerta dos } \\
\text { patamares }\end{array}$ & $\begin{array}{l}\text { - veiculação das informações } \\
\text { completas para os usuários } \\
\text { - intercomunicador para } \\
\text { solicitação de auxílio } \\
\text { - treinamento dos usuários } \\
\text { - auxílio no deslocamento } \\
\text { - gestão de filas } \\
\text { - atendimento preferencial }\end{array}$ \\
\hline $\begin{array}{l}\text { - no percurso de embarque entre } \\
\text { o transporte integrado, o } \\
\text { acesso da estação, os } \\
\text { elementos de circulação } \\
\text { vertical, os bloqueios, } \\
\text { bilheterias ou máquinas de } \\
\text { autoatendimento, os } \\
\text { equipamentos de controle de } \\
\text { acesso, os elementos de } \\
\text { circulação vertical, o local de } \\
\text { embarque na plataforma } \\
\text { - no percurso de desembarque, } \\
\text { entre o local de desembarque } \\
\text { na plataforma, os elementos de } \\
\text { circulação vertical, os } \\
\text { equipamentos de controle de } \\
\text { saída, os elementos de } \\
\text { circulação vertical, a saída, a } \\
\text { conexão ou o transporte } \\
\text { integrado } \\
\text { - nos elementos de circulação } \\
\text { vertical, considerando o fluxo } \\
\text { bidirecional simultâneo nas } \\
\text { escadas fixas e rampas; o fluxo } \\
\text { bidirecional alternado nos } \\
\text { elevadores; e o fluxo } \\
\text { unidirecional nas escadas } \\
\text { rolantes }\end{array}$ & $\begin{array}{l}\text { - sinalização tátil/visual para } \\
\text { identificação da configuração } \\
\text { das opções de percurso de } \\
\text { embarque ou desembarque e } \\
\text { de integração em relação ao } \\
\text { entorno } \\
\text { - sinalização tátil/sonora/ visual } \\
\text { sobre a configuração e o } \\
\text { percurso, considerando as } \\
\text { opções de percursos internos } \\
\text { conforme destinos, as opções } \\
\text { de saída ou de conexão } \\
\text { - sinalização tátil/sonora/ visual } \\
\text { nos percursos para as } \\
\text { bilheterias e máquinas de } \\
\text { autoatendimento, } \\
\text { equipamentos de controle de } \\
\text { acesso e de saída, os elementos } \\
\text { de circulação vertical } \\
\text { - sinalização visual na lateral } \\
\text { dos degraus } \\
\text { - sinalização do sentido de fluxo } \\
\text { das escadas rolantes } \\
\text { - informação sonora sobre o } \\
\text { deslocamento dos elevadores }\end{array}$ & $\begin{array}{l}\text { - integração com outros modos } \\
\text { de transporte (ônibus, vans, } \\
\text { táxis) } \\
\text { - treinamento dos usuários } \\
\text { - existência de funcionários para } \\
\text { auxiliar no deslocamento } \\
\text { - capacitação dos funcionários } \\
\text { para auxílio no deslocamento }\end{array}$ \\
\hline
\end{tabular}




\begin{tabular}{|c|c|c|c|}
\hline & $\begin{array}{l}\text { - interseção entre percursos } \\
\text { vindos dos diferentes acessos } \\
\text { - interseção entre percursos de } \\
\text { embarque para diferentes } \\
\text { plataformas }\end{array}$ & $\begin{array}{l}\text { - sinalização tátil/visual das } \\
\text { opções de percurso }\end{array}$ & $\begin{array}{l}\text { - treinamento dos usuários } \\
\text { - auxílio no deslocamento }\end{array}$ \\
\hline (ja & $\begin{array}{l}\text { - superfície da área de circulação } \\
\text { no mezanino - área livre } \\
\text { - superfície da área de circulação } \\
\text { no mezanino-área paga }\end{array}$ & $\begin{array}{l}\text { - contraste visual entre } \\
\text { equipamentos da estação e } \\
\text { superfícies horizontais e } \\
\text { verticais }\end{array}$ & $\begin{array}{l}\text { - treinamento dos usuários } \\
\text { - auxílio no deslocamento } \\
\text { - gestão de fluxos }\end{array}$ \\
\hline
\end{tabular}

Quadro 47 - Elementos de wayfinding na interface trem-estação.

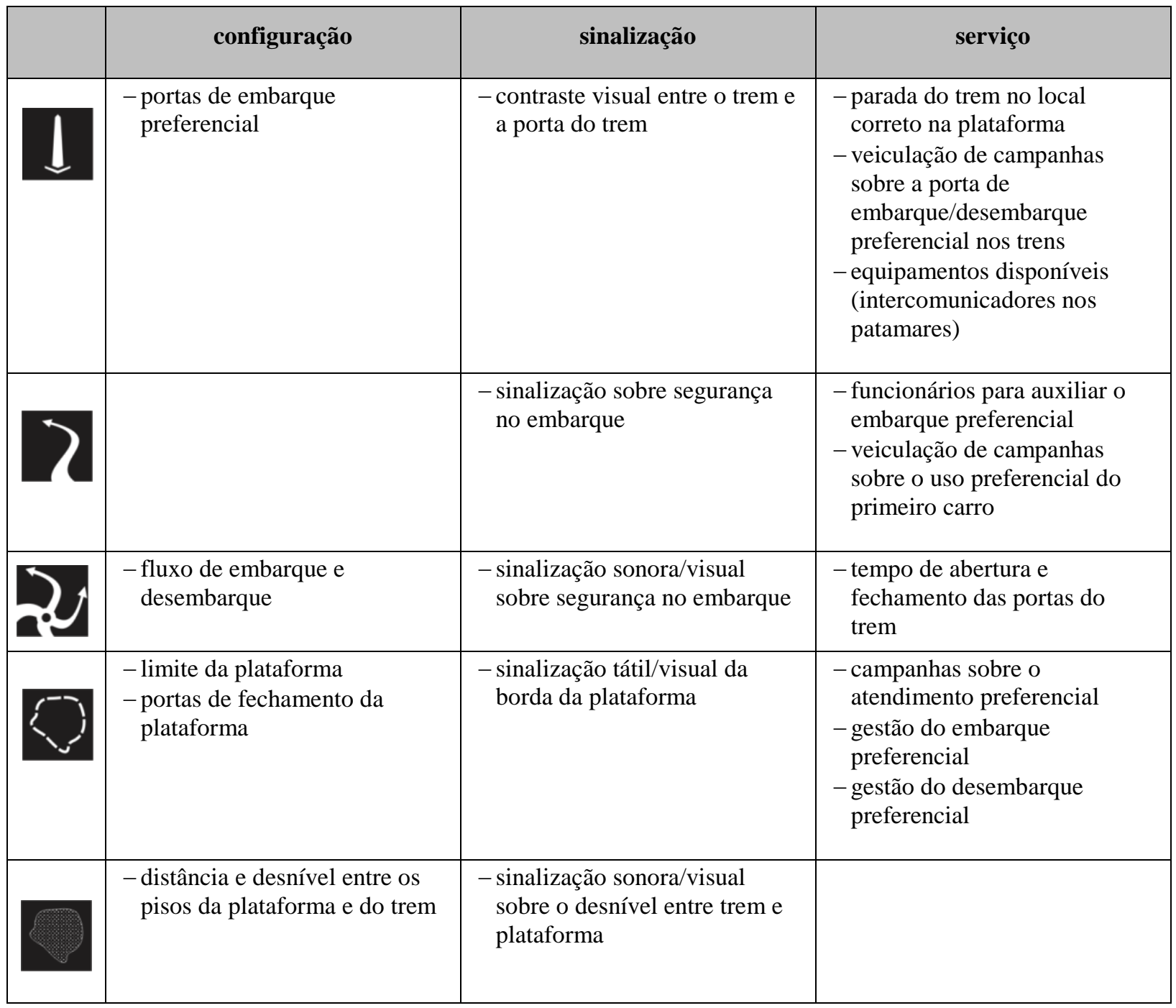


Quadro 48 - Elementos de wayfinding no trem

\begin{tabular}{|c|c|c|}
\hline configuração & sinalização & serviço \\
\hline $\begin{array}{l}\text { - assentos preferenciais } \\
\text { - portas de desembarque } \\
\text { preferencial }\end{array}$ & $\begin{array}{l}\text { - contraste visual entre a } \\
\text { superfície interna/externa e a } \\
\text { porta do trem } \\
\text { - contraste visual entre a } \\
\text { superfície do assento } \\
\text { preferencial e a superfície do } \\
\text { trem } \\
\text { - identificação dos assentos } \\
\text { preferenciais }\end{array}$ & $\begin{array}{l}\text { - campanhas sobre o uso do } \\
\text { assento preferencial } \\
\text { - veiculação de informações } \\
\text { sobre o uso do assento } \\
\text { preferencial }\end{array}$ \\
\hline $\begin{array}{l}\text { - percurso entre a porta de } \\
\text { embarque, o assento } \\
\text { preferencial, a porta de } \\
\text { desembarque } \\
\text { - barras de apoio }\end{array}$ & $\begin{array}{l}\text { - contraste visual entre as } \\
\text { superfícies e as barras de apoio } \\
\text { - informação sonora sobre a } \\
\text { próxima estação/o lado de } \\
\text { desembarque/o deslocamento }\end{array}$ & $\begin{array}{l}\text { - veiculação de campanhas sobre } \\
\text { o uso preferencial do primeiro } \\
\text { carro } \\
\text { - veiculação de informações } \\
\text { sonoras sobre a próxima } \\
\text { estação, lado de desembarque, } \\
\text { ocorrências operacionais }\end{array}$ \\
\hline $\begin{array}{l}\text { - superfície da área de } \\
\text { circulação no interior dos } \\
\text { carros }\end{array}$ & $\begin{array}{l}\text { - sinalização sonora/visual sobre } \\
\text { o fechamento das portas }\end{array}$ & - veiculação de informações \\
\hline
\end{tabular}

Os dados coletados permitem afirmar que os elementos de wayfinding característicos de cada etapa devem ser providos de configuração adequada bem como de sinalização tátil/visual/sonora integrada de forma a facilitar sua identificação por pessoas com deficiência visual e sobressair-se em relação aos demais elementos e informações do ambiente para facilitar sua percepção. Ao mesmo tempo, devem estar presentes e ser ressaltados nas informações veiculadas, especialmente quando da elaboração dos materiais táteis, visuais e sonoros voltados à descrição do ambiente das estações, facilitando a percepção e compreensão dos percursos de embarque e desembarque. 


\section{RECOMENDAÇÕES}

A matriz de avaliação da acessibilidade das redes de transporte, elaborada a partir da interpretação do conceito sobre os fatores-chave de acessibilidade (JUNCÁ, 2011), pressupõe a existência de nove itens de verificação, considerados fatores interdependentes entre ambientes identificados (estação, interface trem-estação e trem) e os temas avaliados (configuração, informação e serviço). A jornada do usuário do sistema metroferroviário identificou a existência de oportunidades de melhoria em aspectos relacionados aos temas informação $(41,5 \%)$ e serviço $(43,9 \%)$. Quando localizadas no espaço, tais oportunidades concentram-se nas estações $(72,7 \%)$ - (Tabela 35).

Tabela 35 - Avaliação da acessibilidade pelas pessoas com deficiência visual.

(\% em relação ao total de relatos registrados nesta etapa)

\begin{tabular}{|c|c|c|c|c|}
\hline & $\underset{\%}{\text { Configuração }}$ & $\begin{array}{c}\text { Informação } \\
\%\end{array}$ & $\begin{array}{c}\text { Serviço } \\
\%\end{array}$ & $\begin{array}{c}\text { Total } \\
\%\end{array}$ \\
\hline $\begin{array}{c}\text { Estação } \\
(1.940 \text { relatos })\end{array}$ & $\begin{array}{r}\text { EC - configuração da } \\
\text { estação } \\
\mathbf{8 , 1}\end{array}$ & $\begin{array}{r}\text { EI - informação na } \\
\text { estação } \\
\mathbf{3 2 , 9}\end{array}$ & $\begin{array}{r}\text { ES - serviço oferecido } \\
\text { na estação } \\
\mathbf{3 1 , 7}\end{array}$ & 72,7 \\
\hline $\begin{array}{c}\text { Interface trem- } \\
\text { estação } \\
\text { (194 relatos) }\end{array}$ & $\begin{array}{r}\text { IC - configuração da } \\
\text { interface trem-estação } \\
\mathbf{3 , 9}\end{array}$ & $\begin{array}{r}\text { II - informação na } \\
\text { interface trem-estação } \\
\mathbf{0 , 2}\end{array}$ & $\begin{array}{r}\text { IS - serviço oferecido } \\
\text { na interface trem- } \\
\text { estação } \\
\mathbf{3 , 1}\end{array}$ & 7,2 \\
\hline $\begin{array}{c}\text { Trem } \\
\text { (536 relatos) }\end{array}$ & $\begin{array}{r}\text { TC - configuração do } \\
\text { trem } \\
\mathbf{2 , 6}\end{array}$ & $\begin{array}{r}\text { TI - informação no } \\
\text { trem } \\
\mathbf{8 , 4}\end{array}$ & $\begin{array}{r}\text { TS - serviço oferecido } \\
\text { no trem } \\
\mathbf{9 , 1}\end{array}$ & 20,1 \\
\hline $\begin{array}{c}\text { Total } \\
(2.670 \text { relatos })\end{array}$ & 14,6 & 41,5 & 43,9 & 100,0 \\
\hline
\end{tabular}

Fonte: Elaborada pela autora a partir de Juncá, 2011 e dos relatos dos usuários coletados nas questões Q12, Q13, Q14 e Q17.

As recomendações para melhoria das condições de acessibilidade serão apresentadas a seguir, segundo os fatores-chave de acessibilidade, considerando as ideias centrais relacionadas aos ambientes identificados e temas avaliados.

\subsection{Estação-configuração}

As recomendações para cada uma das ideias centrais associadas à configuração da estação são apresentadas a seguir: 


\section{EC1 - Independência}

Para que a independência nos deslocamentos seja gradativamente ampliada, deve-se promover a aprendizagem de estratégias de contorno nos treinamentos de orientação e mobilidade, a exemplo das sugestões de rastreamento das paredes das plataformas laterais nas estações e de utilização dos assentos próximos à porta de desembarque nos trens face à impossibilidade de padronização da configuração das estações e das plataformas. A padronização da localização dos equipamentos de circulação, que poderia ser uma estratégia ou solução para facilitar deslocamentos independentes, traz consigo inúmeros inconvenientes e transtornos decorrentes da localização sistemática das escadas e dos elevadores: o congestionamento das plataformas nesses pontos e a lotação excessiva dos carros próximo a elementos de circulação vertical.

\section{EC2 - Instalação de elementos de circulação vertical}

Sempre que possível, deve-se facilitar a compreensão do ambiente e do percurso e minimizar os deslocamentos, posicionando os elementos de circulação vertical - escadas fixas e rolantes e os elevadores - próximos a bloqueios e locais de embarque preferencial. Deve-se instalar elevadores e escadas rolantes entre todos os acessos e os mezaninos, especialmente nas estações antigas, e entre o mezanino e os dois lados das plataformas em todas as estações. Apesar da localização do elevador no meio da plataforma central torná-lo equidistante dos locais de embarque e desembarque nas duas plataformas e minimizar a quantidade de equipamentos, tal solução implica maior deslocamento do usuário na plataforma, entre o elevador e o local de embarque e desembarque preferencial.

\section{EC3 - Condições das instalações existentes}

Em relação ao sistema integrado, devem-se estabelecer requisitos de projeto específicos para configuração dos ambientes e espaços de conexão nas normas técnicas de acessibilidade de forma a garantir uma rota acessível entre diferentes modos de transporte, minimizar as distâncias entre os pontos de parada e terminais urbanos e os acessos das estações e, ao mesmo tempo, diferenciar os ambientes destinados aos diversos modos de transporte integrados por meio de ritos de passagem ou de transição, facilitando sua percepção, compreensão e memorização. Nas áreas externas, deve-se garantir a segurança dos deslocamentos, oferecendo infraestrutura adequada nos arredores das estações (faixas de travessia, semáforos sonoros, iluminação adequada no período noturno) e mantendo as áreas 
de circulação e calçadas no entorno das estações em bom estado de conservação/manutenção e em condições adequadas de segurança, livres de obstáculos como mobiliário, equipamentos, ambulantes, barracas ou comércio. Sempre que possível, devem-se prever acessos em ambos os lados de ruas e avenidas com circulação intensa de veículos. Nas áreas internas, deve-se dar preferência às soluções padronizadas de configuração, sinalização, iluminação e acabamento dos ambientes característicos do sistema metroferroviário, facilitando a percepção, a compreensão e a memorização dos percursos. Para promover condições adequadas de segurança no interior das estações, é importante dimensionar os corredores das estações de acordo com os fluxos e a demanda e garantir o nível de iluminamento adequado dos ambientes construídos em diferentes épocas. Os ambientes devem ser dotados de recursos que facilitem a percepção e a compreensão dos percursos em função da dimensão e complexidade das estações, privilegiando-se ambientes mais legíveis, confinados ou segregados por meio de muretas ou vidros de forma a permitir, simultaneamente, o rastreamento com a bengala e o monitoramento pelas câmeras de vigilância. Outra opção pode ser a utilização de elementos de acabamento ou materiais de revestimento diferenciados em paredes, pisos ou forros, que reverberem mais ou que sejam mais absorventes, ou de contraste de textura e de cor entre pisos, paredes, portas, corrimãos, pilares, painéis de informação e equipamentos da estação. Devem ser remanejados todos os obstáculos (mobiliário e equipamentos existentes próximos ao piso tátil ou paredes ao longo do caminho), posicionando-os de forma a preservar a segurança dos usuários nos corredores e espaços destinados à circulação. É importante estabelecer condições adequadas para a execução de serviços, obras e reformas parciais ou totais, garantindo uma rota acessível para embarque e desembarque. Equipamentos e máquinas de autoatendimento devem dispor de condições adequadas de acessibilidade em relação à sua localização, configuração ou sinalização, com recursos táteis, visuais e sonoros integrados e redundantes. Deve-se evitar a instalação de mobiliário ou equipamentos suspensos, de difícil detecção com bengalas de rastreamento. O mobiliário e os equipamentos típicos do mezanino das estações devem ser disponibilizados em quantidade e localização adequadas, conforme a demanda e o fluxo das estações. Incluem-se nessa condição os equipamentos de controle de entrada e saída bloqueios e contadores. Uma vez que as plataformas são resultantes de inúmeros fatores decorrentes do planejamento e do sistema construtivo da linha, não é possível padronizá-las ou mesmo impedir ou evitar a construção de plataformas centrais ou mistas. Contudo, para aumentar as condições de segurança e minimizar a sensação de insegurança nos 
deslocamentos realizados nas plataformas centrais ou mistas, além de possuir dimensionamento adequado (largura), devem ser colocados elementos de proteção ou portas nas bordas das plataformas, bem como ser instaladas câmeras de monitoramento e sistema de iluminação com intensidade adequada. Para minimizar os conflitos de fluxo nas plataformas com demanda elevada, devem ser previstas plataformas mistas (central e lateral) com dimensões e configurações compatíveis com a demanda, possibilitando o embarque e desembarque em portas distintas do trem.

\section{EC4 - Situação existente dificulta a mobilidade}

A existência de equipamentos ou dispositivos de autoatendimento (bilheterias, máquinas de recarga, bloqueios, elevadores e escadas rolantes) em quantidade suficiente para atendimento à demanda evita a formação de filas e a concentração de pessoas em pontos específicos da estação, facilitando, num primeiro momento, a circulação. Por outro lado, tal condição impede a realização de controle de fluxo para embarque, permitindo que as pessoas cheguem livremente às plataformas, transferindo a aglomeração para um único local: a porta dos trens. No sentido inverso, para desembarque e saída, deve-se dimensionar uma quantidade adequada de equipamentos (bloqueios, elevadores, escadas rolantes) para garantir as condições de abandono e de fuga no caso de ocorrências e emergências. Devem ser estabelecidos requisitos e condições adequadas para execução de obras, intervenções ou serviços na rota acessível para embarque ou desembarque, evitando obstruir ou interromper a sinalização do piso tátil. Eventuais modificações no posicionamento dos equipamentos ou do mobiliário da estação, bem como alterações no fluxo de embarque ou desembarque, devem ser previamente informadas, possibilitando que as pessoas com deficiência visual possam se familiarizar com as novas condições de uso dos equipamentos ou de deslocamento. A substituição dos bloqueios de tripé por bloqueios com portas de vidro ou contadores facilita a mobilidade das pessoas com deficiência, mas impõe que sejam tomados cuidados diferenciados durante sua utilização.

\subsection{Estação - Informação}

As recomendações para cada uma das ideias centrais associadas à informação, comunicação ou orientação veiculadas na estação são apresentadas a seguir: 


\section{EI1 - Piso tátil - contraste tátil e visual}

Para facilitar a percepção do contraste das cores e dos relevos do piso tátil, sugere-se redimensionar a largura da sinalização direcional ou acrescentar uma faixa lisa entre o piso tátil e o piso emborrachado com pastilhas em relevo existentes na estação. Outra opção é utilizar piso semelhante ao empregado na pavimentação dos passeios públicos e dos terminais de ônibus urbanos. Deve-se evitar a utilização de material emborrachado no piso tátil por dificultar o deslizamento da bengala. Para indicar diferentes destinos ou para orientar o percurso para embarque ou conexão entre diferentes operadoras, deve-se instalar piso tátil com cor e textura diferenciadas.

\section{EI2 - Piso tátil - participação no projeto}

Sempre que possível, deve-se envolver ou consultar usuários bem como promover a participação e a consulta às pessoas com deficiência visual antes da implantação da sinalização tátil nas estações.

\section{EI3 - Piso tátil - percurso}

O percurso destinado às pessoas com deficiência visual deve ser igual ao percurso dos demais usuários e considerar os fluxos específicos de embarque, conexão, desembarque ou saída, evitando conflitos de fluxo na sinalização tátil direcional no piso. Os percursos para os elevadores, as escadas fixas ou as escadas rolantes situados próximos do local de embarque devem ser sinalizados com sinalização tátil de piso, possibilitando às pessoas com deficiência visual a opção de utilização dos diferentes equipamentos de circulação vertical, segundo sua preferência. Todos os equipamentos (elevadores, escadas fixas, escadas rolantes, máquinas de autoatendimento) e serviços oferecidos na estação (bilheterias, balcões de informação, baias e pontos de parada de ônibus) devem estar sinalizados. Para melhorar a compreensão sobre o percurso, a sinalização tátil no piso deve ser complementada com mapas táteis ou descrições sonoras, permitindo informação em igualdade de condições com os demais usuários. A sinalização tátil direcional no piso junto às escadas e rampas deve ser padronizada, orientando o fluxo ao longo das rampas ou para os corrimãos laterais de escadas e rampas, evitando direcionar para o corrimão central. Para proporcionar maior segurança nos deslocamentos, deve-se remanejar os obstáculos existentes na edificação ou manter o distanciamento do piso tátil direcional em relação à borda da plataforma, aos obstáculos existentes na edificação 
(colunas, pilares, paredes, quiosques e lojas), ao mobiliário (lixeiras, painéis, assentos), aos equipamentos (extintores, hidrantes), bem como no que se refere aos bloqueios e às escadas fixas ou rolantes para acomodação dos fluxos. Para aumentar a funcionalidade dos deslocamentos, deve-se substituir os percursos ortogonais por percursos diagonais ou em curva pouco acentuadas, aumentar a área de sinalização tátil de alerta nas interseções entre sinalizações direcionais, eliminar o excesso de pisos de alerta instalados nos acessos e instalar piso tátil direcional nas plataformas laterais das estações com plataformas mistas, possibilitando a realização de percursos em igualdade de condições com os demais usuários.

\section{EI4 - Informações nos equipamentos}

Os equipamentos e dispositivos acionados pelos usuários (elevadores, plataformas de elevação, escadas rolantes, intercomunicadores) devem dispor de orientações visuais, sonoras e táteis integradas, redundantes e padronizadas. Devem ser privilegiadas as informações com caracteres em relevo em substituição ao Braille. A localização dos bloqueios preferenciais de entrada e saída deve ser indicada por meio de informações táteis ou sonoras, direcionando o fluxo para bloqueios ou contadores que estejam ligados, em operação ou que disponham de dispositivo de leitura de cartões. Esses equipamentos também devem dispor de retorno sonoro para informar sobre a liberação da passagem e o saldo de viagens nos cartões. Bloqueios com portas de vidro devem dispor de sinalização visual de alerta com faixas contrastantes com dimensões adequadas para alertar pessoas com baixa visão. As escadas rolantes devem dispor de informações táteis e sonoras indicando o sentido de movimento. Os elevadores e as plataformas de elevação devem fornecer informação sonora durante o seu deslocamento, informando destinos ou saídas e possuir botoeiras e dispositivos de comando padronizados. As escadas fixas devem ter faixas refletivas nos espelhos dos degraus.

\section{EI5 - Informações para a pessoa com deficiência visual - antes e depois da viagem}

Os esclarecimentos prévios sobre o atendimento preferencial, a gratuidade, a acessibilidade, os serviços e as condições de operação devem ser veiculados, disponibilizados, distribuídos e atualizados por meio de folhetos, sítios eletrônicos acessíveis, telefone, rádios e redes sociais. As informações sobre o transporte metroferroviário (mapa da rede, estações ou ruas do entorno) devem ser disseminadas por meio de folhetos contendo informações visuais e texto ampliado - para pessoas com baixa visão - ou informações táteis ou em Braille - para as pessoas com deficiência visual alfabetizadas em Braille. Opcionalmente, arquivos sonoros 
podem ser veiculados ou disponibilizados na internet e utilizados tanto por pessoas com deficiência visual como pelos demais usuários contendo audiodescrição da rede, das linhas, da estação ou das ruas do entorno, dos percursos de embarque, desembarque ou entre diferentes estações. Um sistema roteador pode orientar o percurso origem-destino a ser realizado, informando as respectivas referências, as conexões e o tempo estimado de deslocamento.

\section{EI6 - Informações para a pessoa com deficiência visual - estação}

As informações sobre a rede de transporte metroferroviário, as linhas e as estações podem ser veiculadas de forma tátil, visual e sonora, independentes ou integradas. Devem ser criados estímulos e referenciais táteis, visuais e sonoros que facilitem e possibilitem a compreensão dos percursos nos ambientes - estações e conexões com outros modos de transporte - por meio da diferenciação entre sistemas de informação e sinalização, acabamentos, materiais de revestimento e contraste visual de obstáculos, equipamentos e mobiliário. Placas de sinalização com informações dirigidas às pessoas com baixa visão devem, para melhor legibilidade e percepção, ter figuras e textos com tipo ampliado e cor contrastante. Informações táteis, visuais e sonoras sobre as instalações (as principais referências das estações e dos percursos de embarque e desembarque) devem ser disponibilizadas por meio de mapas táteis, audiodescrições, folhetos e manuais, fornecendo informações em igualdade de condições com os demais usuários. As informações veiculadas devem ser claras, objetivas, completas e redundantes, sejam elas de caráter institucional (serviços ofertados, tais como comércio, exposições, espaços institucionais), operacional (anormalidade na circulação de trens, atrasos, ocorrências) ou de segurança (não ultrapassar a faixa amarela, segurar o corrimão das escadas fixas e rolantes). Folhetos e manuais com informações dirigidas às pessoas cegas devem, para melhor legibilidade e percepção, ter figuras em relevo e textos com caracteres em relevo ou em Braille (apenas para o segmento alfabetizado em Braille), veiculando informações sobre a rede metroferroviária, as linhas, as estações - com as principais referências dos percursos de embarque e de desembarque - ou as ruas do entorno. Nas normas técnicas de acessibilidade, devem ser incluídos os requisitos de projeto para sinalização dos ambientes e definição da rota acessível entre diferentes modos de transporte. Deve-se instalar intercomunicador nos acessos, nos terminais de ônibus urbanos e nas plataformas para facilitar a solicitação de auxílio. 


\section{EI7 - Informações para os demais usuários}

Deve-se promover campanhas para orientar os demais usuários sobre a finalidade do piso tátil, sobre o embarque preferencial e sobre a utilização do lado direito das escadas para evitar confrontos e acidentes, subindo por um lado e descendo pelo outro.

\subsection{Estação - Serviços}

As recomendações para cada uma das ideias centrais associadas aos serviços prestados na estação são apresentadas a seguir:

\section{ES1 - Treinamento dos empregados - estação}

A capacitação dos empregados e estagiários deve servir para padronizar o atendimento, incluindo a abordagem e a comunicação adequadas para possibilitar desenvoltura ao oferecer ajuda para condução individual ou em grupo em planos horizontais, rampas, escadas rolantes, escadas fixas e elevadores, incluindo o posicionamento para auxílio durante utilização das escadas rolantes. Os empregados devem ser capazes de prestar informações sobre os pontos de referência e as linhas integradas no entorno das estações bem como atentar para auxiliar o usuário no deslocamento para a saída desejada em função da complexidade das estações. Durante a prestação de auxílio, os empregados devem seguir o percurso do piso tátil e respeitar tanto o ritmo de deslocamento dos usuários quanto a opção pelo uso de elevadores, escadas fixas e escadas rolantes das estações ou por usar ou não o carro preferencial nos trens. A redução do tempo de espera pelos usuários para obter auxílio passa pelas orientações quanto ao limite de atuação dos empregados e ao posicionamento no posto de trabalho.

\section{ES2 - Atendimento pelos empregados}

O quadro de empregados deve ser dimensionado de acordo com a demanda, minimizando o tempo de espera para auxílio nos deslocamentos. Para auxiliar no deslocamento até a estação, os funcionários devem estar nos terminais de ônibus urbanos; para auxiliar o embarque, os empregados devem estar posicionados antes dos bloqueios; para auxiliar o desembarque, devem estar posicionados nas plataformas. 


\section{ES3 - Treinamento dos usuários}

Pessoas com deficiência devem ser capacitadas para saber sobre como proceder em situações de emergência, como utilizar os recursos disponíveis nas estações (tais como o intercomunicador, o piso tátil, os elevadores e plataformas de elevação, em especial sobre as diferenças de acionamento dos dispositivos desses equipamentos) e aguardar a chegada do empregado caso não se sintam seguros para empreender seu deslocamento com independência. As pessoas com deficiência devem ser orientadas a sentar-se tão logo entrem no trem, preferencialmente próximo à porta de desembarque, e a preparar-se para o desembarque tão logo seja anunciada a estação de destino, esperando o trem "quase parar" para então se levantar. Deve-se promover maior integração entre as instituições de reabilitação e as empresas operadoras dos sistemas metroferroviários para viabilizar programas de capacitação e treinamentos específicos de orientação e mobilidade para que as pessoas com deficiência visual possam utilizar as estações com independência seja a partir dos recursos existentes ou a partir de uma nova referência quando os percursos forem alterados. Como alternativa, após a instalação das portas nas plataformas, poderá ser oferecido treinamento pelos empregados em estações, em datas e horários pré-agendados.

\section{ES4 - Comportamento dos demais usuários - estação}

Campanhas devem ser veiculadas para orientar os demais usuários a prestar atenção, respeitar e facilitar o deslocamento preferencial das pessoas com deficiência visual seja com independência ou com auxílio de seus acompanhantes; devem ser orientados também a não permanecerem parados ou colocarem bagagens sobre o piso tátil, a facilitarem o uso do bloqueio preferencial e o embarque e do local preferencial da pessoa com deficiência visual (mesmo quando acompanhadas pelos empregados). Nesse sentido, deve-se controlar o acesso às áreas de embarque ou de atendimento preferencial e incentivar o respeito e a cordialidade entre os usuários com deficiência e os demais usuários. Devem ser enfatizados cuidados básicos, tais como evitar esbarrar ou tropeçar na bengala; empurrar ou machucar as pessoas com deficiência visual e seus acompanhantes; andar na contramão nas escadas ou nos corredores. 


\section{ES5 - Obstáculo próximo ao piso tátil}

Os direcionadores de fila e dispositivos de informação devem ser posicionados a uma distância segura do piso tátil.

\section{ES6 - procedimento operacional - estação}

Devem-se adequar os procedimentos vigentes para agilizar o atendimento pelos empregados quando das transferências entre diferentes operadoras ou mesmo nos arredores das estações. A ampliação do limite de atuação para auxílio no entorno das estações deverá ser avaliada a partir do quadro de empregados, visando não interferir no tempo de espera dos demais usuários. Os empregados devem fazer o mesmo percurso dos demais usuários para embarque, evitando embarcar no contrafluxo. A comunicação entre as estações e o CCO deve ser agilizada para garantir a presença de empregados na plataforma da estação de desembarque. A concessão e a renovação do bilhete especial devem ser agilizadas.

\section{ES7 - Lotação nas estações}

Deve-se organizar o fluxo decorrente do deslocamento simultâneo de um grande número de pessoas nas estações, nos horários de maior movimento, para reduzir os impactos da demanda elevada de passageiros no deslocamento das pessoas com deficiência visual seja com independência ou com auxílio. Deve-se disciplinar o comportamento dos usuários e orientar os fluxos de embarque e desembarque simultâneos junto aos corredores e às escadas fixas e rolantes nas estações de conexão entre diferentes linhas para melhorar as condições de segurança e facilitar o deslocamento com independência das pessoas com deficiência visual nos horários de maior movimento. A gestão e a organização do fluxo de usuários reduzem a lotação nas plataformas e evitam conflitos e cruzamentos de fluxo de embarque e desembarque simultâneos, nos horários de maior movimento, facilitando a prestação de auxílio pelos estagiários.

\section{ES8 - Equipamento de controle de acesso - bloqueios}

Deve-se implementar um dispositivo de segurança para impedir o fechamento das portas de vidro sobre as pessoas durante a passagem pelos bloqueios. 


\section{ES9 - Equipamentos - elevadores}

Deve-se agilizar a liberação do equipamento, a abertura e o fechamento da porta e a manutenção do equipamento quando da ocorrência de falhas. Devem ser implantados procedimentos específicos para disciplinar o uso do elevador pelos demais usuários, o transporte de bagagem e para minimizar o uso ou o acionamento indevidos, que resultam em manutenção excessiva. Deve ser prevista a instalação de detector de presença na altura do cão-guia.

\section{ES10 - Equipamentos - escadas rolantes}

Devem ser implantados procedimentos específicos para evitar o desligamento ou a inversão das escadas rolantes, facilitando a compreensão do percurso de circulação, priorizando o posicionamento para subir nos locais que dispõem de uma única escada rolante.

\section{ES11 - Equipamentos intercomunicadores}

Devem-se manter os intercomunicadores em condições de operação e uso para possibilitar a solicitação de auxílio.

\subsection{Interface - Configuração}

As recomendações para cada uma das ideias centrais associadas à configuração da interface trem-estação são apresentadas a seguir:

\section{IC1 - Vão e desnível}

Deve-se eliminar e minimizar o vão e o desnível existentes entre a plataforma e o trem, atentando para as tolerâncias de projeto, fabricação/construção e manutenção das vias, dos trilhos, das rodas dos trens, dos trens e das plataformas das estações. Cuidados específicos devem ser tomados para alinhar a sinalização tátil da plataforma à porta de embarque no trem.

\section{IC2 - Proteção na plataforma}

Devem-se instalar elementos direcionadores de embarque, barreiras ou portas em todas as plataformas das estações, especialmente nas estações mais lotadas ou com plataforma central, para garantir a segurança nos deslocamentos. 


\subsection{Interface - Informação}

As recomendações para cada uma das ideias centrais associadas à informação, comunicação ou orientação veiculadas na interface trem-estação são apresentadas a seguir:

\section{II1 - Informações para a pessoa com deficiência visual - interface trem-estação}

Deve-se sinalizar o local de embarque preferencial, implementar contrastes de cor entre a porta e a superfície externa do trem bem como aumentar o contraste e as dimensões das informações visuais existentes nas plataformas.

\subsection{Interface - Serviços}

As recomendações para cada uma das ideias centrais associadas ao serviço prestado na interface trem-estação são apresentadas a seguir:

\section{IS1 - Procedimento operacional - interface trem-estação}

Deve-se orientar usuários sobre a importância do embarque no primeiro carro, que permite o auxílio imediato do operador do trem e a prioridade de atendimento pelas equipes de resgate durante incidentes, ocorrências imprevistas ou anormalidades.

\section{IS2 - Treinamento dos empregados - interface trem-estação}

Deve-se oferecer ajuda com técnicas apropriadas durante o desembarque e padronizar o procedimento para auxílio durante o embarque, colocando a mão do usuário nas barras de apoio dos trens.

\section{IS3 - Comportamento dos demais usuários - interface trem-estação}

Devem-se promover campanhas para orientar e conscientizar os demais usuários a não permanecer no local destinado ao embarque preferencial e a estar atentos às pessoas com deficiência que estão na plataforma ou no trem. Orientações específicas devem conscientizar os usuários a respeitar o embarque e desembarque preferencial, a não forçar o embarque simultâneo, e a não empurrar as pessoas com deficiência. 


\subsection{Trem - Configuração}

As recomendações para cada uma das ideias centrais associadas à configuração do trem são apresentadas a seguir:

\section{TC1 - Barra de apoio}

Deve-se padronizar e adequar a configuração e localização das barras de apoio no interior dos trens nas diferentes frotas, incluindo as barras transversais no teto e junto às portas preferenciais.

\section{TC2 - Assentos preferenciais}

Deve-se adequar a quantidade e padronizar a configuração e a localização dos assentos preferenciais nas diferentes frotas, incluindo o assento preferencial para uso por pessoas com cão-guia.

\section{TC3 - Deslocamento do trem}

Devem-se evitar frenagens bruscas dos trens.

\section{TC4 - Conforto térmico}

Deve-se garantir o funcionamento da ventilação e do ar condicionado quando o trem estiver parado no túnel.

\subsection{Trem - Informação}

As recomendações para cada uma das ideias centrais associadas à informação, comunicação ou orientação veiculadas no trem são apresentadas a seguir:

\section{TI1 - Informação para monitoração}

Deve-se possibilitar a comunicação direta entre as estações e implementar um serviço de comunicação direta entre o usuário cego e a estação de destino para informar seu desembarque e agilizar seu auxílio no desembarque. 


\section{TI2 - Informação para a pessoa com deficiência visual - trem}

Deve-se estabelecer contraste de cor e textura entre os elementos de acabamento; instalar sinalização tátil no interior do trem (mapas, orientações ou instruções de uso dos dispositivos de emergência); instalar revestimento tátil para orientar o percurso entre as portas de embarque e o assento preferencial e definir requisitos para padronizar as características dos painéis eletrônicos, dos mapas dinâmicos e da informação sonora. Devem ser emitidas mensagens sonoras para incentivar o respeito aos assentos preferenciais, não incomodar o cão-guia, não permanecer parado ou colocar carrinhos, bagagens ou sacolas junto às portas.

\section{TI1 - Monitoração}

Deve-se agilizar a comunicação entre as estações e o centro de controle.

\subsection{Trem - Serviços}

As recomendações para cada uma das ideias centrais associadas aos serviços prestados no trem são apresentadas a seguir:

\section{TS1 - Treinamento dos empregados - trem}

Deve-se capacitar os operadores de trem em relação à dicção e entonação durante a emissão de mensagens sonoras.

\section{TS2 - Procedimento operacional - trem}

Deve-se fazer a gestão de fluxo nas plataformas para facilitar o embarque e o desembarque preferencial bem como destinar o primeiro carro do trem para uso exclusivo de pessoas com deficiência, orientando os demais usuários sobre o uso dos carros preferenciais.

\section{TS3 - Comportamento dos demais usuários - trem}

Devem ser promovidas campanhas para orientar e conscientizar os demais usuários no interior do trem, incluindo o respeito ao uso dos assentos preferenciais e ao embarque preferencial, evitando o desembarque simultâneo. Deve-se incentivar um comportamento respeitoso e solidário para desembarcar, evitando parar junto à porta ou ouvir música em volume elevado. 


\section{TS4 - Lotação dos trens}

Deve-se fazer a gestão de fluxo nas plataformas para facilitar o desembarque e a localização da pessoa com deficiência visual no momento do desembarque, controlando-se o acesso aos carros preferenciais. Simultaneamente, deve-se adequar o número de trens para atender à demanda das estações e reduzir a lotação no interior dos trens.

\subsection{Requisitos normativos}

As recomendações para melhoria das condições de acessibilidade apresentadas segundo os fatores-chave de acessibilidade considerou as ideias centrais relacionadas aos ambientes identificados e temas avaliados. Contudo, a comparação entre as recomendações apresentadas os requisitos estabelecidos e ora vigentes nas normas técnicas nacionais, permite afirmar que há espaço para incorporação de novos requisitos nas normas técnicas de acessibilidade, de forma a melhorar a percepção, cognição e interação com os ambientes e incentivar deslocamentos independentes no sistema metroferroviário (Quadro 49). 
Quadro 49 - Requisitos para incorporação nas normas técnicas vigentes.

Estação-configuração
- índices de iluminação específicos para a transição entre o ambiente interno e externo
- requisitos para configuração dos espaços de conexão de forma a garantir uma rota acessível entre diferentes
modos de transporte
- posicionamento dos recursos de circulação vertical de forma a facilitar a sua visualização, legibilidade e
compreensão do espaço
Estação - informação

- arquivo sonoro contendo audiodescrição dos ambientes das estações disponibilizados por meio da internet, para auxiliar o planejamento dos deslocamentos

- mapas táteis com recursos sonoros para orientar deslocamentos na estação, posicionados nos pontos de tomada de decisão (acesso/saída, mezanino área paga, mezanino área livre, local de embarque e desembarque preferencial)

- mapas táteis com recursos sonoros para orientar deslocamentos na rede, posicionados nos pontos de tomada de decisão (no mezanino área paga e no local de embarque e desembarque preferencial)

- mapas táteis com recursos sonoros para orientar deslocamentos na entre diferentes sistemas de transporte, posicionados nos pontos de tomada de decisão (acesso/saída, mezanino área paga)

- contraste de cor entre piso, parede, portas, corrimão, pilares, painéis de informação e equipamentos da estação e do trem

- piso tátil direcional para elevadores e escadas

- piso tátil ao longo das rampas, evitando-se terminar junto aos corrimãos

- percursos diagonais e em curva pouco acentuadas em substituição aos percursos ortogonais

- distância mínima entre a sinalização tátil direcional do piso e os elementos da edificação (fixos ou móveis)

- distribuição de mapas e folhetos com tipos ampliados

- requisitos para sinalização dos ambientes de espaços de conexão de forma a garantir uma rota acessível entre diferentes modos de transporte

- requisitos para elementos de acabamento que possam auxiliar a percepção, compreensão e memorização dos percursos

- requisitos de sinalização tátil, visual e sonora integradas para máquinas e equipamentos de autoatendimento, incluindo intercomunicadores, bilheterias, dispositivos para leitura de cartões, bloqueios, elevadores e escadas rolantes

- padronização das botoeiras dos elevadores

- veiculação de informações sonoras nos elevadores, mesmo nos equipamentos com até duas paradas

- detector de presença nas portas dos elevadores na altura do cão-guia

Estação - serviços

- requisitos para padronização do treinamento dos funcionários das diferentes empresas operadoras nos auxílios durante os deslocamentos e para proceder o embarque e o desembarque

- requisitos para padronização do treinamento dos usuários

\begin{tabular}{l}
\hline Interface trem-estação - configuração \\
- instalação de portas ou barreiras nas plataformas \\
\hline Interface trem-estação - informação \\
\hline - distância mínima entre o piso tátil direcional e a borda da plataforma \\
\hline Interface trem-estação - serviços \\
- tempo máximo de espera para auxílio nos deslocamentos \\
\hline Trem - configuração \\
- barras de apoio para embarque e desembarque \\
- requisitos para acomodação do cão guia no interior dos trens \\
- barras de apoio transversais no interior dos trens, junto às portas de embarque e desembarque preferencial \\
- proteção entre carros \\
Trem - informação \\
- requisitos para veiculação das mensagens sonoras no interior dos trens e mensagens visuais nos painéis \\
eletrônicos e mapas dinâmicos \\
- portas de embarque preferencial com cor contrastante em relação à superfície do trem \\
\hline Trem - serviços \\
\hline - requisitos para veiculação das mensagens sonoras e visuais no interior dos trens \\
\hline
\end{tabular}

Fonte: Elaborado pela pesquisadora. (2014) 


\section{CONSIDERAÇÕES FINAIS}

Nos últimos anos, intensificaram-se as políticas públicas para inclusão de pessoas com deficiência na sociedade, com destaque para a mobilidade da população urbana, por se tratar de um direito para viabilizar outros direitos, uma pré-condição para a realização de outros objetivos, tais como trabalho, moradia, educação, lazer, saúde (APEL-MULLER; BORTHGARAY, 2012). A Política Nacional de Mobilidade Urbana ${ }^{35}$ está fundamentada na acessibilidade universal, na equidade do acesso dos cidadãos ao transporte público coletivo e na integração física, tarifária e operacional dos diferentes modos e das redes de transporte público e privado nas cidades, entre outros.

As características e as peculiaridades do sistema metroferroviário e, principalmente, a diversidade dos usuários desse modo de transporte exigem que os profissionais conheçam e compreendam as necessidades das pessoas com deficiência visual para que sejam garantidas a eficácia e a eficiência dos ambientes e dos serviços. Apesar das ações realizadas pelo Metrô de São Paulo para promover a adequação das estações e dos trens segundo a legislação e as diretrizes normativas vigentes, o número de auxílios solicitados por pessoas com deficiência visual durante seus deslocamentos diários permaneceu elevado, totalizando, em média, 92,15\% do total de solicitações de auxílio no período entre 2006 e 2013 (CMSP, 2014).

Reforçando os dados disponibilizados pela empresa, quando verificada a preferência das pessoas com deficiência visual, constatou-se que $60 \%$ entendem que o Metrô deve priorizar a condução por funcionários treinados (deslocamento com auxílio) enquanto que 40\% consideram que o Metrô deve priorizar a adequação das estações (deslocamento com independência).

O auxílio e a independência são opções dos usuários com deficiência visual e, dessa forma, a estratégia oferecida pelas empresas operadoras deve-se adequar a essa condição, reconhecer a diversidade de soluções de projeto dos ambientes e dos serviços e prover as condições para a segurança dos usuários com deficiência visual, bem como dos demais usuários e funcionários que atuam no sistema metroferroviário.

\footnotetext{
${ }^{35}$ A Lei 12.587/2012, de 03/01/2012, instituiu as diretrizes da Política Nacional de Mobilidade Urbana.
} 
A pesquisa levantou, como premissa principal, a afirmativa de que é possível melhorar as condições de acessibilidade das pessoas com deficiência visual a partir de uma visão integrada dos elementos de wayfinding e dos fatores-chave da mobilidade existentes nas etapas da jornada do usuário do sistema metroferroviário. Tal premissa foi comprovada por meio dos resultados apresentados no decorrer desta tese, e as análises e considerações a seguir demonstrarão de que forma a hipótese foi verificada.

Os aspectos relacionados às instalações, aos funcionários e ao comportamento dos demais usuários predominam entre os fatores que interferem nos deslocamentos - sejam estes independentes ou efetuados com auxílio - e são de responsabilidade da empresa prestadora do serviço. Os aspectos relacionados ao preparo dos usuários com deficiência visual treinamento para utilização dos recursos e das instalações - devem ser vistos como de responsabilidade compartilhada entre a empresa operadora, as instituições de reabilitação e o usuário com deficiência visual. Os demais aspectos - grau de deficiência e estado emocional do usuário - não podem ser controlados pela empresa. Dessa forma, entende-se que há espaço para melhorias no serviço prestado pelas empresas de transporte às pessoas com deficiência visual.

Esta pesquisa teve como meta a busca de elementos que pudessem proporcionar uma visão integrada e sistêmica do desempenho funcional da acessibilidade a partir de uma abordagem centrada no usuário com deficiência visual a fim de propor a introdução de novos requisitos de acessibilidade para as estações e os trens, bem como para o design do serviço de transporte metroferroviário. Para viabilizar a concretização dessa meta, foram coletados dados primários junto às pessoas com deficiência visual, usuárias do serviço, para caracterizar seus hábitos de viagem e sua percepção sobre as instalações e o serviço ofertado pelo Metrô de São Paulo, de forma a registrar suas necessidades nas diversas etapas da viagem. Os dados comportamentais coletados a partir da observação de fluxo e de comportamento dos usuários com deficiência visual e dos demais usuários nas estações permitiram identificar sinergias e conflitos de interesse. Adicionalmente, os dados coletados a partir do registro dos relatos das demais pessoas-chave e especialistas envolvidos no processo de prestação do serviço possibilitaram captar não somente a percepção desses profissionais sobre as instalações e os serviços prestados, mas também o grau de empatia e conhecimento sobre as reais necessidades dos usuários com deficiência visual. 
A análise dos relatos das entrevistas aplicadas aos especialistas e pessoas-chave permite afirmar que os profissionais responsáveis pelo treinamento de orientação e mobilidade e os estagiários que auxiliam os deslocamentos têm uma percepção mais real das necessidades desse segmento em relação à configuração e sinalização das instalações - fato que pode ser explicado pela convivência mais próxima nas situações reais de deslocamento. Por outro lado, os funcionários das estações e do CCO tendem a uma visão de causa e efeito, das ações e consequências dos serviços prestados, sem atentar para as questões relacionadas à configuração ou sinalização das instalações. Num campo intermediário, situam-se os responsáveis pelo treinamento dos empregados, que têm uma visão mais sistêmica do serviço cotidiano, dos auxílios prestados numa estação e sua consequência em outra estação, complementada por uma posição mais crítica em relação às instalações - fato que pode ser explicado pela convivência simultânea com os estagiários e funcionários das estações e do CCO, bem como com os professores de O\&M. Nesse mesmo campo intermediário, também estão os profissionais responsáveis pelo estabelecimento dos requisitos normativos, que têm uma visão mais sistêmica sobre as instalações, complementada por um conhecimento básico em relação ao serviço prestado, explicado pela convivência simultânea com os profissionais responsáveis pelo projeto e com os usuários com deficiência visual. Por fim, os dados coletados junto aos profissionais responsáveis pela elaboração do projeto das estações e dos trens confirmaram que estes profissionais têm maior conhecimento técnico e específico sobre as instalações sob sua responsabilidade mas pouca possibilidade de convivência ou de contato direto com as pessoas com deficiência visual para pautar soluções de projeto centradas no usuário.

A partir de uma abordagem multimétodo junto ao público-alvo, foram coletados dados que possibilitaram a geração de evidências para as etapas da jornada do usuário do sistema metroferroviário em São Paulo que permitiram ora contrapor, ora corroborar a percepção dos usuários, convergindo para uma visão abrangente sobre a acessibilidade da rede metroferroviária. A comparação entre os dados obtidos junto aos usuários com deficiência visual e os demais dados coletados junto às pessoas-chave e especialistas, somada às observações e medições realizadas e às melhores práticas identificadas junto aos outros sistemas metroferroviários, possibilitou a elaboração de um diagnóstico de cada uma das etapas da jornada do usuário e a identificação dos aspectos positivos e as oportunidades de melhoria para proporcionar à pessoa com deficiência visual uma experiência de viagem de 
acordo com suas expectativas e segundo sua opção, seja com independência ou com auxílio nos deslocamentos.

Simultaneamente, foi possível obter uma visão integrada dos elementos de wayfinding existentes nas diversas etapas da jornada do usuário. Tais dados possibilitarão, num segundo momento, o estabelecimento de novos requisitos para garantir a independência nos deslocamentos realizados, configurando uma experiência que poderá ser aplicada para outros estudos de caso, para outros segmentos de usuários ou até mesmo para outros sistemas de transporte.

Uma das questões formuladas no início desse estudo estava relacionada à possibilidade de correlacionar a época de construção das estações e o atendimento às necessidades das pessoas com deficiência visual. Após a análise e interpretação dos dados coletados, conclui-se que as estações construídas mais recentemente oferecem melhores condições de acessibilidade quando comparadas às estações mais antigas somente por disporem de portas nas plataformas, uma vez que essa condição cria uma percepção de segurança às pessoas com deficiência visual. A facilidade de compreensão dos ambientes e dos percursos não se confirmou uma vez que, mesmo nas novas estações, observa-se um elevado índice de solicitação de auxílios nos deslocamentos. Em relação aos percursos, foi possível observar que o fato de a sinalização tátil no piso não diferenciar fluxos e contrafluxos nas áreas de circulação, dificulta a realização dos deslocamentos com independência. Some-se a isso a alteração significativa dos ambientes construídos: as antigas estações são mais funcionais e legíveis na forma como são apresentadas às pessoas que não têm a visão como canal principal de percepção, seja em função das estruturas, dos pisos, das aberturas ou dos fechamentos. Nas novas estações, a percepção do espaço dá-se em sua plenitude, e não em suas contenções. Portanto, os espaços amplos e abertos são vazios que transpassam os pavimentos e são transpassados pelos elementos de circulação vertical, comprometendo a percepção e dificultando sua compreensão pelas pessoas com deficiência visual. Dessa forma, entende-se que outros fatores - tais como a complexidade da configuração e a lotação das estações - são igualmente determinantes para a legibilidade e a compreensão do espaço e dos percursos de embarque e desembarque, impactando a independência dos deslocamentos.

Em relação aos requisitos estabelecidos nas leis e nas normas técnicas de acessibilidade vigentes no Brasil, entende-se que estes foram interpretados e aplicados pelo Metrô de São 
Paulo, ainda que de forma incompleta. Até o momento desta pesquisa permaneciam como não atendidos os requisitos relacionados à existência de intercomunicadores nos acessos e plataformas, bem como ao vão e ao desnível entre o trem e a plataforma. Assim, quando analisados isoladamente, não se pode afirmar que os requisitos estabelecidos e vigentes sejam insuficientes para garantir o deslocamento das pessoas com deficiência visual com independência no sistema metroferroviário uma vez que tais aspectos - intercomunicadores, vão e desnível - tiveram pouca relevância na avaliação realizada pelos usuários.

Entretanto, considerando que as recomendações atualmente existentes não fazem referência a determinados requisitos considerados indispensáveis ao deslocamento com independência no sistema metroferroviário nem enfatizam aspectos relacionados ao percurso a ser realizado com auxílio da sinalização tátil no piso nas áreas públicas ou de uso comum de circulação entende-se como necessário o estabelecimento de novos requisitos.

Inicialmente, pode-se destacar a necessidade de sinalização tátil no piso desde a origem até o destino, passando pelas áreas de interesse, de uso ou de serviços onde seja necessária a orientação do deslocamento da pessoa com deficiência visual. Tal sinalização deve considerar todos os aspectos envolvidos no deslocamento de pessoas com deficiência visual, tais como fluxos de circulação de pessoas e pontos de interesse, seguindo o fluxo das demais pessoas, inclusive na circulação vertical. Ao mesmo tempo, deve-se evitar o cruzamento, o confronto de circulações, as interferências com áreas de formação de filas, com pessoas sentadas em bancos ou com demais áreas de permanência de pessoas, ou ainda com obstáculos permanentes ou temporários das edificações.

Em diferentes ambientes de um mesmo edifício a sinalização tátil direcional deve-se considerar a padronização de soluções e a utilização de relevos e contrastes de luminância semelhantes. Tal sinalização deve ser complementada por informação redundante sobre a origem, o percurso e o respectivo destino da sinalização tátil direcional, por meio de informação tátil e visual; visual e sonora; ou tátil e sonora.

A identificação de melhores práticas observadas em outros sistemas metroferroviários contribuiu para gerar subsídios que puderam ser comparados aos requisitos ora vigentes nas normas técnicas nacionais. Dessa forma, sugere-se que sejam acrescentados novos requisitos normativos que possam, no futuro, ser apresentados e discutidos pela sociedade civil organizada - pessoas com deficiência, fabricantes, operadores, especialistas, projetistas - e, 
após consenso, transformados em requisitos a serem incorporados nas normas técnicas relativas à acessibilidade no sistema de trens urbanos e metropolitanos.

Acredita-se que, somente a partir da interação contínua dos profissionais de diferentes áreas do conhecimento e do registro formal das informações obtidas junto aos usuários e demais pessoas envolvidas - especialistas e pessoas-chave -, será possível incorporar outras premissas para a construção de novas estações ou para a aquisição de novos trens, para modernização das estações e dos trens existentes, para a contratação de um novo serviço ou para a capacitação ou requalificação dos empregados que atendam às expectativas e satisfaçam os usuários, gestores e investidores. Dessa forma, entende-se que esta tese apresenta uma contribuição aos profissionais das diversas áreas para que as questões aqui apresentadas por todos os interessados possam dar início a um debate sobre o tema.

Não se pode apontar uma característica única que faz o conjunto todo funcionar. É a obra como um todo, todas suas partes juntas, integradas, trabalhando para criar um efeito global, que criam a grandeza duradoura. Cabe ressaltar que não são apenas as partes grandes, mas também os detalhes aparentemente sem importância, que garantirão que o sistema metroferroviário possa atender às necessidades das pessoas com deficiência visual.

A apresentação das recomendações, segundo uma matriz de avaliação da acessibilidade elaborada a partir da interpretação do conceito dos fatores-chave de acessibilidade no sistema de transportes (JUNCÀ, 2011), e a incorporação do relato dos usuários na forma do Discurso do Sujeito Coletivo ressaltam a interdependência das condições de acessibilidade dos ambientes identificados (estação, interface trem-estação e trem) e dos temas avaliados (configuração, informação e serviços) e possibilitam maior empatia dos profissionais em relação aos problemas apresentados, permitindo que o projeto e o serviço sigam uma mesma estratégia, adaptando-se mutuamente.

Com relação à importância do aprofundamento dos aspectos relacionados ao wayfinding, entende-se que os espaços públicos destinados ao deslocamento de um grande fluxo de pessoas, tais como os terminais de transporte, devem ser claros, legíveis, de fácil compreensão e orientação por meio de elementos de referência ou de sinalização específica, sempre que necessário. Conhecer o fluxo e o comportamento dos usuários do sistema de transporte é fundamental para a construção de um eficiente sistema de informação, bem como para a veiculação de campanhas de conscientização para orientar comportamentos que possam 
melhorar a convivência e a interação entre os usuários com deficiência visual, os demais usuários e os funcionários. No caso específico das estações de metrô, existem outros agravantes: a complexidade dos ambientes, a diversidade de público e a elevada demanda. Quanto mais complexo o ambiente, mais urgente é a necessidade de identificar os elementos de wayfinding existentes, a fim de se obter uma visão integrada destes elementos - segundo os fatores-chave de acessibilidade dos sistemas de transporte - e facilitar a compreensão dos percursos de embarque e desembarque.

Por fim, buscou-se a validação dos instrumentos para avaliação da acessibilidade no sistema metroferroviário a partir da aplicação de métodos e técnicas da APO na jornada do usuário. Este recurso mostrou-se adequado, especialmente por permitir uma visão multifacetada da jornada do usuário a partir dos vários envolvidos e, consequentemente, possibilita a proposição de soluções convergentes de forma a atender anseios individuais e coletivos. Por tratar-se de um ambiente complexo, onde a impossibilidade de padronização - dos ambientes, dos equipamentos, dos elementos, dos veículos -, associada à elevada demanda, à heterogeneidade dos usuários, à diversidade de características e necessidades das pessoas com deficiência visual, impõe a adoção de soluções multifacetadas, integradas e sistêmicas, que possam gerar impactos positivos, com diferentes intensidades, nos detalhes ou no conjunto.

Os procedimentos utilizados para avaliar o desempenho funcional de acessibilidade do sistema metroviário a partir de uma abordagem centrada no usuário foram considerados fundamentais para o desenvolvimento desse estudo, possibilitando o estabelecimento de sugestões e recomendações para melhoria no processo de projeto, na concepção da configuração e do sistema de informação das estações e dos trens, bem como na gestão dos serviços prestados.

Em função dos dados coletados, das análises efetuadas e das considerações formuladas, apresentam-se a seguir algumas alternativas de encaminhamento para pesquisas futuras, uma vez comprovada a possibilidade de aplicação de métodos e técnicas da APO às etapas da jornada do usuário. Para o desenvolvimento de pesquisas futuras relacionadas à aplicação da APO em sistemas metroferroviários, sugere-se a aplicação de métodos e técnicas da APO na jornada do usuário com outras deficiências, que não a visual, para identificar outros requisitos que possam vir a ser incorporados às normas técnicas, promovendo e facilitando a inclusão de pessoas com deficiência na sociedade. 
Sugere-se o envolvimento dos profissionais de outras áreas do conhecimento, além dos profissionais das áreas de planejamento, projeto, construção, operação e manutenção, para que as ações possam gerar resultados positivos para todos os envolvidos, em todas as etapas do ciclo de vida do empreendimento, complementando as premissas e requisitos estabelecidos.

Entende-se que a utilização de bancos de dados já disponíveis nas empresas operadoras bem como registros formais dos novos dados devem contribuir para a utilização da APO como um instrumento de gestão permanente, possibilitando a contínua realimentação do processo de projeto, seja para promover melhorias nos aspectos funcionais ou estruturais, seja para promover a gestão do conhecimento empresarial. Além disso, podem ser envolvidas as entidades setoriais e os profissionais de outras empresas durante a elaboração do estudo como forma de oportunizar a troca de informações, compartilhando os avanços e as dificuldades vivenciadas bem como os resultados obtidos e relacionados aos temas pesquisados.

Sugere-se o desenvolvimento de pesquisas específicas em sistemas de informação que possam auxiliar os deslocamentos das pessoas com deficiência visual nos grandes centros urbanos e nos sistemas de transportes, bem como de pesquisas integrando diferentes áreas do conhecimento como forma de prover uma visão sistêmica e abrangente sobre os problemas que afetam as pessoas com deficiência, possibilitando gerar soluções viáveis do ponto de vista técnico, econômico e social. 


\section{REFERÊNCIAS}

ALOUCHE, P. L. Desenvolvimento tecnológico em sistemas metroferroviários. In: ASSOCIAÇÃO NACIONAL DE TRANSPORTES PÚBLICOS - ANTP, BANCO NACIONAL DE DESENVOLVIMENTO SOCIAL - BNDES. Transporte metroferroviário no Brasil: Situações e perspectivas. Série Cadernos Técnicos, v.2, São Paulo: ANTP; BNDES, 2005. p. 78-114.

ANUÁRIO METROFERROVIÁRIO 2012. A demanda cresceu em dez sistemas. In: Anuário Metroferroviário 2012: um raio-X dos principais sistemas metroferroviários do país. Ano 4, n. 4. São Paulo: OTM Editora, 2012. p. 6-12.

APEL-MULLER, M.; BORTHGARAY, A. A cidade legível. D2B - Design to Branding Magazine / GAD'- vol. 1, n.1. São Paulo: D2B Publicações e Promoções, 1994. p 74-81.

ARTHUR, P.; PASSINI, R. Wayfinding: people, signs and architecture. Toronto: McGrawHill Ryerson, 1992. 201 p.

ASOCIACIÓN ESPAÑOLA DE NORMALIZACIÓN Y CERTIFICACIÓN. La calidad en el transporte público de pasajeros. Madrid: AENOR, 2011. 220 p.

ASSOCIAÇÃO BRASILEIRA DE NORMAS TÉCNICAS. NBR 14021: transporte acessibilidade no sistema de trem urbano ou metropolitano. Rio de Janeiro, 2005.

ASSOCIAÇÃO BRASILEIRA DE NORMAS TÉCNICAS. NBR 15250: acessibilidade em caixa de autoatendimento bancário. Rio de Janeiro, 2005.

ASSOCIAÇÃO BRASILEIRA DE NORMAS TÉCNICAS. NBR 15290: acessibilidade em comunicação na televisão. Rio de Janeiro, 2005.

ASSOCIAÇÃO BRASILEIRA DE NORMAS TÉCNICAS. NBR 15599: acessibilidade na comunicação na prestação de serviços. Rio de Janeiro, 2008.

ASSOCIAÇÃO BRASILEIRA DE NORMAS TÉCNICAS. NBR 9050: acessibilidade para pessoas com deficiência a edificações, mobiliário, espaços e equipamentos urbanos. Rio de Janeiro, 1994.

ASSOCIAÇÃO BRASILEIRA DE NORMAS TÉCNICAS. NBR 9050: acessibilidade a edificações, espaço, mobiliário e equipamentos urbanos. Rio de Janeiro, 2004.

ASSOCIAÇÃO BRASILEIRA DE NORMAS TÉCNICAS. NBR NM 195: escadas rolantes e esteiras rolantes - requisitos de segurança para construção. Rio de Janeiro, 1999. 
ASSOCIAÇÃO BRASILEIRA DE NORMAS TÉCNICAS. NBR NM 313: elevadores de passageiros - requisitos de segurança para construção e instalação - requisitos particulares para a acessibilidade das pessoas, incluindo pessoas com deficiência. Rio de Janeiro, 2007.

BARBOSA, M. B. Ações de acessibilidade. Revista Engenharia, São Paulo, n. 594, p. 115118, jul./dez. 2009.

BARBOSA, M. B. Acessibilidade nos Transportes Metroferroviários. In: ASSOCIAÇÃO NACIONAL DE TRANSPORTES PÚBLICOS - ANTP, BANCO NACIONAL DE DESENVOLVIMENTO SOCIAL - BNDES. Transporte metroferroviário no Brasil:

Situações e perspectivas. Série Cadernos Técnicos, v.2, São Paulo: ANTP; BNDES, 2005. p. 57-77.

BARBOSA, M. B.; ORNSTEIN, S. W. Da especificidade à multifuncionalidade: aspectos do projeto das estações de metrô. In: SALGADO, M. S.; RHEINGANTZ, P.A.; AZEVEDO, G. A. N.; SILVOSO, M. M. (Org.) Projetos complexos e seus impactos na cidade e na paisagem. Rio de Janeiro: UFRJ/FAU/PROARQ; ANTAC, 2012. p. 40-65.

BAUER, M. W.; GASKELL, G. (Org.). Tradução de Pedrinho A. Guareschi. Pesquisa qualitativa com texto, imagem e som. Petrópolis: Vozes, 2011. 516 p.

BECHTEL, R. Environment and Behavior: An introduction. Thousand Oaks: Sage Publications, 1997. $679 \mathrm{p}$.

BELL, J. Como realizar um projecto de investigação. Trad. Maria João Cordeiro. Lisboa: Gradiva Publicações S.A., 2010. 245 p.

BERNARDI, N. et al. O desenho universal no processo de projeto. In: KOWALTOWSKI, D. C. C. K. et. al. (Org.). O processo de projeto em arquitetura: da teoria à tecnologia. São Paulo: Oficina de Textos, p. 222-244, 2011.

BERSCH, R. Introdução à tecnologia assistiva. Porto Alegre: Centro Especializado em Desenvolvimento Infantil, 2008. 19 p. Disponível em: <http://proeja.com/portal/images/ semana-quimica/2011-10-19/tec-assistiva.pdf >. Acesso em: 13 ago. 2012.

BEST, K. Fundamentos de gestão do design. Trad. André de Godoy Vieira. Porto Alegre: Bookman, 2012. 208 p.

BRASIL. Decreto Federal n. 6.949, de 25 de agosto de 2009. Promulga a Convenção Internacional sobre os Direitos das Pessoas com Deficiência e seu Protocolo Facultativo, assinados em Nova York, em 30 de março de 2007. Diário Oficial da União, Brasília, 2009.

BRASIL. Decreto n. 5.296, de 2 de dezembro de 2004. Regulamenta as Leis n. 10.048, de 8 de novembro de 2000, que dá prioridade de atendimento às pessoas que especifica, e 10.098, de 19 de dezembro de 2000, que estabelece normas gerais e critérios básicos para a promoção 
da acessibilidade das pessoas portadoras de deficiência, ou com mobilidade reduzida, e dá outras providências. Diário Oficial da União, Brasília, 2004.

BRASIL. Lei Federal n. 12.587, de 3 de janeiro de 2012. Institui as diretrizes da Política Nacional de Mobilidade Urbana e dá outras providências. Diário Oficial da União, Brasília, 2012.

CAMBIAGHI, S. Desenho universal: métodos e técnicas para arquitetos e urbanistas. São Paulo: Editora Senac, 2007. 269 p.

CARPMAN, J. R.; GRANT, M. A. Wayfinding: a broad view. In: BECHTEL, R.; CHURCHMAN, A. Handbook of environmental psychology. New York: John Wiley \& Sons, 2002. p. 427-442.

CASALS, B. C. Movilidad con perro-guía: bastón y guía vidente como elementos complementarios de familiarización con nuevos entornos. Integración - Revista Sobre Ceguera y Deficiencia Visual, n. 52, dez. 2007, p. 33-37. Disponível em:

<http://www.once.es/serviciosSociales/index.cfm>. Acesso em: 28 jun. 2011.

CHARMAZ, K. A construção da teoria fundamentada: guia prático para análise qualitativa. Porto Alegre: Artmed, 2009. 272p.

COMMUNITY OF METROS - COMET. COMET Benchmarking 2012: Accessibility Barrier Free Design. Final Report. . London: Imperial College, 2012.

COMMUNITY OF METROS - COMET. COMET Clearinghouse Universal Accessibility - Functional Specifications: Level of progress. Final Report. London: Imperial College, 2009.

COMPANHIA DO METROPOLITANO DE SÃO PAULO. Diretoria de Operações. Relatório Operacional RO2013. Compact-disc. CMSP, 2014 b.

COMPANHIA DO METROPOLITANO DE SÃO PAULO. Gerência de Operações. Por Dentro da Operação - 2013, São Paulo: CMSP, 2014. 136 p.

COMPANHIA DO METROPOLITANO DE SÃO PAULO. Gerência de Operações. Comportamento dos usuários - 2014. Relatório Técnico GOP/OPR nº 08 de Ago.2014. 15p.

COMPANHIA DO METROPOLITANO DE SÃO PAULO. Sítio eletrônico. Disponível em: $<$ http://www.metro.sp.gov.br > . Acesso em: 04 jan.2015.

COORDENADORIA NACIONAL PARA INTEGRAÇÃO DA PESSOA PORTADORA DE DEFICIÊNCIA - CORDE. Secretaria Especial dos Direitos Humanos. Ata da VII Reunião do Comitê de Ajudas Técnicas - CAT, realizada nos dias 13 e 14 de dezembro de 2007. 
Disponível em: <http://portal.mj.gov.br/corde/arquivos/doc/Ata_VII_Reunião_do_Comite de_Ajudas Técnicas.doc $>$. Acesso em: 10 jul. 2012.

CORREAA, H. L.; CAON, M. Gestão de serviços: lucratividade por meio de operações e de satisfação dos clientes. São Paulo: Atlas, 2002. 479 p.

COSTA, R.X; ELALI, G.A. Lendo trajetos em museu-paisagem: Um estudo de wayfinding no Instituto Inhotim, Minas Gerais. Anais do III Encontro da Associação Nacional de Pesquisa e Pós-graduação em Arquitetura e Urbanismo. Arquitetura, cidade e projeto: uma construção coletiva. São Paulo, 2014.

CUREDALE, R. Design thinking. Topanga: Design Community College, 2013. 190 p.

DISCHINGER, M.; BINS ELY, V. H. Como criar espaços mais acessíveis para pessoas com deficiência visual a partir de reflexões sobre nossas práticas projetuais? In: ORNSTEIN, S. W; PRADO, A. R. A.; LOPES, M. E. Desenho Universal: caminhos da acessibilidade no Brasil. São Paulo: Annablume, 2010. p. 95-104.

DUFFY, B. Análise de dados documentais. In: BELL, J. Como realizar um projecto de investigação. Trad. Maria João Cordeiro. Lisboa: Gradiva Publicações S.A., 2010. p 101-115.

EDWARDS, B. The Modern Station: New approaches to railway architecture. London: E \& FN Spon, 1997. 186 p.

ELALI, G. A.; PINHEIRO, J. Q. Analisando a experiência do habitar: algumas estratégias metodológicas. In: VILLA, S. B.; ORNSTEIN, S. W. Qualidade Ambiental na habitação: avaliação pós-ocupação. São Paulo: Oficina de Textos, 2013. p. 15-35.

EVANS, G. A importância do ambiente físico. In: TASSARA, E. T. O. (ed.). Psicologia e ambiente. Revista Psicologia USP; Instituto de Psicologia. São Paulo: Universidade de São Paulo, 2005. p.47-52.

FÁVERO, E. A. G. Direito das pessoas com deficiência: garantia de igualdade na diversidade. Rio de Janeiro: WVA Editora, 2004. 344 p.

FELIPPE, J. A. M. Caminhando Juntos: manual das habilidades básicas de orientação e mobilidade. São Paulo: Laramara - Associação Brasileira de Assistência ao Deficiente Visual, $2001.57 \mathrm{p}$.

FELIPPE, J. A. M., FELIPPE, V. L. R. Orientação e Mobilidade. São Paulo: Laramara Associação Brasileira de Assistência ao Deficiente Visual, 1997. 179 p.

FEHR, L. $O$ projeto frente a questões contemporâneas da cidade e da arquitetura: 0 museo de la memoria de Santiago do Chile. 2010. Tese (Doutorado em Arquitetura), Faculdade de Arquitetura e Urbanismo, FAUUSP, Paulo, 2010. 218 p. 
FERNANDES, J. Transporte urbano na macrometrópole de São Paulo. Trabalho apresentado no $\mathbf{1 8}^{\circ}$ Congresso Brasileiro de Transporte e Trânsito. Rio de Janeiro. 18 a 21 de outubro de 2011. Disponível em: <http://portal1.antp.net/rep/18cng/ 18cng14pnlt02.pdf.> Acesso em: 12 jan. 2012.

FINKEL, G. Wayfinding performance by people with visual impairments. In: STEINFELD, E.; DANFORD, G. S. (Ed.) Enabling Environments: measuring the impact of environment on disability and rehabilitation. New York: Kluwer Academic, Plenum Publishers, 1999. p. 331-349.

FITZSIMMONS, J. A.; FITZSIMMONS, M. J. Administração de serviços: operações, estratégia e tecnologia da informação. Trad. Jorge Ritter. 4. ed. Porto Alegre: Bookman, 2005. 564 p.

FLICK, U. Introdução à metodologia de pesquisa. Trad. Magda Lopes. Porto Alegre: Penso, 2013. 256 p.

FLICK, U. Introdução à pesquisa qualitativa. Porto Alegre: Artmed, 2009, 405 p.

FORGUS, R. H. Percepção: o processo básico do desenvolvimento cognitivo. Trad. Nilce Pinheiro Mejias. Brasília: Ed. Univ. Brasília; São Paulo: Editora Universidade de São Paulo, 1971. $528 \mathrm{p}$.

GALÀN, J. H. Introducción. In: FUNDACIÓN ONCE; FUNDACIÓN ARQUITECTURA COAM. Accesibilidad Universal y Diseño para Todos. Arquitectura y Urbanismo. Madrid: Artes Gráficas Palermo, 2011, p.15-20.

GARCIA, N. Como desenvolver programas de orientação e mobilidade para pessoas com deficiência visual. In: MOTA, M. G. B (Coord.). Orientação e mobilidade: Conhecimentos básicos para a inclusão do deficiente visual. Brasília: MEC, SEESP, 2003. p. 66-121.

GIL, A. C. Métodos e técnicas de pesquisa social. 6. ed. São Paulo: Atlas, 2010. 200 p.

GRAY, D. Pesquisa no mundo real. Trad. Roberto Cataldo Costa. 2. ed. Porto Alegre: Penso, 2012. 488 p.

GRIFFIN, K. W. Building type basics for transit facilities. New Jersey: John Wiley \& Sons Inc., 2004. 356 p.

GUEDES, R. A. P. As estratégias de prevenção em saúde ocular no âmbito da saúde coletiva e da Atenção Primária à Saúde - APS. Revista APS, v.10, n.1, p. 66-73, jan./jun. 2007.

Disponível em: 〈http://www.ufjf.br/nates/files/2009/12/Socular.pdf $>$. Acesso em: 10 jul. 2012. 
GÜNTHER, H.; ELALI, G. A.; PINHEIRO, J. Q. In: PINHEIRO, J.Q.; GÜNTHER, H. A abordagem multimétodos em estudos pessoa-ambiente: características, definições e implicações. Métodos de Pesquisa nos Estudos Pessoa-Ambiente. São Paulo: Casa do Psicólogo, 2008. p. 369-396.

GÜNTHER, I. O uso da entrevista na interação pessoa-ambiente. In: PINHEIRO, J.Q.; GÜNTHER, H. Métodos de Pesquisa nos Estudos Pessoa-Ambiente. São Paulo: Casa do Psicólogo, 2008. p. 53-74.

GUSTEMS, I. VALLÉS, L. L. Accessibilitat al tren en cadira de rodes. Cap a un estàndard intenacional del gap d'embarcament. Colección Estudis. Barcelona: Disputación de Barcelona, 2009. $81 \mathrm{p}$.

HADDAD, M. A. O. Atenção médico-oftalmológica na reabilitação da pessoa com deficiência visual ou baixa visão. São Paulo, 2012. Palestra ministrada em 18 de junho de 2012 no curso de Extensão Universitária de Orientação e Mobilidade. Promoção: Secretaria de Estado da Pessoa com Deficiência, Associação Laramara, Fatec Zona Sul e Fundação de Apoio à Tecnologia (FAT). Notas de aula.

HALL, E. T. A dimensão oculta. Trad. Waldéa Barcellos. São Paulo: Martins Fontes, 2005. $258 \mathrm{p}$.

LARAMARA. Baixa visão. Disponível em: <http://laramara.org.br/ deficienciavisual/definicoes>. Acesso em: 10 jul. 2012.

HOFFMAN, K. D.; BATESON, J. E. G. Princípios de marketing de serviços: conceitos, estratégias e casos. Trad. Brasil Ramos Fernandes. São Paulo: Pioneira Thompson Learning, 2003. $631 \mathrm{p}$.

IDEA - CENTER FOR INCLUSIVE DESIGN AND ENVIRONMENTAL ACCESS. Design Resources. DR-01 Architectural Wayfinding. New York, 2010. 8 p. Disponível em: <http://udeworld.com/documents/designresources/pdfs/ArchitecturalWayfinding.pdf $>$. Acesso em: 30 out. 2011.

IDEA - CENTER FOR INCLUSIVE DESIGN AND ENVIRONMENTAL ACCESS. Universal Design New York. New York, 2001. 124 p. Disponível em: <http://www.ap.buffalo.edu/idea/ Publications/pdfs/udny1.pdf >. Acesso em: 10 jun. 2010.

IIDA, I. Ergonomia: projeto e produção. 2. ed. São Paulo: Blucher, 2005. 614 p.

INSTITUTO BRASILEIRO DE GEOGRAFIA E ESTATÍSTICA - IBGE. Censo demográfico 2010. Características da população e dos domicílios. Resultados do universo. Rio de Janeiro, 2011. 211 p. Disponível em: <http://www.ibge.gov.br/home/estatistica/populacao/censo2010/caracteristicas_da_populacao /resultados_do_universo.pdf>. Acesso em: 16 abr. 2012. 
JUNCÁ, J. A. U. Diseño de transporte accesible. In: Fundación ONCE, Fundación Arquitectura COAM. Accesibilidad Universal y Diseño para Todos. Arquitectura y Urbanismo. Madrid: Artes Gráficas Palermo, 2011. p. 164-201.

JUNCÁ, J. A. U. Estudio de viabilidad para la mejora de la accesibilidad de la red del Metro de Barcelona. Documentos Técnicos. Madrid: Ministerio de Asuntos Sociales, 1992. $213 \mathrm{p}$.

JUNCÁ, J. A. U. Movilidad Accesible. In: FERNÁNDEZ, J. B. et al. Manual para un Entorno Accesible. Madrid: Real Patronato sobre Discapacidad, Centro Español de Documentación sobre Discapacidad, 2005, p. 95-258. Disponível em: <http://sid.usal.es/idocs/F8/FDO17241/ manualparaunentornoaccesible.pdf >. Acesso em: 05 fev. 2011.

KELLEY, T; KELLEY, D. Confiança criativa: libere sua criatividade e implemente suas ideias. Trad. Cristina Yamagami. São Paulo: HSM do Brasil, 2014. 264 p.

LEFEVRE, F; LEFEVRE, A. M. C. Depoimentos e discursos: uma proposta de análise em pesquisa social. Brasília: Liber Livro Editora, 2005. 97 p.

LOPES, M. E.; BURJATO, A. L. P. F. Ergonomia e Acessibilidade. In: ORNSTEIN S.W.; PRADO, A. R. A.; LOPES, M. E. Desenho Universal: caminhos da acessibilidade no Brasil. São Paulo: Annablume, 2010. p. 69-79.

LORA, T. D. P. Descobrindo o real papel das outras percepções, além da visão, para a orientação e mobilidade. In: Ministério da Educação. Secretaria de Educação Especial. Orientação e Mobilidade: conhecimentos básicos para a inclusão da pessoa com deficiência visual. Brasília: MEC, SEESP, 2003, p. 58-65. Disponível em: < http://portal.mec.gov.br/seesp/arquivos/pdf/ori_mobi.pdf>. Acesso em: 28 ago. 2011.

LYNCH, K. A imagem da cidade. Trad. Jefferson Luiz Camargo. São Paulo: Martins Fontes, 1997. $227 \mathrm{p}$.

MACHADO, E. V. Desenvolvimento da criança e políticas públicas de inclusão. In: Ministério da Educação. Secretaria de Educação Especial. Orientação e Mobilidade: conhecimentos básicos para a inclusão da pessoa com deficiência visual. Brasília: MEC, SEESP, 2003, p. 22-34. Disponível em: <http://portal.mec.gov.br/seesp/arquivos/pdf/ ori_mobi.pdf> Acesso em: 28 ago. 2011.

MARTIN, B.; HANINGTON, B. Universal methods of design. Beverley: Rockport Publishers, 2012. 208 p. 
MASI, I. Conceitos - Aquisição básica para a orientação e mobilidade. In: Ministério da Educação. Secretaria de Educação Especial. Orientação e Mobilidade: conhecimentos básicos para a inclusão da pessoa com deficiência visual. Brasília: MEC, SEESP, 2003, p.38-55. Disponível em: 〈http://portal.mec.gov.br/seesp/arquivos/pdf/ori_mobi.pdf> Acesso em: 28 ago. 2011.

MATTAR, F. N. Pesquisa de Marketing: metodologia, planejamento. São Paulo: Atlas, 1999. $337 \mathrm{p}$.

MINISTÉRIO DA EDUCAÇÃO. Saberes e práticas da inclusão: desenvolvendo competências para o atendimento às necessidades educacionais especiais de alunos cegos e de alunos com baixa visão. 2. ed. Coordenação geral SEESP/MEC. Brasília: Secretaria de Educação Especial, 2006. 208 p.

MINISTÉRIO DAS CIDADES. Caderno de Implantação de Sistemas de Transporte Acessíveis. Programa Brasileiro de Acessibilidade Urbana - Brasil Acessível - Caderno 5, 2006. Disponível em: <http://www.cidades.gov.br/images/stories/ArquivosSEMOB/ Biblioteca/BrasilAcessivelCaderno05.pdf >. Acesso em: 09 jul. 2012.

MINTRA ACCESSIBILITY OFFICE - MINTRA. EI plan de ampliacón de Metro de Madrid 2003-2007: Arquitectura, accesibilidad y ate público. Comunidad de Madrid: Consejeria de Transportes e Infraestructura. Madrid: Gráficas Monterreina, 2007. 225 p.

MINTRA ACCESSIBILITY OFFICE - MINTRA. Functional Specifications for Universal Accessibility. Comunidad de Madrid: Consejería de Transportes e Infraestructura, 2006. 10 p. Disponível em: 〈http://www.mintramadrid.es/pdf/MEDIDASAUESTACIONES.pdf>. Acesso em: 14 mai. 2010.

MOLINA, L. Acessibilidade na prática - Deficiência visual: formas de leitura e acessibilidade à informação. Disponível em: <http://www.braillu.com/2011/03/acessibilidadena-pratica-deficiencia.html $>$. Acesso em: 10 jul. 2012.

MOLLERUP, P. Wayshowing \& wayfinding. Amsterdam: BIS Publisher, 2013. 240 p.

MORENO, D. G. Diseño de sistemas de orientación espacial: wayfinding. In: Fundación ONCE, Fundación Arquitectura COAM. Accesibilidad Universal y Diseño para Todos. Arquitectura y Urbanismo. Madrid: Artes Gráficas Palermo, 2011. p. 36-56.

MORENO, F. O.; BRAGA, M. O uso das informações do cliente para orientar o comportamento cidadão. Revista Engenharia, São Paulo, n. 607, p. 183-184, 2011.

NORMAN, D. A. Design emocional: porque adoramos (ou detestamos) os objetos do dia-adia. Trad. Ana Deiró. Rio de Janeiro, Rocco, 2008. 278 p.

NORMAN, D. A. O design do dia-a-dia. Trad. Ana Deiró. Rio de Janeiro: Rocco, 2006. 271 $222 \mathrm{p}$. 
OKAMOTO, J. Percepção ambiental e comportamento: visão holística da percepção ambiental na arquitetura e na comunicação. São Paulo: Mackenzie, 2002.

ORGANIZAÇÃO MUNDIAL DA SAÚDE - OMS.Relatório mundial sobre a deficiência. World Health Organization; The World Bank. World report on disability 2011. Trad. Lexicus Serviços Linguísticos. São Paulo: SEDPcD, 2012. 334 p. Disponível em:

<http://www.pessoacomdeficiencia.sp.gov.br/usr/share/documents/RELATORIO_MUNDIAL _COMPLETO.pdf >. Acesso em: 13 mar. 2012.

ORNSTEIN, S. W.; PRADO, A. R. A.; LOPES, M. E. (Org.). Desenho universal: caminhos da acessibilidade no Brasil. São Paulo: Annablume, 2010. 306 p.

PINHEIRO, J. Q.; ELALI, G. A.; FERNANDES, O. S. Observando a Interação PessoaAmbiente: vestígios ambientais e mapeamento comportamental. In: GÜNTHER, H.; PINHEIRO, J. Q. (Org.). Métodos de Pesquisa nos Estudos Pessoa-Ambiente, São Paulo: Casa do Psicólogo, 2008. p. 75-104.

PREISER, W. F. E. Evaluating universal design performance. In: PREISER, W. F. E.; VISCHER, J. C. Assessing Building Performance. Oxford: Elsevier, 2005. p. 170-179.

RÈGIE AUTONOME DES TRANSPORTS PARISIENS - RATP. Blue eyes. 2010. Disponível em: <https://vimeo.com/9042132> Acesso em: 25 jul.2011.

REIS, A. T. L. Edificações e espaços urbanos: percepção, cognição e métodos de avaliação. In: FABRICIO, M. M.; ORNSTEIN, S. W. Qualidade no Projeto de Edifícios. São Carlos: RiMa Editora, ANTAC, 2010. p. 165-190.

REIS, A. T. L.; LAY, M. C. D. Métodos e técnicas para levantamento de campo e análise de dados: questões gerais. In: Anais do Workshop Avaliação Pós-Ocupação. Anais. São Paulo, 1994. p. 17- 39.

RESKINOFF, S. et al. Global data on visual impairment in the year 2002. Bulletin of the World Health Organization 2004, 82 p. p. 844-851. Disponível em:

<http://www.who.int/bulletin/volumes/82/11/en/844.pdf>. Acesso em: 27 jul. 2012.

RHEINGANTZ, P. A. et al. Observando a qualidade do lugar: procedimentos para avaliação pós-ocupação, FAU/UFRJ, Rio de Janeiro, 2009. Disponível em:

<http://www.fau.ufrj.br/prolugar/arq_pdf/livros/obs_a_qua_lugar.pdf $>$. Acesso em: 14 nov. 2009.

RHEINGANTZ, P. A.; PEDRO, Cinco décadas de pesquisa habitacional no LNEC e a metodologia de APO. In: Villa, S.B.; Ornstein, S. W. (org.) Qualidade ambiental na edificação: avaliação pós-ocupação. São Paulo: Oficina de Textos, 2013. p.316-341. 
RICHARDSON, J. R. et al. Pesquisa social: métodos e técnicas. 3. ed. São Paulo: Atlas, 2011. $334 \mathrm{p}$.

ROGERS, Y.; SHARP, H.; PREECE, J. Design de interação: além da interação humanocomputador. Trad. Isabela Gasparini. Porto Alegre: Bookman, 2013. 585 p.

ROMÉRO, M. A.; ORNSTEIN, S. W. Avaliação Pós-Ocupação: métodos e técnicas aplicados à habitação social. Associação Nacional de Tecnologia do Ambiente Construído Coleção Habitare. Porto Alegre: ANTAC, 2003. 293 p.

ROSS, J. Railway Stations: planning, design and management. Oxford: Architectural Press, 2000. 350 p.

SAMPAIO, M. W.; HADDAD, M. A. O.; KARA-JOSÉ, N. Auxílios para baixa visão. São Paulo: Laramara, 2001. 97 p.

SANTOS FILHO, G. M. Construindo um itinerário histórico do Desenho Universal: a normatização nacional e internacional da acessibilidade. In: ORNSTEIN, S. W; PRADO, A. R. A.; LOPES, M. E. Desenho Universal: caminhos da acessibilidade no Brasil. São Paulo: Annablume, 2010, p. 35-43.

SANTOS, G. M.; BARBOSA, M. B. Os transportes e a acessibilidade. In: LICHT, F. B.; SILVEIRA, N. (Org.). Celebrando a diversidade: pessoas com deficiência e direito à inclusão. São Paulo: Planeta Educação. 2012. Disponível em:

〈http://www.planetaeducacao.com.br/portal/Celebrando-Diversidade.pdf $>$. Acesso em: 27 set. 2012.

SBARRA, M. H. Observação incorporada e análise do discurso no contexto do pósestruturalismo e da pós-modernidade: revisão crítica da contribuição do grupo ProLugar para a avaliação pós-ocupação e para a pesquisa em arquitetura. 2007. Dissertação (Mestrado em Arquitetura), Faculdade de Arquitetura e Urbanismo, UFRJ, Rio de Janeiro, 2007.

SELLTIZ, C.; JAHODA, M.; DEUTSH, M.; COOK, S. W. Métodos de pesquisa nas relações sociais. Trad. Dante Moreira Leite. Coleção Ciências do Comportamento. São Paulo: Editora Pedagógica Universitária, 1974. 687 p.

SIAULYS, M. A inclusão do aluno com deficiência visual no ensino regular. Brasília: Ministério da Educação, Secretaria de Educação Especial, 2006. Disponível em: <http://praticasinclusivas.files.wordpress.com/2011/04/a-inclusc3a3o-do-aluno-com-baixavisc3a3o-no-ensino-regular.pdf >. Acesso em: 10 jul. 2012.

SIAULYS, M.; ORMELEZY, E. M.; BRIANT, M. E. A deficiência visual associada à deficiência múltipla e o atendimento escolar especializado. Encarando desafios e construindo possibilidades. São Paulo: Laramara, 2010. 302 p.

SMITSHUIJZEN, E. Signage Design Manual. Baden: Lars Müller Publishers, 2007. 455 p. 
SOCIÉTÉ NATIONALE DES CHEMINS DE FER FRANÇAIS - SNCF. Dossier de presse. Montparnasse: Gare laboratoire de l'áccessibilité. Paris: SNCF, 2006. 16 p. Disponível em: 〈http://www.accessibilite.sncf.com/IMG/pdf/dossier_presse_gare_labo_resultats.pdf $>$. Acesso em: 28 jun. 2011.

SOCIÉTÉ NATIONALE DES CHEMINS DE FER FRANÇAIS - SNCF. Le Bilan Accessibilité 2004-2011. SNCF: 2011. Disponível em: <http://www.accessibilite. sncf.com/IMG/pdf/SNCF-Bilan_Accessibilite_2004_2011-FR_06-2-2.pdf $>$. Acesso em: 16 abr. 2012.

STICKDORN, M. SCHNEIDER, J. et al. Isto é design thinking de serviços. Trad. Mariana Bandarra. Porto Alegre: Bookman, 2014. 380 p.

TAMASHIRO, S. Tendências da tecnologia de material rodante. Revista Engenharia, São Paulo, n. 564, p.136-137, 2004.

TEIXEIRA, C. Ambientação das Estações do MetrôRio. Consórcio de Design e Arquitetura, 2013. Apresentação realizada em 28 mar.2014.

TIMÓTEO, C. A. F.; FREITAS, J. H. Z.; GUERRA, W. Evolução na automação do sistema de sinalização. Revista Engenharia, São Paulo, n. 564, p. 564-565, 2004.

TRANSPORT FOR LONDON. Accessibility guides. Disponível em: https://tfl.gov.uk/forms/ 12387.aspx . Acesso em 02 ago. 2014.

TRANSPORT FOR LONDON. Taking foward the Mayor's Transport Strategy Accessibility Implementation Plan. 2012. Disponível em: <https://www.tfl.gov.uk/cdn/static/cms/ documents/taking-forward-the-mts-accessibilityimplementation-plan-march-2012.pdf >. Acesso em: 02 set.2013.

TRANSPORTS FOR LONDON. London Underground: Towards an Accessible Tube. Our Plans. Our Priorities. Your Views. Londres: Mayor of London, Transport for London, 2007. Disponível em: <www.tfl.gov.uk/microsites/interchange/documents/Towards_an_ Accessible_Tube_12pt1.pdf >. Acesso em: 25 jul. 2011.

TRANSPORTS METROPOLITANS DE BARCELONA. Pla Director d'Accessibilitat Universal. Barcelona: Gramagraf, 2010. 199 p.

UNION INTERNATIONALE DES TRANSPORTS PUBLICS - UITP. Access to Public transport. Core Brief. Ed. Jun 2001. 4 p. Disponível em: 〈http://www.uitp.org/sites/default/ files/cck-focus-papers-files/01\%20ACCESS\%20TO\%20PUBLIC\%20TRANSPORT.pdf >. Acesso em: 20 jun. 2008. 
UNION INTERNATIONALE DES TRANSPORTS PUBLICS - UITP. One small step. How to bridge the step and gap in Regional and Suburban Railway Passenger Services. Brussel: International Association of Public Transport, 2009. 55p. Disponível em: < http://growpublictransport.org/wp-content/plugins/download-monitor/download.php?id=42>. Acesso em: 01 jun. 2012.

UNIVERSITY OF WESTMINSTER. Guide to Post Occupancy Evaluation. Higher Education Funding Council for England (HEFCE), 2006, p. 28-31. Disponível em: <http://www.aude.ac.uk/info-centre/goodpractice/AUDE_POE_guide>. Acesso em: 10 out. 2010.

VIANNA, M.; VIANNA, Y.; ADLER, I . K.; LUCENA, B.; RUSSO, B. Design thinking: inovação em negócios. Rio de Janeiro: MJV Press, 2013. 162 p.

VILADÀS X. El diseño a su servicio. Como mejorar una idea de negocio con la ayuda de un diseñador. Barcelona: Index Book. 2010. 162 p.

VILLA, S. B. Multimétodos em avaliação pós-ocupação e sua aplicabilidade para o mercado imobiliário habitacional. In: Villa, S.B.; Ornstein, S. W. (org.) Qualidade ambiental na edificação: avaliação pós-ocupação. São Paulo: Oficina de Textos, 2013. p. 113-148.

WIESENFELD, E. A psicologia ambiental e as diversas realidades humanas. In: Psicologia USP; Instituto de Psicologia. Psicologia e ambiente. São Paulo: Universidade de São Paulo, 1990. p.53-69.

YIN, R.K. Estudo de caso: planejamento e métodos. 4. ed. Porto Alegre: Bookman, 2010. $248 \mathrm{p}$.

ZEITHAML, V. A.; BITNER, M. J. Marketing de Serviços: a Empresa com Foco no Cliente. Trad. Martin Albert Haag e Carlos Alberto Silveira Netto Soares. 2. ed. Porto Alegre: Bookman, 2003. 536 p. 


\section{BIBLIOGRAFIA}

ALBARELLO, L. et al. Práticas e métodos de investigação em ciências sociais. Lisboa: Gradiva Publicações S.A., 2005. 245 p.

ALOUCHE, P. L. Mobilidade urbana no contexto do plano estratégico do SP2040. Apresentação realizada no Sindicato dos Engenheiros do Estado de São Paulo - SEESP em 09/02/2012, São Paulo, 2012.

AMARAL, L. A. Pensar a diferença/deficiência. Brasília: CORDE - Coordenadoria Nacional para a Integração da Pessoa Portadora de Deficiência, 1994. 91 p.

AMIRALIAN, M. L. T. M. Compreendendo o cego: uma visão psicanalítica da cegueira por meio de desenhos-estórias. São Paulo: Casa do Psicólogo, 1997. 321 p.

ANGROSINO, M. Etnografia e observação participante. Porto Alegre: Artmed, 2009. 138 p.

APELT, R.; CRAWFORD, J.; HOGAN, D. J. Wayfinding Design Guidelines. CRC for Construction Innovation, Brisbane, 2007. 52 p. Disponível em: <http://eprints.qut.edu.au/ 27556>. Acesso em: 05 jun. 2010.

ASOCIACIÓN ESPAÑOLA DE NORMALIZACIÓN Y CERTIFICACIÓN. Accesibilidad universal. Requisitos de espacios públicos urbanizados, entornos edificados, transporte e comunicación. Madrid: AENOR, 2009. 196 p.

ASSOCIAÇÃO BRASILEIRA DE NORMAS TÉCNICAS. Inovação e Tecnologia: a importância das Normas Técnicas para as MPE. São Paulo: Montandon \& Dias Comum. Editora Ltda, 2009. 16 p.

ASSOCIAÇÃO NACIONAL DE TRANSPORTES PÚBLICOS. BANCO NACIONAL DE DESENVOLVIMENTO SOCIAL. Transporte metroferroviário no Brasil: Situações e perspectivas. São Paulo: ANTP; BNDES, v. 2, 2005. 168 p.

ASSOCIAÇÃO NACIONAL DE TRANSPORTES PÚBLICOS. BANCO NACIONAL DE DESENVOLVIMENTO SOCIAL. Acessibilidade nos transportes. São Paulo: ANTP; BNDES, v. 4, 2006. 140 p.

ASSOCIAÇÃO NACIONAL DE TRANSPORTES PÚBLICOS; THE WORLD BANK. Sistemas inteligentes de transportes. São Paulo: ANTP; WORLD BANK, v. 8, 2012.164 p. 
ASSOCIAÇÃO NACIONAL DOS TRANSPORTADORES DE PASSAGEIROS SOBRE TRILHOS. A mobilidade na rota dos trilhos. Revista Mobilidade sobre Trilhos. Brasília, DF: Vox Editora, n. 1, 2012. 88 p.

BAIRD, G. et al. Building Evaluation Techniques. New York: McGraw-Hill, 1995. 207 p.

BARBOSA, M. B.; ALBUQUERQUE, R. M. A. Comunicação, Sinalização e Acessibilidade. In: ORNSTEIN, S. W.; PRADO, A. R. A.; LOPES, M. E. (Org.). Desenho Universal: caminhos da acessibilidade no Brasil. São Paulo: Annablume, 2010. p. 279-290.

BECHTEL, R. B.; MARANS, R. M.; MICHELSON, W. (Ed.). Methods in Environmental and Behavioral Research. New York: Van Nostrand Reinhold Company, 1987. 415 p.

BECHTEL, R.; CHURCHMAN, A. Handbook of environmental psychology. New York: John Wiley \& Sons, 2002. 722 p.

BERGER, C. M. Wayfinding: Designing and Implementing Graphic Navigational Systems. Switzerland: RotoVision, 2005. 176 p.

BERNARDI, N. A aplicação do conceito do Desenho Universal no ensino de arquitetura: o uso de mapa tátil como leitura de projeto. 2007. 340 f. Tese (Doutorado em Engenharia Civil) - Universidade Estadual de Campinas, Campinas.

BRASIL. Constituição (1988). Constituição da República Federativa do

Brasil: promulgada em 5 de outubro de 1988.

BRASIL. Decreto n. 3956, de 8 de outubro de 2001. Promulga a Convenção Interamericana para a Eliminação de Todas as Formas de Discriminação contra as Pessoas Portadoras de Deficiência. Diário Oficial da União, Brasília, 2001.

BRASIL. Lei Federal n. 11.126, de 27 de junho de 2005. Dispõe sobre o direito da pessoa com deficiência visual ingressar e permanecer em ambientes de uso coletivo acompanhado de cão-guia. Diário Oficial da União, Brasília, 2005.

CALABI, D. História do urbanismo europeu: questões, instrumentos e casos exemplares. São Paulo: Perspectiva, 2012. 722 p.

CANADIAN TRANSPORTATION AGENCY. MINISTER OF PUBLIC WORKS AND GOVERNMENT SERVICES CANADA. Guide to Removing Communication Barriers for Travelers with Disabilities, Canada, 2004. Disponível em: <http://www.cta.gc.ca〉 Acesso em: 03 abr. 2005. 
CARDOSO, E.; KOLTERMANN, T. L. S. Recursos para Acessibilidade em Sistemas de Comunicação para Usuários com Deficiência. Design e Tecnologia, Porto Alegre, n. 2, UFRGS, 2010, p. 8-21. Disponível em: <http://www.pgdesign.ufrgs.br/designetecnologia index.php/det/article/view/18>. Acesso em: 19 fev. 2011.

CAVAlCANTE, S.; ELALI, G. A. (Org.). Temas básicos em psicologia ambiental. Petrópolis: Vozes, 2011. 318 p.

CENTRO DE ESTUDOS DA ADMINISTRAÇÃO MUNICIPAL - CEPAM. Acessibilidade nos municípios: como aplicar o Decreto 5.296/04. São Paulo, 2008. 208 p.

COMISIÓN CANADIENSE DE DERECHOS HUMANOS. Mejores prácticas internacionales de diseño universal: una revisión global, 2006. 98 p. Disponível em: <http://www.gaates.org/documents/BP_es.pdf> Acesso em: 04 jan. 2012

COMMUNITY OF METROS - COMET. COMET Benchmarking 2009: New index proposal to benchmark metro stations accessibility. Moscow: Management Meeting, 2010.

COMMUNITY OF METROS - COMET. COMET Case Study 2006: Safe Movement of Passengers within Stations. Final Report. London: Imperial College, 2010.

COMMUNITY OF METROS - COMET. COMET Case Study 2010: Station and Platform Train Interface Safety. Final Report. London: Imperial College, 2010.

COMMUNITY OF METROS - COMET. COMET Case Study 2011: Control of Passenger Flow. Final Report. London: Imperial College, 2010.

COMMUNITY OF METROS - COMET. COMET Clearinghouse 2002: Mobility Impaired People Report. Final Report. London: Imperial College, 2002.

COMMUNITY OF METROS - COMET. COMET Clearinghouse 2004: Accessibility Barrier Free Design. Final Report. London: Imperial College, 2004.

COMMUNITY OF METROS - COMET. COMET Clearinghouse 2009: Accessibility Update. Final Report. London: Imperial College, 2009.

COMPANHIA DO METROPOLITANO DE SÃO PAULO. CPTM 20 ANOS. São Paulo: CPTM, 2012. 227 p. 
COMPANHIA DO METROPOLITANO DE SÃO PAULO. Gerência de Operações. Sistema Estatístico da Operação - SEO - 2014, São Paulo: CMSP, 2014a.

COMPANHIA DO METROPOLITANO DE SÃO PAULO. Relatório de Sustentabilidade 2013. São Paulo: CMSP, 2014c. Disponível em: <http://www.metro.sp.gov.br>. Acesso em: 01 jun. 2014.

DINIZ, D.; MEDEIROS, M.; SQUINCA, F. Reflexões sobre a versão em Português da Classificação Internacional de Funcionalidade, Incapacidade e Saúde. Cadernos de Saúde Pública, Rio de Janeiro, v. 23, n. 10, p. 2507-2510, 2007.

DUWE, M.; HADLICH, A.; VELO, E.; JUNIOR, V.; TURRA, C. Arquitetura de Metrô. São Paulo: VJ Editora, 2012. 206 p.

EDWARDS, B. Sustainability and design of transport interchanges. New York: Routledge, 2011.194p.

FABRICIO, M. M.; ORNSTEIN, S. W. (Org.). Qualidade no projeto de Edifícios. São Carlos: RiMa Editora, ANTAC, 2010. 274 p.

FALZON, P. Ergonomia. Coord. Trad. Laerte Idal Sznelwar. São Paulo: Editora Blucher, 2007. $640 \mathrm{p}$.

FARIAS, N.; BUCHALA, C. M. A Classificação Internacional de Funcionalidade, Incapacidade e Saúde da Organização Mundial da Saúde: Conceitos, Usos e Perspectivas. Revista Brasileira de Epidemiologia, v. 8, p. 187-193, 2005.

FERNANDES, B. Transformações das estações ferroviárias com o advento da integração com a rede do metrô em São Paulo. Tese de Doutorado em Arquitetura e Urbanismo. Faculdade de Arquitetura e Urbanismo da Universidade de São Paulo. São Paulo: FAUUSP, 2012. $140 \mathrm{p}$.

FERTÉ, D. L'accessibilité en pratique: de la règle... à l'usage. Paris: Groupe Moniteur. Paris, 2008. 200 p.

FOQUÉ, R. Building Knowledge in Architecture. Brussels: University Press Antwerp, 2010. 239 p.

FRANÇA, A. J. G. L.; ORNSTEIN, S. W.; ONO, R. Mapas de diagnóstico: procedimentos de Avaliação Pós-Ocupação (APO) voltados à qualidade de projeto. Anais do $\mathbf{2}^{\circ}$. Simpósio Brasileiro de Qualidade do Projeto no Ambiente Construído; X Workshop Brasileiro de 
Gestão do Processo de Projeto na Construção de Edifícios. 3 e 4 de novembro de 2011, Rio de Janeiro-RJ, 2011, p. 297-307.

FRANCO, J. R.; DIAS, T. R. A cegueira ao longo da história. A pessoa cega no processo histórico: um breve percurso. Revista Benjamin Constant. 30 abr.2005. Disponível em: <http://deficienciavisual9.com.sapo.pt/r-olhares.htm>. Acesso em: 08 set. 2012.

GIBBS, G. Análise de dados qualitativos. Trad. Roberto Cataldo Costa. Coleção Pesquisa Qualitativa. Porto Alegre: Artmed, 2009. 198 p.

GIBSON, D. The wayfinding handbook: information design for public places. New York: Princeton Architectural Press, 2009. 152 p.

GIL, M. Deficiência: Uma Forma de Viver o Mundo. In: FUNDAÇÃO PREFEITO FARIA LIMA - CEPAM. Unidade de Políticas Públicas - UPP. Município acessível ao cidadão. São Paulo, 2001. p. 11-28.

GINNERUP, S. Comité de Expertos sobre Diseño Universal. Hacia la plena participación mediante el Diseño Universal. [Acuerdo Parcial (PR-RR-UD)]. Colección Documentos. Serie Documentos Técnicos. Madrid: Ministerio de Sanidad y Política Social; Secretaría General de Política Social y Consumo; Instituto de Mayores y Servicios Sociales (IMSERSO), 2010. 106 p. Disponível em: <http://www.ceapat.org/InterPresent1/groups/ imserso/documents/binario/21019participacionmediantedise.pdf.> Acesso em: 01 ago. 2012.

GOFFMAN, E. Estigma: notas sobre a manipulação da identidade deteriorada. Rio de Janeiro: LTC, 2012. 158 p.

GOLLEDGE, R. G (Ed.). Wayfinding behavior: cognitive mapping and other spatial processes. Baltimore: The John Hopkins University Press, 1999. 428 p.

GOMES FILHO, J. Ergonomia do objeto: sistema técnico de leitura ergonômica. 2. ed. São Paulo: Escrituras Editora, 2010. 269 p.

GOMIDE, T. L. F.; PUJADAS, F. Z. A.; FAGUNDES NETO, J. C. P. Técnicas de Inspeção e Manutenção Predial: vistorias técnicas, check-up predial, normas comentadas, manutenção, valorização patrimonial e análise de risco. São Paulo: Editora Pini, 2006. 227 p.

GRANDJEAN, E. Ergonomia: Adaptando o trabalho ao homem. Trad. João Pedro Stein. Porto Alegre: Artes Médicas, 1998. Xxx p. 
GROAT, L.; WANG, D. Architectural research methods. New York: John Wiley \& Sons, 2002. 389 p.

GROSBOIS, L. Handicap et construction. Paris: Groupe Moniteur, 2010. 510 p.

GÜNTHER, H. Como elaborar um questionário. In: PINHEIRO, J.Q.; GÜNTHER, H.

Métodos de Pesquisa nos Estudos Pessoa-Ambiente. São Paulo: Casa do Psicólogo, 2008. p. 105-147.

GÜNTHER, H.; PINHEIRO, J. Q.; GUZZO, R. S. L. (Org.) Psicologia ambiental: entendendo as relações do homem com seu ambiente. 2. ed. Campinas: Editora Alínea, 2006. $200 \mathrm{p}$.

HERCE, V. M. Sobre la movilidad en la ciudad; propuestas para recuperar un derecho ciudadano. Estudios Universitarios de Arquitectura. Barcelona: Editorial Reverté, 2009. 328 p.

HERSH, M .A.; JOHNSON, M. A. (editors). Assistive technology for visually impaired and blind people. London: Springer-Verlag, 2008. 725 p.

HÖPFNER, J. N. Gestión de la accesibilidad universal. In: Fundación ONCE, Fundación Arquitectura COAM. Accesibilidad Universal y Diseño para Todos. Arquitectura y Urbanismo. Madrid: Artes Gráficas Palermo, 2011. p. 202-217.

INSTITUTO BRASILEIRO DE GEOGRAFIA E ESTATÍSTICA - IBGE. Censo demográfico 2000. Disponível em: <http://www.ibge.gov.br/home/estatistica/populacao/ censo2000/default.shtm>. Acesso em: 17 jun. 2011.

INSTITUTO DA MOBILIDADE E DOS TRANSPORTES TERRESTRES - IMTT. Pacote da Mobilidade - território, acessibilidade e gestão da mobilidade. Interfaces de transportes de passageiros. 2011, 37 p. Disponível em: <http://www.conferenciamobilidade.imtt.pt/ pacmob/interfaces_tpassageiros/Interfaces_de_transportes_de_passageiros_Marco2011.pdf $>$. Acesso em: 30 out. 2011.

INSTITUTO DA MOBILIDADE E DOS TRANSPORTES TERRESTRES - IMTT. Pacote da Mobilidade - território, acessibilidade e gestão da mobilidade. Sistemas de informação ao público. 2011a, 29 p. Disponível em: <http://www.conferencia

mobilidade.imtt.pt/pacmob/si_publico/Sistemas_de_Informacao_ao_Publico_Marco2011.pdf >. Acesso em: 17 jul. 2012. 
INSTITUTO DE MIGRACIONES Y SERVICIOS SOCIALES - IMSERSO. Accesibilidad y supresión de barreras. El procedimiento en la Comunidad de Madrid. Madrid: Ministerio de Trabajo y Asuntos Sociales, 1996. 127 p.

INSTITUTO DE MIGRACIONES Y SERVICIOS SOCIALES - IMSERSO. Evaluación del Programa de Transporte Accesible del Imserso. Madrid: Ministerio de Trabajo y Asuntos Sociales, 1999. $381 \mathrm{p}$.

INTERNATIONAL ORGANIZATION FOR STANDARDIZATION - ISO. Assistive products for blind and vision impaired persons - Tactile walking surface indicators. ISO/DIS 23599. Geneve: ISO, 2010. 34 p.

INTERNATIONAL ORGANIZATION FOR STANDARDIZATION - ISO. Building construction - Accessibility and usability of the built environment. ISO/FDIS 21542:2011(E). Geneve: ISO, 2011. 159 p.

LAY, M. C. D. e REIS, A. T. L. Métodos e técnicas para levantamento de campo e análise de dados: questões gerais. In: Anais do Workshop Avaliação Pós-Ocupação.

ANTAC/NUTAU, São Paulo, 1994, p. 17-39.

LEFEVRE, F.; LEFEVRE, A. M. C. Pesquisa de representação social: um enfoque qualiquantitativo. Brasília: Liber Livro Editora, 2012. 224 p.

LIDWELL, W.; HOLDEN, K.; BUTLER, J. Princípios universais do design. Trad. Francisco Araújo da Costa. Porto Alegre: Bookman, 2010. 272 p.

LOPES, M. E. Metodologia de análise e implantação de acessibilidade para pessoas com mobilidade reduzida e dificuldade de comunicação. São Paulo, 2005. Tese de Doutorado em Arquitetura e Urbanismo. Faculdade de Arquitetura e Urbanismo da Universidade de São Paulo, v. 1 e v. 2.

MALORY-HILL, S.; PREISER, W. F. E.; WATSON, C. Enhancing Building Performance. United Kingdom: Wiley-Blakell, 2012. 330 p.

MANDUCHI, R.; KURNIAWAN, S. Assistive technology for blindness and low vision. Boca Raton: Taylor \& Francis Group, 2013. 423 p.

MELHADO, S. B. (Coord.). Coordenação de Projetos de Edificações. São Paulo: O Nome da Rosa, 2006. 120 p. 
MEUSER, P. Accessible Architecture. Construction and Design Manual. Berlin: DOM Publishers, 2010. 304 p.

MILA, A. O Edifício. São Paulo: FAUUSP, 1973. 147 p.

MIN, H. Y.; SAMPAIO, M. W.; HADDAD, M. A. O. Baixa visão: conhecendo mais para ajudar melhor. São Paulo: Laramara, 2001. 32 p.

MINTRA ACCESSIBILITY OFFICE - MINTRA. Medidas en accesibilidad en el material móvil. Comunidad de Madrid: Consejeria de Transportes e Infraestructura, 2006a. 10 p. Disponível em: 〈http://www.mintramadrid.es/pdf/ MEDIDASAUMATERIALMOVIL.pdf>. Acesso em: 14 mai. 2010.

MINTRA ACCESSIBILITY OFFICE - MINTRA. Medidas en accesibilidad en estaciones. Comunidad de Madrid: Consejeria de Transportes e Infraestructura, 2006a. 10 p. Disponível em: 〈http://www.mintramadrid.es/pdf/ MEDIDASAUESTACIONES.pdf >. Acesso em: 14 mai. 2010.

MOTA, M. G. B. (Coord.) Orientação e Mobilidade: Conhecimentos básicos para a inclusão do deficiente visual. Brasília: MEC, SEESP, 2003. 167 p.

MOUBRAY, J. Manutenção centrada em confiabilidade. Trad. Kleber Siqueira. 2. ed. Lutterworth: Aladon Ltd, 2003. 426 p.

NASAR, J.; EVANS-COWLEY, J. (Ed.) Universal Design and visitability: from accessibility to zoning. Columbus: Ohio State University, 2007, 175 p. Disponível em: <https://kb.osu.edu/dspace/handle/1811/24833>. Acesso em: 03 jun. 2010.

OMOTE, S. Inclusão e a questão das diferenças na educação. Revista Perspectiva, Florianópolis, v. 24, n. Especial, p. 251-272, jul./dez. 2006. Disponível em: <http://www.perspectiva.ufsc.br/perspectiva_2006_especial/13_Sadao.pdf >. Acesso em: 02 ago. 2012.

ORGANIZAÇÃO PANAMERICANA DA SAÚDE - OPAS. ORGANIZAÇÃO MUNDIAL DA SAÚDE - OMS. CIF-CJ: Classificação Internacional de Funcionalidade, Incapacidade e Saúde: versão para crianças e jovens. Trad. Centro Colaborador da Organização Mundial da Saúde para a Família de Classificações Internacionais em Português. São Paulo: Edusp, 2011. 312 p.

ORGANIZACIÓN NACIONAL DE CIEGOS ESPAÑOLES - ONCE. Accesibilidad para personas con ceguera y deficiencia visual. 1. ed. Madrid: ONCE, 2003. 279 p. 
ORNSTEIN, S. W.; BARBOSA, M. B. Da especificidade à multifuncionalidade: aspectos do projeto das estações do metrô. In: SALGADO, M. S.; RHEINGANTZ, P. A.; AZEVEDO, G. A. N.; SILVOSO, M. M. (Org.). Projetos complexos e seus impactos na cidade e na paisagem. 1. ed. Rio de Janeiro: PROARQ/FAU-UFRJ/ANTAC, 2012, v. 1, p. 40-65.

ORNSTEIN, S. W.; BRUNA, G. C.; ROMÉRO, M. A. Ambiente construído \& comportamento: a avaliação pós-ocupação e a qualidade ambiental. São Paulo: Nobel: FAUUSP: FUPAM, 1995. 216 p.

ORNSTEIN, S. W.; ONO, R.; IMAI, C.; FRANÇA, A. J. L.; BARBOSA, M. B. PostOccupancy Evaluation in Brazil: its impact on professional practice. In: MALLORY-HILL, S.; PREISER, W. F. E.; WATSON, C. (Org.). Enhancing building performance. West Sussex: John Wiley \& Sons, 2012. p. 249-258.

PALLASMAA, J. Os olhos da pele: a arquitetura e os sentidos. Trad. Técnica Alexandre Salvaterra. Porto Alegre: Bookman, 2001. 76 p.

PREISER, W. F. E. Das políticas públicas à prática profissional e à pesquisa de avaliação de desempenho voltadas para o desenho universal. In: ORNSTEIN, S. W.; PRADO, A. R. A.; LOPES, M. E. Desenho Universal: caminhos da acessibilidade no Brasil. São Paulo:

Annablume, 2010. p. 19-32.

PREISER, W. F. E.; RABINOWITZ, H. Z.; WHITE, E. T. Post-Occupancy Evaluation. New York: Van Nostrand Reinhold, 1988. 198 p.

PREISER, W. F. E.; SMITH, K.H. Universal Design Handbook. 2 ed. New York: McGrawHill, 2011.

QUIVY, R.; CAMPENHOUDT, L. V. Manual de investigação em ciências sociais. Trad. João Minhoto, Maria Amália Mendes e Maria Carvalho. Lisboa: Gradiva, 2008. 282 p.

RED NACIONAL DE FERROCARRILES ESPAÑOLES - RENFE. Dirección de Accesibilidad, Innovación y Sostentabilidad. Entra, renfe te lleva. Plan de accesibilidad universal. Madrid: Renfe, 2010, 105 p. Disponível em: <http://www.sid.es/idocs/F8/FD) 26151/plan_accesibilidad_universal_renfe.pdf>. Acesso em: 26 jan. 2012.

RED NACIONAL DE FERROCARRILES ESPAÑOLES - RENFE. Resumen ejecutivo. Informe Anual 2007. Disponível em:

<http://www.renfe.com/docs/2007_resumen_ejecutivo.pdf $>$. Acesso em: 26 jan. 2012. 
RÈGIE AUTONOME DES TRANSPORTS PARISIENS - RATP. Accessibilité des réseaux. Le guide. 2010. 32 p. Disponível em: <http://www.ratp.fr/fr/upload/docs/ application/pdf/2010-12/guideacc.pdf >. Acesso em: 25 jul. 2011.

RÈGIE AUTONOME DES TRANSPORTS PARISIENS - RATP. Le guide 'Accessibilité des réseaux' au format áudio. Metro. Disponível em:

<http://www.ratp.fr/fr/ratp/r_37590/metro/>. Acesso em: 25 jul. 2011.

RIBEIRO, L. G. Onde estou? Para onde vou? Ergonomia em Ambiente Construído: wayfinding e aeroportos. Tese de Doutorado [Área?]. Pontifícia Universidade Católica do Rio de Janeiro. Rio de Janeiro: PUC-RJ, 2009. 252 p.

RICHESIN, C.; GRACE, G.; IANTKOW, M.; GILLIES, T. K. Access needs of blind and visually impaired travelers in transportation terminals: a study and design guidelines. Rapport final. Toronto: Institut National Canadien pour les Aveugles, 1987. 195 p. Disponível em: <http://archive.org/details/designguidelines00cana>. Acesso em: 18 ago. 2012.

SANNOF, H. A Visioning Process for Designing Responsive Schools. North Carolina State University, 2001. Disponível em: <http://www4.ncsu.edu/unity/users/s/sanoff/ www/schooldesign/visioning.pdf >. Acesso em: 15 set. 2008.

SANNOF, H. School Building assessment methods. North Carolina State University, 2001. Disponível em: <http://www4.ncsu.edu/unity/users/s/sanoff/www/schooldesign/ schoolassess.pdf >. Acesso em: 15 set. 2008.

SANNOF, H. Visual research methods in design. New York: Van Nostrand Reinhold, 1991. $223 \mathrm{p}$.

SERRA, G. G. Pesquisa em Arquitetura e Urbanismo. Guia prático para o trabalho de pesquisadores em pós-graduação. São Paulo: EDUSP, Mandarim, 2006. 256 p.

SOCIÉTÉ NATIONALE DES CHEMINS DE FER FRANÇAIS - SNCF. Dossier de presse. Accessibilité: mieux comprendre, mieux agir. Paris: SNCF, 2008, 22 p. Disponível em: <http://www.accessibilite.sncf.com/IMG/pdf/dossier_presse_access_300108.pdf $>$. Acesso em: 28 jun. 2011.

SOCIÉTÉ NATIONALE DES CHEMINS DE FER FRANÇAIS - SNCF. Guide Mobilité Réduite Information Voyageurs. SNCF: 2011a. Disponível em:

<http://www.accessibilite.sncf.fr/IMG/pdf/guide_de_mobilite reduite_2011-2.pdf $>$. Acesso em: 16 abr. 2012. 
SOLOMON, M.R. O comportamento do consumidor: comprando, possuindo e sendo. $10^{\text {a }}$. ed. Porto Alegre: Bookman, 2011.

SOMMER, R.; SOMMER, B. A practical guide to behavioral research: tools and techniques. 5. ed. New York: Oxford University Press, 2002. 380 p.

STEINFELD, E. Universal Design in Mass Transportation. In: PREISER, W. F. E.; SMITH, K. H. Universal Design Handbook. [2. ed.] New York: McGraw-Hill, 2011, p.19.1-19.10.

STEINFELD, E.; DANFORD, G. S. Enabling environments: measuring the impact of environment on disability and rehabilitation. New York: Kluwer Academic, Plenum Publishers, 1999. 418 p.

STEINFELD, E.; MAISEL, J. Universal Design: Creating Inclusive Environments. New Jersey: John Wiley \& Sons, 2012. 382 p.

STRAUSS, A.; CORBIN, J. Pesquisa Qualitativa: técnicas e procedimentos para o desenvolvimento de teoria fundamentada. Trad. Luciane de Oliveira da Rocha. 2. ed. Porto Alegre: Artmed, 2008. 288 p.

THE WORLD BANK. Cidades em Movimento: estratégias de transporte urbano do Banco Mundial. Trad. Antônio Carlos de Campos Elias. São Paulo: Sumatra Editorial, 2003. 255 p.

TRANSPORTS FOR LONDON. Accessibility guides. Disponível em:

<http://www.tfl.gov.uk/tfl/gettingaround/accessibility-guides/default.aspx>. Acesso em: 02 jul. 2012

TRANSPORTS FOR LONDON. Assistance for disabled customers travelling on London Underground. 7 p. Disponível em: <www.tfl.gov.uk/assets/downloads/assitance-policydisabled-customers.pdf>. Acesso em: 02 jul. 2012.

TRANSPORTS FOR LONDON. Audio Tube Map. Disponível em: <http://www.tfl.gov.uk/ gettingaround/22857.aspx>. Acesso em: 02 jul. 2012.

TRANSPORTS FOR LONDON. Avoiding stairs Tube guide. Londres: Mayor of London, Transport for London, London Underground, 2012. Disponível em: <http://www.tfl.gov.uk/assets/downloads/avoiding-stairs-guide.pdf>. Acesso em: 02 jul. 2012. $16 \mathrm{p}$. 
<http://www.tfl.gov.uk/assets/downloads/getting-around-london-large-print.pdf $>$. Acesso em: 02 jul. 2012.

TRANSPORTS FOR LONDON. Inclusivity Report 2010. Londres: Mayor of London, Transport for London, 2010, 23 p. Disponível em: <http://www.tfl.gov.uk/microsites/legiblelondon/downloads/Inclusivity_Status_Report.pdf>. Acesso em: 02 jul. 2012.

TRANSPORTS FOR LONDON. Interchange Best Practice Guidelines 2009 - Quick Reference Guide. Londres: Mayor of London, Transport for London, 2009, 42 p. Disponível em: <http://www.tfl.gov.uk/microsites/interchange/documents/interchange-best-practiceguide-qrg.pdf $>$. Acesso em: 30 out. 2011.

TRANSPORTS FOR LONDON. Making the Tube accessible - What should we work on first. Our plans. Your views. 2007a, 47 p. Disponível em: <www.tfl.gov.uk/microsites/ interchange/documents/Whatshouldweworkonfirst.pdf>. Acesso em: 25 jul. 2011.

TRANSPORTS FOR LONDON. Step-Free Tube Guide. Disponível em: < http://www.tfl. gov.uk/assets/downloads/olympic-step-free-tube-guide.pdf>. Acesso em: 02 jul. 2012.

TRANSPORTS FOR LONDON. Transport Accessibility. Tube. Disponível em: <http://www.tfl.gov.uk/ gettingaround/transportaccessibility/1169.aspx>. Acesso em: 25 jul. 2011.

TRANSPORTS FOR LONDON. Unlocking London for All. Our plans for a more accessible Underground network. 2002. 16 p. Disponível em: <http://www.childdisability.co.uk/pdf/unlocking-london-for-all.pdf>. Acesso em: 07 jun. 2012.

TRANSPORTS METROPOLITANS DE BARCELONA - TMB. Consulta les installacions accessibles de la xarxa de metro. Disponível em: <http://www.tmb.cat/ca/transportaccessible>. Acesso em: 02 jul. 2012.

TRANSPORTS METROPOLITANS DE BARCELONA - TMB. Plan Director d'Accessibilitat Universal. Barcelona: TMB, 2010. 199 p.

UNION INTERNATIONALE DES TRANSPORTS PUBLICS - UITP. Passenger

Information. Core Brief. Ed. Mar 2001. 4 p. Disponível em: <http://www.uitp.org/ mos/corebrief/CBrief\%20-Information-en.pdf >. Acesso em: 20 jun. 2008.

VASCONCELOS, E. A. Transporte urbano, espaço e equidade: análise das políticas públicas. São Paulo: Annablume, 2001. 218 p. 
VIVARTA, V. (Coord). Mídia e deficiência. Série Diversidade, v. 2. Brasília: ANDI, Fundação Banco do Brasil, 2003. 184 p.

WOODSON, W. E.; TILLMAN, B.; TILLMAN, P. Human factors design handbook: information and guidelines for the design of systems, facilities, equipment and products for human use. New York: McGraw-Hill, 1992. 846 p.

ZEISEL, J. Inquiry by Design: environment/behavior/neuroscience in architecture, interiors, landscape and planning. New York: W.W. Norton \& Company, 2006. 400 p.

ZIMRING, C. Post occupancy Evaluation: Issues and Implementation. In: BECHTEL, R.; CHURCHMAN, A. Handbook of environmental psychology. New York: John Wiley \& Sons, 2002. p. 306-319. 


\section{APÊNDICE A}

\section{Questionário 2 - modelo - frente}

\section{AVALIAÇÃo DE ACESSIBILIDADE DO METRÔ}
Horário:
[ ] A
Estação:
[ ] B
$\mathbf{N}^{\circ}$ QUEST

\section{Dados Pessoais}

Idade: [ ] C Sexo: 1-Masculino 2-Feminino [ ] D

Nome:

Endereço:

E-mail:

Telefones - res:

com:

cel:

Escolaridade:

1 - Analfabeto / $3^{\mathrm{a}}$ série E.Fundamental

2 - da $4^{a}$ a $7^{a}$ série E. Fundamental

2. A sua deficiência visual é:

1 - cegueira total 2 - baixa visão $\quad[\quad] \mathrm{F}$

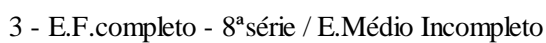

4 - E.M. Completo/Universitário Incompleto

5 - Universitário Completo

3. Com que idade adquiriu a deficiência visual ?

- cego de um olho/baixa visão do outro

4. Já realizou treinamento de orientação e mobilidade? (não é exclusivo para o metrô)

1 - Sim 2 - Não

5. Quantos dias na semana o(a) $\operatorname{Sr}(a)$ costuma usar o metrô?

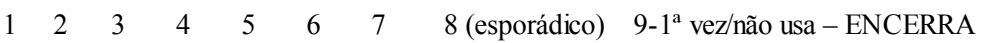

6. Antes de sair, o(a) $\operatorname{Sr}(a)$ busca informações sobre trajetos ou funcionamento do metrô?

1 - Sim 2 - Não

Se sim, onde se informa? (até 2)

1 - Central de informações

$$
\begin{aligned}
& 3 \text { - Folhetos } \\
& 4 \text { - Direto do Metrô (sms/celular) }
\end{aligned}
$$

5 - Família/Amigos

2 - Site

6- Outros

7. Em seus deslocamentos, costuma andar:

1 - Sozinho(a) $\quad 2$ - Acompanhado(a)

8. Para quem anda acompanhado:

Utiliza o bilhete do acompanhante?

$1-\operatorname{Sim} 2-$ Não $\quad[\quad] N$
3- com cão guia

Para quem anda sozinho/cão guia:

No metrô o(a) $\mathbf{S r}(a)$ solicita a ajuda de alguém para se deslocar?

$$
1 \text { - Sim } 2 \text { - Não }
$$

Se sim, De quem?

1 - Empregados

2 - Outros usuários

9. Mencione as estações que mais usa (limite até 6):

Estação 1:

] R Usa a estação como: [

Estação 2:

] S Usa a estação como:

] $] \mathrm{Y}$

Estação 3:

Estação 4:

] U Usa a estação como: [

] AA

Estação 5:

V Usa a estação como:

Estação 6

] W Usa a estação como: [

] $\mathrm{AC}$

10. Pensando na primeira estação mencionada (ESTAÇÃO 1!), que conduções usa para chegar e sair da estação?
Chegada:
[ ] $\mathrm{AD}$ [ ] AE
Saída:
1. nenhuma ou a pé
7. lotação/vans/IRREGULARES
2. táxi
8. ônibus de outros municípios
3. lotação/vans/micro-ônib. REG.
4. condução da firma
5. bicicleta
6.ônibus capital-SP
9. trem
10. ponte orca
11. moto
12. carro particular
13. carona
14. ônibus rodoviário
15. ônibus intermunicipal
16. ônibus fretado
99. outros

[ ] AF [ ] AG 


\section{Questionário 2 - modelo - verso}

11. Pensando apenas nas necessidades dos deficientes visuais, o(a) $\operatorname{Sr}(a)$ considera que as estações do Metrô estão:

1 - Totalmente adaptadas

2 - Quase totalmente adaptadas

3 - Mais ou menos adaptadas

$[\quad] \mathrm{AH}$

4 - Pouco adaptadas

5 - Não estão adaptadas

12. Em sua opinião, o Metrô considerou todas as necessidades das pessoas com deficiência visual na adequação das estações

$1-\operatorname{sim}$ 2 - não

Se não, o que foi desconsiderado ?

13. Pensando nas ESTAÇÕES do metrô em geral, quais as maiores dificuldades enfrentadas no deslocamento ?

(Até 3 menções)

14. Pensando na viagem de TREM, quais as maiores dificuldades enfrentadas pelos deficientes ?

(Até 3 menções)

15. Qual dessas ações o Metrô deveria priorizar:

1 - Adequação das estações para o deficiente visual

2 - Condução dos deficientes por empregados treinados

16. Gostaria que o(a) $\operatorname{Sr}($ a) ordenasse do mais importante ao menos importante os aspectos que interferem no deslocamento do deficiente visual nas estações e trens do metrô:

O nível de lotação das estações e trens

A adequação das instalações, piso tátil, comunicação tátil, auditiva, etc [ ] AS

A falta de treinamento especifico para andar no metrô [ ] AT

O grau de deficiência visual da pessoa $\quad[\quad] \mathrm{AU}$

O estado emocional da pessoa, como a maior ou menor insegurança, entre outros [ ] AV

O preparo dos empregados na condução e tratamento do deficiente [ ] AW

A quantidade de empregados para atender aos deficientes $\quad$ [ ] AX

Outros. O que ?

17. $\mathrm{O}(\mathrm{a}) \mathrm{Sr}(\mathrm{a})$ tem alguma sugestão para facilitar o uso das estações ou a viagem de trem pelas pessoas com deficiência visual ? 
APÊNDICE B

Classificação das ideias centrais - mapa mental 


\section{APÊNDICE C \\ Entrevista individual - roteiro - funcionários das estações \\ (presencial)}

Entrevistado:

Formação:

Tempo de atuação profissional nesta estação:

Tempo de atuação profissional no Metrô:

Data:

Hora início:

h

Hora término:

h

Introdução para explicar o motivo e a finalidade da entrevista.

Estou elaborando minha Pesquisa de Mestrado, cujo tema é a "avaliação do atendimento às pessoas com deficiência visual em ambiente de transporte de alta capacidade a partir da adaptação à acessibilidade." O objetivo é identificar os aspectos relacionados à gestão dos serviços, à configuração e à sinalização das estações metroviárias que impactam - direta ou indiretamente - no deslocamento e na viagem dos usuários com deficiência visual. Os sistemas de transporte estão promovendo a adaptação de suas instalações, compartilhando dificuldades e problemas enfrentados e experiências de sucesso. Quanto mais informações forem obtidas das experiências - positivas e negativas - mais chance existe de que projetos e investimentos na construção de novas estações ou modernização das existentes (retrofit) atendam às expectativas e possam, portanto, satisfazer aos usuários e também aos investidores. $O$ diagnóstico deverá resultar em orientações de projeto de sistemas de informação integrada em estações e trens de metrô, de forma a garantir o uso do transporte com segurança e autonomia, por todas as pessoas. Solicito sua contribuição, como profissional responsável pelos serviços prestados nas estações. Suas considerações são importantes para o desenvolvimento da minha pesquisa. Desde já, obrigada.

Considerando a configuração desta estação, ou seja, a disposição e localização dos acessos e plataformas em relação ao mezanino, quais são os aspectos positivos e negativos para o deslocamento das pessoas com deficiência visual?

1. Como é o preparo dos empregados em situações de anormalidade no sistema metroviário em especial para atendimento às pessoas com deficiência visual? Quais ações são tomadas junto às pessoas com deficiência visual nas situações de anormalidade?

2. Os sistemas de transporte de alta capacidade, como é o caso dos metrôs - implicam na existência de um grande fluxo de pessoas nas estações e trens. Como você avalia a demanda e o fluxo nesta estação?

3. Como os empregados das estações e trens contribuem para a segurança nos deslocamentos das pessoas com deficiência visual?

4. Como as informações - visual, tátil e sonora - disponibilizadas aos usuários contribuem para a segurança nos deslocamentos das pessoas com deficiência visual?

5. Considerando as necessidades dos usuários com deficiência visual e os serviços prestados pelo metrô nesta estação: quais os aspectos que poderiam ser aperfeiçoados? 


\section{APÊNDICE D}

\section{Entrevista individual - roteiro - profissionais que atuam no CCO (presencial)}

\section{Entrevistado:}

\section{Formação:}

\section{Tempo de atuação nesta função:}

\section{Tempo de atuação profissional no Metrô:}

Data: Hora início: h

Hora término: h

\section{Introdução para explicar o motivo e a finalidade da entrevista.}

Estou elaborando minha Pesquisa de Mestrado, cujo tema é a "avaliação do atendimento às pessoas com deficiência visual em ambiente de transporte de alta capacidade a partir da adaptação à acessibilidade." O objetivo é identificar os aspectos relacionados à gestão dos serviços, à configuração e à sinalização das estações metroviárias que impactam - direta ou indiretamente - no deslocamento e na viagem dos usuários com deficiência visual. Os sistemas de transporte estão promovendo a adaptação de suas instalações, compartilhando dificuldades e problemas enfrentados e experiências de sucesso. Quanto mais informações forem obtidas das experiências - positivas e negativas - mais chance existe de que projetos e investimentos na construção de novas estações ou modernização das existentes (retrofit) atendam às expectativas e possam, portanto, satisfazer aos usuários e também aos investidores. $O$ diagnóstico deverá resultar em orientações de projeto de sistemas de informação integrada em estações e trens de metrô, de forma a garantir o uso do transporte com segurança e autonomia, por todas as pessoas. Solicito sua contribuição, como profissional responsável pelas atividades prestados no CCO. Suas considerações são importantes para o desenvolvimento da minha pesquisa. Desde já, obrigada.

1. Como é feita a monitoração para atendimento às pessoas com deficiência visual?

2. Os sistemas de transporte de alta capacidade - como é o caso dos metrôs - implicam na existência de um grande fluxo de pessoas nas estações e trens, inclusive de pessoas com deficiência visual. Quais ações são tomadas junto aos empregados visando o atendimento às pessoas com deficiência nas situações de anormalidade?

3. Considerando as necessidades dos usuários com deficiência visual e o serviço prestado pelo Metrô: quais os aspectos poderiam ser aperfeiçoados? 


\begin{abstract}
APÊNDICE E
Entrevista individual - roteiro - profissionais que elaboram normas técnicas

(por e-mail)
\end{abstract}

Entrevistado:

Formação:

Tempo de atuação profissional:

Tempo de atuação profissional na ABNT:

Introdução para explicar o motivo e a finalidade da entrevista.

Estou elaborando minha Pesquisa de Mestrado, cujo tema é a "avaliação do atendimento às pessoas com deficiência visual em ambiente de transporte de alta capacidade a partir da adaptação à acessibilidade." O objetivo é identificar os aspectos relacionados à gestão dos serviços, à configuração e à sinalização das estações metroviárias que impactam - direta ou indiretamente - no deslocamento e na viagem dos usuários com deficiência visual. Os sistemas de transporte estão promovendo a adaptação de suas instalações, compartilhando dificuldades e problemas enfrentados e experiências de sucesso. Quanto mais informações forem obtidas das experiências - positivas e negativas - mais chance existe de que projetos e investimentos na construção de novas estações ou modernização das existentes (retrofit) atendam às expectativas e possam, portanto, satisfazer aos usuários e também aos investidores. O diagnóstico deverá resultar em orientações de projeto de sistemas de informação integrada em estações e trens de metrô, de forma a garantir o uso do transporte com segurança e autonomia, por todas as pessoas. Solicito sua contribuição, como profissional responsável pela elaboração de normas técnicas, respondendo às questões abaixo. Sua contribuição é muito importante para o desenvolvimento da minha pesquisa. Peço que me sejam devolvidas até o dia 15/06/2011. Assim, agradeço, antecipadamente, sua colaboração. Atenciosamente, Maria Beatriz Barbosa

1. Qual é a importância das normas técnicas de acessibilidade?

2. Quais as características e especificidades das normas técnicas de acessibilidade?

3. Qual a principal dificuldade hoje enfrentada na elaboração das normas de acessibilidade?

4. Considerando as normas de acessibilidade existentes e o ambiente de transporte, como você avalia as facilidades relacionadas à configuração e à sinalização para os passageiros?

5. Especificamente no caso das pessoas com deficiência visual, como você avalia as recomendações existentes nas normas vigentes?

6. Os sistemas de transporte de alta capacidade - como é o caso dos metrôs - implicam na existência de um grande fluxo de pessoas nas estações e trens. Como as normas podem contribuir para a segurança e para a autonomia das pessoas com deficiência visual?

7. De que forma o sistema de informação integrada - tátil, visual e sonora - pode contribuir no processo? 


\section{APÊNDICE F}

\section{Entrevista individual - roteiro - professores de orientação e mobilidade \\ (por e-mail)}

\section{Entrevistado:}

\section{Formação:}

\section{Tempo de atuação profissional:}

\section{Tempo de atuação como professor de $O \& M$ :}

\section{Introdução para explicar o motivo e a finalidade da entrevista.}

Estou elaborando minha Pesquisa de Mestrado, cujo tema é a "avaliação do atendimento às pessoas com deficiência visual em ambiente de transporte de alta capacidade a partir da adaptação à acessibilidade." O objetivo é identificar os aspectos relacionados à gestão dos serviços, à configuração e à sinalização das estações metroviárias que impactam - direta ou indiretamente - no deslocamento e na viagem dos usuários com deficiência visual. Os sistemas de transporte estão promovendo a adaptação de suas instalações, compartilhando dificuldades e problemas enfrentados e experiências de sucesso. Quanto mais informações forem obtidas das experiências - positivas e negativas - mais chance existe de que projetos e investimentos na construção de novas estações ou modernização das existentes (retrofit) atendam às expectativas e possam, portanto, satisfazer aos usuários e também aos investidores. $O$ diagnóstico deverá resultar em orientações de projeto de sistemas de informação integrada em estações e trens de metrô, de forma a garantir o uso do transporte com segurança e autonomia, por todas as pessoas. Solicito sua contribuição, como profissional responsável pelo treinamento de pessoas com deficiência visual, respondendo às questões abaixo. Sua contribuição é muito importante para o desenvolvimento da minha pesquisa. Peço que me sejam devolvidas até o dia 15/06/2011. Assim, agradeço, antecipadamente, sua colaboração. Atenciosamente, Maria Beatriz Barbosa

1. Qual é a importância e como é realizado e do treinamento de Orientação e Mobilidade para pessoas com deficiência visual?

2. Com relação às questões de segurança e funcionalidade, quais pontos são enfatizados no treinamento das pessoas com deficiência visual nas estações do metrô?

3. O treinamento foi alterado a partir da instalação do piso tátil nas estações? Quais as principais dificuldades observadas em sua utilização pelas pessoas com deficiência visual? Percursos ortogonais (ângulos de $90^{\circ}$ ) facilitam ou dificultam a utilização do piso?

4. Considerando a necessidade de memorização dos percursos em cada estação, como avalia as alternativas a seguir:

a. Realização do mesmo percurso do piso tátil pelos estagiários que auxiliam o embarque e desembarque.

b. Existência de maquete (mapa tátil) com as principais referências da estação (localização dos acessos, bloqueios (catracas), opções de percursos, elevadores e escadas, plataformas). 
c. Descrição sonora dos percursos de embarque e de desembarque em cada uma das estações disponibilizado na internet.

d. Descrição sonora dos percursos de embarque e de desembarque em cada uma das estações disponibilizado na própria estação, transmitido via celular.

5. Considerando a necessidade de memorização dos percursos na rede de transporte e no percurso no entorno da estação, como avalia as alternativas a seguir:

a. Mapas táteis - rede / linha / arredores ou entorno das estações.

b. Roteirizador disponível na internet (usuário informa origem e destino para saber sobre o percurso e as conexões)

6. Caso tenha ministrado treinamento nas estações Ana Rosa, Sacomã e Palmeiras-Barra Funda, qual a principal dificuldade enfrentada pelos alunos em cada estação?

7. Qual a principal dificuldade hoje enfrentada pelo professor de O\&M nos treinamentos no Metrô? 


\section{APÊNDICE G}

\section{Entrevista individual - roteiro - elaboradores de treinamento de funcionários \\ (por e-mail)}

\section{Entrevistado:}

\section{Formação:}

\section{Tempo de atuação profissional:}

\section{Tempo de atuação como instrutor:}

\section{Introdução para explicar o motivo e a finalidade da entrevista.}

Estou elaborando minha Pesquisa de Mestrado, cujo tema é a "avaliação do atendimento às pessoas com deficiência visual em ambiente de transporte de alta capacidade a partir da adaptação à acessibilidade." O objetivo é identificar os aspectos relacionados à gestão dos serviços, à configuração e à sinalização das estações metroviárias que impactam - direta ou indiretamente - no deslocamento e na viagem dos usuários com deficiência visual. Os sistemas de transporte estão promovendo a adaptação de suas instalações, compartilhando dificuldades e problemas enfrentados e experiências de sucesso. Quanto mais informações forem obtidas das experiências - positivas e negativas - mais chance existe de que projetos e investimentos na construção de novas estações ou modernização das existentes (retrofit) atendam às expectativas e possam, portanto, satisfazer aos usuários e também aos investidores. $O$ diagnóstico deverá resultar em orientações de projeto de sistemas de informação integrada em estações e trens de metrô, de forma a garantir o uso do transporte com segurança e autonomia, por todas as pessoas. Solicito sua contribuição, como profissional responsável pelo treinamento de funcionários dedicados ao atendimento em serviços de transporte, respondendo às questões abaixo. Suas considerações são importantes para o desenvolvimento da minha pesquisa. Peço que me sejam devolvidas até o dia 15/06/2011. Desde já, obrigada. Atenciosamente, Maria Beatriz Barbosa

1. Qual é a importância do treinamento dos empregados?

2. Quais as características e especificidades dos treinamentos dos empregados e dos estagiários?

3. Quais temas são abordados nesses treinamentos?

4. Qual a principal dificuldade hoje enfrentada no treinamento dos empregados?

5. Como você relaciona esses treinamentos com os princípios, valores e normas da empresa?

6. Como são abordadas as questões relacionadas à segurança das pessoas com deficiência visual no uso do sistema metroviário?

7. Como é o preparo dos empregados em situações de anormalidade no sistema metroviário em especial, para atendimento às pessoas com deficiência visual?

8. Os sistemas de transporte de alta capacidade - como é o caso dos metrôs - implicam na existência de um grande fluxo de pessoas nas estações e trens. Como os treinamentos podem contribuir para a segurança nos deslocamentos das pessoas com deficiência visual?

9. De que forma o sistema de informação pode contribuir no processo? 


\section{APÊNDICE H}

Entrevista em grupo - roteiro - profissionais responsáveis pelos projetos das estações (presencial)

Entrevistados:

\begin{tabular}{l|l|c|c} 
nome & formação & $\begin{array}{c}\text { Tempo atuação } \\
\text { profissional }\end{array}$ & $\begin{array}{c}\text { Tempo atuação no } \\
\text { Metrô }\end{array}$ \\
\hline & & & \\
\hline & & & \\
\hline & & & \\
\hline
\end{tabular}

Data: Hora início: h Hora término: h

\section{Introdução para esclarecer o motivo da reunião}

Estou elaborando minha Pesquisa de Mestrado, cujo tema é a "avaliação do atendimento às pessoas com deficiência visual em ambiente de transporte de alta capacidade a partir da adaptação à acessibilidade." O objetivo é identificar os aspectos relacionados à gestão dos serviços, à configuração e à sinalização das estações metroviárias que impactam - direta ou indiretamente - no deslocamento e na viagem dos usuários com deficiência visual. Os sistemas de transporte estão promovendo a adaptação de suas instalações, compartilhando dificuldades e problemas enfrentados e experiências de sucesso. Quanto mais informações forem obtidas das experiências - positivas e negativas - mais chance existe de que projetos e investimentos na construção de novas estações ou modernização das existentes (retrofit) atendam às expectativas e possam, portanto, satisfazer aos usuários e também aos investidores. $O$ diagnóstico deverá resultar em orientações de projeto de sistemas de informação integrada em estações e trens de metrô, de forma a garantir o uso do transporte com segurança e autonomia, por todas as pessoas. Desde já, obrigada.

\section{Questões para discussão}

1. "Nenhum outro edifício concentra, em termos de obra de engenharia, a escala do movimento humano e a complexidade da função" (Edwards, 1997). Como é projetar uma estação?

2. "Nas estações de conexão, onde as pessoas se transferem de um modo de transporte para outro, os ritos de passagem devem ser celebrados em novas formas de estrutura, novas configurações internas e novos métodos de orientar grandes fluxos de passageiros" (Ross, 2000). Os requisitos de acessibilidade já são realidade nos novos projetos e nas novas estações. Como essa questão é tratada em termos de configuração e de sinalização dos percursos de embarque, de desembarque e de conexão?

3. Considerando aspectos como orientação, deslocamento, uso dos ambientes e comunicação estes componentes e a demanda elevada das estações, imaginemos uma pessoa cega utilizando a atual rede de transporte metropolitano; quais seriam suas dificuldades? 
4. As pessoas cegas memorizam caminhos, conexões, referências. Imaginem um cego utilizando estações projetadas em diferentes épocas. Como seriam esses deslocamentos?

5. Quais seriam suas dificuldades em termos de fluxo e de segurança durante o uso, em situação de normalidade?

6. Considerando a expansão da rede, as inovações tecnológicas... imaginemos uma pessoa cega utilizando a futura rede de transporte metropolitano; quais seriam suas facilidades? 


\section{APÊNDICE I}

\section{Entrevista em grupo - roteiro - profissionais que elaboram as especificações dos trens (presencial)}

\section{Entrevistados:}

\begin{tabular}{l|l|l|l} 
nome & formação & $\begin{array}{c}\text { Tempo atuação } \\
\text { profissional }\end{array}$ & $\begin{array}{c}\text { Tempo atuação no } \\
\text { Metrô }\end{array}$ \\
\hline & & & \\
\hline & & & \\
\hline & & & \\
\hline & & & \\
\hline
\end{tabular}

Data: Hora início: h Hora término: h

\section{Introdução para esclarecer o motivo da reunião}

Estou elaborando minha Pesquisa de Mestrado, cujo tema é a "avaliação do atendimento às pessoas com deficiência visual em ambiente de transporte de alta capacidade a partir da adaptação à acessibilidade. "O objetivo é identificar os aspectos relacionados à gestão dos serviços, à configuração e à sinalização dos trens que impactam - direta ou indiretamente - no deslocamento e na viagem dos usuários com deficiência visual. Os sistemas de transporte estão promovendo a adaptação de suas instalações, compartilhando dificuldades e problemas enfrentados e experiências de sucesso. Quanto mais informações forem obtidas das experiências - positivas e negativas - mais chance existe de que projetos e investimentos na construção de novas estações ou modernização das existentes (retrofit) atendam às expectativas e possam, portanto, satisfazer aos usuários e também aos investidores. $O$ diagnóstico deverá resultar em orientações de projeto de sistemas de informação integrada em estações e trens de metrô, de forma a garantir o uso do transporte com segurança e autonomia, por todas as pessoas. Desde já, obrigada.

\section{Questões para discussão}

1. Como a evolução dos requisitos de acessibilidade estabelecidos nas normas técnicas ABNT impactou ao longo dos anos nos projetos - configuração e sinalização - dos trens, em especial dos carros preferenciais?

2. Em relação às frotas existentes, como você vê a necessidade de adaptação dos trens/dos carros preferenciais em relação à configuração e aos sistemas de informação para as pessoas com deficiência?

3. Face à necessidade de implementação e identificação dos assentos preferenciais, assentos para obeso, espaço para cadeira de rodas - como são atendidos tais requisitos nas diferentes frotas em função da diversidade de configuração e de layout dos trens/dos carros preferenciais? Quais são os impactos mais relevantes?

4. Quais inovações tecnológicas vem sendo implementadas nas novas frotas e como essas novas tecnologia podem ser estendidas às frotas existentes? Quais as facilidades e dificuldades evidenciadas nesse processo? 


\section{APÊNDICE J}

Entrevista em grupo - roteiro - estagiários que auxiliam pessoas com deficiência visual (presencial)

Entrevistados:

\begin{tabular}{l|l|l} 
nome & idade & $\begin{array}{c}\text { Tempo atuação no } \\
\text { Metrô }\end{array}$ \\
\hline & & \\
\hline & & \\
\hline & & \\
\hline
\end{tabular}

Data: Hora início: h Hora término: h

\section{Introdução para esclarecer o motivo da reunião}

Estou elaborando minha Pesquisa de Mestrado, cujo tema é a "avaliação do atendimento às pessoas com deficiência visual em ambiente de transporte de alta capacidade a partir da adaptação à acessibilidade." O objetivo é identificar os aspectos relacionados à gestão dos serviços, à configuração e à sinalização dos trens que impactam - direta ou indiretamente - no deslocamento e na viagem dos usuários com deficiência visual. Os sistemas de transporte estão promovendo a adaptação de suas instalações, compartilhando dificuldades e problemas enfrentados e experiências de sucesso. Quanto mais informações forem obtidas das experiências - positivas e negativas - mais chance existe de que projetos e investimentos na construção de novas estações ou modernização das existentes (retrofit) atendam às expectativas e possam, portanto, satisfazer aos usuários e também aos investidores. $O$ diagnóstico deverá resultar em orientações de projeto de sistemas de informação integrada em estações e trens de metrô, de forma a garantir o uso do transporte com segurança e autonomia, por todas as pessoas. Desde já, obrigada.

\section{Questões para discussão}

1. O que vocês acham desse serviço prestado pelo Metrô e realizado por vocês? Como se sentem realizando esta atividade?

2. Na sua opinião deles porque os usuários com deficiência precisam de ajuda?

3. Como os deficientes visuais pedem ajuda para pegar um ônibus? O que eles pedem?

4. Qual o local mais difícil: no acesso ou na plataforma? Por quê?

5. O que mais dificulta a condução de pessoas com deficiência visual? O percurso, a distância, o desnível ou as outras pessoas?

6. O que é mais difícil: auxiliar o embarque, o desembarque ou a conexão de uma linha para outra?

7. Qual das escadas é mais difícil de usar - Fixa ou rolante? Por que?

8. Quando eles estão guiando um deficiente visual, se eles perguntam por onde ele deseja ir de elevador ou de escada? 
9. Mesmo a maioria preferindo ir de escadas, quando a estação está muito cheia eles não pedem para ir de elevador?

10. O treinamento recebido foi suficiente para permitir que fizessem bem o seu trabalho?

11. Qual sua sugestão para melhorar sua atividade ou o seu resultado?

\section{Conclusões do grupo:}

12. Dentre todas as questões apontadas por vocês: O que deveria ser priorizado?

13. Quais fatores são considerados difíceis na condução dos usuários?

- no deslocamento entre o acesso e a plataforma?

- a configuração da plataforma, o desnível entre o acesso, o mezanino e a plataforma, a falta de respeito dos demais usuários?

- entre o embarque e o desembarque?

- entre o embarque, o desembarque ou a conexão de uma linha para outra? 


\title{
APÊNDICE K
}

\author{
Checklist - modelo
}

\section{CHECKLIST - ITENS A SEREM OBSERVADOS}

\section{A. Desembarque do sistema de transporte integrado}

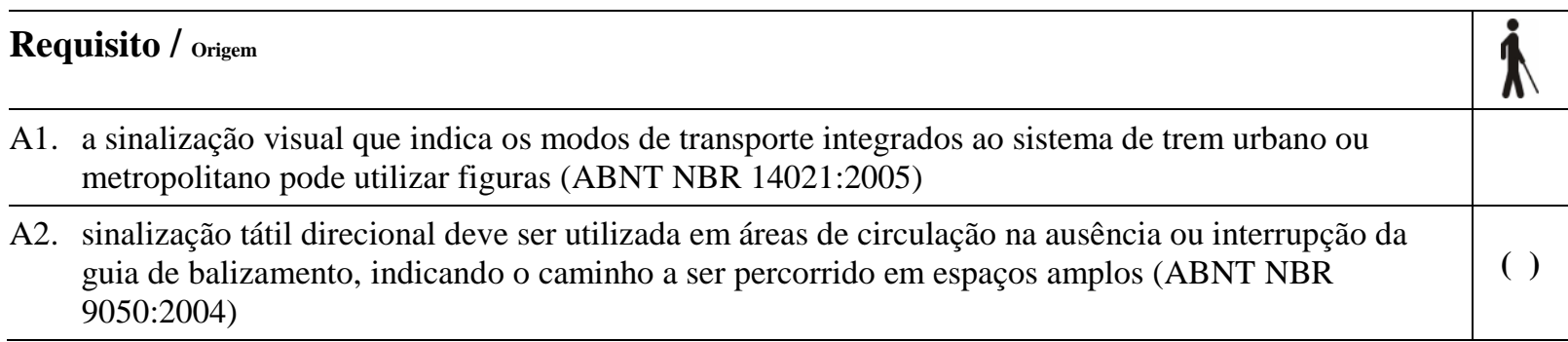

\section{B. Acesso à estação}

\section{Requisito / Origem / Beneficiários}

B1. os acessos devem facilmente reconhecidos e integrados com o sistema de sinalização urbana e sistemas de transporte (Benchmark)

B2. identificação da porta de acesso à estação com alarme de baixa intensidade (Benchmark)

B3. sinalização visual e tátil no lado externo dos acessos, contendo: nome da estação e da(s) linha(s) a que pertence e respectiva figura; horário de funcionamento da estação; horário de funcionamento do acesso e do acesso alternativo; identificação do acesso, através de número, letra ou nome (ABNT NBR 14021:2005)

B4. impressão em relevo do nome da estação e da linha do metrô à qual a entrada pertence em local comum a todas as estações (Benchmark)

B5. sinalização visual com o Símbolo Internacional de Acesso no lado externo dos acessos para pessoas com deficiência ou com mobilidade reduzida (ABNT NBR 14021:2005)

B6. sinalização visual informando a localização do acesso para pessoas com deficiência ou com mobilidade reduzida nos demais acessos (ABNT NBR 14021:2005)

B7. é recomendável haver símbolo de identificação para cada estação, localizado nos acessos e nas plataformas, próximo ou visível do local de embarque e desembarque para pessoa com deficiência ou com mobilidade reduzida (ABNT NBR 14021:2005)

B8. existência de assentos/apoios em áreas de circulação e espera (Benchmark)

B9. escadas, elevadores, posto de supervisão e controle, bilheterias, dispensadores de bilhetes e os principais serviços da estação devem ser facilmente identificados;

B10. a existência serviços específicos devem ser informados por meio de pictogramas (ABNT NBR 14021:2005)

\section{Aquisição do bilhete}

\section{Requisito / origem / Beneficiários}

C1. Bilheterias e equipamentos de venda de bilhetes devem estar agrupados, facilitando sua localização e visualização e ser servidos pela rota tátil

C2. bilheterias e equipamentos de venda de bilhetes devem ser equipados com sistema de indução magnética possibilitando uso de aparelhos auditivos

C3. equipamentos de venda de bilhetes devem ter sinalização visual com caracteres ampliados 
C4. equipamentos de venda de bilhetes devem ter sinalização tátil e sonora, software amigável adaptado para cegos e tela adaptada;

C5. a sinalização visual indicativa do atendimento ou o uso preferencial dos equipamentos e serviços oferecidos pode utilizar pictogramas (ABNT NBR 14021:2005)

C6. sinalização visual de bilheterias e de equipamentos de autoatendimento deve utilizar símbolo (ABNT NBR 14021:2005)

C7. informação sobre tipos de bilhetes e tarifas deve ser visual e sonora (ABNT NBR 14021:2005)

C8. as informações sonoras e visuais necessárias para uso dos equipamentos de autoatendimento para venda de bilhetes ou crédito de viagens devem conter apenas uma oração - uma sentença completa, redigida de forma clara e objetiva; estar na forma ativa; estar na forma afirmativa; evitar o uso de palavras ou expressões pouco comuns; estar na sequência das ações, enfatizando a maneira correta de realização da tarefa (ABNT NBR 15520:2005)

C9. bilheterias ou equipamentos de autoatendimento devem ter sinalização tátil no piso informando o posicionamento para sua utilização (ABNT NBR 14021:2005)

D. Validação do bilhete

\section{Requisito / origem / Beneficiários}

D1. piso tátil direcional desde as entradas da estação até o bloqueio de embarque (ABNT NBR 14021:2005); bloqueios acessíveis servidos pela rota tátil

D2. cancelas com largura suficiente para passagem de pessoas com mobilidade reduzida (ABNT NBR 9050:2004)

D3. bloqueios com largura suficiente para passagem de pessoas com mobilidade reduzida (ABNT NBR 14021:2005)

D4. bloqueios com temporizador adequado à passagem de pessoa com mobilidade reduzida

D5. identificação do bloqueio quanto ao uso embarque preferencial deve ter o Símbolo Internacional de Acesso, posicionado sobre o equipamento, com altura livre mínima de 2,10m ABNT NBR 14021:2005)

D6. a sinalização visual que indica o atendimento ou o uso preferencial dos equipamentos e serviços oferecidos pode utilizar pictogramas (ABNT NBR 14021:2005)

D7. equipamentos de controle de acesso devem ser sinalizados quanto ao uso para embarque ou saída, exclusividade de uso e tipo de bilhete ou cartão. Recomenda-se que essa sinalização seja posicionada sobre os equipamentos, considerando altura livre mínima de 2,10m (ABNT NBR 14021:2005)

D8. equipamento de controle de acesso utilizados por usuários com deficiência visual deve ter sinalização tátil no piso informando o posicionamento do usuário para sua utilização (NBR 14021:2005)

D9. equipamentos de controle de acesso devem ter sinalização visual e tátil indicando o local para inserção ou posicionamento dos bilhetes e cartões e informação visual e sonora sobre a quantidade de créditos restantes no bilhete ou cartão (NBR 14021:2005)

D10. próximo ao equipamento de controle de acesso deve haver informação tátil indicando as linhas e a seqüência das estações, destacando a estação onde o usuário se encontra e as estações de transferência (NBR 14021:2005)

D11. próximo ao equipamento de controle de acesso deve haver informação visual indicando as linhas e a sequiência das estações, destacando a estação onde o usuário se encontra e as estações de transferência (NBR 14021:2005)

\section{E. Acesso à plataforma}

\section{Requisito / origem / Beneficiários}

E1. sinalização clara, estrategicamente colocada, facilita a identificação da plataforma de embarque 
E2. rota alternativa acessível através de elevadores ou escadas rolantes levando a cada uma das plataformas

E3. piso tátil direcional até o local do embarque preferencial

E4. existência de assentos/apoios em áreas de circulação e espera

E5. sinalização de circulação de embarque deve indicar, a partir dos acessos, as áreas essenciais da estação e plataformas de embarque, utilizando a expressão 'embarque'(ABNT NBR 14021:2005)

E6. mapas fornecem detalhe do número da linha, destino, paradas futuras, frequência de trens, tempos de viagem, mapa da rede, desenho da estação mostrando escadas fixas, escadas rolantes e elevadores (Benchmark)

E7. a comunicação e a sinalização informam o esquema de distribuição das linhas pelas plataformas, com redundância, de forma visual, sonora e tátil (ABNT NBR 15599:2008)

\section{F. Espera pelo trem}

\section{Requisito / origem / Beneficiários}

F1. identificação da estação visível para a maioria dos usuários, sentados ou em pé, dentro do trem, em qualquer dos carros (ABNT NBR 14021:2005)

F2. todas as plataformas devem ser identificadas através de letras, números ou nomes (ABNT NBR 14021:2005)

F3. se houver trens com destinos diferentes, circulando na mesma via, deve haver informação visual e sonora na plataforma, informando o destino de cada trem (ABNT NBR 14021:2005)

F4. identificação do local de embarque preferencial - sinalização visual de piso e suspensa alinhada com o espaço reservado dentro do trem (ABNT NBR 14021:2005)

F5. identificação do local de embarque preferencial - sinalização tátil no piso alinhada com o espaço reservado dentro do trem (ABNT NBR 14021:2005)

F6. dispositivo para solicitação de auxílio sinalizado com o Símbolo Internacional de Acesso (ABNT NBR 14021:2005)

F7. informação visual permanente indicando a linha e a estação onde o usuário se encontra e as estações de transferência (ABNT NBR 14021:2005)

F8. piso tátil de alerta - borda de plataforma, de cor e textura contrastante (ABNT NBR 14021:2005)

F9. sinalização visual de alerta na borda da plataforma (ABNT NBR 14021:2005)

F10. indicação de pontos de risco de quedas

F11. faixas de segurança fotoluminescentes no piso e nas portas de vidro ou iluminação de balizamento sinalizando a chegada do trem

F12. existência de assentos preferenciais nas plataformas marcados com pictograma para indicar sua função (ABNT NBR 14021:2005)

F13. existência de apoio nas plataformas marcados com um pictograma para indicar sua função

F14. existência de assentos para obesos marcados com um pictograma para indicar sua função

\section{G. Embarque}

\section{Requisito / origem / Beneficiários}

G1. informação visual e sonora alertando quanto ao vão ou desnível entre o trem e a plataforma, para vão $>10 \mathrm{~cm}$ ou desnível >8cm (ABNT NBR 14021:2005)

G2. sinalização visual e tátil de alerta com largura entre $0,25 \mathrm{~m}$ a $0,50 \mathrm{~m}$, cromodiferenciado ou não, distando no mínimo 0,50 m da borda da plataforma (ABNT NBR 14021:2005) 
G3. a sinalização da borda da plataforma pode se limitar às projeções das portas de plataforma (ABNT NBR 14021:2005)

G4. sinalização com o Símbolo Internacional de Acesso, na lateral externa, junto à porta de embarque e desembarque do carro destinado às pessoas com deficiência ou com mobilidade reduzida (ABNT NBR 14021:2005)

G5. informação visual do destino do trem na parte frontal ou lateral do primeiro carro, legível para o usuário que se encontra na plataforma (ABNT NBR 14021:2005)

G6. alarme sonoro, audível interna e externamente ao carro, para informar o fechamento iminente das portas (ABNT NBR 14021:2005)

G7. alarme visual, visível interna e externamente ao carro, para informar o fechamento iminente das portas (ABNT NBR 14021:2005)

G8. existência de dispositivo entre o trem e a plataforma no local de embarque/desembarque em cor contrastante ou ter sinalização em cor contrastante, nos limites da área de circulação. (ABNT NBR 14021:2005)

G9. instruções de uso informando quanto aos cuidados durante o acionamento ou utilização desses dispositivos para redução vão / desnível (ABNT NBR 14021:2005)

G10. GAP máx entre o trem e a plataforma vão horizontal $<6 \mathrm{~cm}$ e vertical $<2 \mathrm{~cm}$ (Benchmark)

\section{H. Viagem (interior do trem)}

\section{Requisito / Origem / Beneficiários}

H1. informação visual permanente na parte interna do trem, próximo às portas, contendo nome e sequência das estações, destacando estações de transferência (ABNT NBR 14021:2005)

H2. dispositivo para solicitação de auxílio em situação de emergência (ABNT NBR 14021:2005)

H3. dispositivos de sinalização visual para informar anormalidade na circulação de trens, estação em que o trem se encontra, próxima estação e lado de desembarque (ABNT NBR 14021:2005)

H4. dispositivos de sinalização sonora para informar anormalidade na circulação de trens, estação em que o trem se encontra, próxima estação e lado de desembarque (ABNT NBR 14021:2005)

H5. sinalização indicativa da finalidade dos assentos preferenciais (ABNT NBR 14021:2005)

H6. sinalização tátil com caracteres em relevo e Braille, contendo informações

H7. sobre o número do carro ou trem (ABNT NBR 14021:2005)

H8. portas devem ser ou ter moldura em cor contrastante, com alarmes de fechamento quando automáticas (Benchmark)

H9. contraste de cor entre a superfície e as portas dos trens (Benchmark)

H10. portas de embarque/desembarque acessível identificadas (ABNT NBR 14021:2005)

H11. abertura automática das portas do carro acessível (Benchmark)

H12. abertura automática de todas as portas em todas as estações (Benchmark)

\section{Desembarque}

\section{Requisito / Origem / Beneficiários}

I1. sinalização visual em painel suspenso, instalado transversalmente à plataforma e alinhado ao acesso ao equipamento de circulação para pessoa com deficiência ou com mobilidade reduzida (ABNT NBR 14021:2005)

I2. informação visual e sonora alertando quanto ao vão ou desnível entre o trem e a plataforma, para vão $>10 \mathrm{~cm}$ ou desnível >8cm (ABNT NBR 14021:2005)

I3. sinalização visual e tátil de alerta com largura entre $0,25 \mathrm{~m}$ a 0,50 m, cromodiferenciado ou não, distando no mínimo 0,50 m da borda da plataforma (ABNT NBR 14021:2005) 
I4. a sinalização da borda da plataforma pode se limitar às projeções das portas de plataforma (ABNT NBR 14021:2005)

I5. alarme sonoro, audível interna e externamente ao carro, para informar o fechamento iminente das portas (ABNT NBR 14021:2005)

I6. alarme visual, visível interna e externamente ao carro, para informar o fechamento iminente das portas (ABNT NBR 14021:2005)

\section{J. Saída da estação}

\section{Requisito / Origem / Beneficiários}

J1. sinalização de circulação de saída deve indicar, a partir da plataforma de desembarque, as áreas essenciais da estação, as saídas, os modos de transporte integrados e os locais de interesse no entorno, utilizando a expressão 'saída'(ABNT NBR 14021:2005)

J2. sinalização de alerta e direcional para deslocamento desde o local de desembarque até o local de atendimento especial para saída ou acesso ao terminal de transporte integrado (ABNT NBR 15599:2008)

J3. mapas fornecem mapa da rede, ruas e pontos de interesse na área ao redor da estação, desenho da estação mostrando as saídas, escadas fixas, escadas rolantes e elevadores (Benchmark)

\section{K. Embarque no sistema integrado}

\section{Requisito / Origem / Beneficiários}

K1. rota acessível até o ponto de parada deve estar sinalizada (ABNT NBR 15599:2008)

K2. se os pontos de parada estiverem localizados em sequência e atenderem a trajetos distintos (partindo de diferentes pontos, para diferentes destinos), as informações devem incluir a identificação e o itinerário das linhas que param naquele ponto de parada; a que distância se encontram os pontos de parada anterior e posterior; qual o marco referencial do trajeto das linhas que param nos pontos anterior e posterior (ABNT NBR 15599:2008)

K3. informações que identifiquem linhas, destinos e itinerários dos veículos devem estar disponíveis de forma visual, tátil e sonora (ABNT NBR 15599:2008)

K4. a sinalização visual que indica os modos de transporte integrados ao sistema de trem urbano ou metropolitano pode utilizar figuras (ABNT NBR 14021:2005)

K5. sinalização tátil direcional deve ser utilizada em áreas de circulação na ausência ou interrupção da guia de balizamento, indicando o caminho a ser percorrido em espaços amplos (ABNT NBR 9050:2004)

K6. informações essenciais sobre a rede de transporte distribuídas ao longo das várias linhas, estações de conexão com outra estação ou com outros modos de transporte(incluindo trem, ônibus, estacionamentos (Benchmark)

\section{Circulação vertical}

\section{Requisito / origem / Beneficiários}

L1. A sinalização visual e tátil deve indicar as diferentes possibilidades de circulação, informando a existência e a localização dos equipamentos de circulação, escadas e rampas (ABNT NBR 9050:2004)

L2. A sinalização visual dos equipamentos de circulação devem utilizar símbolos de circulação-elevador, escada rolante, escada, plataforma, rampa, esteira (ABNT NBR 9050:2004)

\section{Rampas e escadas fixas}

\section{Requisito / origem / Beneficiários}

M1. degrau ou escada deve ter sinalização visual de alerta em cor contrastante, medindo entre $2-3 \mathrm{~cm}$ de largura - na projeção dos corrimãos laterais > 20cm de extensão (ABNT NBR 9050:2004) 
M2. patamares no início e final das escadas com sinalização tátil contrastante e antiderrapante (ABNT NBR 9050:2004)

M3. escadas com degrau ou faixa antiderrapante (ABNT NBR 9050:2004)

M4. corrimãos fixos, contínuos nos patamares, em ambos os lados a $92 \mathrm{~cm}$ superior e $70 \mathrm{~cm}$ inferior, com prolongamento de 30 antes do início e depois do término, unidos na extremidade (ABNT NBR 9050:2004)

M5. corrimãos de escadas e rampas sejam sinalizados através de anel com textura contrastante com a superfície do corrimão, instalado 1,00 m antes das extremidades (ABNT NBR 9050:2004)

M6. corrimãos de escadas e rampas sejam sinalizados em Braille, informando sobre os pavimentos no início e no final das escadas fixas e rampas, instalada na geratriz superior do prolongamento horizontal do corrimão (ABNT NBR 9050:2004)

M7. corrimãos em cor contrastante com a parede próxima (Benchmark)

M8. sinalização visual dos diferentes pavimentos no início e término da escada (Benchmark)

\section{N. Escadas rolantes}

\section{Requisito / origem / Beneficiários}

N1. Sinalização visual permanente contendo instruções de uso, indicação da posição para embarque e indicação dos pavimentos atendidos (ABNT NBR 14021:2005)

N2. obrigatoriedade de escadas rolantes e corrimãos com velocidade coordenada, limitada a $27 \mathrm{~m} / \mathrm{s} \mathrm{em}$ desníveis de $4 \mathrm{~m}$ para subida e $6 \mathrm{~m}$ para descida (Benchmark)

N3. sinalização de alerta visual na cor amarela nas extremidades dos degraus e sinalização de orientação de movimento/fluxo no lado direito (ABNT NBR 14021:2005)

N4. sistema sonoro para identificação da direção das escadas rolantes (Benchmark)

N5. quando estiverem fora de uso - barreira de segurança identificável visualmente, com altura entre $0,90 \mathrm{~m}$ e $1,07 \mathrm{~m}$ em cor contrastante, preferencialmente amarela e preta (Benchmark)

N6. sinalização tátil no piso, antes do equipamento, nos dois pavimentos atendidos (ABNT NBR 14021:2005)

\section{O. Esteiras rolantes}

\section{Requisito / origem / Beneficiários}

O1. Sinalização visual permanente contendo instruções de uso, indicação da posição para embarque e indicação dos pavimentos atendidos (ABNT NBR 14021:2005)

O2. obrigatoriedade de escadas rolantes e corrimãos com velocidade coordenada (Benchmark)

O3. sinalização de alerta visual na cor amarela nas extremidades laterais e sinalização de orientação de movimento/fluxo no lado direito (ABNT NBR 14021:2005)

O4. quando estiverem fora de uso - barreira de segurança identificável visualmente, com altura entre 0,90m e 1,07m em cor contrastante, preferencialmente amarela e preta (Benchmark)

O5. sinalização tátil no piso, antes do equipamento, nos dois pavimentos atendidos (ABNT NBR 14021:2005)

\section{P. Elevadores}

\section{Requisito / origem / Beneficiários}

P1. devem ser preferencialmente transparentes e situados em áreas de boa visibilidade fora do fluxo principal de tráfego de pedestres (Benchmark) 
P3. alarme visual de abertura e fechamento de portas dos elevadores (Benchmark)

P4. alarme sonoro de abertura e fechamento de portas dos elevadores

P5. dispositivos de operação, botoeiras e sistemas de informação, orientação com alarmes visuais luminosos e complementados com sistema de avisos sonoros (ABNT NBR NM 313:2007)

P6. externo - alarme visual e sonoro no pavimento, indicando a chegada e o sentido de deslocamento do elevador (ABNT NBR NM 313:2007)

P7. interno - informação visual e sonora do pavimento desejado (ABNT NBR NM 313:2007)

P8. alarme visual e sonoro no pavimento indicando a chegada e o sentido de deslocamento do elevador (ABNT NBR NM 313:2007)

P9. interno - alarme de emergência visual (na cor amarela) e sonoro e intercomunicador (ABNT NBR NM 313:2007)

P10. botoeiras internas com indicação em Braille no próprio botão ou abaixo dele, complementada com caracteres e símbolos claros em fundo escuro e em relevo, localizados à esquerda (ABNT NBR NM 313:2007)

P11. cabine interna - informação sonora e visual quando o elevador abrir a porta na plataforma, orientando sobre o número da linha, a direção do trem e informação sonora da distância entre o elevador e a borda da plataforma (Benchmark)

\section{Q. Plataformas inclinadas}

\section{Requisito / Origem / Beneficiários}

Q1. plataformas de elevação inclinada devem ter sinalização visual no piso, em cor contrastante com a adjacente, indicando a área de espera e o limite da projeção do percurso do equipamento aberto ou em funcionamento (ABNT NBR 14021:2005)

Q2. dispositivos de comando dos equipamentos de circulação devem utilizar as expressões 'embarque' e 'saída' para orientar a circulação direcional (ABNT NBR 14021:2005)

Q3. alarme sonoro durante o funcionamento (ABNT NBR 14021:2005)

Q4. alarme visual durante o funcionamento (ABNT NBR 14021:2005)

\section{R. Circulação horizontal}

\section{Requisito / Origem / Beneficiários}

R1. superfícies de paredes, pisos, portas, maçanetas, corrimãos, lixeiras, móveis, placas publicitárias e serviços e equipamentos colocados à disposição não devem ser brilhantes ou refletivas e devem ser contrastantes em $70 \%$ (Benchmark)

R2. tampas de poços de inspeção, grelhas e ralos devem ter superfície antiderrapante e ser nivelados com o piso (Benchmark)

R3. espelhos são proibidos em áreas de circulação (Benchmark)

R4. superfícies em vidro devem ter sinalização em cor contrastante, instaladas entre $85-100 \mathrm{~cm}$ e entre 140 $160 \mathrm{~cm}$ (Benchmark)

R5. materiais de acabamento devem facilitar a compreensão dos espaços e ambientes

R6. textura lisa para as áreas de circulação e superfície rugosa para áreas onde existam mobiliário ou obstáculos (Benchmark)

R7. a localização e a entrada de instalações comerciais devem ser marcadas e incorporadas em todos os sistemas de informação e a sinalização comercial não deve provocar reflexos, ofuscamentos ou ter luzes intermitentes (Benchmark)

R8. sinalização visual e linha-guia em circulações de embarque e saída (ABNT NBR 14021:2005) 
R9. piso tátil direcional desde a entrada da estação até a plataforma de embarque e vice-versa, indicando a localização de sistemas de informação, serviços, bilheterias, máquinas de venda de bilhetes, pontos de informação, mobiliário, áreas de espera e de mudanças de direção (ABNT NBR 15599:2008)

R10. sinalização de alerta e direcional orientando o deslocamento nos percursos desde o acesso principal ao local de atendimento preferencial na bilheteria, do acesso principal ao local de atendimento especial para embarque e do local de desembarque ao local de atendimento especial para saída do terminal (ABNT NBR 15599:2008)

R11. piso tátil direcional - encaminhamento com cor e textura contrastante em $30 \%$ com o piso adjacente, com faixa lateral de 30 a $60 \mathrm{~cm}$ (Benchmark)

R12. mudanças de direção devem ocorrer em ângulos retos(Benchmark)

R13. piso tátil direcional não direcionado para escadas rolantes em função da possibilidade de inversão do sentido de deslocamento (Benchmark)

R14. sinalização tátil de alerta deve ser instalada perpendicularmente ao sentido de deslocamento, indicando: obstáculos suspensos, rebaixamento de calçadas, início e término de escadas fixas, escadas rolantes e rampas, portas dos elevadores e desníveis, tais como plataformas de embarque e desembarque, palcos, vãos (ABNT NBR 9050:2004)

R15. espaços com altura menor que $2 \mathrm{~m}$ devem ter, em todo o seu perímetro, elementos fixos detectados por bengala (Benchmark)

R16. corrimãos nas rotas horizontais, fixos, contínuos, coloridos e antiderrapantes, em ambos os lados, em 2 alturas $(0,92 \mathrm{~cm}$ e $70 \mathrm{~cm})$ unidos na extremidade (Benchmark)

R17. orientação sonora do deslocamento de pessoas com deficiência visual por meio de sistema de sinalização infravermelho (Benchmark)

R18. localização e dimensionamento das áreas comerciais devem ser compatíveis com o funcionamento da estação (Benchmark)

R19. recomenda-se que sejam instaladas esteiras rolantes em corredores maiores que 50m (Benchmark)

\section{S. Sinalização de emergência}

\section{Requisito / Origem / Beneficiários}

S1. rotas de fuga e as saídas de emergência devem ser sinalizadas com informações visuais e sonoras (ABNT NBR 9050:2004)

S2. escadas que interligam os diversos pavimentos deve haver sinalização tátil e visual informando o número do pavimento (ABNT NBR 9050:2004)

S3. saídas de emergência devem ter alarmes sonoros e visuais (ABNT NBR 9050:2004)

S4. alarmes sonoros e vibratórios devem estar associados e sincronizados aos alarmes visuais intermitentes (ABNT NBR 9050:2004)

S5. mecanismos e dispositivos de emergência devem conter informações táteis e visuais, representadas através de símbolos (ABNT NBR 9050:2004)

S6. áreas de resgate deve ser identificada com sinalização em material fotoluminescente ou ser retroiluminada (ABNT NBR 9050:2004)

S7. balaústres em cor contrastante com o revestimento do trem e com característica fotoluminescente localizados junto à porta de embarque e desembarque de pessoa com deficiência visual e junto à porta de emergência (ABNT NBR 14021:2005)

S8. sinalização visual no trem indicando a localização das saídas de emergência (ABNT NBR 14021:2005)

S9. indicações de saída de emergência (evacuação) precisam ser claras, posicionadas nas entradas, saídas e áreas de circulação e ser visíveis no escuro (ABNT NBR 14434:2004)

S10. deve haver contraste de cor entre a superfície das paredes e a superfície, as placas de informação e os textos e figuras (Benchmark) 
S11. faixa de segurança fotoluminescente na borda da plataforma, visível em situações de falta de energia (Benchmark)

S12. sinalização temporária em situações de emergência deve incluir avisos sonoros, luzes de emergência e alarmes, vinculadas ao sistema de alimentação principal, cujo funcionamento deve ser contínuo mesmo nas situações de emergência (Benchmark)

S13. sistema completo de comunicação, controle e alarme de emergência localizado nas diversas zonas da estação (Benchmark)

S14. informações sobre "como proceder em situações de emergência" devem estar disponíveis em vários formatos e mídias incluindo mapas com rotas de fuga e saídas de emergência, orientações para os passageiros entre estações (Benchmark)

S15. treinamentos para simular o atendimento em situações de emergência devem ser realizados periodicamente com a participação de usuários (Benchmark)

S16. procedimentos de resgate devem incluir informações sobre resgate de pessoas com deficiência ou com mobilidade reduzida (ABNT NBR 14021:2005)

\section{T. Mobiliário}

\section{Requisito / origem / Beneficiários}

T1. mobiliário e os equipamentos com altura igual ou inferior a 2,10 m, instalados nas plataformas, devem ser posicionados de forma a não interferir na rota acessível e estar distantes no mínimo 1,20 m da faixa amarela (ABNT NBR 14021:2005)

T2. demarcação dos locais de embarque preferencial para garantir que o mobiliário e os equipamentos estejam distantes no mínimo 1,50 m da faixa amarela (ABNT NBR 14021:2005)

\begin{tabular}{l|l}
\hline T3. mínimo de dois assentos preferenciais por plataforma (ABNT NBR 14021:2005) & $($ ) \\
\hline T4. localizados fora das áreas de fluxo de pessoas (Benchmark) & $($ ) \\
\hline T5. identificáveis a partir do nível do solo, permitindo rastreamento com bengalas (Benchmark) & $($ ) \\
\hline T6. bordas das superfícies acessíveis ao toque devem ser arredondadas - raio 3 mm (Benchmark) & $($ ) \\
\hline
\end{tabular}

\section{U. Iluminação}

\section{Requisito / origem / Beneficiários}

U1. contraste de iluminância não deve ser superior a 1/10 nas áreas de uso público e nas áreas essenciais (ABNT NBR 14021:2005)

U2. acomodação visual entre o ambiente interno e o externo, diurno ou noturno (ABNT NBR 14021:2005)

U3. a variação da iluminação entre áreas de trabalho e de fluxos de pedestres ou entre duas áreas de fluxos de pedestres não deve ultrapassar 300 lux

U4. iluminação longitudinal ao sentido de deslocamento (ABNT NBR 14021:2005)

U5. iluminação longitudinal à via, alinhada à faixa amarela (ABNT NBR 14021:2005)

U6. iluminância média mínima de 5 lux nas áreas de circulação assistida de usuários e rotas de fuga (túneis), medida no nível do piso (ABNT NBR 14021:2005)

U7. postos de serviço (bilheterias, informações, borda da plataforma, etc.) devem ter maiores níveis de iluminação e uma cor mais quente (Benchmark)

U8. nível de iluminamento com 400lux junto aos elevadores (Benchmark)

U9. nível de iluminamento com 600lux junto às escadas (Benchmark) 


\section{Comunicação}

\section{Requisito / origem / Beneficiários}

V1. sinalização indicativa de atendimento prioritário ou uso preferencial deve indicar os beneficiários desse direito por meio de símbolos (ABNT NBR 15599:2005)

V2. para sinalização dos equipamentos ou serviços de comunicação devem ser utilizados os símbolos internacionais de informação (i ou ?), telefone, telefone com teclado ou dispositivo de amplificação sonora (ABNT NBR 9050:2004)

V3. O símbolo internacional de pessoas com deficiência visual deve indicar a existência de equipamentos, mobiliário e serviços para pessoas com deficiência visual (ABNT NBR 9050:2004)

V4. o símbolo internacional de pessoa com surdez deve ser utilizado em todos os locais, equipamentos, produtos, procedimentos ou serviços para pessoa com deficiência auditiva (surdez) (ABNT NBR 9050:2004)

V5. campanhas institucionais de prevenção de acidentes e promoção da cidadania devem utilizar os recursos de acessibilidade em comunicação, com redundância (ABNT NBR 15599:2005)

V6. atendimento que disponha de intérprete de LIBRAS deve estar identificado com o símbolo internacional de surdez e ter os locais, dias e horários do atendimento divulgados (ABNT NBR 15599:2005)

V7. serviços de atendimento ao público, seja via telefone, equipamento de auto-atendimento ou Internet, de empresas prestadoras ou concessionarias do serviço devem propiciar tempo, segundo os critérios da usabilidade, para que as pessoas com deficiência possam utilizar esses serviços com autonomia e ter disponíveis, para consulta e resposta ao cidadão, múltiplos meios de comunicação: correio eletrônico, fax, telefone, TS, CAS, SISO, videofone, atendimento online via internet etc (ABNT NBR 15599:2008)

V8. atendimento ao cidadão através de linha telefônica com TS deve estar identificado com o símbolo de telefone para surdo (ABNT NBR 15599:2008)

V9. todo serviço de atendimento ao consumidor (serviços 0800 e 0300) com TS instalado deve estar sinalizado, com o símbolo internacional de telefone para surdo (ABNT NBR 15599:2008)

V10. central de atendimento de serviços de emergência deve receber ligações telefônicas provindas de TS e de telefones celulares com mensagem de texto (ABNT NBR 15599:2008)

V11. central de atendimento de serviços de emergência deve ter pessoal com noções de LIBRAS e de LIBRAS tátil, de modo a se comunicar e interagir com o usuário de LIBRAS, em atendimento de emergência (ABNT NBR 15599:2008)

V12. todo serviço de atendimento ao consumidor, via Internet, deve estar em formato digital que possa ser processado por sistemas de leitura e ampliação de tela (ABNT NBR 15599:2008)

V13. todo serviço de atendimento ao consumidor (serviços 0800 e 0300) deve estar apto a fornecer informações e esclarecimentos, para pessoas com deficiência visual ou auditiva (ABNT NBR 15599:2008)

V14. interfones possibilitam comunicação com o centro de informações a partir de diversos pontos da estação (Benchmark)

V15. intercomunicadores, mensagens pré-gravadas e alarmes devem ser instalados no percurso (Benchmark)

V16. interfone na plataforma conectado à supervisão de controle da estação (Benchmark)

V17. postos de informação "i” ao longo da rede, com atendentes para prestar informações em diversos idiomas e língua de sinais - para se comunicar com surdos ou pessoas com dificuldades auditivas (Benchmark)

V18. informações devem ser apresentadas de várias formas e mídias, incluindo folhetos, avisos sonoros, sites, painéis (Benchmark)

19. sistema de informação completo disponibilizado on-line via website acessível, possibilitando compra e reserva de bilhetes, planejamento antecipado das viagens (Benchmark)

20. postos de informação equipados com sistema de indução magnética possibilitando que pessoas com deficiência auditiva usem um aparelho auditivo na posição adequada (Benchmark) 
V21. infravermelho por meio de transmissores localizados em toda a estação e receptores usados pelos usuários possibilitam a construção de um mapa mental da estação e orientam sobre o percurso para chegar à plataforma ou à saída (Benchmark)

V22. sistema de som de alta qualidade e alto contraste, transmitidas pelo sistema de aviso ao público e sincronizada com as mensagens escritas (Benchmark)

V23. sistemas de informação sonoras usando transmissores e receptores para pessoas com deficiência visual podem ser utilizados para orientar os percursos (Benchmark)

V24. dispositivos que possam ser conectados aos aparelhos auditivos - pessoa com deficiência auditiva (Benchmark)

\section{W. Informação}

\section{Requisito / origem / Beneficiários}

W1. informações visuais devem seguir premissas de textura, dimensionamento e contraste de cor dos textos e das figuras para que sejam perceptíveis por pessoas com baixa visão (ABNT NBR 9050:2004)

W2. dimensão das letras e números deve ser proporcional à distância de leitura, obedecendo à relação 1:200 (ABNT NBR 9050:2004)

W3. para a sinalização interna dos ambientes, a dimensão mínima das figuras deve ser de $15 \mathrm{~cm}$, considerando a legibilidade a uma distância máxima de $30 \mathrm{~m}$, sendo que para distâncias superiores deve-se obedecer à relação 1:200 (ABNT NBR 9050:2004)

W4. deve haver contraste entre a sinalização visual (texto ou figura e fundo) e a superfície sobre a qual ela está afixada, cuidando para que a iluminação do entorno - natural ou artificial - não prejudique a compreensão da informação (ABNT NBR 9050:2004)

W5. textos, figuras e fundo das peças de sinalização devem ter acabamento fosco, evitando-se reflexão (ABNT NBR 9050:2004)

W6. quando a sinalização for retroiluminada o fundo deve ter cor contrastante, a figura e o texto devem ser translúcidos e a luz deve ser branca (ABNT NBR 9050:2004)

W7. textos contendo orientações e instruções de uso de áreas, objetos ou equipamentos, regulamentos e normas de conduta e utilização devem: conter as mesmas informações escritas em Braille; conter apenas uma oração - uma sentença completa, com sujeito, verbo e predicado, nesta ordem; estar na forma ativa e não passiva; estar na forma afirmativa e não negativa; estar escritos na sequência das ações, enfatizando a maneira correta de se realizar uma tarefa (ABNT NBR 9050:2004)

W8. informações sonoras verbais podem ser digitalizadas ou sintetizadas, e devem ter as seguintes características: conter apenas uma oração - uma sentença completa, com sujeito, verbo e predicado, nesta ordem; estar na forma ativa e não passiva;

W9. estar na forma imperativa (ABNT NBR 9050:2004)

W10. informações dirigidas às pessoas com baixa visão devem utilizar texto impresso em fonte tamanho 16, com traços simples e uniformes e algarismos arábicos, em cor preta sobre fundo branco (ABNT NBR 9050:2004)

W11. informações visuais podem estar associadas aos caracteres em relevo (ABNT NBR 9050:2004)

W12. recomenda-se a combinação de letras maiúsculas e minúsculas (caixas alta e baixa), exceto quando forem destinadas à percepção tátil (ABNT NBR 9050:2004)

W13. informações em Braille não dispensam a sinalização visual com caracteres ou figuras em relevo, exceto em folheto informativo. As informações em Braille devem estar posicionadas abaixo dos caracteres ou figuras em relevo (ABNT NBR 9050:2004)

W14. textos, figuras e pictogramas em relevo devem estar associados ao texto em Braille (ABNT NBR 9050:2004)

W15. toda mensagem sonora deve ser precedida de um prefixo ou de um ruído característico para chamar a atenção do ouvinte (ABNT NBR 9050:2004)

W16. alarmes sonoros e alarmes vibratórios devem estar associados e sincronizados aos alarmes visuais 


\begin{tabular}{l|l}
\hline intermitentes (ABNT NBR 9050:2004) & ( ) \\
\hline W17. símbolos em relevo devem ser instalados entre 1,40 m e 1,60 m do piso (ABNT NBR 9050:2004) & ( $\begin{array}{l}\text { a sinalização vertical em Braille ou texto em relevo deve ser instalada de maneira que a parte } \\
\text { W18. } \\
\text { (ABNerior da cela Braille ou do símbolo ou do texto esteja a uma altura entre 0,90 m e 1,10 m do piso }\end{array}$
\end{tabular}

W19. sinalização em Braille e caracteres em relevo devem estar posicionados à esquerda do texto - textos em Braille com até 10 palavras devem ter a respectiva transcrição e acima de 10 palavras podem ser abreviados (Benchmark)

W20. a sinalização vertical deve ter a respectiva correspondência com o piso tátil (ABNT NBR 9050:2004)

W21. superfícies horizontais ou inclinadas (até $15 \%$ em relação ao piso) contendo informações táteis em Braille, planos e mapas devem ser instaladas à altura entre 0,90 m e 1,10 m (ABNT NBR 9050:2004)

W22. informações em meio digital devem ser processáveis por sistemas de leitura e ampliação de tela e outros que a tecnologia permitir (ABNT NBR 15599:2008)

W23. sistemas informatizados devem ter disponíveis programa de ampliação de tela e sistema composto por leitor de tela, sintetizador de voz e display Braille (ABNT NBR 15599:2008)

W24. painéis eletrônicos e monitores de vídeo devem estar associados a sinais de luz (ABNT NBR 15599:2008)

W25. painéis eletrônicos e monitores de vídeo devem estar sincronizados com informação sonora verbalizada (ABNT NBR 15599:2008)

W26. terminais de passageiros devem prover mapas táteis com a descrição do espaço utilizado pelo público (ABNT NBR 15599:2008);

27. mapa tátil da estação, com informações em Braille, localizados no acesso, no saguão, na plataforma e em pontos de troca de direção, permitindo identificar a rota para chegar até a plataforma ou saída ; sinalização tátil deve estar posicionada na rota acessível, nos acessos das estações, nas plataformas junto ao local de embarque / desembarque e nos pontos intermediários e incluir mapas em relevo indicando a localização das bilheterias, escadas, elevadores, piso tátil existente nas áreas de circulação (Benchmark)

W28. informações que identifiquem linhas, destinos e itinerários dos veículos devem estar disponíveis de forma visual, tátil e sonora (ABNT NBR 15599:2008)

W29. sistema de sinalização deve ser claro, compreensível e integrado em uma unidade estética, universal e uniforme, sistemático e lógico, utilizando os mesmos códigos de cores, tipologias, superfícies e localização, legível para assegurar a segurança do usuário, prover informações gerais de orientação, direção e identificação (Benchmark)

W30. informações visuais também devem ser atualizadas regularmente e incluir sinalização em grande dimensão, pictogramas e versões em Braille e em relevo

W31. informações de identificação indicam onde os usuários estão e as informações gerais informam sobre as linhas interrompidas, trabalhos e reparos, sendo que pontos de interesse devem ser destacados

W32. informações de orientação devem permitir a compreensão da relação onde de se está e as opções disponíveis, as áreas de espera ou de serviços e são representadas normalmente através de mapas ou desenhos em planta (mapa da cidade, mapa da rede de transporte, mapa da estação, etc); 


\section{APÊNDICE L}

Ficha ambiente - modelo

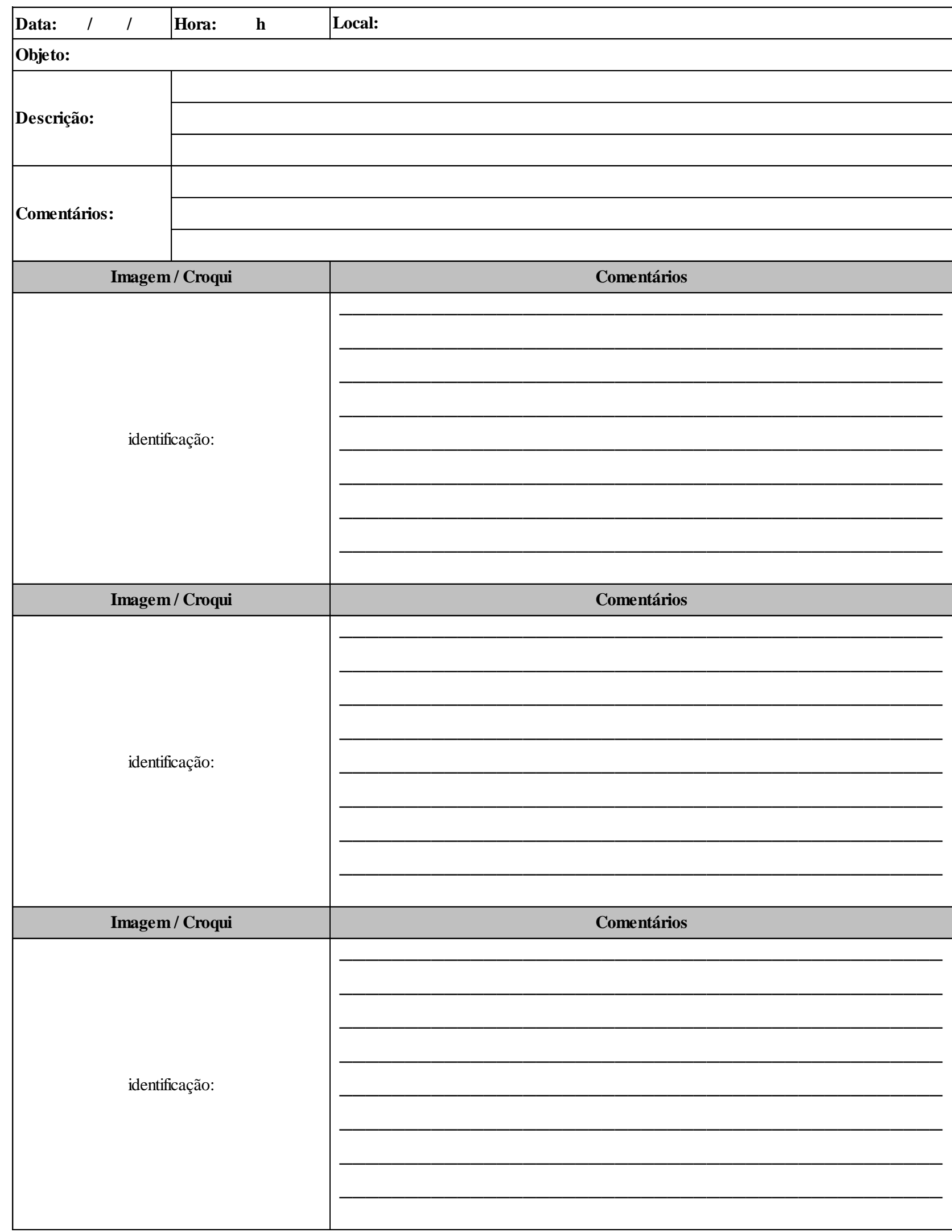




\section{APÊNDICE M}

Ficha de observação - comportamento - modelo

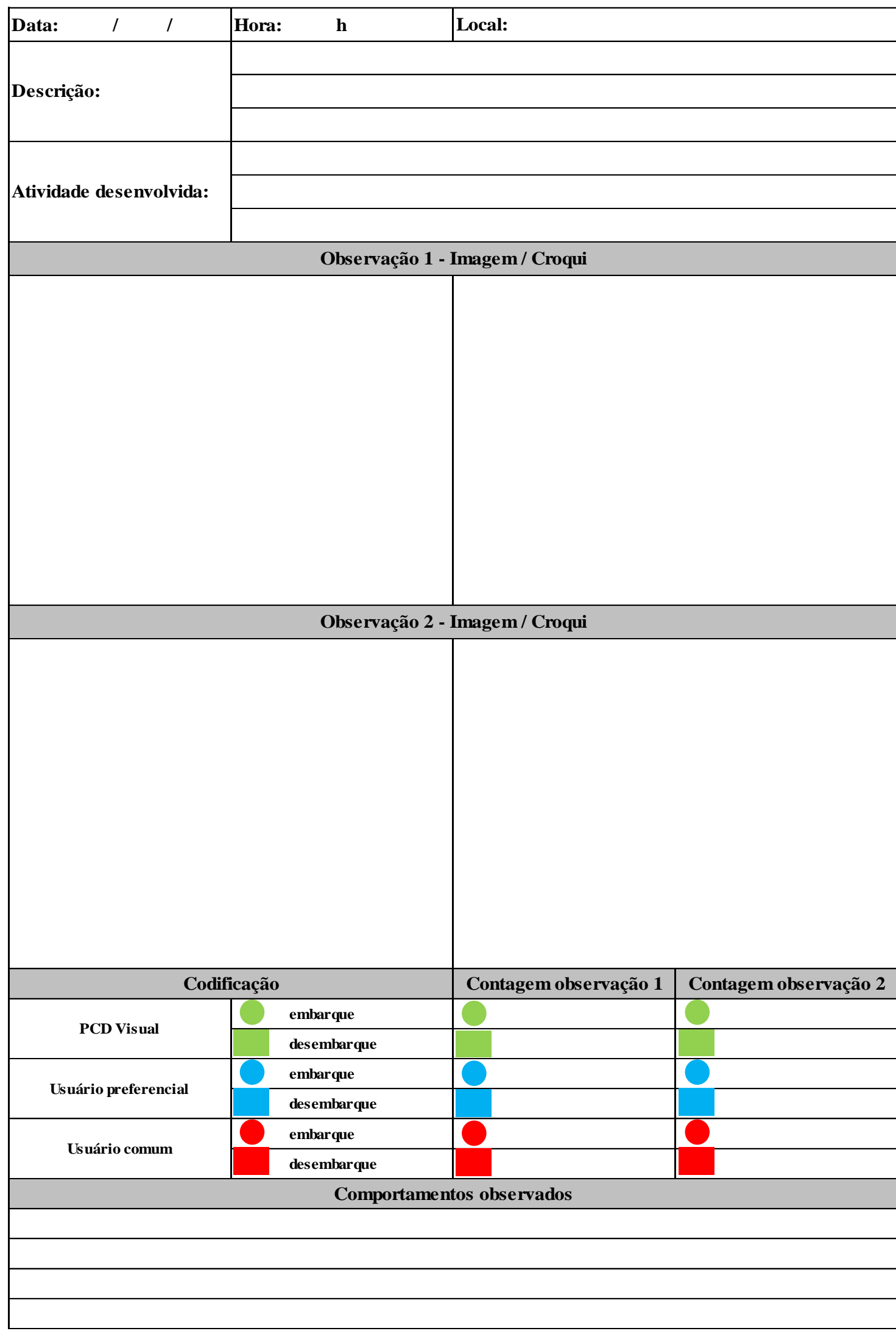




\section{APÊNDICE N}

Ficha de observação - fluxo - modelo

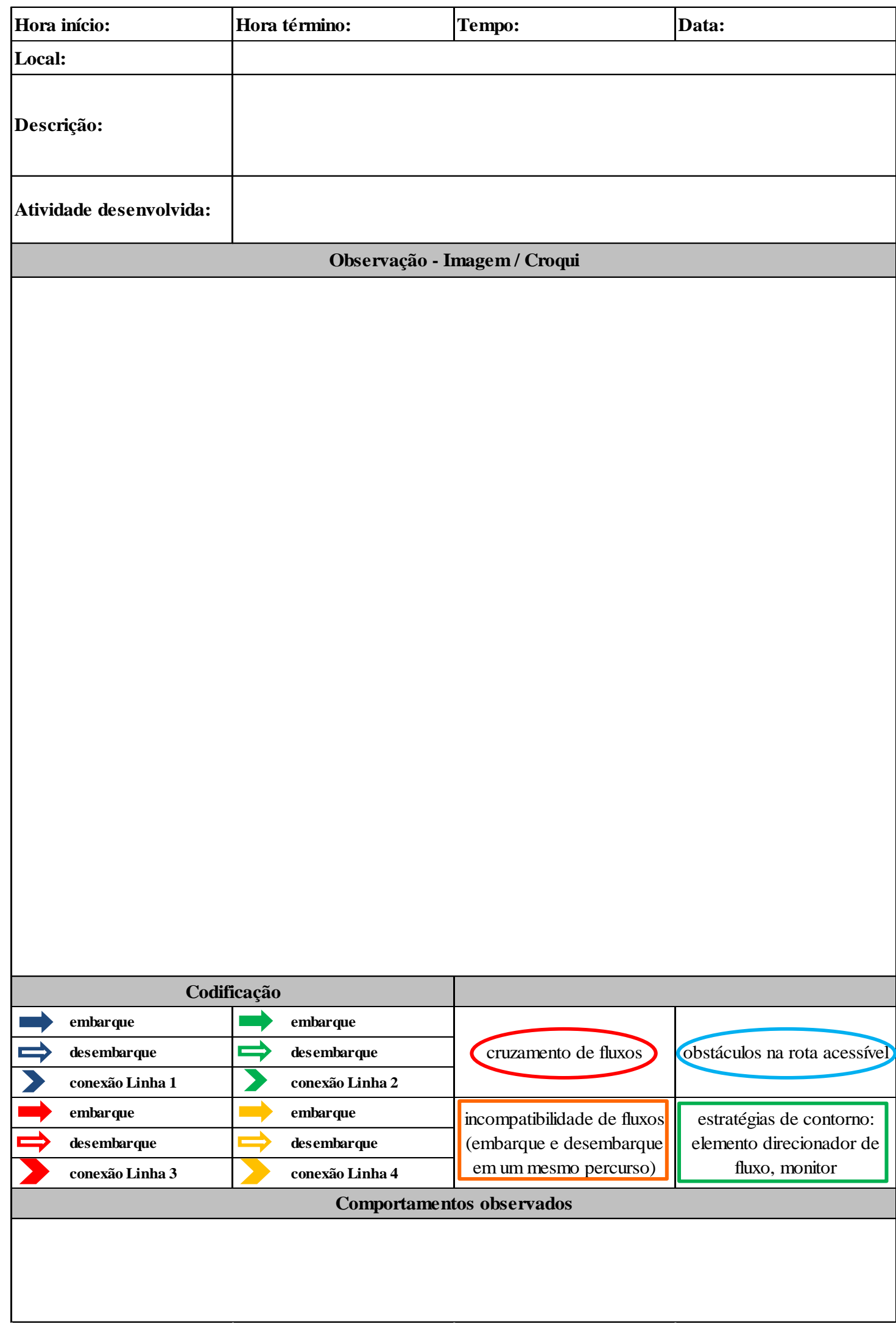

